\title{
LUIS ENRIQUE OREGGIONI
}

\section{MORE WITH LESS}

Ideias para uma nova geração de Equipamentos Coletivos na Periferia da Grande Montevidéu geradores de urbanidade, e baseados na desespecialização programática como ferramenta de projeto.

VOLUME 01

São Paulo

2018 



\section{LUIS ENRIQUE OREGGIONI}

\section{MORE WITH LESS}

VOLUME 01

Ideias para uma nova geração de equipamentos coletivos na periferia da grande Montevidéu geradores de urbanidade, e baseados na desespecialização programática como ferramenta de projeto.

Tese apresentada à Faculdade de Arquitetura e Urbanismo da Universidade de São Paulo para obtenção do título de Doutor em Ciências. Programa de Arquitetura e Urbanismo, Área de Concentração: Projeto de Arquitetura.

EXEMPLAR REVISADO E ALTERADO EM RELAÇÃO À VERSÃO ORIGINAL, SOB RESPONSABILIDADE DO AUTOR E ANUÊNCIA D̉O ORIENTADOR.

A versão original de data 16 de julho de 2018 em formato digital, ficará arquivada na Biblioteca da Faculdade.

São Paulo, 1 de fevereiro de 2019.

Orientador: Prof. Dr. Francisco Spadoni 
Autorizo a reprodução e divulgação total ou parcial deste trabalho, por qualquer meio convencional ou eletrônico, para fins de estudo e pesquisa, desde que citada a fonte.

E-MAIL DO AUTOR: lucho.oreggioni@gmail.com

Catalogação na Publicação

Serviço Técnico de Biblioteca

Faculdade de Arquitetura e Urbanismo da Universidade de São Paulo

Oreggioni, Luis Enrique

More with less: Ideias para uma nova geração de

equipamentos coletivos na periferia da grande Montevidéu

geradores de urbanidade, e baseados na desespecialização

programática como ferramenta de projeto. / Luis Enrique

Oreggioni; orientador Francisco Spadoni. - São Paulo, 2018.

727 p. 2 volumes.

Tese (Doutorado) - Faculdade de Arquitetura e Urbanismo da Universidade de São Paulo. Área de concentração: Projeto da Arquitetura.

1. Desespecializaçào Programática. 2. Fórum. 3.

Equipamentos. 4. Periferia. I. Spadoni, Francisco, orient.

II. Título.

Elaborada eletronicamente através do formulário disponível em: <http://www.fau.usp.br/fichacatalografica/> 
OREGGIONI, L. More with less. Ideias para uma nova geração de equipamentos coletivos na periferia da grande Montevidéu geradores de urbanidade, e baseados na desespecialização programática como ferramenta de projeto. 2018. 727 pag. em dois volumes. Volume 1 p.1 a 380 Volume 2 p.381 a 722

Tese (Doutorado em Arquitetura e Urbanismo), Universidade de São Paulo, São Paulo, 2018)

Aprovado em:

\section{BANCA EXAMINADORA}

Prof. Dr.

Instituição

Julgamento

Prof. Dr.

Instituição

Julgamento

Prof. Dr.

Instituição

Julgamento

Prof. Dr.

Instituição

Julgamento

Prof. Dr.

Instituição

Julgamento 



\section{RESUMO}

OREGGIONI, Luis Enrique. More with less: Ideias para uma nova geração de Equipamentos Coletivos na Periferia da Grande Montevidéu geradores de urbanidade, e baseados na desespecialização programática como ferramenta de projeto. 2018. 703 páginas. Tese (Doutorado) Área Projeto de Arquitetura. Faculdade de Arquitetura y Urbanismo. Universidade de São Paulo. São Paulo, 2018.

A tese "More with less" realiza uma indagação propositiva sobre uma nova geração de Equipamentos Coletivos para as periferias da Montevidéu Metropolitana. Nessas regiões a intervenção publica historicamente tem privilegiado ações isoladas de habitação, gerando territórios fragmentados e carentes de espaço público e centralidades. A hipótese, com base em estudos desde as ciências do homem, propõe a reformulação dos equipamentos coletivos desde a complexidade como paradigma e se baseia na desespecialização programática do projeto, visando uma viragem de qualidade na criação de urbanidade nas periferias da Grande Montevidéu. As condições de formulação desses novos equipamentos coletivos implicam: oferta de espaço publico de qualidade, escala significativa, imagem representativa que proponha um aporte estético e cultural, planejamento em rede visando o estabelecimento de relações urbanas ativadoras, concentração sinérgica de atividades e apertura programática para evoluir no tempo segundo a mudança das necessidades sociais e as politicas publicas. Esses equipamentos se constituem em Fórum, no sentido dos antigos romanos: um conjunto de equipamentos e espaços públicos atratores que estruturam e urbanizam. A definição do Fórum é estabelecida em termos abstratos como metaprojeto e é submetida a uma indagação projetual em contexto de laboratórios de ensino e pratica do projeto. $O$ conjunto de projetos imagina, reconhece e expande as possibilidades da hipótese.

Palavras chave: Projeto de arquitetura. Equipamentos. Desespecializaçào programática. Fórum. Periferia. 



\section{ABSTRACT}

OREGGIONI, Luis Enrique. More with less: Ideas for a new generation of Public Equipment in the peripheral areas of metropolitan Montevideo, generators of urbanity and based on programmatic despecialization as a tool of project. 2018. 703 pages Thesis (Doctorate) Project Architecture Area. School of Architecture and Urbanism, University of San Pablo. San Pablo, 2018.

The doctoral dissertation "More with less" carries out a proactive research on a new generation of public equipment for the peripheral areas of metropolitan Montevideo. In these urban zones, public intervention has historically favored isolated housing developments which have produced fragmentary and unqualified public spaces and centralities.

The hypothesis, based on human sciences studies, puts forward a reformulation of collective equipment assuming complexity as a new paradigm and starting from programmatic despecialization, aiming at improving urban conditions in the peripheral areas of metropolitan Montevideo.

The formulation conditions for this new public equipment include: quality public space, significant scale, representative presence introducing aesthetic and cultural contributions, network design, looking forward to create triggering urban relationships, synergic concentration of activities and an open range of programs, in order to evolve in accordance with changes in social needs and political agendas.

This equipment will turn into a forum (as in ancient Roman cities): a group of attracting pieces of equipment and public spaces capable of structuring and urbanizing the land.

The definition of the forum is abstract. It is conceived as a metaproject and is the subject of a design research carried out within design teaching and practice labs.

The set of projects imagines, recognizes and expands the hypothesis potential.

Keywords: Architectural Project. Public equipment, Programmatic despecialization. Forum. Periphery. 



\section{AGRADECIMENTOS}

Ao tutor, Francisco Spadoni por seus comentários que contribuíram decisivamente com a pesquisa.

Joubert Lancha, Helena Ayoub e Eduardo Nardelli pelos comentários nas bancas Mestrado e Doutorado.

Bernardo Martin, Gustavo Scheps, Marcelo Roux

Alina del Castillo, Alfredo Peláez, Andrés Cabrera, Sharon Recalde, a turma uruguaia na Pós-graduação da FAU USP, equipe e convívio.

Malú Refinetti promotora do convenio FAU FADU, e ajuda entranhável. Leninha Ayoub, Rafael Perrone, Cristina

Arguejo, Claudia Stinco, Ruben Otero. Escola da Cidade, Angelo Bucci, Martha Bogéa, Luciana Mello, Juliana Braga, Fernando Viégas, Marta Moreira, Francesco Perrotta-Bosch.

Apoio bolsa Capes e Fadu

Prefeitura de Montevidéu: Silvana Pissano, Patricia Roland, Ramón Mendez, Ana Rivera, Marcelo Bednarik.

Milton Gianoni CEDEL Casavalle, German de Giobbl SACUDE, Agustín Flores (Los olvidados).

Entrevistados: Eduardo Alvarez Pedrosian, Jack Couriel, Herbert Inchusti, Alvaro Trillo, Adriana Rojas, Andrés

Fernández, Gustavo Leal, Julio Llanes, Fernando Cabezudo, Myrna Campoleoni, Roberto Elissalde. Ing. Agrim. Ricardo

Martínez, Daniel Velo, Eduardo Laurito. Daniel Daners, Juan Pablo Labat. Daniel Wainstein, Mario Corrales, Pedro

Barrán, Lucía Lombardi, Daniel Velo, Luis Fulco, Antonio Gervaz, Ricardo Martinez, Eduardo Laurito, Carlos Folco,

Adriana Gorga, Santiago Lenzi, Marcos Lowenstein, Andrea Gnesetti, Alicia Dauría,

Prefeitura de São Paulo: Eduardo Dalcanale Martins, Alexandre Delijaicov, Andrei Takiya.

Paola Carretto

Fernanda Ríos, Javier Díaz, Enrique Martínez, Pablo Bacchetta, Juan Martín MInassian, Andrés Varela.

Verónica Dighiero, Lucía Lombardi, Ignacio de Souza, Elena Roland. Elías Martínez.

Gilles Delalex.

Fadu: Marcelo Danza, Carina Strata, Ximena Villemur

Mvotma: Salvador Schelotto, Raul Vallés.

Projeto Gráfico: Diego Morera, Carolina Gilardi. Produção Gráfica: Mariana Facio.

Rosina Cortegoso (estagio pesquisa). Colaboradores Trinidad Baldomir, Mauricio Wood, Santiago Zunini, Marianela

Barrera, Valentina Juanicó, Patricia Dabezies

Traducao e revisão Portugués: Priscila Molina. Luiz Felipe Lied. Luciana Mello. Inglês María Alicia Correa.

Mariana Echevarría.

Workshop Marconi. Disciplina FAU USP. Prof. Helena Ayoub Silva. Andrés Cabrera Recoba, Alina del Castillo, Alfredo Peláez, Sharon Recalde, Luis Oreggioni. 2013.

Alunos: Carolina Miki Ojima, Chayene Cardoso, Diego Morera, Luis A. K. Jacob, Luiz E. V. Junqueira, Mauricio Wood, Priscila Belézia, Santiago Veas. Lucia Leal, Paula Redondo, Paola Faguaga, Cecilia Zorzon, Glaucia Dalmolin, Leandro Leão, Luis Fernando Meyer, Thiago Lee. Alex Garcia Smith, Mariana Caramella, Júlia Borrelli, Fernanda Panontin Tsuda, Nathalia Lorezzetti, Florencia Paredes, Sara Yarisolian, Diego Miguez. Javier Bechi, Samantha Bosco, Lucia Cabrera Alcorta, Belén García Chagas, Osvaldo Gama Neto, Germán Irazusta de Vargas, Caue Massuda Ortiz Volpe, Henrique Passarello. Corina Bianco, Carlos Parma, Carlos Coronel Gareca. Kim de Paula, Gustavo Wierman, Gustavo Vanini, Alexis Arbelo, Natali Cáceres, Natalia Paredes. Augustina Rodriguez, Belén Garicoits, Bruna Bertuccelli, Camila Sendic, Letícia Bressane. Maria Fernanda Brandi, Mariane Martins, Romina Bizzotto

Disciplina EP Pós-graduação FADU Foros_MVD: Bernardo Martín, Fernanda Ríos. 2018.

Alunos: Martín Suarez, Natalia Fleitas, Federico Bergamino, Christian Flores, Fabiana Castillo, Viviana Lugo, Lauro Vicente, Juan L. Viñar, Mariana Benzo, Anahí Bermúdez, Fernando Errandonea, Valeria Esteves, Pablo Martínez, Federico Rodriguez, Agustina, Sánchez e a participação de Maria Imbert.

PTE Ateliê Scheps: Matias Carballal, Carolina Gilardi, Diego Facio, Elisa Porley, Martina León. Engenheiros Sebastian Dieste, Martín Reina, Fiorella Mondino, Mihdí Caballero, Alejandra Berruti e Francisco Vidovich. 2018. Alunos: Agustin Lagreca, Santiago Licandro, Franco Taglioretti, Mathias Cabrera, Gustavo Maya, Facundo Presa, Florencia Martinez, Daniela Romero, Camila Pistone, Patricia Pistone, Lucia Lin, Juliana Ramirez, Patricia Olivera, Sofía Sabjan, Ines Saldombide, Diego de León, Indara Sena, Jorge Carbonell, Silvina Alpino, Pablo Miranda, Fabrizio Libralesso, Camilo Méndez, Pierina Romero, Vanessa Sacco, Paula García, Silvina Porro, Magdalena Reolón, Federico García, Javier Clérici, Florencia Olmos, Mauricio Tarragona, Sofia Eugui, Lucia Echavarria, Andres Henon, Ismael Laxague, Fabricio Hernandez, Eliana Perlas, Lautaro Bozzolasco, Gabriela Gómez, Eduardo Zapata, Marcos Duarte, José Silva, Alba Alvarez, Florencia Chiva, Natalia Otero, Lucia Rey, Camila Iglesias, Renata Kauke, Guillermina Vassallo, Sofía Devesa, Francisco Núñez Saldanha, Lou Perdreau, Ricardo Gómez, e a participação de Daniela Lopez TFC Ateliê Scheps: Equipe Docente.

Alunos: Ismael Laxague, Fabricio Hernandez, Camila Gil, Elena Petit, Eugenia Cedrani, Valentina Massud, Mara Fleitas, Florencia Guedes, Oscar Deleon, Gustavo Belhot, Camilo Alvarez, Sebastian Camacho, Nicolás Ramos, Martina Leon, Lucía Paez, Stephanie García, María José Milans, Eduardo Salinas, Nadia Ostraujov, Soledad Brito Dardo Bertiz. Horacio Flora, Adriana Barreiro, Emilio Nissivoccia. Juliana Espósito, Colo Rois, Claudio Solari, Marco Antonio Delgadillo Villanueva Equipe Servicio Posgrados y Educación Permanente FADU. Equipe Biblioteca FADU. Beatriz Flora AA library.

À família: Elisa, Bruno e todos. 


\section{VOLUME 1}

RESUMO / ABSTRACT

SUMARIO

p.013_INTRODUÇÃO

p.019_1.ECM EQUIPAMENTOS MONTEVIDEANOS

p.019_1.ECM.1 INTRODUÇÃO

p.021_1.ECM.2 EQUIPAMENTOS MODERNOS

p.024_1.ECM.3 EQUIPAMENTOS COLETIVOS MONTEVIDÉU

EDUCACIONAL

p.037_1.ECM 4. PERIFERIAS

O SISTEMA DOS EQUIPAMENTOS

TERRITORIALIZAÇÃO EXTREMA DA DESIGUALDADE

MUNDO PERIFERIA

p.044_1.ECM.5 EQUIPAMENTOS DE PERIFERIA

p.049_1.ECM.6 EQUIPAMENTOS CASAVALLE

CONSELHO CASAVALLE

PLANO CASAVALLE

DE MUITOS LUGARES É POSSÍVEL VER O CASAVALLE EQUIPAMENTOS CASAVALLE

SACUDE

CENTRO CÍVICO LUISA CUESTA

CEDEL

ABRANGÊNCIA TERRITORIAL

OUTROS EDIFÍCIOS

p.065_1.ECM.7 DESTACAMENTOS

p.069_2.DPL DESESPECIALIZAÇÃO PROGRAMÁTICA

p. 069_2.DPL.1 ESPECIALIZACAO DESESPECIALIZACAO

p.077_2.DPL.2 PROGRAMA FUNÇÃO ESPÁCIO

PARA O PROGRAMA: BASÍLICAS

PARA O PROGRAMA: MOTIVO

NAVES E MALHAS

PROGRAMA DE MODERNIDADE

PROGRAMA CONTEMPORÂNEO

PROGRAMA DESESPECIALIZADO

PROJETO DESESPECIALIZADO

ABSTRAÇÃO

UM FAROL DESESPECIALIZADO

p.121_2.DPL.3 ARQUITETURAS DA DESESPECIALIZAÇÃO

BRANCO NOLLI

METAFORA DESLOCAMENTO INTELETUAL

DESLOCACCOES EM BRANCO

p.131_2.DPL.4 DESLOCAÇÃO 1: RUINAS

O CAPITAL

ELEMENTAR

FASCINAÇÃO ROMANTICA

OBRA

PROGRAMA?

PÓS-INDUSTRIAL

30 VARIACCÕES PÓS-INDUSTRIAIS

PÓS-PRODUÇÃO

RUÍNA MONO-FUNCIONAL

AL HUESO: DEPOIS DO PROGRAMA

TEMPO

p.171_2.DPL.5 DESLOCAÇÃO 2: PRAIAS

PRAIA PAULISTA

EQUIPAMENTO PRAIA

EQUIPAMENTO DESESPECIALIZADO DA CIDADE

PRIMEIRA: PADRÃO E IMPLANTAÇÃO

TERCEIRA: TERRITÓRIO CEU

TERRITÓRIO DO TERRITÓRIO

BRANCO CEU

AS IDEIAS E AS COISAS

PRAIAS DE TODOS, PRAIAS DE CADA UM

p.197_2.DPL.6 DESLOCAÇÃO 3: RUAS

UNIVERSIDADE DE RUA EM LONDRES

ARTEFACTO FUN PALACE

DISCIPLINAS 


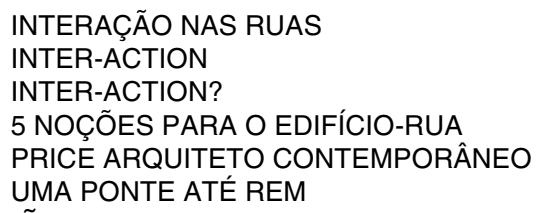

p.355_REFERÊNCIAS

p.131_DISSOLUÇÃO PROGRAMÁTICA E ESPACIAL

p.391_CATÁLOGO

p.392_CATÁLOGO EQUIPAMENTOS UY

p.501_CATÁLOGO EQUIPAMENTOS CASAVALLE

p.551_CATÁLOGO EQUIPAMENTOS MUNDO

p.598_CATÁLOGO CASAVALLE FÓRUM

p.610_FÓRUM CCZ17

p.617_APÊNDICES

p.618_MUNICIPIOS AREA METROPOLITANA DESIGUALDADES

p.646_LEVANTAMENTO SOBRE AS POLÍTICAS PÚBLICAS E OS EQUIPAMENTOS COLETIVOS p.677_ANEXOS

p.679_FÓRUM CCZ 17 PROJETOS CURSO PÓS-GRADUAÇÃO FADU

AQUA 


\section{P01}

\section{CAIF}

Ano: 2018 e anteriores.

Localização: Casavalle, UY.

V02 Pg 393, 502

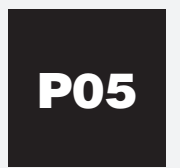

\section{CEA}

Autor: PAEMFE Arq. Andrea Gnesetti Ano: 2017

Localização: Casavalle Montevideo. UY

V02 Pg 409, 510

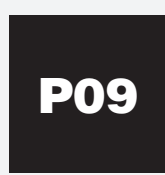

\section{ESCOLA 178}

\section{Autor: sd}

Ano: 1956

Localização: Casavalle, UY

V02 Pg 427, 519

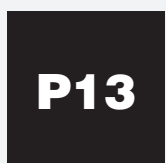

POLICINICA 2/3 consult Autor: ASSE Div. Arquitetura

Ano: 2015

Localização: Varias, UY.

V02 Pg 451

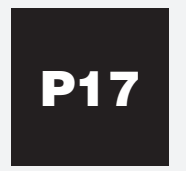

\section{PLAZA N'11}

Autor: Arq. L. Cracco / Secr. Esporte Ano: 2010

Localização: Cerro, UY.

V02 Pg 469

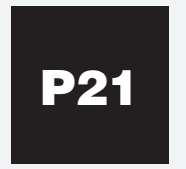

\section{CEDEL}

Autor: IMM Arqs. Morán e Sandoval.

Localização: Casavalle, UY.

V02 Pg 54

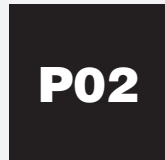

\section{CEC}

Autor: PAEMFE sd

Ano: 2010 e depois

Localização: Casavalle, UY.

V02 Pg 397

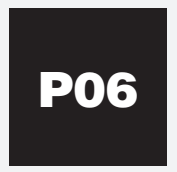

\section{ETC 91A Modular}

Autor: PAEPU. Arq. Pedro Barrán Ano:2017. Projeto

Localização: Projeto Tipo

V02 Pg 413

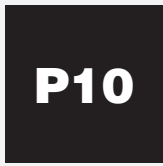

LICEO Ciudad del Plata Autor:PAEMFE - Arq. Bernardo Martin Ano: 2013

Localização: Ciudad del Plata, UY.

V02 Pg 431

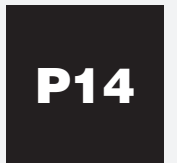

POLICLINICA Casavalle Autor: IM DIv. Saude. Arq. M. Gregorio Ano: 2012

Localização: Casavalle, UY.

V02 Pg 455, 523

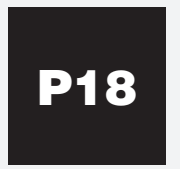

\section{COMISARIA}

Autor: Ministerio Interior. Sd.

Ano: 2013

Localização: Casavalle, UY.

V02 Pg 527

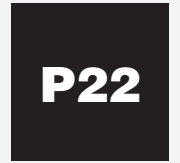

PAC

Autor: AGESIC

Localização: Varias

V02 Pg 474

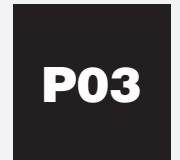

V02

JARDÍM DE INFÂNCIA

Autor: PAEPU - Arq Carlos Sitya

Ano: 2018

Localização: Neptunia, UY.

V02 Pg 401

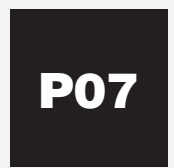

\section{ESCOLA CHINA}

Autor: PAEPU Arq. Lucía Lombardi

Ano: Projeto

Localização: Casavalle, UY.

V02 Pg 514

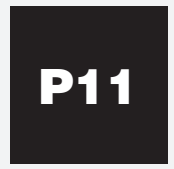

\section{POLO TECNOLOGICO}

Autor: PAEMFE. Projeto Tipo.

Ano: Projeto 2017

Localização: Varias, UY.

V02 Pg 437

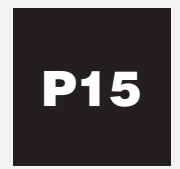

POliclínica C. PLATA Autor: PRIS / ASSE Div. Arquitetura Ano: 1999/2016

Localização: Ciudad del Plata, UY.

V02 Pg 459

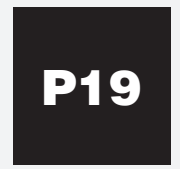

\section{BOMBEROS}

Autor: Dir. Bombeiros. Luis E. Salesi

Ano: 1988

Localização: Casavalle, UY.

V02 Pg 531

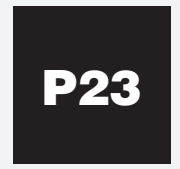

CB PEÑAROL

Autor: Políticas Territoriais OPP

Ano: 2014

Localização: Peñarol, UY.

V02 Pg 478

\section{P04}

\section{ESCOLA 320}

Autor: sd

Localização: Casavalle, UY.

V02 Pg 405, 506

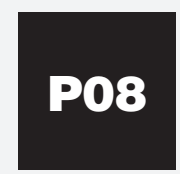

\section{ETC 384}

Autor: PAEPU Pedro Barran

Ano: 2016

Localização: Montevideo, UY.

V02 Pg 422

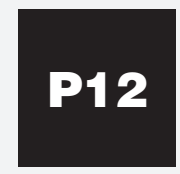

PROTOTIPO EDUCAC.

Autor: PRIS Arq Antonio Gervaz

Ano: 1994

Localização: Várias. Melo, UY.

V02 Pg 446

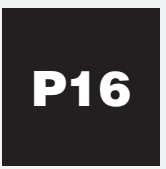

\section{POLIDEPORTIVO}

Autor: CND. Arquitetura

Ano: 2017

Localização: Varias, UY.

V02 Pg 464

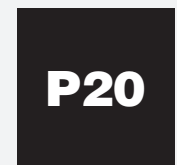

\section{SACUDE}

Autor: Int. Montevideo. PIAI

Ano: 2013

Localização: Casavalle, UY.

V02 Pg 535

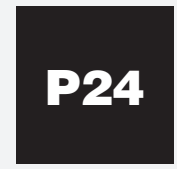

\section{CENTRO Cívico}

Casavalle

Autor: Int. Montevideo. Arq. Juan Díaz Ano: 2014

Localização: Casavalle

V02 Pg 546 

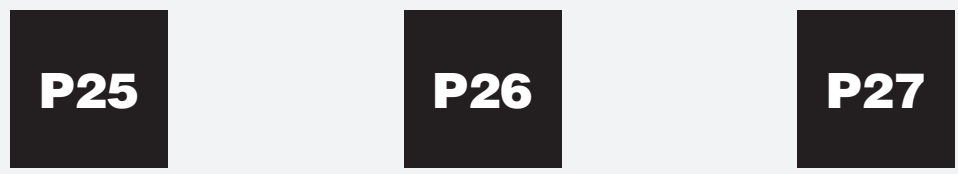

P28

CEU

Autor: Equipo CEU SMDU

Ano: 2013-2016 (não concluido)

Localização: San Pablo, BR.

V02 Pg 552

FUN PALACE

Autor: Cedric Price

Ano: 1960-1966

Localização: Londres, UK

V02 Pg 570

INTERACTION

Autor: Cedric Price

Ano: 1970-1981 2003

Localização: Camden Town, Londres,

UK

V02 Pg 574
STADSTHEATER

Autor: SANAA

Ano: 1998-2007

Localização: Almere, NL

V02 Pg 580

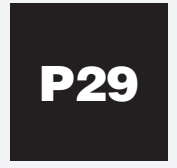

MUSEO SIGLO XX

Autor: SANAA

Ano: 1999-2004

Localização: Kanasawa, JP

V02 Pg 586

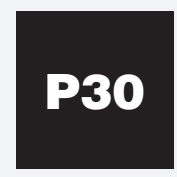

MUSEO DE TOLEDO

Autor: SANAA

Ano: 2001-2006

Localização: Toledo, USA

V02 Pg 592 



\section{MORE WITH LESS}

ESTRUTURA DA TESE

Capítulos

Apendices

Anexos
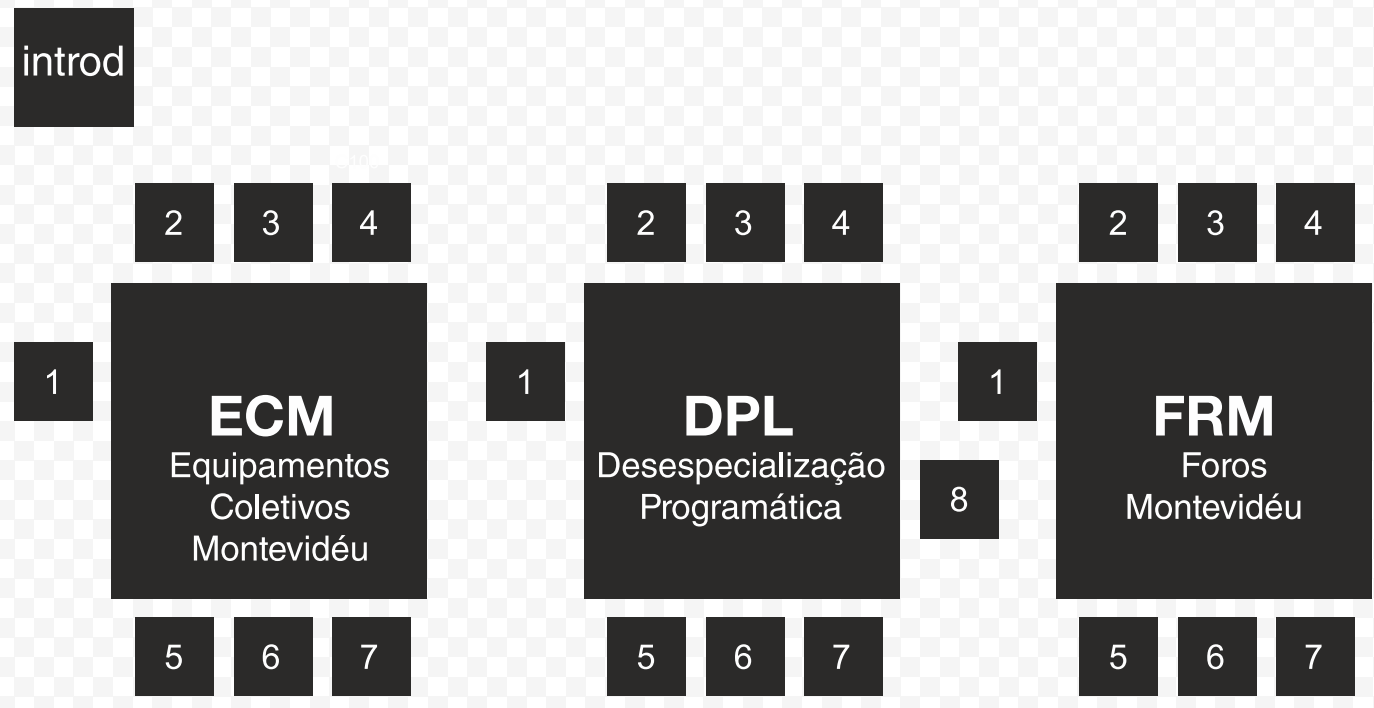
MORE WITH LESS

ESTRUTURA DA TESE 


\section{INTRODUÇÃO}

A tese que se apresenta, imagina uma realidade que não existe. Projeta uma nova condição para os espaços urbanos das regiões mais precárias de uma pequena metrópole do terceiro mundo, e chama para uma lógica de abertura espacial que visa obter um maior proveito do meio construído.

A hipótese da pesquisa propõe a possibilidade de desenvolvimento de uma nova geração de Equipamentos Coletivos para a Montevidéu Metropolitana. Este novo sistema de equipamentos teria a capacidade de produzir uma transformação espacial de qualidade que estimule a sinergia entre os diversos atores públicos e os sujeitos. Essa transformação se originaria em qualidades dos projetos de uma entidade abstrata (que vai ser definida como metaprojeto) que deriva da articulação imbricada de edifício e espaço público, chamada Fórum. O Fórum supõe para esta nova geração de equipamentos maior escala obtida pela concentração colaborativa de instituições e atividades. Qualidade arquitetônica e urbana e proposta estética, porque a mudança quantitativa não é suficiente. O desenvolvimento de projetos (combinado com a leitura de projetos existentes) será o procedimento de indagação, apenas uma demonstração de uma possibilidade.

More with less, o Fórum e a desespecializaçào programática poderiam ser lidos como uma resposta (e de fato eles são) à situação extrema. A desespecializaçào programática é achada no primigênio, estratégia básica de supervivência, que poderia ser abandonada quando a complexidade se acrescentar. Também aparece como uma resposta a situações imprevisíveis, uma ficção cientifica. More with less então poderia ser entendido desde uma logica de eficiência, uma indagação cuja restrição de validade fosse estabelecida pela carência. Muito pelo contrario, não é esse o raciocínio da pesquisa que estabelece relações com a arquitetura disciplina em sentido amplo. $O$ desenvolvimento das noções se impregna de práticas colombianas e brasileiras, mas também britânicas e japonesas, encontrando em todas as situações e momentos referências validas. O domínio de validade da pesquisa, com suas limitações, não é a contingência da escassez, é a arquitetura disciplina. Desespecializaçào programática junto à especificidade do projeto.

More with less opera com deslocações, metáforas vivas que permitem olhar de novo para o cotidiano do projeto: edifícios como espaços públicos, como ruínas, como infraestruturas, como pesquisas. 
More with less convoca Mies e Venturi. Pier Vittorio Aureli resgata a habitação CO-OP de Hannes Meyer, e diz: "menos é suficiente", mais como combinação de eficiência é prazer (AURELI, 2016).

Enquanto sair da arquitetura, o nome da tese convoca significados descartáveis em este contexto acadêmico: "More with less ${ }^{\circledR}$ " a pura eficiência do capitalismo global, os manuais de autoajuda, e o minimalismo banalizado.

Muitas das perguntas sobre as que a tese se debruça, dialogam com uma atmosfera contemporânea que procura trabalhar desde a reflexão crítica e desde a prática do projeto nas relações entre arquitetura, espaço, programa, capacidade, infraestrutura e cidade. Nos seis anos transcorridos desde a primeira formulação como projeto de pesquisa para a aceitação na FAU USP e na CAPES, apareceram vários trabalhos próximos aos da tese que enriqueceram a reflexão, sejam produções teóricas e projetuais como trabalhos acadêmicos. Vários de estes últimos são teses apresentadas em Madri, Montevidéu, Minas Gerais e São Paulo entre outras. A tese é uma conversação com todos eles.

\footnotetext{
A arquitetura se promove como uma disciplina criativa. Na medida em que a criatividade é predicada no novo, na invenção, é diferente da lógica, que é predicada na dedução. Às vezes criatividade e logica se sincronizam, mais frequentemente confrontam. (DE GRAAF, 2018, p.8, tradução nossa)
}

A tese pesquisa sobre projeto, com o modo de fazer projeto, a heurística da arquitetura. Recorre a procedimentos lógicos, a conexão de assuntos de diferente natureza e temporalidade, e também a intuição. A tese se inscreve na construção epistemológica da pesquisa em projeto, mas também numa sensibilidade de nosso tempo:

Si. Un tapiz que se dispara en muchas direcciones.

Después recordé unas antiguas palabras de Tabucchi, unas palabras dichas en una entrevista, dichas en los días en que él comenzaba a ser conocido por su libro "Dama de Porto Pim", modelo de tapiz que se dispara en muchas direcciones: "El conocimiento actual es más fragmentado, más frágil y, por tanto, posiblemente, la narración se adapte mejor a él. Yo he escrito dos novelas, pero son un tanto extrañas porque participan de otros materiales literarios que no son sólo los de la novela. Novelas de muchas historias, como un mosaico como un tapiz. No sería capaz de escribir una novela de carácter tradicional". (VILA MATAS, 2003, p.154) 



\section{MORE WITH LESS}

ESTRUTURA DA TESE

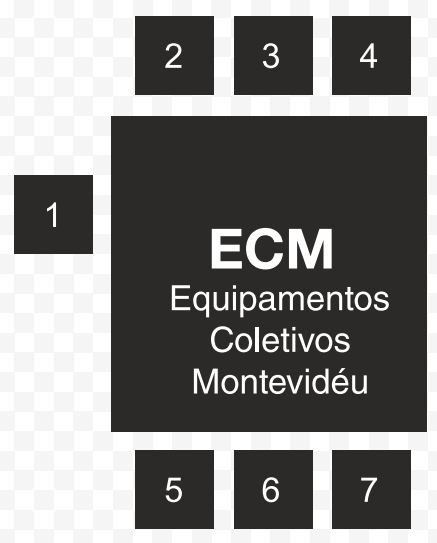


Fig.01. Quadrado preto, Kazimir Malevich, 1915.

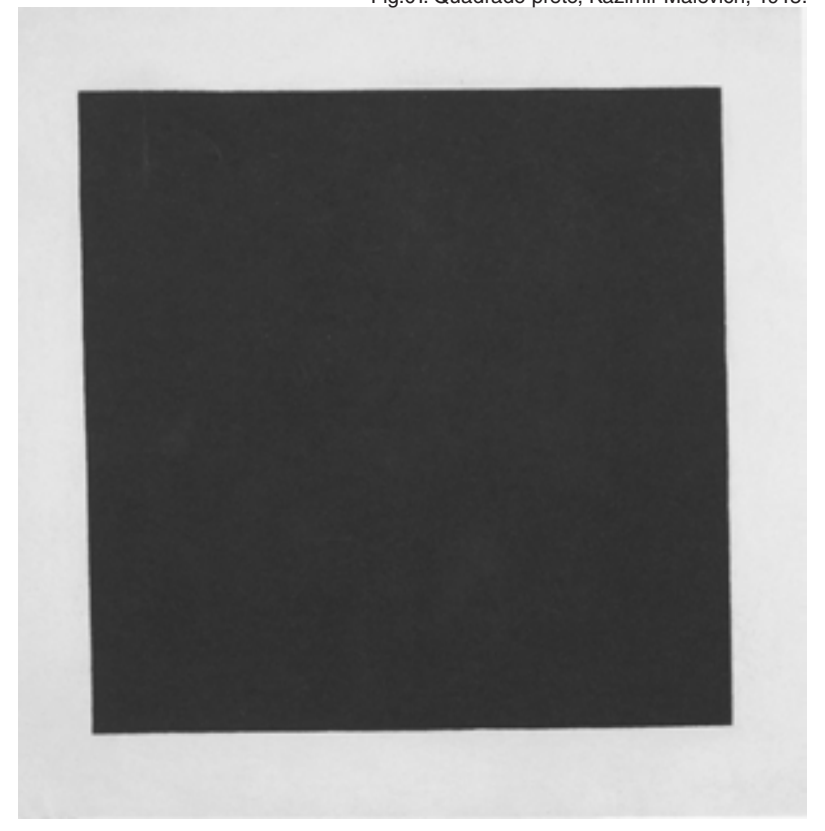




\section{ECM EQUIPAMENTOS MONTEVIDEANOS}

\section{ECM.1 INTRODUÇÃO}

Os equipamentos são, de acordo com as definições mais frequentes, expressões espacializadas das políticas públicas, equipamentos e territórios estão inseparavelmente ligados. Os equipamentos dividem-se a partir da estrutura funcional e institucional do Estado, que surge do seu desenvolvimento histórico moderno até se consolidar no século $X X$.

O dicionário da Real Academia Espanhola confirma uma coincidência que vincula equipamentos a outros dispositivos definindo Equipamento como "o conjunto de todos os serviços necessários em indústrias, urbanizações, exércitos, etc.” (RAE, 2018). Os equipamentos são, de acordo com esta definição, dispositivos, (aqueles que permitem o funcionamento da cidade) da mesma forma que servem o exército ou a indústria. Descobrir dentro das modalidades em que opera, permite reconhecer suas lógicas registradas naquelas do Estado uruguaio, o aparelho que as gera, imersas por sua vez em uma sociedade e cultura concretas.

Esta descrição ganha densidade e complexidade ao identificar equipamentos como dispositivos, lemos a partir da definição proposta por Agamben:

\footnotetext{
Generalizando mais tarde a já muito ampla classe de dispositivos foucaultianos, chamarei literalmente de dispositivo qualquer coisa que tenha, de algum modo, a capacidade de capturar, guiar, determinar, interceptar, modelar, controlar e garantir os gestos, comportamentos, opiniões e discursos da seres vivos. Portanto, não apenas as prisões, manicômios, o panóptico, as escolas, a confissão, as fábricas, as disciplinas, as medidas legais, etc., cuja conexão com o poder está, de certa forma, evidente, mas também a caneta, a escrita, a literatura, a filosofia, a agricultura, o cigarro, a navegação, os computadores, os celulares e - por que não - a linguagem em si, que é talvez o mais antigo dos dispositivos, em que milhares e milhares de anos um primata - provavelmente sem perceber as consequências que se seguiriam - teve a inconsciência de se deixar capturar. (AGAMBEN, 2011, p.257)
} 


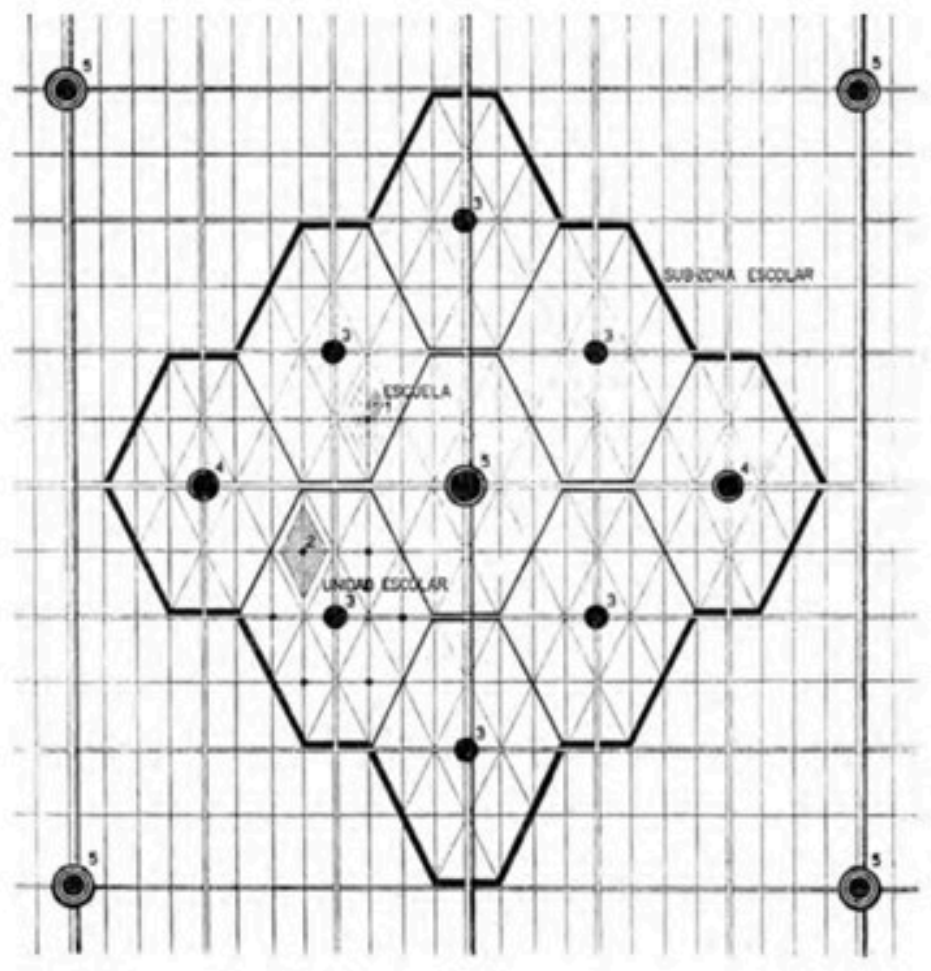

Fig.2. Localização de equipamento integral, ITU FADU, 1963.
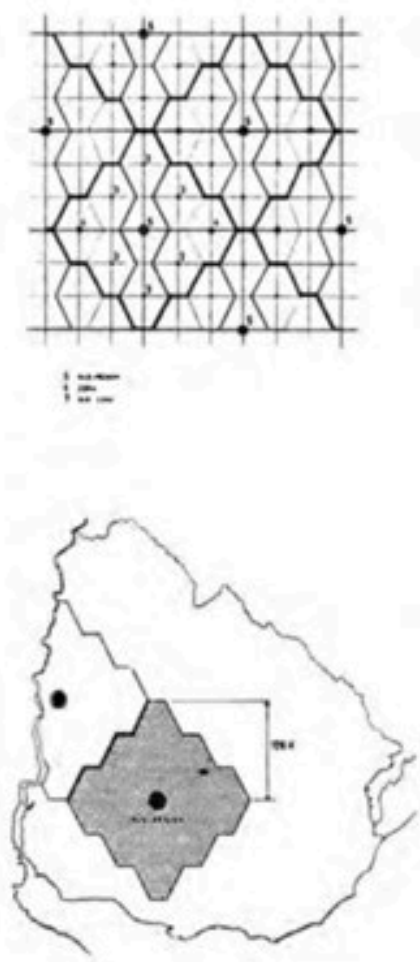


\section{ECM.2 EQUIPAMENTOS MODERNOS}

O planejamento dos Equipamentos necessariamente envolve o quantitativo e o qualitativo. A visão positivista que inunda o planejamento no século XX salienta os aspetos quantitativos sustentando visões qualitativas de compromisso social.

A "Carta de Atenas" de 1933 propõe os equipamentos como parte central da cidade moderna e crítica sua má condição na cidade no começo dos anos 30 , visando uma consideração global e sistemática:

\footnotetext{
O beneficio dessas instituições coletivas é evidente, mas sua necessidade ainda é mal compreendida pela massa. Sua realização foi apenas esboçada da maneira mais fragmentar e desvinculada das necessidades gerais da habitação (CIAM, 1993, p.56)
}

A teoria urbanística moderna local, sob a influencia da Carta de Atenas procura uma visão sistemática e totalizadora da ação no território e teve uma fortíssima presença na formação dos arquitetos da Faculdade de Arquitetura da Universidade da República, especialmente a partir da produção e presença de Gomez Gavazzo que começa nos anos 50 a direção do Instituto de Teoria e Urbanismo da Faculdade, e dirige também um ateliê de projetos. Em 1932 Gomez, recém formado obtém uma bolsa de viagem que aproveita para trabalhar por vários meses no escritório de Le Corbusier em Paris. Toda sua produção reflete uma profunda reflexão baseada na teoria dos CIAM. Gomez produz planejamentos e manuscritos, tendo forte influência na redação do Plano Diretor de Montevidéu de 1959 de inspiração moderna. A "Arquitetura das comunidades" livro publicado em 1964 estabelece uma visão global do território, que deve ser compreendido e planejado a partir de estudos quantitativos e inspiração humanista. Sua intenção científica para agir com a complexidade do território o leva a produzir um conjunto de ferramentas teórico-conceptuais como a "Equação do desenvolvimento", sempre incluindo uma simultaneidade de variáveis na consideração do território. A publicação "Planificación Escolar" (ITU, 1963) coleta um relatório para as autoridades da educação na qual sistematiza os critérios para o enclave dos edifícios escolares atendendo a estrutura do território e a distância/tempo e outras teorias e métodos de cálculo para a otimização dos equipamentos.

Quinze anos mais novo, Justino Serralta faz um percurso similar ao de Gomez, trabalhando com Le Corbusier durante três anos, intervindo na década de 40 no projeto da "Unité d’Habitation" de Marseille e desenvolvendo trabalhos teórico-matemáticos como contribuição para o "Modulor 2". Ele também trabalha no ITU sob a direção de 
Es una herramienta que posibilita aislar las "cosas"

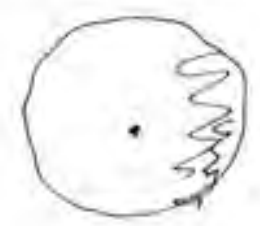

y hace imposible la consideración aislada de las "cosas"

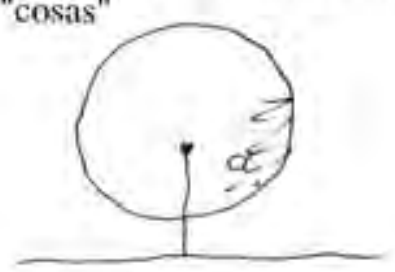

Entre el Orden y el Desorden: EI UNITOR

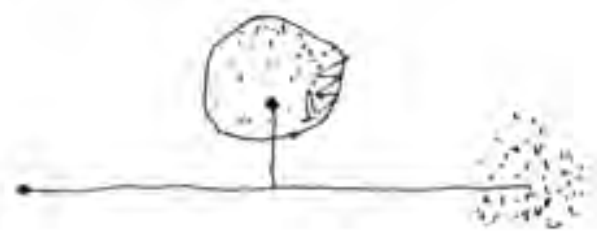


Gomez e dirige a partir de 1960 um ateliê de projetos. Serralta desenvolve uma produção sobre o território e o projeto de inspiração corbusiana que contribui com o entendimento moderno do território, embora tenha raiz mais abstrata que a de Gomez Gavazzo: seu "Unitor" e particularmente seu "Programator" são instrumentos para pensar um sistema global, as partes que o constituem, e agir com as escalas dos equipamentos no território.

Aquele admirável e quimérico entusiasmo do pensamento moderno, hoje é superado por visões de complexidade que reconhecem a impossibilidade de um planejamento que se propõe em vão programar cada milímetro quadrado do território, e entender cada necessidade de cada indivíduo.

A partir de uma versão mais pragmática e em contemporaneidade com aquelas produções acadêmico teóricas, muitos arquitetos fazem arquitetura moderna pública de alta qualidade, como é o caso da produção da arquitetura educativa no Ministério de Obras Públicas (MTOP) dos anos 50 a 70, onde um grupo de arquitetos projetistas fez uma sistematização dos programas de arquitetura e opções pela clareza e a generosidade espacial, partindo de um repertorio moderno fez arquiteturas de excelente qualidade, permanência e reconhecimento da população (IHA, 2015). 


\section{ECM.3 EQUIPAMENTOS COLETIVOS MONTEVIDÉU}

O planejamento dos equipamentos hoje, 55 anos depois da publicação do trabalho do ITU e Gomez Gavazzo sobre planejamento escolar, não seguiu as lições modernas (provavelmente isso não fosse possível), nunca atingindo uma consideração sistemática como a pretendida pelos mestres. Aqueles dispositivos de pensamento e projeto territorial desenvolvidos na academia são recordados nebulosamente com nostalgia enquanto os critérios de enclave de equipamentos respondem mais às demandas concretas da comunidade, a intuições, ou a impulsos isolados, que a uma reflexão sistemática e transversal, isto é territorial. As entrevistas realizadas com um conjunto de profissionais e acadêmicos que trabalham com os equipamentos públicos "Montevidéu levantamento de opiniões qualificadas sobre as políticas públicas e os equipamentos coletivos gerados a partir dos anos 90"1, chamam a atenção sobre uma dupla carência na consideração territorial dos equipamentos: de um lado as decisões especializadas de cada instituição não sempre são sistemáticas, do outro (e mais claramente) falta coordenação horizontal entre instituições.

A distribuição dos diversos equipamentos no território segue critérios díspares e não há (salvo algumas exceções) políticas específicas que vinculem de maneira sistemática as demandas com suas materialização. Os mecanismos de consideração transversal das práticas institucionais ficam restritos (quando possível) ao âmbito estadual, municipal e (sobretudo) local.

Nos últimos anos foram feitos alguns esforços para sistematizar experiências e atender centralmente as políticas públicas, particularmente a partir de esforços da Secretaria de Planejamento e Orçamento da Presidência da República (OPP).

O desenvolvimento dos Sistemas de Informação Geográfica públicos (iniciado pela prefeitura de Montevidéu há muitos anos, e hoje estendido a boa parte do Estado) deixa visível a forma que os equipamentos se implantam no território permitindo um entendimento mais complexo e sobretudo articulado destas ações.

Existe a percepção (LABAT, 2018) ${ }^{2}$ de que o volume de informação disponível é muito maior do que a capacidade para transforma-lo em práticas efetivas, e ao mesmo tempo

\footnotetext{
${ }^{1}$ Apéndice $\mathrm{C}$

2 Palestra ministrada por Juan Pablo Labat (Director Nacional de Evaluación y Monitoreo MIDES) realizada como parte da Disciplina de Pós-graduação e Educação Permanente Foro_MVD_MWL o 5 de abril de 2018. FADU UDELAR.
} 
que também, é preciso produzir novas informações para dar conta de processos sociais e territoriais recentes que se aprofundarão mais adiante no texto.

As definições quanto à localização de equipamentos conjugam relações desestruturadas e assistemáticas em uma série de parâmetros: a resposta às necessidades, as reclamações da sociedade civil, os interesses políticos (e às vezes partidários), a disponibilidade de solo (fator regularmente decisivo) e as lógicas e organizações das instituições. Os diferentes equipamentos são pensados e implementados em instituições de nível nacional e estadual a partir de uma forte compartimentalização funcional, que resulta em práticas unidimensionais e monotemáticas.

A teoria urbanística moderna de Gomez Gavazzo tem (até os anos 80) uma forte presença na formação dos arquitetos da Faculdade de Arquitetura da Universidade da República, muitos deles atuando hoje em diferentes organismos. Aquelas ideias são lembradas nebulosamente com nostalgia, enquanto o pragmatismo, e o entusiasmo (ou sua carência) produzem melhores ou piores edifícios institucionais.

Nos últimos 13 anos com a superação da crise de 2002 e uma mudança de governo em 2005, se incrementou o orçamento para as políticas públicas de prioridade social traindo uma diversificação no perfil das políticas públicas que atendem à diversificação da agenda social, um crescimento dos equipamentos públicos, a construção de novos edifícios.

A partir de 2005 com a criação do Ministério de Desenvolvimento Social (MIDES), se multiplicou o universo das políticas sociais destinadas aos habitantes da cidade dos pobres. Uma infinidade de programas específicos atendendo a problemas específicos, vão na direção do reconhecimento de diversidades e operar com elas no território. Passa-se de um paradigma de igualdade social e econômica a um mais complexo que alcança além das dimensões territorial, étnico-racial, intergerações e de gênero.

Uma ação pública de definições estratégicas e ações táticas dispersas. A preocupação em responder à diversidade superando o paradigma universalista poderia não estar produzindo conjunção e eventualmente fortalecer a fragmentação. A sistematização dessa diversidade é apresentada num Guia de Recursos Sociais, com versão papel e web incluindo um SIG (MIDES e DINEM, 2016) e no website do Ministério (MIDES, 2018). Os Recursos Sociais são, entendidos assim: 
garantir o exercício de direitos. São dispositivos geridos por órgãos públicos de alcance nacional, que oferecem prestações às que a população pode acessar diretamente seja por postulação ou por derivação institucional.

Trata-se de um conjunto de 312 recursos públicos, oferecidos por 23 instituições públicas nacionais. MIDES e DINEM 2016, p.3, tradução nossa)

A mudança de paradigma traz com ela uma dispersão das políticas e dos locais de atuação, que devolve uma fragmentação pelo geral incompreensível para os cidadãos mais carentes.

\section{EDUCACIONAL}

Observemos um subconjunto de recursos, os educativos. Com sua maior tradição e extensão, também diversifica a sua oferta e perfil, em muitos casos saindo fora do local escolar para ir para a casas dos alunos e a suas famílias. Existe um processo de migração de modelo educacional, abandonando o paradigma que construíra o Uruguai integrado da primeira metade do Século $X X$, em que a educação é a preparação para se formar na Universidade Pública (UDELAR que mantém seu ingresso sem restrições, e continua sendo a única Universidade).

As próprias instituições se multiplicam procurando combater os pontos de fuga do sistema. Por outro lado a produção de projetos públicos também está fragmentada: Todos os projetos educacionais dependem da Direção Setorial de Infraestrutura que depende diretamente das autoridades da Educação e estabelece alinhamentos gerais para novos edifícios mais também intervém no conjunto de prédios já construídos. $A$ divisão de Projeto que faz alguns dos projetos depende dela. Também dependem dela duas instituições designadas Projetos Operativos autônomos: PAEPU (Projeto de apoio a Escola Pública) e PAEMFE (Projeto de Apoio ao Ensino Médio e a Formação em Educação) são os escritórios de arquitetura encarregados do projeto de edifícios novos ou ampliações. A CND ("Corporação Nacional para o Desenvolvimento") faz projeto de alguns equipamentos escolares e é responsável pela gestão das licitações e supervisão das obras. Os últimos três funcionam sob diretivas públicas mas no âmbito do direito privado, as duas primeiras se mantendo com orçamento internacional. Os centros CAIF, (Centros de Atendimento Integral a Infância e a Família) são projetados em outro escritório público pois eles dependem do INAU (Instituto da Criança e o Adolescente do Uruguai). Cada uma dessas repartições encarregada de projetos tem seus próprios critérios e competências, ganhando em descentralização e dificultando a coordenação. Semelhante dispersão dificulta a coordenação territorial, espacial, técnica, e a obtenção 
de economias de escala, produzindo uma grande diversidade de resultados, quando observados segundo diferentes critérios: localização, ação em rede no território, qualidade espacial, estética e material, etc.

A complexidade dos problemas educacionais, particularmente em "contexto crítico" leva à multiplicação de instrumentos educacionais para o aprimoramento dos frágeis vínculos que os estudantes mantém com a instituição educativa. Esses instrumentos se dirigem a populações genéricas ou a setores específicos, acontecem dentro dos prédios educacionais e também em outros locais da cidade.

O plano CAIF, Centros de Atendimento a Infância e a Família criado há 30 anos se encarrega da atenção da primeira infância de 0 a 3 anos, gerando uma institucionalização muito precoce, mas necessária para pais e mães trabalhadores, garantindo locais de contenção e estimulação.

Nos últimos anos se desenvolvem novas instituições de ensino médio técnico umas que procuram a sinergia com a escola primaria, um local carente, mas de maior visibilidade, reconhecimento e concorrência: os CEA (Centro Educacional Associado) que são construídos junto a escolas primarias; e a multiplicação da oferta de formação técnica com os CEC (Centro Educacional Comunitário)

No ponto de vista da pesquisa e partindo da necessidade de qualificação sinérgica de presença pública em territórios frágeis, parece necessária uma arquitetura produzida em contextos muito mais articulados para substituir a dispersão que surge da resolução independente da particularidade de cada recurso social e a sua geração em âmbitos de projeto isolados.

Em sentido contrário ao da dispersão da reflexão e da produção de arquitetura pública, existem algumas experiências que escolhem a criação de uma massa crítica especificamente arquitetônica e urbana como opção pela sistemicidade.

Muito atrás no tempo aparece a experiência já referida do Escritório de Projetos no MTOP nos anos 50 e 60, que também tem antecedentes mais antigos.

Num contexto diferente, nos anos 90, a experiência do Programa de Investimento Social, PRIS concentrou numa equipe coordenadora multidisciplinar para a definição de estratégias centrais vinculadas ao programa, terreno, projeto, obra, e gestão de equipamentos novos: Centros de Saúde, Policlínicas, Lares De Terceira Idade, Liceus, Escolas, Jardins de Infância e Creches, Residenciais Estudantis, Centros de Bairro e 
Refeitórios (PRIS, 1993). Essa equipe elaborou estratégias de fazer projetos padrão capazes de se adaptar a situações urbanas e de terreno diversos ${ }^{3}$. Visando também a sinergia da intervenção com o aproveitamento de terrenos públicos de grandes dimensões foram feitos alguns conjuntos de jardim de infância, escola (pré-escola mais 6 anos de escola primária) e liceu (ensino médio obrigatório de 6 anos), procurando combinar a racionalização com a construção tradicional (FULCO, 1996). O caso é a demonstração das limitações da departamentalização isolada, em especial a oportunidade de uma intervenção de alto impacto urbano só pode ser lida quando as decisões estão relacionadas.

Outra experiência que em termos de sistemicidade foi interessante é a da PAEPU que se encarrega de um projeto pedagógico e técnico em relação a Escola Pública por meio de um instrumento, a Escola de Tempo Completo (ETC) criado a partir da segunda metade dos anos 90 (CARDOZO, 2017). A equipe de projeto e obra se encarrega de vários equipamentos educacionais, mas sua responsabilidade central é o projeto das ETC. Esse programa foi avaliado e sistematizado em termos de implantação, escala, e programação. O resultado do projeto fica aberto para o arquiteto responsável de projeto (OROZCO, BARRAN et al., 2011).

Uma discussão especificamente arquitetônica e de contexto histórico explica parte da dispersão, na atual negação nos principais âmbitos de projeto para a procura de projetos sistematizados, abertos e de pensamento de espaços capazes. A experiência de sistematização já referenciada no PRIS foi a ultima inspiração sistemática, em que se hibridam duas tradições disciplinares: a arquitetura sistêmica dos anos 70 e a pósmoderna do fins dos anos 80, com um resultado de edifícios de linguagem pósmoderna. Nos anos 90 se instala uma visão crítica sobre esses resultados, avaliando-os num ponto de vista influenciado pelo regionalismo crítico que enfatiza em que cada projeto deve ser único e dar resposta específica a uma situação urbana.

\footnotetext{
${ }^{3}$ Fica aberta uma linha de trabalho de sistematização da experiência PRIS
} 


\section{O SISTEMA DOS EQUIPAMENTOS}

Com independência da discussão e momentos da disciplina fica claro que a multiplicação de programas diversos num contexto de crescente mudança social e cultural, pede uma arquitetura atenta às demandas, mas também consciente da temporalidade cada vez mais curta dos programas. Um projeto aberto poderia sediar essas diferenças temporais e manter sua presença, qualidade e visibilidade, ao mesmo tempo aprimorando os resultados, soluções tecnológicas, e sobretudo produzindo uma massa crítica na presença pública no território indo contra a dispersão que a torna menos visível. Dois projetos contemporâneos indagam e prefiguram a possibilidade do projeto aberto e ao mesmo tempo especifico, discussão que vai ser desenvolvida no segundo e terceiro capitulo, Desespecialização programática DPL e Forum Montevidéu FRM. O projeto recentemente desenvolvido na Argentina no Ministério de Educação que propõe um sistema de projetos de edifícios educacionais de diferentes programas, e o projeto "Naves Nodrizas" desenvolvido na DIRSEC em Montevidéu (ANEP, 2013) como metaprojeto para a exploração das possibilidades do uso sistemático de pré-fabricados de concretos em edifícios educacionais.

A principal conclusão que se tira logo depois de se fazer uma visualização da grande quantidade de políticas públicas autistas na cidade, é a necessária consideração dos equipamentos como um sistema integrado e em diálogo. Uma versão a partir da institucionalidade para o território é necessária (acima para abaixo) mais também os atores locais podem influir para fazer funcionar o conjunto de equipamentos como um sistema no plano local. Trata-se de um problema político que decididamente tem a ver com os arquitetos e suas práticas que não são neutras.

A consideração dos equipamentos como sistema é uma parte do interesse do livro "Los Equipamientos del Poder. Ciudades, territorios y equipamientos colectivos." 4 de Fourquet e Murard (1978), uma pesquisa pós-maio francês de inspiração marxista, que procura vincular a noção de "equipamento" (de tradição francesa, e utilizada com ênfases diferentes) como convergência do poder, território e produção. É a partir deste ponto de partida que eles constroem o conceito de que cada equipamento é uma serie

\footnotetext{
${ }^{4}$ A pesquisa que se publica no livro, foi desenvolvida no CERFI (Centro de Estudos, Pesquisa e Formação Institucionais) dirigido por Félix Guattari. Durante a investigação foram realizados alguns intercâmbios documentados no livro com um grupo de pesquisadores vinculados a essa instituição, entre eles Michel Foucault, Gilles Deleuze e Felix Guattari.
} 
DISSOLUÇÃo PROGRAMATICA E ESPACIAL

PROGRAMAS

MARGENS DE ÁREAS PARA DISSOLUÇÃO
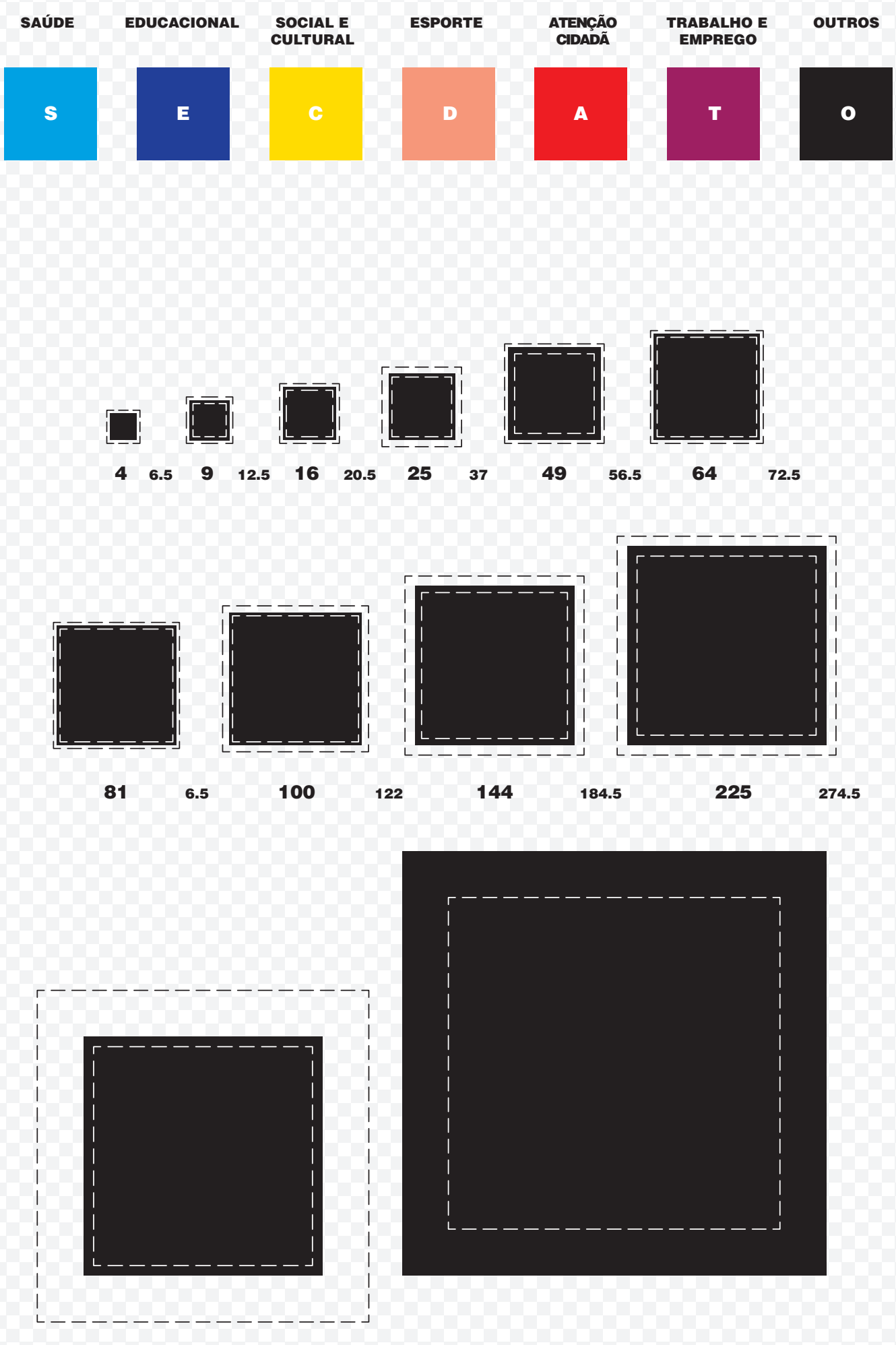
descontínua e variável na historia, insistindo na necessidade de entender os equipamentos coletivos como um sistema.

Partindo da arquitetura e do intuito desta tese, é possível se apropriar desta ideia:

Sem uma política estatal de equipamentos coletivos, não há equipamentos coletivos: há hospitais, escolas, rodovias, etc. (Ibid. p.125, tradução nossa).

\section{CATÁlOGO EQUIPAMENTOS UY}

Um grande conjunto de equipamentos são projetados e construídos pelas políticas públicas. A partir da preocupação pela fragmentação do pensamento arquitetônico sobre o sistema de equipamentos, se propõe a realização de um Catálogo de Equipamentos que simplesmente coloca juntos projetos e espaços, retirando-os do contexto institucional, social e territorial que os cria. O conjunto é incompleto e sua validade não reside na extensão senão na qualidade de análise proposta. O catálogo é feito a partir de um levantamento físico dos equipamentos (prédios e projetos a serem construídos), uma classificação por perfil e uma tipificação dos seus espaços.

Se realiza uma classificação programática dos equipamentos, baseada no Guia de Recursos do MIDES e adaptada para aqueles recursos que precisam ser colocados em prédios. Essa classificação os separa em Saúde, Educação, Social e Cultural, Esporte, Atenção Cidadã, Trabalho e Emprego, e Outros. A taxonomia também e contingente e provisional, não é entendida como ferramenta universal, embora a metodologia escolhida pode ser reformulada em outros contextos.

Todos os espaços dos edifícios são padronizados de maneira abstrata, a partir de sua superfície e margens intermediárias: 4, 9, 16, 25, 49, 64, 81, 100, 144, 225, 324, 1024 metros quadrados.

Um primeiro passo depois da arquitetura é passar para o diagrama e fazer uma classificação dos espaços de um equipamento de acordo a seu perfil programático e sua condição dimensional, processo que chamamos de Dissolução Programática, retirando muitas condições e ficando só com a metragem de cada local e sua designação programática.

Um segundo passo, que chamamos de Dissolução Espacial, retira o perfil programático assumindo que as qualidades do espaço mais básicas, são intercambiáveis para o uso em outras situações por outros programas. Neste momento é retirada a condição do 
programa para ficar com um repertório de "espaços capazes", só o volume de ar contido em cada um.

O propósito de fazer a desespecialização programática é de primeiro reconhecer o perfil de "uso" para logo tira-lo e ficar só com o espaço e sua capacidade. O ponto de partida para estudar edifícios e entender primeiro a arquitetura e a sua configuração espacial, para logo fazer uma desespecialização programática e espacial. A ferramenta para a dissolução é uma taxonomia espacial que permite identificar qualidades homogêneas em espaços.

Ao descontextualizar a demanda espacial, pretende-se evitar a disjunção intelectual que fabrica o específico e operar gerando uma nova contextualização, em que a demanda seja formulada em termos especificamente arquitetônicos. Ela pode servir para entender um edifício existente ou como mecanismo para um novo projeto.

A operação de "Dissolução" é definida pela analogia à "Dissolução Geométrica" dos Sistemas de Informação Geográfica que se entende como "um processo de união de dois ou mais polígonos mediante a eliminação dos lados comuns. A dissolução normalmente se realiza para generalizar informação sobre a temática, unindo os polígonos vizinhos que compartem valores iguais que algum de seus atributos". No nosso caso, a dissolução supõe a eliminação das diferenças entre dois espaços com grande similaridade enquanto que estes compartem atributos espaciais. Um segundo procedimento levará a realização de uma "Dissolução Espacial" que suprime a atribuição programática espacial. Isso permite gerar uma descrição espacial e topológica que habilita a identificação de qualidades homogêneas em espaços formulados desde cenários de especialidade programática. Ao descontextualizar a demanda espacial, pretende-se evitar a disjunção intelectual que fabrica o específico e operar gerando uma nova contextualização, em que a demanda seja formulada em termos especificamente arquitetônicos. Busca-se regularidades e singularidades, que permitam articular espaços "capazes", espaços formulados para suportar a alocação de múltiplas atividades, variáveis e diversas.

O Catálogo de Equipamentos UY se encerra com dois resumos. O primeiro oferece a tipificação dos espaços segundo e a sua dimensão é colocada em comum. Desta maneira se obtém a incidência dos tipos de espaço por programas, evidenciando a possibilidade de intercambiar usos entre espaços do mesmo tipo. O segundo apresenta a incidência dos distintos tamanhos dos espaços no conjunto, e ele pode ser 
entendido como um resumo de proporções do conjunto dos programas, assim temos: 4 metros quadrados (0,41\%), 9 (2,75\%), 16 (5,66\%), 25 (8,84), 49 (25,55\%), 64 (7,15\%), $81(3,9 \%), 100$ (1,85\%), 144 (6,8\%), 225 (12,55\%), 324 (15\%), 1024 (9,5\%). Este resumo pode ser um começo de um trabalho sobre um equipamento genérico que foi tirado o programa.

O processo remete quase literalmente ao paradigma da complexidade proposto por Edgar Morin: distinção e conjunção (MORIN,2007), e baseia-se nos aforismos do cientista Jorge Wagensberg: "Classificar é comprimir", "Comprimir é compreender". (WAGENSBERG, 2004, p.67, tradução nossa) 

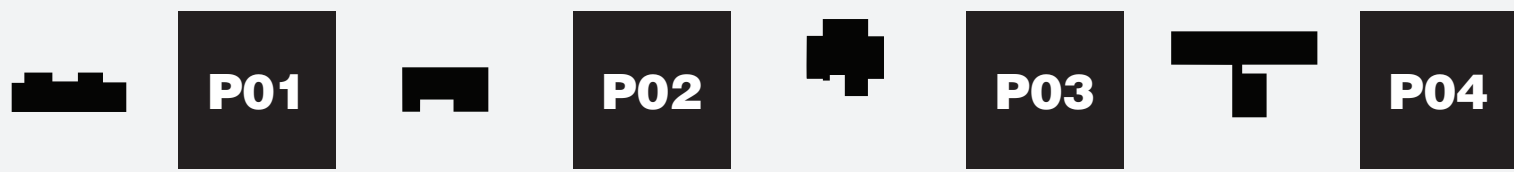

\section{JARDÍM DE INFÂNCIA} Autor: PAEPU - Arq. Carlos Sitya Ano: 2018

Localização: Neptunia, UY.

Ano: 2010 e depois

Localização: Casavalle, UY.

Ano: 2018 e anteriores.

Localização: Casavalle, UY.

V02 Pg 393
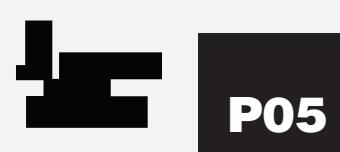

\section{CEA}

Autor: PAEMFE Arq. Andrea Gnesetti Ano: 2017

Localização: Casavalle, Montevideo. UY

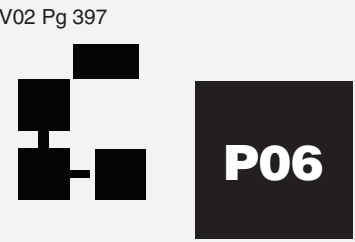

\section{ETC 91A Modular}

Autor: PAEPU. Arq. Pedro Barrán

Ano:2017. Projeto

Localização: Projeto Tipo

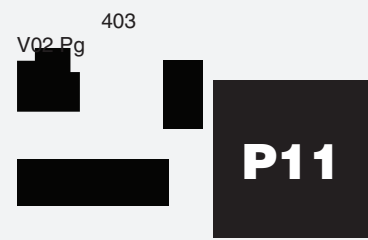

POLO TECNOLOGICO

Autor: PAEMFE. Projeto Tipo.

Ano: Projeto 2017

Localização: Varias, UY.

V02 Pg 437
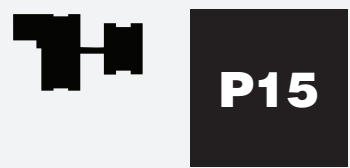

POLIClínica C. PLATA

Autor: PRIS / ASSE Div. Arquitetura Ano: 1999/2016

Localização: Ciudad del Plata, UY. Ano: 2012

Localização: Casavalle, UY.

V02 Pg 455

V02 Pg 459

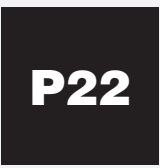

\section{PAC}

Autor: AGESIC

Ano: 2007/ 2013-hoje

Localização: Varias

V02 Pg 474
V02 Pg 401
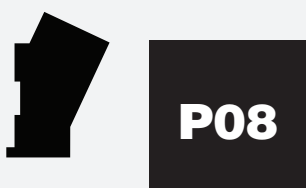

\section{ETC 384}

Ano: 2016

Localização: Montevideo, UY.

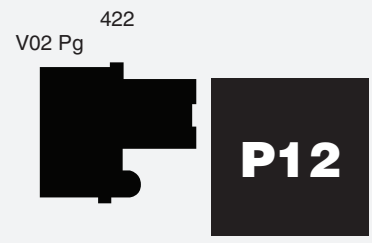

PROTOTIPO EDUCAC.

Autor: PRIS Arq. Antonio Gervaz

Ano: 1994

Localização: Várias. Melo, UY.

V02 Pg 446

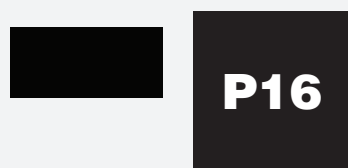

POLIDEPORTIVO

Autor: CND. Arquitetura

Ano: 2017

Localização: Varias, UY

V02 Pg 464
Autor: Pedro Barran

\section{ESCOLA 320}

Autor: sd

Ano: sd

Localização: Casavalle, UY.

V02 Pg 405

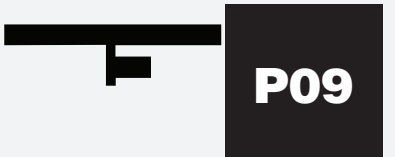

ESCOLA 178

Autor: sd

Localização: Casavalle, UY

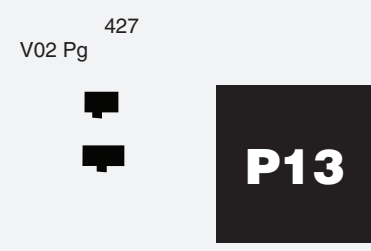

POLICINICA 2/3 consult Autor: ASSE Div. Arquitetura Ano: 2015

Localização: Varias, UY.

V02 Pg 451

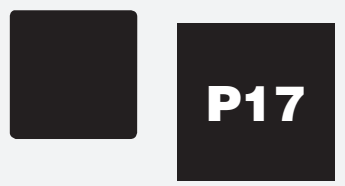

\section{PLAZA N¹1}

Autor: Arq. L. Cracco / Secr. Esporte Ano: 2010

Localização: Cerro, UY.

V02 Pg 469

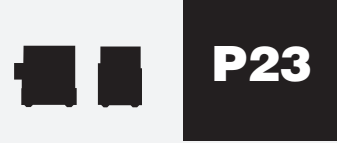

\section{CB PEÑAROL}

Autor: Políticas Territoriais OPP

Ano: 2014

Localização: Peñarol, UY.

V02 Pg 478 


\section{ÁREAS}

Margem de áreas

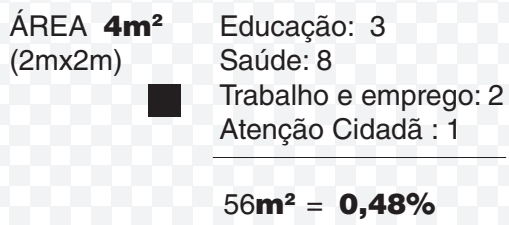

Trabalho e emprego: 2 Atenção Cidadã : 1

$56 m^{2}=0,48 \%$

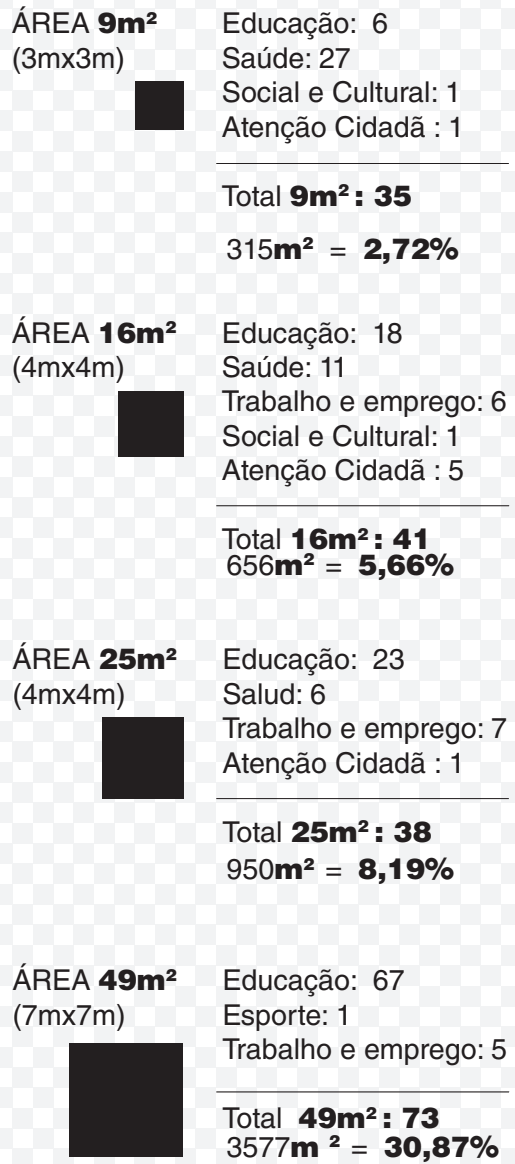

)

Salud: 6

Trabalho e emprego: 7

Atenção Cidadã : 1

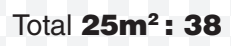

$950 \mathbf{m}^{2}=\mathbf{8}, \mathbf{1 9} \%$

Educação: 67

Esporte: 1

Trabalho e emprego: 5

Total $\mathbf{4 9 m ^ { 2 }}: \mathbf{7 3}$

$3577 \mathrm{~m}^{2}=\mathbf{3 0 , 8 7 \%}$

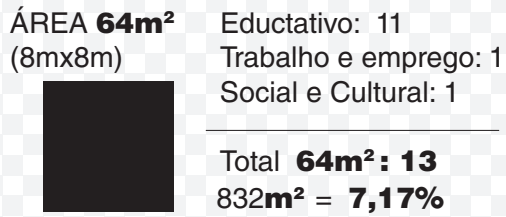

ÁREA $\mathbf{8 1} \mathbf{m}^{2}$ Eductativo: 4 $(9 \mathrm{~m} \times 9 \mathrm{~m})$

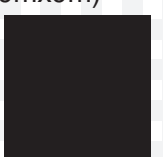

\section{Esporte: 1}

Trabalho e emprego: 1

Total $81 \mathrm{~m}^{2}$ : 6

$504 m^{2}=4,25 \%$
ÁREA 100m $\mathbf{m}^{2}$ Esporte: 1

$(10 \mathrm{~m} \times 10 \mathrm{~m})$

Social e Cultural: 1

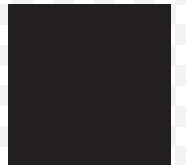

Total $100 \mathrm{~m}^{2}$ : 2

$200 \mathbf{m}^{2}=1,74 \%$

ÁREA 144m² Educação: 3

$(12 \mathrm{~m} \times 12 \mathrm{~m})$

Social y Cultural: 2

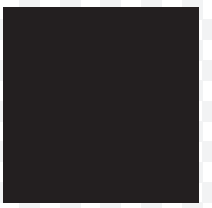

Total $144 \mathrm{~m}^{2}$ : 5 $720 m^{2}=6,8 \%$

ÁREA 225m² Educação: 3 (15mx15m) Saúde: 1

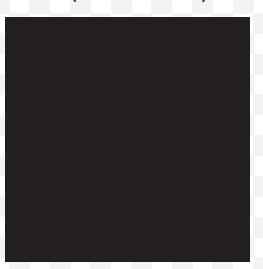

Esporte: 1

Trabalho e emprego: 1

Total 225 $\mathbf{m}^{2}$ : $6 \vec{\circ}$

$1350 m^{2}=11,65 \%$

ÁREA 324m² Educação: 5

$(18 \mathrm{mx} 18 \mathrm{~m}) \quad$ Esporte: 1

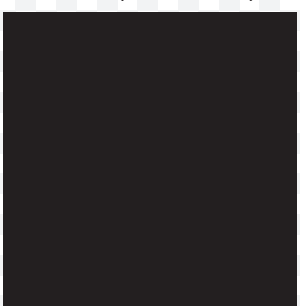

Total $324 \mathrm{~m}^{\mathbf{2}}$ : $\mathbf{6}$

$1404 \mathbf{m}^{2}=12,11 \%$
ÁREA 1024m² Esporte: 1

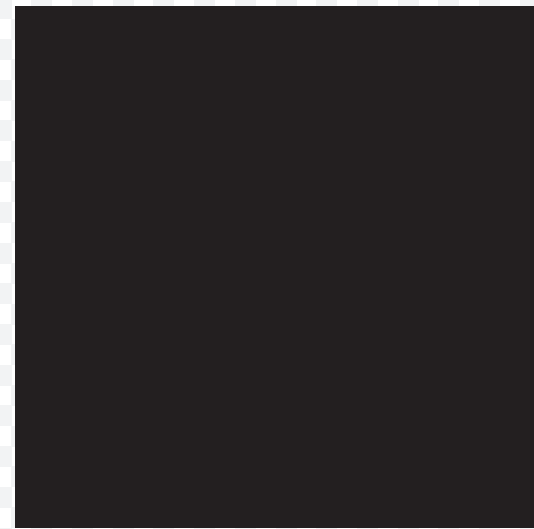

Total 1024 : 1 $1024 \mathbf{m}^{2}=\mathbf{9 , 5} \%$ 


\section{AREA METROPOLITANA POR MUNICÍPIOS}

Municípios com pelo menos uma necessidade básica insatisfeita

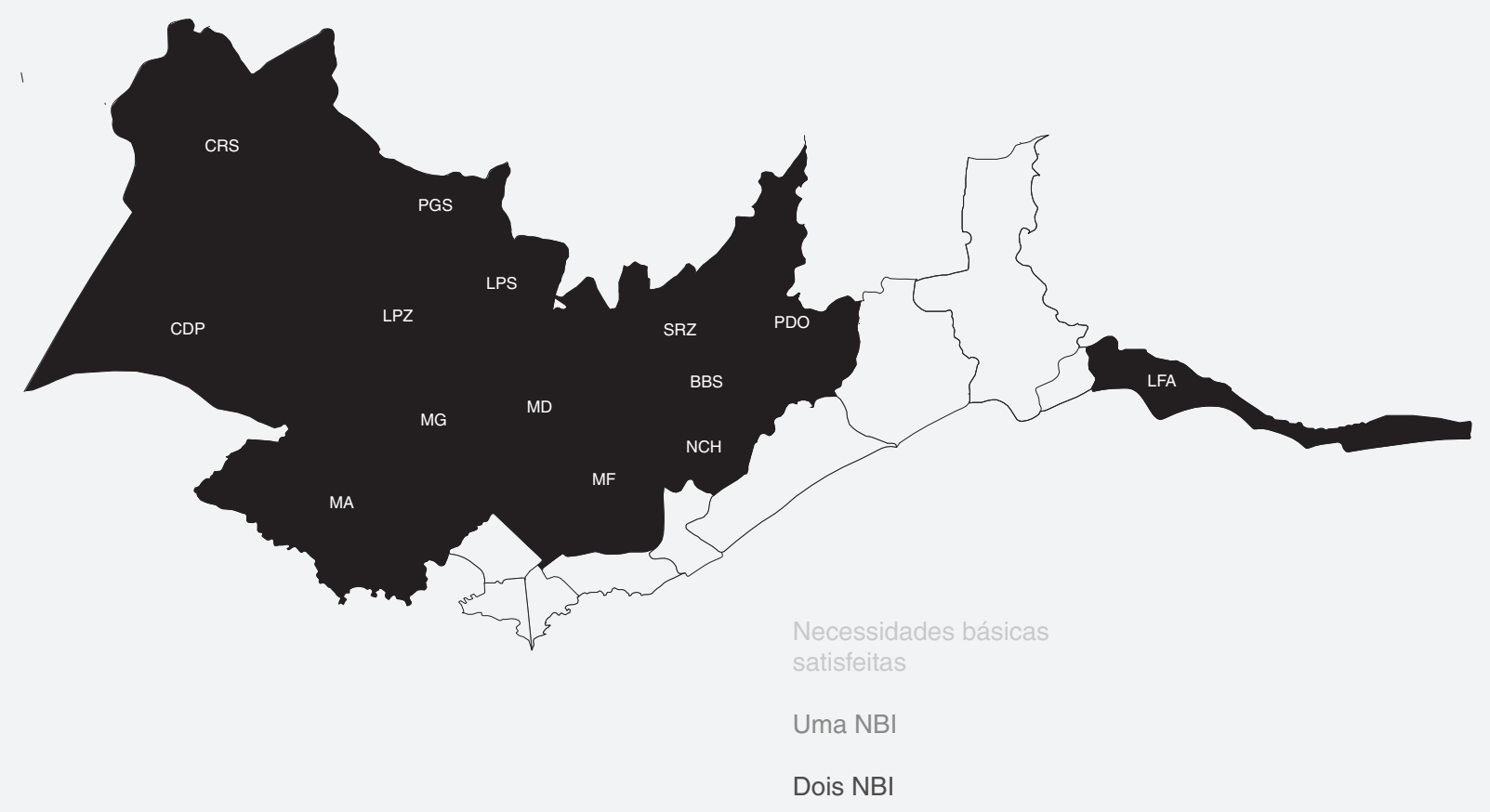

Três ou mais NBI

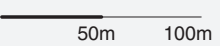

Municípios com porcentagens maiores a $29,0 \%$

Municípios com porcentagens menores a $29,0 \%$ 


\section{ECM 4. PERIFERIAS}

\section{TERRITORIALIZAÇÃO EXTREMA DA DESIGUALDADE}

A primeira parte desta seção se enfoca nas periferias da Área Metropolitana em geral e reúne pontos de vista das ciências sociais e humanas (também de outras disciplinas) que identificam o território como uma dimensão principal da segregação social e portanto, sustentam a ideia de que fazer cidade e território de qualidade é um componente imprescindível para as políticas públicas.

Algumas experiências internacionais, entre elas Medelín, são um caso paradigmático e mostram caminhos exitosos direcionados por esta hipótese. É necessário uma forma de entender a arquitetura partindo da sua densidade conceitual e operativa (o projeto completo) assim como prática integrada a um conjunto social e político (as políticas públicas como um sistema complexo).

\section{MUNDO PERIFERIA}

Existe um consenso geral sobre a relação entre exclusão e o território. Desde os anos 70 do século passado, tanto a região metropolitana de Montevidéu como todo Uruguai assistem a processos de fragmentação tipicamente latino-americanos. Desmonta-se o mito de uma "Suíça da América" com uma capital culta e integrada que dá identidade ao Uruguai moderno e desenvolvido desde começos do século XX. Esta afirmação é consensual para os que estudam a sociedade e sua relação com o território.

\footnotetext{
A sociedade hiperintegrada que se consolidou durante a primeira metade do século $\mathrm{XX}$ foi seguida por uma sociedade fragmentada que se caracteriza por valores crescentemente diferentes entre os setores sociais, fragmentação que também se expressa em uma crescente segregação territorial, assim como desigualdade entre gêneros e gerações. (CALVO e PELLEGRINO, 2005, tradução nossa).
}

O novo Uruguai, inserido nas lógicas do capitalismo global, vem sendo submetido aos processos que a academia e as políticas públicas procuram compreender e atender. Loïc Wacquant estuda casos de marginalização no primeiro mundo (especificamente em Chicago e Paris) e propõe um olhar e ação em direção a uma nova condição contemporânea a que se denomina "marginalidade avançada".

O termo "avançada" pretende indicar que aquelas formas de marginalidade não estão em nosso passado, nem estão sendo absorvidas progressivamente, seja pela expansão do "livre mercado" (isto é, por meio de um aprofundamento da mercantilização da vida social), seja através dos 
braços do Estado de Bem-Estar social, porém, mais exatamente, impõemse em nosso futuro.

A menos que novas formas de intervenção política sejam elaboradas para coibir ou redirecionar as forças estruturais que as produzem - entre outras, o crescimento econômico concentrado e a dualização do mercado de trabalho - a casualidade do emprego e autonomização da economia de rua em áreas urbanas degradadas, o desemprego em massa que conduz a uma completa desproletarização para grandes segmentos da classe trabalhadora, especialmente entre os jovens e políticas estatais de contenção de gastos urbanos, quando não de total abandono. E que novos mecanismos de medição social sejam postos em prática para reincorporar as populações excluídas espera-se que a marginalidade urbana continue a aumentar e a difundir-se e, com ela, a violência de rua, a alienação política, a desertificação organizacional e a informalização da economia que infestam cada vez mais os bairros de excluídos das metrópoles na sociedade avançada. (WACQUANT, 2001, p.165-166)

Nestes novos processos o território assume uma condição determinante na fragmentação social, de tal modo que muitos acadêmicos e profissionais das ciências sociais ${ }^{5}$ creem que uma das principais formas de reverter a marginalidade é a atuação sobre o espaço da cidade, e demandam tanto da arquitetura como do planejamento novas ideias e novas intervenções. Num país de uma urbanização que chega a quase 95\% dos habitantes, e com uma Área Metropolitana que concentra quase $60 \%$ da população, os problemas urbanos e metropolitanos são temas de primeira ordem nacional.

A demanda por ideias sólidas e que sejam capazes de reconfigurar os territórios marginais de nossas cidades é um assunto central do trabalho e se formula como uma interrogação: os arquitetos de Montevidéu estão pensando em intervenções radicais dada sua alta qualidade - onde o equipamento e o espaço público são peças chaves na redefinição de nossos territórios?

A questão se apresenta como uma oportunidade que a arquitetura deverá construir a partir de ideias especificamente disciplinares que se colocam em comum com o resto dos atores, especialmente políticos e sociais. Medelín demonstra o enorme potencial da convergência desses atores na transformação da cidade e na resolução de problemas sociais gravíssimos.

Nos fins dos anos noventa, Bervejillo e Lombardi (BERVEJILLO, 2008) descreveram essa fragmentação da região metropolitana de Montevidéu sob um modelo de três

\footnotetext{
${ }^{5}$ Katzman, Filardo, Veiga, Leal y muchos otros. Ver como exemplo os trabalhos de Katzman e Retamoso (2006) que analisam a relação entre segregação espacial e pobreza, e entre ela e os desafios à equidade educacional.
} 
cidades que se contrastavam em um conjunto de variáveis: a cidade de composição social mista, (áreas centrais e intermediarias de Montevidéu) em situação de estagnação ou perda de população em favor das restantes; a cidade com predomínio de setores de renda média-alta, (costa de Montevidéu e Cidade da Costa) e por último a cidade com predomínio de setores de baixa renda (periferias montevideanas e metropolitanas) que concentram a população mais empobrecida.

Estes pobres urbanos eram $32 \%$ da população total da região metropolitana de Montevidéu, (segundo dados estudados por Bervejillo (Ibid.) no censo de 2004) e um terço deles (10\% do total da população metropolitana) vivia em assentamentos irregulares. O perfil destes habitantes é diferente da média metropolitana: são mais jovens, com maior índice de fecundidade, suas casas são mais numerosas, detém mais baixos níveis de educação e a maior quantidade de necessidades básicas insatisfeitas. Habitam uma cidade de baixa qualidade e vivem amontoados em seus lares. A Área Metropolitana além de Montevidéu (situada sobretudo nas vizinhas prefeituras de Canelones e São José) apresenta perfis socioeconômicos ainda mais baixos que os da Capital nacional: "mais de 50\% dos lares correspondem aos níveis baixo e médio-baixo, enquanto que os setores médios correspondem a apenas $28 \%$ dos lares". (VEIGA, 2008, p.23, tradução nossa).

Um dos fatores que resultam mais preocupantes para os que estudam estes fenômenos sócio-territoriais é o protagonismo de imaginários e práticas de realização pessoal vinculadas à ilegalidade que debilitam a ação das políticas públicas. A presença do narcotráfico como um sistema operativo em setores destes territórios (especialmente em assentamentos e outros enclaves irregulares) é uma realidade inevitável há mais de uma década e nos últimos anos teve uma visibilidade crescente a partir de ações táticas sobre o espaço público que questionam a presença e a autoridade do aparelho estatal.

A "cidade dos pobres" expressão da "marginalidade avançada", habitada por um terço dos cidadãos metropolitanos, opera com processos de exclusão sinérgicos: laborais, educativos e residenciais tal como Katzman (2011) caracteriza para as cidades latinoamericanas e estuda em detalhe em alguns trabalhos específicos. Nela se constroem imaginários alternativos, ocupa-se um território descontínuo e a cidade apresenta um espaço público esquálido que combina sem hierarquia tecidos regulares e desqualificados (gerados em boa parte por autoconstrução e crescimento rumo ao interior do terreno), assentamentos irregulares e conjuntos habitacionais de promoção 
pública ou cooperativa. Os assentamentos irregulares metropolitanos, que, segundo censo de 2010, habitam 130.000 pessoas $^{6}$, foram constituídos em solos privados ou públicos e em muitos casos em meios ambientalmente comprometidos, terrenos contaminados e leitos de curso aquático que se encontram sob inundações periódicas.

É uma cidade alimentada pela migrações para a capital, ondas geradas pelas crises econômicas (a última de grande impacto foi a de 2002), a desindustrialização progressiva e a informalização das relações trabalhistas como consequência da globalização. Álvarez Pedrosian (2009) a chama de "depósito" que reúne diversos tipos de indivíduos que não haviam elegido viver neste local, entretanto, foi o que lhes restou. Qual é a relação entre as condições sociais que ocorrem no "social" e as condições habitacionais que se produzem no "território"?

O território não é apenas um reflexo das desigualdades sociais, é uma de suas dimensões que devemos conhecer melhor para atuar com melhores possibilidades de êxito. (SABTTINI ${ }^{7}$ apud COURIEL, 2010, p. 65, tradução nossa)

Nascer nesta cidade, habita-la, marca e condiciona: a territorialidade torna-se produtora de pobreza e marginalização, especialmente para os que nela nascem.

Nesta perspectiva, assumimos que a segregação urbana não é uma simples consequência das desigualdades sociais, senão resultado da diferenciação social no território e constituem processos que se retroalimentam na medida em que, tanto a posição como a identidade de uma área, estão condicionadas por sua estrutura socioeconômica. De tal forma, as diversas formas de segregação residencial e educativa são manifestações da distribuição das classes e a exclusão social no território. Neste contexto, ainda que em sociedades (como a uruguaia) com altos níveis relativos de igualdade no contexto internacional, a falta de integração social retroalimenta a segregação e coloca a desigualdade social como um tema fundamental a ser enfrentado pelas políticas públicas e pela população.

Em realidade, as transformações profundas que vem sendo produzidas no marco da globalização, em se tratando de família, escola, bairro e emprego, estão provocando mudanças significativas nas normas, nos valores e na

\footnotetext{
${ }^{6}$ Estimação propria. Seriam 6,7\% dos quase 2 milhões de habitantes metropolitanos. (PMB-PIAI, 2012)

${ }^{7}$ SABATTINI Francisco. Alicia en el País de las Estadísticas: Sobre Espejos, Escalas y Desigualdades.

[ponenecia] Seminario Internacional .Chile en la Tarea de medir las brechas de desigualdad. Instituto Santiago de Chile: Nacional de Estadísticas.30 y 31 de Mayo de 2005.
} 
conduta social. Esta interação, desse modo, reproduz os estigmas, a exclusão e a segregação de diversos grupos nas cidades. (VEIGA, 2015, p.70, tradução nossa)

Mas ainda admitindo que as oportunidades de emprego sejam causas importantes tanto dos deslocamentos rumo aos bairros que concentram pobres como do "novo" empobrecimento de seus antigos residentes, também é necessário reconhecer que, uma vez que as pessoas que se estabelecem ou permanecem nestes bairros de pobreza mais concentrada e homogênea, seus eventuais vínculos com o mercado de trabalho serão afetados pelos fatores e processos próprios dos entornos com altas densidades de carências. Os efeitos do contexto de residência vão ser revelados com maior nitidez nas gerações socializadas nestas vizinhanças, onde a influência do bairro claramente antecede as suas intenções de inserção laboral. (KATZMAN e RETAMOSO, 2005, p.139, tradução nossa)

As referências nos mostram como estamos longe de uma cidade horizontalmente contínua e integrada. Um gueto significa, para o dicionário da Real Academia Española, um "bairro ou subúrbio em que vivem pessoas marginalizadas pelo resto da sociedade" ou uma "situação ou condição marginal em que vive um povo, uma classe social ou um grupo de pessoas". Poderíamos afirmar, amparados nesta definição que as periferias metropolitanas de Montevidéu são guetos sem confinamento nem fronteiras rígidas, mas, sobretudo, como veremos a seguir, sem identidade comum. Com precisão sociológica Wacquant questiona o uso do termo para definir alguns fenômenos urbanos latino-americanos aos que prefere chamar de "territórios urbanos relegados. No entanto, quanto o autor propõe uma elaboração teórica a partir do estudo de um hipergueto em Chicago, refere-se a aspectos comuns com setores de nossas periferias.

Mais precisamente, aponta a necessidade de elaborar de maneira teórica e
empírica as conexões entre a desolação urbana e a denegação simbólica
no centro urbano racializado dos Estados Unidos e os variados territórios de
relegação nas metrópoles dualizadas das sociedades avançadas
(Wacquant, 2008): como a experiência cotidiana da dilapidação material, a
exclusão étnico-racial e a marginalidade socioeconômica se traduzem na
corrosão do eu, na aspereza dos laços interpessoais e na distorção das
políticas públicas em direção a mediação de cognições cáusticas fixadas em
um lugar difamado" (WACQUANT, 2011, p. 8, tradução nossa). ${ }^{8}$ Estas mesmas condições de vida duras e de exclusão em relação ao resto da sociedade se vivem em nossas periferias. Vê-se a presença do Estado e das organizações da sociedade civil, mas na maior parte das vezes encriptada em lógicas que replicam ou geram fragmentação. Os diferentes modos de vida convivem mais ou menos isolados entre a formalidade e a informalidade, entre o legal e o ilegal. As relações colaborativas,

\footnotetext{
${ }^{8}$ Alvarez Pedrosian fala sobre Casavalle com as idéias de Wacquant em um sentido relacionado com este raciocínio.
} 
vinculadas à tradição da esquerda militante, com as organizações sociais e religiosas são minoritárias. As pessoas vivem isoladas e introvertidas, para muitos o espaço público em vez de espaço de encontro é normalmente associado a um espaço perigoso. Assim a cidade é um suporte diferente ao imaginário da cidade moderna contínua e integrada, tal como apresenta esse excerto sobre as periferias montevideanas de Eduardo Álvarez Pedrosian:

As zonas segregadas, mais que à homogeneização, tendem a uma diferenciação radical, mas sim é acompanhado por uma homogeneização no interior de cada fragmento urbano, unidade de espaço que se replica sobre si mesma. Uma pluralidade de entidades espaciais proliferam, cada uma com suas qualidades específicas, no contexto de solapamento mútuo permanente e de novas ocupações que reconfiguram a cartografia em sua totalidade. (ÁLVAREZ PEDROSIAN, 2010, p.11-12, tradução nossa)

As periferias seriam em si mesmas um conjunto de fragmentos, micro-guetos frágeis, e em conjunto um lugar onde se entrecruzam tempos, lógicas e isolamentos: um "lugar estratificado" à maneira como define Michel de Certeau.

No entanto, sob a escrita fabricante e universal da tecnologia, permanecem lugares opacos e inflexíveis. As revoluções da historia, as mutações econômicas, as misturas demográficas são estratificadas e aí permanecem, à espreita, dentro dos costumes, ritos e práticas espaciais. Os discursos legíveis que os articulavam, não faz muito tempo que desapareceram, ou não deixaram de ser mais que fragmentos na linguagem. Este lugar, em sua superfície, parece um collage. Na verdade, trata-se de uma ubiquidade na densidade. Um amontoamento de camadas heterogêneas. Cada uma, como a página de um livro deteriorado, remete a um modo diferente de unidade territorial, de repartição socioeconômica, de conflitos políticos e de simbolização identificadora. (DE CERTEAU, 1996, p.221, tradução nossa)

Ao entender as periferias deste modo, torna-se clara a necessidade de um novo paradigma e ações que levem a uma presença pública de alta visibilidade e coordenação, capaz de trabalhar para romper a fragmentação e auto-absorção das populações da periferia. Por sua vez, esta fragmentação deve ser entendida como pauta de projeto das periferias e seus equipamentos, abandonando, como de certa forma vêm sendo feito nos últimos anos, as políticas universais e homogêneas para desdobrar ações que deem resposta às diversas qualidades destes setores. O dilema está em que as políticas específicas não se tornem réplicas da fragmentação.

Para isso é preciso reconhecer o específico e entender a trama de relações multiescalas que produzem a metrópole montevideana. Evitar o procedimento que produz a fragmentação que podemos ver construído em Casavalle e nas periferias em geral: 
bonecas russas de isolamento, assuntos resolvidos encapsuladamente, sem entender nem estimular a produção de relações na cidade.

Coletando a demanda que a sociedade e outras disciplinas fazem para a arquitetura, podemos voltar a interrogar a disciplina: Nós, arquitetos, estaríamos pensando em intervenções radicais - dada sua formulação e qualidade - que sejam peças chave na costura e geração de continuidade entre estes fragmentos urbanos?

O Estado, as políticas públicas e os arquitetos que às implementam, vêm sendo produtores desta fragmentação. As novas formas de inserir-se no território periférico entendendo-o como um fenômeno complexo devem por sua vez operar para dentro da cidade dos pobres, realiza-lo para fora mitigando a grande fragmentação que define estas três cidades para que sejam promotoras de uma cidade integrada. Novamente o exemplo colombiano aporta algumas lições de uma abordagem concentrada que opera em muitos níveis, atravessando a fragmentação institucional e até criando uma institucionalidade nova e, também, confiando na qualidade dos espaços e de sua arquitetura. 


\section{ECM.5 EQUIPAMENTOS DE PERIFERIA}

O Centro Cívico Casavalle Luísa Cuesta, aberto ao público se encontra na Praça Casavalle. O prédio é fechado por uma chapa expandida, com portões que parecem fechados, mas estão abertos. Ao passar pelos portões nos encontramos em um espaço de acesso coberto, de quase $100 \mathrm{~m}^{2}$ que é transparente em direção a Praça e ao fundo, onde funcionam vários equipamentos escolares.

A visita ao Centro foi informal. A Diretora não se encontrava presente, e o percorremos conversando com funcionários. Havia poucos vizinhos. O edifício, que recupera uma das construções abobadadas da Unidade de Habitação Casavalle, se mostra impecável. Bem equipado com salas que em diferentes horários dispõe de atenção de quase todo o Estado e é possível realizar os mais diversos trâmites públicos, uma vez que está orientado à atenção de todos os indivíduos frágeis da zona: crianças, estudantes com algum tipo de dificuldade acadêmica, pessoas vítimas de violência, recém saídos da prisão em busca de oportunidades de reinserção, entre outros. A presença pública se condensa neste espaço que convoca todos os vizinhos e evita deslocamentos. O espaço principal é uma biblioteca que tem locais de leitura para crianças e adultos. Alguns metros quadrados de espaço aberto articulam o espaço entre as salas. $O$ programa municipal Esquinas da Cultura que funciona em toda a cidade rastreando e amparando expressões culturais locais, tem, por exemplo, no Centro, oficinas de Hip Hop, Capoeira e Teatro.

Quando perguntamos aos funcionários se tinham ideia sobre que carências o Centro teria, um deles que até então nos havia observado em silêncio disse: "Falta mais espaço para que a gente possa estar, vir e apenas estar aqui". Num território em que a rua, por suas condições ambientais e de segurança, já não é mais de todos, se faz necessário um espaço seguro e protegido. Em muitas ruas não há calçadas, se existissem não se poderia afirmar, como faziam as crianças de poucas décadas atrás nos bairros montevideanos, que "a calçada é pública".

Nos últimos 20 anos, as periferias viram a atenção de políticas públicas incrementadas, tanto por programas que atende a toda a população como a um conjunto de programas específicos que atendem assuntos específicos. Muitos deles surgidos no novo Ministério de Desenvolvimento Social. Por sua vez, a dimensão territorial das políticas públicas começa a cobrar um novo vigor a partir da criação de uma institucionalidade e lei específica sobre Planejamento Territorial (Ley 18.308, de Ordenamiento Territorial y 
Desarrollo Sostenible) a geração de planejamento territorial tanto regional como urbano, e de desenvolvimento de um terceiro nível de governo abaixo do Nacional e do Estadual: o Municipal.

Desde a metade dos anos 90 as políticas educativas estão desenvolvendo dispositivos específicos para crianças em situação vulnerável através da criação de escolas públicas de Contexto Social Crítico e de Tempo Integral que estão sendo desenvolvidas baixo um modelo pedagógico, com inclusão de refeitórios escolares e um planejamento referente à localização no território que atendam a indicadores sociais.

O relatório Uruguai do Fundo Monetário Internacional de 2015 aborda algumas destas novas realidades:

\begin{abstract}
Experiência do Uruguai com crescimento inclusivo:
Uruguai tem uma longa história de alto nível de vida comparáveis a muitos países desenvolvidos e tem seguido avançando na melhora das condições sociais na última década. A recessão que levou a crise de 2002 afetou drasticamente os indicadores sociais. No entanto, o aumento do emprego e dos salários, assim como a introdução das transferências públicas focalizadas, manteve a pobreza em uma tendência de queda depois de 2005 e reduziu aos menores níveis em muitas décadas. A desigualdade salarial também diminuiu após 2007. O gasto público social aumentou em $20 \%$ do PIB em 2005 para $25 \%$ em 2012, o que significa um esforço deliberado de política social. $\mathrm{O}$ governo colocou em prática um plano sociotemporal de emergência entre 2005 e 2007 cujo objetivo foi o de reduzir a pobreza extrema através de transferências monetárias localizadas/pontuais/focalizadas. O Plano de Igualdade mais integral e permanente posto em prática em 2007 incluiu uma expansão da cobertura e o montante das transferências de assistência social, assim como de grande alcance em reformas tributárias e de atenção médica. A reforma fiscal introduziu impostos sobre a renda da pessoa física e melhorou a progressividade do sistema fiscal, enquanto a reforma na saúde duplicou em 2010 a cobertura de seguro médico nos planos público. (IMF9 apud VEIGA, 2015, p.62, tradução nossa)
\end{abstract}

Em uma entrevista de 2008, realizada com um conjunto de atores sociais das distintas zonas metropolitanas que, por sua inserção institucional (governo e sociedade civil) ou pelo conhecimento de sua zona, pudessem aportar elementos para detectar a percepção que estas ações têm em suas regiões tratam de alguns pontos em comum, que em geral reconhecem um incremento das políticas públicas e do Estado e destacam algumas características favoráveis e desfavoráveis:

A visualização de obras e intervenções concretas como a melhora dos acessos secundários, o vale transporte metropolitano (ônibus), oficinas e

${ }^{9}$ IMF. Uruguay Country Report No. 15/81. Uruguay‘s Experience with Inclusive Growth. FMI Washington. 2015 
aulas gratuitas são alguns dos exemplos. Também se menciona outro tipo de ações, que tratam de um novo modo de gestão e de "fazer política" tanto a nível municipal como Central. Os exemplos apontados são as mudanças na gestão e na atenção ao público e no relacionamento com os vizinhos nas repartições, no planejamento estratégico, nas assembleias de cultura, no debate educativo, nos médicos da família e nos professores comunitários. Tais elementos contribuem à proximidade entre população e política.

No entanto, tais ações, que dada à grave situação social, demandam muito tempo para que sejam percebidas, além de continuidade. As expectativas dos ritmos das mudanças, por parte da população, são maiores que a realização das mesmas. Estas opiniões são manifestadas por atores locais, quando se queixam dos ritmos lentos do Estado (burocracia) e da dificuldade na concretização dos projetos, do déficit de recursos (financeiros e humanos) e da geração de fontes de trabalho e da conformação de uma identidade local para o desenvolvimento. Estes dois últimos elementos referenciam problemas de caráter estrutural e requerem políticas de desenvolvimento, que vão além dos serviços sociais. Sua superação dependerá das políticas de desenvolvimento integral e não somente econômico, tanto em escala local como nacional que ainda não são passíveis de serem vistas, mesmo que não explicitamente. (VEIGA, 2008, p.30, tradução nossa)

A distribuição dos diversos equipamentos no território segue critérios díspares e não há (salvo algumas exceções) políticas específicas que vinculem de maneira sistemática às demandas com sua materialização. Os mecanismos de consideração transversal das práticas institucionais ficam restritos (quando possível) ao âmbito estadual, municipal e (sobretudo) local. Nos últimos anos alguns esforços foram feitos para sistematizar experiências e atender centralmente às políticas públicas, em particular a partir de esforços da Secretaria de Planejamento e Orçamento da Presidência da República. Os Sistemas de Informação Geográfica (SIG) permitem obter informação de qualidade sobre os territórios e o desempenho social e são ferramentas de muita utilidade para o redesenho das políticas públicas integradas.

O desenvolvimento da informação disponível sobre o território ultrapassa por muito a capacidade de agir com essa informação. Há aspectos quantitativos relacionados com o orçamento para as políticas públicas, mas também há aspectos qualitativos que dependem da maneira em que o orçamento é empregado. As definições quanto à localização de equipamentos conjugam relações desestruturadas e assistemáticas em uma série de parâmetros: a resposta as necessidades, as reclamações da sociedade civil, os interesses políticos (e as vezes partidários), a disponibilidade de solo (fator às vezes decisivo) e a lógica e organização das instituições. Os diferentes equipamentos são pensados e implementados em instituições de nível nacional e estadual a partir de 
uma forte compartimentalização funcional, que resulta em práticas unidimensionais e monotemáticas.

Reconhecem-se os esforços (ainda isolados e minoritários) de articulação e coordenação que podem acontecer, não tanto entres as direções das instituições públicas como nas práticas concretas dos atores locais. Uma política sistemática de coordenação e articulação produziria efeitos benéficos na realização dos equipamentos nos territórios tornando-os mais visíveis e atrativos. $\mathrm{O}$ isolamento em que se encontram as instituições públicas no espaço físico parece um problema central, mas de ordem instrumental. Talvez exista um problema ainda maior que não é instrumental, mas sim conceitual: a necessidade de formular um novo paradigma de intervenção na sociedade e no território das periferias. Se seguirmos a reflexão de Wacquant quando define o termo "marginalidade avançada" como um fenômeno inovador e crescente do capitalismo global, concluímos a necessidade de explorar um novo tipo de políticas públicas:

\begin{abstract}
A terceira, e progressista, resposta para a polarização urbana a partir de baixo aponta para uma fundamental reconstrução do Estado de Bem-Estar, que adequaria sua estrutura e políticas às condições sociais e econômicas emergentes. Inovações radicais, tais como a instituição de um salário cidadão (ou concessão de renda incondicional), desvinculariam a subsistência das condições e possibilidades do trabalho, expandiriam o acesso à educação durante a vida e garantiriam acesso universal aos bens públicos, como moradia, saúde e transporte, que são necessários para estender os direitos sociais e interromper os efeitos perniciosos da transformação do trabalho assalariado (Van Parijs, 1996). No final, esta terceira opção é a única resposta viável ao desafio que a marginalidade avançada representa para as sociedades democráticas enquanto se preparam para cruzar o limiar do novo milênio. (WACQUANT, 2001, p. 195196)
\end{abstract}

Além da discussão sociológica e política que planteia o autor, nos interessa tomar pegar a necessidade de refundar paradigmas de intervenção para estes contextos duros que implicam modificações transcendentes. Produzir fragmentos de periferia de alta qualidade que tenham a capacidade de induzir novos estados em seus entornos (interconectando estilhaços isolados) uma vez que articulam estas periferias com a cidade. A respeito dos equipamentos da nova geração que estão sendo licitados no formado de Participação Público-Privada (PPP) dos quais alguns chegarão a Casavalle: Deveria haver tido uma maior aposta quanto ao controle de qualidade e do desenho destes no processo ao qual se concede ao ofertante uma grande autonomia? As soluções tecnológicas não deveriam ter privilegiado opções que assegurassem uma alta durabilidade? 
UNIDAD DE HABITACION CASAVALLE

H. H t incion
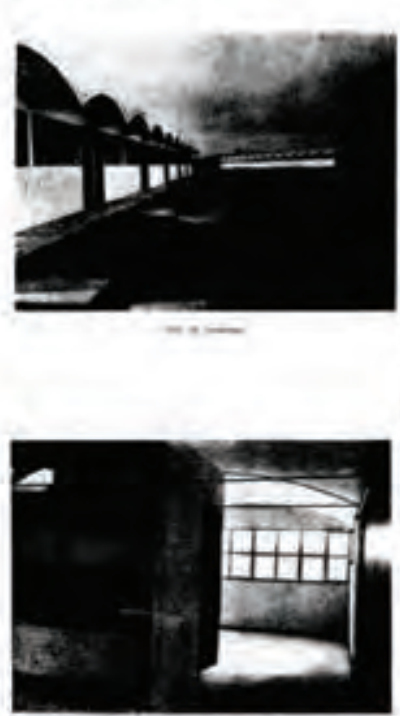

$-+m+\infty$

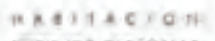

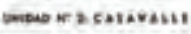

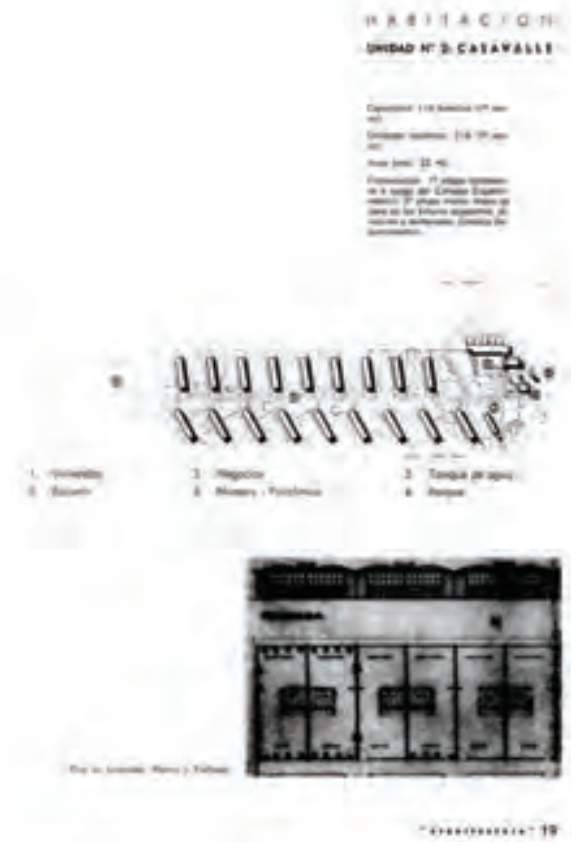

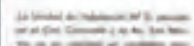

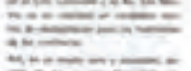

$=0$

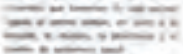

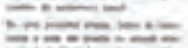

픈

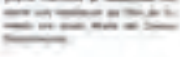

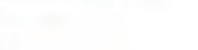




\section{ECM.6 EQUIPAMENTOS CASAVALLE}

Os casos que examinamos nos mostram o fracasso de muitas políticas e práticas disciplinares autistas. Em particular, as crenças numa arquitetura que fosse capaz de produzir uma sociedade melhor e que apenas formam parte de uma história de boas intenções e péssimos resultados, que precisamos lembrar.

A Unidade Habitacional Casavalle foi realizada como parte integrante do programa habitacional do Plano Diretor Municipal de 1956, a principal ferramenta de planejamento moderno que existiu na cidade de Montevidéu no século XX. Casavalle foi projetado junto com a Unidade de Buceo (construída), com a de Cerro (construída em bloco por Román Fresnedo em Cerro Sul), para Alto Malvín (para 40.000 pessoas que acabaram formando ou atual Malvín Norte).

O critério adotado: superar a dispersão das intervenções municipal em moradia popular que geraram pequenos bairros de baixa densidade com base em casas geminadas ou isoladas em seu terreno (privado), e que definiram pequenos trechos bem caracterizadas desde um ponto de vista urbano. As novas são grandes intervenções de moradia que cumpriram alguns fins estipulados no Plano Diretor, têm localização estratégica e incorporam serviços na vizinhança, como núcleos de vida coletiva/espaços comunitários. O bloco é o principal argumento do projeto e o terreno livre (público) ao seu redor aposta na qualidade ambiental, que nestes contextos de alta pressão tornouse terra de ninguém que suportou ocupações informais que desnaturalizaram a qualidade ambiental.

A ação em Casavalle apresenta duas singularidades que podemos destacar para a intervenção contemporânea:

$\mathrm{Na}$ apresentação do projeto na Revista da Sociedade de Arquitetos fica manifestada a idealização redentora da arquitetura. Destinada a 216 famílias residentes em "favelas" da região:

\footnotetext{
A Unidade Habitacional no 2, localizada em Caminho Casavalle esquina com Av. San Martín, é em realidade um verdadeiro centro de readaptação para os habitantes de assentamentos precários. Na próxima etapa, na zona norte e leste do terreno, se edificará outra parte da Unidade constituída por blocos de moradia que serão levantados pelos próprios moradores já readaptados mediantes uma ampliação do Plano de Moradia por Auxílio Mútuo do Conselho Departamental. (REVISTA ARQUITECTURA, 1958, p.18, tradução nossa)
} 
O projeto previa também o traslado dos habitantes de maneira temporária dos seus antigos casebres. Poucos anos depois, em vez de se construir blocos para a nova etapa, se realiza um segundo conjunto de 120 moradias de características similares às primeiras, ocupando parte do terreno previsto para a Nova Unidade Habitacional em blocos, que nunca chegou a ser realizada.

Há 60 anos daquela primeira iniciativa: desfiguradas por sucessivas ocupações de terrenos baldios, as moradias com suas abóbadas permanecem negando a dupla ilusão originária pois não são redentoras nem duradouras.

A Bacia do Arroio Casavalle, um lugar particularmente crítico na área metropolitana, tem uma história particular nos últimos anos e há passado por um processo específico onde a revisão pode fornecer elementos para a atuação contemporânea. Toma-se como ponto de partida a Casavalle do novo século, nele confluem algumas circunstancias que habilitarão novas modalidades nas políticas

A pergunta da pesquisa se refere ao estudo de possibilidade para uma nova geração de Equipamentos Coletivos na periferia da Montevidéu Metropolitana, que sejam capazes de gerar urbanidade e se baseiam na desespecialização programática como ferramentas de projeto. Fazer mais com menos.

Casavalle é singular entre estas periferias: é identificada como "campo de experimentação das diferentes políticas urbanas e de moradia" (Cecílio, Couriel, Spallanzani, 1999) ou como "depósito urbano" (ÁLVAREZ PEDROSIAN, 2009).

"Apesar da fragmentação espacial e subjetiva em geral, verificou-se uma tendência e continua construindo pontes entre os fragmentos, entre individualidades isoladas e fechadas sobre si mesmas. Se trata-se das condicionantes, todas tendem à fragmentação, desde a morfologia das unidades habitacionais empreendidas pelos diferentes governos em meio século, ao abandono do equipamento urbano e dos serviços prestados que teria que, pelo menos, associar os distintos fragmentos. Deste modo geramse grandes diferenças hierárquicas no interior da zona, entre os fragmentos assim como no seus interiorer, até a unidade familiar individual. Além dos discursos, dos símbolos e dos significados, a necessidade leva a existência de uma mobilidade entre os fragmentos no interior da zona, assim como com o exterior, principalmente a partir dos assentamentos. $O$ "depósito" não deixa de estar conectado em todas as direções, obviamente, através dos produtos advindos da segregação social e da marginalidade.

E é por essa razão que, apesar de jamais perder as relações com o exterior, o isolamento é efetivo. A lógica de segregação vai acompanhada a de fragmentação, com que os elementos se relacionam mais com os do exterior que com os contíguos e semelhantes. A produção de subjetividade fica fortemente determinada por estas premissas que atuam sobre todo tipo de estratificação: o trabalho, o consumo, a saúde, etc. A maioria das mulheres se dedica a trabalhos domésticos em casas das zonas da cidade 
ocupadas pelas classes médias e média-alta, a presença de militares de baixa e mediana patente militar é crescente, assim como o lixo que é a principal fonte de recursos gerada pelos que mais podem consumir e levada até os assentamentos para ser classificadas e vendida aos centros de reciclagem do entorno. (Ibid., p.11-12, tradução nossa)

\title{
Conselho casavalle
}

Em setembro de 2009, o prefeito de Montevidéu Ricardo Ehrlich, assina a resolução 3754 que cria o Conselho do Programa Bacia do Riacho/Córrego de Casavalle. O Conselho tem como principais funções atuar como espaço de coordenação interinstitucional e definir estratégias de ação.

\begin{abstract}
Integrar o Conselho acima com representantes dos Ministérios de Desenvolvimento Social; Saúde Pública, Interior, Moradia, Organização Territorial e Meio Ambiente; Educação e Cultura; Trabalho; Economia e Finanças; a Administração Nacional de Educação Pública; Conselho Nacional de Drogas e Prefeitura Municipal.

Autorizar o Conselho de Programas da Bacia do Vale de Casavalle a solicitar a participação de outras instituições como convidados quando for apropriado.

Criar uma equipe de trabalho de composição municipal, com a tarefa de fornecer apoio técnico e operacional ao Conselho. Integrar a equipe de trabalho acima mencionada com representantes de todas as secretarias municipais para produzir transversalidade operacional.

Integrar o Conselho acima com representantes dos Ministérios de Desenvolvimento Social; Saúde Pública, Interior, Moradia, Organização Territorial e Meio Ambiente; Educação e Cultura; Trabalho; Economia e Finanças; a Administração Nacional de Educação Pública; Conselho Nacional de Drogas e Prefeitura Municipal.

Autorizar o Conselho de Programas da Bacia do Vale de Casavalle a solicitar a participação de outras instituições como convidados quando for apropriado.

Criar um grupo de trabalho composto municipalmente, com a tarefa de fornecer suporte técnico e operacional ao Conselho. Integrar o mencionado grupo de trabalho com representantes de todos os departamentos municipais a fim de produzir transversalidade operacionais. (IM, 2009)
\end{abstract}

A frieza textual reconhece uma dupla falta de ação pública: por um lado, o Plano de Organização Territorial, aprovado há uma década tinha um delineamento estratégico: "a necessidade de alcançar o reequilibro sócio-urbano, como modelo alternativo ao da segregação sócio-espacial”, sendo necessário para este reequilíbrio operar estruturalmente sobre "os equipamentos coletivos e o ambiente urbano". A partir do Plano Montevidéu a cidade desenvolveu políticas específicas para as várias zonas caracterizadas, apostando à consolidação de trechos característicos mais ligado a assuntos patrimoniais e morfológicos que a assuntos de emergência social, com 
exceção da abordagem sobre o Arroio Miguelete, área de emergência ambiental e social.

Por outro, reconhece que o Estado havia sido responsável direto por suas ações e omissões na produção da extrema precariedade social e urbana da região de Casavalle. Cita especificamente o estudo da arquiteta Cecilia Lombardo e da socióloga Verónica Filardo realizado para a Cepal, que contém uma série de diagnósticos e propostas.

$\mathrm{Na}$ resolução o Conselho se incumbe de delimitar a área de atuação (uma revelação sobre a própria indeterminação territorial que afeta a zona), fazer uma coordenação interinstitucional multinível (governo nacional, uma articulação transversal da rígida estrutura de governo estadual e a incorporação de modo necessariamente protagonista do terceiro nível de governo, através do Município D) e definir as estratégias de ação no território.

O conhecimento acadêmico e as políticas públicas encontram-se nesta nova etapa de Casavalle. Os trabalhos citados de Lombardo e Filardo da primeira metade dos anos 2000 aportam um olhar crítico sobre a ação do Estado, apresentam uma leitura do território e da sociedade de Casavalle e se posicionam em outras abordagens de sociologia urbana e da arquitetura.

Seus estudos neste momento detectam a presença dos governos nacional e estadual, um grande conjunto de ONGs, e muitas organizações da sociedade civil. A sociedade fez um esforço econômico considerável que foi calculado neste estudo, revelando a incapacidade estrutural deste esforço para reverter a situação.

Segundo o diagnostico realizado, a área estudada apresenta sintomas críticos de pobreza, practicamente desde que este bairro foi construído. Há mais de quatro gerações que se reproduz esta situação sem que seja apresentada mudanças favoráveis nos indicadores selecionados. Olhando a evolução, nos últimos anos inclusive, a tendência é de incremento dos níveis críticos. Considerando a dimensão temporal, a análise é imprescindível em estudos deste tipo.

Apesar da concentração registrada de transferência de recursos da sociedade para esta área, do numero de ONGs trabalhando e da quantidade de programas sociais que funcionam nela, além dos subsídios mais ou menos claros com a população residente neste território pode contar (a população não paga por diferentes motivos impostos municipais, ou por exoneração, ou simplesmente são morosos no que thes corresponde). Eles são sistematicamente insuficientes e claramente ineficientes em reverter a situação inicial. .(FILARDO, 2005, p.73, tradução nossa)

Paralelamente a cooperação público-público não há tido o impulso necessário na agenda política nacional. As insuficiências e ineficiências das 
relações interinstitucionais operaram negativamente na direção dos objetivos das distintas políticas sociais e contribuíram minimamente na redução da pobreza. No caso de Casavalle elas representam um investimento importante de recursos humanos e econômicos da sociedade uruguaia. (LOMBARDO, 2005, p.13, tradução nossa)

\begin{abstract}
O fortalecimento da integração social da população de Casavalle é trabalhado a partir de vários modos simultaneamente, dado que a "desintegração" progressiva desta população ocorreu a partir de três elementos básicos, que, além de tudo, se retroalimentam: Dificuldades em acessar o mercado de trabalho, Dificuldades em acessar o nível médio do sistema educacional, e Dificuldades de acessar o uso de espaços públicos compartilhados com outros setores sociais da cidade. (FILARDO, op. cit., p.80, tradução nossa)
\end{abstract}

Filardo, além de um detalhado estudo referente as atividades econômicas e sociais, tece uma proposta de orientação produtiva para enfrentar o conjunto de problemas sociais. Propõe o desenvolvimento de um projeto produtivo estruturado com um conjunto de subprojetos, estes envolvem um alto numero de habitantes e redefine a matriz produtiva da zona. Trata-se de um Viveiro fomentado com apoio estatal e organização cooperativa, projeto que gera atividade econômica e a ressemantiza: "de gestão e produção lixo a paisagem".

Lombardo (2005) realiza um estudo territorial que se baseia em (e amplia) um trabalho detalhado de Cecilio, Couriel e Spallanzani (1997) avançando em algumas ideias de intervenção no sentido de dotar tal área de estrutura e interconexões e propõe uma hipótese que posteriormente é incorporada no planejamento municipal: eliminar total ou parcialmente o conjunto Unidade Missões (Los Palomares), que é o conjunto de moradias mais precário.

\title{
plano casavalle
}

A partir da constituição do Conselho Casavalle e como resultado do processo de planejamento estabelecido pela Lei de Organização Territorial, surge o Plano Parcial de Organização, Recuperação e Integração Urbana de Casavalle. Desta chamada aberta a equipes multidisciplinares, selecionou-se o consórcio integrado pelo arquiteto Federico Bervejillo e pelas consultoras "CSI Engenheiros" e "Equipos Mori”.

O plano reafirma a ideia de propor a presença pública na periferia a partir de ações de forte intensidade e visibilidade, e se posiciona a partir da hipótese da implementação de políticas coordenadas a nível público e com atores da sociedade civil. Em sintonia com as leituras aqui apresentadas em relação às periferias, e em especial a partir das de 
Casavalle, se propõe três eixos prioritários que se entrecruzam e se retroalimentam: a formação de capacidades coletivas para a gestão, o desenvolvimento cultural e a educação e geração de "urbanidade", e se identifica um setor de atenção prioritária dentro de Casavalle onde se concentra o núcleo de situações sócio-territoriais mais críticas.

O plano propõe três Operações Urbanas complexas, estratégicas e prioritárias que atualmente se encontram em diferentes estados de desenvolvimento e gestão: o Eixo Cívico Cultural, a Recuperação do "Córrego Matilde Pacheco" com reassentamento de moradias em suas margens e a Reprogramação Habitacional e Reurbanização do Conjunto Missões e as Unidades Casavalle 1 e 2.

Destes três, o Eixo Cívico Cultural apresenta-se como o mais consolidado neste território e em sua gestão. Trata-se de uma operação física e simbólica que conecta dois equipamentos principais de Casavalle, o o SACUDE (Salud, Cultura y Deporte) e o CEDEL (Centro de Desarrollo Económico Local), atravessando a principal edificação de equipamentos públicos escolares e de saúde (setor da Unidade de Habitação Casavalle destinado a espaços comuns) procurando criar uma nova centralidade no bairro. Posteriormente a redação do relatório da Consultora e como parte da gestão do Conselho Casavalle, o Plano se incorpora a Praça Casavalle que fortalece de forma significativa a viabilidade e intensidade do Eixo. Uma linha em direção Norte-Sul sutura o território, reconhece e aponta singularidades e prepara novas intervenções em sua extensão. O plano propõe agir simultaneamente sobre a infraestrutura e sistema viário, realizando uma recuperação ambiental e criando um novo espaço público. Trata-se de uma operação ambiciosa que depende, de certa forma, tanto da qualidade como da concretização de suas ações.

Na primeira hora da tarde em junho de 2013, Caio Silva guiou um grupo de estudantes e professores da Faculdade de Arquitetura em um passeio por todo o Bairro Marconi. Fomos para preparar um workshop de projetos na Universidade de São Paulo, para fazer um projeto de intervenção em Marconi (uma das partes de Casavalle onde aproximadamente 4000 pessoas vivem) e necessitávamos conhecer o lugar de antemão. O "Workshop Marconi" tomava como ponto de partida a iniciativa de melhoria no bairro do "Plano 7 zonas" que a Prefeitura de Montevidéu estava analisando junto ao Conselho Casavalle e o Ministério do Interior. Caio "referente do local", como se chama na gíria das organizações sociais, uma pessoa conhecida e conhecedora no bairro que 
goza de maior estigma de Montevidéu, como zona vermelha, como lugar de tráfico e consumo de drogas, permitiu a visita inimaginável sem a sua companhia.

Atualmente, em 2018, Caio integra, como suplente, o Conselho de Vizinhos do Município D e tem uma trajetória de participação e organização no bairro. Aos 7 anos um policial matou equivocadamente seu tio, isso aconteceu na zona onde viveu toda sua vida. Por conta da violência em Marconi, policial particularmente, um jornalista narrou o relato de Caio:

Como foi dado pelo seu tio, debulha um rosário de estórias de maltrato
policial que encheria essa matéria. Ultimamente a mais conhecida é a de
"Bebe", Alvaro Sosa: foi assassinado por um policial em outubro de 2012
com atestado de impunidade certificado pela Prefeitura de Montevidéu e
pelo Poder Judicial. [...] Sabemos que Marconi é uma zona conflituosa. No
entanto, durante anos a Polícia cometeu uma quantidade enorme de
abusos. Vamos afiançar, que aqui nem todo mundo é delinquente. Aceito
que atire em quem anda roubando e o que queira, mas se eu estou na
esquina a Polícia não tem porque me insultar e mandar que desapareça
dali. Não vou coisa nenhuma. Porque é meu bairro e aqui vou estar todos
os dias do ano. (ACOSTA, 2015, tradução nossa)

Silva nos mostra o funcionamento do Bairro, descreve tanto a atividade econômica legal como a ilegal, fala com trabalhadores municipais que iniciam a recuperação do espaço junto ao anfiteatro Marconi, um espaço de espetáculos abandonado onde, embaixo do cenário repleto de lixo, alguns garotinhos dormem sua soneca de crack, cumprimenta todos os vizinhos, a maior parte dos que estão na ativa trabalha como reciclador nos terrenos em que vivem. Nosso passeio termina numa pracinha triangular ao final da Orla do Riacho Casavalle. Falando nas dificuldades para conseguir trabalho quando se vive em Marconi, perguntamos pelos cursos do CEDEL Casavalle. Responde: "as pessoas de Marconi não vão ao CEDEL que fica lá longe". A 600 metros, com portas abertas o CEDEL faz capacitação laboral com várias atividades e oficinas, incubando empreendimentos e articulando demandas de produtos entre produtores dispersos. A fragmentação atinge também aos militantes mais envolvidos.

Em 2012 surge no Governo Nacional a "Estratégia pela Vida e Convivência" oriunda do Ministério do Interior e dirigida pelo Sociólogo Gustavo Leal. Uma de suas linhas de trabalho se enfoca na População em situação de pobreza extrema (indigência e vulnerável à indigência) equivalente neste momento a $5 \%$ dos lares. A estratégia se territorializa no "Plano 7 zonas" identificada como um dos maiores núcleos de pobreza do país. Uma delas encontra-se em Casavalle: o Bairro Marconi. O acordo entre os Planos, 7 zonas e Casavalle permite a melhoria local de Marconi e por sua vez decide 
na instalação de uma Praça de convivência, a atual Praça Casavalle, num terreno baldio que na interseção do Bulevar Aparício Saravia com o Eixo Cívico do Plano Casavalle. Este processo, possibilitado pela presença do Conselho Casavalle, permitiu adotar uma política específica e segmentada dirigida ao Marconi de um olhar global de toda a Bacia. Se o Eixo e a Praça consolidam-se, Marconi ficará mais perto do CEDEL.

\section{De muitos lugares é possível Ver o casavalle}

O panorama de fragmentação se mostra evidente ao se analisar a pesquisa realizada com os moradores no marco do Plano, nela se estuda a identidade territorial de seus habitantes mediante a seguinte pergunta: "Poderia dizer como se chama este bairro?" Isso nos permite medir a subjetividade em relação ao âmbito físico que cada morador se sente parte. As zonas menos críticas de Casavalle reference-se a bairros ou setores instalados de reconhecimento público, como zonas consolidadas da cidade, por outro lado na Zona 1, as respostas se referem a pequenos setores ilegíveis para quem não conhece profundamente a zona.

Os moradores da zona 1 carecem completamente de qualquer referência comum sobre o bairro: a pergunta de como se chama seu bairro foi respondida de 51 formas distintas. Isso poderia indicar a presença de fortes barreiras culturais e simbólicas que mantêm separadas essa zona do resto da cidade e, portanto, seus moradores geram identidades de resistência muito diminutas territorialmente (associadas geralmente ao assentamento, a cooperativa, ao conjunto habitacional, a unidade menor) que lhes permite diferenciar-se e evitar dessa maneira um olhar estigmatizante desde fora. Este é um aspecto a ser levado em conta no momento de pensar o alcance territorial das propostas e projetos. (IM, 2018).

A Casavalle "depósito estigmatizante" é habitada por 89.000 pessoas e tem, dessa forma, uma taxa de crescimento de $7,3 \%$ entre os censos de 2004 e 2011 , o que resulta em uma alta significante se comparado com a queda no estado de Montevidéu (-0,07\%), e com os níveis de crescimento nos outros estados da Área Metropolitana: Canelones $(+0,96 \%)$ e São José $(+0,68 \%)$ e o quase estancamento da população nacional $(+0,19 \%) .7 .000$ novos habitantes (que chegam ou são nascidos) neste período é uma cifra enorme para Casavalle, e um produtor de segregação.

"Desde muitos lugares é possível ver Casavalle", este é o título de uma reportagem que duas professoras da zona enviaram ao jornal La Diária, em reação a cobertura 
sensacionalista e deformada de um canal de televisão sobre o dia em que se realizaram festas de final de ano escolar e houve algumas ameaças de conflito armado entre grupos de narcotraficantes. Elas contrastaram algumas das diversas visões e exigem que os meios de comunicação e a cidadania tenham uma atenção profunda sobre um lugar que tende a ser simplificado: zona vermelha, violência, narcotráfico, etc.

O entendimento complexo que as professoras reclamam enriquece com estes pontos de vista:

\begin{abstract}
Mas ainda assim, a prisão é um dado muito possível para estas populações, como também o é a morte na juventude. Um jovem infrator que entrevistei começou a lembrar-se de seus amigos e que somam uns 10 mortos antes dos 20 anos e alguns que ficaram incapacitados por tiros da Polícia, ou pelo pior inimigo de um narcotraficante: outro narcotraficante. (PEREYRA, 2018, tradução nossa)
\end{abstract}

O processo de criação de identidade, ameaçado permanentemente pela estigmatização sustenta desde o bombardeio midiático, e se vê dificultado ante a negação da possibilidade em si mesma, desprovido de material em uma vida cotidiana sofrida como uma eterna transitoriedade em um alto grau de efervescência. Vizinhos de uma mesma passagem, em uma mesma viela, de algum caminho compartilhado dentro de um assentamento, rejeitam a existência do outro. A polis enquanto configuração de cidadãos, intersubjetividade produtora de vínculo, emerge de maneira descontínua e fragmentada, implicando em um esforço gigantesco por parte dos vizinhos que se mobilizam em diferentes redes locais. Os vizinhos, além de ter que "trabalhar para trabalhar", sobrecarregados por uma economia excludente e precária, têm de tomar em suas mãos o destino do espaço público transbordado de lixo, revolvido por perdigueiros infectados, ratos e baratas. (ALVAREZ PEDROSIAN, 2013, p.278, tradução nossa)

Trabalhamos em um bairro de gente trabalhadora, de crianças que fazem oficinas na praça, de famílias que compartilham cuidados, de adolescente que de pouco tempo para cá têm uma escola de ensino médio, de calçadas cheias de verde e jardins. Também é uma zona em que o narcotráfico demonstra todo seu poder territorial. Ali se reproduz uma lógica capitalista onde os poderosos se valem da pobreza para lucrar como bem entender. Neste lugar decidimos trabalhar e entendemos essa comunidade como parte da construção pedagógica que realizamos em conjunto e de portas abertas. Estamos ali para fazer nosso trabalho, que nada mais é do que ensinar a o que é justo e que todas e todos aprendam. (COUSILLAS e MICHELENA, 2017, tradução nossa)

\title{
EQUIPAMENTOS CASAVALLE
}

Da arquitetura também é possível ver Casavalle.

Entender a possibilidade de um compromisso é um papel específico na superação destas problemáticas, associada a um trabalho disciplinar e em diálogo com outras disciplinas. 
A associação de equipamentos em um território produz o encontra entre diferentes programas púbicos e habilita desta forma uma sinergia que potencializa a ação de cada parte, este é o ponto de partida desta investigação.

Desta hipótese estudam-se, um a um, os principais equipamentos que funcionam em Casavalle, visando a formação de um catálogo de Equipamentos de Casavalle.

\section{SACUDE}

Atletismo, animações juvenis, basquete, canto para crianças, capoeira, cerâmica, circo, contos e plástica, esportes coletivos, futebol adolescente feminino e infantil misto, voleibol, hip-hop, karatê, patinação, recreação, teatro, boxe, combate ao fumo, eternas primaveras, reforço escolar, ginástica para adultos, crianças, grupos de obesos, grupos para "Rádio Língua Livre", musculação, dança, salsa, candombe e comparsa, taichi, oficina literária, zumba, apoio a leitura, percussão de candombe, violão, entre outros. Essa é a lista de atividades semanais do SACUDE que funciona com uma agenda abundante, coadministrada pelos vizinhos, técnicos da Prefeitura e do Município. Está localizado ao norte de Casavalle e é parte de um bairro de promoção pública municipal. A reforma e ampliação foi realizada em 2010 através da regularização fundiária de três assentamentos da zona: Bairros Unidos, Curitiba e 3 de Agosto. Os programas de melhorias nos bairros (PMB) exigem uma parte do orçamento que se dedique à geração de espaços públicos e equipamentos. Os vizinhos decidiram abrir mão do investimento em suas moradias e dedicar um percentual (muito superior ao mínimo exigido) para construir em conjunto esse Complexo. O investimento foi de $40 \%$ do total do orçamento de 900.000 dólares.

O SACUDE oferece acesso a cultura, esporte e saúde aos vizinhos e instituições de todo Casavalle e zonas próximas. Mais de 2500 pessoas por semana participam de suas atividades e a policlínica atende mais de 3000 pessoas. A programação esportiva, recreativa e cultural funciona durante todo o dia.

O edifício atual é integrado pela ampliação do Clube Municipal, construído em 1941, como equipamento das moradias municipais, e a policlínica Los Angeles que funciona há mais de 25 anos. Um grande ginásio com espaços complementares define a área esportiva. O teatro é um enorme galpão com equipamento técnico básico. Os espaços comuns, os degraus e alguns espaços externos estão frequentemente cheios de gente, 
alguns esperando, outros se encontrando ou pessoas que passam e se conectam a internet.

O maior e mais concorrido equipamento de Casavalle foi promovido em sua gestação, por um esforço privado e não público: realizado pela comunidade dos assentamentos organizada no marco de sua regularização. Muitos recursos públicos permitem o funcionamento, direcionados a gestão e a remuneração dos professores e animadores.

O SACUDE é um espaço desespecializado que opera em grandes espaços neutros que são geridos e mudam ao longo do tempo. Seus 2000 metros quadrados são dedicados $60 \%$ ao esporte e $25 \%$ a atividades Sociais e Culturais. A agenda de atividades mostra que a delimitação entre estas áreas programáticas que instrumentalizam o nosso estudo e rígida demais para representar a vida do complexo.

\section{Centro cívico luisa cuesta}

O Centro Cívico Casavalle Luisa Cuesta foi apresentado em um relato que nos conta sobre a condição sui generis do espaço público em Casavalle e da importância dos equipamentos como espaços públicos, para além de sua programação particular.

De iniciativa municipal e inscrita no Plano Casavalle foi inaugurada em 2015, embaixo das abóbadas onde originalmente funcionava a policlínica da Unidade Casavalle. A substituição programática outra vez sustenta o argumento da desespecialização.

O Centro está em frente à Praça, inaugurada dois anos antes, formando um par cívico sinérgico. De seus $560 \mathrm{~m}^{2}$, cede uma porção ao contíguo Jardim de Infância. O Espaço de Atenção Cidadã com seus $110 \mathrm{~m}^{2}$ de salas compartilhadas ao longo da semana, com dias de atenção fixos por diversas repartições públicas, oferece serviços únicos em Casavalle de trâmites públicos, operando com um Polo de Atenção Cidadã (PAC), além de oferecer atenção e orientação cidadã dentro dos programas do MIDES. A biblioteca define o programa principal do Centro.

\section{CEDEL}

O Centro de Desenvolvimento Econômico e Local fundado em 2007 assume dois papeis fundamentais, o de Promoção e Capacitação para o trabalho. Tem um perfil diverso comparado aos perfis de formação e de empreendimentos que apoia ou empresta suas instalações. Atende a população de toda a Bacia, e em alguns projetos de Promoção relaciona-se com pessoas e empresas espalhadas por toda a cidade. 
Seus espaços se dedicam principalmente ao trabalho e emprego embora uma parte dessas áreas se utilize em formato de Capacitação, que assume a espacialidade e as demandas de um equipamento educativo convencional.

Como parte de um Convênio com o Ministério de Educação e Cultura (MEC), a Usina Cultural Casavalle funciona no edifício. Embora o centro seja especializado existe alguma margem para a abertura de articulações institucionais.

O edifício se define por dois Pavilhões separados. Um vinculado às atividades públicas, incluindo a capacitação e outro vinculado às atividades produtivas.

\section{ABRANGÊNCIA TERRITORIAL}

Um estudo real da cobertura territorial de cada um dos equipamentos permitiria medir a capacidade dos equipamentos para servir como referência em todo Casavalle. Isso também permitiria calibrar a incidência da fragmentação social e cultural que domina a zona. A partir dos dados recolhidos tanto no SACUDE como no CEDEL alguns elementos são fornecidos e permitem verificar a presença real no território.

\section{OUTROS EDIFícIOS}

O conglomerado de equipamentos públicos se forma por um conjunto de edifícios de equipamentos. Nesta apresentação aprofundou-se o estudo e a descrição dos que tem um papel central na construção do Fórum Casavalle, embora a rigor todos os edifícios e espaços públicos dão forma a esse conglomerado. 


\section{CATAlogo equipamentos CASAVAlle}
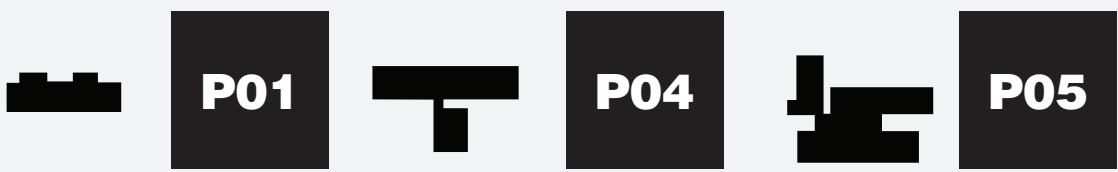

\section{CAIF}

Autor: Arquitectura INAU

Ano: 2018 e anteriores.

Localização: Casavalle, UY

V02 Pg 502

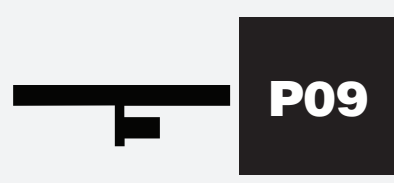

ESCOLA 178

Autor: sd

Localização: Casavalle, UY

V02 Pg 519
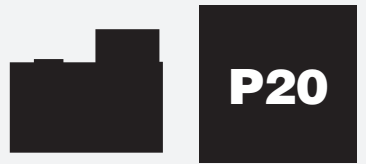

\section{SACUDE}

Autor: Int. Montevideo. PIA

Ano: 2013

Localização: Casavalle, UY.

V02 Pg 535

\section{ESCOLA 320}

Autor: sd

Ano: sd

Localização: Casavalle, UY.

V02 Pg 506

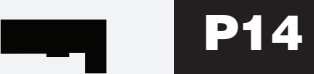

POLiclinica Casavalle Ano: 2012

Localização: Casavalle, UY.

V02 Pg 523

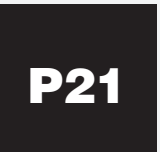

CEDEL

Autor: Int. Montevideo. Arqs. Morán e

Sandoval.

Ano: 2004

Localização: Casavalle, UY

V02 Pg 541 Autor: IM DIv. Saude. Arq. M. Gregorio
CEA

Autor: PAEMFE Arq. Andrea Gnesett

Ano: 2017

UY

V02 Pg 510

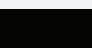

\section{P18}

\section{COMISARIA}

Autor: Ministerio Interior. Sd. Ano: 2013

Localização: Casavalle, UY.

V02 Pg 527

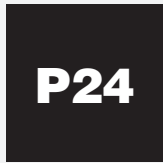

\section{Centro cívico}

CASAVALLE

Autor: Int. Montevideo. Arq. Juan Díaz Ano: 2014

Localização: Casavalle, UY.

V02 Pg 546
Localização: Casavalle, Montevideo.

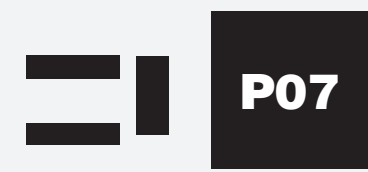

\section{ESCOLA CHINA}

Autor: PAEPU Arq. Lucía Lombardi Ano: Projeto

Localização: Casavalle, UY.

V02 Pg 514

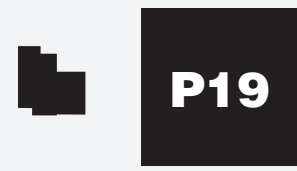

\section{BOMBEROS}

Autor: Dir. Bombeiros. Luis E. Salesi Ano: 1988

Localização: Casavalle, UY.

V02 Pg 531 
Fig.5. Página do livro "El medio es el masaje" de McLuhan e Fiore, 1988.

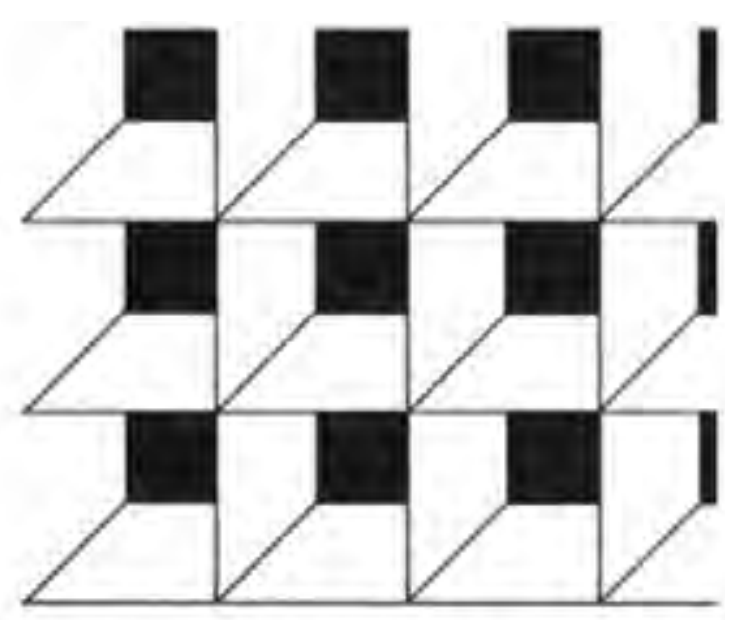

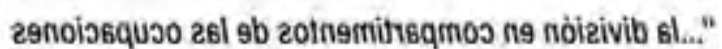
gtngmnùmos bebivitjs 9 b oqit 929 sา6q92 292919tni s

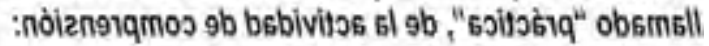

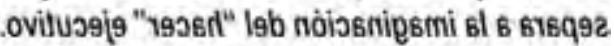
,1spul uz snpizs sl 92 zabsbivitos zв29 9b snu sbsว A. - otene al ngdhazab gup zol :9279ngtnern gdgb abnob

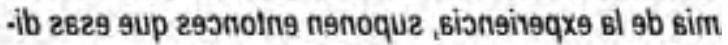
sl gb smeim nöisufitznos sl E zgtnפาgrini noz z9noiziv Y9w9Q nidol.

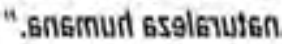




\title{
1.ECM.7 DESTACAMENTOS
}

\begin{abstract}
A divisão em compartimentos de ocupações e interesses separa esse tipo de atividade normalmente chamada de "prática" da atividade de compreensão: ela separa a imaginação do "fazer" executivo.

Cada uma dessas atividades é atribuída ao seu lugar, onde deve ser mantida; aqueles que descrevem a anatomia da experiência, supõem então que essas divisões sejam inerentes à própria constituição da natureza humana. (DEWEY, 2008, p.24)
\end{abstract}

Os equipamentos são, voltando ao início, na definição da RAE: dispositivos necessários em industrias, urbanizações e exércitos. A departamentalização e isolamento que os equipamentos são dispostos no território, nos leva a pensar que a pratica pública atua como seus equipamentos como se tratasse mais de um exército que de uma cidade. Desde este ponto de vista os equipamentos seriam destacamentos como os militares, setores da tropa destacados num local particular para cumprir uma missão especifica, uma função.

A visão contrária aos destacamentos é aquela que prioriza o sentido dos equipamentos pela sua capacidade de gerar "capital social" e produzir lugares. O sociólogo urbano colombiano Mayorga Henao (2008) estuda os equipamentos além de sua função especifica e propõe uma visão sistemática:

Essa abordagem foi feita sob a hipótese de que somente esses espaços permitem gerar processos comunicativos que propiciem o conhecimento entre diferentes grupos da sociedade, interajam e proponham respostas, aos problemas apresentados por seu espaço de vizinhança, primeiro, e ao espaço de a cidade, em segundo lugar.

Desta forma, considerou-se que em qualquer intervenção urbana, envolvendo a integração física dos habitantes pobres da cidade, as instalações coletivas não devem ser entendidas simplesmente como um espaço físico ou material para uma determinada função, mas devem ser planejadas antes de tudo como lugares com um significado, onde se pode construir histórias e representações, a partir da possibilidade do encontro. Motivo porque, no processo de planejamento de equipamentos coletivos, pensava-se que, para serem efetivamente e eficientemente usufruídos, não poderiam ser distribuídos casualmente, uma vez que uma certa sistematicidade deve ser buscada em relação às demais funções e tipologias urbanas. (Ibid.p.197, tradução nossa) 



\section{MORE WITH LESS}

ESTRUTURA DA TESE

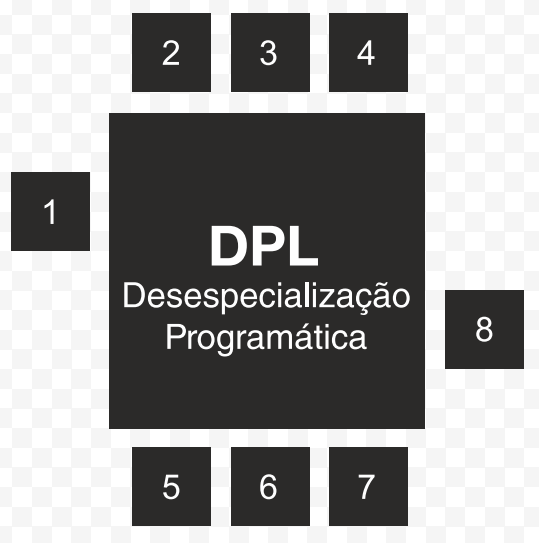




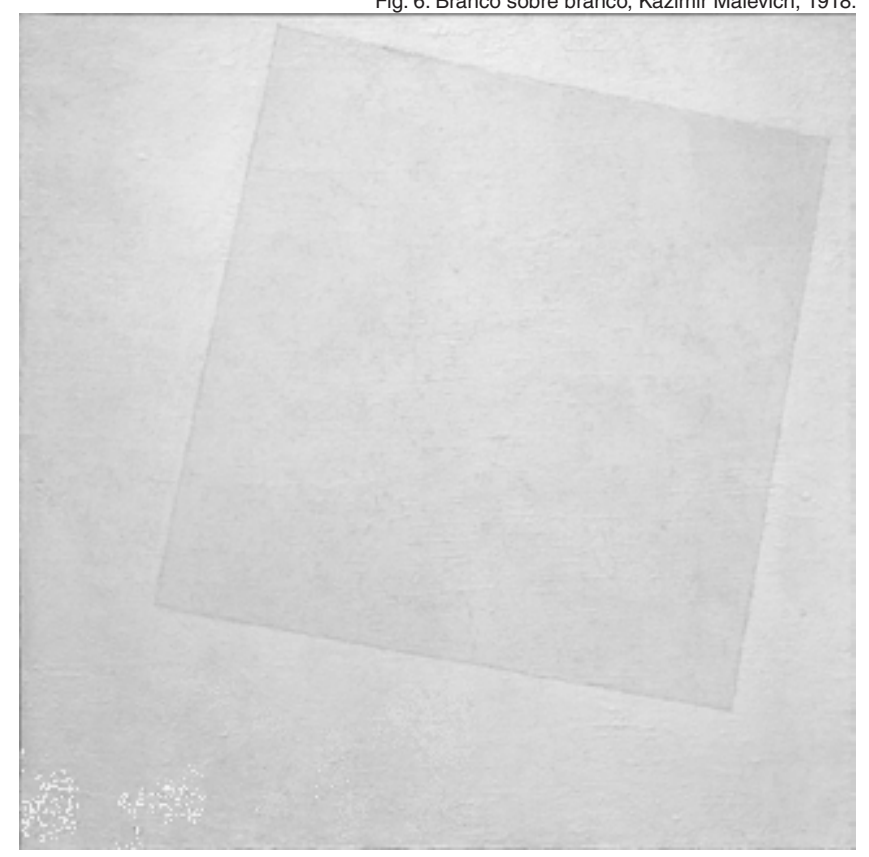




\title{
2.DPL DESESPECIALIZAÇÃo PROGRAMÁtica \\ 2.DPL.1 ESPECIALIZAÇÃO DESESPECIALIZAÇÀO
}

\begin{abstract}
Eu digo, assim "disse Sancho," sendo, como eu falei, vocês dois sentados à mesa, o fazendeiro discutia com o cavalheiro para que ele tomasse a cabeceira da mesa, e o fidalgo também insistia que era o fazendeiro que deveria tomá-la, porque em sua casa ele tinha que fazer o que ele mandasse; mas o fazendeiro, que se julgava cortês e bem criado, nunca o quis, até que o cavalheiro, com as mãos nos dois ombros, o fez sentar à força, dizendo: "Sente-se, teimoso, onde quer que eu esteja sentado, será a sua cabeceira." E esta é a história e, na verdade, acho que não foi trazida aqui fora de propósito. (CERVANTES, 2004, p.790-791, tradução nossa)
\end{abstract}

A desespecialização programática em arquitetura é uma categoria aberta, não se refere a um corte disciplinar ou historiográfico específico, por isso será necessário propor uma definição ao longo deste segundo capítulo.

O conceito e sua operacionalidade distinguem-se da consideração disciplinar autônoma e da absorção nas instrumentalizações técnicas da produção do espaço: projeto, tecnologia, etc. A desespecialização programática deve atender à vida nos espaços, evitando o determinismo funcionalista que supõe práticas únicas e estáveis nesses suportes.

A vida dos edifícios tem sido responsável por transbordar profusamente os limites e utilidades que os arquitetos e sociedades os atribuem quando os produzem.

A especialização é "limitar algo a um uso ou propósito específico"(RAE, 2018). Em termos de arquitetura, especializar-se é limitar um edifício a um uso ou propósito específico, uma ação que é tão desnecessária quanto impossível.

No arbítrio do limite e relatividade de uso é onde a desespecialização se torna uma condição necessária. A especialização projetada é desmontada na prática pela apropriação do espaço dado, e como é pesquisado neste trabalho, é uma ferramenta de projeto. Os momentos embrionários da história urbana ignoram a especialização, eles produzem um espaço carregado de energia potencial. A abertura do uso não é uma decisão, mas sim a consequência do gesto inicial e mínimo, da escassez de recursos. Em seu livro "Las nubes", Juan José Saer narra uma Santa Fé inicial em que há um longo edifício "multifuncional":

A cidade real ocupava alguns quarteirões ao redor da praça, formando ruas de areia, a maioria sem calçadas, paralelas ou perpendiculares ao rio; umas duas igrejas, uma prefeitura, um prédio comprido que era ao mesmo tempo 


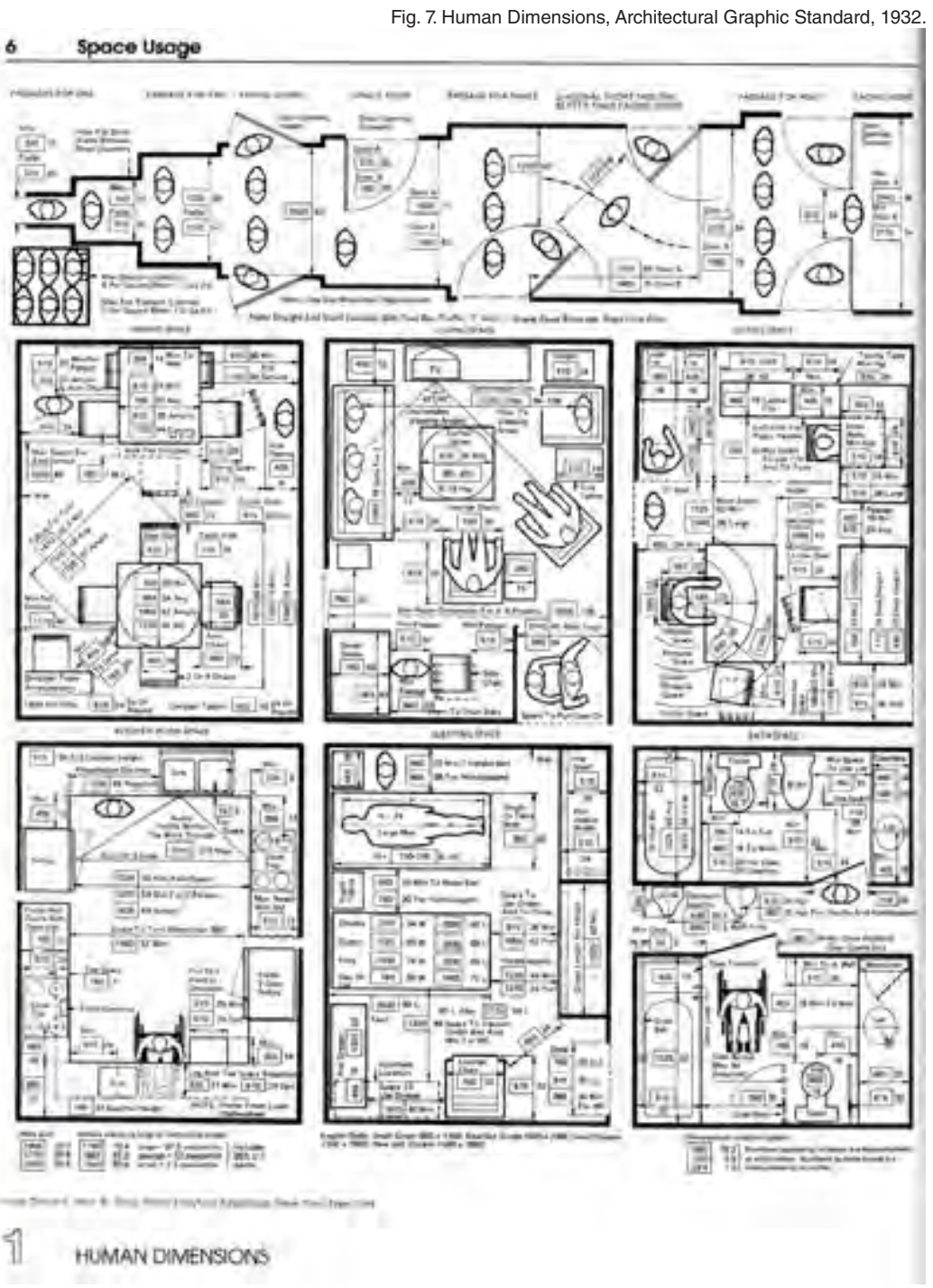


alfândega, prisão, hospital e delegacia de polícia, casas térreas com telhado de telhas e janelas com grades tão baixas que pareciam sair do chão, e também árvores frutíferas laranjeiras, tangerinas e limoeiros carregados de frutos, figueiras e pessegueiros descascados pelo frio, nespereiras, campos de cactos de tuna, enormes acácias, jacarandás, ipês, paineiras, ceibos e muitos salgueiros que traíam a onipresença da água. (SAER, 2002, tradução nossa)

A especialização de tipo biológico é um processo que produz "a adaptação de um órgão ou parte para servir uma função especial ou acomodar uma maneira de vida particular". A definição poderia vir (como realmente acontece) do dicionário Oxford da Língua Inglesa, ou de um manual funcionalista em arquitetura. ${ }^{1}$ A desespecialização programática exige a possibilidade de um distanciamento calculado entre o desenho da parte (construção ou espaço) e as circunstâncias mais concretas que definem o modo particular de vida (as demandas que se originam em uma circunstância específica a criação de um edifício ou espaço).

Nem tanto a insistência da mensagem recorrente "a forma segue a função"
entendida como as formalizações espaciais geradas diretamente a partir de
funções específicas, mas o fato de entender "espaço como material de
programação". O espaço como potencializador de múltiplos usos, o espaço
como condição física para estabelecer relações e como o último atractor das
ações. Dar espaço para nossas ações.(SANTACANA, 2013, p.257, tradução
nossa) Desespecializar, em oposição à especialização, é expandir algo (um edifício, um projeto, um programa, uma cidade, uma política pública) para quantos usos ou fins forem possível e razoável. Ir mais além de circunstâncias concretas de gestação desse algo para amplificá-las em cenários abertos, mais semelhantes à complexidade do mundo do que à segmentação do laboratório. A medida em que a produção é afastada de uma tradução exata e instantânea de determinados modos de vida ou atividades, ela supera a crença da precisão arquitetônica científica. A desespecialização fornece uma abertura que permite que as práticas no espaço sejam redefinidas instantaneamente e em períodos curtos, bem como incorporar transformações nos estilos de vida ao longo do tempo.

A partir dos anos 70, Edgar Morin $(1999,2007)$ estabelece o conceito de pensamento complexo para substituir o conhecimento especializado. A sua filosofia já propõe o paradigma da "distinção/conjunção" para superar o corte anti-sistêmico da

${ }^{1}$ Especialização. 1.2 Biology. A adaptação de um órgão ou parte dele para servir uma função especial ou para se adequar a um modo particular de vida. "A maneira como diferentes músculos são construídos permite a especialização da função", "os morcegos mostram especializações fisiológicas elegantes na esfera auditiva". (OXFORD, 2018, https://en.oxforddictionaries.com/definition/us/specialization) 


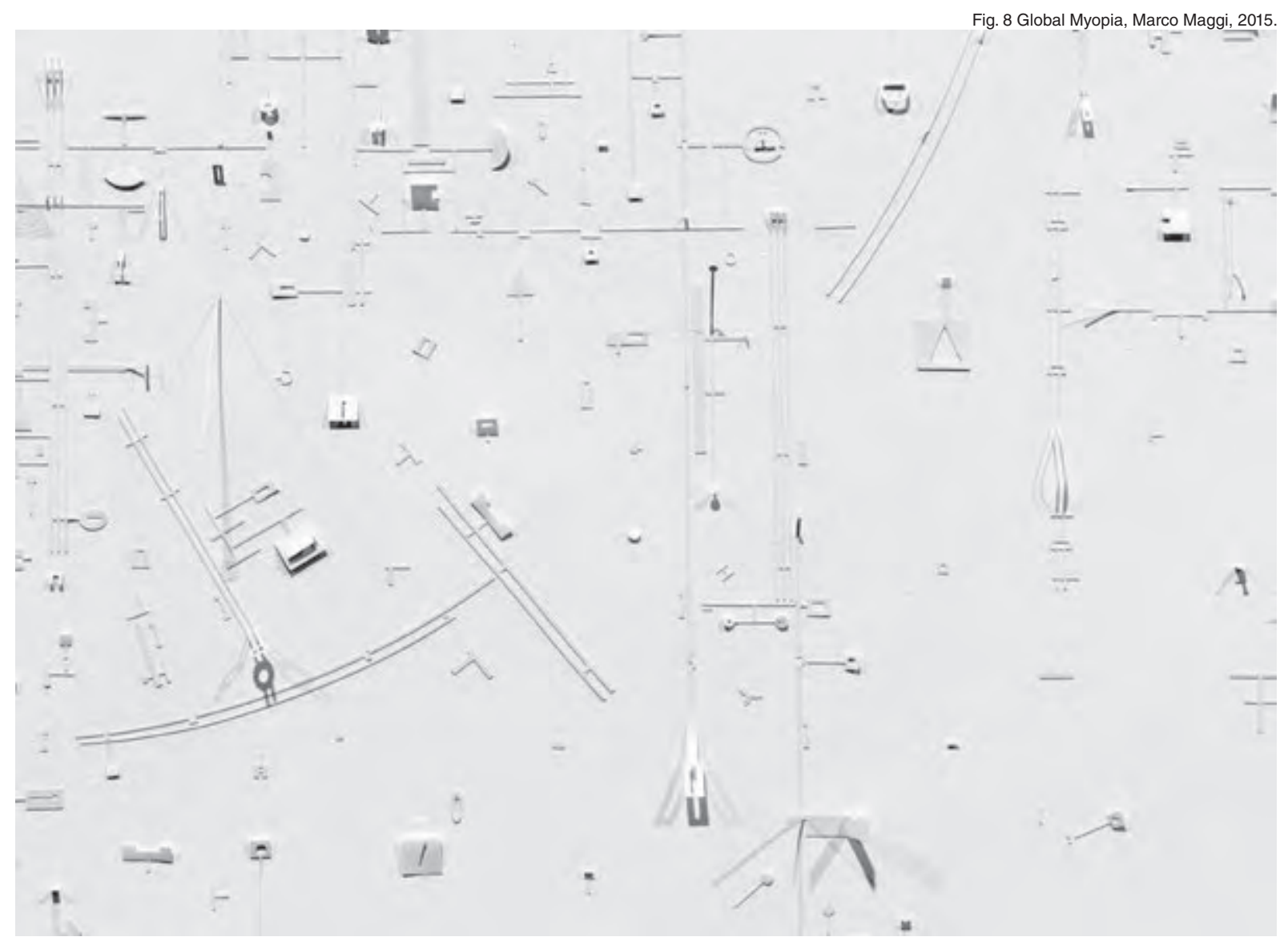


"disjunção/redução/unidimensionalização", que segundo sua interpretação dominou o pensamento científico.

O conhecimento especializado é uma forma especial de abstração. A especialização «abstrai», em outras palavras, extrai um objeto de seu contexto e de seu conjunto, rejeita os laços e as intercomunicações com seu meio, o coloca em um setor conceitual abstrato que é o da disciplina compartimentada cujas fronteiras racham arbitrariamente a sistemicidade (relação de uma parte com o todo) e a multidimensionalidade dos fenômenos. Isso conduz a uma abstração matemática que opera em si mesma uma cisão com o concreto, privilegiando tudo que é calculável e formalizável. A inteligência parcelada, compartimentada, mecanicista, disjuntiva e reducionista quebra a complexidade do mundo em fragmentos separados, fraciona os problemas, separa o que está unido, unidimensiona o multidimensional. É uma inteligência míope que termina normalmente por cegar-se. (MORIN, 1999, p.19, tradução nossa)

A dificuldade do pensamento complexo é que deve afrontar o entrelaçado (o jogo infinito de inter-retroações), a solidariedade dos fenômenos entre si, a bruma, a incerteza, a contradição. Mas nós podemos elaborar alguns dos conceituais úteis, alguns dos princípios para essa aventura, e podemos entrever $\mathrm{o}$ aspecto do novo paradigma de complexidade que deveria emergir. [...] Assim é que, haveria que substituir o paradigma de disjunção/ redução/ unidimensionalização por um paradigma de distinção/ conjunção que permita distinguir sem desarticular, associar sem identificar ou reduzir. (Id., 2007, p.33-34, tradução nossa)

Morin propõe devolver ao sujeito à consideração do pensamento, deslocado pelo pensamento originado no positivismo que entendeu que os objetos com existência independente aos sujeitos poderiam ser descritos de forma autônoma. A ciência contemporânea reivindicou de muitos campos do conhecimento a impossibilidade desse pensamento objetivo absoluto.

Para continuar por onde se começa: em um jogo narrativo sutil de bonecas russas, a cabeceira da mesa se torna o tema no capítulo XXXI da segunda parte do Dom Quixote. Uma discussão sobre a cortesia de se ocupar a cabeceira na casa de um duque que o Dom Quixote vai visitar, termina com o Cavalheiro sentado no lugar privilegiado. A cena pode ser descrita pela pintura de El Greco "La fiesta de Simón" que é contemporânea ao texto de Cervantes. Sancho perturba a conversa trazendo uma discussão anterior sobre a cabeceira da mesa, que é onde esta seção começa. A mesa é um objeto, uma figura retangular de relativa neutralidade, sobre a qual se sobrepõe uma construção cultural que dá proeminência e poder à cabeceira. Uma produção simbólica baseada nas leis da geometria qualifica um dos lados menores do retângulo. Desconstruindo a convenção cultural, a estória ilustra uma prática de desespecialização simbólica: para Quixote não será o espaço que organiza a singularidade e a autoridade, 


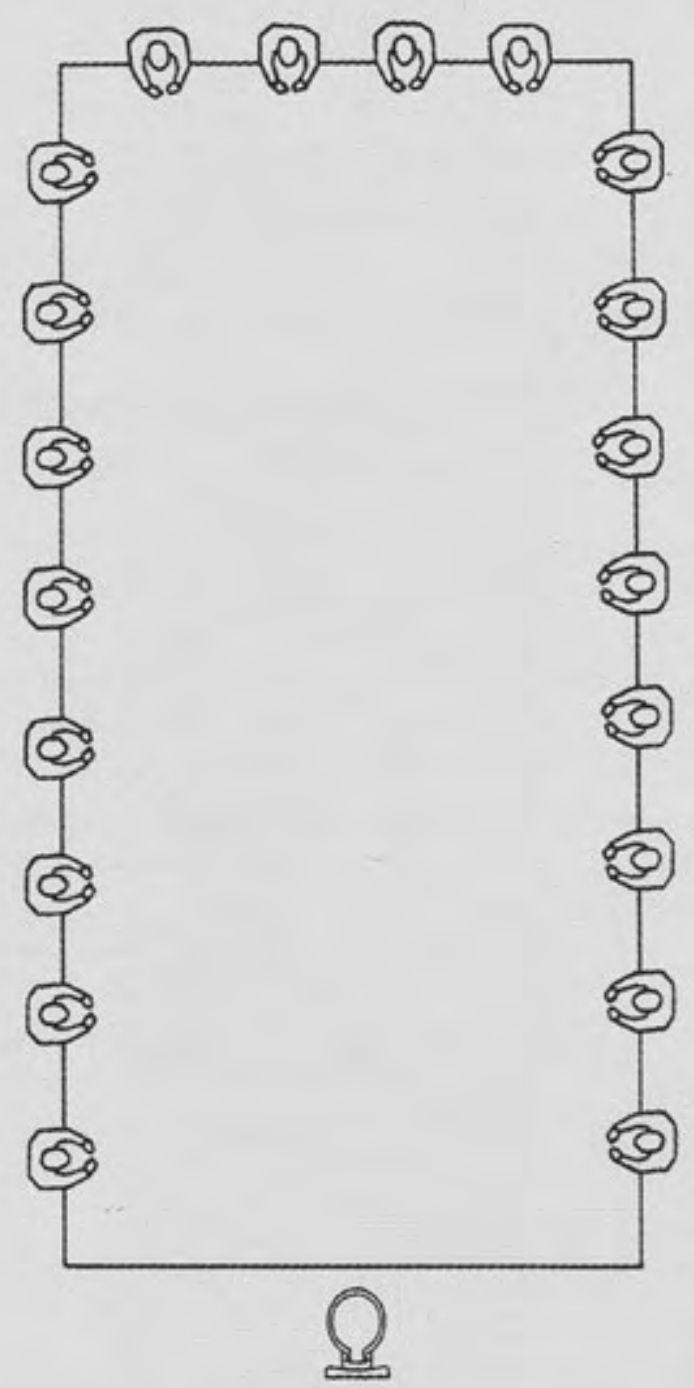

की 
mas sim há uma produção subjetiva autônoma do objeto, a forma e a convenção, um agregado de "informação" que redefine os papéis: "Sente-se, teimoso, onde quer que eu esteja sentado, será a sua cabeceira.' Este é o conto e, na verdade, não acho que tenha sido trazida aqui fora de propósito." (CERVANTES, 2004, p.791, tradução nossa) 
Fig.10. Faculdade de Arquitetura, Nantes, Francia.

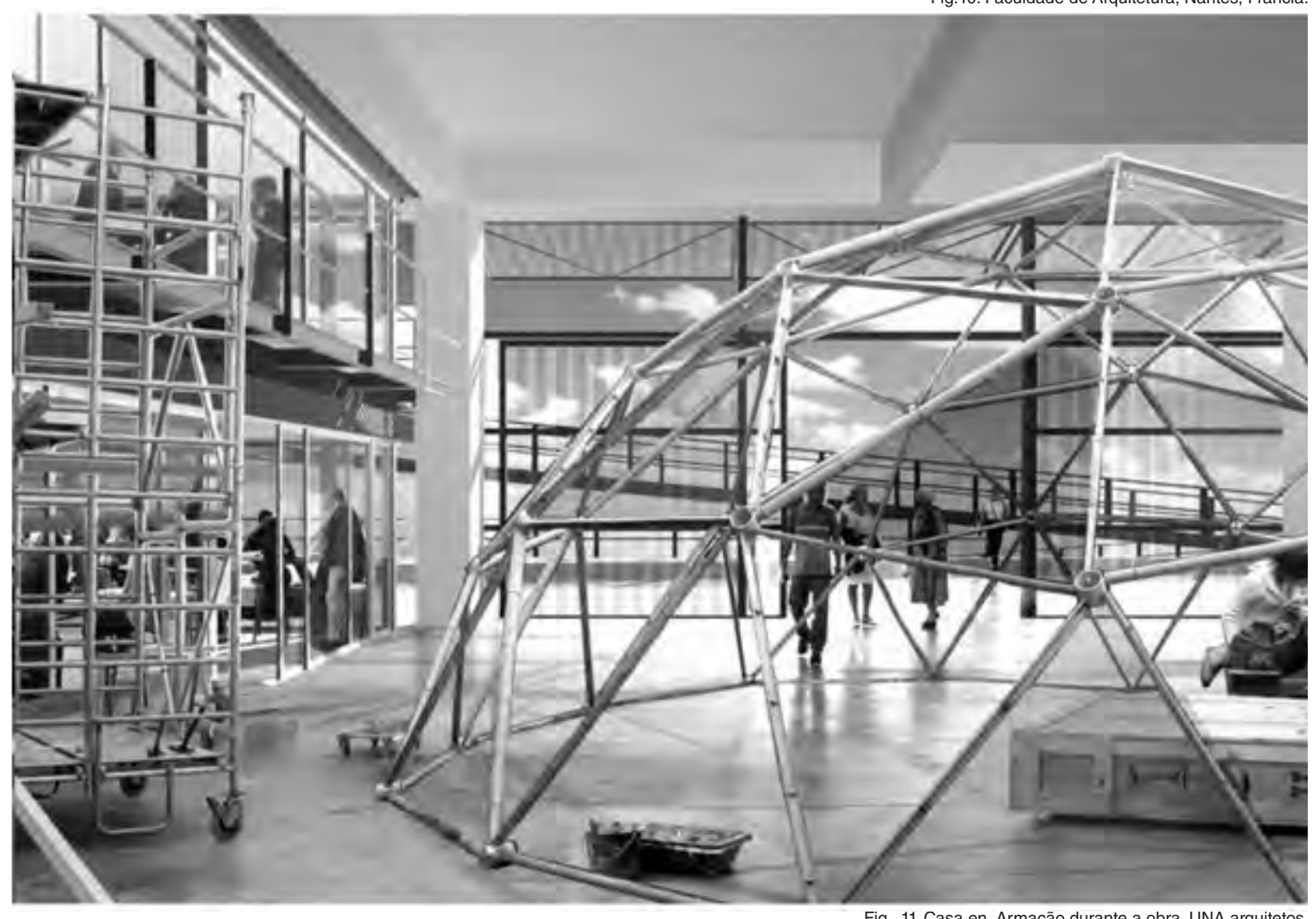

Fig 11. Casa en Armacāo durante a obra. UNA arquitetos.

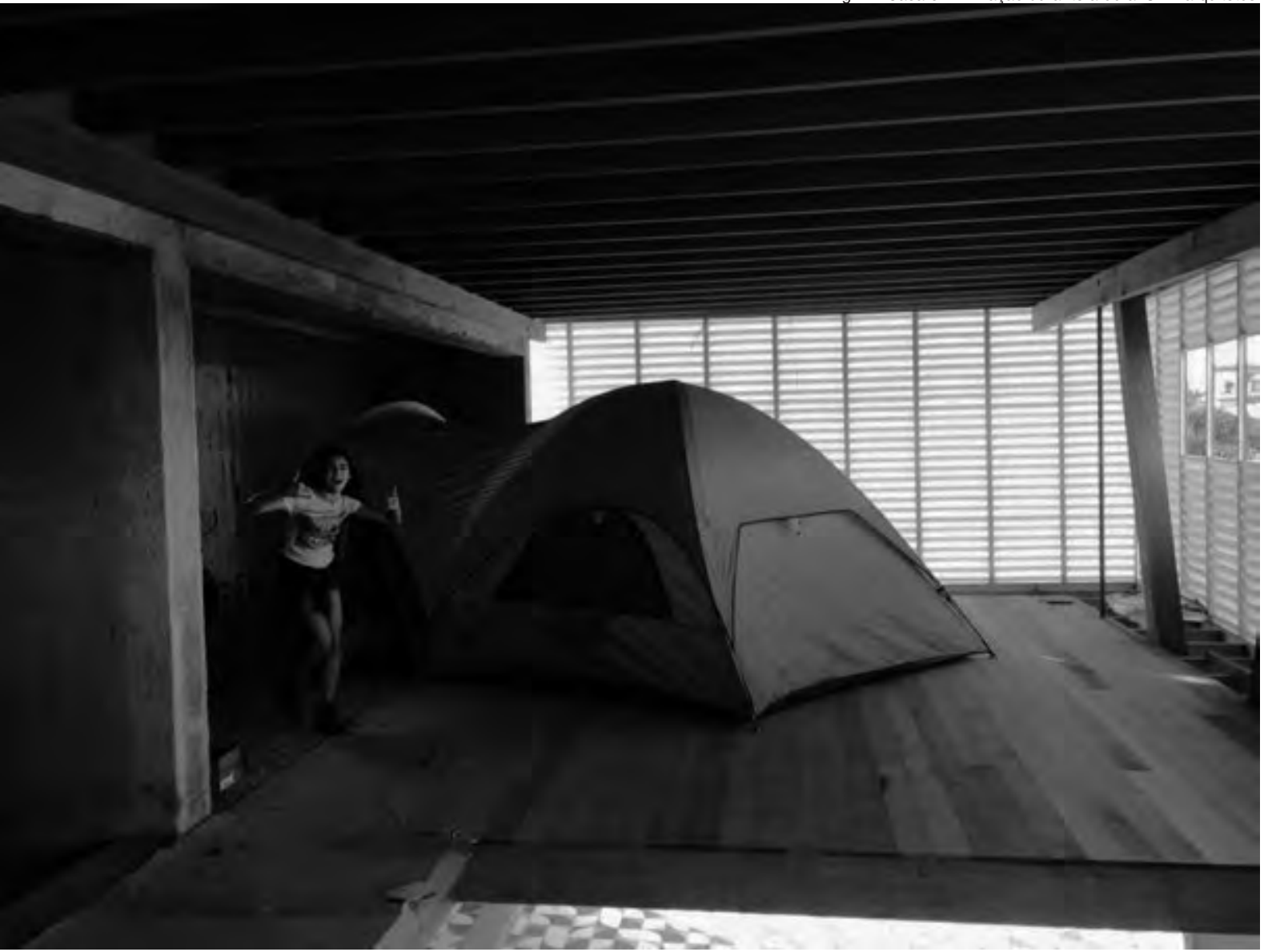




\title{
2.DPL.2 PROGRAMA FUNÇÃO ESPAÇO
}

\author{
Para os muitos casos do uso da palavra "significado" - mas não para todos \\ os casos - esta palavra pode ser explicada como segue: O significado de \\ uma palavra é seu uso na linguagem. (WITTGENSTEIN,1999, p. 23, \\ tradução nossa)
}

Paráfrase ao Wittgenstein como liminar para uma abordagem do programa a partir da desespecialização: Os espaços são (podem ser, embora não para todos os casos) o que as práticas (as disciplinas de arquitetura no projeto e as indisciplinadas no espaço dado) estabelecem sobre elas, independentemente dos "significados", as atividades que uma sanção nominativa chamada programa funcional, estabelece para eles.

Esta tese propõe uma abordagem do espaço arquitetônico a partir do paradigma da complexidade que implica a relação necessária entre objetos e sujeitos. Os objetos e sua relação com os sujeitos, que produzem o espaço habitado. O projeto da desespecialização é o caminho para multiplicar os possíveis usos de um espaço entendido como espaço capaz ou potencial.

O programa é um termo incorporado na disciplina, um componente da prática que estabelece uma visão codificada e supostamente de pré-projeto. A etimologia confirma essa condição: "Pré (anterior), Grama (escrita, grafia). Antes de escrever, antes de desenhar." (SANTACANA, 2013, p.21) Programa de acordo com os dicionários da RAE e Oxford refere-se a uma projeção para o futuro, onde as ações são prefiguradas de uma maneira geral ou detalhada. Um programa pode ser um programa político carregado de intencionalidade e ideologia.

Ao mesmo tempo, também se refere ao mundo da informática, abrindo novas camadas de significado, que esta tese explora com base na distinção bem conhecida entre hardware e software.

O programa e sua relação com o projeto sob a fórmula de utilitas acompanha a arquitetura desde que foi pensada como uma disciplina, com o primeiro tratado de sistematização arquitetônica que foi formulado como um espaço de articulação entre prática e reflexão, ainda quando a arquitetura e a construção pareciam fusionados. Em "De Architectura", Vitruvio formula a tríade Venustas, Firmitas y Utilitas. Geneticamente, o prédio parece fixo para o seu uso. O tratado, uma ferramenta de divulgação de conhecimento acumulado, abrange questões de natureza diversa sobre arquitetura como um fato técnico e estético em sua relação com ordens canônicas, é dedicado em 


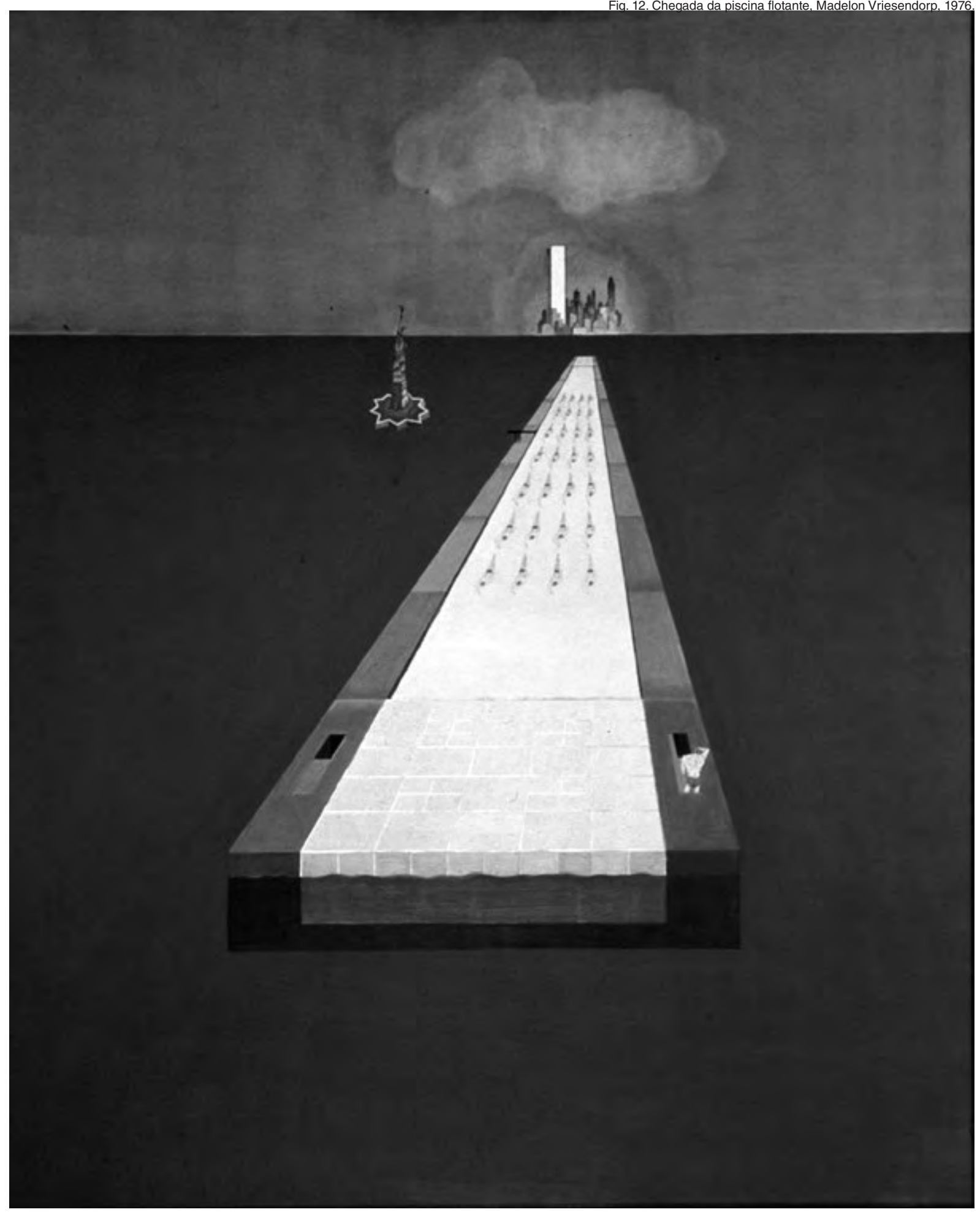


parte aos problemas de disposição e distribuição de diferentes famílias de arquitetura: religiosas e civis, isto é, arquitetura pública e também privada. Vitruvio dedica um de seus 10 livros para estabelecer regras gerais para o projeto de diferentes tipos de edifícios: Fóruns, Basílicas, Erários, Prisões, Curias, Teatros, Banheiros, Estádios, Portos e Estaleiros.

O vínculo entre o espaço e o uso é um fato histórico cuja permanência é sustentada por Renato de Fusco: "Vitruvio tem valor não apenas pelo que define e transmite da cultura antiga, mas sobretudo pelo que gerou na cultura moderna" (DE FUSCO², 1968, p.112113. apud PATETTA, 1984, p.85, tradução nossa). Vinte séculos depois, alguns discursos e práticas do movimento moderno promovem uma posição "cientificista" da arquitetura baseada em uma pretendida consideração sistemática do programa.

\section{PARA O PROGRAMA: BASÍlicas}

Era lógico que quisessem ir para a os Estados Unidos, especialmente para Nova York. De certa forma, a piscina era uma quadra de Manhattan feita em Moscou que alcançaria seu destino natural. Certa manhã, em plena década stalinista de 1930, os arquitetos se afastaram de Moscou, nadando incessantemente em grupos em direção das lâmpadas douradas do Kremlin. (KOOLHAAS, 2004b, p.307-308, tradução nossa)

Como os nadadores soviéticos de "O conto da piscina", que conseguem mover a piscina flutuante no mar, apenas se eles nadam dentro dela na direção oposta a para onde querem ir, este texto se volta para trás para moldar a ideia de desespecialização programática.

Como nos propõe Agamben, a condição da contemporaneidade só é entendida com uma certa construção intencional que revisita criativamente seu passado a partir de hoje.

\footnotetext{
"Isso significa que o contemporâneo não é apenas aquele que, percebendo as trevas do presente, compreende a luz incerta. É também aquele que, dividindo e interpolando o tempo, é capaz de transformá-lo e de colocá-lo em relação com outros tempos, de ler a história de maneira inédita, de "citála" segundo uma necessidade que não provém de jeito nenhum da sua vontade e sim de uma exigência a que ela não pode responder. (AGAMBEN, 2006, tradução nossa)
}

Formular a desespecialização do programa implica compreender como a noção de programa é definida na história da arquitetura: o programa como uma categoria e sua 


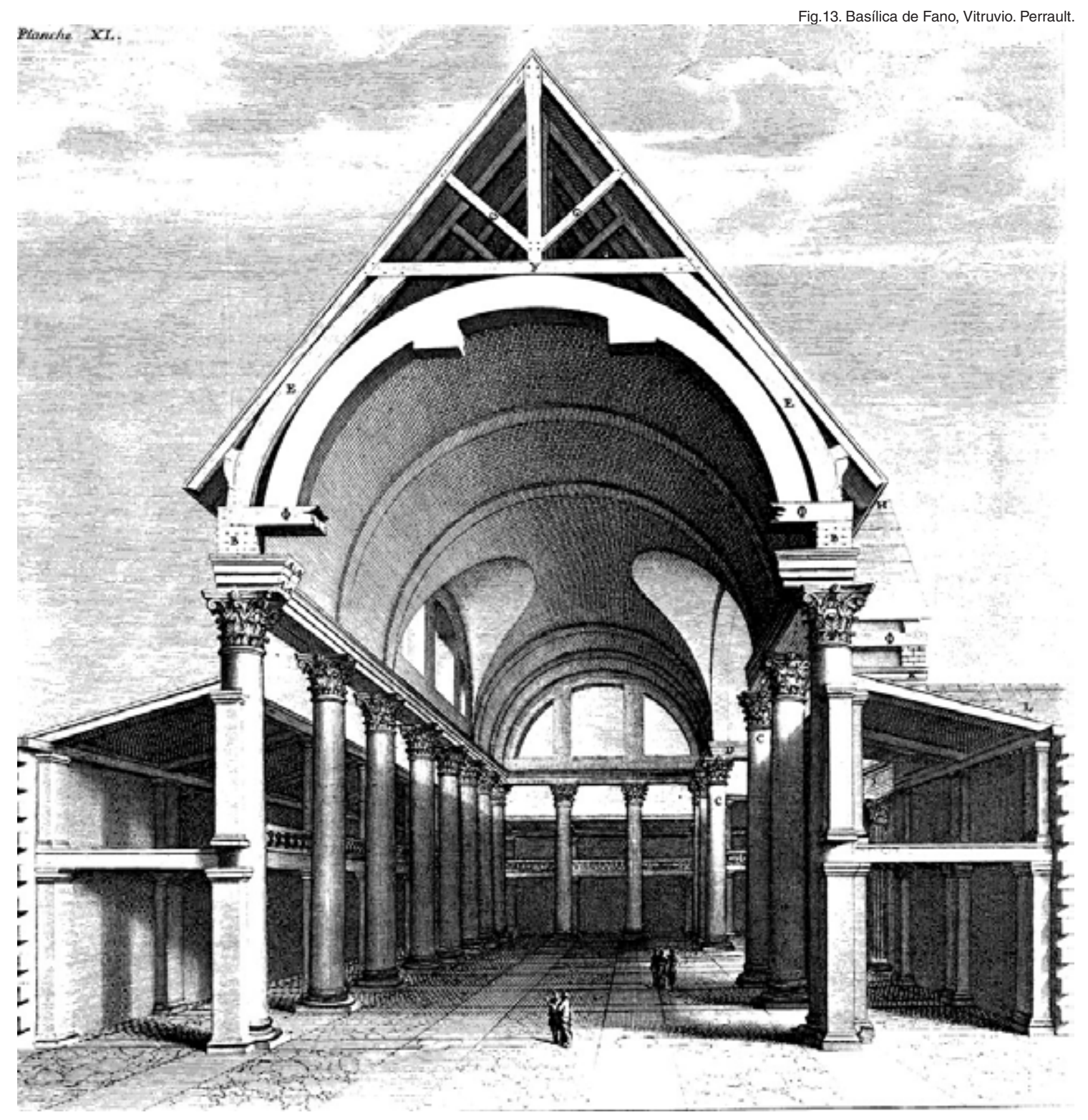


relação com o espaço, uso e projeto. O caminho é estritamente operativo para a categoria e coordenadas de sua escrita e, portanto, revê um conjunto de episódios de história heterogênea e descontínua sem pretender construir uma genealogia sistemática.

Vitrúvio descreve esses edifícios com sua atividade cívica como concebida pelos romanos no último século antes de Cristo:

\begin{abstract}
É conveniente que os terrenos das basílicas estejam o mais próximo possível dos fóruns, na parte mais quente, de modo que durante o inverno seja possível de dedicar aos negócios sem os inconvenientes do mau tempo. Sua largura não medirá menos que um terço nem mais que a metade de seu comprimento, a menos que seja impedida pela configuração do lugar e seja obrigada a modificar suas proporções de outras maneiras. Se o terreno for mais alongado, coloque nas extremidades alguns alpendres para conversar ou para o comércio, como vemos na Basílica Julia em Aquileia. A altura das colunas das basílicas deve ser ajustada à largura do patamar, que medirá um terço da superfície intermediária de onde será construída. Como dissemos antes, as colunas superiores serão menores que as colunas inferiores. O parapeito que vai ser colocado entre as colunas superior e inferior também medirá um quarto a menos do que as colunas superiores, de modo que os transeuntes que caminhem no primeiro andar da basílica não podem ser vistos pelos comerciantes. (VITRUVIO, 1995, p. 191-192, tradução nossa)
\end{abstract}

Vitruvio apresenta as Basílicas e sua relação com o Fórum. Sua lógica espacial e sua adaptação aos sistemas construtivos que foram usados por séculos the deram essa permanência. A basílica é um arquétipo espacial elementar em sua configuração que absorveu usos muito diversos ao longo da história: lugar "real" em suas origens gregas, mercado, praça coberta, praça de tribunais. Isso até se consolidar como a origem de inúmeros modelos de edifícios cristãos, cobrindo 2000 anos de produção de edifícios. Durante o seu funcionamento no Império, ele teve um uso intenso como edifício principal associado à vida do fórum, conectado a ele pelo lado longo ou pelo lado curto. Como Zanker (HESBERG e ZANKER, 2012) se refere a seu status de espaço amplo e coberto e dá a possibilidade de várias apropriações: comercial, judicial, política que incluiu a veneração do imperador e como um espaço para a passeio. Às vezes, era subdividido com toldos para configurar partes de usos específicos e temporários.

Quando o cristianismo passa a prevalecer entre os romanos, no contexto das mutações e declínio das cidades, como explica Ward-Perkins (em Id.), ele não se apropria dos templos romanos, dos espaços abertos configurados de acordo com os costumes religiosos pagãos, mas faz uso das basílicas porque sua qualidade espacial era mais 
Fig. 14. Reprodução da Igreja de S.Maria della Divina Provvidenza, Luigi

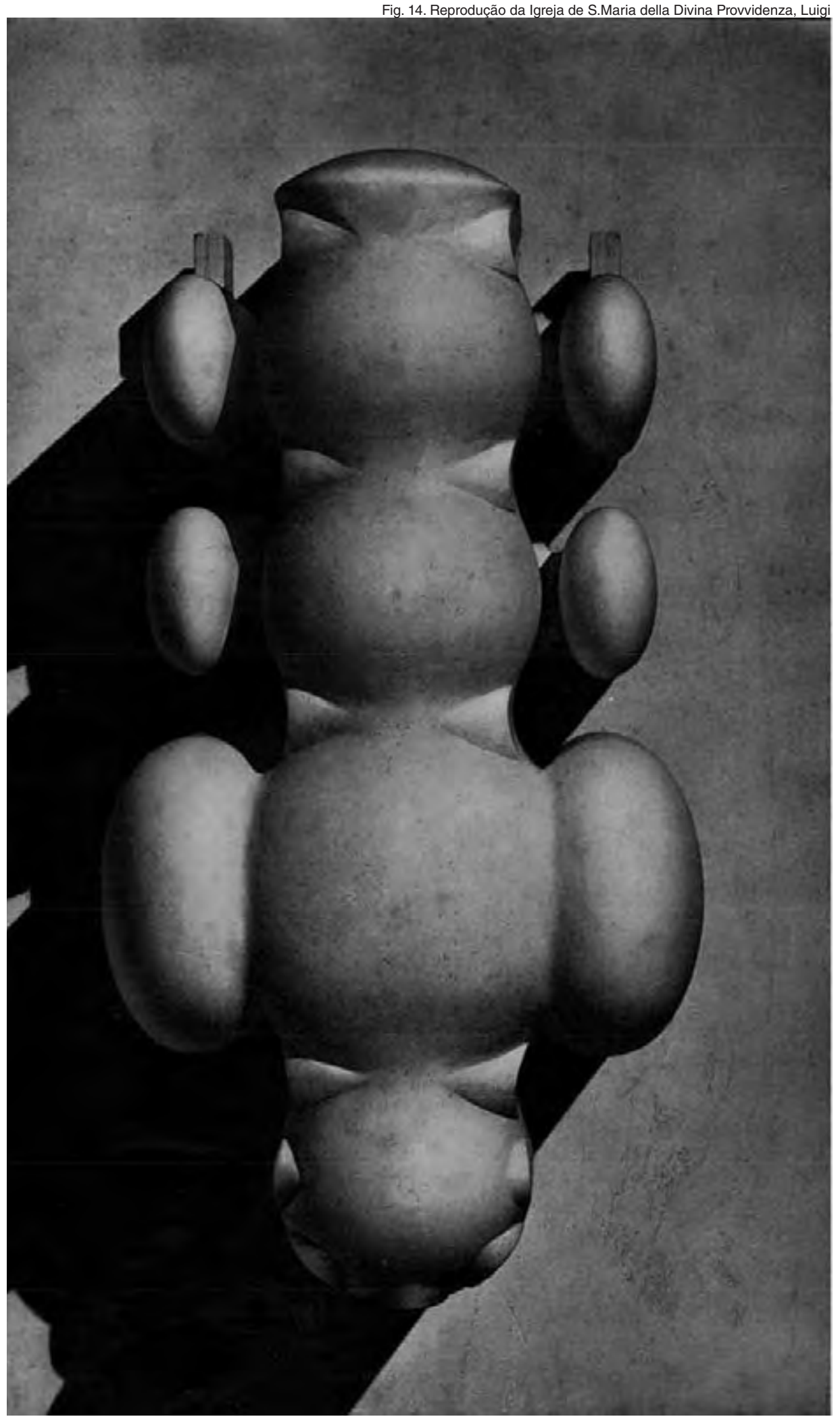


adequada para as práticas religiosas romanas. Assim começa o longo processo de adoção da basílica como o suporte espacial dominante da igreja cristã.

A partir da leitura da desespecialização programática, a capacidade da basílica é um valor que é demonstrado pela sucessão de apropriações e usos que ocuparam um dado espaço e nele desenvolveram suas atividades. O espaço e suas circunstâncias mostram que ele é carregado de uma energia potencial como descrita pela física mecânica ${ }^{3}$, referindo-se a um sistema ou corpo que tenha energia armazenada definida por fatores de posição e/ou configuração, podemos dizer de forma e de estrutura

Auguste Choisy referindo-se à planta das catedrais góticas, observa que essas igrejas cívicas deviam servir para uma dupla finalidade:

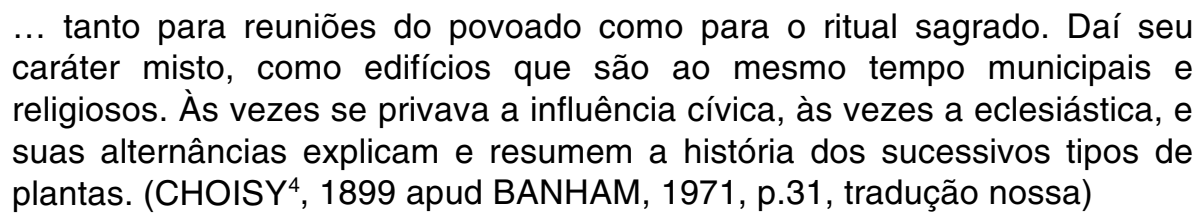

As exigências de uma sociedade urbana emergente fizeram com que, séculos depois, durante a Idade Média, a construção da Igreja Católica fosse ao mesmo tempo um centro religioso e um centro cívico. Choisy enfatizou a maior influência de um ou outro destino para discriminar os tipos edilícios, mas seu argumento também pode ser lido de outra maneira: as igrejas medievais permitiam os usos civis e religiosos, em um momento em que os espaços não necessariamente carregavam uma lógica monofuncional o espaço é dado e nele coexiste uma razão pragmática de diversos usos. A subsequente codificação simbólica funcional do sagrado e sua incompatibilidade com outros usos asseguraram especialização.

\section{PARA O PROgRAMA: MOtIVO}

Vai ser uma codificação posterior que complicará a taxonomia espacial vinculada a um enriquecimento e especialização crescente na vida social. A partir do Renascimento, e particularmente com a produção de Alberti, a tradição vitruviana é retomada e começa uma produção teórica e prática sistematizada. No entanto, os aspectos sobre onde

3 "A energia potencial é um tipo inativo de energia armazenada disponível para uso, é a energia que os corpos possuem em virtude de sua posição ou configuração (forma ou estrutura)." (MARTín DEL CAMPO, 2010, tradução nossa)

${ }^{4}$ CHOISY, A. Histoire de l'architecture, Paris: Gauthier - Villars, 1899. 


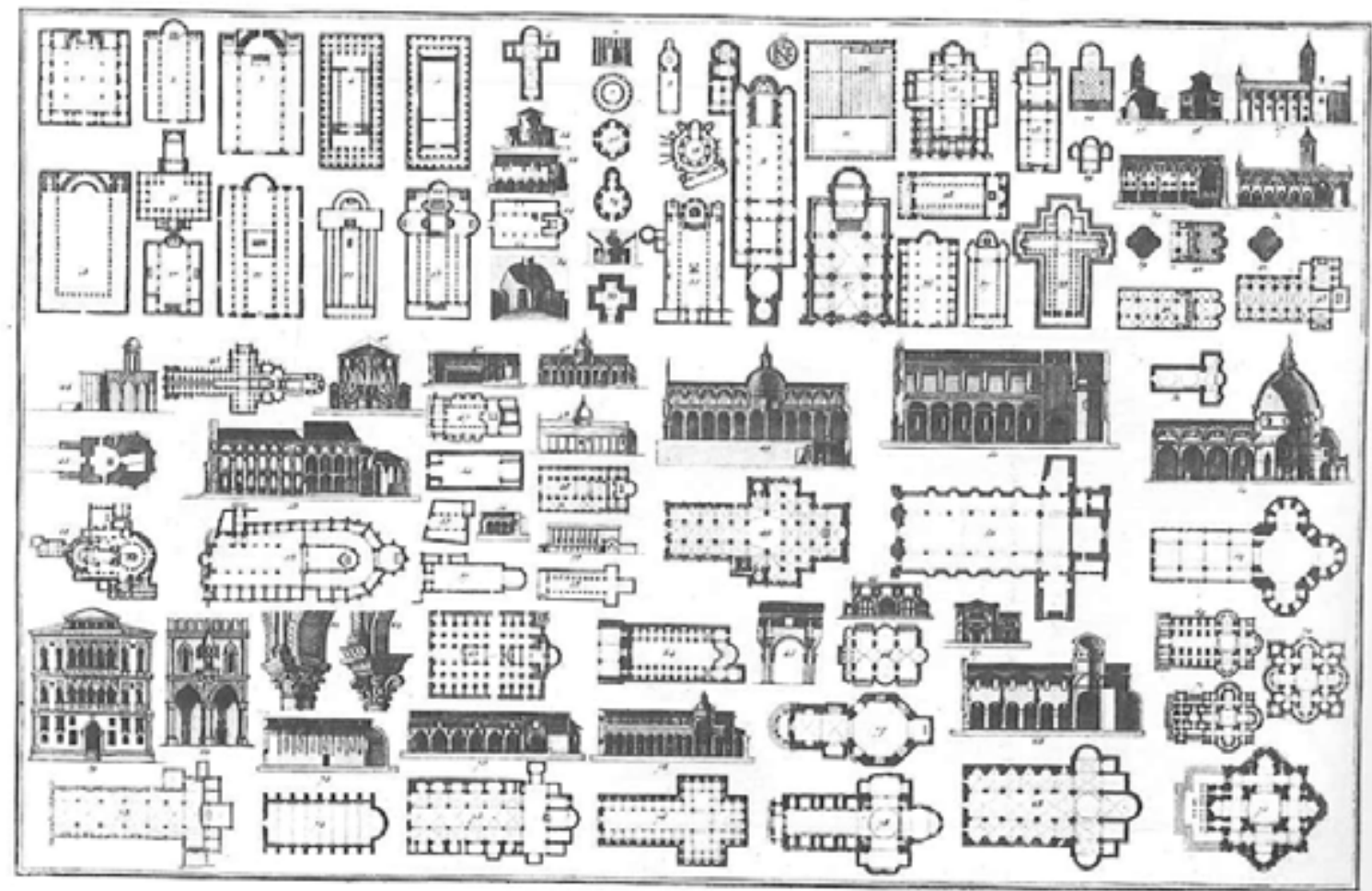

155. Séroux d'Agincourt, eResumen y cuadro general de los monumentos que han servido para formar la historia de la decadencia de la arquitecturas. 
concentra a disciplina nascente da época está concentrada na forma, proporção, hierarquia e ordens, e não em sua relação com o uso de edifícios.

O lluminismo é um período chave para o aparecimento do programa e tem uma forte conexão com o desenvolvimento do movimento moderno no século XX. Essa conexão tem sido objeto de debates e antagonismos, mas vale destacar que, mesmo com diferentes ênfases e abordagens, diversos críticos como Kaufmann nos anos 30 e Banham nos anos 60 visualizam a influência da acumulação histórica de lluminismo no século XIX, que decanta nas ideias das vanguardas e seus desenvolvimentos posteriores. Nas últimas décadas, Anthony Vidler contribuiu com visões contemporâneas que tornam o panorama do lluminismo mais rico, mais sutil e contraditório.

A nascente sociedade indústrial e os processos de urbanização associados a ela definirão de forma estável a relação entre determinadas atividades da sociedade e novas configurações espaciais. Ao referir-se a esse período, Vidler percebe o surgimento de novos paradigmas que afetam a maneira como a arquitetura é pensada e especializa certos programas.

\footnotetext{
Em primeiro lugar, o sentido tradicional de um edifício que incorporava a "beleza" em suas proporções e suas geometrias tridimensionais gradualmente se subordinava à ideia de uma ordem geométrica que seguia os ditames de necessidades sociais ou ambientais. Em segundo lugar, a teoria clássica da representação - na qual uma hierarquia rígida de ornamento respondia à conveniência social - se ampliou como uma teoria da comunicação arquitetônica facilmente acessível ao público. Nesse "funcionalismo primitivo", a organização de uma fábrica - a divisão do espaço construído - fica isolada como um instrumento de controle e reforma do social, enquanto se identificaram as características da fachada legível a fim de tornar prédio uma escola de sensações e ensinamentos morais. [...] Inspirados pela filosofia social e teoria econômica dos enciclopedistas e seus círculos, beneficiando-se da pesquisa acadêmica em medicina e física, assim como com a crescente profissionalização de arquitetos $e$ engenheiros, os debates afetaram a redefinição da fábrica, do hospital, da prisão, do asilo e toda a gama de construções públicas que prestavam serviço para a cidade e o campo, dos mercados aos cemitérios. (VIDLER, 1997, p.16, tradução nossa)
}

Foi recentemente, a partir dos arquitetos marginais do século XVIII que uma nova maneira de pensar a arquitetura começa a surgir baseada em uma racionalidade associada à técnica construtiva e ao uso. É o começo de um caminho de oscilações, mas que cada vez mais promove a racionalidade da disciplina. 
Fig 16. Partes de Edificios. J.LN. Durand.

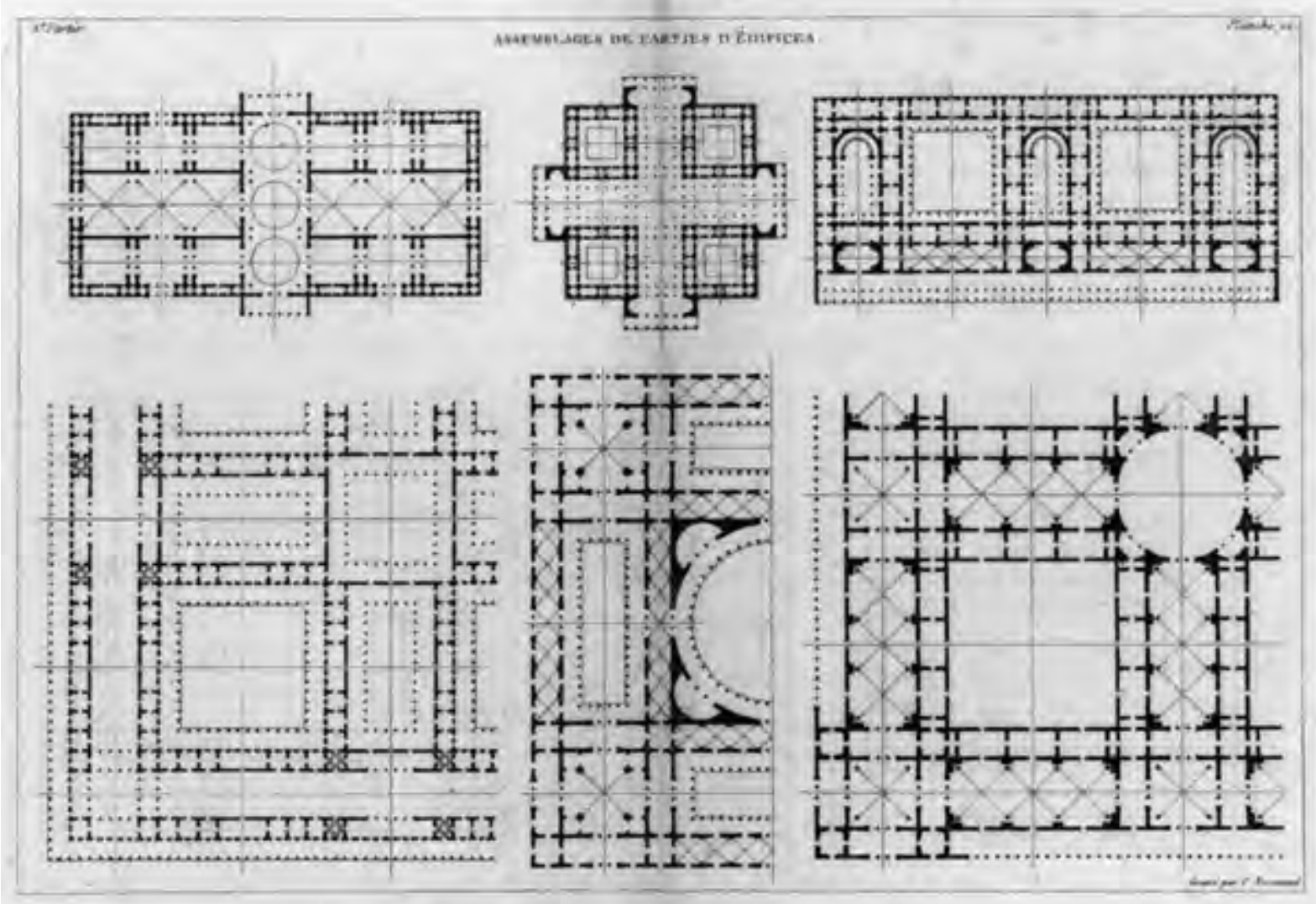


Emil Kaufmann (1974), em seu livro "La arquitectura de la llustración" e Rafael Moneo em seu prólogo dão conta do processo de aparecimento de algumas figuras que começam a trabalhar com o impulso racional e técnico, uma nova doutrina funcionalista que substitui uma formalista. Lodoli, bastante isolado na Itália, enfatiza a natureza dos materiais. Na França, com mais influência sobre todo o pensamento e a produção, Laugier propõe ideias semelhantes que começam a reivindicar um racionalismo direto que permite negar o culto pela tradição e os mestres do passado. Propõe um novo sistema de avaliação baseado na capacidade de dar respostas com naturalidade e simplicidade a uma necessidade concreta. A beleza não é dada por um sistema formal autônomo, mas tem a ver com a capacidade de expressar concretamente o que está sendo resolvido, o programa é o que deve ser representado para fazer uma boa arquitetura.

Durante o lluminismo e a Revolução Francesa, novas instituições e projetos são criadas que dão uma resposta, como no caso de Ledoux apresentado por Hannes Meyer:

Começou a interpretar por vias arquitetônica e muito autônoma os ideais da
burguesia libertadora: desenvolveu um "Templo da Juventude" onde se co-
educariam os dois sexos em uma nova coexistência arcádia. Desenvolveu
uma "Cidade de Salinas" em que o centro - em vez do castelo e da catedral
- colocou os dois edifícios representativos do novo poder civil e econômico
burguês, a prefeitura e a administração da salina conquistada pela
burguesia (MEYER, 1972 p. 231 apud PATETTA, 1984, p. 206, tradução
nossa) Nesse contexto começa uma preocupação intensa da arquitetura para levar em consideração essa maior complexidade da estrutura social, reconhecendo-a por meio da especialização programática sistemática. J.N.L Durand na Ecole Polytechnique inclui essa sistematização reunindo em seus dois principais livros as plantas desenhadas para cada um desses novos programas públicos: palácios, tribunais, munícipios, escolas, bibliotecas, museus, observatórios, faróis, mercados, abatedouros, bolsas, alfândegas, locais de exposições e feiras, teatros, banheiros, hospitais, prisões e quartéis.

Esta tradição será retomada durante o século XIX, na produtiva polêmica que foi, em si mesma, a geradora da modernidade do próximo século, entre a École des Beaux-Arts de Guadet e a École Polytechnique, liderada por Choisy. A relação entre programas e projetos típicos é um tema de agenda nesse século, e particularmente desde a Ecole de 
Fig. 17. Diagrama analítico da Casa Domino, Peter Eisenman
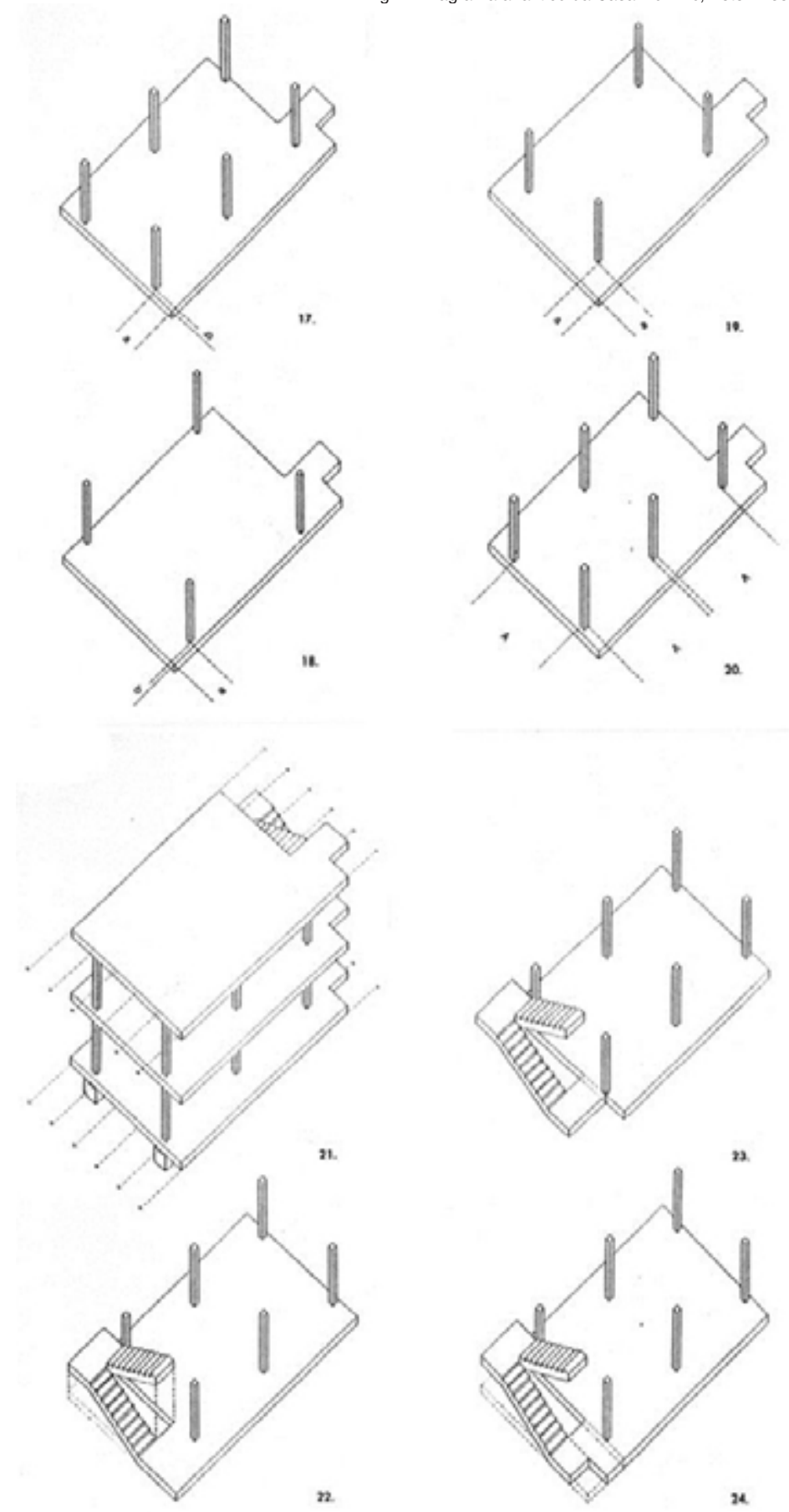
Beaux-Arts, Julien Guadet no seu livro "Eléments et Théories" multiplica a produção de desenhos tipo para todos os diversos imagináveis de edifícios públicos.

\begin{abstract}
Em suma, cinco volumes de sabedoria pré-digerida sobre problemas funcionais, tudo isso de segunda mão e em grande parte antiquado, mas sendo na sua totalidade vital para o sucesso, ali onde floresceu o sistema de Beaux-Arts;... (BANHAM, 1971, p.20, tradução nossa)
\end{abstract}

\title{
NAVES E MALHAS
}

Voltando a Durand (1799 ou 1800), em seu livro "Recueil et parallèle des édifices de tout genre, ancien et modernes: remarquables par leur beauté, par leur grandeur, or par leur singularité, et dessinés sur une même échelle" ele apresenta magníficas coleções de edifícios expressos em uma mesma escala.

Essas coleções em uma primeira leitura definida pelo seu posicionamento na linha do tempo são fundamentais no desenvolvimento da relação tipo programa-tipo ou funçãoforma, isso se dá por sua contribuição para tornar mais complexas a lista de edifícios públicos tipificados que vieram da antiguidade e o tratado de Vitrúvio.

Uma segunda leitura detecta uma possível origem para o pensamento da desespecialização: se observamos sua lâmina sobre as basílicas, podemos ler, a partir da relação entre o espaço basilical e os usos que ela abriga ao longo da história, como um ensaio de arquitetura capaz, isto é de capacidade para usos expandida.

A lâmina apresenta um conjunto de naves, um esquadrão de possibilidades. Estudar essa sequência desprogramada como a trajetória de um padrão espacial, construtivo e geométrico que foi capaz de acomodar diversas atividades é uma forma de compreender a possibilidade de separar os espaços de uma atribuição de uso a priori e considerá-los a partir de sua forma, por suas possibilidades de apropriação.

É algo semelhante ao que Eisenman propõe em 1980 ao estudar a Maison Dom-Ino, outro arquétipo espacial:

... o único aspecto da obra de Le Corbusier que faz dele um autêntico modernista: seu status como um símbolo auto-referencial, sua existência como arquitetura sobre arquitetura (EISENMAN, 2017, p.87, tradução nossa)

Encontra um lugar para pensar a partir da especificidade disciplinar (uma heurística) em termos de espaços, proporções, materialidade; incluindo a capacidade de ocupação como mais uma variável. Ao projetar a estrutura de um edifício, se estuda os estados de carga assumindo várias situações e posições de atividade associadas às cargas: a 
Fig.18. Combinação de predios. J.L.N.Durand

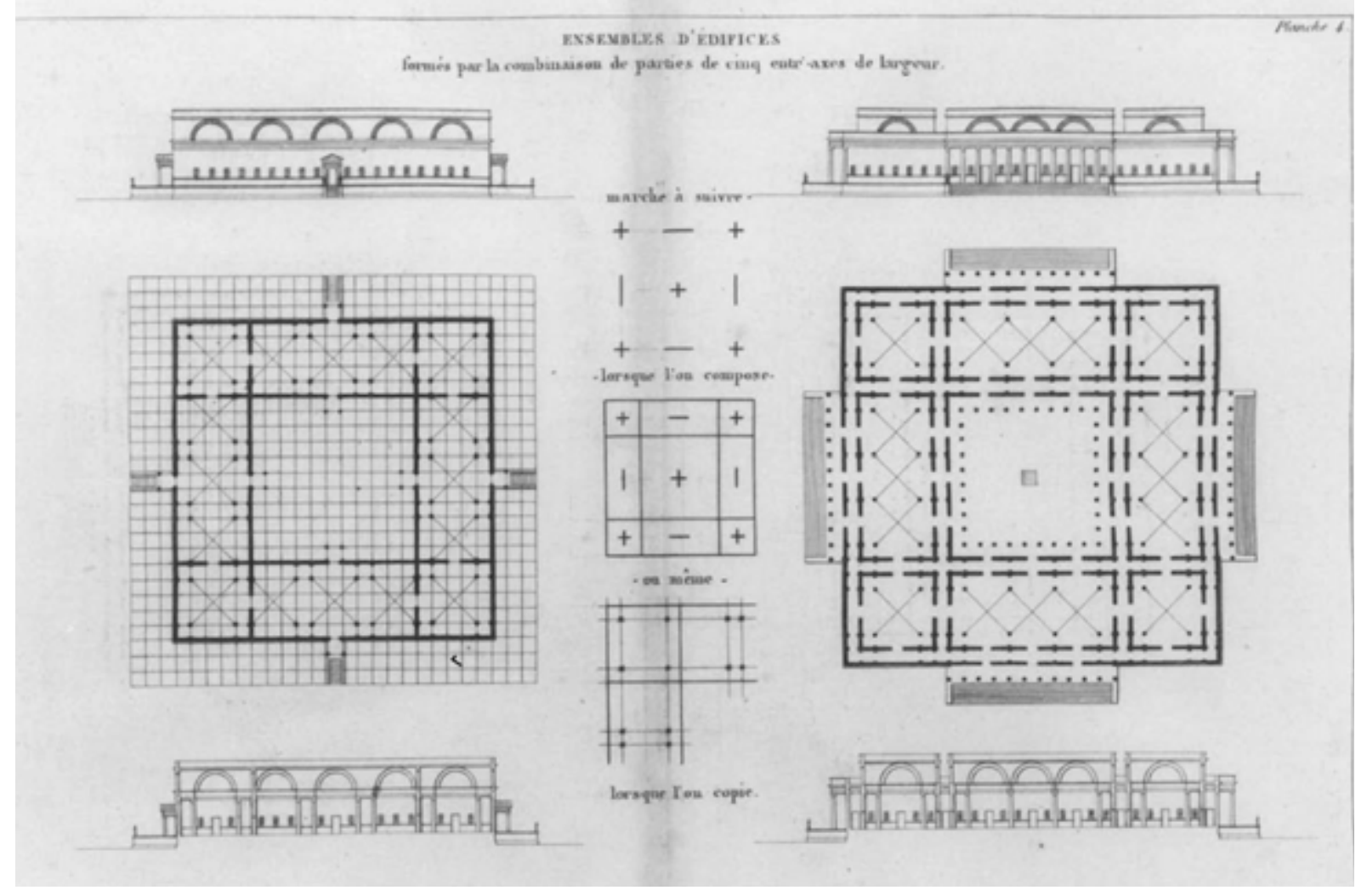


capacidade de ocupação expressa esta forma desespecializada de pensar a arquitetura. Uma forma que não só se encaixa nas possibilidades previsíveis pela nossa imaginação ou estudo, mas também aquelas que são imprevisíveis. Esse caminho nos permite trabalhar em um projeto que pode encontrar um espaço específico além da relação forma-função, sem fazer a reinvindicação absoluta e paralisante de uma arquitetura completamente autônoma ou auto-satisfatória.

Há outra origem para este pensamento desespecializado para JNL Durand em seu segundo livro, "Précis des leçons d'architecture données à l'école polytechnique", que traria um elemento novo no projeto e no programa: pois o projeto não parte de um tipo, mas que a composição aparece como tema, elaborada a partir de um repertório de malhas, eixos e pela soma de seus componentes. Este método permite compor edifícios assim como conjuntos de edifícios. Kaufmann refere-se a esse modo de composição como "pavilion system" (KAUFMANN, 1985, p.38) (um modelo revolucionário que substituiria a unidade do projeto barroco) no qual a parte mantém certa autonomia estruturada na totalidade.

\begin{abstract}
Diante disso, o método que o professor de arquitetura da École Polytechnique, J.N.L. Durand, surge como alternativa já que anula toda evocação da teoria da imitação de um arché lendário. Não existe em sua construção teórica o apelo à origem, mas um sistema de peças intercambiáveis que tem a geometria como fundamento e permite, mediante leis de composição rígida, construir um repertório flexível que utiliza toda a bagagem da tratadística como material de trabalho e isso permite a criação de estruturas completas do ponto de vista da organização morfológica e funcional. (ALIATA, 2013, p.36, tradução nossa)
\end{abstract}

De fato, e para lembrar-nos que em arquitetura é sempre necessário separar o discurso sobre o projeto do próprio projeto, o mecanismo que propõe J. N. L. Durand incorpora e desenvolve as malhas como suporte do projeto que substituem outros mecanismos de composição mais rígidos, mesmo que se acompanhe eixos e adição de volumes:

O método aconselhado por Durand - projetar a planta sobre papel
quadriculado - dramatiza esta nova realidade: cada quadrado do papel é
equivalente aos demais, sobre ele pode assentar-se o espaço mais
importante ou o mais insignificante. Se isto não acontece ainda no início do
século XIX é porque as pautas compositivas herdadas preservam a
hierarquização formal, vai acontecer no Século XX: já não haverá hierarquia
espacial a priori. (CORONA MARTíNEZ, 1991, p.108, tradução nossa)

As malhas de Durand, na leitura de Corona Martínez e Fernando Aliata, ao mesmo tempo que preparam as estratégias compositivas da modernidade ao abandonar as 


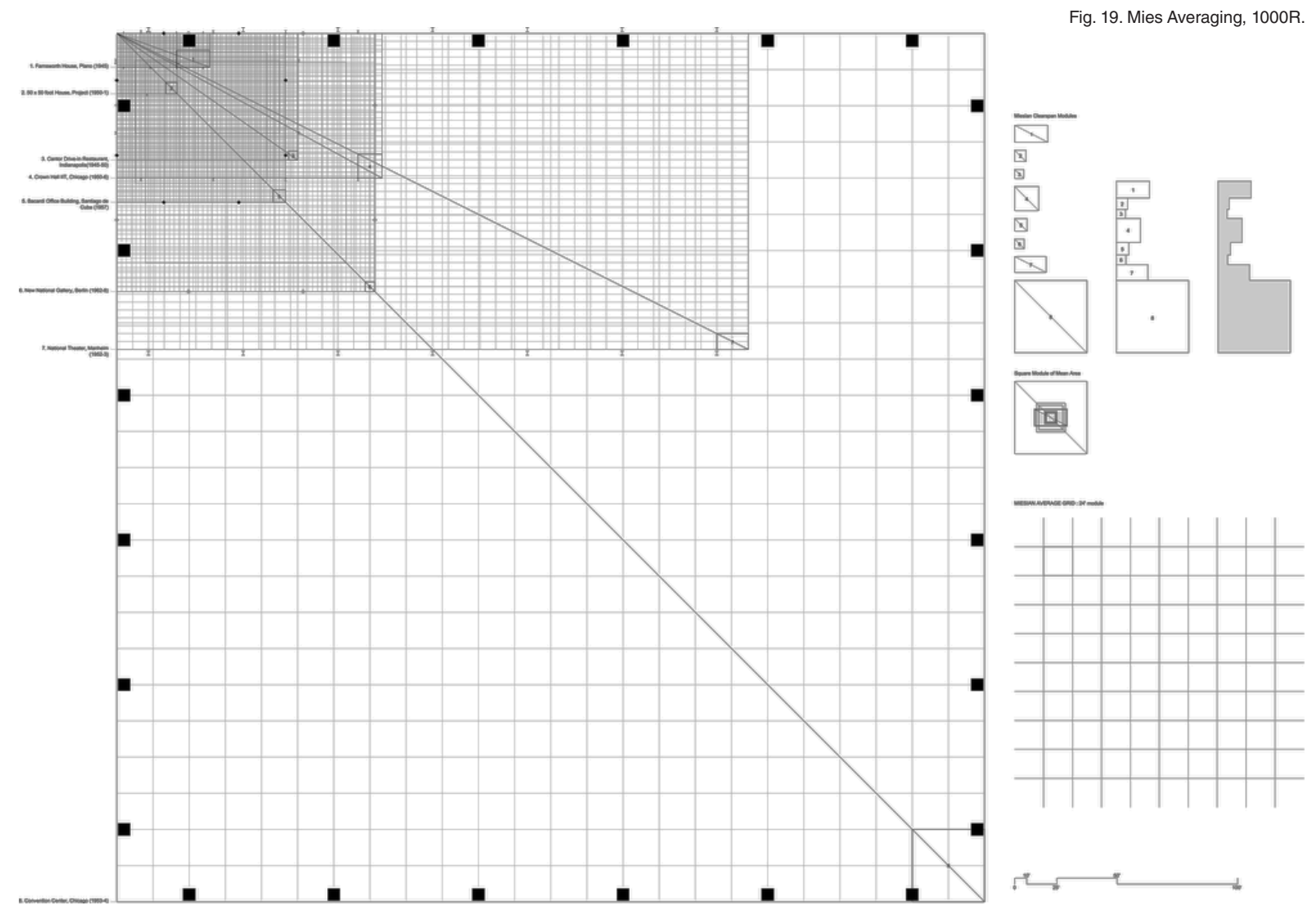


hierarquias geométricas, abrem o caminho daqueles projetos abertos que se desenvolvem com o paradigma da desespecialização.

\title{
PROGRAMA DE MODERNIDADE
}

O programa como categoria específica surgiu no século XIX, conforme descrito por Corona Martínez:

\begin{abstract}
Chamar de funcionalidade à utilidade de um edifício equivale a dizer que os edifícios "funcionam" como os organismos funcionam - para a fisiologia - ou para as máquinas que o fazem. Falar do funcionalismo do edifício é aderir a algumas metáforas explicativas que forma implementadas no século XIX, quando se procura fora da arquitetura explicações para sua essência".

"Anteriormente, a adaptação de um edifício a um destino não era apresentava pela distribuição. Havia disposições tipológicas firmes, confirmavam, por exemplo, um palácio como tal, e não o confundiam com outro uso, tanto quanto os habitantes dos diferentes tipos edilicios eram diferenciados por classe e nascimento, ou por vocações irrevogáveis. A função não pertence a um tipo em que é "imanente" desde o século XIX: ela está nos Elementos de Composição e nas suas conexões, que definem as diferentes respostas projetuais a diferentes programas de arquitetura. Nós entendemos melhor agora porque não havia programas antes do século XIX. (Ibid., p.102-108, tradução nossa)
\end{abstract}

Quando o tipo se esgota como uma categoria em virtude da complexidade das instituições, inicia-se um processo que fundamenta a modernidade em que o programa é definido especificamente para cada edifício (ou conjunto de edifícios) que estabelece parâmetros espaciais de relações e de desempenho.

No século XX, o programa recebeu um tratamento central no mundo da arquitetura, como parte das profundas mudanças cultivadas desde o lluminismo, que explodiram nas primeiras décadas do século. No entanto, a maneira como o programa é tratado (como qualquer outro assunto relevante do projeto) está longe de ser homogênea no complexo e contraditório mundo da arquitetura moderna.

Assim, em 1956, o Crown Hall foi inaugurado, o prédio da escola de arquitetura do Illinois Institute of Technology (IIT), uma peça que rompe com as regras estabelecidas pelo próprio Mies no "Master Plan", para se tornar uma experiência única no seu conjunto. O trabalho é reconhecido pelos críticos e pelo autor como uma de suas melhores realizações. Uma planta principal quase vazia, uma espacialidade sutil, que expressa uma abstração programática, cujo programa principal (e quase único) é a sua condição elucidativa em torno da "verdade na arquitetura".

Seu trabalho pode ser interpretado como uma tentativa ininterrupta de caracterizar um espaço genérico, que poderia ser chamado de espaço, cuja 

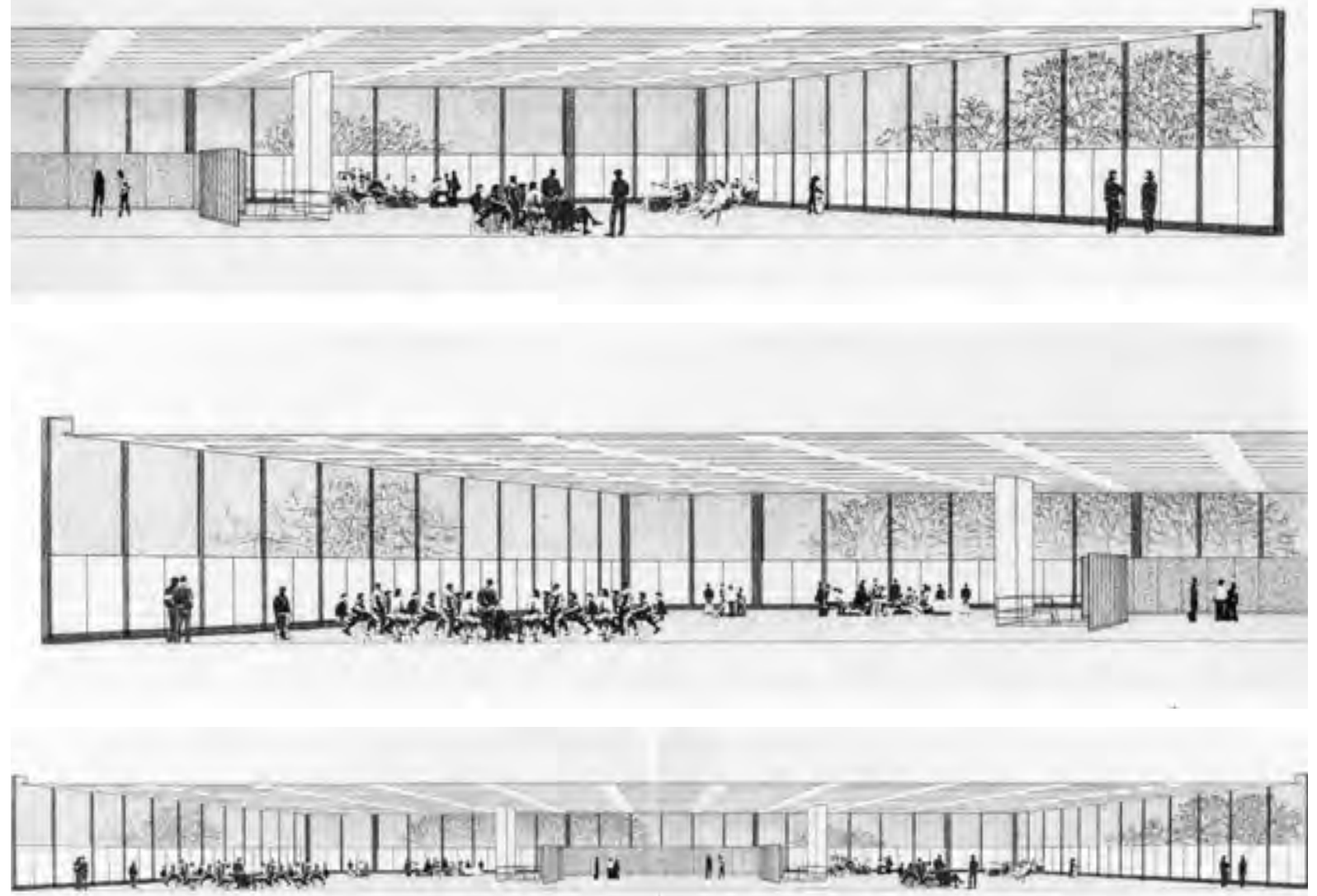
arquitetura é simples materialização. De acordo com essa noção, a tarefa do arquiteto é capturar o espaço idealizado através da definição de seus componentes abstratos. Como o físico, o arquiteto deve primeiro conhecer os elementos da matéria e do espaço em si. Assim, ele estão capacitado para isolar uma parte desse espaço para formar um edifício de concreto. Ao construir o edifício, encerra esse espaço e, ao fazê-lo, constrói um edifício caracterizado não pelo seu uso como escola, hospital, igreja, etc., de acordo como era no século XIX, mas sim um "espaço" no qual uma atividade pode ser produzida depois. Deste ponto de vista, o Campus do IIT deve ser entendido mais como um espaço - um fragmento físico do espaço conceitual - do que como um conjunto de edifícios submetidos a um processo de composição arquitetônica.

[...] Mies nunca esteve atento a funções ou materiais, ele era um construtor de forma-espaço. (MONEO, 1978, p.32, tradução nossa)

Essa lógica de distanciamento do funcionalismo é ilustrada em uma estória contada sobre Mies e Hugo Häring, que aconteceu cerca de trinta anos antes. Os dois arquitetos compartilharam o espaço físico para seus estudos e compartilharam o impulso para renovar a arquitetura. Häring concentrou-se em um funcionalismo extremo, no qual a forma deveria resultar de estudos funcionais meticulosos, projetava a fazenda Gut Garkau e encontrava dificuldades para resolver o projeto. Mies propõe uma solução que o define: "Hugo, faça apenas suas salas grandes, então você pode fazer tudo nelas" (JORMAKKA, 2007, p. 118, tradução nossa). A estratégia de Mies que poderia parecer frívola tem um significado profundo em relação à desespecialização, um superdimensionamento controlado, que pode melhorar a capacidade dos espaços.

Um ano depois da inauguração de Chicago (e com um oceano no meio), em busca de uma visão conceitual e teórica que supere até este momento as descrições predominantemente formais ou estilísticas da arquitetura moderna, propõe Summerson ${ }^{6}$ :

\footnotetext{
A fonte unificadora da arquitetura moderna é a esfera social, ou seja, o programa arquitetônico. Desde os tempos antigos (um mundo de formas) até o programa (um fragmento local do tecido social): isso sugere um giro na psicologia dos arquitetos, quase violenta demais para ser crível. (SUMMERSON em OCKMAN, 1993, p.232, tradução nossa)
}

Summerson se dedica a construir a credibilidade do giro. A partir de sua interpretação, o programa e suas relações com o projeto são um articulador da produção moderna. Nesse sentido, se lê como uma peça autônoma e independente do ato projetual, como a previsão da organização espaço-temporal que pode responder às regularidades e singularidades que surgem da atividade a ser abrigada, libertando-se da rigidez compositiva que foi dada a priori pela arquitetura clássica. Desta forma, pode ser dada 


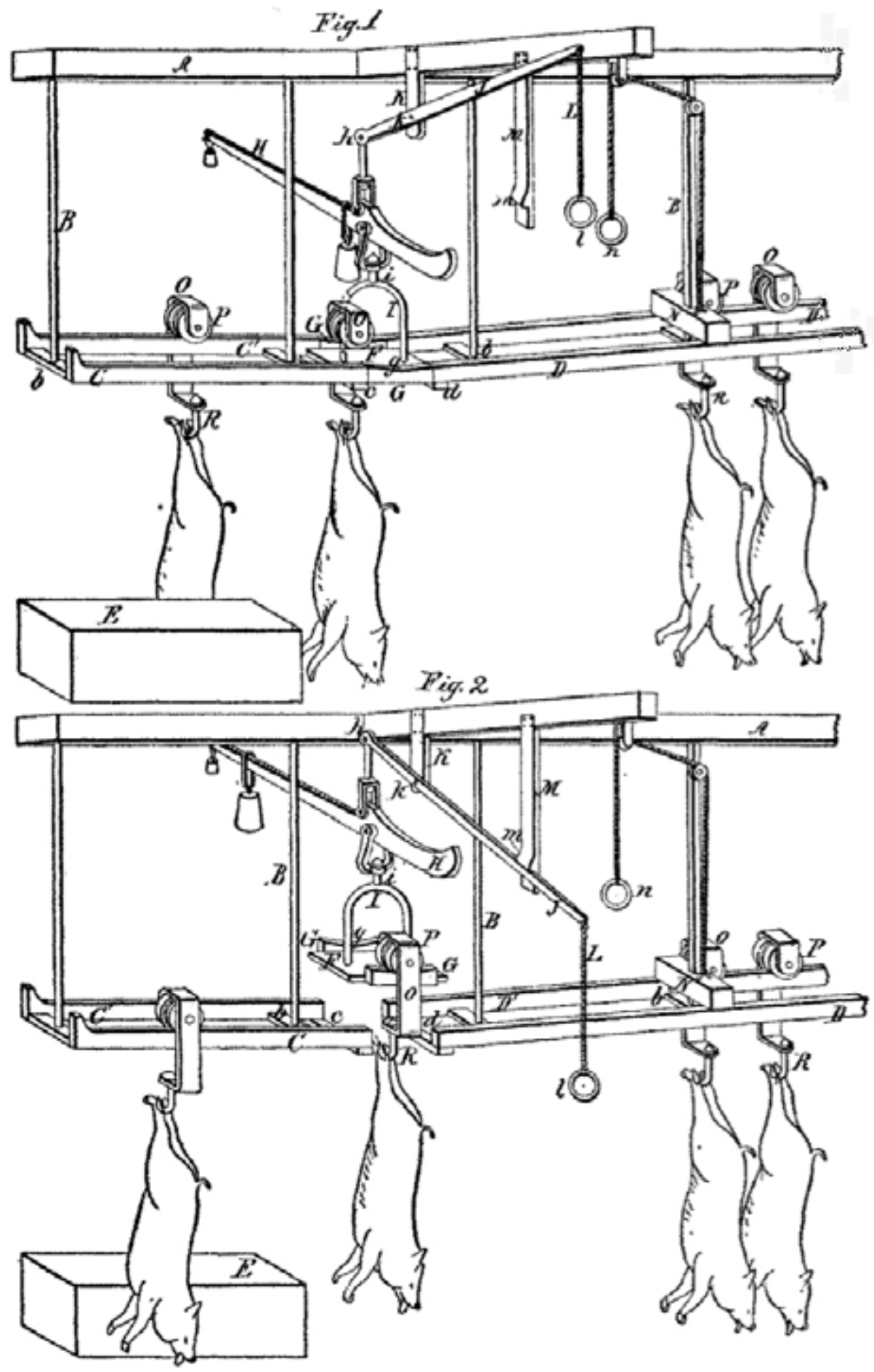

50. Automatic Hog-Weighing Apparatus for Use in Packing Houses. Cincinnati, 1869. This device intented by a Cincinnatian shoses that the late $1860^{\circ} \mathrm{s}$ had considerable practice in combining the overhead raitray with sections of the assembly line. (U.S. Patent 92,083, 29 June 1869) 
uma resposta qualitativa para demandas mais exigentes e desafiadoras derivadas das demandas do mundo moderno. A abordagem é especialmente interessante porque procura construir-se a partir da especificidade disciplinar. Summerson questiona a possibilidade de uma identidade formal como uma segunda fonte possível de unidade.

E como Summerson nega o visual como um fator de profundidade, ele deixa de se preocupar com a forma. Alan Colquhoun, nos anos 70 , visualiza um mecanismo paradoxal na tensão entre o que ele chama de "determinismo biotecnológico" e a ausência de um corpus formal que liberta o gênio criativo: "O que aparece na superfície como uma disciplina de projeto rígido e racional, paradoxalmente resulta em uma fé mística no processo intuitivo" (COLQUHOUN, 1973, p.52, tradução nossa).

A citação anterior de Sullivan: "A forma segue a função, e esta é a lei. Onde a função não muda, a forma não muda"(SULLIVAN, 1896, p.408, tradução nossa), não pode descrever a sofisticada autonomia teórica defendida por Summerson, que admite que para a mesma função cabem várias respostas arquitetônicas partindo do mundo, para ele secundário à forma, e para o visual; nem a visão de Colquhoun sobre a forma como um resultado intuitivo e genial.

No entanto, "a forma segue a função" tornou-se um clichê de sucesso de um pensamento simplificado que consagra o funcionalismo moderno, já que cumpre com a disciplina de caráter supostamente científico.

Existe outra maneira de fazer as conexões entre o projeto dos "modernos" e a sua relação com a sociedade que atende a influência do pensamento positivista e dos novos modos de produção e organização do trabalho, que acaba tendo uma repercussão nos modos em que se produz a arquitetura, a cidade e o território:

A disciplina corporal alentada por Taylor gira sobre a perfeita assimilação dos homens à mecânica da fábrica conseguindo a metamorfose do "material inculto" convertendo-o em mais uma peça da imensa cadeia de montagem: é o Charles Chaplin em Tempos Modernos. Mas a descoberta de Taylor ainda permite algo mais, isto é especializar "cientificamente" a produção por não dizer o capital - nas grandes oficinas e com isso construir um método e um espaço perfeitamente coerente com a lógica irrepreensível da eficiência.

Basta observar muitos dos estudos sobre habitação mínima da Europa do início do pós-guerra, manuais como o de Ernst Neufert, A arte de projetar em arquitetura, ou exemplos tão paradigmáticos como a cozinha Frankfurt de Ernst May e Grete Schütte- Lihotzky, para perceber até que ponto a especialização da fábrica sistematizada pelo Scientific Management, ao ser transportada sem desperdício ao interior da cultura arquitetônica, se torna concretamente- espaço arquitetônico. (NISIVOCCIA, 2004, p.23, tradução nossa) 


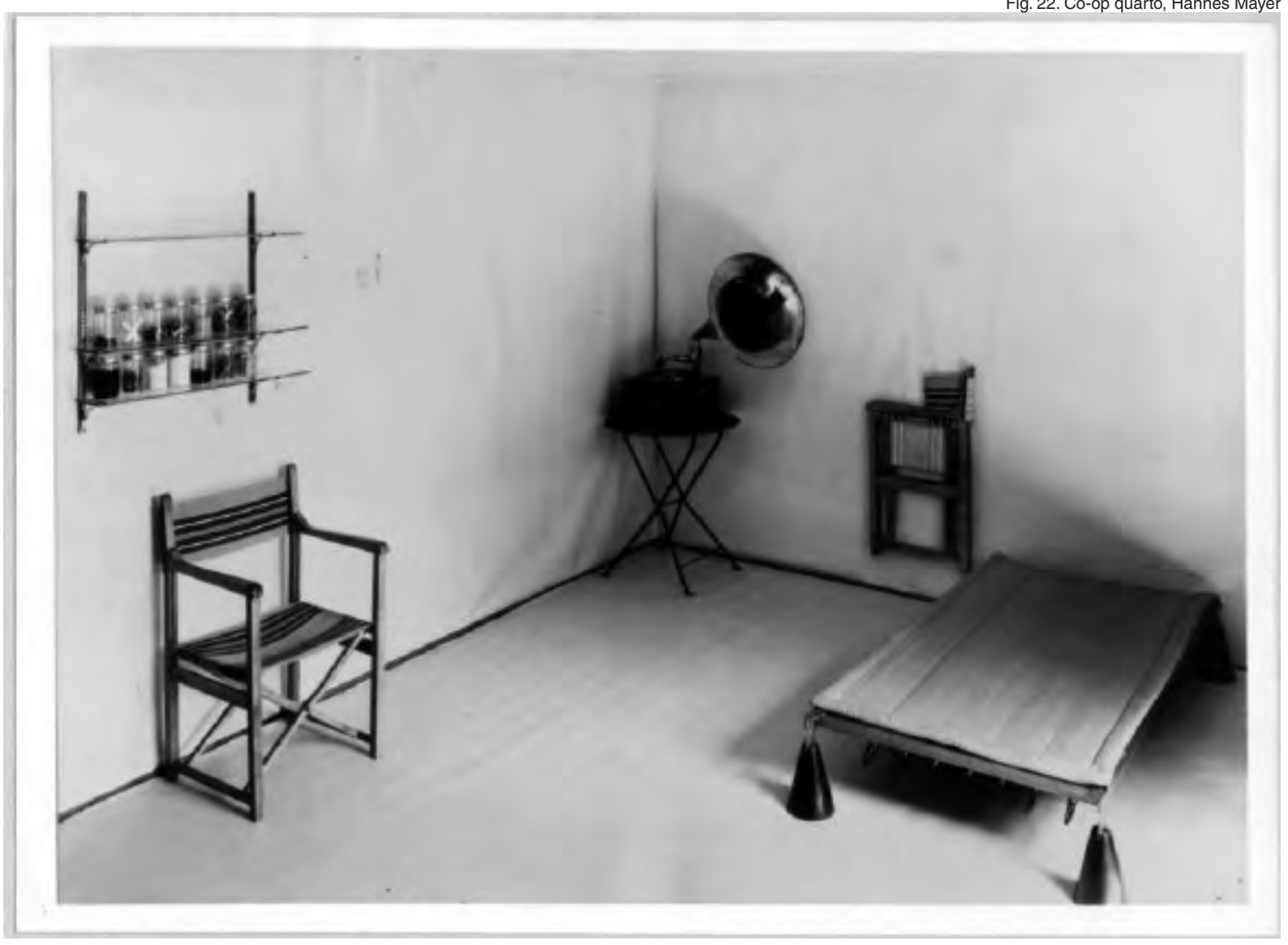


O funcionalismo arquitetônico, opera com a disjunção, separando cada fragmento do espaço para um "uso" particular, gerado a partir da pretensão da capacidade do arquiteto e o programa de um conhecimento científico absoluto sobre o que vai acontecer num edifício, pretensão que só pode conduzir a um pensamento a partir da redução e a "unidimensionalização":

Por esta via pode-se compreender o fenômeno da unifuncionalidade, que foi considerado durante boa parte deste século como o equivalente da "funcionalidade". (CORONA MARTÍNEZ,1991, p.110, tradução nossa)

\title{
PROGRAMA CONTEMPORÂNEO
}

A crítica ao funcionalismo radical hoje não é discutível. Mas ele tem uma persistência na arquitetura e nas práticas contemporâneas que não pode ser ocultada. Iñaki Ábalos, no início deste século, estabelece uma hipótese sobre essa continuidade baseada na influência do pensamento positivista:

\begin{abstract}
Mas talvez, o problema que a arquitetura carrega ainda hoje para superar este tipo de casa, para aprender a esquecer de suas grandes limitações, não é apenas a influência do positivismo vigente nos sistemas de formação do arquiteto, senão sua profunda capacidade de penetração na mecânica produtiva através das normativas que nos deixou de herança. [...] A tarefa de quem quiser pensar e projetar moradias e também a de como escapar às referências, não só epistemológico senão também normativo, da modernidade. (ABALOS, 2000, p.82, tradução nossa) ${ }^{7}$
\end{abstract}

Afirmando que a arquitetura moderna nunca foi capaz de explicar a natureza radical do projeto moderno e seus desenvolvimentos no mundo da ciência e da arte, Eisenman propôs, em 1976, a superação do funcionalismo como a única maneira de realizar o projeto moderno em arquitetura, associado a sua visão filosófica da necessária superação do humanismo.

Assim, o "pós-funcionalismo" é um termo de ausência. Em sua negação do funcionalismo, ele sugere certas alternativas teóricas positivas - a existência de fragmentos de pensamento que, uma vez examinados, podem servir como uma moldura para o desenvolvimento de uma estrutura teórica mais ampla - mas que em si mesma não é proposta como um rótulo para um nova consciência arquitetônica que, na minha opinião, poderia ser encontrada muito perto de nós. (EISENMAN, 2017, p.81, tradução nossa)

O caminho adotado por Eisenman sugere abandonar a oposição da função de forma a substituí-la por uma relação dialética entre os dois termos, que se sintetiza na forma (e

\footnotetext{
${ }^{7}$ A ideia de que existe uma certa especificidade no projeto de habitação pode ter uma analogia com a especialização com que a produção de equipamentos diversos em diversas instituições do Estado é estruturada e normalizada.
} 
$\square \square \square \square \square$

$\square \square \square$

回回回

回回回

$\square \square \square \square$

$\square$

$\square$ 血回

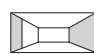

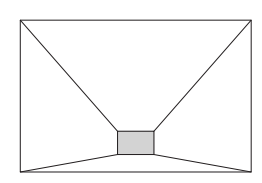

$\mathrm{I}$

घ曰 $\quad \square \square$

D四四

D四 $\square \square$

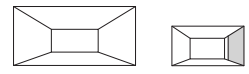

$\square \square$

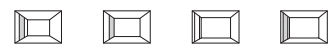

$\square \quad \square \square$ 回回 $\square \square \square \square \square$ 回回回四

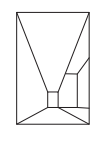

\section{回回}

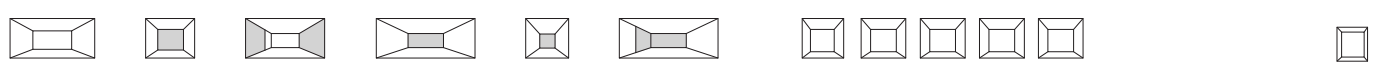

口回回四四四四四四四

$\square \square \square$

四

\#而回

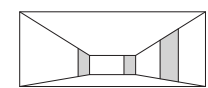

四四四 
espaço) arquitetônica. Esta posição terá diferentes versões em sua trajetória posterior, apesar de estar sempre preocupada em reconhecer a implicação cultural do projeto e da arquitetura.

O programa como é usado atualmente na arquitetura refere-se a tanto a um tipo de edifício como ao documento que descreve de maneira codificada e quantificada como deve ser um edifício de concreto. É a segunda versão que nos interessa aqui, pois ela intervém no processo do projeto e é geralmente estabelecida como um "pro-grama" que antecipa o projeto. A autonomia da produção do programa na prática profissional como consequência da crescente especialização e divisão do trabalho que desagrega o projeto, consolida o status. Nesses casos, é um documento que estabelece algumas considerações gerais sobre o que se espera do edifício e estabelece a descrição, quantificação e definição dos benefícios de suas partes e estabelece as relações entre eles.

Um programa é um sistema, um conjunto de partes relacionadas por uma estrutura que, longe da suposta condição de documento objetivo, designada por Summerson (que é designada desde o século XIX), geralmente também possui opções de "partido". Partido no sentido da expressão do lluminismo que segue na sequência do projeto para o programa, é aqui que a elaboração de um programa é um ato projetual normalmente oculto. O projetista em frente ao programa, quando ele quer manipular o projeto, deve desconstruir o projeto do programador para reformular sua própria versão.

\section{PROGRAMA DESESPECIALIZADO}

"Por que sou artista e não filósofo? Porque penso de acordo com as palavras e não de acordo com as ideias" (CAMUS,1996, tradução nossa)

Camus estabelece uma dialética radical, que parece opor as palavras ao pensamento. Claro, Camus não nega as ideias, mas reivindica seu trabalho com as palavras como um exercício específico da literatura. Essas ideias nos ajudam a pensar sobre a especificidade disciplinar: parafraseando, pensar como arquitetos "de acordo com espaços" (nossas palavras) e não de acordo com ideias que deixam os espaços de fora.

O ponto de vista desta tese questiona a disjunção programa-projeto e reivindica relações sinérgicas entre os dois termos.

O programa como uma categoria tem sido um foco pouco frequente na reflexão teórica, e a desespecialização programática é uma noção em construção. Esta é uma 


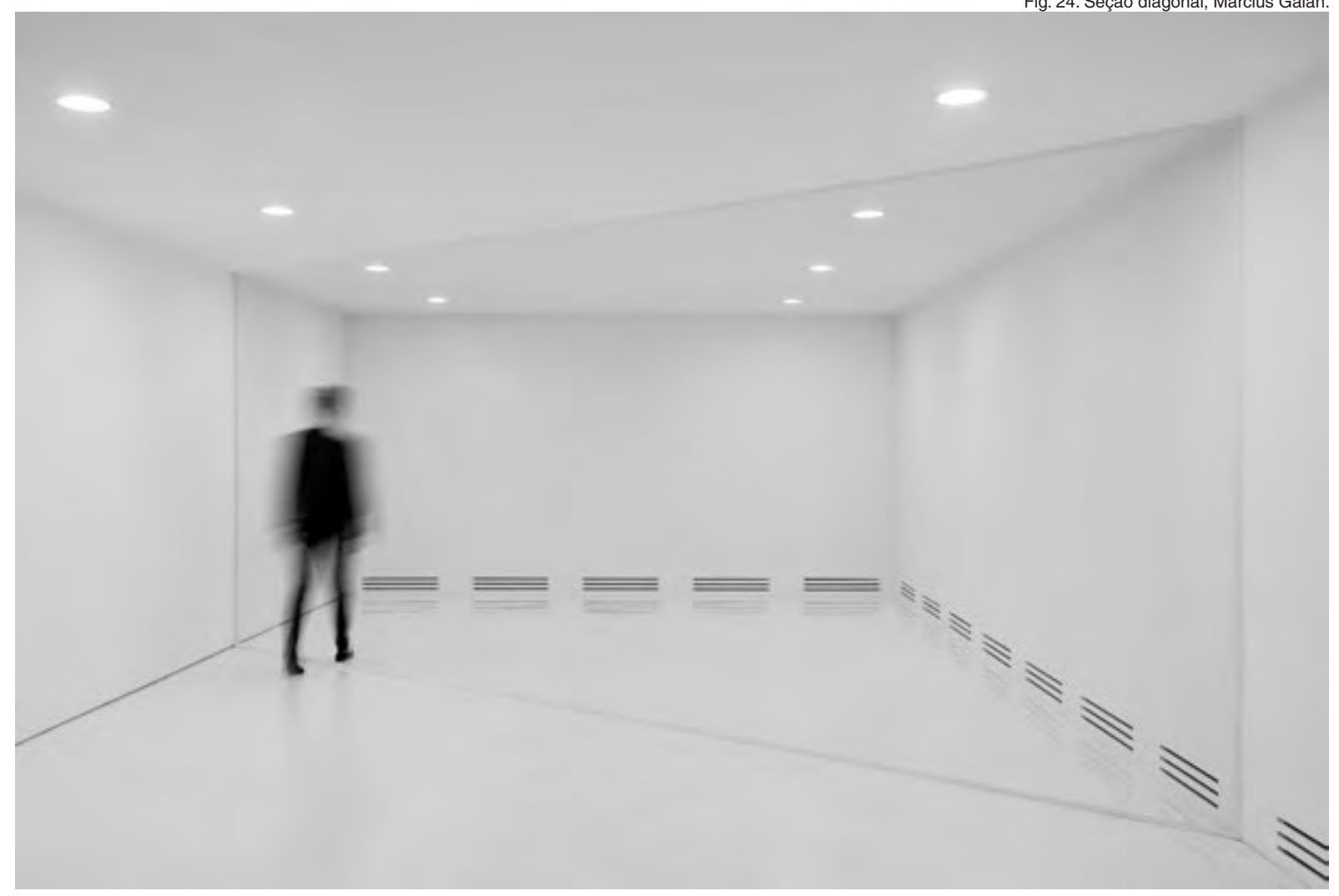


investigação arquitetônica sobre ideias e projetos e que, ao longo da história, oscilam entre a especialização e seu oposto. A noção de especialização em arquitetura é desmontada, investigando as noções de função e uso, a partir da ideia de que é possível pensar e projetar o espaço arquitetônico a partir de suas qualidades e potencialidades, relativizando a abordagem superespecializada. Alguns atributos espaciais vão aparecer: polivalente, aberto, intercambiável, modificável, associável, etc. Algumas estratégias de arranjo espacial do programa: homogeneidade, estratificação, hibridização, etc.

A noção de disposição espacial apresenta um potencial para a definição de projetos desde a desespecialização programática, pois ela contém intenções e estratégias de projeto, de espaço, apesar de que pode ser precedente ao projeto.

O programa como um elemento definidor do projeto vem se expandindo em considerações disciplinares e acadêmicas há várias décadas. O trabalho de Cedric Price, especialmente a partir do Fun Palace, um projeto desenvolvido durante os anos 60 , redefine completamente a noção do programa, fundindo-o com o projeto, no âmbito de uma reconsideração do papel do arquiteto e seu envolvimento com o mundo.

No início, Rem Koolhaas, com seu projeto de graduação no AA "Los prisioneros voluntarios de la arquitectura" de 72 e "Delirious New York" de 78, propôs o programa como um centro operacional e projetual, tirando o foco do interesse dominante de seus contemporâneos pela forma e pelo significado.

Tschumi (1994) na introdução de "Architecture and Disjunction", que compila ensaios publicados entre 1975 e 1991, baseia-se na hipótese de que não há arquitetura sem programa, sem ação e sem evento. O argumento retoma a ideia de valor de uso de Marx: "Um vestido, por exemplo, só se torna um vestido real ao ser usado; uma casa desabitada não é, de fato, uma casa real"8; mas ele também confronta seus contemporâneos que reivindicam a autonomia da arquitetura, capaz de ser reduzida à forma ou linguagem pura.

"Programa e distanciamento" é a estratégia que Tschumi enuncia para definir seu projeto para o Parc de la Villette, a malha é um dispositivo abstrato que se afasta da

${ }^{8}$ O texto de Marx é citado e analisado por Josep Quetglas (1994, p.4-5) 
Fig. 25. Michigan Theatr Detroit, Ph:George Steinmetz, 2006.

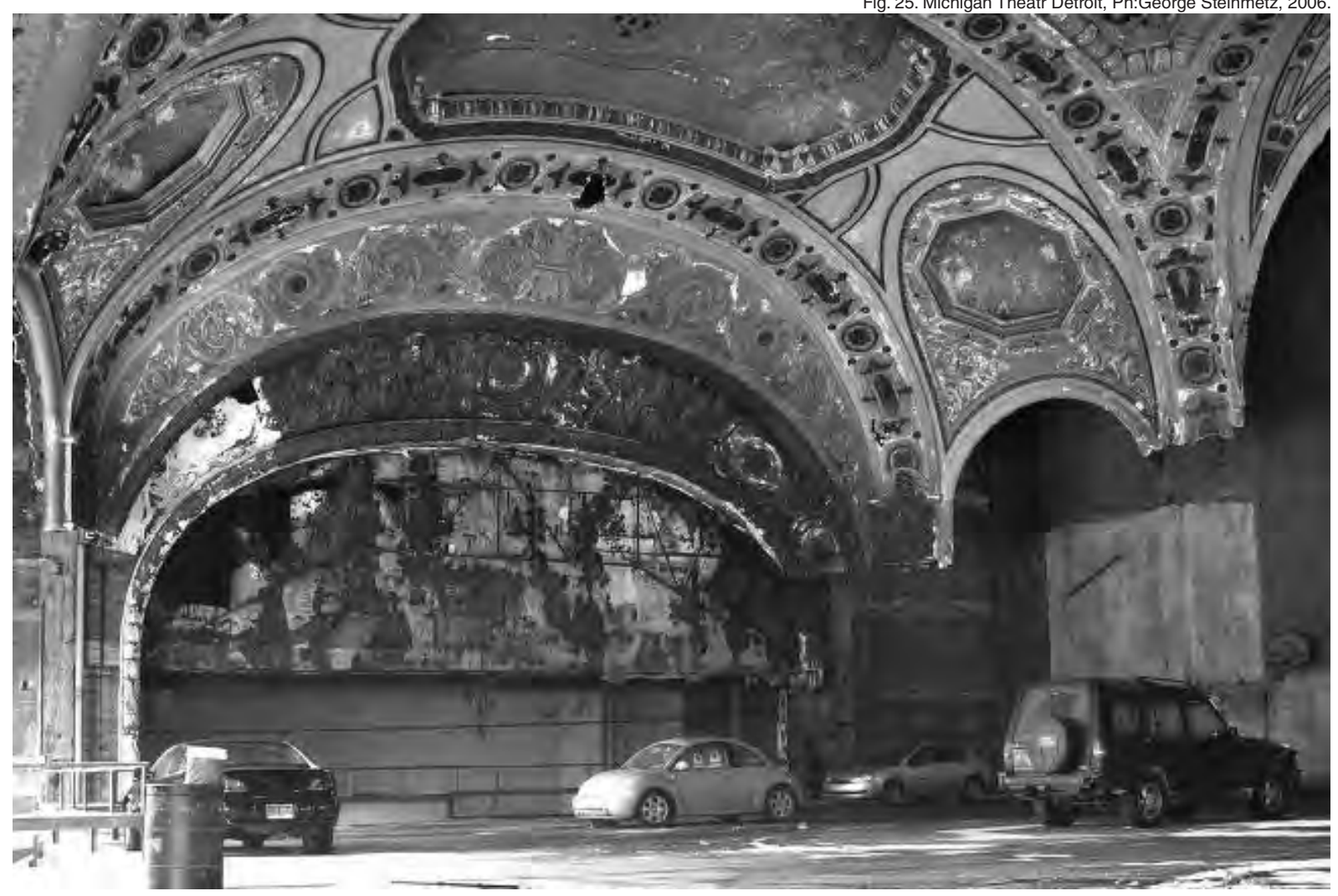


representação do programa. E propõe outras relações possíveis, um conjunto estimulante de ideias sobre o programa como campo de pesquisa:

Crossprogramming: Usar uma determinada configuração espacial para um
programa para o qual ela não foi projetada, isto é, usar a construção de uma
igreja para um boliche. Parecido com um deslocamento tipológico: uma
prefeitura dentro da configuração espacial de uma prisão, ou um museu
dentro da estrutura de um estacionamento. Referência: Crossdressing

Transprogramming: Combinar dois programas, sem abordar suas incompatibilidades, junto com suas respectivas configurações espaciais. Referência: planetário + pista de patinação.

Disprogramming: Combinar dois ou mais programas, onde os requisitos espaciais da configuração do programa $A$ contaminam o programa $B$ e sua possível configuração. $O$ novo programa $B$ poderia ser extraído das contradições internas contidas no programa $A$, e os requisitos espaciais de B poderiam ser aplicados a A. (TSCHUMI, 1994, p.205, tradução nossa)

Uma linha de pesquisa baseada em ideias análogas é "Made in Tokyo", do Atelier Bowwow, publicada como livro em 2001. Com isso, se propõe descrever um conjunto de associações programáticas típicas na capital japonesa, mas imprevisíveis no mundo ocidental. Por um conjunto de circunstâncias, essas associações configuram um formato recorrente na Tóquio contemporânea (submetida a um valor de terra altíssimo que torna o custo de construção muito baixo) resultando em um encurtamento radical dos ciclos de vida dos edifícios, que só em uma pequena proporção são projetados por arquitetos: "Se não podemos transformar edifícios "desagradáveis" em recursos, não há razão para ficar em Tóquio." (KAJIMA; KURKUDA; TUKAMOTO, 2001, p.8, tradução nossa).

"Made in Tokyo" é um guia de outra arquitetura, um relatório de edifícios estranhos e anônimos marcados por uma sobreposição programática não convencional. A arquitetura que dispensa argumentos de forma e estéticos para simplesmente existir, é para Bow-wow uma arquitetura Da-me (não boa), ou como eles chamam, em uma piscada ocidental, edifícios "Classe B". A ênfase do estudo não é estilística, nostálgica ou pop (nesse contraste com "Learning from Las Vegas", embora a referência seja clara), mas apenas vinculada ao uso. Um olhar "plano", despojado de modelos urbanos e metáforas. Investiga híbridos nascidos de uma interdependência prática sem preconceitos: que com uma estrutura única associam programas não relacionados a priori, a ampliação interna em vários edifícios existentes, ou a compressão de uma ecologia incomum em um único edifício. Para definir essas combinações, usam o termo "Unidades Ambientais", que permite que saiam da noção de construção e encontrem novas relações entre o público e o privado, e nas definições do limite. A experiência 


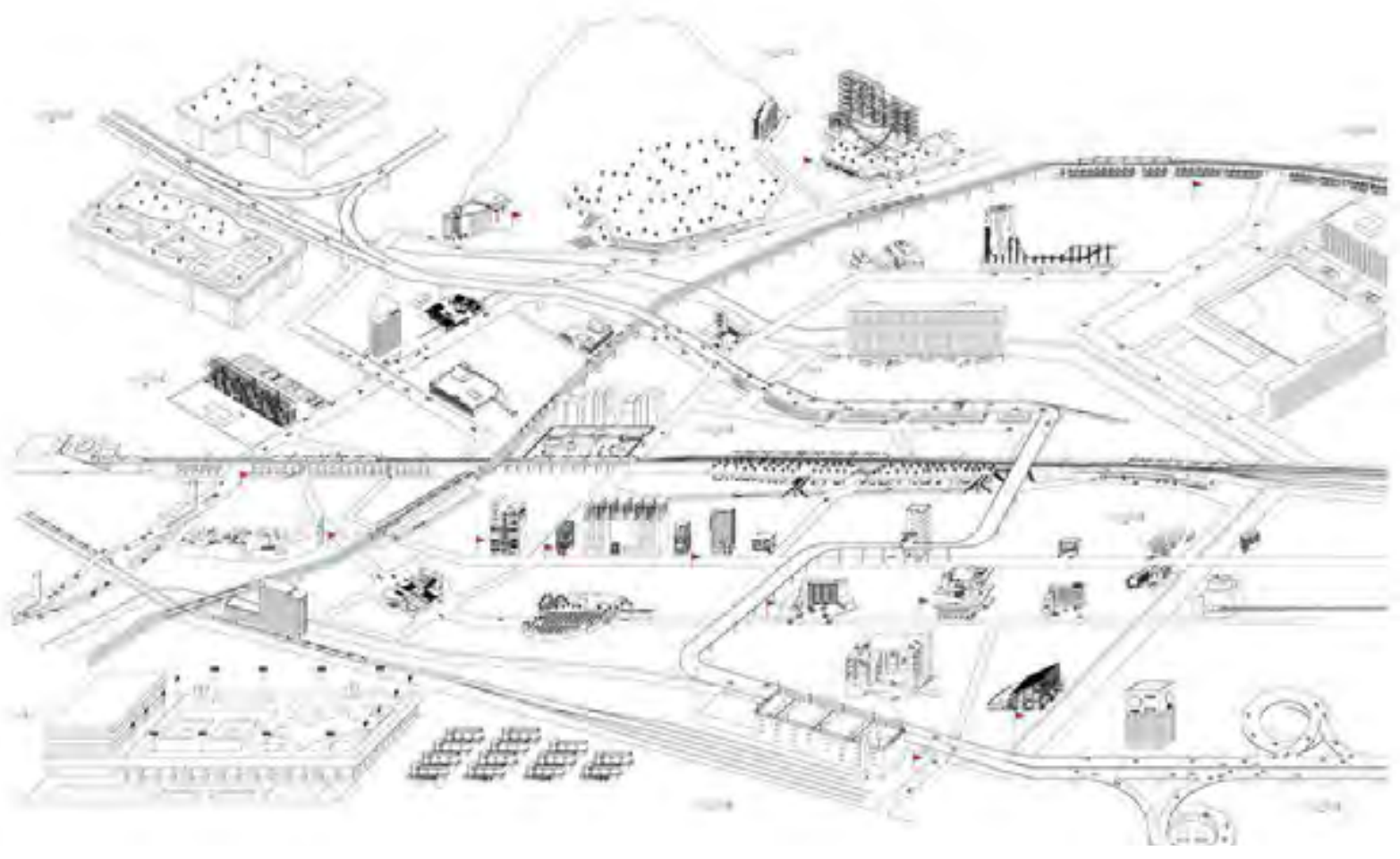


urbana de Tóquio envolve o constante cruzamento de diferentes ambientes arquitetônicos, em vez de uma experiência ordenada. Para o seu guia, eles propõem 3 ordens: categoria, estrutura e uso.

Quando se referem a "categorias cruzadas", descrevem uma realidade que não é tão diferente da de uma periferia de uma cidade latino-americana:

O planejamento urbano moderno evidencia separações e especializações. As separações mais radicais são entre a arquitetura e engenharia civil, ou entre o plano arquitetônico e o urbano, separações que podem ser vistas na burocracia e na academia. Vários problemas emergem dessa situação, mas o mais imediato é que um local específico não pode ser pensado pela sua totalidade. Existem inúmeras instâncias do ambiente que são realmente agravadas pelo desenvolvimento de ideias não coordenadas geradas em diferentes campos, e isso deixando de lado as perdas econômicas.

Então, seria bom se pudéssemos criar e manter nosso ambiente, perdendo as definições estritas entre categorias como arquitetura, engenharia e planejamento, assim como publicidade, agricultura e geografia. Esse é o cenário de cruzamentos da produção urbana. Se as categorias puderem ser cruzadas, as ferramentas para organizar um ambiente coordenado podem de repente aumentar de maneira geométrica. Esse tipo de hibridização é condensado nos exemplos de Made in Tokyo. (Ibid. p.22, tradução nossa)

No final do século $X X$, há um crescente interesse e confiança na manipulação criativa do programa, pois ele define a entrada que leva seu nome no "Diccionario Metápolis de Arquitectura Avanzada" (GAUSA et al., 2001), e que de alguma forma sintetiza a trajetória da última década da influente revista Quaderns dirigida naquela época por Manuel Gausa, e em evidente diálogo com as ideias de Tschumi:

Programa: Compor hoje significa criar os programas. Nós inventamos ou propomos; nós misturamos, damos apoio ou desnaturalizamos.

O programa não é igual à função. Mais ainda, porque não é unívoco ou direto. $E$ menos, porque é defendido por ações e atividades (verbos) e não por convenções (substantivos). Também é mutável, transformável no tempo. Temos que definir os programas para depois esquecê-los ou transformálos. ${ }^{9}$ (Ibid., p. 484)

\footnotetext{
${ }^{9}$ A entrada foi escrita por Federico Soriano.
} 



\title{
PROJETO DESESPECIALIZADO
}

Anthony Vidler atua ao mesmo tempo e, em busca de posições cultural e políticamente envolvidas, propõe um olhar retrospectivo aos anos 60:

\begin{abstract}
A insistência de Banham no papel da estética - do observador e da experiência - na criação de um significado, invoca a possibilidade de reconceber a noção de um programa de uma maneira que supera a lacuna fatalista do modernismo entre forma e função, incorporando questões ambientais, tecnológicas e a invenção formal como partes integrantes de um único discurso. "Une architecture autre" foi em 1960 a promessa de um amanhã; sua realização hoje se tornou não apenas possível mas acima de tudo urgente. ${ }^{10}$ (VIDLER, 2003, p.74, tradução nossa)
\end{abstract}

A condição para desenvolver o projeto com a desespecialização como ferramenta será a de fugir do determinismo do uso previsto, reconhecendo a incerteza e a variabilidade que sempre acompanhou a vida dos edifícios. A abordagem proposta aqui não é a de uma nova relação de programa desespecializado-forma como um par autônomo, mas que esta abordagem singular do programa contribui na definição do projeto e do edifício entendido como um dispositivo complexo e multifatorial, onde a tecnologia, a paisagem e a implicação cultural da arquitetura são partes indissolúveis.

No texto "Condições de Campo", Stan Allen fala das "Instituições distribuídas" fazendo uma retrospectiva dos últimos períodos da arquitetura colocando em relação programa e projeto, para concluir seus questionamentos sobre essas relações propondo um "ajuste frouxo entre uma atividade e seu invólucro" (ALLEN in SYKES, 2013, p.102)

Faz uma revisão entre as instituições surgidas no século XIX e anteriores, e as regras compositivas da arquitetura clássica. A reformulação da arquitetura moderna dessas instituições foi sobre tudo material e visual, mesmo adotando as estratégias decantadas da tradição compositiva de Durand e a dos acadêmicos, como já foi dito aqui. Allen propõe, colaborando com o desenvolvimento das ideias da desespecialização, que:

Talvez seja necessária uma mudança mais radical. É ainda mais urgente porque as instituições estão se transformando por dentro sob a pressão de mudanças tecnológicas e sociais. [...] Os princípios organizacionais propostos aqui sugerem novas definições das "partes" e maneiras alternativas de conceber o problema das relações entre elas. A forma dessas instituições não tenta representar metaforicamente a nova condição da instituição, nem tenta instigar diretamente novas maneiras de pensar ou se comportar. Pelo contrário, ao conformar a instituição dentro de uma condição de campo direcionada, ligada à cidade ou à paisagem, deixa-se espaço para as improvisações dos futuros usuários. (lbid., p.102)

\footnotetext{
${ }^{10}$ Refere ao texto BANHAM, R., Architecture After 1960. Architectural Review 127, no. 755 (January 1960), p. 9.
} 


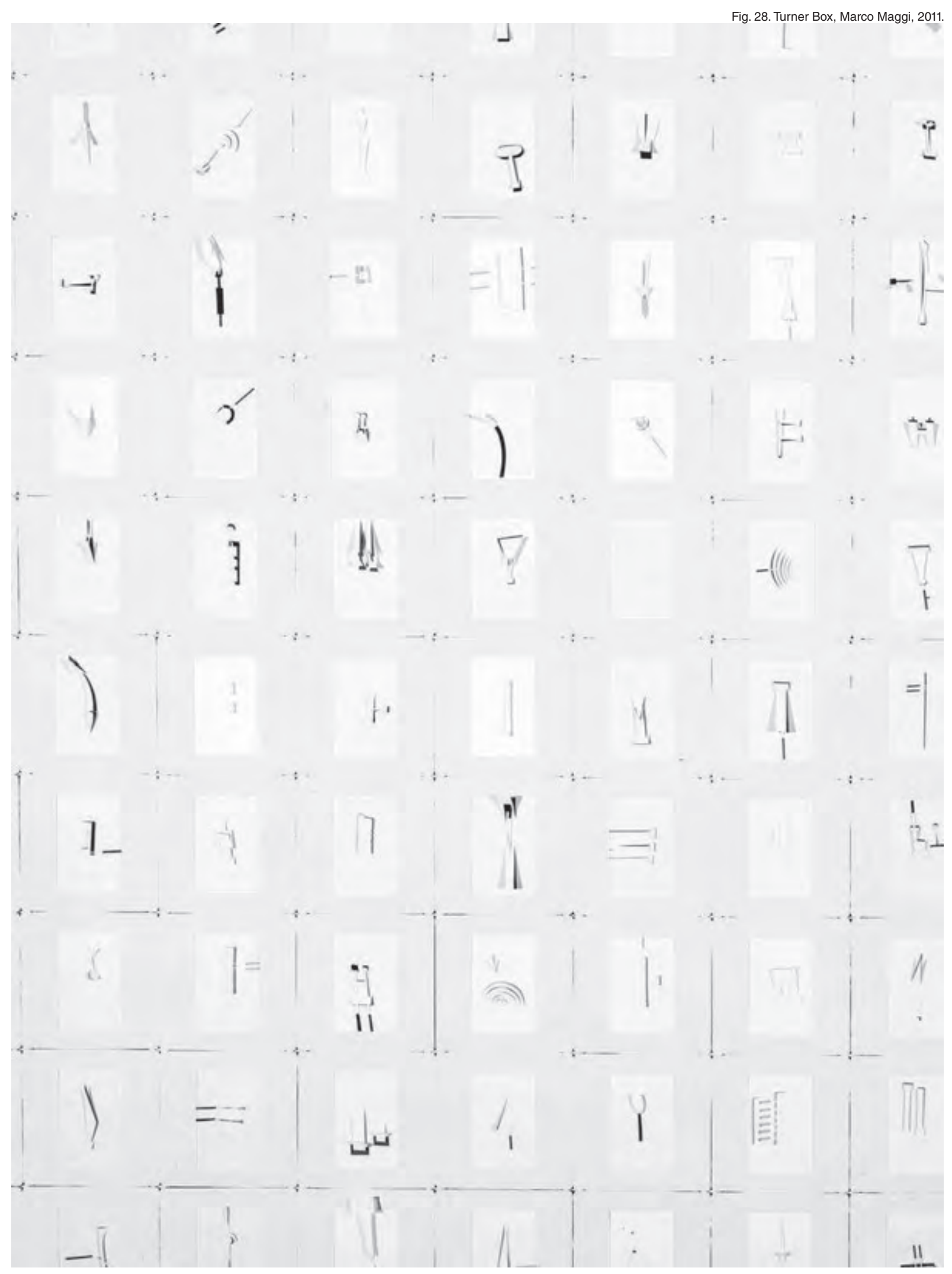


A maneira de pensar essas novas definições das "partes" do projeto, e a atenção focalizada na relação entre essas partes, permite reconhecer diversidade (distinção) e sua articulação (conjunção). Estudar um prédio em função das suas relações urbanas e paisagísticas permite estabelecer relações, não entender o projeto desde o isolamento (disjunção) ou a tábula rasa, colaborando com esta ideia de projeto complexo. "ajuste folgado" é uma modalidade pós-funcionalista seguindo a denominação de Peter Eisenman, e envolve a capacidade de dar respostas às demandas especificas, mas relativiza-as atendendo à incerteza e à instabilidade das instituições.

\section{ABSTRAÇÃo}

O trabalho de Durand, elaborado num momento de mudanças profundas na disciplina e na cultura aporta um elemento significativo ao considerar as partes do projeto por separado, descobrindo certas regularidades que se repetem em diversos programas. Só por meio da abstração, isto é, de uma consideração que se distancia com as circunstâncias especificas da demanda que é produzida fora da arquitetura, e que a arquitetura pode estabelecer uma formulação especifica e também considerar as similaridades como outras demandas atuais possíveis e ainda não imagináveis.

Abstrato pode ser entendido a partir das definições de diferentes dicionários ${ }^{11}$, como uma produção de ideias que atende a produção de ideias e de objetos separando-as dos sujeitos e dos eventos. O momento da abstração não nega os sujeitos nem os eventos, mas é um momento especifico da produção da forma que produz espaços, e pode ser entendido como parte da heurística própria da arquitetura.

É claro que a abstração pode ser empregada para desenvolver uma arquitetura autônoma, puramente abstrata sem comunicação com o mundo concreto dos sujeitos, posição que é oposta à sustentada neste trabalho. Desde a consideração da desespecialização, a abstração é um meio para produzir a capacidade de sediar sujeitos e eventos em diferentes condições e momentos, se separando de uma demanda muito particular $^{12}$ e não formulada desde o entendimento geral das regras do espaço arquitetônico, ela é uma versão do "ajuste folgado" proposto por Stan Allen. A abstração também permite encontrar regularidades aonde aparecem diferenças insubstanciais, 0

\footnotetext{
${ }^{11}$ Dicionário Aulete da Língua Portuguesa. (AULETE, 2018) Diccionario de la Real Academia Española. (RAE, 2018) Oxford Dictionary Oxford University Press. (OXFORD, 2018) ${ }^{12}$ Esta noção é aplicável à demanda daqueles que não são arquitetos, mas também e muito frequentemente produzida a partir da separação do programa do projeto, ficando a programação como uma atividade especializada e separada do projeto de arquitetura.
} 


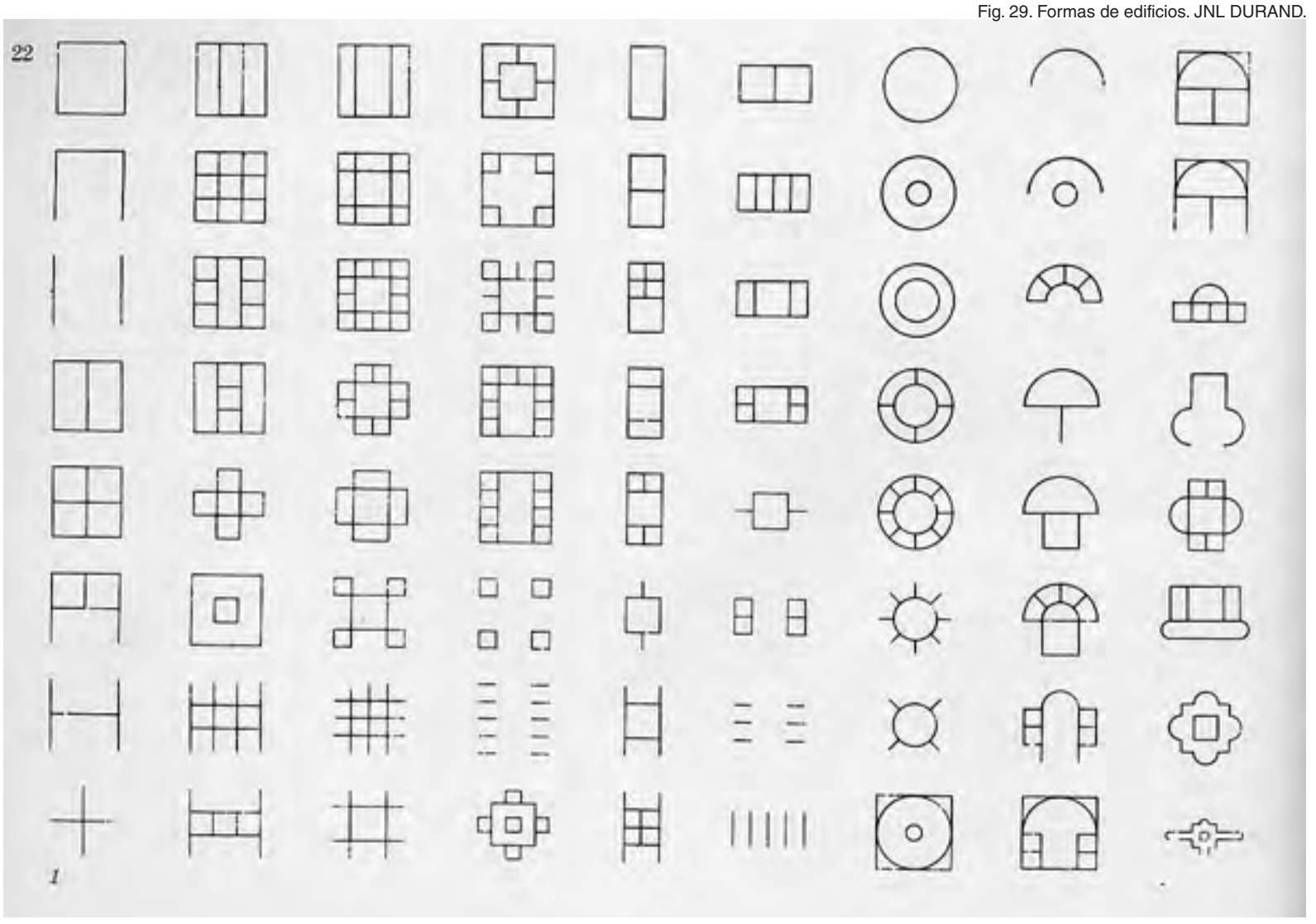


que dá "capacidade" ao espaço e sua evolução, e também permite associar o programa com as lógicas da estrutura e geometria que fazem parte indissociável da arquitetura.

Essas ideias sobre a abstração e sua relação com a arquitetura moderna são sintetizadas na hipótese da tese de doutorado de Anthony Vidler que conclui:

\begin{abstract}
O que um modernismo poderia reconceber como um continuum, dentro do qual um pós-modernismo "pós-histórico" encontra seu lugar momentâneo e recorrente para a prática contemporânea? Em primeiro lugar, não esperamos ver um ressurgimento do estilo, ou estilos, moderno, mas sim uma resistência consistente ao estilo e uma reexploração dos potenciais de abstração para desenvolver uma forma coerente de expressão. Tal abstração, no entanto, não se basearia nas várias linguagens de vanguarda dos anos 1920, mas sim nas demandas programáticas e tecnológicas do presente . (VIDLER, 2008, p.216, tradução nossa)
\end{abstract}

Uma aproximação da abstração da arquitetura é um dos núcleos de pesquisa do arquiteto Gustavo Scheps ${ }^{13}$ a partir de seu questionamento da heurística do projeto arquitetônico, articulando uma reflexão teórico/prática sobre os processos específicos de pensamento no processo do projeto (e particularmente durante a sua intangível gestação) combinando sua própria experiência professional e a sua atividade docente. No livro "Puerto" ele propõe uma aproximação especificamente disciplinar, mas procurando abstrair ideias gerais a partir de processos concretos. Acaba definindo uma série de categorias que o projeto atravessa ou inclui na sua gestação: "Campos" como âmbitos de propriedades homogêneas (as "partes" do projeto que refere Allen), "Estrutura de Campos" que envolve o sistema de relações entre os campos, "Sistema Referencial" que inclui o universo cultural e subjetivo do projetista e as "Estratégias de Projeto" que colocam em relação as categorias anteriores. Particularmente propõe a existência de atributos ou propriedades dos "Campos": posição, extensão, tropismo, curvatura, textura. Finalmente ele acaba propondo num diagrama a noção do Campo como aquela entidade que é a intersecção entre função e forma:

\footnotetext{
Em termos compositivos, a concepção de uma estrutura de campos sintetiza complexos argumentos, os objetiva e os faz disciplinarmente operáveis. Sua natureza analítico-propositiva é chave na construção da "legalidade" que direciona a deriva do pensamento projetual". (SCHEPS, 2002, p.41, tradução nossa).
}

\footnotetext{
${ }^{13}$ Dr. Arq. Gustavo Scheps. Diretor do ateliê de projeto Taller Scheps, Faculdade de Arquitectura Design e Urbanismo (FADU) da UDELAR desde 2005 e até 2017. Desde 2009 é até 2017 foi também Decano da FADU UDELAR.
} 


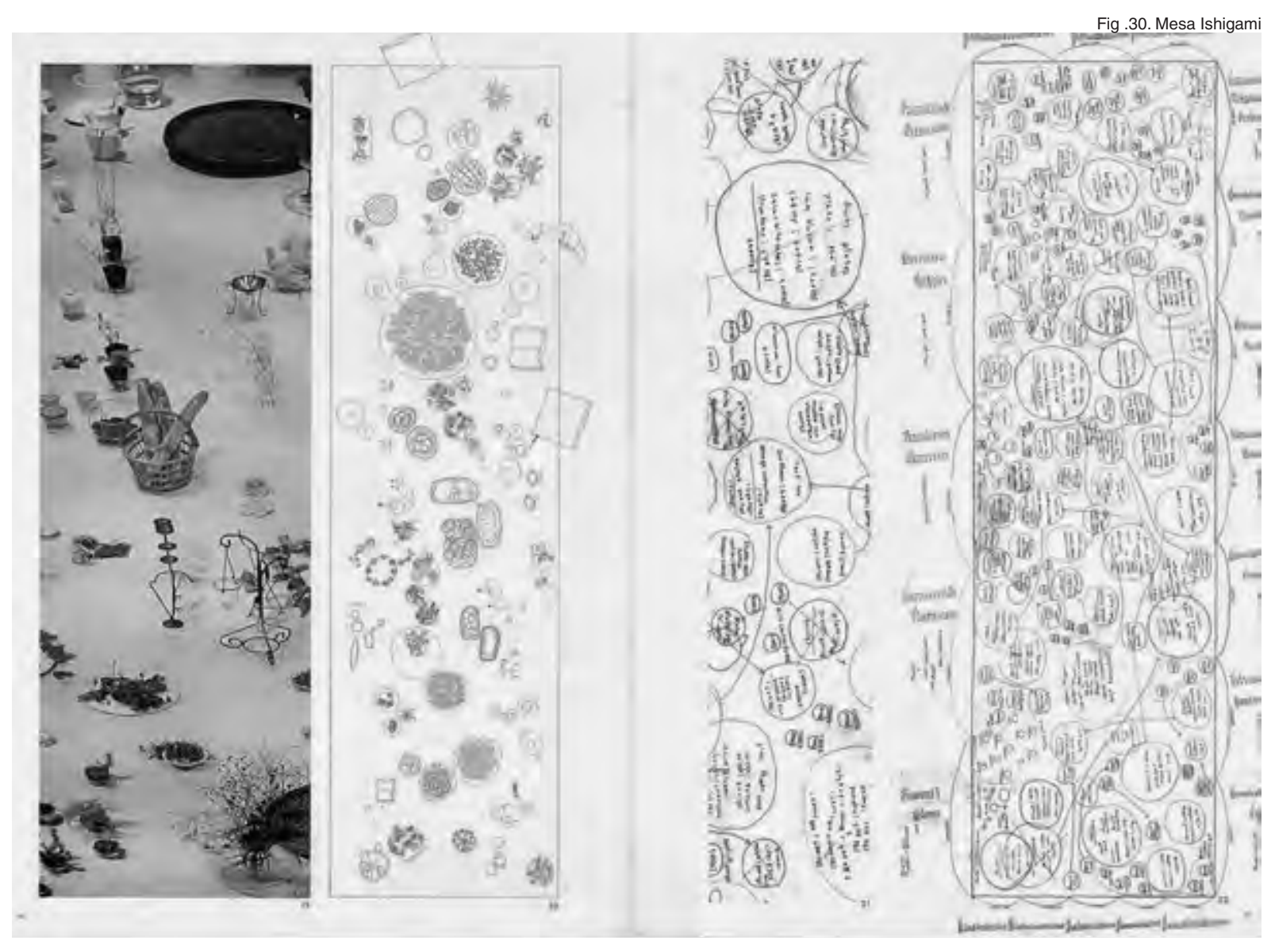


O suporte conceptual de Gustavo Scheps, é uma contribuição para sair da disjunção, um entendimento do projeto como ato complexo, pelo que é necessária a produção com espírito de abstração. Ele é projetado para se distanciar de dois processos clássicos de projeto e produzir conceitos perduráveis.

A tese pressupõe um acercamento às periferias de Montevidéu, onde detecta uma multiplicidade de políticas públicas segmentadas e propõe a possibilidade de articulá-las territorialmente como forma de remeter a especialização segmentada dessas políticas, colocando-as em relação a produzir sinergias de baixo para acima. E para isso propõe um território arquitetônico concebido a partir da desespecialização programática, que abriga atividades concretas e estudadas que resultam em diversas necessidades espaciais, mas acima de tudo reconhecíveis e recorrentes. Um espaço específico em suas qualidades, pensado como um espaço potencial para novas atividades, que é baseado na abstração para lidar com a complexidade que Morin descreve, "afrontar o entrelaçado (o jogo infinito de inter-retroações), a solidariedade dos fenômenos entre si, a bruma, a incerteza, a contradição" (MORIN, 2007, p.33, tradução nossa).

\section{UM FAROL DESESPECIALIZADO}

A partir da desespecialização programática podemos encontrar formulações que a estimulam assumindo a abertura do projeto como hipótese. No planejamento de edifícios da Universidade da República do Uruguai (Udelar), uma instituição que (em grande parte) está localizada dispersa na Montevidéu consolidada, são propostos processos sinérgicos que permitem a colaboração para a gestão do espaço das diferentes faculdades e escolas que a compõem, e para que as diferentes funções da instituição sejam desenvolvidas. Em 2009, foi feita uma convocação para um concurso de projetos para o Centro Universitario Regional Este (CURE) na cidade de Maldonado. As bases do concurso explicitamente convocam a noção de Plataformas:

Duas condições estruturais fundamentais: a concepção modular e a concepção evolutiva devem nortear o processo do projeto em todas as suas etapas, tendo em vista a concepção de edifícios universitários concebidos a partir do conceito de plataformas, conceito orientador dos desenvolvimentos edilícios de médio e longo prazo da Universidad de la República no futuro. [...]

O conceito de Plataformas refere-se a edifícios com estruturas espaciais, tipo e quantidade de locais, instalações, conforto e dimensões adequadas ao melhor desenvolvimento de uma atividade universitária concreta e específica. Parte da base das diferentes atividades que são desenvolvidas em uma universidade (ensino, pesquisa com alta tecnologia, pesquisa em humanidades e ciências sociais, governo e administração) e propõe uma 
Fig. 31a. Aulario Jose Luis Massera. Redesenho axonométrico.

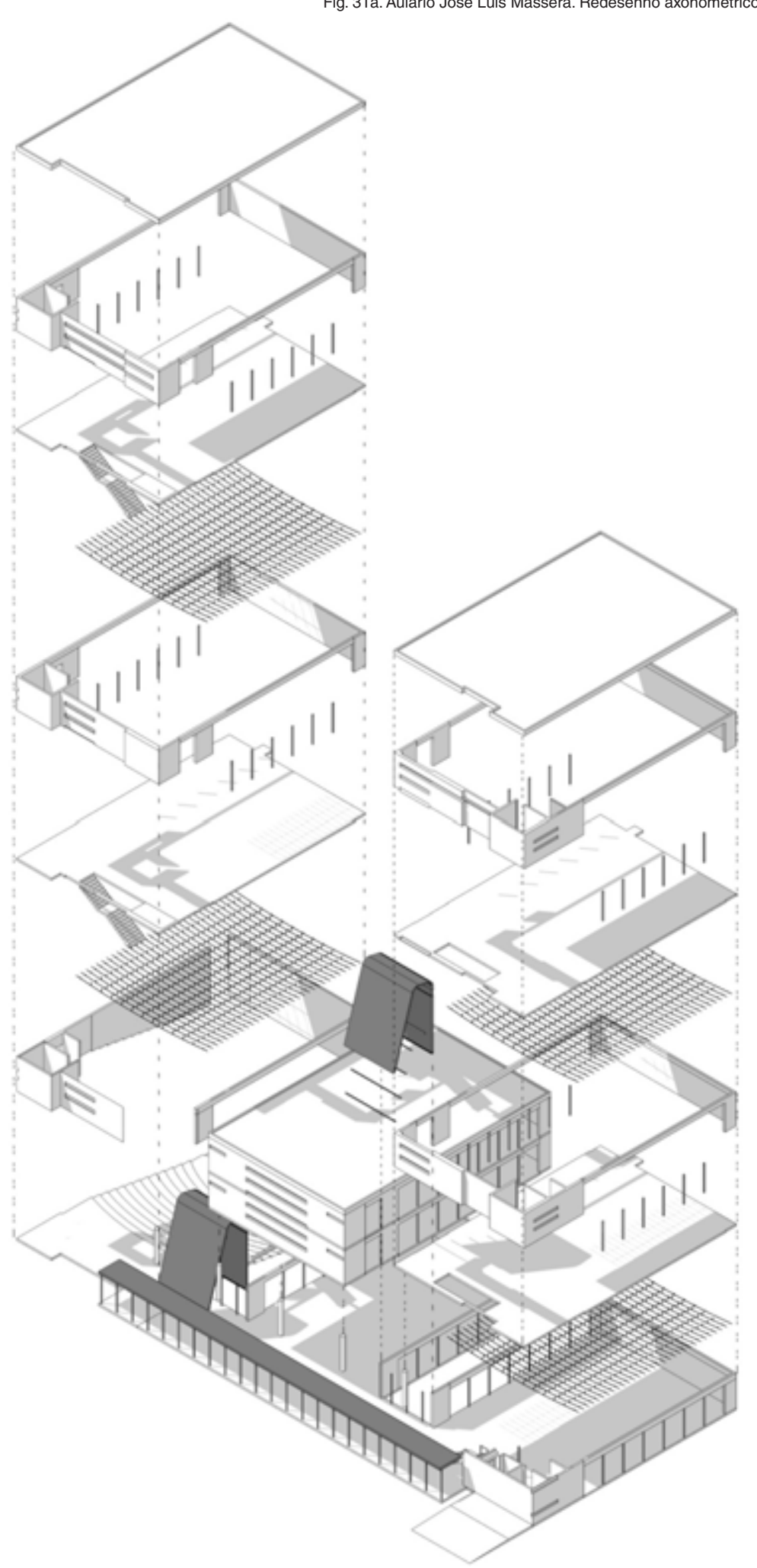


concepção de edifício que responde em seus benefícios a cada uma dessas atividades concretas com todos os requisitos que essas atividades geram. Tem como objetivo solucionar problemas de necessidades locais de diversos serviços universitários, apostando numa economia de escala, e um uso mais intenso e racional das premissas, o que permite otimizar o desempenho dos recursos investidos e melhorar a qualidade dos espaços universitários, oferecendo soluções flexível adaptável ao uso compartilhado por diferentes serviços. (UDELAR, I.Ma, 2009, p.30, tradução nossa)

O conceito havia sido formalizado, pelo Escritório de Planejamento de Obras de Médio e Longo Prazo da Udelar em 2008, havia começado a delinear a ideia de edifícios compartilhados por várias faculdades e funções universitárias no Plano Diretor de 2001 (FOLCO; URRUZOLA, 2001) .

O "Aulario José Luis Massera" (vulgarmente conhecido como "El Faro", "O Farol" devido à sua proximidade à quadra de um antigo clube de basquetebol com esse nome), um edifício universitário destinado a salas de aula e um auditório para três faculdades, foi projetado em 2003 amparando-se nas ideias mencionadas e em gestação. Projetado na chave da abertura e desespecializaçào programática por Gustavo Scheps, o edifício é composto por três corpos educacionais de três níveis cada um, interligados, e foi construído em três etapas, bloco a bloco cuja primeira parte foi inaugurada em 2007 e todo o edifício em 2011. Os blocos educacionais de 16x20 metros e separados por 6 metros compõem 9 espaços-plataformas que podem ser ocupadas em diferentes formatos de sala de aula. A luz livre completa dos mezaninos é composta por um sistema sólido de laje de concreto armado de 16 centímetros de espessura e uma estrutura de suporte inferior de aço corten. Uma das plataformas, no térreo, é especificamente montada como um auditório para 350 pessoas, e as outras formam salas de aula de até 400 alunos, subdivididas em duas partes, uma de 100 e outra de 300 alunos, e permitem possibilidades de subdivisão em espaços menor, seja nas salas de aula ou nos espaços de pesquisa. O projeto e a obra de "Aulario Massera", foi um manifesto catalisador de uma ideia em gestação.

O concurso do CURE Maldonado teve então um edital escrito e um projeto de "farol" (o "El Faro") que funcionou como uma possível referência para o conceito de Plataformas ${ }^{14}$. Uma nova versão de marca similar obtém o primeiro prêmio com o projeto de Santiago Lenzi e Álvaro Toledo, propõe um bloco de 50x40 metros, subdividida em três "bases" de alta abertura programática, uma opção em diálogo claro 
Fig.31b. CURE Maldonado. Santiago Lenzi y Alvaro Toledo.

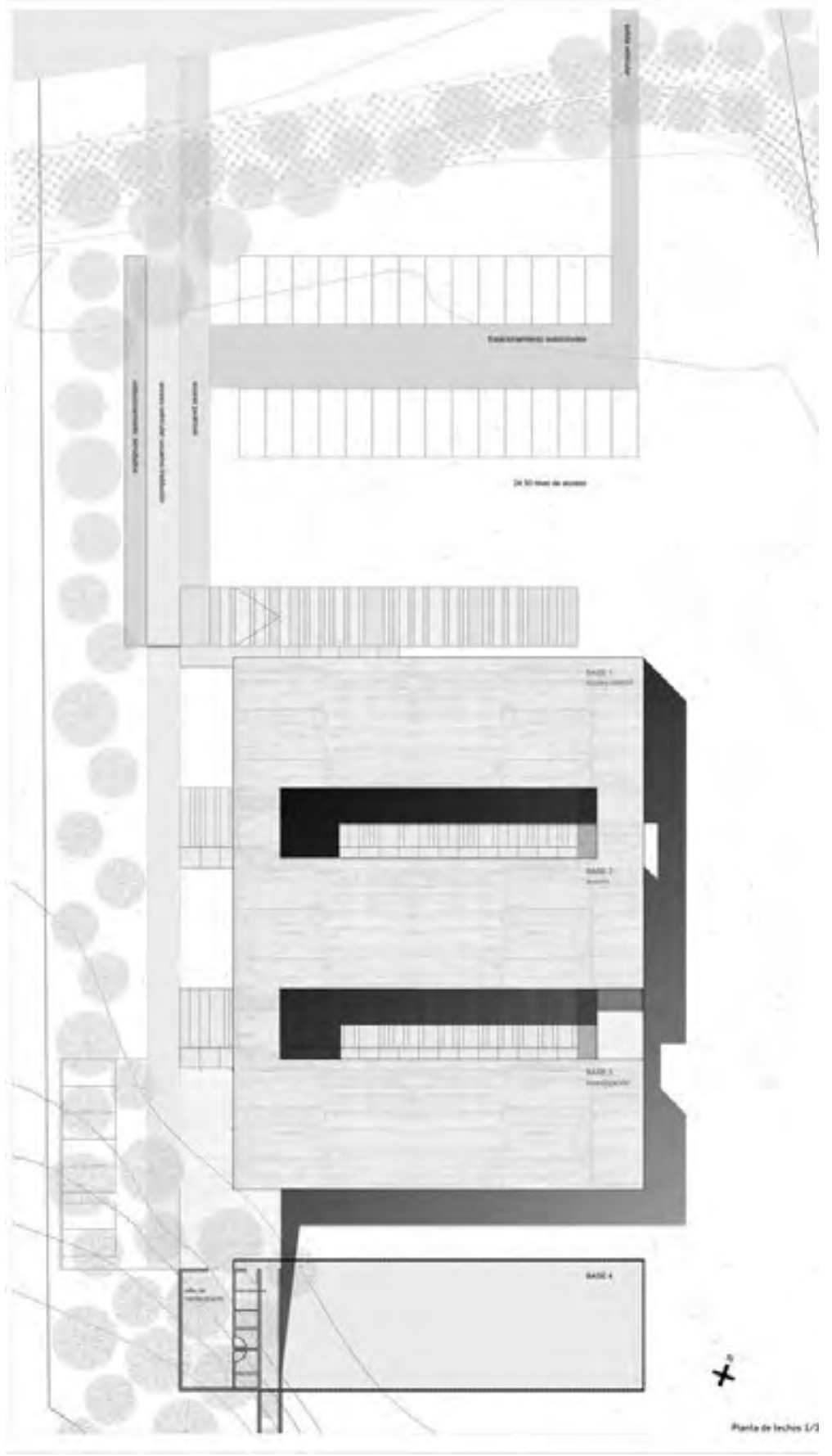


com o farol mencionado anteriormente; o bloco de concreto armado único e severo, parece ser o argumento escolhido para funcionar como referência em um contexto urbano um pouco sem graça. No concurso diversas propostas foram apresentadas em sua forma e interpretação do programa proposto. ${ }^{15} \mathrm{O}$ que interessa aqui é a sequência que é abordada na elaboração de uma ideia abstrata de desespecialização programática, que se formula a partir de um projeto do Faro, que então colabora para desenvolver uma ideia abstrata de organização, a Plataforma, unindo o programa estabelecido no edital de um concurso CURE, e depois o primeiro prêmio que o grupo conceitual adota e reformula em uma nova exploração do projeto.

${ }^{15}$ No site do Fadu "La ciudad imaginada" pode ser visto todos os detalhes do concurso e os três primeiros prêmios. (DELGADO, MAGNONE e STARICCO, 2016-2017) Os prêmios e menções podem ser vistos em Plataforma Arquitectura (PASTORELLI, 2009) 
Fig 32a. Nuova Planta de Roma, Giambattista Nolli.

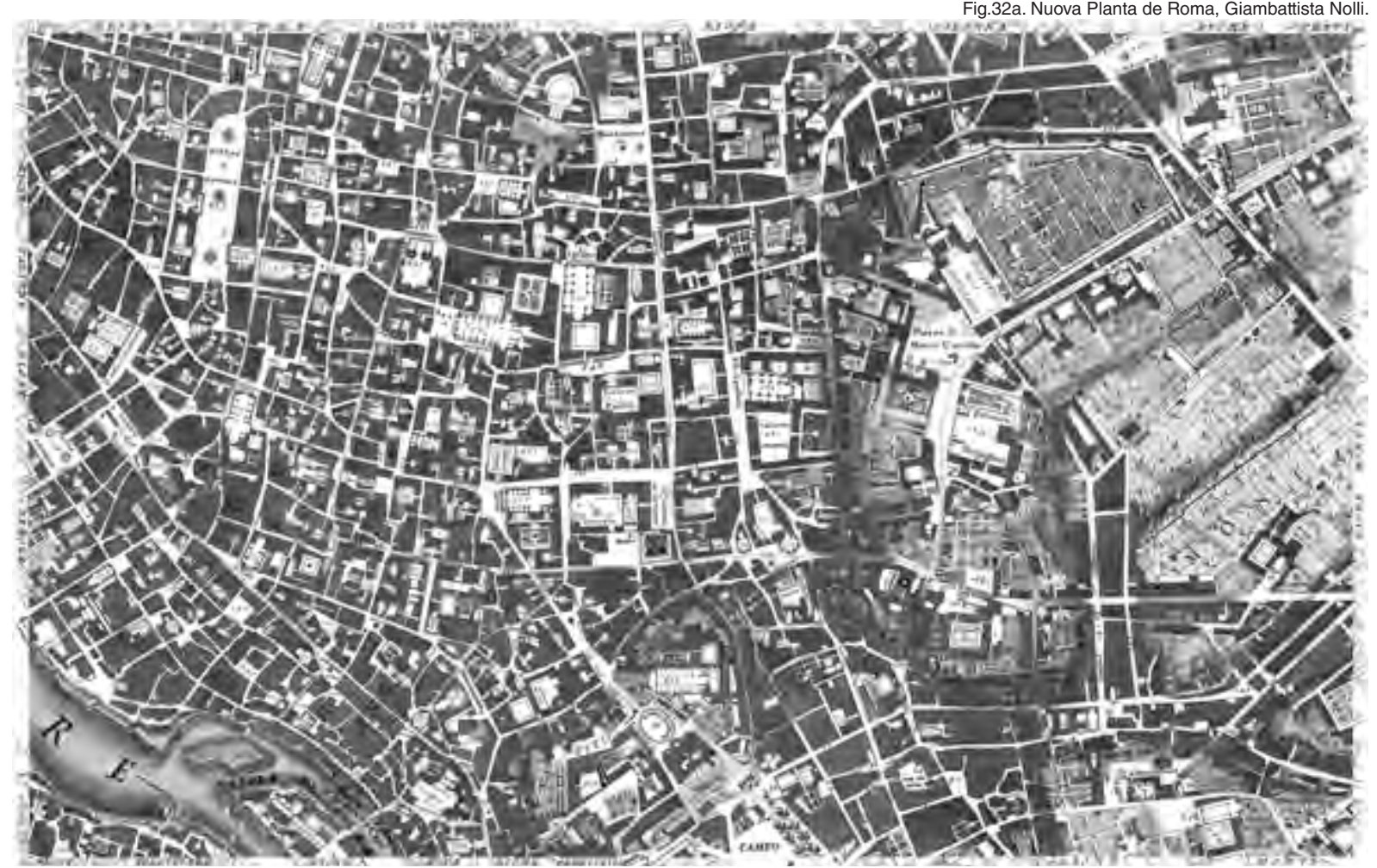




\section{DPL.3 ARQUITETURAS DA DESESPECIALIZAÇÃO}

\section{BRANCO NOLLI}

Uma arbitragem produz uma disjunção e separa o espaço público do equipamento público. O que é externo e o que é interno, embora ambos sejam públicos, foram deslocados para outras esferas intelectuais e operacionais. Essa divisão pragmática, de utilidade prática discutível, gerou uma especialização disciplinar, institucional e acadêmica que multiplica a distância entre os dois campos, tão próxima na realidade, na experiência urbana e cuja relação é fundamental para essa tese. Assim, o limite arbitrário que separa os dois campos é questionado, interrogado e atravessado, buscando a conexão no essencial que é comum a eles, e o que os torna específicos e, portanto, diferentes. Sua essência pública, isto é, que pertence ao povo (a todos) coloca em segundo plano a ruptura operativa produzida pela departamentalização do conhecimento e da prática humana.

$\mathrm{Na}$ fundação do Parque do Ibirapuera, Niemeyer projeta um conjunto de blocos de edifícios públicos distribuídos no Parque e interligados pela Marquise, uma cobertura e piso quase paralelos de $28.000 \mathrm{~m}^{2}$. Caminhar pelo parque e se aproximar da Marquise permite descobrir a sua autonomia, como ressalta Ruth Verde Zein: "Mas com os anos, a marquise passou a ser ela mesma. Sem sair de onde estava, tornou-se independente". (VERDE ZEIN, 2012). Os espaços sob a Marquise do Parque do Ibirapuera $^{16}$ são uma interface de condição ambígua: edifício e espaço público ao mesmo tempo. Um espaço aberto (no sentido programático, desespecializado) que abriga formas de vida infinitas e sempre renovadas. ${ }^{17}$

Se desenharmos a planta do parque necessariamente teremos que deixar esse espaço no mesmo branco em que desenharíamos suas infinitas área verdes e sendeiros ${ }^{18}$.

\footnotetext{
${ }^{16}$ Veja a tese: Marquise do Ibirapuera: suporte ao uso indeterminado.(GURIAN, 2014).

${ }^{17}$ A exposição Panorama 33 de 2013, com curadoria de Lisette Lagnado, questiona o MAM SP como instituição, convidando um grupo de artistas para ativar essa condição e propõe ideias para um grupo de 6 estúdios de arquitetura para discutir o status do museu como um habitante permanente espaço da Marquisa. (LAGNADO, 2013)

${ }^{18}$ Interpretação serve o raciocínio de desespecialização programática. E como argumento adicional, a arquiteta Marta Moreira apresentando o SESC 24 de Maio, projeto de Paulo Mendes da Rocha com seu estúdio MMBB, compila os grandes vazios produzidas pela arquitetura que compõem a fusão radical da escola paulista entre arquitetura e espaço público: Vão livre do Masp, Salão Caramelo da FAUUSP, Marquise do Ibirapuera. E nessa genealogia, ela afirma que o mais importante prédio que Niemeyer fez no lbirapuera foi a Marquise. Palestra no Ateliê Scheps FADU UDELAR, 24 de maio de 2018.
} 
Fig 33. Tabela do Oceano, Lewis Carroll.

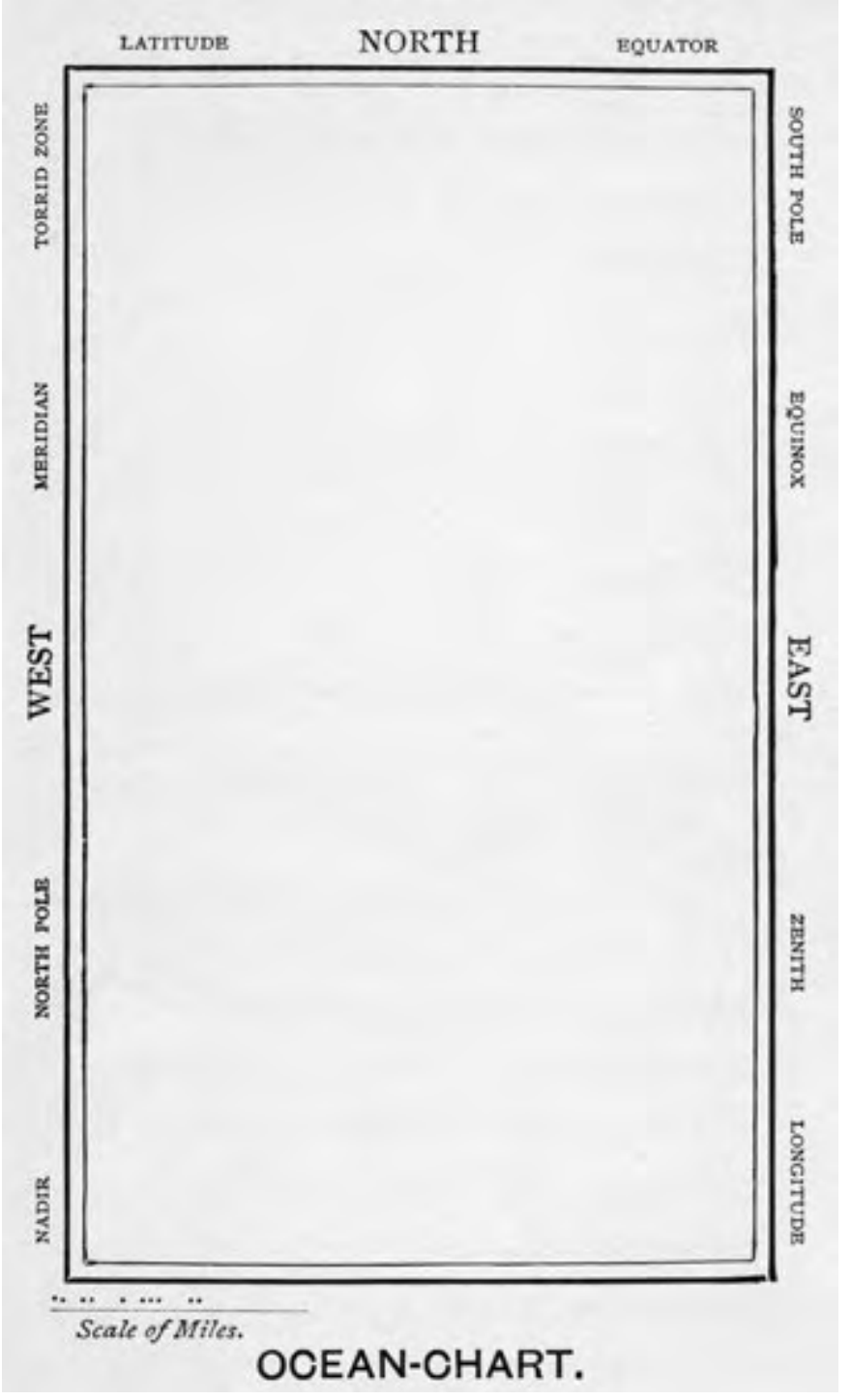


Branco é o mapa com que o capitão que Lewis Carroll cria em "The Snark Hunt", com que ele pretende navegar pelos mares, questionando convenções arbitrárias.

\footnotetext{
O próprio capitão todos o colocavam nas nuvens.

Que equilíbrio, que naturalidade e que graça!

Que solenidade também! Qualquer um podia ver que ele era um homem sábio, apenas olhando para o rosto dele!

Ele havia comprado um grande mapa do mar, sem um único vestígio de terra.

E toda a equipe ficou encantada, vendo que era um mapa compreensível para eles.

"Qual é o uso das zonas do Equador, Pólo Norte e Mercator, Trópicos e Meridianos?"

Foi o que o capitão disse. E a tripulação respondeu:

"Eles são apenas sinais convencionais!"

"Outros mapas têm formas, com as ilhas e as capas, mas devemos agradecer ao nosso bravo capitão (é assim que a tripulação falou) que nos comprou o

melhor... um mapa branco perfeito e absoluto!"

Isso era maravilhoso, sem dúvida, mas logo descobriram que o capitão, a quem eles tinham tanta estima, só tinha uma ideia para cruzar o oceano, tocar seu sino.(CARROLL, 2006, p. 6, tradução nossa)
}

Branco (e preto) usa Giovanni Battista Nolli. A delimitação estrita entre espaço público e edifício público, era alheia à "contradição principal" das ideias que Nolli elaborou em sua "Nuova Pianta di Roma" de 1748, um plano encomendado pelo Papa Bento XIV que tinha como finalidade definir com precisão a cidade para fins de controle e gestão urbana, que na época se tornou um registro exaustivo da Roma de seu tempo. A leitura do plano de Nolli deu origem a sucessivas leituras ao longo do tempo. No caso de More with less podemos ler a partir de sua disjunção elementar pública/privada, como um manifesto da concepção urbana do público. O plano possui um rigor técnico, meticuloso e de precisão fora do comum, comprovado até pelos registros contemporâneos de satélites, motivo porque permaneceu como referência cadastral até o final do século XX. Tudo o que é branco no mapa é coletivo ou público (como se poderia entender nessa categoria na época e a partir de um comissionamento papal), associando na figura o espaço público de ruas e praças, e o espaço público de edifícios cujos andares inferiores são representados em branco e com detalhes refinados da arquitetura que os abriga. A continuidade do branco poderia ser lida como simplificação banal, e hoje podemos lê-la a partir do paradigma da complexidade urbana como a compreensão das relações íntimas que se estabelecem na esfera do público e do coletivo, e da qual o Fórum Romano é uma expressão. A distinção estabelecida entre o espaço coberto ou fechado e o espaço exterior de ruas e praças permite descobrir e entender com precisão os espaços e as relações da cidade. 


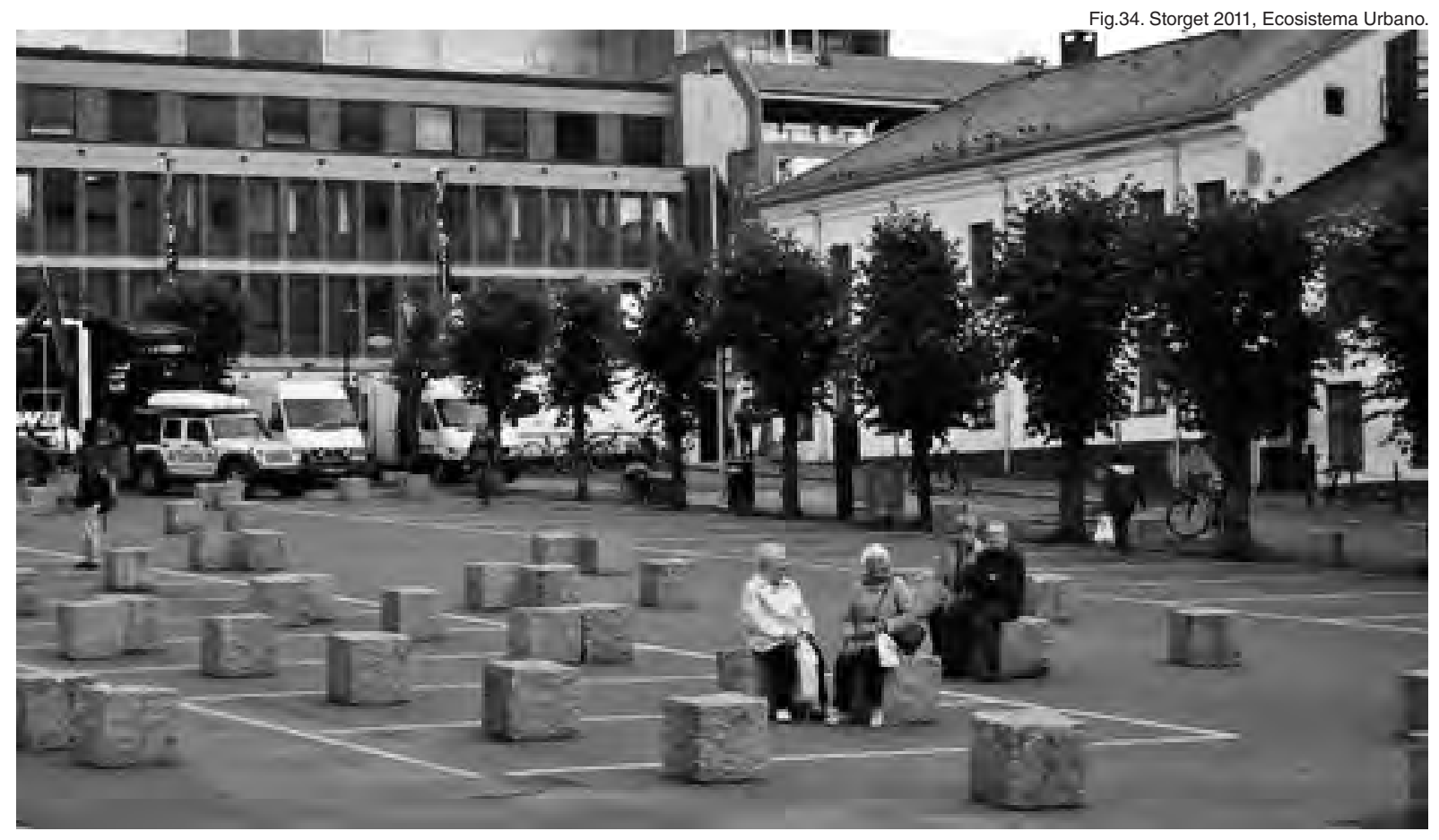




\section{METAFORA DESLOCAMENTO INTELETUAL}

O transporte na língua grega contemporânea tem o nome desta palavra: metáfora. A metáfora é escolhida aqui no sentido preciso de um transporte intelectual, um deslocamento que nos ajuda a sair do concreto e olhar com novos olhos para o projeto de arquitetura imaginando algumas possibilidades que os protocolos da profissão e das instituições, as vezes freiam. Um deslocamento que é de ida e volta, que não pretende traduções literais para o projeto, mas emprega figuras que nos colocam em uma posição mais independente do caso particular.

Emmánuel Lizcano licenciado em matemáticas e doutor em filosofia, mostra como o pensamento (e particularmente o cientifico) esta impregnado de metáforas que se opacam no hábito, impedindo a visualização do papel que as analogias possuem na construção de um imaginário do conhecimento.

Até aqui, temos sugerido a utilidade da analise metafórico para indagar a
dimensão instituída do imaginário, para mergulhar no seus pre-supostos e
pre-concepções. Acabemos mencionando seu proveito para explorar
também a sua dimensão instituinte, essa da qual emergem a criatividade e a
mudança social. Por oposição às metáforas mortas ou zombes, podemos
falar de metáforas vivas, aquelas que estabelecem uma conexão
insuspeitada entre dos significados até então desvinculados, aquelas que
abruptamente oferecem uma nova perspectiva sobre algo familiar e nos
fazem vê-lo com novos olhos (ou saboreara-lo com um paladar novo),
tensadas, ocultando como o conhecimento se constrói a partir de imagens
que funcionam como analogias.
Isso é tudo. Espero, senão haver-Ihes ilustrado, sim pelo menos haver-Ihes
contagiado a minha paixão pelas metáforas, esses surpreendentes duendes
do imaginário que nos habitam em segredo. Sustentai-as e vão conservar o
mundo. Muda-as e vão mudar o mundo.(LIZCANO, 2006, p.67-70, traduçao
nossa) Um primeiro argumento de deslocamentos metafóricos já empregado no Capítulo Um (ECM) recorre a um paralelo entre o espaço arquitetônico e os sistemas de informação, a tecnologia que muda o mundo da modernidade indústrial na contemporânea: a "dissolução programática e espacial". A "Dissolução Geométrica" dos Sistemas de Informação Geográfica (Dictionary of GIS Terminology: KENNEDY, 2000), se entende como um processo de união de dois ou mais polígonos mediante a eliminação dos lados comuns. A dissolução costuma realizar-se para generalizar a informação temática, unindo os polígonos vizinhos que compartem valores iguais (ou que pertencem a rangos de similaridade) para algum atributo; é um processo de remoção de limites desnecessários na produção cartográfica. 
Fig.35. El zócalo, Francis Alÿs.

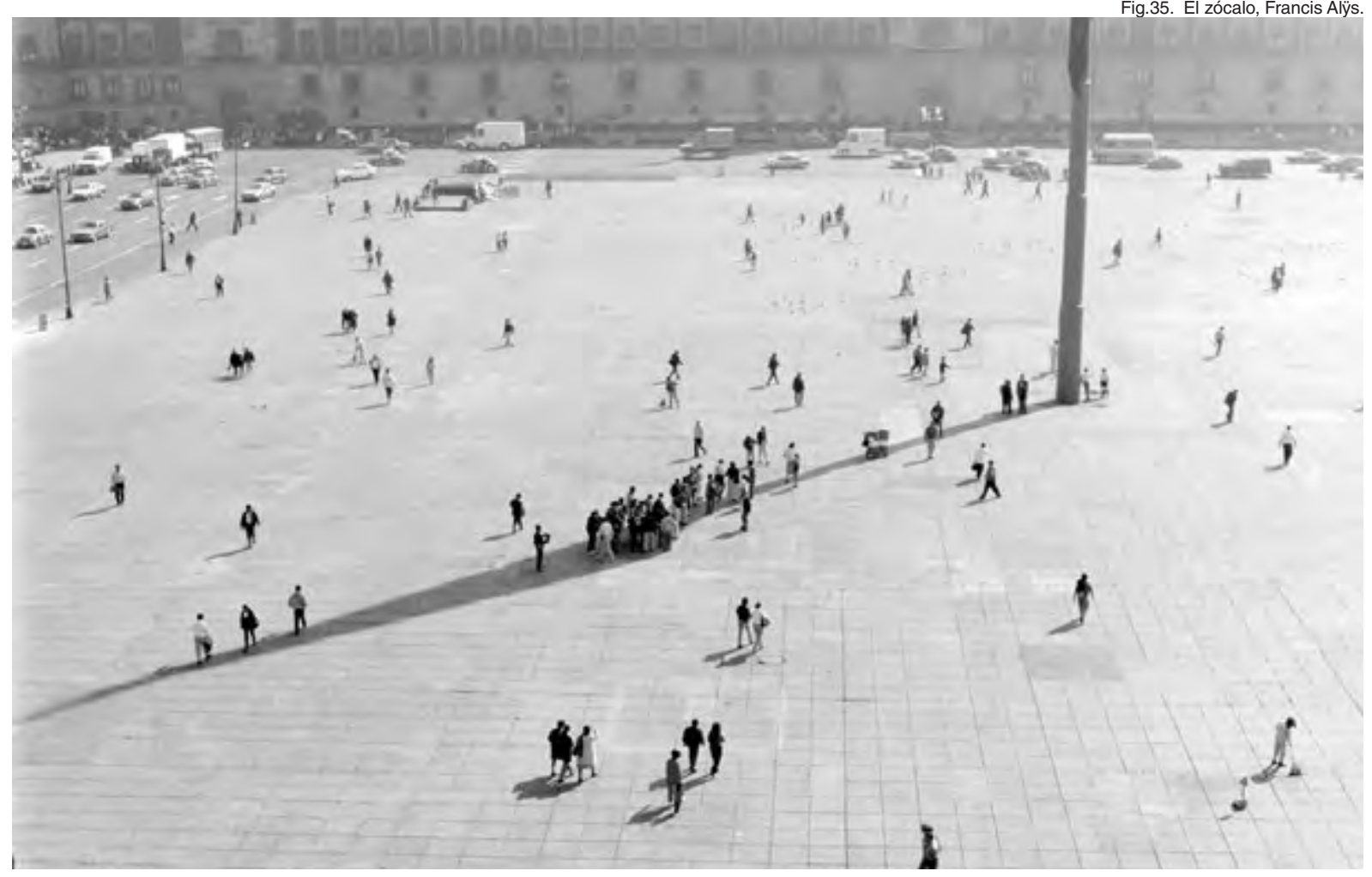


Se propõe então o termo Dissolução Programática, como a eliminação das diferenças entre dois espaços, enquanto estes compartilham qualidades espaciais, com independência de pertencer ao mesmo programa arquitetônico e possuir diferencias pequenas, ou si eles integram diferentes programas arquitetônicos. A dissolução propõe tomar distância do mais especifico para propor uma maneira que ganhe em abstração na maneira de entender o programa abrindo possibilidades, algumas que já podem ser previstas no momento do projeto, e outras que só vão ser descobertas durante a vida dos prédios, a partir da "imprevisibilidade da vida" que refere Paulo Mendes da Rocha:

Então, a ideia de funcionalismo em arquitetura é meio tola. Inclusive nós, não estamos prontos ainda. $O$ homem não possui uma forma definitiva. Existe uma ideia de um eterno inacabamento da nossa existência. Uma arquitetura que considera e ampara a imprevisibilidade das ações humanas. (ROCHA, 2012, p.128)

Essa maneira de pensar os programas, é diferente às maneiras e procedimentos institucionais que perdem de vista a complexidade de um projeto de arquitetura, particularmente das múltiplas razões pelas quais uma lógica geométrica ajuda na qualidade do espaço e descomplica aquilo que é secundário. A parte (o programa concreto de um local de um prédio) e a sua especificidade devem ser consideradas sempre em relação a uma totalidade, aquela do edifício e da instituição. Deslocamentos disciplinares dispostos a absorver o contemporâneo deixando para trás as associações mecânicas ou biomecânicas que marcaram o pensamento de especialização e funcionalismo.

A analogia entre o modo como os equipamentos de Montevidéu são distribuídos no território e os destacamentos (com seu significado militar) permitiu-nos discutir críticamente o modo isolado e autístico em que as forças do público e do coletivo são territorializadas (em geral, enquanto estudam os processos sinérgicos excepcionais), e como essas forças operam como parte de exércitos autônomos e não dos "aliados" do púbico.

As metáforas são usadas como um mecanismo de reflexão e não se infiltram aqui como figuração no campo da arquitetura. A transposição linear de conceitos para formas arquitetônicas produziu versões literais excessivas e não-férteis da arquitetura, como alguns episódios de figuração maquínica que discutiremos mais adiante, como a versão pós-moderna que Rem Koolhaas descreveu como um "pesadelo semântico" ou a tradução mais recente da dobra deleuziana em figuras arquitetônicas representativas do 
Fig. 36. City Metaphors, M. O. Ungers.
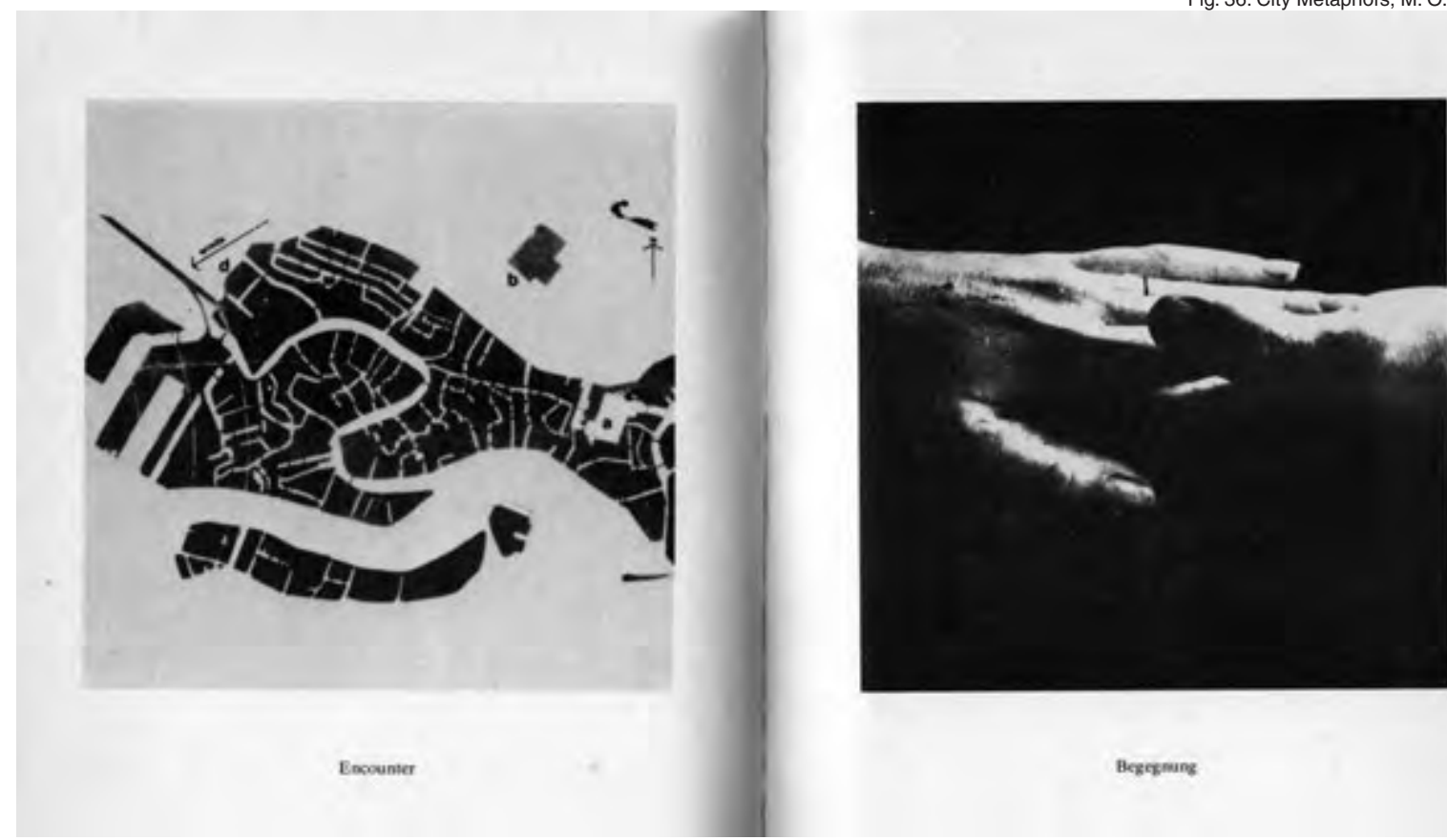

Begegnuing 
conceito. Em suas metáforas urbanas, Oswald Mathias Ungers (2017) ${ }^{19}$ propôs na década de 1980, analogias visuais estimulantes entre a figura das cidades vistas na planta e um grande número de imagens. O procedimento é um jogo refinado de transposição visual que exibe a sensibilidade projetual. A partir de um conjunto significativo de planos, fragmentos ou texturas urbanas, se propõe uma associação com gráficos, geralmente fotos e um conceito que capta a relação. Os pares propostos, associados ao conceito de morfologia e ao momento da cultura arquitetônica em que o livro foi gerado, sugeriram a possibilidade de reduzir a cidade e o projeto a operações puramente formais, empobrecendo a complexidade transbordante do fato urbano. Apoiado no caso apresentado no livro com a analogia da difusão do projeto vencedor do concurso de Brasília, esse empobrecimento tem na palmeira de Dubai a expressão paradigmática da caricatura antiurbana, a pior retroversão possível das metáforas de Ungers.

Neste capítulo concentrado na desespecialização programática propomos uma série de metáforas, deslocamentos que ligam a arquitetura das instalações coletivas às figuras urbanas e espaciais.

A maioria deles se refere especificamente a espaços públicos paradigmáticos para imaginar equipamentos ou observar edifícios existentes.

${ }^{19} \mathrm{O}$ livro contém um ensaio que fornece elementos significativos sobre as relações no mundo visual que é o da arquitetura, em termos de metáforas, analogias e outras figuras. 
Fig.37 Conical Intersect, Gordon Matta Clark.

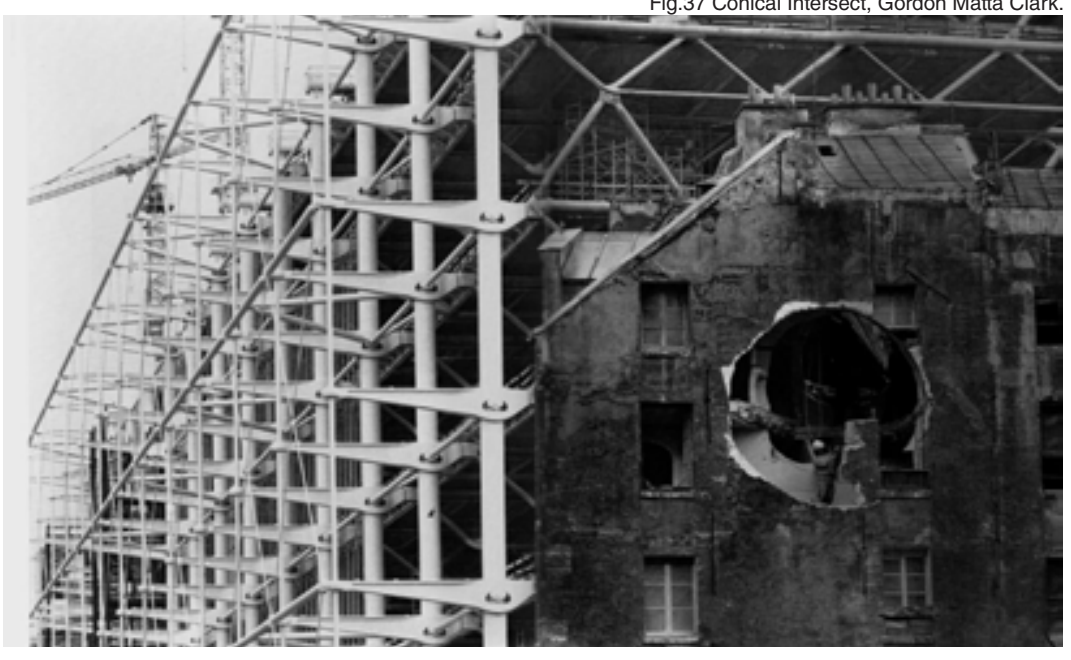




\section{DESLOCAÇÕES EM BRANCO}

Seguem considerações sobre a desespecialização programática no projeto a partir de espaços públicos: praias, ruas e parques como metáforas conceituais com as quais entender (desespecializar) o papel público, aberto e específico, de alguns edifícios de interesse.

O espaço público não é entendido como um lugar mítico, harmonioso, estável e ideal, mas sim como um espaço complexo e contraditório que faz parte das transformações territoriais contemporâneas. Branco não significa puro. Dessa condição que define nossas cidades, "onde podemos ver a epifania do que foi definido como especificamente urbano: o inesperado, o imprevisto, o surpreendente, o oscilante..." (DELGADO, 1999, p.33, tradução nossa), tem sua capacidade decodificar o projeto do equipamento público O primeiro deslocamento da série escolhe um caso singular: a ruína. Alguns arquétipos arquitetônicos como escola, casa e torre contribuem com outros deslocamentos possíveis que só se enunciam, na capacidade de contribuir para a compreensão do projeto de equipamentos públicos.

\section{DPL.4 DESLOCAÇÃO 1: RUÍNAS}

Gordon Matta Clark realiza em ritmo vertiginoso seu "Conical Intersect" em Paris ao lado do Beaubourg em construção. Concedem pouco tempo para que ele produza sua primeira obra europeia, usando os prédios ao lado do novo ícone da cultura contemporânea, que em breve será demolido por "insalubre", mas especialmente para dar visibilidade e espaço livre ao monumento da cultura e tecnologia para as massas. $O$ Pompidou produz ruínas que Matta Clark desfaz como tal, para transformá-las em obra, com seus cortes cirúrgicos nos pesados muros estruturais. Gordon trabalha o vazio, destrói seletivamente a ruína. Aliás, produz um poderoso efeito óptico ao transparenciar o processo da novidade que cresce e se vê através dela. A obra de Matta Clark é conhecida por ser efêmera. As máquinas a demolia ao remover a massa que, sendo negada, a definia. Os caminhões levaram, (presumivelmente) para preencher a construção dos grandes conjuntos da periferia parisiense, os escombros das casas vizinhas. Quem e onde se levou o vazio da Conical Intersect?

O impressionante artefato Beaubourg, produto de um concurso que marcou a cultura arquitetônica da época, começou a ser construído quatro anos depois do maio francês e foi a iniciativa do então presidente Georges Pompidou, que havia sido significativamente 
Fig 38. Centro Pompidou, Paris.

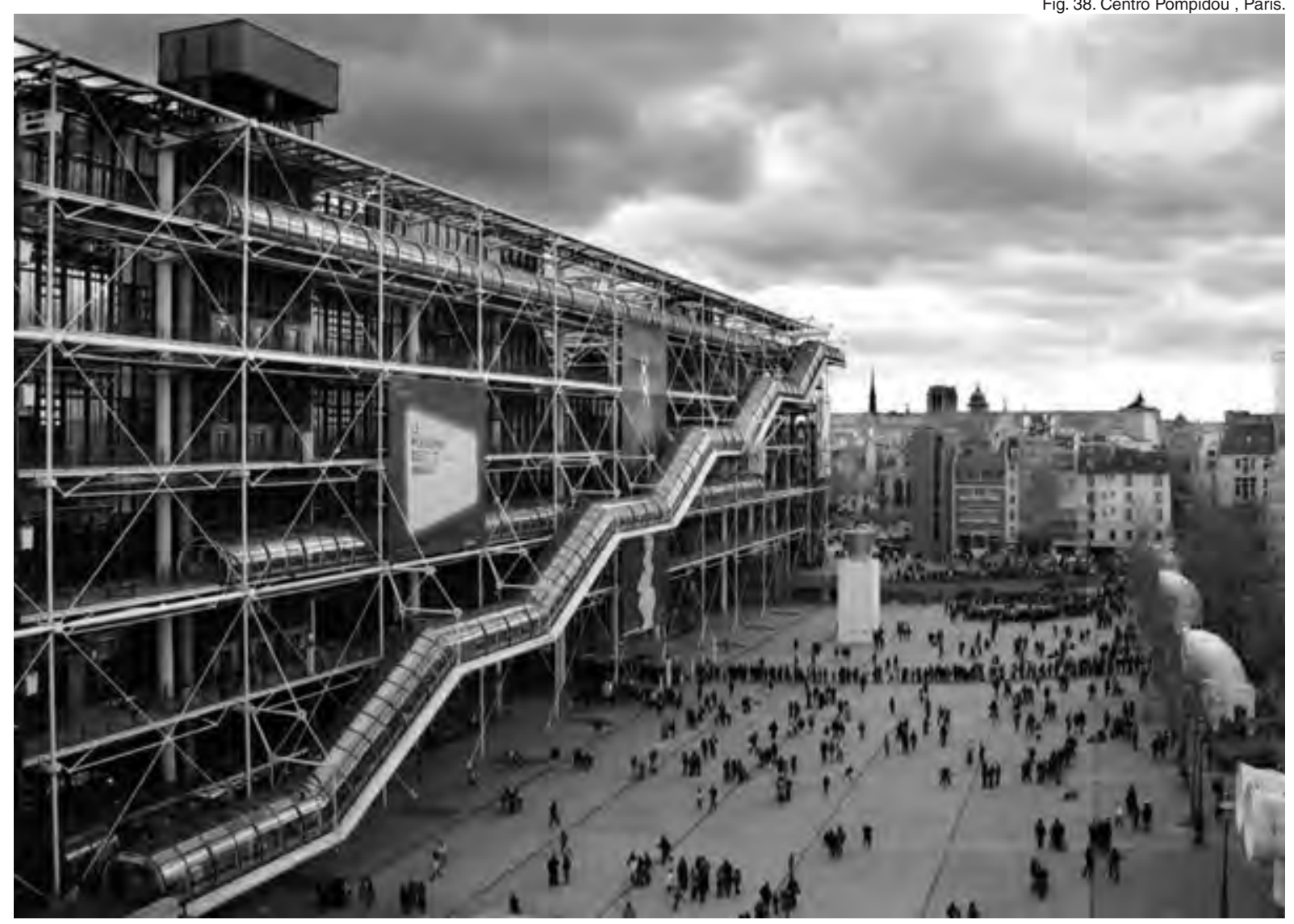


o primeiro-ministro do general de Gaulle durante a repressão da revolta de 68 . O conflito político e a oposição entre a rua e o equipamento faziam parte da cultura do momento. A relação dupla de ruína e construção inscreve-se num sistema de relações e coincidências geográficas alarmantes que propõe uma genealogia do debate incrustrado mais amplamente na história de Paris e na arquitetura do século XX:

Nos anos 20, Cuervo imaginou a tabula rasa para um setor e não para qualquer setor de Paris; nos anos 60 , onde precisamente se teria erguido um cruciforme, o espaço se rende à deriva situacionista, ao gosto agridoce do vazio e da ruína, caindo sem permissão no anti-filme de Debord. Nos anos 70 ele é esfaqueado por Matta Clark enquanto nas suas costas cresce o violento espetáculo pela arte da adoração; no campo histórico recente tudo se presume coincidente, tudo é parte do mesmo, tudo se sente como uma passagem circular, um eterno retorno, tudo é mapa inimigo e melancólico para um simultâneo retângulo de Paris". (ROUX, 2017, p.16, tradução nossa)

Concluída a demolição da obra ficou o vazio, e a construção da obra que produz vazios, - Beaubourg permanece sozinho e visível com seu esqueleto metálico, sua retórica tecnológica. O centro dará origem a muitas polêmicas na cultura daquele momento. Quase simultaneamente a abertura do Centre Pompidou em 1977, Jean Baudrillard a vê como uma operação de implosão, uma nova demolição, neste caso cultural:

O efeito Beaubourg, a máquina Beaubourg, a "coisa" Beaubourg - que nome você daria a ela? É um enigma este esqueleto de fluxos e signos, de redes e circuitos - a última realidade consistente em traduzir uma estrutura que já não tem nome, a das relações sociais expostas a uma avaliação superficial (revitalização, autogestão, informação, mass media), e implosão irreversível em profundidade. Monumento aos jogos de simulação de massa, o Centro funciona como um incinerador absorvendo toda a energia cultural e devorando-a - algo semelhante ao monólito negro de 2001: a convecção sem sentido de todos os conteúdos que chegam para se materializar, absorver e aniquilar nesta obscura e misterioso massa. (BAUDRILLARD, 1978, p.77, tradução nossa)

Em 1980, Michel de Certeau afirmava sem se referir ao Beaubourg:

Toda "renovação" urbana prefere, no entanto, a tábula rasa sobre a qual escreve em cimento a composição feita em laboratório, sobre a base de "necessidades" distintas às quais darem respostas funcionais. Ao dividi-la, o sistema também produz a necessidade, "substância" básica desta composição. Esta unidade é exata como uma cifra. Ademais, a insatisfação que define cada necessidade chama e justifica por adiantado a construção que a combina com outras. Lógica da produção: desde o século XVIII, engendra seu espaço, discursivo e prático, a partir de pontos de concentração: o escritório, a fábrica, a cidade. Rejeita a pertinência de lugares que não cria.(DE CERTAU, 1996, p.221, tradução nossa)

O projeto do jovem Piano e Rogers (33 e 37 anos na época do concurso), escolhido por um júri (composto por 9 membros, incluindo os três arquitetos Jean Prouvé, Philip 
Fig. 39. Generator, Cedric Price.

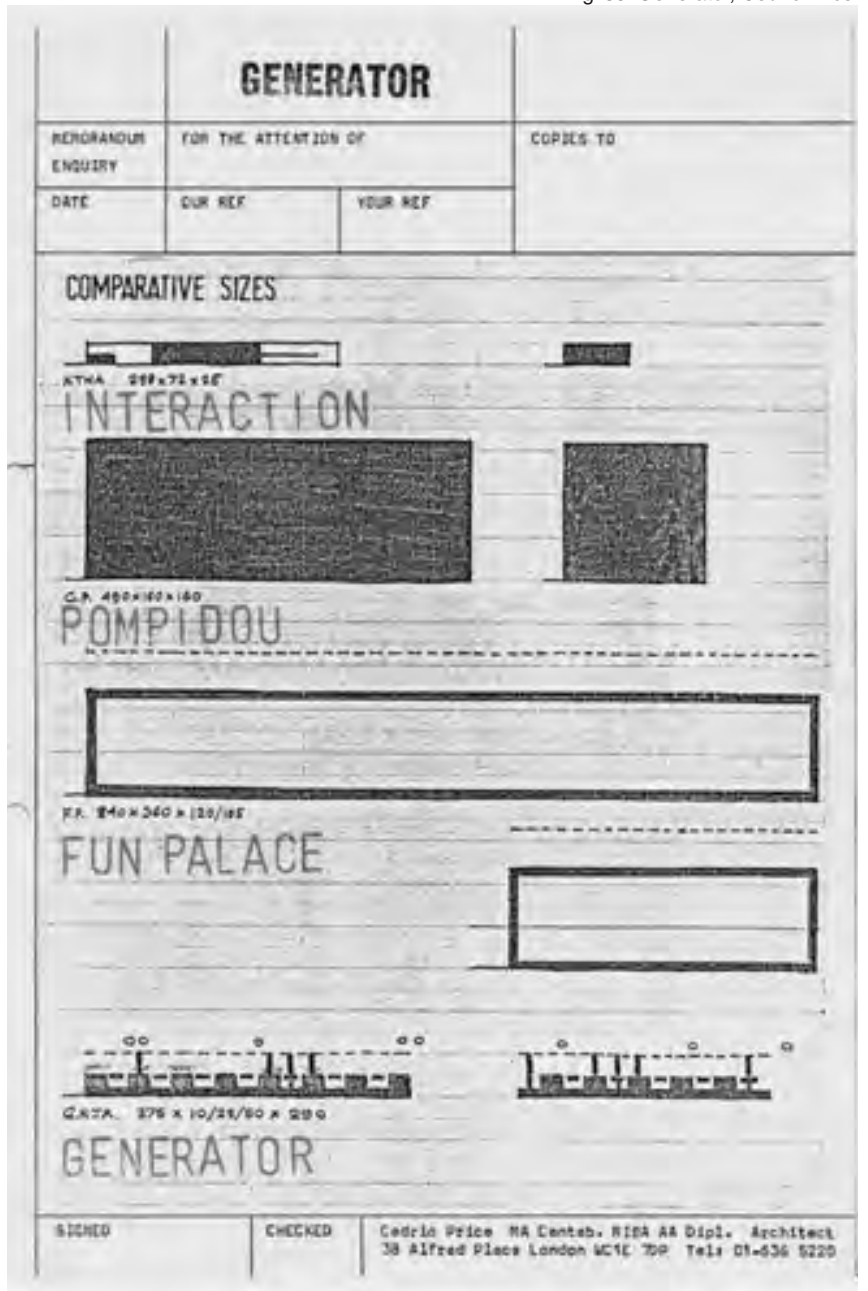


Johnson e Oscar Niemeyer) é um esforço bem-sucedido para absorver a construção e o possível ao fantástico Archigram, e sobre tudo ao radical e arquitetônico Fun Palace.

Mas depois de contextualizado, é preciso cuidar do espaço, daquilo que transcendeu o intenso momento de sua produção e hoje ainda nos é oferecido como uma estante de espaços não especializados capazes de abrigar todo tipo de produção, associada a uma poderosa instituição cultural e artística. O prédio conecta-se com a cidade por uma esplanada levemente inclinada, a piazza, um espaço público magnético que teve que dar lugar a ruína. Um dado que deixa para trás a figuração do edifício é que dos 681 projetos apresentados no concurso o único que libertou metade da propriedade para um espaço público, foi o vencedor (ARIZA, 2014).

Hoje, 40 anos depois dessa inauguração e renovação urbana, podemos nos perguntar sobre a capacidade mostrada pela estante. Muito além da obsolescência da retórica de tubos e minhocas, essa nave aberta e desprogramada, deu origem a uma enorme diversidade de atividades e usos e também gerou grandes problemas para o seu funcionamento dada a sua enorme abertura espacial, um aprendizado que deve ser estudado a partir da desespecialização programática. É assim que Jean Nouvel afirma, no ano 2000, imediatamente depois da transformação, que no final dos anos 90 voltou o prédio convencional, dividiu os vazios e escondeu alguns ossos no seu interior, discutindo com Baudrillard o pensador que propôs precocemente a implosão institucional.

\footnotetext{
O mais interessante no conceito do Beaubourg em sua origem era a liberdade que havia em seu interior, na própria concepção do espaço. Imaginava-se que a máquina para abrigar a arte -ou fabricar a arte-podia esperar iria a funcionar. Teria que ter tido dentro dela acontecimentos absolutamente imprevisíveis, esses cenários podiam viver com complementos, suportes, extensões móveis, tudo devis se organizar da melhor maneira possível na dialética suporte-aporte. Beaubourg foi antes de tudo um suporte. Mas o espaço, que se tornou "funcional" mais tarde, modificou completamente seu primeiro sentido.

¿A instituição pode aceitar a subversão? ¿Ela pode programar 0 desconhecido, o imprevisível?

¿Como reencontrar a subversão que esse espaço quer suscitar, tal como ele havia sido desenhado no inicio? (NOUVEL em BAUDRILLARD e NOUVEL, 2001, p.59-62, tradução nossa).
}

Segundo a ideia de Jean Nouvel, a verdadeira implosão ocorreu com a mudança que impediu o edifício de continuar sendo aberto e estimular aquilo que não podia ser previsto. Pode ser que ele fosse um artefato para uma cultura do amanhã, com toda a sua modéstia em relação ao fantástico Fun Palace, o Beaubourg seria uma arquitetura 

para um futuro próximo que ainda não chegou. Mesmo que a sua renovação urbana seja indiscutível, e o grande sucesso da piazza e do prédio como lugar público, provavelmente sua condição de espaço capaz foi deixada de lado, e o centro mudou a atenção para a sua condição espetacular, e a atenção da multidão aos aspectos mais superficiais do passeio.

\title{
O CAPITAL
}

O Hermitage de São Petersburgo é um dos maiores museus do mundo, com uma coleção de mais de três milhões de peças que foram acumuladas pelos czares ao longo dos séculos e que, com a revolução russa de 1917, tornou-se uma coleção pública. O gigantesco museu está no início do novo século em um mal estado de manutenção. Após a queda do Muro de Berlim e o impulso para a incorporação de investimentos e capitais, em 2001 a administração do museu se propõe a modernizá-lo e posicioná-lo no mundo. Procurando a renovação do Hermitage e uma ampliação de uma nova ala do museu, a instituição começa um diálogo com o Guggenheim. Koolhaas e Gehry, junto com Thomas Krens (na época diretor-geral do Guggenheim), foram convidados a visitar São Petersburgo para conhecer o edifício e propor ideias para a renovação. Dessa visita saiu a seguinte conversa, que retratava as posições de cada um:

\footnotetext{
"Onde está o espaço para as motos?", Pergunta Krens.

"Onde está o espaço para a arte americana?" Grita Gehry.

"Há muito espaço aqui", sussurra Koolhaas.

(KOOLHAAS, 2004a, p. 397, tradução nossa)
}

\begin{abstract}
Krens e Gehry exigem o que não existe: não há salas de tamanho suficiente para a inclusão de obras de grande escala ou de exposições não convencionais - como a famosa exposição "A Arte da Motocicleta" (1998), idealizada por Krens e projetada por Gehry. No lado oposto, Koolhaas percebe e reconhece o valor do pré-existente. (LÓPEZ UJAQUE, 2017, p.230, tradução nossa)
\end{abstract}

O Hermitage podia ser entendido a partir do paradigma da arte contemporânea global e espetacularizado como uma ruína inutilizável. É assim que Krens e Gehry calibram seu objeto de estudo com base no que já fizeram. Koolhaas resgata o que a "ruína" tem de autêntico, e propõe algo novo, que pode ser feito a partir dela. A inteligência pragmática do holandês permite uma leitura que valoriza o real e o utiliza como ponto de partida, procurando um museu que, em vez de replicar os padrões dominantes dos museus, se posicionado a partir de sua valiosa coleção e em seu próprio espaço, uma matriz quase infinita de salas. 
Fig. 41. Diagramas Hermitage OMA.

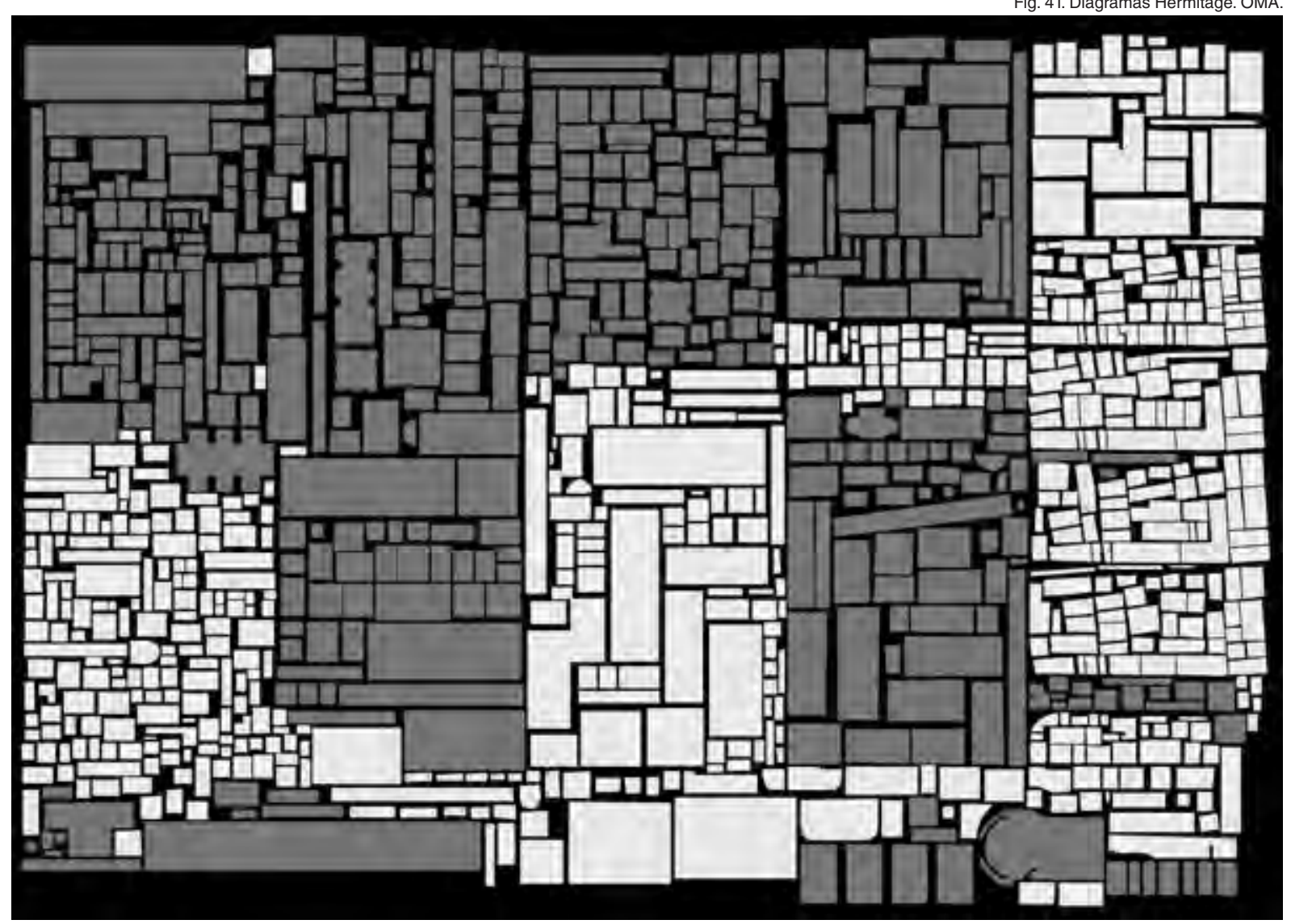


"The New Yorker" dedicou uma extensa reportagem a Rem Koolhaas, onde o holandês discute vários de seus projetos com o editor Daniel Zalewski (2005), e a ruína russa e soviética chama a atenção no diálogo: "Em vez de apagar essa história, por que não destacar-la? 'Seria tão original', disse ele” (Ibid.)

OMA (Office for Metropolitan Architecture) propõe uma intervenção "invisível" em que o edifício, sua história e seu padrão espacial são o ponto de partida para alguns jogos espaciais que se apropriam do espaço de uma maneira contemporânea e mutável do edifício. Koolhaas desafia o mundo da arte reclamando o desenvolvimento de estratégias curatoriais específicas e inovadoras. O edifício principal, com seus 800 espaços, seria uma oportunidade para a criatividade dos curadores: por que não ter uma exposição em que em cada espaço há uma única obra? Ou então, porque não saturar os espaços com obras de um mesmo ano, propondo um caminho de cápsulas do tempo?, ele propõe aos russos, entre outras coisas, para convencê-los de sua ideia. $O$ desenvolvimento do projeto foi configurando intervenções que se formavam desde a manutenção absoluta do estado original até certos níveis de transformação, algumas intervenções de demolição que permitiram peças de formato grande (talvez fosse possível expor as 114 motocicletas que Krens e Gehry colocaram na rampa helicoidal de Wright?), e um sistema de interconexão global na sequência neutra de espaços para permitir a organização, circulação e infraestrutura do conjunto.

Sua proposta radical, fora dos padrões (que tiveram a astúcia de deixar fora de jogo o autor do Guggenheim de Bilbao, modelo do status quo) permitiu iniciar uma colaboração prolongada com a instituição, inaugurando em 2005 sua primeira intervenção e em 2014 uma segunda. A celebração e compreensão do valor da ruína foi o ponto de partida.

\footnotetext{
"Há beleza na deterioração". "É totalmente hipnótica." Eu pensei que esta sala seria um lugar interessante para exibir os modelos de seus projetos mais luxuosos"."A justaposição flagrante pode ser emocionante". (KOOLHAAS in ZALEWSKY, 2005, tradução nossa)
}

\section{ELEMENTAR}

A ruína como deslocamento metafórico implica na depuração no tempo, permanece a que tem maior estabilidade, e tudo que era fungível ou acessório foi eliminado. Entendemos a ruína como uma descrição dos principais determinantes do espaço, uma forma radical (raiz) associada à estrutural, e que libera o espaço das restrições acessórias. Nesse estado de arquitetura elementar, encontramos a possibilidade de pensar o espaço como especificidade e sua capacidade de abrigar diversos usos. 


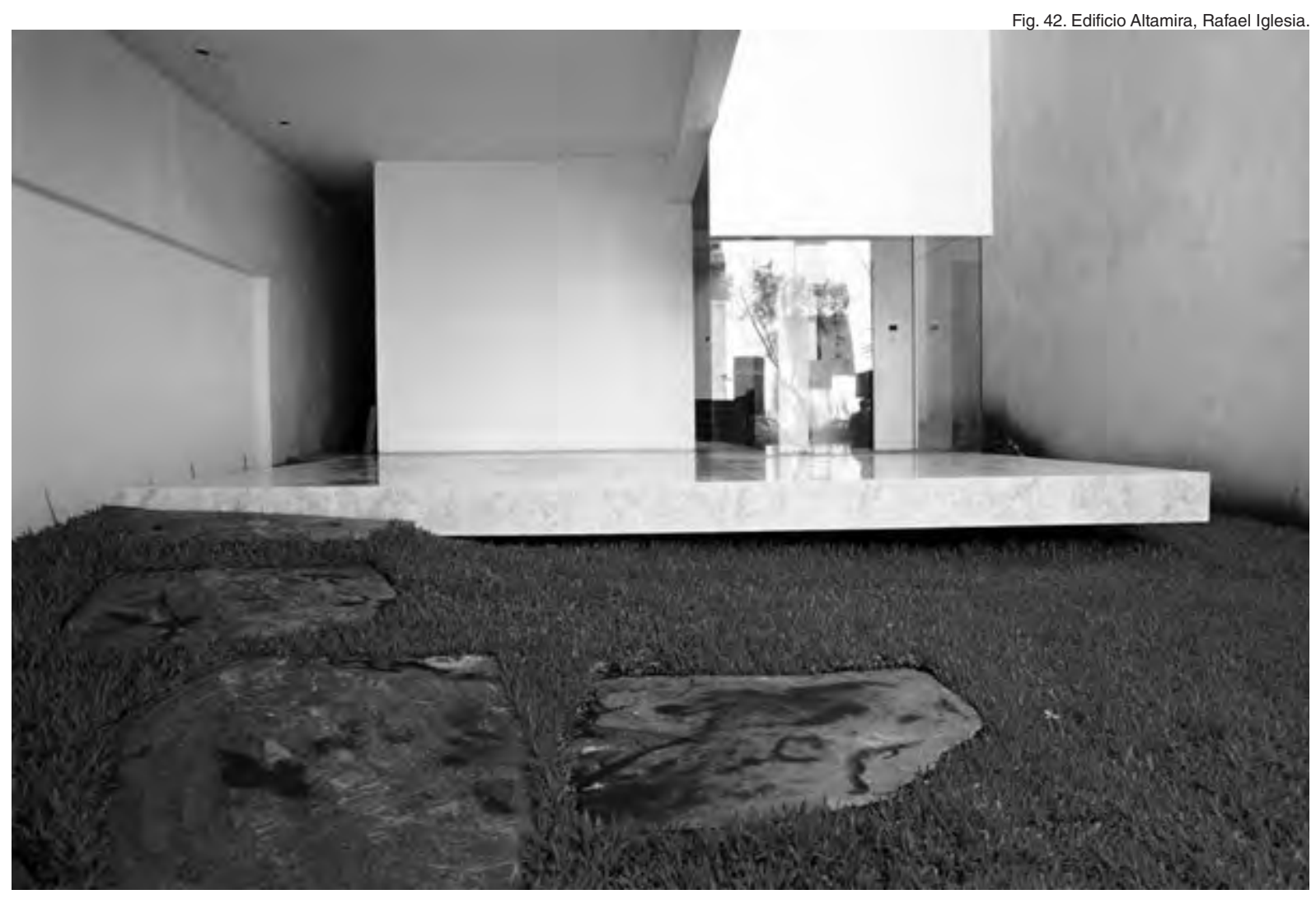


Na memória do projeto para o concurso do Parque Hipólito Yrigoyen, em Rosário, Rafael Iglesia escreve que a missão do arquiteto é "projetar boas ruínas", falando de uma arquitetura em sua forma mais pura, despojada do acessório, uma arquitetura: atemporal? O genial (e único como acontece com os gênios) Rafael Iglesia, desenvolveu suas explorações espaciais sempre a partir do jogo estrutural, desconsiderando convenções e regras. No relatório que apresenta seu edifício de moradias do ano 2001 na rua San Luis 470 em Rosário, estabelece um elo entre o esqueleto e o espaço através do programa representado no desenvolvimento de espaços habitáveis desespecializados das convenções domésticas:

\begin{abstract}
Neste projeto estou interessado em destacar dois aspectos em relação aos outros. Primeiro, um questionamento sobre o que é um apartamento de moradia e como funciona, ou seja: o programa. Em segundo lugar, a resolução estrutural. Fingindo que a linguagem do edifício é apenas sua forma de apoio. A maneira como as cargas chegam o solo. Esta é uma discussão que mantenho com a linha de gravidade rotineira (IGLESIA em GIMÉNEZ; MIRÁS; VALENTINO, 2005, p. 8, tradução nossa)
\end{abstract}

\title{
FASCINAÇÃO ROMANTICA
}

As ruínas foram uma fonte de inspiração ao longo da história da arquitetura. Os sucessivos retornos à inspiração clássica recuperaram tanto a arquitetura que foi produzida e desenhada na Grécia e Roma, quanto as ruínas que se tornaram um motivo em si. Giovanni Battista Piranesi, que havia sido um jovem desenhista de Nolli (o mesmo do plano da Roma público), passou boa parte de sua vida em Roma estudando e reconhecendo o valor espacial dessa arquitetura, que estudou e representou com exatidão e fantasia em sua obra "Antichità Romane" quatro volumes publicados a partir de $1756^{20}$. É uma representação sutil e contraditória, cheia de personagens dramáticos, muito diferente da abstração que sustentava as claras regras de Nolli. Se a fantasia na representação das ruínas já eram consideradas como insumo criativo, Piranesi transformou essa bagagem de ruínas em insumo projetual para propor espaços fantásticos em seu "Carceri", gravuras que propõem espaços saturados de referências a diferentes períodos, e que permitiram um reconhecimento contemporâneo e uma forte influência na arquitetura.

Ao espalhar o amor pelas ruínas entre o público em geral, que no final do século XVIII se limitava a alguns artistas e poetas, a influência de Piranesi

${ }^{20}$ Notas retiradas da exposição "Piranesi. La fábrica de la utopía", Museo de Roma. 2017. (FICACCI e TOZZI, 2017) 
Fig. 43. Old Colonnial Office no Bank of England, John Soane, 1818.

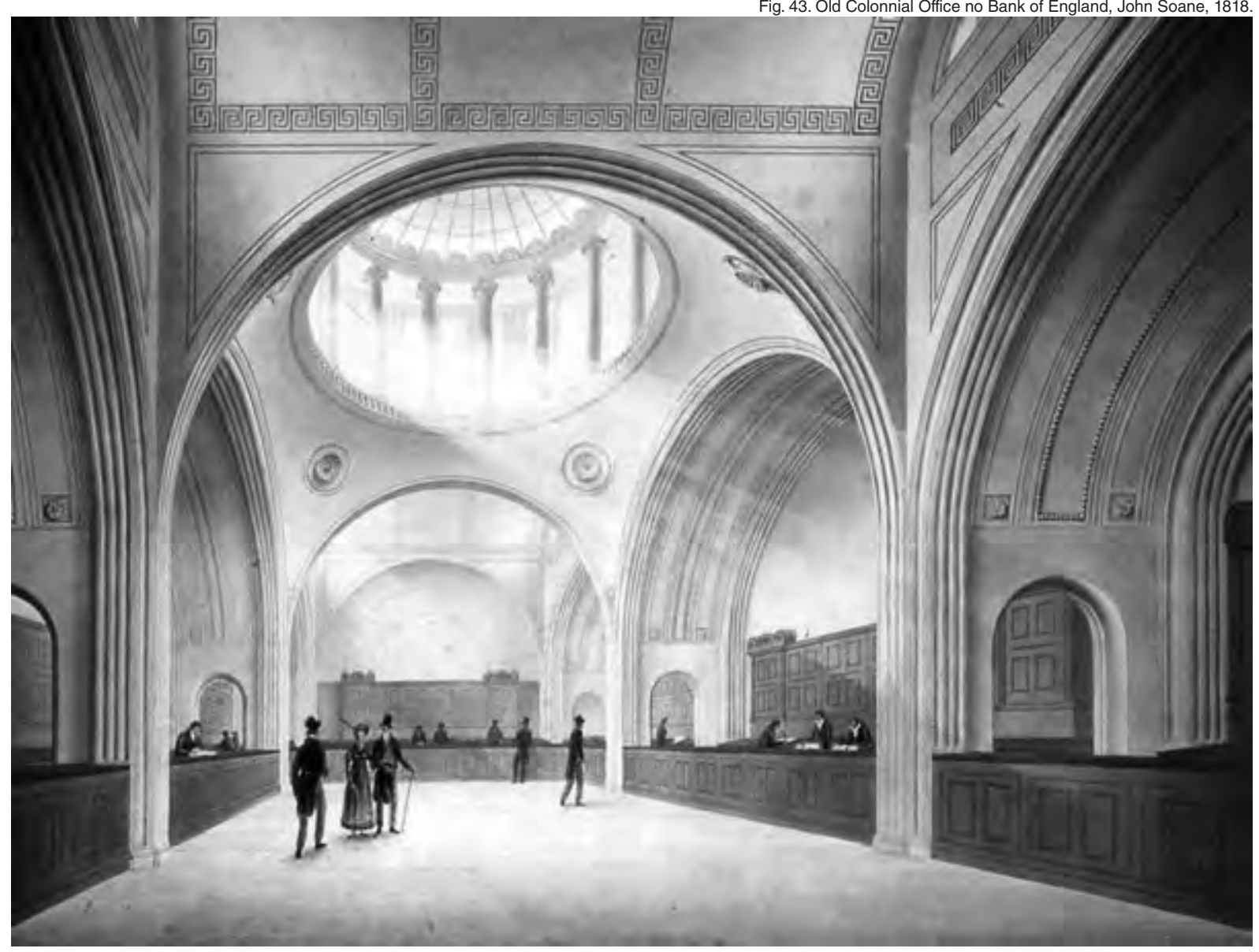


deu o resultado paradoxal de modificar a própria ruína. O desejo de preservar e restaurar, às vezes abusivamente, as obras da arte antiga é muito mais antigo do que preservar e restaurar os escombros daqueles que foram embora. Até o dia em que se desenvolveu essa poesia da arqueologia, cujos primeiros sinais aparecem nos álbuns de Piranesi, as ruínas com pouquíssimas exceções eram consideradas como uma mina onde extrair obras de arte que foram então transportadas para as coleções papais ou principescas... (YOURCENAR, 2012, tradução nossa).

O gosto pelas ruínas constrói o olhar romântico de John Soane, que fez seu trabalho mais significativo no conjunto de intervenções no edifico do Banco da Inglaterra ao longo de 45 anos, formando um quarteirão inteiro composto por séries de espaços de diferentes profundidades dispostas em torno de pátios, "uma sequência infinita de espaços interiores" (FABRIZI, 2016, tradução nossa). Uma pintura de 1830 feita pelo colaborador de Soane e pintor, Joseph Gandy, reflete a paixão de ambos pela condição ruinosa, e em particular com as gravuras de Piranesi: nelas se mostra o edifício do Banco da Inglaterra, a obra em que Soane trabalhava há décadas, como uma ruína. A ideia, além de expressiva quanto ao gosto da época, uma frustração frente a contingência que fantasia sobre um futuro distante e heroico, sugere ao mesmo tempo a possível beleza e durabilidade do trabalho como legado para as gerações futuras; seu valor espacial preservado, sua aura permanente.

Se os restos se tornam monumentos de uma época heroica, um legado do passado, nossas obras são uma ruína futura, parecem propor Soane e Gandy. A produção do espaço e sua ligação inseparável com o tempo aparecem como uma marca de tempo que é uma contribuição para pensar o espaço a partir de sua relação com o programa que o origina. Do ponto de vista da desespecialização, um convite à abordagem distanciada e abstrata que escapa, sempre que possível, da resposta às circunstâncias específicas que dão lugar à demanda inicial, e pensar na capacidade de um outro estado, um estado que ainda não podemos prever, mesmo antes do edifício deixar de existir, e passar para aquela nova condição que examina essa seção.

\section{OBRA}

Uma ruína é também um canteiro de obras. Muitas vezes os esqueletos de concreto ou aço dos prédios em construção são a sugestão de uma capacidade e abertura que acaba enquanto aparece a alvenaria, gesso ou as fachadas dos arquitetos, falando em assuntos concretos. Um canteiro de obra pode ser entendido também como uma 


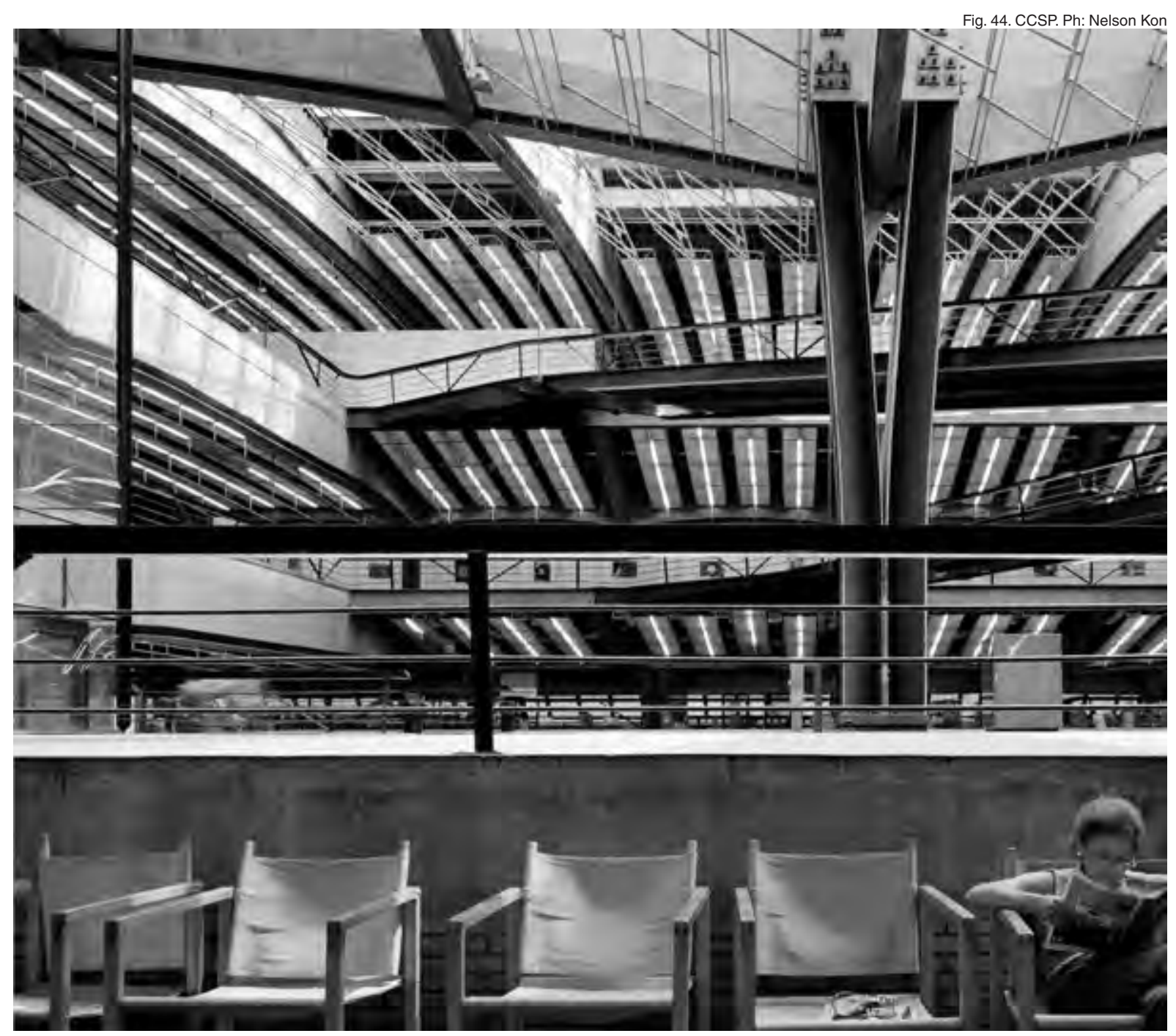


oportunidade de ação de projeto. O Centro Cultural São Paulo ${ }^{21}$ oferece várias ideias cujo estudo colabora no entendimento dos conceitos de desespecialização. O projeto feito pelos arquitetos Prado Lopes e Telles, com um espaço interior aberto e interconectado, estruturado em relação a uma sequencia de espaços públicos, ruas e praças, por sua vez abertas e conectadas à cidade. O espaço não é uma grande nave simples, ela é um espaço complexo definido a partir do teto e o sistema estrutural de grandes vãos que permite dispor espaços de diferentes propriedades, desde grandes espaços como no caso da atual biblioteca e sala de exposições, até locais de menor tamanho. Sua seção transversal propõe uma articulação entre os espaços de uso público nos níveis superiores, e os de serviço, ateliers, oficinas e escritórios nos inferiores, embora isso varie de acordo com os espaços que vão se acomodando.

O projeto já avançado em termos de arquitetura, foi pensado para sediar a Biblioteca Central, mas o programa virou, numa mudança de gestão política municipal, num Centro Cultural. O novo programa significou uma nova instituição, um espaço de programas diversos.

...chegou-se a conclusão de que se devia fazer um centro cultural e não
uma biblioteca. Era preciso eliminar a ideia de finalidade exclusiva de uso,
criar o multiuso, a finalidade que concentra e ao mesmo tempo dispersa,
uma unidade multiplicadora. Agregar portanto, neste espaço, mídias,
musica, cinema, teatro, espaço de exposição, pesquisa, biblioteca,
biblioteca para deficientes visuais, ateliers para crianças. Criar um espaço
onde não há divisões etárias, de classes sociais, que tenha o mínimo de
portas, intercomunicante, se possível integrado com a paisagem, manter a
paisagem dentro do Centro Cultural, fazer vidros e não paredes
opacas.(CHAIME, 2006, p.20)
O partido arquitetônico não mudou e a transformação da biblioteca em
Centro Cultural ocorreu com adaptações pontuais.[...]
"O resto foi tudo mais ou menos contemplado, porque já estava de certa
forma previsto: as exposições, a música, o som, tudo isso estava previsto",
diz Telles. (SERAPIÃO, 2012, p.81) A mudança de programa, que apareceu primeiramente como um desafio para os arquitetos se tornou uma revelação sobre as possibilidades do projeto e sua lógica de grande peça: a mudança foi menor e muito fácil de ser feita segundo a testemunha dos projetistas. A ruína do projeto da biblioteca foi espaço capacitado para o Centro Cultural São Paulo.

${ }^{21}$ Parte de informação referida sobre o projeto provém de Centro Cultural São Paulo. Espaço e vida (SERAPIÃO, 2012) 
Fig. 45. Terminal Salto. Eladio Dieste.

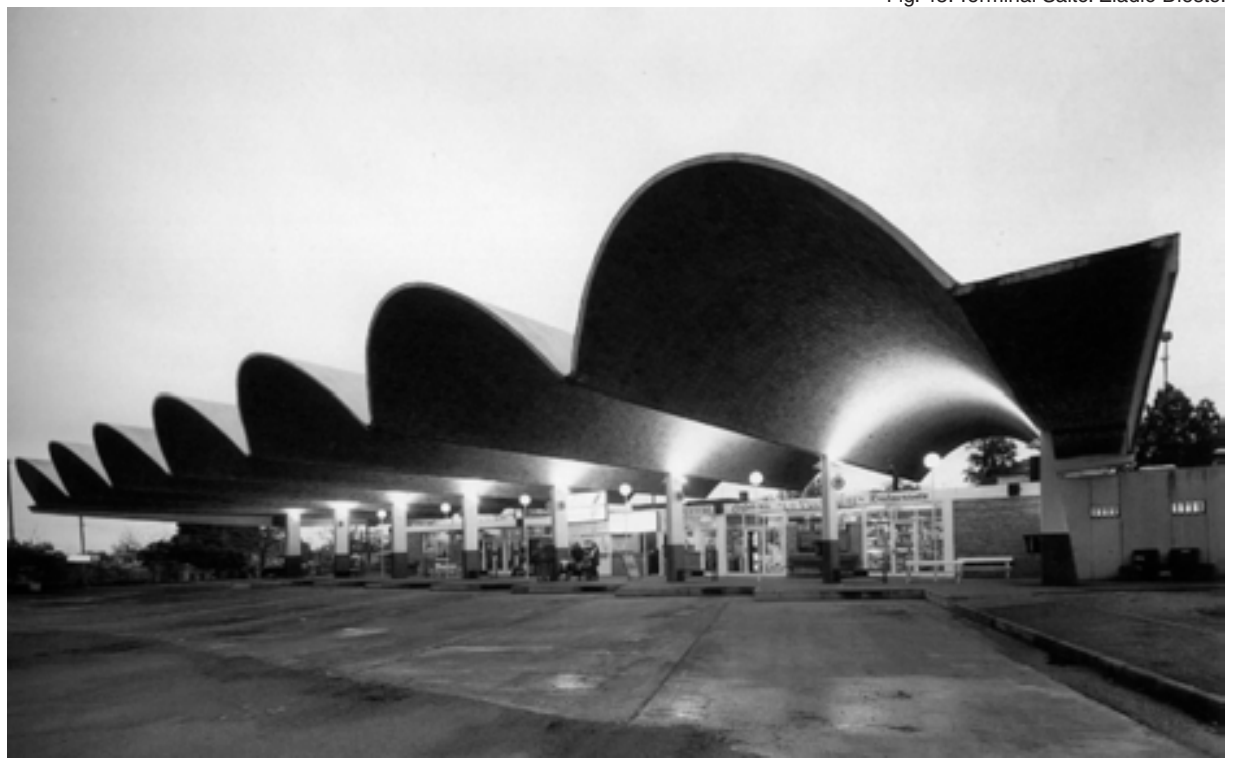




\section{PROGRAMA?}

No ano 2001 o arquiteto holandês Kees Christiaanse (2001) faz uma apresentação sobre uma nova relatividade do programa como motor dos projetos, contestando a avaliação feita especialmente por Bernard Tschumi e Rem Koolhaas nas décadas anteriores: "Fuck the programme?", escreveu. No artigo ele junta assuntos bem diferentes. Um deles é uma versão crítica do abandono do programa para certa arquitetura do "star system" e o espetáculo global no final do século XX, e que não tem nada a ver com a preocupação desta tese, trazendo uma história que é trágica, mas verdadeira:

Peter Eisenman explicou, também em Berlim, diante de pelo menos 400 pessoas, seu projeto vencedor para um museu no terminal de balsas de Staten Island, uma estrutura "morfeada-deformada". Um estádio de beisebol foi adicionado ao projeto e depois removido por ordem de um cliente caprichoso. Durante a apresentação do projeto, o prefeito de Nova York perguntou: "O que tem dentro ?" "Um museu", respondeu Eisenman, "mas, o Sr. se importa?"

"E se eu me importar? O que você quer dizer?" Perguntou o prefeito. "Conhece Bilbao? " - perguntou Eisenman. "Sim", respondeu o prefeito. "Você realmente acha que importa se há ou não um museu lá dentro?", Eisenman perguntou com uma careta nos lábios, ao que o prefeito respondeu: "Ei, mm... não!..., tudo bem, vamos construir também uma bolaBuy-0 ». (Christiaanse, p..87)

E outro que, pelo contrário, fica no centro do interesse da pesquisa que trata de uma ruína, que é assunto comum do projeto de arquitetura contemporâneo: a renovação dos espaços industriais e grandes galpões de depósito. Primeiro com a mudança das indústrias e portos para fora do centro da cidade, e depois com a desindustrialização de regiões inteiras do planeta, apareceu um gigante espaço de oportunidade para o projeto de arquitetura partindo dessas naves de grandes vãos libres:

\footnotetext{
O sucesso desta forma de reciclagem cultural reside não só na componente histórica e na localização, mas também no forte carácter arquitetônico e numa certa generosidade nas dimensões (o que não deve ser confundido com o conceito ingênuo de" flexibilidade" que sempre resulta em uma construção insípida). Os edifícios a que me refiro devem seu apelo à resistência que o novo usuário precisa vencer. Evidentemente, os edifícios se transformam melhor quando não são projetados para um programa específico, e somos forçados a fazer reajustes radicais entre o edifício e o programa. (Ibid., p. 86)
} 
Fig.46. SESC Pompeia. Lina Bo Bardi.

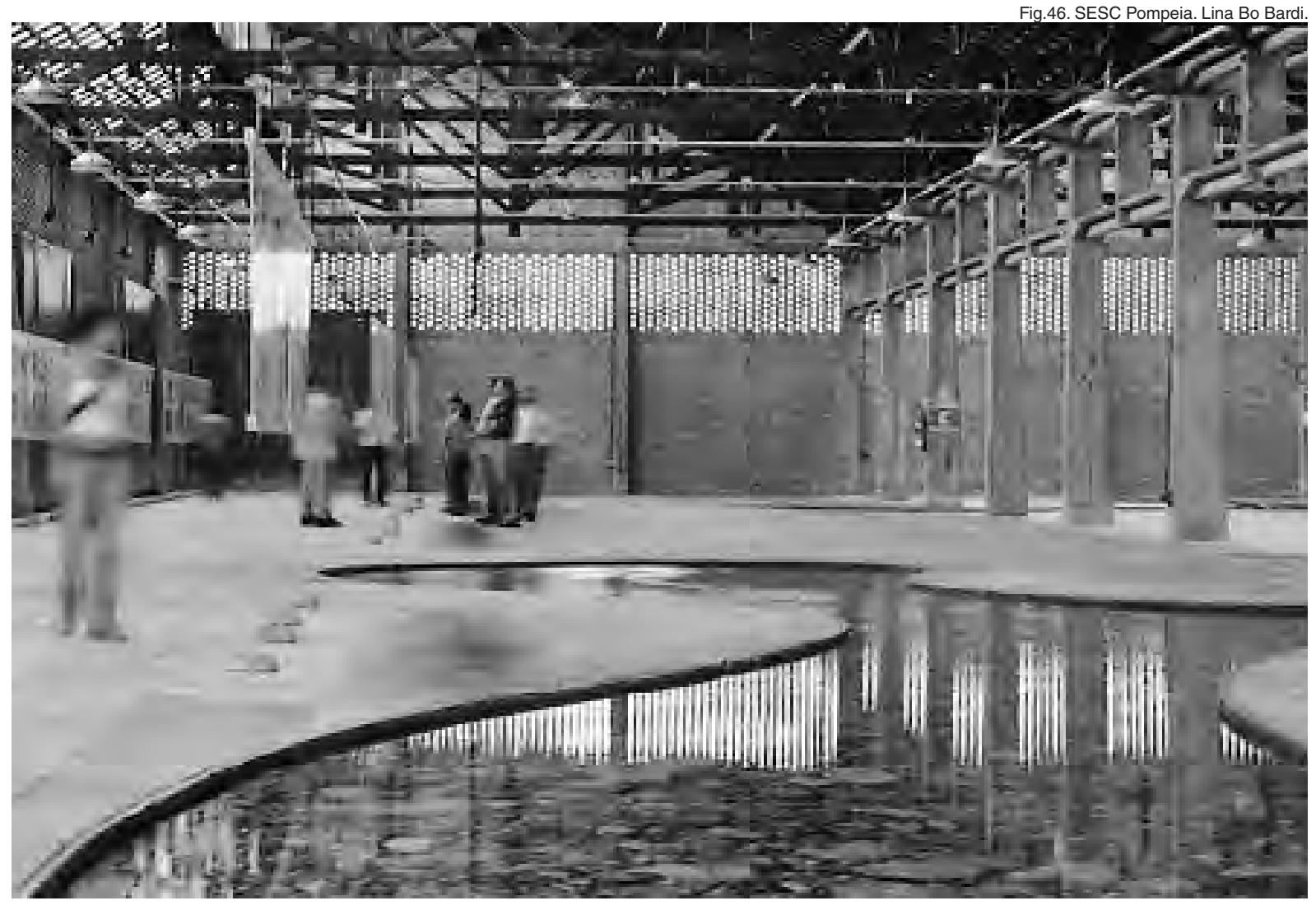




\section{PÓS-INDUSTRIAL}

Foi essa a origem do SESC (Serviço Social do Comércio) Pompéia, uma fábrica originalmente destinada à demolição para a que fosse feito um projeto novo e especializado para o SESC, uma combinação de atividades culturais e esportivas. A arquiteta italiana Lina Bo Bardi conseguiu, depois de uma visita conjunta à fabrica, convencer às autoridades a não demolir o prédio e fazer o projeto a partir do que lá estava já ${ }^{22}$, houve toda uma mudança de sensibilidade nos modernos anos 70 do Brasil militarizado e com o "milagre econômico". O projeto de Lina Bo Bardi reutiliza a partir de uma compreensão profunda das lógicas espaciais e estruturais do edifício original. $O$ estabelecimento desde o primeiro dia do escritório de projeto no local permitiu a Lina e a seus colaboradores entender o uso do espaço que já estava sendo utilizado para atividades culturais, esportivas e de lazer.

Lina, muito rapidamente, captou o lugar: "O que queremos é exatamente manter e amplificar aquilo que encontramos aqui, nada mais". (FERRAZ, 2013, p.33, tradução nossa)

A mudança temporal, de programa e necessidades foram absorvidas pela estrutura original e suas intervenções parciais; uma lição das capacidades do espaço arquitetônico muito além das definições programáticas concretas do momento em que o edifício é projetado, um caso de desespecialização não planejada. A intervenção expõe a fábrica, utiliza os grandes espaços industriais para acomodar grandes espaços com vocação didática e deixa ver uma estrutura de concreto armado pioneira, e no mesmo sentido há a intervenção, colocando em diálogo a intervenção com o original.

Lina, com olhar arguto e culto, descobre que a velha fábrica possui uma estrutura moldada por um dos pioneiros do concreto armado no início do século XX, o francês François Hennebique. Talvez a única deste tipo conhecida no Brasil até esse momento. Essa descoberta/revelação dá ao conjunto um valor especial. (Ibid. p.31, tradução nossa)

Mas o diálogo não é retórico senão programático e espacial, criando espaço (distinções) para dar forma e proporção capaz de conter certas partes específicas do programa, e sobretudo para estabelecer uma relação sinestésica com o edifício original, propondo novos pontos de vista e relações corporais com o artefato original. O grande conjunto espacial que abrange a Sala de Exposições, a Biblioteca e o Espaço de Convivência, que fica contido por 5 naves industriais e mede aproximadamente 70x50

\footnotetext{
${ }^{22}$ Segundo testemunho oral de Marcelo Ferraz ao autor, feita em 2010 em Montevidéu.
} 
Fig. 47. Vista Axonometrica Paylana

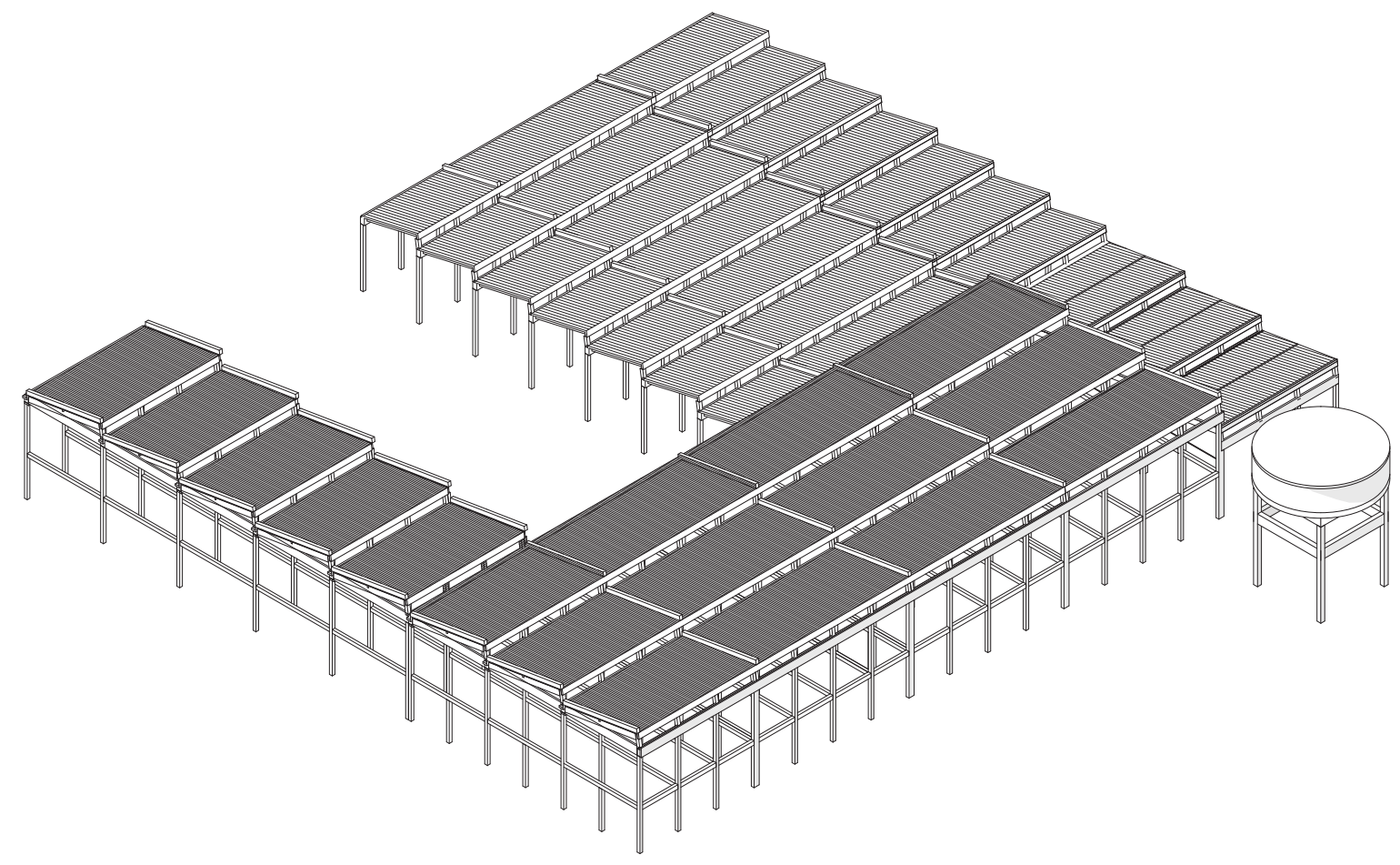


metros. No momento do projeto ele aparecia aos colaboradores da Lina Bo Bardi como grande demais:

\footnotetext{
Mas voltando ao nosso projeto... Lina nos tranquilizou dizendo: "um pouquinho de água, um foguinho e está tudo resolvido. As pessoas se juntam à volta desses elementos para brincar, conversar ou simplesmente observar". E assim foi. Este é um dos espaços mais comoventes, do centro, e um dos mais utilizados; o espaço de "fazer nada".(Ibid., p.19, tradução nossa)
}

O setor das quadras é resolvido com uma nova edificação de dois blocos conectados e separados da fábrica. A introdução do espaço público num projeto que tem um único ponto de acesso é muito simples e intensa, feita para manter e intensificar a qualidade da rua interna como espaço público que acaba na "praia do paulistano" e nas quadras esportivas, colocadas ao final do percurso, mas também intermediando (até às vezes fazer parte deles) entre os diversos programas. Esta "prainha" vai se somar ao conjunto de praias que vão ser analisadas mais adiante.

O SESC Pompeia não é nem o primeiro nem o único edifício indústrial transformado em peça de arquitetura contemporânea, mas ele apresenta uma relação com o tema dos equipamentos e a desespecialização programática a partir de uma instituição, o SESC é importante para o Brasil, e totalmente surpreendente para quem vem de fora.

\section{VARIAÇÕES PÓS-INDUSTRIAIS}

O caso que segue, da Fabrica Paylana, também não é único mas apresenta uma situação recente de discussão sobre a renovação de uma região desindustrializada de uma cidade uruguaia e o papel que essa intervenção pode ter na combinação de habitação com equipamentos públicos.

Um concurso de ideias de arquitetura convocado no Uruguai pela Prefeitura do departamento de Paysandú (Intendencia Municipal de Paysandú- IMP) e o Ministério de Habitação, Planejamento Territorial e do Meio Ambiente (Ministerio de Vivienda Ordenamiento Territorial y Medio Ambiente- MVOTMA), pedia ideias de projetos para um terreno que tinha sido a principal instalação da fabrica Paylana em Paysandú, uma cidade com uma população de 120.000 pessoas e que teve um forte desenvolvimento indústrial partir dos anos 40. Paylana era uma fábrica de tecidos de lã que fora fechada depois de que os proprietários faliram e que também faliu uma cooperativa de produção dos antigos trabalhadores da fábrica. O conjunto foi comprado pela prefeitura e nele existem vários galpões industriais que totalizam 33.266 metros quadrados construídos 

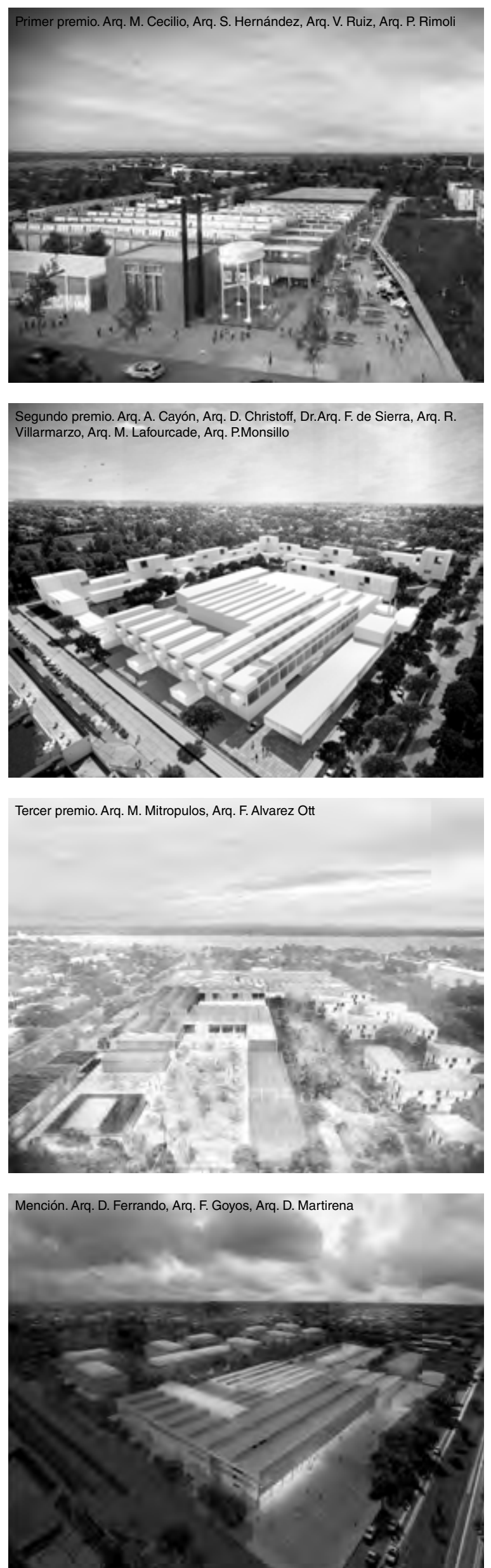
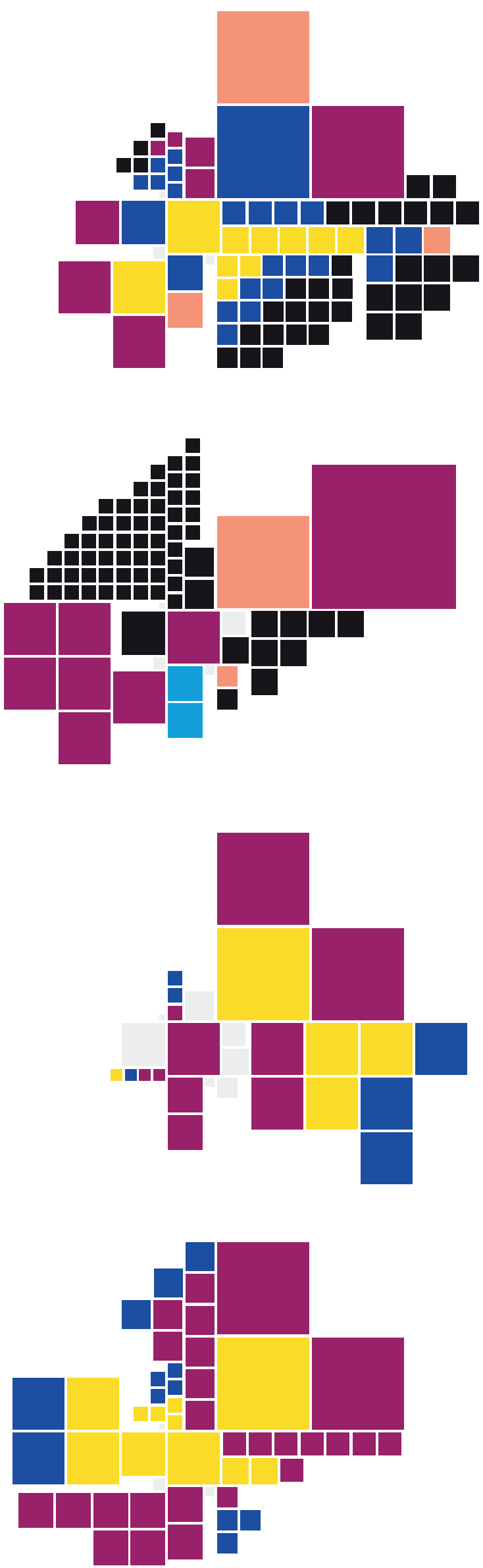

Fig. xx Paylana 
Mención. Arq. P. Bacchetta, Arq. J. Díaz, Arq. B. Martín, Arq. E. Martínez, Arq. L. Oreggioni, Arq. F. Ríos
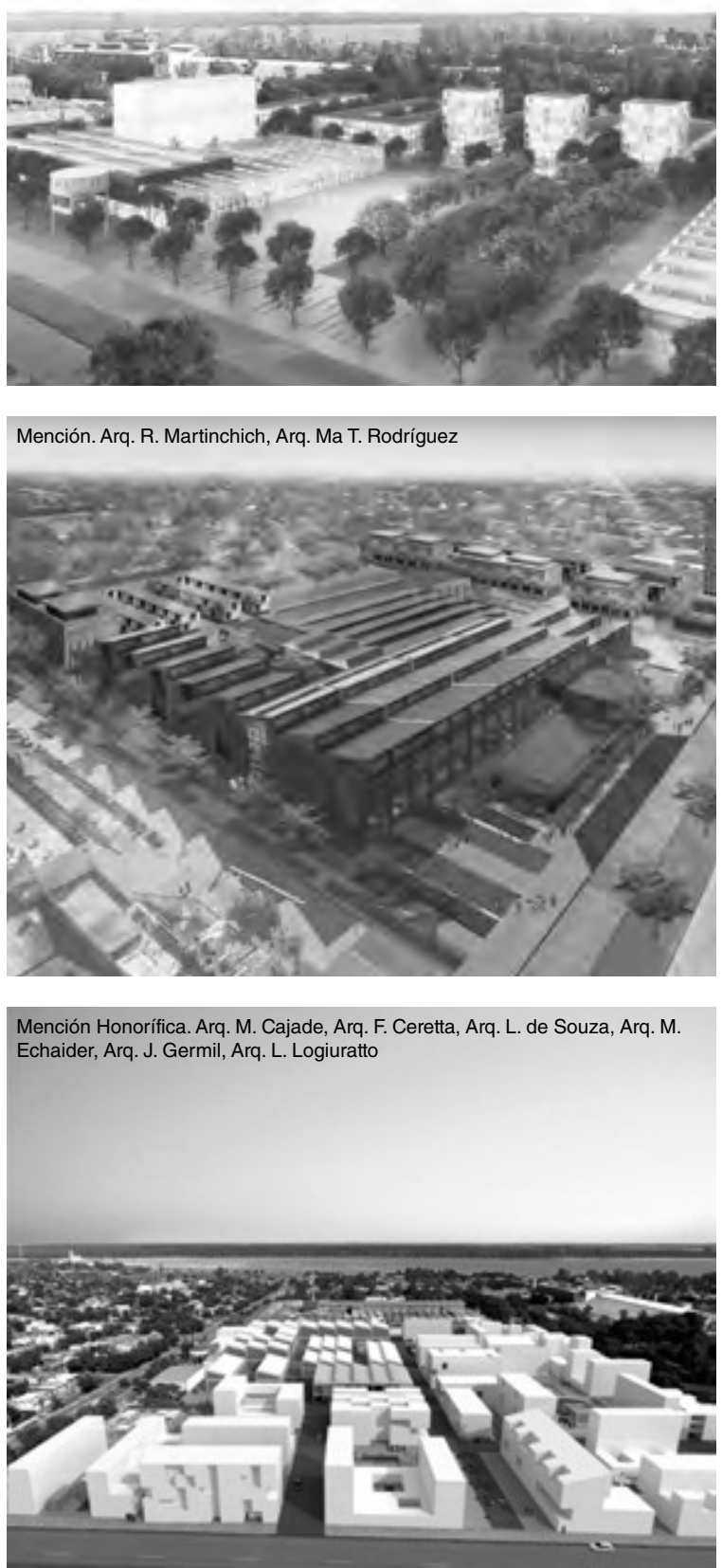

Mención Honorífica. Arq. R. García Fernández, Arq. C. Gazzaneo, Arq. L. Neira,

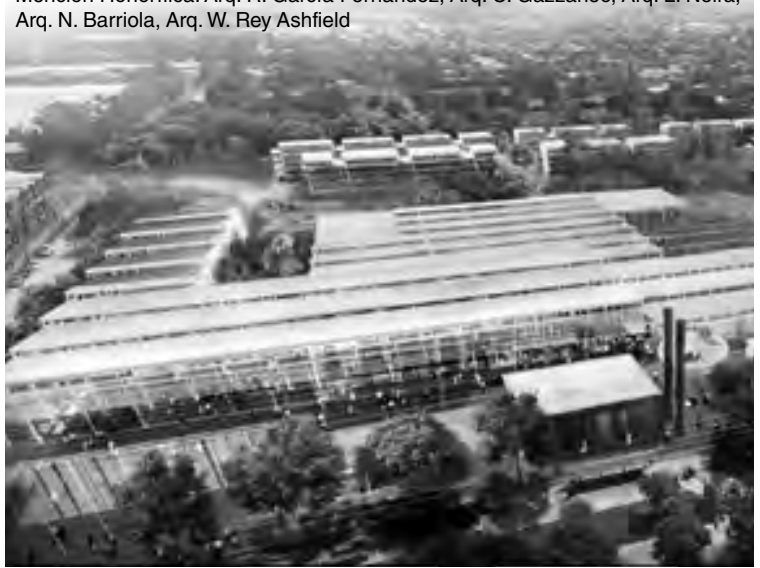

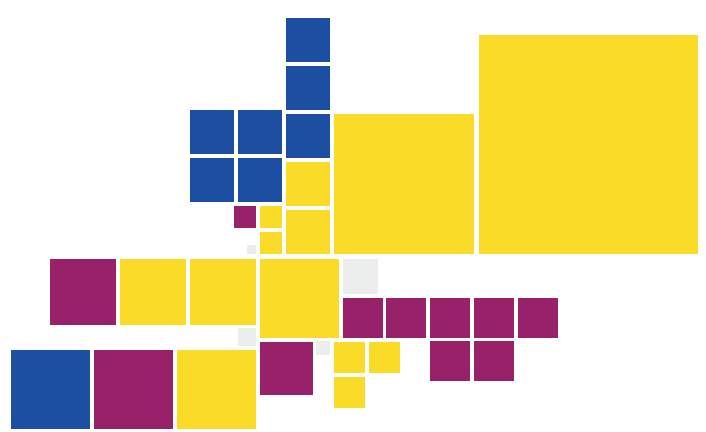
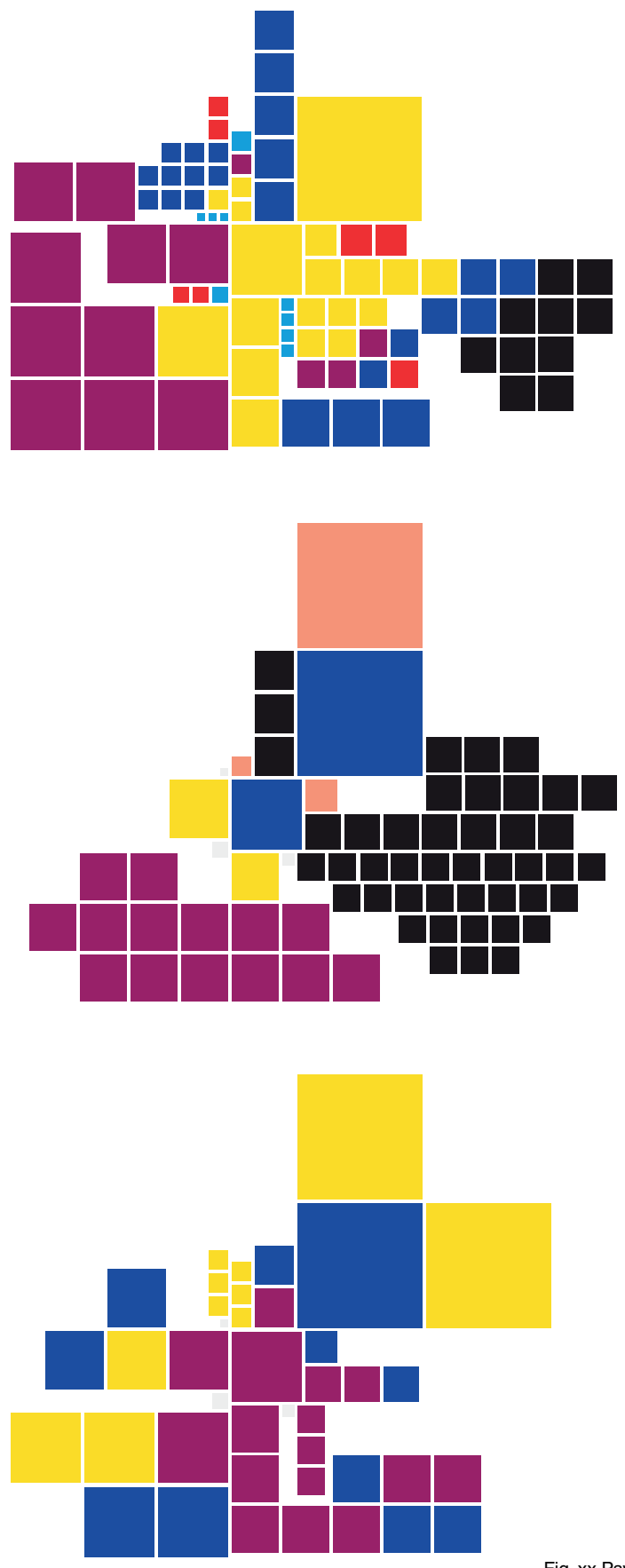

Fig. xx Paylana 


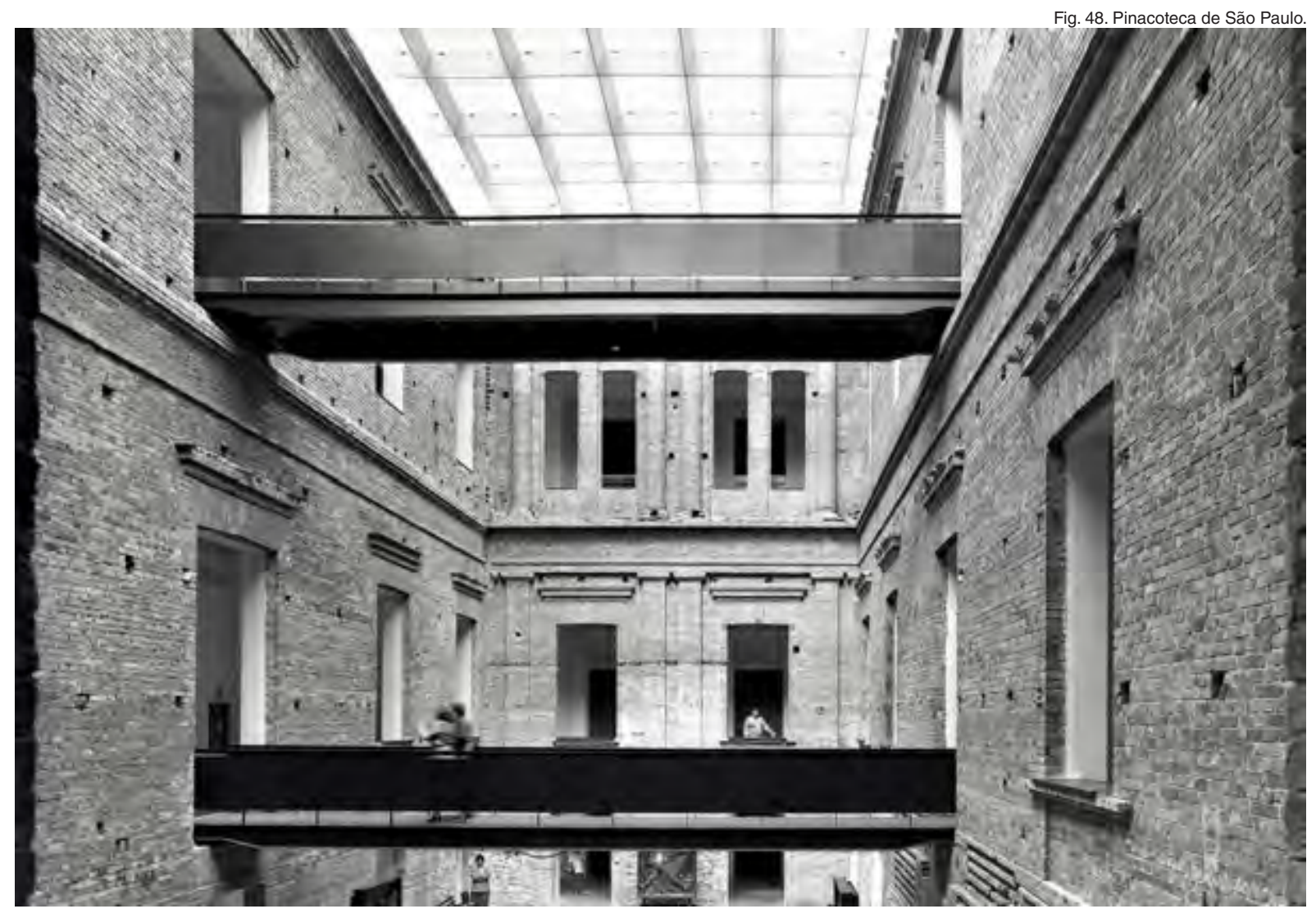


num terreno de quase 5 hectares. Do conjunto destaca-se uma construção indústrial de estrutura de concreto armado de quase 12.000 metros quadrados construídos baseada numa malha regular de $5 \times 5$ metros que define os pórticos com cobertura em "shed" de iluminação indireta, que tem forte presença como um símbolo do passado industrial.

\begin{abstract}
O objetivo deste concurso de ideias de arquitetura e urbanismo é reformular, ressignificar e desenvolver este espaço urbano, que historicamente se estabeleceu como um marco significativo para a cidade e que se parece ter potencial de se tornar uma referência para seu desenvolvimento futuro, buscando, de uma perspectiva contemporânea, dar uma resposta programática às diversas necessidades, demandas e exigências da população da cidade de Paysandú e seus arredores imediatos. [...]

O contexto em que acontece o presente convite é feito é definido pela perspectiva de revitalização e reformulação da referida propriedade e seu entorno, a partir de uma visão estratégica do desenvolvimento habitacional urbano, incorporando preferencialmente serviços habitacionais, institucionais, culturais, esportivos e comunitários, bem como de forma complementar, pequenas e médias empresas produtivas e de prestação de serviços, amigáveis ao meio ambiente e compatíveis com o uso residencial, de acordo com os regulamentos departamentais e nacionais, adequando-se às particularidades e exigências estabelecidas nestes Termos e Condições. (MVOTMA e IMP, 2017, p.28-29, tradução nossa)
\end{abstract}

O concurso é de ideias, e então a resposta frente a semelhante ruína pós-indústria fica aberta às ideias dos arquitetos. No concurso se apresentaram 30 projetos que trouxeram versões muito diferentes para a cidade, de intervenção no conjunto e particularmente na estrutura de concreto armado do principal prédio. O interesse aqui é estudar como as propostas inseriram usos diversos, mantendo totalmente ou mudando parcialmente a estrutura principal. Ela teve a capacidade de abrigar, nos diferentes projetos, a partir de sua malha quase regular de 5 por 5 metros, todo tipo de equipamentos, e também habitação em diferentes formas de ocupação. A ruína original é um espaço, um "espaço fortemente capaż, a partir de sua simples regularidade.

\title{
PÓS-PRODUÇÃo
}

"É simples, o ser humano produz obras. Pois bem, a gente faz com elas o que tem que ser feito: gente se serve delas". Serge Daney.

Com esta citação começa o livro de Nicolas Bourriaud (2009a), "Pós-produção". O livro publicado na França em 2004 é uma reflexão sobre a possibilidade de que o fenômeno que nomeia o livro ligado às práticas contemporâneas da cultura digital pode ser um caminho de interesse para a arte. Esse caminho tem começado muito antes da sociedade da informação com a apropriação exemplificada nos "ready-mades" de Marcel Duchamp, e uma genealogia depois do Duchamp. No livro se estudam diferentes 
Fig.49. Palais de Tokyo.

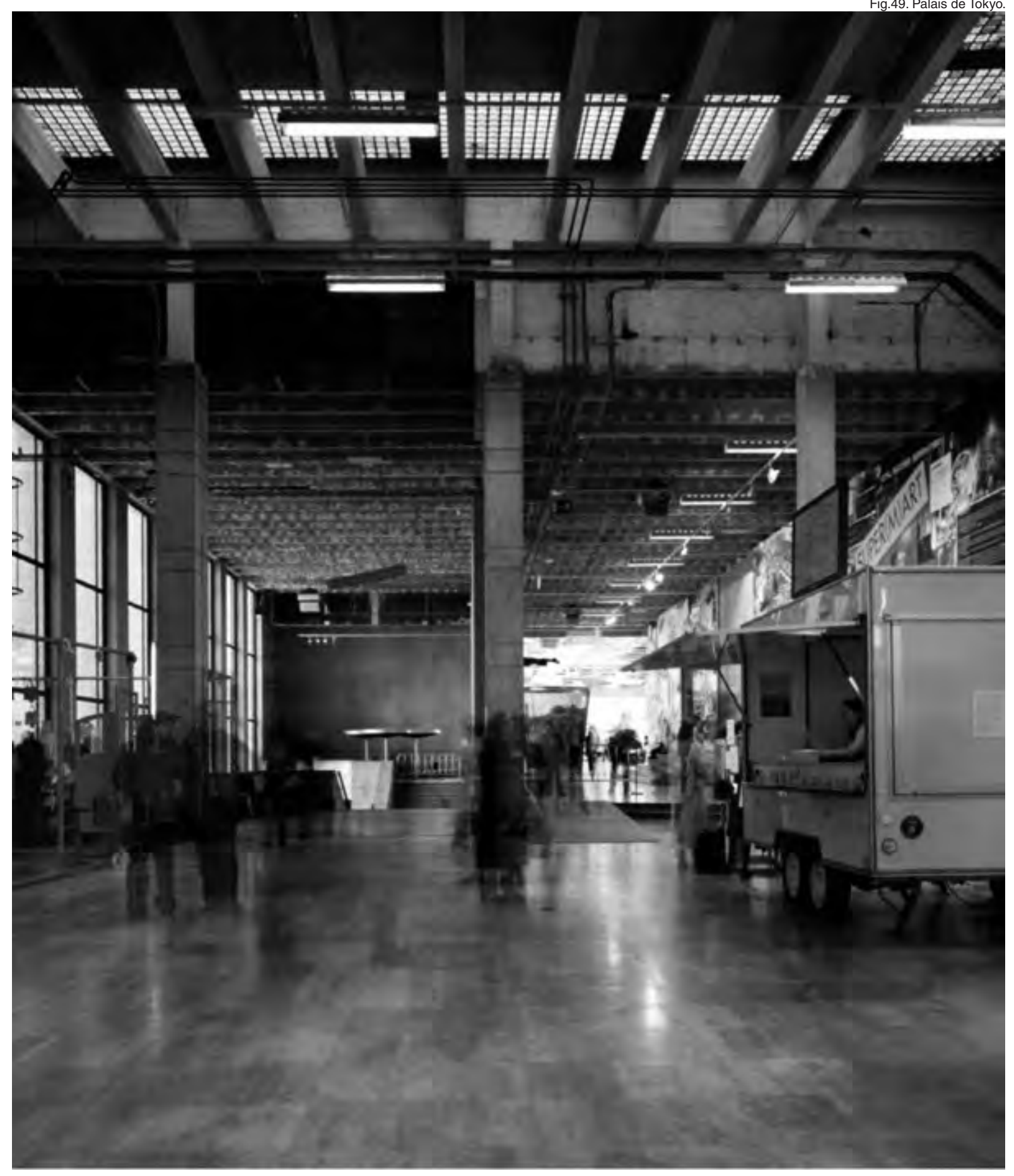


maneiras de produção de arte contemporânea por meio de estratégias em vinculação com o conceito de fazer a partir daquilo que já foi feito. Bourriaud publicou em 1998 outro libro, "Estética Relacional", que defende uma estética que "julga a obra de arte em função das relações inter-humanas que figuram, produzem ou criam”. (BOURRIAUD, 2009b, p.151). Um ano depois desse livro, Bourriaud e Jerome Sans são escolhidos para dirigir o "Palais de Tokyo" uma nova instituição em Paris para a exibição e a produção da arte contemporânea que ia ocupar um prédio-ruína muito especial. A sua proposta se dirige aos "artistas jovens do mundo inteiro, a instituição propõe um espaço para o confronto de ideias, produzindo sinergias e redes" (LÓPEZ UJAQUE, 2017, p. 211-212, tradução nossa).

O prédio escolhido era uma ruína produzida por acumulação de intervenções. Construído em 1933 como Museu de Arte Moderna, ele perde seu uso principal com a criação do novo Beaubourg aonde são levadas as suas coleções de arte. Passou por vários usos e acabou caindo no desinteresse apesar de sua posição privilegiada na beira do Sena e próximo à Tour Eiffel. Nos anos 90 foi feito um concurso de arquitetura com grande orçamento para construir o "Palais do Cinema". A obra foi apenas começada, se retiraram escadarias, elevadores e instalações, e foram feitas muitas demolições. Nessa condição no mesmo ano de 1999 foi convocado um concurso de arquitetura para recondicionar o prédio para o uso temporário de 5 anos para a nova instituição de arte contemporânea. Quem ganhou o projeto foram os arquitetos Lacaton e Vassal com uma ideia muito simples: a beleza do estado ruinoso do prédio e a grande luz zenital como principal valor seriam o cenário ideal para abrigar a produção e mostras de arte contemporânea. A indeterminação do espaço se valoriza como ideal para a apropriação da arte contemporânea. Os arquitetos fazem a metáfora de produzir um lugar similar à praça Djemaa-el-Fnaa em Marraquech, um espaço cujo uso vai mudando ao longo do dia pela luta corpo a corpo entre carros, bicicletas e motos, vendedores ambulantes e outros personagens que convocam uma multidão e impedem os carros de continuar passando. A decisão de fazer quase nada, não agregar nem mudar nada. Apenas condicionar: reforçar a estrutura, prover infraestruturas.

A dicotomia entre massa internas e externas que envolve o Palais de Tokyo em seu espaço é, ao contrário, o produto de um processo de desobstrução e reordenação, a eliminação das partições internas - que eram obstáculos para o uso total do edilício - leva a um nova hierarquização do espaço interior em conexão com seu envoltório. Entre as salas de exposição iluminadas pela continuidade horizontal da claraboia e as salas polivalentes "piraneslanas" do porão, se cria toda uma gama de situações diferentes a 
Fig.50. Potsdamer Platz,Wesely.

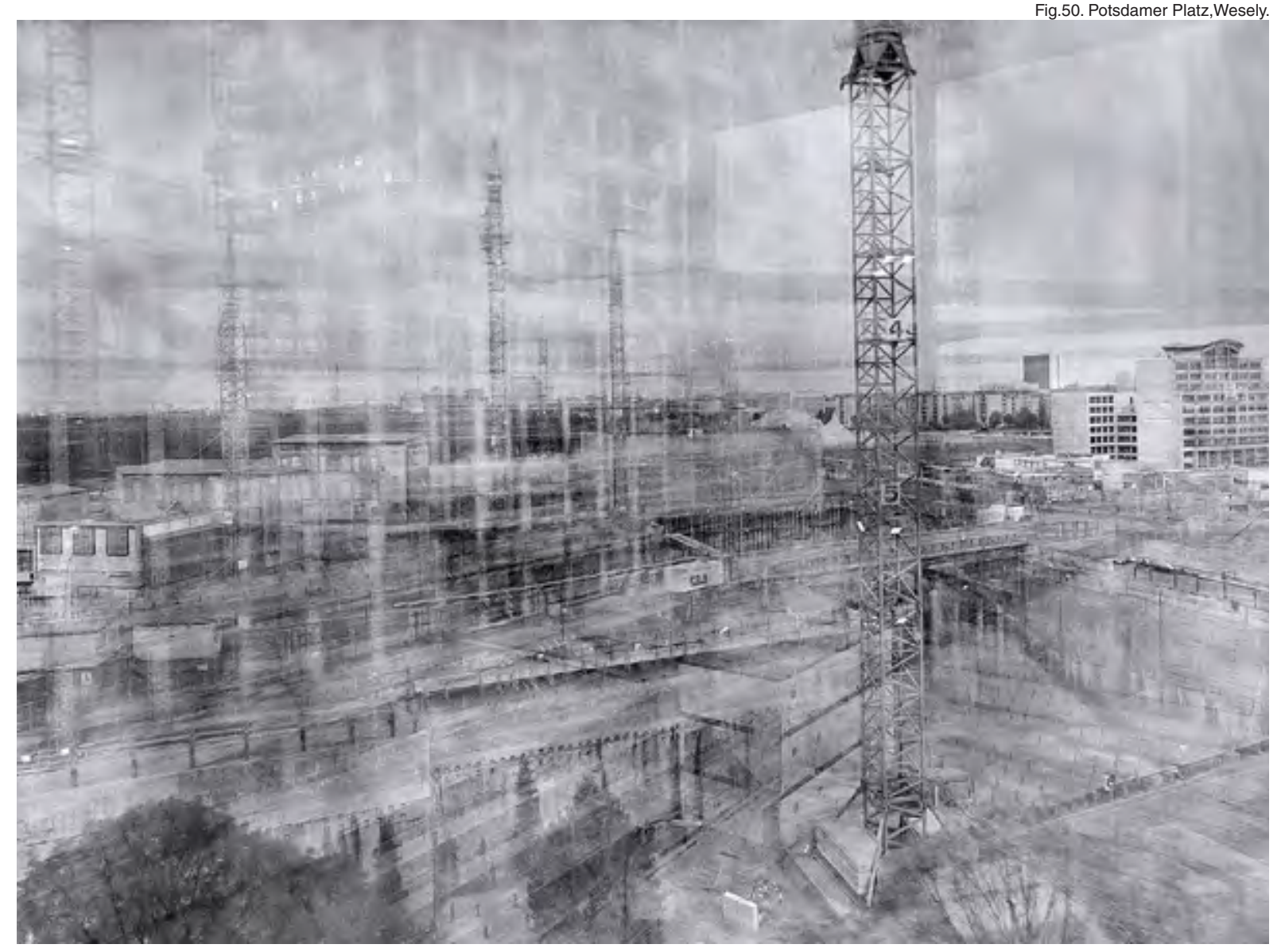


partir da relação entre uma nova partição interna, uma partição mais virtual que é construída, e estrutura imutável do edifício. $O$ espaço polivalente de ambas as instalações culturais - o FRAC de Dunquerque e o Palais de Tokyo de Paris - não é um contínuo homogêneo ilusório, mas um apoio espacial desigual, divergente e diferente. (RIVKIN, 2015, p.38, tradução nossa)

Depois da intervenção que revitaliza aproximadamente 8000 metros quadrados da ruína (uma superfície maior ainda da previsão do concurso como consequência da estratégia de simplificação) o Centro de Criação Contemporânea e o prédio viram grande sucesso e uma novo projeto é pedido aos arquitetos para intervir sobre o setor que ainda é ruína pura, não condicionada (LACATON e VASSAL, 2006, 2017). O projeto consegue ser aberto e continuo em seu espaço e ao mesmo tempo específico, com caráter e variações, aquilo que a desespecialização programática deve assumir como próprio. $\mathrm{O}$ espaço não deve ser neutro e indeterminado (genérico) senão que pode ser aberto e qualificado.

Para esse segundo projeto que toma conta da totalidade do prédio $(22.0000 \mathrm{~m} 2)$ os arquitetos procuram uma nova referência que confirma a vocação singular da sua intervenção no Palais de Tokyo, que é o Fun Palace de Cedric Price. De praça dinâmica do terceiro mundo para edifício-rua uma ideia revolucionaria e ainda não construída (Id., 2012).

A sucessão de projetos acumulados desde 1937 até hoje no prédio do Palais de Tokyo é uma lição sobre a imprevisibilidade e a durabilidade relativa das circunstância $s$ no momento de produção de um edifício.

Se fosse possível produzir no "Palais de Tokyo" uma única foto que durasse 90 anos, feita por uma lente como a que Michael Wesely faz para testemunhar lentas mudanças no mundo físico, seria possível perceber o prédio totalmente definido (sem maiores mudanças) e só a bruma de uma atmosfera em mudança, aquela dos contínuos movimentos de pessoas praticando o espaço.

Os sevilhanos Cruz e Ortiz falaram em uma entrevista há mais de 25 anos (LEVNE, R; MÁRQUEZ, F, 1991) sobre a prudência com que a arquitetura deveria ter ritmos de produção e tempos de duração, mais longos do que a maioria dos produtos que estão sujeitos a ciclos cada vez mais rápidos. Se propunham pensar em uma atemporalidade relativa da obra para não submeter seu pensamento e seu projeto ao ritmo frenético da mudança de ideias e modas. Koolhaas diz mais ou menos o mesmo no "Content", citando sem avisar Cedric Price: "a arquitetura é muito lenta..." 
Fig.51. Bunker de carvão, Becher+Becher

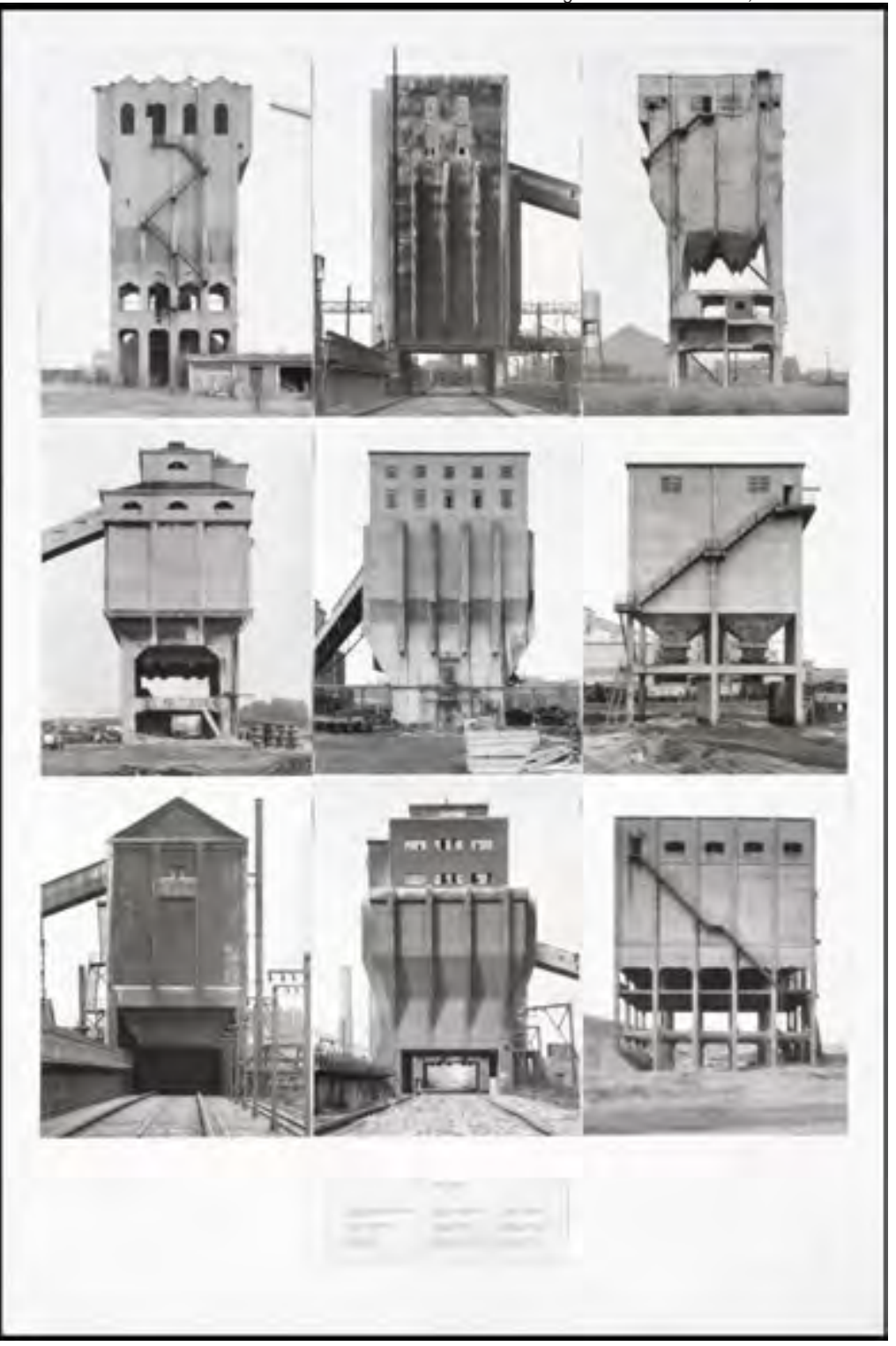


O projeto é uma Pós-produção que não aparece no livro de Bourriaud de 2004 porque o autor não faz referências à arquitetura.

\begin{abstract}
Neste momento, as palavras que Iñaki Ábalos pronunciou em uma palestra de Lacaton \& Vassal em Harvard são interessantes para definir a condição estética do estudo francês e que resultam no aparecimento das 'ruínas decoradas': "Deixe-me concluir com um comentário sobre sua estética. Como Jean-Philippe disse no final, ama a arquitetura moderna, mas, ao mesmo tempo, também gosta de um tipo de "adhocismo" para coisas que estão quase em estado de ruína. Uma predisposição para deixá-los como ruínas não decoradas que funcionam bem e não como ruínas decoradas". (LÓPEZ UJAQUE, 2017, p. 199, tradução nossa)
\end{abstract}

A Pós-produção é um termo que ajuda no entendimento da vitalidade da arquitetura, a duração dos prédios e suas sucessivas oportunidades para abrigar usos diversos. Um convite para atender o projeto do hoje com olhos nessa possível vida não predita na origem. E a opção é um compromisso disciplinar, de rigor com a abstração frente as demandas concretas do programa e um compromisso com a qualidade espacial. $\mathrm{O}$ projeto abre oportunidades quando ele é um espaço atrativo e estimulante que sabe lidar com as circunstâncias que o produzem. Juan Herreros aponta essa qualidade pouco ressaltada do trabalho dos franceses:

\begin{abstract}
Por isso, da mesma forma que Roland Barthes propôs retornar à origem do sujeito literário e da linguagem para parar de falar sobre livros e autores, parece necessário falar de L\&V de uma maneira diferente, da arquitetura como uma disciplina, sem referir-se à seus edifícios para destacar suas virtudes, nem para as referências mais óbvias de seu trabalho para buscar outras práticas que legitimam as suas.[...]

Em uma reunião recente com Anne Lacaton, ela explicou o quanto os seguidores de seu trabalho valorizavam o aumento da área de superfície, a redução de custos, a facilidade e a velocidade de implementação, o enriquecimento programático... mas como isso às vezes demora para ser entendido que, acima de tudo, é o esforço para oferecer uma arquitetura melhor (HERREROS, 2015, p.360-364, tradução nossa)
\end{abstract}

\title{
RUÍNA MONO-FUNCIONAL
}

Bernd e Hilla Becher produzem, a partir dos anos 50 do século passado, uma série de fotografias nas quais documentam peças da paisagem indústrial. Suas séries de silos, edifícios fabris, tanques de gás, altos-fornos e tanques de água documentam os artefatos que constroem uma paisagem sem propô-los, de uma forma que seja resposta técnica pura a uma demanda específica de infraestrutura. A série apresenta a estranha beleza dessas peças sem intenção estética, e cujo único significado é o de sua própria função, mas o conjunto transborda a circunstância de relacionar o conjunto, fazendo com que suas variações transformem cada um em um personagem diferente. 
Fig.52. UVA da imaginação, Colombia.

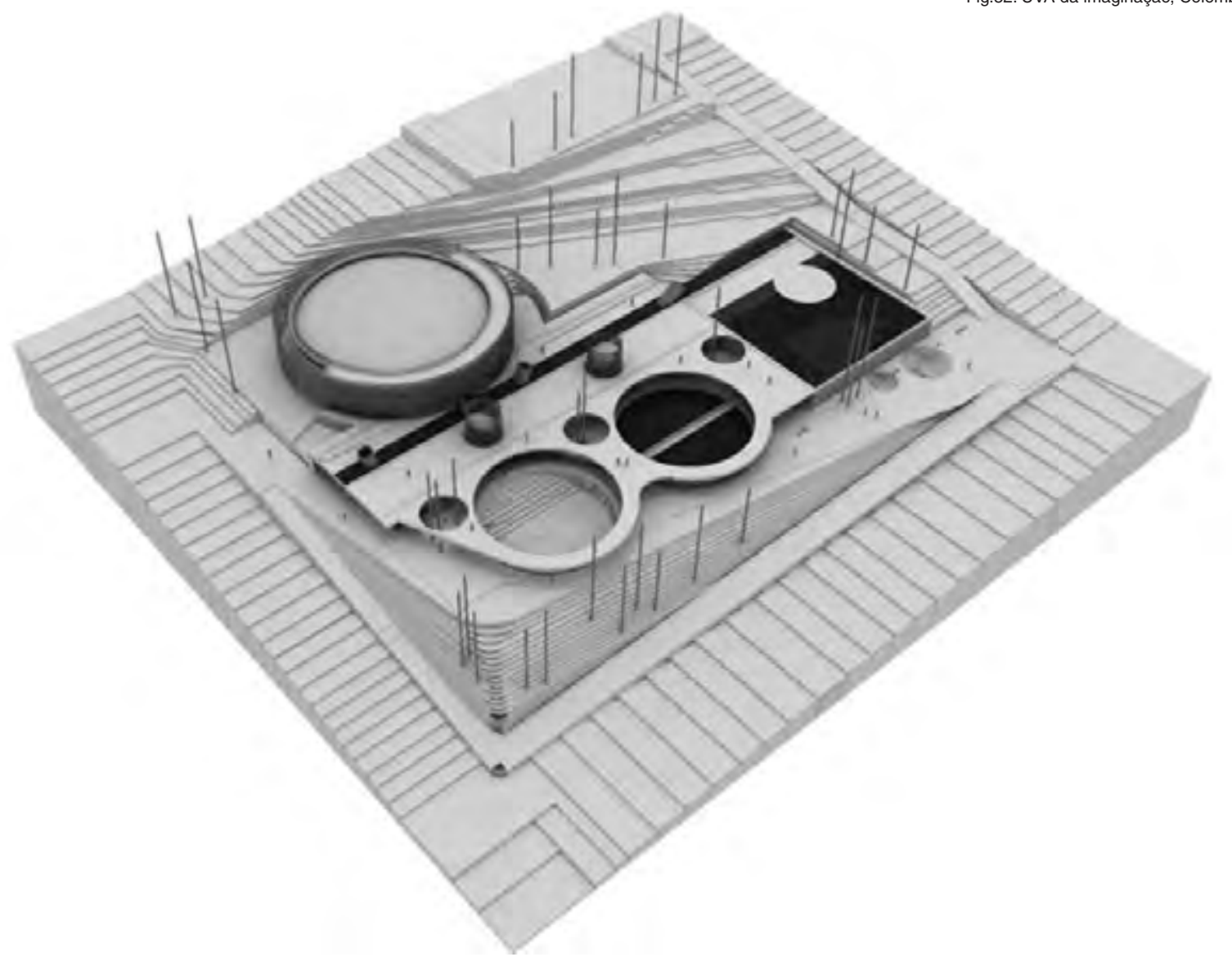


$\mathrm{Na}$ cidade contemporânea a ideia de ter grandes dispositivos dedicados em exclusividade a uma função se apresenta como oportunidade urbana perdida. A oportunidade enunciada por Tschumi no "Crossprogramming", e a descoberta feita no livro "Made in Tokyo" das convivências surpreendentes num mesmo prédio ou equipamento, sugerem um caminho para o projeto.

Como parte de uma série de intervenções que serão analisadas mais adiante, Medellín desenvolve Unidades de Vida Articuladas (UVA), instalações públicas multiprogramadas que atendem a setores sociais desfavorecidos da cidade. Uma Medelín que se torna uma cidade para seus habitantes, e que atende especialmente os bairros de periferia, um novo olhar é encontrado para tanques de água e outras instalações isoladas, considerando-as como uma ruína, no sentido de que a reversão de sua condição autista é uma oportunidade de multiplicar seu uso e a do solo generoso que servem. Com o slogan "Remover a cerca para ficar mais próximo", a UVA abre esses terrenos especializadas por meio de equipamentos e espaços públicos definidos em seu caráter e administrados através de processos de participação comunitária. Os projetos são feitos por concurso de ideias arquitetônicas. Existem algumas Unidades, aquelas que reúnem o uso do tanque de água, que se concentram na criação do espaço público e alguns equipamentos simples, um exemplo marcante para o seu projeto é o Orfanato UVA que cria um espaço público de $10.000 \mathrm{~m}^{2}$ e um superfície coberta de $1020 \mathrm{~m}^{2}$. O projeto foi vencido no concurso pelo "Colectivo 720" e coexiste com dois tanques em operação e dois que não estavam funcionando. O programa inclui salas de aula, teatro ao ar livre (e um grande número de espaços públicos, em que se destaca um mirante urbano O equipamento UVA e seu senso público é diretamente administrado pela empresa pública de energia, gás e água, que assume entre suas tarefas (geralmente especializadas nos serviços que presta) oferecer esses equipamentos públicos. A própria instituição assume a desespecialização como estratégia para se inserir na complexidade da rede social. O complexo aberto ao público e à convivência habita o desperdício de um espaço concebido de forma autista.

\section{AL hUESO: DEPOIS DO PROGRAMA}

Um conjunto de edifícios de Montevidéu. Arquitetura de qualidade que lida com programas diversos e trabalha com atenção às relações entre a manipulação do espaço, a sua relação com a estrutura e a geometria. Construídos em diferentes circunstância s 
Fig.53. Urnario municipal.

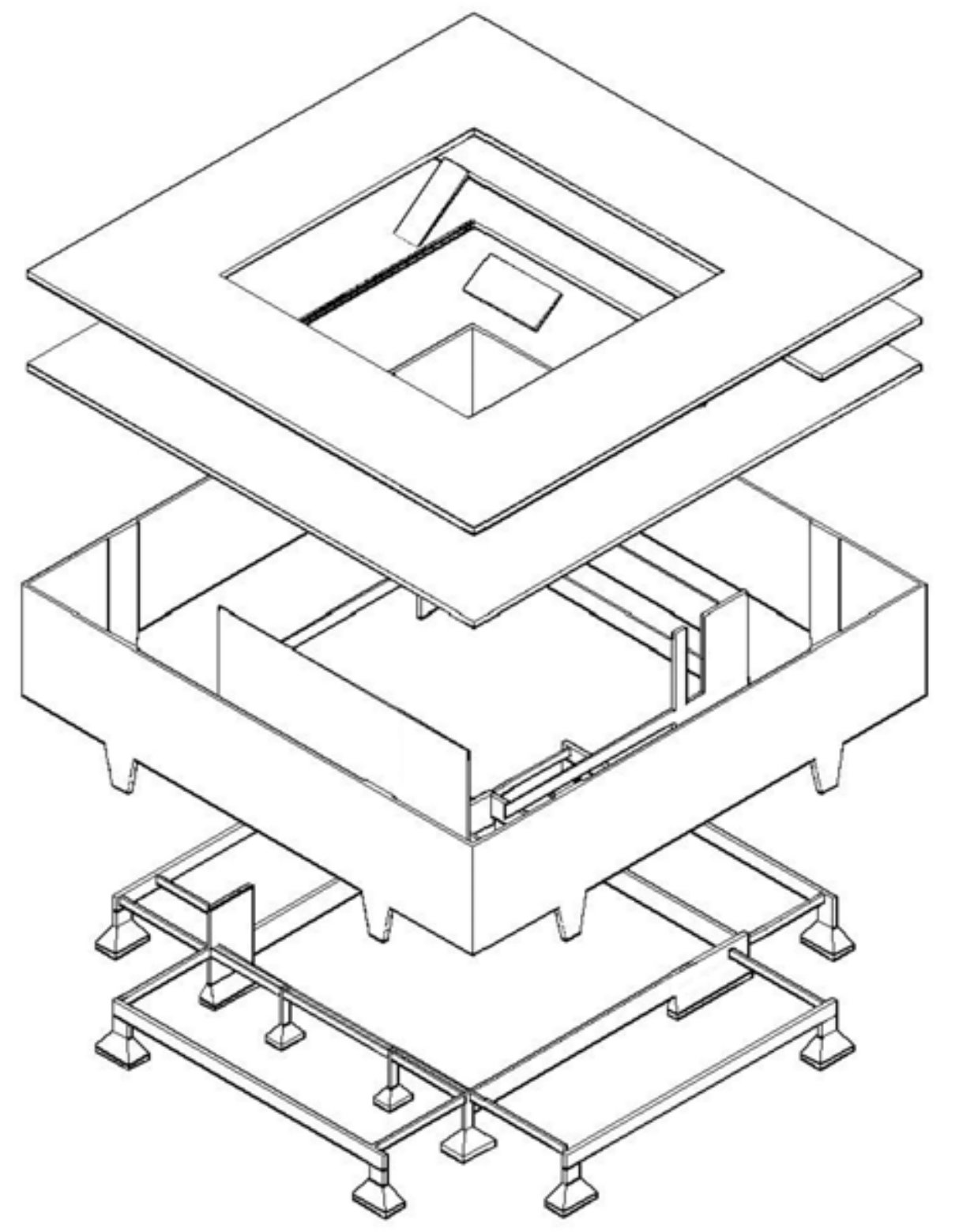


históricas do Uruguai entre 1959 e 2008. Prédios ou partes de prédios com superfícies entre 1200 e 4200 metros quadrados:

Um edifício para um Banco construído em um bairro consolidado de Montevidéu, em uma propriedade entre paredes divisórias de 20 metros de largura, concebido como um espaço diáfano que se apoia apenas nas paredes divisórias e escava a terra para produzir espaços pequenos e compartimentados; um Edifício universitário definido como um conjunto de salas de aula organizadas em três pavilhões (o Farol Desespecializado que analisamos anteriormente): uma escola católica com uma capela que se forma como uma galeria duplo, gerando sutis variações espaciais enquanto caminhamos horizontalmente e verticalmente, o ginásio de uma imensa residência de estudantes universitários faz jogos espaciais e estruturais sutis e admitiu a conversão nos principais equipamentos do Instituto de Educação Física; um Liceu em uma área crítica de Montevideo formado em volta de um pátio em dois níveis que são dois pátios; um Pavilhão que faz parte de uma série que funciona como laboratórios de tecnologia, repetição e diferença espacial, pequenas adaptações funcionais; uma Biblioteca que ocupa um andar de um antigo Edifício Indústrial vertical reconvertido ao Edifício Universitário; uma sala polivalente de um conjunto de cooperativas que funciona como peça central e articuladora, atravessando o terreno, ligando duas ruas e absorvendo todo o espaço comum do conjunto; um Urnario em um cemitério, um esqueleto de concreto armado separado do chão como uma caixa flutuante que abriga urnas funerárias.

O Urnario, último caso, é o mais distante em termos de programa dos programas de equipamentos públicos que norteiam o curso desta tese. Essa distância que é deliberada demonstra a relatividade da relação entre forma e função. O maravilhoso edifício extremamente simples e sofisticado em suas formas e proporções, se tornou um esqueleto que demonstra as possibilidades do ponto de vista. Permite discutir sobre o espaço, o programa e suas delimitações. Como tudo relacionado à morte, ele é acompanhado por uma mitologia fantástica, cujas perguntas não pedem respostas, mas confirmam as hipóteses que trabalhamos: Bayardo conheceu Vilanova Artigas? $\mathrm{O}$ Urnario é a ruína antecipada da FAU USP de Vilanova Artigas? ${ }^{23}$

\footnotetext{
${ }^{23}$ Uma sólida documentação sobre as influências e vinculações de Bayardo, aqueles que definem a rede cultural e pessoal local, as influências de Le Corbusier e outros internacionais e ainda com a cultura brasileira feita em MÉNDEZ Mary (2013)
} 
Fig.54. Palacio Salvo. Ph: Nicolas Garrido.

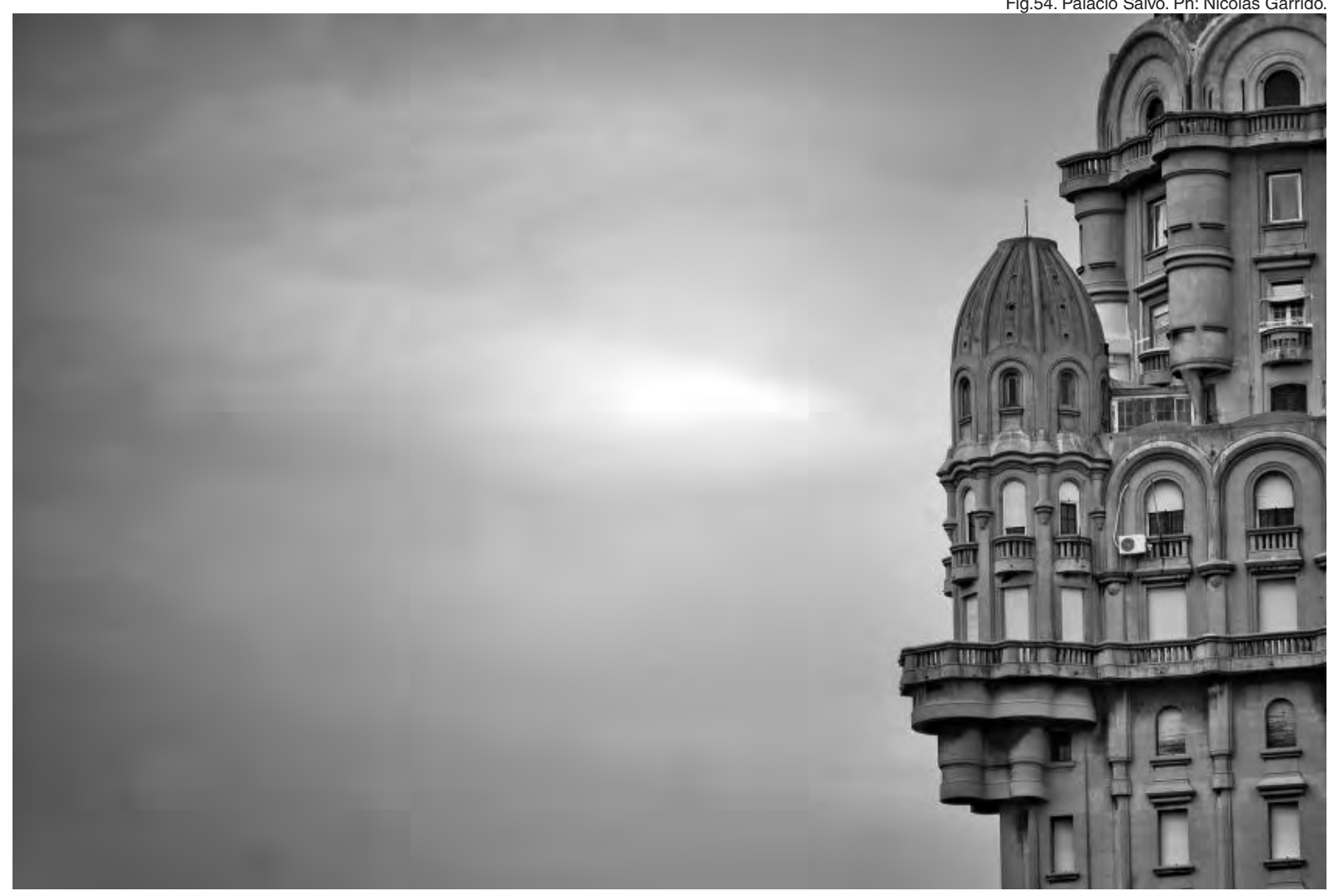


Esse é o ponto de partida de um trabalho de estudo de desespecialização programática que se propõe tirar tudo o que não é estrutura (material e espacial) nesses projetos, entender a capacidade dos espaços depois de tirar o programa, ficando com as proporções, as dimensões, os metros cúbicos de ar manipulados de uma maneira especifica. No laboratório do ateliê de arquitetura se realiza o processo de purificação. Encontre nos esqueletos que definem esses espaços a única condição irreversível de suas matrizes espaciais.

Al hueso é uma expressão popular utilizada no Rio da Prata para se referir a uma atenção aprofundada e direta num assunto. É também o nome de esse trabalho de laboratório feito pelos estudantes de arquitetura em dez dias num curso do quarto ano no ateliê de projeto Scheps ${ }^{24}$, na FADU de Montevidéu. Uma disciplina proposta sobre o projeto de equipamentos atendendo a sua condição urbanizadora, a desespecialização programática, a abertura e especificidade do espaço em relação com a estrutura.

\section{TEMPO}

Pode ocorrer uma ruína antes que um objeto termine seu ciclo de vida? Robert Smithson fez de suas "Ruins in reverse" um ensaio publicado em 1967, uma chamada de atenção sobre a produção de infraestrutura anódina na periferia americana (New Jersey como periferia de Nova York) que se tornam ruínas mesmo em seu processo de construção, por serem objetos enigmáticos sem sentido prático e estético. Smithson encontra algumas ruínas em marcha a ré, ruínas que vêm do futuro. Porque até agora vimos as ruínas que pertencem a um passado distante ou recente, e procuramos entender sua lógica essencial e apropriar-se delas para habitá-las.

Se o esmagador mundo americano dos anos 60 se permitiu detectar ruínas em sua periferia em marcha a ré, a lenta Montevidéu, que parece estar condenada a viver com o inacabado, apresenta uma coleção daquelas ruínas que Smithson teria aproveitado, detectado e documentado.

O espaço contém tempo, como Bachelard propõe: "Em seus mil alvéolos, o espaço conserva o tempo comprimido. O espaço serve para isso" (BACHELARD, 1965, p.38, tradução nossa). O tempo é, portanto, um fator de antecipação também para o projeto 
Fig.55. L'aval. Studio Muoto.
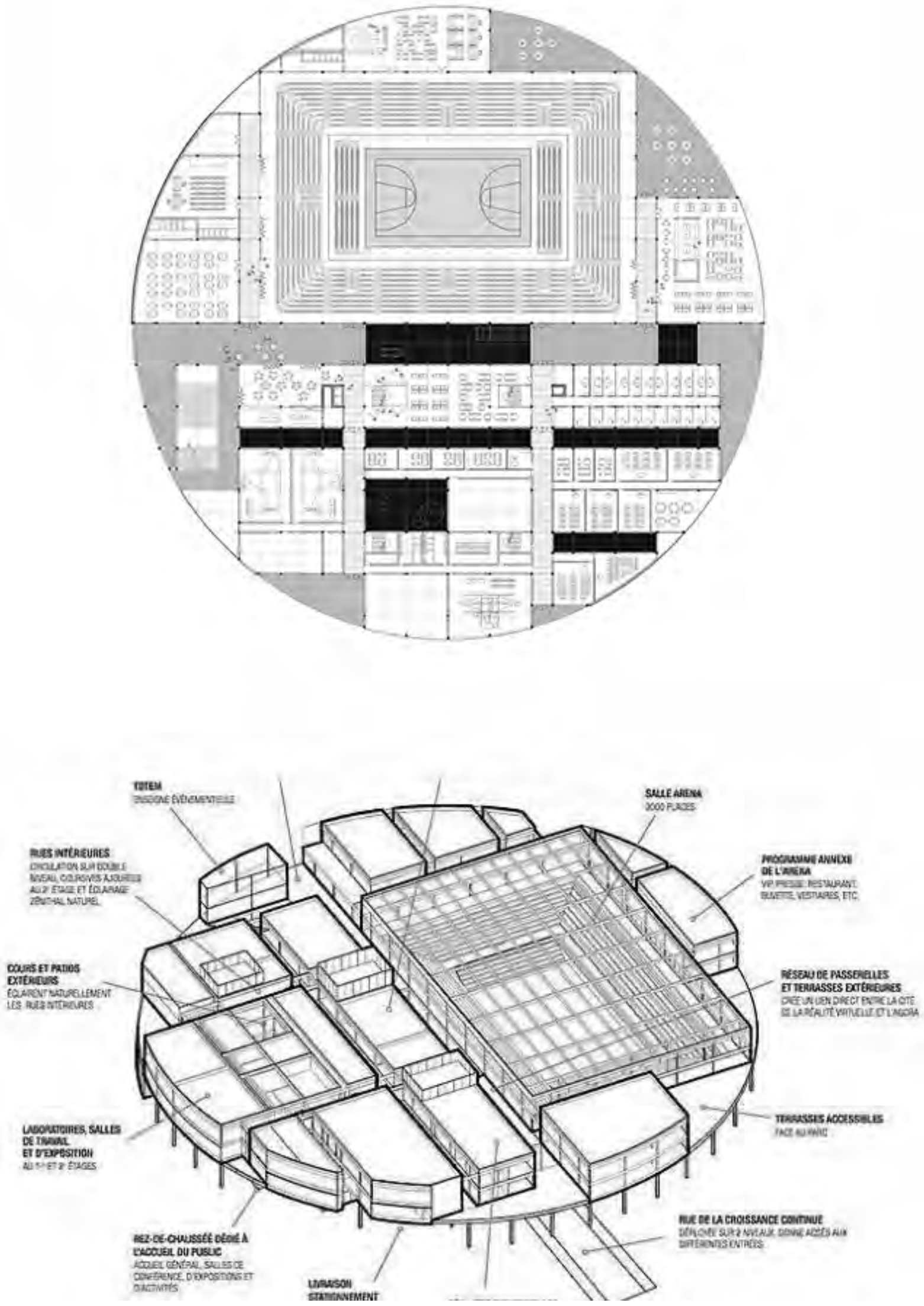
no sentido de durabilidade, a maneira em que o edifício incorpora a passagem do tempo e a forma como ele é apropriado.

Essa dimensão temporal opera como um fator de distanciamento, que também pode ser assumido por uma arquitetura desespecializada que enfoca os espaços que produz e as possibilidades que concede, e não tanto em sua figuração. Assim, o deslocamento no tempo pode ser uma ferramenta de pensamento, afastar-se para o futuro e pensar nos edifícios que projetamos como ruínas, e não naquela previsão romântica de Soane, mas sim de ruínas de um futuro incerto. Gilles Delalex do Studio Muoto apresentou em abril de 2018 em Montevidéu, como parte de uma conferência chamada "Uma modernidade arcaica", seu projeto de equipamento público universitário no campus de Paris-Saclay, um edifício desespecializado em excelência, como uma futura ruína:

Avec ce projet, nait l'idée d'une ruine particulière, qui est une ruine en devenir. II ne s'agit pas d'une ruine romantique qui se délite. Et ce n'est pas non plus une ruine à l'envers telle que l'imaginait Smithson, parce qu'il n'est pas question d'entropie. C'est une ruine qui annonce. Une ruine joyeuse, qui témoigne d'un état de transition, précaire. Et qui suggère que le bâtiment peut évoluer dans le temps, et qu'il aura peut-être même plusieurs vies. (DELALEX, 2017)

Muoto propõe uma visão otimista gerada a partir da proposta de um esqueleto duradouro, aberto a novas oportunidades que não podemos imaginar. Muoto administra duas estratégias de projeto que estão associadas a intervir em lugares da periferia do Primeiro Mundo, o mesmo que Smithson visitava 40 anos antes, e agora re-propõe a geometria com a malha e o espaço desespecializado como argumentos fundacionais com seus projetos, textos que constroem contextos. Como as colônias com que os romanos construíram território, a partir de malhas, um sistema de malhas. Essas ruínas do século XXI são novas ruínas que se abrem deliberadamente para vidas futuras, algumas arquiteturas abstratas e de alguma forma deliberadamente enigmáticas.

Quando o deslocamento no tempo é esticado ao extremo até que nossa civilização seja terminada, tudo se torna incerto, até mesmo a interpretação de certas arquiteturas da desespecialização que propõem o silencio como argumento expressivo e estético:

Um projeto sempre reflete sua visão do mundo. É um processo de interpretação e localização dos elementos de um determinado programa. Imagine a escavação de ruínas há dois mil anos, sobre cujo propósito e uso é difícil fazer conjecturas. Se algum dos edifícios de Sejima e Nishizawa fosse descoberto dois mil anos depois, seria difícil analisar se era uma casa, um hospital ou uma prisão. (HASEGAWA, 2000, p.20, tradução nossa) 
Fig.56. Palais de Tokyo. Lacaton\&Vassal.

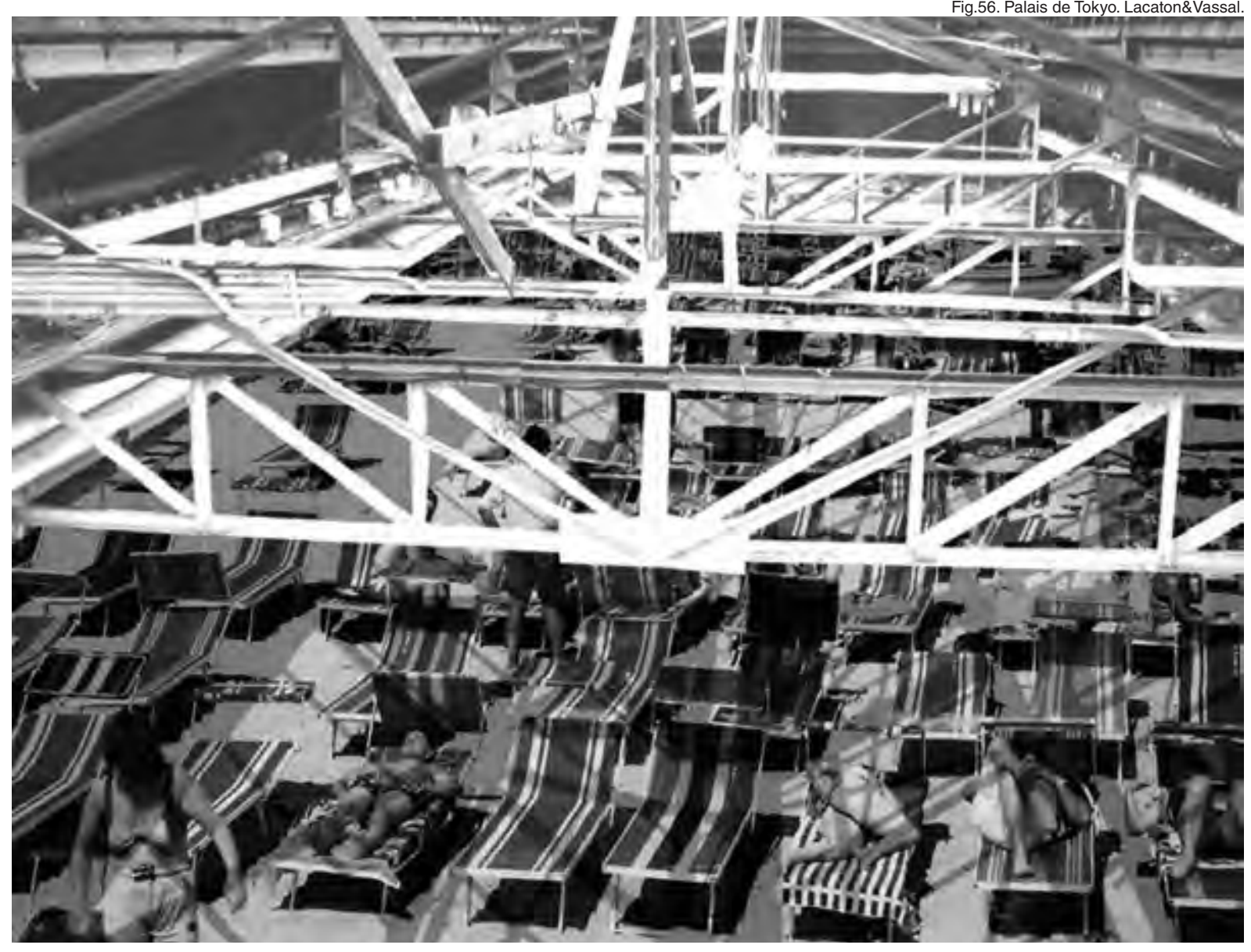




\section{DPL.5 DESLOCAÇÃO 2: PRAIAS}

Praia, uma margem branca ambígua e mutante submetida às forças da natureza. Captura a fantasia e sonhos, um espaço de liberdade.

Deserta, selvagem, balneário, urbano, naturista, nudista, areia, rochas...

Na margem do oximoro: praia natural e praia artificial.

Dentro do absurdo: praia particular. A praia é pública!

Um milhão de quilômetros de costa definem na Terra a interface terra-mar, uma boa parte dela é de praias. Na ocupação da praia existem regras relacionadas à ordem da paisagem e da geografia, afetadas pelas marés e ventos. A vocação moderna tem tentado reconfigura com resultados diversos. O mar e o clima, pacientemente e brutalmente, estabelecem os limites da possível artificialização.

A costa e a praia são um presente para uma cidade. Pelo menos isso é o que parece em Montevidéu, que tem um longo desenvolvimento na costa com uma avenida chamada Rambla e muitas praias urbanas. A Rambla é a principal alameda, em seus muitos quilômetros, nos fins de semana, pessoas de toda a cidade, todas idades e classes sociais se reúnem. É o espaço público por excelência. A praia de Pocitos é uma pequena Copacabana, entre a lógica costeira e a arquitetura moderna que a circunda.

A praia é um espaço desprogramado, onde modos infinitos e incertos de viver podem ser acomodados, a arquitetura não a ordena, é condicionada por convenções culturais e, eventualmente, ocupações temporárias. A praia é um ponto de partida para deslocarnos e pensar sobre o projeto de arquitetura a partir da desespecialização programática.

\section{praia paulista}

São Paulo é mediterrânea. Não tem exatamente a condição de beira-mar. São Paulo e Rio são duas cidades próximas, sendo diferentes. Essa relação com o mar e a praia aprece como uma explicação provavelmente marginal mas significativa das diferencias.

Em Brasília é veraneio/ No Rio é banho de mar/ O país todo de férias/ E aqui é só trabalhar/ Porém com todo defeito/ Te carrego no meu peito/ São, São Paulo/ Quanta dor/ São, São Paulo/ Meu amor.(ZÉ, 1968) 
Fig. 57. Domingo no CEU Ph: A Rosso.

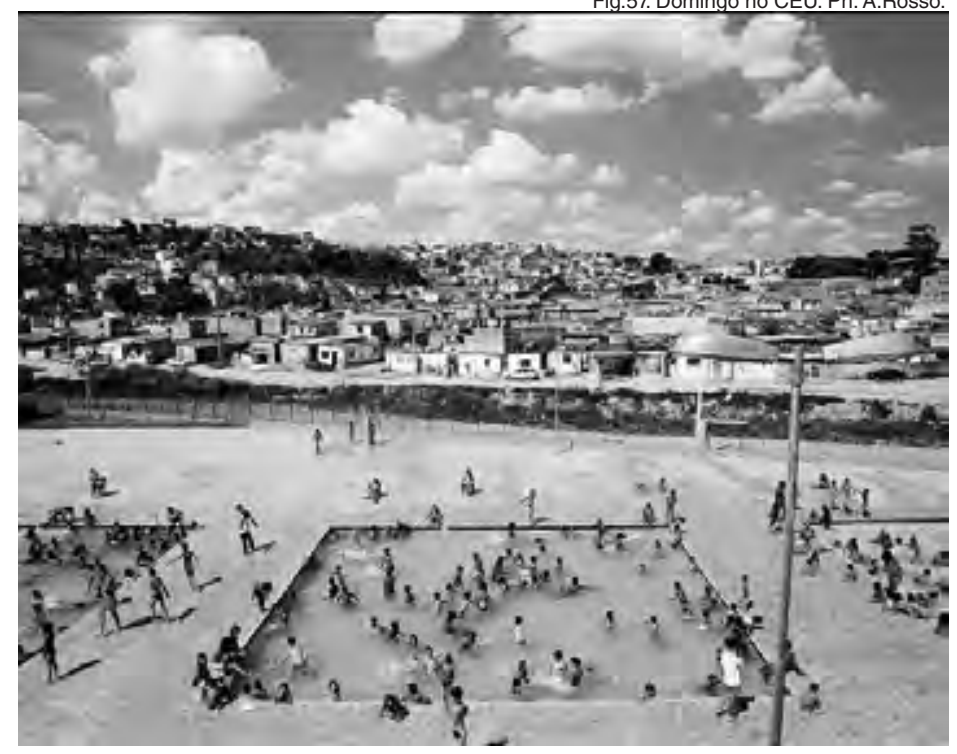


A praia para os paulistas é apenas para aqueles que podem viajar na sexta feira até o litoral, mas ela não existe, nem para as pessoas da periferia nem para a maioria dos trabalhadores.

Existem piscinas públicas em São Paulo, os SESC distribuídos pela cidade têm sempre equipamentos para esportes aquáticos. Lina Bo Bardi decidiu que o SESC Pompéia teria uma piscina de lazer no térreo do bloco esportivo, perto do deck. Deck e piscina juntos viram a prainha do SESC Pompéia. Sábado e domingo no Centro Educacional Unificado (CEU), três piscinas semiolímpicas e um solário fazem uma praia urbana como aquelas de Montevidéu ou Rio de Janeiro. Elas são parte de um equipamento exemplar que combina e coordena instituições e equipamentos diversos oferecidos pela Prefeitura da cidade ocupando $13.500 \mathrm{~m}^{2}$ por prédio. A fantasia de ter uma praia em São Paulo chega na periferia. Um domingo no CEU.

\section{EQUIPAMENTO PRAIA}

O CEU é um conjunto de equipamentos que abrangem vários programas. O programa se resolve por meio de uma inovadora coordenação no governo municipal da gestão cotidiana de varias Secretarias de Prefeitura, cada uma delas está acostumada a gerir e projetar equipamentos e políticas independentes. Temos que pensar o CEU como um equipamento com a lógica da cidade e da população e não com a logica da estrutura da organização estatal, é um ato politico que tem um sentido urbano, social e espacial significativo. É aquele sentido que a sociologia urbana reclama com os arquitetos e as instituições que agem com a periferia: fazer cidade e espaço público é parte da luta contra a desigualdade de oportunidades.

O CEU, então, não e só uma praia em termos do uso, ele é uma praia em termos de ter conseguido retirar a compartimentação burocrática estimulando a convivência e o encontro nos territórios, uma praia no sentido de juntar o que foi separado artificialmente. Essa nova condição pode ser conseguida desde o projeto de arquitetura, mas sempre dependente da gestão, e as vezes só a gestão consegue quebrar a especialização. Essas piscinas poderiam ter ficado fechadas no fim de semana, se por exemplo fossem parte de um equipamento escolar que só abre de segunda a sextafeira. O verdadeiro sentido do CEU como praia não é de ter colocado muitas piscinas que viram praias, senão ter feito desses equipamentos que viraram praia a concepção do equipamento público e a sua relação com a cidade. 

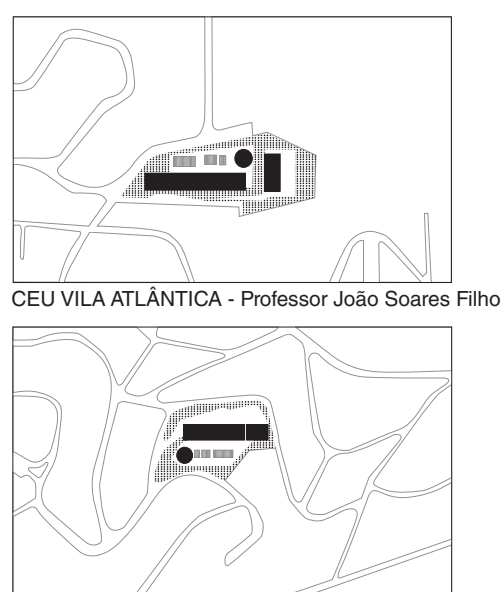

CEU PÉRA MARMELO

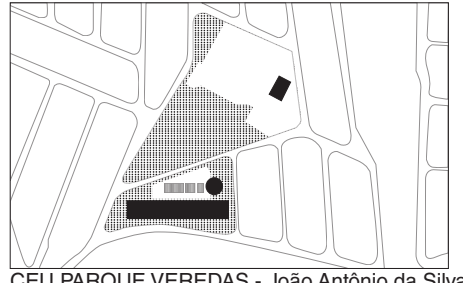

CEU PARQUE VEREDAS - João Antônio da Silva

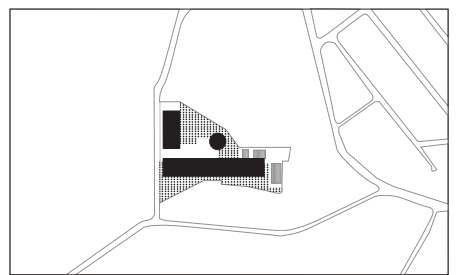

CEU TRËS LAGOS
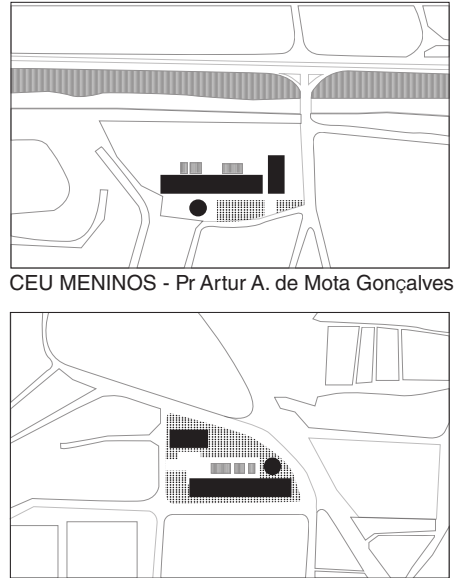

CEU SÃO RAFAEL

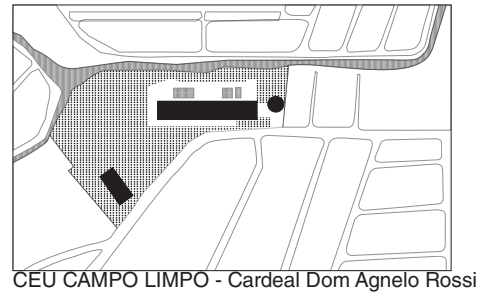

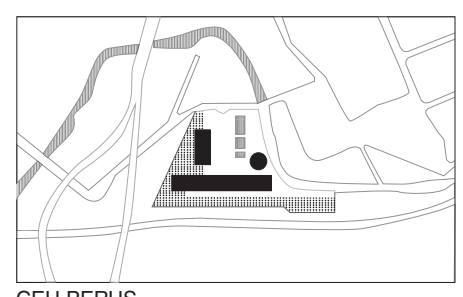

CEU PERUS

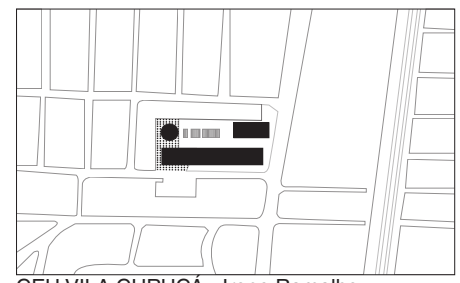

CEU VILA CURUÇA - Irene Ramalho

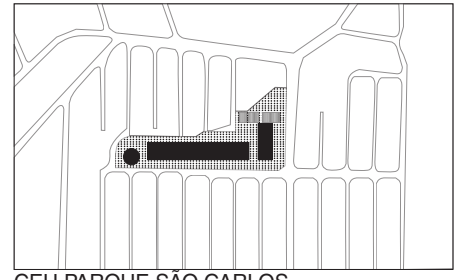

CEU PARQUE SÃO CARLOS

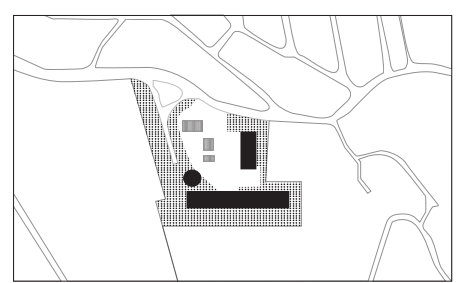

CEU ALVARENGA

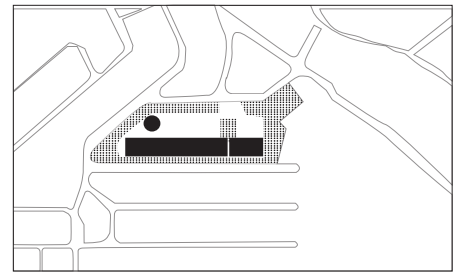

CEU ROSA DA CHINA

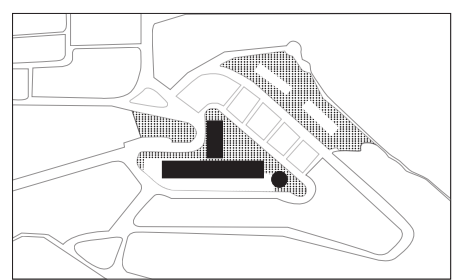

CEU INÁCIO MONTEIRO

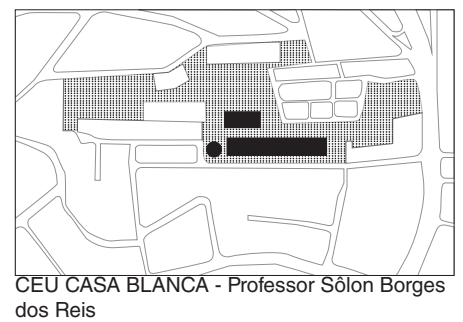

Fig.58. Diagrama implantações CEU 1.
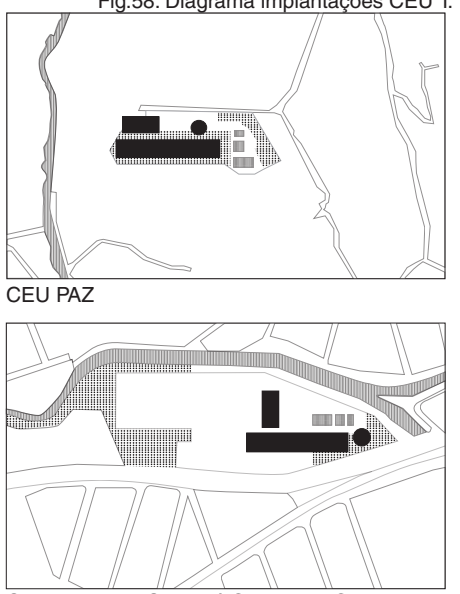

CEU JAMBEIRO - José Guilherme Gianetti

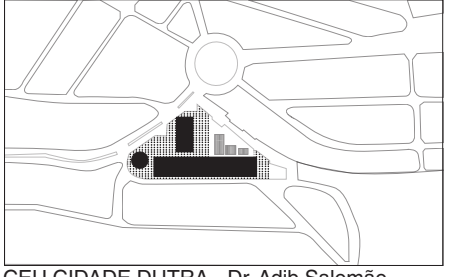

CEU CIDADE DUTRA - Dr. Adib Salomão

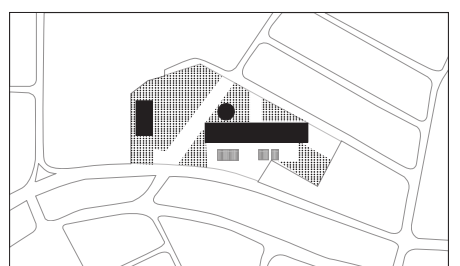

CEU ARICANDUVA - Professora Irene Galvão de Souza
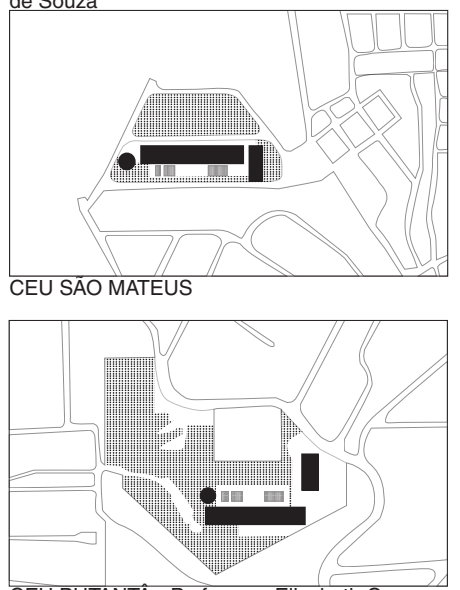

CEU BUTANTÅ - Professora Elizabeth Gaspar Tunala

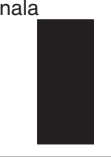

1 [1] [1] [1]

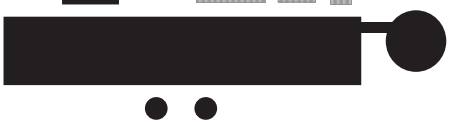

PROJETO PADRAO

Fig. XX Implantaçoes CCEU 1a Geração 


\section{EQUIPAMENTO DESESPECIALIZADO DA CIDADE}

O projeto já acumulou três gerações com diferentes abordagens arquitetônicas e também políticas. $O$ estudo aqui centra-se na primeira e última gerações, que podemos entendê-las como um acúmulo e evolução de ideias.

A primeira geração dos CEUs foi desenvolvida durante os anos 2003 e 2004 . O programa se centra no perfil educativo, com ensino infantil e fundamental de crianças, e também integra atividades esportivas (quadras fechadas, quadras de futebol, piscinas e pistas de skate) e culturais (teatro, espaços para oficinas com equipamento para dança e musica, biblioteca, centro multimídia) (DORIA e PEREZ, 2007). A ideia de um conjunto de atividades diversas conectadas por meio do espaço publico do conjunto propõe a convivência das diferenças. O espaço público é entendido desde a desespecialização como estratégia de integração, ele é um lugar da cidade.

O projeto de arquitetura é desenvolvido no Departamento de Edificações EDIF, pelos arquitetos Alexandre Delijaicov, André Takiya e Wanderley Ariza. Como parte deste projeto foram lançados 45 CEUs na Prefeitura de São Paulo. O projeto foi formulado a partir de lógicas pautadas pela necessidade de uma execução rápida e de alto impacto por decisões de projeto, tecnológicas e de gestão publica, acabando com um primeiro grupo de 21 conjuntos construídos.

A terceira geração é uma reformulação do projeto atendendo a uma maior complexidade programática e uma menor demanda de terreno, que foi avaliada como uma das principais complicações da primeira geração, resultando numa maior desespecialização e abertura dos projetos. Ela foi projetada entre 2013 e 2017. Então esta nova geração vai procurar fazer uma intervenção em terrenos públicos a partir de uma agrupação mais aberta, compacta e verticalizada, mantendo a utilização de sistemas pré-fabricados em concreto. Também vai propor uma leitura mais integrada no território da cidade, de fato ela é chamada de Território CEU. O projeto de arquitetura é assumido pela Equipe CEU da prefeitura sob a coordenação de Eduardo Dalcanale Martini e Wanderley Ariza junto a um grande grupo de arquitetos.

A principal mudança se refere ao uso do terreno pois já não e viável conseguir novos terrenos, aparece então o pedido feito para a arquitetura para consumir menos terreno no projeto. A estratégia incorpora o uso de terrenos que já têm usos públicos ou comunitários: 

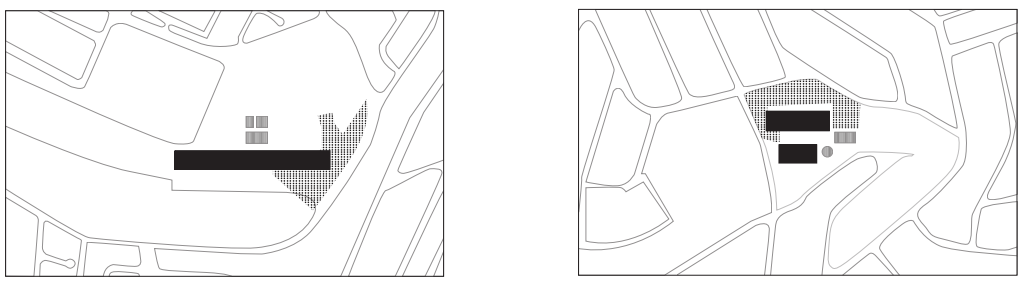

Fig.59. Diagrama implantações CEU 3.
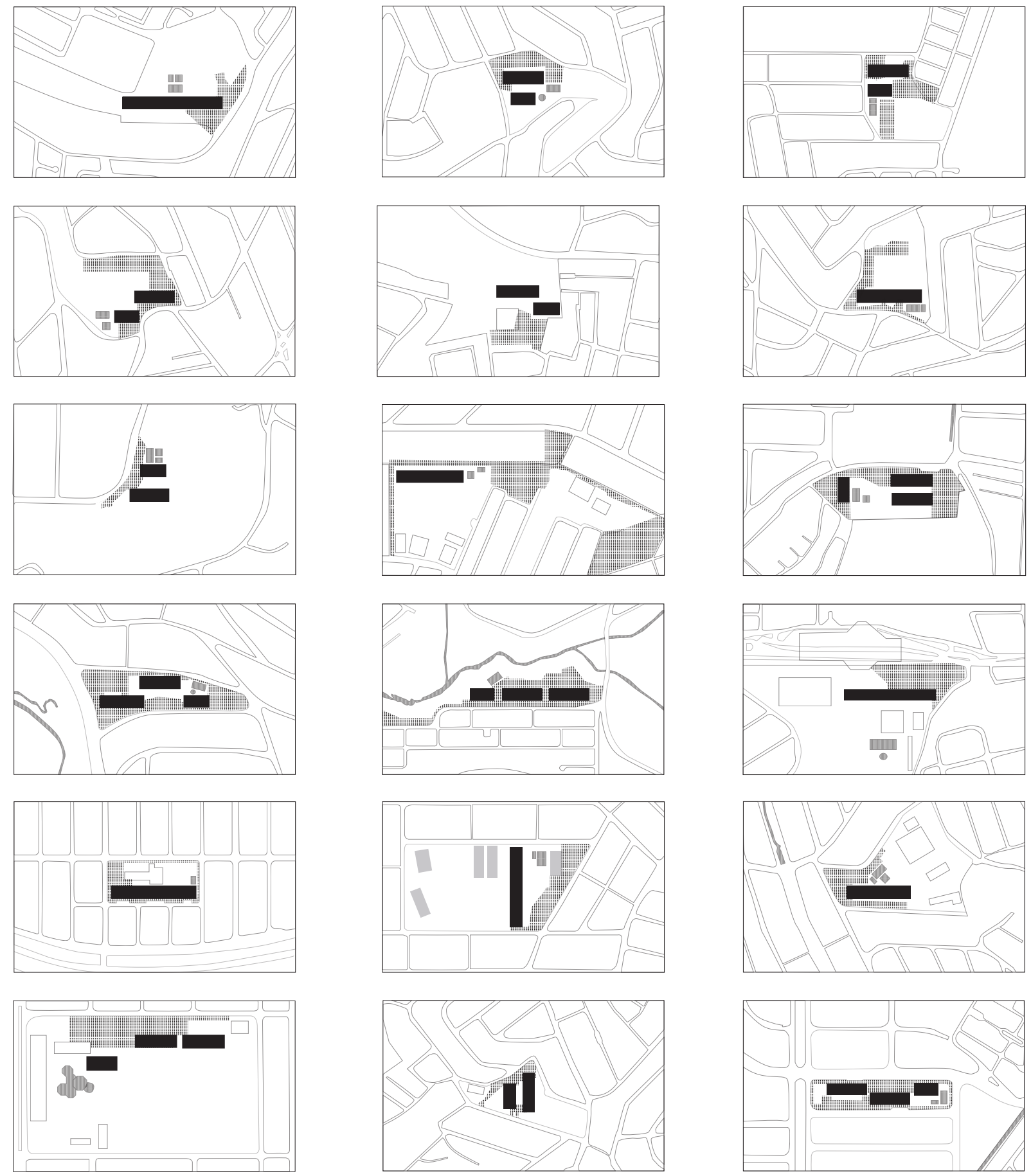
Como não temos mais terrenos para construir CEUs na cidade de São Paulo, e demora mais tempo para tirar a população, desocupar e desapropriar do que construir, a ideia do Território CEU é aproveitar uma região onde já exista, por exemplo, um centro de esporte, centro de saúde, escolas, e integrar esses espaços e as políticas setoriais que já existem em um novo projeto arquitetônico e urbanístico.

Também será preciso construir teatro, piscina, ginásio e outros espaços, mas pode-se também melhorar o que a região já oferece. Em uma determinada região, um clube privado pode resolver ceder seu espaço para - Território CEU que será construído, de forma que as crianças possam usar as instalações do local. Algo muito interessante é que serão CEUs com mais praças, corredores e alamedas, já que os trajetos deverão ser feitos a pé. (CARLINI ${ }^{25}$ em MEKARI e RIBEIRO, 2015)

Essa mudança gera uma consequência interessante a partir da definição do brancoespaço publico: o CEU compartilha terreno com outros equipamentos e os projetos de implantação estabelecem uma estratégia de quebra-muros para integrar o espaço publico dos diferentes equipamentos, e também com a cidade. O projeto inclui também uma intervenção no espaço publico, uma qualificação do branco que estabelece uma leitura da região aprimorando e equipando os trajetos principais. Finalmente, o projeto já não é um padrão a ser implantado, senão um sistema de partida para projetos abertos a composições e agrupamentos diversos, o que permite a adaptação a situações de implantação diferentes.

Outra mudança é a programática e tem a ver com a incorporação dos serviços de assistência social (em SP, os CRAS, Centro de Referência em Assistência Social), que estabelecem uma coordenação entre as diversas políticas públicas e a assistência social, antes desenvolvida por canais separados.

Desde o começo, a grande novidade do programa do CEU é a articulação de políticas publicas normalmente isoladas no território como consequência da rígida estrutura burocrática do Estado. A iniciativa muda os termos e estende na cidade o que for preciso, desde uma gestão transversal de governo, uma prática dotada de sistemicidade e multidimensionalidade, caraterísticas do pensamento complexo que postula Edgar Morin (2007).

O programa associado é uma revolução conceitual desde o ponto de vista institucional. Em termos de entendimento do ponto de vista da arquitetura, é conveniente separar o espaço do programa que estabelece o funcionamento em esperado. $O$ programa de funcionamento tem uma mudança em termos de abertura nos mais de dez anos que

\footnotetext{
${ }^{25}$ Maria Cecília Carlini Coordenadora de Educação Integral e CEUs da Cidade de São Paulo.
} 
Fig.60. Axonometria CEU 3.

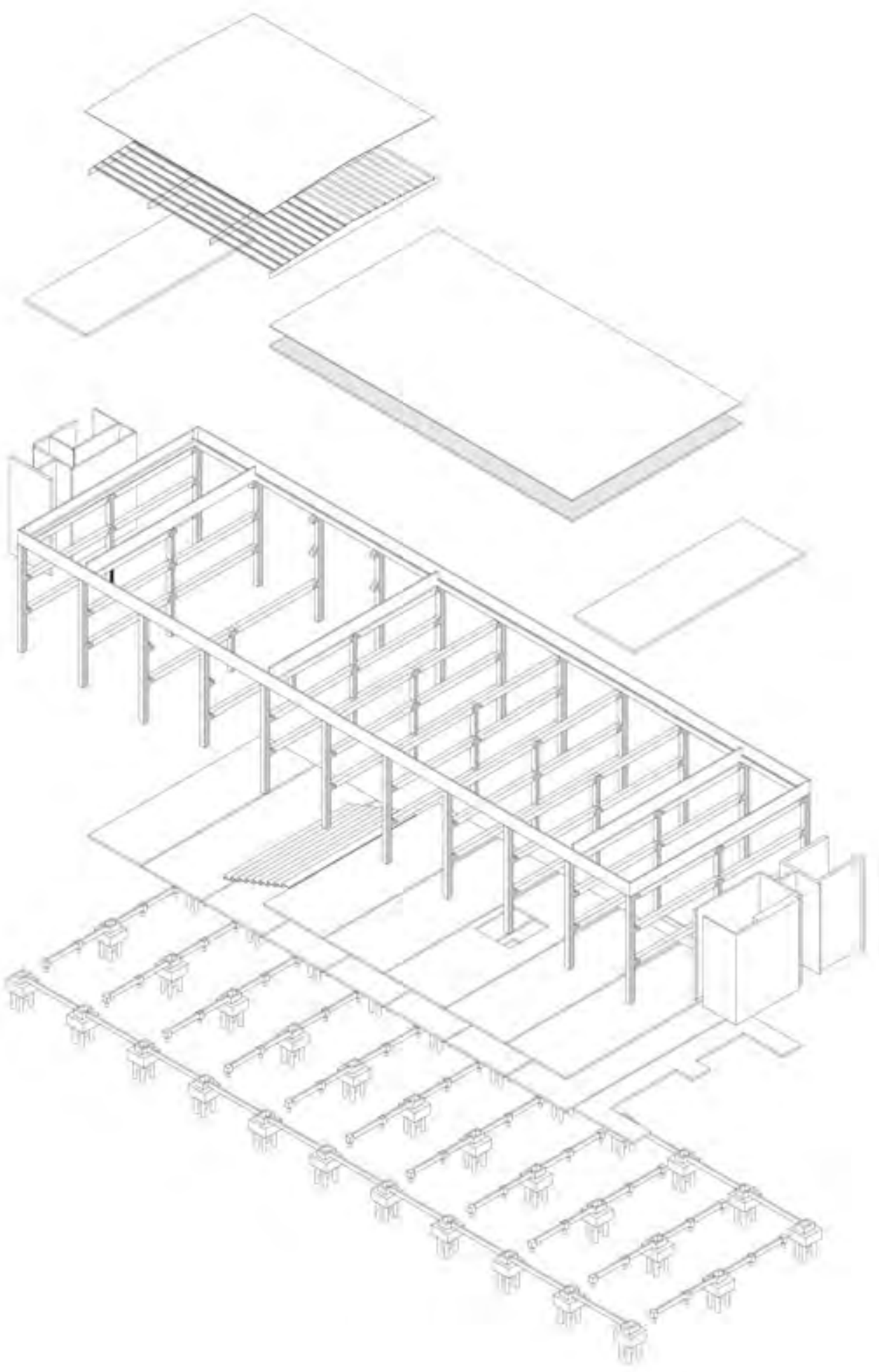


separam as duas experiências analisadas. O espaço dos projetos, especialmente a partir da organização e a estrutura escolhida, apresenta sempre um grande potencial de usos e modificações além das previsões. Embora a tipologia desenhada na primeira geração é sempre idêntica nos 21 edifícios construídos, a intensa gestão dos CEUs permite mudanças. Na formulação da terceira geração houve uma etapa de processo anterior a etapa de projeto, a de discussão sistemática com a comunidade de cada região para conseguir dela um maior envolvimento na gestão. Somando a isso a maior complexidade edilícia e territorial do projeto permite imaginar novas oportunidades de reformulação programática.

\section{PRIMEIRA: PADRÃO E IMPLANTAÇÃO}

A ideia chave é a realização de um Projeto Padrão que deve ser adaptado a cada localidade. O programa dos CEUs, a partir da formulação do Projeto Padrão, se articula em três edifícios diferenciados e outros equipamentos dispersos

O Pavilhão Educativo é um bloco de 150 por 20 metros resolvido em três pavimentos destinados às salas de aula, biblioteca, centro multimídia, e equipamentos de apoio como salas dos professores, administração das unidades escolares, cozinha, refeitório etc. A biblioteca é pública, e o centro multimídia fornece computadores e internet à população da região, num entendimento amplo e comunitário do conceito de educação. Trata-se de uma nave com duas circulações abertas e cobertas, com uma série de colunas principais na fachada a cada 7,50m e separadas por $20 \mathrm{~m}$. Essa configuração estrutural e espacial deixa em aberto muitas opções de organização espacial que até permite receber uma quadra esportiva, o que permite a evolução dos espaços durante o tempo. As galerias de 2,60m de largura são espaços de circulação mas são também espaços de encontro e de relação com o resto do conjunto do CEU. O programa educativo que contém diversos níveis didáticos e organizacionais e fica continuamente conectado pela galeria-varanda e as três escadas que conectam os três níveis do prédio. O setor destinado às salas pode conter espaços de 14,50 ou $6,25 \mathrm{~m}$ de profundidade.

"O Bloco Cultural, com cinco pavimentos, onde encontramos duas salas de teatro, os ateliês de arte, a sala de dança, os estúdios de rádio e fotografia e o ginásio de esportes, além do núcleo administrativo e sala da diretoria". São quase $1000 \mathrm{~m}^{2}$ por pavimento numa planta de 20 por 45 metros. O programa é estruturado de forma muito 
Fig 61. CEU Butantã. Ph: Nelson Kon.

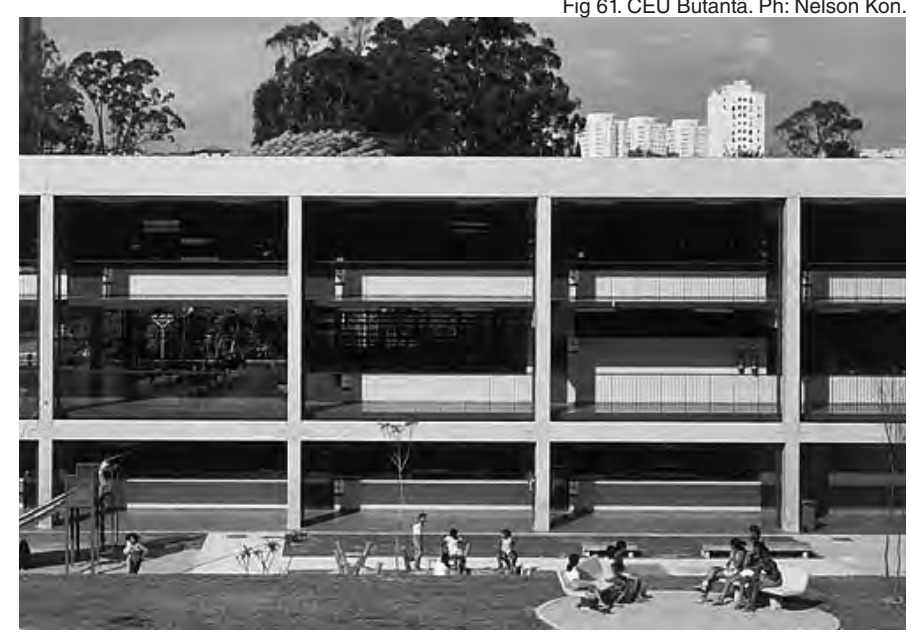


simples, colocando os dois espaços mais altos de um lado (o teatro embaixo e a quadra em cima) e cinco níveis mais baixos de outro lado, separados pela circulação vertical.

"O prédio redondo tem 11 metros de raio formando os 600 metros de área construída do Centro de Educação Infantil (CEI). Nesse espaço circular com um grande saguão iluminado por claraboia, as salas são modulares e se intercomunicam com portas de correr que funcionam como paredes móveis $\mathrm{O}$ prédio é a singularidade formal e estrutural do programa, disposto no primeiro andar em balanço suportado por um cilindro central.

Os Blocos Educativo e Cultural têm um projeto claramente aberto para usos futuros diferentes dos usos concretos que definem o programa original e a clareza na organização respalda essas possibilidades. Eles são um exemplo de espaços capazes pela sua abertura às mudanças. Trata se de um grande equipamento que fica aberto das 7 às 23 horas durante a semana toda, e que os moradores da região atravessam frequentemente para pegar ônibus ou metro para a sua casa. Nesse sentido o equipamento comporta-se como um centro de gravidade que produz cidade. A ideia da água tem muito a ver com esta visão geográfica e urbanizadora dos CEUs, que relaciona cada intervenção com o enorme conjunto hídrico de rios e córregos que foi parte do território original de São Paulo. As piscinas convidam ao uso e estão investidas de um caráter simbólico ligado a esse uso. "Esta prática ilustra ou faz pensar em um urbanismo em rede, aplicado à São Paulo" (DELIJAICOV, 2011). ${ }^{26}$ Da mesma maneira que acontece com experiências exitosas na Colômbia (Medelín e Bogotá), o programa dos CEUs é um Equipamento Público que faz parte de uma rede, que vai muito além dos programas concretos a que fazem parte, é uma experiência em que o rascunho foi feito na primeira geração e se desenvolve com mais força na terceira.

A implantação do projeto padrão foi desenvolvida por um escritório diferente em para cada CEU, contratado pela prefeitura, o que gera um conjunto de adaptações dos três blocos às condições concretas do local do projeto. A extensão dos três pavilhões e dos espaços exteriores no terreno se obriga a ter grandes lotes de 1 a 7 hectares, o que foram conseguidos, desapropriando terrenos privados nas regiões selecionadas.

No curso dos estudos de pós-graduação na FAU USP, se visitou o CEU Butantã, um dos 21 primeiros. Este centro foi visitado por quatro horas junto com arquitetos da 
Fig.62. CEU Butantã. Nelson Kon.

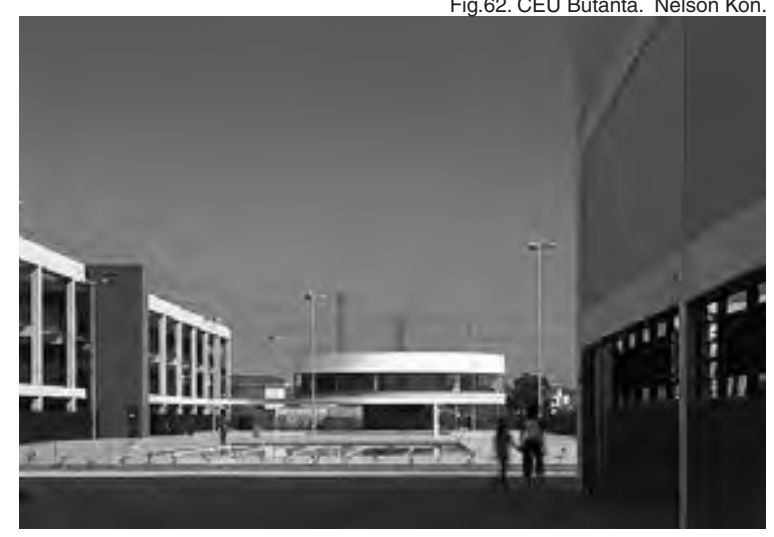


equipe do projeto do EDIF Alexandre Delijaicov e André Takiya, e uma equipe da Direção do $\mathrm{CEU}{ }^{27} \mathrm{~A}$ visita permitiu conseguir informação de primeira mão sobre o projeto com alguns dos seus autores e o pessoal do CEU. O momento foi único, pois acontecia o encontro entre os arquitetos e os responsáveis do conjunto dez anos depois da sua inauguração. Nesse período a direção original do CEU Butantã tinha saído com a mudança de Prefeito e partido politico no governo da Cidade, e voltava à direção com a volta ao governo do partido original e inspirador do CEU. No período intermediário, a direção não concordava com a ideia de um espaço continuo para os diferentes usuários do CEU, e instalou grades para separar os diferentes níveis educacionais. Além da estória aparece uma evidência sobre as limitações da arquitetura e o projeto, sua dependência na gestão e uso cotidiano, e também sua dependência nas decisões políticas que podem promover ou rejeitar uma maneira de construção de espaço publico.

Os CEUs vem sendo estudados no Brasil desde seu inicio. Uma discussão aprofundada sobre o espaço e a sua capacidade é feita por Vinicius Spira, arquiteto com pósgraduação em antropologia. Ele estabelece um estudo contrapondo dois modelos, o da primeira geração com a integração do espaço continuo, e o da segunda geração que não é estudado nesta tese, baseado numa compartimentação espacial funcional.

As dificuldades aparecem não apenas nos meios, mas também nos fins, já que, como vimos ao longo da pesquisa, a implantação exclusiva de extensividades não traz apenas efeitos desejáveis. Nos termos de Latour, podemos dizer que há discursos que procuram "purificar" as extensividades, não enxergando suas vinculações com impurezas ou "híbridos". Em nossos termos, isso significa: as extensividades são vistas apenas como garantidoras de liberdade de ação e interação, sem que se perceba sua vinculação com incertezas, desacelerações e outras ambiguidades, contradições e complexidades caracterizadoras do cotidiano de um centro educacional. $\mathrm{Na}$ verdade, podemos supor que, por serem ignorados ou negados pelos discursos purificados, os híbridos ou impuros encontram terreno para proliferar: "quanto mais nos proibimos os híbridos de pensar, mais seu cruzamento se torna possível. (LATOUR, op. cit., p. 16-17)". (SPIRA, 2015, p.196).

\section{TERCEIRA: TERRITÓRIO CEU}

O conceito de Território CEU aporta um forte desenvolvimento da ideia de funcionamento em rede, que já foi apontado na primeira geração, envolvendo a noção

${ }^{27}$ TAKIYA, André, DELIJAICOV, Alexandre e equipe de pesquisa sobre equipamentos coletivos da FAU. Equipe de Direção do CEU Butantã. 6 de agosto de 2013. Disciplina AUP 5866 Arquitetura, Tecnologia e Meio Construído, no dia 12 de julho de 2013. 
Fig 63. CEU 3

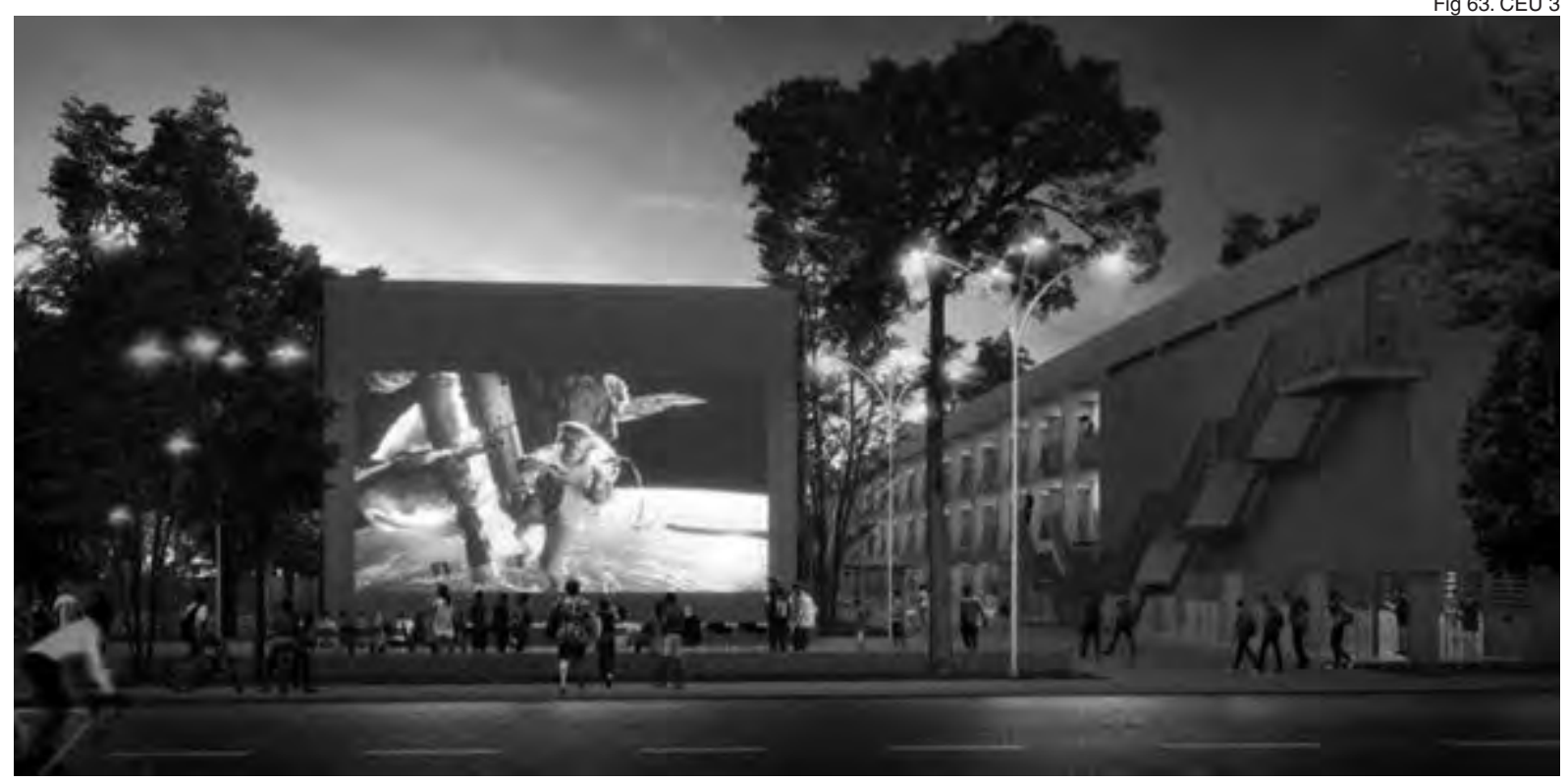


de equipamentos e espaço público como um conjunto, ele já não fica dentro de um terreno que atrai, mas sim que estabelece uma efusão de intervenções na cidade.

\begin{abstract}
Com essas conexões, configura-se também um território pleno de possibilidades pedagógicas a serem incorporadas ao programa de Educação Integral, que reafirmam São Paulo como Cidade Educadora. Este programa requer um grande esforço de articulação entre secretarias e órgãos públicos e constante diálogo entre equipes técnicas e representantes do governo local e da comunidade. Ao tripé tradicional de secretarias originalmente envolvidas na implantação do programa Educação, Cultura e Esportes - foram incorporadas as secretarias de Assistência Social (implantação do Centro de Referência de Assistência Social - CRAS) e a de Direitos Humanos e Cidadania (Programa Juventude Viva). A integração com a rede de equipamentos ampliou ainda mais o leque de secretarias envolvidas, integrando ações das secretarias municipais do Verde e Meio Ambiente (SVMA), de Infraestrutura Urbana (SIURB), de Serviços e da Companhia de Engenharia de Trânsito (CET).

O registro do processo de elaboração do programa e dos projetos do Território CEU tem o intuito de contribuir para a formulação de políticas públicas integradas, que se pautam na escuta cuidadosa e no diálogo constante com a comunidade local. Trata-se de uma ação afirmativa da construção de uma rede integrada de espaços públicos como território de cidadania. (DE MELLO em SMDU, 2016, p.3).
\end{abstract}

As constrições de implantação obrigam uma reformulação do projeto partindo das lógicas programáticas e construtivas da primeira etapa de projetos que gerou um novo sistema de organização e materialização dos edifícios.

\footnotetext{
Diante dessas premissas, criou-se um novo sistema compositivo com o rompimento do conceito de tipologia fixa que, embora procure recuperar os preceitos arquitetônicos do projeto original, com que inexoravelmente se identifica, foi organizado na forma de um sistema semiaberto e programado de composição, mediante critérios de seriação calculada e flexibilidade planejada.[...]

Dividiu-se a estruturação do projeto em duas características fundamentais: variação e flexibilidade; e duas partes intrinsecamente correlacionadas, agrupamentos e arranjos.

Variação na organização de arranjos constituindo diferentes edifícios. Flexibilidade na organização de agrupamentos configurando variações em edifícios.[...]

O programa de necessidades foi organizado em diferentes níveis de disposição.

Primeiro, foram sistematizados em agrupamentos funcionais de acordo com o organograma e o fluxograma de relações internas de funcionamento de cada área programática (educação, cultura, esportes e uso múltiplo). Depois, foram feitas em relação às articulações técnicas de possíveis composições construtivas (sistema estrutural, prumadas de instalações e de circulação). (Ibid., p.36-37)
}

Além da adaptabilidade já mencionada para conseguir um maior aproveitamento do terreno, o projeto das partes do CEU foi pensado para a maximização das possibilidades de combinação a partir do mesmo sistema estrutural e construtivo: colunas, vigas e lajes de concreto pré-fabricado que cobrem 10 × 7,50 metros, 


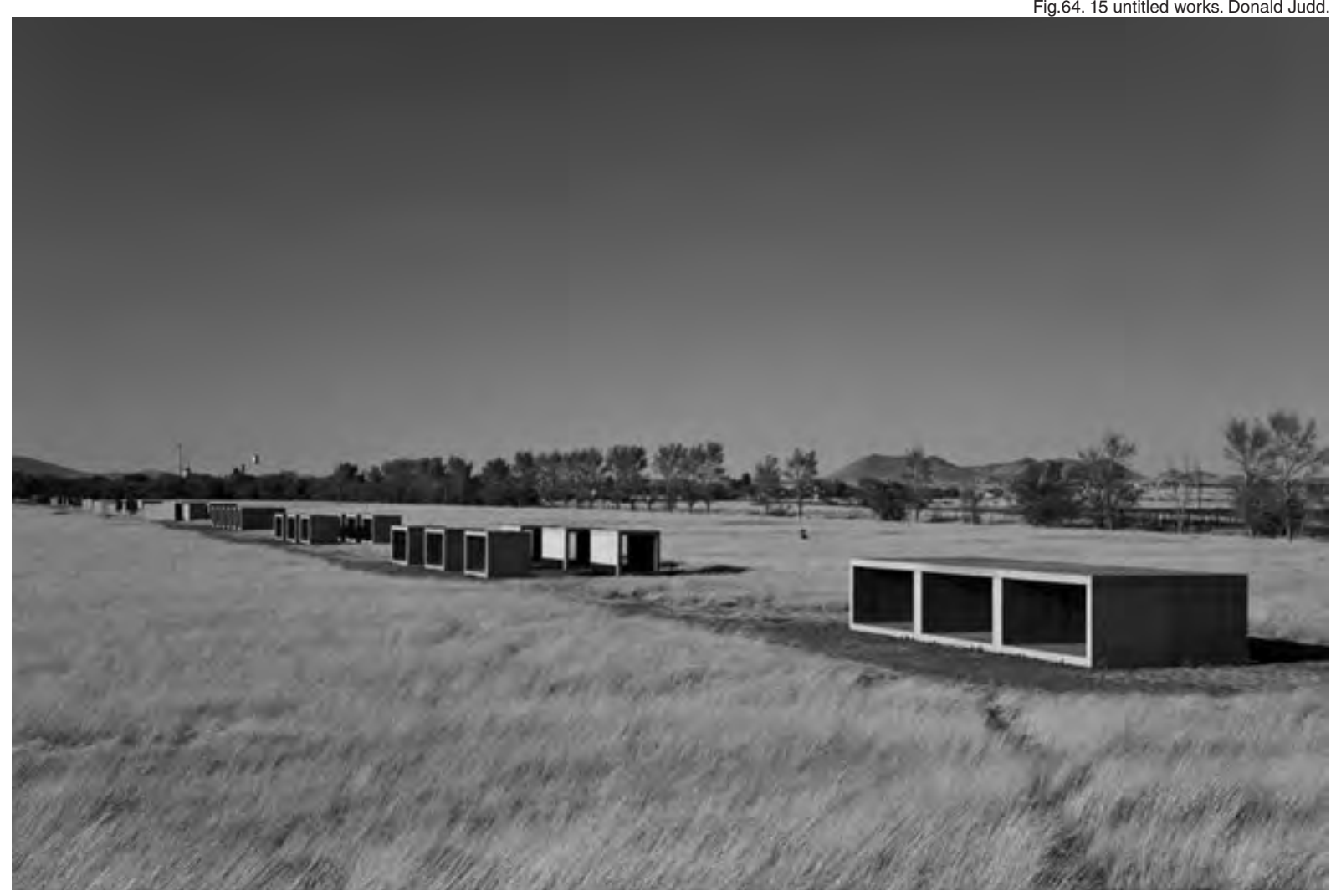


organizados em blocos de 20 metros de largura, coberturas de chapa que permitem resolver no ultimo nível os 20 metros de vão livre quando for preciso. Propõem-se "agrupamentos" combináveis horizontal e verticalmente: educacional, cultural, usomúltiplo e esporte. O bloco esportivo tem uma solução estrutural particular para resolver o apoio da quadra sobre a piscina e resolver os 20 metros que não tem suporte conseguindo com essa única variação estrutural resolver todo o programa. O desenho das circulações e os núcleos de serviços ampliam a possibilidade combinatória para situações diversas, permitindo a alteração de posicionamento, espelhamentos, rotações, e acréscimo ou supressão de módulos. Parte dos locais do CEU não têm função única pois recebe um uso variável ao longo do $\mathrm{dia}^{28}$.

Os "arranjos" são definidos a partir da combinação das "agrupações" conseguindo três arranjos típicos: vertical, paralelo e linear, a partir deles geram-se variações. A abertura do sistema permite que os resultados sejam variáveis na organização e na superfície construída que se alterna entre 9.000 y $13.500 \mathrm{~m}^{2}$ para a maioria de terrenos entre $0,9 \mathrm{e}$ 9 hectares.

\section{TERRITÓRIO DO TERRITÓRIO}

A nova implantação do Território CEU foi pensada para multiplicar a abrangência e a qualificação da região. Nos projetos do começo dos anos 2000 os conjuntos abrem em um horário de funcionamento estendido, mas os terrenos são fechados com grades, com a ideia de algum dia poder tirá-las. Os novos projetos mantém o fechamento mas procuram se complementar oferecendo sempre uma praça pública aberta 24 horas, em geral em conexão com os locais destinados às atividades culturais do centro e mantendo a segurança dos terrenos.

A efusão no território se produz também pela realização de um projeto de qualificação da região a partir de um mapeamento dos equipamentos e serviços presentes no setor urbano próximo e a geração de um circuito em rede de conexão entre todos os equipamentos. Este projeto atende à mobilidade e infraestrutura e qualifica as ruas da região com um conjunto completo de intervenções de arborização, iluminação, sinalização, ciclo-faixas, priorização da circulação dos pedestres, parklets, etc.

\footnotetext{
${ }^{28}$ Dados obtidos em entrevista com Eduardo Dalcanale Martini, coordenador da equipe de arquitetura dos CEU Território. 08/09/2015 na Prefeitura de São Paulo.
} 
Fig. 65. Centro Civico Rural. Richard Neutra.

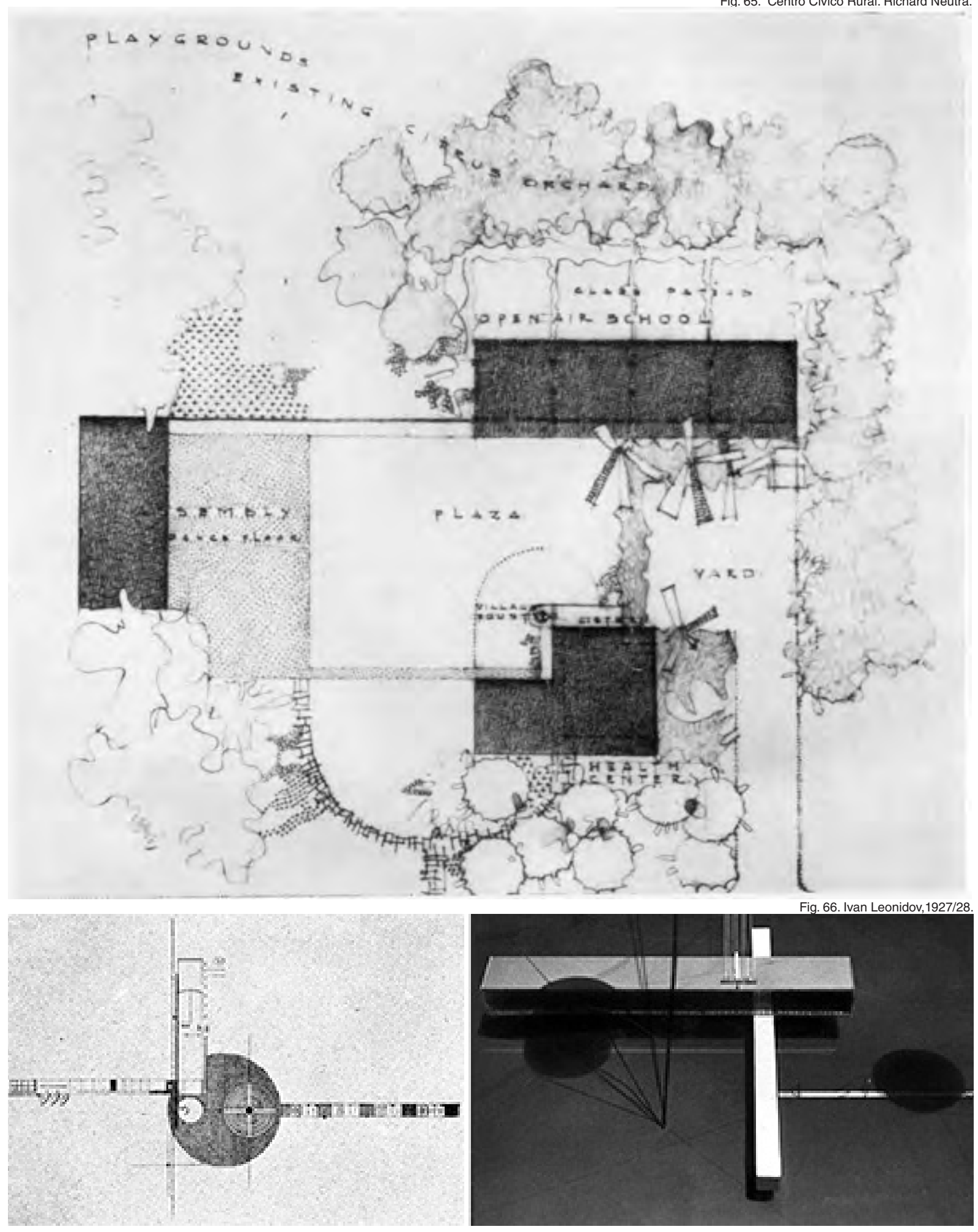


A instalação de um CEU já é um fator de urbanização que nesta nova estratégia se multiplica no conjunto de intervenções diretas na região. Um CEU Território é um conjunto de edifícios interconectados por espaços públicos, como se fosse um Fórum da Roma antiga.

\section{BRANCO CEU}

A relação do projeto CEU reconhece sua própria tradição brasileira (como sempre acontece no Brasil) com algumas experiências educacionais da historia do século $\mathrm{XX}$ : as Escolas Parque na Bahia do educador Anisio Píres com ideias de projeto desenvolvidas por Helio Duarte, conceito dos anos 50 posto em prática só em forma parcial. Duarte depois dirige o Convênio Escolar em São Paulo, desenvolvendo junto a outros arquitetos, valorados projetos de arquitetura. ${ }^{29}$ Estes projetos seguem as ideias colocadas por ele

Porque arquitetura é isto mesmo - ordem, questão de organização, estabelecimento de espaços ordenados com dimensões apropriadas de sorte a assegurar com um mínimo de esforço humano a ligação lógica das peças afim de que o conjunto seja, necessariamente, uma unidade congruente e definitiva. É sob este ponto de vista que a arquitetura é, precisamente, trabalho de síntese.(DUARTE ${ }^{30}$ apud MOREIRA, 2000, p.68)

Duarte, professor da Facultade de Arquitetura e Urbanismo de la Universidade de São Paulo (FAU USP) escreve em 1957 sua tese para obter a livre-docência trabalhando ideias que hoje (reformuladas) contribuem para a noção da desespecialização programática: "Espaços Flexíveis, uma Tendência em Arquitetura". ${ }^{31}$

Os CEU absorvem a experiência moderna brasileira, tradição que cumpre a profecia antropofágica da cultura brasileira (DE ANDRADE, 1928). Na década anterior às experiências referidas de Bahia e São Paulo, Richard Neutra visita o Brasil, trazendo seus projetos de escolas e centros de saúde de Porto Rico e propondo a sua aplicabilidade nos países de clima tropical. A visita do austríaco-americano acontece em 1945 e 3 anos depois é publicado um livro em que apresenta os projetos e se converte em forte influência dos arquitetos da época. ${ }^{32}$

\footnotetext{
${ }^{29}$ PEREZ Maria Aparecida, TAKIYA, André, DELIJAICOV, Alexandre. Palestra: Centro Educacional Unificado, na FAU Maranhão como parte da disciplina AUP 5866 Arquitetura, Tecnologia e Meio Construído, no dia 12 de julho de 2013.

${ }^{30}$ DUARTE, H. Convenio escolar. Revista Habitat.\#4, 1951. P4-5.

${ }^{31}$ HÉLIO Duarte. In: ENCICLOPÉDIA Itaú Cultural de Arte e Cultura Brasileiras, 2018

${ }^{32}$ Ver sobre a influencia dessa visita: Loureiro, C. e Amorim, L. (2002)
} 


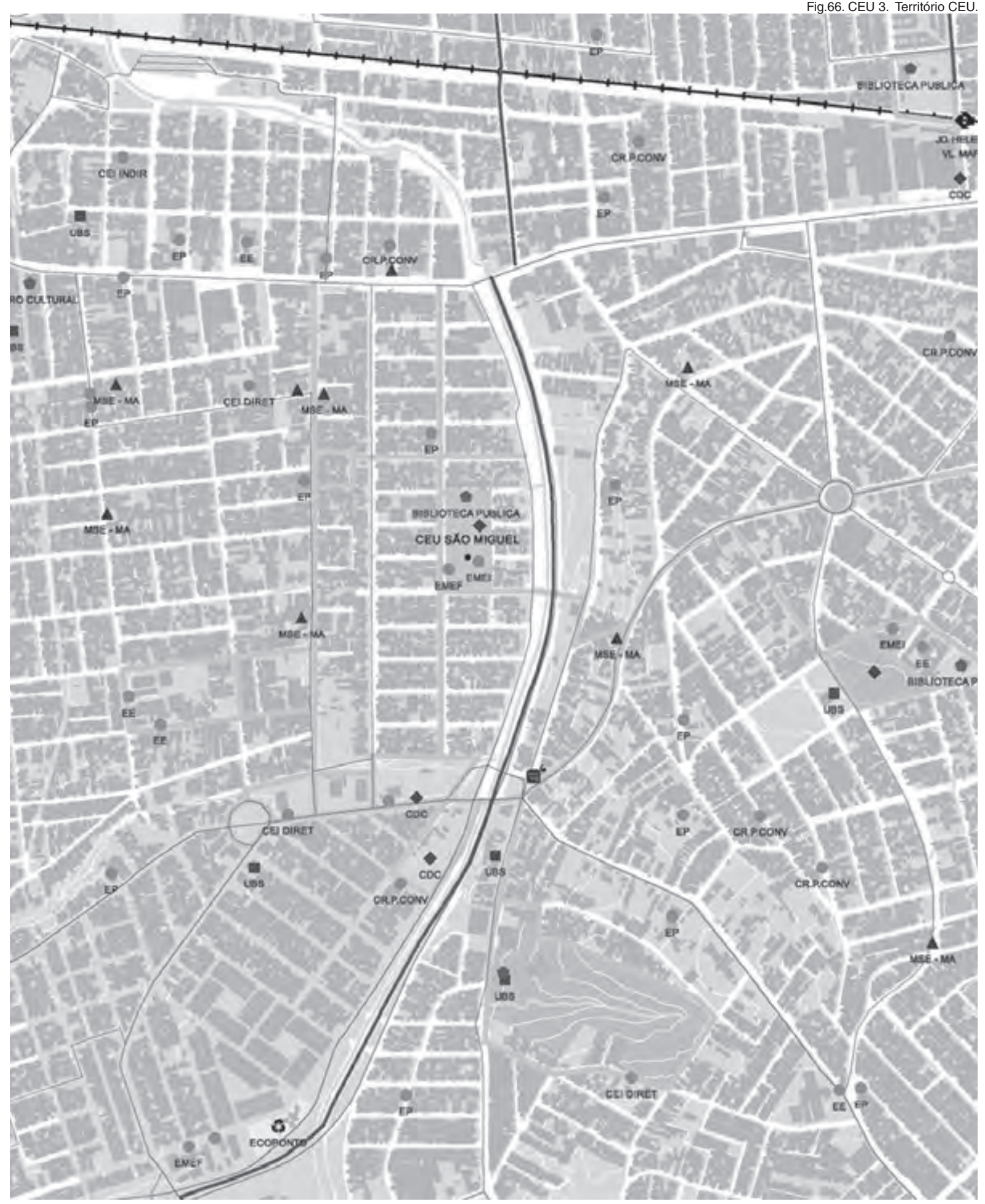


A influência dos modernos das vanguardas também fica evidente diretamente nos projetos e no diagrama dos CEUs em geral, lembram obras e desenhos de Ivan Leonidov, como seu projeto para o Instituto Lenin, de 1927, ou os Clubes Sociais de Novo Tipo de 1928. A conexão soviética vai além da forma, enquanto o programa do CEU tem muito a ver com os Clubes Sociais, e os Condensadores Sociais desenvolvidos nos primeiros anos da revolução soviética.

Os projetos analisados são observados juntos a partir da relação com seus pontos de partida (projeto padrão, sistema de arranjos e agrupações) que se desdobra um ballet modernista com coreografia de Wassily Kandinsky: "Ponto e linha sobre o plano". O dispositivo de composição dos projetos dos CEUs pode ser entendido em relação ao lema do Kandinsky. Os conjuntos são constituídos por uma linha principal, a nave educativa, e dos pontos, o edifício disco e o bloco do teatro. Mas para Kandinsky, o jogo de ponto e linha só tem sentido num plano básico: "Por plano básico entende-se a superfície material chamada a receber o conteúdo da obra” (KANDINSKY, 1959, p. 139). O plano básico dos CEUs com suas variações é o plano do chão, como primeiro suporte do espaço público. É nesse sentido que podemos entender o plano básico como a figura principal do projeto, desbordando a atenção nos objetos para ele, o branco das praias da periferia.

A terceira geração observa o território da região que faz a intervenção, definindo assim os CEUs simultaneamente como unidades locais de importância no bairro e como parte uma ampla rede social organizada na escala metropolitana. Essa reflexão propõe um novo e mas amplo "plano básico" que são as periferias e a geração de uma cidade mais integrada.

Um detalhe já incluído na primeira geração ilumina essa maneira de pensamento multiescalar: as pistas de skate foram todas desenhadas diferentes e por um arquiteto skatista. Assim elas servem à comunidade local e também à comunidade skatista de São Paulo que estabelece um circuito nas diferentes pistas que apresentam diferentes configurações e permitem provas diversas. A desespecialização adquire aqui uma visão virtuosa que faz da repetição diferenças, como propõe Deleuze (2002, "Diferencia e Repetição" escrita em 1968) na sua tese de doutorado. 
Fig.67. CEU 3. Canteiro de Obra.

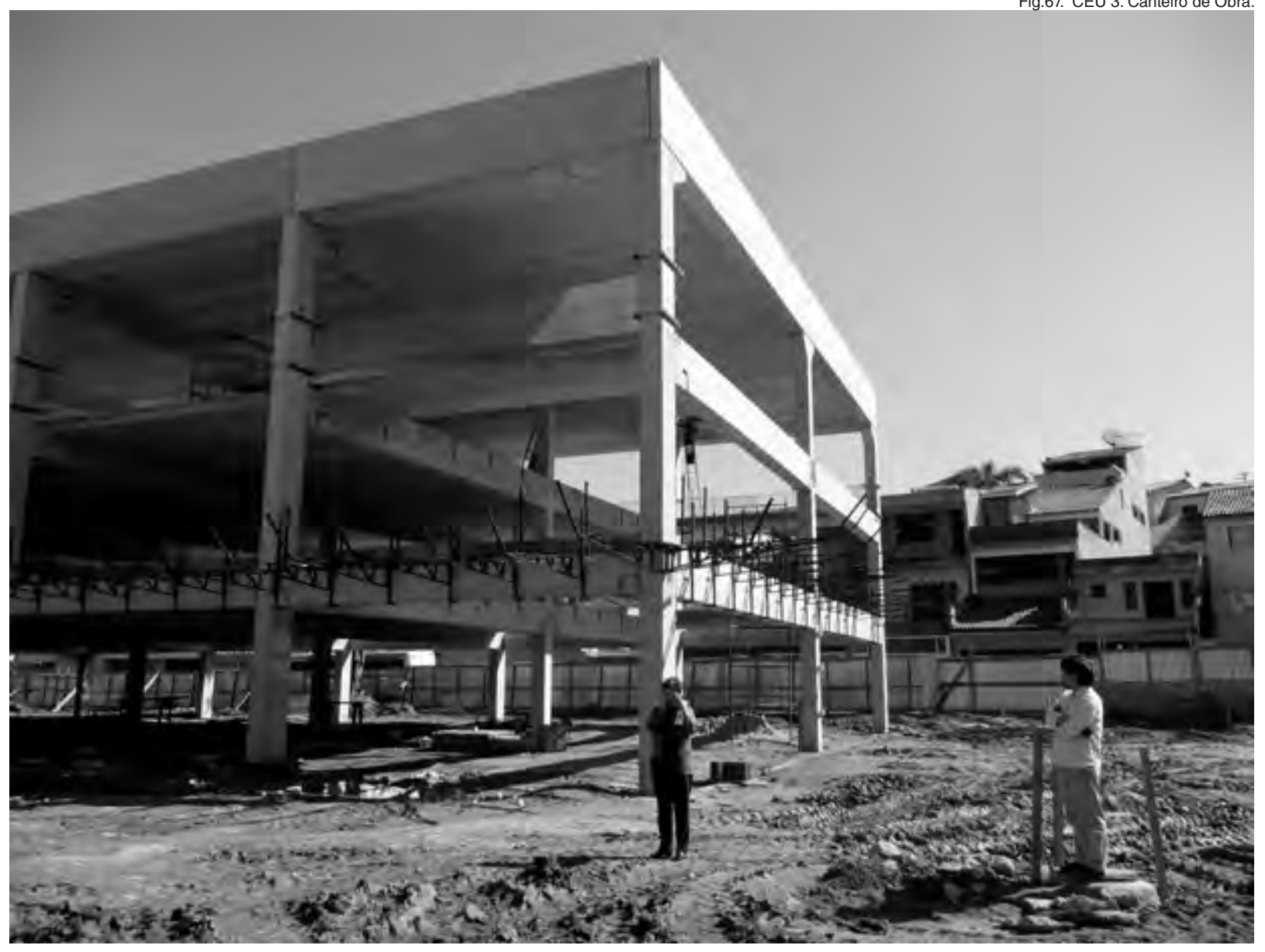




\section{AS IDEIAS E AS COISAS}

Fazer arquitetura tem a ver com a capacidade rigorosa de conseguir o trânsito das ideias-projetos às coisas-prédios, os CEUs da primeira geração apresentam uma experiência arquitetônica bem-sucedida para as condições do terceiro mundo, que emprega inteligência e engenhosidade para conseguir a boa materialização de um projeto muito arriscado e exigente da Prefeitura. A possibilidade de que o projeto como espaço de reflexão e produção consiga seu lugar no contexto de alta pressão por resultados da política, permite as qualidades valorizadas assinaladas assim como uma boa durabilidade dos prédios. A valorização surge ao contrastar estas experiências com as experiências de equipamentos uruguaios recentes que se apresentam no capitulo 1 : nelas nem o projeto nem a qualidade material dos prédios são o elemento central.

No caso da terceira geração o projeto consegue uma versão mas ainda sofisticada, do ponto de vista da complexidade da ideia e sua relação com a realidade urbana e social. De novo, a alternância de partidos no governo da cidade e a crise econômica aparecem como um problema para as ideias, o estado atual é de um canteiro de obras parado por questões políticas e econômicas.

É possível ver esses canteiros de obra como as "ruins in reverse" do Robert Smithson (1967). Também podemos propor essa excepcional parada no tempo, como uma oportunidade para a ação e a imaginação do projeto e entender os canteiros como ruínas antecipatórias como as que propõe Muoto e imaginar a partir delas.

Essas praias podem assumir a relação com a comunidade envolvida com uma maior especificidade local? A implantação passaria a ser desse jeito não somente um problema de arquitetura, mas sim também de definição da instituição, da relação com a comunidade e de estabelecer a proteção dessas praias à alternância dos partidos políticos. Podemos pensar em termos de arquitetura, possibilidades múltiplas e novas além das imaginadas no projeto para esses futuros CEUs, que estão em construção, uma nova evolução da terceira geração de praias de periferia partindo dos esqueletos no estado atual?

Para uma compreensão desde esse ponto de vista, o projeto desta terceira geração e estudado no catalogo que segue, sometido ao processo de dissolução programática passando do projeto concreto e suas definições programáticas até entende-lo primeiro como um espaço capaz 


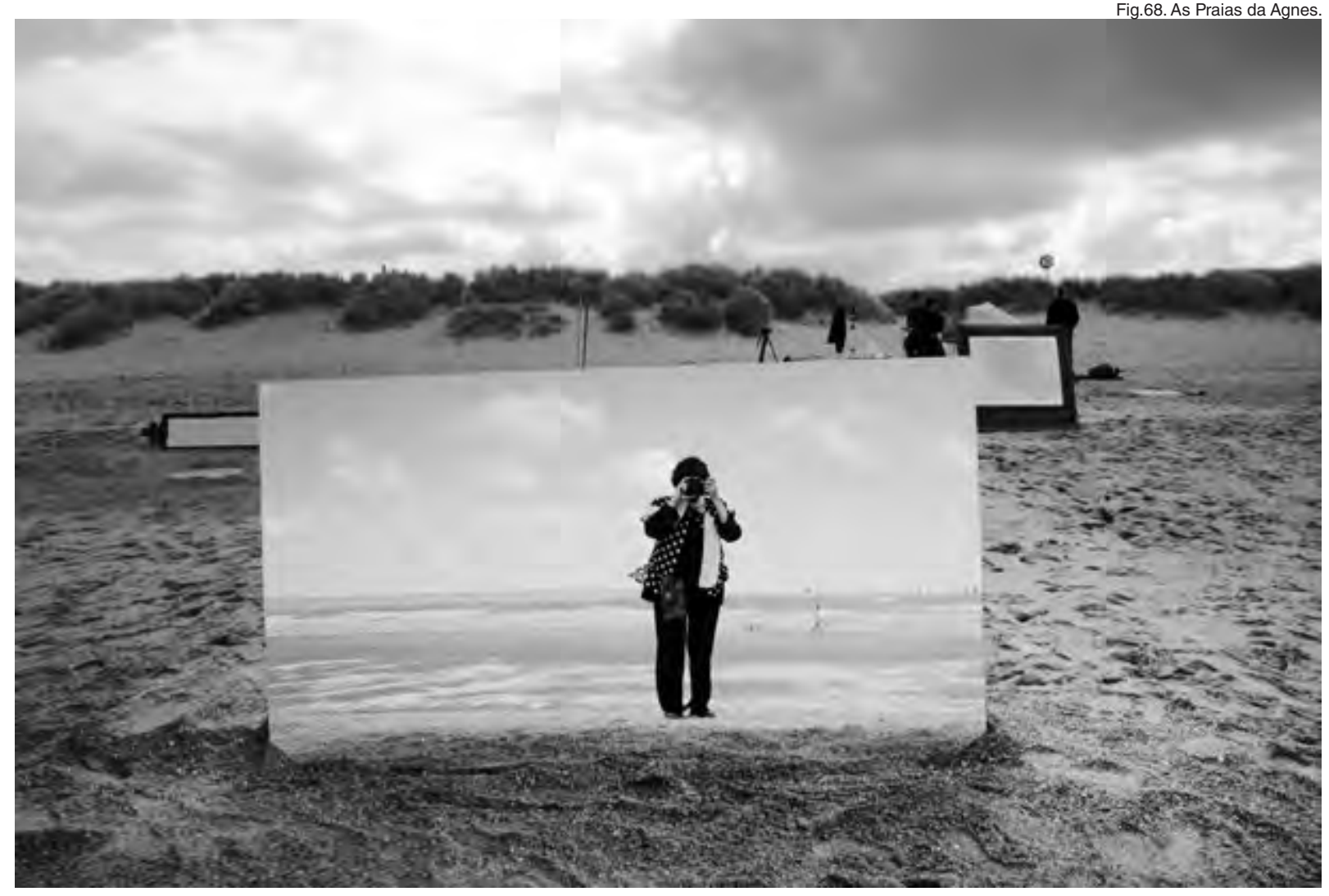


de mudar seu uso, para logo voltar-se uma nova entidade de dissolução espacial, sem forma nem função. Essa dissolução espacial, que coloca as condições especificas do espaço fora, é uma praia para imaginar novos projetos.

\section{PRAIAS de todos, PRAIAS de CADA UM}

"Se você abrir uma pessoa, irá encontrar paisagens.

Se me abrir, encontrará praias". (VARDA, 2008, tradução nossa)

"As praias de Agnés" é um filme auto referencial em que a diretora Agnés Varda faz um depoimento de sua visão sobre fazer cinema depois de 50 anos de carreira. Ela, que também é artista e fotografa, fez parte da "Nouvelle vague" no começo da sua carreira. "As praias.." é um collage no qual escolhe trechos de muitos dos seus filmes anteriores, estruturado a partir de suas intervenções. Algumas das intervenções são realizadas da mesma forma, utilizando uma peça com espelhos para produzir efeitos visuais de sobreposição de imagens e paisagens da praia. A ocupação da praia que ela propõe, o efeito espacial e o seu registro fotográfico, transmitem com beleza a ideia da praia como infinito, como espaço de liberdade, como espaço que se torna próprio, apropriado.

“Sous les pavés, la plage!", era uma das expressões mais repetidas e grafitadas no maio francês (DELMAS, 2018), aludindo à luta pela busca de uma nova sociedade e contra a repressão policial nas ruas de Paris, no conflitivo e fértil ano de 1968. 
Fig.69. Fun Palace. Cedric Price.

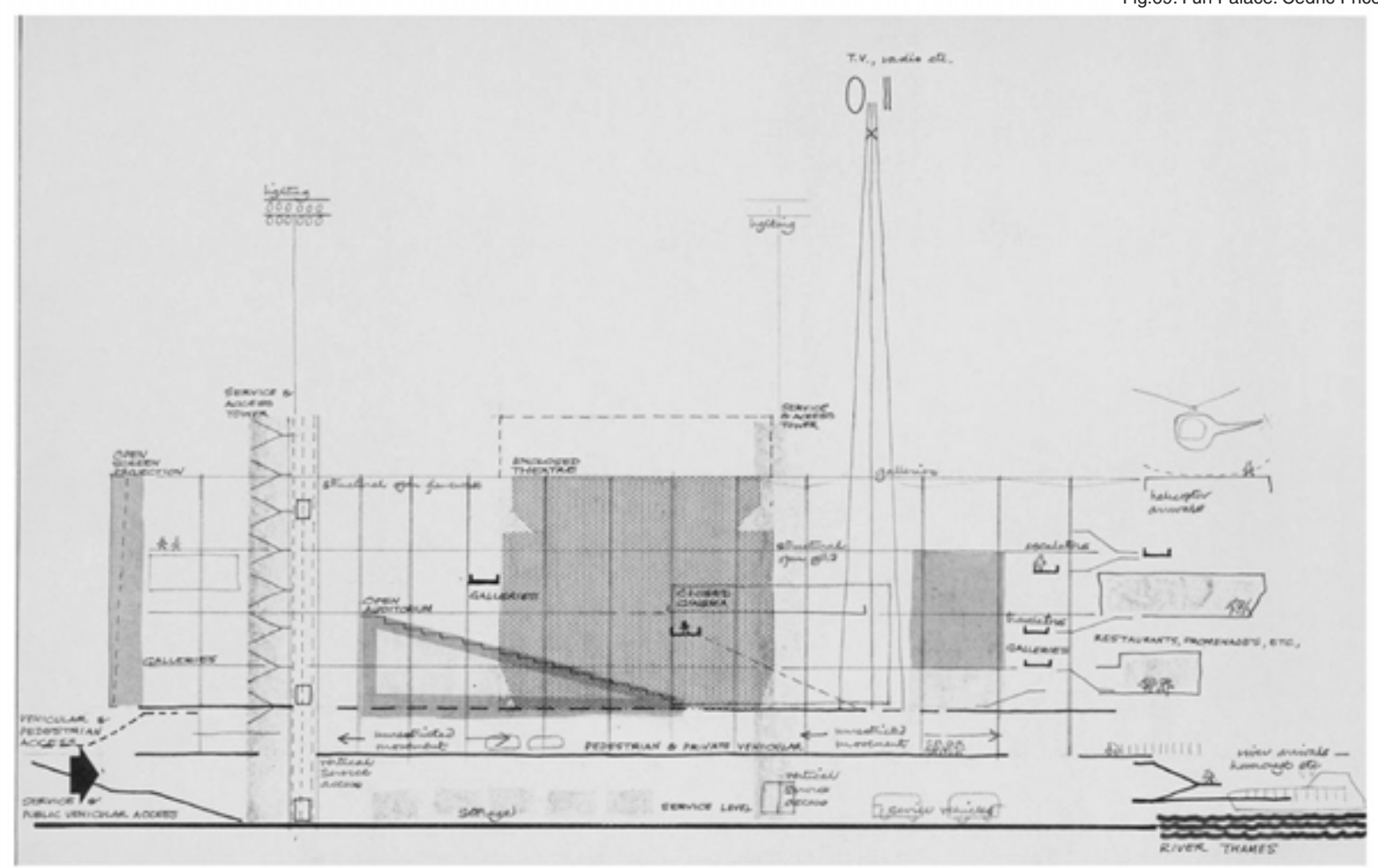




\title{
2.DPL.6 DESLOCAÇÃO 3: RUAS
}

\author{
Em Londres, vamos criar uma universidade das ruas - não um parque \\ elegante, mas uma antevisão dos prazeres do [futuro] 1984. \\ (LITTLEWOOD, J. ${ }^{33} 1968$ Apud HARDINGHAM, 2016, p. 93, tradução \\ nossa)
}

1968 é o sexto ano de trabalho do projeto "Fun Palace", produto de um grande coletivo intelectual e profissional. A referência que faz Joan Littlewood (diretora teatral e primeira idealizadora do "Fun Palace") não pode ser apenas uma coincidência com os acontecimentos do maio francês. O "Fun Palace" queria ser a universidade das ruas por oposição à universidade fechada e exclusiva, instituição discutida nesse momento. As ruas como espaço público, como expressão do coletivo, de manifestações, de lazer, do "derivar", da discussão. Um programa sem especialização de uso, embora seja para a banalização funcionalista moderna (já muito discutida depois da segunda guerra), o espaço de circulação. O espaço público é para Michel de Certeau, escrevendo nos anos 70 um lugar das táticas, o procedimento dos fracos por oposição aos procedimentos do poder que são, ou seja estratégicos. As ruas são brancas mesmo sem procurar a areia embaixo delas.

\section{UNIVERSIDADE DE RUA EM LONDRES}

Essa rua, aquela universidade das ruas que é o "Fun Palace", não é apenas um projeto de arquitetura. Trata-se da invenção de uma instituição que redefine as modalidades de lazer e criação de seu tempo, propondo um papel ativo para o visitante, com quem o artefato do Palácio da Diversão deve interagir. A ideia surgiu e se desenvolveu em diálogo entre Cedric Price e Joan Littlewood, uma diretor e produtora radical do teatro britânico de muito tempo, cujas obras frequentemente propunham intensa interação entre os atores e o público. O propósito da inovação e as ideias tratadas levam à busca de apoio Cibernético e da Teorias dos Jogos, começando pela incorporação precoce e entusiástica de Gordon Pask, uma referência no mundo cibernético britânico. $O$ desenvolvimento material e técnico do projeto deve muito à colaboração inicial do engenheiro estrutural Frank Newby, um colaborador regular de Price. A incorporação do mundo da cibernética é decisiva para a definição do "Fun Palace", que considera uma arquitetura capaz de aprender e interagir com os usuários.

${ }^{33}$ LITTLEWOOD Joan. Non-Program. A Laboratory of fun. The Fun Palace. The Drama Review: TDR, vol. 12, no. 3, 1968, p. 130 
Fig.70. Fun Palace. Cedric Price.

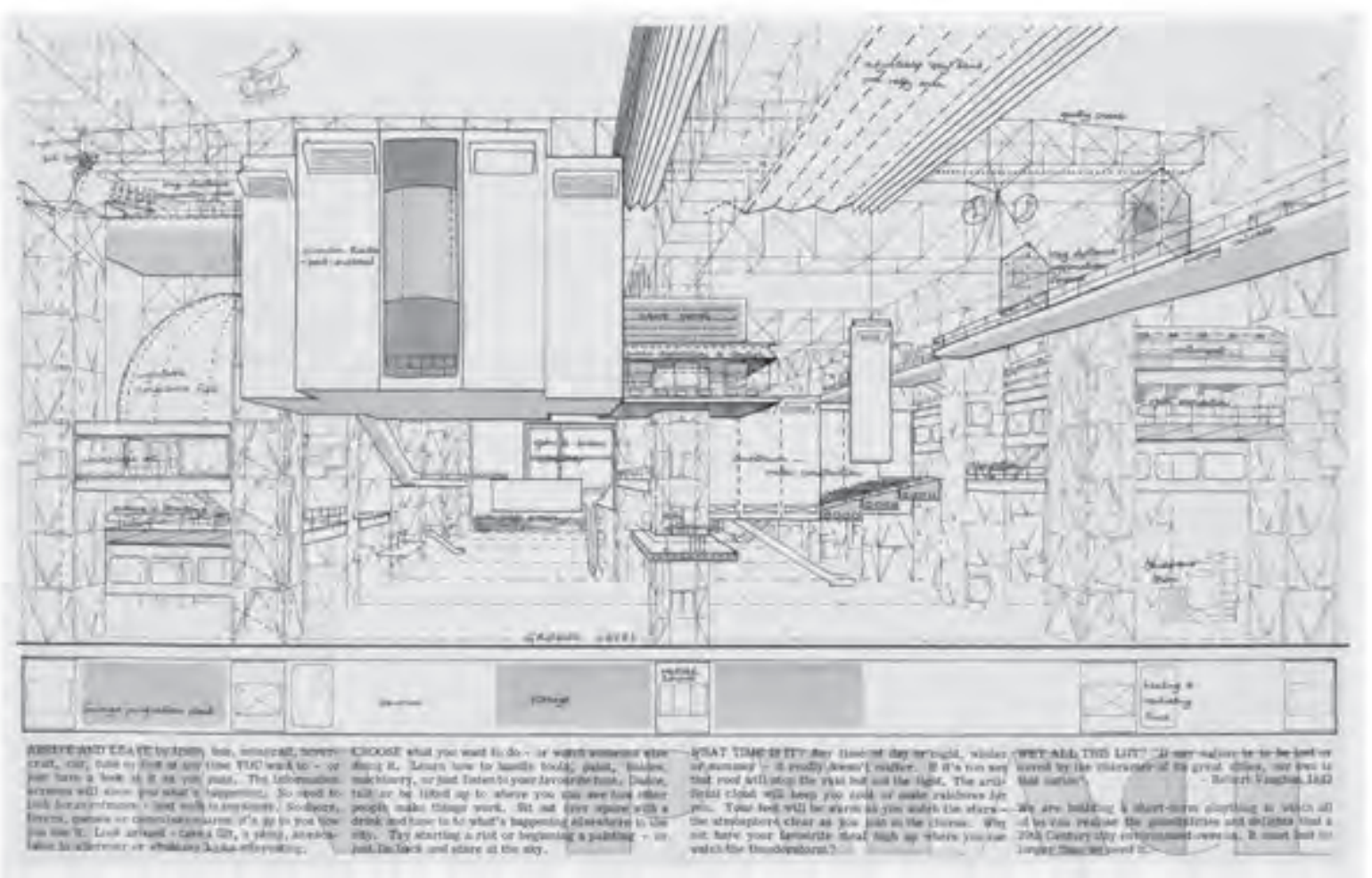


O "Fun Palace" estabelece uma relação clara com a sua condição de espaço público, que no trecho é lida em três níveis definidos: um térreo público e que admite o tráfego veicular privado, um inferior que é um subsolo técnico onde todos os insumos entram e se gera uma conexão de infraestruturas, e vários níveis acima do nível "rua" onde é implantado um conjunto variável de equipamentos com atividades. Essa estratificação fala da dissolução da fronteira que separa o espaço público do equipamento. O "Fun Palace" é um espaço público e seu térreo uma é uma rua aberta a diversas atividades que anunciam outros espaços contemporâneos:

\begin{abstract}
Haverá um "playground da ciência", onde o visitante poderá assistir a palestras-demonstrações com o apoio de filmes educativos, televisão em circuito fechado e modelos de trabalho. À noite, a área se tornará uma ágora ou "kaffee-klatsch", onde os Sócrates, os Abelardos, os poetas da Sereia, os estudiosos errantes do futuro, os místicos, os céticos e os sofistas podem discutir até o amanhecer. (LITTLEWOOD em Ibid., p.93, tradução nossa)
\end{abstract}

\title{
ARTEFACTO FUN PALACE
}

O "Fun Palace" é uma invenção arquitetônica, uma nova maneira de construir um edifício, ou melhor, de fazer arquitetura. Nunca foi construído, mas é um ato de arquitetura completa, projetado ao longo dos anos com uma vocação firme para viabilidade, detalhado em sua formulação técnica, que recorre e se apropria de todas as tecnologias disponíveis.

Vamos imaginar uma percepção da cidade ou do rio (tinha vários locais possíveis em Londres, um deles ao lado do Tâmisa) um artefato de 256 por 119 metros de planta que pode ser realizado de qualquer direção, que não tem um acesso. Ele é definido por 75 torres dispostas em 5 linhas e separadas de 18,3 e 36,6 metros uma da outra. As torres definem a altura do prédio de 36,6 metros, encima se movem duas pontes rolantes que servem como dispositivo auxiliar para a montagem e transferência dos diferentes espaços e configurações que são montados no enorme espaço vazio.

\footnotetext{
O Fun Palace desafiou a própria definição de arquitetura, pois não era realmente um "edifício", mas sim uma matriz que circundava uma máquina interativa, uma arquitetura virtual unindo arte e tecnologia. Por um breve período, o Fun Palace tornou-se um ponto de encontro para muitos intelectuais que o viam como um vasto experimento social em novas formas de construir, pensar e ser. (MATHEWS, 2007, p. 13, tradução nossa)
}

$\mathrm{O}$ artefato não possui fachadas projetadas, mas sim a imagem sempre varia de acordo com as atividades, é um conjunto de sistemas móveis que permitem cobrir, fechar, 
Fig.71. Fun Palace. Cedric Price.

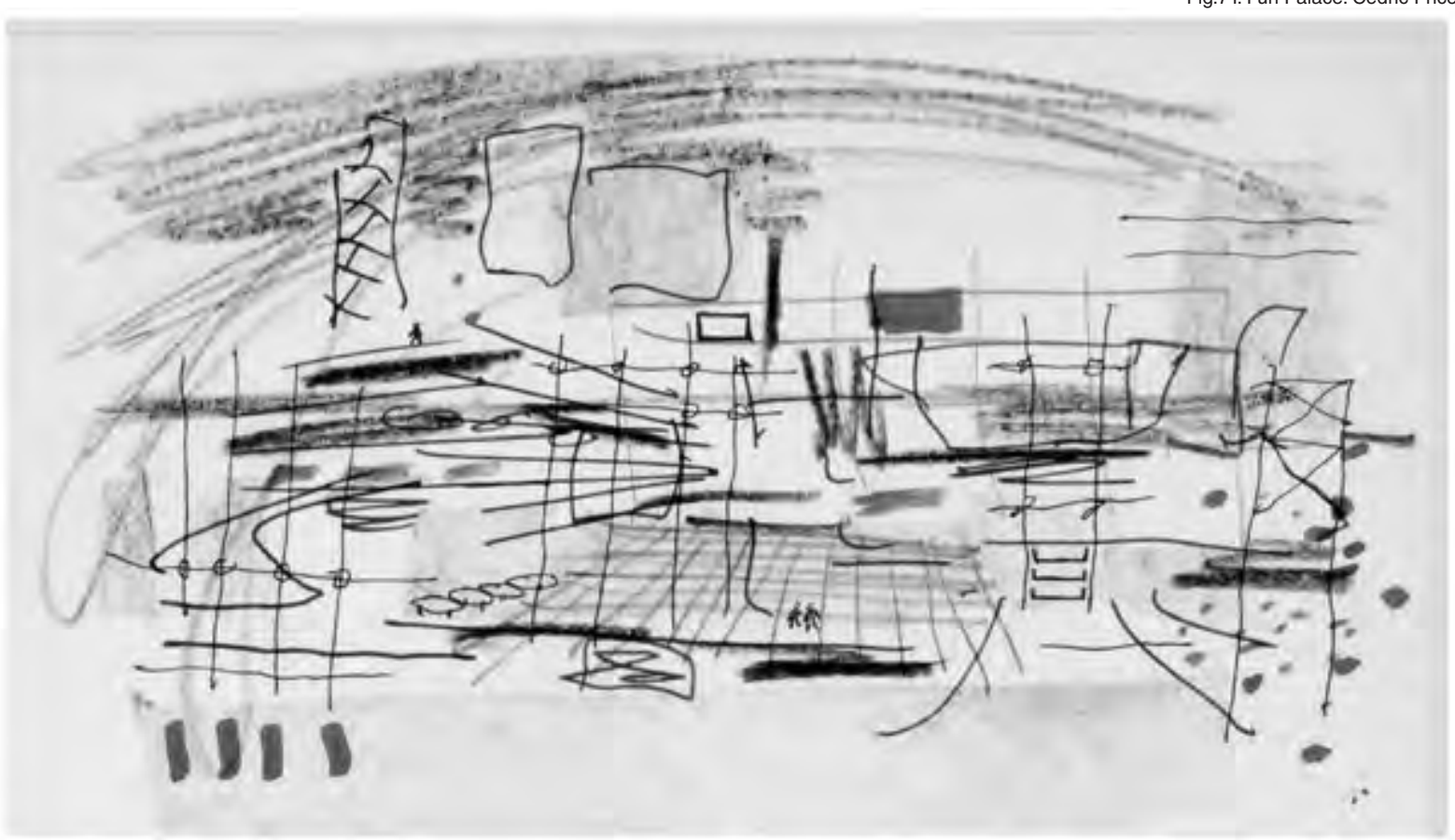


climatizar e isolar o interior. As circulações verticais e serviços estão hospedados nas torres, peças de estrutura metálica de 4,50m no lado que conecta o espaço principal com o subsolo técnico. Um repertório de espaços configuráveis para diferentes usos é formado pela montagem de estruturas e painéis de fechamentos ou dispositivos infláveis, diferentes dependendo se estão nos espaços centrais ou nos lados. Plataformas abertas e fechadas, auditórios abertos e fechados (estudos para configurações espaciais entre 1000 e 10 pessoas), laboratórios, salas de conferência, estúdios de cinema e TV, pista de dança, espaços para projeção de filmes, restaurante, lanchonetes, observatório que permitiu visualizar o espetáculo de diversão e no fundo da cidade, um espaço para jogos, cafés, bares, telas de informação, escadas rolantes móveis permitem acessibilidade aos grandes espaços quando estão em conformidade.

Toda esta implantação em constante mutação tem um suporte cibernético que a torna possível, na verdade, o edifício pode ser entendido melhor como um programa de computador do que com uma descrição arquitetônica: variações espaciais complexas definidas a partir de decisões humanas e sustentadas em um suporte virtual. "A estrutura tridimensional do "Fun Palace" foi a matriz espaço-temporal operativa de uma arquitetura virtual". (Id, 2006, p. 39)

Nas palavras de Price, sua inovação reside particularmente na capacidade do edifício em substituir a forma estática por uma constituição variável em relação às práticas dos ocupantes, para dar origem ao coletivo:

\begin{abstract}
As atividades variadas e em constante mudança irão determinar a forma do local. Para incluir estas atividades, o anti-edifício deve ter flexibilidade igual. Assim, a principal motivação da área é causada pelas pessoas e suas atividades, e a forma resultante depende continuamente delas. $O$ fato de que tal diversão ocorra dentro das áreas tristes das favelas de Londres dá uma pista do imenso potencial de diversão de uma área que incentiva movimentos aleatórios e múltiplas atividades. ${ }^{34}$ (PRICE, C. em: MATHEWS, 2007, p. 73)
\end{abstract}

\title{
DISCIPLINAS
}

A sociedade da informação dá seus primeiros passos, certos pensadores preveem o mundo a partir de seu impacto e a arquitetura tenta entrar em sintonia com ele. A produção de Price pode ser vista em relação a algumas ideias pertencentes ao clima cultural mais amplo dos anos 60 e 70, de onde podem ser traçadas duas referências 


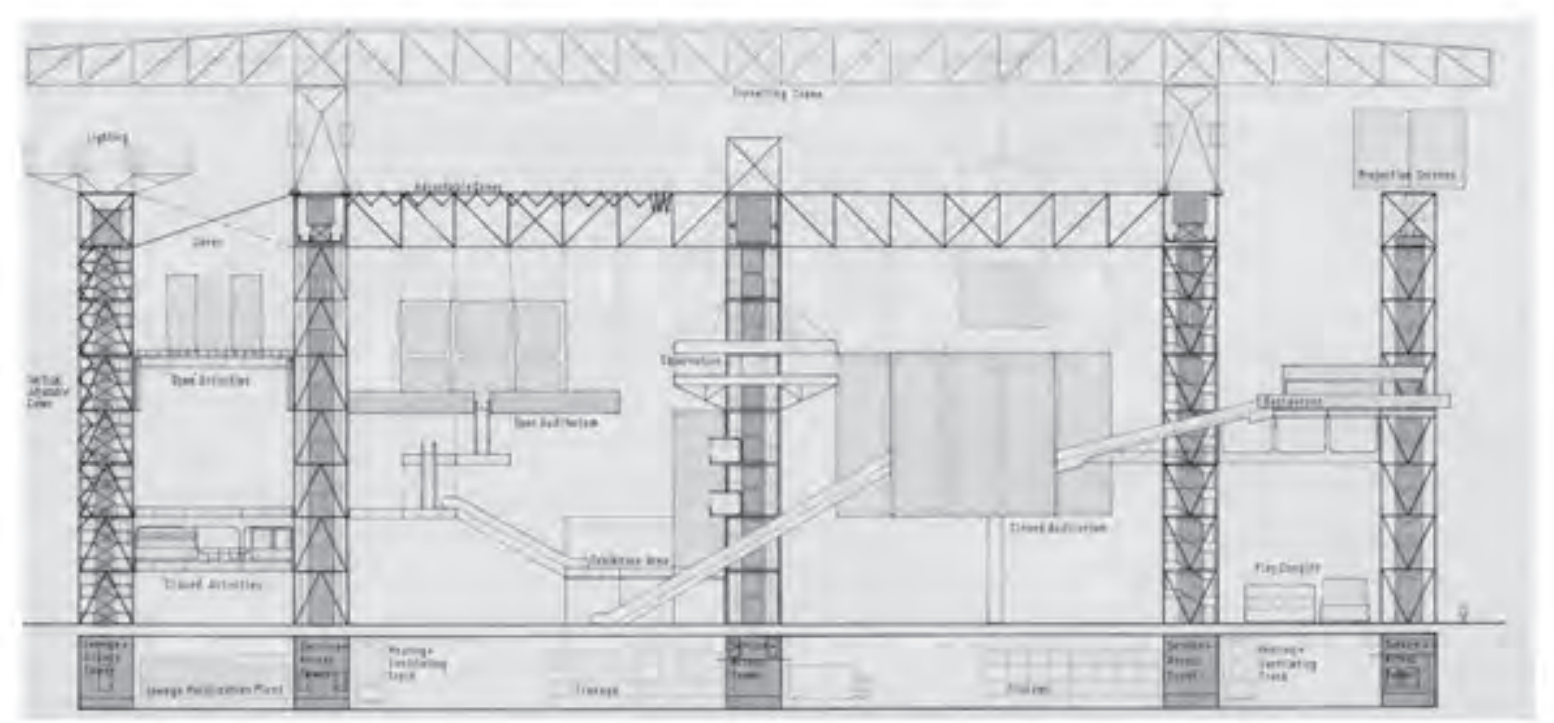


precisas: "Obra Aberta" de Umberto Eco de 1962 e "A Morte do Autor" por Roland Barthes de 1973. Ao mesmo tempo, há um conjunto incompleto de referências que funcionam como eventuais inspirações: o músico John Cage, o pintor Gustav Metzger e sua arte autodestrutiva, Fluxus, Joseph Beuys, o pensamento de Karl Popper, Bruno Munari e suas máquinas inúteis, o Situacionismo, Marshall McLuhan, John Lennon entre outros. De forma contemporânea, o número de Architectural Design (um laboratório de publicações estreitamente ligado à Architectural Association e, em particular, à Price), de setembro de 1969, tem Roy Landau como editor convidado (FRAZER, 2001). Landau é alguém que explora as conexões da arquitetura com o pensamento e a cibernética e reúne na edição vários artigos que reúnem experimentos de sistemas computacionais e suas possibilidades em relação à arquitetura com artigos de Peter Kamnitzer, Gordon Pask e Nicholas Negroponte, e que também tem contribuições sobre filosofia e epistemologia com nomes como Imre Lakatos ou Karl Popper, ou comentários sobre trabalhos de Noam Chomsky. A universidade proposta, além de ser da rua, prática as relações frutíferas entre disciplinas e indivíduos, ela é colaborativa. É inegável que o projeto de arquitetura se faz em relação ao coletivo que inventou a instituição, mas há um ato criativo que é genuinamente arquitetônico, e onde a figura de Price é primordial.

O "Fun Palace" se torna objeto de discussão pública, uma causa para o apoio de certos setores intelectuais e para a firme rejeição de conservadores. Com o passar do tempo, um grande número de profissionais de disciplinas tão diversas como cientistas, sociólogos, psicólogos, cibernéticos, políticos, atores culturais, arquitetos e engenheiros se uniram voluntariamente ao projeto e se organizaram em vários comitês consultivos. Essa organização coletiva complexa ${ }^{35}$ desenvolve estratégias que Price projetará e destilará ao longo de sua carreira posterior.

O "Fun Palace" será o projeto da vida de Price. Depois de anos de propostas políticas ele não consegue ser realizado. Mesmo no início dos anos 70, quando as comissões que promovem o projeto ainda estão ativas e tentam concretizações parciais, são sempre rejeitados pelas autoridades. A marca do Fun Palace aparece especificamente em projetos posteriores de Price como o "Oxford Corner House", "Generator", "Magnet "e especialmente no "Inter-action Center".

\footnotetext{
${ }^{35}$ Não sem argumentos e contradições relevantes, para entender a relação entre o projeto e os sujeitos ocupantes que oscilavam entre a posição de Price e Littlewood, que buscam uma implicação criativa dos sujeitos, e a visão de Gordon Pask que, ao contrário, pensa projetos cibernéticos como mecanismos de controle sobre os sujeitos, propondo o arquiteto como "engenheiro social".
} 


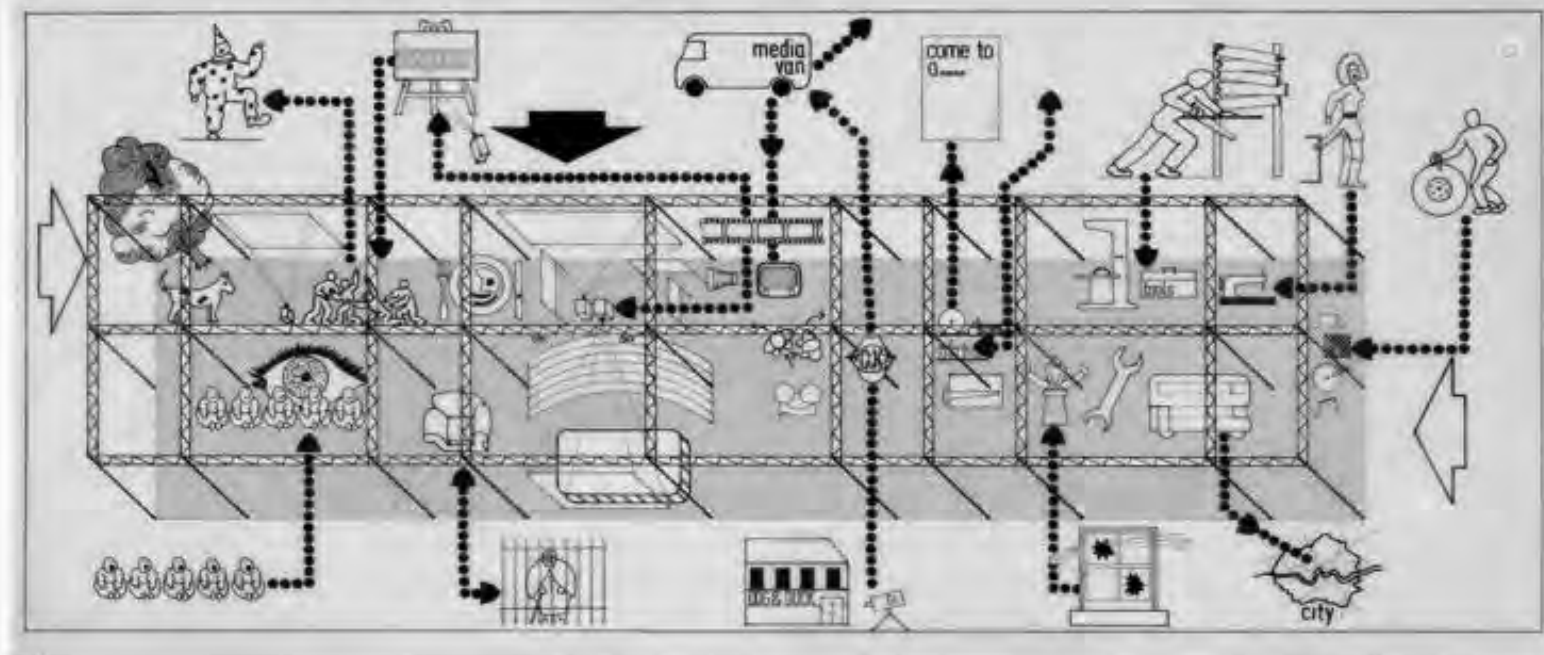




\section{INTERAÇÃO NAS RUAS}

O "Inter-action Center" (I-A.C, no jargão do estúdio de Price) terminado em 1977 é uma peça significativa na construção de curta duração de Cedric Price. O "Fun Palace" aparecerá de forma recorrente: explicando os suportes conceituais do projeto e soluções usadas no I-AC; também como uma figura nebulosa, uma ficção de arquitetura que impregna seu falecido alter ego com toda sua importância de inovação. Uma figura que ficou no papel, mas também no clima cultural britânico dos anos 60 e início dos 70, e que nos deixou um legado polêmico para um futuro que não é mais recente e que acompanhou e guiou as discussões e ideias até os dias de hoje.

O "Inter-action Centre", construído ao longo de cinco anos entre 1973 e 1977, foi desmontado (não demolido) em $2003^{36}$.

Encomendado pela empresa "Inter-action" dirigida por Ed Berman, um americano, que chega a Oxford em 1962 radicado na Grã Bretanha para desenvolver projetos de arte comunitária e funda no significativo ano de 1968 a empresa "Inter-action". O que foi pedido a Berman era um centro polivalente, base de operações para sua empresa dirigida a setores marginais, mas especialmente voltada para a juventude; um pedido aberto e sob medida de Price: "O programa verbal que recebi do cliente foi: um edifício que não seja um edifício" (PRICE ${ }^{37}, 1978$, apud COADE, 2003, p. 14, tradução nossa).

O centro está localizado em Kentish Town, dentro de um espaço livre para uso público, o Talacre Public Open Space ao lado da ferrovia. O espaço foi alugado pela prefeitura da cidade para o Inter-action Trust por um período de 27 anos.

Ed Berman ${ }^{38}$ é um proeminente ativista cultural americano, diretor e produtor de teatro de vanguarda e comprometido socialmente. Uma das influências de Berman é a aplicação da Teoria dos Jogos no teatro e a interação com o espectador como mecanismo criativo. Sua "Inter-action Trust", exibe ações artísticas como parte de um grupo instalado em Kentish Town, e gerencia vários projetos paralelos que apoiarão o novo edifício: grupos teatrais, espaços esportivos, sítios e hortas comunitárias. A figura de Berman, o "cliente" artista comprometido, se recarrega na experiência de Price com Joan Littlewood, produtora teatral, inspiradora e coautora da ideia do "Fun Palace".

\footnotetext{
${ }^{36}$ As fontes variam na data do desmonte, entre 1999 e 2003, mas sabe-se com certeza que isso ocorreu antes da morte de Cedric em 2003.

${ }^{37}$ PRICE, C in Revista Domus 581. Abril 1978, p.17.

${ }^{38}$ Para uma referência mais general sobre Ed Berman, ver Pver Unfinished Histories [website] (CROFT, S.

HIGGS, J., 2006).
} 


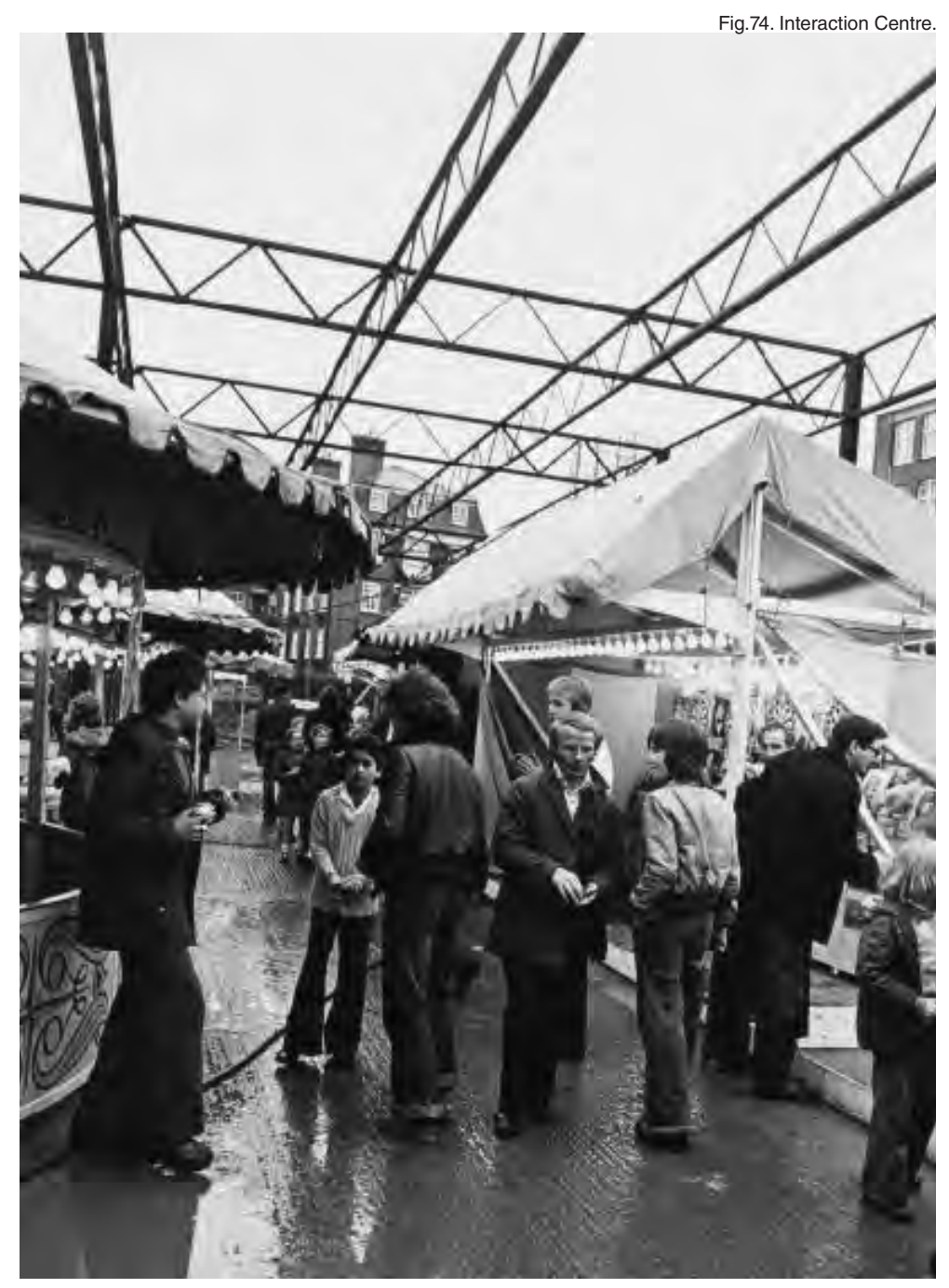


O programa articulado nas conversas com Berman, prevê espaços para funcionar como oficinas, espaços de ensaio, um auditório, estúdios, salas de aula, um local para o atendimento a crianças, refeitório e escritórios administrativos.

O projeto tem a restrição temporal estabelecida desde o seu início e Price decidiu encurtar ainda mais o ciclo de vida, projetando-o para durar 20 anos e ser desmontado. A documentação final do projeto, inclui planos e instruções para a sua desmontagem, insistindo em uma ideia que ele já tinha levantado para o "Fun Palace", que foi pensado para durar apenas 10 anos.

Os recursos da empresa são escassos e quando o projeto começa a disponibilidade econômica fica reduzida. A estratégia da Price foi fornecer um espaço ao ar livre, tratado arquitetonicamente e capaz de se tornar um centro de eventuais atividades que, ao mesmo tempo em que cumpria sua finalidade prática, permitiria arrecadar fundos para a construção do edifício. A transição do espaço público para o equipamento público é gradual e demonstra mais uma vez as conexões entre ambos. Price dá mais pistas sobre esse ato:

Isso é o que eu estava tentando superar: Eu sabia que haveria pelo menos
doze meses quando eles não teriam dinheiro para me pagar concluir os
projetos ou para terminar qualquer trabalho em outro edifício.
Naquele ínterim, que geralmente não é mencionado, esse período de limbo
- para usar um termo católico tradicional - em que não é nem uma coisa
nem outra, com relação a isso, eu disse que tínhamos que ocupar esse
espaço. Mas nós não iríamos ocupá-lo com prédios, nós iríamos ocupá-lo
nas mentes dos "vereadores" que disseram que poderíamos ter esse
espaço. Portanto, construímos uma estrutura que ocupava todo o espaço,
todo o edifício e muito mais, em três dimensões: não era apenas o espaço
que nos tinham atribuído no plano, mas ficou tão alto quanto poderíamos
pensar antes que você obtivesse uma interferência insuportável dos trens
passando por ela. (PRICE em: OBRIST, 2009, p.88-89, tradução nossa)

Assim, uma laje contendo todas as instalações do futuro prédio e uma estrutura metálica sem teto de altura dupla, produziu uma ocupação espacial primária mas intensamente arquitetônica da propriedade que permitiu a implantação de eventuais ocupações espaciais, feiras, espetáculos de circo, etc. O espaço foi conquistado com o tempo e coletivamente. A ideia parece simples e de senso comum, mas contém uma redefinição de papéis e sequências de prática profissional, de significado profundo, uma reformulação de relações forma-função que poderia surpreender um jovem arquiteto colaborador do projeto (POWELL, 2001).

O papel de Price não é o de um profissional passivo, que espera obter o orçamento, mas o de um ator envolvido culturalmente, que encontra na situação uma oportunidade 
Fig 75. Interaction Centre.

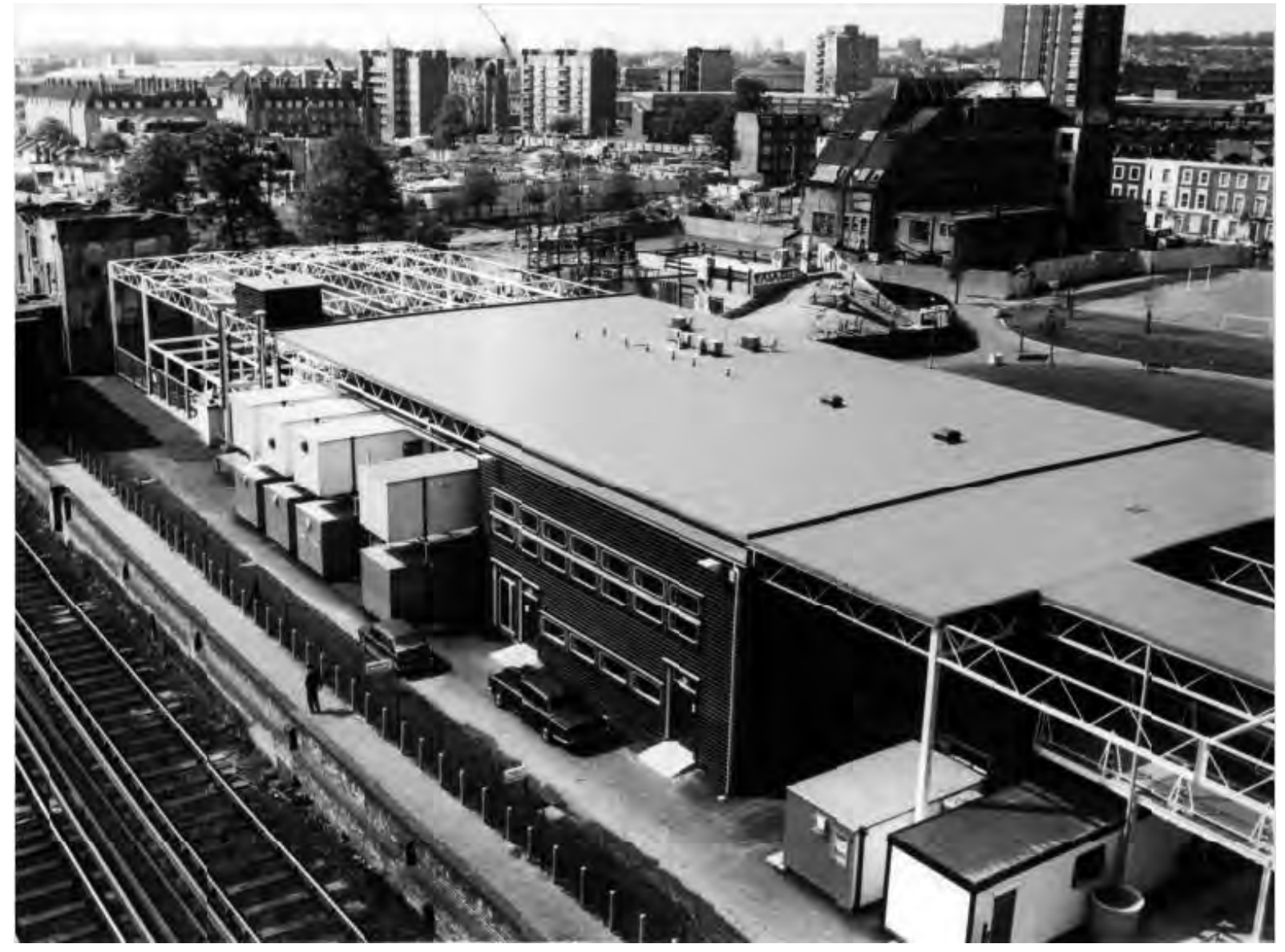


para a invenção arquitetônica, que se concentra em obter o máximo resultado com os mínimos recursos disponíveis. Sua proposta é colonizar o local com uma marca mínima que permita a ocupação criativa e performática (conceitual e literalmente atendendo aos seus ocupantes), de uma espacialidade quase virtual, mas definida arquitetonicamente. Royston Landau usou a palavra inglesa "enabling" ${ }^{139}$, cujos múltiplos sentidos: facilitar, viabilizar ou possibilitar alguma coisa, ativar; descrevem o posicionamento de Price. A forma não segue a função, como Alsop descobre com seu chefe, mas o ato arquitetônico material, a forma habilita a comunidade. Há espaço para o previsível e se estipula o que não se pode prever.

\section{INTER-ACTION}

Esses primeiros componentes fundacionais e facilitadores são projetados como parte de um sistema complexo e aberto, que já prevê o edifício acabado e sua lógica aberta. Uma estrutura reticular, mínima e nua, e colunas de suporte metálicas recebem um conjunto de componentes intercambiáveis que podem ser facilmente incorporadas posteriormente. Algumas locais são definidas a partir de contêiners industriais e outros por meio de elementos de catálogo escolhidos por conveniência: painéis de fecho, escadas, varandas, portões, portas típicas de construção indústrial, janelas tipo persianas, etc. O sistema de construção dos painéis de fachada montados deslizando através dos perfis permite montar e desmontar a fachada. Algumas cabanas escandinavas de troncos têm seu saudosismo e se somam ao repertório. O projeto deve ser adaptável, ficar aberto às mutações e também ter a desmontagem como parte do projeto.

O projeto não deve responder a um cânon formal único (nem propor um), mas sim ele vai ser o resultado da interação entre o suporte arquitetônico e os habitantes. Muitos dos espaços do projeto são containers pré-fabricados, que podem mudar de lugar, juntos ou separados, a partir de um sistema de fixação. O tempo é também material de projeto, e as modificações no projeto são desejadas. "Add or subtract" convida Cedric. O sentido do projeto como ato performativo adquire para Price um sentido mais profundo ao envolver às ações dos habitantes na construção do espaço e até na geração do projeto.

\footnotetext{
39 "A visão de arquitetura de Price tem uma dimensão profundamente ética, no centro da qual está o efeito que uma arquitetura pode ter sobre seus ocupantes ou observadores". (LANDAU, 1985)
} 


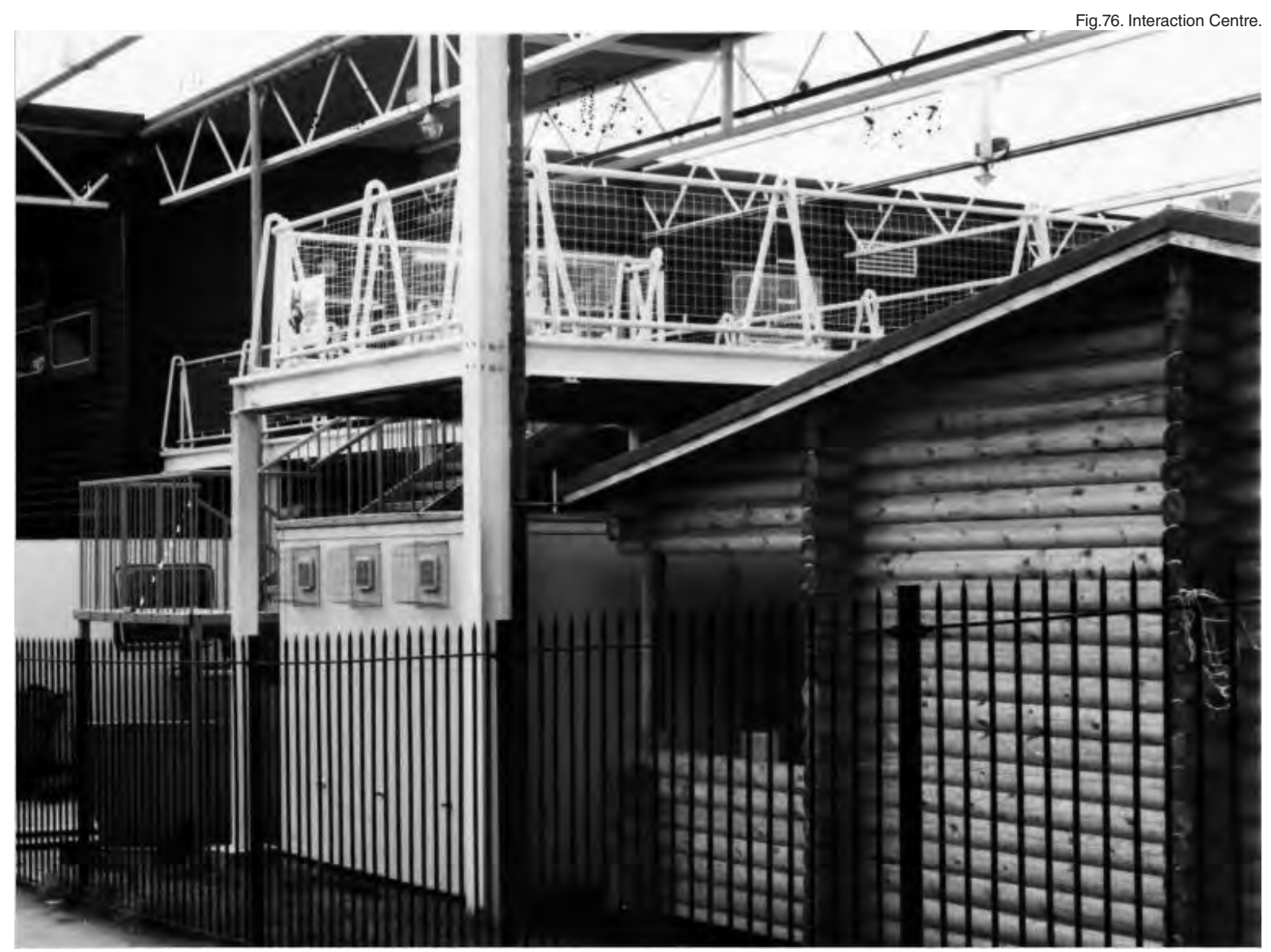


Boa parte da estrutura funcionava como renovação espacial do espaço exterior. A estrutura metálica superior também se comporta como um andaime para a mobilidade de contêineres e outros dispositivos, um sistema estrutural secundário que foi montado conforme a necessidade de mudança no edifício, permitindo posicionar e sustentar horizontalmente e verticalmente os contêineres e outros elementos.

O edifício de $112 \mathrm{~m}$ de comprimento por 25 de largura é implantado paralelamente aos trilhos de trem elevados. O lado do comprimento na direção dos trilhos do trem recebe as atividades de serviço molhadas: serviços de higiene, cozinhas, armazéns, impressoras, sala de fotografia, oficinas de eletrônicas. O lado da largura se conecta com o parque (onde uma boa parte dos programas externos do "Inter-action Trust" está localizado) através dos espaços exteriores sob a estrutura metálica, por meio de um volume fechado central em dois níveis que contém todos os espaços públicos e principais. Um programa cultural aberto que inclui oficinas de projeto, vídeo, gravação e edição, um ginásio, loja, administração, alguns espaços de apoio e um grande espaço multiuso de cerca de $300 \mathrm{~m}^{2}$ para shows, ensaios, teatro, eventos esportivos, etc. Um grande portão automático permite que este espaço esteja ligado ao parque e, eventualmente, trabalhe na sua direção.

\section{INTER-ACTION?}

Há uma abertura na lógica do projeto que distancia ainda mais sua idealização do modo de projetar funcionalista, segundo a leitura que Mathews faz do projeto.

O design de Price para o projeto consistiu de uma série de diagramas
relativamente diretos das várias funções programáticas. A cada atividade foi
atribuída uma forma generalizada. Mas onde a prática arquitetônica
convencional procuraria organizá-los no padrão ótimo dentro de uma grade
estrutural ou recinto de construção, Price categorizava cada espaço de
atividade em um tamanho modular que seria incorporado à matriz estrutural
de várias maneiras. Isso o ajudou a visualizar a qual deveria ser a amplitude
da estrutura geral para acomodar o programa, sem realmente atribuir ou
dedicar certas partes e áreas a qualquer parte específica dele... Preço
destinado ao Inter-action Centre para ser parte teatro, parte comum, parte
escola e parte do lugar de reprodução criativa. (MATHEWS, 2007, p. 183-
187, tradução nossa). O projeto da grade baseado em um módulo de cerca de 4,25 metros, permite diferentes arranjos para os mesmos espaços, assim como a intercambiabilidade de suas posições. Deste modo, a liberdade do espaço (e do projetista no momento do projeto) fica definida pelo seu distanciamento das condições concretas de produção daquele espaço que, observadas a partir da lógica abstrata da grade, explora toda a sua "capacidade". Desta 


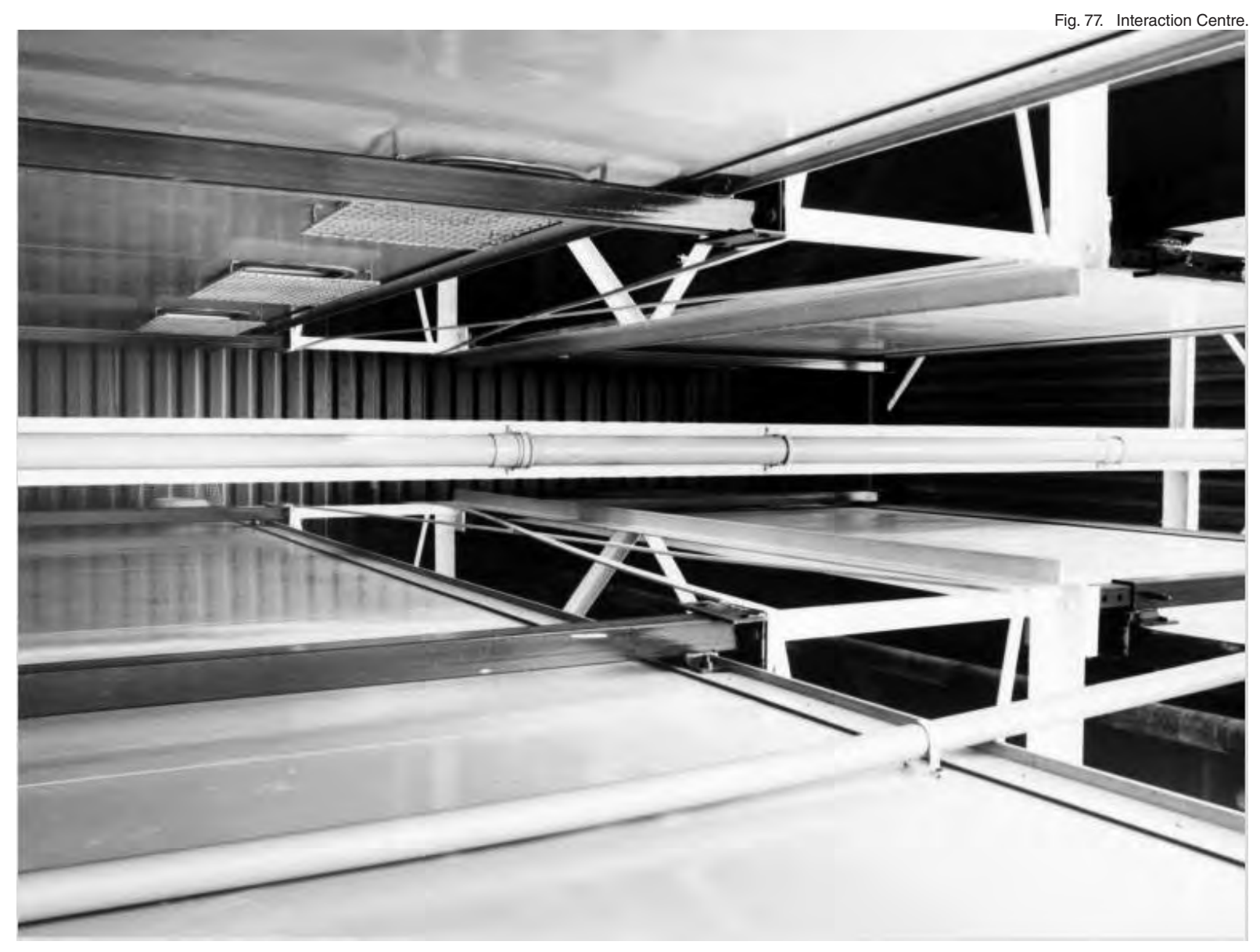


forma, a capacidade de um edifício de se adaptar à vida não é tanto a possibilidade de mudança material pós-ocupação, mas uma constante possibilidade de colonização variável do projeto, do momento de sua elaboração, até sua implementação e seu ciclo de vida.

É da vontade da maquina robô que o projeto (assim como muitos dos projetos de Price) perde sua intensidade. Essa vontade definida como o principal interesse do projeto é exatamente o que Will Alsop (STUDIO NAUTA, 2015) ${ }^{40}$ foi conferir quando visitou o edifício pouco antes do seu desmonte. Alsop, que nesse momento já fez sua própria e reconhecida trajetória como arquiteto, procura encontrar aquilo que fez parte de seu "imprinting" junto a Price: "tudo deve poder ser montado com ferramentas comuns para várias bicicleta"(ibid., tradução nossa). Os mesmo espaço podem ser estimulante e conseguir sucesso entre seus ocupantes, mantém em boa medida a mesma configuração que tinha em 1977. Os dispositivos de mobilidade e a transformação física do edifício não aconteceram. O que Price teria lido como uma falha, pode ser compreendido como sucesso da abertura do espaço enquanto ele, com sua configuração estável, permitia diferentes ocupações ao longo do tempo. O sucesso está, então, mais na "capacidade" do espaço, na sua desespecialização, e menos na sua mudança física concreta. A testemunho da diretora de teatro Jude Kelly, pode confirmar essa interpretação:

\footnotetext{
Não é tratar com paternalismo nem com comprometimento e sua flexibilidade forneceu uma contribuição criativa própria. Isso fez com que grandes ideias parecessem possíveis e deu elegância às pequenas ideias.(KELLY, J. em: HARDINGHAM, S., 2011, p.89, tradução nossa)
}

A incerteza pode ter saído fora dos cálculos do projeto (belo paradoxo). O I-A. C. tinha expectativas de estimular os moradores. Uma formulação análoga pode feita pelas palavras de Rem Koolhaas, Price faz uma "autoritária insistência na liberação do sujeito" (KOOLHAAS, 2004c, p.75). No fundo o que está em discussão é a capacidade da arquitetura para produzir uma mudança nos sujeitos, cujas limitações são observadas pelo mesmo Michel Foucault referindo-se especificamente à arquitetura:

Os homens sonhavam com máquinas libertadoras, mas não há, por definição, máquinas de liberdade. Não acredito (pelo contrário) na existência de algo que fosse funcionalmente - por sua verdadeira natureza -

40 Testemunha de Will Alsop. Architect. Former member of the office. On: Inter-action Centre em Cedric Price Memory Bank. 


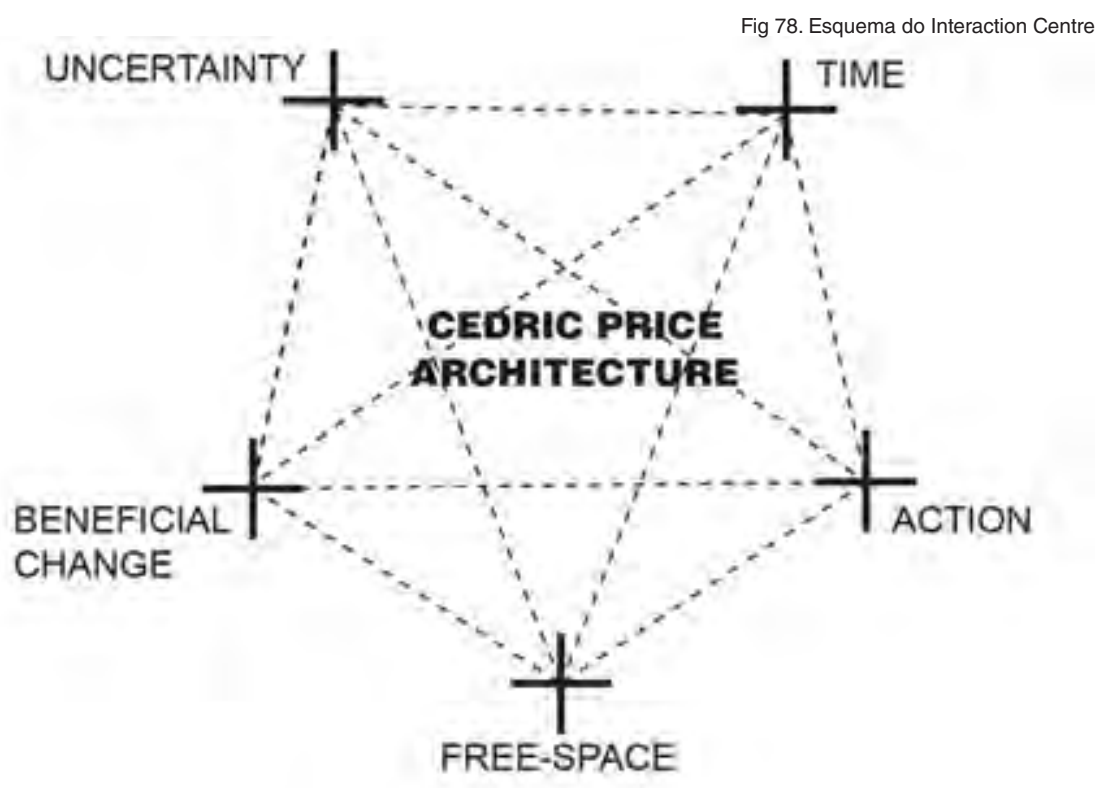


radicalmente libertador. Liberdade é uma prática. (FOUCAULT, 2015, tradução nossa)

\section{NOÇões PARA O EDIFícIO-RUA}

No livro "Cedric Price AA Works" editado pela "Architectural Association" e dirigido pelo arquiteto, apresentam-se projetos desde a criação do escritório em 1960 até 1984. Os projetos e alguns documentos organizam-se na base de cinco categorias temáticas com em que o projeto teria alguma vinculação particular. Essas categorias são em síntese (e com seu nome inteiro em inglês): ação ("action and inaction"), tempo ("time and timing"), incerteza ("uncertainty and delight in the unknown"), mudança ("beneficial change and inevitable ageing"), espaço livre ("free space and its operational matrix"). Na publicação, o I-A.C. e o "Fun Palace", junto ao já referenciado "Oxford Corner House", aparecem dentro de "incerteza e o prazer pelo desconhecido". A "incerteza e o prazer do desconhecido" junto aos projetos reforça algumas debilidades já apontadas daqueles projetos, mas sobretudo permite valora-los, e significa um desafio para o projeto.

Embora seja interessante estudar os critérios que Price utilizou para fazer a taxonomia dos seus projetos por meio dessas categorias, em conjunto elas podem ser lidas como o manifesto do edifício-rua, e particularmente dos equipamentos coletivos, desde noções de conexão com as dinâmicas da vida, colocando a condição pública de Branco Nolli em primeiro lugar. Esse manifesto, muito além dos projetos concretos, é um programa de interesse para o projeto contemporâneo desde a desespecialização programática.

\section{PRICE ARQUITETO CONTEMPORÂNEO}

De modo ampliado, a produção de Cedric Price, obras, projetos, livros, entrevistas e palestras, apresentam uma serie de leituras do entendimento da arquitetura que são contribuições para uma agenda do projeto contemporâneo, e que contribuem para o intuito deste trabalho:

a) Uma arquitetura como prática cultural e política, não funcionalista:

Promover novos desejos. "A arquitetura é lenta demais para resolver problemas" (PRICE in OBRIST, 2004, p.136, tradução nossa).

b) Propor nova arquitetura a partir das indagações da ciência.

c) Colaboração. A arquitetura é sempre feita com outros.

d) Pragmatismo. "O pequeno não é belo. O tamanho adequado é correto" (quase uma contestação antecipatória da "Bigness" koolhaasiana). 


$$
\text { lack of theatal antomume }
$$

the Trunetes of the Fun Palace) nuida your to wae their toy -

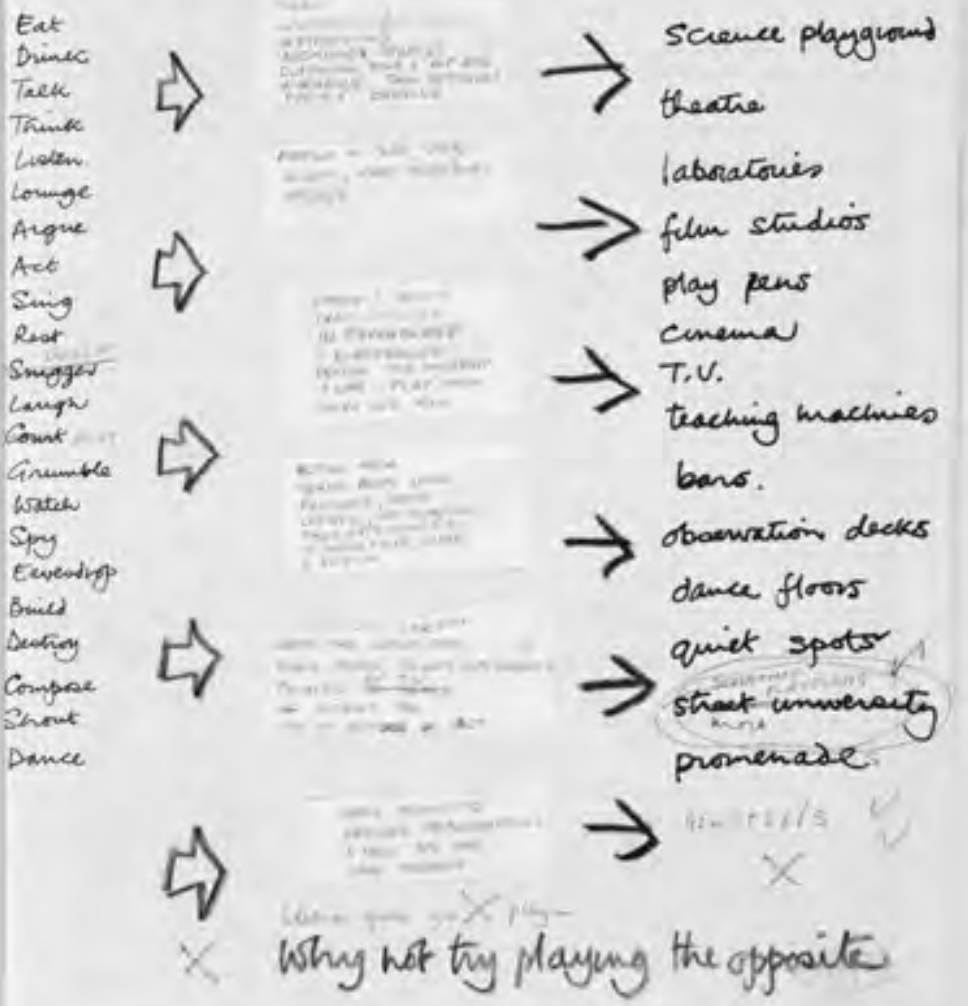


e) Capacidade multi-escalar do pensamento do arquiteto. De um pequeno edifício, "BTDB Computer Centre", a uma proposta de reconversão territorial, "Potteries Thikbelt", existe a mesma disposição intelectual.

f) Arquitetura é técnica. "A tecnologia é a resposta. Mas qual era a pergunta?" (PRICE ${ }^{41}$ apud HARDINGAM, 2016b, p. 327, tradução nossa)

g) Processo sobre ou produto. "Enabling".

h) Não permanência da arquitetura. "A necessidade de sua duração deve ser demostrada, não é evidente." (CEDRIC ${ }^{42}$ apud HARDIGHAM, 2016b, p. 212, tradução nossa)

i) Projetos como pesquisas. "Design was treated a form of research". (WIGLEY, 2004, p.22) ${ }^{43}$

Price não foi uma figura isolada, ele fez parte de um momento muito rico da Grã Bretanha em termos de arquitetura e da sociedade em geral. Ele ficou muito próximo ao ambiente da arquitetura (na academia em contato com a Architectural Association, e com uma relação particular com o critico Reyner Banham), mas sua produção é independente, e aberta para o fértil ambiente além da disciplina. As contribuições de Price para a arquitetura contemporânea e a definição do papel do programa são fundamentais (VIDLER, 2003) para a constituição de uma agenda ampliada que tem preocupações ambientais, tecnológicas e formais articuladas num discurso único. A maneira de eludir as convenções da arquitetura e propor abordagens novas derivadas de um pensamento lúdico e sistemático ao mesmo tempo.

Uma conexão direta a partir do entendimento do projeto como estratégico é estabelecida entre Cedric Price e Rem Koolhaas (GARCÍA GERMAN, 2012), entendendo a semelhança nas técnicas operativas empregadas. Essa conexão relaciona o procedimento de elaboração do projeto do "Fun Palace" a partir de listas de ações no espaço (e não de espaços para fazer ações), e as primeiras formulações dos projetos de OMA com ênfase na justaposição de atividades.

Podemos chamar esse procedimento de estratégico, já que a partir de orçamentos não prefixados (nem mesmo a tecnologia era um apriorismo

\footnotetext{
${ }^{41} \mathrm{PRICE}, \mathrm{C}$. Technology is the answer, but what was the question? [Pidgeon audiovisual. 1970] [online] London: World Microfilms Publications Ltd, 2018.

${ }^{42}$ PRICE, C. On Safety Pins and Other Magnificent Designs, Pegasus.

${ }^{43}$ No mesmo assunto, ver a palestra de Cedric Price na AA, "Research and cooperation" jul 1984.
} 
Fig.80. Diagramas Magnets. Cedric Price.

\section{MAGNET}
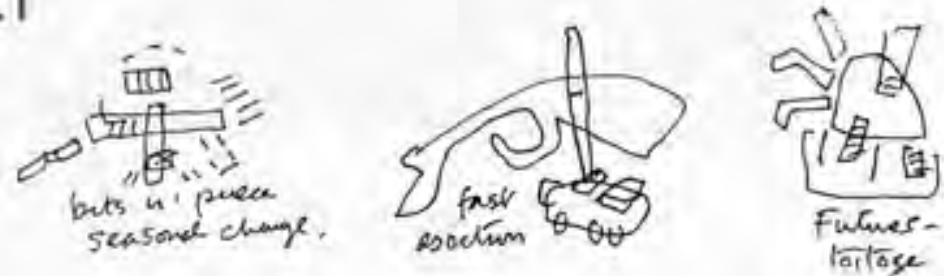

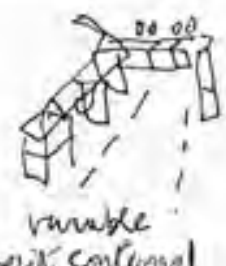

refit contenal

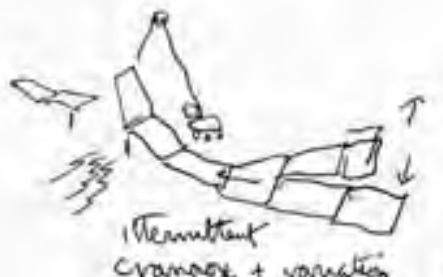

cramage t vomation

(seasonal!) of form

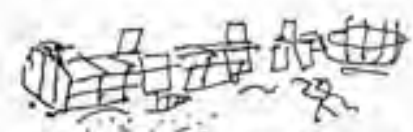

lougtern

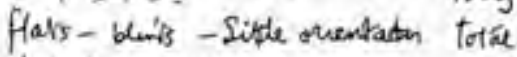

Hovenprothet - oecassiencel

movenout.

hrovereatit

a anage

6y pemanent inoveluat of hark walkongs. 
para Price, ao contrário do que é comumente aceito) foi estabelecido um plano para atingir o maior efeito com um mínimo de conteúdo arquitetônico. (conteúdo material, esforço, econômico, etc.). Um plano que não foi executado dentro de qualquer paradigma estabelecido, mas que se justifica devido ao resultado produzido pela sua execução. (Ibid., p.35, tradução nossa)

Quando olhamos esse manifesto junto aos projetos de Price aparecem ideias para o futuro da arquitetura. Do ponto de vista da desespecialização programática os projetos estudados aqui apresentam particularidades.

O "Fun Palace" é um enorme espaço de 30.000 metros quadrados, e um milhão de metros cúbicos, que pode ser ocupado por uma infinidade de dispositivos que são montados e desmontados de acordo às atividades desejadas. A sua diversidade no tempo e tal, que não é possível apresenta-lo desde os diagramas de dissolução espacial e programática.

O "Inter-action Centre", pelo contrario, embora não tenha mudado no tempo como Price esperava, ele define um espaço que acolheu como uma companhia de teatro e que poderia ser usado para diversos tipos de espaços, como é apresentado nos diagramas de desespecialização que seguem. 


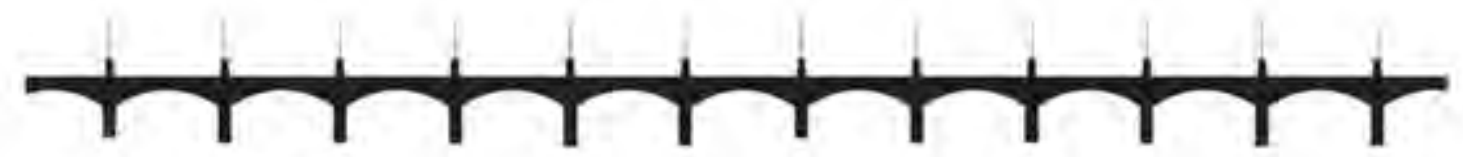

PONT DE PIERRE

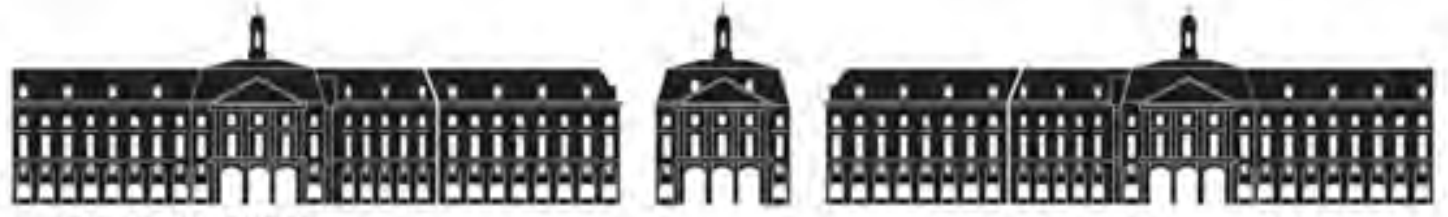
PLACE DE LA BOURSE

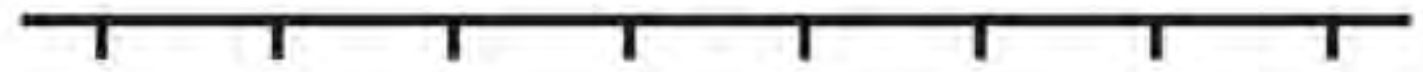

PLATE-FORME NEUTRE

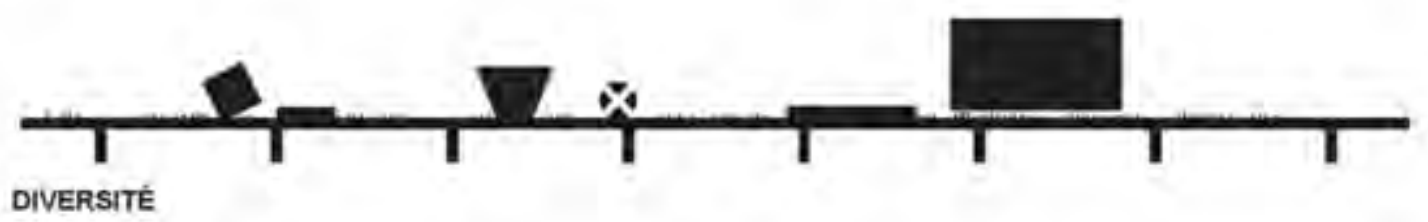




\title{
UMA PONTE ATÉ REM
}

Rem Koolhaas admira profundamente Cedric Price. Faz isso a partir da distância que tem com aquele arquiteto de muitas ideias e bem poucos edifícios construídos, da sua condição de "arquiteto surfista", aquele que compreendeu as chaves para operar críticamente e construir edifícios em processos simultâneos e ambíguos. Cedric foi uma referência desde o momento em que chegou a Londres para estudar na AA em 1968.

Nos inúmeros arquivos da AA depois da morte de Price, aparecem alguns textos que vale lembranças, entre eles o de Koolhaas que conclui falando da generosidade de sua criação de ideias para outros, da sua capacidade para questionar, e acaba dizendo: "Ele era um espirito difícil mas poderoso, e ele era casualmente um arquiteto, e isso é o melhor para esta profissão" (KOOLHAAS, 2004c, p77, tradução nossa).

Rem também escreve a introdução do livro $R E: C P$, com recopilações de artigos e desenhos de Price. Nele estabelece a sua medida da influência de Price para a arquitetura:

\begin{abstract}
Ninguém teve a capacidade de mudar a arquitetura com a economia de meios como o que fez Cedric Price. Com epigramas lapidares, desenhos esqueletais e um gênio polêmico para mobilizar o real contra as pretensões de uma profissão ainda surpreendentemente megalomaníaca, ele mudou o território da arquitetura. Nos anos 60, uma espécie de Oscar Wilde puritano, Price usava o ridículo e o humor com o efeito devastador de desmontar uma a uma as ambições mais sagradas de uma profissão incapaz de se questionar. (KOOLHAAS in ORBIST, 2003, p. 6, tradução nossa)
\end{abstract}

Em 2012 foi chamado um concurso de arquitetura para uma ponte em Bordeaux, França. O concurso é ganhado pelo escritório OMA de Rem Koolhaas. O projeto é obtido não pelo desenho da estrutura ou pela singularidade da forma, senão pela ideia de transformar a ponte em uma plataforma para atividades diversas, um espaço capaz. Com uma largura excepcional de 44 metros acomoda varias faixas de trânsito de carros, ônibus e bondes, bicicletas, e deixa a largura maior para os pedestres. O memorial do projeto estabelece na sua desespecialização a diferencia da proposta com outras maneiras possíveis de abordar o projeto:

A ponte [como objeto] não é um evento da cidade, mas sim tem a capacidade para acolher eventos na cidade. [...] A ponte pode ser uma solução menos técnica, menos lírica, mas finalmente ela é a solução estrutural mais concisa e eficaz. (OMA, 2013, tradução nossa) 
FLEXIBILITE
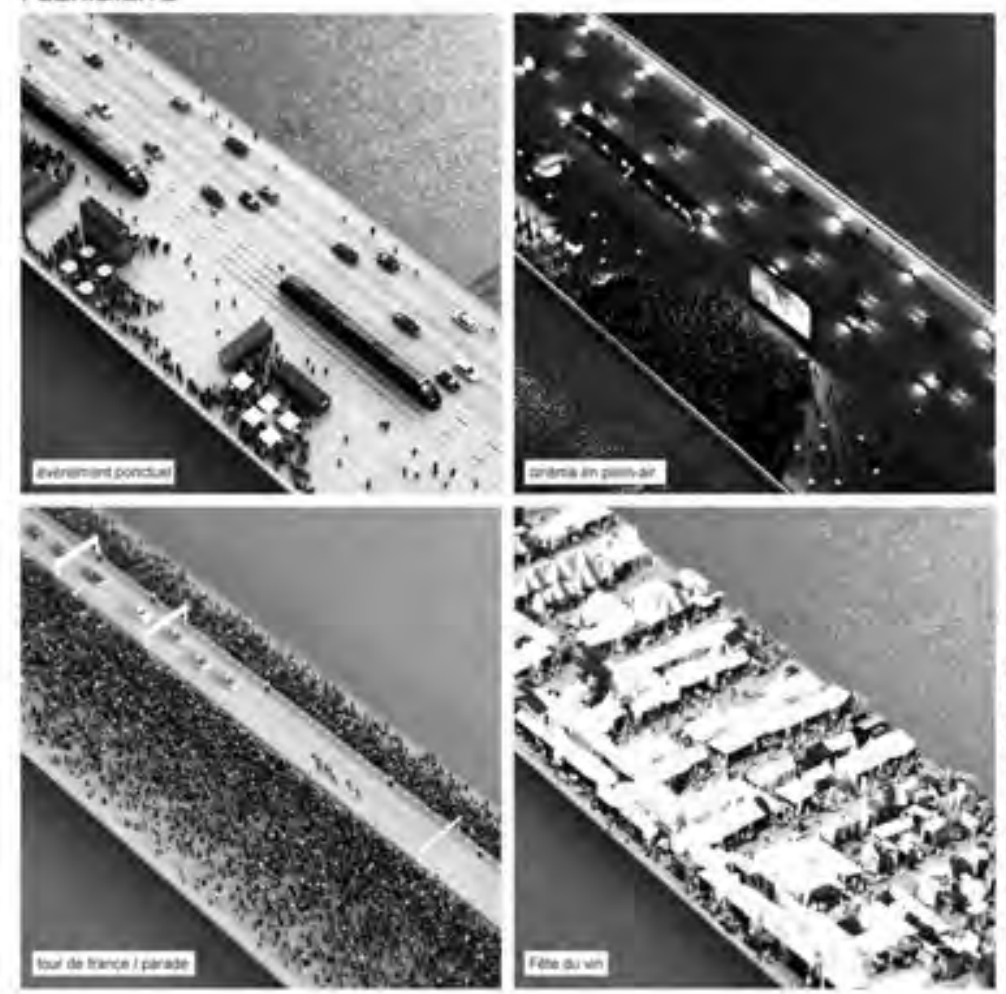

12

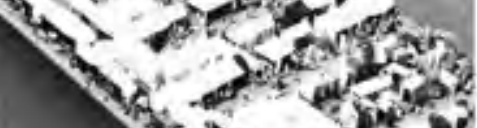

1. "n

32

Fig. 82. Simon Veil Bridge. OMA.

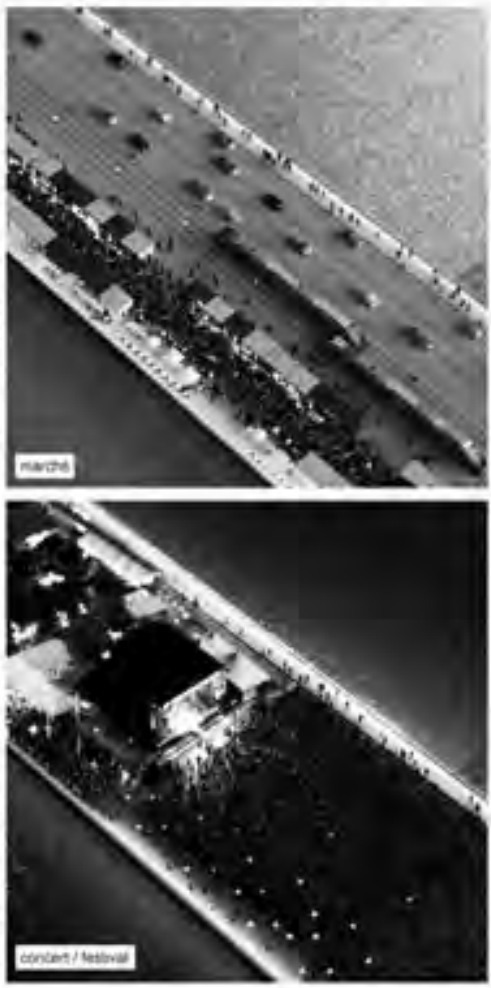


A ideia desloca o centro da discussão do concurso, lembrando e amplificando (pela superposição de atividades à infraestrutura mono-funcional) uma ideia de Cedric Price: "Ninguém deveria estar interessado no projeto de pontes, eles deveriam se preocupar em como chegar ao outro lado." (CEDRIC ${ }^{44}$ apud HARDIGHAM, 2016b, p. 213, tradução nossa)

Rem Koolhaas entrega uma bela novidade para a cidade de Bordeaux, um Cedric Price elevado ao quadrado, com sua ponte-espaço publico. 

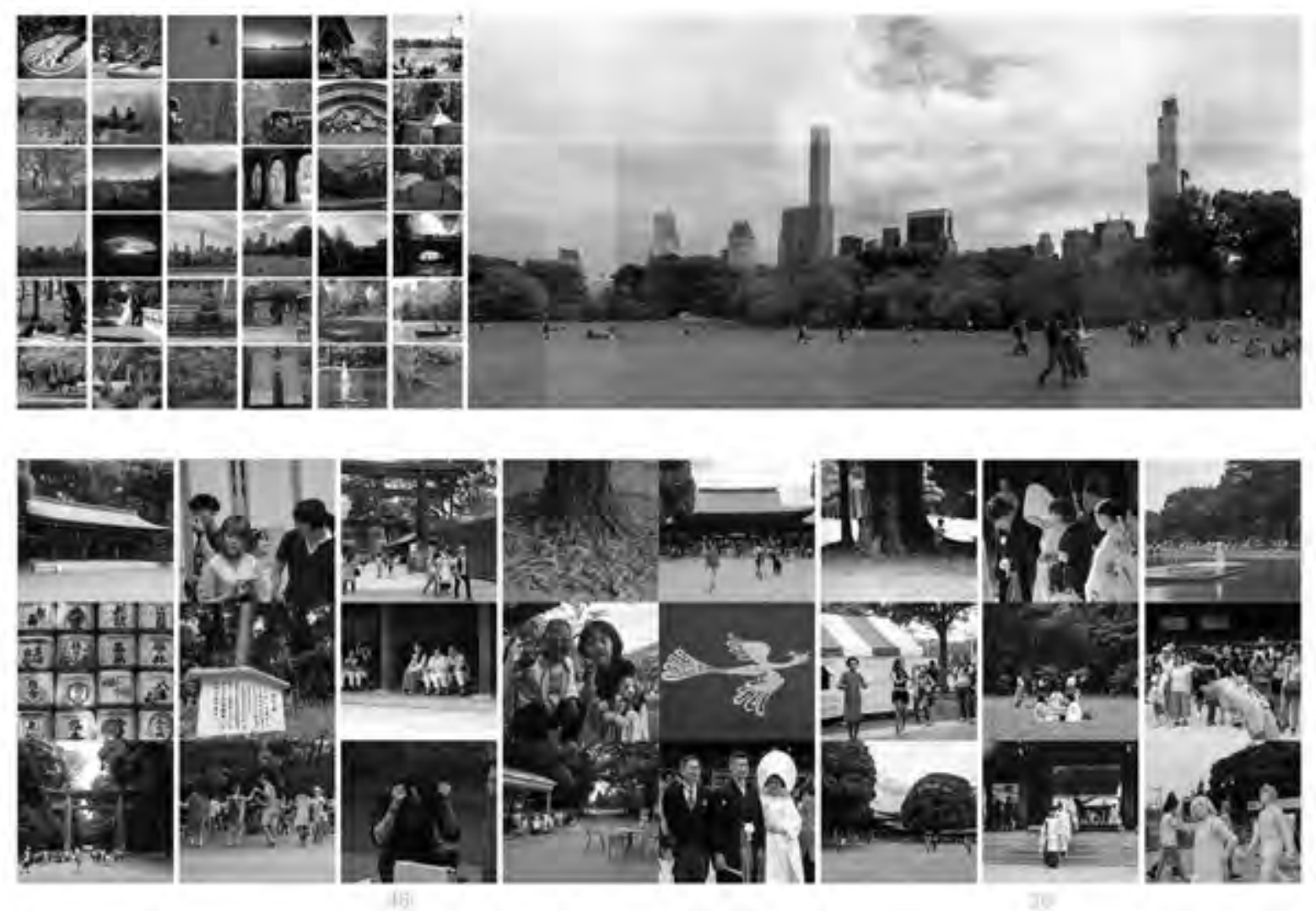


\section{DPL.7 DESLOCAÇÃo 4: PARQUES}

Todos os anos, um grande grupo de estudantes da Faculdade de Arquitetura e Design da Universidade da República (FADU-Udelar) viaja pelo mundo em uma excursão de estudo visitando obras arquitetônicas, cidades e territórios com uma equipe de professores que é renovada a cada a ano. A experiência, única no mundo, se consolidou nos últimos anos com atividades curriculares associadas. Na edição de 2016 a equipe de ensino propõe aos quase 300 alunos um conjunto de atividades, entre elas a realização de alguns registros coletivos chamados HR, Hiper Registros. Em cada viagem, a cada ano, os viajantes capturam obsessivamente e individualmente suas visões no ritmo frenético da fotografia digital.

"O HR é uma maneira de operar a fotografia como uma ferramenta, [...] eles
tentam maximizar a condição de "excesso" (hiper), que a Viagem de
Arquitetura propõe como uma abordagem a partir de uma multiplicidade de
níveis possíveis de reflexão". (MARTINEZ, 2018, tradução nossa) Foram escolhidos diversos formatos para a captura coletiva, dois deles estão concentrados em parques: "HR01 NYC" no Central Park (341 Há) combinando registros individuais e um panorama coletivo e o "HR02 Yoyogi Park" no parque de mesmo nome em Tóquio (54Há), registro coletivo e disperso, dando liberdade a cada participante para escolher seus registros. Os dois parques são enormes peças urbanas, naturezas artificiais embutidas nas duas metrópoles, espaços de celebração do ócio urbano, o tempo livre que é usado ao ar livre, para reencontrar essa natureza e reencontrar a sociedade. O HR implementa o coletivo como um olho capacitado que busca nos aproximar do infinito e do pequeno, à enorme diversidade de espaços, situações, eventos, grupos e tribos que visitam um parque no um final de semana.

Os parques são espaços para implementação de identidades e práticas diversas. Fenômeno semelhante ao que se observa em boa parte dos domingos no Parque do Ibirapuera (158Há) e na Rambla de Montevidéu. Um parque é um espaço que contém infinitos "programas", onde o público e as inumeráveis subjetividades do indivíduo e do coletivo se cruzam. 


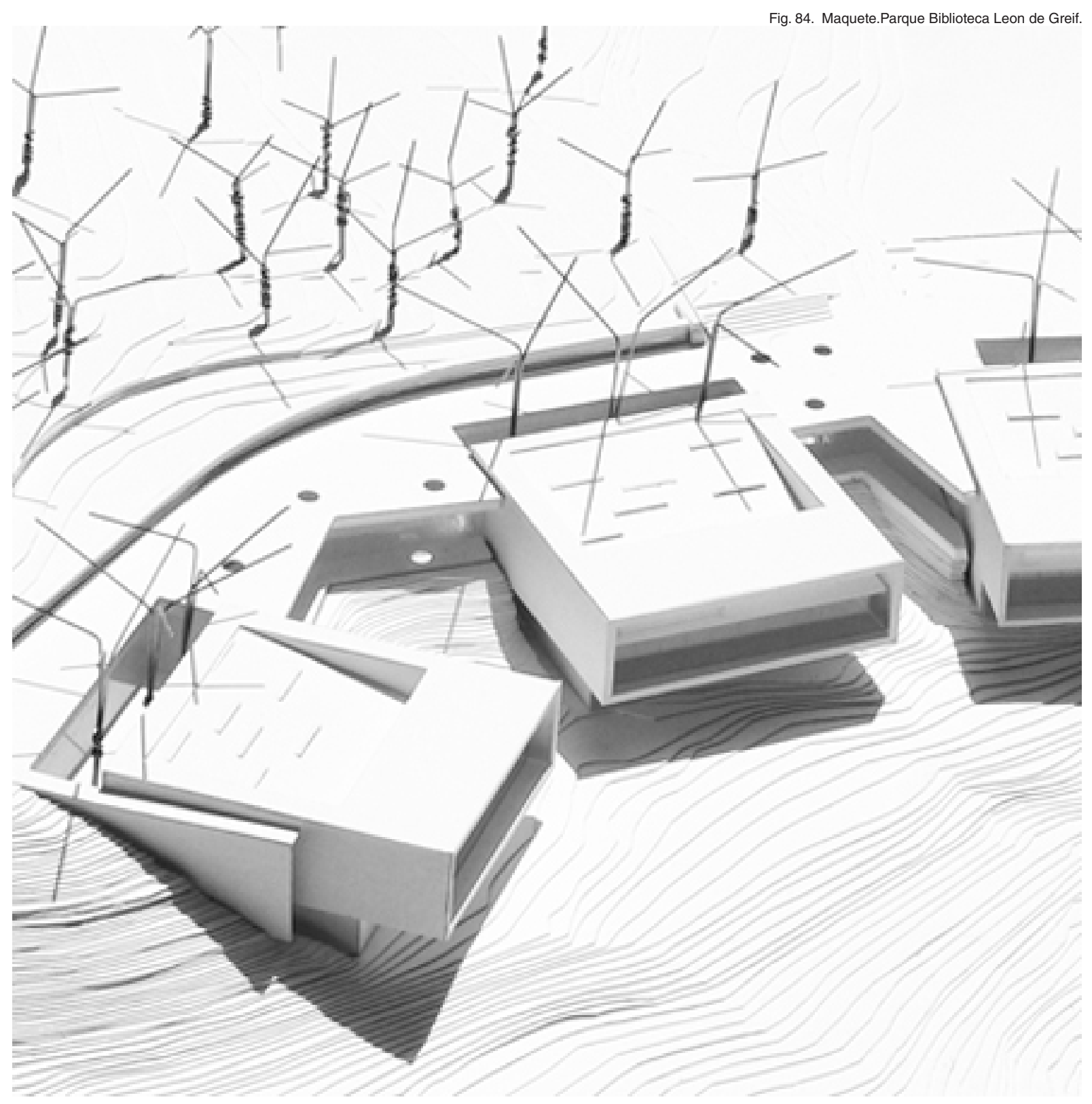




\section{PARQUES EQUIPAMENTO}

Parques Biblioteca e Parques Educativos. Dois nomes para definir dois equipamentos públicos que articulam espaço e edifício público. O nome convoca o Parque, o espaço público de tempo livre e lazer, e o associa a atividades públicas que acontecem dentro dos edifícios. Nome e programa supõem uma continuidade que não conhece o limite. $O$ Parque é a figura que convoca, aquela que desespecializa a cultura e a funde com o lazer. Assim como Lina Bo Bardi, que chamava as atividades culturais de ócio (lazer) para tirar o $\mathrm{C}$ maiúsculo e aproximá-las das menos previsíveis.

Os dois programas do Parque (educativo e biblioteca) fazem parte de um complexo sistema de requalificação social e urbana realizado em Antioquia e sua capital, Medellín, a partir do final da década de 1990, que visa recuperar uma sociedade devastada pela pobreza e pela violência. O sistema origina-se de uma leitura global da sociedade e se compromete com a qualificação territorial como parte central das estratégias sociais: formar uma cidade para a integração e convivência. Além do compromisso com o trabalho e o desenvolvimento econômico, a infraestrutura é redefinida e a mobilidade urbana é totalmente transformada. A oferta se multiplica em todos os níveis, e de maneira semelhante crescem os equipamentos de saúde e esportes. Os espaços públicos se entendem como um sistema de multi-escala.

Nos últimos anos, Medellín tem se concentrado em sistematizar a requalificação para o saneamento do rio que a atravessa, tornando em uma ferramenta para o desenvolvimento ambiental, paisagístico e territorial. O projeto, resultado de um concurso público internacional para o "Parque del Río", abrange uma região que se estende além da cidade de Medellín, afetando 423 hectares dos quais 328 estão localizados no município da cidade, com um desenvolvimento linear de quase 20 quilômetros.

A transformação de Medellín recorreu a modelos de gestão integrada onde atores públicos governamentais articulam suas ações a partir de um marco institucional articulado, entre os quais as Empresas Públicas de Medellín, propriedade do Município, que prestam serviços de energia, gás, água e telecomunicações, incorporando o desenvolvimento urbano e social entre seus objetivos institucionais. As políticas urbanas do Município são pensadas e projetadas na Empresa de Desenvolvimento Urbano de Medellín, e têm um componente de participação comunitária que busca envolver e intervir na definição de projetos. 
Fig. 85. Maquete. Parque Biblioteca Espanha.

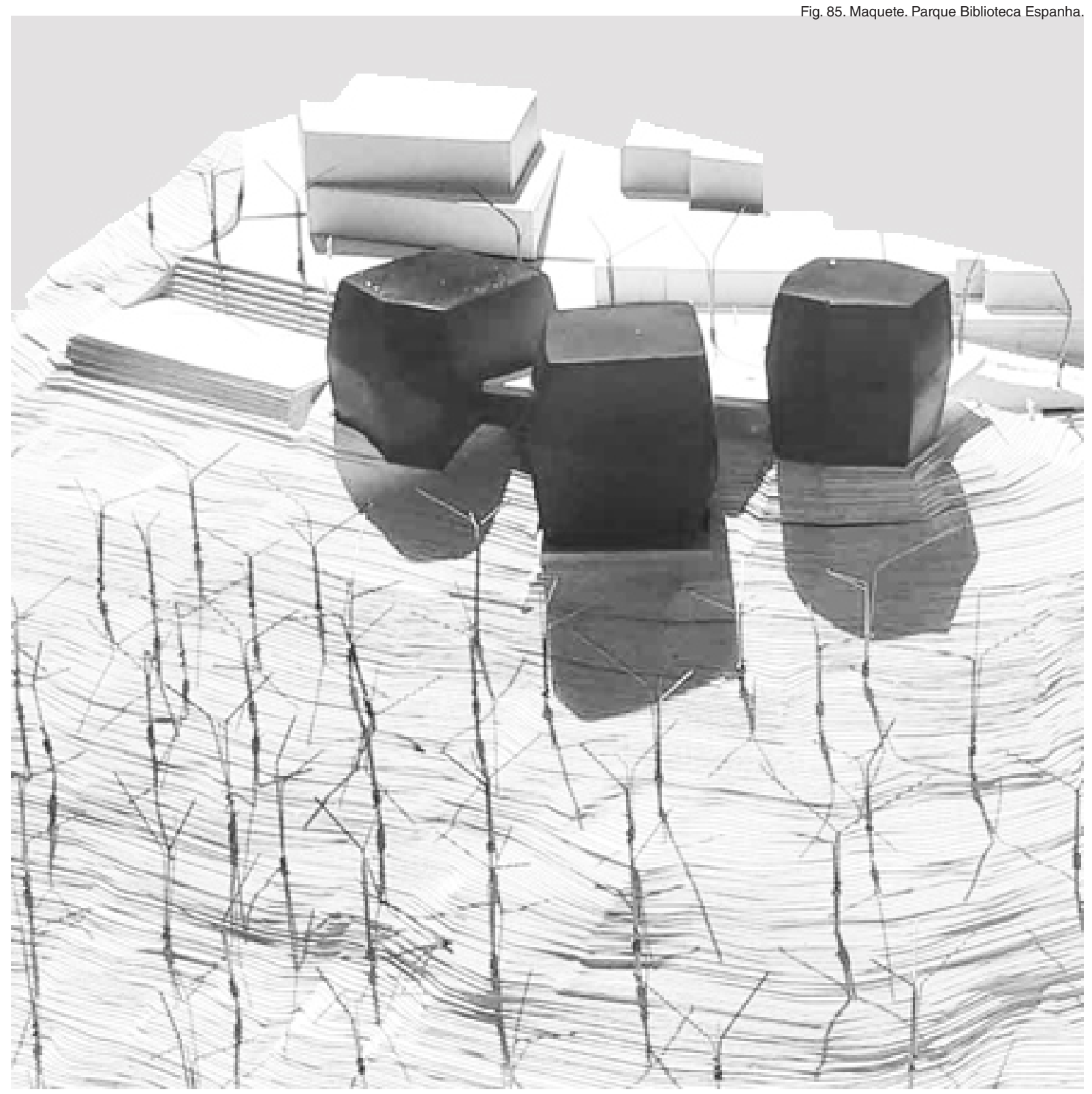


Essas modalidades de gestão aparecem como um fator-chave para a implementação de políticas que pensam a cidade em termos de complexidade integrada, e assumem um paradigma diferente daquele que conhecemos em Montevidéu, guiado pelas operações autistas de algumas estruturas estatais ramificadas. Nos últimos anos, Medellín ganhou vários prêmios em avaliações internacionais sobre seu processo urbano.

Medelín dá grande importância ao projeto dentro da promoção da qualidade de vida, reconhece o papel das disciplinas do projeto do território para os objetos. Os edifícios e espaços públicos estão sujeitos a processos de concurso ou, em alguns casos, a outros mecanismos de seleção profissional por antecedentes. Várias camadas de talentosos arquitetos, muitos deles muito jovens, concordaram em realizar projetos dessa maneira, gerando um arquipélago de "arquipélagos de arquitetura"45.

Dentro deste sistema que muda a percepção e as oportunidades de acesso à cidade e sua oferta para os mais humildes, entram estes parques-equipamentos.

Os Parques Biblioteca, localizados nas áreas de menor índice de desenvolvimento humano da cidade, são espaços que sempre associam um espaço público importante e um edifício com um programa que permite um conjunto de atividades diversas. Não é apenas uma biblioteca, mas também contém um programa para promover o empreendedorismo local, salas de leitura de livros e virtual, auditório, uma sala destinada para difundir a cultura do bairro onde o Parque Biblioteca for implantado, salão de exposições e serviços como lanchonete e local comercial Os edifícios têm uma superfície de entre 3.500 e $5.000 \mathrm{~m}^{2}$ e os espaços públicos superam em todos os casos os $10.000 \mathrm{~m}^{2}$, o primeiro deles, San Javier foi inaugurado em 2006 e hoje existem nove Parques. Esses parques funcionam em uma rede compartilhando e distribuindo conteúdo, para que não sirvam apenas a sua região, mas algumas atividades como conferências, concertos e exposições se realizam em uma delas, para que o Parque Biblioteca atenda a toda a cidade. A imagem dos turistas subindo o bondinho para chegar ao Parque Biblioteca na Espanha é frequente, demonstrando a capacidade que tem o sistema de mobilidade e equipamentos associados para integrar uma região deprimida e anteriormente isolada ao corpo da cidade.

\footnotetext{
${ }^{45}$ Com referência ao livro "Archipiélago de Arquitectura", publicado em 2010, reúne as trajetórias de uma geração através de 7 escritórios renomados de arquitetura, cujos nomes dão conta de um espírito: Oficina Informal, Camilo Restrepo, CTRL G + Federico Mesa, Manuel Villa, Mesa Editores, Paisajes Emergentes, Plan B: Arquitetos Gerações anteriores e arquitetos mais jovens que estes, configuram "os arquipélagos" que estão tendo chances e responsabilidades que gera esse sistema de transformação do território. (MESA,2010)
} 


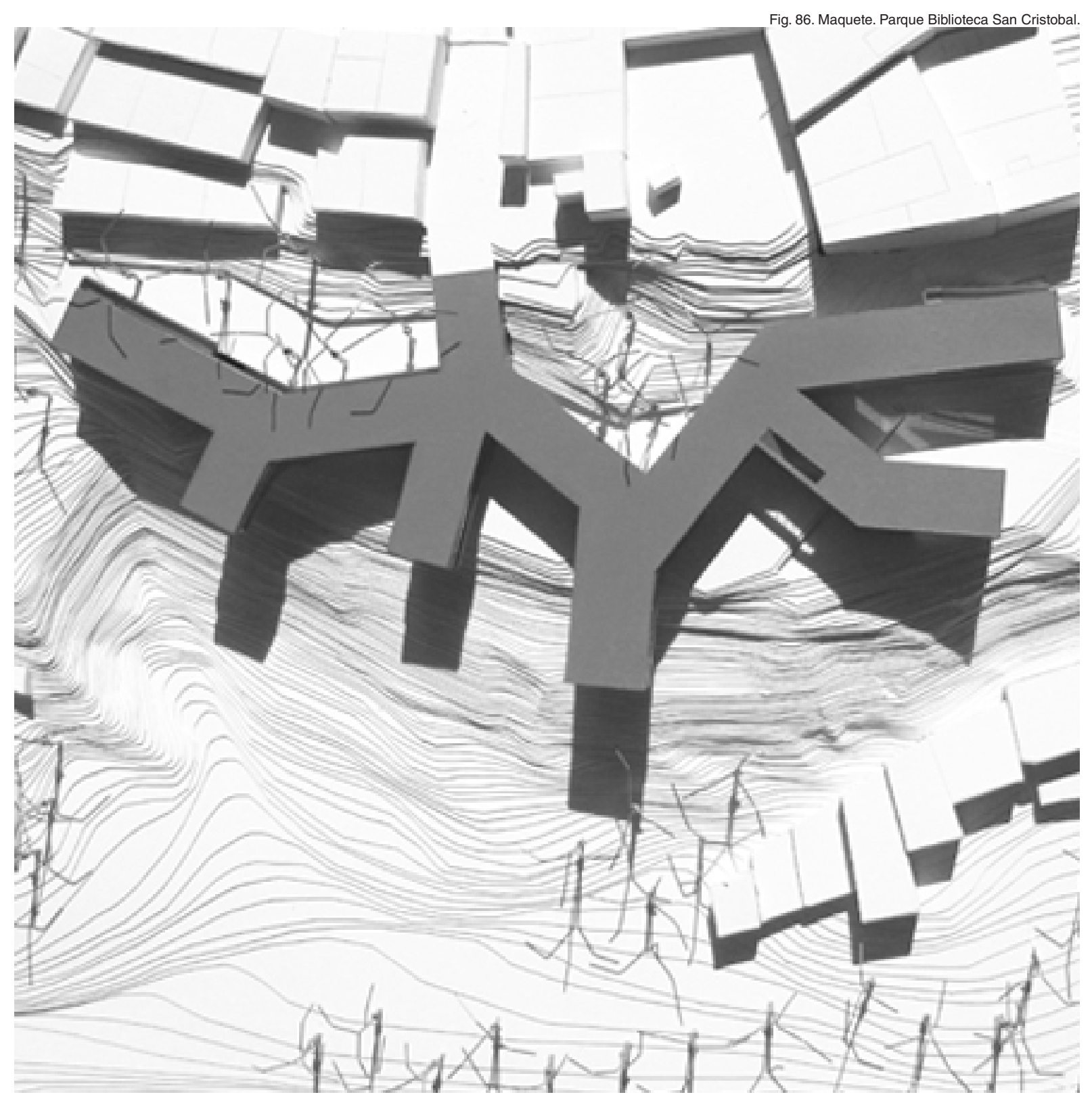


Os Parques Educativos são um empreendimento de todo o Departamento de Antioquia, em que Medelín faz parte, e estão localizados em pequenas cidades do departamento com um programa básico de aproximadamente mil metros quadrados, variam de caso a caso, que em geral tem uma pequena biblioteca, uma, duas ou três salas de aula ou oficinas e uma sala polivalente. A implantação dos 80 parques, realizados na segunda década de 2000, busca atender as transições entre o espaço urbano e o interior, oferecendo espaços externos de qualidade. Essas edificações e as atividades que eles abrigam, realizados na segunda década dos anos 2000, têm a capacidade de ter um alto impacto nos pequenos municípios, tornando-se centros de urbanidade. A trajetória dos Parques Educativos tem estado em problemas de discrepâncias políticas partidárias na alternância do governo de Antioquia.

A ausência de problemas seria impossível neste contexto de Terceiro Mundo, o que é surpreendente é a capacidade para uma transformação integral tão profunda, produzida em um contexto singularmente dramático. Um dos Parques Biblioteca chama-se Gabriel García Márquez, sugerindo talvez que a experiência só pode existir em um contexto de realismo mágico. Assim se expressa um dos mecanismos de transformação:

Um Parque Biblioteca é um mapa humano feito de reuniões e conversas. É
um mapa onde você pode pintar a vida com as cores da pele, desenhar a
semana sem o tédio da rotina, sonhar, sentir e pensar sem pedir licença,
viajar como uma floresta cheia de livros, sons, jogos e imaginação, visitar
seus lugares como se vai até a intimidade, ao amor e à amizade, aprender
brincando e brincar descobrindo, compartir a dignidade, a paixão, a
esperança e as necessidades. Um Parque Biblioteca é um mapa que vai
sendo desenhado e lido com a vida das pessoas. (MEDELLín, 2006, p.1,
tradução nossa) A citação faz parte do Pacto do Cidadão, documento em que se estabelece um compromisso em relação ao programa dos Parques Biblioteca de Medellín. Nela, o prefeito, a equipe do Sistema de Bibliotecas da cidade, os trabalhadores e os moradores da cidade de Medellín concordam ${ }^{46}$ : "Declarando os Parques Biblioteca como espaços de liberdade"(Ibid. p.2).

As duas experiências da Parques Equipamento, integradas em um sistema complexo de intervenção no território, têm a capacidade de reestruturá-lo. São ágoras ou fóruns, espaços de encontros que operam muito além dos programas que oferecem, daí seu status de parque simbólico e espacial ao mesmo tempo.

${ }^{46}$ Orlanda Jaramillo (2011 p. 263-264) explica em sua tese como o Pacto do Cidadão faz parte de uma estratégia de construção institucional e coletiva para conseguir a apropriação do Parque pelos moradores. 


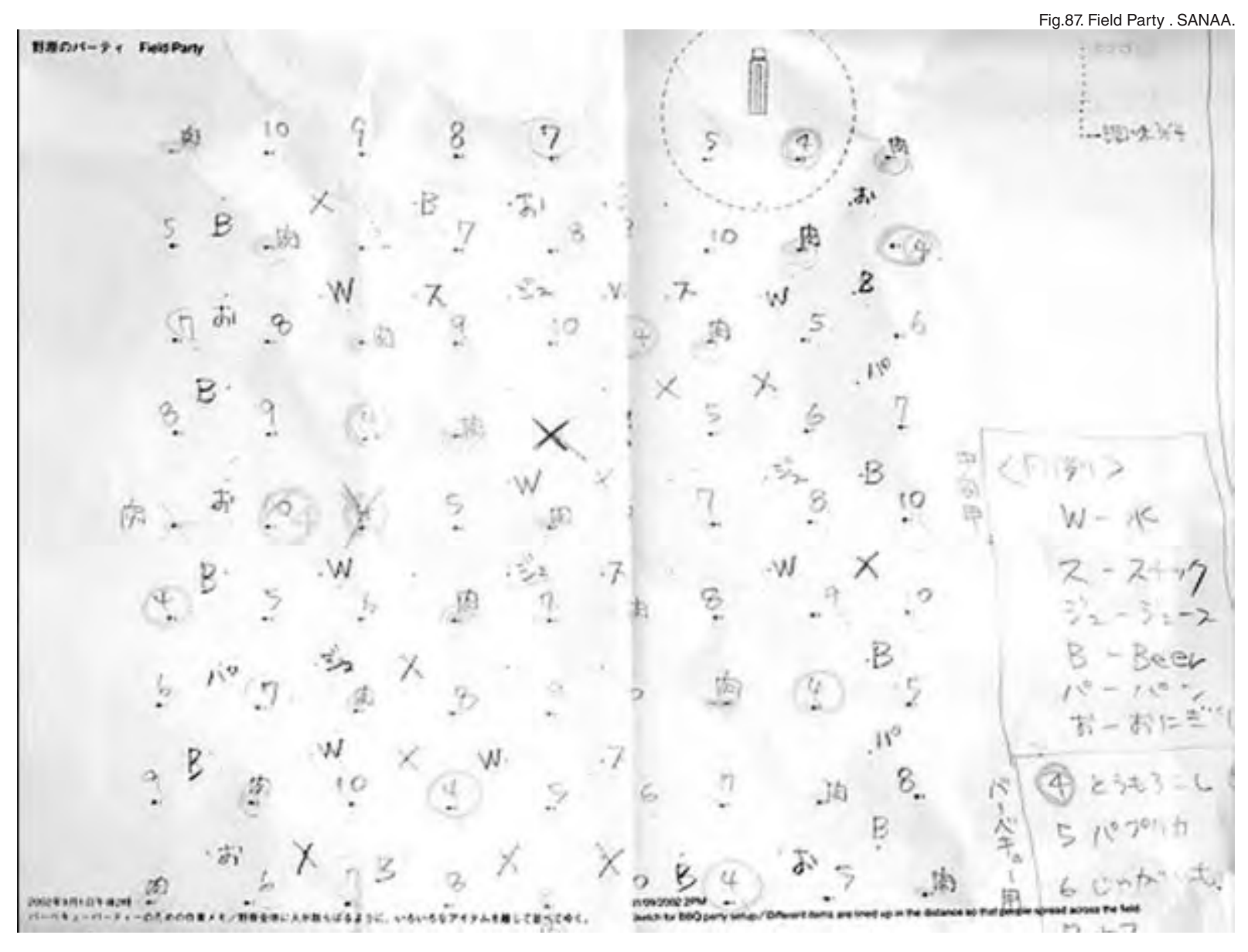




\section{TRÊS EDIFÍcIOS COMO PARQUES}

Um novo campo, verde e horizontal, em um subúrbio recente de Tóquio, é um lugar desolado, não por vocação, mas porque ainda não foi inaugurado pela vida. Um parque que não é um parque. Nele, Sejima e Nishizawa realizam um workshop em 2002, com a Keio University (um grupo de estudantes da Sejima) e em colaboração com o fotógrafo Takashi Homma. O resultado é uma intervenção no parque "Field Party" (IDENBURG, 2010), que convida para a interação dos vizinhos, através de um evento em que 100 pontos dispostos no parque têm churrasqueiras com componentes (carne, legumes, bebidas) para um piquenique no parque. Se você for a um dos pontos, encontrará apenas um desses componentes, então, preparar uma refeição completa pede para que você se mova no espaço e gere encontros. "A festa parece desconectada, mas as pessoas compartilham a chegada do pôr do sol e estão felizes" (SEJIMA em: IDENBURG, 2010, p.19, tradução nossa). Os churrascos são organizados de acordo com uma grade regular separada por 12 metros, e em todo o parque há algumas cadeiras que os participantes podem movimentar livremente. Como parte do evento, foi instalado um guindaste que oferecia a possibilidade de subir e observar o parque de cima, mostrando a organização da intervenção e os vizinhos, o que não podiam ver do chão. O parque foi ativado em 2002, ano seguinte ao SANAA concluir o projeto executivo do Museu do Século XXI (GARCÍA FERNÁNDEZ, 2015).

O parque como uma ideia para pensar edifícios, é uma noção que a dupla japonesa vem desenvolvendo há alguns anos. O deslocamento é explicitado em uma entrevista com Sejima.

\footnotetext{
Mas isso foi há muito tempo. Então estava interessada em fazer esse tipo de espaço, um tipo de parque, semelhante ao conceito de parque japonês. Esse tipo de espaço permite que pessoas diferentes estejam no mesmo espaço ao mesmo tempo. Pessoas diferentes e de diferentes gerações podem compartilhar o mesmo espaço, elas podem estar juntas. Da mesma forma, em um parque se pode reunir um grande grupo, mas ao mesmo tempo uma única pessoa pode estar sozinha lendo um livro ou bebendo suco. Eu gosto desse sentimento ou desse personagem em prédios públicos. Naquela época, eu costumava explicar que estava interessado em fazer esse tipo de parque, mas nunca tive a oportunidade de desenvolvê-lo. O Stadstheater de Almere é o primeiro projeto em que apliquei diretamente essa ideia de espaço público. Nele tentamos planejar as diferentes rotas e o sistemas de circulações para que as pessoas pudessem ir a qualquer lugar da maneira mais direta, mas ao mesmo tempo escolher caminhos diferentes. Essa abordagem acabou modificando as proporções usuais dos corredores. (SEJIMA in DÍAZ MORENO e GARCÍA GRINDA, 2003a, p.23, tradução nossa)
} 
Fig 88. Desenho do Stadstheatre do Almere
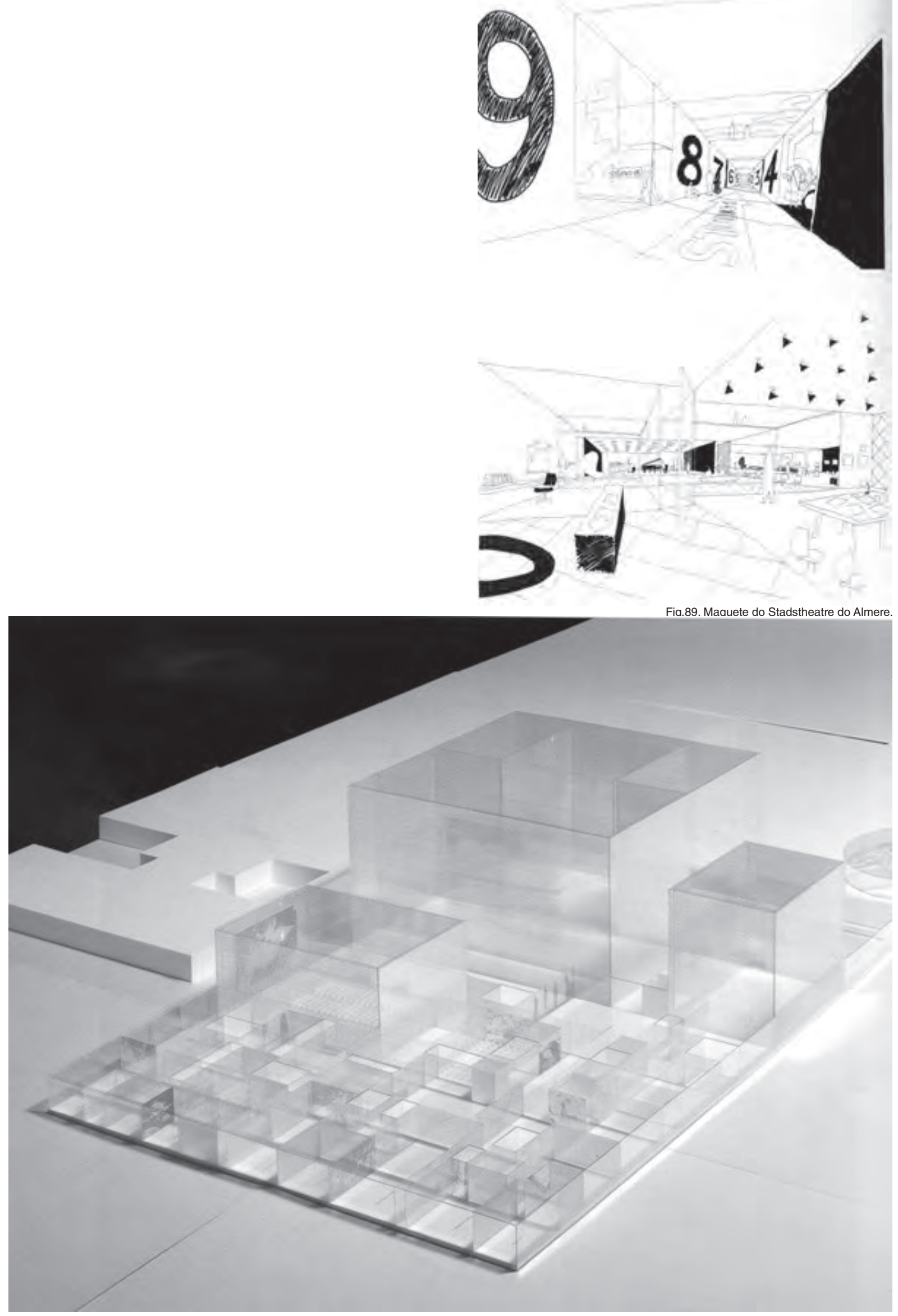
O uso metafórico do conceito de parque de Sejima e sua relação com a arquitetura tem sido estudado (JARAíZ, 2012), enfatizando seu compromisso com um espaço neutro que de alguma forma permite aos visitantes incorporar sua própria subjetividade, seu próprio modo de relacionar-se com espaço, como acontece em um parque. Jaraíz classifica os parques de SANAA de um ponto de vista espacial e morfológico entre Parques Contínuos e Parques por Acumulação, distinção que não será central nesta consideração a partir da desespecialização programática. Segue uma abordagem a um grupo de três projetos projetados entre 1998 e 2001, nos quais podem ser lidas alguns invariantes e algumas mutações na forma como o projeto é tratado como um todo e suas partes (que correspondem aos parques por acumulação de Jaraíz). Este grupo é chamado de "Edifícios como Parque" e é composto pelo já mencionado Stadstheater de Almere, o Museu do Século XXI e o Museu de Vidro de Toledo. A seção de Parques, que se fecha com outro projeto logo depois, concursado em 2004: o Rolex Learning Center, que pertence ao conceito de parque contínuo.

O "Edifício como Parque 1", projetado pela SANAA, é o Stadstheater de Almere, "De Kunstlinie". Um concurso vencido em 1998 integrado ao Plano Diretor desenvolvido pela OMA, dá a este edifício um quarteirão que entra em um lago artificial. O edifício foi inaugurado em 2007, integrando dois programas: Centro Cultural e Teatro com duas grandes salas. Um plano construído de uns 110 por 90 metros, como se estivesse flutuando na água, compacta esses dois componentes em uma única geometria e em uma única jornada espacial que anuncia sua vocação de parque como um espaço de troca e encontros. A maquete de acrílico transparente apresentado ao concurso expressa essa contiguidade espacial. Todos os espaços públicos acontecem neste nível principal (quase único) que abriga cerca de 11.000 dos 15.000 metros quadrados construídos. O projeto SANAA surge de um processo de abstração, jogando entre diferenças e similaridades. O programa não é expresso ou narrado, simplesmente se converte em espaço e forma dentro da malha ortogonal. A estrutura de suporte nunca é separada dos limites dos espaços, para os quais se faz um esforço de projeto e estrutural. No exterior, as diferentes alturas dos espaços singulares são "coordenadas z" de alguns dos quadrantes que elevam o edifício do nível geral da "plataforma mais baixa" e são lidos como meras elevações da massa contínua que é o retângulo original de um nível. Alguns dos quadrantes interiores são " $\mathrm{z}=0$ " e eles se tornam pátios que levam a diversos espaços que são expostos à visão de outros análogos, mas diferentes. 


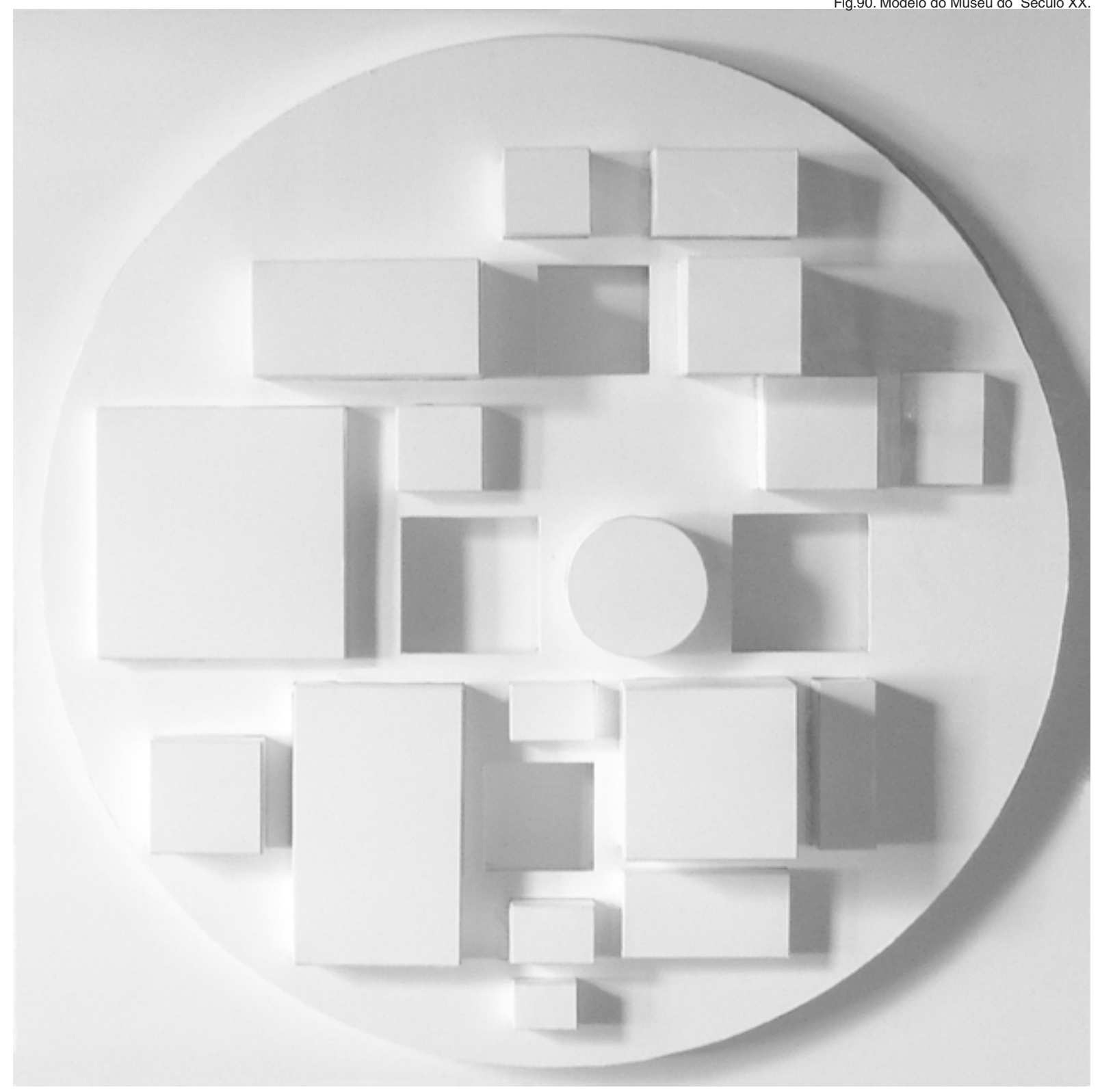


O museu do século XXI em Kanazawa, "Edifício como Parque", foi projetado e apresentado a concurso em 1999. Como em Almere, o programa do concurso previa dois programas: um museu e um centro comunitário. A proposta de Sejima e Nishizawa que acaba ganhando o concurso, parte da combinação dos dois programas em uma só peça, ao invés de separá-los, como foi feito em outras propostas. A organização do conjunto é feita através de uma forma aberta em todas as direções.

\footnotetext{
Para SANAA "um museu é uma comunidade e uma comunidade é um museu. "47 A proposta incluiu a ideia de "um museu como um parque", aberto à cidade, que ia fazer parte da comunidade aberto à cidade muito além dos seus programas. (GARCÍA FERNÁNDEZ, 2015, p.31, tradução nossa).
}

Um círculo de 112,5 metros de diâmetro dividido por uma malha de 3 metros é ocupado de figuras retangulares ou quadradas de diferentes tamanhos, que ocupam os espaços das salas de exposição. Estas salas são de diferentes alturas segundo um ajuste espacial e de proporções, brancas e opacas em seu entorno. Elas estão sempre separados, deixando zonas intermediárias que definem a condição mais pública do edifício.

Elas estão sempre separadas, deixando zonas intermediárias que definem a condição mais pública do edifício. O sistema de relações proposto, assume pleno significado na conexão com o exterior, o parque-parque e a cidade, alguns destes espaços intermédios, permitem atravessar visualmente o edifício. "A semelhança dos caminhos de um parque, organizamos corredores interiores e exteriores de vários tipos, dimensões e níveis de eficácia" (SANAA em CROQUIS, 2000, p.210, tradução nossa). O processo do projeto é longo, e o trabalho é produzido por depuração que combina uma atenção obsessiva ao programa e um cuidado formal extremo, mas sem preconceitos. Foram produzidos 100 maquetes de discos acrílicos (HASEGAWA in SEJIMA, K. e NISHIZAWA, R., 2007) para ajustar as relações no processo do projeto executivo do Museu do Século XXI, onde a atenção às rigorosas exigências funcionais do museu se combina com os interesses dos arquitetos (HASEGAWA, 2000). Os encontros e a simultaneidade de uso do espaço propõem algumas surpresas propostas pelos arquitetos como os espaços do Teatro e do Auditório que, às vezes durante um ensaio, são visíveis a partir do piso principal. Outros jogam com a mesma lógica,

\footnotetext{
${ }^{47}$ KUROSAWA, Iromi. "In the name of the citizens" en ELIASSON, Olafur. "Your Chance Encounter" 21st Century
} Museum of Contemporary Art. Lars Muller Publishers, Zurich, 2010. [Referido em GARCíA FERNÁNDEZ, 2015] 
Fig. 91. Diagramas do Glass Museum.
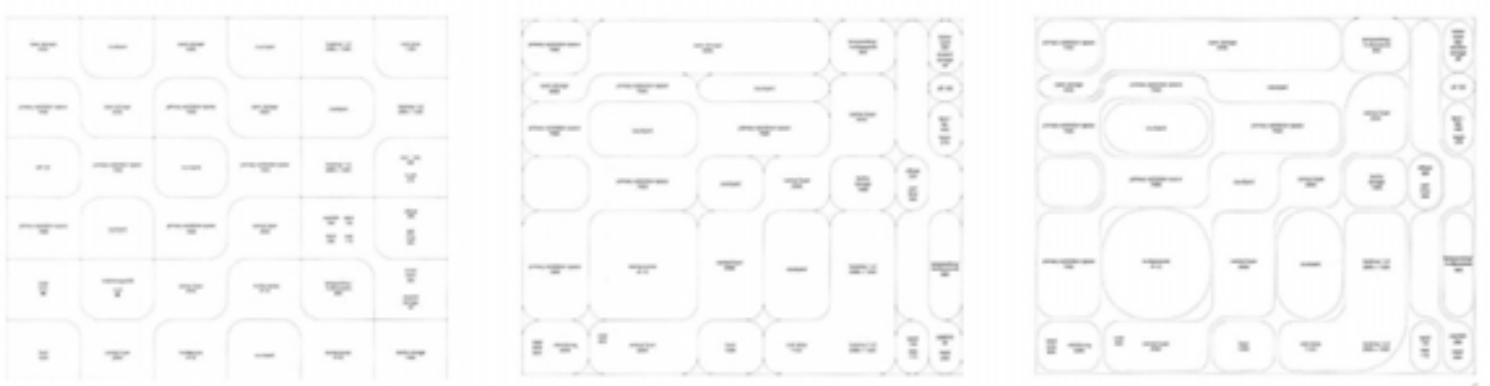
proposta por artistas como a Piscina de Erlich (1999), obra encomendada ao artista pelo Museu que propõe uma relação semelhante.

O "edifício como parque 3", é o Pavilhão de Vidro do Museu de Toledo (projetado em 2001 e inaugurado em 2006) e vai um passo à frente na Desespecialização Programática, o espaço intermediário e os fragmentos se fundem em uma única entidade, os espaços que em Kanazawa são intermediários para o deslocamento e os encontros (o termo circulações é evitado nesta descrição), são tratados analogamente aos espaços principais. O projeto, um pavilhão de exposições de 62 por 62 metros, origina-se numa grade neutra de 6 por 6 quadrados cada um com uma área de cerca de 100 metros. Os diferentes espaços ocupam essa grade em padrões associativos diagonais, respondendo às dimensões, qualidades espaciais e relações do programa de necessidades. O uso do vidro gera novas relações espaciais que visualmente comunicam espaços destinados a diversas atividades, uma tensão aparece no "contraste entre os movimentos abruptos das oficinas de fabricação de vidro, com seus fornos de temperatura altíssima e a calmaria elegante dos expositores da coleção de vidro" (HASEGAWA in SEJIMA, K. e NISHIZAWA, R., 2007, p.185, tradução nossa).A forma de cada espaço "flutuante" se configura guiada por essas regras do sistema, que vão se refinando em instâncias sucessivas, como mostrado por uma sequência de diagramas que descrevem a evolução do projeto. A ambiguidade espacial, que sempre convida o visitante a colocar algo de si, se refina neste projeto de vidro que propõe todas as nuances da matéria, luz e percepção: transparências, reflexos, opacidades, etc.

Os Edifícios como Parque são propostos como um todo que contém fragmentos, elementos abstratos que apresentam certo grau de especialização programática, e que se aglomeram entre si, assumindo ambiguidade e abertura de usos. O todo e as partes promovem diversas relações de várias maneiras: formais, espacial e de sujeito.

Um processo de remoção de todo o lastro figurativo parece guiar estes projetos do SANAA, portanto desaparece a informação que deveria relacionar os espaços com seus programas (HASEGAWA, 2000), o produto com o processo (DÍAZ MORENO e GARCÍA GRINDA, 2003a,b.), para a estrutura e seus esforços, ou qualquer outra consideração descritiva. A forma e a matéria são componentes puros colocados a serviço da operação global. Yuko Hasegawa (Op.cit.) identifica alguns desses procedimentos de remoção de toda contingência com o conceito de leveza. A forma elementar resulta de um processo 
Fig.92. The Neufert Suite, G.Kuitka, 2002.
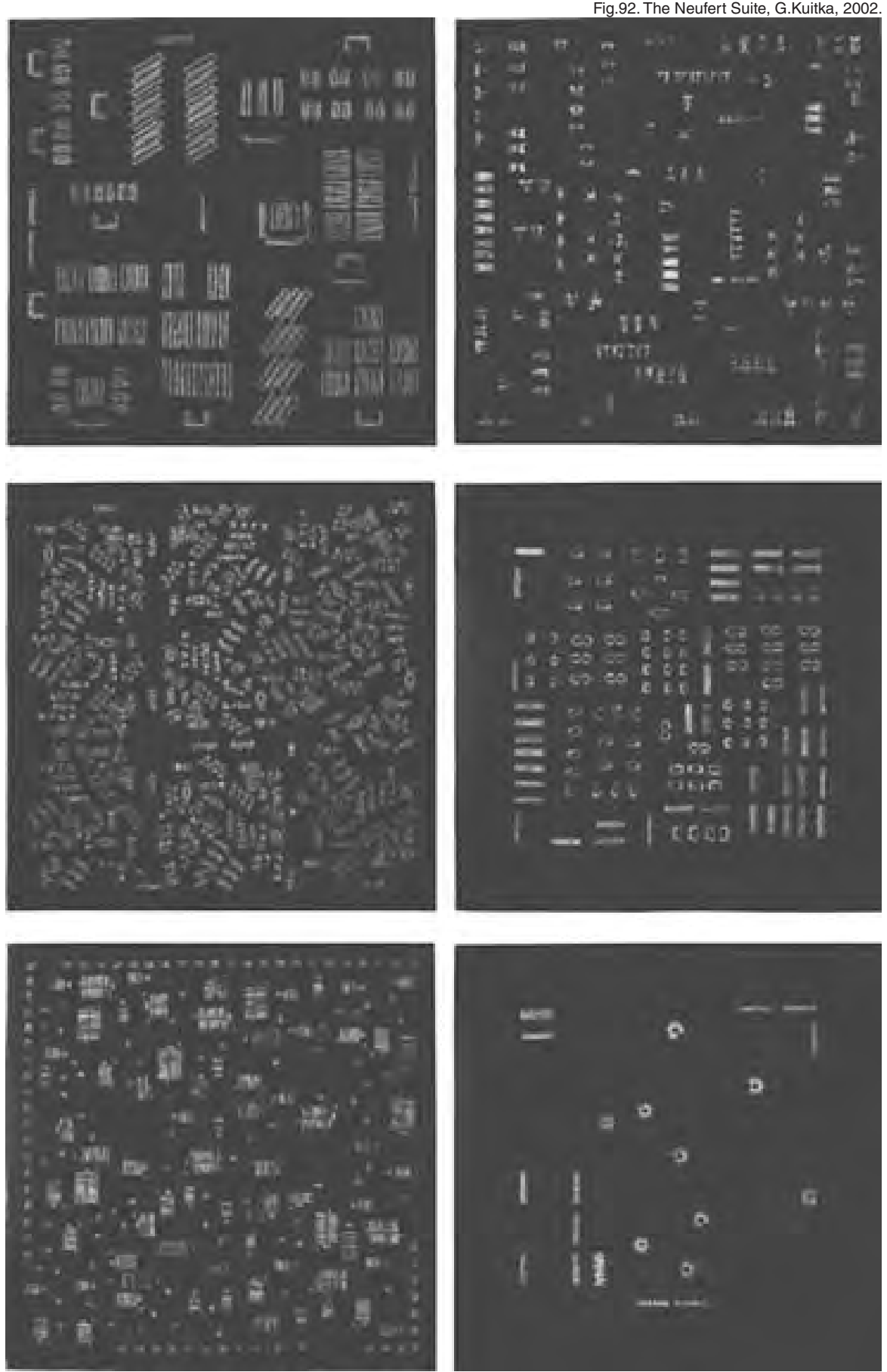
de "destilação" (que ela chama de "interpretação universal"), em que as demandas e restrições se reconhecem e manipulam para submetê-las a um despojado e autônomo sistema expressivo. Alta abstração e variações sutis.

A condição contemporânea dos projetos SANAA é evidente e se pode ler muitas conexões. A relação com Yuko Hasegawa, curador do Museu do Século XXI durante o processo de comissionamento e depois da obra construída, e através dela com artistas destacados contemporâneos que instalam obras e exposições no Museu, explicam algumas dessas conexões a partir dos anos 2000 Outros provavelmente só têm a ver com certos temas do nosso tempo: em 2003, Lars von Trier estreia "Dogville", um filme em que a simultaneidade e eliminação dos limites físicos de um povo, trata o espaço como protagonista, propondo relações que eles são frequentemente encontrados no espaço construído pelos japoneses.

Os projetos cuidadosos em sua forma não são "esculturas" da auto-expressão da subjetividade, mas sim apoios para a experiência espacial. A obra de SANAA tem sido vinculada à abordagem da arte relacional:

A essência desses projetos é baseada em fomentar (sem forçar) e expor sistemas de relações. (IDENBURG, 2010, p. 18, tradução nossa).

A arquitetura se tornará um espaço específico de troca que cria zonas livres" e formas de perceber o tempo que contrastam com os que estruturam o cotidiano, e que estimulam as trocas intersubjetivas, fazendo recair sobre as pessoas e suas ações recaiam em todo o interesse de arquitetura ". (DÍAZ MORENO e GARCÍA GRINDA, 2003b, p38, tradução nossa)

No livro A Estética Relacional afirma-se:

A possibilidade de uma arte relacional (uma arte que toma como horizonte teórico a esfera das interações humanas em seu contexto social mais do que a afirmação de um espaço simbólico autônomo e privado) atesta uma inversão radical dos objetivos estéticos, culturais e políticos postulados pela arte moderna. (BOURRIAUD, 2009b, p.19)

O trabalho dos japoneses mostra até que ponto esta condição depende intensamente da forma, entendida como segue:

Ou que chamamos de forma? Uma unidade, coerente, uma estrutura (entidade autônoma de dependências internas) que apresenta as características de um mundo: a obra de arte não detém o monopólio da forma; ela é apenas um subconjunto na totalidade das formas existentes.(Ibid., p. 26) 
Fig.93. Redesenho de diagramas, StadsTheatre de Almere, SANAA
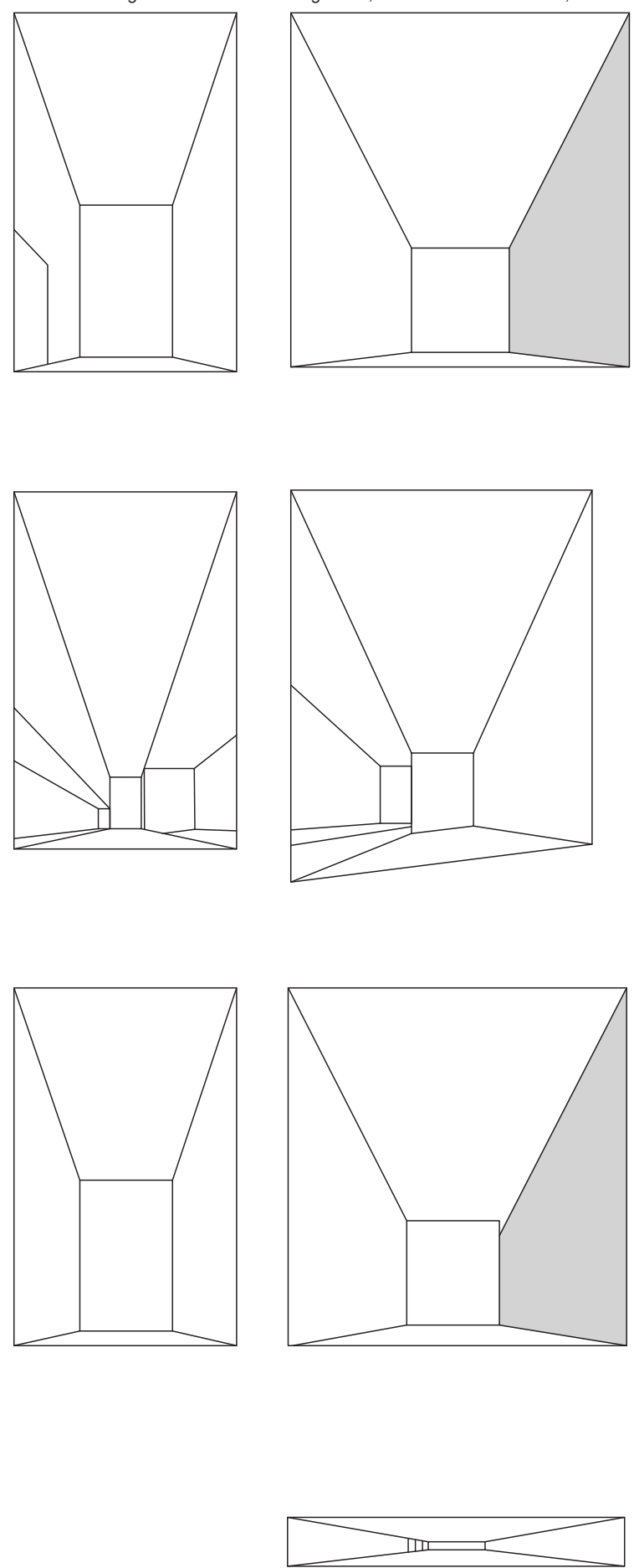
A serie dos três Edifícios Parques apresentada como momento particular da trajetória de SANAA, mesmo que boa parte da sua obra pode ser lida desde a noção da desespecialização programática. A silenciosa abstração, aquela que Yuko Hasegawa prediz como incompreensível para futuras gerações, é um ponto de partida estimulante para apropriações diversas a partir dos padrões espaciais propostos nos projetos e seus espaços. Os diagramas de desespecialização programática e espacial apresentados em seguida poderiam ser um ponto de partida para um trabalho de projeto na escola de arquitetura de ocupação com outros programas diversos. 


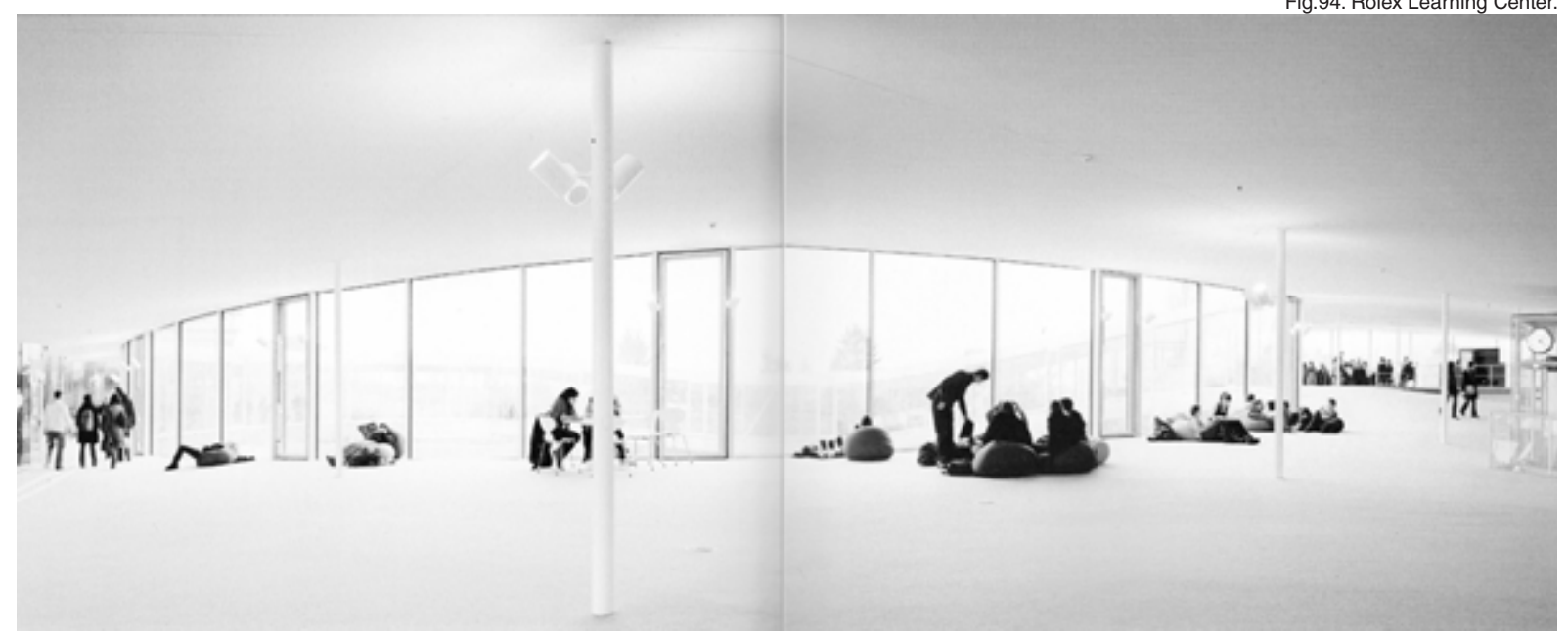




\section{COMO UM PARQUE BRANCO}

Edifícios, como pessoas, estão sujeitos ao tempo/ e existem em um mundo tridimensional./ É por isso que o nosso filme é em 3D./ É um convite para passear/ experimentar e ouvir, pelo menos uma vez. (WENDERS, 2010, tradução nossa)

Wim Wenders, diretor de culto de arquitetos por seu olhar refinado e profundo de territórios e cidades, filmou filmes exemplares como "Paris-Texas", "Asas do desejo" e muitos outros. Convidado por Kazuyo Sejima, diretora da Bienal de Veneza de 2010, intitulada "People meets in Architecture", ele filma um curta-metragem em que apresenta o EFPL Learning Center como um personagem em relação a outros personagens, os temas que o "habitam". Utiliza tecnologia 3D e o tempo (condições de espaço arquitetônico) para apresentar essa relação.

O edifício projetado por SANAA (Sejima and Nishizawa Associated Architects) é um espaço singular, definido como um programa múltiplo de auditório, biblioteca física e digital, escopo de estudo e acima de tudo um ponto de encontro para todos os membros da comunidade acadêmica, sem hierarquias estatutárias, estimulando o trabalho em equipe. O edifício é proposto como um centro de vida para o campus hierárquico da École Fédéral Polytechnique de Lausanne, um edifício-espaço público contínuo, que permite a coexistência de 10.000 pessoas por dia (della CASA \& EUGÉNE, 2010). Uma excepcional manipulação arquitetônica de um programa desespecializado, para uma instituição que se exige minimizar as compartimentalizações para configurar uma ágora da comunidade acadêmica. O edifício é proposto como uma geografia, um enclave a meio caminho entre a natureza e o artifício, um parque completamente branco. A laje de piso e do teto, se separam e se juntam sutilmente formandos espaços de diversas propriedades em continuidade espacial.

O espaço profundo moldado mas dominante horizontal, um retângulo de 110 por 149 metros que requer uma engenharia complexa para resolver sua estrutura e suas funcionalidades ambientais, pode ser visto como uma possível realização de outro espaço, horizontal, profundo e desespecializado, projetado em termos de condensação especulativa das possibilidades técnicas disponíveis a partir dos anos 70: a "No-stop City" de Archizoom. (MARTíNEZ CAPDEVILLA, 2014). ${ }^{48}$

${ }^{48}$ Pablo Martínez Capdevilla faz um estudo sobre os desenvolvimentos da No-stop City. 
Fig.95. Marquise do Ibirapuera. E. Gurian, 2014.

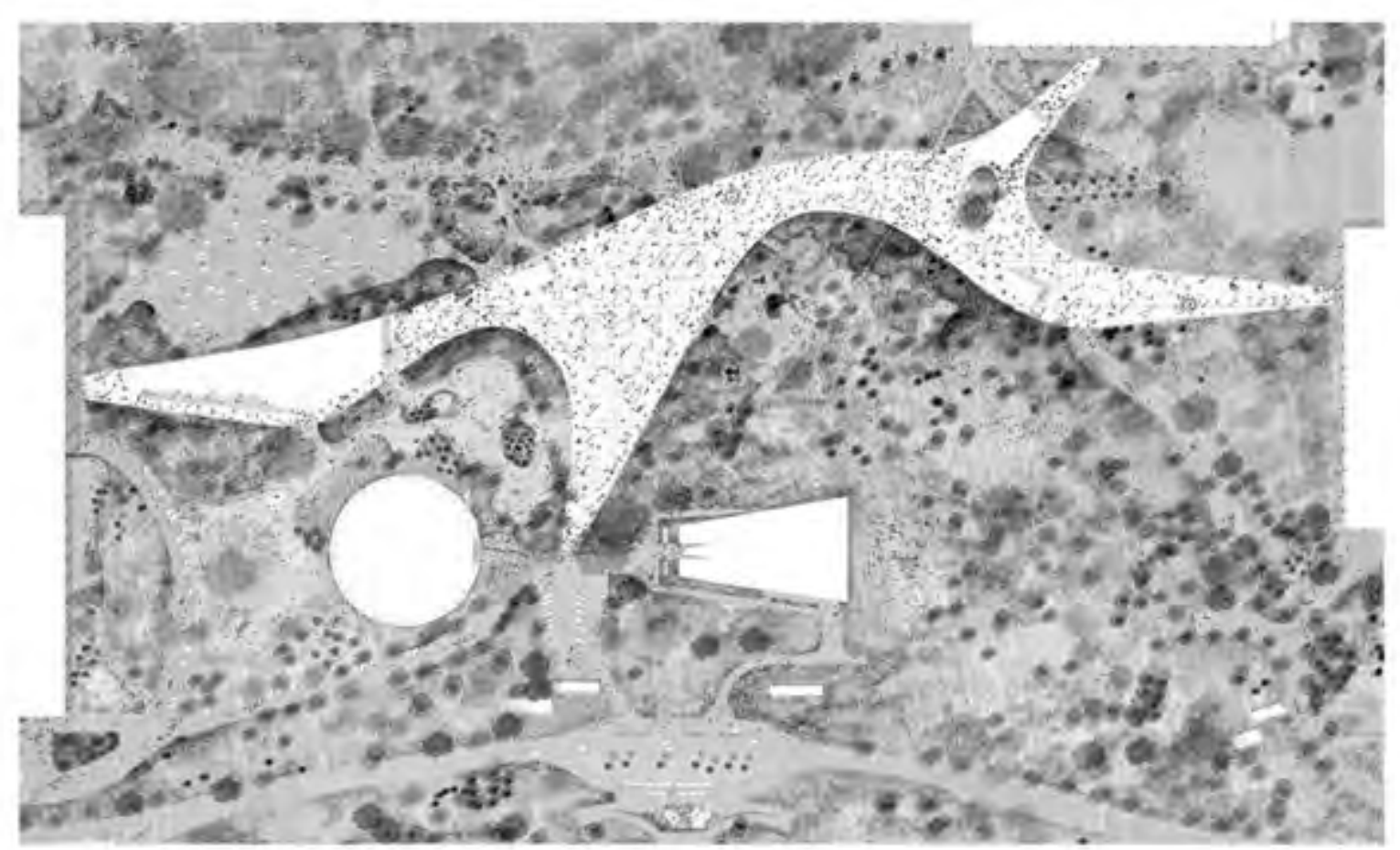


Voltando ao "Field Play", aparece a dualidade que define a arquitetura do SANAA: A disposição do guindaste na intervenção do parque "Field Play" que permitia que o piquenique fosse observado e entendido a partir da visão aérea e abstrata, coloca em evidência um procedimento em relação ao espaço e ao projeto, que vai desde a abstração no papel e propõe certas relações no espaço, que ganham sentido com as relações entre os assuntos que são produzidos. A visão zenital devolve o contingente ao abstrato, o mecanismo do projeto ocorre de um lado para o outro.

\section{BRANCO DO PARQUE}

O plano de piso e o plano do teto do EFPL Learning Center, lembram sutilmente à Marquise do Ibirapuera. É uma imagem muito similar para dois projetos diferentes em termos de programa, época e geografias, mas que compartilham uma condição de abertura que as reúne neste argumento sobre a desespecialização programática e o projeto dos equipamentos públicos.

A Marquise já foi apresentada neste mesmo capitulo, pela impossibilidade de entende-la a partir das disjunções convencionais: Ela é arquitetura edilícia ou projeto de espaço público? Ela é um projeto secundário para a conexão de objetos principais, ou, ela por ela mesma, o melhor projeto do Niemeyer como propõe Verde Zein?

Ela é um objeto cuja importância principal são suas prestações não o objeto pelo objeto. Mas a especificidade do projeto, suas qualidades espaciais, são cuidadosamente desenhadas. Não existe contradição entre as duas apreciações, pelo contrario, elas se complementam.

Eduardo Pereira Gurian apresenta uma dissertação de mestrado na FAU-USP que enfoca a Marquise como suporte aberto (GURIAN, 2014). A dissertação faz um estudo do projeto, sua origem, sua vida e os diferentes usos e atividades que tem acolhido nos 60 anos de vida, para acabar com um registro gráfico e textual dos "Usos Cotidianos. A marquise ocupada", descrevendo a vida na Marquise hoje. Esse registro é uma aproximação de estudo e comunicação às múltiplas situações, personagens e fatos que envolvem a vida de um espaço público ao longo de um dia de fim de semana. Essa condensação da abertura e complexidade do espaço publico, contribui para o deslocamento dessas qualidades nos equipamentos, partindo da desespecialização. 


\section{CATALOGO EQUIPAMENTOS MUNDO}

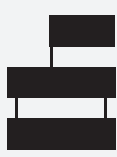

CEU

Autor: Equipo CEU SMDU

Ano: 2013-2016 (não concluido)

Localização: San Pablo, BR.

V02 Pg 552
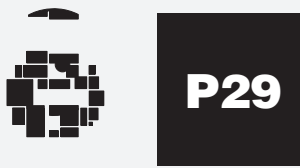

MUSEO SIGLO XXI

Autor: SANAA

Ano: 1999-2004

Localização: Kanasawa, JP

V02 Pg 586

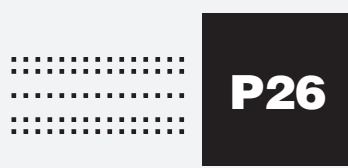

\section{FUN PALACE}

Anto: 1960-1966

Localização: Londres, UK

V02 Pg 570

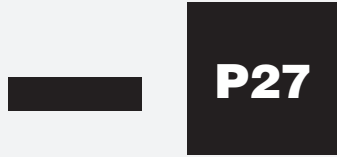

INTERACTION

Autor: Cedric Price

Ano: 1970-1981 2003

Localização: Camden Town, Londres,

V02 Pg 574

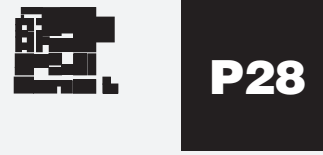

STADSTHEATER

Autor: SANAA

Ano: 1998-2007

V02 Pg 580

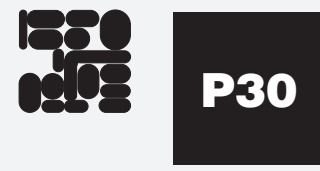

MUSEO DE TOLEDO

Autor: SANAA

Localização: Toledo, USA

V02 Pg 592 
Fig.96. “Galerias” FADU. Di Bello, Lombardi e Fazakas, 2017.
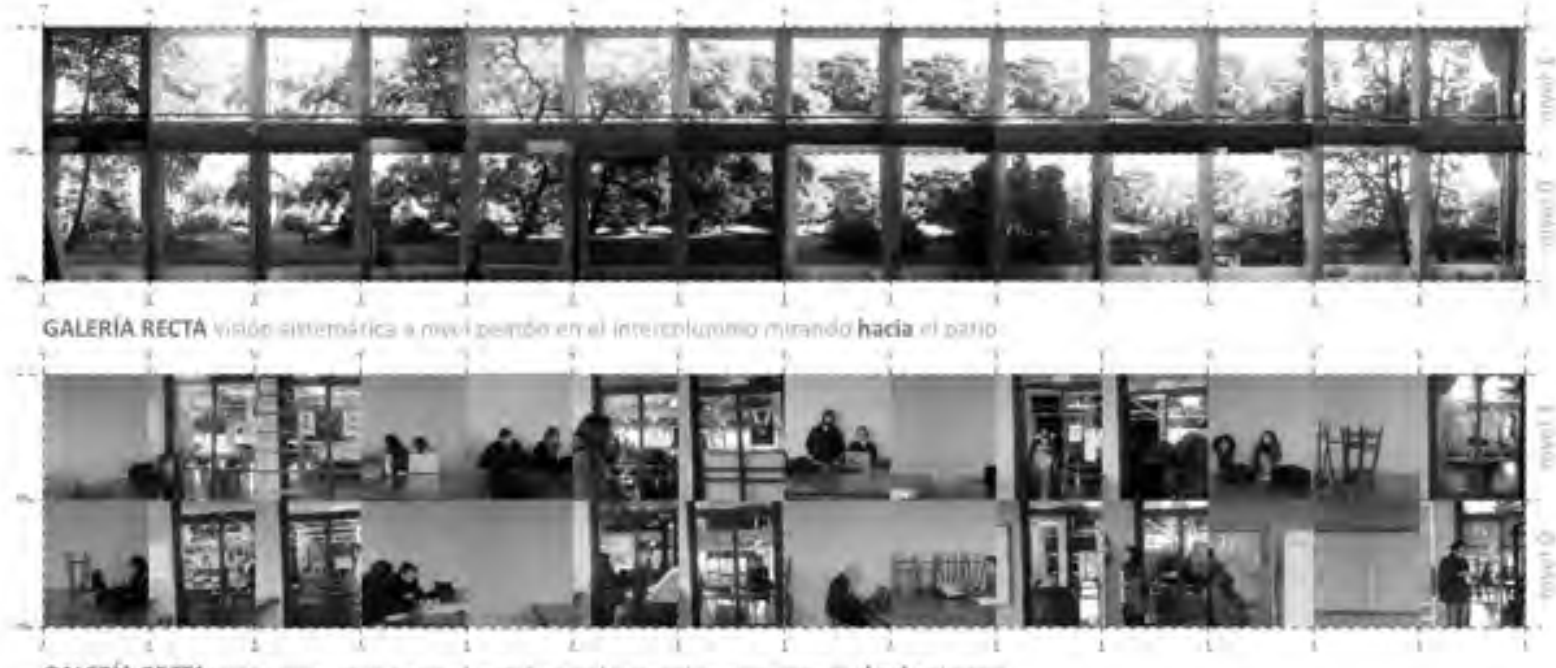

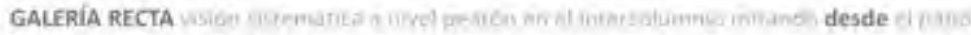

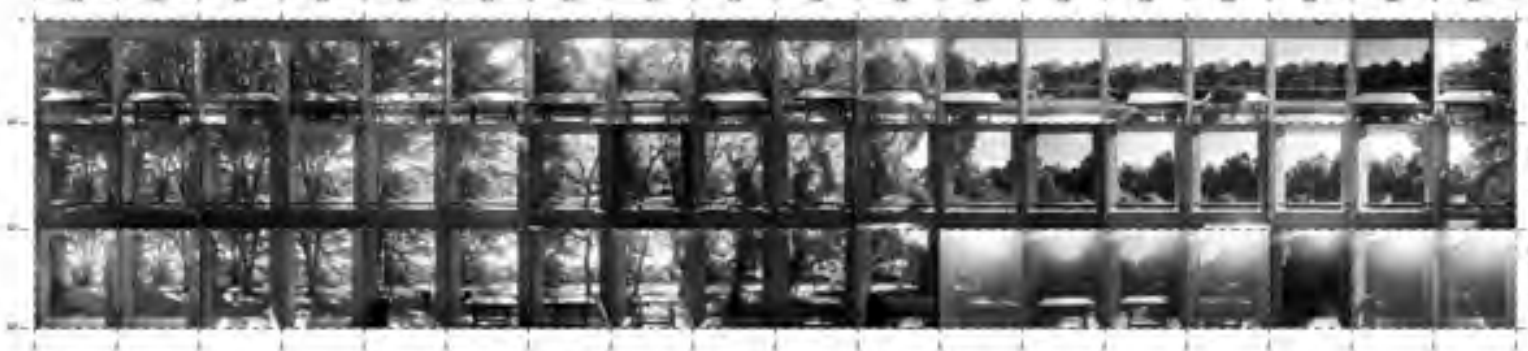

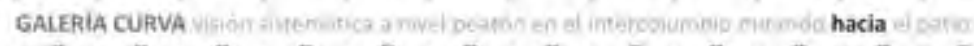

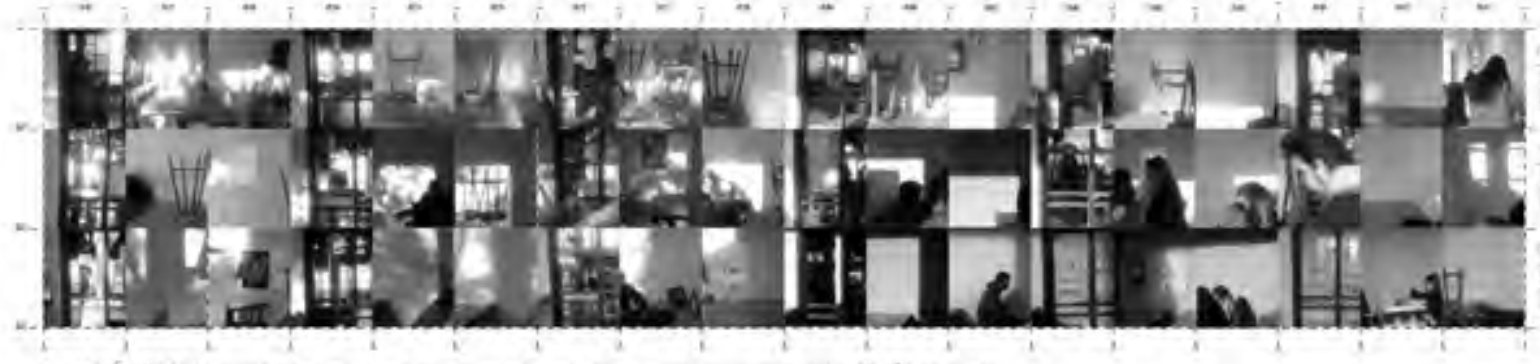

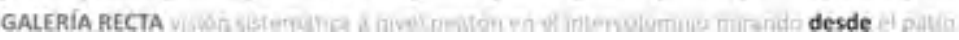




\section{OUTRAS DESLOCAÇOES}

A construção da noção de desespecialização programática permite movermos em outras direções. Depois do arquétipo das ruínas, e depois de considerar três espaços públicos emblemáticos: praia, rua e parque, volta-se a pensar em edifícios, alguns casos de edifícios cuja expressão não se refere imediatamente a instalações públicas. Materiais que permanecem em rascunhos, como possíveis trajetórias para trabalhos futuros, se apresentam brevemente.

A primeira surge da experiência como estudante e professor, que observa algumas faculdades e escolas de arquitetura a partir da relação entre programa e espaço. As Faculdades de Arquitetura dão lições que se aprendem através da experiência, dos projetos e da maneira como são apreendidas e praticadas por seus habitantes particulares (sem juízo de valor positivo ou negativo): arquitetos, professores e futuros arquitetos.

Uma delas, a Faculdade de Arquitetura, Design e Urbanismo (ex. FARQ UDELAR, Montevidéu, Uruguai) que passou por um concurso e foi projetada em 1938 e terminada em 1946. Seu projeto para 500 alunos em um ambiente caracterizado por um pátio e uma lagoa central, e um edifício ao seu redor (narrando esquematicamente um projeto cuidadoso em sua geometria, proporções espaciais e relações) em um sistema de galerias abertas e salões que se repetem e que olham para as ruas. O edifício hoje absorve a presença de cerca de 5 mil estudantes com base na generosidade de seus espaços, em suas galerias cobertas e abertas para o pátio (que nos planos originais são rotulados como "circulação") são um espaço de atividades diversas. Uma gestão do uso do espaço que otimiza drasticamente a ocupação, a informação qualifica o espaço.

Duas contemporâneas dos anos 60 , momento em que a função calculada assumiu sua instabilidade.

Edifício da FADU Universidade de Buenos Aires, pavilhão 3 da Cidade Universitária, Eduardo Catalano inaugurado para Arquitetura em 1966 e projetado desde 1960 por Eduardo Catalano e Horacio Caminos. Edifício da FAU USP de João Vilanova Artigas e Carlos Cascaldi, projetado a partir de 1960 e inaugurado em 1969. Eles compartilham datas e traços, embora sejam muito diferentes em sua concepção. A FAU (BAROSSI, 2016) é um espaço inter-relacionado e muito cuidadoso em suas proporções e espacialidades ricas e contrastantes, com uma concepção do programa como um espaço de encontro que incorpora uma indeterminação que convida a diversos usos. $O$ 


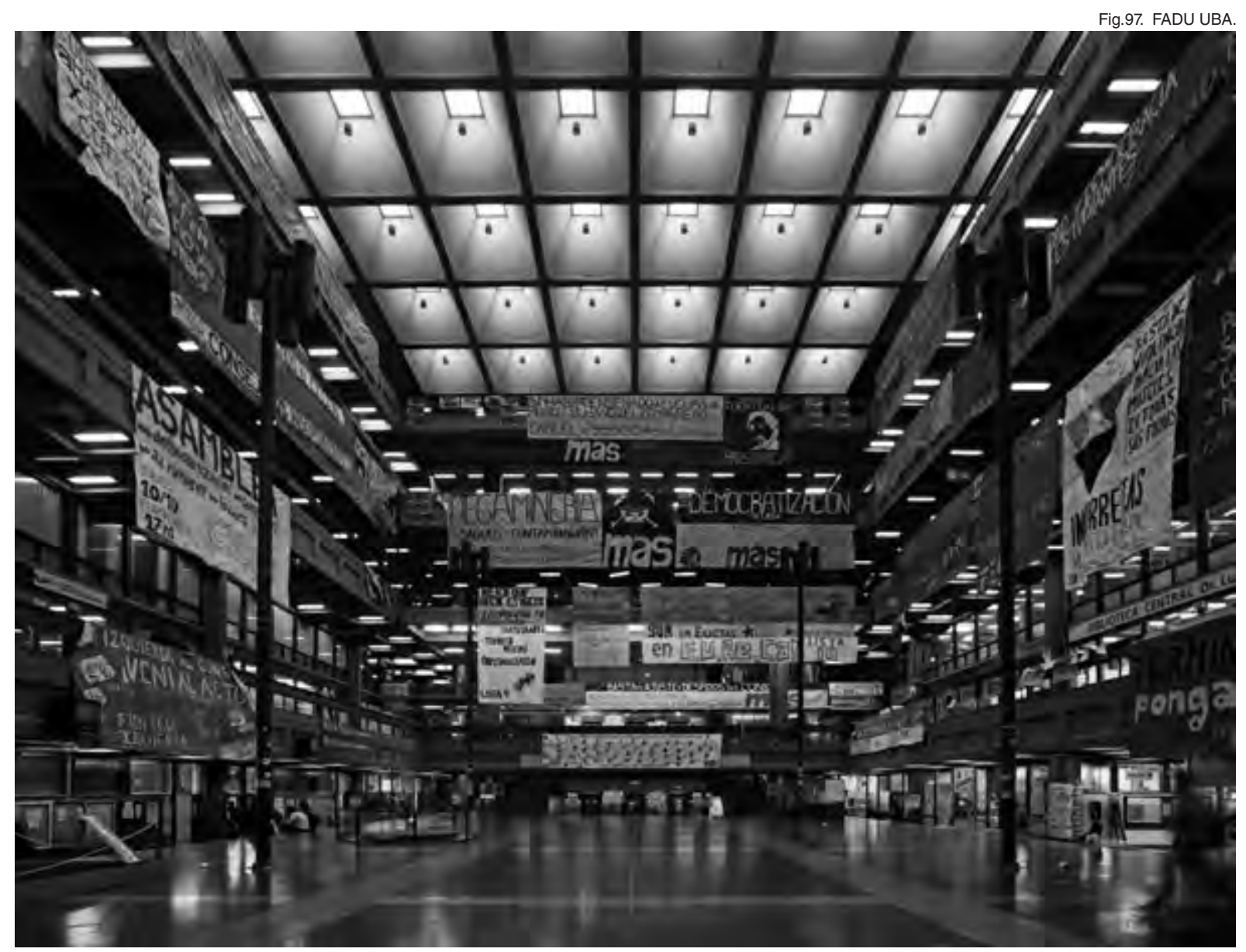

Fig. 98. Pavimento. FADU UBA.. UBA.

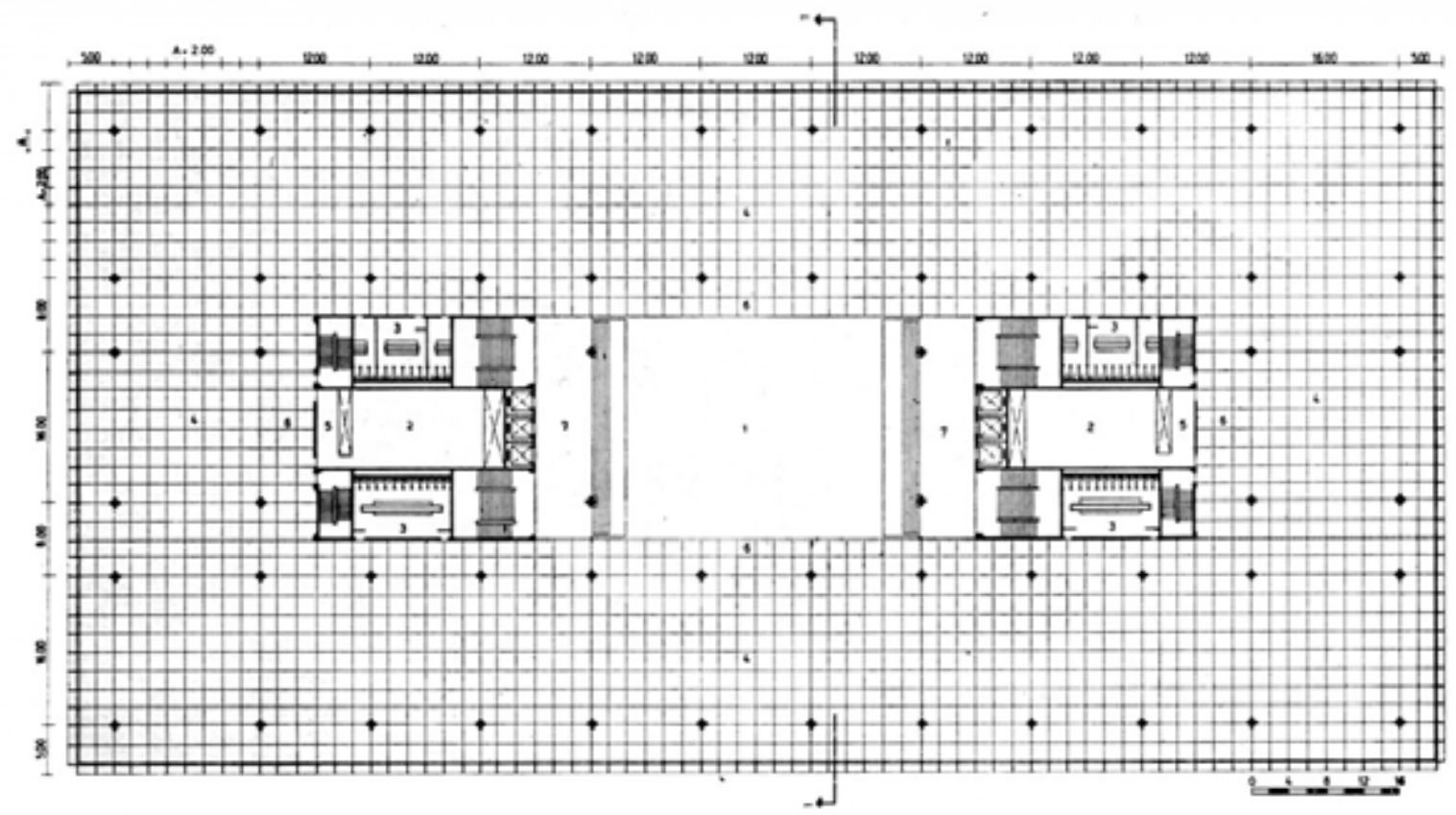


espaço "Caramelo" é a definição dessa espacialidade sofisticada e sua condição aberta que brilha depois de sua recente restauração. O Pavilhão 3 da UBA é um dos vários no projeto que foi feito como uma variante do 2. O projeto é mais abstrato e impessoal e, como destaca Marcelo Faiden (2014), tem nessa condição, e as cuidadosas decisões técnicas que combinam estrutura, as instalações e o espaço, que a apoiam, sua virtude da capacidade, aberta a modalidades de organização de diversos espaços.

Outras faculdades do mundo, que são muitas, e que é inevitável comparar a estes exemplos. O "Crown Hall" de Mies com seu espaço silencioso (mas que fala da Arquitetura); a Faculdade de Arquitetura de Nantes de Lacaton e Vassal (2009) (LÓPEZ UJAQUE, 2017), com seu espaço extra oferecido sem custo adicional, para eventos imprevistos (a serem criados) e suas capacidades de expansão já dimensionadas na estrutura: capacidade de superdimensionamento controlado.

\section{TORRE}

O espaço público é geralmente horizontal, Nolli o reconhece dessa maneira quando resolve a continuidade de seu alvo no nível do solo. A torre como multiplicação vertical do solo privado é uma invenção americana que muda a história da arquitetura, cujo episódio de NY está sujeito a dissecção e produção de manifesto retroativo em "Delirious New York". O solo no momento da sua reprodutibilidade técnica. Com maior dureza, Koolhaas analisa a planta tipo do arranha-céu de escritórios em "Planta Tipo" (KOOLHAAS, 1995, p. 335-349). Com sua repetição despojada de singularidade e especificidade, produz um espaço abstrato que se comporta como um suporte espacial neutro, ou seja, no sentido deste trabalho, desespecializado. O projeto destes edifícios se realiza em grandes estúdios, é puramente técnico e, a partir de malhas geométricas, orquestra complexos sistemas de estruturas e infraestruturas capazes de formar o ambiente regularmente repetido. Koolhaas propõe que sua condição de interior anódino possa se entender melhor quando dialoga com algumas expressões estéticas da cultura do século XX que se afastam das narrativas: poesia concreta, suprematismo, minimalismo, arte conceitual, art-brut, música atonal, música concreta etc.

Mas o que é vertical também pode ser associado ao que é público. Há muitos exemplos a serem estudados, apenas se analisam dois casos que contribuem para 0 desenvolvimento da tese. 
Fig. 99. Seção Mediateca de Sendai. T. Ito.

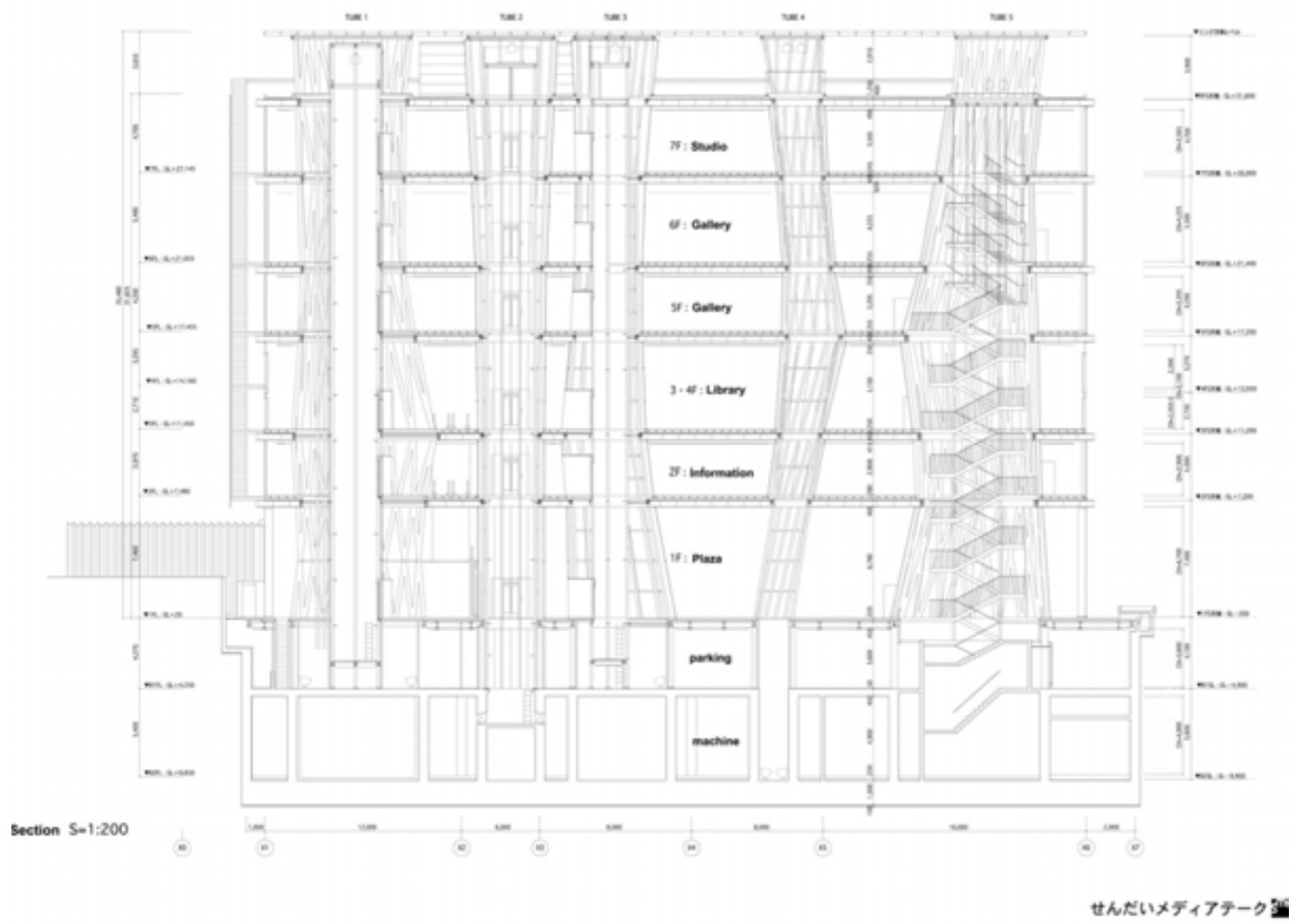


A Midiateca de Sendai de Toyo Ito de Sendai que passou por um concurso em 1995 e foi inaugurada em 2001 (KOBAYASHI em ITO, 2001), é uma exploração do vertical a partir da deformação da organização na planta, pautada pela malha regular da torre, propondo um sistema de fixação de distribuição irregular que hierarquiza porções do espaço horizontal. A fusão entre a estrutura e a infraestrutura em 13 tubos, propõe uma nova versão da lógica da Planta Tipo, em que os conectores verticais públicos, os elevadores definem a principal modalidade da experiência de trânsito pelo edifício, tornando-se novamente "promenade" maquínica. A sucessão de planos horizontais quase quadrados de 50 por 50 metros, adota alturas variáveis que acomodam diversos programas, a "coordenada z" é uma segunda qualificação do espaço, que é acompanhada por modalidades de organização autônomas andar por andar. $\mathrm{O}$ programa é a justaposição de um museu, uma biblioteca e espaços de oficinas, totalizando 21.600 metros quadrados. Não há mais repetição mecânica, mas sim uma desespecialização capaz de apoios que constroem cada um sua própria paisagem, procurando espaços ambíguos e abertos:

... O edifício tem muitos espaços livres, isto é, espaços que não tem
intenção, como são as salas, de servir funções específicas. Tais espaços
existem, por exemplo, entre os tubos e o perímetro do edifício. Os visitantes
poderão usar esses lugares como eles usam as ruas da cidade, para várias
atividades. Espero que, como tal, a Médiathèque se torne "um lugar para
pensar a cidade". .(ITO, 2001, p.8, tradução nossa)

A Biblioteca de Seattle (2004) propõe um caminho de verticalização que articula o especializado e o desespecializado, gerando espaços dedicados às diferentes modalidades de uma biblioteca contemporânea (livros, mídias digitais, jornais, som, vídeo etc.) e alguns espaços de programas ambíguos "entre" os dedicados ao cruzamento de atividades e o público, lugares para estar e olhar.

O Sesc 24 de Maio de Paulo Mendes da Rocha e o MMBB, é o Pompeia do século XXI. Para o Centro São Paulo, só faz sentido a verticalidade, então o que foi para Lina a desespecialização horizontal na ruína dos galpões, para Paulo será vertical. O edifício absorve a ruína de um edifício comercial por departamentos, utilizando um vazio central de 14 por 14 metros para colocar os principais programas. Propõe-se algo como um empilhamento de pisos públicos verticais, com um andar térreo muito aberto para as duas ruas de pedestre, e um sistema de grandes rampas como caminhos públicos (este é a "promenade" da 24 de Maio) associado a um conjunto de elevadores de distribuição eficiente. Dois andares intermediários completos (que somam ao telhado com a piscina 


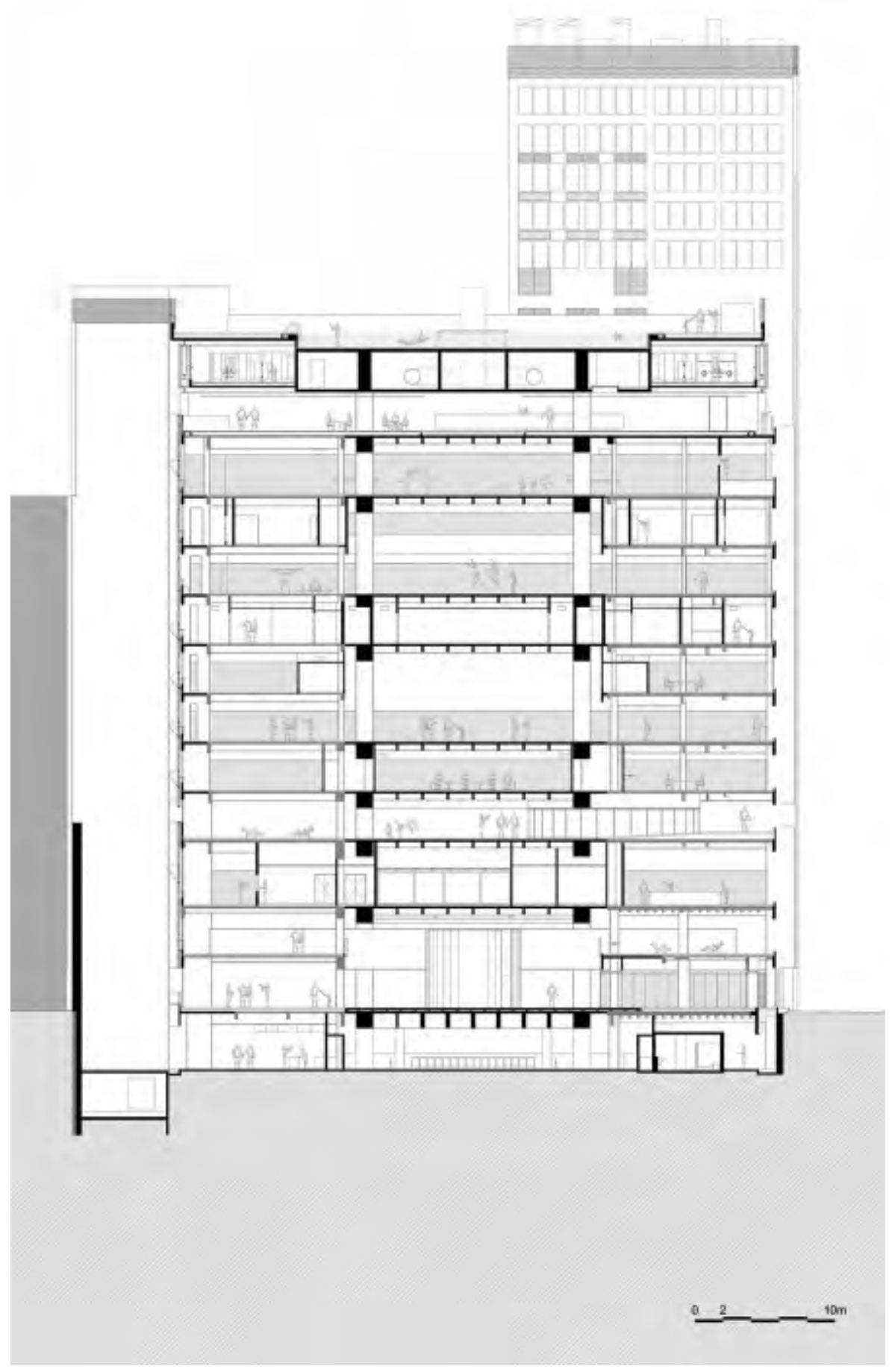


aberta), são espaços públicos sem fechamentos: no quarto andar há um espaço de "Convivência" um lugar para estar, trabalhar, estudar, com diversos equipamentos. No $11^{\circ}$ andar há uma cafeteria self-service com várias mesas de diferentes tipos. Os SESCs são instituições que combinam programas de uso público (para o público, já que a instituição é privada) são referência para a criação da urbanidade e nos bons exemplos (principalmente nos dois citados) estão carregados de espaços públicos não programados, locais de encontro abertos que são oferecidos para a cidade. Os programas variam de uma unidade do SESC a outra em detalhes, mas eles sempre têm atividades esportivas, recreativas e culturais, além de arquitetura (uma instituição interessada em sua proposta cultural, incluindo a arquitetura com um prédio de quase 28.000 metros quadrados, algo para ser destacado no terceiro mundo), de acordo com Danilo Miranda, diretor do SESC São Paulo:

Arquitetura para nós é programa, é substância, é essência. É assunto de conteúdo sólido, importante, que realiza uma proposta que está no fundamento da Instituição. (MIRANDA em SERAPIAO, 2016, p.20) 


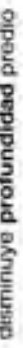
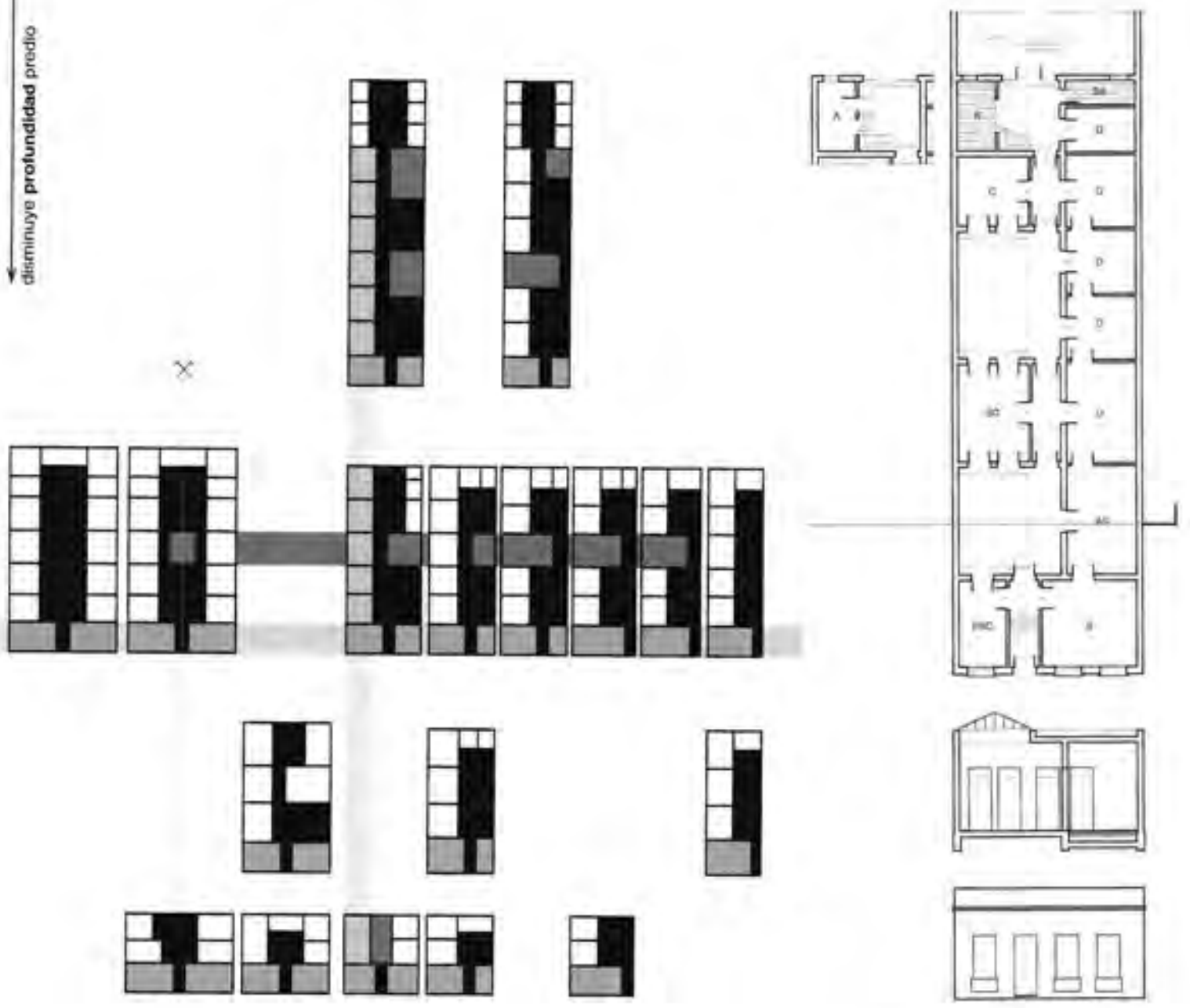


\section{CASA}

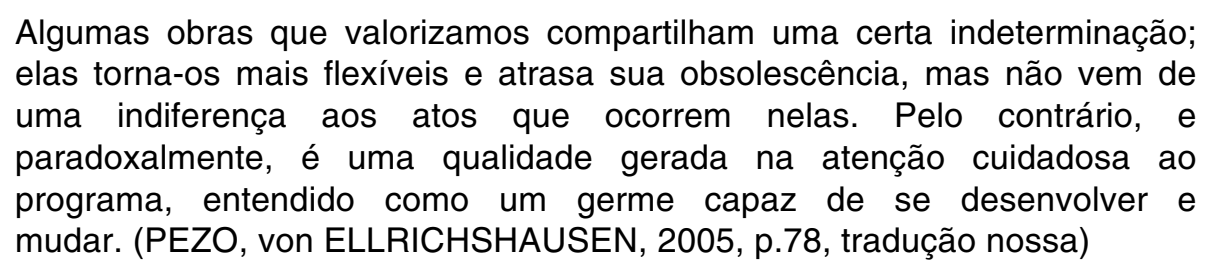

A casa é o lugar da intimidade.

Casas anônimas não têm programa, mas são definidas por uma sequência de espaços repetidos. Alguns deles são originários da "Casa Patio Pompeyana" (RAVETLLAT, P.J., 1985), que são clonados e adaptados ao redor do mundo. Em Montevidéu existem as casas pátio, também chamadas de "estandar", estruturadas em torno de pátios de claraboias e (com única distinção para a cozinha e alguns pequenos locais de serviço) são definidas a partir da repetição de um espaço cúbico de 4 por 4 por 4 metros, onde depois os moradores organizam diferentes espaços de convivência (PANTALÉON et al., 2002). Muitos deles sem projeto arquitetônico, feitos diretamente por construtores que aplicam um conhecimento do ofício, apresentam uma variedade inumerável de subtipos que se moldam a dimensões do padrão e outras condições. Espaços domésticos para colonizar, desespecializados.

A casa, projetada por um arquiteto, é geralmente um lugar de expressão da singularidade programática e espacial, um ajuste a um determinado núcleo familiar particular em um dado momento, uma resposta a um programa concreto, um espaço especializado. Alguns arquitetos contemporâneos mudaram a casa para um lugar de abertura espacial, que ajuda à formulação da desespecialização, investigando novas formas de relacionamento espacial e social. Estas são casas experimentais que se explicam em circunstâncias de convergência excepcional entre habitantes e projetistas. Além disso, essas casas experimentais podem surgir como resultado de uma densa rede de restrições, tais como aquelas apresentadas para habitações individuais em Tóquio, que dão lugar para produtos convencionais brutalmente pousados em parcelas minúsculas, ou para micro experimentos arquitetônicos que são registrados em "Zipped. Arquitetura residencial japonesa contemporânea produzida em fortes estruturas de restrição de projeto derivadas de condições geométricas e dimensionais" (MARTíN, 2017). 


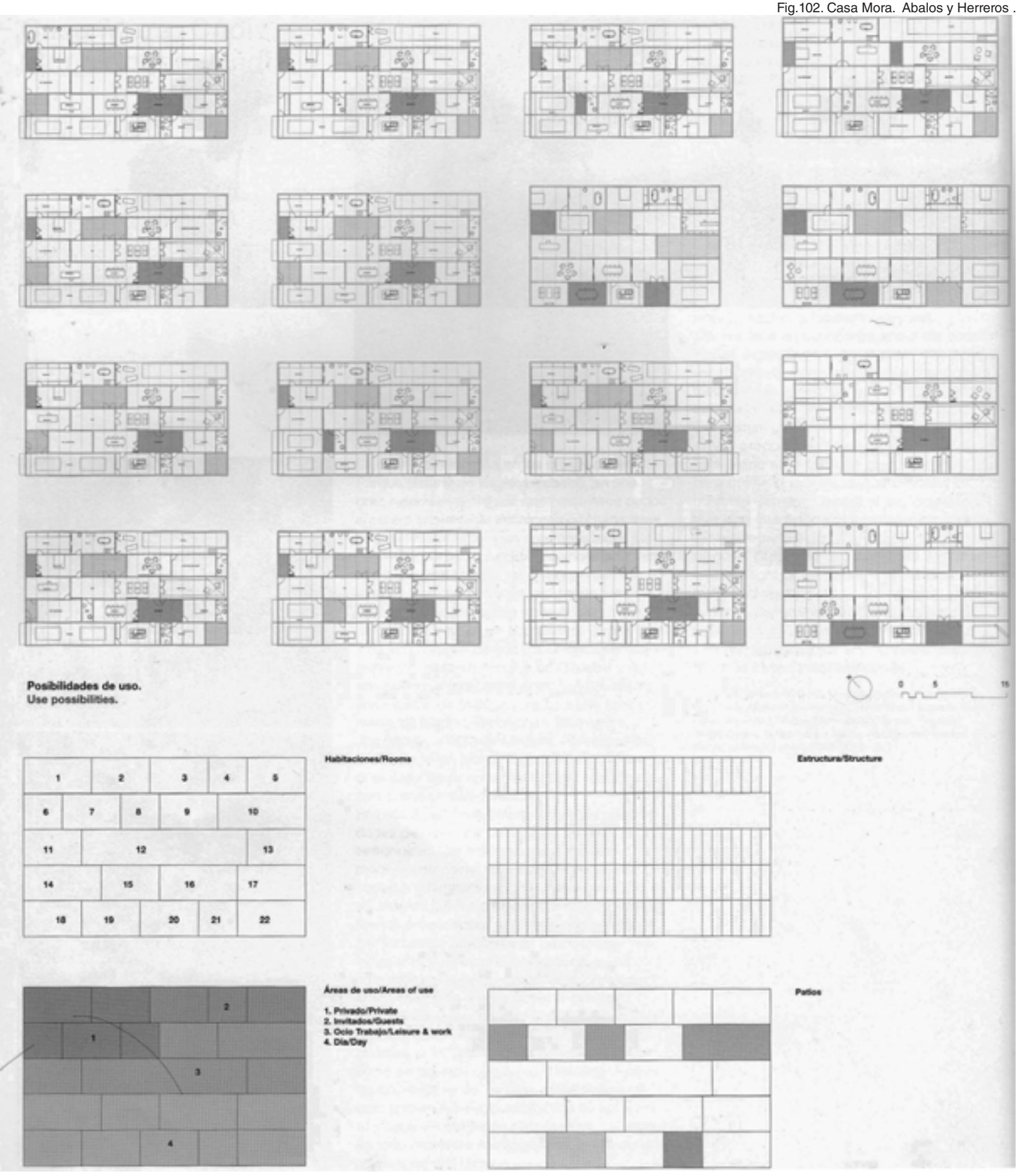


Uma lista decididamente incompleta incluiria muitas das casas de Shigeru Ban, particularmente a "9 Square Grid House" (1997) (BAN, 2000) que propõe um espaço único subdivisível em nove salas separadas por duas faixas que ocupam dois lados opostos do quadrado e deixam os outros dois lados em contato com o exterior.

A "Casa Mora" de Ábalos y Herreros (2000-2003) (ABALOS \&HERREROS et al., 2002, p.48-51) que elimina as circulações, propondo uma sequência de quartos equivalentes contíguas (algumas deles exteriores).

A "Casa na China" (2003) de Nishizawa, com um esquema similar ao da "Mora", sua anterior "Casa do Fim de Semana" (1997) ( SEJIMA e NISHIZAWA, 2007) de três pátios que comprimem um quadrado formando pulsos no espaço que acomoda as principais atividades.

A "Casa Poli" de Pezo e von Ellrichshausen (2005) que, além de ser uma casa de fim de semana para dois casais, alterna seu uso com o de um centro cultural, adotando uma estratégia singular diante de uma paisagem exuberante: definindo a espessura do perímetro que abriga todos os serviços, as circulações verticais, o armazenamento da privacidade que a mudança de usos requer, e o contato com o exterior, definindo no espaço contido uma sequência de espaços habitáveis e vazios.

A "Casa Y2K" (1998-1999) (KOOLHAAS, 2004a, p.302) um projeto não construído e cancelado da OMA que se define com um espaço vazio central em que ao seu redor se aglomera peças privadas para os diferentes membros da família e com uma formalização morfológica irregularmente facetada, transforma-se repentinamente no esquema inicial do Concurso "Casa da Música" no Porto em 1999 (Ibid. p.304), um edifício que contém duas salas de concertos e que foi concluído em 2004. O projeto de transferência que pula programas e circunstâncias, acaba sendo chocante e é um bom motivo para desmontar preconceitos: "é uma alegoria sobre a instável relação entre forma e uso, uma mistura de psicologia, pesquisa científica e oportunismo nu" (KOOLHAAS em WIGLEY, 2008, p.155, tradução nossa). Se as casas anteriormente apresentadas desespecializam a casa, a Casa da Música do Porto desespecializa a especificidade programática como ponto de partida para ganhar um concurso e desenvolver um projeto executivo e uma obra que mantém a organização inicial fazendo sentido espacial e urbano. 


\section{DPL.8 INFORMAÇÃO / MÁQUINA}

\section{MÁQUINAS}

Em 1923 Le Corbusier publicou a primeira edição de seu "Vers une Architecture", onde argumentava a favor da arquitetura e fazia com que algumas peças da arquitetura clássica convivessem com muitos produtos industriais do século XIX e XX: fábricas, navios, aviões e carros. A frase martelada "O sábio jogo dos volumes sob a luz" foi impressa em uma página acompanhada de fotos de silos industriais. A mensagem era clara, a revolução indústrial e a engenharia estavam dando passos gigantescos e a arquitetura só poderia se apropriar desses avanços para produzir espaços realmente valiosos e comoventes. A "máquina para habitar" era o seu slogan ${ }^{49}$. Em 1924 Rietveld terminou a Casa Schröder, com um espaço principal completamente transformável através de um painel que permitia a dois estados básicos o espaço único e a compartimentalização extrema e muitos estados intermediários da organização do espaço. Esta casa é um dos vários projetos da década de 20 , talvez o mais renomado (KRONENMBURG, 2007), e cuja condição mecânica e espacialmente mutante foi ofuscada pela pregnância da estética neoplasticista. Em 1926, Gropius projeta o Teatro Total para Erwin Piscator, um dispositivo com uma forte impressão mecânica que resolve vários formatos de configuração teatral e a ideia de uma experiência imersiva, um projeto que não foi realizado apesar de Gropius ter construído alguns teatros depois do Piscator.

Em 1935, a cidade de Clichy convoca um concurso para cobrir um mercado ao ar livre em um terreno de 40 por 50 metros quadrados. O concurso foi vencido pelos arquitetos Beaudouin e Lods (Jean Prouvé e Vladimir Bodiansky trabalharam junto aos primeiros no projeto executivo e à engenharia de construção) com uma proposta que agrega um programa ao do concurso, intensificando o uso da terra com uma solução de alta complexidade mecânica que adiciona um nível acima do de mercado. Este novo nível está destinado a ser usado como salão de festas, sala de conferências, cinema e escritórios para sindicatos e outras organizações.

\footnotetext{
${ }^{49} \mathrm{O}$ enunciado foi complicado depois por Le Corbusier em polêmica com a corrente mais difícil da modernidade, e propôs na reedição do livro de 1928: "uma casa - um palácio", sugerindo uma casa que emociona. O vírus maquínico já havia sido posto em movimento e o Corvo estava tomando distância.
} 
Pisos, tetos envidraçados e painéis móveis se mobilizam para obter variações programáticas. O edifício foi restaurado nos anos 90 e nunca foi utilizado de acordo com o previsto.

Nos anos 60, o "Fun Palace" é, como discutimos anteriormente neste capítulo, o projeto que eleva ao cubo as possibilidades de um edifício por sua capacidade de mudança permanente baseada em dispositivos mecânicos e uma cibernética incipiente. Não é essa condição em que o projeto revela seu excessivo otimismo tecnológico, mas a partir de uma perspectiva mais conceitual e menos literal, que a desespecialização programática pode pegar das ideias de Price.

Reyner Banham alguém próximo a Price raciocina sobre a complexidade tecnológica envolvida na operação do "Fun Palace", e embora seu argumento aponte em outra direção ${ }^{50}$, deixa em evidência a engenhosidade da exposição:

O Fun Palace foi considerado como um volume adaptável, em que os
pavimentos, telhados, divisórias e serviços poderiam variar à vontade, com
o mínimo de restriçães em qualquer uma das suas três dimensões. Parece
muito questionável que um Homo ludens de andar por aí pudesse ter
redistribuído, à vontade e sem qualquer ajuda, qualquer uma das unidades
propostas por Price, exceto talvez as menores. A rápida criação de uma
sala de conferências de seiscentas localidades, por exemplo, com uma
altura de entrada de 11,43 metros, que seria alcançada por escadas
rolantes a partir do nível da rua, implica claramente a colaboração de uma
considerável equipe técnica. Por essa razão, é provável que a proposição
fosse inaceitável para Constant e anatematizada pela linha dura dos
situacionistas, mas não inaceitável para alguém educado na tradição teatral
ou para os profissionais progressistas da esquerda britânica. Nenhum grupo
acharia nada de errado com uma pequena ajuda profissional nos bastidores
para os prazeres participativos do público. (BANHAM, 1978, p.88, tradução
nossa) As máquinas têm sido uma referência para a arquitetura do século $X X$, não apenas $O$ funcionalismo ortodoxo, como vemos, a incerteza calculada e o espaço livre de Price levados à prática, também são atravessados por uma lógica mecânica que os deixa próximos de um versão de "funcionalismo após o monofuncionalismo". A capacidade dos espaços, sem a necessidade de grandes mudanças físicas, é um limiar inicial para a desespecialização programática. Flexibilidade é um conceito que tenta-se evitar neste trabalho porque seu significado está impregnado de suas relações com esse funcionalismo maquínico. A desespecialização possui um sentido capacitador (no

${ }^{50} \mathrm{O}$ comentário tem a ver com o maior pragmatismo da experiência do Fun Palace, em relação a outros protagonistas do mundo radical europeu. Constant foi um dos muitos arquitetos que aderiram aos comitês de apoio do Fun Palace. 
sentido de "enabling" de Price) e, em qualquer caso, conecta-se com essa maneira de entender a flexibilidade:

A flexibilidade não é a antecipação exaustiva de todas as possíveis mudanças. A maioria das mudanças é imprevisível [...] Flexibilidade é a criação de margem - excesso de capacidade que permite interpretações e usos diferentes ou até oposto. (KOOLHAAS, 1995, p.240, tradução nossa)

\section{IMPREVISIBILIDADE}

A lógica mecânica está em crise como forma de entender e operar com o mundo.

A imprensa, um recurso repetidor. A imprensa, um recurso repetidor. A imprensa, um recurso repetidor...(McLUHAN e FIORE, 1988, p.49, tradução nossa)

Martela McLuhan (enquanto observa atentamente os inícios da sociedade da informação) em seu livro visual publicado em 1967, para as páginas seguintes diz:

"Quando a informação se trançam com informações...os resultados são surpreendentes e eficazes. A busca incessante da implicação, da plenitude, assume muitas formas (Ibid. p. 76-78, tradução nossa)

As descobertas científicas desenvolvidas ao longo do século $\mathrm{XX}$ e do presente deslocaram as certezas da ciência clássica. O cientista llya Prigogine, autor de relevantes inovações científicas que o levaram ao Prêmio Nobel de Química em 1977, constrói paralelamente uma reflexão humanista sobre os novos paradigmas científicos, baseada em "sistemas abertos", um mundo que está "longe do equilíbrio" e no "fim das certezas":

A física tradicional vinculava conhecimento e certeza, que em certas condições iniciais apropriadas garantiam a previsibilidade do futuro e a possibilidade de refazer o passado. Uma vez que a instabilidade é incorporada, o significado das leis da natureza assume um novo significado. Daí para frente expressam possibilidades. (PRIGOGINE, 1997, p.12, tradução nossa $)^{51}$

Acho que estamos no começo da ciência, só começamos a ver a complexidade do mundo. A ilusão que tínhamos vinha da escolha do objeto que fizemos (por exemplo, o pêndulo), e depois extrapolamos esses objetos simples para nos referir ao mundo como um todo. Isso causou confusão por muito tempo, porque muitas das coisas que descobrimos agora poderiam ter sido descobertas muito antes. (PRIGOGINE em FIRED, 2005, p. 417, tradução nossa) 
Das visões sociais da contemporaneidade, aparecem ecos semelhantes que reconhecem a incerteza e a mudança como principais variáveis:

\begin{abstract}
A 'condição trágica' da humanidade é precisamente o fato de que nenhum problema é resolvido por antecipação. Temos de criar o bem em condições incertas e desconhecidas. O projeto de autonomia é fim e guia, não nos resolve situações efetivamente reais (CASTORIADIS ${ }^{52}$ apud MACIEL, 2015, p. 253 , tradução nossa)

Perspectivas.

O futuro é construído não pela previsão, mas pela aptidão para a mudança (não sei mais de onde peguei esta ideia). (MORIN, 2012, p. 226, tradução nossa)
\end{abstract}

Somos parte de um mundo em mudança e difícil de prever. Um mundo líquido, de acordo com a poderosa metáfora de Zigmunt Bauman, leve, associado ao software e deixando para trás o hardware e o pesado. A condição social líquida tem sua forma de ser no espaço, nos seus usos e na velocidade com que estes se transformam.

Essa parte da história, que agora chega ao fim, poderia ser chamada, por
falta de um nome melhor, de "a era do hardware" ou "modernidade pesada"
- a modernidade obsessiva pelo grande tamanho, a modernidade do
"grande é melhor ", ou do tipo "tamanho é poder, volume é sucesso"-. Essa
foi a era do hardware, a era das máquinas pesadas e morosos, dos altos
muros das fábricas que rodeavam plantas cada vez maiores e que ingeriam
propriedades cada vez maiores, das enormes locomotivas e gigantescos
vapores oceânicos. Conquistar o espaço era o objetivo supremo... apropriar-
se de tudo que se podia e poderia manter, marcando-o com todos os sinais
tangíveis de posse e com sinais de "propriedade privada". O território foi
uma das maiores obsessões modernas, sua aquisição foi uma de suas
maiores compulsões e a proteção das fronteiras tornou-se um dos vícios
modernos mais onipresentes, inflexíveis e permanentes. (BAUMAN, 2016, p.
56, tradução nossa)

Mesmo antes destas manifestações tomarem forma, os arquitetos sabiam que não era possível prever o uso do espaço projetado ao longo da vida de um edifício, viram com os próprios olhos e o negaram construindo um edifício de certezas originado na "razão científica" do lluminismo e do Positivismo.

Revimos neste capítulo muitos episódios que apoiam a noção de um espaço que possui relativa autonomia em relação aos programas, que tem a capacidade de ser vivido de diferentes maneiras: "Função segue a forma" inverte os termos Yona Friedman (FRIEDMAN in HUGHES y SADLER, 2000) propondo uma arquitetura de suporte de apropriações táticas em seu interior. Há no humor de Friedman e Cedric Price um

${ }^{52}$ CASTORIADIS in BAUMAN, Zygmunt. Bauman sobre Bauman. Rio de Janeiro: Jorge Zahar Editor, 2011, p.49. 
deslocamento autoral, uma resignação do ego que, ao mesmo tempo em que afirma o projeto, ambienta o processo.

A partir dos anos 1960, surgem ideias que estabelecem um clima cultural vinculado a esse deslocamento que, a partir da literatura e da arte, permeia todas as disciplinas ligadas à criação, incorporando o acaso, a mobilidade, a aleatoriedade e a indeterminação (BOSSEUR, 2013) dos quais podemos indicar um nome capital: John Cage e três referências precisas: "Obra Aberta", de Umberto Eco, em 1962, "A morte do autor", de Roland Barthes, em 1973, e a declaração de Joseph Beuys, em 1972, "Todo homem, um artista".

O paradigma ocidental do autor, inaugurado no Renascimento (questionado na modernidade e ainda permanece no pensamento contemporâneo), é alheio aos chineses que carecem da ideia de originalidade, a tal ponto que a cópia não tem o mesmo significado que para ocidentais: um original é anotado e alterado por estudiosos e colecionadores, uma reprodução exata de uma obra tem o mesmo valor que o original para eles.

Por outro lado, a figura fundamental do pensamento chinês não é o ser uniforme e único, mas sim o processo poliforme e heterogêneo. Uma obra de arte chinesa nunca permanece idêntica a si mesma. (HAN, 2016, p.21, tradução nossa)

A arquitetura de São Paulo tem uma tradição própria que combina arquitetura de espaços abertos e determinação firme na capacidade do projeto; baseado em um alfabeto de origem moderna e com vários vieses pessoais. Lina faz o Sesc Pompeia que analisamos a partir do modo de re-habitar uma ruína com espaço aberto e controlado. Ela já tinha feito antes o MASP e o vazio construído na Avenida Paulista, o "vão livre do MASP", que Perrota-Bosch nos apresenta o encontro estético com John Cage como uma desculpa para afirmar uma relação similar entre autoria e abertura:

\footnotetext{
A arquiteta segue uma linha tênue entre a permissão ao acaso no interior de sua obra e a proposição de uma possibilidade de ocupação ideal. Portanto, há uma contradição positiva: Lina Bo Bardi não determina, para poder determinar depois. Assim, durante sua trajetória, a arquiteta não questiona a noção de projeto, pois compreende a indeterminação como estratégia para que ocasiões possam ser concebidas por ela e pelas pessoas que ocupem sua arquitetura.(PERROTTA-BOSCH, 2013)
}

Flavio Motta, historiador e artista profundamente envolvido com a arquitetura e seu ensino, nos propõe um olhar semelhante para designar espaços para o coletivo (os 
brancos Nolli) como "concentração de pessoas como eventos naturais", sugere a existência de espaços capazes, "sem nome":

...então poderíamos ler novamente a expressão "concentração de pessoas corno acontecimento natural" - para clube, corno para praça ou outro espaço qualquer que venha a surgir com nome ou sem nome. Sim, porque há espaços profundamente significativos, sem nome. [...]

É proposta que pede resposta, por que é trabalho criador com sua implícita responsabilidade social. (MOTTA, 1973, p.21)

Em São Paulo há um conjunto de espaços capazes, que têm um nome e seu nome convoca uma cor: "Caramelo".

Em Madri, Bernardo Ynzenga desenvolveu um espaço de reflexão e pesquisa ${ }^{53}$ sobre os "Espaços Zero":

...nome genérico para se referir a vazios, áreas, fragmentos, espaços ou momentos que oferecem ou geram oportunidade incondicional, suscetíveis de serem usados ou apropriados por um ou muitos, com um caráter instantâneo, efêmero ou duradouro ou por ações de tipos muito diferentes, reversíveis no todo ou em parte ou em nada. São um campo frágil de liberdade de ação, proposta e projeto. (YNZENGA, 2014, p.11, tradução nossa)

O programa tem um novo valor na concepção de uma arquitetura desespecializada, que consegue fazer mais com menos. As possibilidades e a abertura multiplicam-se até a vertigem quando Georges Perec nos propõe em sua reflexão sobre os espaços, um desafio filosófico implica aos arquitetos:

Em várias ocasiões tentei pensar em um apartamento onde havia uma peça inútil, absoluta e deliberadamente inútil [...] um espaço sem função. Não "sem função precisa", mas precisamente sem função; não plurifuncional (que todo mundo sabe fazer), mas sim funcional. [...] Eu nunca cheguei a nada realmente gratificante, mas acho que não perdi completamente o tempo tentando ultrapassar esse limite improvável:

Tenho a impressão de que, através desse esforço se transparece algo que pode ter o status de habitável.(PEREC, 2001, p.59-61, tradução nossa)

\section{INFORMAÇÃO}

No início do capítulo, o engenhoso fidalgo dom Quixote de la Mancha redefine o espaço acrescentando informação, modificando-o sem modificá-lo fisicamente.

A informação opera em nosso tempo como paradigma associado ao digital, ao "ser digital", e permite compreender o espaço a partir do conceito de "dispositivo aberto"

\footnotetext{
${ }^{53} \mathrm{Na}$ ETSAM, se desenvolveu um Seminário de Pós-graduação parte do Master em Projetos Arquitetônicos Avançados, 2013-2014, ETSAM UPM.
} 
(GAUSA, 2010, p.20 e 870). A influência do digital sobre a arquitetura redefine de forma crescente a experiência e as possibilidades da arquitetura, e já demonstra sua capacidade de agregar "informação" ao espaço por meio da interação com diversos fatores, sejam eles climáticos, temporários, de presença, de atividade. etc. Uma prefiguração dessas possibilidades é dada pela instalação específica do local "The Weather Project", de Olafur Eliasson, na "Tate Modern" em Londres, onde uma atmosfera, um clima artificial, é produzida no grande espaço da sala das turbinas que produz uma atmosfera, um clima artificial com sol e neblina. Sobre o projeto Bruno Latour (in GARCÍA-GERMÁN, 2010, p.106) ${ }^{54}$ apontou com delicadeza a ironia de que o trabalho que pertence ao mundo da alteração atmosférica contemporânea é implantado no vácuo deixado por uma moderna instalação indústrial em desuso.

\section{SEMICONDUTORES E MULTIPLATAFORMAS}

A informação atua como uma nova metáfora tecnológica, que descreve a sociedade da complexidade contemporânea. Para articulá-la, recorreremos aos Sistemas de Informação que atuam sobre uma base material e produzem informação.

O material que está na base técnica da informática, os "semicondutores", são materiais que podem variar seu comportamento segundo as condições do contexto em que operem: o campo elétrico ou magnético, a pressão, a radiação que incide, ou a temperatura do ambiente, o que definirá um comportamento isolante ou condutor. Esta condição variável do mesmo elemento se apresenta como um sinal icônico dos nossos tempos, e também, chave arquitetônica relevante para esta investigação em termos da capacidade de alteração das respostas do espaço em diferentes situações ou demandas.

A geração de informação e mais adaptável se o sistema possui uma capacidade de operação "multiplataforma" termo utilizado em informática para indicar a capacidade de um dispositivo para estabelecer uma interoperabilidade em diferentes sistemas operativos ou plataformas. Esta interoperabilidade pode ser lida da arquitetura como a articulação da diversidade em termos de exigências diferenciais para o mesmo espaço.

A possibilidade de trazer o termo multiplataforma para a arquitetura é uma derivação do conceito "Plataforma" já apresentado em relação aos projetos de arquitetura da Udelar, e ela tem explicação como parte do contexto cultural da arquitetura em Montevidéu nos

${ }^{54}$ O texto faz parte do Catálogo da exposição "The Weather Project" 
anos 90 sob a influencia de algumas arquiteturas globais, influência que é muito maior no Uruguai que no Brasil. Os primeiros projetos domésticos do Kazuyo Sejima construídos a partir de 1987 são chamados de "Plataformas"; no amplamente divulgado "Dicionário de Arquitetura Avançada Metápolis", a definição de Plataformas foi proposta, através de seus nomes em francês e espanhol.

\begin{abstract}
"Plateaux" (por plataformas). (Ver "meseta", "suelo" y "topografías operativas"). Os "mille plateaux" de Deleuze-Guattari, traduzido por "mil platôs". Eles também poderiam ter sido por plataformas, bandejas, suportes, bacias ou, simplesmente, pisos. Topografias topológicas. Em qualquer caso, material de suporte flexível. (Entrada escrita por Manuel Gausa).

"Plataformas". Para resumir as características dos novos solos, seria necessário, em primeiro lugar, referir-se à sua natureza fundamentalmente ativa. Podemos defini-las recorrendo ao sentido contemporâneo do termo "plataforma" mais relacionado com o conceito de sistema operacional do que com o significado clássico de "base", que sugere a neutralização do quadro de ação e a criação de um fundo ideal para converter o trabalho arquitetônico a um sentido legível. ${ }^{55}$ (GAUSA et al., 2001, p.470, tradução nossa)
\end{abstract}

\title{
Código aberto
}

A arquitetura de código aberto é uma das formas de pensar a arquitetura a partir de metáforas digitais que estão conceitualmente conectadas com a desespecialização programática. O movimento surge a partir das ideias de John Habraken e sua "Teoria do Design de Suportes", desenvolvida a partir de 64 na Holanda e publicada em 1974 (HABRAKEN, 2000), distinguindo entre uma estrutura arquitetônica projetada pelo arquiteto (suportes) e uma estrutura arquitetônica interposta pelos usuários (unidades separáveis). A experiência teve desenvolvimentos posteriores com experiências de desenho participativo em um esquema de baixo para cima, onde o arquiteto assume novos papéis de articulador de decisões dos usuários, descritos pela figura do "Choral architect" (RATTI, 2015). Essas experiências, aplicadas com sucesso no trabalho com grupos sociais de alta organização, especialmente em habitação, comportam-se de forma análoga ao software livre de onde eles tiram seu nome: eles envolvem minorias ativistas e são difíceis de aplicar em contextos massivos.

\footnotetext{
${ }^{55}$ Entrada escrita por Alejandro Zaera Polo, que venceu o concurso do Terminal Yokohama em 1995 com uma grande plataforma na agua.
} 


\title{
DE ARQUITECTURA.
}

\begin{abstract}
"A forma de festa teve interesse especial para Philipe Pareno, cujo projeto de exposição no Consortium de Dijon (janeiro de 1995) consistia em 'ocupar duas horas de tempo em vez de metros quadrados de espaço' com a organização de uma festa cujos componentes levavam à produção de formas relacionais: aglomerações de pessoas em volta de objetos artísticos em situação..." (BOURRIAUD, 2009b, p.45).
\end{abstract}

Uma alteração qualitativa do espaço pode ser dada pela maneira como o entendemos, ou quando o acionamos, modificamos com ações e ao longo de "um tempo". O mesmo espaço de um edifício, a mesma superfície de apoio $\left(\mathrm{m}^{2}\right)$, o mesmo volume $\left(\mathrm{m}^{3}\right)$, pode ter diferentes situações de uso ao longo do tempo $\left(\mathrm{m}^{4}\right)$.

A Mesquita de Córdoba é uma construção, uma paisagem em um andar de pouco mais de 2,3 hectares. Um edifício que contém uma enorme acumulação espaço-tempocultural-religiosa. Basílica visigoda (século VI) enterrada. Mesquita árabe (século VIII) com ampliações sucessivas em que se consolida uma malha regular que estabelece um espaço com direção principal, mas trabalha com neutralidade possibilitando a direção perpendicular e a obliquidade; um espaço interior neutro associado a um espaço exterior neutro, o pátio. A partir do século XIII, o edifício recebe práticas religiosas católicas com alterações mínimas em um setor que forma uma nave. Uma Igreja Católica (mais uma basílica, agora dedicada à sua função religiosa dos séculos $X V$ e XVI) se insere alterando a neutralidade e usando a estrutura existente, uma espécie de apropriação violenta e dócil ao mesmo tempo. "A função segue a forma" diria Yona Friedman. A longa história acumula uma série de intervenções arquitetônicas de diferentes tamanhos no que hoje é chamado Mesquita-Catedral e que durante todos os dias destes 1200 anos (HERRERO ROMERO, 2015) abrigou usos religiosos e não-religiosos, e sempre foi visto guiado pela lógica espacial e pela estrutura original:

A mesquita de Córdoba é talvez um exemplo excepcional: suas características, seus mecanismos formais de composição, são tão firmes que, uma vez definidas, fixam para sempre tanto a imagem quanto a estrutura do prédio, sem um ou outro eles se viram substancialmente alterados pelas intervenções que ocorreram ao longo do tempo. (MONEO, 1985, p.115, tradução nossa)

A Mesquita-Catedral tem uma densidade extrema que parece não se encaixar em 23.400 metros quadrados, e nos mostra quão relativo é um programa de usos. Parece recordar a "El libro de arena" de Borges:

Ele carregava uma pequena ilustração, como é usada nos dicionários: uma âncora desenhada para a caneta, como a desajeitada mão de uma criança. 
Foi então que o estranho me disse:

- Olhe bem. Nunca mais o verá.

$[\ldots]$

Ele me disse que seu livro se chamava Livro da Areia, porque nem o livro nem a areia têm um começo ou um fim.

Ele me pediu para procurar a primeira página.

Coloquei minha mão esquerda na capa e a abri com o polegar quase tocando o dedo indicador. Tudo foi inútil: várias folhas sempre se interpunham entre a capa e a mão. Era como se surgissem do livro.

$[\ldots]$

O número de páginas neste livro é exatamente infinito. Nenhuma é a primeira; nenhuma a última. Não sei por que elas estão numeradas dessa forma arbitrária. Talvez para implicar que os termos de uma série infinita admitem qualquer número. (BORGES, p.149-150, tradução nossa) 

MORE WITH LESS

ESTRUTURA DA TESE

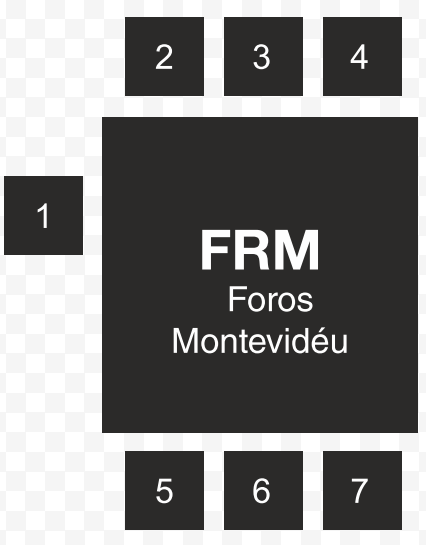


Fig.103. Cruz (preto), Kazimir Malevich, 1915.

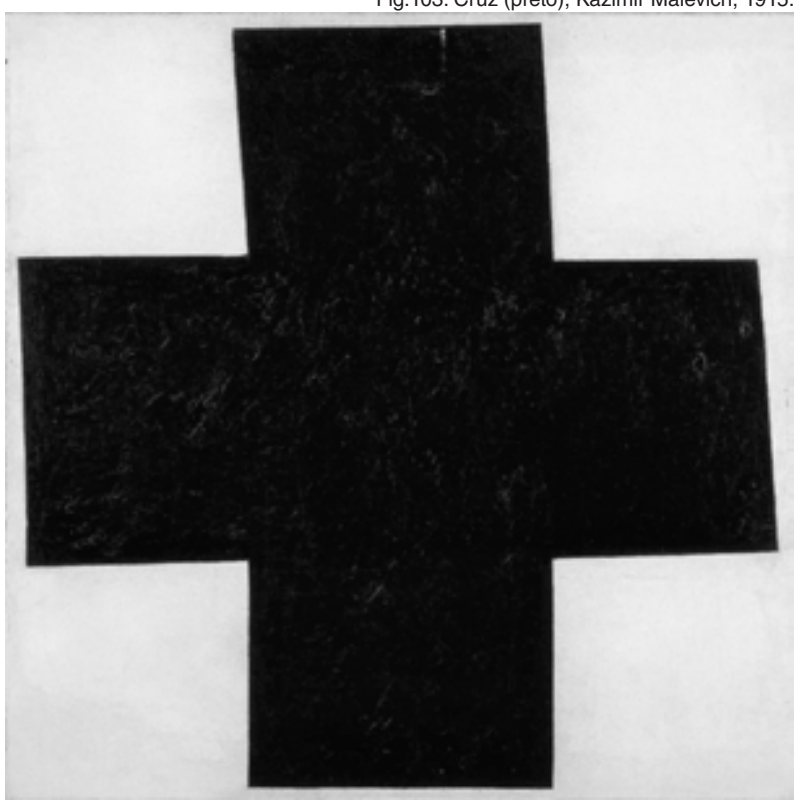




\section{FRM FORUM MONTEVIDÉU}

\section{FRM.1 SINERGIA NÃO ESPECIALIZAÇÃO}

Montevidéu tem uma tradição urbana de qualidade e periferias com uma urbanidade relegada à sua condição fragmentária. Como foi apresentado, a urbanidade é ao mesmo tempo definidora e parte das condições de deterioração social que vivem esses territórios. As intervenções públicas nas periferias replicaram e até reproduziram a condição fragmentária do território, razões pelas quais são necessárias novas intervenções radicalmente transformadoras. É necessário fazer uma cidade para integrar a sociedade no contexto da marginalidade avançada: esta é a conclusão que os acadêmicos chegaram no que se refere às ciências sociais e todos aqueles que pensam sobre a cidade.

Não se trata de quantidade, mas de qualidade e quantidade, como nos mostra a transformação de Medellín.

A fragmentação das políticas públicas analisadas no ECM pode ser criticada por sua especialização burocraticamente compartimentada. O americano Buckminster Fuller, de formação acadêmica científica e práticas diversas, autor de projetos inovadores e ousados que forçam o conhecimento técnico, reflete sobre o problema da especialização em 1969:

\footnotetext{
É claro, nossos fracassos são uma consequência de vários fatores, mas possivelmente um dos mais importantes é o fato de que a sociedade age com a teoria de que a especialização é a chave para o sucesso, não percebendo que a especialização impede um pensamento mais abrangente (BUCMINSTER FULLER, 2003, p.36, tradução nossa)

Começamos evitando o papel de especialistas que lidam apenas com partes. Tornando-se deliberadamente expansivo em vez de retrativo, perguntamos: "Como pensamos em termos de totalidades?" Se é verdade que quanto maior o raciocínio se torna o mais duradouro e eficaz, devemos perguntar:

How big can we think? (Idem, 2008, p.67, tradução nossa)
}

A grandeza do pensamento não se refere ao tamanho, está associada à compreensão de todos, à compreensão do território como sistema e à superação da desespecialização com o antídoto que ele propõe: ação sinérgica.

Daniel Burnham, o arquiteto de Chicago, autor de muitos edifícios naquela cidade, designer da proa mais conhecida de Nova York (a do "Flatiron") e pioneiro do urbanismo moderno, diz no começo do século passado: 


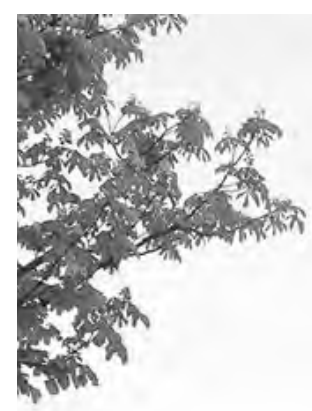

Fig.104. Make no little plans. Monadnock.

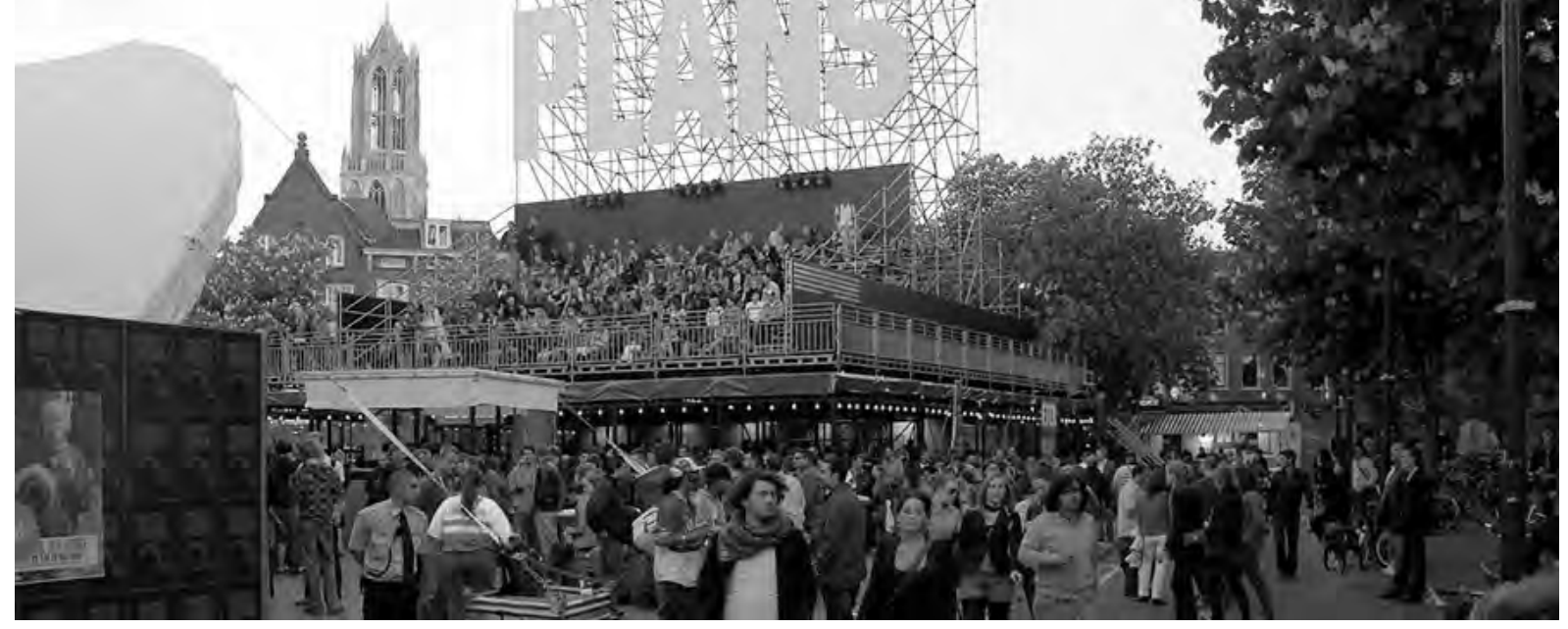


Não faça planos pequenos, eles não têm mágica para agitar o sangue dos homens e provavelmente eles não serão realizados. Faça planos grandes, almeje a esperança e o trabalho, lembrando que, para o diagrama nobre e lógico, uma vez registrado jamais morrerão, mas muito depois de termos partidos, eles seguirão vivos, afirmando-nos com uma insistência cada vez maior. (McBRIEN, 2010, tradução nossa)

"Make big plans". "Make no little plans" a aposta com a grandeza que podemos assumir hoje é qualitativa e complexa, um apelo a todo pequeno ato no território, que toda ação pública na periferia seja pensada e articulada com um todo, e não como parte encapsulada em suas lógicas institucionais. Isso nos permite pensar em novas formas de entender o mundo, "do ser isolado ao futuro estruturado" (NAJMANOVICH, 2008, p.131, tradução nossa), assim nos obrigam a fazer as condições de fragmentação e exclusão.

O sociólogo urbano François Ascher (2007) nos propõe passar da especialização espacial para a complexidade da cidade em rede, concebendo espaços com pluralidade conceitual, espaços que não tenham três ou quatro, mas "n dimensões" sociais e funcionais.

\section{DA PERIFERIA E DA CIDADE INTEIRA}

A hipótese deste trabalho, propõe pensar grandes planos pela reformulação dos equipamentos coletivos tendo em vista a complexidade como paradigma. Parte da desespecialização do projeto é a de uma forte aposta na criação de uma maior urbanidade nas periferias da Grande Montevidéu. Estes novos equipamentos coletivos são, além disso, os espaços públicos e prédios que propõem: concentração sinérgica de atividades, desespecialização programática (que Ihes permita evoluir no tempo ao absorver atividades e programas que irão transformando-se com a vida do equipamento), um projeto pensado em rede com outros, apostando na criação de relações que ativem o espaço público e toda a cidade. São condições de desenho especificas tanto para gerar um espaço público estimulante como uma imagem representativa que signifique aporte estético e cultural: quantidade e qualidade.

Fórum da periferia, mas sobre tudo fórum da cidade. Fórum em rede com outros da sua classe e de outras classes, fazendo pluralidade sinérgica no território metropolitano. 
Fig. 105. Forum Romano.

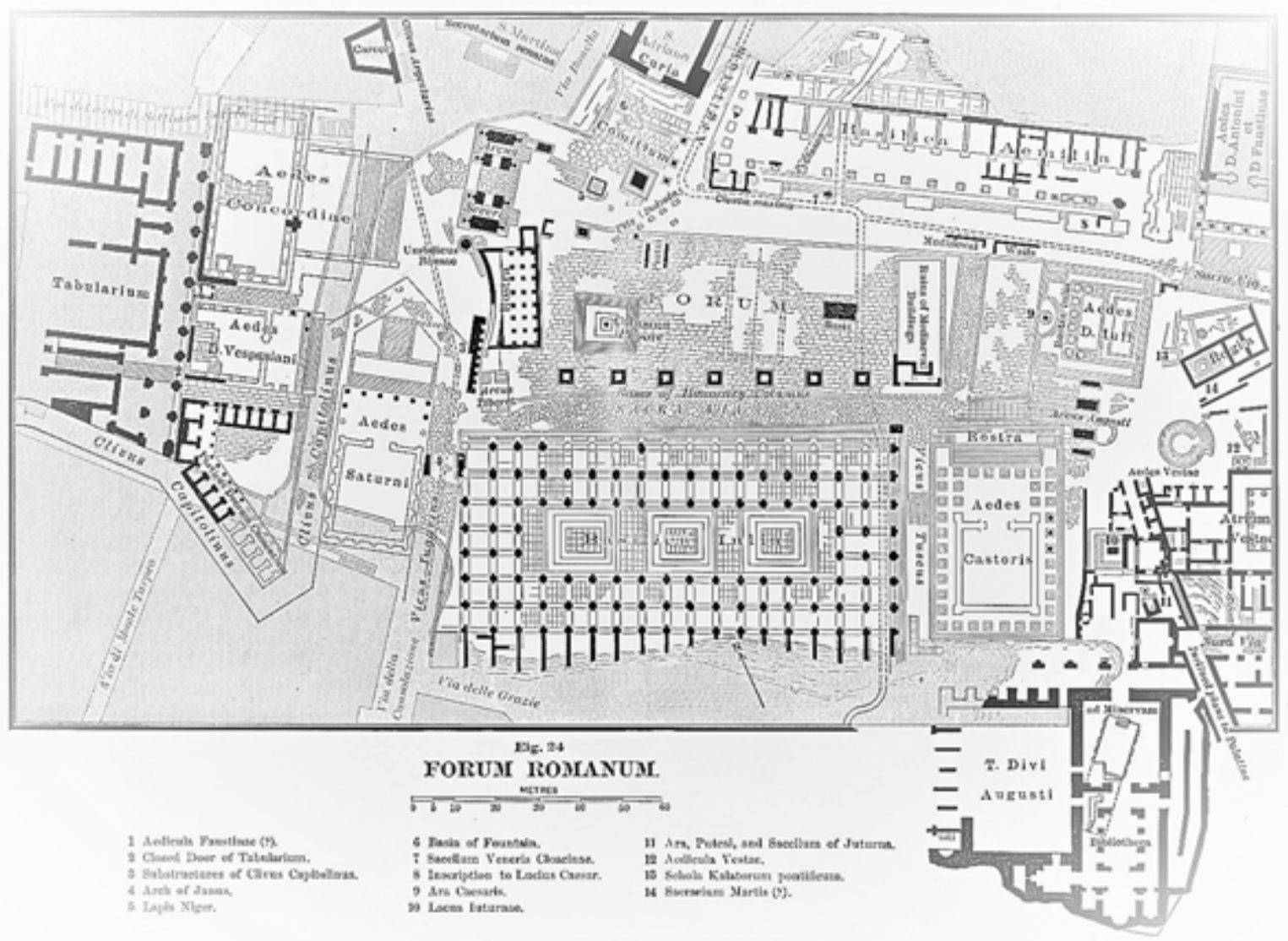




\section{FRM.2 FÓRUM ROMANO}

Fórum, no sentido do espaço que produziram os antigos romanos: um conjunto de equipamentos e espaços públicos centrais que estruturam e criam cidade. $O$ deslocamento escolhido não é a Ágora (antecessora grega do Fórum) embora a sociedade de Atenas seja mais democrática e por isso aparece como espaço paradigmático dos encontros e socialização. ${ }^{1}$. É a complexidade física, hibrida, e a capacidade urbanizadora do Fórum o que fundamenta a sua escolha.

O Fórum é o lugar de encontros, sede de atividades mercantis, espetáculos e atividades diversas. Ele aparece no tratado de Vitruvio, com indicações de proporções do espaço em função da condição de usos diversos do espaço publico (e também em função do tamanho da cidade), e ao mesmo tempo aparece vinculado à arquitetura do seu perímetro, os prédios que o conformam.

\footnotetext{
A largura do foro será estabelecida da seguinte maneira: dividir seu comprimento em três partes, dois terços são para sua largura, portanto, sua estrutura será alongada e sua distribuição adequada para espetáculos

As colunas superiores se elevarão a uma quarta parte menos que as colunas inferiores, já que elas devem suportar todo o peso, portanto devem ser mais sólidas que as superiores. (VITRUVIO, 1995, p.191, tradução nossa)
}

Como já foi dito no capítulo DPL, o Fórum é o lugar da Basílica desespecializada e também de templos, às vezes de cúrias, erários ou teatros. O centro do Fórum é a interseção do cardo e o decúmanos, eixos principais que cimentam a cidade e a sua repartição por uma malha regular.

No livro "Mutaciones", Rem Koolhaas e o "Harvard Project on the City" (KOOLHAAS, BOERI, KWINTER, TAZI, e OBRIST, 2001) exploram a instabilidade da cidade contemporânea, é a cidade genérica. O primeiro ensaio do livro chama-se "Como construir uma cidade. Sistema operativo romano", e estabelece a estreita relação que existe entre a construção do império e a construção do território e da cidade: "o tema mais elevado e o objeto mais útil do Império Romano". Nele se salienta a relação entre cidade e território, ela existe em conexão com o território a partir das infraestruturas: aquedutos e vias, e também os limites: muralhas e valas. $\mathrm{O}$ modelo geral aplicado para a fundação das novas Colônias, tem capacidade de gerar uma cidade genérica no

\footnotetext{
${ }^{1} \mathrm{Na}$ sua descrição dos três espaços da sociedade ocidental Santiago Alba Rico escolhe a Ágora como o espaço representativo da sociedade pública e coletiva, em oposição à sociedade da religião monoteísta, a Catedral, e o espaço da sociedade de consumo, o Corredor do aeroporto. Cada um deles estabelece uma relação com o corpo humano, sendo a Ágora o lugar do corpo como revelação. (ALBA RICO, 2017).
} 
Fig 106. Forum de Timgad.

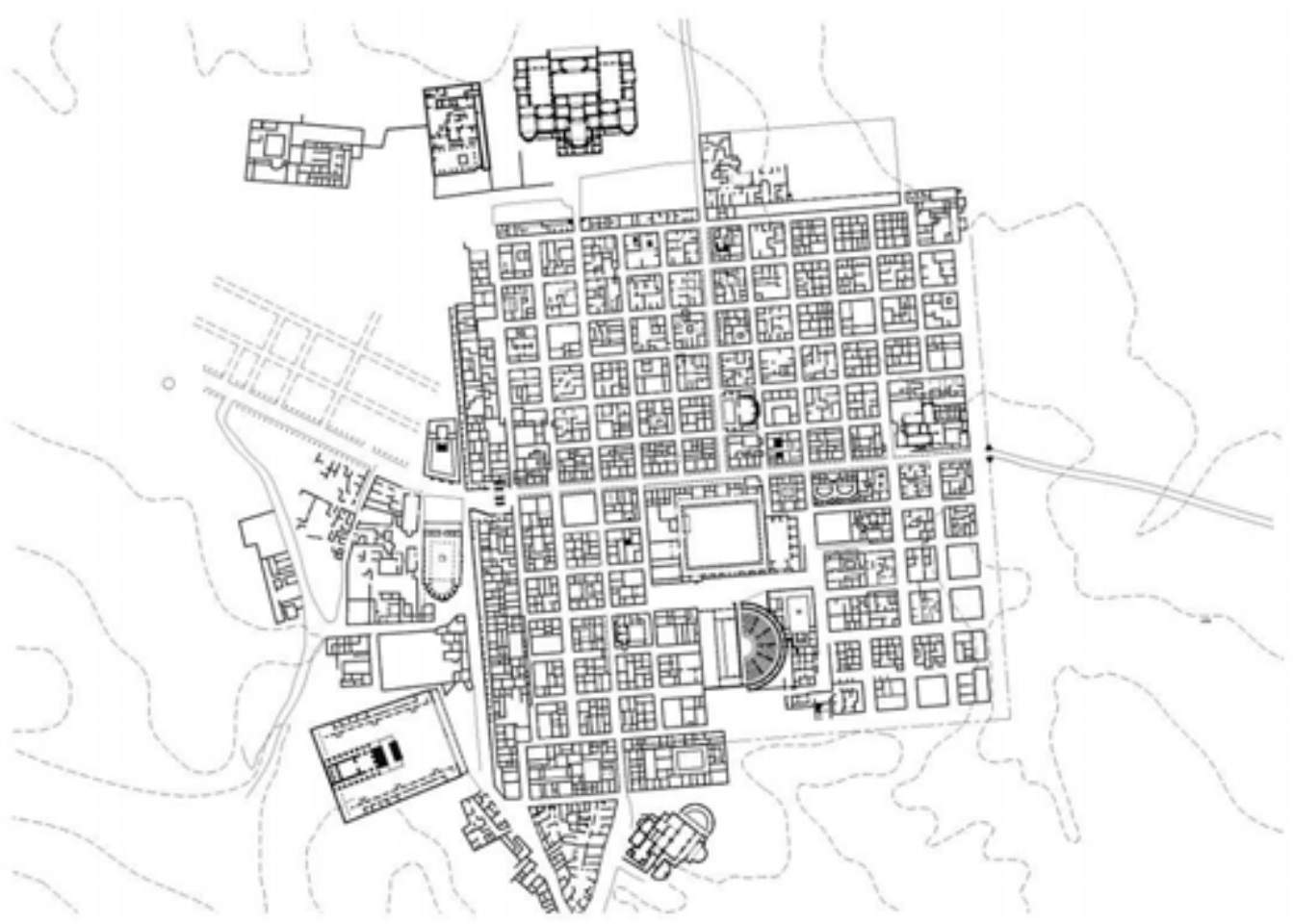


Império e depois acaba construindo boa parte das cidades da América Latina colonizadas pela Espanha, em quanto as "Leyes de Indias" (o "sistema operativo espanhol") absorvem as prescrições de fundação de cidades romana, pegando os critérios do Tratado de Vitruvio.

O Fórum Romano foi uma figura adaptável. Se bem fora parte de planejamento, central e estruturador nas colônias e nos manuais de fundação de cidades, também foi um centro difuso, aluvial, construído com o tempo, de acordo com a topografia local e às preexistências urbanas na capital do Império e outras cidades já existentes.

A interpretação de um Fórum em termos contemporâneos não é literal senão conceptual, e está necessariamente ligada a uma condição relacional e não necessariamente à geometria do antigo. O interesse está na capacidade de condensação de espaço público e equipamentos para produzir maior intensidade e relações urbanas. Nesse sentido o Fórum do nosso tempo está vinculado às "Condições do Campo" apresentadas por Stan Allen (em SYKES, 2013, p. 91-103) que referem a qualquer lógica ou matriz formal onde há uma relação entre elementos, (os equipamentos do fórum no nosso caso), e deles com o resto do território: "A forma importa, mas não tanto as formas das coisas, e sim as formas entre as coisas" (Ibid., p.93).

A compreensão das relações multiescalares que acontecem no território e a maneira de operar com este Fórum, que deve estudar as intrincadas relações locais para logo operar nelas. 

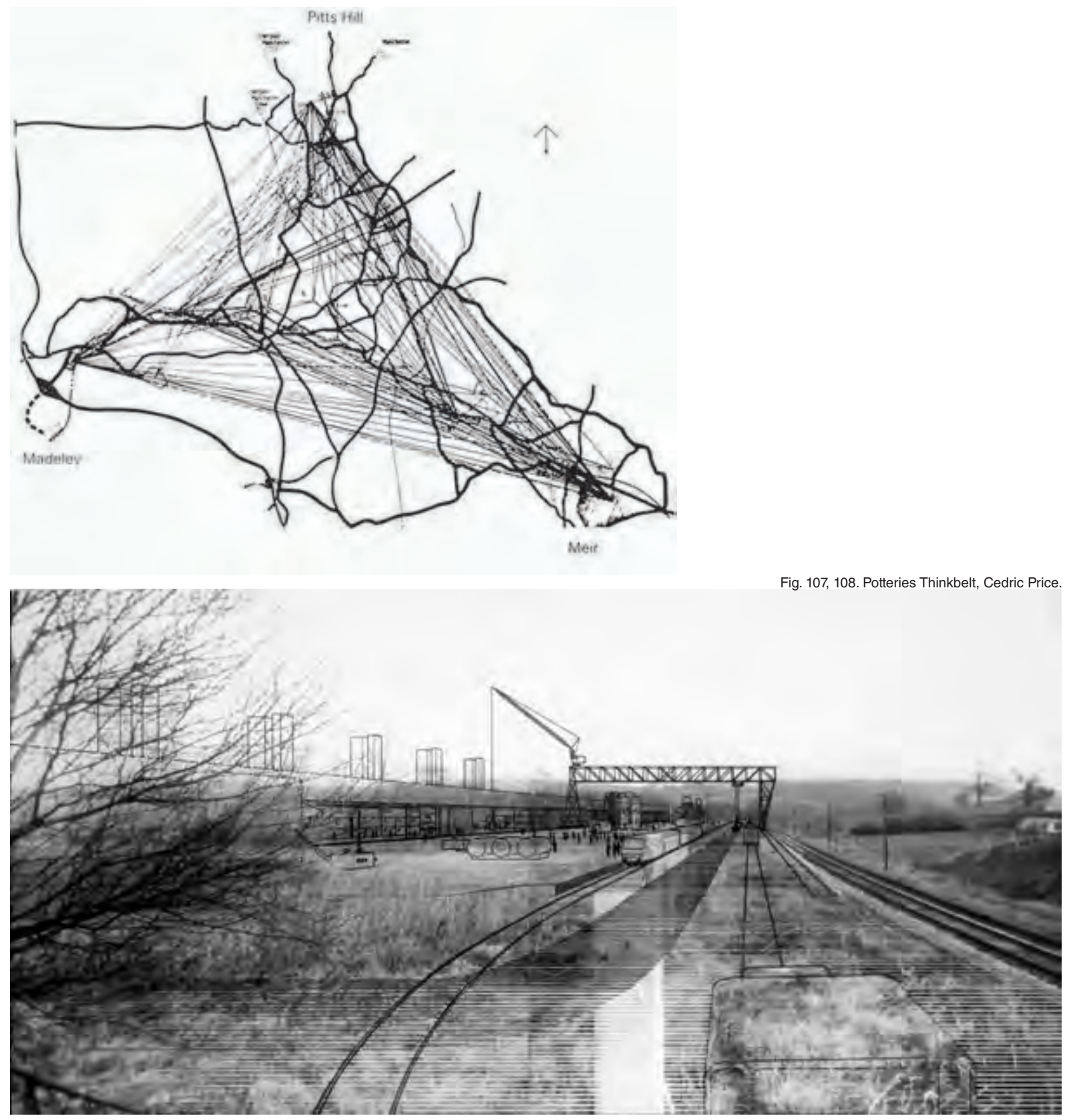


\section{FRM.3 FORUM MONTEVIDÉU}

A ideia de um Fórum pode estar relacionada a como entender e operar com os fenômenos do território. Os romanos o desenvolveram como identidade urbana e ao dialogar com os suportes espaciais desenvolveram adaptabilidade às condições locais. Um Fórum age com o território e os equipamentos existentes.

A proposição do Fórum de periferia supõe uma concentração sinérgica de atividades: vários programas associados num mesmo equipamento com independência sem importar a configuração e oferecendo espaço publico de qualidade. Uma vinculação com a coletividade em diferentes níveis, para construir centralidades referenciais.

O equipamento assume esta noção de autonomia das instituições, dos destacamentos que atualmente propõem para seus equipamentos, pois se assume uma hipótese fora do controle da arquitetura de uma elevada coordenação pública. Os especialistas

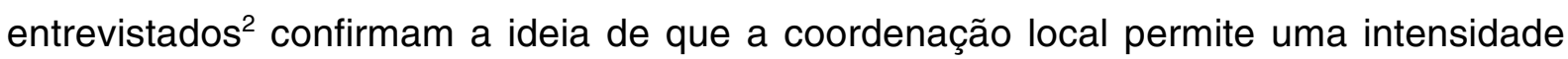
sinérgica "bottom-up" que é muito difícil de conseguir a partir da verticalidade institucional pública.

A abertura dada pela desespecialização programática, ferramenta de projeto para o Fórum, chama para uma gestão continua do espaço, o que pode tornar-se um promotor das iniciativas e atividades locais, muitas vezes fracas. O propósito é obter uma economia de escala pela consideração simultânea de um conjunto de problemas que normalmente são pensados e resolvidos (ou não) em âmbitos compartimentados. Aproveitar os recursos existentes (sociais e edilícios) e colocar em relação a outros novos a serem projetados e construídos.

A condensação de atividades e espaços do Fórum não implica uma disposição concreta, senão uma operabilidade. Pode estar concentrada em um ponto ou dispersa em vários: um Fórum Edifício e um Fórum Território como uma "Instituição distribuída" segundo a terminologia de Allen (Ibid.). O primeiro tem relação com a maioria dos casos estudados na Desespecializaçào Programática, Parques Educativos e CEUs por exemplo, e o

\footnotetext{
${ }^{2}$ Anexo. Montevidéu: levantamento de opiniões qualificadas sobre as políticas públicas e os equipamentos coletivos gerados desde os anos 90 .
} 


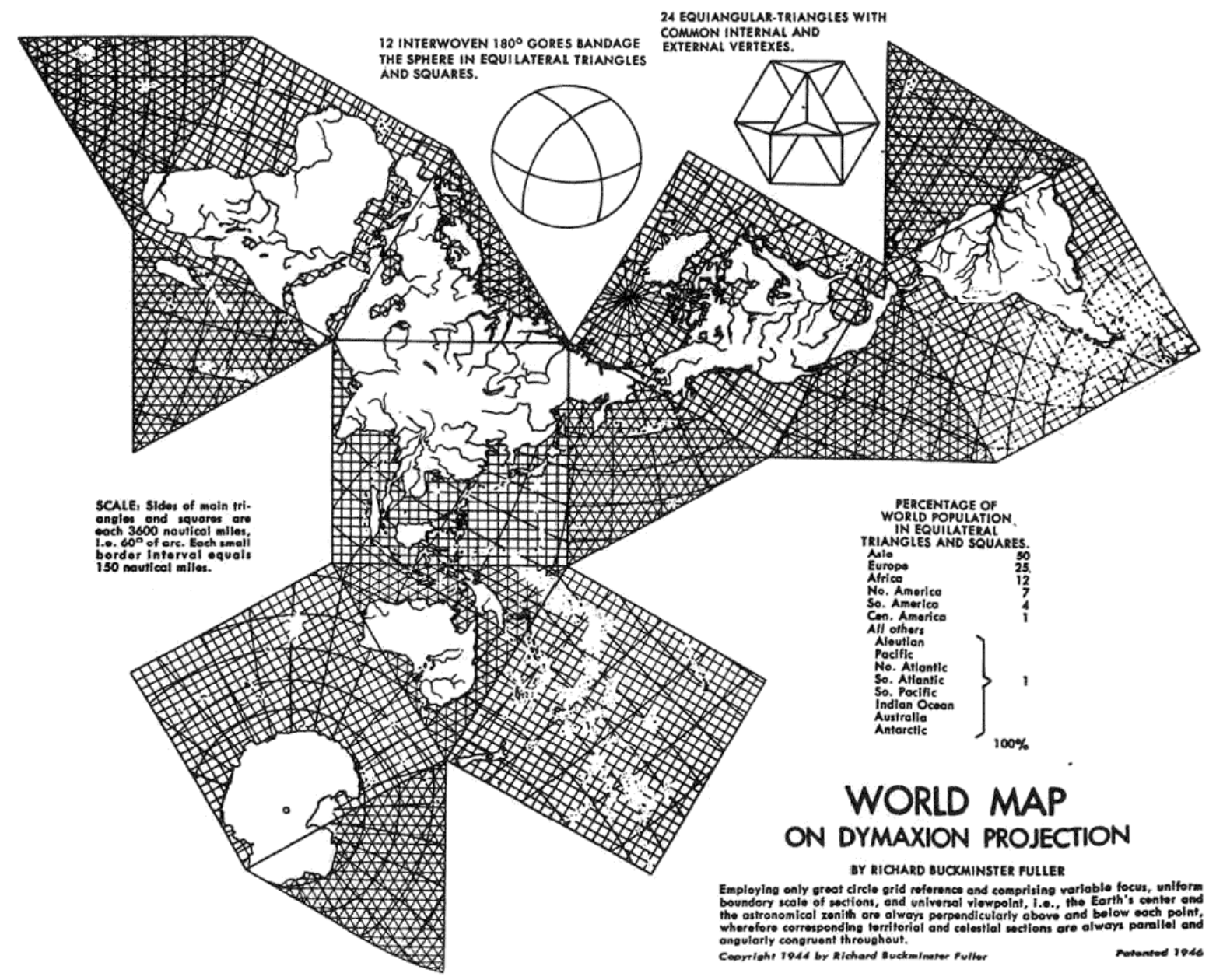


segundo se referencia ao projeto de Cedric Price "Potteries Thikbelt" que ele entende como uma cidade originada pela aprendizagem ${ }^{3}$ (HARDINGHAM, 2016a).

\section{PARA A tRANSFormação das periferias}

As intervenções públicas recentes na periferia da Grande Montevidéu são múltiplas mas fracas, têm sido chamadas de "urbanismo incrementista", por esquecer da escala zonal ou metropolitana, intervindo na pequena escala e na vizinhança. Dessa maneira se perde a possibilidade de "impactar na construção verdadeira de cidadania e de identidades coletivas mais amplas" (BERVEJILLO, 2010, p.5, tradução nossa). O urbanismo para as periferias precárias deve atender as dimensões culturais e simbólicas na requalificação urbana apontando a algumas poucas operações "fortes" orientadas a criar espaços públicos e equipamentos excepcionais à escala zonal ou distrital.

A estratégia propõe formular critérios que, assumindo a impossibilidade de praticar um pensamento "funcionalista", incorporam a abertura, a indeterminação e as dinâmicas temporais como variantes do projeto. A arquitetura é relacional, ampara sujeitos e subjetividades que são alheios ao projetista. A participação social é entendida como um componente necessário desse processo, dando assim sustentabilidade aos fóruns, uma nova micropolítica ${ }^{4}$ para quebrar a debilidade no invólucro.

Para a melhoria por meio de uma forte intervenção, que chamamos Fórum, é necessário compreender as lógicas dos Equipamentos Coletivos de Montevidéu. Focar-se no estudo de caso atendendo a dispersão, especificidade e variabilidade dos recursos sociais de apoio às populações das periferias.

Uma particularidade associada ao desenvolvimento de tecidos informais na Grande Montevidéu e a dupla condição de extensão horizontal da mancha urbana e o crescimento de população nulo que implica em uma perda de densidade e desaproveitamento das qualidades urbanas da cidade consolidada. Há um consenso

\footnotetext{
${ }^{3} \mathrm{O}$ projeto de 1966 propõe uma universidade dispersa no território, conectada pelas infraestruturas do trem de uma região na Grã Bretanha que sofre um processo de desindustrialização. A mobilidade seria uma condição ativadora de toda a região.

4 "A questão micropolítica - isto é, a questão de uma análise das formações de desejo no campo social - fala de como o nível das diferenças sociais mais amplas (que eu chamei de" molar") se cruza com isso que chamei de "molecular". [...] Da mesma forma, as lutas sociais são, ao mesmo tempo, molares e moleculares "." (GUATTARI e ROLNIK, 2006, p.149, tradução nossa)
} 


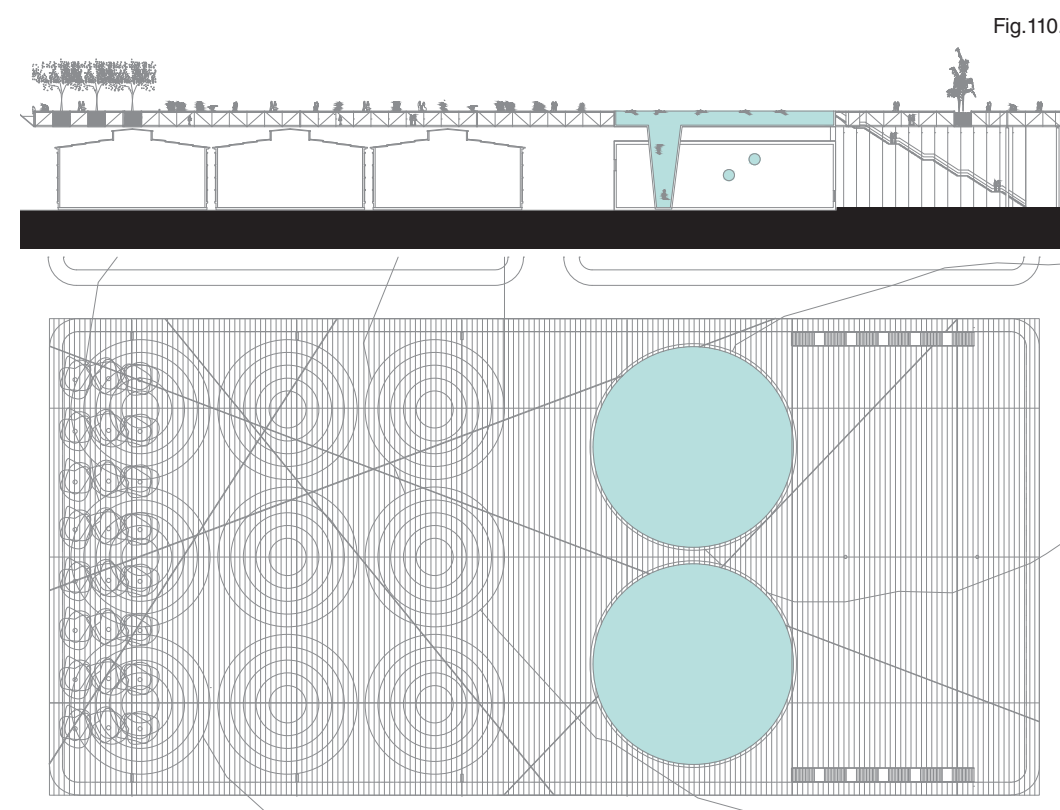

Fig.110.Forum Cerrito. Batista, Cardoso, Castro y Perez. DIP 2015
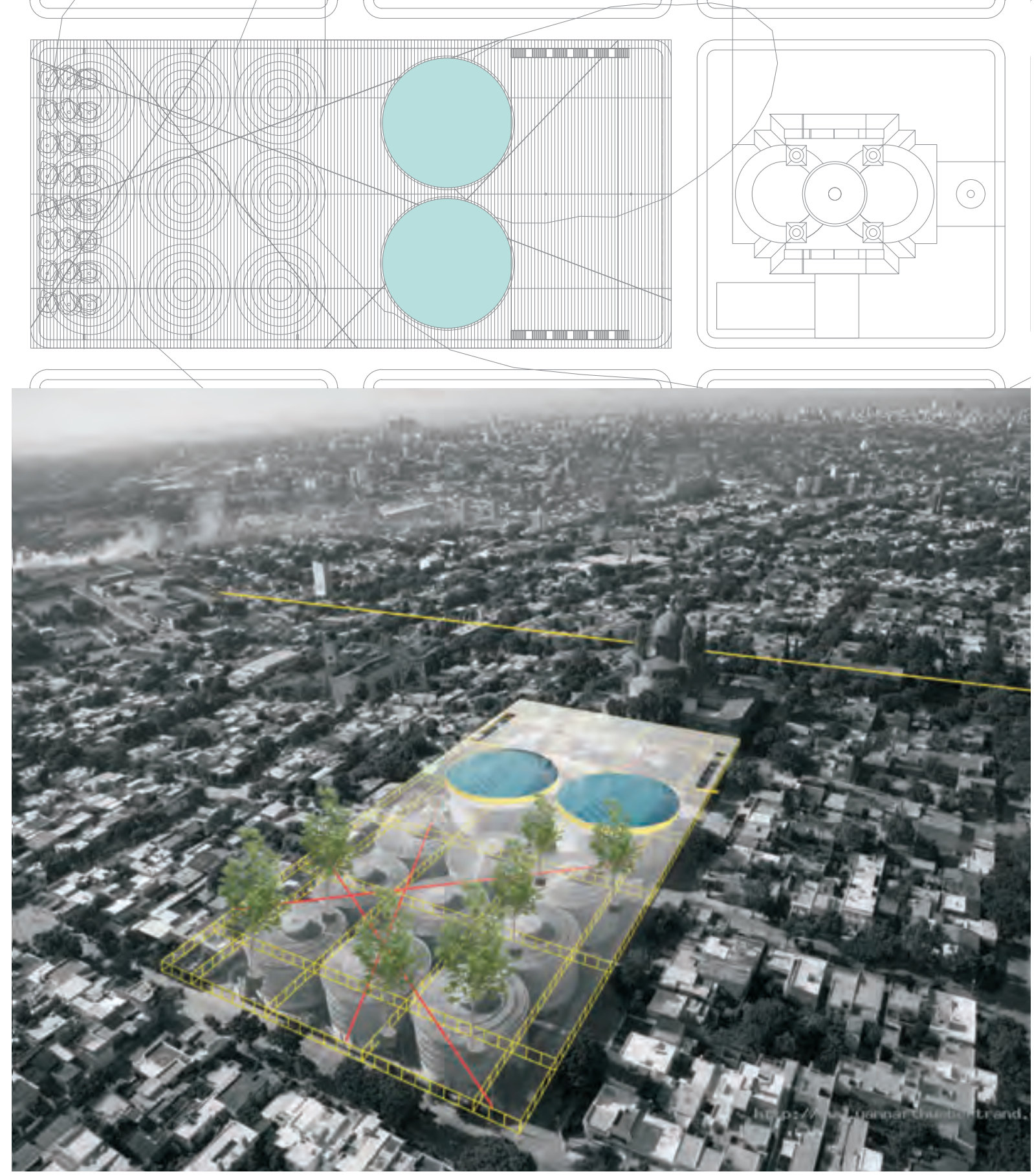
acadêmico e de planejamento urbano na necessidade de incrementar a densidade nessa Montevidéu consolidada.

\begin{abstract}
Desde a construção de um cenário de equidade de oportunidades para o conjunto dos cidadãos, é fundamental promover a requalificação das periferias urbanas que atualmente se encontram em condições críticas. Estes espaços de segmentação social e segregação urbano-residencial requerem planos zonais minuciosamente elaborados. Parece sensato enfatizar a implementação de programas de melhorias dos bairros, acumulativos no tempo, que sejam capazes de hierarquizar os estruturadores urbanos e os benfeitores de uso comunitário exteriores e fechados e evitar dentro do possível a densificação habitacional destes benfeitores sem heterogeneidade social, o que significa uma mudança radical de enfoque.(COURIEL, 2010, p.133, tradução nossa).
\end{abstract}

De acordo à leitura de Jack Couriel, originada de uma perspectiva territorial e urbana, é relevante atender a qualidade dos Equipamentos Coletivos na periferia urbana da Montevidéu Metropolitana como parte de um conjunto de estratégias destinadas a mitigar a fragmentação social. As periferias, lugares estratificados, não são homogêneas. No o ponto de vista urbano, se alternam, muitas vezes sem solução de continuidade, trechos de cidade formal gerados durante os séculos XIX e XX, com fragmentos formalizados em intervenções modernas e contemporâneas que implicam descontinuidades (conjuntos de moradia, moradias de re-localização da informalidade, etc.) e fragmentos de informalidade (descritos na linguagem mais consolidada nas últimas décadas como Assentamentos Irregulares). Um dilema frequente na intervenção urbana na Grande Montevidéu é atender às melhorias da cidade informal que não pode ser eliminada nem apagada pela sua inconveniência, mas reverter seu crescimento com políticas urbanas que procurem o retorno da população para a cidade consolidada. $O$ urbanismo incrementista e outras intervenções públicas, ainda mais as locais e sem perspectiva territorial, tem consolidado a informalidade indesejável: as ações públicas muitas vezes tem multiplicado a fragmentação urbana.

A estratégia do Fórum deve atender a essas questões promovendo a cidade consolidada e propondo a sutura do informal com o formal, para quebrar a fragmentação social e territorial associada à informalidade. 
Fig.111. TFC (TFG) Martina Leon y Nicolas Ramos.
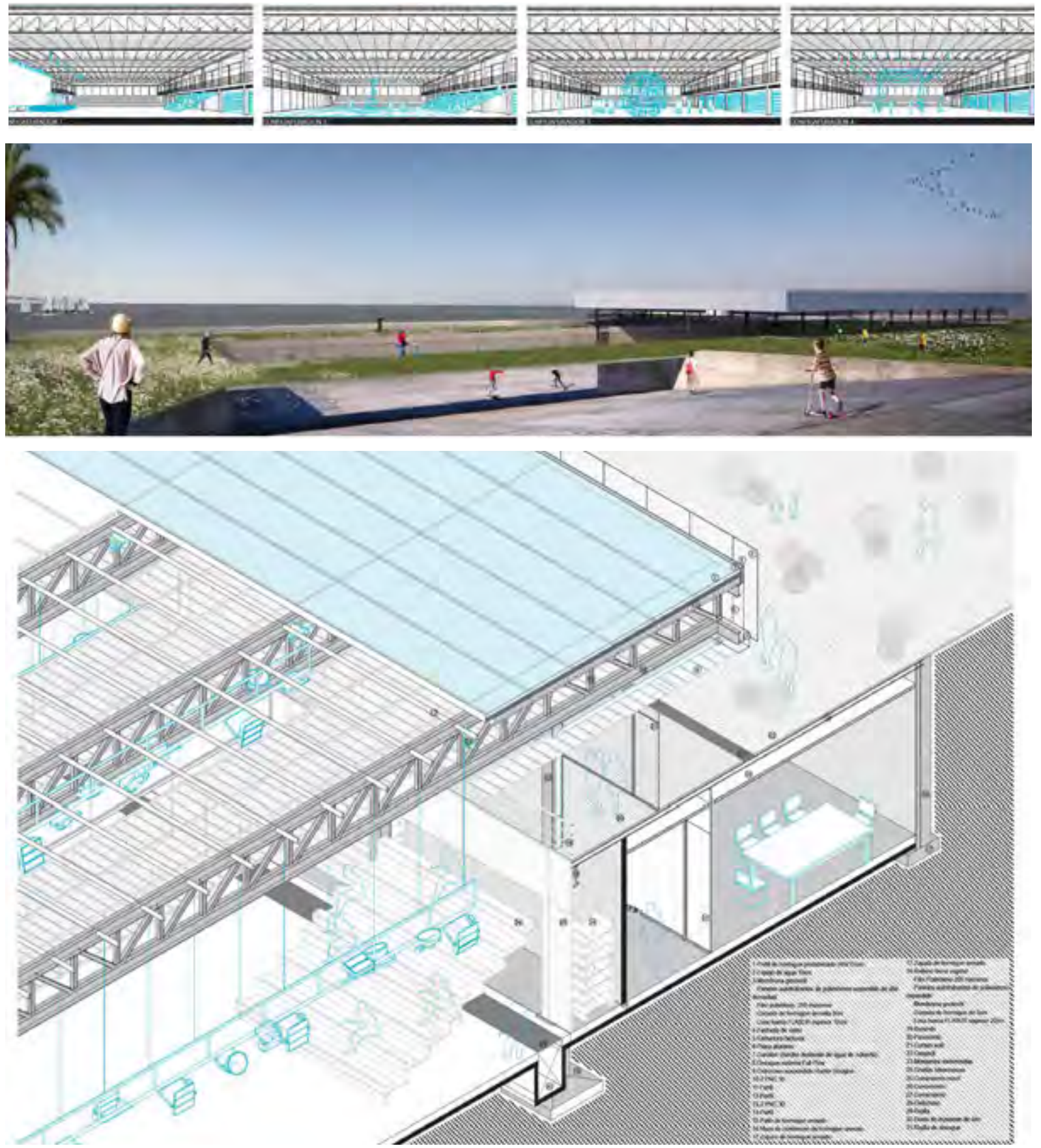


\section{ENCLAVES}

A formulação dos Fóruns nos diversos territórios da periferia sempre será mutável considerando-se o mapeamento dos territórios, contemplando a presença pública e as demandas locais. Busca-se operar registrando os equipamentos e os recursos disponíveis, programando uma intervenção em rede, sempre adaptável e desenhada com atenção a sua múltipla repercussão em escalas locais, municipais e metropolitana, identificando e propondo recursos únicos que posicionam cada um deles singularmente dentro da cidade.

A combinação que dá a consistência de atividades ao Fórum fica aberta a circunstancias particulares, mais combina programas: Educativos, Esportivos, Sociais e Culturais e de Atenção Cidadã, todos eles articulados em termos de integração, arquitetura de equipamentos a partir da desespecializaçào e das metáforas dos espaços públicos. Esses programas serão ainda associados a outros serviços, e sempre estruturados a partir de um espaço público de alta qualificação espacial e conexão com o espaço urbano, um campo que suporta e faz parte dos equipamentos mais do que um espaço exterior a eles.

O estudo de enclaves de cada Fórum é feito a partir de algumas hipóteses estabelecidas em um conjunto de discussoes sobre a estratégia da pesquisa. Foi realizado um "Levantamento de opiniões qualificadas sobre as políticas públicas e o seu desdobramento territorial a partir dos anos 90", que é resumido em Anexo. Também foi estudada a estrutura da Área Metropolitana de Montevidéu e particularmente sua estruturação governamental, fazendo parte de três departamentos (segundo nível de governo depois do governo nacional) Montevidéu, São José e Canelones e subdividida em 24 municípios (terceiro nível de governo). Dessas 24 unidades espaciais se faz uma primeira separação de urgência em função do indicador de Necessidades Básicas Insatisfeitas ficando com as 13 mais críticos. ${ }^{5}$ Adota-se o axioma de um Fórum por cada município prioritário, com um máximo de abrangência de 80-100.000 pessoas o que significa que os municípios de Montevidéu (com população maior a essa quantidade) teriam mais de um. A particularidade de cada situação pede a definição do território de abrangência. Na pesquisa se propõe uma modalidade hipotética, e depois se analisam dois casos particulares: Casavalle, e CCZ17.

\footnotetext{
${ }^{5}$ Esse número sobe para 16 quando se considera uma maior exigência do indicador ou critério, se baseia em critérios estabelecidos por cientistas sociais e possui na pesquisa um valor de hipótese provisional para chegar os testes do Fórum.
} 

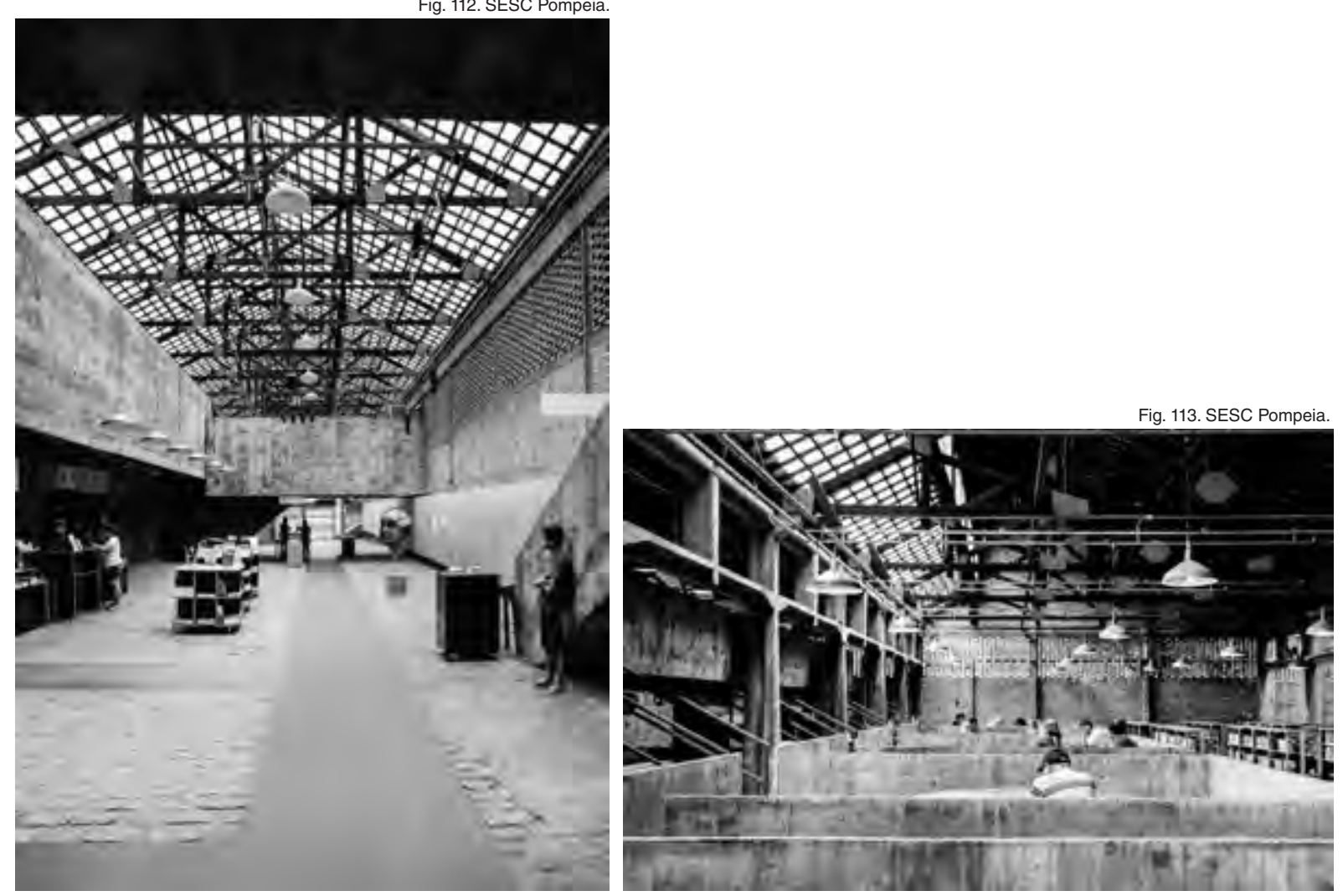


\section{FRM.4 FÓRUM HIPOTÉTICO}

Salientando a condição de laboratório, o "Fórum Hipotético", é uma reflexão sobre assuntos de diferente natureza, muitos deles ficam fora do alcance da atuação exclusiva da arquitetura. A simplificação permite chegar aos objetivos e alcance da pesquisa, mas ela não tem validade geral, fora do estudo: um estudo multidisciplinar de modelização e aplicação deve ser feito com uma sistemicidade e complexidade que não são possíveis nem desejáveis no contexto desta pesquisa

Um levantamento cartográfico especulativo produz um primeiro processo de abstração considerando um grande setor da Área Metropolitana, de geometria simplificada, em que é possível levantar e apresentar os recursos da região. Essa informação trata do que é a dispersão estrutural e a falta de hierarquia na implantação dos equipamentos no território já analisadas.

Quando uma área metropolitana é representada por subsistemas de recursos, permitese aprofundar sua especialização funcional natural em relação a cada serviço como território e comunidade. Esses mapas recolhem cada tipo de equipamento e três níveis de informação: a própria localização do equipamento, seu raio de influência (de caráter hipotético) e as relações que esse equipamento estabelece (ou poderia estabelecer) com aqueles que pertencem ao mesmo subsistema de recursos públicos. Nesse universo de equipamentos a pesquisa propõe a identificação de um equipamento principal e sem especialização, mas que é fundamental na qualidade urbana e sua relação com o os equipamentos públicos, que são os Espaços Públicos.

Uma vez entendida a inserção global dos equipamentos e as redes especializadas, é preciso voltar para o sistema completo, sobrepondo todos eles para entender as complexas relações estabelecidas no território e particularmente com a comunidade.

Finalmente dentro desta Amostra, região complexa e com muitos equipamentos diversos, vai testar a hipótese de inserção de um Fórum. Nos desenhos que seguem, propõe-se no mesmo nível especulativo e abstrato o resultado da inserção do Fórum como conjunção aberta de uma série de equipamentos em um espaço público de alta qualificação e conexão com outros espaços da cidade. Esses equipamentos contidos no Fórum darão lugar a variados raios de abrangência que já não é só a soma algébrica de cada equipamento, mas a expressão da sinérgica centralidade produzida na região. 


\section{ÁREA METROPOLITANA UNIVERSO DE EQUIPAMENTOS}

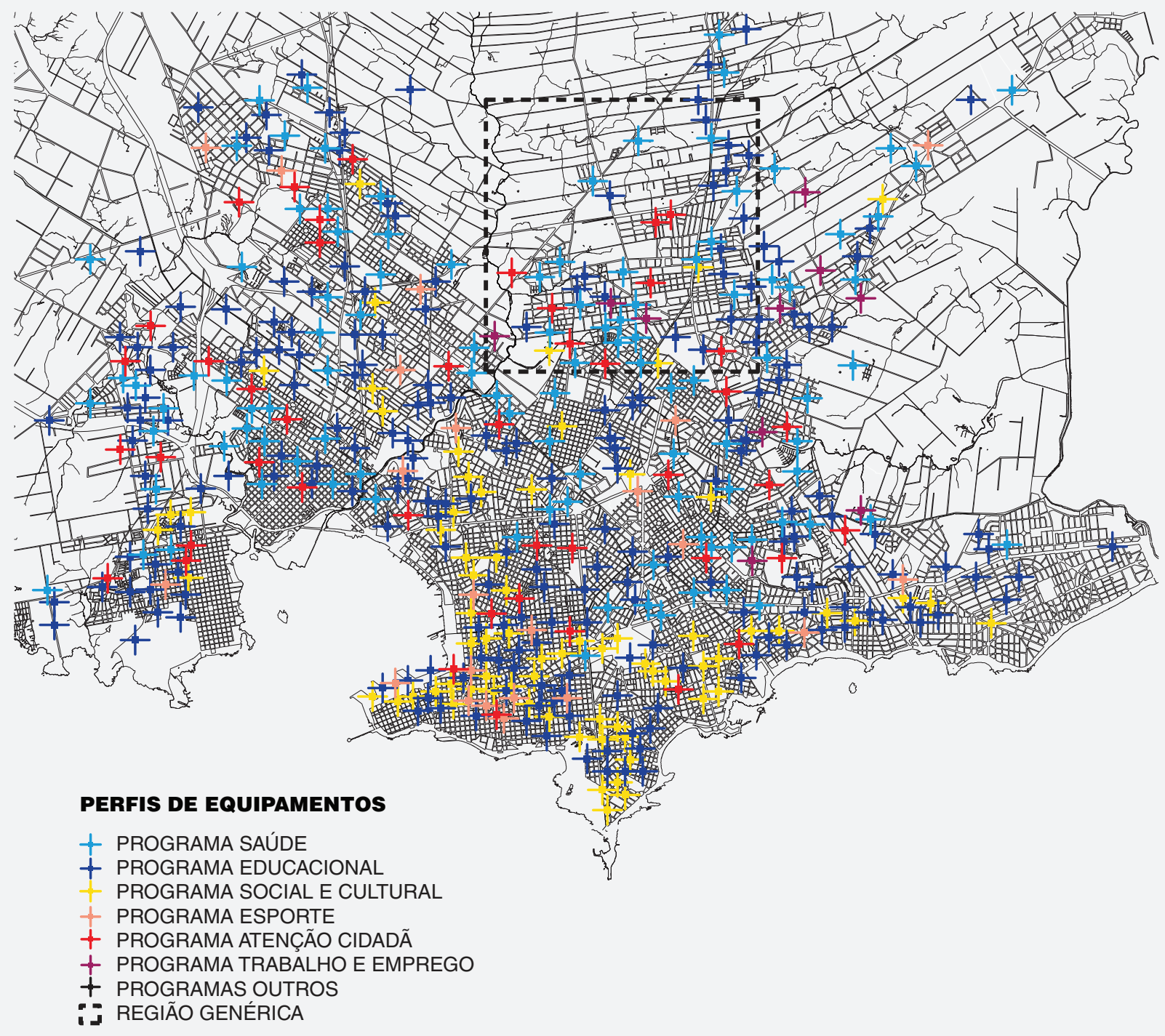

Informação obtida de:

IM_www.sig.montevideo.gub.uy

MIDES_www.mapas.mides.gub.uy/

ANEP_www.sig.anep.edu.uy/siganep OPP_www.municipios.gub.uy/ 
MAPA ABSTRAÇÃO OO REGIÃO GENÉRICA

UNIVERSO DE EQUIPAMENTOS

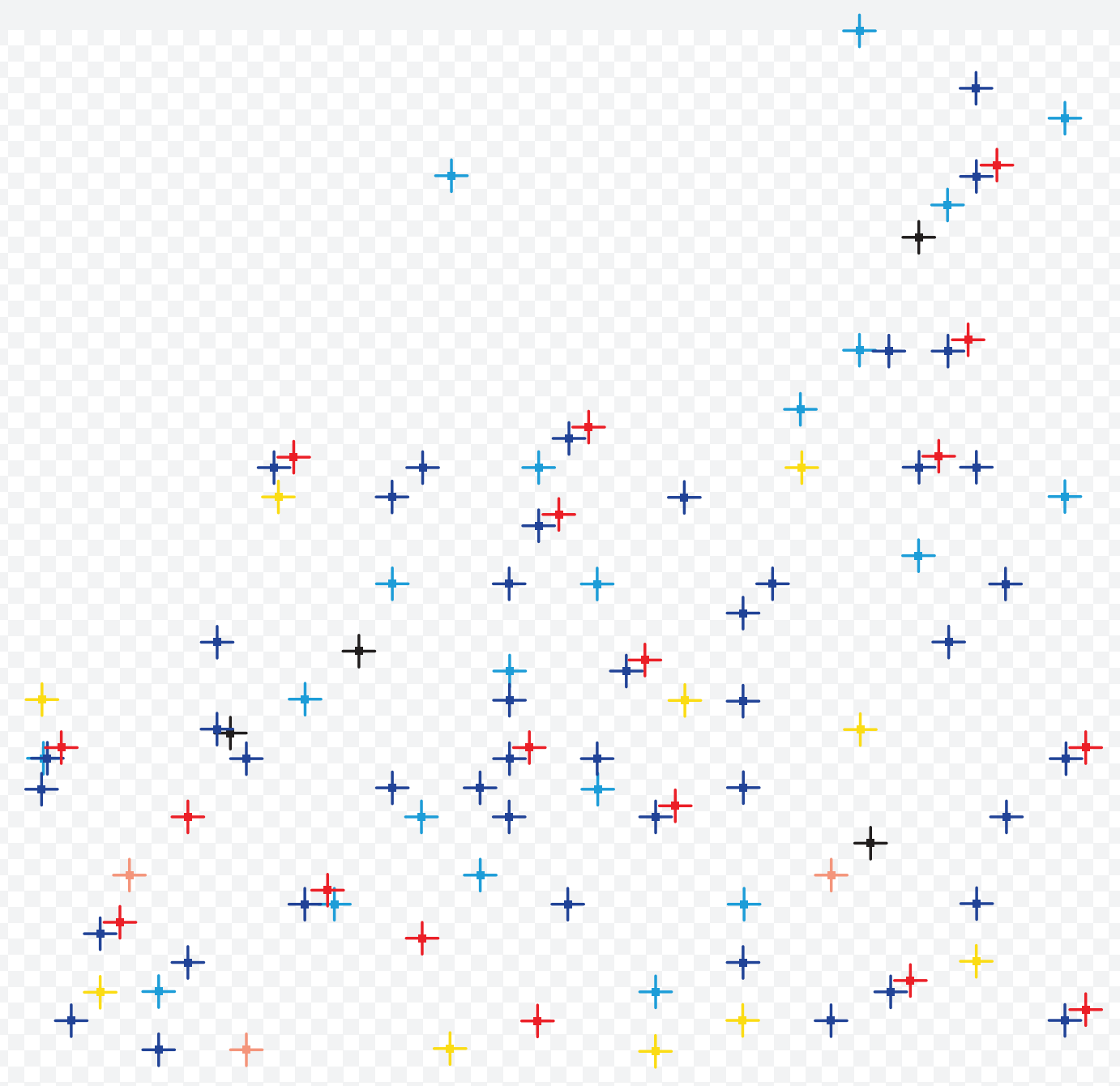

PERFIS DE EQUIPAMENTOS

+ PROgRAMA SAÚDE

+ PROGRAMA EDUCACIONAL

PROGRAMA SOCIAL E CULTURAL

PROGRAMA ESPORTE

+ PROGRAMA ATENÇÃO CIDADÃ

+ PROGRAMA TRABALHO E EMPREgo

+ PROGRAMAS OUTROS 


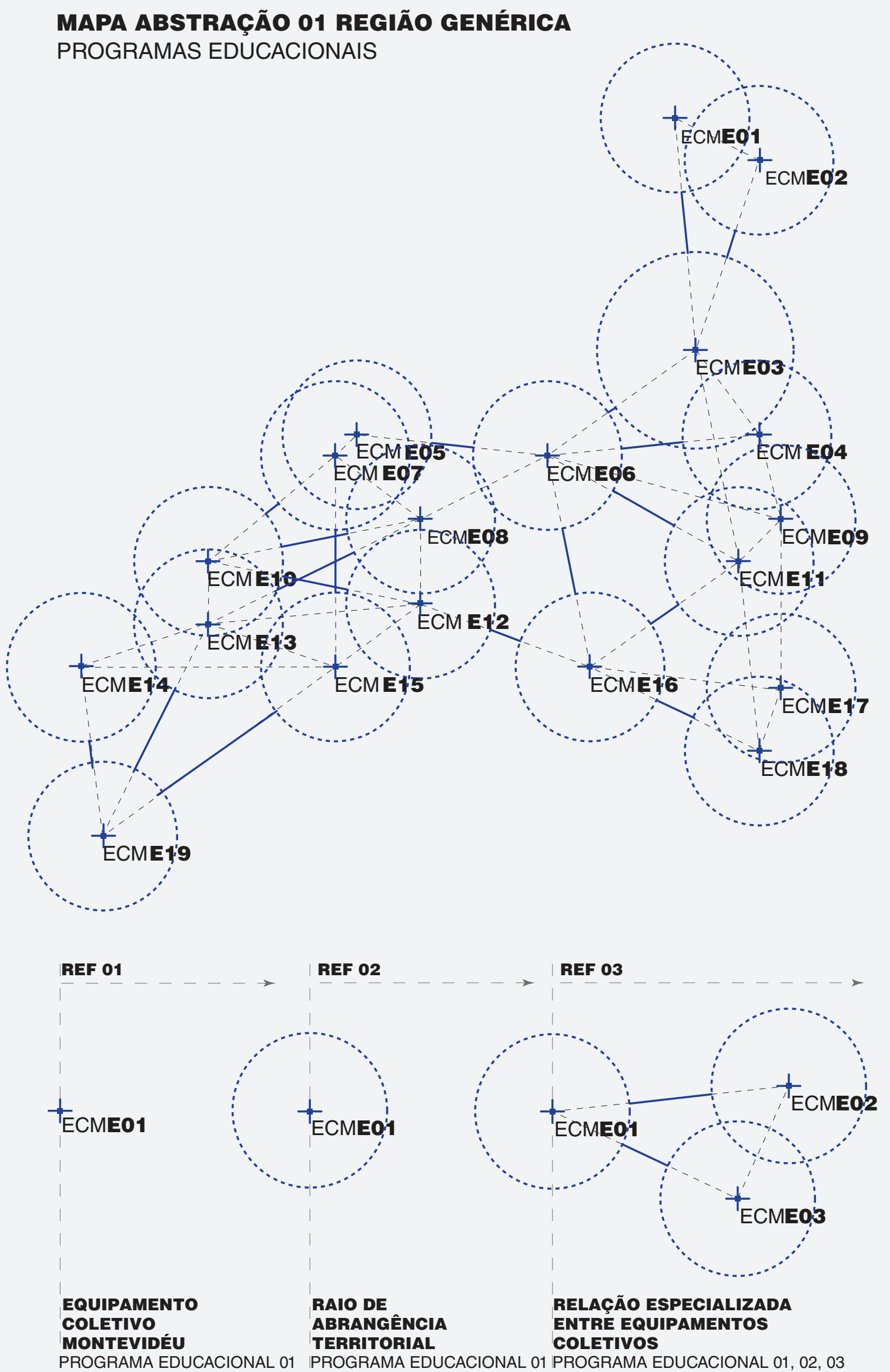


MAPA ABSTRAÇÃO 02 REGIÃO GENÉRICA

PROGRAMAS ATENÇÃO CIDADÃ

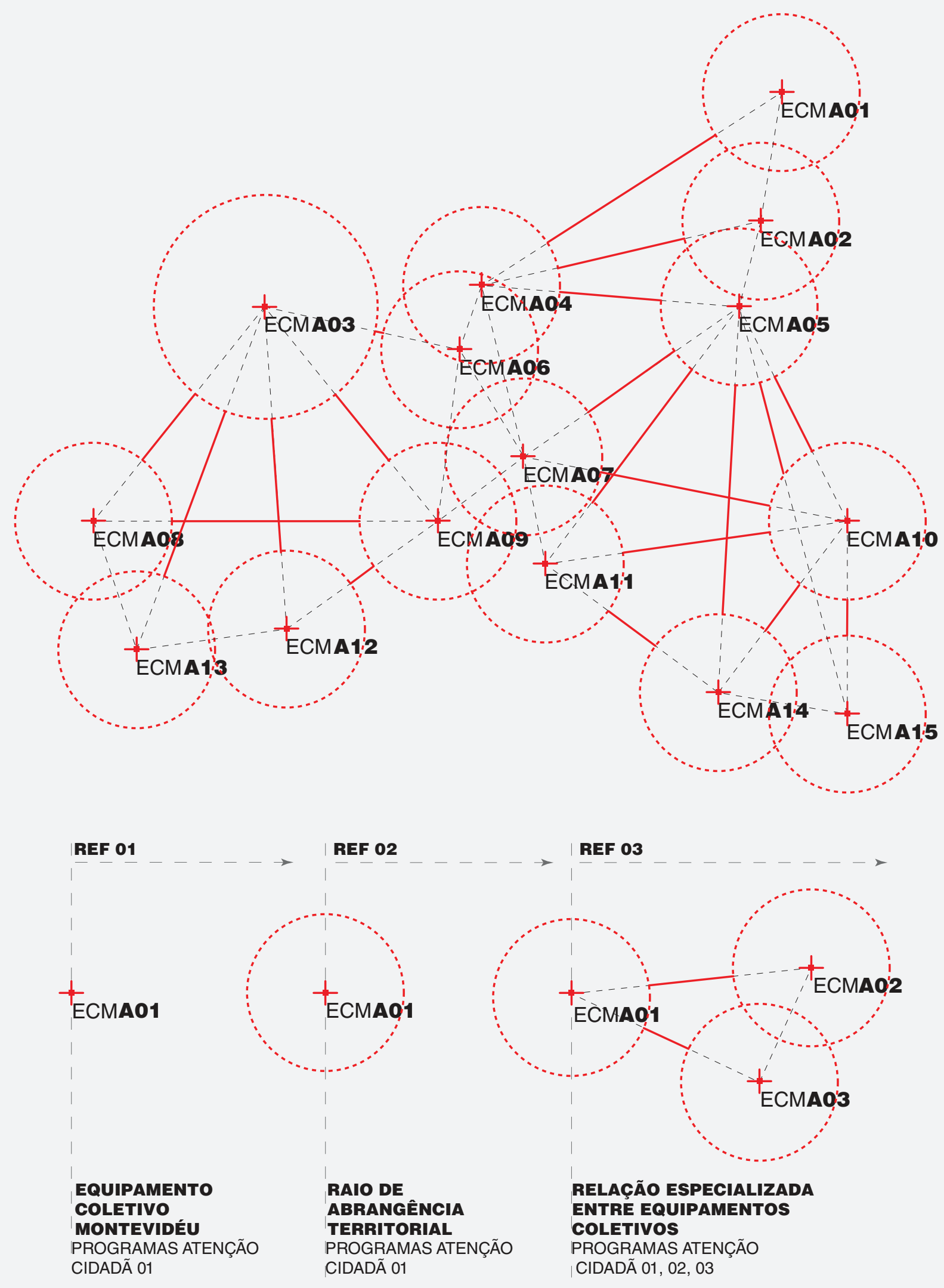


MAPA ABSTRAÇÃo 03 REGIÃo GENÉRICA

PROGRAMAS SOCIAIS E CULTURAIS

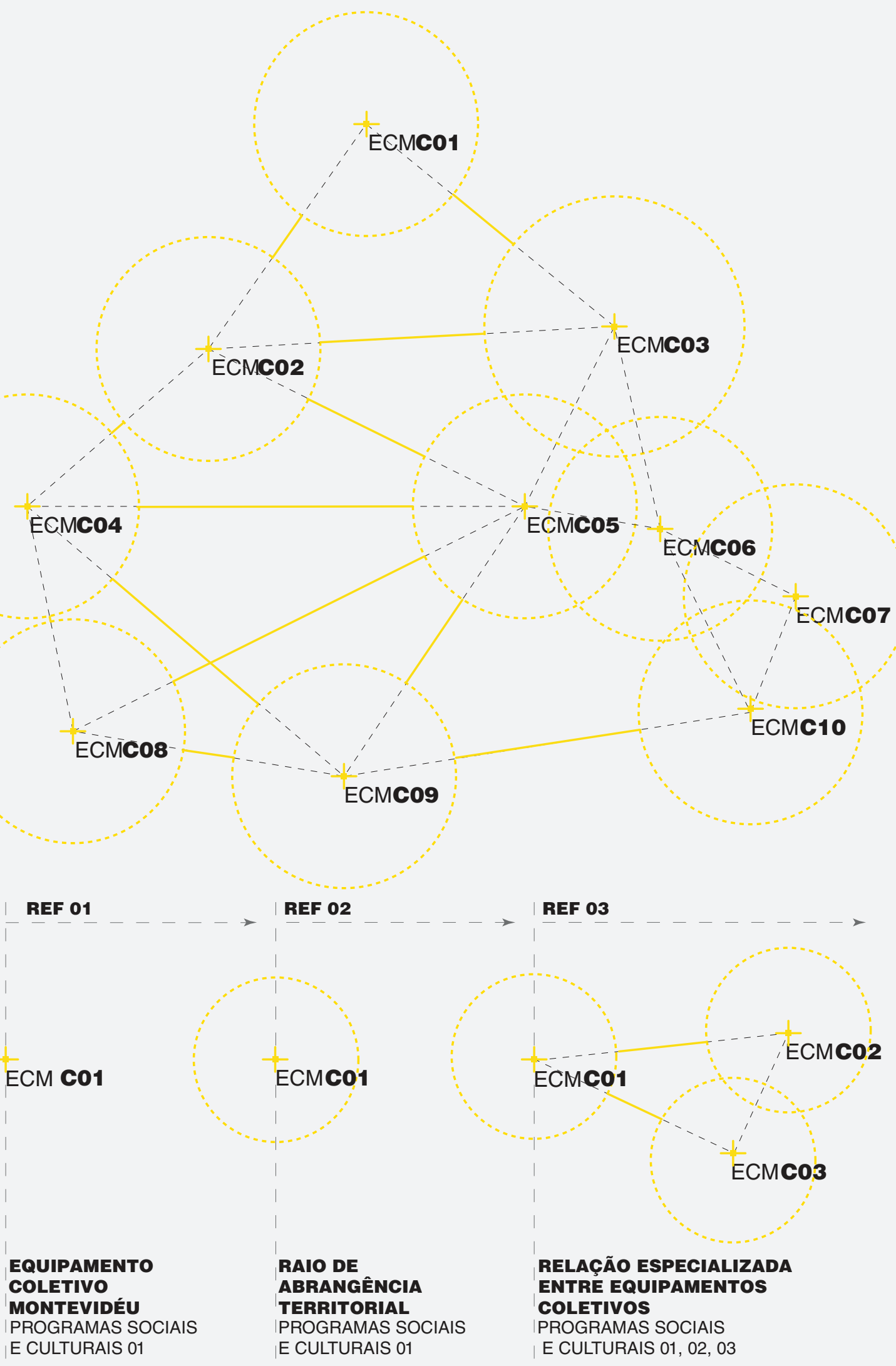


MAPA ABSTRAÇÃO 04 REGIÃO GENÉRICA

PROGRAMAS SAÚDE
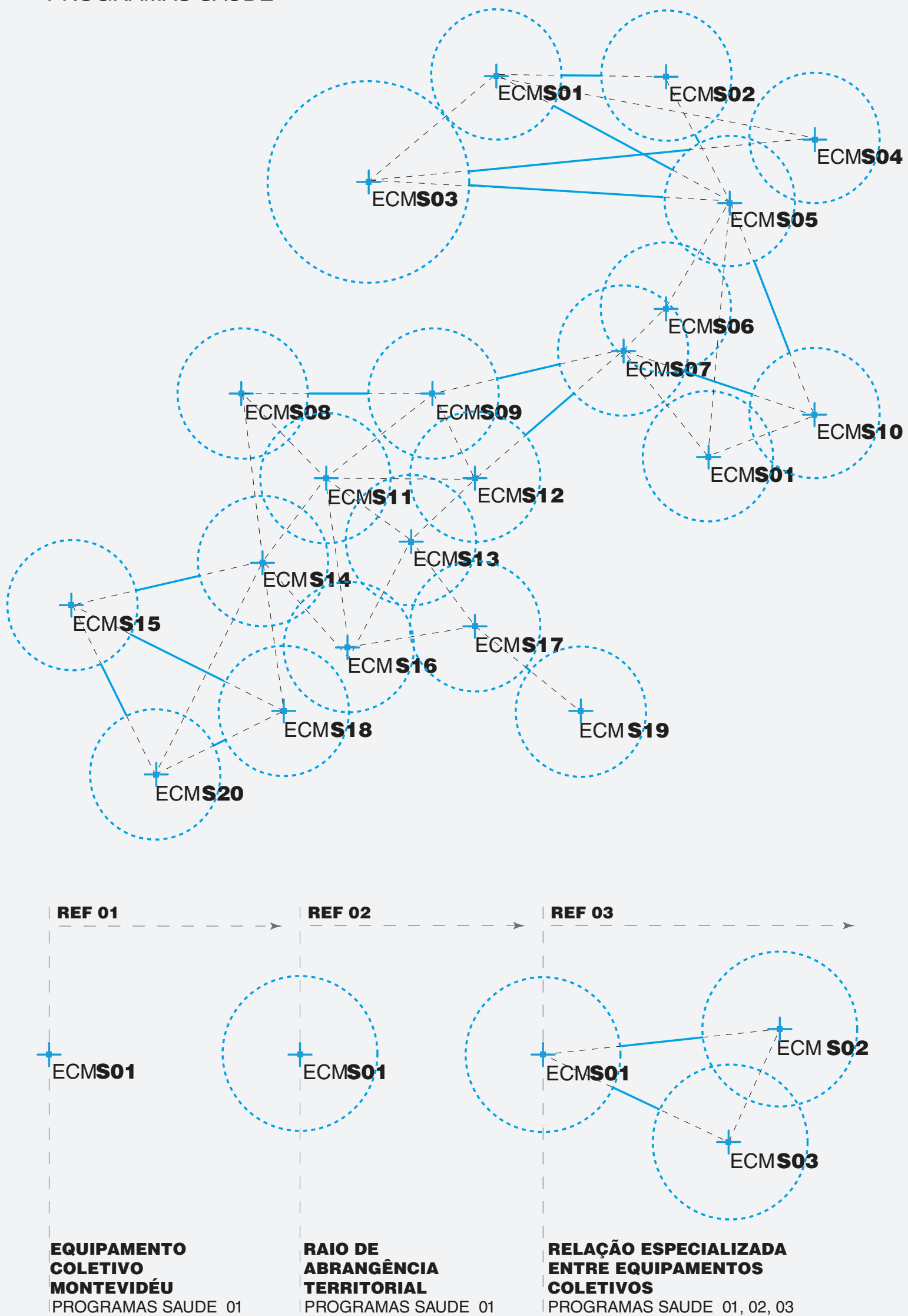
MAPA ABSTRAÇÃO 05 REGIÃO GENÉRICA

ESPAÇOS PÚBLICOS

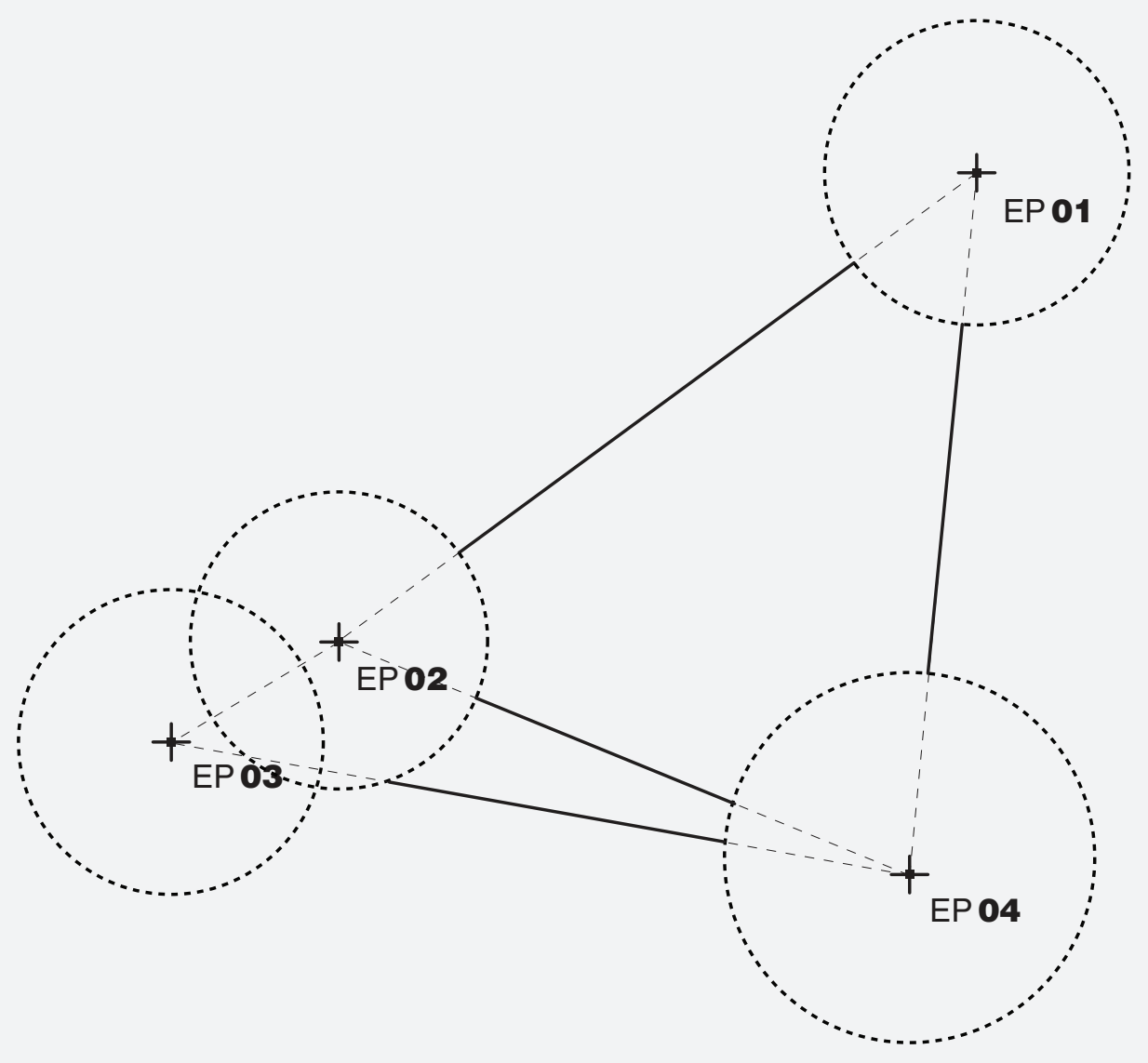

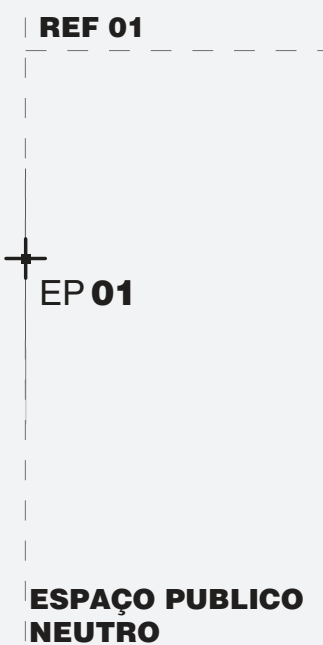

REDE VIÁRIA

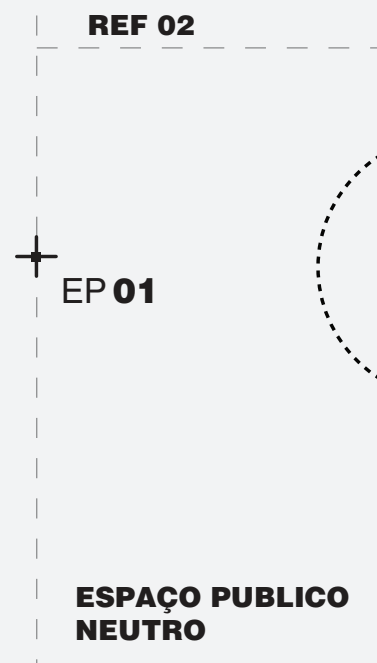

ESPAÇOS PÚBLICOS 01
REF 03

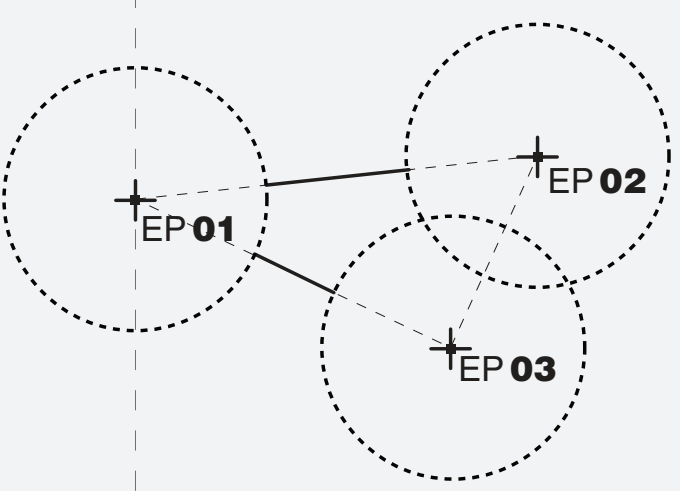

RAIO DE ABRANGÊNCIA TERRITORIAL

ESPAÇOS PÚBLICOS 01 
MAPA ABSTRAÇÃO 06 REGIÃO GENÉRICA

SUPERPOSIÇÃO DE EQUIPAMENTOS E

SELEÇÃO HIPOTÉTICA DA AMOSTRA

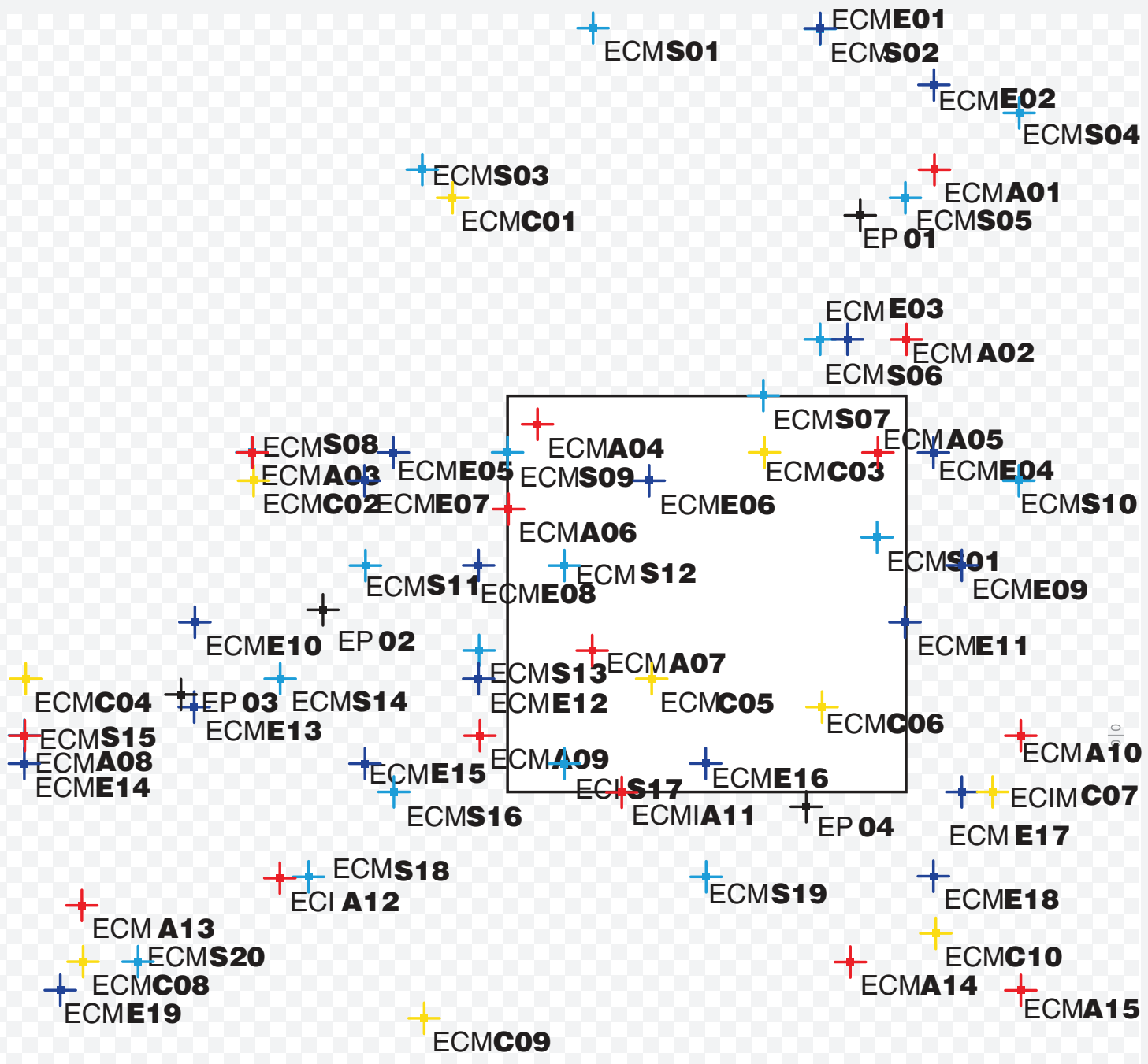

PERFIS De EquiPAMENTOS

+ PROGRAMA SAÚDE

+ PROGRAMA EDUCACIONAL

PROGRAMA SOCIAL E CULTURAL

- PROGRAMA ESPORTE

+ PROGRAMA ATENÇÃO CIDADÃ

+ PROGRAMA TRABALHO E EMPREgo

+ PROGRAMAS OUTROS 


\section{AXONOMETRIA ABSTRAÇÃO \\ SUPERPOSIÇÃO DE EQUIPAMENTOS E SELEÇÃO HIPOTÉTICA DA AMOSTRA}

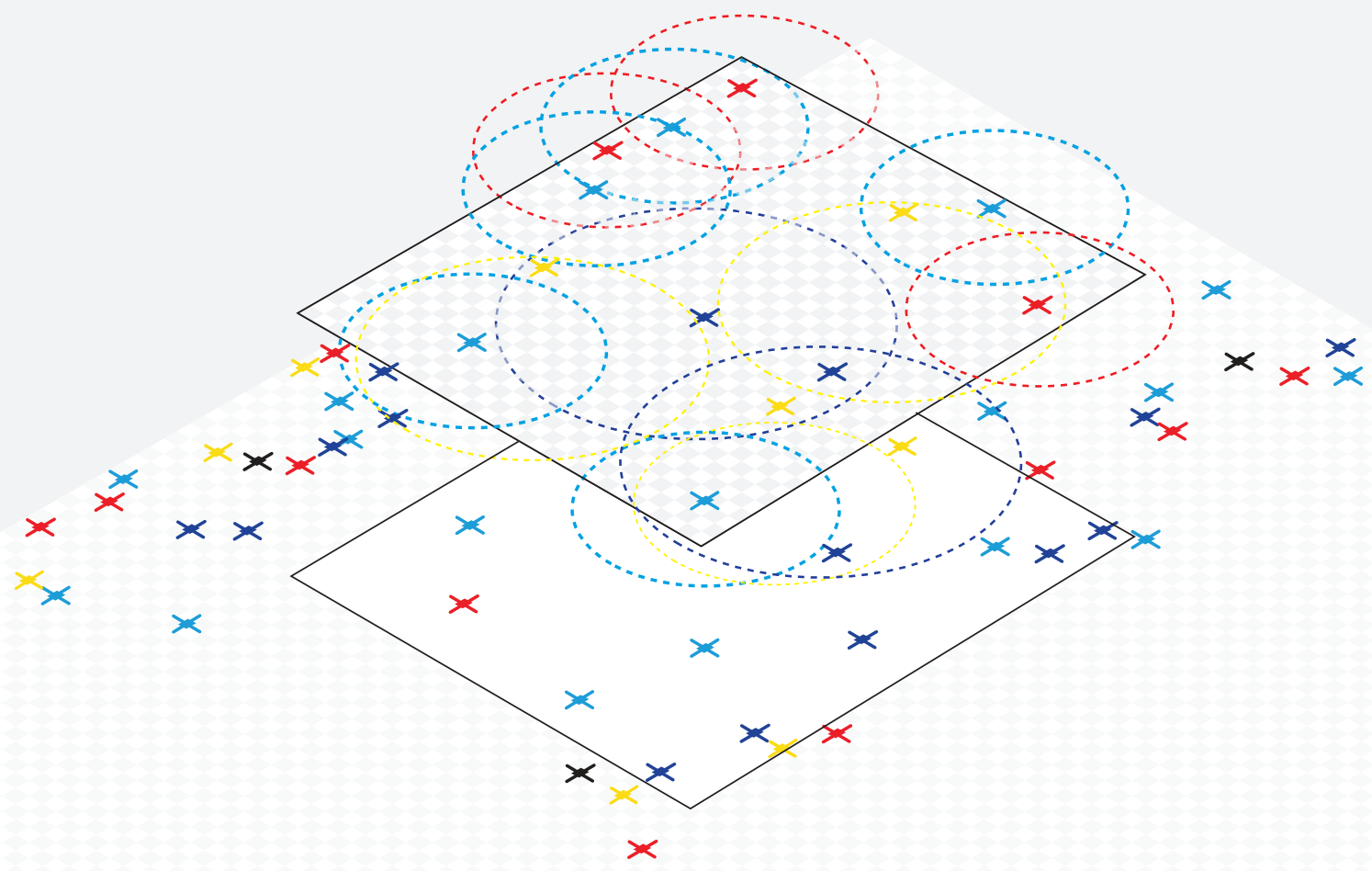

\section{Critérios de seleção da amostra.}

_População equivalente à de um Município.

_População máxima 80.000 a 100.000 habitantes.

_Avaliação de necessidades básicas insatisfeitas. (1, 2 ou 3)

_Carências e abrangências e de equipamentos coletivos principais escolhidos.

_Qualidade de espaços públicos disponíveis

_Qualidade da informação disponível. 


\section{MAPA ABSTRAÇÃO 07 REGIÃO GENÉRICA}

ZOOM DE AMOSTRA HIPOTÉTICA

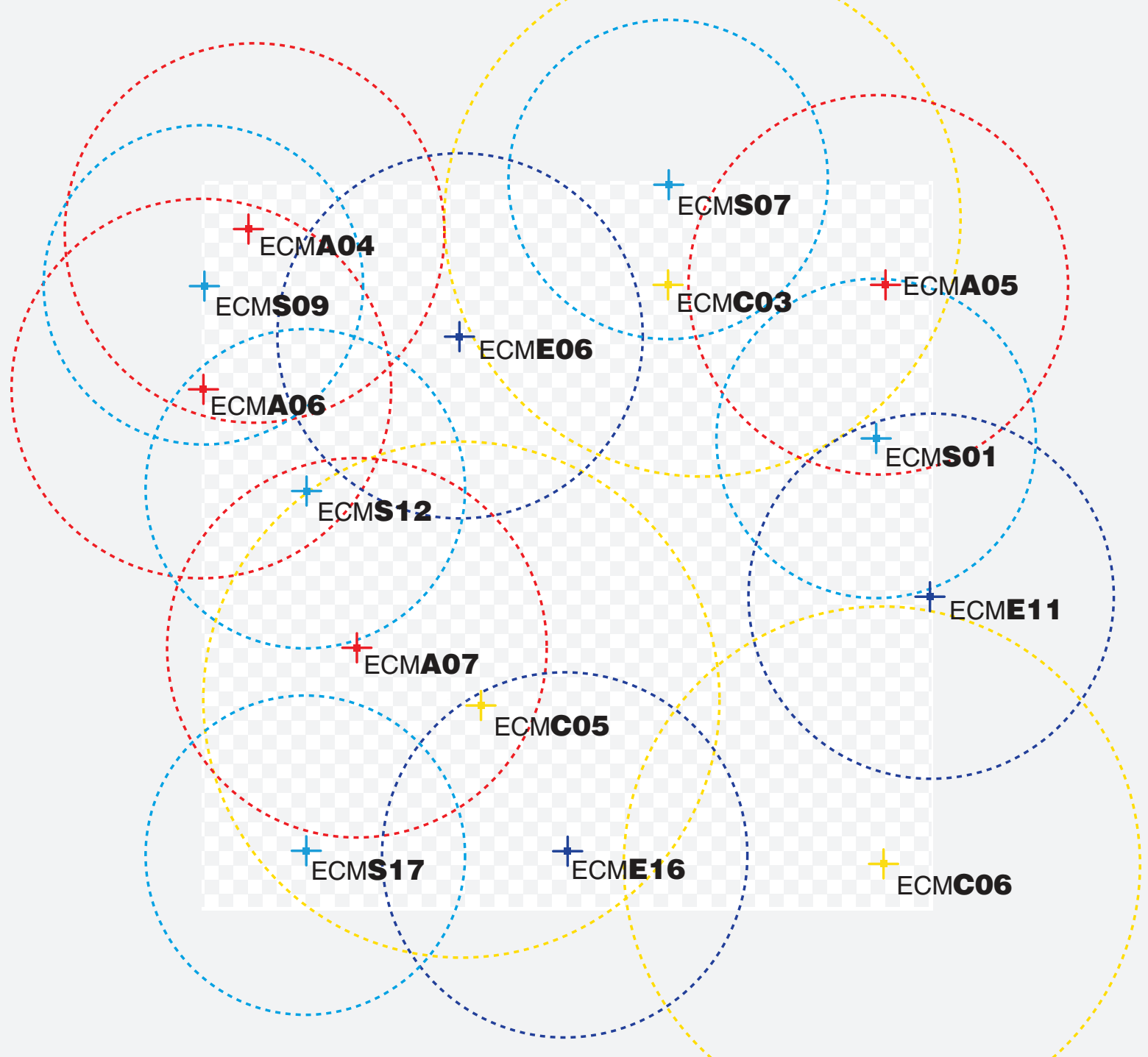


MAPA ABSTRAÇÃO 08

FÓRUM HIPOTÉTICO

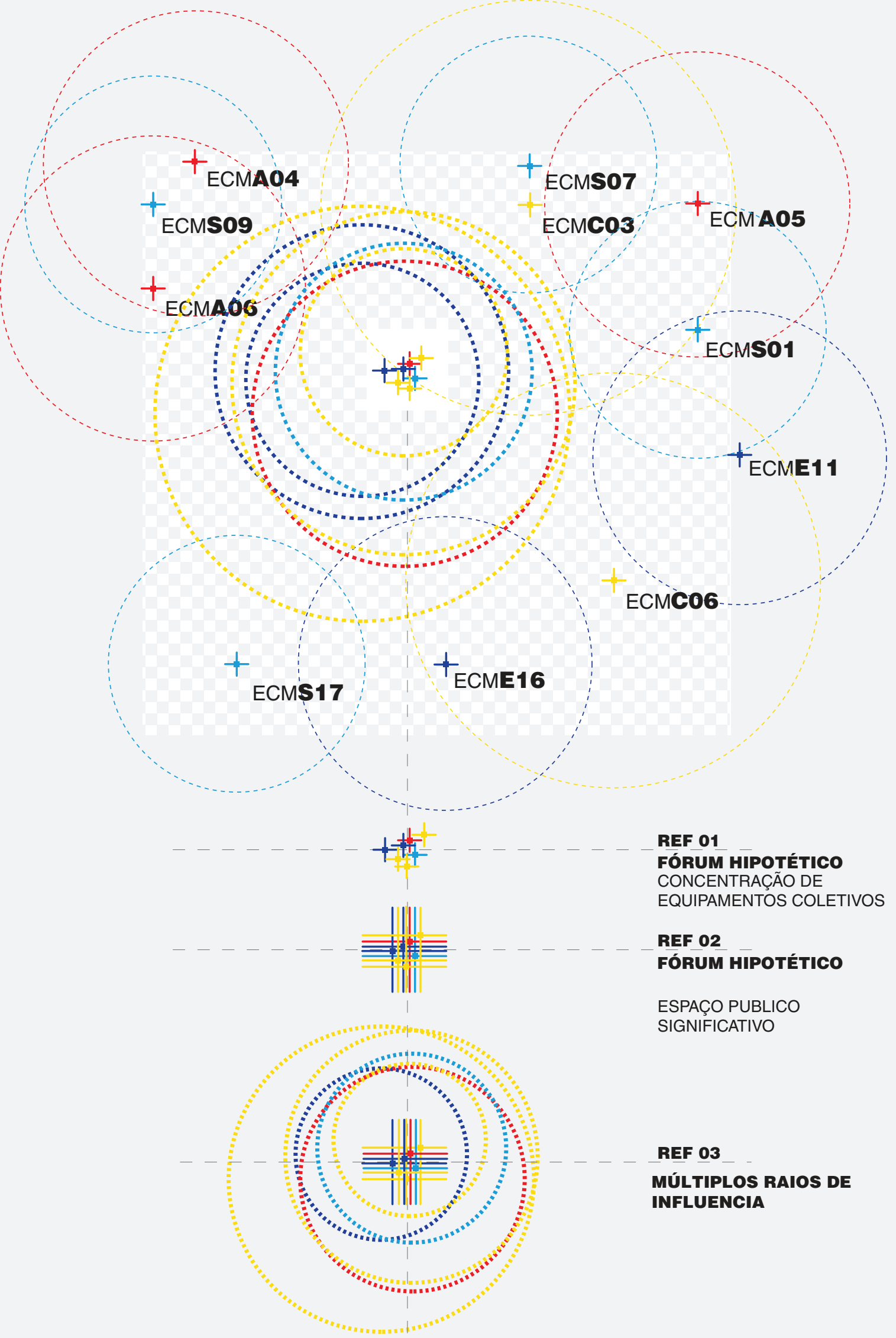



Fig.114. SESC 24 de Maio. PMdR + MMBB

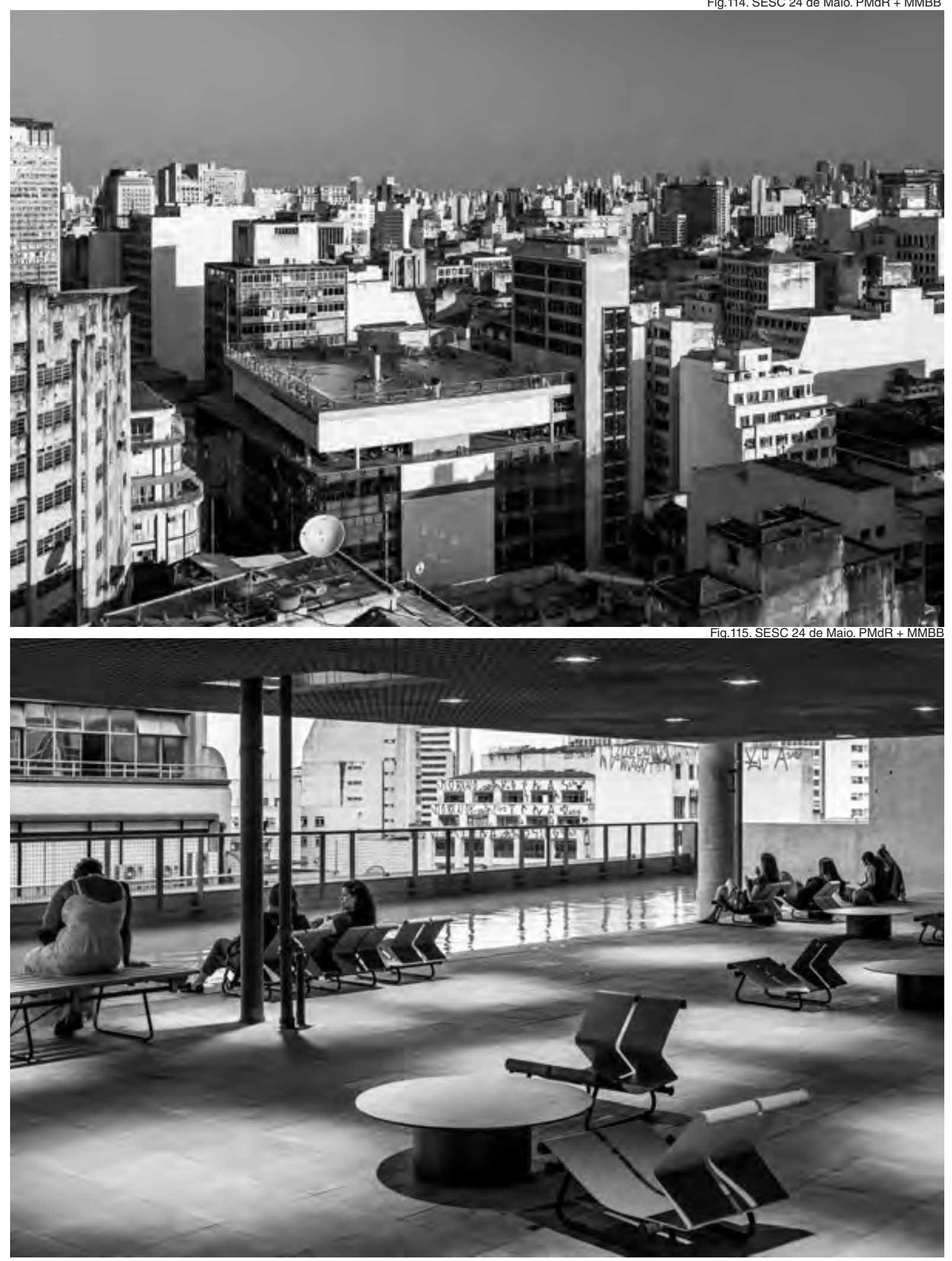


Os limites do laboratório são evidentes, trata-se de uma representação "simplificada da complexidade", uma "Flatland" (ABBOTT, 2008). As figuras do raio de abrangência como círculos perfeitos e homogéneos que, mesmo tendo pregnância e aparência cientifica, opacam a complexidade do território, particularmente aquele de condição fragmentaria da periferia: as diferencias de densidade, as fronteiras territoriais subjetivas que descrevem os fragmentos culturais e físicos da região, as fronteiras geográficas que estabelecem separações, os eixos viários principais que estruturam o território e condensam a mobilidade urbana, os recursos coletivos existentes, a informalidade e a delinquência que atuam com força e não aparecem nos SIG e muitos outros. 


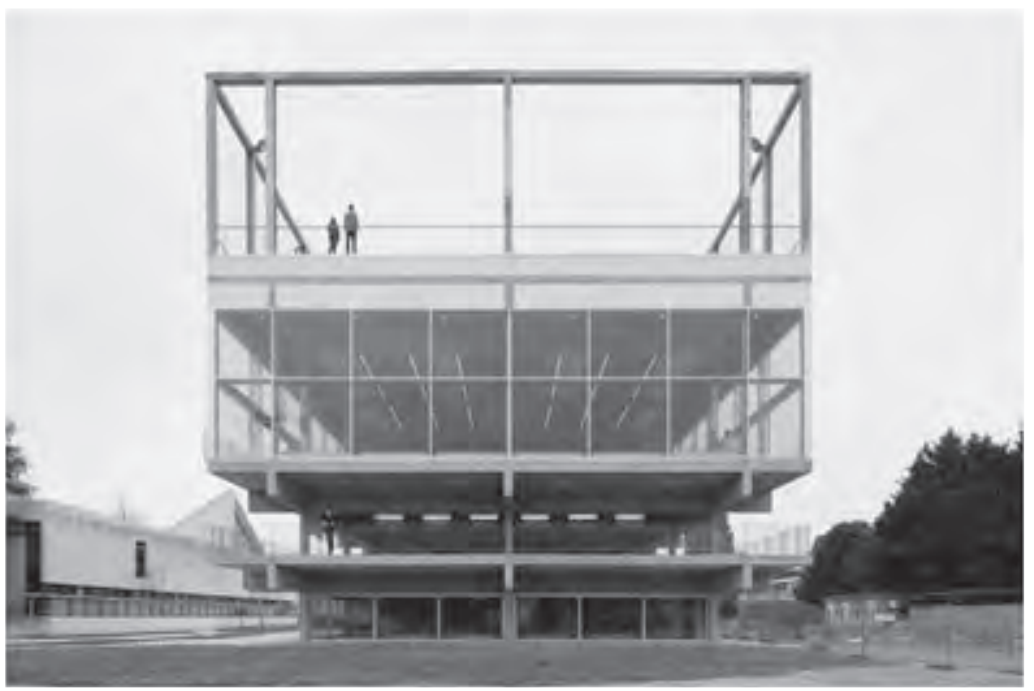

Fig.117. Saclay. Muoto Architects

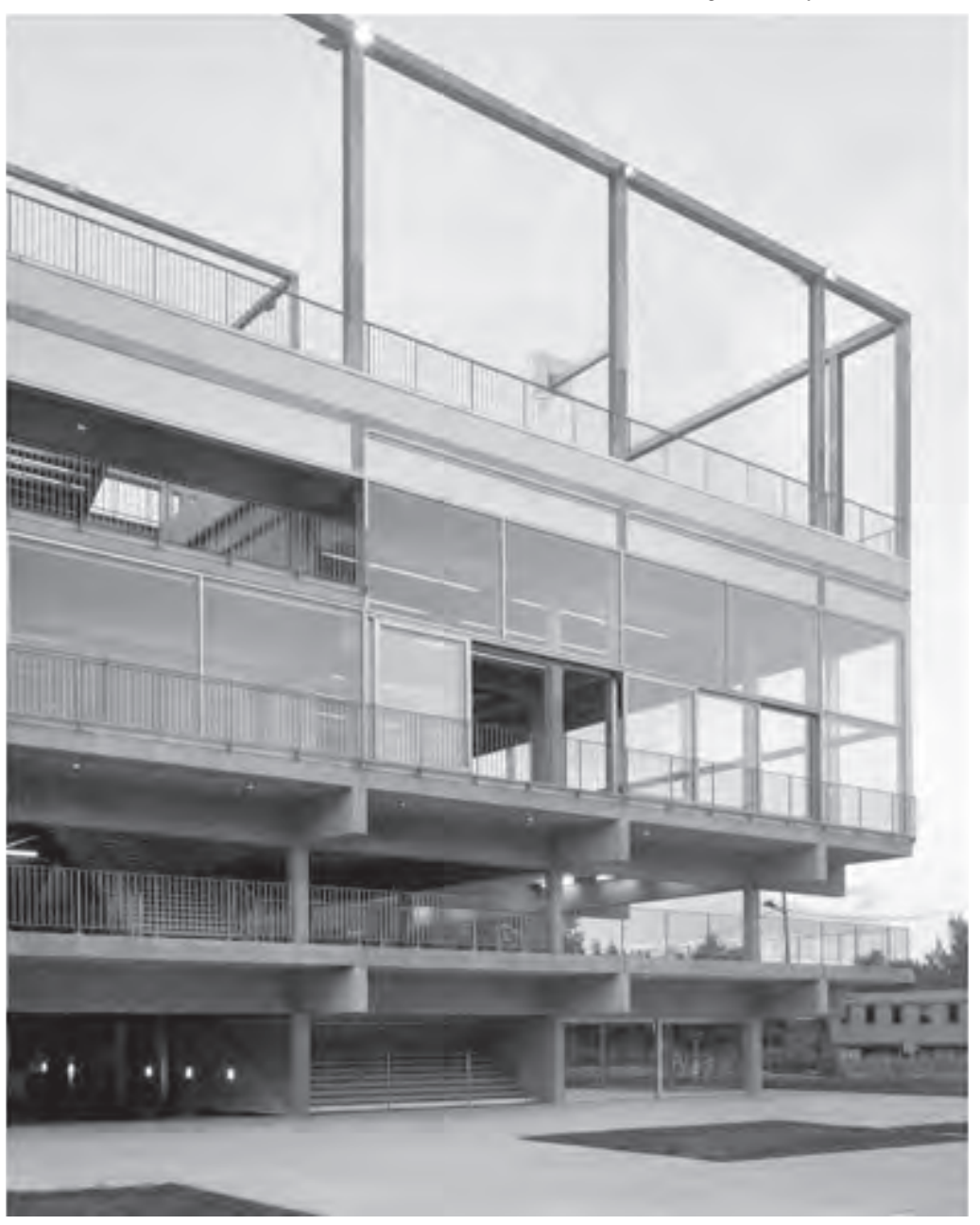




\section{FRM.5 METAPROJETO PESQUISA}

Onde a investigação científica procura dar resposta à questão de como as coisas
são, a investigação projetual procura dar resposta à questão de como as coisas
poderiam ser. (FOQUÉ, 2010, p.45 tradução nossa)

A partir da hipótese estabelecida na pesquisa, um intuito pela criação de uma nova realidade, uma possibilidade no sentido da citação de Richard Foqué ${ }^{0}$ que requer projetos, imagens como desenvolvimento das ideias.

O Fórum ainda não existe como é formulado nesta pesquisa, que estabelece alguns indícios experimentais de sua possibilidade sustentados numa forma de trabalho ad-hoc, pois não deriva de uma teoria ou metodologia já existente

Como em outras profissões, especialmente na arquitectura, a maior parte do
conhecimento é gerado e legitimado pragmaticamente, não provem de uma
derivação logica da teoria. (Ibid. p.150, tradução nossa)

As especificidades do processo de projeto, a sua compreensão e a sua relação com a pesquisa, faz parte da cultura recente na FADU UDELAR. Já foi referida no capítulo DPL, a contribuição teórica de Gustavo Scheps (1996) (sobre o processo de projeto) e prática (sobre seu ensino, e a sua própria produção projetual) permitiu reconhecer uma heurística do projeto complexo (Idem, 2002). A formulação desta pesquisa deve muito a sua influência, depois de ter compartilhado com ele o trabalho no Ateliê e na Faculdade.

A partir de criação do programa I+P (Pesquisa + Projeto) montado em 2010, e os posteriores cursos de pós-graduação em pesquisa projetual: Diploma, Mestrado e Doutorado, se desenvolveu na FADU uma massa critica de trabalhos que percorrem essas relações. A tese da FAU USP "O papel do projeto na pesquisa académica em arquitetura" de Alina del Castillo (2017) analisa a citada produção e a coloca em contexto teórico geral.

A argumentação do Fórum se concentra em dois níveis. De um modo abstrato o Fórum é um "metaprojeto" baseado na desespecialização programática e num entendimento sobre o território metropolitano de Montevidéu. O metaprojeto é entendido como a abertura de um campo de possibilidades (JAENICKE, 2015), uma formulação preprojetual para projetos diversos. Assim toda a apresentação textual sobre o Fórum, e o Fórum Hipotético constituem esse metaprojeto, que também é um metaprograma como sinergia aberta a formulações específicas. O metaprojeto é a formulação abstrata de uma ideia, a versão de uma hipótese. É importante salientar a condição abstrata, mas 


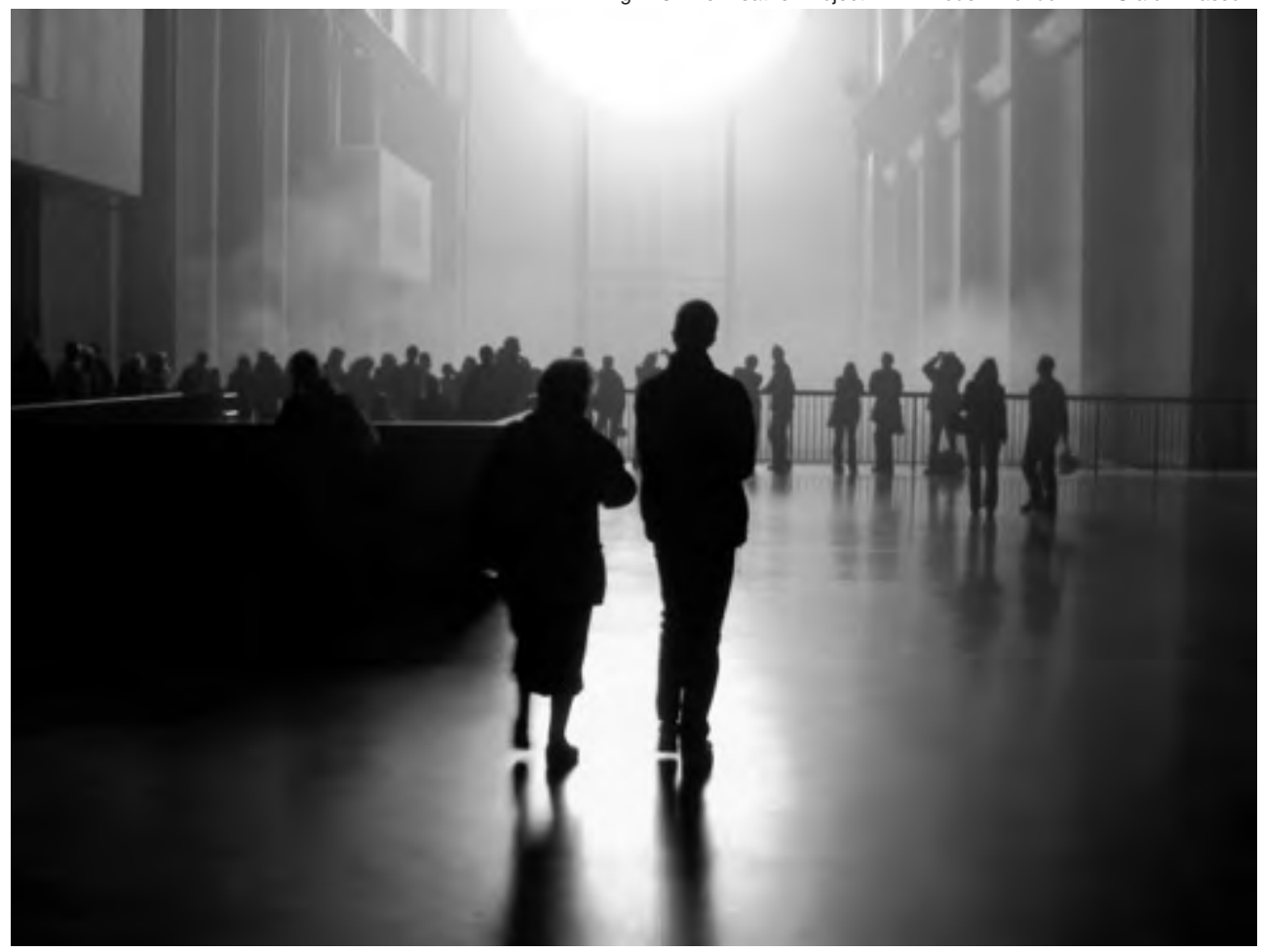


arquitetônica da ideia: trata-se de uma abstração que destila outros projetos, desde os romanos até hoje, projetos estudados, feitos no escritório (ou imaginados) e estimulados e acompanhados desde a docência. O metaprojeto é arquitetura aberta para muitos projetos.

Assim o metaprojeto pode ser entendido também em relação com uma ideia de operação com "modelos", seguindo a definição de Olafur Eliasson (2009) o metaprojeto é uma criação aberta à possiblidade de coprodução com outros atores: no momento do projeto diferentes projetistas podem desenvolver projetos. Os modelos são um entendimento do projeto contemporâneo como fusão de espaço, tempo, geometria e práticas. Depois do projeto do Fórum, o espaço aberto e habitável por instituições e sujeitos que the darão vida, é uma chamada para a coprodução no tempo. A quarta dimensão multiplicada, espaços "n dimensionais" nas palavras de Ascher. 
catálogo casavalle dSL

EQUIPAMENTOS PRINCIPAIS

凹

$\square$

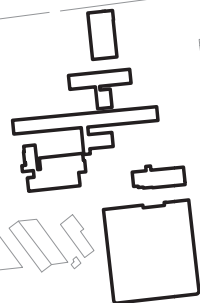

ロㅁ 


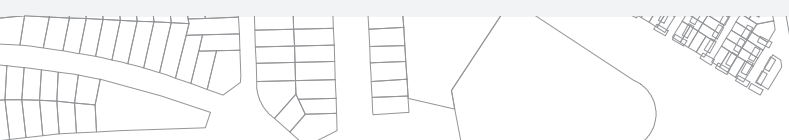

Nitile eliti

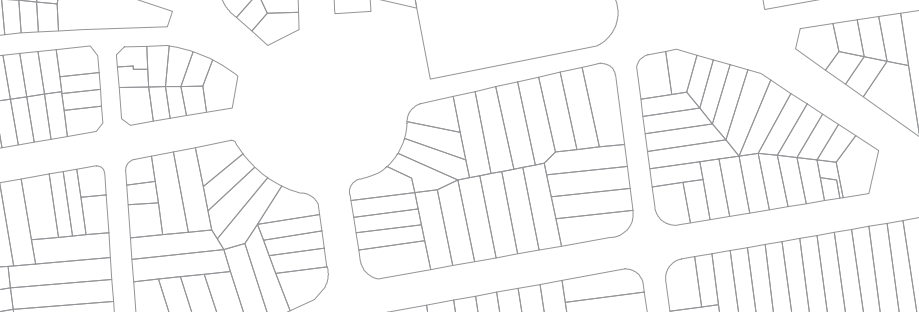

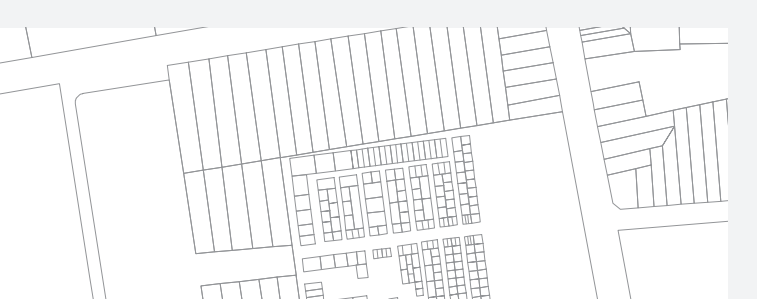

MUTIIF

Alll

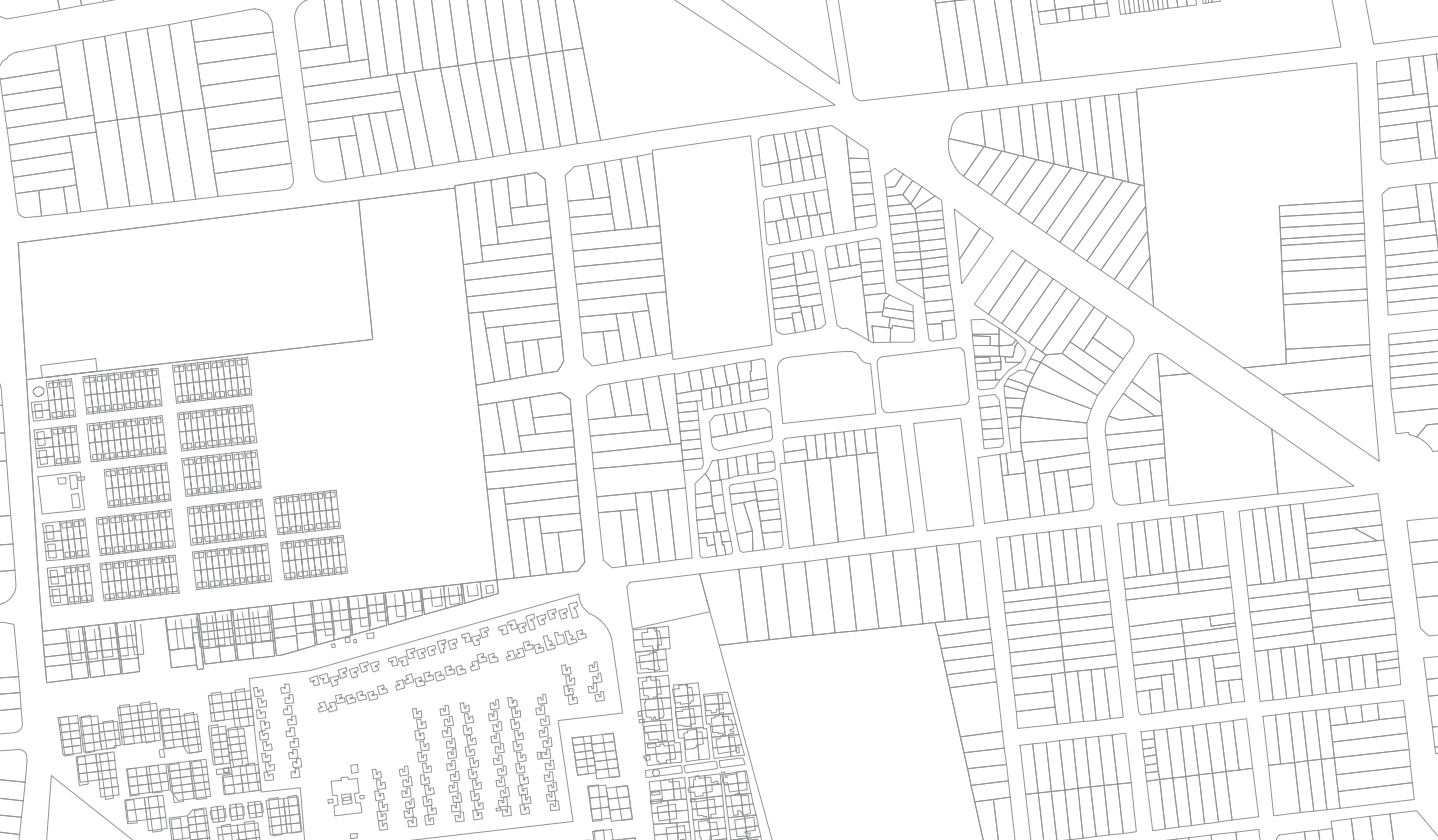

(III)

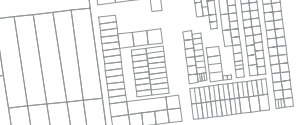

$-2$

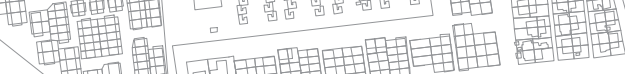

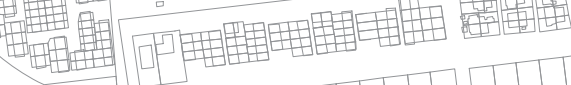

G MIMTD
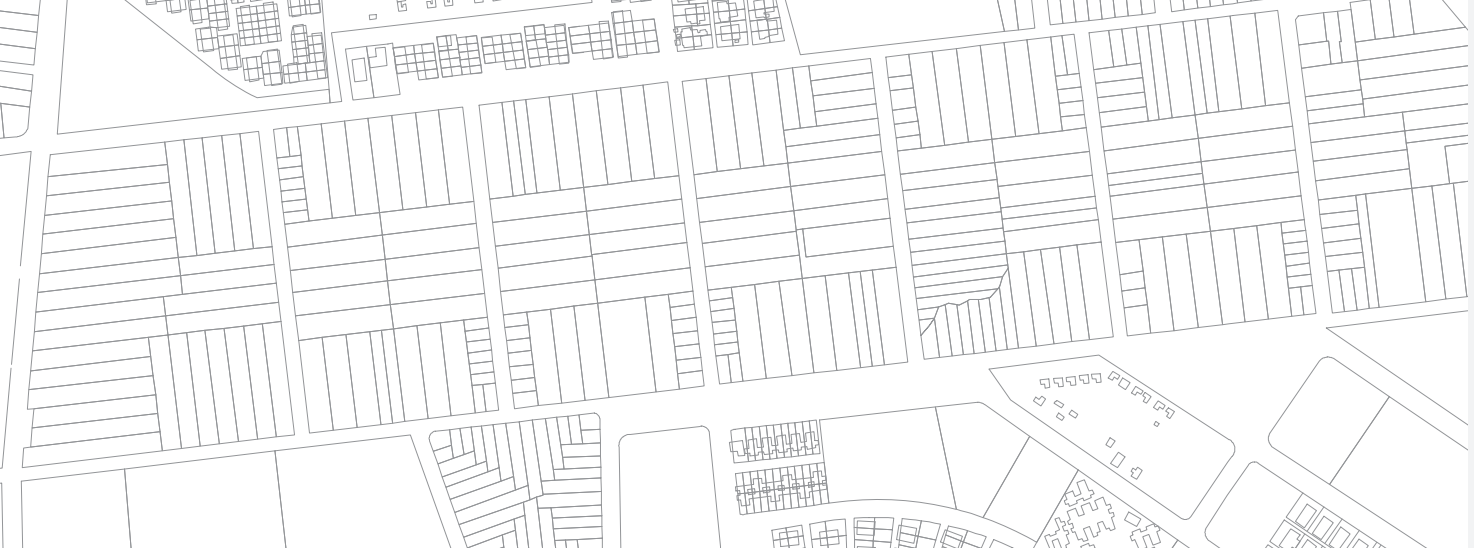

or of of of

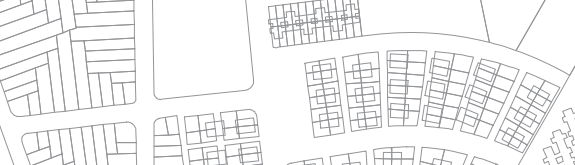

证的

D 
catálogo casavalle dSL

CASAVALLE DSL DISSOLUÇÃO PROGRAMÁTICA

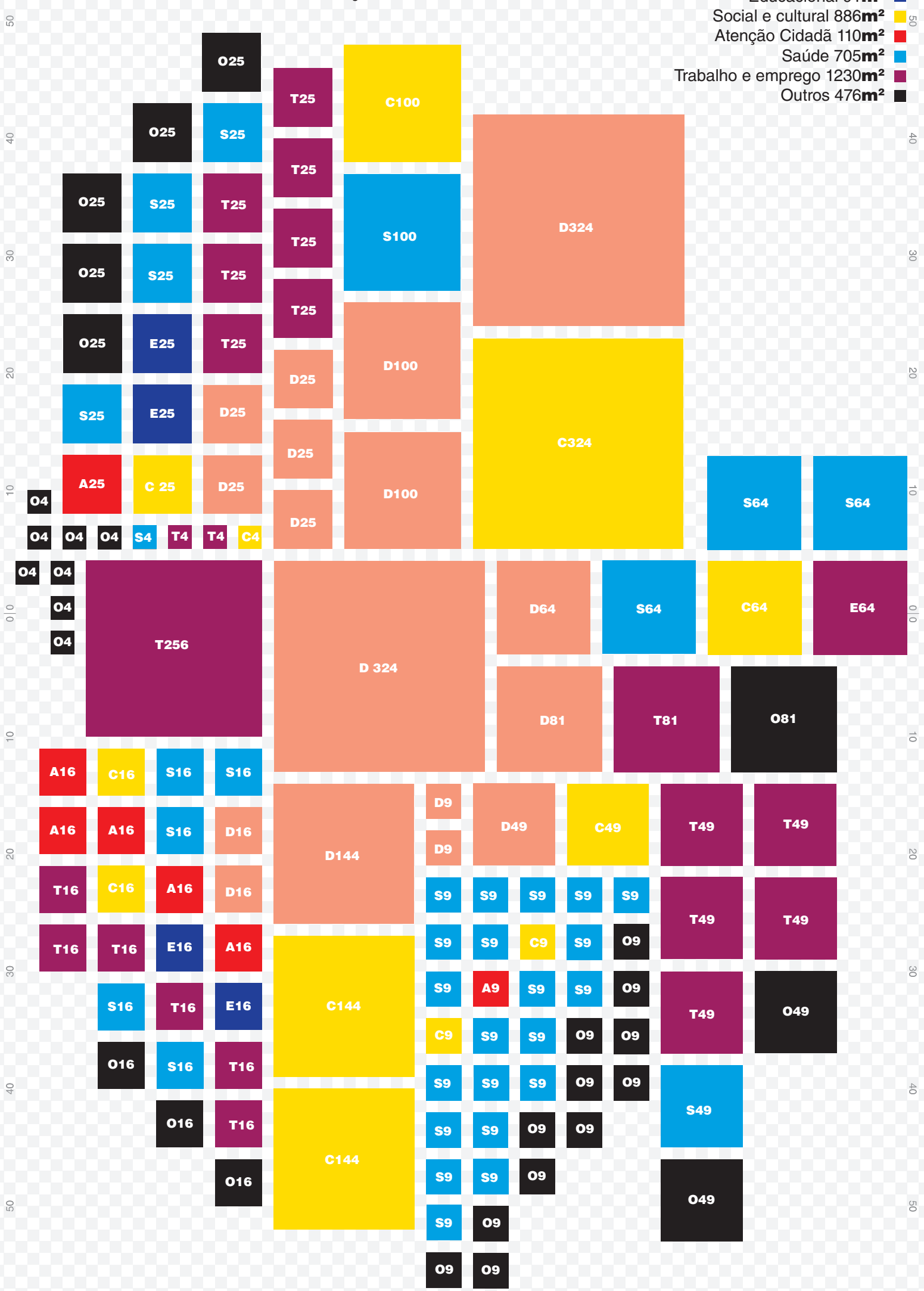

Esporte $1677 \mathbf{m}^{2}$ Educacional $91 \mathbf{m}^{2}$ ocial e cultural $886 \mathbf{m}^{2}$ Cidadã $110 \mathbf{m}^{2}$ Outros $476 \mathbf{m}^{2}$ 


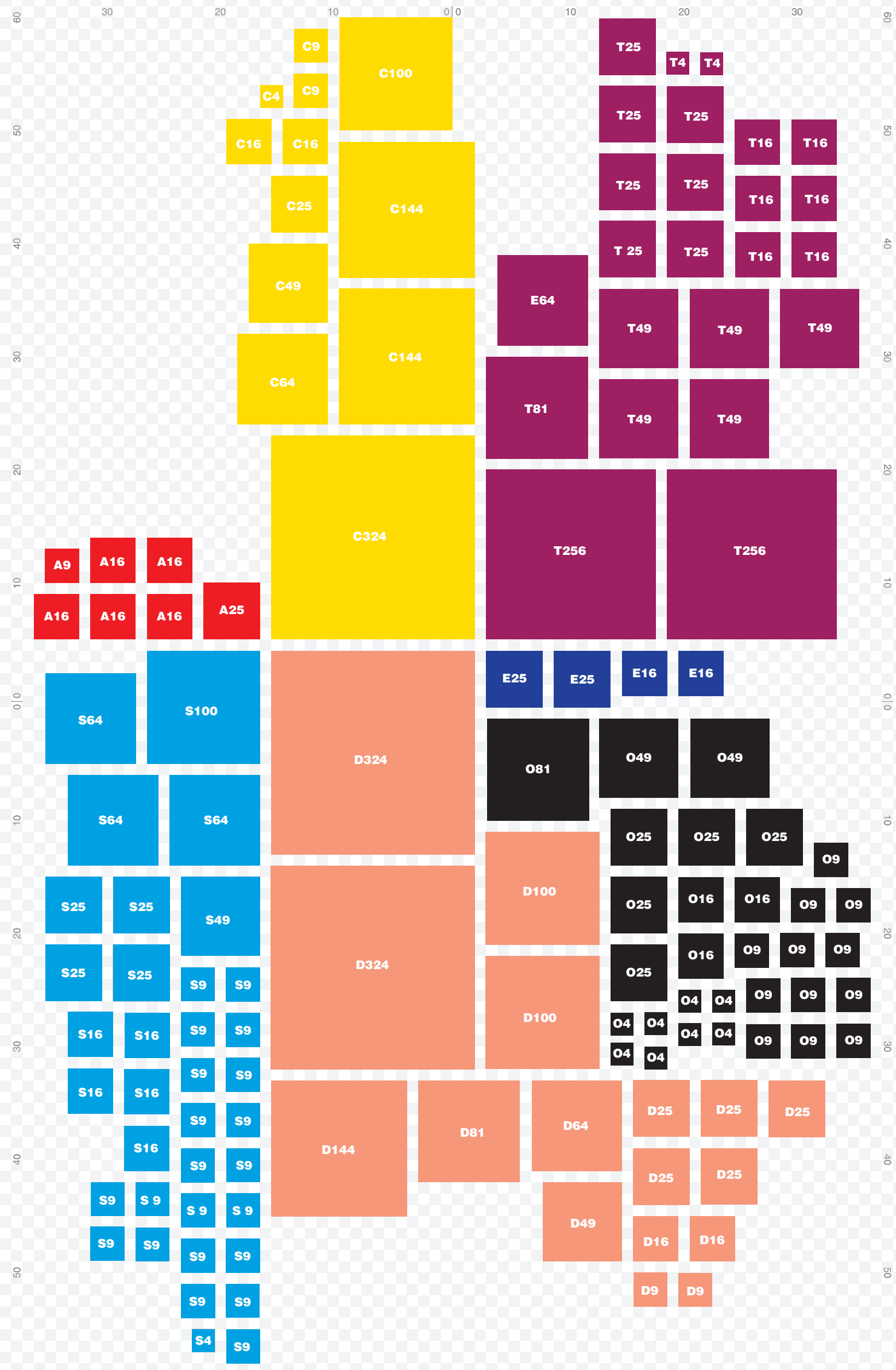




\section{catálogo casavalle dSL}

CASAVALLE DSL DISSOLUÇÃO ESPACIAL

Área Construída $4702 m^{2}$

Área Exterior Coberta $\mathbf{5 2 9 \mathbf { m } ^ { 2 }}$

Pátios 2372m²

Terreno $12000 \mathrm{~m}^{2}$ 

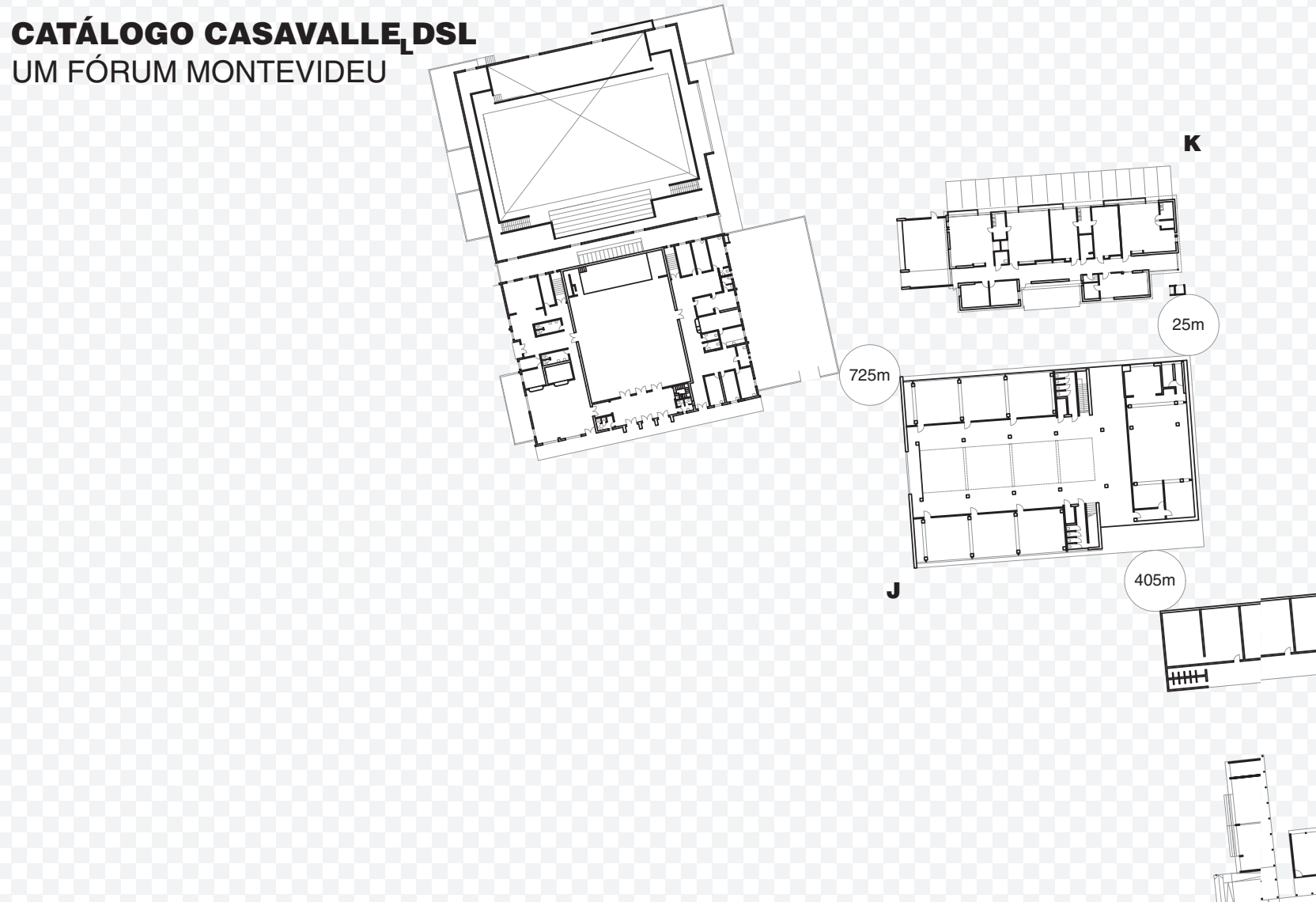

c
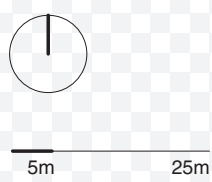
A Plaza Casavalle
B Centro Cívico Casavalle
c CEA
D Escuela 1
E Escuela 2
F Policlínica
G Bomberos
H Comisaría
I CEDEL
J Escuela China
K CAIF
L SACUDE 

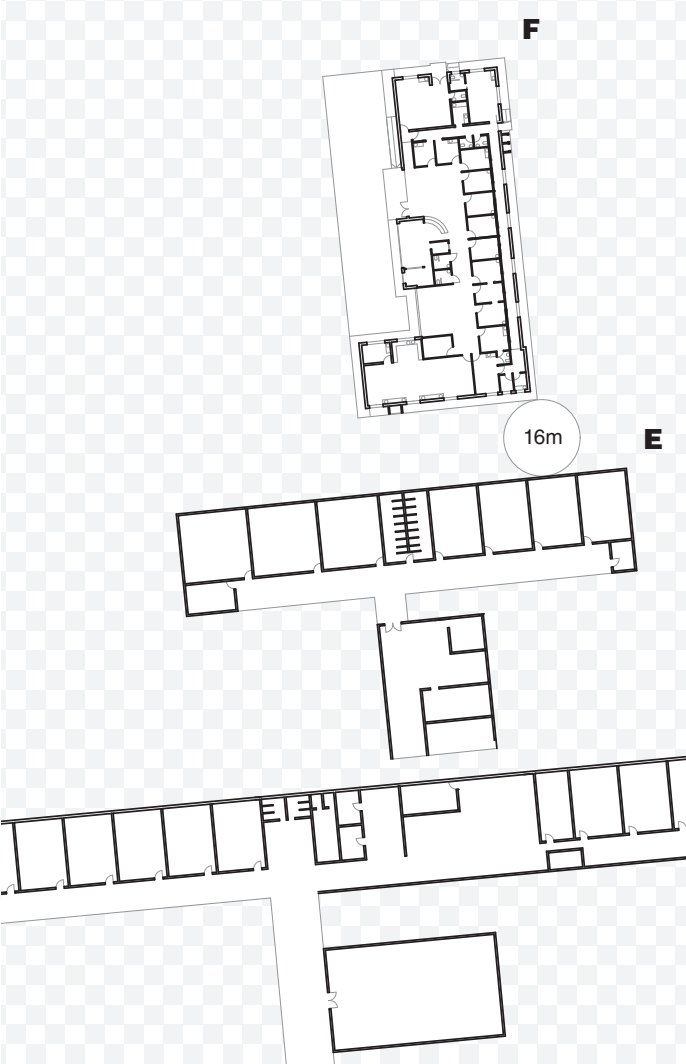

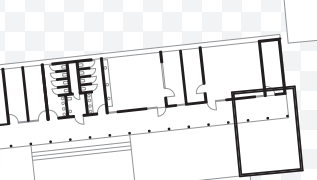

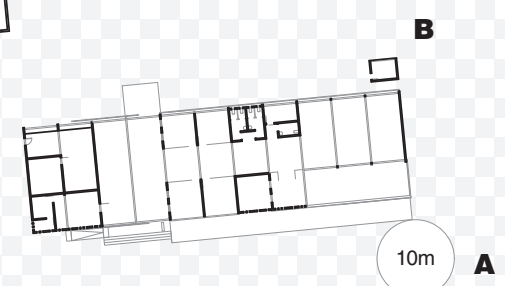

$177 \mathrm{~T}$
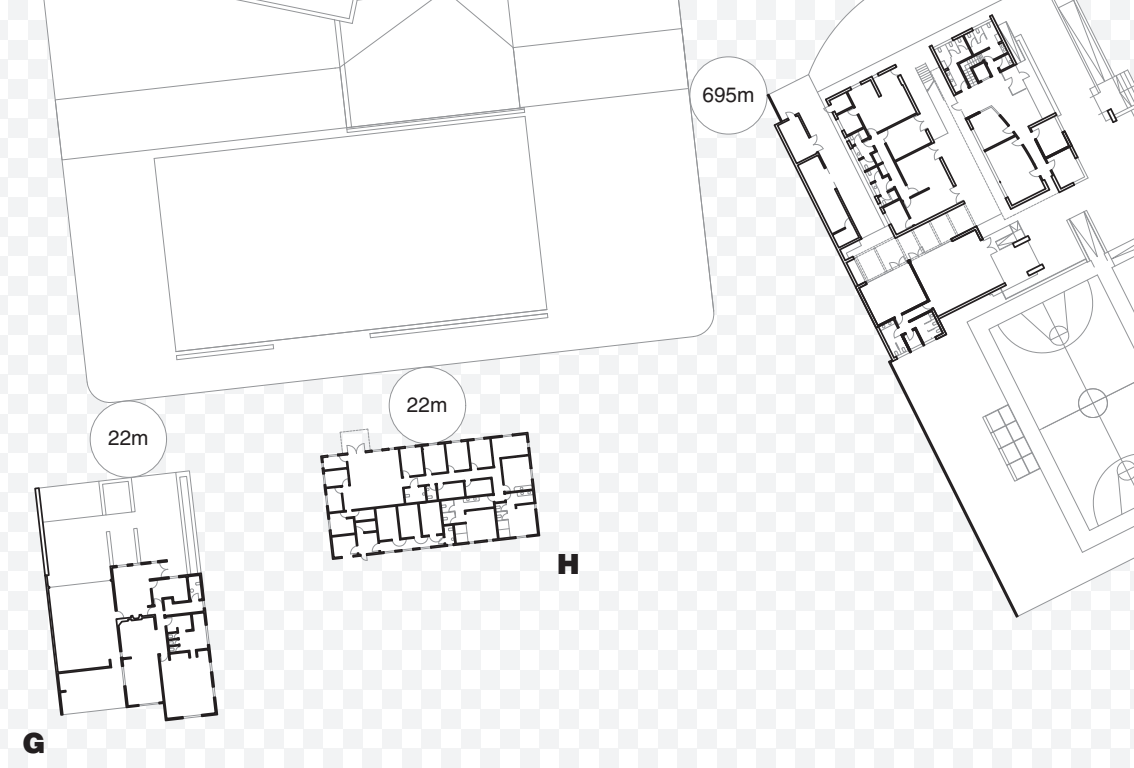
FORÚM CSVLL

EQUIPAMENTOS SEGUNDO PERFIS

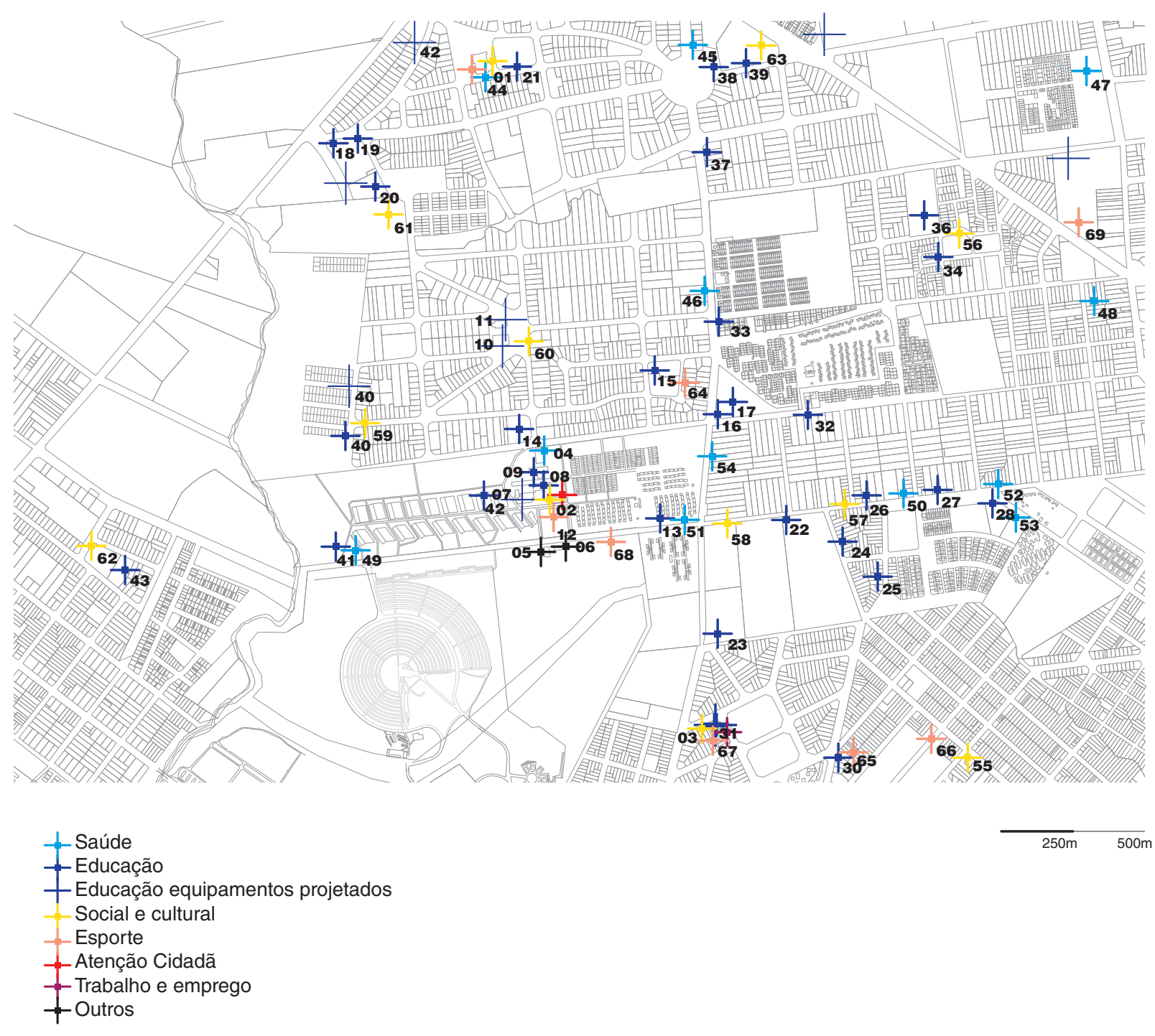

$\begin{array}{ll}\mathbf{0 1} & \text { SACUDE } \\ \mathbf{0 2} & \text { CENTRO CIVICO } \\ \mathbf{0 3} & \text { CEDEL }\end{array}$ 


\section{FRM.6 FÓRUM CASAVALLE}

Uma primeira maneira de testar a ideia do Fórum é atender à realidade procurando qualidades similares. Um Fórum pode existir, disperso no território e sem ter sido projetado "ex-novo", formado por um acumulo de ações ao longo do tempo, uma convergência.

A região de Casavalle estudada a partir do seu território e seus equipamentos pode receber a pergunta: Existe um Fórum em Casavalle?

O registro de todos os equipamentos analisados e o seguimento feito às atuações públicas, permite-nos ter uma avaliação sobre a implantação territorial das políticas públicas em Casavalle. O processo que abordaremos agora funciona por engenharia reversa. Dado o território, seus processos de gestão e projeto, seus equipamentos analisados no capítulo ECM, vamos desarmar suas lógicas para relaciona-las com as que dão lugar ao conceito dos Fóruns Montevidéu.

Os marcadores para avaliar a região Casavalle são os traços que definem um Fórum: concentração sinérgica dos programas, funcionamento em rede, capacidade para fazer cidade, criação de espaço público de qualidade, imagem como aporte estético e cultural, desespecialização do projeto e abertura programática

Uma parte destes projetos foi gerada de maneira autônoma ao Plano Casavalle, enquanto alguns foram construídos recentemente e outros projetados incorporaram-se ao processo de gestão do Plano e entraram em acordo com o Conselho Casavalle quanto sua localização, alguns aspectos programáticos ou até mesmo questões de desenho. Em particular, o Conselho Casavalle foi protagonista na escolha do local e de como seria constituída a Praça Casavalle, espaço central desta entidade que propomos chamar de Fórum Casavalle.

O Eixo Cívico é proposto como espaço público aglutinante dos principais equipamentos da zona, apostando na produção de uma centralidade inédita que se baseia em uma estrutura emergente. Se o traçado que vai em direção Norte do Bulevar Aparicio Saravia aparece integrado no território, o tramo Sul chegando até o CEDEL apresenta-se ainda fraco quanto a seu traçado, pois atravessa um vazio urbano e o desenho previsto não leva em consideração as vias existentes. A concretização do mesmo depende de certa forma, da superação de dificuldades que a administração encontrou tendo em vista a contaminação do terreno da "Cantera de Burgues". 
FORÚM CSVLL

EQUIPAMENTOS SEGUNDO PERFIS

\section{† EDUCAÇÃO}

13 Escuela de Oficios Don Bosco

14 Colegio Santa Berardita

15 Liceo $\mathrm{N}^{\circ} 73$

16 Escuela N $N^{\circ} 350$

17 Jardin de infantes $N^{\circ} 325$

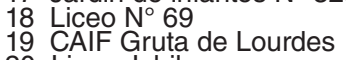

20 Liceo Jubilar

21 Escuela No 168 - Rumania

22 Colegio Obra Banneux

23 Liceo Impulso

24 CAIF Caritas Felices

25 CAIF Casilda

26 CAIF Nuevos Rumbos

27 CAIF Santa Maria

28 CAIF Santa Rita

29 CEC Casavalle - UTU

30 Instituto De Eenseñanza lintegral Juana Fernandez

31 CAIF Tierra Nueva

32 Jardin De Infantes N. 325

33 Jardin de infantes 222

34 CAIF Mensajeros de la Paz II

35 CAIF Santa Clara

36 CAIF CADI I

37 CAIF CADI III

38 CAIF Nueva Vida

40 CAIF Mi Casita

41 Escuela de Tiempo Completo $n^{\circ} 92$

42 CEA - Escuela N³54

† SAÚDE

44 Policlinica Los Angeles

45 Policlinica Salud publica San Martin II

46 Policlinica Salud publica P. del Padre Cacho

47 Policlinica Salud publica P. Ios Reyes

48 Consultorio de Medicina Familiar

49 Policlinica Zully Sanchez

50 Policlinica Misurraco

51 Consultorio de Area Emaus

52 Consultorio de Area en Asentamiento los Paraisos

53 Consultorio de Area en espacio adolescente Ruben Alonso

54 Consultorio de Area 2 de Julio

SOCIAL E CULTURAL

55 Centro Juvenil OMBU

56 Centro Juvenil LAS REDES

57 Centro Juvenil CARLOS FAVRE ESC OFICIOS

58 Centro Juvenil PIRINCHO

59 Centro Juvenil EDUCATIVO NUEVA VIDA
60 Centro Juvenil OBRA ECUMENICA

61 Centro Juvenil CUENCA CASAVALLE

62 Centro Juvenil TACURU APOYO PEDAGOGICO

63 Centro de Apoyo al Desarrollo Integral

\section{ESPORTE}

64 Cancha Sede Baby Futbol San Martin Bonomi

65 Sede y cancha de futbol Corralito

66 Estadio Cr. J P Damiani

67 Cancha Cedel

68 Parque Maracana

69 Club Flores Palma De Baby Futbol 
A criação deste eixo, não apoiado num estruturador viário principal da região, pode resultar discutível em uma primeira aproximação, ela é considerada em concorrência com a Avenida San Martín, paralela, próxima e de maior hierarquia viária e conectiva. Entendo o eixo a partir de sua condição de estruturador local de trafego lento, com ciclofaixa e ênfase para pedestres, pode ser entendido como um par complementar no qual a Avenida concentra o trafego rápido de cruzamento da região. $O$ desenho urbano do trecho Norte $^{6}$ fornece muitos espaços públicos e principalmente verdes, gerando interrogações se haverá massa critica para usar e manter esses espaços.

A Praça Casavalle é o espaço livre por excelência, lugar de encontros. A Criação da Praça significou uma mudança radical para os habitantes de Casavalle, que encontraram um novo espaço público, cuidado e seguro. A intensidade de uso é alta, e pelo menos no início teve uma gestão permanente. Regularmente organizam-se atividades que atraem a população. Mas igual em Roma, a urbanidade inclui o conflito. A disputa territorial entre os grupos de traficantes e suas incipientes tentativas de questionar a presença do Estado e de apropriar-se de partes deste território, faz com que irrompam à Praça como uma forma de marcar presença e autoridade na comunidade. Para fechar o circuito da espacialização das relações conflituosas, o lado sul da Praça está definido por dois equipamentos de segurança: a delegacia e o corpo de bombeiros. A praça situa-se ao lado do Bulevar Aparicio Saravia que segue na direção Leste-Oeste e é a via de maior fluxo entre as que compõem o sistema viário de Casavalle, uma vez que pertence ao "sistema de conexão urbano-nacional" e é atravessada pelo Eixo Cívico: Decumano e Cardo.

\section{Casavalle aluvional}

A existência e a vitalidade do Fórum Casavalle enquanto um âmbito não projetado, mas sim gerado através da acumulação de práticas, e por tentativa e erro, precisa ser estudada a fundo, para tanto, se intensifica como sofre permanentemente revisões, além da possibilidade de ser reaplicada em outros âmbitos.

O acúmulo de trabalhos acadêmicos e institucionais sobre Casavalle que vem se retroalimentando permite multiplicar e refinar estratégias de intervenção. A articulação do conhecimento profundo de Casavalle gerado desde a academia e desde diversas disciplinas foi coletada pela administração municipal que, dessa forma, alimentou a 
FORÚM CSVLL

FAVELAS

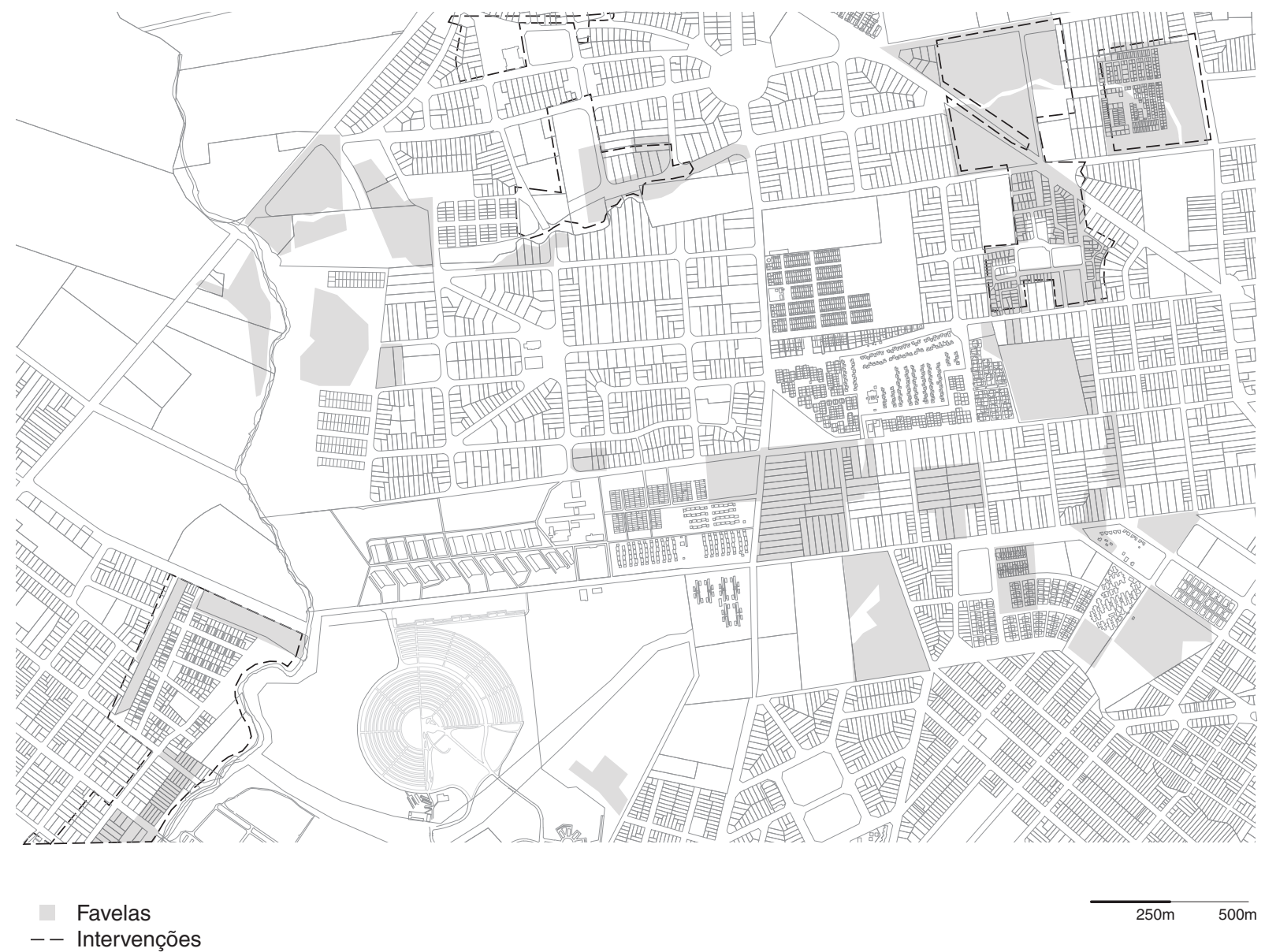


produção de conhecimento e as intervenções na zona. Um círculo fértil que em muitas outras ocasiões se vê desacreditado pela falta de confiança e oportunidades de encontro.

A coordenação pública interinstitucional do Conselho Casavalle (uma institucionalidade excepcional e necessária em outras periferias) no local produz sinergia efetiva que multiplica a intensidade de cada intervenção institucional. O compromisso pessoal de muitos dos atores sociais que foram encontrando neste processo a possibilidade, antes inimaginável, de ter um olhar otimista, faz com que se multiplique sua participação e seu rigor. A partir do objetivo do Plano Casavalle de desenvolver um sistema dinâmico de atores sociais e governamentais estes sinais positivos foram se multiplicando num ambiente frágil e submetido a lógicas e interesses violentamente contraditórios.

A gestão feita com olhar espacial e objetivos de transformação claros permitiu que muitas decisões referentes à localização das diversas instituições públicas se alinhassem para a consolidação do Eixo Cívico Casavalle. A produção de cidade formal de uma qualidade até então nunca vista na zona é uma ferramenta de transformação social. O território é um espaço de encontros e coordenações.

Os edifícios dos equipamentos de Casavalle tiveram uma história, variações programáticas no tempo. Os edifícios foram gerados por projetos municipais, o SACUDE, a partir de um Auditório já existente e um grande equipamento esportivo especialmente projetado aparece como mais aberto a transformações, o que de fato tem se produzido nos últimos anos. O CEDEL com um projeto sob medida, um pouco mas rígido e especializado, mas que permite a incorporação de atividades diversas. Quanto aos outros equipamentos, cada um foi pensado desde lógicas autônomas.

Os projetos, com exceção do SACUDE, não consideraram as oportunidades de ser pensados como "espaços capazes", praticando uma relação com o programa desde o "ajuste frouxo" ou "superdimensionamento controlado" e por tanto não estimulam as possiblidades fora do seu funcionamento especializado. O pedido do trabalhador do Centro Cívico Casavalle por mais lugares para "estar" estabelece a demanda de mais lugares como o SACUDE. Saúde, Cultura, Esporte e Abertura "a imprevisibilidade da vida". Pode se pensar numa operação que resulte num "Pompéia" ou um "24 de Maio" em Casavalle, de arquiteturas particularmente estimulantes. Quantidade e qualidade. 
FORÚM CSVLL

EQUIPAMENTO PRINCIPAL E

ESPAÇOS PÚBLICOS

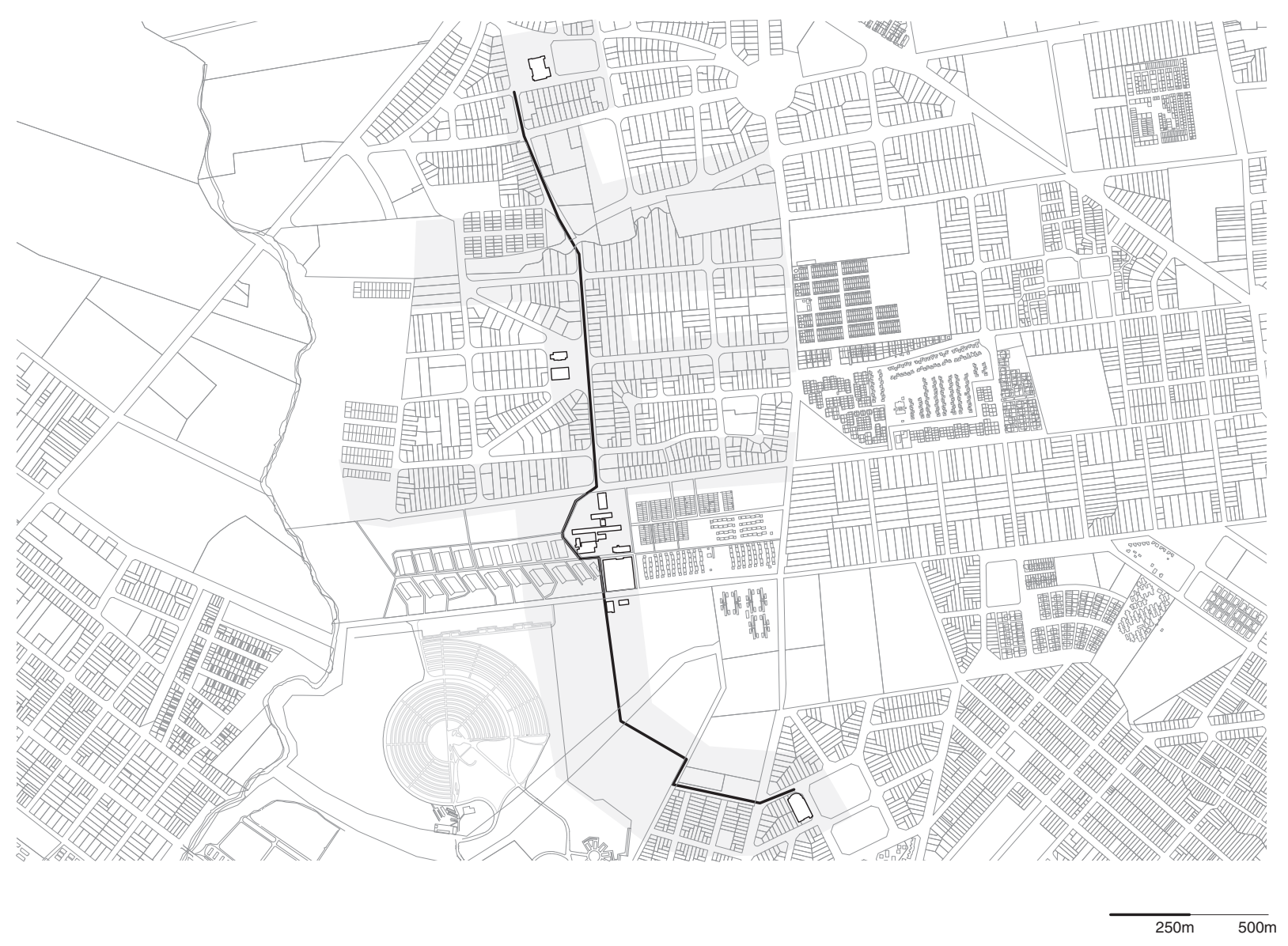


O Fórum existe, e ele poderia ser muito aprimorado com mais intervenções desde a desespecialização programática, baseados na especificidade espacial e na qualidade do projeto como ferramentas de qualificação da vida urbana.

Os edifícios de equipamentos Casavalle tiveram uma história, algumas variações programáticas durante o tempo que sustentam a ideia do projeto a partir da desespecialização programática, a geração de "espaços capazes" para diversos programas que se baseiam na especificidade espacial e qualidade de projetos como ferramentas para a qualificação da vida urbana.

A partir deste ponto de vista existem duas atuações públicas em agenda na região que poderiam ser tomadas como oportunidade no sentido proposto: a intervenção sobre o conjunto de habitação social "Los Palomares" que enfrenta a Praça Casavalle e o enorme terreno da "Cantera de Burgues" (relacionado com o setor mais frágil do projeto do Eixo Cívico) são altamente relevantes para a requalificação do Fórum Casavalle, quanto problemáticos no seu contexto humano e ambiental. Nova habitação, equipamentos de qualidade, e um relançamento contemporâneo do modo de vida dos recicladores de lixo (uma parte importante dos mais relegados da região mais relegados) parecem ser alguns dos possíveis desfechos quanto a intervenção.

Na perspectiva aqui exposta, que propõe os Fóruns como entidades que transbordem o local e que se coloquem em relação a toda a metrópole, visualiza-se uma oportunidade: ambientar em Casavalle um programa ou equipamento singular que seja único em toda ela. Uma razão iniludível para visitar Casavalle como forma de estar em Montevidéu. 
326

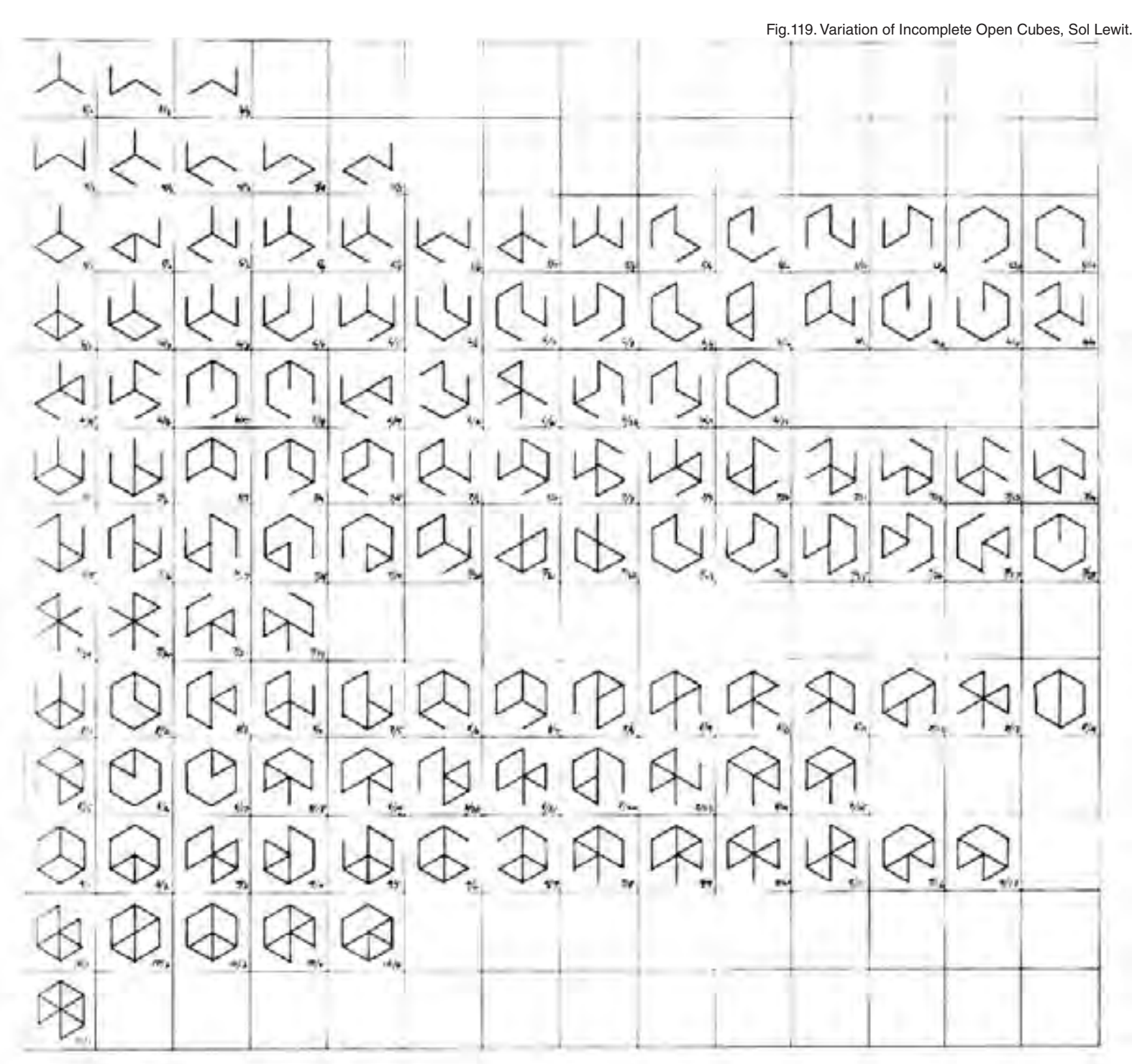




\section{FRM.7 N-FÓRUM CCZ 17}

"Para saber há que se imaginar", propõe Didi-Huberman (2004, p.17, tradução nossa) sobre o valor das imagens em relação ao conhecimento. Os projetos que seguem apresentados partindo da desespecialização programática e do Fórum respondem ao exercício de passagem do metaprojeto para projetos concretos, uma constelação de imagens que produz vários níveis de conhecimento.

\section{PROJETOS E METAPROJETO}

[...] tratamos de demostrar a hipótese de geradores urbanos, ou sistemas arquitetônicos que são verdadeiros catalizadores para todo tipo de atividade ou função, independentemente da forma que podam tomar. Nesses geradores-decidade, funções e programas se combinam e intersectam num sem-fim de "desprogramações" e "programações cruzadas". (TSCHUMI, 1996, p.12, tradução nossa)

No livro Event-cities (praxis), Bernard Tschumi (Ibid.) apresenta seus projetos agrupados por hipóteses de trabalho sobre a arquitetura e a cidade, a hipótese citada afirma a ideia do Fórum como projeto urbanizador e desespecializado. Além disso, Tschumi propõe uma heurística, os projetos agrupados desenvolvem uma hipótese, que pode ser entendida como metaprojeto, uma formulação pré-projetual (ou também pós-projetual). Os projetos que se apresentam, envolvidos com as ideias da Tese, "imaginam" diferentes maneiras de entender o metaprojeto incluído na pesquisa. No sentido proposto por Didi-Huberman, produzem conhecimento gerando imagens de uma cidade resultado posta em prática a partir da hipótese proposta. A relação entre a pesquisa e o curso estabelece uma coprodução em que os projetos são criações em diálogo com a proposta de trabalho e no mesmo tempo eles descobrem sentidos para o Fórum que é prefigurado.

O termo "multiplataforma" foi referido no capítulo DPL, como uma qualidade de interoperabilidade que são descritos nos sistemas de informação, certos dispositivos que possuem a capacidade de agir em diferentes sistemas operativos, diferentes especializações. Multiplataforma foi também o nome que o Fórum teve durante o desenvolvimento da pesquisa (que se fecha nesta tese), nome como deslocação do mundo da informação para a arquitetura. Como parte dos estudos de mestrado desenvolvidos na FAUUSP, na disciplina Arquitetura, Tecnologia e Meio Construído" ministrada pela Prof. Helena Ayoub Silva e durante julho de 2013 inclui um workhsop de projetos sobre uma microrregião de Casavalle particularmente critica: o Marconi. No 


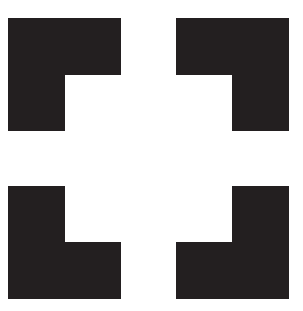

ABRIGAR

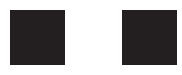

IMITAR

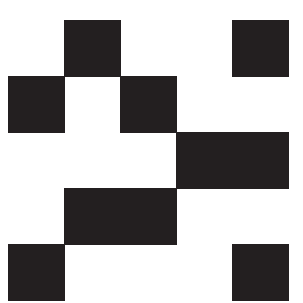

DISEMINAR

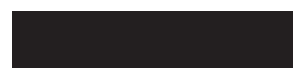

CUBRIR

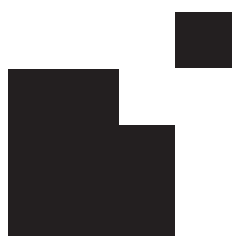

COMPLEMENTAR

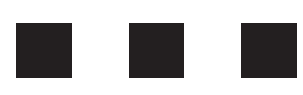

INVADIR

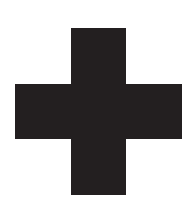

IDENTIFICAR

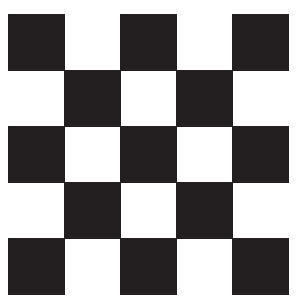

AMALGAMAR

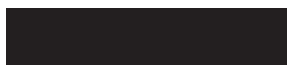

GESTIONAR 
workshop participaram estudantes de pós-graduação e de graduação brasileiros, uruguaios e argentinos. 18 estudantes de graduação de Montevidéu viajaram especialmente para o trabalho, entre eles os agora arquitetos Diego Morera e Mauricio Wood que integraram uma das equipes de projeto. De volta a Montevidéu, eles desenvolvem uma "tesina" (MORERA e WOOD, 2015), parte dos seus estudos de graduação com a orientação do doutorando. O trabalho estabelece uma indagação estratégico-projetual a partir das hipóteses da pesquisa do doutorando e particularmente da ideia do edifício Multiplataforma (agora Fórum) na região de Casavalle. A indagação inclui uma formulação propositiva ainda abstrata, um metaprojeto do metaprojeto, que poderia ser descrita com a noção que Angelo Bucci propõe na sua tese de doutorado como "disposições espaciais", em referencia a um método de projeto descrito por Paulo Mendes da Rocha:

\footnotetext{
Então, como não poderia deixar de ser, após desmontar a forma que aprisiona, ele lança as suas proposições servindo-se da forma como estrutura das suas proposições arquitetônicas - tese 2.033. - é assim que Paulo Mendes da Rocha elabora as suas "disposições espaciais" como imagens - modelos da realidade que se desdobram em projetos. Para elas, como diz a tese 3.1431, não há sinais escritos que lhes possam traduzir.

Então, as disposições espaciais não são projetos?

Não. Não são porque não têm a especificidade e a objetividade que exige um projeto de arquitetura. As disposições espaciais são como algoritmos abertos, que se podem desdobrar em diversas finalizações como diversos projetos. $E$ isso 0 arquiteto sabe bem pelo que demonstra na condução do processo do seu trabalho de modo que elas se desdobrem em projetos de arquitetura - com o perdão da expressão - primorosos. BUCCI, 2005, p.58-72)
}

As disposições espaciais de Morera e Wood são definidas como enunciação de vínculos de atração, congregação e articulação, cada uma é apresentada com três imagens representativas de três ações diferentes. 


\section{FÓRUM CCZ17}

\section{FAVELAS}

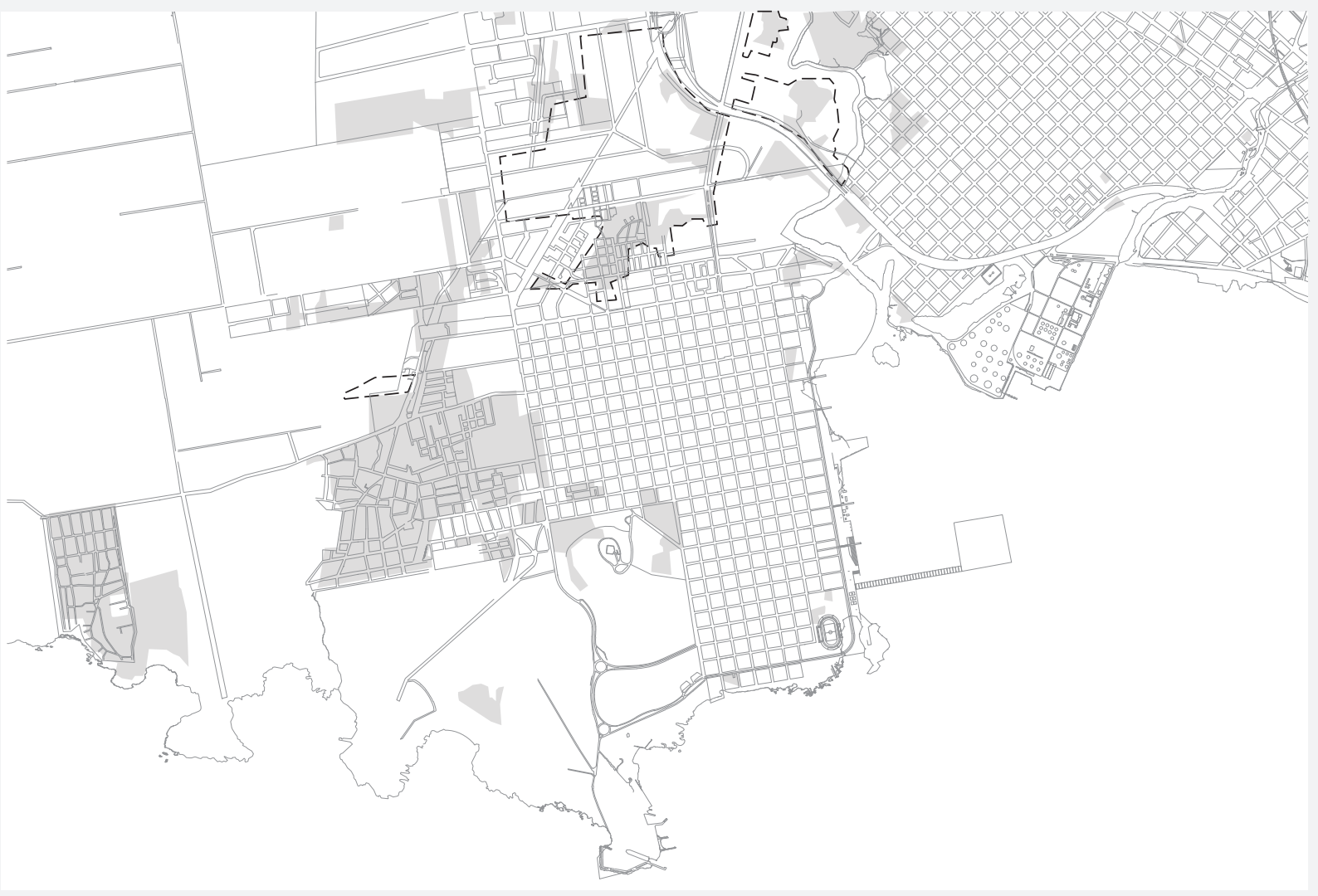




\section{FÓRUM CCZ17}

SANEAMENTO

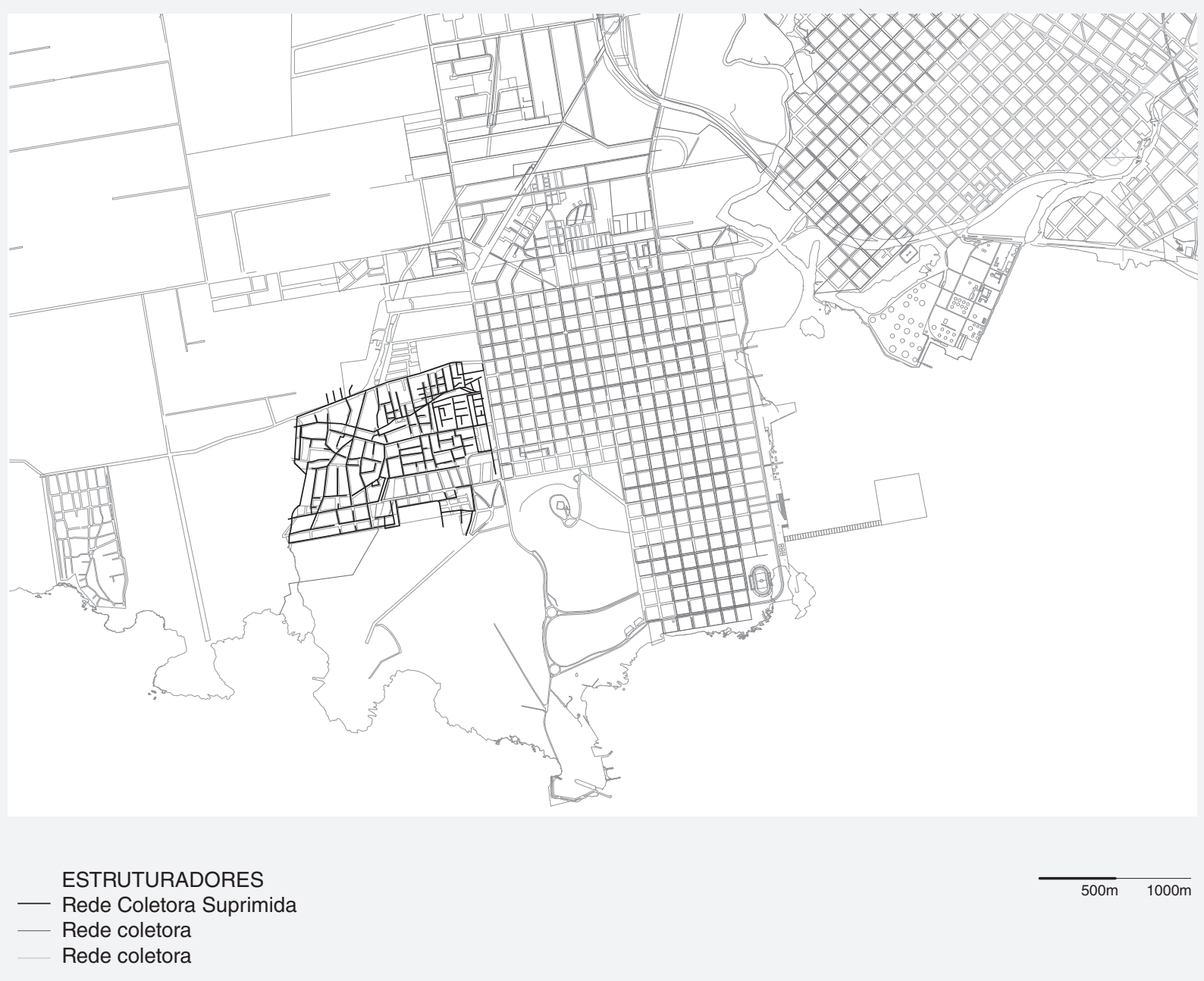




\section{FÓRUM CCZ17}

EQUIPAMENTOS SEGUNDO PERFIS

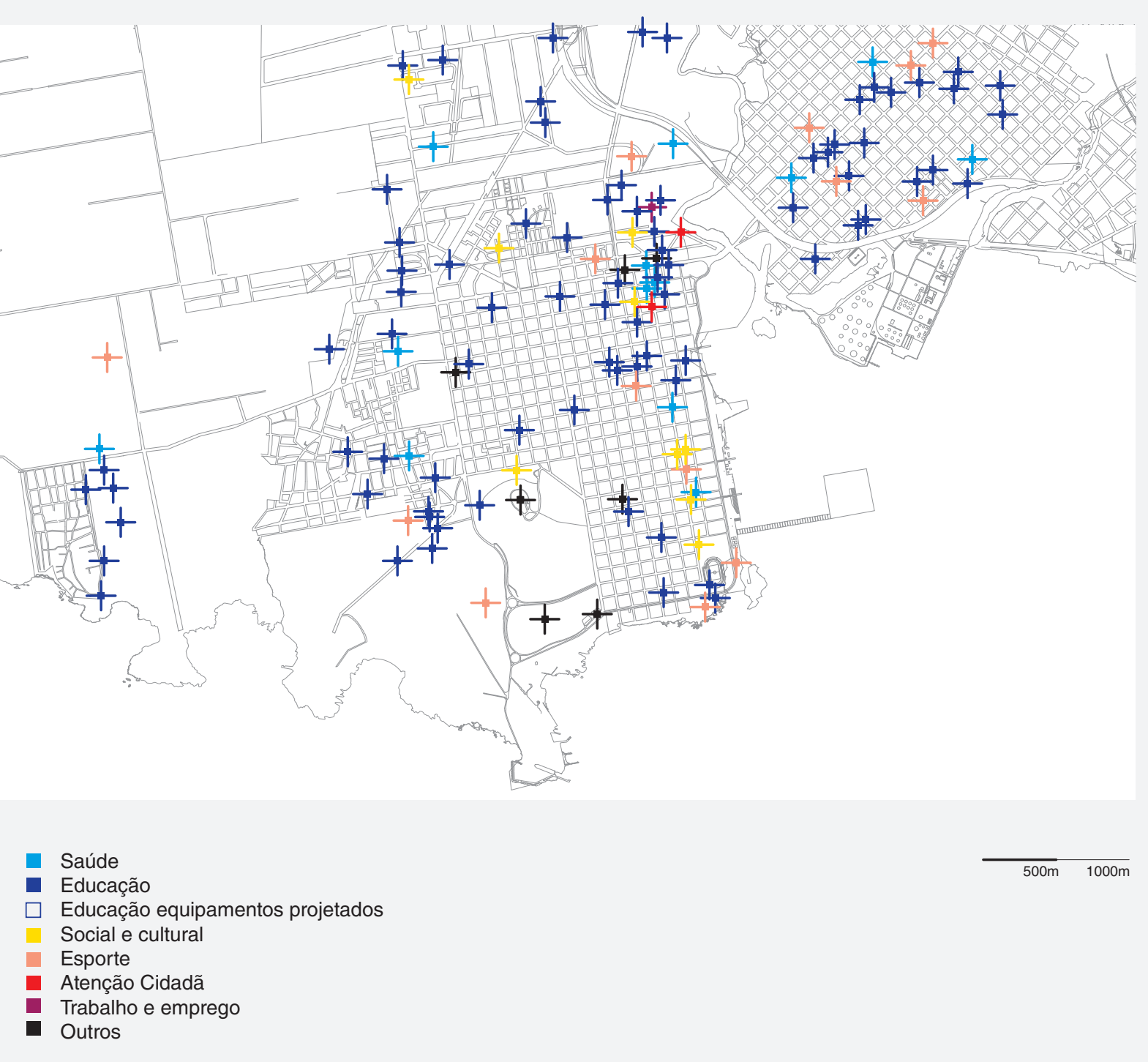


FÓRUM CCZ17

EQUIPAMENTOS SEGUNDO PERFIS
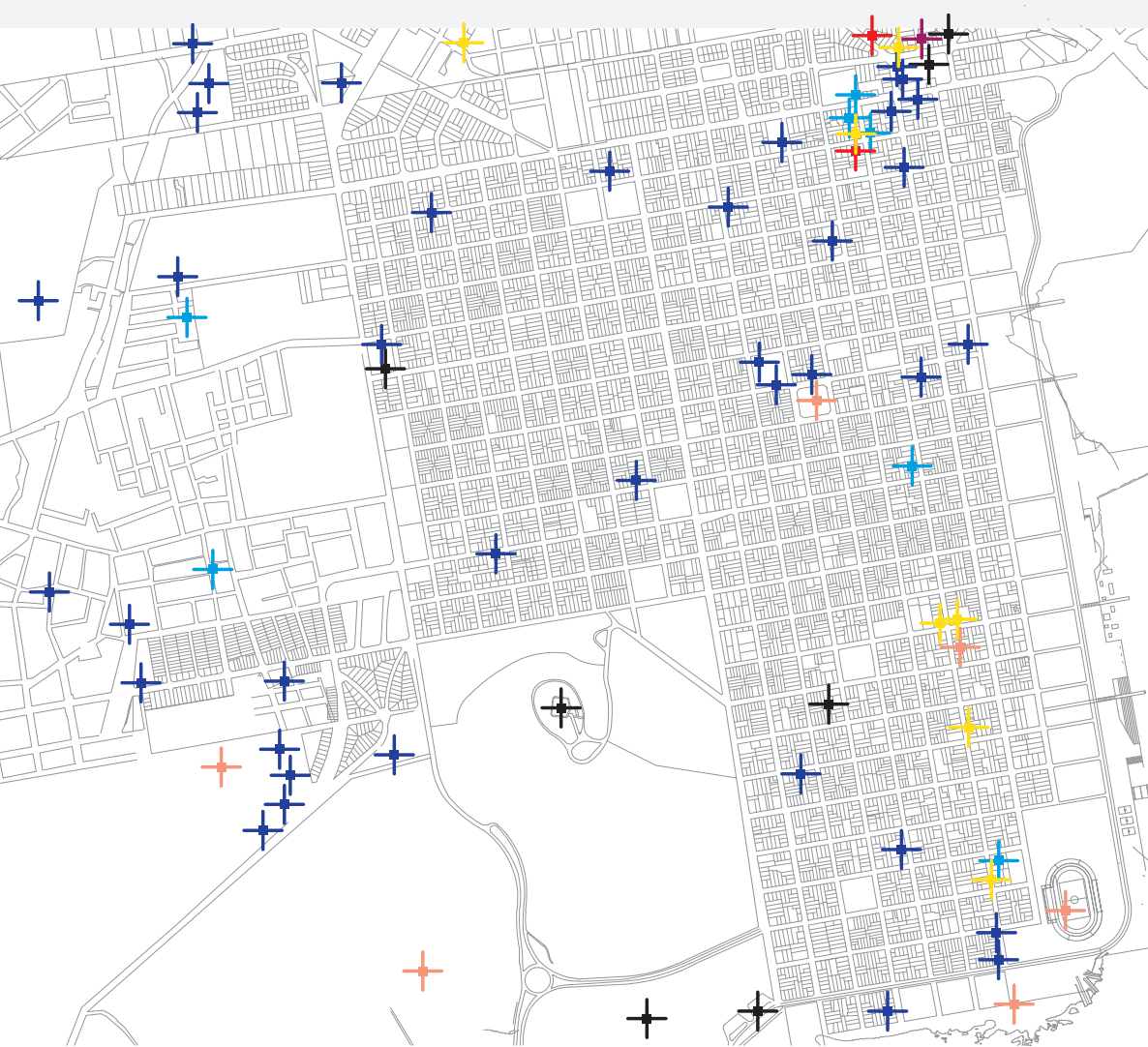

Saúde

- Educação

Educação equipamentos projetados

Social e cultural

Esporte

- Atenção Cidadã

Trabalho e emprego

- Outros 


\section{FÓRUM CCZ17}

EQUIPAMENTOS PRINCIPAIS

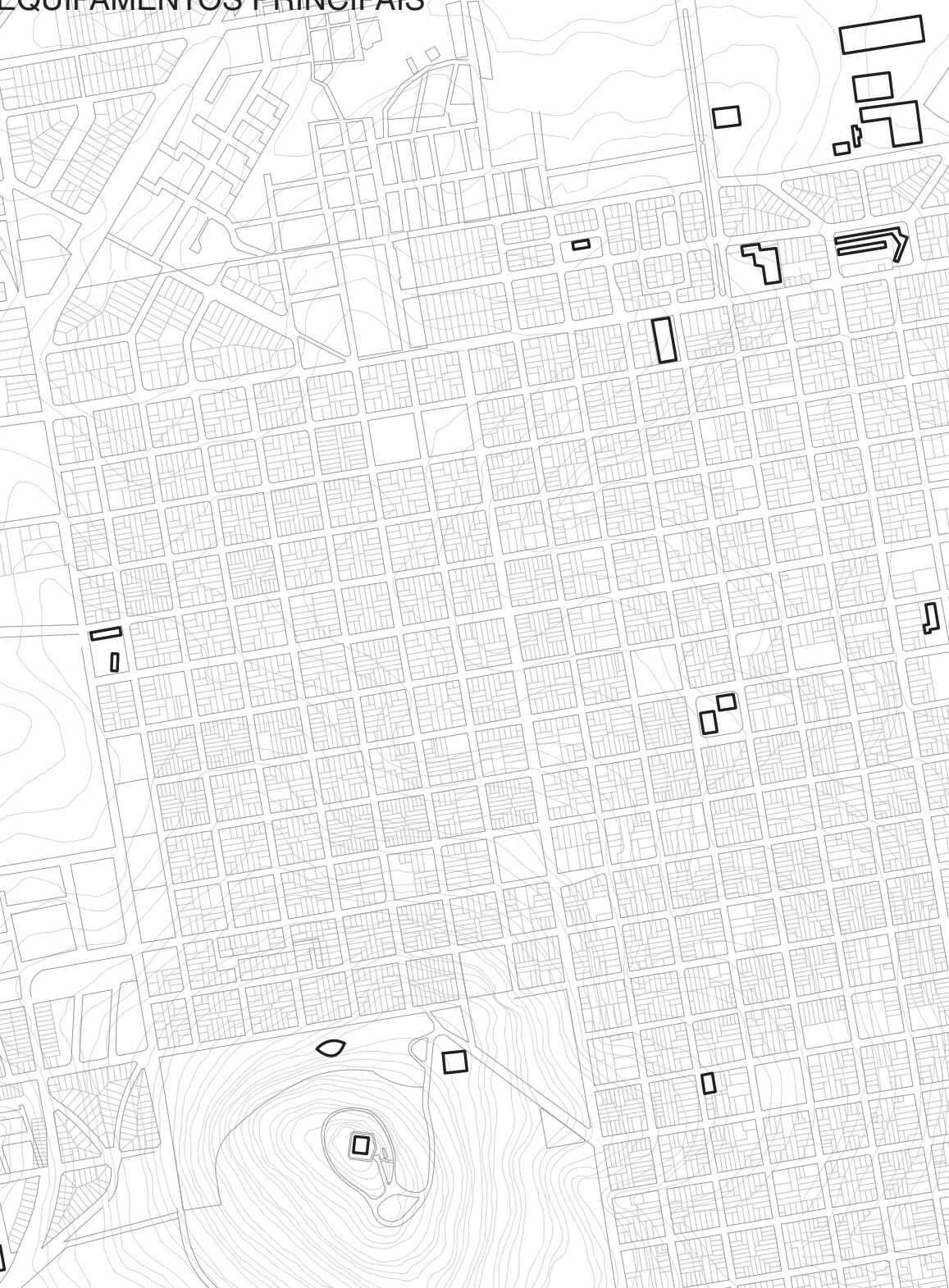

ㅁ
I 


\section{CerRo de monteVidéu / CCZ 17}

O estudo do Fórum Casavalle, a ideia de entender esse conjunto aluvial de intervenções por meio dessa noção, foi apresentada durante a pesquisa à Prefeitura de Montevidéu. Uma nova oportunidade de estudo aparece em conjunto com as autoridades municipais, a prefeitura tem duas oportunidades para intervir no Cerro de Montevidéu: Um novo projeto de Rambla no bairro do Cerro sobre a Baia de Montevidéu está sendo desenvolvido, intervenção de repercussão metropolitana; e um problema para fazer frente que é a reconstituição de um parque pela relocalização de um conjunto de ocupações habitacionais informais (que atinge quase 500 vivendas e 2000 pessoas) sobre terrenos públicos no parque da "Fortaleza de Montevidéu" (um forte com farol) no topo do Cerro com uma das mais impressionantes visões da Baia de Montevidéu e da cidade. As intervenções planejadas e outras já feitas procuram fortalecer o pertencimento do Cerro à cidade (como é a instalação de um segundo cartaz "Montevideo" e se procura a chegada do Ônibus Turístico para visitar a Fortaleza), procuram atrair o turismo e apresentam relações de escala metropolitana.

Pela visão do Fórum e atendendo a desigualdade territorial e social o problema pode ser redefinido. Partindo das duas intervenções da prefeitura, é possível reconhecer uma região do "Município A" onde moram 81.215 pessoas (LABAT, 2018, p.5) e que inclui duas partes diferenciadas: um setor que é parte da cidade consolidada, o Bairro do Cerro (17.595 habitantes), região historicamente vinculada à cidade e a produção frigorifica e industrial, bairro operário tradicional, de imigrações múltiplas e forte identidade; e um conjunto de setores fortemente informalizados (63.620 habitantes) que inclui o bairro Casabó hoje entendido como o maior assentamento informal de Montevidéu, e os bairros de Cerro Norte, La Paloma e Santa Catalina. O resto do "Município A" fica separado pela autovia "Ruta 1", e a região escolhida coincide com o Centro Comunal Zonal 17 (CCZ 17, uma subdivisão do departamento de Montevidéu para a descentralização anterior á criação nacional dos Municípios) o que faz a identificação da região de atuação para um equipamento urbanizador Fórum ser de fácil operabilidade.

Se elabora um relatório da zona a partir de entrevistas com Juan Pablo Labat (Diretor de Avaliação e Monitorização do MIDES), os responsáveis da Prefeitura Silvana Pissano (diretora de Desenvolvimento Urbano), Patricia Roland (Diretora de Espaços Públicos), Ramón Mendez (Diretor de Planejamento), Adriana Rojas (Equipo Técnico da Assessoria de Desenvolvimento Municipal e Participação), Marcelo Bednarik (Arquiteto 

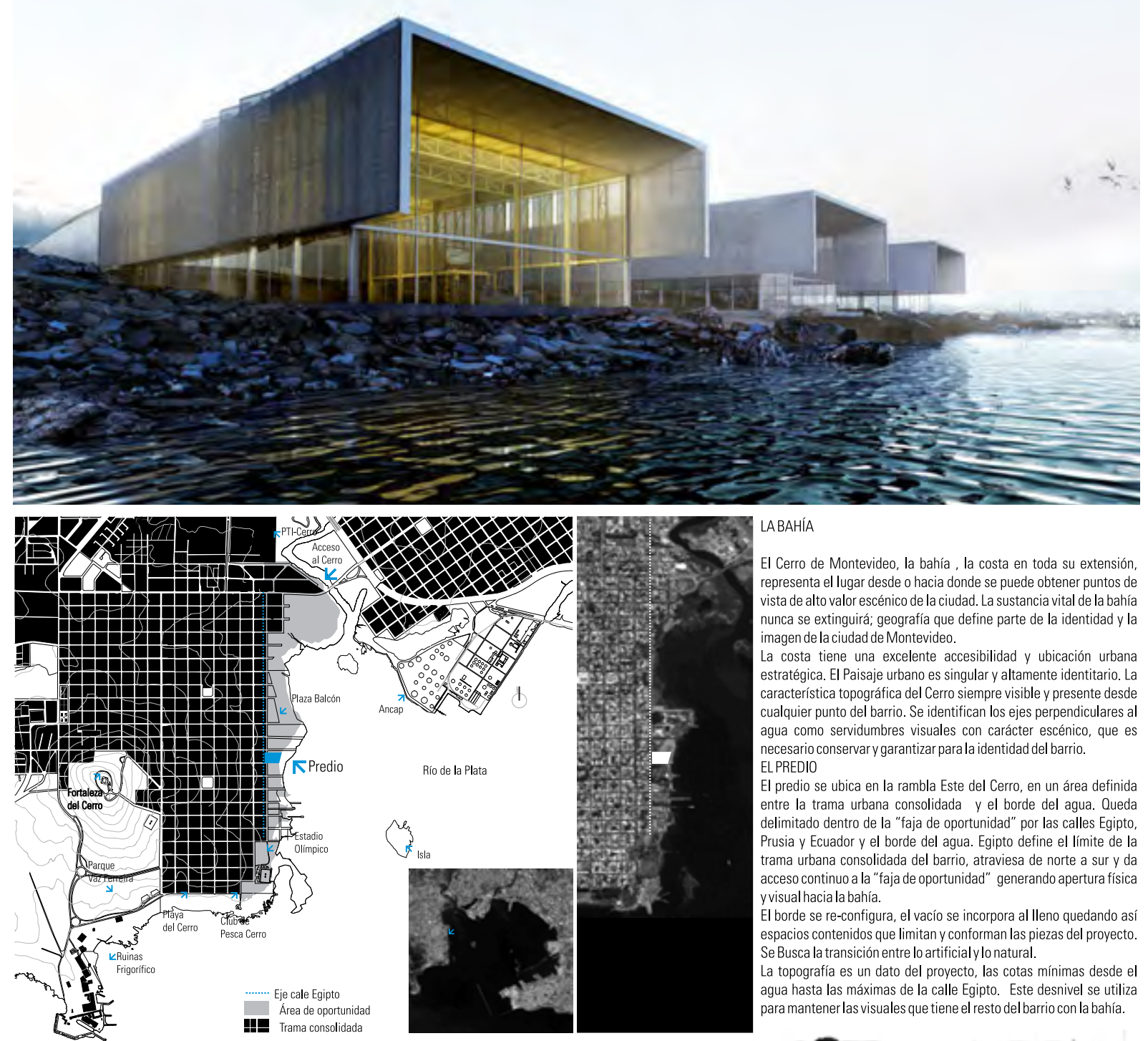

El Cerro de Montevideo, la bahía la costa en toda su extensión, representa el lugar desde o hacia donde se puede obtener puntos de vista de al to valor escénico de la ciudad. La sustancia vital de la bahía nunca se extinguirá; geografía que define parte de la identidad y la imagen de la ciudad de Montevideo

La costa tiene una excelente accesibilidad y ubicación urbana estratégica. El Paisaje urbano es singular y altamente identitario. La característica topográfica del Cerro siempre visible y presente desde cualquier punto del barrio. Se identifican los ejes perpendiculares al agua como servidumbres visuales con carácter escénico, que es necesario conservary garantizar para la identidad del barrio. ELPREDIO

ELPREDIO entre la trama urbana consolidada y el borde del agua. Queda delimitado dentro de la "faja de oportunidad" por las calles Egipto, Prusia y Ecuador y el borde del agua. Egipto define el límite de la trama urbana consolidada del barrio, atraviesa de norte a sur y da acceso continuo a la "faja de oportunidad" generando apertura física y visual hacia la bahía.

El borde se re-configura, el vacío se incorpora al lleno quedando así espacios contenidos que limitan y conforman las piezas del proyecto. Se Busca la transición entre lo artificial y lo natura.

La topografía es un dato del proyecto, las cotas mínimas desde el para mantener las visuales que tiene el resto del barrio con la bahía.

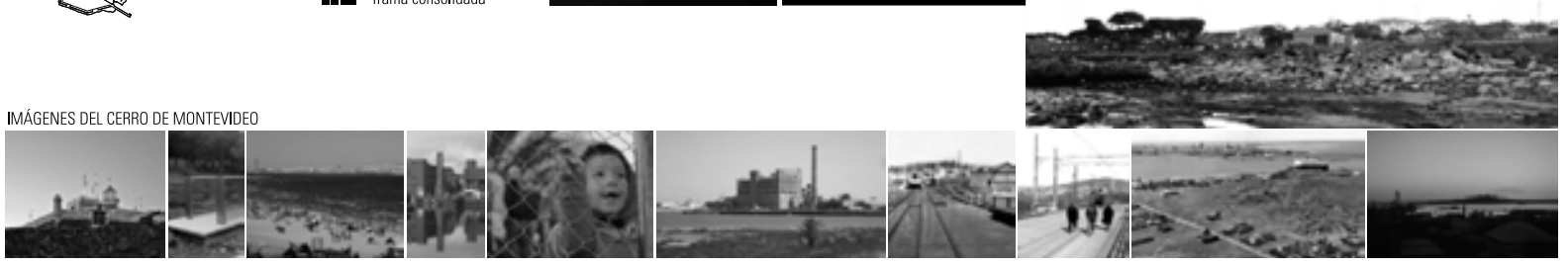


Responsável pelo Projeto Rambla. Projeto Urbano Territorial. Departamento de Planejamento).

$\mathrm{Na}$ entrevista com Adriana Rojas ${ }^{7}$ se comprova o que já se conhece de outras regiões: os programas públicos se desenvolvem de forma isolada. A coordenação precisa de um espaço de referencia para articular todas as políticas públicas, pois a distribuição territorial do MIDES não coincide com a dos Municípios, terceiro nível de Governo. $O$ MIDES tem muitos programas específicos de vizinhança que apontam às pessoas mais vulneráveis, mas eles não têm referencia territorial que seja visível na região e então os vizinhos muitas vezes procuram referencia no governo local. Daí surge a ideia de que um Fórum deve possuir uma centralidade que concentre as atividades públicas e possa coordenar a orientação aos cidadãos. Ela salienta a particular condição de centralidade descentralizada que possui o Terminal de ónibus do Cerro sediado no (quase) único ponto de conexão com o resto de Montevidéu.

A pesquisa produz uma sistematização a partir do estudo bibliográfico sobre a região e a localização geográfica dos diferentes SIG públicos, discriminando por perfil de equipamentos e serviços. Também se estudam e se reconhecem aqueles equipamentos principais que podem, funcionando em rede, integrar-se para constituir um novo Fórum na região.

A condição do pesquisador, de professor de projetos da FADU UDELAR (Ateliê Scheps, Departamento de Projetos, Fadu UDELAR) oferece uma possibilidade para a pesquisa: montar algumas experiências pedagógicas de projeto oferecendo o metaprojeto Fórum como teste partindo de uma contextualização no CCZ17.

São escolhidas duas aproximações diferentes com ênfase particular para o desenvolvimento dos projetos de graduação e pós-graduação.

\footnotetext{
${ }^{7}$ Entrevista com Adriana Rojas Departamento da Prefeitura. Equipo Técnico da Assessoria de Desenvolvimento Municipal e Participação. 12 de abril de 2018.
} 
PIER habitar la bahia

Maria Imbert

Pablo Martinez

Federico Rodriguez

Agustina Sanchez

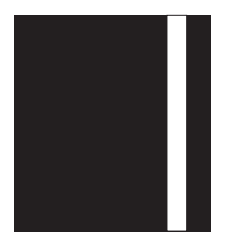

\section{DISPERSE}

Mariana Benzo

Anahi Bermudez

Fernando Errandonea

Valeria Esteves

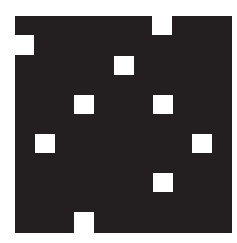

FORUM CONNECT

Fabiana Castillo

Viviana Lugo

Lauro Vicente

Juan L Viñar

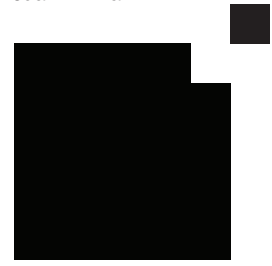

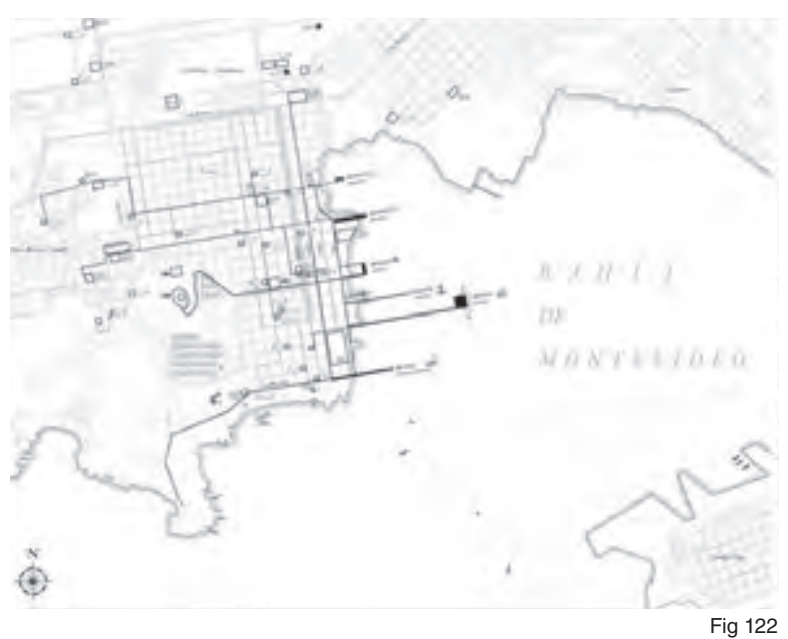
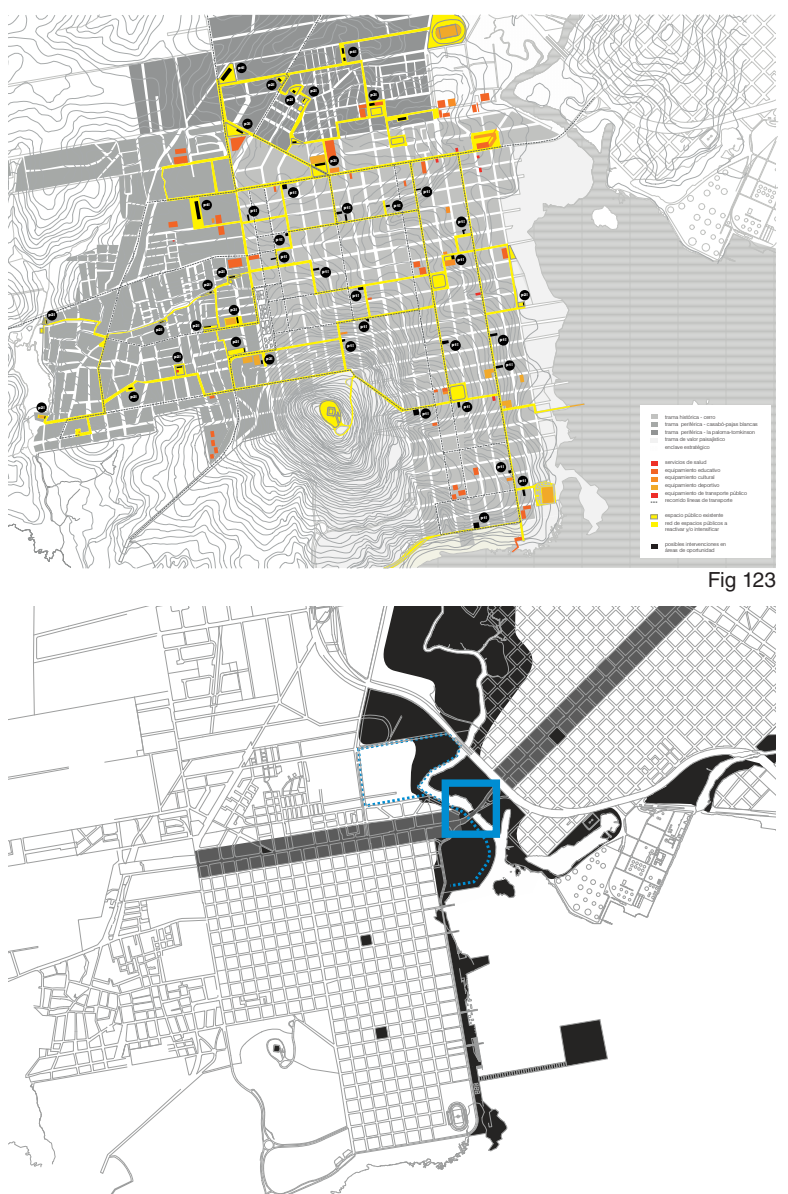

Fig 124

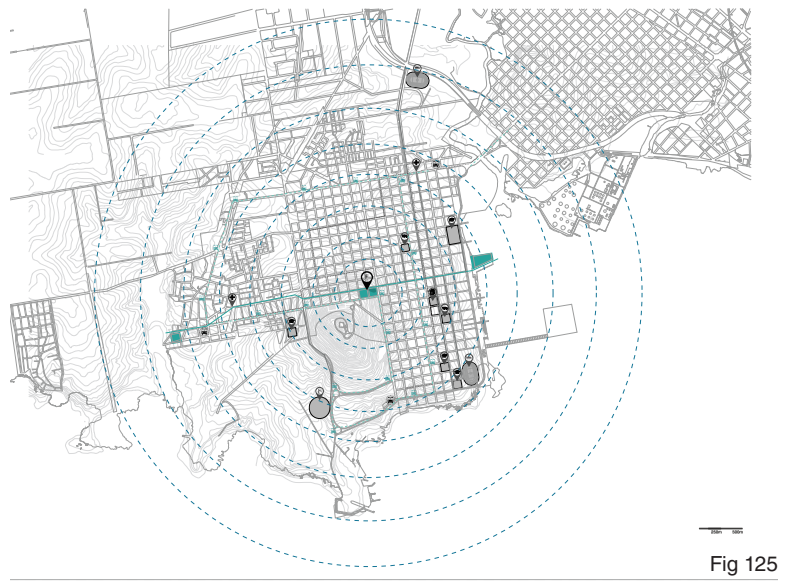

\section{AQUA}

Martin Suarez

Natalia Fleitas
Federico Bergamin

Christian Flores

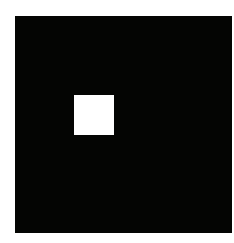




\section{FÓRUM CCZ 17 / TERRITÓRIO}

De um lado o Fórum Território é estudado (projetado) numa disciplina de Pós-graduação e Educação Permanente, a proposta é a formação de um Fórum em rede com os equipamentos já existentes sobre a ideia de projetar $10.000 \mathrm{~m}^{2}$ de equipamento seja num único edifício ou na distribuição que os estudantes escolham. O terreno para o projeto é a região inteira. O curso Foros_Mvd_MWL (MARTíN, RíOS e OREGGIONI, 2018) de 6 créditos, é ministrado por Bernardo Martín, Fernanda Ríos e o autor durante 15 encontros no primeiro semestre de 2018.

No começo do curso são apresentadas as hipóteses do trabalho da pesquisa More with Less, a interpretação do Fórum Casavalle e o relatório sobre a região do CCZ 17 . Se propõe uma mesa redonda com três apresentações: Marcelo Bednarik (projeto "Rambla Cerro"), Jack Couriel ("Sugerencias de políticas urbano-habitacionales para los espacios periféricos") e Juan Pablo Labat ("Vulnerabilidad social y estructura de servicios en el oeste de Montevideo. Observación de brechas") e comentários dos responsáveis da Prefeitura. Durante uma semana o curso assume formato intensivo que coincide com a visita ao curso do arquiteto francês Gilles Delalex.

O resultado do workshop são quatro projetos de intervenção na região com quatro pontos de partida (e chegada) diferentes: "Aqua" (Martín Suarez, Natalia Fleitas, Federico Bergamino, Christian Flores), "Conecta” (Fabiana Castillo, Viviana Lugo, Lauro Vicente, Juan L. Viñar), "Disperse" (Mariana Benzo, Anahí Bermúdez, Fernando Errandonea, Valeria Esteves) e "Pier" (Pablo Martínez, Federico Rodriguez, Agustina, Sánchez e a participação de Maria Imbert).

"Aqua", propõe o Fórum com uma intervenção principal concentrada em sobrepor um conjunto de edifícios e espaços públicos a uma caixa d'água em funcionamento, ruina mono-funcional. A localização da infraestrutura no topo do Cerro e sem tratamento urbano algum é a descoberta inicial para desenvolver um argumento de projeto associado com a água como tema, como programa um conjunto de piscinas e espaços públicos, uma cobertura/paisagem/plataforma, que cobre um conjunto de espaços capazes que podem operar como programas cívicos e de lazer. Um Fórum d' Água, que é também da região, procurando certas conexões urbanas como outros pontos, a água da Baia, Cerro e Casabó, mas assume a sua centralidade e a singularidade temática como atração para a comunidade: 


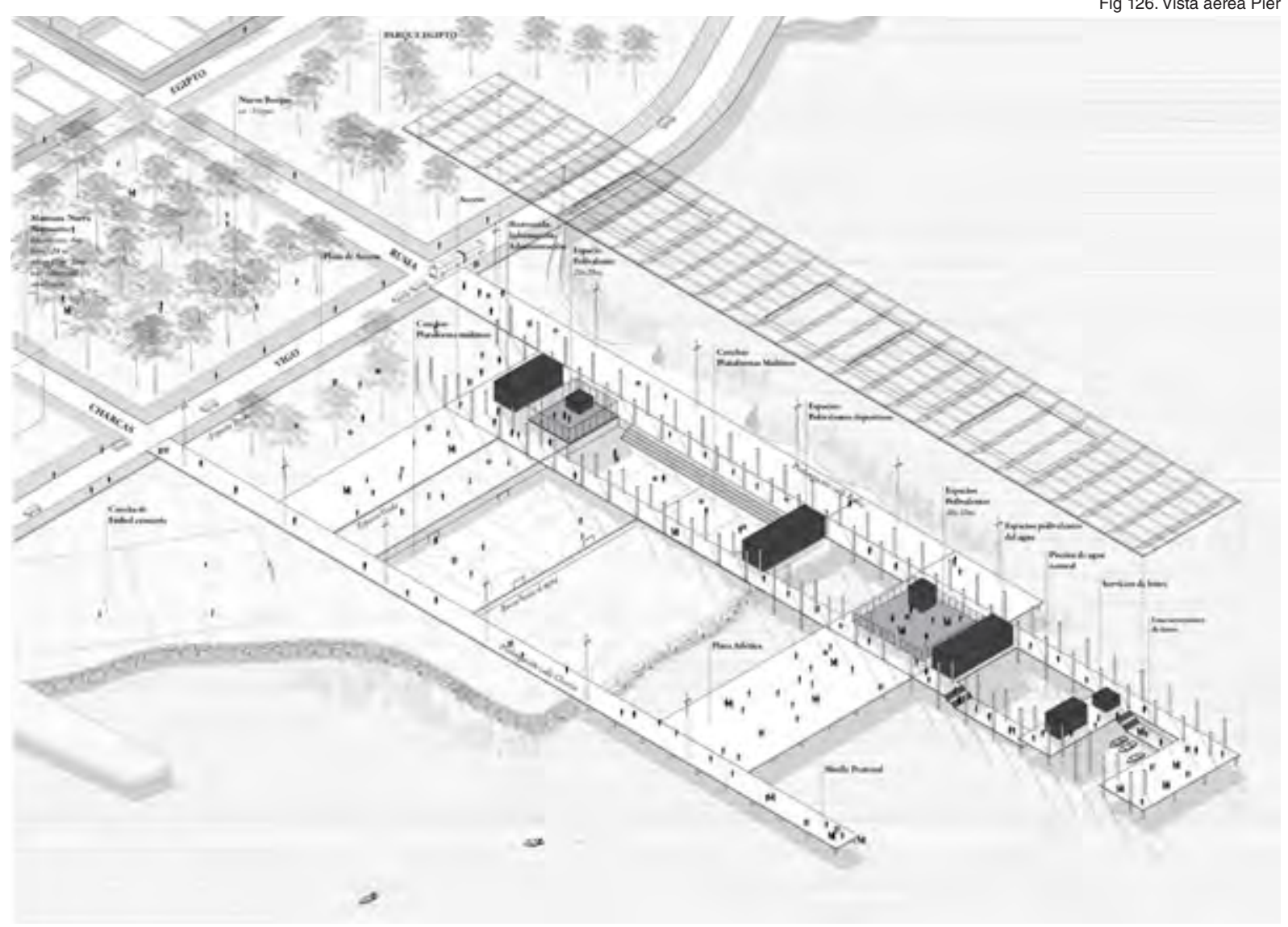


Uma Praia artificial com os visuais mais privilegiadas, o direito ao luxo para todos. Um centro aquático de alto rendimento, uma oportunidade, um centro de saúde em vinculação com a água, uma necessidade. Se cria assim, o Fórum d’Água.

"Conecta" escolhe uma razão simples mais absolutamente poderosa: a região, e se relaciona com a cidade num nó por onde os cidadãos da zona passam todos os dias, esse é o lugar do Fórum. Estabelece a partir de sua localização uma segunda leitura de hierarquia e conexão, reconhecendo na avenida Carlos María Ramirez um estruturador do Município A inteiro, e no córrego Pantanoso e sua foz na Baia uma oportunidade de paisagem. "Conecta" propõe um espaço público próprio que se estende sobre a ponte do Pantanoso e faz conexão também em vertical por meio de um equipamento edifício Centro Cívico e de Educação e Pesquisa, que sedia também atividades universitárias da UDELAR com muita historia na região.

Conecta produz conexões: eixo Carlos María Ramírez, Wetland e Córrego Pantanoso, Baia de Montevidéu, Tecido Urbano

"Disperse" se implanta na cidade real, propondo um trabalho corpo a corpo com diferentes situações urbanas para a criação de um fórum disperso, uma instituição que vive de espaços e eventos e de relações entre os diferentes espaços. O projeto assume a condição diversa e fragmentada da região e procura produzir suturas entre as partes da região, e não fugir da informalidade. Disperse é uma coleção de modos de intervir partindo de oportunidades típicas e repetidas, a enunciação do Fórum através de protótipos sugere uma intervenção aberta e progressiva:

\footnotetext{
O Fórum "Disperse" se apresenta como um dispositivo espacial que não responde a uma função concreta, mas que trabalha como suporte facilitador de usos e programas diversos, sincrônica e diacronicamente alterna atividades de lazer, educação, cultura, produção, cívicas
}

"Pier. Habitar a Baia". O projeto assume a reformulação da orla da Baia no já consolidado bairro Cerro. Ele se debruça sobre a identidade de Montevidéu, a Rambla como espaço principal e propõe um projeto diferente ao desenvolvido na Prefeitura. A ideia parte do conjunto de docas já existente para inaugurar um novo trecho da Rambla, diferente de todos os outros e definido pela multiplicação linear do contato com a Baia, produzindo uma grande quantidade de espaço público e espaço programável e simultaneamente "especializa" cada doca com uma identidade programática. A metáfora do equipamento gerado a partir do espaço público aqui é gerada literalmente como um "Fórum como Rambla", com grande capacidade de atração para os locais estabelecendo com naturalidade a relação com o tecido do Cerro e sua prolongação em 
Fig 127. Projeto Aqua
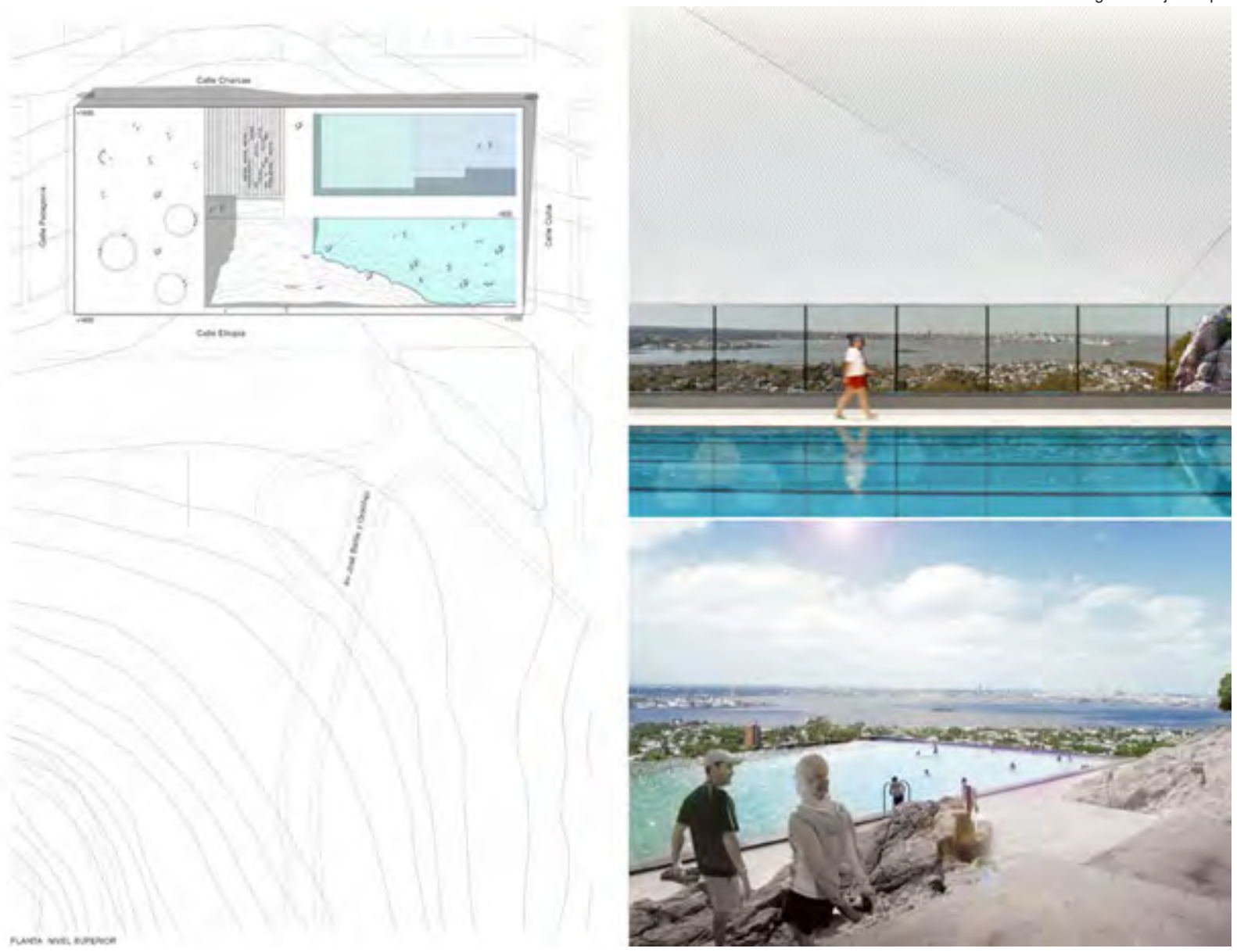
Casabó um "Fórum como ruas", que também atrai a cidade inteira, um equipamento metropolitano.

\author{
VÍNCULOS RELACIONES \\ O Plano Pier continua com o tecido do bairro, com o conceito da cidade através de \\ suas ruas e espaços públicos por excelência, entrando na água e se tornando \\ docas. Desta forma, se gera uma lógica de conexão transversal com a baía e a \\ cidade consolidada atual.
}

Os 4 projetos estabelecem pontos de chegada possíveis como desenvolvimentos criativos a partir do metaprojeto do Fórum, atendendo a realidades e propondo transformações possíveis e necessárias. O exercício entendido agora a partir do concepto de disposição espacial, propõe quatro disposições para o Fórum do CCZ17. A ideia de disposição espacial pode ganhar em riqueza lida com o significado da palavra que propõe uma conexão com a capacidade (como sinónimo de aptidão) e com uma vontade estruturada ${ }^{8}$. E pode ganhar em contexto disciplinar quando é lida a partir do livro Open de Manuel Gausa (2010, p.343-365), que aponta na "disposição" como um modo de projeto contemporâneo, como substituição da "posição" moderna e da "composição" clássica.

Uma realização do metaprojeto na região deveria analisar estas hipóteses de projeto ao mesmo tempo que considera assuntos de complexidade técnica que aqui não aparecem. Além de valorização de cada projeto, os projetos podem até ser entendidos de maneira mais aberta da sua formulação com o próprio conceito de desespecialização programática. O Fórum está contido no conjunto de projetos e sua capacidade de transformação urbana profunda.

\footnotetext{
8 "Disposición: Meio que se emprega para executar un propósito, ou para evitar ou atenuar um mal” (RAE, 2018, tradução nossa); " Disposição: As qualidades inerentes de uma pessoa à mente e ao caráter. [...] O poder de lidar com algo da maneira que mais agrade" (OXFORD, 2018, tradução nossa)
} 


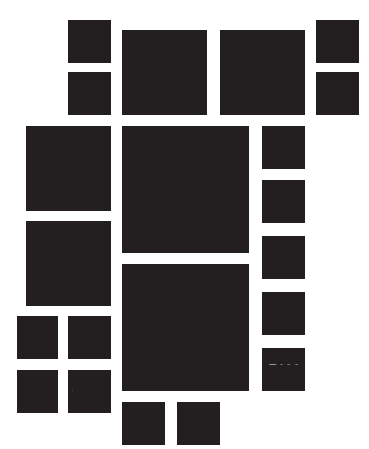

DSL_Jorge Carbonel, Indara Sena, Alba Alvarez

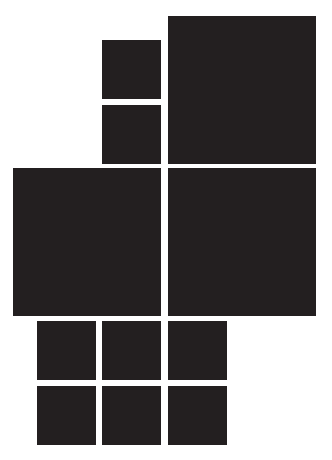

DSL Silvina Alpino

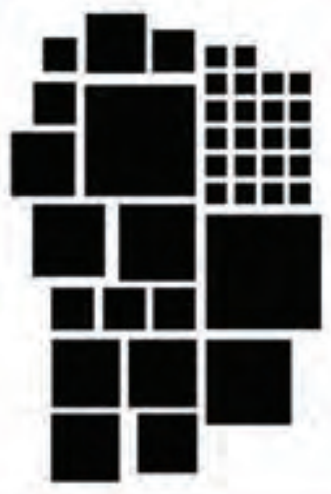

DSL_Lucia Lin y Juliana Batista

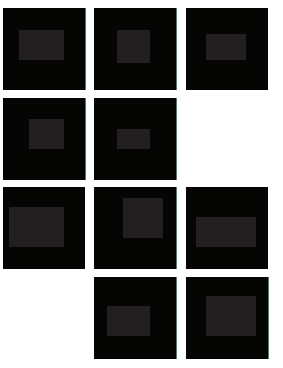

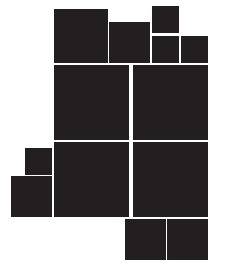

DSL_Ismael Laxague y Fabricio Hernandez

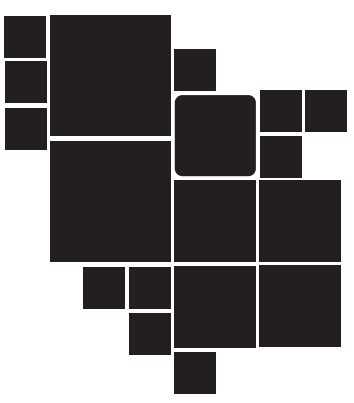

DSL_Sofia Sabjan y Patricia

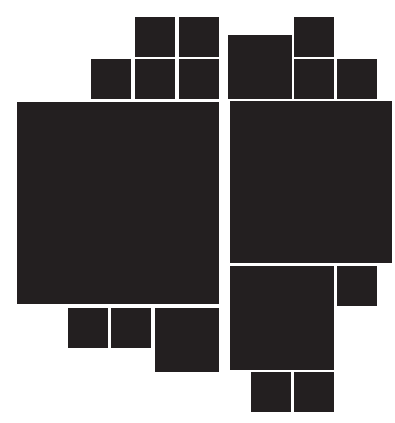

DSL_Fabrizio Libralesso, Pierina Romero y Camilo Mendez

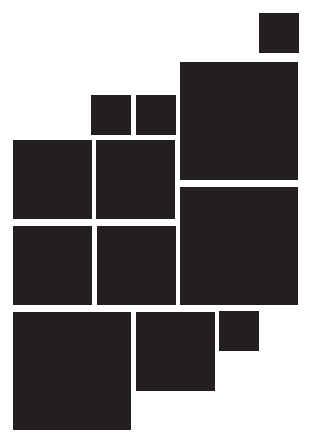

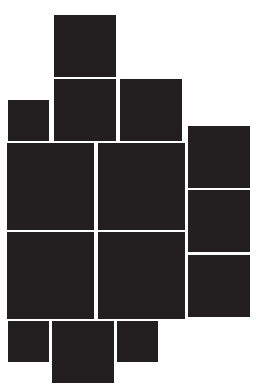

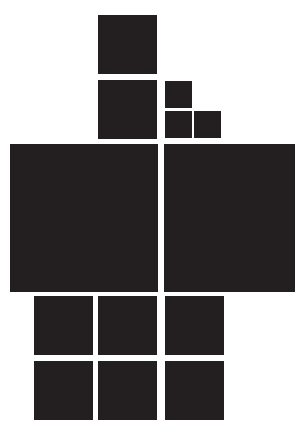

DSL_Lautaro Bozzolasco

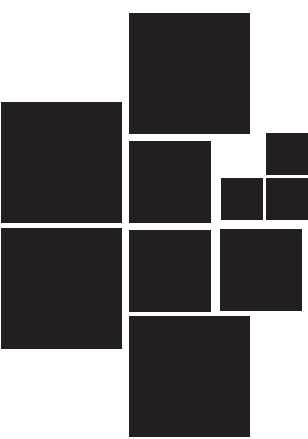

DSL_Mathias cabrera, Franco Maya, Gustavo Taglioretti
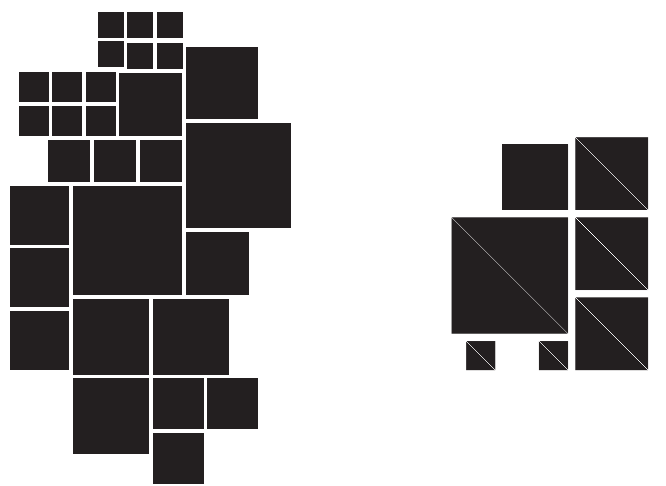


\section{FÓRUM CCZ 17 / EDIFícIO}

Foro_Mvd, urbanizador desespecializado, dispõe de espaço público e diferentes programas coletivos. Uma peça arquitetônica poderosa e de qualidade que constrói uma cidade. Estratégia contra a fragmentação urbana e social. "Learning from Medellín"

Complexo que reúne vários programas, incentiva a colaboração de ações públicas, estimula novas experiências urbanas e naturaliza o encontro de diferentes sujeitos. Cada Fórum tem uma lógica territorial e programação que é configurada em uma rede com instalações existentes na região, projeta e estimula uma sinergia urbana.

Buckminster Fuller desespecializado e sinérgico nos desafia:

"How big can we think?"

O projeto é concebido a partir da despecialização programática, "espaços capazes" para diversos programas que não renunciam à especificidade espacial.

Manipulação abstrata de lógicas geométricas e estruturais. Teste de articulações programáticas concretas. Ensaios de possíveis estados de uso que mudam: reprogramação, evento e apropriação.

$[\ldots]$

Projetar um equipamento público nas bordas da Colina de Montevidéu, ao lado da Fortaleza. Um Fórum contemporâneo que está posicionado entre as periferias e um bairro consolidado, um setor de uma cidade fragmentada e tensa onde vivem quase 100.000 pessoas. Um pedaço quase no topo da colina torna-se referência para esses territórios e sujeitos. De sua sacada ele contempla (e é visível) a Baía de Montevidéu.

Para 100.000 e para 2.000 .000 (OREGGIONI et al., 2018, p.1, tradução nossa) ${ }^{9}$

O exercício de projetação do Fórum Edifício se desenvolve numa disciplina da graduação voltada para estudantes de quarto ano de arquitetura, uma disciplina "Projeto de Tema Especifico" do Ateliê Scheps, para desenvolver um Edifício Fórum de $5.000 \mathrm{~m}^{2}$ com um terreno de $10.000 \mathrm{~m}^{2}$ num local específico dentro do Parque da Fortaleza, olhando para o Norte e no limite entre a parte formal e informal da região.

A disciplina Foros_Mvd de 12 créditos, é ministrada pelo autor e por Matias Carballal, com Diego Facio, Carolina Gilardi, Elisa Porley e Martina León. São propostas três ênfases específicas para o projeto: o entendimento da sinergia urbana a ser produzida, a desespecialização programática e uma atenção aos aspetos estruturais que permitem a criação desses espaços capazes. Se desenvolveu uma experiência não usual na FADU, convidando o escritório de engenharia estrutural RDA para participar da preparação e depois em três atividades do trabalho durante a disciplina, com participação dos engenheiros Sebastian Dieste e Martín Reina junto a seus colegas Fiorella Mondino, Mihdí Caballero, Alejandra Berruti e Francisco Vidovich.

Durante a presença do convidado Gilles Delalex, ele comentou sobre o conjunto de 27 trabalhos e apresentou em detalhes o projeto de Paris Saclay das mesmas noções que estruturam o exercício do Fórum: implantação e organização do prédio para voltar-se a

\footnotetext{
${ }^{9}$ Apresentação do curso Tema Específico: FORO_MVD do primeiro semestre 2018 de quarto ano.
} 


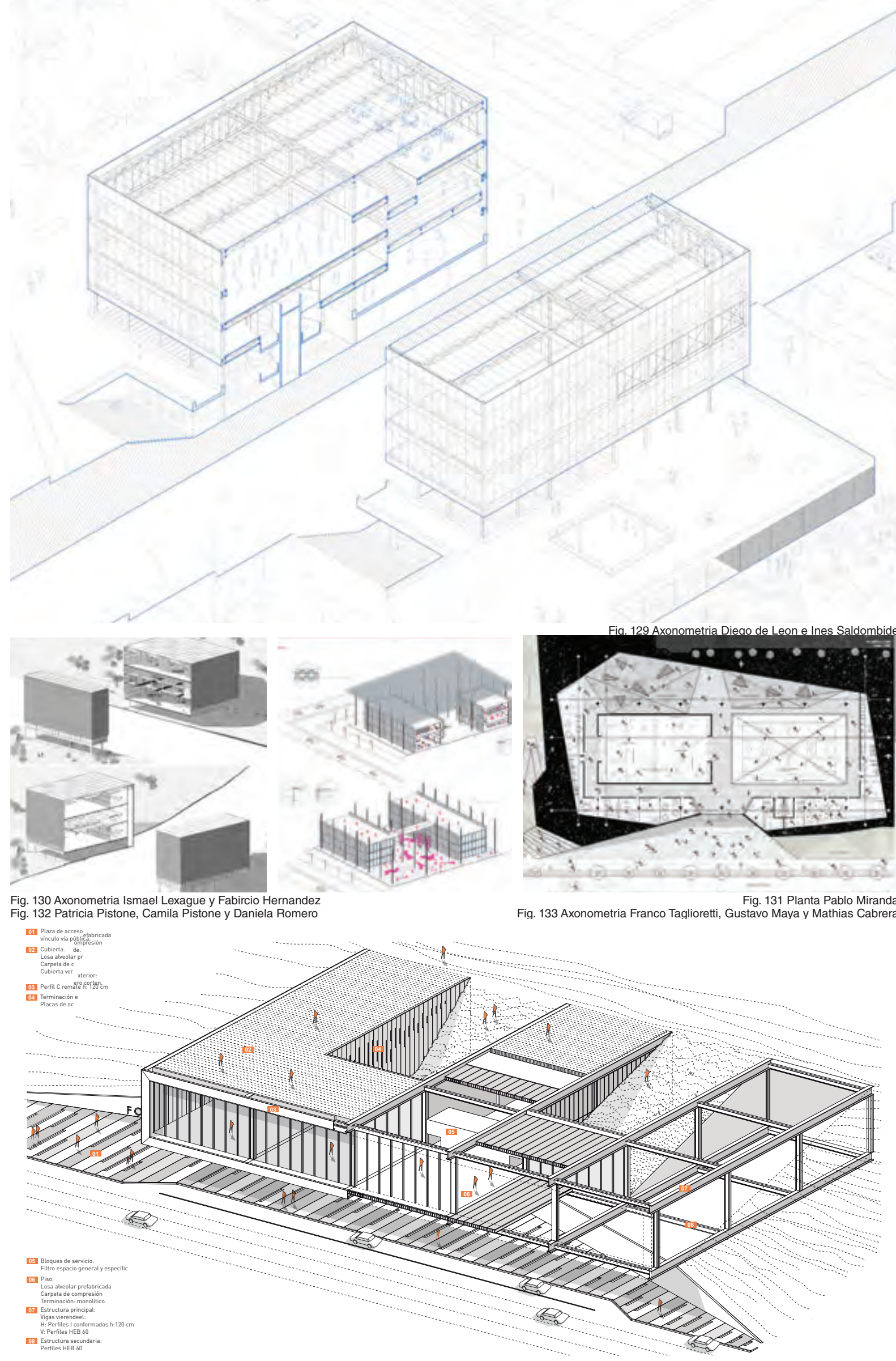



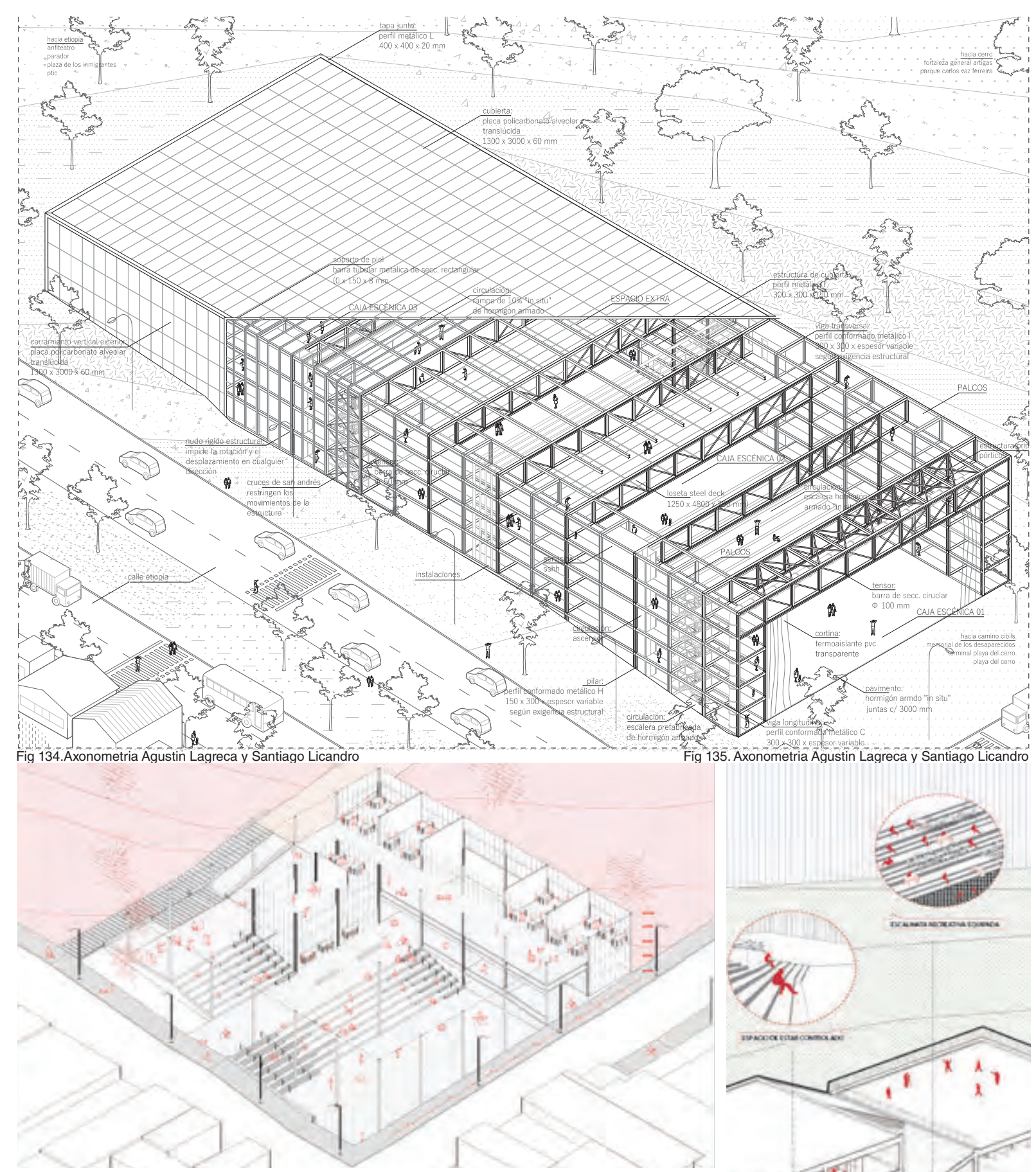

Fig. 136. Axonometria Lucia Rey y Natalia Otero

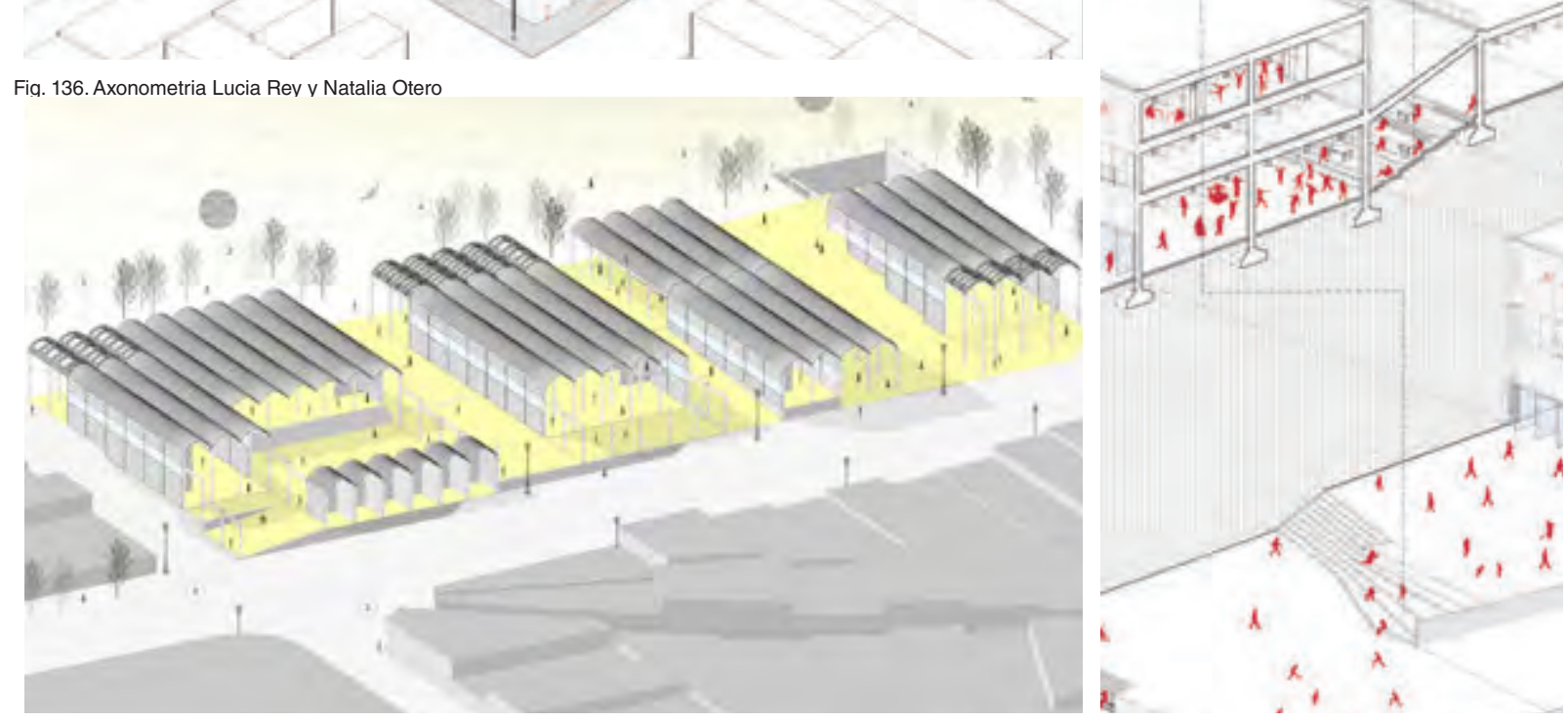




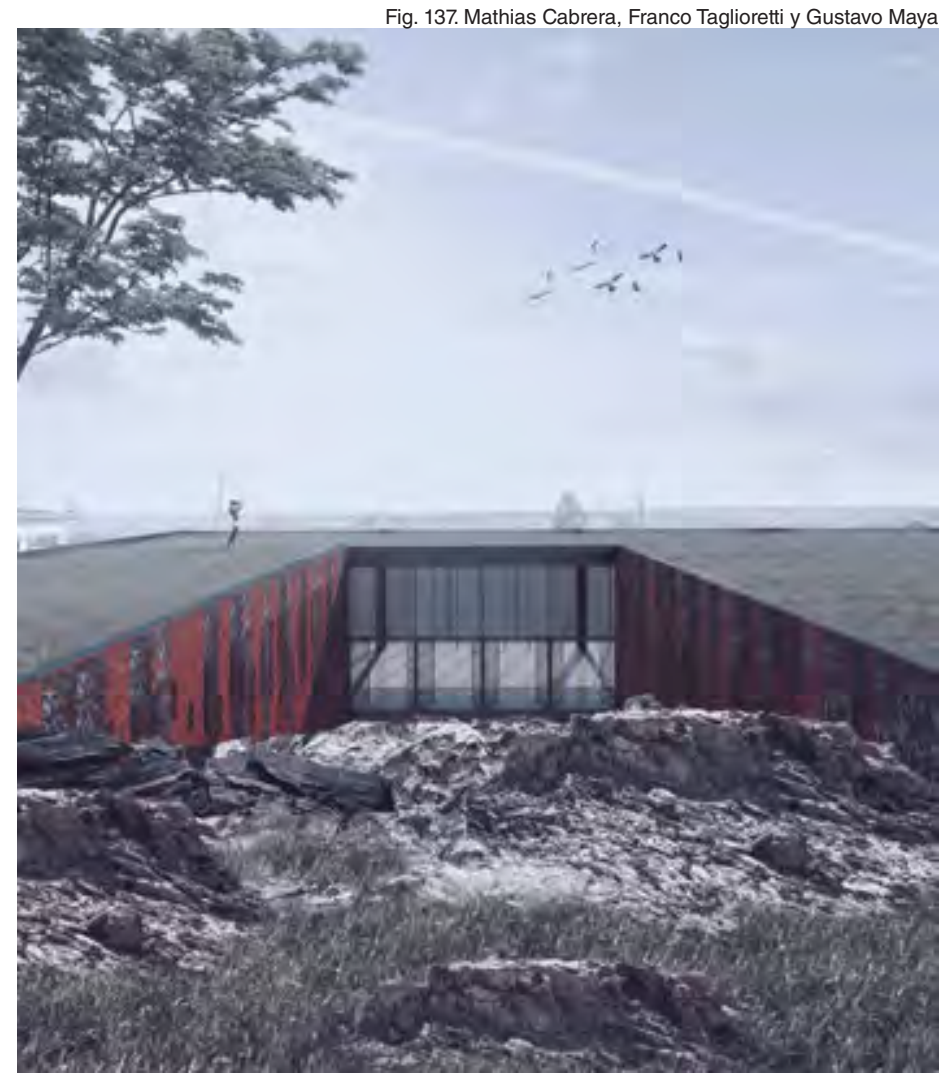

Fig 138. Alba Alvarez, Indara Sena y Jorge Carbonel
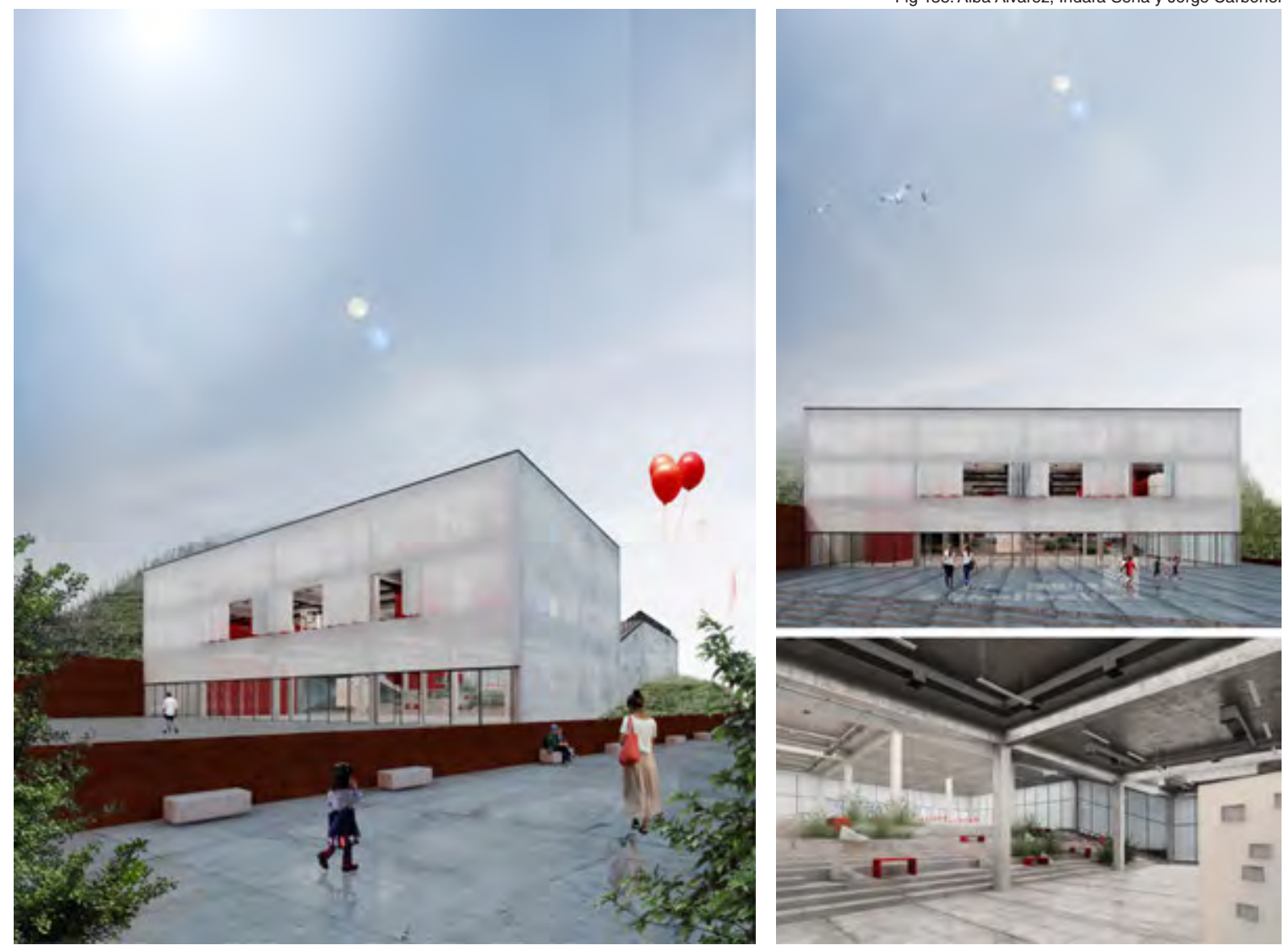
uma referencia dentro do Campus, um Condensador como eles o chamam, e as decisões espaciais e funcionais, estruturais e construtivas que produzem o resultado do projeto.

Um conjunto de 28 variações sobre o mesmo tema: Fórum originado na Desespecializaçào Programática num único terreno e com atenção aos aspectos materiais que sustentam a abertura do espaço. A paisagem do morro, a forte topografia aparece como uma intensa particularidade fora dos temas principais do projeto, uma variável adicional que é resultado da oportunidade do trabalho com um tema e localização de agenda pública.

A multiplicação das possibilidades de entendimento do Fórum a partir de estratégias diferentes de projetos fica clara na diversidade do conjunto: organização e qualidades de espaços, abertura para tipos de programas, materialidade, estruturas, perfis programáticos, relações com a comunidade, com a paisagem, etc. etc. etc. As explorações instalam o metaprojeto num novo estado, arquiteturas possíveis e diversas ao mesmo tempo desespecializadas no programa, e específicas no espaço e no projeto. 



\section{MORE WITH LESS}

ESTRUTURA DA TESE 
Fig.139. Cedric Price.

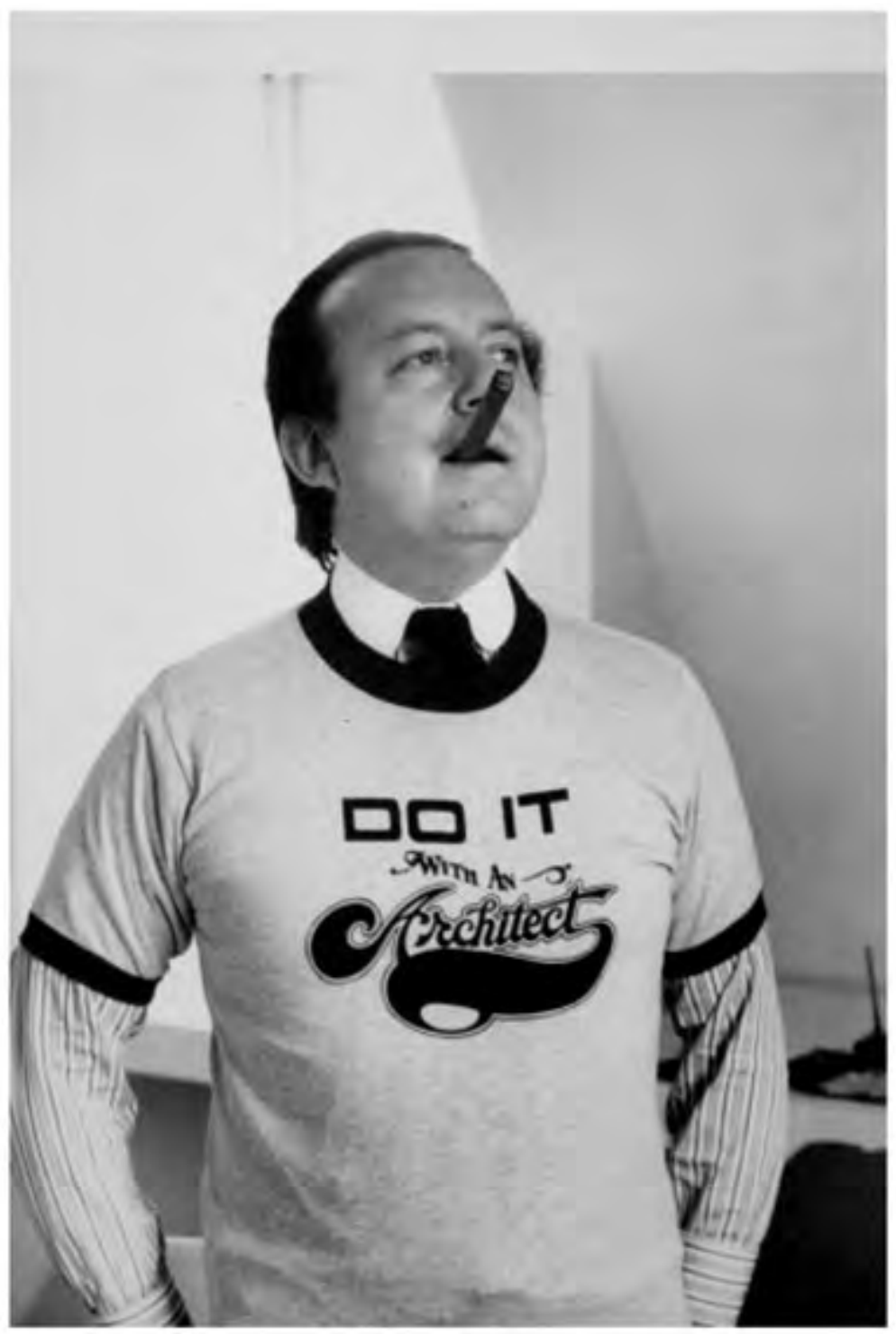




\section{CONCLUSÕES}

Imaginar para criar conhecimento, propor uma nova realidade.

Embora não é possível demonstrar o que ainda não existe, a indagação apresentada gera indícios críticos e propositivos que mostram a possibilidade de existência do Fórum.

O Fórum, é uma entidade arquetípica e nova ao mesmo tempo, que é proposta para ensaiar uma maneira de fazer projetos desdobrando de maneira sinérgica instituições públicas no território, isto é uma maneira de pensar os equipamentos e a cidade. $\mathrm{O}$ trabalho visa uma transformação urbana de qualidade de alto impacto, uma mudança na escala de aproximação, e de projetar simultaneamente dispositivos que são normalmente produzidos de maneira isolada. O Fórum aparece na pesquisa como um conjunto de rascunhos.

Esses esboços pertencem a um campo de trabalho específico, o projeto de arquitetura entendido como construção intelectual e sensível, num mundo de limites difusos nos que é preciso afirmar a especificidade para trabalhar em coprodução.

O metaprojeto Fórum é um dispositivo de projeto. Uma especificidade aberta para um conjunto de interpretações e versões que se apresentam fragmentariamente, como indícios, como partes de um processo que não se fecha com a produção destas páginas, pois segue com projetos de estudantes em curso, e na prática do projeto e da pesquisa.

O Fórum é baseado em ideias e práticas de arquitetura e também em práticas sociais nas quais a arquitetura é só uma parte.

O conjunto, deliberadamente heterogêneo de referencias externas ao Uruguai e à disciplina, confirma recorrentemente que a arquitetura e a produção de cidade de qualidade, são geneticamente necessárias, parte de um todo, mas parte primordial. Muitos dos projetos apresentados são resultado de concursos, e outros de escolhas de arquitetos que possuem o "physique du rôle" para ser parte significativa da criação de umas condições espaciais e relacionais estimulantes. $O$ "rôle" apresentado na pesquisa, e de uma arquitetura que produz condições e estimula relações, contrario a figura do arquiteto estrela autossuficiente; uma arquitetura more with less, baseada em ideias de intervenção mínima (GARCíA GERMÁN, 2010. LOPEZ UJAQUE, 2017). 
A postulação do Fórum Casavalle põe em valor a gestão política de um processo inusual. A partir da sua capacidade de escuta da produção acadêmica, pela realização de um planejamento especifico, pelo fato de ter pensado o território como centro de ação desvanecendo apenas a compartimentação institucional, e procurar uma relação real com a população local (DON CONY, 2012. COUSILLAS e MICHELENA, 2017. FLORES, 2018), se gerou um Fórum. Trata-se de um débil, pela extrema condição da região e a sua população, e por uma carência de projetos de arquitetura, quando ele e visto junto aos CEUs e a experiência de Medelín.

No campo ampliado e de limites difusos do nosso tempo, os arquitetos devemos fazer o nosso aporte especifico e interagir com outras práticas, coproduzir. O Fórum periferia só poderá demostrar sua viabilidade na vida, à qual estas ideias procuram contribuir. 


\section{REFERÊNCIAS dE CITAÇõES}

ABALOS\&HERREROS et al. Revista 2G \#22 Abalos\&Herreros. Barcelona: Gustavo Gili, 2002.

ABBOTT, E. A. Flatland: A romance of many dimensions. Salt Lake City: Project Gutemberg, 2008.

Disponível em: <https://www.gutenberg.org/ebooks/45506> Acesso: 06 jun. 2018.

ACOSTA, V. ‥ BRECHA [semanário] EDICIÓN \#1552. Montevideo, 20 agosto 2015

AGAMBEN, G. ¿Qué es ser contemporáneo? In: CURSO DE FILOSOFÍA TEORÉTICA, 2006 y 2007. Venecia: Facultad de Artes y Diseño, 2006 y2007. [Conferencia] Disponível em:

<https://etsamdoctorado.files.wordpress.com/2012/12/agamben-que-es-lo-contemporaneo.pdf> Acesso em: 04 jun. 2018.

¿Qué es un dispositivo?. Sociológica, año 26, número 73, México. mayo-agosto de 2011. p. 249-264. Disponível em: <http://www.scielo.org.mx/pdf/soc/v26n73/v26n73a10.pdf> Acesso: 06 jun. 2018

ALBA RICO, S. Ser o no ser (un cuerpo). Barcelona: Seix Barral, 2017.

ALIATA,F. Estrategias proyectuales. Los géneros del proyecto moderno. Buenos Aires: Diseño, 2013.

ALVAREZ PEDROSIAN, E, Casavalle: una zona, un barrio, un lugar. Periferia urbana y fragmentación de la subjetividad. [Artículo] 14 p. VIII Jornadas de Investigación de la Facultad de Ciencias Sociales: El futuro del país en debate. Montevideo: UdelaR, 8 y 9 de septiembre de 2009.Publicado en el CD homónimo de las Jornadas, 2009 (ISBN 9789974-0-05662).

Casavalle bajo el sol. Investigación etnográfica sobre territorialidad, identidad y memoria en la periferia urbana de principios de milenio. Montevideo: Ediciones Universitarias, Unidad de Comunicación de la Universidad de la República, 2013.

Transformar la fragmentación urbana. Barcelona Metrópolis \#80. Revista de Información y Pensamiento Urbanos. Barcelona, Ajuntament de Barcelona: 2010 p.10-15.

ANEP. Dirección Sectorial de Infraestrutura. [Documento de trabajo] Estructuras prefabricadas pesadas para arquitectura educativa. Plataforma para proyectos. Montevideo: DIRSEC, febrero 2013.

ARIZA, H. Centro Pompidou. Controversia en el corazón de París. In: Architectural visit [website] 5 feb 2014. Disponível em: <http://architecturalvisits.com/es/2014/02/05/centre-pompidou-beaubourg/> Acesso em: 04 jun. 2018.

ASCHER, F. Los nuevos principios del urbanismo. El fin de las ciudades no está a la orden del día. Madrid: Alianza Editorial, 2007.

AULETE. Dicionário Aulete da Lingua Portuguesa. [on line]Lexicon Editora digital, 2018. Disponível em: <http: //www.aulete.com.br/> Acesso: 06 jun. 2018.

AURELI, P. V. Menos es suficiente. Barcelona: Gustavo Gili, 2016. p.32

BAChElARD, G. La Poética del Espacio. Buenos Aires: Fondo de Cultura Económica, 1965.

BAN, SH. Conversa amb Shigeru Ban. Quaderns d'arquitectura i urbanisme [on line], 2000, Núm. 226 , p. 132-135. Disponível em:

<https://www.raco.cat/index.php/QuadernsArquitecturaUrbanisme/article/view/234753> Acesso: 06 jun.2018

BANHAM, R. Megaestructuras. Futuro urbano del pasado reciente. Barcelona: GG, 1978.

Teoría y diseño arquitectónico en la era de la máquina. Buenos Aires: Nueva Visión, 1971.

BAROSSI A.C. [org.] $O$ edifício da FAU-USP de Vilanova Artigas. São Paulo: Editora da Cidade, 2016. 
BAUDRILLARD, J e NOUVEL, J. Los objetos singulares. Buenos Aires : Fondo de Cultura Económica, 2001.

BAUDRILLARD, J. Cultura y Simulacro. Barcelona: Kairós, 1978.

BAUMAN, Z. Modernidad Líquida.[ epub] Epublibre: diegoan, 2016.

BERVEJILLO, F. El proceso de metropolización y los cambios urbanísticos. Em CALVO, J.J. e MIERES, P.[ Coord.] Sur, migración y después. Propuestas concretas de políticas de población en el Uruguay. Montevideo; UNFPA, Rumbos, Montevidéu, 2008.p.129-190.

BERVEJILLO, Federico. Planteo conceptual y propuesta metodológica para la Licitación Abreviada 362/2010 de la Intendencia de Montevideo. Contratación de un equipo técnico interdisciplinario para la elaboración del plan de ordenación, recuperación e integración urbana de Casavalle. 2010. [Propuesta] Empresa CSI Ingenieros, Consultora Equipos Mori. Montevideo, 2010. Disponível em: <http://plancasavalle.blogspot.com.uy/2011/03/propuesta-del-equipo-tecnico-contratado.html> Acesso: 01 jul. 2018

BORGES, J.L. El libro de arena em EI libro de arena. Buenos Aires: Debolsillo, 2015, p.148-150.

BOSSEUR, J.Y, L’œuvre ouverte d'un art à l’autre. Paris: Minerve, 2013.

BOURRIAUD, N. Pós-produção. Como a arte reprograma o mundo contemporâneo. São Paulo: Martins Fontes, 2009a.

Estética Relacional. São Paulo: Martins Fontes, 2009b.

BRAGA, Milton Liebentritt de Almeida. Infra-estrutura e projeto urbano. 2006, 203 p. Doutorado, Área projeto, espaço e cultura. Faculdade de Arquitetura e Urbanismo, Universidade de São Paulo, 2006.

BUCCI Angelo. São Paulo: quatro imagens para quatro operações (da dissolução dos edifícios e de como atravessar paredes). 2005. 138 p. Doutorado em Arquitetura e Urbanismo. Facultade da Arquitetura e Urbanismo. Universidade de São Paulo. São Paulo, 2005

BUCKMINSTER FULLER, R. EI capitán etéreo y otros escritos. Murcia: Colegio Ofcianl de Aparejadores y Arquitectos técnicos de la región de Murcia, Consejería de Educación y Cultura de la región de Murcia y Fundación Cajamurcia, 2003.

Operating Manual for Spaceship Earth. Baden: Lars Müller Publishers, 2008.

CALVO, J.J. e PELLEGRINO A. Veinteaños no es nada. Em: CAETANO, G. [Dir.] 20 años de democracia. Uruguay 1985-2005. Miradas Múltiples. Uruguay. Montevideo: Santillana, 2005.p.251-268.

CAMUS, A. Carnets 2. Obras 4. Madrid: Alianza, 1996.

CARDOZO, S. [Coord] Evaluación de impacto de las escuelas de Tiempo Completo en Uruguay 2013-2016. Montevideo: ANEP, CEIP e PAEPU, diciembre 2017. Disponível em: <http://ceip.edu.uy/documentos/2017/varios/1971/Libro.pdf> Acesso: 08 jul 2108.

CARROLL,L. La Caza del Snark. [online] Buenos Aires: Biblioteca Virtual Universal, 2006 Disponível em: < http://www.biblioteca.org.ar/libros/130165.pdf> Acesso 06 jun.2018.

CECILIO, M.; COURIEL, J. e SPALLANZANI, M. La gestión urbana en la generación de los tejidos residenciales de la periferia de Montevideo. Montevideo: Farq, Udelar, 1997.

CERVANTES SAAVEDRA, M. EI ingenioso hidalgo Don Quijote de la Mancha. Madrid: Real Academia Española y Alfaguara, 2004.

CHAMIE, M. Depoimento para a biblioteca Mario de Andrade. In: Memoria Oral. Biblioteca Mario de Andrade. San Pablo: Biblioteca Mario de Andrade, 2006. Disponível em: <http://www.prefeitura.sp.gov.br/cidade/upload/Depoimento_Mario_Chamie_1256675522.pdf>Acesso: 06 mar 2014. 
CHRISTIAANSE, K. Fuck the programme? Quaderns d'arquitectura i urbanisme [online], Núm 230, p.869, 2001. Disponível em:

<lhttps://www.raco.cat/index.php/QuadernsArquitecturaUrbanisme/article/view/236689/337312> Acesso: 08 jun. 2018

CIAM [vários autores] A Carta de Atenas. São Paulo: Edusp, 1993.

COADE, Colegio Oficial de Arquitectos de Extremadura [Ed.] Revista Oeste. \# 16. Extremadura, Año 2003.

COLQUHOUN, A. Tipología y método de diseño. Cuadernos de arquitectura y urbanismo. Barcelona, Núm.: 96, p. 51-53, 1973. Disponível:

<http://www.raco.cat/index.php/CuadernosArquitecturaUrbanismo/article/viewFile/111638/160975.> Acesso: 09 mar. 2013.

CORONA MARTINEZ, A. Ensayo sobre el proyecto. Buenos Aires: CP67, 1991.

COURIEL, J. De cercanías y lejanías. Fragmentación socio-urbana del Gran Montevideo. Siete propuestas. Montevidéu: Editorial Trilce, 2010

COUSILLAS, F. e MICHELENA, E. Desde muchos lugares se puede ver Casavalle. La Diaria [online] Diciembre 23, 2017. Sección Posturas. Disponível em: <https://ladiaria.com.uy/articulo/2017/12/desde-muchoslugares-se-puede-ver-casavalle/> Acesso: 08 jul. 2018.

CROFT, S. HIGGS, J. (Dir.) Unfinished Histories [website] London: Unfinished Histories Ltd. , 2006. Disponível em: <http://www.unfinishedhistories.com/ > Acesso: 14 mar. 2015.

DE ANDRADE, O. Manifesto Antropófago. In: Revista Antropofagia Ano I, No.1, maio de 1928. p 3 y 7.

DE CERTEAU, M. La invención de lo cotidiano. México: Universidad Iberoamericana/ ITESO/ Centro Francés de Estudios Mexicanos y Centroamericanos,1996.

DE GRAAF, R. Four walls and a roof: the inevitable box. AR \# 1445. October 2017 After the Revolution. London: 2017, p.7-22

DEL CASTILLO, Alina. 0 papel do projeto na pesquisa acadêmica em arquitetura: reflexões a partir das práticas. 2017. 706 p. Doutorada em Arquitetura e Urbanismo. Facultade e Arquitetura e Urbanismo. Universidade de São Paulo. São Paulo, 2017

DELALEX, G. Une modernité archaïque. Conferencia. Montevideo: FADU, abril 2017. Dismponível em : <https://vimeo.com/272942097> Acesso: 08 jun 2018.

DELEUZE, G. Diferencia y repetición. Madrid: Amorrortu, 2002.

DELGADO, M. EI animal público. Hacia una antropología de los espacios urbanos. Barcelona: Anagrama, 1999.

DELGADO, V; MAGNONE, F e STARICCO, M. Ciudad imaginada. 100 años de concursos de arquitectura en Uruguay. [website] Montevideo: Facultad de Arquitectura, Diseño y Urbanismo. Universidad de la República, 2016-2017. Disponível em: <http://concursos.fadu.edu.uy/> Acesso: 08 jun. 2018.

DELIJAICOV, A. Arquitetura do lugar. Piseagrama, Belo Horizonte, número 03, página 30 - 31, 2011. Disponível em: <http://piseagrama.org/artigo/488/arquitetura-do-lugar/> Acesso: 04 jun. 2018.

della CASA F. \& EUGÉNE. Rolex Learning Center. Lausana: EFPL Press, 2010

DELMAS, A. Mots d’ordre. Mots de désordre. Libération.19 [website] mai, 2018. Disponível em: <http://www.liberation.fr/apps/2018/05/1968-mots-d-ordre-mots-de-desordre/>. Acesso em: 4 jun. 2018.

DEWEY, J. EI arte como experiencia. Barcelona: Paidós Ibérica, 2008.

DÍAZ MORENO, C. e GARCÍA GRINDA, E. . Fragmentos de una conversación. Campos de Juego Líquidos. [entrevista a Kazujo Sejima y Ryue Nishizawa]. EI Croquis SANAA 1998-2004 \#121-122. 2003a. Madrid: EI croquis editorial, p.9-25. 
DÍAZ MORENO, C. e GARCÍA GRINDA, E. Un océano de aire. EI Croquis SANAA 1998-2004 \#121-122. 2003b. Madrid: El croquis editorial, p.26-39.

DIDI-HUBERMAN, G. Imágenes pese a todo. Memoria visual del holocausto. Barcelona: Paidós Ibérica, 2004.

DORIA, R e PÉREZ, M.A. (Og) Educação, CEU e cidade: breve história da educação pública brasileira nos 450 anos na cidade de São Paulo. Porto Alegre: Livraria do Arquiteto FA-UFRGS, 2007.

\section{DURAND J.N.L. Recueil et parallèle des édifices de tout genre, anciens et modernes:}

remarquables par leur beauté, par leur grandeur, ou par leur singularité, et dessinés sur une même échelle. Paris: l'Imprimerie de Gillé fils, 1799 or 1800 Disponível em: <http://gallica.bnf.fr/ark:/12148/bpt6k85721q.image> Acesso: 04 jun. 2018.

EISENMAN, P. 11 +L Una antología de ensayos. Puente Editores. Barcelona 2017.

ELIASSON, O. Los modelos son reales. Barcelona: Gustavo Gili, 2009.

Enciclopédia Itaú Cultural de Arte e Cultura Brasileiras. São Paulo: Itaú Cultural, 2018. Disponível em: <http://enciclopedia.itaucultural.org.br/pessoa211708/h\%C3\%A9lio-duarte>. Acesso em: 14 de Jun. 2018. Verbete da Enciclopédia.

ERLICH, L. Swimming Pool. 1999. [obra site-specific] Kanazawa: The 21st. Century Museum of Art of Kanazawa.

FABRIZI, M. Infinite Sequence of Interior Space: John Soane's Bank of England (1788-1833). Socks. 26 avr. 2016. Disponível em: < http://socks-studio.com/2016/04/26/infinite-sequence-of-interior-space-john-soanes-bankof-england-1788-1833/ > Acesso: 08 jun. 2018.

FAIDEN, M. Ciudad universitaria de Buenos Aires, el proyecto inmaterial de Catalano y Caminos. Revista Summa+ no135. Mayo, 2014, p. 126-128. Disponível em: <http://www.revistasummamas.com.ar/revista_pdf/135/126\#visor> Acesso: 06 jun. 2018

FERRAZ, M. Sesc Pompeia. Coleção Conferencias \#6 . Montevideo: farq-uruguay, 2013.

FICACCI, L. e TOZZI, S. (Cur). Piranesi. La fábrica de la utopia. Exposición. Roma: Museo di Roma, 2017

FILARDO, V. Hacia la resignificación de Casavalle: Montevideo Uruguay. [documento de Proyecto] CEPAL Santiago de Chile 2005.

FOLCO, C e URRUZOLA, J.P. Unidad Plan Director Udelar. Lineamientos conceptuales. Montevideo: Udelar, 2001.

FOQUÉ Richard. Building Knowledge in Architecture. Maryland: UPA, 2010.

FOUCAULT, M. Espacio, Saber y Poder [entrevista a Michel Foucault in RABINOW, P. The Foucalut reader. New York: 1982] Revista Bifurcaciones [online] № 19, inv. 2015. Talca, 2015. Disponível em: <http://www.bifurcaciones.cl/2015/06/reserva/> Acesso: 09 jun 2018-06-16

FOURQUET, F.e MURARD L. Los Equipamientos del Poder. Ciudades, territorios y equipamientos colectivos. Barcelona: Gustavo Gili, 1978.

FRAZER, J.H. The Cybernetics of Architecture: A Tribute to the Contributionof Gordon Pask. Kybernetes. The International Journal of Systems \& Cybernetics Vol. 30(5/6). 2001.p. 641-651. Disponível em: <https://eprints.qut.edu.au/10781/1/10781.pdf> Acesso: 06 jun.2018.

FRIED SCHNITMAN, D. et. al. Nuevos paradigmas, cultura y subjetividad. Buenos Aires: Editorial Paidós, 2005.

FRIEDMAN, Y. Function follows form. In HUGHES, J. e SADLER, S. [ed] Non-Plan. Essays on freedom participation and change in modern architecture and urbanism. p. 104- 115. Nueva York: Architectural Press, 2000. 
FULCO, L. Infraestructura para la educación. Una aporte metodológico a través de la experiência. Elarqa\# 17, Año V, marzo 1996. Montevideo: Dos puntos s.r.l., 1996, p.10-13.

GARCÍA FERNÁNDEZ, Carlos. La construcción de la transparencia : Museo de Arte Contemporáneo del siglo 21 de Kanazawa - SANAA. Madrid.2015. 392 p. Doctorado en Arquitectura. Escuela Técnica Superior de Arquitectura. Universidad Politécnica de Madrid. Madrid, 2015. Disponível em: <http://oa.upm.es/view/institution/Arquitectura/> Acesso: 06 jun. 2018.

GARCÍA-GERMÁN, J. Estrategias operativas en arquitectura. Técnicas de proyecto de Price a Koolhaas. Buenos Aires: Nobuko, 2012.

GARCÍA-GERMÁN, J.[ed] De lo mecánico a lo termodinámico. Por una definición energética de la arquitectura y del territorio. Barcelona: Gustavo Gili, 2010.

GARCÍA-GERMÁN, J. De la mesa de laboratorio a la oficina de patentes. Circo No165 [online]. Madrid, 2010. 8 p. Disponível em: <http://www.mansilla-tunon.com/circo/epoca7/pdf/2010_165.pdf>. Acceso: janeiro 2018.

GAUSA, M et al. Diccionario Metápolis de Arquitectura Avanzada. Barcelona: Actar, 2001.

GAUSA, M. Open. Barcelona, Nueva York: Actar, 2010.

GIMÉNEZ, C; MIRÁS, M e VALENTINO, J. Fragmentos de teoría: Memorias descriptivas de proyectos recientes. Seminario De Crítica Del Instituto De Arte Americano E Investigaciones Estéticas Uba. Buenos Aires, 2005.Disponível em: < http://www.iaa.fadu.uba.ar/publicaciones/critica/0151.pdf> Acesso: 04 jun. 2018.

GUATTARI, F e ROLNIK, S. Micropolítica. Cartografías del deseo. Madrid: Traficantes de Sueños, 2006.

GURIAN, Eduardo Pereira. Marquise do Ibirapuera: suporte ao uso indeterminado. 2014. Dissertação (Mestrado em Projeto de Arquitetura) - Faculdade de Arquitetura e Urbanismo, Universidade de São Paulo, São Paulo, 2014. doi:10.11606/D.16.2014.tde-29072014-155335. Acesso em: 14 jun. 2018.

HABRAKEN N.J. EI diseño de soportes. Barcelona: Gustavo Gili, 2000.

HAN, B. Shanzai. EI arte de la falsificación y la deconstrucción en China. Buenos Aires: Caja Negra Editora, 2016.

haRdingham S. [Ed.] Cedric Price Works 1952-2003. A forward minded retrospective. Volume 1. Projects. London: Architectural Association, London; Canadian Centre for Architecture, Montreal, $2016 \mathrm{a}$.

[Ed.] Cedric Price Works 1952-2003. A forward minded retrospective. Volume 2. Articles \& Talks. London: Architectural Association, London; Canadian Centre for Architecture, Montreal, $2016 \mathrm{~b}$.

[Ed.] Cedric Price. Opera. Sussex: Wiley-Academy, 2011

HASEGAWA Y. Un espacio que desdibuja y borra los programas. El Croquis Kazuyo Sejima Ryue Nishizawa 1995-2000, \#99, 2000. Madrid: El croquis editorial. p. 20-25.

Kazujo Sejima + Ryue Nishizawa. SANAA. Milán: Electa, 2011.

HERRERO ROMERO, Sebastián. Teoría y práctica de la restauración de la Mezquita-catedral de Córdoba durante el siglo XX. Madrid, 2015, 176 p. Doutorado, Escuela Técnica Superior de Arquitectura. Universidad Politécnica de Madrid. Madrid, 2015. Disponível em:

<http://oa.upm.es/39987/1/SEBASTIAN_HERRERO_ROMERO.pdf> Acesso: 01 jul.2018.

HERREROS, J. Nada excepcional. 7 acciones revisitadas en la obra de Lacaton \& Vassal. Revista EI Croquis 177/178 Lacaton \& Vassal 1993-2015. El Croquis: Madrid, 2015. p. 360-369.

HESBERG, H. von e ZANKER, P. [Cur.] Storia dell'architettura italiana. Architettura Romana. La Città in Italia. . Milan: Mondadori Electa, 2012.

IDENBURG, F. Relations. Milán: Postmedia Srl, 2010. 
IHA- Instituto de Historia de la Arquitectura Liceos Modernos. Montevideo: FADU, 2015.

IM [Intendencia de Montevideo] Presentan Eje Cívico Cultural. Municipio D [website] Montevideo, 8 março de 2016. Disponível em: < http://municipiod.montevideo.gub.uy/comunicacion/noticias/presentan-ejecivico-cultural> Acesso: 06 jun. 2018

ITO, T. The japan architect. Toyo Ito 2001. JA [revista]. Tokio. \#41,131 p., Spring 2001.

ITU [Instituto de Teoría y Urbanismo]. Planificación escolar. Montevideo: FADU, 1963. Disponível em: <http://www.fadu.edu.uy/itu/files/2014/09/Folleto-Divulgacion-Tecnica-20.pdf> Acesso: 07 jul. 2018.

JAENICKE FONTAO, Miguel. Arquitectura modal o ensamblaje de repertorios, procesos y disposiciones. Madrid, 2015. 726 p. Doctorado en Arquitectura. Escuela Técnica Superior de Arquitectura. Universidad Politécnica de Madrid. 2015.

JARAÍZ, J. EI parque. Espacios, limites y jerarquias en la obra de Sanaa. 482 p. Doutorado em Arquitectura, Universidad Politécnica de Madrid, Escuela Técnica Superior de Arquitectura de Madrid (ETSAM), 2012. Disponível em; <http://oa.upm.es/12741/1/JOSE_JARAIZ_PEREZ.pdf.> Acesso: 06 jun. 2018.

SANAA. Espacios, límites y jerarquias. Buenos Aires: Diseño, 2013.

JARAMILLO, Orlanda. La Biblioteca pública, lugar para la construcción de ciudadanía: una Mirada desde la educación social. Medellín. 2011. 270p. Doctorada en Educación-Línea de Educación ciudadana. Facultad de educación. Universidad de Antoquia. Medellín, 2011. Disponível em:

<http://ayura.udea.edu.co:8080/jspui/bitstream/123456789/42/1/PB0625.pdf> Acceso: 20 jun 2018.

JORMAKKA, K. The Manhattan Project. Can architecture initiate change, as the modernists always promised? IN. SHAMIYEH, M [ed.] e DOM Research Laboratory. Organizing for change. Profession. Integrating architectural thinking in other fields. Basel: Birkhäuser, 2007 p.113-140.

KAJIMA, M; KURUKODA, J; TUKAMOTO, Y. Made in Tokyo. Tokyo: Kajima Institute Publishing Co, 2001.

KANDINSKY, V. Punto y línea sobre el plano. Buenos Aires: Nueva Visión, 1959.

KATZMAN, R. e RETAMOSO, A. Segregación Residencial en Montevideo. Desafíos para la equidad educativa. Serie Documentos de Trabajo del IPES / Colección Monitor Social №7. Montevideo: Universidad Católica del Uruguay, 2006.

KAUFMANN, E. La arquitectura de la Ilustración. Barroco y posbarroco en Inglaterra, Italia y Francia. Barcelona: Gustavo Gili,1974.

Madrid: Gustavo Gili, 1985

De Ledoux a Le Corbusier. Origen y desarrollo de la arquitectura autónoma.

KAZTMAN, R. E RETAMOSO, A. Segregación espacial, empleo y pobreza en Montevideo. Revista de la Cepal \# 85. Santiago de Chile: 2005. P. 131-148. Disponível em:

<http://archivo.cepal.org/pdfs/revistaCepal/Sp/085131148.pdf> Acesso: 08 jul. 2018.

KAZTMAN, R. Seducidos y abandonados: el aislamiento social de los pobres urbanos. Revista de la CEPAL \# 75, Santiago de Chile, diciembre 2001. P.171-189.

KENNEDY, H. [Ed.] Dictionary of GIS Terminology. Redlands, California: ESRI Press, 2000 Disponível em: <http://www.spatialauthority.yolasite.com/resources/GIS\%20Terminology.pdf> Acesso: 06 jun. 2018.

KOOLHAAS, R e MAU, B. S, M, L, XL. OMA. New York: The Monacelli Press, 1995.

KOOLHAAS, R. ; BOERI, S.; KWINTER, S, TAZI, N e OBRIST, H. Mutaciones. Barcelona: Actar, 2001.

KOOLHAAS, R. Content. KöIn: Taschen, 2004a.

Delirio de Nueva York. Barcelona: Gustavo Gili, 2004b. 
Dismantling Power. In Cedric Price Disappears. AA Files, No. 50 (Spring 2004), P.70-79

London: Architectural Association School of Architecture, 2004c. Disponível em:

<http://www.jstor.org/stable/29544771.> Acesso; 15 mar. 2015

KRONENBURG Robert. Flexible. Architecture that responds to change London: Laurence King, 2007.

LABAT, J. P. Vulnerabilidad social y estructura de servicios en el oeste de Montevideo.

Observación de brechas. [paper apresentado na FADU UDELAR, 5 abril 2018] DINEM. MIDES Abril, 2018.

LACATON, A e VASSAL, J.P. 2G: Lacaton \& Vassal. Barcelona: Gustavo Gili, 2006.

Comme un paysage sans limite / Like an endless landscape [entrevistadores CARRASCO,D. E

STAEBLER, C.] Palais N¹5 Français-Anglais / French-English, France: Palais de Tokyo SAS, 2012.

Disponível em: <https://www.lacatonvassal.com/data/documents/20120501-

2045271204PalaisMagazine15.pdf> Acesso: 06 jun. 2018.

Conference at GSAPP Columbia University. Wood Auditorium, Avery Hall. Graduate School of Architecture, Columbia University. New York, 11 set. 2017. Disponível em: <https://www.youtube.com/watch?v=Twiz-dw9-e4 > Acesso: 06 jun. 2018.

LAGNADO, L. (Curadora) $3^{\circ}$ Panorama de Arte Brasilera. Catálogo. São Paulo: Ministerio da Cultura e Museu de Arte Moderna, 2013.

LANDAU, R. A Philosophy of Enabling: The Work Of Cedric Price. AA Files, No. 8, January: 1985, P.3-7.

London: Architectural Association School of Architecture, 1985. Disponível em:

<http://www.jstor.org/stable/29543432> Acceso: 14 mar. 2015.

LEVNE, R e MÀRQUEZ, F. Entrevista a Antonio Cruz y Antonio Ortíz. El Croquis Cruz y Ortiz Oiza Torres I Martínez Lapeña Cortés. \# 48. Año X. Madrid, jun. 1991. p.5-11.

LIZCANO, E. Metáforas que nos piensan. Sobre ciencia, democracia y otras poderosas ficciones. Madrid: Bajo Cero y Traficantes de Sueños, 2006. Disponível:

<https://www.traficantes.net/sites/default/files/pdfs/Metaforas\%20que\%20nos\%20piensan-TdS.pdf> Acesso: 09 jun. 2018.

LOMBARDO, C. Hacia la resignificación de Casavalle. Montevideo, Uruguay; lineamientos físico territoriales. [documento de Proyecto] CEPAL Santiago de Chile 2005. Disponível em: <https://repositorio.cepal.org/bitstream/handle/11362/3632/S2005055_es.pdf?sequence=1\&isAllowed=y> Acesso: 08 jul.2018.

LÓPEZ UJAQUE, José Manuel. Prefiriendo hacer (casi) nada en arquitectura: postproducción a través de cuatro declinaciones activamente perezosas. 328 p. Doutorado em Arquitetura. Departamento de Proyectos Arquitectónicos, Escuela Técnica Superior de Arquitectura de Madrid: 2017. Disponível em: <http://oa.upm.es/45417/1/JOSE_MANUEL_LOPEZ_UJAQUE.pdf> Acesso: 08 jun. 2018.

LOUREIRO, C.; AMORIM, L. Por uma arquitetura social: a influência de Richard Neutra em prédios escolares no Brasil. Arquitextos, São Paulo, ano 02, n. 020.03, Vitruvius, jan. 2002 Disponível em: <http://www.vitruvius.com.br/revistas/read/arquitextos/02.020/813>. Acesso: 08 jun. 2018.

MACIEL, Carlos Alberto Batista. Arquitetura como infraestrutura. Belo Horizonte, 3 de março de 2015. 420p. Doutorado en Arquitetura e Urbanismo. Escuela de Arquitetura de la Universidade Federal de Minas Gerais. Belo Horizonte, 2015.

MARTÍN DEL CAMPO, C. Utilizando la energía de manera eficiente: Diversidad y aplicaciones. Revista Hypatia No. 35 Año 10 Julio - Septiembre 2010. Disponível em: <https://revistahypatia.org/ingenieria-revista35.html> Acesso 01 avr. 2018.

MARTÍN, B.; RÍOS, F e OREGGIONI, L. Foro MVD_ More with less. [Documento: apresentação do curso de educação permanente] Facultad de Arquitectura, Diseño y Urbanismo, Universidad de la República, 2018. Disponível em: <http://www.fadu.edu.uy/sepep/educacion-permanente/foros_mvd-more-with-less/> Acesso: 06 jun. 2018.

MARTÍN, Bernardo. Zipped. Arquitectura residencial japonesa contemporánea producida en fuertes marcos de restricción de proyecto derivados de condiciones geométricas y dimensionales. Montevideo, 2017. 678 p. 
Doctorado en Arquitectura. Facultad de Arquitectura, Diseño y Urbanismo de la Universidad de la República. Montevideo, 2017.

MARTÍNEZ CAPDEVILLA, Pablo. Andrea Branzi y la "Città Senza Architettura" de la No-Stop City a los Modelos de urbanización débil. 2014. 324 p. Doutorado em Arquitetura, Escuela Técnica Superior De Arquitectura, Universidad Politécnica De Madrid. Madrid. 2014

MARTÍNEZ, E. et al. Atlas 100+1. Montevideo: FADU, 2018. [em preparação]

MATHEWS, S. From Agit-Prop to Free Space: The Architecture of Cedric Price. Londres: Black Dog Publishing, 2007.

The Fun Palace as Virtual Architecture: Cedric Price and the Practices of Indeterminacy. Journal of Architectural Education (1984-) [online] Vol. 59, No. 3, Feb., 1974, pp. 39-48. Washington DC: Taylor \& Francis, Ltd., 2006

MAYORGA HENAO, José Mario. Planeación de equipamientos colectivos: una politica estrategica de integracion social de poblacion en estado de pobreza.2008, 245p. Maestrado en Planeación Urbana y Regional, Facultad de Arquitectura y Diseño., Universidad Javeriana. Bogotá,2008 Disponível em: <http://www.javeriana.edu.co/biblos/tesis/arquitectura/tesis03.pdf> Acesso: 08 jul. 2018.

McBRIEN, J. Make no little plans. Daniel Burnham and the American City. Film color (56 min). USA: Perkins + Will and Wentworth Institute of Technology , 2010

McLUHAN, M. e FIORE, Q. EI medio es el masaje. Un inventario de efectos. Barcelona: Paidós Iberíca, 1988.

MEDELLín. Alcaldía. Red de Bibliotecas Medellín Área Metropolitana. Folleto. Pacto Ciudadano. Medellín: Alcaldía de Medellín. Disponível em:< http://bibliotecasmedellin.gov.co/content/uploads/2015/07/Pactociudadano.pdf > Acceso: 20 jun 2018.

MEKARI, D. e RIBEIRO, R. CEUs completam 12 anos como referência de política para uma Cidade Educadora. [Entrevista a María Cecília Carlini] Portal aprendiz. São Paulo: 1ro de ago. 2015. Disponível em: <http://portal.aprendiz.uol.com.br/2015/08/01/ceus-completam-12-anos-como-referencia-de-politica-para-umacidade-educadora/> Acesso: 14 de jun. de 18.

MÉNDEZ, M. Umbral concreto. Sobre el Urnario de Montevideo. In: Docomomo Brasil Arquitetura Moderna e Internacional: conexões brutalistas 1955-75, X. Curitiba. 15-18 out. 2013.. Disponível em:< http://docomomo.org.br/wp-content/uploads/2016/08/OBR_07.pdf> Acesso: 04 jun.2018.

MESA, F. et al. Archipiélago de Arquitectura. Medellín: Mesa Editores, 2010

MIDES e DINEM .Cartilla de Recursos Sociales. Relevamiento de organismos Nacionales. Montevideo: MIDES, DINEM e Observatorio Social, Junio 2016. Disponível em:

<http://www.mides.gub.uy/innovaportal/file/26847/1/cartilla-6-9-16.pdf> Acesso: 08 jul. 2018.

MIDES. Guía de Recursos Sociales Ministerio de Desarrollo Social. [website] <http://guiaderecursos.mides.gub.uy/> Montevideo, 2018.

MONEO, R. La vida de los edificios. Arquitectura COAM \# 256, Colegio Oficial de Arquitectos de Madrid, 1985. p. 104-115.

On Typology. Oppositions \# 13. Chicago: MIT press, 1978.p. 23-45.

MONTEVIDEO. Departamento de Planificación. IM [Memoria] Plan de Ordenación, Recuperación e Integración Urbana de Casavalle. Memoria de Información Ordenación Gestión y Seguimiento. Montevideo, Intendencia de Montevideo, 2015. Disponível em: <http://www.montevideo.gub.uy/sites/default/files/biblioteca/plancasavallememoriasjunio2015.pdf> Acesso: 08 jul. 2018.

MONTEVIDEO. Secretaría Genera IM [resolución] Se crea el Consejo del Programa Cuenca de la Cañada Casavalle y un equipo de trabajo de composición municipal, con el cometido de ofrecer el sustento técnico y operativo al citado Consejo. Resolución N³3754/09, 07 setiembre de 2009. Disponível em: 
<http://municipiod.montevideo.gub.uy/sites/municipiod/files/resolucion_de_im_numero_3754_de_2009_creacion_ del_consejo_del_programa.pdf> Acesso: 08 jul. 2018

MOREIRA, Nancy Saraiva. Construção Escolar - desenvolvimento, políticas e propostas para a escola rural visando a democratização do campo. 2000. 199 p. Mestrado em Estruturas Ambientais Urbanas, Faculdade de Arquitetura e Urbanismo, Universidade de São Paulo, São Paulo, 2000. doi:10.11606/D.16.2000.tde-04082010-085513. Disponível em: <http://www.teses.usp.br/teses/disponiveis/16/16131/tde-04082010-085513/pt-br.php> Acesso: 12 jun. 2018.

MORERA Diego e WOOD Mauricio. Multiplataforma Casavalle. Tesina de grado. 73 p. 2014-2015. Facultad de Arqutectura, Universidad de la República. Montevideo: 2015.

MORIN, E. Los siete saberes necesários para la educación del futuro. Francia: Santillana Unesco. 1999. Disponível em: <http://unesdoc.unesco.org/images/0011/001177/117740so.pdf>Acesso: 06 jun.2018.

Diário da Califórnia. São Paulo: Edições Sesc São Paulo, 2012.

Introducción al pensamiento complejo. Barcelona: Gedisa, 2007.

MOTTA, F. Textos informes. São Paulo: FAU-USP, 1973

NAJMANOVICH, D. Mirar con nuevos ojos. Nuevos paradigmas en la ciencia y pensamiento complejo. Buenos Aires: Biblos, 2009.

NISIVOCCIA, E. De la cama hasta el living. Apuntes contra la metafísica en arquitectura y a favor de lo inútil. dEspacio No01. Montevidéu: Editorial agua;m, agosto 2004.p 14-33.

OBRIST, H. U. , Cedric Price / Hans Ulrich Obrist. The Conversation Series. Koln: Verlag der Buchhandlung Walther Konig, 2009

[Ed.] Re: CP by Cedric Price. Basel, Boston, Berlín: Birkhäuser Architecture, 2003

OCKMAN, J [Ed.]; Architecture Culture 1943-1968. A documentary Anthology. New York: Rizzoli \& Columbia University, 1993.

OMA. Leads the Final Round for Jean-Jacques Bosc Bridge International Competition in Bordeaux. Em: OMA [website] jun. 2013. Disponível em: < http://oma.eu/news/oma-leads-the-final-round-fopont-jean-jacques-bosc-bridge-international-competition-in-bordeaux> Acesso 09 jun. 2018.

OPP. Pris Informa \# 1 [Boletín] Montevideo: Programa de Inversión Social, 1993

OREGGIONI, L. et al. Foro_ MVD. [Documento: apresentação do curso de graduação] Montevideo: Facultad de Arqquitectura, Diseño y Urbanismo, Universidad de la República, 2018. Disponível em: <http://cargocollective.com/tallerscheps/TE_Tema-Especifico> Acesso: 06 jun. 2018.

OROZCO, M.M.; BARRÁN, P. et al. Escuelas de Tiempo Completo en Uruguay. Montevideo: PAEPUANEP, 2011.

OXFORD. English Dictionary. [online] Oxford University Press, 2018. Disponível em: $<$ https://en.oxforddictionaries.com/ > Acesso 06 jun. 2018.

PANTAleón, C. et al. Casa Patio. Su capacidad potencial de transformación y adaptación a nuevos requerimientos funcionales. Montevideo: Facultad de Arquitectura UDELAR, 2002.

PASTORELLI, G. Concurso para la sede Centro Universitario Regional Este (CURE) Plataforma Arquitectura [online] 11 junio 2009. Disponível em: <https://www.plataformaarquitectura.cl/cl/0220642/concurso-para-la-sede-centro-universitario-regional-este-cure> Acesso 06 jun 2018.

PATETTA, L. [Ed.] Historia de la Arquitectura. Antología crítica. Madrid: Hermann Blume, 1984.

PEREC, G. Especies de Espacios. Barcelona: Montesinos, 2001. p. 59-61. 
PEREYRA, G. Casavalle, la tiranía de los hombres rotos. El Observador [online].Enero 8, 2018 Disponível em: <https://www.elobservador.com.uy/casavalle-la-tirania-los-hombres-rotos-n1156878> Acesso: 08 jul. 2018

PERROTTA-BOSCH, F. Arquitetura dos Intervalos. Revista Serrote [online] \#15 nov.2013. Brasil: Intituto Moreira Sales. 2013. Disponivel https://www.revistaserrote.com.br/2013/12/a-arquitetura-dos-intervalos-porfrancesco-perrotta-bosch/. Acesso: 06 jun.2018.

PEZO, M; VON ELLRICHSHAUSEN, S. Casa Poli: Tomé, Chile. ARQ [revista]. Santiago \# 61, p. 7883, dic. 2005 . Disponível em: <https://scielo.conicyt.cl/pdf/arq/n61/art18.pdf>. Acesso: 18 jun. 2018.

PMB-PIAI Relevamiento de asentamientos irregulares. Primeros resultados de población y viviendas a partir del censo 2011. [Informe técnico] Montevideo: PIAI -Unidad de Evaluación y Monitoreo, MVOTMA, 2012. Disponível em:

<http://pmb.mvotma.gub.uy/sites/default/files/informe_asentamientos_censo_2011_19-10-2012.pdf> Acesso: 08 jul. 2018.

POWELL, K. Will Alsop book 1. London: Lawrence King Publishing:, 2001.

PRICE, C. Research and cooperation [conferencia- archivo audiovisual] London: AA School of Architecture, 06 jul. 1984. Disponível em:

<https://www.youtube.com/watch?v=qDmRVDMaOh8\&index=9\&list=PLI1nDzeohfnn1USwgj87uX3mxVSsdxOTO $>$ Acesso: 09 jun. 2018.

PRIGOGINE, I. ¿Qué es lo que sabemos? A Parte Rei. Revista de Filosofia [online] \#10, octubre 2000. Madrid, 2000. Disponível em: <http://serbal.pntic.mec.es/\%7ecmunoz11/prigogine.pdf> Acesso: 01 jul. 2018.

Bello, 1997

EI fin de las certidumbres. Buenos Aires, Santiago de Chile, México y Barcelona: Andrés

QUETGLAS, J. Habitar. Circo No15 [online]. Madrid, 1994. 8 p. Disponível em: <http:// www.mansillatunon.com/circo/epoca1/pdf/1994_015.pdf>. Acceso: junio de 2005.

RAE. Diccionario de la lengua española. [online] Real Academia Española, 2018. Disponível em: <http://dle.rae.es/> Acesso: 06 jun. 2018.

RATTI, C. [Ed.] Open Source Architecture. Nueva York: Thames \& Hudson, 2015.

RAVETLLAT, P.J. La casa pompeyana = The pompeian house. Quaderns d'arquitectura i urbanisme [em línea] , \#166. Barcelona, 1985, p. 108-115. Disponível em:

<https://www.raco.cat/index.php/QuadernsArquitecturaUrbanisme/article/view/203912> Acesso: 01 jul. 2018.

RIVKIN, A. Espaciar. El horizonte post-mediático de la obra de Lacaton \& Vassal. Revista EI Croquis 177/178 Lacaton \& Vassal 1993-2015. El Croquis: Madrid, 2015. p. 32-47.

ROCHA, P. M. da [autor] WISNIK, G [org.]. Encontros. Paulo Medes da Rocha. Río de Janeiro: Beco do Azougue, 2012.

ROSA, M. L. CEU. Piseagrama, Belo Horizonte, número 03, página 31 - 32, 2011. Disponível em: < https://piseagrama.org/ceu/> Acesso: 04 jun. 2018.

ROUX, Marcelo. Cartografías Provisionales. Los pasajes del mapa a través del campo histórico reciente. Montevideo. 2017. 354 p. Maestrado en Ordenamiento Territorial y Desarrollo Urbano. Facultad de Arquitectura, Diseño y Urbanismo de la Udelar. Montevideo, 2017.

SAER, J.J. Las nubes. Barcelona: El Aleph, 2002.

SANTACANA, Amadeu. EI acontecimiento en un mundo como yuxtaposición. Relaciones programáticas, situaciones y reacciones. Catalunya. 2013. 325 p. Doutorado em Arquitectura. Universitat Politècnica de Catalunya. Departament de Projectes Arquitectònics, Barcelona, 2013. Disponível em: <http://hdl.handle.net/10803/123720> Acesso: 05 jun.2018

SAO PAULO (Cidade). Secretaría Municipal de Desenvolvimento Urbano-SMDU.[informe de gestión] Território CEU: Rede de equipamentos e espaços públicos. São Paulo: SMDU, 2016. 204p. Disponível em: < 
http://gestaourbana.prefeitura.sp.gov.br/wp-content/uploads/2016/12/GEST\%C3\%83Oterritorio_ceu_rede_de_equipamentos_e_espacos_publicos.pdf> Acesso: 04 jun.2018.

SAU. Revista Arquitectura 235. Montevideo: Sociedad de Arquitectos del Uruguay, Noviembre1958.

SCHEPS, G. Puerto. Montevidéu: autoedição com o apoio do ABN-AMRO Bank Uruguay, 2002.

SCHEPS, G. et al. Redes invisibles. Interpretación del proceso de proyecto. Montevidéu: Facultad de Arquitectura, Taller Folco UDELAR, 1996

SEJIMA, K. e NISHIZAWA, R. -SANAA. Casas. Barcelona: Actar y Museo de Arte Contemporáneo de Castilla y León, 2007.

SERAPIÃO, F. [Ed.] Sesc-SP arquitectura. Coleçao Monolito, 33. São Paulo: Editora Monolito, 2016.

Centro Cultural São Paulo. Espaço e vida. São Paulo: Editora Monolito, 2012.

SMITHSON, R. A The Monuments of Passaic. Artforum. New York, dec. 1967, p.52-57.

SPIRA, Vinícius. Desafios do acolhimento e práticas espaciais: os Centros Educacionais Unificados (CEUs) de São Paulo. 2015. 207 p. Mestrado em Antropologia Social. Faculdade de Filosofia, Letras e Ciências Humanas da USP, São Paulo, 2015. Disponível em: <http://www.teses.usp.br/teses/disponiveis/8/8134/tde09062015-121048/es.php > Acesso: 09 jun. 2018.

STUDIO NAUTA et al. Cedric Price Memory Bank [website] [2015 -?] Disponível em: $<$ http://www.cedricprice.com/\#/> Acesso: 09 jun. 2018.

SULLIVAN, L. H. The Tall Office Building Artistically Considered. Lippincott's Magazine. March 1896, p. 403-409. Disponível em: < https://archive.org/details/tallofficebuildi00sull> Acesso : 06 jun. 2018

TSCHUMI, B. Architecture and Disjunction. Cambridge and London: The Mit Press, 1994.

Event Cities (praxis). Cambridge, Massachusetts: the MIT Press, 1996.

UNGERS, O.M. Designing and thinking in images metaphors and analogies.Morphology. City Metaphors.

Cologne: Buchhandlung Walter König, 1982. In: Atlas of places. [online] Ginebra, octubre 2017. Disponível: <http://atlasofplaces.com/Morphologie-City-Metaphors-O-M-Ungers> Acesso: 09 jun. 2018.

URUGUAY. MVOTMA e IMP. Concurso Público Nacional. Ideas Arquitectónicas y Urbanísticas para el predio donde funcionara la antigua industria lanera Paylana. Paysandú, 2017. Disponível em:

<http://www.sau.org.uy/wp-content/uploads/2017/03/BASES-CONCURSO-PREDIO-EX-PAYLANA.pdf > Acesso: 04 jun. 2018.

URUGUAY. Udelar e IMMa. Concurso. Anteproyectos para La Sede Universitaria. De ideas urbanas y paisajísticas para el entorno inmediato. Sede Maldonado. Centro Universitario Regional Este. Marzo 2009.

Disponível em: <http://concursos.fadu.edu.uy/wp-content/uploads/2009_cure-bases.pdf> Acesso: 08 jun. 2018.

VARDA,A. Les plages d'Agnès. Film color (110 min) Francia: Ciné Tamaris e Art France Cinesmas, 2008.

Varios autores; SYKES, K. (Org) O campo ampliado da arquitetura. Antología Teórica 1993-2009. Sao Paulo: Cosac Naify, 2013.

VEIGA, D. Desigualdades sociales y territoriales en el Uruguay. Csic Udelar, Montevideo: 2015.

Fragmentación socioterritorial y desigualdades en el área metropolitana de Montevideo. Revista Pampa. Revista Interuniversitaria de Estudios Territoriales_a4_n4 2008. Santa Fé: Universidad Nacional del Litoral, 2008. P.11-36.

VERDE ZEIN, R. A Marquise do Ibirapuera. Revista aU [online] São Paulo, Edição 226, Jan. 2012. Disponível em: <http://au17.pini.com.br/arquitetura-urbanismo/226/artigo275965-1.aspx> Acesso em: 02 fev. 2013.

VIDLER, A. Histories of the Immediate Present. Inventing Architectural Modernism. Boston: The MIT Press:, 2008 
Madrid: Alianza,1997.

EI Espacio de la Ilustración: la teoría arquitectónica en Francia a finales del siglo XVIII.

Toward a Theory of the Architectural Program. October, Boston, \#106, The MIT Press, 2003, p.

59-74. Disponível: <http://www.jstor.org/stable/3397632. > Acesso: 08 jun 2018.

VILA MATAS, E. Regreso al tapiz que se dispara en muchas direcciones. Em:VILA MATAS, E. Aunque no entendamos nada. Santiago de Chile: J.C. Saéz, 2003 p.139-160

VITRUVIO. Los diez libros de Arquitectura. Madrid: Alianza Forma, 1995.

WACQUANT, L. Os condenados da cidade: estudo sobre marginalidade avançada. Rio de Janeiro: Revan; FASE, 2001.

Desolación urbana y denigración simbólica en el hipergueto. Revista Astrolabio \#6. Córdoba: Universidad Nacional de Córdoba, 2011, p.1-18. Disponível em: <https://revistas.unc.edu.ar/index.php/astrolabio/article/view/321/318> Acesso: 09 jul. 2018.

WAGENSBERG, J. Si la Naturaleza es la Pregunta ¿Cuál era la respuesta? Barcelona: Tusquets Editores, 2004.

WENDERS, W. If Buildings Could Talk... [poema] Neue road movies [website] http://neueroadmovies.com/ , 2010. Disponível em: <eueroadmovies.com/film/if-buildings-could-talk/> Acesso: 08 jun.2018

WIGLEY, M. Anti-buildings and anti-architects. Domus N 866. 2004.Milan: Editoriale Domus S.P.A. p.15-23

Casa da Música. Porto: Fundação Casa da Música, 2008

WITTGENSTEIN, L. Investigaciones filosóficas. Barcelona: Altaya, 1999.

YNZENGA, B. Espacios zero: casa-vivienda, ciudad, territorio y tiempo. Buenos Aires: Diseño, 2014.

YOURCENAR, M. EI negro cerebro de Piranesi. Mount Desert Island, 1959-1961. Biblioteca Ignoria [online]. May 2012. Disponível em : <https://bibliotecaignoria.blogspot.com/2012/05/marguerite-yourcenar-elnegro-cerebro.html> Acesso: 06 jun 2018.

ZALEWSKI, D. Intelligent Design. Can Rem Koolhaas kill the skyscraper? The New Yorker. [online] New York, 14 mar. 2005. Disponível em: <https://www.newyorker.com/magazine/2005/03/14/intelligent-design> Acesso 08 jun.2018.

ZÉ, T. São, São Paulo. In: Grande Liquidação. Sao Paulo: Rozenbit, 1968. 1 disco sonoro (36 min 39) Lado A, faixa 1 (3 $\min 29 s)$

\section{BIBLIOGRAFIA GERAL}

ALLEN, Stan. Del Objeto al Campo. Condiciones de Campo en la Arquitectura y el Urbanismo. Em ÁBALOS, Iñaki (editor). Naturaleza y Artificio. El ideal pintoresco en la arquitectura y el paisajismo contemporâneos. Barcelona: Gustavo Gili, 2009.

AR \# 1445. October 2017 After the Revolution. London: 2017.

ARPA, J.; MOZAS, J.; FERNÁNDEZ PER, A. This is Hybrid. An analysis of mixed-use buildings by a+t. España: a+t architecture publishers, 2011.

BAL, Mieke. Conceptos viajeros en las humanidades. Revista Estudios Visuales \# 3. Murcia: CENDEAC, 2006. Pag. 28-77

BANHAM, Reyner. La arquitectura del entorno bien climatizado. Buenos Aires: Infinito, 1975.

BARTHES, R. EI susurro del lenguaje. Barcelona: Paidós, 1987.

BAUDRILLARD, J. EI Sistema de los Objetos. México: Siglo XXI, 1997. 
BERIO, H.; DEL CASTILlO, A. e LAMOGLIE, G. MVDLab. Em: Premio Julio Vilamajó A\&D 2012: Aportes Originales desde la reflexión y la práctica. Selección de ponencias. Montevideo: Facultad de Arquitectura, Universidad de la República, 2013, p. 185-203

BERVEJILLO, F. e LOMBARDI, M. Globalización, integración y expansión metropolitana en Montevideo. Hacia una región urbana de la Costa Su [ ponencia] $\mathbf{V}$ Seminario Internacional de la Red Iberoamericana de Investigadores sobre Globalización y Territorio, Toluca, 1999.

BIGGS, M e BUCHLER, D. Oito critérios para pesquisa acadêmica em áreas de prática projetual. Em Revista Pós v.17 n.27. São Paulo, junho 2010.p.136-152 2009. P.168-183

Pesquisa acadêmica e prática projetual. Em Revista Pós v.16 n.26. São Paulo: dezembro BLASER, W. Mies Van Der Rohe. Crown Hall. Illinois Institute of Techonology of Chicago. Basel, Boston, Berlin: Birkäuser- Publishers for Architecture, 2001.

BOESIGER, W. Le Corbusier. Obra completa. Zurich: Les Editions d'Architecture, 1964.

BONTA, J.P. Sistemas de significación en arquitectura. Barcelona: Gustavo Gili, 1977.

BOUDON, Ph. Sur l'espace architectural. Essai d'épistemologie de l'architecture. Paris: Dunod, 1977.

CAIRA GITAHY, M.L. e CORREIA de LIRA, J. T. Introdução da coleção Em: CAIRA GITAHY, M.L. e CORREIA de LIRA, J. T.[Org.] Tempo, cidade e arquitetura. Arquiteses 1. São Paulo: FAU/Annablume/FUPAM, 2007. p.7-12

CALVINO, I. Seis Propuestas para el próximo milenio. Madrid: Siruela, 1989.

CCA [Canadian Centre for Architecture.] Arquivo Cedric Price [online] Disponível em:<https://www.cca.qc.ca/en/search/details/collection/object/380477> Acesso: 08 jul.2018.

CONDE, Y. Arquitectura de la Indeterminación. Barcelona: Actar, 2000.

COURIEL, J. e MENÉNDEZ, J. Vivienda. Dónde vivimos los uruguayos. Montevideo: Nuestro Tiempo, comisión del Bicentenario, 2013/2014.

CUNEO, R. e CUNEO, D. [Ed.] Hacia una nueva actitud. Argentina: Mac Gaul, 1971.

DA SILVA LEME, M. C. Texto de apresentação da coleção Arquiteses. Em: CAIRA GITAHY, M.L. e CORREIA de LIRA, J. T.[Org.] Cidade: impases e perspectivas. Arquiteses 2. São Paulo: FAU/Annablume/FUPAM, 2007. p.4

DEBORD, G. Teoría de la deriva. Internacional situacionista, vol. I: La realización del arte. Madrid: Literatura Gris, 1999

EAMES, Ch. e EAMES R. Powers of Ten. Film color (9min) Los Angeles: Universal, 1968. Disponível em:< http://www.powersof10.com/film www.powersof10.com. > Acesso: março 2014.

Revista. Cruz y Ortiz. EL CROQUIS, \# 48, abril- mayo 1991 Madrid: El Croquis Editorial, 1991.

FAD (Fomento de Artes Decorativas). Cruzados. Nuevos territórios del diseño de vanguardia. Barcelona: Ediciones de I'Any del Disseny(FAD) y Actar, 2003.

FOQUÉ, R. Building Knowledge by Design. IV Jornadas Internacionales sobre Investigación en Arquitectura y Urbanismo. Valencia, 2011. Disponível em: <https://riunet.upv.es/handle/10251/15030 > Acesso: 06 jun. 2018.

FRAIMAN, R. e ROSSAL, M. Si tocás pito te dan cumbia. (Esbozo antropológico de la violencia en Montevideo). Montevideo: Ministerio del Interior, 2009.

GIEDION, S. Espacio, tiempo y arquitectura. Origen y desarrollo de una nueva tradición. Barcelona: Reverté, 2009. 
La mecanización toma el mando. Barcelona y Santiago: Gustavo Gili, 1978.

GRAHAM, D. EI arte con relación a la arquitectura. La arquitectura con relación al arte. Barcelona: Gustavo Gilli, 2009.

GROYS, B. Volverse público. Las transformaciones del arte en el ágora de la contemporaneidad. Buenos Aires: Caja Negra, 2016.

HAN, B.Ch. Sociedade da Transparência. Río de janeiro: Vozes, Petrópilis, 2017.

HARDingham, S. e RATTEMBURY, K. Cedric Price. Potteries. Thinkbelt. Supercrit \# 1. Londres: Routledge, 2007.

HEIDEGGER, M. Construir, habitar, pensar. Conferencias y Artículos. Barcelona: Serbal, 1994.

HILL, J. Actions of Architecture: Architects and Creative Users. Londres: Routledge,2003

HUSTWIT, Gary. Urbanized. U Film Color (85 min) U.S.A. e U.K.: Lucy Raven y Gary Hustwit, Swiss Dots, 2011. Disponível em: < http://urbanizedfilm.com> Acesso: fevreiro 2014.

IKONNIKOV, Andrei. Años de efervescencia. El nacimiento de la arquitectura soviética. Em Revista A\&V 29. Madrid: Revista A\&V, 1991.

INFRANET LAB/ LATERAL OFFICE. Coupling. Strategies for infrastructural Opportunism. Em Revista Pamphlet Architecture 30. New York: Princeton Architectural Press, 2011.

KATINSKY, J. R. Pesquisa Acadêmica na FAU USP. São Paulo: USP, 2011.

KAZTMAN, R. , FILGUEIRA, F. eFURTADO,M. Nuevos desafios para la educación en Uruguay. Revista de la CEPAL \# 72, Santiago de Chile, diciembre 2001. P.79-97

KOOLHAAS, R. E EISENMAN, P. Supercrít. Sao Paulo: Cosac Naif, 2013.

LATOUR, Bruno. Reensamblar lo social. Una introducción a la teoría del actor-red. Manantial: 2005.

LE CORBUSIER. Hacia una arquitectura. Buenos Aires: Poseidón, 1964.

LEFAIVRE, L. e TZONIS, A. The emergence of modern architecture: a documentary history from 1000 to 1810 London and New York: Routledge. ,2004

LefebVRe, H. The Production of Space. Oxford: Blackwell, 1991.

LINK, Daniel. León Ferrari: brailles y relecturas de la Biblia. Buenos aires: MALBA, 2009.

LOBSINGER, M- L. Cedric_Price. An Architecture of Performance. Daidalos: Architecture, Art, Culture \# 74 Octubre, 2000. p.22-29 Disponível em:

<https://www.academia.edu/1442541/_Cedric_Price._An_Architecture_of_Performance_> Acesso: 06 jun.2018.

MARTÍNEZ LUQUE, V. Tupy Or Not Tupy: Antropofagia, Cultura y Identidad. Diálogos \#9 v. 9, n. 3. Maringúa: $\mathrm{DHI} / \mathrm{PPH} / \mathrm{UEM}, 2005$, p. 31-38.

MARTÍNEZ, E. Transformaciones Urbanas/Suburbanas y sus pobladores metropolitanos. [documento de trabajo]Montevideo: ITU_FARQ_UdelaR, 1985, 1996, 2004.

MENÉNDEZ, J. F. Análisis comparativo entre las condiciones en los asentamientos irregulares y el tejido residencial formal a la luz de la encuesta continua de hogares. Documentos temáticos nำ. Montevideo: INE (Instituto Nacional de Estadística), 2009.

MONEYS, X. e FUERTES, P. Casa Collage. Barcelona: Gustavo Gilli, 2001.

MOSTAFAVI, M. e DOHERTY, G. [Ed.] Ecological Urbanism. Harvard University Graduate School of Design. Suiza: Lars Müller Publishers, 2010-2013. 
NOBRE, A. L.; VAZ MILHEIRO, A. e WISNIK, G. Coletivo: arquitetura paulista contemporânea. São Paulo: Cosac Naify, 2006.

OLIVEIRA FARKAS, S [Cur.] Joseph Beuys. A Revoluçao somos nós. [catálogo de muestra] São Paulo: Associaçao cultural videobrasil, SESC, 2010.

OREGGIONI, L. Viviendo Vivienda. Montevideo: FArq, UdelaR y Zona Editorial, 2012.

PARICIO, I. Construyendo hábitos. Alternativas a la vivienda: del estuche a la caja. Em Arquitectura Viva 49, Julio-agosto de 1996. P.19-24

PERRONE, R. A Cunha. EI Proyecto como investigación académica en posgrado. [artículo] IV Jornadas Internacionales sobre Investigación en Arquitectura y Urbanismo. Valencia: ETSAV, 1, 2 y 3 de junio de 2011

PEZO, M. La máquina inútil. Arquitetura revista [online]- Vol.3, $\mathrm{n}^{\circ}$ 1, janeiro/junho de 2007, ISSN 18085741 p.37-41 Disponible em:en:<http://www.redalyc.org/articulo.oa?id=193615506004> Acesso: 06 jun.2018.

PRICE, C.The Square Book. London: The Wiley Academy, 2003. [Reimpressão do livro: PRICE Cedric / Cedric Price. AA Works 1. London: Architectural Association, 1984]

Generator. Catálogo da exposição do arquiteto na Waddington Galleries em 1981. Middlesex: The Hillingdon Press: 1981.

SCHEPS, G. 17 Registros. Facultad de Ingeniería de Montevideo (1936-1938) de Julio Vilamajó, arquitecto. 592p. Doctorado en Arquitectura, Departamento de Proyectos Arquitectónicos, Escuela Técnica Superior de Arquitectura, Universidad Politécnica de Madrid, Madird, 2008. Disponóvel em:

<http://oa.upm.es/2920/1/JUAN_GUSTAVO_SCHEPS_GRANDAL_2.pdf> Acesso: 08 jun.2018.

SERRES, M. Atlas. Madrid: Ediciones Cátedra, 1995.

SMITHSON, A. e SMITHSON, P. Cambiando el arte de habitar. Barcelona: Gustavo Gili, 2001.

TAFURI, M. e Dal CO, F. Arquitectura contemporánea. Madrid: Aguilar, 1978.

La arquitectura del Humanismo. Madrid: Xarait, 1982.

Teorías e Historia de la Arquitectura. Madrid: Celeste, 1997.

VENTURI, R. Complejidad y Contradicción en la Arquitectura. Barcelona: Gustavo Gilli, 2012.

VERB, Architecture Boogazine. Connection. Barcelona: Actar, 2004.

VIRILIO, P. Advertencia de Paso, Un paisaje de acontecimientos. Quaderns d'arquitectura i urbanisme \# 223 [online], Barcelona: Actar, 2000.p.18-19.

WAIN, A. [Ed.] Ferrari por León. Buenos Aires: Libraria, 2016.

WALKER, E. [Ed.] Lo ordinario. Barcelona: Gustavo Gilli, 2010. 


\section{REFERÊNCIAS DE IMAGENS}

Fig.1_Quadrado preto, Kazimir Malevich, 1915.

Fonte: www.monoskop.org/

Fig.2_Localizaçao do Equipamento integral, ITU-FADU, 1963.

Fonte: ITU

Fig.3_El Unitor, Justino Serralta, 1981

Fonte: SERRALTA, J. EL Unitor, Montevideo: Trilce, FCU, 1995.

Fig.4_Revista SAU\#235. Unidad Casavalle.

Fonte: Revista SAU\#235

Fig.5_Página do Livro "el médio es el masaje" de McLuhan e Fiore ,1988.

Fonte: McLUHAN e FIORE (1988)

Fig.6_ Branco sobre branco, Kazimir Malevich, 1918.

Fonte: www.monoskop.org/

Fig.7_Human Dimensions, Architectural Graphic Standard,1932

Fonte: http://www.africa-first.com/

Fig.8_ Global Myopia, Marco Maggi, 2015.

Fonte: BENTANCUR, p.[Ed.] Global Myopia. Montevideo: MEC, 2015.

Fig.9_ Sin título, León Ferrari, 1980.

Fonte: Giunta, A. [Ed.] León Ferrari. Retrospectiva. Obras 1954-2006. Sao Paulo: Cosacnaify, 2006.

Fig.10_Faculdade de Arquitetura_ Nantes, Francia.

Fonte: https://www.lacatonvassal.com/

Fig.11_Casa en armação durante a obra. UNA arquitetos.

Fonte: UNA Arquitetos.

Fig.12_ Chegada da piscina flotante, Madelon Vriesendorp, 1976.

Fonte: http://ilovenyz-blog.tumblr.com/

Fig.13_ Basílica de Fano ,Vitruvio_Perrault.

Fonte: http://bauforschungonline.ch/aufsatz/was-architekten-lasen-und-kopierten-schw.html

Fig.14_Reprodução da Igreja de S.Maria della Divina Provvidenza, Luigi Moretti.

Fonte: Rivista "Spazio" n.7, 1953.

Fig.15_Mundo Basilical, Seroux d'agincourt_ Fonte_VIDLER, 1997.

Fig. 16 _ Partes de Edificios, J.L.N. Durand Fonte: DURAND, 1799

Fig.17_ Diagrama analítico da Casa Dominó, Peter Eisenman.

Fonte: EISENMAN, 2017.

Fig.18_Ensambles de edifícios. Durand

Fonte: DURAND, 1799.

Fig.19_Mies Averagine_1000 R.

Fonte: www.onethousand.com

Fig.20_Perspectiva Crown Hall, IIT Chicago_Pao-chi Chan, 2000

Fonte: BLASER, 2001. 
Fig.21_Automatic Hog-Weighing Aparatus.

Fonte: GIEDION, 1978

Fig.22_ Co-op quarto. Hannes Meyer

Fonte: https://www.researchgate.net/

Fig.23_Redesenho de diagramas, Stadstheatre de Almere, SANAA.

Fonte: Redesenho do autor.

Fig.24_Seção Diagonal, Marcius Galan.

Fonte: http://www.pipaprize.com/

Fig. 25_Michigan Theatre Detroit, George Steinmetz, 2006

Fuente: https://quod.lib.umich.edu/

Fig.26_ Made in Tokyo

Fonte: KAJIMA, M; KURUKODA, J; TUKAMOTO, Y (2001)

Fig.27_Cinerama Dome, 1993. Sugimoto, H.

Fonte: www.sugimotohiroshi.com/

Fig.28_Turner Box, Marco Maggi, 2011

Fonte: BENTANCUR, p.[Ed.] Global Myopia. Montevideo: MEC, 2015.

Fig. 29_Formas de edifícios, JNL Durand, 1809.

Fonte: MONEO, 1978.

Fig.30_ Mesa Ishigami

Fuente: http://socks-studio.com/

Fig.31a_Aulario José Luis Massera. Redisenho axonométrico.

Fonte: Redisenho PTE_FORO MVD_Atelier Scheps.

Fig.31b_CURE Maldonado. Santiago Lenzi, Álvaro Toledo.

Fonte: Plan de Obras. Udelar.

Fig.32a_Plano de Roma, Giambattista Nolli.

Fonte: https://upload.wikimedia.org/wikipedia/commons/3/31/Giovanni_Battista_Nolli-

Nuova_Pianta_di_Roma_\%281748\%29_05-12.JPG

Fig.33_Tabela do Oceano, Lewis Carroll

Fonte: CARROLL, 2006.

Fig. 34_Storget 2011_Dreamhamar_Ecosistema

Fonte: http://ecosistemaurbano.com/

Fig.35_El Zócalo, Francis Alÿs.

Fonte: http://museotamayo.org

Fig.36_City metaphors, M.O. Ungers

Fonte: http://modemity.blogspot.com/2010/08/city-metaphors.html

Fig.37_ Conical Intersect, Gordon Matta-Clark, París, 1975. Ph: Pedro Donoso Fonte: http://artishockrevista.com/

Fig.38_Pompidou, Paris.

Fonte: http://www.arquine.com/

Fig.39_Generator, Cedric Price.

Fonte: CANADIAN CENTRE OF ARCHITECTURE [ DIGITAL ON LINE]

Fig.40_Quadrado preto de Malevich no Hermitage

Fuente: www.oma.eu 
Fig.41_ Diagramas Hemitage, OMA.

Fuente: www.oma.eu

Fig.42_Edificio Altamira, Rafael Iglesia.

Fonte: https://www.plataformaarquitectura.cl/

Fig.43_ Old Colonial Office in the Bank of England, John Soane, 1818 Fonte: http://socks-studio.com/

Fig.44_CCSP. Ph: Nelson Kon

Fonte: http://www.nelsonkon.com.br/

Fig.45_Terminal de ônibus, Salto. Eladio Dieste.

Fonte: SMA, FADU, Udelar. http://www.fadu.edu.uy/eladio-dieste/

Fig. 46_SESC Pompeia, Lina Bo Bardi

Fonte: http://www.nelsonkon.com.br/

Fig.47_Edificio industrial Paylana. Axonometría.

Fonte: Edital Concurso.

Flg. 48_Pinacoteca de São Paulo. Paulo Mendes de Rocha.

Fonte: https://www.archdaily.com.br

Fig. 49 Palais de Tokyo.

Fonte: www.lacaton-vassal.com

Flg. 50_ 4.4.1997 - 4.6.1999, Potsdamer Platz, Berlin, Michael Wesely. Fonte: http://www.stadtaspekte.de/

Fig. 51 Coal Bunkers Bernd Becher and Hilla Becher 1974

Fonte: www.tate.org.uk

Fig. 52 UVA da Imaginacao.. Medellín. 720 arquitectura.

Fonte: https://www.colectivo720.com/uva

Fig. 53 Urnario Municipal de Montevideu. Axonometría.

PTE Atelié Scheps. Perlas, Ramirez, Lin, Iglesias, Kauke, Chiva.

Fig. 54 Palacio Salvo Montevidéu. Palantai.

Jornal El Observador. Nicolás Garrido.

Fig. 55 Laval. Cité de la Realilte Virtualle. Studio Muoto.

http://www.studiomuoto.com/.

Fig. 56 Palais de Tokyo. Montagem.

Fonte: www.lacaton-vassal.com

Fig. 57. Domingo no CEU.

Fonte: Piseagrama. Foto André Rosso.

Fig. 58. Diagrama Implantações. CEU $1^{\text {a }}$ Geração

Fonte: Autor. Dados: SMDU

Fig. 59. Diagrama Implantações. CEU $3^{\text {a }}$ Geração

Fonte: Autor. Dados: SMDU

Fig. 59. Diagrama Implantações. CEU $3^{a}$ Geração

Fonte: Autor. Dados: SMDU

Fig. 60. Axonometria. CEU $3^{a}$ Geração

Fonte: Autor. Dados: Prefeitura São Paulo. 
Fig. 61. CEU Butantã

Fonte:www.nelsonkon.com.br Autor Nelson Kon.

Fig. 62. CEU Butantã

Fonte: www.nelsonkon.com.br Autor Nelson Kon.

Fig. 63. CEU 3a geração. Montagem.

Fonte: Prefeitura São Paulo

Fig. 64. "15 untitled works in concrete", 1980-1984, Donald Judd.

Fonte: https://www.chinati.org/collection/donaldjudd2.php

Fig. 65. Centro Civico Rural Puerto Rico. Richard Neutra.

Fonte: Architecture of Social Concern. Richard Neutra.

Fig. 65. Centro Civico Rural Puerto Rico. Richard Neutra.

Fonte: Architecture of Social Concern. Richard Neutra.

Fig. 65. Ivan Leonidov. Clube Social de Novo Tipo 1927. Ivan Leonidov. Instituto Lenin 1928. Fonte: https://www.waseda.jp/inst/wias/assets/uploads/2017/03/RB008-079-094.pdf

Fig. 66. CEU $3^{a}$ geração. Território CEU.

Fonte: Prefeitura São Paulo

Fig. 67. CEU $3^{a}$ geração. Canteiro de obra.

Fonte: Helena Ayoub

Fig. 68. As práias de Agnés. .

Fonte: Agnés Varda, 2008.

Fig. 69. Corte esquemático. Fun Palace. Cedric Price.

Fonte: Canadian Centre Of Architecture [Arquivo Digital On Line]

Fig. 70. Croqui em folheto de difusão. Fun Palace. Cedric Price.

Fonte: Canadian Centre Of Architecture [Arquivo Digital On Line]

Fig. 71. Croqui. Fun Palace. Cedric Price.

Fonte: Canadian Centre Of Architecture [Arquivo Digital On Line]

Fig. 72. Corte Fun Palace. Cedric Price.

Fonte: Canadian Centre Of Architecture [Arquivo Digital On Line]

Fig. 73. Diagrama Inter-action Centre. Cedric Price.

Fonte: Canadian Centre Of Architecture [Arquivo Digital On Line]

Fig. 74. Foto de feria no Inter-action Centre. Cedric Price.

Fonte: Canadian Centre Of Architecture [Arquivo Digital On Line]

Fig. 75. Fotografia. Inter-action Centre. Cedric Price.

Fonte: Canadian Centre Of Architecture [Arquivo Digital On Line]

Fig. 76.Fotografia Inter-action Centre. Cedric Price.

Fonte: Canadian Centre Of Architecture [Arquivo Digital On Line]

Fig. 77. Detalhe De Montagem. Inter-Action Centre. Cedric Price. Fonte: Canadian Centre Of Architecture [Arquivo Digital On Line]

Fig. 78. Diagrama. 5 pontos Cedric Price

Fonte: Autor.

Fig. 79. Esquema programático. Fun Palace. Cedric Price.

Fonte: Canadian Centre Of Architecture [Arquivo Digital On Line] 
Fig. 80. Diagramas Magnet. Cedric Price.

Fonte: Canadian Centre Of Architecture [Arquivo Digital On Line]

Fig. 81. Diagram Simon Veil Bridge Bordeaux. OMA..

Fonte: www.oma.eu

Fig. 82. Estados de uso. Simon Veil Bridge Bordeaux. OMA..

Fonte: www.oma.eu

Fig. 83. HR Yoyogi Park. Central Park. Fotomontagem.

Fonte: Elias Martinez et al. FADU.

Fig. 84.Maquete Parque Biblioteca León de Greiff.

Fonte: www.elequipodemazznti.com

Fig. 85. Maquete Parque Biblioteca Espanha.

Fonte: www.elequipodemazznti.com

Fig. 86. Maquete Parque Biblioteca San Cristóbal.

Fonte: www.elequipodemazznti.com

Fig. 87 Field party. SANAA.

Fonte: LAYOUT= SPAZIO + FUNZIONE. FRANCESCA VARGIU

Fig. 88 Croquis Stadstheater Almere. SANAA.

Fonte: El Croquis 99.

Fig. 89 Maquete. Stadtstheater Almere. SANAA.

Fonte: El Croquis 99.

Fig. 90. Maquete. Museu do Século XXI. SANAA.

Fonte: www.blog.naver.com

Fig. 91. Diagramas. Glass Museum. Toledo. SANAA.

Fonte: https://issuu.com/briankato/docs/building_analysis

Fig. 92. The Neufert Suite. Guillermo Kuitca.

Fonte: https://mutualart.com

Fig. 93. Re-desenho de diagramas, Stadstheatre de Almere, SANAA.

Fonte: Re-desenho do autor

Fig. 94. Rolex Learning Center. SANAA.

Fonte: della CASA F \& EUGÉNE. 2010.

Fig. 95. Desenho da Marquise do Ibirapuera. 2014. GURIAN E.

Fonte: Teses USP.

Fig. 96 Montagens e disenho das "Galerias" FADU UDELAR. 2017 DiBELLO, FAZAKAS, LOMBARDI.

Fonte: Trabalho "Agenciamientos" Autoras. Trabalho de Mestrado em Projeto da FADU.

Fig. 97. Faculdade de Arquitetura UBA. Fotografia.

Fonte: Moderna Buenos Aires. https://www.modernabuenosaires.org

Fig. 98. Faculdade de Arquitetura UBA. Pavimento Terreo.

Fonte: Moderna Buenos Aires. https://www.modernabuenosaires.org

Fig. 99. Seção Mediateca de Sendai. Toyo Ito.

Fonte: https://www.digitaltoolsforarchitects.com

Fig.100. Seção SESC 24 de Maio. Paulo Mendes da Rocha e MMBB.

Fonte: www.MMBB.com.br 
Fig.101. Casa Patio. Esquemas de Casa Estandar Montevidéu.

Fonte: Livro Casa Patio. PANTALEÓN C., et al. 2002 IdD. Fadu. Udelar.

Fig.102. Casa Mora. Esquemas de Planta.

Fonte: Revista 2G\#22.

Fig.103_Cruz (preto). Kazimir Malevich, 1918.

Fonte: www.monoskop.org/

Fig.104_Make no little plans. Monadnock

Fonte: www.monadnock.nl

Fig.105_Plan Fórum Romano.

Fonte:http://www.skidmore.edu/classics/map/map16/map44.jpg

Fig.106_Planta Timgad..

Fonte:http://socks-studio.com

Fig.107_Potteries Thinkbelt. Cedric Price.

Fonte: Canadian Centre Of Architecture [ Digital On Line]

Fig.108_Potteries Thinkbelt. Cedric Price.

Fonte: Canadian Centre Of Architecture [ Digital On Line]

Fig.109_World Map. Buckminster Fuller.

Fonte: www.bibliotecapleyades.net

Fig.110_Fórum Cerrito. Batista Cardoso, Castro, Perez. World Map. DEIP 2015.

Disciplina Diploma Pós-graduação

Fig.111_TFC Martina León e Nicolás Ramos. 2018.

TFG Ateliê Scheps

Fig.112_Sesc Pompeia. Lina bo Bardi

Fuente; ARCHDAILY [website] <http://www.archdaily.com>

Fig.113_Sesc Pompeia. Lina bo Bardi

Fuente; ARCHDAILY [website] < http://www.archdaily.com>

Fig.114. Foto SESC 24 de Maio. Paulo Mendes da Rocha e MMBB.

Fonte: www.MMBB.com.br

Fig.115. Foto SESC 24 de Maio. Paulo Mendes da Rocha e MMBB.

Fonte: www.MMBB.com.br

Fig.116. Paris Saclay. Public Condenser. Studio Muoto

Fonte: www.studiomuoto.com

Fig.117. Paris Saclay. Public Condenser. Studio Muoto

Fonte: www.studiomuoto.com

Fig.118_THE WEATHER PROJECT_Tate Modern, London, 2003 Photo: Olafur Eliasson

Fonte: Tate Galery [website] <https://www.tate.org.uk/>

Fig.119_Variation of Incomplete Open Cubes. THE WEATHER PROJECT_Tate Modern, London, 2003 Photo: Olafur Eliasson

Fonte: Tate Galery [website] <https://www.tate.org.uk/>

Fig.120_Estrategias para um foro. M.Wood D. Morera. Trabalho de pesquisa na graduação Fonte: Autores.

Fig.121_ 127_Projetos realizados por alunos no FORO_MVD _ MWL.

Fonte: Autores. 
Fig.128_ Diagrmas de desespecialização espacial feito pelos autores dos projetos Fonte: Autores.

Fig.129 a 138 _ Projetos realizados por alunos no FORO_MVD.

Fonte: Autores.

Fig.139_Cedric Price

Fonte: https://architexturez.net/ 


\section{ÍNDICE de ABREVIAÇÕES REFERIDAS NA TESE}

Incluem se no índice as abreviações que aparecem na Tese e o conjunto de abreviações incluídas no referido Guia de Recursos do MIDES (ver a significação da sigla embaixo)

O Estado Uruguaio e grande por um conjunto de circunstancias que não podem ser apresentadas na Tese, mas podem se referir duas referencias de contexto:

No começo do século XX o Uruguai protagonizou um processo de modernização da mão do Presidente José Batlle y Ordoñez que separou o Estado da Igreja Católica, e começou um processo de criação de politicas publicas exemplares.

Durante boa parte do Século XX a obtenção da condição de funcionário publico foi conseguida por critérios de clientela politico partidária, e a gestão do Estado foi ficando mais pobre e burocratizada.

A multiplicação das Abreviações, até o gosto por elas, e uma particularidade cultural uruguaia.

ANEP Administración Nacional de Educación Pública

ANII Agencia Nacional de Investigación e Innovación

ANV Agencia Nacional de Vivienda

APEX Programa de Aprendizaje en la Experiencia

ASSE Administración de los Servicios de Salud del Estado

BHU Banco Hipotecario del Uruguay

BPC Base de Prestaciones y Contribuciones

BPS Banco de Previsión Social

CAIF Centros de Atención Integral a la Infancia y las Familias

CCZ Centro Comunal Zonal de IM Montevideo.

CECAP Centro de Capacitación y Producción, del MEC

CEIP Consejo de Educación Inicial y Primaria, de la ANEP

CEPEs Centros Públicos de Empleo, del MTSS

CES Consejo de Educación Secundaria, de la ANEP

CETP Consejo de Educación Técnico Profesional, de la ANEP

CFE Consejo de Formación en Educación, de la ANEP

CGN Contaduría General de la Nación 
CIU Cámara de Industria del Uruguay

CND Corporación Nacional para el Desarrollo

CNR Centro Nacional de Rehabilitación

COCAP Consejo de Capacitación Profesional

CODICEN Consejo Directivo Central, de la ANEP

DICyT Dirección de Innovación, Ciencia y Tecnología

ETAF Equipo Territorial de Atención Familiar, del Proyecto Cercanías

FADU Facultad de Arquitectura Diseño y Urbanismo.

FCPU Federación de Cooperativas de Producción del Uruguay

FOCEM Fondo Para la Convergencia Estructural del MERCOSUR

FPB Formación Profesional Básica

IAMC Institución de Asistencia Médica Colectiva

IM Intendencia de Montevideo

INACOOP Instituto Nacional del Cooperativismo

INAU Instituto del Niño y Adolescente del Uruguay

INC Instituto Nacional de Colonización

INDA Instituto Nacional de Alimentación

INIA Instituto Nacional de Investigaciones Agropecuarias

INEFOP Instituto Nacional de Empleo y Formación Profesional

INJU Instituto Nacional de la Juventud

INR Instituto Nacional de Rehabilitación

JND Junta Nacional de Drogas

LATU Laboratorio Tecnológico del Uruguay

MDN Ministerio de Defensa Nacional

MEC Ministerio de Educación y Cultura

MEVIR Movimiento por la Erradicación de la Vivienda Insalubre Rural

MGAP Ministerio de Ganadería Agricultura y Pesca

MI Ministerio del Interior

MIDES Ministerio de Desarrollo Social

MIEM Ministerio de Industria Energía y Minería

MSP Ministerio de Salud Pública 
MTD Ministerio de Turismo y Deporte

MTOP Ministerio de Transporte y Obras Públicas

MTSS Ministerio de Trabajo y Seguridad Social

MVOTMA Ministerio de Vivienda Ordenamiento Territorial y Medio Ambiente

OPP Oficina de Planeamiento y Presupuesto

OSC Organizaciones de la Sociedad Civil

PAC Programa Aulas Comunitarias

PMB Programa de Mejoramiento de Barrios

PMC Programa Maestros Comunitarios

PNEL Patronato Nacional de Encarcelados y Liberados

PNUD Programa de las Naciones Unidas Para el Desarrollo SIRPA Sistema de Responsabilidad Penal Adolescente

SNIS Sistema Nacional Integrado de Salud

UCC Uruguay Crece Contigo

UDELAR Universidad de la República

UEC Unidad de Estudios Cooperativos, de la UdelaR

UTU Universidad del Trabajo del Uruguay

ECM Equipamentos Coletivos de Montevideo (Capítulo um da Tesis)

DPL Desespecialización Programática (Capítulo dois da Tesis)

FRM Fórum Montevidéu (Capítulo três da Tesis)

IIT Illinois Institute of Technology (US)

FADU UBA (Facultad de Arquitectura, Diseño y Urbanismo, Universidad de Buenos Aires (AR)

FADU Facultad de Arquitectura, Diseño y Urbanismo (Udelar -UY)

CURE Centro Universitario Regional Este (Udelar- UY)

Udelar Universidad de la República (UY)

IM Intendencia de Montevideo (UY)

IMMa Intendencia de Maldonado (UY)

SMDU Secretaría Municipal de Desenvolvimento Urbano (São Paulo- BR)

SESC Serviço Social do Comércio (BR)

CEU Centro Educativo Unificado (BR)

OMA Office for Metropolitan Architecture (NL)

SANAA Sejima and Nishizawa and Associates (JP) 
MMBB Mello Moreira Braga Bucci (BR)

IMP Intendencia Municipal de Paysandú (UY)

MVOTMA Ministerio de Vivienda Ordenamiento Territorial y Medio Ambiente (UY)

UVA Unidades de Vida Articuladas (CO)

FAU Facultade de Arquitetetura e Urbanismo (BR)

USP Universidad de Sao Paulo (BR)

CEDEL Centro de Desarrollo Económico (UY) 
São Paulo

2018 


\section{LUIS ENRIQUE OREGGIONI}

\section{MORE WITH LESS}

Ideias para uma nova geração de Equipamentos Coletivos na Periferia da Grande Montevidéu geradores de urbanidade, e baseados na desespecialização programática como ferramenta de projeto.

VOLUME 02

São Paulo

2018 


\section{LUIS ENRIQUE OREGGIONI}

\section{MORE WITH LESS}

VOLUME 02

Ideias para uma nova geração de equipamentos coletivos na periferia da grande Montevidéu geradores de urbanidade, e baseados na desespecialização programática como ferramenta de projeto.

Tese apresentada à Faculdade de Arquitetura e Urbanismo da Universidade de São Paulo para obtenção do título de Doutor em Ciências. Programa de Arquitetura e Urbanismo, Área de Concentração: Projeto de Arquitetura.

EXEMPLAR REVISADO E ALTERADO EM RELAÇÃO À VERSÃO ORIGINAL, SOB RESPONSABILIDADE DO AUTOR E ANUÊNCIA D̉O ORIENTADOR.

A versão original de data 16 de julho de 2018 em formato digital, ficará arquivada na Biblioteca da Faculdade.

São Paulo, 1 de fevereiro de 2019.

Orientador: Prof. Dr. Francisco Spadoni 
Autorizo a reprodução e divulgação total ou parcial deste trabalho, por qualquer meio convencional ou eletrônico, para fins de estudo e pesquisa, desde que citada a fonte.

E-MAIL DO AUTOR: lucho.oreggioni@gmail.com

Catalogação na Publicação

Serviço Técnico de Biblioteca

Faculdade de Arquitetura e Urbanismo da Universidade de São Paulo

Oreggioni, Luis Enrique

More with less: Ideias para uma nova geração de

equipamentos coletivos na periferia da grande Montevidéu

geradores de urbanidade, e baseados na desespecialização

programática como ferramenta de projeto. / Luis Enrique

Oreggioni; orientador Francisco Spadoni. - São Paulo, 2018.

727 p. 2 volumes.

Tese (Doutorado) - Faculdade de Arquitetura e Urbanismo da Universidade de São Paulo. Área de concentração: Projeto da Arquitetura.

1. Desespecializaçào Programática. 2. Fórum. 3.

Equipamentos. 4. Periferia. I. Spadoni, Francisco, orient.

II. Título.

Elaborada eletronicamente através do formulário disponível em: <http://www.fau.usp.br/fichacatalografica/> 



\section{VOLUME 1}

p.013_INTRODUÇÃO

RESUMO / ABSTRACT

SUMARIO

p.019_1.ECM EQUIPAMENTOS MONTEVIDEANOS

p.019_1.ECM.1 INTRODUÇÃO

p.021_1.ECM.2 EQUIPAMENTOS MODERNOS

p.024_1.ECM.3 EQUIPAMENTOS COLETIVOS MONTEVIDÉU

EDUCACIONAL

p.037_1.ECM 4. PERIFERIAS

O SISTEMA DOS EQUIPAMENTOS

TERRITORIALIZAÇ̃̃O EXTREMA DA DESIGUALDADE

MUNDO PERIFERIA

p.044_1.ECM.5 EQUIPAMENTOS DE PERIFERIA

p.049_1.ECM.6 EQUIPAMENTOS CASAVALLE

CONSELHO CASAVALLE

PLANO CASAVALLE

DE MUITOS LUGARES É POSSÍVEL VER O CASAVALLE

EQUIPAMENTOS CASAVALLE

SACUDE

CENTRO CÍVICO LUISA CUESTA

CEDEL

ABRANGÊNCIA TERRITORIAL

OUTROS EDIFÍCIOS

p.065_1.ECM.7 DESTACAMENTOS

p.069_2.DPL DESESPECIALIZAÇÃO PROGRAMÁTICA

p. 069_2.DPL.1 ESPECIALIZACAO DESESPECIALIZACAO

p.077_2.DPL.2 PROGRAMA FUNÇÃO ESPÁCIO

PARA O PROGRAMA: BASÍLICAS

PARA O PROGRAMA: MOTIVO

NAVES E MALHAS

PROGRAMA DE MODERNIDADE

PROGRAMA CONTEMPORÂNEO

PROGRAMA DESESPECIALIZADO

PROJETO DESESPECIALIZADO

ABSTRAÇÃO

UM FAROL DESESPECIALIZADO

p.121_2.DPL.3 ARQUITETURAS DA DESESPECIALIZAÇÃO

BRANCO NOLLI

METAFORA DESLOCAMENTO INTELETUAL

DESLOCACÕES EM BRANCO

p.131_2.DPL.4 DESLOCAÇÃO 1: RUINAS

O CAPITAL

ELEMENTAR

FASCINAÇÃO ROMANTICA

OBRA

PROGRAMA?

PÓS-INDUSTRIAL

30 VARIACÕES PÓS-INDUSTRIAIS

PÓS-PRODUÇÃO

RUIINA MONO-FUNCIONAL

AL HUESO: DEPOIS DO PROGRAMA

TEMPO

p.171_2.DPL.5 DESLOCAÇÃO 2: PRAIAS

PRAIA PAULISTA

EQUIPAMENTO PRAIA

EQUIPAMENTO DESESPECIALIZADO DA CIDADE

PRIMEIRA: PADRÃO E IMPLANTAÇÃO

TERCEIRA: TERRITÓRIO CEU

TERRITÓRIO DO TERRITÓRIO

BRANCO CEU

AS IDEIAS E AS COISAS

PRAIAS DE TODOS, PRAIAS DE CADA UM

p.197_2.DPL.6 DESLOCAÇÃO 3: RUAS

UNIVERSIDADE DE RUA EM LONDRES

ARTEFACTO FUN PALACE

DISCIPLINAS 


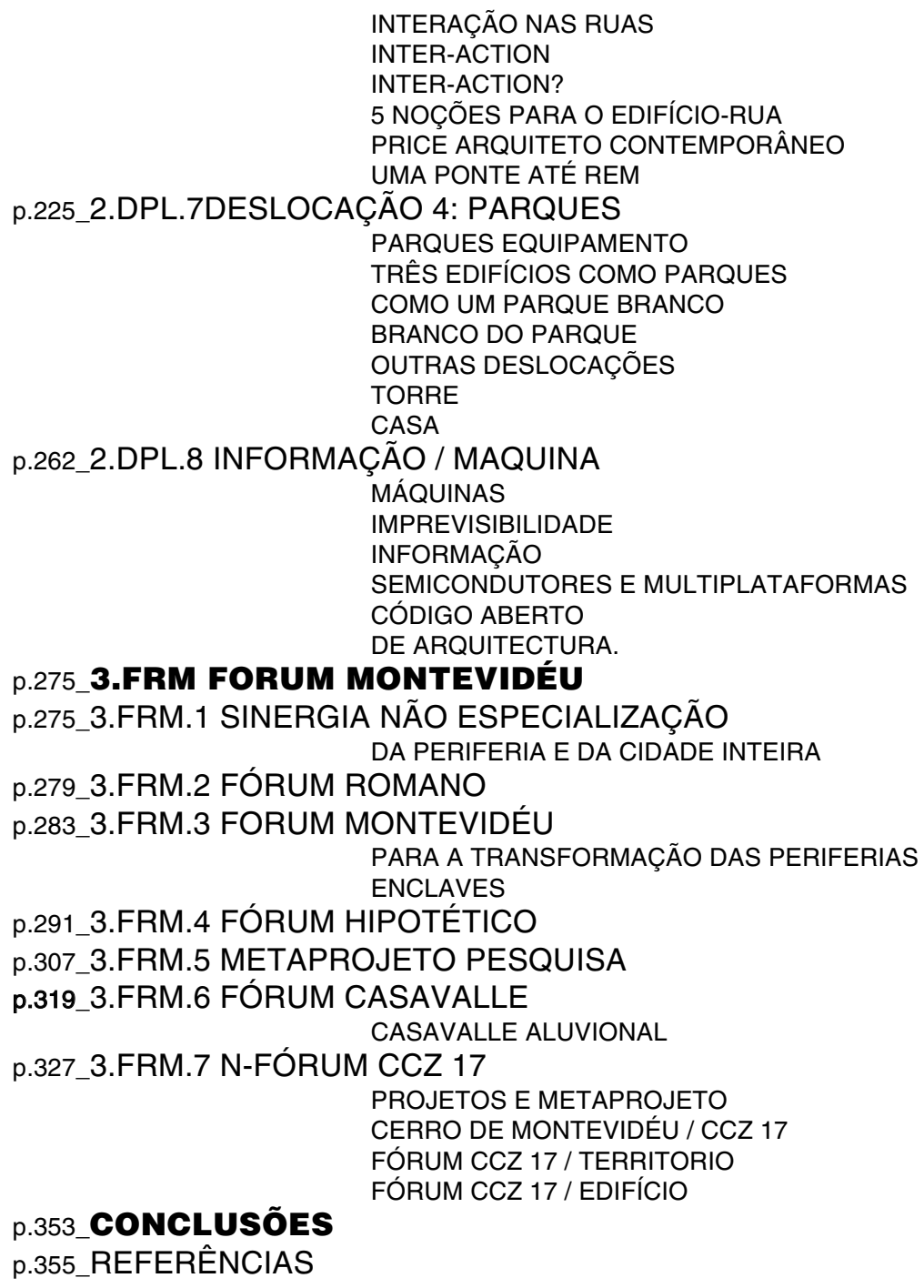

p.355_REFERÊNCIAS

\section{VOLUME 2}

p.131_DISSOLUÇÃO PROGRAMÁTICA E ESPACIAL

\section{p.391_CATÁLOGO}

p.392_CATÁLOGO EQUIPAMENTOS UY

p.501_CATÁLOGO EQUIPAMENTOS CASAVALLE

p.551_CATÁLOGO EQUIPAMENTOS MUNDO

p.598_CATÁLOGO CASAVALLE FÓRUM

p.610_FÓRUM CCZ17

p.617_APÊNDICES

p.618_MUNICIPIOS AREA METROPOLITANA DESIGUALDADES

p.646_LEVANTAMENTO SOBRE AS POLÍTICAS PÚBLICAS E OS EQUIPAMENTOS COLETIVOS

p.677_ANEXOS

p.679_FÓRUM CCZ 17 PROJETOS CURSO PÓS-GRADUAÇÃO FADU

AQUA

CONNECT

DISPERSE

PIER 


\section{P01}

\section{CAIF}

Autor: Arquitectura INAU

Ano: 2018 e anteriores.

Localização: Casavalle, UY.

V02 Pg 393, 502

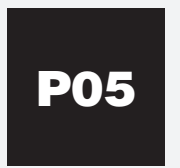

\section{CEA}

Autor: PAEMFE Arq. Andrea Gnesetti Ano: 2017

Localização: Casavalle, Montevideo. UY.

V02 Pg 409, 510

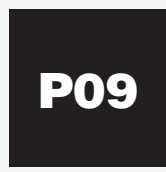

\section{ESCOLA 178}

\section{Autor:}

Ano: 1956

Localização: Casavalle, UY

V02 Pg 427, 519

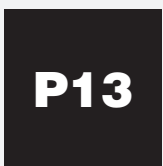

POLICINICA 2/3 consult Autor: ASSE Div. Arquitetura

Ano: 2015

Localização: Varias, UY.

V02 Pg 451

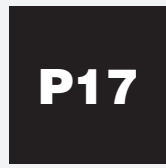

\section{PLAZA N¹1}

Autor: Arq. L. Cracco / Secr. Esporte

Ano: 2010

Localização: Cerro, UY.

V02 Pg 469

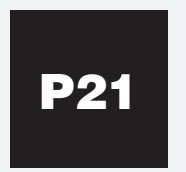

CEDEL

Autor: IMM. Arqs. Morán e Sandoval.

Ano: 2004

Localização: Casavalle, UY.

V02 Pg 54

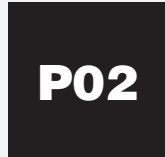

\section{CEC}

Ano: 2010 e depois

Localização: Casavalle, UY.

V02 Pg 397

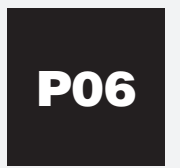

\section{ETC 91A Modular}

Autor: PAEPU. Arq. Pedro Barrán

Ano:2017. Projeto

Localização: Projeto Tipo

V02 Pg 413

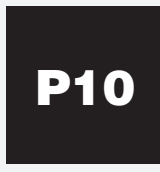

LICEO Ciudad del Plata Autor:PAEMFE - Arq Bernardo Martin Autor:PAEMr Localização: Ciudad del Plata, UY.

V02 Pg 431

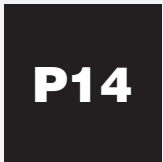

POLICLINICA Casavalle Autor: IM DIv. Saude. Arq. M. Gregorio Ano: 2012

Localização: Casavalle, UY.

V02 Pg 455, 523

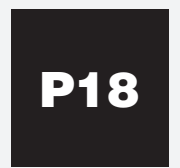

\section{COMISARIA}

Autor: Ministerio Interior. Sd.

Ano: 2013

Localização: Casavalle, UY.

V02 Pg 527

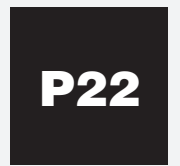

PAC

Autor: AGESIC

Ano: 2007/ 2013-hoje.

Localização: Varias

V02 Pg 474

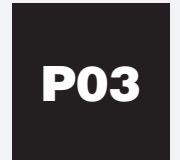

V02

JARDÍM DE INFÂNCIA

Autor: PAEPU - Arq. Carlos Sitya

Ano: 2018

Localização: Neptunia, UY. Localização: Casavalle, UY

V02 Pg 401

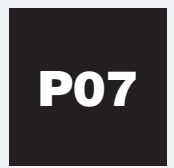

\section{ESCOLA CHINA}

Autor: PAEPU Arq. Lucía Lombardi

Ano: Projeto

Localização: Casavalle, UY.

V02 Pg 514

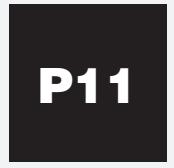

\section{POLO TECNOLOGICO}

Autor: PAEMFE. Projeto Tipo.

Ano: Projeto 2017

Localização: Varias, UY.

V02 Pg 437

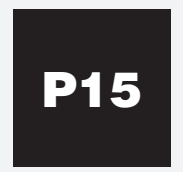

POLIClínica C. PLATA Autor: PRIS / ASSE Div. Arquitetura Ano: 1999/2016

Localização: Ciudad del Plata, UY.

V02 Pg 459

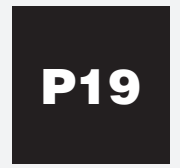

\section{BOMBEROS}

Autor: Dir. Bombeiros. Luis E. Salesi Ano: 1988

Localização: Casavalle, UY.

V02 Pg 531

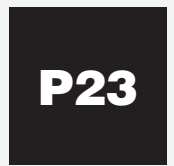

\section{CB PEÑAROL}

Autor: Políticas Territoriais OPP

Ano: 2014

Localização: Peñarol, UY.

V02 Pg 478

\section{ESCOLA 320}

Autor: sd

V02 Pg 405, 506

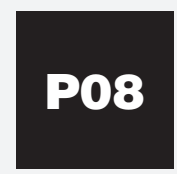

ETC 384

Autor: PAEPU Pedro Barran

Ano: 2016

Localização: Montevideo, UY.

V02 Pg 422

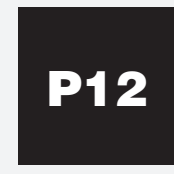

PROTOTIPO EDUCAC.

Autor: PRIS Arq. Antonio Gervaz

Ano: 1994

Localização: Várias. Melo, UY.

V02 Pg 446

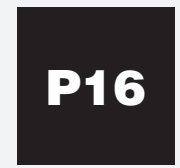

\section{POLIDEPORTIVO}

Autor: CND. Arquitetura

Ano: 2017

Localização: Varias, UY.

V02 Pg 464

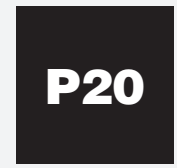

\section{SACUDE}

Autor: Int. Montevideo. PIA

Ano: 2013

Localização: Casavalle, UY.

V02 Pg 535

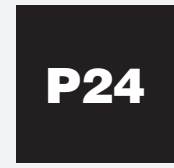

\section{CENTRO CÍvICO}

casavalle

Autor: Int. Montevideo. Arq. Juan Díaz

Ano: 2014

Localização: Casavalle

V02 Pg 546 

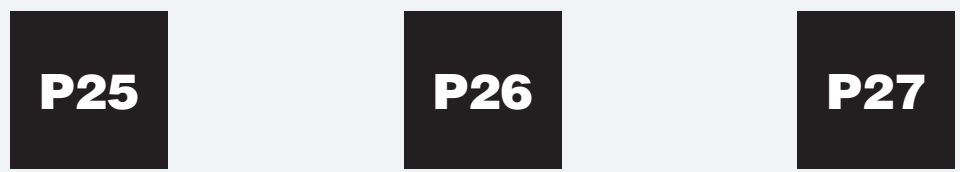

P28

CEU

Autor: Equipo CEU SMDU

Ano: 2013-2016 (não concluido)

Localização: San Pablo, BR.

V02 Pg 552

FUN PALACE

Autor: Cedric Price

Ano: 1960-1966

Localização: Londres, UK

V02 Pg 570

INTERACTION

Autor: Cedric Price

Ano: 1970-1981 2003

Localização: Camden Town, Londres,

UK

V02 Pg 574
STADSTHEATER

Autor: SANAA

Localização: Almere, NL

V02 Pg 580

\section{P29}

MUSEO SIGLO XX

Autor: SANAA

Ano: 1999-2004

Localização: Kanasawa, JP

V02 Pg 586

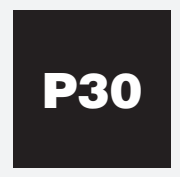

MUSEO DE TOLEDO

Autor: SANAA

Ano: 2001-2006

Localização: Toledo, USA

V02 Pg 592 
DISSOLUÇÃO PROGRAMATICA E ESPACIAL

PROGRAMAS

MARGENS DE ÁREAS PARA DISSOLUÇÃO
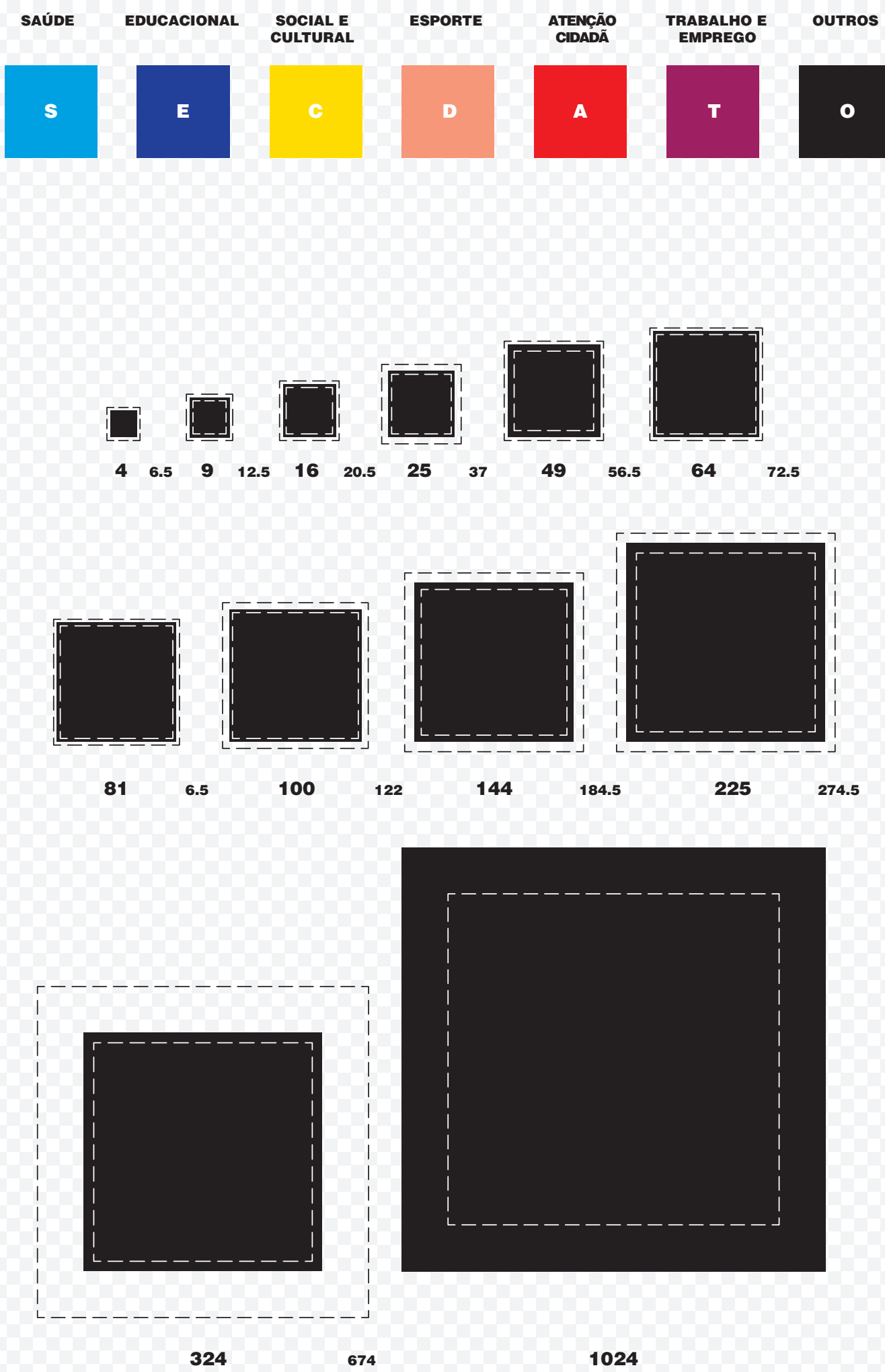

MORE WITH LESS

ESTRUTURA DA TESE 


\section{CATALOGO EQUIPAMENTOS UY}
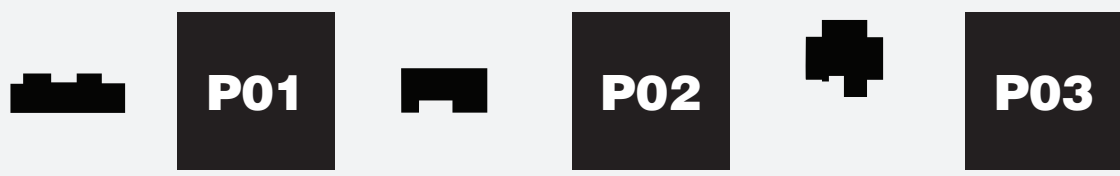

\section{JARDÍM DE INFÂNCIA} Autor: PAEPU - Arq. Carlos Sitya Ano: 2018

Localização: Neptunia, UY.

V02 $\mathrm{Pg}_{401}$

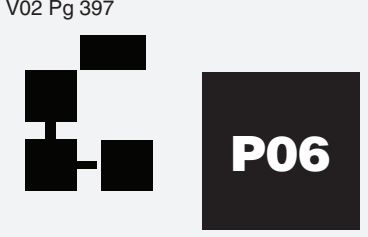

ETC 91A Modular

Autor: PAEPU. Arq. Pedro Barrán

Ano:2017. Projeto

Localização: Projeto Tipo
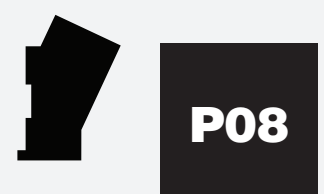

ETC 384

Autor: Pedro Barran

Ano: 2016

Localização: Montevideo, UY.

Localização: Casavalle, Montevideo. UY

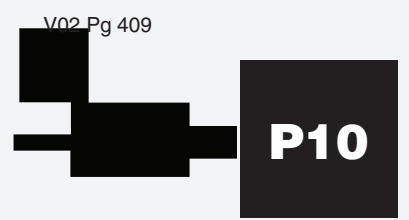

LICEO Ciudad del Plata Autor:PAEMFE - Arq. Bernardo Martin Ano: 2013

Localização: Ciudad del Plata, UY.

V02 Pg 431

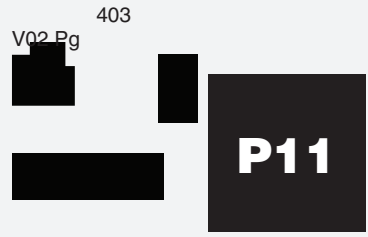

POLO TECNOLOGICO Autor: PAEMFE. Projeto Tipo.

Ano: Projeto 2017

Localização: Varias, UY.

V02 Pg 437
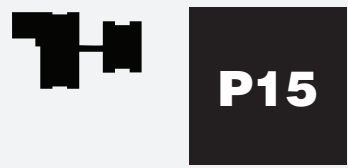

POLICLINICA Casavalle Autor: IM Dlv. Saude. Arq. M. Gregorio Ano: 2012

Ano: 2012 Localização: Casavalle, UY.

V02 Pg 455

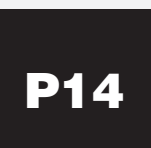

POLICLÍNICA C. PLATA

Autor: PRIS / ASSE Div. Arquitetura

Ano: 1999/2016

Localização: Ciudad del Plata, UY.

V02 Pg 459

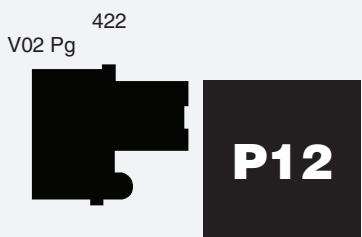

PROTOTIPO EDUCAC.

Autor: PRIS Arq. Antonio Gervaz

Ano: 1994

Localização: Várias. Melo, UY.

V02 Pg 446
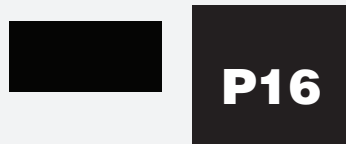

POLIDEPORTIVO

Autor: CND. Arquitetura

Ano: 2017

Localização: Varias, UY

V02 Pg 464

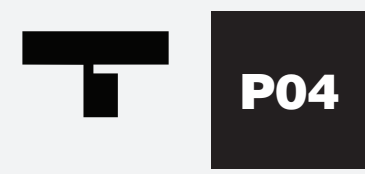

ESCOLA 320

Autor: sd

Ano: sd

Localização: Casavalle, UY.

V02 Pg 465

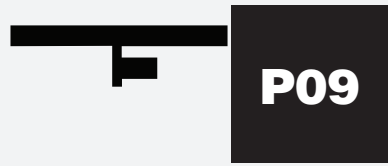

\section{ESCOLA 178}

Autor: sd

Localização: Casavalle, UY.

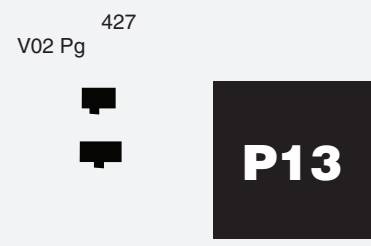

POLICINICA 2/3 consult Autor: ASSE Div. Arquitetura

Ano: 2015

Localização: Varias, UY.

V02 Pg 451

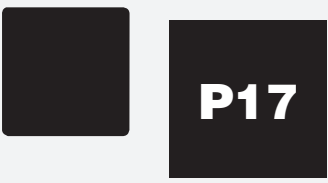

\section{PLAZA N¹1}

Autor: Arq. L. Cracco / Secr. Esporte Ano: 2010

Localização: Cerro, UY.

V02 Pg 469

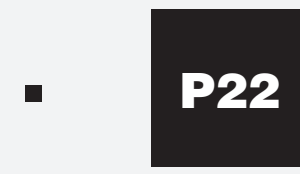

PAC

Autor: AGESIC

Ano: 2007/ 2013-hoje

Localização: Varias

V02 Pg 474

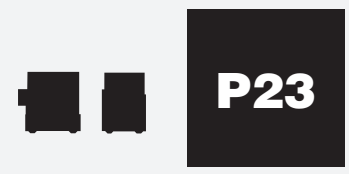

\section{CB PEÑAROL}

Autor: Políticas Territoriais OPP

Ano: 2014

Localização: Peñarol, UY.

V02 Pg 478 


\section{CATÁLOGO EQUIPAMENTOS DSL}

CAIF CENTROS DE ATENÇÃO À INFÂNCIA E A FAMÍLIA

Ano 2018 e anteriores

Área total $495 \mathrm{~m}^{2}$

Autor Arquitectura INAU

Localização PROYECTO TIPO - Barrio Casavalle, Montevideo. UY.

Organização gestora CND

Organização responsável INAU

Fonte CND

https://www.cnd.org.uy/index.php/sala-de-prensa/1672-infraestructura-educativa
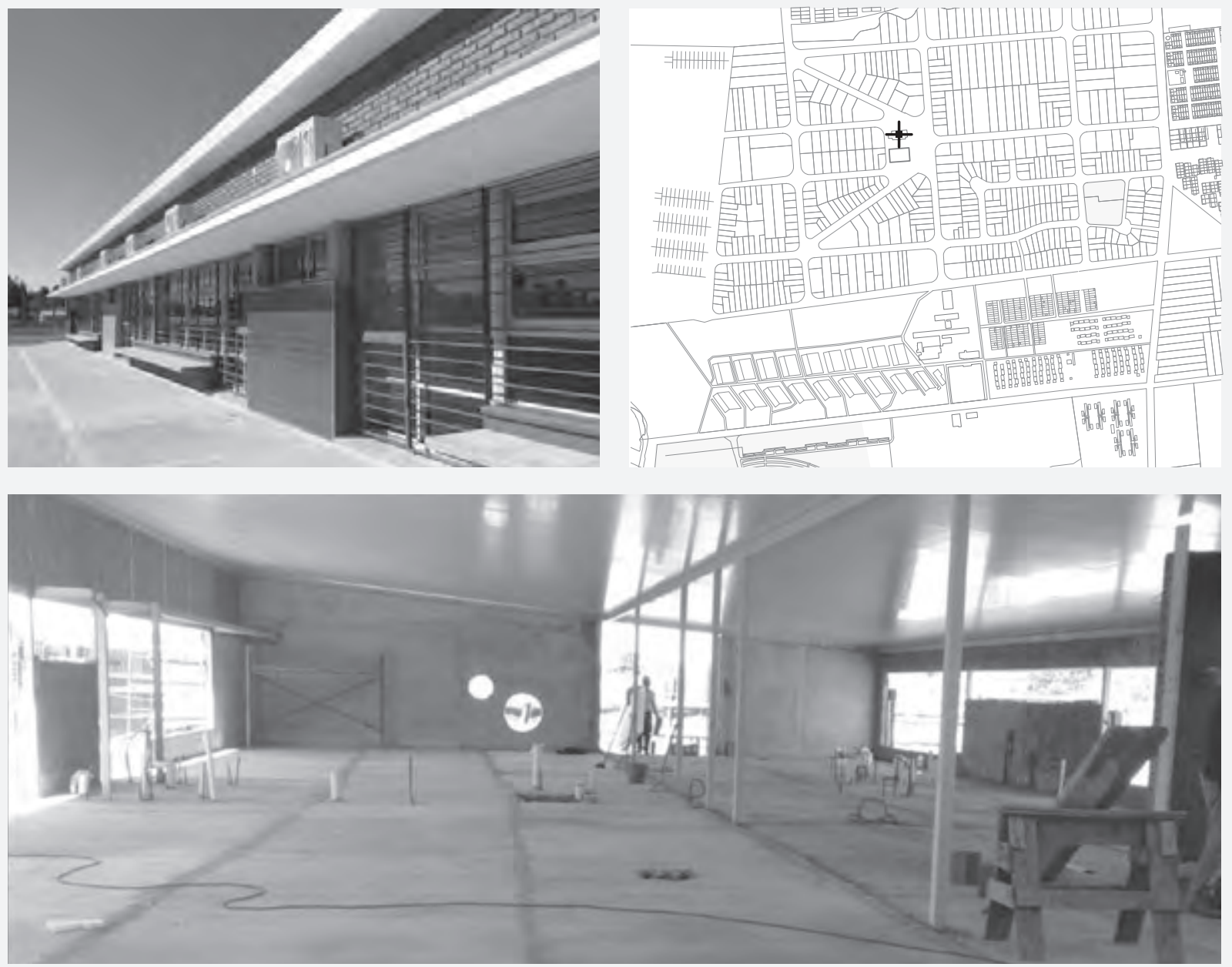
CATÁLOGO EQUIPAMENTOS DSL

CAIF CENTROS DE ATENÇÃO À INFÂNCIA E A FAMÍLIA

Pav. Térreo

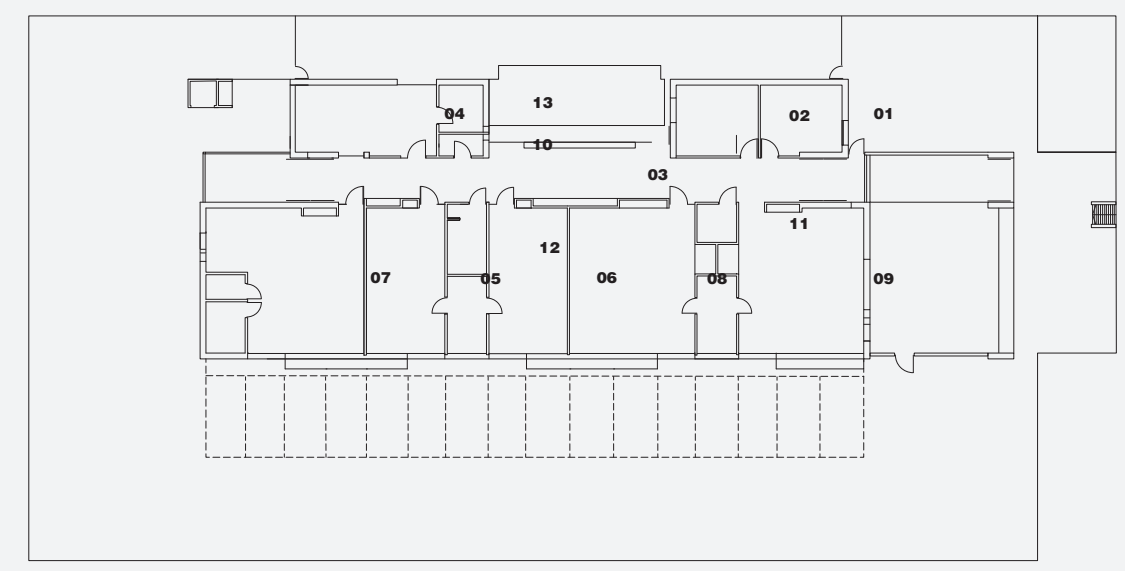

Área Construída $495 \mathrm{~m}^{2}$

Área Exterior Coberta $161 \mathrm{~m}^{2}$

Pátios ---m²

Ocupação de Solo $\mathbf{8 3 1} \mathbf{m}^{\mathbf{2}}$

Taxa Ocupação de Solo $\mathbf{3 7 \%}$

Terreno $1350 \mathbf{m}^{2}$

Educação $\mathbf{2 5 3} \mathbf{m}^{\mathbf{2}}$

Esc. 1.500

EDUCACIONAL

\begin{tabular}{|c|c|c|c|c|c|c|}
\hline & & $\mathrm{L}$ & I & Alt. & Sup. & DSL \\
\hline & Administração & $4,16 \mathrm{~m}$ & $3,5 \mathrm{~m}$ & var. $3,45 / 2,80 \mathrm{~m}$ & $14,56 \mathrm{~m}^{2}$ & E25* \\
\hline 02 & Atendimento & $4,16 \mathrm{~m}$ & $3,6 \mathrm{~m}$ & var. $3,45 / 2,80 \mathrm{~m}$ & $14,9 \mathrm{~m}^{2}$ & E25* \\
\hline 03 & Hall & $23,7 \mathrm{~m}$ & $2,25 \mathrm{~m}$ & var. $3,45 / 2,80 \mathrm{~m}$ & $53,3 \mathrm{~m}^{2}$ & E49 \\
\hline 04 & Cozinha & $7,16 \mathrm{~m}$ & $3,6 \mathrm{~m}$ & var. $3,45 / 2,80 \mathrm{~m}$ & $25,7 \mathrm{~m}^{2}$ & E25 \\
\hline & Sala 1 com Banh. & $7,35 \mathrm{~m}$ & $4 \mathrm{~m}$ & var. $3,45 / 2,80 \mathrm{~m}$ & $33,9 \mathrm{~m}^{2}$ & E25 \\
\hline 06 & Sala 2 com Banh. & $7,35 \mathrm{~m}$ & & var. $3,45 / 2,80 \mathrm{~m}$ & $33,9 \mathrm{~m}^{2}$ & E25 \\
\hline & Sala Psicomotricidade com Banh. & $8 \mathrm{~m}$ & $7,35 \mathrm{~m}$ & $\begin{array}{l}\text { var. } 3,45 / 2,80 \mathrm{~m} \\
\text { val }\end{array}$ & $58,8 \mathrm{~m}^{2}$ & E64 \\
\hline & Berçário com Banh. & $7,35 \mathrm{~m}$ & $\begin{array}{l}6,35 \mathrm{~m} \\
6,100\end{array}$ & $\begin{array}{l}\text { var. } 3,45 / 2,80 \mathrm{~m} \\
\text { val }\end{array}$ & $53 \mathrm{~m}^{2}$ & E49 \\
\hline & Berçário com Banh. & $7,35 \mathrm{~m}$ & $6,35 \mathrm{~m}$ & var. $3,45 / 2,80 \mathrm{~m}$ & $53 \mathrm{~m}^{2}$ & E49 \\
\hline & Banh. Adulto & $2,25 \mathrm{~m}$ & $1,1 \mathrm{~m}$ & var. $3,45 / 2,80 \mathrm{~m}$ & $2,4 n$ & \\
\hline & Banh. Discap & & $1,95 \mathrm{~m}$ & var. $3,45 / 2,80 \mathrm{~m}$ & $3,9 n$ & $16 *$ \\
\hline & Depósit & $3,55 \mathrm{~m}$ & & var. $3,45 / 2,80 \mathrm{~m}$ & 7,11 & E16 \\
\hline & Despensa & $2,4 \mathrm{~m}$ & $2,25 \mathrm{~m}$ & var. $3,45 / 2,80 \mathrm{~m}$ & $5,4 \mathrm{~m}^{2}$ & * \\
\hline
\end{tabular}


CATÁLOGO EQUIPAMENTOS DSL

CAIF DSL DISSOLUÇÃO PROGRAMÁTICA

Educacional $253 \mathbf{m}^{2}$ 口 


\section{CATÁLOGO EQUIPAMENTOS DSL}

CAIF DSL DISSOLUÇÃO ESPACIÅL

Área Construída $495 \mathrm{~m}^{2}$

Área Exterior Cobierta $161 \mathrm{~m}^{2}$

Pátios ---m²

Terreno $1350 \mathrm{~m}^{2}$
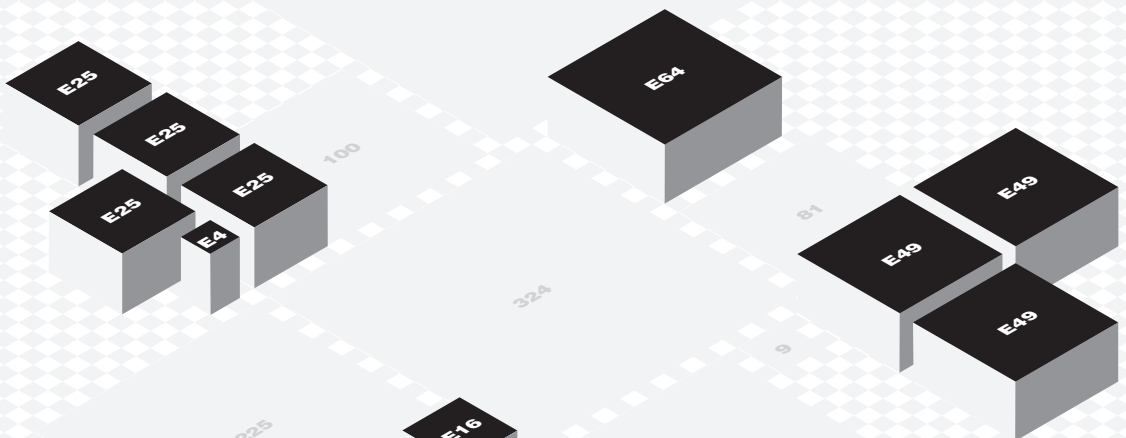


\section{CATÁLOGO DE EQUIPAMENTOS DSL}

CEC CENTRO EDUCACIONAL COMUMITARIO

Anos 2010 e depois.

Área total $510 \mathrm{~m}^{2}$

Autor PAEMFE sd

Localização Montevideo: Bella Italia, Casabó, Casavalle, La Teja.

Maldonado: Maldonado Nuevo, Lomas de San Martín.

Organização gestora CND

Organização responsável ANEP - CETP

Fonte Licitações públicas CND FIDEICOMISO INAU

https://www.cnd.org.uy/index.php/fideicomiso-anep
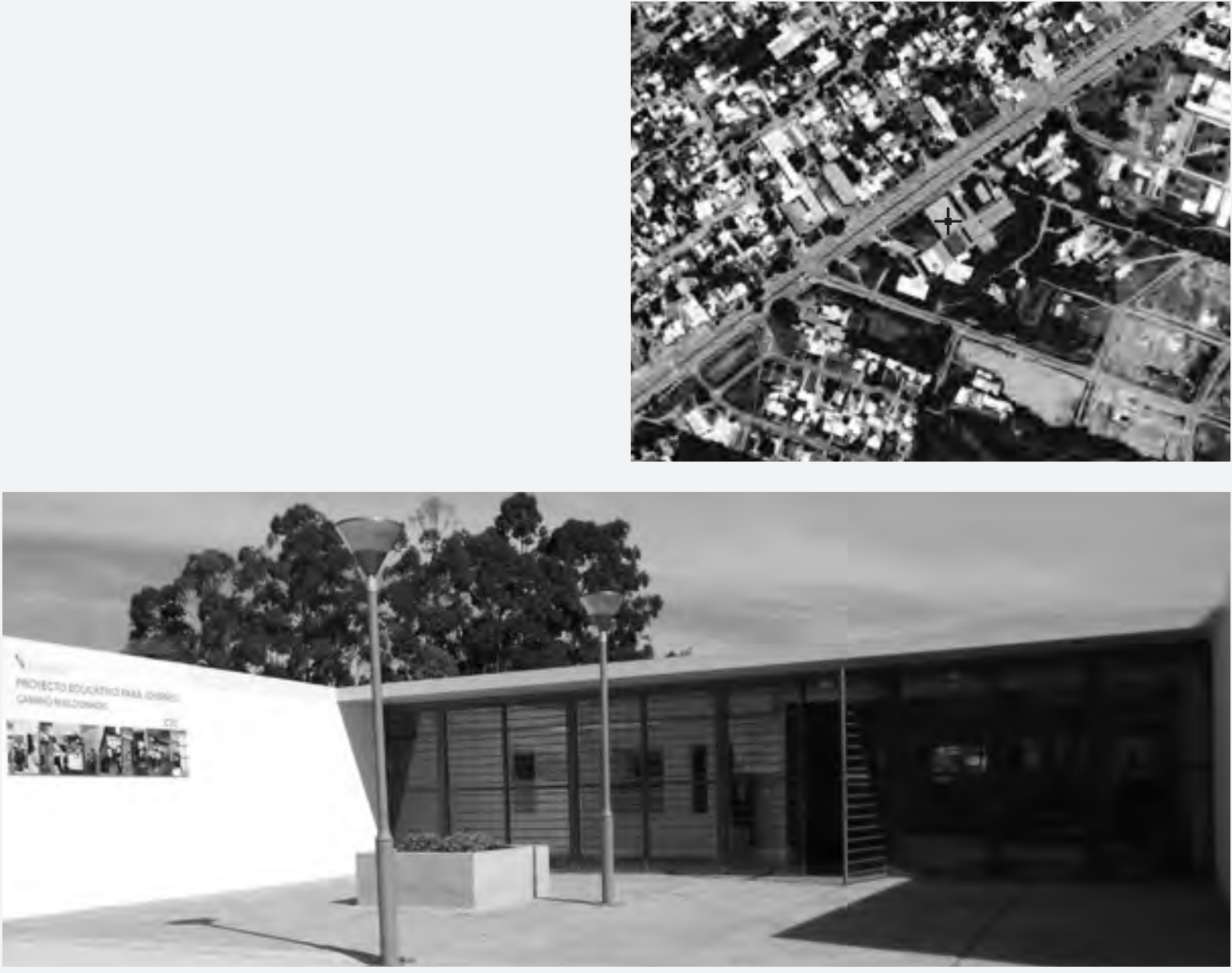
CATÁLOGO DE EQUIPAMENTOS DSL

CEC CENTRO EDUCACIONAL COMUMITARIO

Pav. Térreo

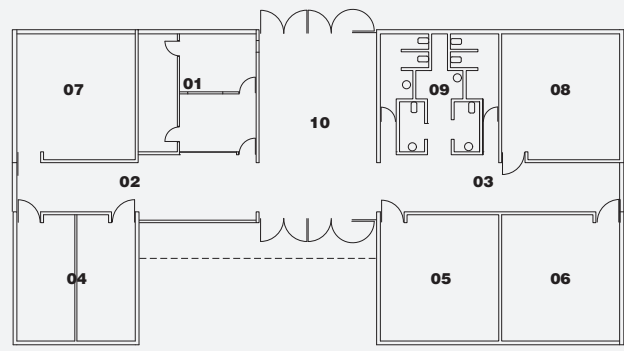

Área Construída $510 \mathbf{m}^{2}$

Área Exterior Coberta ---m $\mathbf{m}^{2}$

Pátios 195 $\mathrm{m}^{2}$

Ocupação de Solo $\mathbf{7 1 0 \mathbf { m } ^ { 2 }}$

Taxa Ocupação de Solo 41\%

Terreno 1240m²

Educação $\mathbf{3 7 5} \mathbf{m}^{\mathbf{2}}$

Esc. 1.500

EDUCACIONAL

Administração

Circulação I

Circulação II

Sala de Aula I

Sala de Aula II

Sala de Aula III

Laboratório I

Laboratório I

Laboratorio

Hall

* Local, soma de vários locais

** Local fora de margen. Majoração de superfície para DSL.

$\begin{array}{lllll}\text { L } & \text { I } & \text { Altt. } & \text { Sup. } & \text { DSL } \\ 6 m & 6 m & \text { var. } 3,00 / 2,80 m & 36 m^{2} & \text { E25 } \\ 12,35 m & 2,9 m & \text { var. } 3,20 / 3,00 m & 35,8 m^{2} & \text { E64* }^{*} \\ 12,3 m & 2,5 m & \text { var. } 3,20 / 3,00 m & 30,75 m^{2} & \text { E64* }^{*} \\ 6 m & 6 m & \text { var. } 3,20 / 2,80 m & 36 m^{2} & \text { E49** }^{*} \\ 6 m & 6 m & \text { var. } 3,20 / 2,80 m & 36 m^{2} & \text { E49** } \\ 6 m & 6 m & \text { var. } 3,20 / 2,80 m & 36 m^{2} & \text { E49** } \\ 6 m & 6 m & \text { var. } 3,00 / 2,80 m & 36 m^{2} & \text { E49** } \\ 6 m & 6 m & \text { var. } 3,00 / 2,80 m & 36 m^{2} & \text { E49** } \\ 6 m & 6 m & \text { var. } 3,00 / 2,80 m & 36 m^{2} & \text { E49** } \\ 9,45 m & 5,95 m & \text { var. } 3,00 / 2,80 m & 56,3 m^{2} & \text { E49 }\end{array}$

DSL

25

64*

49**

E49**

$49 * *$

49**

E49 
CATÁLOGO DE EQUIPAMENTOS DSL

CEC DSL DISSOLUÇÃO PROGRAMÁTICA 


\section{CATALOGO DE EQUIPAMIENTOS}

CEC DSL DISSOLUÇÃO ESPACIAL

Área Construída $510 \mathbf{m}^{2}$

Área Exterior Coberta ---m²

Pátios $195 \mathrm{~m}^{2}$

Terreno $1240 \mathbf{m}^{2}$
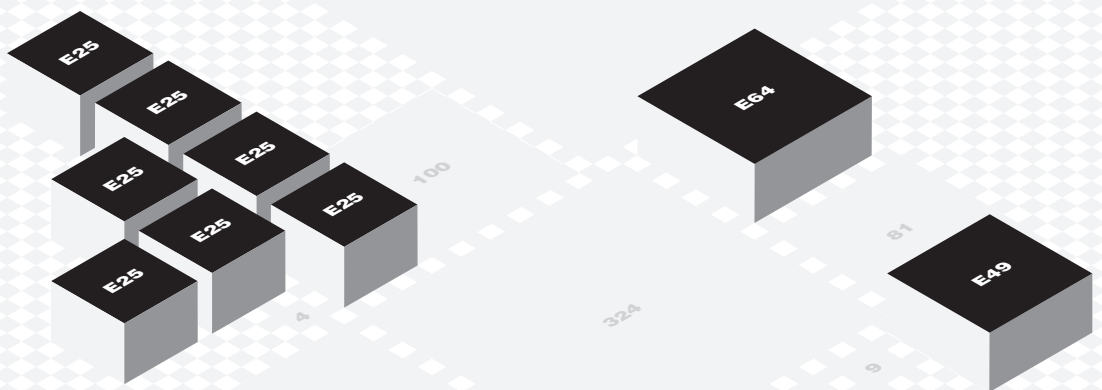
CATÁLOGO EQUIPAMENTOS DSL

JARDÍM DE INFÂNCIA

\section{Ano 2018}

Área total $\mathbf{5 7 3 \mathbf { m } ^ { 2 }}$

Autor PAEPU - Arq. Carlos Sitya , Arq. M Ponce de León

Localização Jardím 305 Neptunia / Projeto Tipo

Organização gestora CND

Organização responsável ANEP CEIP

Fontes PAEPU / CND

https://www.cnd.org.uy/index.php/sala-de-prensa/1672-infraestructura-educativa
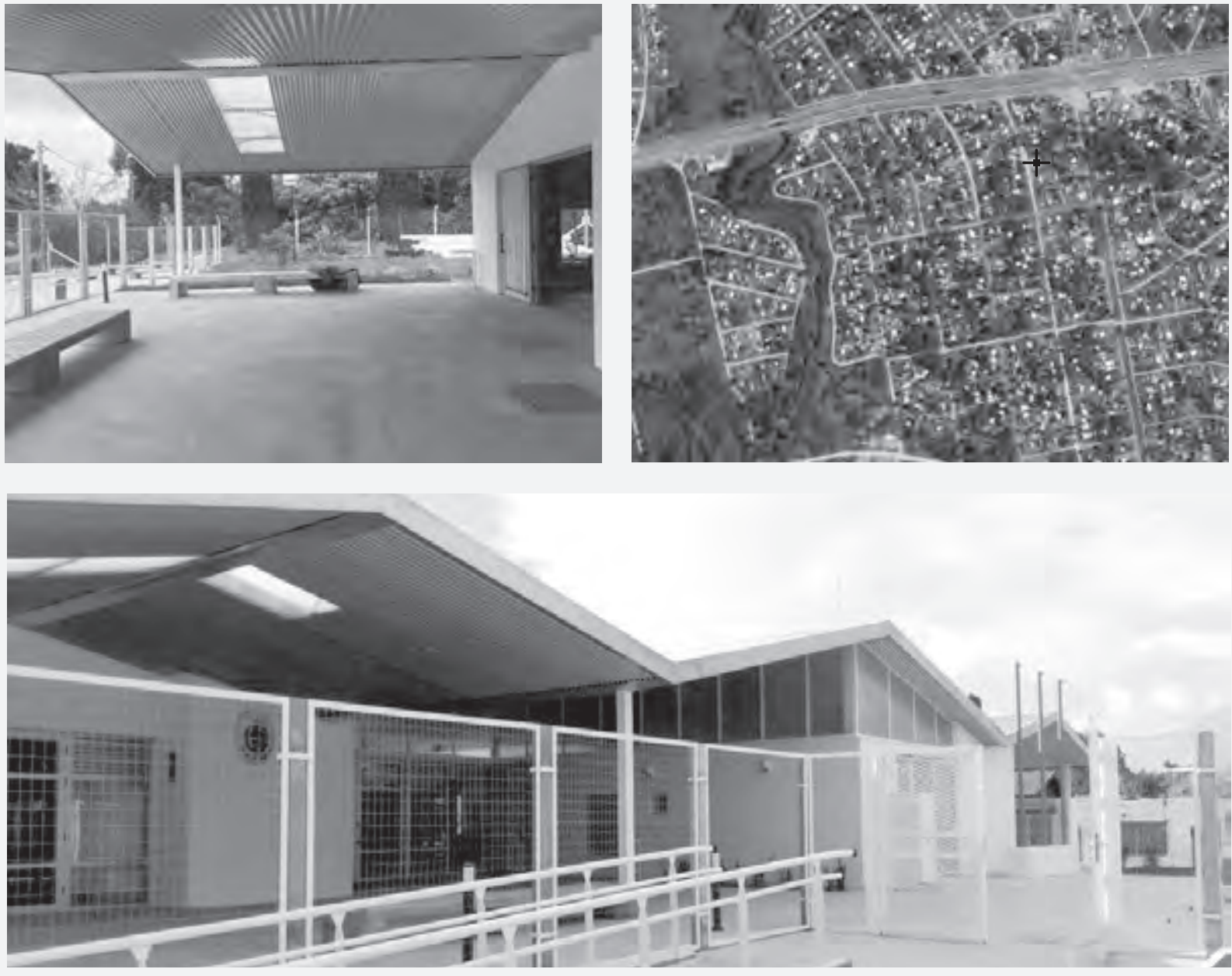
CATÁLOGO EQUIPAMENTOS DSL

JARDÍM DE INFÂNCIA

Pav. Térreo

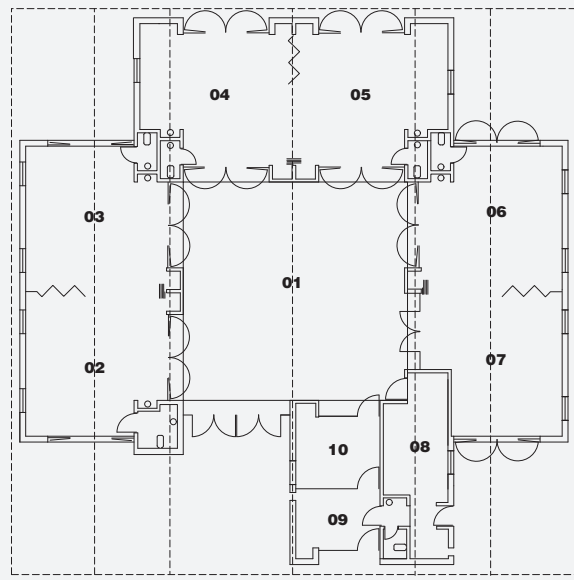

Área Construída $\mathbf{5 7 3 \mathbf { m } ^ { 2 }}$

Área Exterior Coberta $\mathbf{2 5 0 \mathbf { m } ^ { 2 }}$

Pátios ---m²

Ocupação de Solo $\mathbf{8 2 4} \mathbf{m}^{2}$

Taxa Ocupação de Solo 47,8\%

Terreno $1200 \mathbf{m}^{2}$

Educação $514 \mathbf{m}^{2}$

Esc. 1.500

EDUCACIONAL

$\begin{array}{ll}01 & \text { Pátio coberto } \\ 02 & \text { Sala de Aula I com Banh. } \\ 03 & \text { Sala de Aula II com Banh. } \\ 04 & \text { Sala de Aula III com Banh. } \\ 05 & \text { Sala de Aula IIII com Banh. } \\ 06 & \text { Sala de Aula IIIII com Banh. } \\ 07 & \text { Psicomotricidade } \\ 08 & \text { Cozinh } \\ 09 & \text { Direção } \\ \text { 10 Sala de maestros } & \text { * Espaço: soma de varios espaços }\end{array}$

L

$12,73 \mathrm{~m} \quad 11 \mathrm{~m} \quad$ var. $4,70 / 3,90 \mathrm{~m}$ var. $3,47 / 2,60 \mathrm{~m}$ var. $3,47 / 2,60 \mathrm{~m}$ var. $4,70 / 3,90 \mathrm{~m} \quad 51,5 \mathrm{~m}^{2}$ var. $3,47 / 2,60 \mathrm{~m} \quad 52,56 \mathrm{~m}^{2}$ var. $3,47 / 2,60 \mathrm{~m} \quad 54,72 \mathrm{~m}^{2}$ var. $4,70 / 3,90 \mathrm{~m} \quad 25,6 \mathrm{~m}^{2}$ 
CATÁLOGO EQUIPAMENTOS DSL

JARDÍM DE INFÂNCIA DSL DISSOLUÇÃO PROGRAMÁTICA

Educacional $514 \mathbf{m}^{2}$
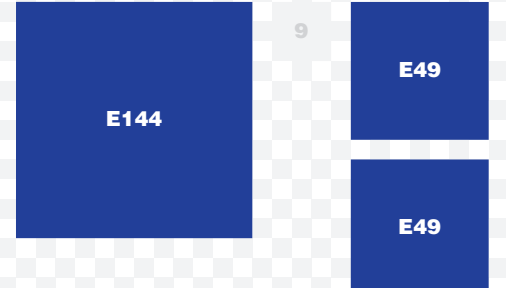
CATÁLOGO EQUIPAMENTOS DSL

JARDÍM DE INFÂNCIA DSL DISSOLUÇÃO ESPACIAL

Área Construída $573 \mathrm{~m}^{2}$

Área Exterior Coberta $\mathbf{2 5 0 \mathbf { m } ^ { 2 }}$

Pátios ---m²

Terreno 1200m²
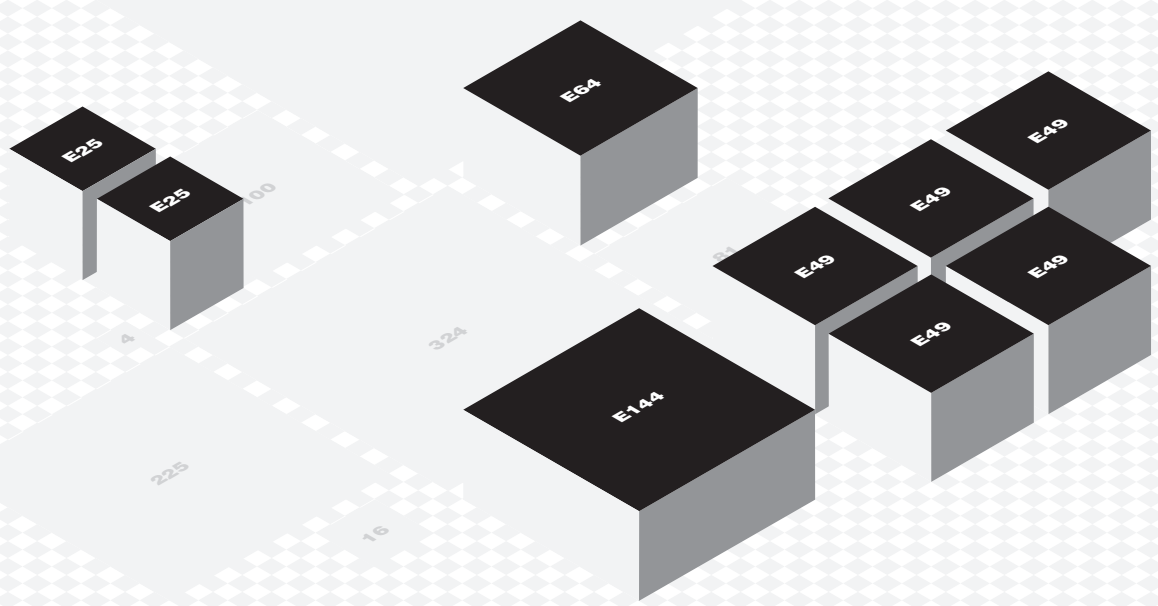


\section{CATÁLOGO EQUIPAMENTOS DSL}

\section{ESCOLA 320 CASAVALLE}

Ano sd

Área total $840 \mathrm{~m}^{2}$

Autor sd

Localização Barrio Casavalle, Montevideo. UY.

Organização gestora ANEP

Organização responsável ANEP CEIP

Fontes IM / REVISTA SAU 235 noviembre 1958
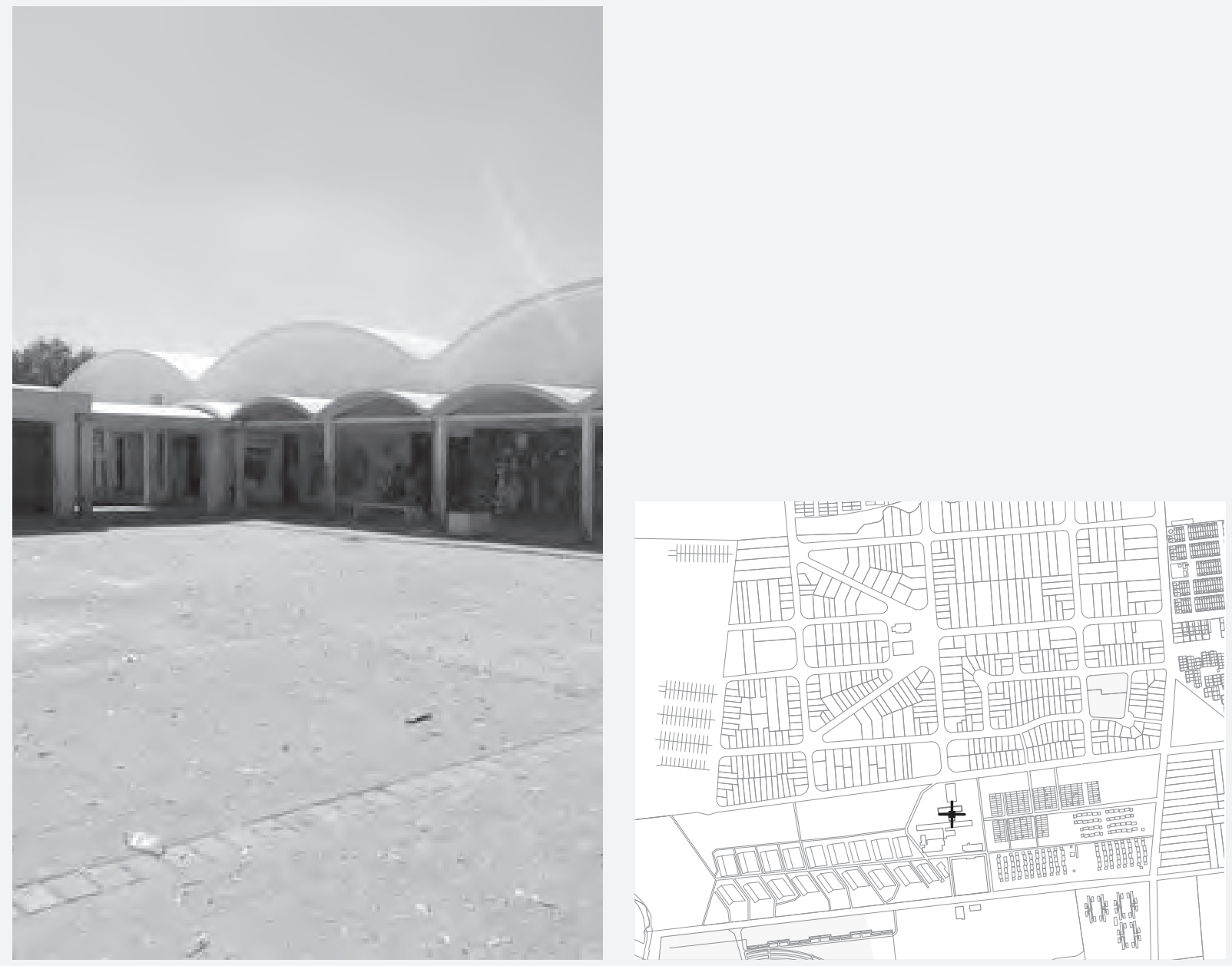
CATÁLOGO EQUIPAMENTOS DSL

ESCOLA 320 CASAVALLE

Pav. Térreo

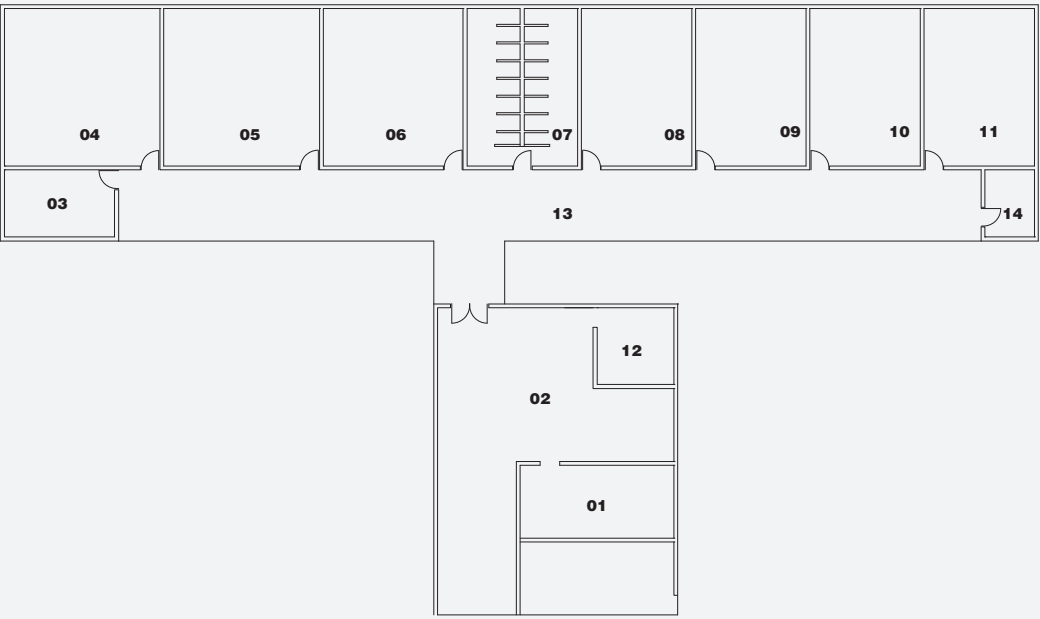

Área Construída $840 \mathrm{~m}^{2}$

Área Exterior Coberta ----m²

Pátios 930m²

Ocupação de Solo $\mathbf{8 4 0 \mathbf { m } ^ { 2 }}$

Taxa Ocupação de Solo 46\%

Terreno $1800 \mathbf{m}^{2}$

Educação $\mathbf{7 3 0 \mathbf { m } ^ { 2 }}$

Esc. 1.500

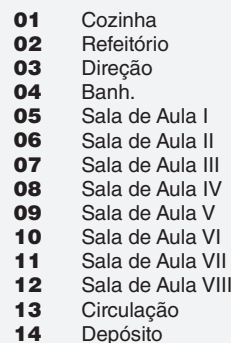

$\begin{array}{lll}\text { L } & \text { I } & \text { Alt. } \\ & & \\ 7,8 \mathrm{~m} & 3,7 \mathrm{~m} & 2,5 \\ 12 \mathrm{~m} & 7,8 \mathrm{~m} & 2,5 \\ 5,6 \mathrm{~m} & 3,4 \mathrm{~m} & 2,5 \\ 8 \mathrm{~m} & 5,8 \mathrm{~m} & 2,5 \\ 8 \mathrm{~m} & 7,9 \mathrm{~m} & 2,5 \\ 8 \mathrm{~m} & 7,9 \mathrm{~m} & 2,5 \\ 8 \mathrm{~m} & 7,9 \mathrm{~m} & 2,5 \\ 8 \mathrm{~m} & 5,6 \mathrm{~m} & 2,5 \\ 8 \mathrm{~m} & 5,6 \mathrm{~m} & 2,5 \\ 8 \mathrm{~m} & 5,6 \mathrm{~m} & 2,5 \\ 8 \mathrm{~m} & 5,6 \mathrm{~m} & 2,5 \\ 3,9 \mathrm{~m} & 3,9 \mathrm{~m} & 2,5 \\ 43,8 \mathrm{~m} & 3,6 \mathrm{~m} & 2,5 \\ 3,5 & 2,4 \mathrm{~m} & 2,5 \\ & & \end{array}$

Sup.

DSL

$28,86 \mathrm{~m}^{2}$

E100

63,2 $\mathrm{m}^{2} \quad$ E64

$63,2 \mathrm{~m}^{2} \quad \mathbf{E 6 4}$

$63,2 \mathrm{~m}^{2} \quad$ E64

$49 \mathrm{~m}^{2} \quad$ E49

$49 \mathrm{~m}^{2}$

$15,21 \mathrm{~m}^{2}$

$15768 \mathrm{~m}^{2} \quad$ E16

$8,4 \mathrm{~m}^{2} \quad$ E9 


\section{CATÁLOGO EQUIPAMENTOS DSL}

ESCOLA 320 DSL DISSOLUÇÃO PROGRAMÁTICA

Educacional $730 \mathbf{m}^{2}$ -
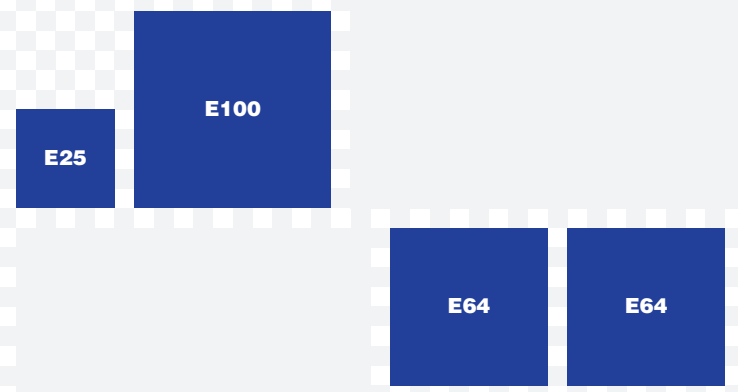

E16

E16

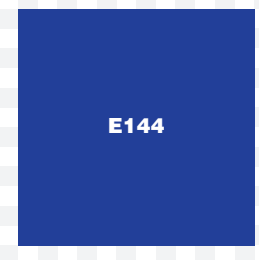

$\mathbf{E 9}$

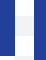


CATÁLOGO EQUIPAMENTOS DSL

ESCOLA 320 DSL DISSOLUÇÃO ESPÃCIAL

Área Construída $840 \mathrm{~m}^{2}$

Área Exterior Coberta ---m²

Pátios $930 \mathrm{~m}^{2}$

Terreno $\mathbf{1 8 0 0 \mathbf { m } ^ { 2 }}$

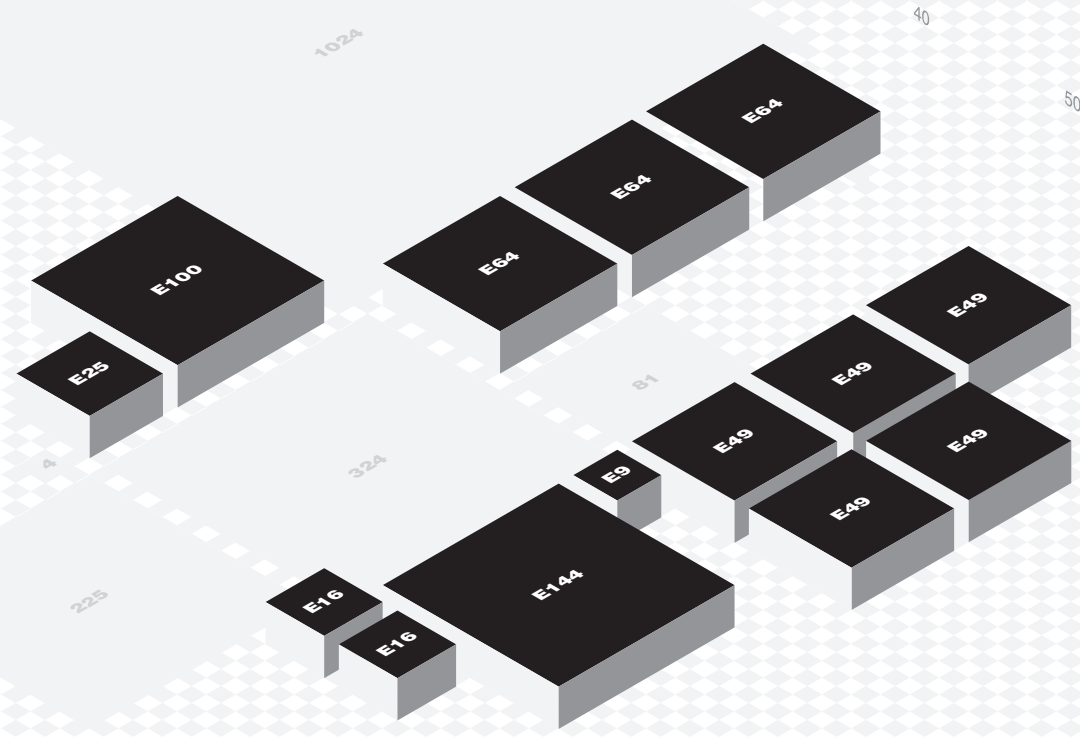




\section{CATÁLOGO EQUIPAMENTOS DSL}

CEA CENTRO EDUCACIONAL ASSOCIADO (a escola 178)

Ano PROYECTO 2017

Área total $1000 \mathrm{~m}^{2}$

Autor PAEMFe Arq. Andrea Gnesetti

Localização Barrio Casavalle, Montevideo. UY.

Organização gestora CND

Organização responsável ANEP - CETP

Fonte IM

https://www.comprasestatales.gub.uy/consultas/detalle/mostrar-Ilamado/1/id/656035
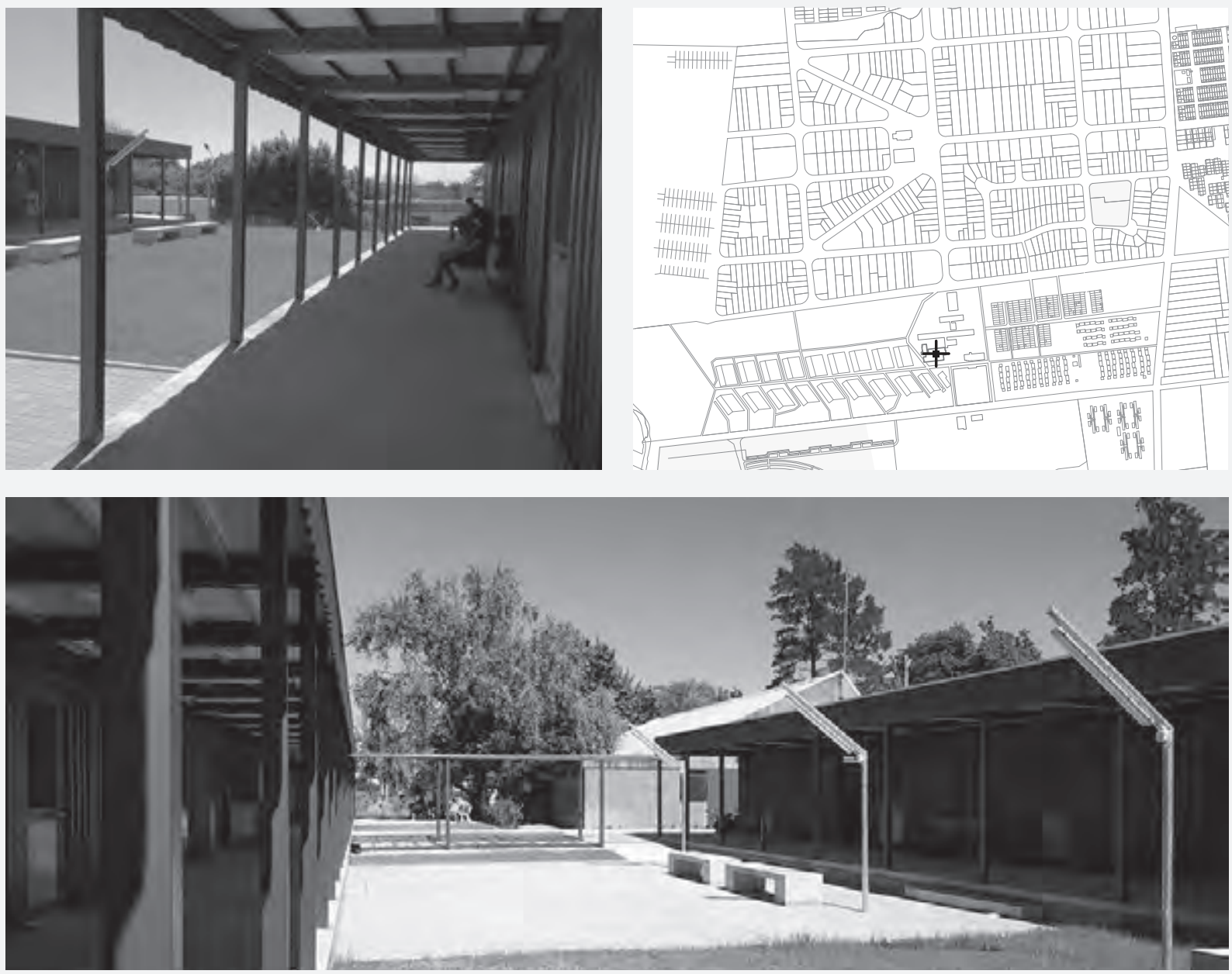
CATÁLOGO EQUIPAMENTOS DSL

CEA CENTRO EDUCACIONAL ASSOCIADO (a escola 178)

Pav. Térreo

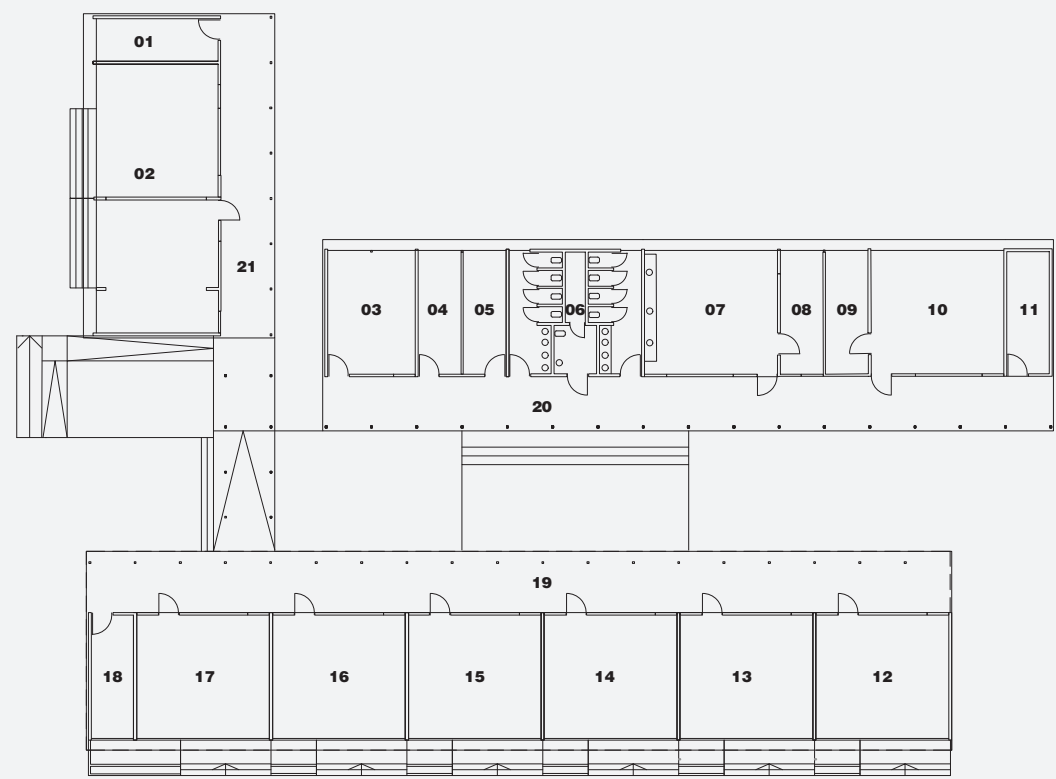

Área Construída $1000 \mathrm{~m}^{2}$

Área Exterior Coberta ---m²

Pátios ---m²

Ocupação de Solo $\mathbf{1 2 6 0 \mathbf { m } ^ { 2 }}$

Taxa Ocupação de Solo $\mathbf{7 1 \%}$

Terreno $1400 \mathbf{m}^{2}$

Educação 915m²

Esc. 1.500

EDUCACIONAL

\begin{tabular}{|c|c|c|c|c|}
\hline L & 1 & Alt. & Sup. & DSL \\
\hline $6,2 m$ & $2,15 \mathrm{~m}$ & var. $2,50 / 2,70 m$ & $13,33 \mathrm{~m}^{2}$ & E16 \\
\hline $13,65 \mathrm{~m}$ & $6,2 \mathrm{~m}$ & var. $2,50 / 2,70 \mathrm{~m}$ & $84,63 \mathrm{~m}^{2}$ & E81 \\
\hline $6,28 m$ & $4,45 \mathrm{~m}$ & var. $2,50 / 2,70 \mathrm{~m}$ & $27,94 m^{2}$ & E25 \\
\hline $6,28 m$ & $2,16 \mathrm{~m}$ & var. $2,50 / 2,70 \mathrm{~m}$ & $13,56 \mathrm{~m}^{2}$ & E16 \\
\hline $6,28 \mathrm{~m}$ & $2,16 \mathrm{~m}$ & var. $2,50 / 2,70 \mathrm{~m}$ & $13,56 \mathrm{~m}^{2}$ & E16 \\
\hline $6,75 \mathrm{~m}$ & $6,28 \mathrm{~m}$ & var. $2,50 / 2,70 \mathrm{~m}$ & $42,39 \mathrm{~m}^{2}$ & E49 \\
\hline $6,75 \mathrm{~m}$ & $6,28 \mathrm{~m}$ & var. $2,50 / 2,70 \mathrm{~m}$ & $42,39 \mathrm{~m}^{2}$ & E49 \\
\hline $6,28 \mathrm{~m}$ & $2,16 \mathrm{~m}$ & var. $2,50 / 2,70 \mathrm{~m}$ & $13,56 \mathrm{~m}^{2}$ & E16 \\
\hline $6,28 \mathrm{~m}$ & $2,16 \mathrm{~m}$ & var. $2,50 / 2,70 \mathrm{~m}$ & $13,56 \mathrm{~m}^{2}$ & E16 \\
\hline $6,28 \mathrm{~m}$ & $6,75 \mathrm{~m}$ & var. $2,50 / 2,70 \mathrm{~m}$ & $42,39 m^{2}$ & E49 \\
\hline $6,28 \mathrm{~m}$ & $2,15 \mathrm{~m}$ & var. $2,50 / 2,70 \mathrm{~m}$ & $13,50 \mathrm{~m}^{2}$ & E16 \\
\hline $6,75 \mathrm{~m}$ & $6,28 \mathrm{~m}$ & var. $2,50 / 2,70 \mathrm{~m}$ & $42,39 m^{2}$ & E49 \\
\hline $6,75 \mathrm{~m}$ & $6,28 \mathrm{~m}$ & var. $2,50 / 2,70 \mathrm{~m}$ & $42,39 m^{2}$ & E49 \\
\hline $6,75 \mathrm{~m}$ & $6,28 \mathrm{~m}$ & var. $2,50 / 2,70 \mathrm{~m}$ & $42,39 m^{2}$ & E49 \\
\hline $6,75 \mathrm{~m}$ & $6,28 \mathrm{~m}$ & var.2,50 / 2,70m & $42,39 m^{2}$ & E49 \\
\hline $6,75 \mathrm{~m}$ & $6,28 \mathrm{~m}$ & var. $2,50 / 2,70 \mathrm{~m}$ & $42,39 m^{2}$ & E49 \\
\hline $6,75 \mathrm{~m}$ & $6,28 \mathrm{~m}$ & var. $2,50 / 2,70 \mathrm{~m}$ & $42,39 m^{2}$ & E49 \\
\hline $2,15 \mathrm{~m}$ & $6,28 \mathrm{~m}$ & var. $2,50 / 2,70 \mathrm{~m}$ & $13,50 \mathrm{~m}^{2}$ & E16 \\
\hline $43,9 m$ & $3,12 \mathrm{~m}$ & var. $2,50 / 2,70 \mathrm{~m}$ & $136,96 \mathrm{~m}^{2}$ & E324* \\
\hline $37,1 \mathrm{~m}$ & $3,12 \mathrm{~m}$ & var. $2,50 / 2,70 \mathrm{~m}$ & $115,75 \mathrm{~m}^{2}$ & E324* \\
\hline $27,3 m$ & $2,7 \mathrm{~m}$ & var. $2,50 / 2,70 \mathrm{~m}$ & $73,71 \mathrm{~m}^{2}$ & E324* \\
\hline
\end{tabular}

Sala de Aula comum I Sala de Aula comum II Sala de Aula comum III Sala de Aula comum IV Sala de Aula comum V Profs. Associados 


\section{CATÁLOGO EQUIPAMENTOS DSL}

CEA DSL DISSOLUÇÃO PROGRAMÁTICA

Educacional $915 \mathbf{m}^{2}$ -

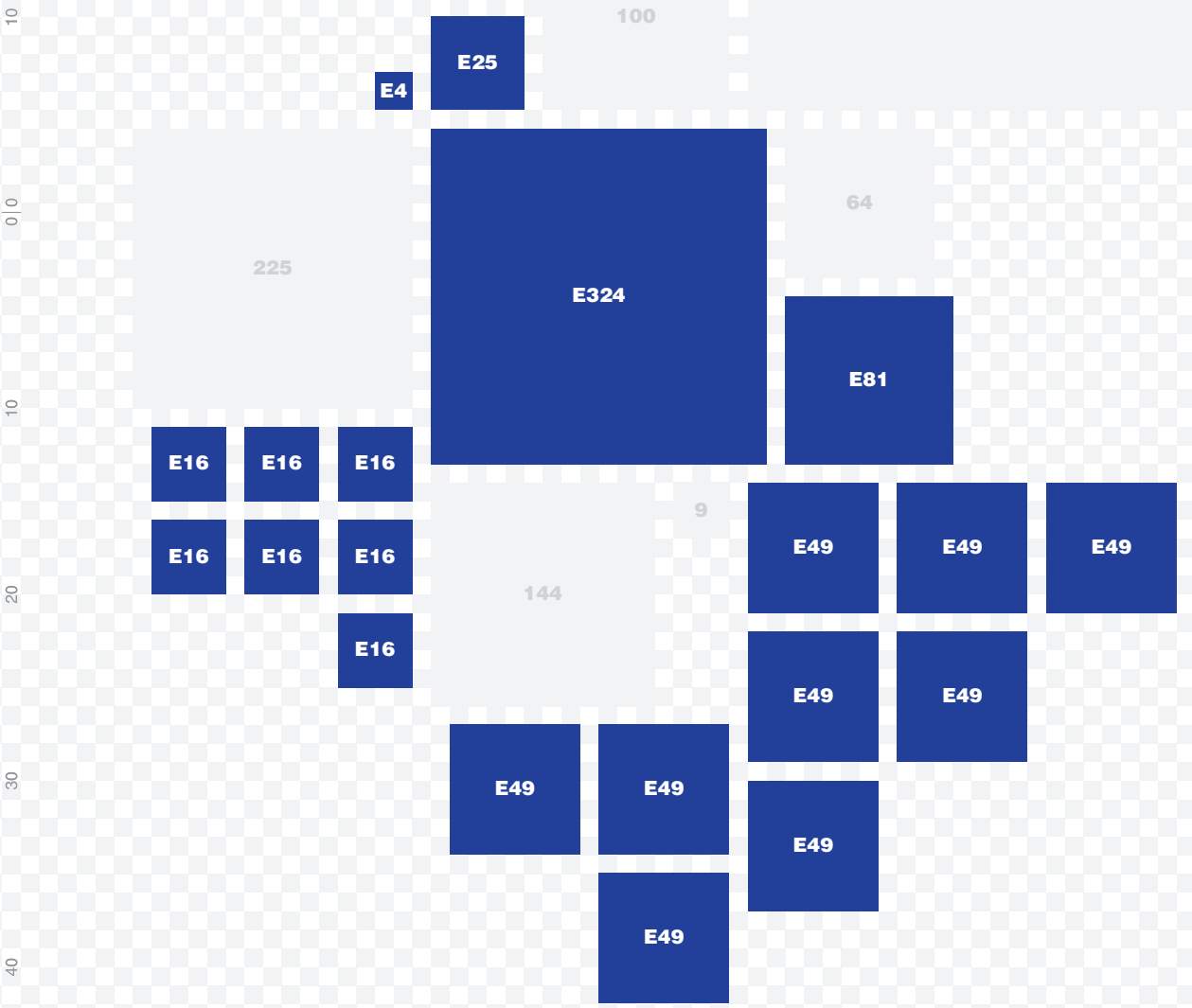


CATÁLOGO EQUIPAMENTOS DSL

CEA DSL DISSOLUÇÃO ESPACIAL

Área Construída $1000 \mathrm{~m}^{2}$

Área Exterior Coberta ---m $\mathbf{m}^{2}$

Pátios ---m²

Terreno $1400 \mathrm{~m}^{2}$

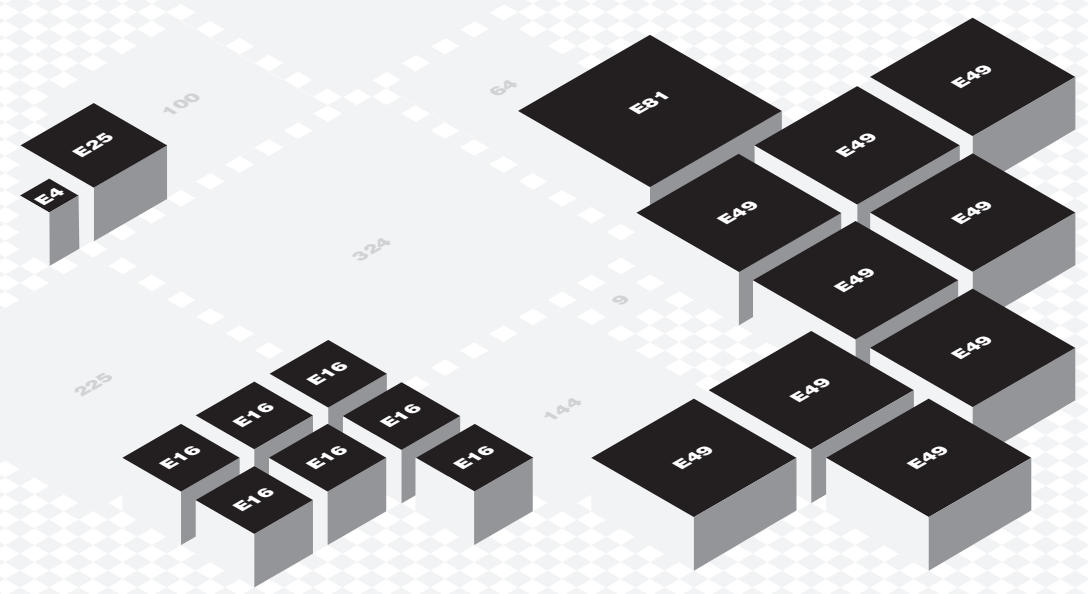


CATÁLOGO EQUIPAMENTOS DSL

ESCOLA TEMPO COMPLETO 91A MODULAR

Ano 2017. Projeto

Área total $1042 \mathrm{~m}^{2}$

Autor PAEPU. Arq. Pedro Barrán

Localização Projeto Tipo

Organização gestora CND

Organização responsável ANEP CEIP

Fonte CND

https://www.cnd.org.uy/index.php/sala-de-prensa/1780-segundo-llamado-para-proyecto

s-ppp-en-infraestructura-educativa
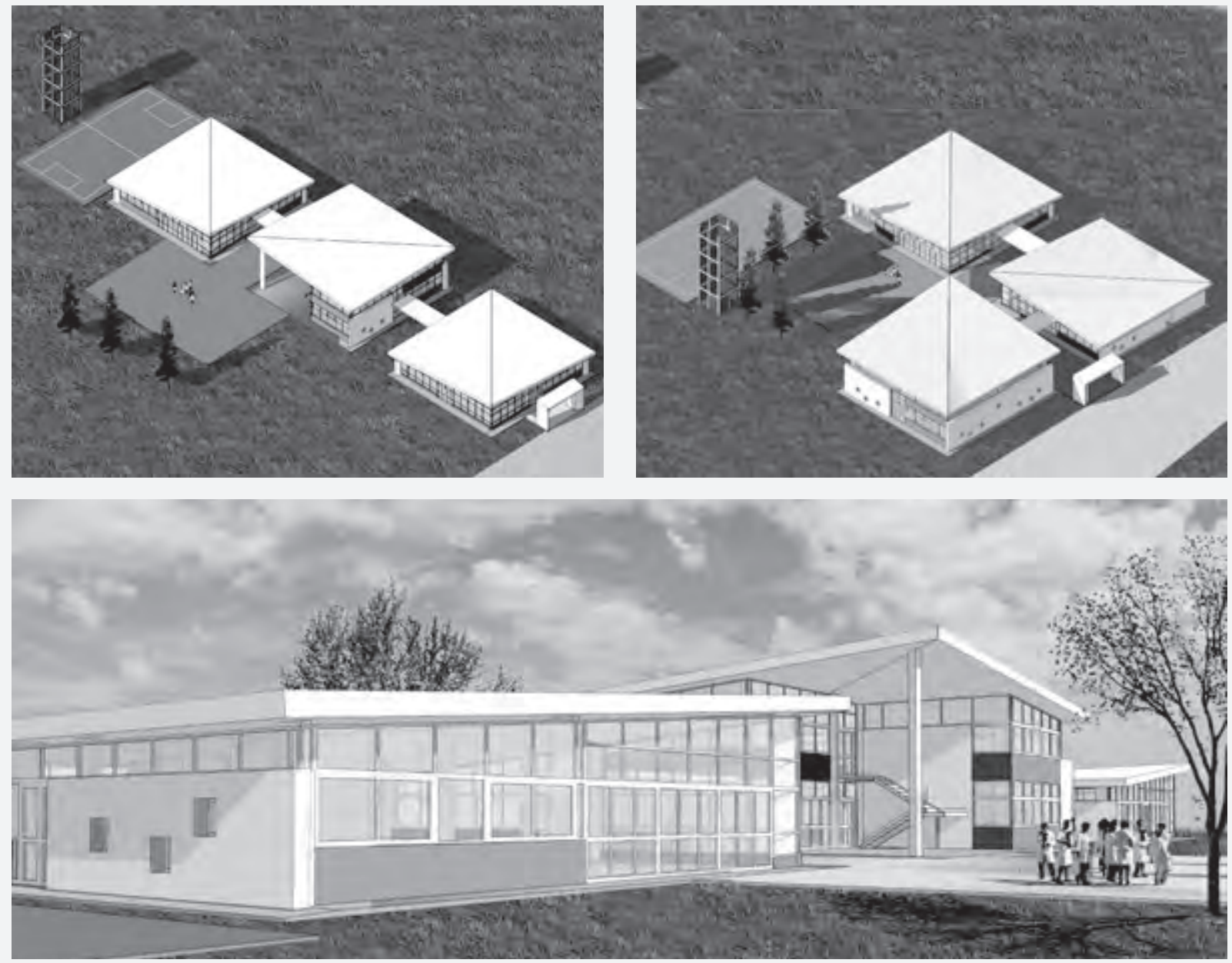
CATÁLOGO EQUIPAMENTOS DSL

ESCOLA TEMPO COMPLETO 91A MODULAR

Pav. Térreo MÓDULO 1 - ACESSO

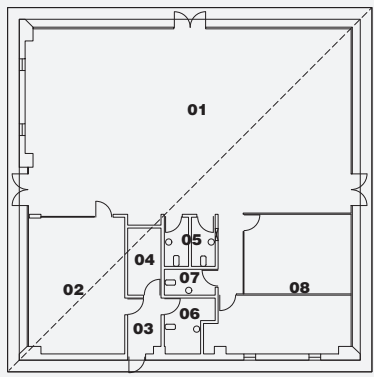

\section{Pav.TErro MODULO 1 -ACESSO}

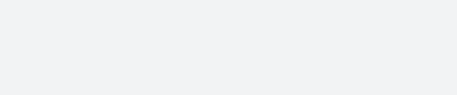


CATÁLOGO DE EQUIPAMENTOS DSL

ESCOLA TEMPO COMPLETO 91A MODULAR

Pav. Térreo MÓDULO 2 - 6 SALAS DE AULAS
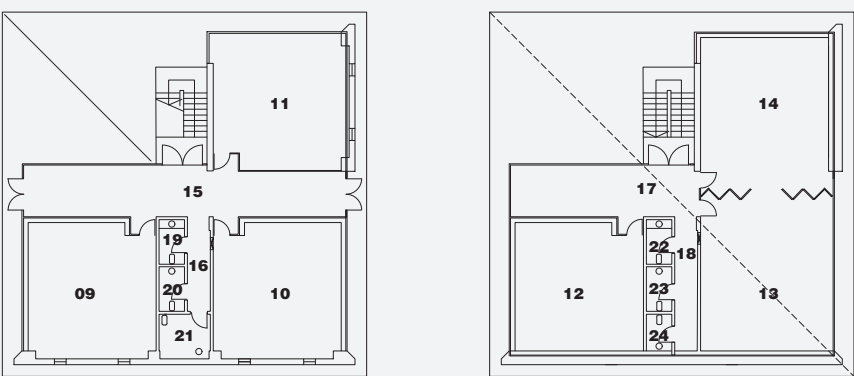

Área Construída $464 \mathrm{~m}^{2}$

Área Exterior Coberta $60 \mathrm{~m}^{2}$

Pátios ---m²

Ocupação de Solo ---m²

Taxa Ocupação de Solo $\mathbf{5 7 \%}$

Terreno $\mathbf{6 0 0 \mathbf { m } ^ { 2 }}$

Educação $\mathbf{3 6 5 \mathbf { m } ^ { 2 }}$

Esc. 1.500

EDUCACIONAL

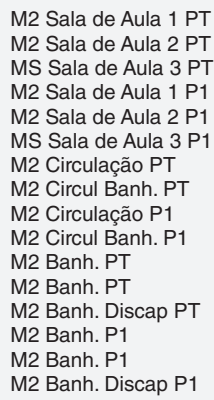

L

Alt. 
CATÁLOGO EQUIPAMENTOS DSL

ESCOLA TEMPO COMPLETO 91A MODULAR

Pav. Térreo MÓDULO 3 - SALAS DE AULAS PRÉ ESCOLAR
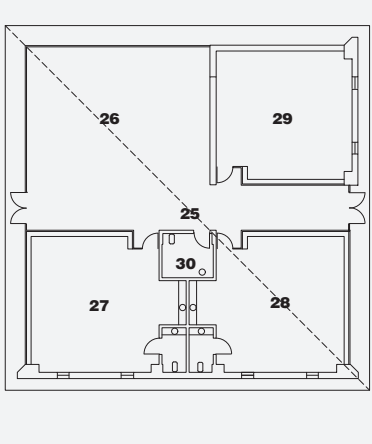

Área Construída $\mathbf{2 8 9} \mathbf{m}^{2}$

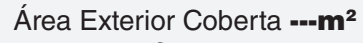

Pátios ---m²

Ocupação de Solo ---m²

Taxa Ocupação de Solo $\mathbf{5 7 \%}$

Terreno $\mathbf{6 0 0 \mathbf { m } ^ { 2 }}$

Educação 246m²

Esc. 1.500

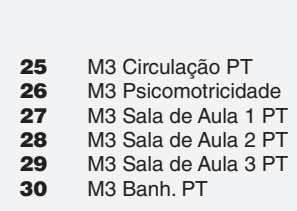

L $\quad$ Alt.

Sup.

DSL

ำ

EDUCACIONAL

$17 \mathrm{~m}$

$2,4 \mathrm{~m} \quad$ var. $2.80 / 4,28 \mathrm{~m} \quad 40,8 \mathrm{~m}^{2}$

$8,9 \mathrm{~m} \quad 6,5 \mathrm{~m} \quad$ var. $2.80 / 4,28 \mathrm{~m} \quad 57,85 \mathrm{~m}^{2}$

$7,9 \mathrm{~m} \quad 6,5 \mathrm{~m} \quad$ var. $2.80 / 4,28 \mathrm{~m} \quad 50 \mathrm{~m}^{2}$

$7,9 \mathrm{~m} \quad 6,5 \mathrm{~m}$ var. $2.80 / 4,28 \mathrm{~m} \quad 50 \mathrm{~m}^{2}$

$6,5 \mathrm{~m} \quad 6,5 \mathrm{~m} \quad$ var. $2.80 / 4,28 \mathrm{~m} \quad 42,25 \mathrm{~m}^{2}$

$2,6 \mathrm{~m} \quad 2,25 \mathrm{~m} \quad$ var. $2.80 / 4,28 \mathrm{~m} \quad 5,85 \mathrm{~m}^{2}$ 


\section{CATÁLOGO EQUIPAMENTOS DSL}

ESCOLA TEMPO COMPLETO 91A MODULAR

Pav. Térreo MÓDULO 4 - 3 SALAS DE AULAS

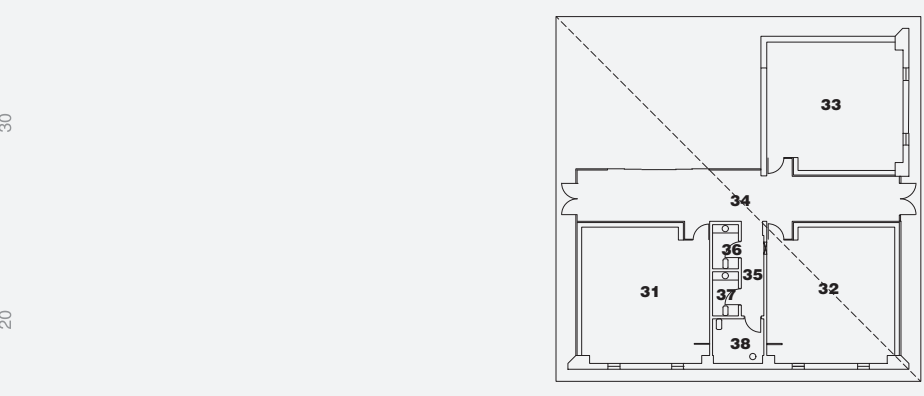

Área Construída $\mathbf{2 3 2 \mathbf { m } ^ { 2 }}$

Área Exterior Coberta ---m²

Pátios ---m²

Ocupação de Solo ---m²

Taxa Ocupação de Solo $\mathbf{5 7 \%}$

Terreno $\mathbf{6 0 0 \mathbf { m } ^ { 2 }}$

Educação $185 \mathrm{~m}^{2}$

Esc. 1.500

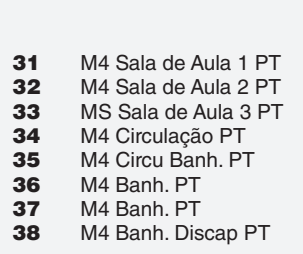

L

Alt.

Sup.

DSL

$6,5 \mathrm{~m} \quad 6,5 \mathrm{~m} \quad$ var. $2.80 / 4,28 \mathrm{~m}$

$6,5 \mathrm{~m} \quad 6,5 \mathrm{~m} \quad$ var. $2.80 / 4,28 \mathrm{~m}$

$6,5 \mathrm{~m} \quad 6,5 \mathrm{~m} \quad$ var. $2.80 / 4,28 \mathrm{~m}$

$17 \mathrm{~m} \quad 2,4 \mathrm{~m} \quad$ var. $2.80 / 4,28 \mathrm{~m}$

$5 \mathrm{~m} \quad 1,2 \mathrm{~m} \quad$ var. $2.80 / 4,28 \mathrm{~m}$

$\begin{array}{lll}2,25 \mathrm{~m} & 1,25 \mathrm{~m} & \text { var. } 2.80 / 4,28 \mathrm{~m} \quad 2,8125 \mathrm{~m}^{2}\end{array}$

$2,25 \mathrm{~m}$ var. $2.80 / 4,28 \mathrm{~m} \quad 5,4 \mathrm{~m}^{2}$

* Local, soma de vários locais 
CATÁLOGO EQUIPAMENTOS DSL

ESCOLA TEMPO COMPLETO 91A MODULAR

Pav. Térreo

Área Construída $1042 \mathrm{~m}^{2}$

Área Exterior Coberta $\mathbf{9 6}^{\mathbf{2}}$

Pátios $\mathbf{7 2 7 \mathbf { m } ^ { 2 }}$

Ocupação de Solo $1527 \mathbf{m}^{2}$

Taxa Ocupação de Solo $\mathbf{3 4 , 5 \%}$

Terreno $\mathbf{3 0 0 0 \mathbf { m } ^ { 2 }}$

Educação 1208m²

Esc. 1.500
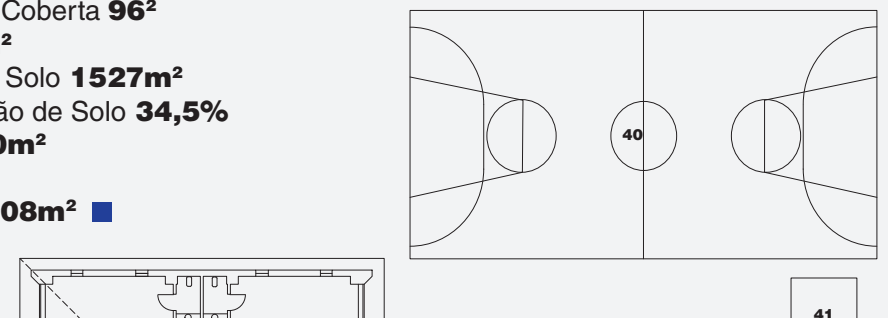

C.

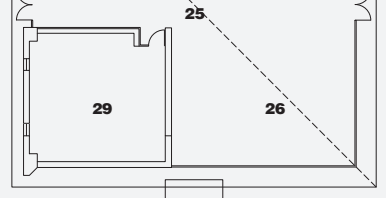

39

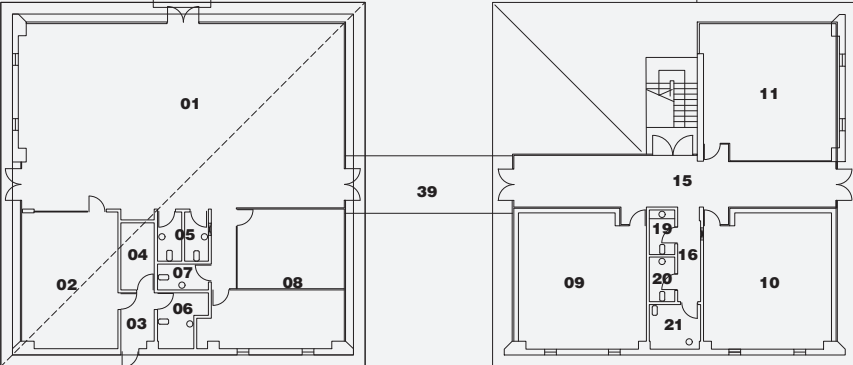

M1 Refeitório

M1 Cozinha

M1 Pátio Serviço

M1 Despensa

M1 2Banh. Pub

M1 Banh. Funcionários

M1 Banh. Admin.

M1 Admin

M2 Sala de Aula 1 PT

M2 Sala de Aula 2 PT

MS Sala de Aula 3 PT

M2 Sala de Aula 1 P1

M2 Sala de Aula 1 P1

M2 Sala de Aula 2 P1

MS Sala de Aula 3

M2 Circulação PT

M2 Circul Banh. PT

M2 Circulação P1

M2 Circul Banh. P1

M2 Banh. PT

M2 Banh. PT
M2 Banh. Discap PT

M2 Banh. P1

M2 Banh. P1

M2 Banh. Discap P1

M3 Circulação PT

M3 Psicomotricidade

M3 Sicomotridade

M3 Sala de Aula 2 PT

M3 Sala de Aula 3 PT

M3 Banh. PT

$\begin{array}{llll}\text { L } & \text { I } & \text { Alt. } & \text { Sup. } \\ & & & \\ 17 \mathrm{~m} & 8,9 \mathrm{~m} & \text { var. } 2.80 / 4,28 \mathrm{~m} & 151 \mathrm{~m}^{2} \\ 6,5 \mathrm{~m} & 5 \mathrm{~m} & \text { var. } 2.80 / 4,28 \mathrm{~m} & 33 \mathrm{~m}^{2} \\ 2,85 \mathrm{~m} & 1,7 \mathrm{~m} & \text { var. } 2.80 / 4,28 \mathrm{~m} & 5 \mathrm{~m}^{2} \\ 3,4 \mathrm{~m} & 1,7 \mathrm{~m} & \text { var. } 2.80 / 4,28 \mathrm{~m} & 6 \mathrm{~m}^{2} \\ 2,5 \mathrm{~m} & 2,5 \mathrm{~m} & \text { var. } 2.80 / 4,28 \mathrm{~m} & 6 \mathrm{~m}^{2} \\ 2,85 \mathrm{~m} & 2,5 \mathrm{~m} & \text { var. } 2.80 / 4,28 \mathrm{~m} & 7 \mathrm{~m}^{2} \\ 2,6 \mathrm{~m} & 1,3 \mathrm{~m} & \text { var. } 2.80 / 4,28 \mathrm{~m} & 3 \mathrm{~m}^{2} \\ 6,5 \mathrm{~m} & 6,5 \mathrm{~m} & \text { var. } 2.80 / 4,28 \mathrm{~m} & 42 \mathrm{~m}^{2} \\ 6,5 \mathrm{~m} & 6,5 \mathrm{~m} & 2.80 \mathrm{~m} & 42,25 \mathrm{~m}^{2} \\ 6,5 \mathrm{~m} & 6,5 \mathrm{~m} & 2.80 \mathrm{~m} & 42,25 \mathrm{~m}^{2} \\ 6,5 \mathrm{~m} & 6,5 \mathrm{~m} & 2.80 \mathrm{~m} & 42,25 \mathrm{~m}^{2} \\ 6,5 \mathrm{~m} & 6,5 \mathrm{~m} & \text { var. } 2.60 / 4,08 \mathrm{~m} & 42,25 \mathrm{~m}^{2} \\ 7,7 \mathrm{~m} & 6,5 \mathrm{~m} & \text { var. } 2.60 / 4,08 \mathrm{~m} & 50,05 \mathrm{~m}^{2} \\ 7,7 \mathrm{~m} & 6,5 \mathrm{~m} & \text { var. } 2.60 / 4,08 \mathrm{~m} & 50,05 \mathrm{~m}^{2} \\ 17 \mathrm{~m} & 2,4 \mathrm{~m} & 2.80 \mathrm{~m} & 40,8 \mathrm{~m}^{2} \\ 5 \mathrm{~m} & 1,2 \mathrm{~m} & 2.80 \mathrm{~m} & 6 \mathrm{~m}^{2} \\ 8,9 \mathrm{~m} & 2,4 \mathrm{~m} & \text { var. } 2.60 / 4,08 \mathrm{~m} & 21,4 \mathrm{~m}^{2} \\ 6,5 \mathrm{~m} & 1,2 \mathrm{~m} & \text { var. } 2.60 / 4,08 \mathrm{~m} & 7,8 \mathrm{~m}^{2} \\ 2,25 \mathrm{~m} & 1,25 \mathrm{~m} & 2.80 \mathrm{~m} & 2,8 \mathrm{~m}^{2} \\ 2,25 \mathrm{~m} & 1,25 \mathrm{~m} & 2.80 \mathrm{~m} & 2,8 \mathrm{~m}^{2} \\ 2,4 \mathrm{~m} & 2,25 \mathrm{~m} & 2.80 \mathrm{~m} & 5,4 \mathrm{~m}^{2} \\ 2,25 \mathrm{~m} & 1,25 \mathrm{~m} & \text { var. } 2.60 / 4,08 \mathrm{~m} & 2,8 \mathrm{~m}^{2} \\ 2,25 \mathrm{~m} & 1,25 \mathrm{~m} & \text { var. } 2.60 / 4,08 \mathrm{~m} & 2,8 \mathrm{~m}^{2} \\ 2,25 \mathrm{~m} & 1,25 \mathrm{~m} & \text { var. } 2.60 / 4,08 \mathrm{~m} & 2,8 \mathrm{~m}^{2} \\ 17 \mathrm{~m} & 2,4 \mathrm{~m} & \text { var. } 2.80 / 4,28 \mathrm{~m} & 40,8 \mathrm{~m}^{2} \\ 8,9 \mathrm{~m} & 6,5 \mathrm{~m} & \text { var. } 2.80 / 4,28 \mathrm{~m} & 57,85 \mathrm{~m}^{2} \\ 7,9 \mathrm{~m} & 6,5 \mathrm{~m} & \text { var. } 2.80 / 4,28 \mathrm{~m} & 50 \mathrm{~m}^{2} \\ 7,9 \mathrm{~m} & 6,5 \mathrm{~m} & \text { var. } 2.80 / 4,28 \mathrm{~m} & 50 \mathrm{~m}^{2} \\ 6,5 \mathrm{~m} & 6,5 \mathrm{~m} & \text { var. } 2.80 / 4,28 \mathrm{~m} & 42,25 \mathrm{~m}^{2} \\ 2,6 \mathrm{~m} & 2,25 \mathrm{~m} & \text { var. } 2.80 / 4,28 \mathrm{~m} & 5,85 \mathrm{~m}^{2} \\ & & & \end{array}$




\section{CATÁLOGO EQUIPAMENTOS DSL}

\section{ESCOLA TEMPO COMPLETO 91A MODULAR}

M4 Sala de Aula 1 PT M4 Sala de Aula 2 PT MS Sala de Aula 3 PT M4 Circulação PT M4 Circu Banh. PT M4 Banh. PT

M4 Banh. PT

M4 Banh. Discap PT

Galerias

alerias

Tanques

Local, soma de vários locais

$\begin{array}{lll}\text { L } & \text { I } & \text { Alt. } \\ 6,5 \mathrm{~m} & 6,5 \mathrm{~m} & \text { var. } 2.80 / 4,28 \mathrm{~m} \\ 6,5 \mathrm{~m} & 6,5 \mathrm{~m} & \text { var. } 2.80 / 4,28 \mathrm{~m} \\ 6,5 \mathrm{~m} & 6,5 \mathrm{~m} & \text { var. } 2.80 / 4,28 \mathrm{~m} \\ 17 \mathrm{~m} & 2,4 \mathrm{~m} & \text { var. } 2.80 / 4,28 \mathrm{~m} \\ 5 \mathrm{~m} & 1,2 \mathrm{~m} & \text { var. } 2.80 / 4,28 \mathrm{~m} \\ 2,25 \mathrm{~m} & 1,25 \mathrm{~m} & \text { var. } 2.80 / 4,28 \mathrm{~m} \\ 2,25 \mathrm{~m} & 1,25 \mathrm{~m} & \text { var. } 2.80 / 4,28 \mathrm{~m} \\ 2,4 \mathrm{~m} & 2,25 \mathrm{~m} & \text { var. } 2.80 / 4,28 \mathrm{~m} \\ 6,5 \mathrm{~m} & 3 \mathrm{~m} & 2.50 \mathrm{~m} \\ 24 \mathrm{~m} & 13 \mathrm{~m} & 2.50 \mathrm{~m} \\ 3,5 \mathrm{~m} & 3,5 \mathrm{~m} & 2.50 \mathrm{~m}\end{array}$

Sup.

DSL

$42,25 \mathrm{~m}^{2}$ 
CATÁLOGO EQUIPAMENTOS DSL

ESCOLA 91A MODULAR DSL DISSOLUÇÃO PROGRAMÁTICA

Educacional $1208 \mathbf{m}^{2}$

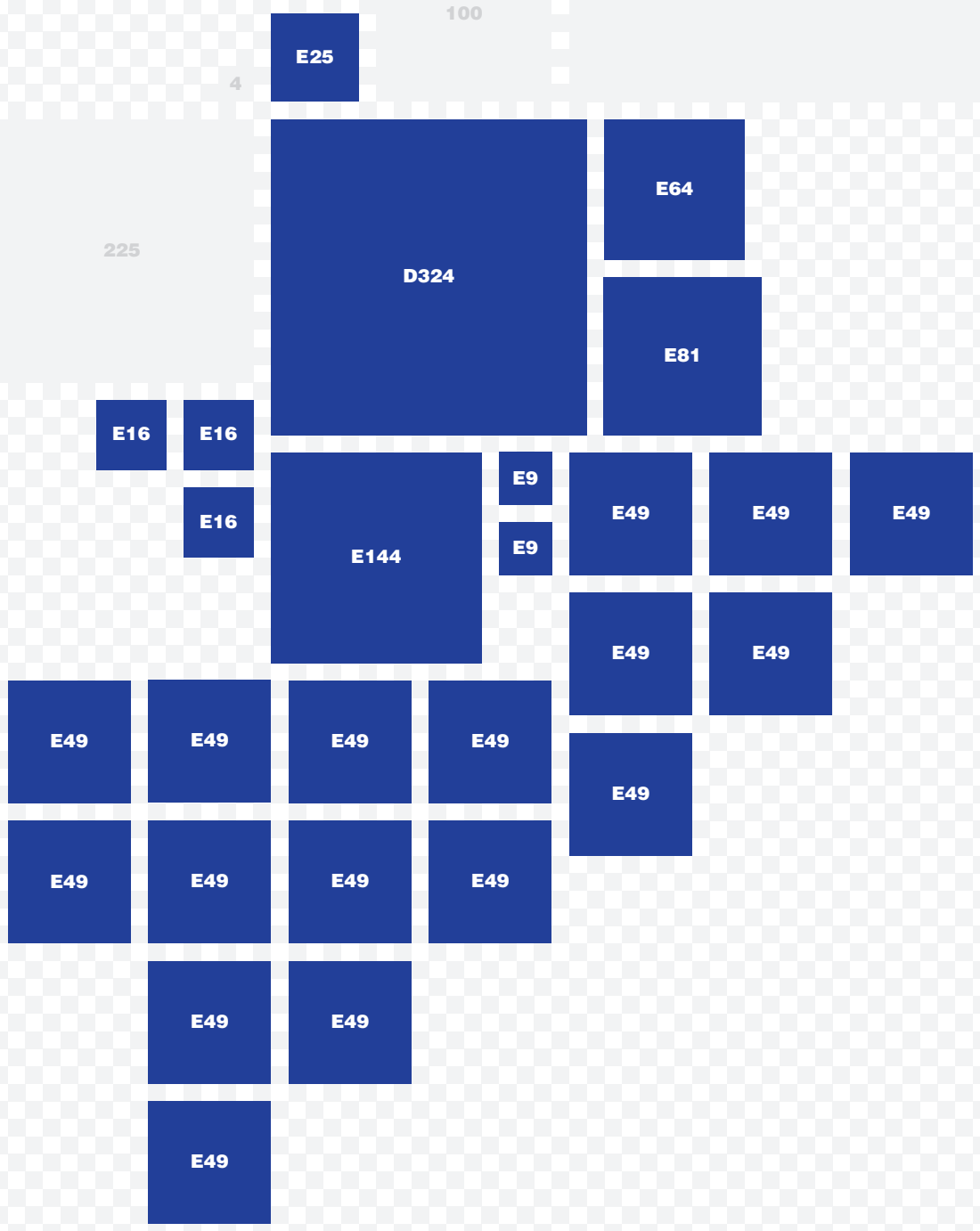





\section{CATÁLOGO DE EQUIPAMENTOS DSL}

\section{ETC 384 PLAN JUNTOS}

Ano 2016

Área total $1609 \mathrm{~m}^{2}$

Autor Pedro Barran

Localização Montevideo. UY.

Organização gestora CND

Organização responsável ANEP CEIP

Fonte IM. REVISTA SAU 235 noviembre 1958
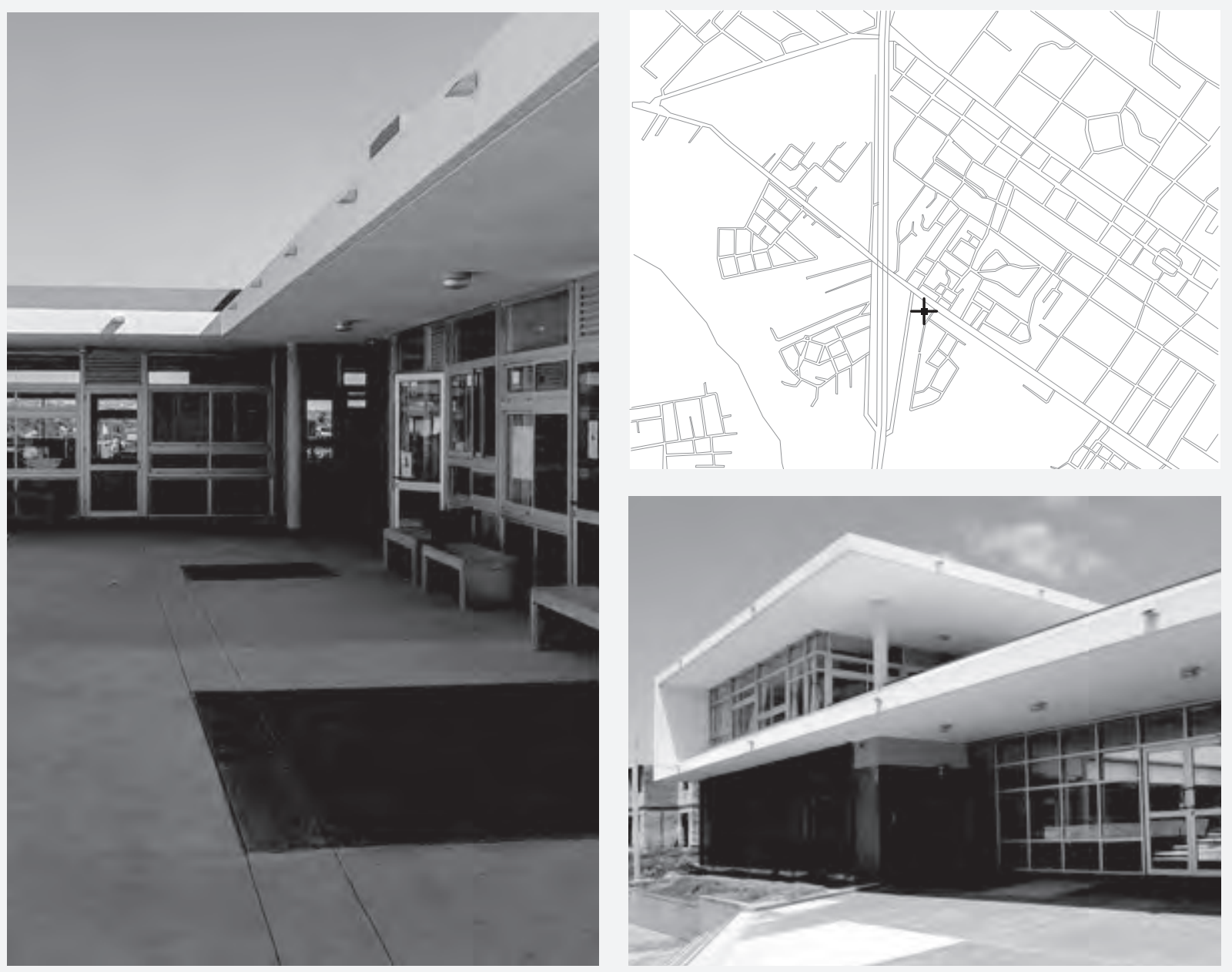
CATÁLOGO DE EQUIPAMENTOS DSL

ETC 384 PLAN JUNTOS

Pav. Térreo

Área Construída $1609 \mathrm{~m}^{2}$

Área Exterior Coberta $498 \mathrm{~m}^{2}$ Pátios 653 $\mathrm{m}^{2}$

Ocupação de Solo $\mathbf{2 0 9 2 \mathbf { m } ^ { 2 }}$ Taxa Ocupação de Solo $\mathbf{2 0 \%}$

Terreno $\mathbf{2 4 5 0 \mathbf { m } ^ { 2 }}$

Educação $953 \mathbf{m}^{2}$

Esc. 1.500

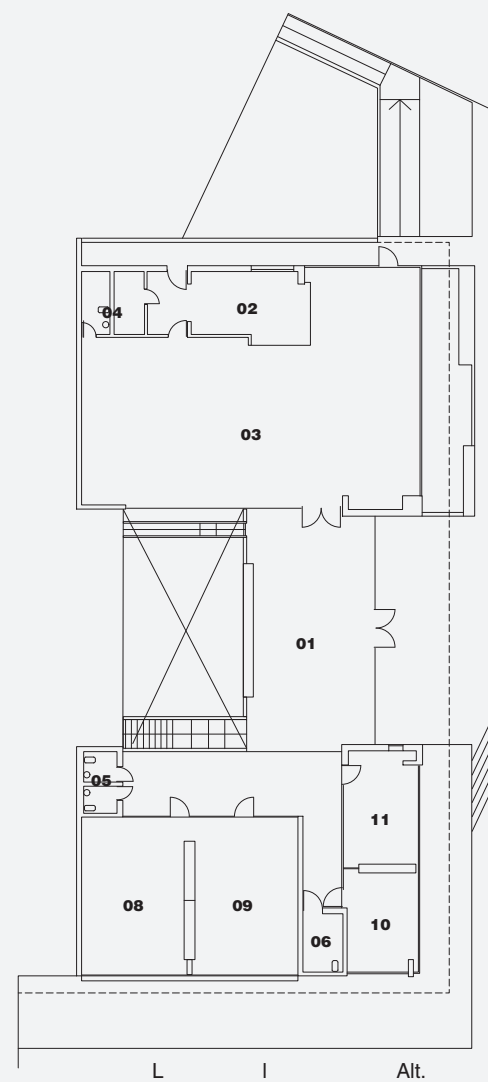

EDUCACIONAL

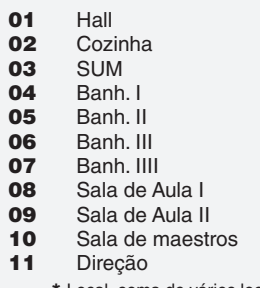

$11,58 \mathrm{~m} \quad 6,5 \mathrm{~m}$

$2,8 m$
$2,8 m$

$17,3 \mathrm{~m} \quad 8,3 \mathrm{~m}$

$3,2 \mathrm{~m} \quad 1,45 \mathrm{~m}$

$2,95 \mathrm{~m} \quad 2,05 \mathrm{~m} \quad 2,8 \mathrm{~m}$

$8,5 \mathrm{~m} \quad 2,05 \mathrm{~m} \quad 2,8 \mathrm{~m}$

$8 \mathrm{~m} \quad 5,25 \mathrm{~m} \quad 2,8 \mathrm{~m}$

$8 \mathrm{~m} \quad 5,25 \mathrm{~m} \quad 2,8 \mathrm{~m}$

$5,25 \mathrm{~m} \quad 3,6 \mathrm{~m} \quad 2,8 \mathrm{~m}$

$5,7 \mathrm{~m} \quad 3,6 \mathrm{~m} \quad 2,8 \mathrm{~m}$ 
CATÁLOGO DE EQUIPAMENTOS DSL

ETC 384 PLAN JUNTOS

Pav. 1 


\section{CATÁLOGO DE EQUIPAMENTOS DSL}

ETC 384 PLAN JUNTOS DSL DISSOLUÇÃO PROGRAMÁTICA

Educacional $953 \mathbf{m}^{2}$

Educacional $953 m^{2}$ 
CATÁLOGO DE EQUIPAMENTOS DSL

ETC 384 PLAN JUNTOS DSL DISSOLUÇÃO ESPACIAL

Área Construída $1609 \mathrm{~m}^{2}$

Área Exterior Coberta $498 \mathrm{~m}^{2}$

Pátios $653 \mathrm{~m}^{2}$

Terreno 2450m²

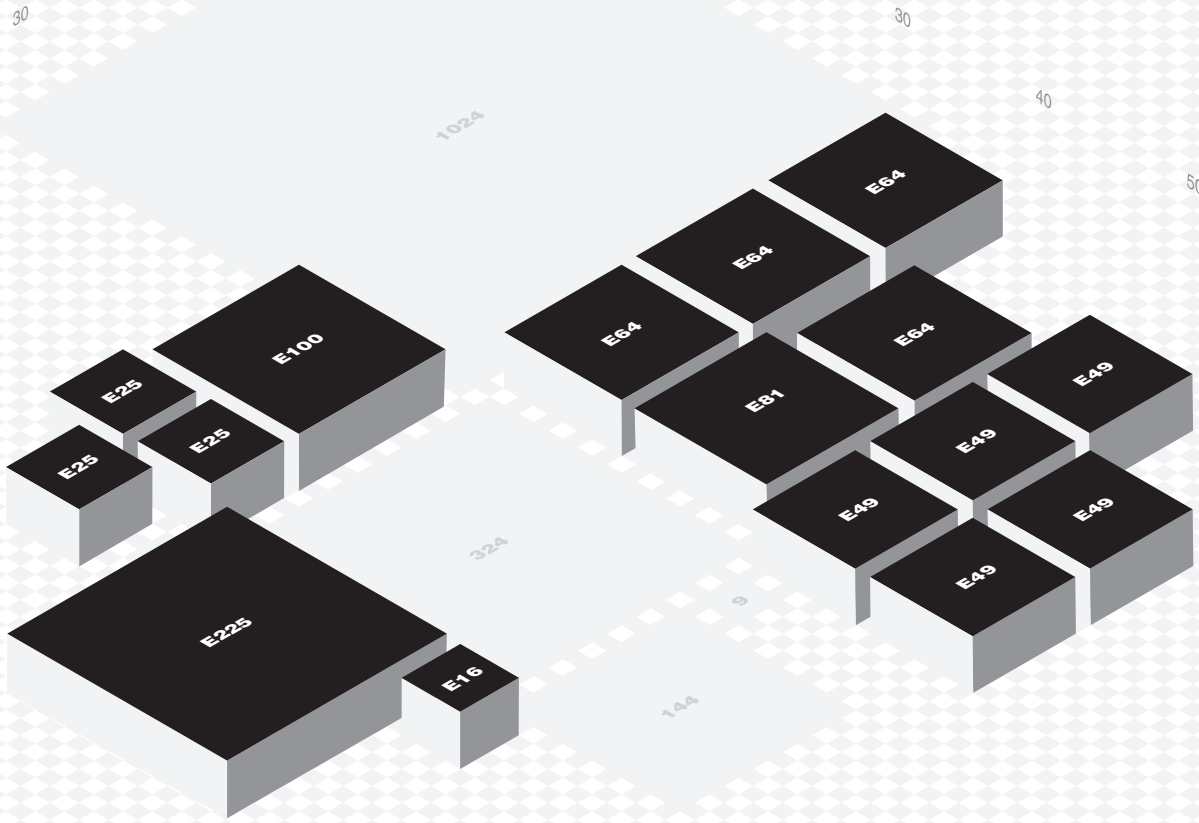


CATÁLOGO DE EQUIPAMENTOS DSL

ESCOLA PRIMARIA 178 CASAVALLE

Ano 1956

Área total $1860 \mathrm{~m}^{2}$

Autor sd

Localização Barrio Casavalle, Montevideo. UY.

Organização gestora ANEP

Organização responsável ANEP CEIP

Fonte IM REVISTA SAU 235 noviembre 1958
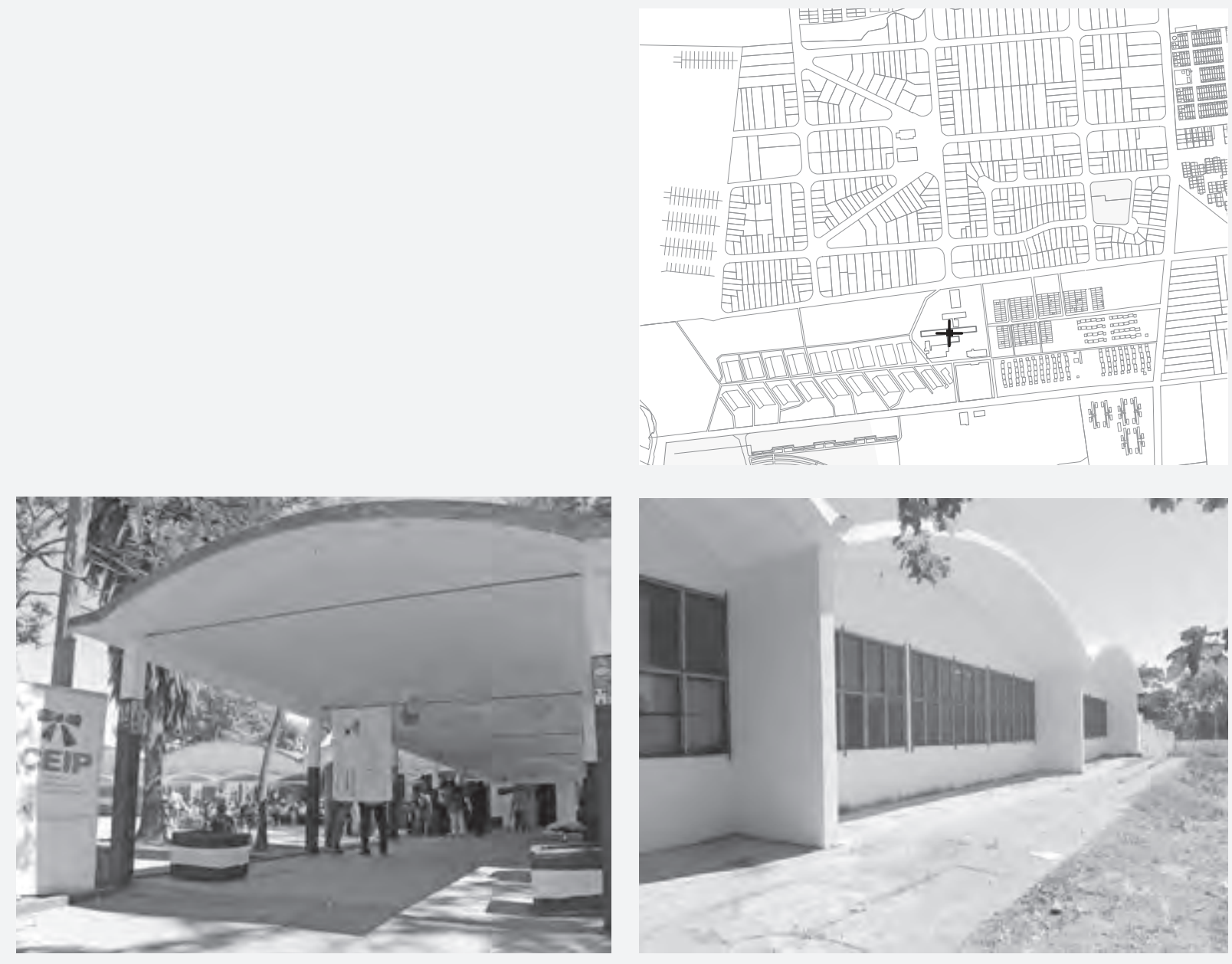
CATÁLOGO DE EQUIPAMENTOS DSL

ESCOLA PRIMARIA 178 CASAVALLE

Pav. Térreo
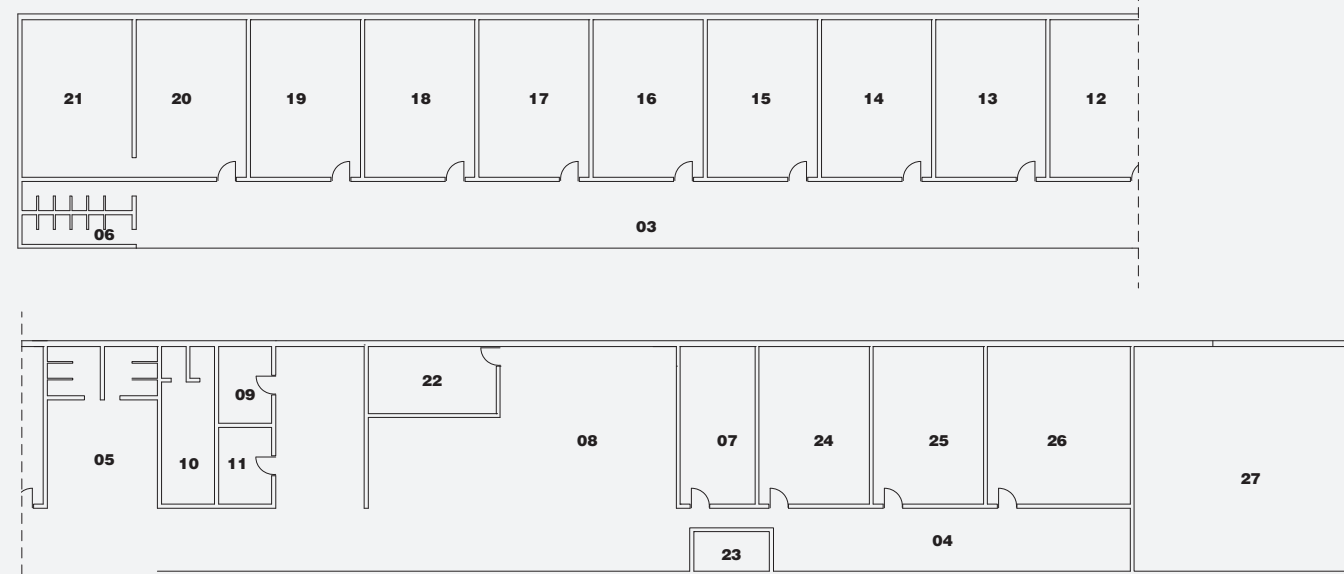

Área Exterior Coberta .... $\mathbf{m}^{2}$

Pátios $1435 \mathrm{~m}^{2}$

Ocupação de Solo $1860 \mathbf{m}^{2}$

Taxa Ocupaçấo de Solo $\mathbf{5 6 \%}$

Terreno $3300 \mathbf{m}^{2}$

Educação $1705 \mathbf{m}^{2}$

Esc. 1.500

EDUCACIONAL

$\begin{array}{lll}\text { L } & \text { I } & \text { Alt. } \\ 19,8 m & 11,8 m & 2,5 m \\ 23,2 m & 5,6 m & 2,5 m \\ 68,3 m & 3,2 m & 2,5 m \\ 18,3 m & 3,2 m & 2,5 m \\ 8,2 m & 5,6 m & 2,5 m \\ 5,6 m & 3,2 m & 2,5 m \\ 8 m & 3,8 m & 2,5 m \\ 15,65 m & 11,4 m & 2,5 m \\ 3,9 m & 2,7 m & 2,5 m \\ 8 m & 2,7 m & 2,5 m \\ 3,9 m & 2,7 m & 2,5 m \\ 8 m & 5,6 m & 2,5 m \\ 8 m & 5,6 m & 2,5 m \\ 8 m & 5,6 m & 2,5 m \\ 8 m & 5,6 m & 2,5 m \\ 8 m & 5,6 m & 2,5 m \\ 8 m & 5,6 m & 2,5 m \\ 8 m & 5,6 m & 2,5 m \\ 8 m & 5,6 m & 2,5 m \\ 8 m & 5,6 m & 2,5 m \\ 8 m & 5,6 m & 2,5 m \\ 6,5 m & 3,4 m & 2,5 m \\ 3,4 m & 2,5 m & 2,5 m \\ 8 m & 5,6 m & 2,5 m \\ 8 m & 5,6 m & 2,5 m \\ 8 m & 7,25 m & 2,5 m \\ 11,4 m & 10,8 m & 2,5 m\end{array}$

Sup.

DSL

$233,6 \mathrm{~m}^{2}$

$129,9 \mathrm{~m}^{2}$
$218,5 \mathrm{~m}^{2}$

$58,5 \mathrm{~m}^{2}$

$45,9 \mathrm{~m}^{2}$

$17,9 \mathrm{~m}^{2}$

$30,4 \mathrm{~m}^{2}$

$178,4 \mathrm{~m}^{2}$

$10,5 \mathrm{~m}^{2}$

$21,6 \mathrm{~m}^{2}$

$10,53 \mathrm{~m}^{2}$

$44,8 \mathrm{~m}^{2}$

$44,8 \mathrm{~m}^{2}$

$44,8 \mathrm{~m}^{2}$

$44,8 \mathrm{~m}^{2}$

$44,8 \mathrm{~m}^{2}$

$44,8 \mathrm{~m}^{2}$

$44,8 \mathrm{~m}^{2}$

$44,8 \mathrm{~m}^{2}$

$44,8 \mathrm{~m}^{2}$

$44,8 \mathrm{~m}^{2}$

$44,8 \mathrm{~m}^{2}$

$22,1 \mathrm{~m}^{2}$

$8,5 \mathrm{~m}^{2}$

$44,8 \mathrm{~m}^{2}$

$44,8 \mathrm{~m}^{2}$

$58 \mathrm{~m}^{2}$

$123,12 \mathrm{~m}^{2}$ 
CATÁLOGO DE EQUIPAMENTOS DSL

ESCOLA 178 DSL DISSOLUÇÃO PROGRAMÁTICA

Educacional $1705 \mathbf{m}^{2}$

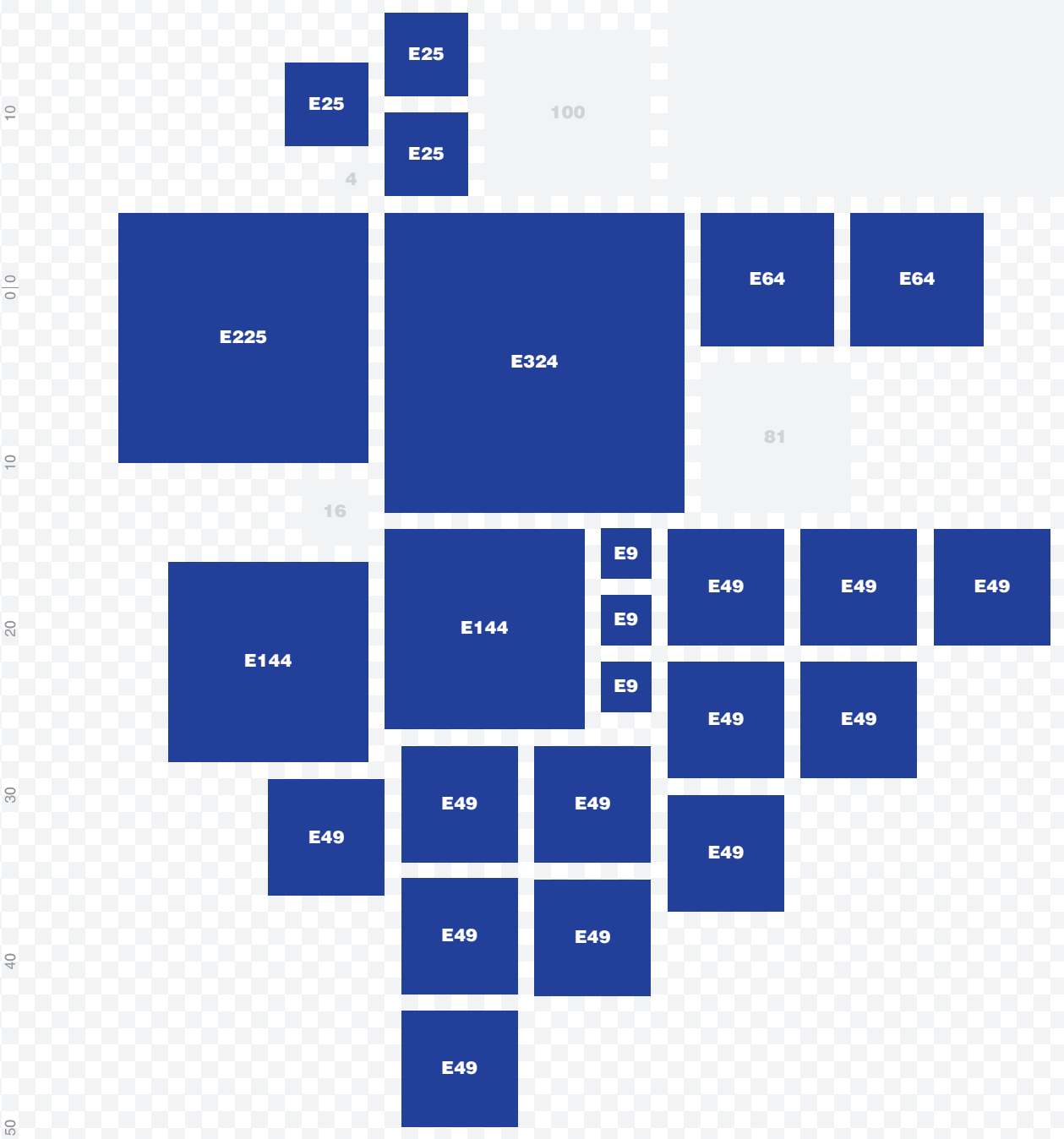


CATÁLOGO DE EQUIPAMENTOS DSL

ESCOLA 178 DSL DISSOLUÇÃO ESPÅCIAL

Área Construída $1860 \mathrm{~m}^{2}$

Área Exterior Coberta ---m²

Pátios $1435 \mathrm{~m}^{2}$

Terreno $\mathbf{3 3 0 0 \mathbf { m } ^ { 2 }}$

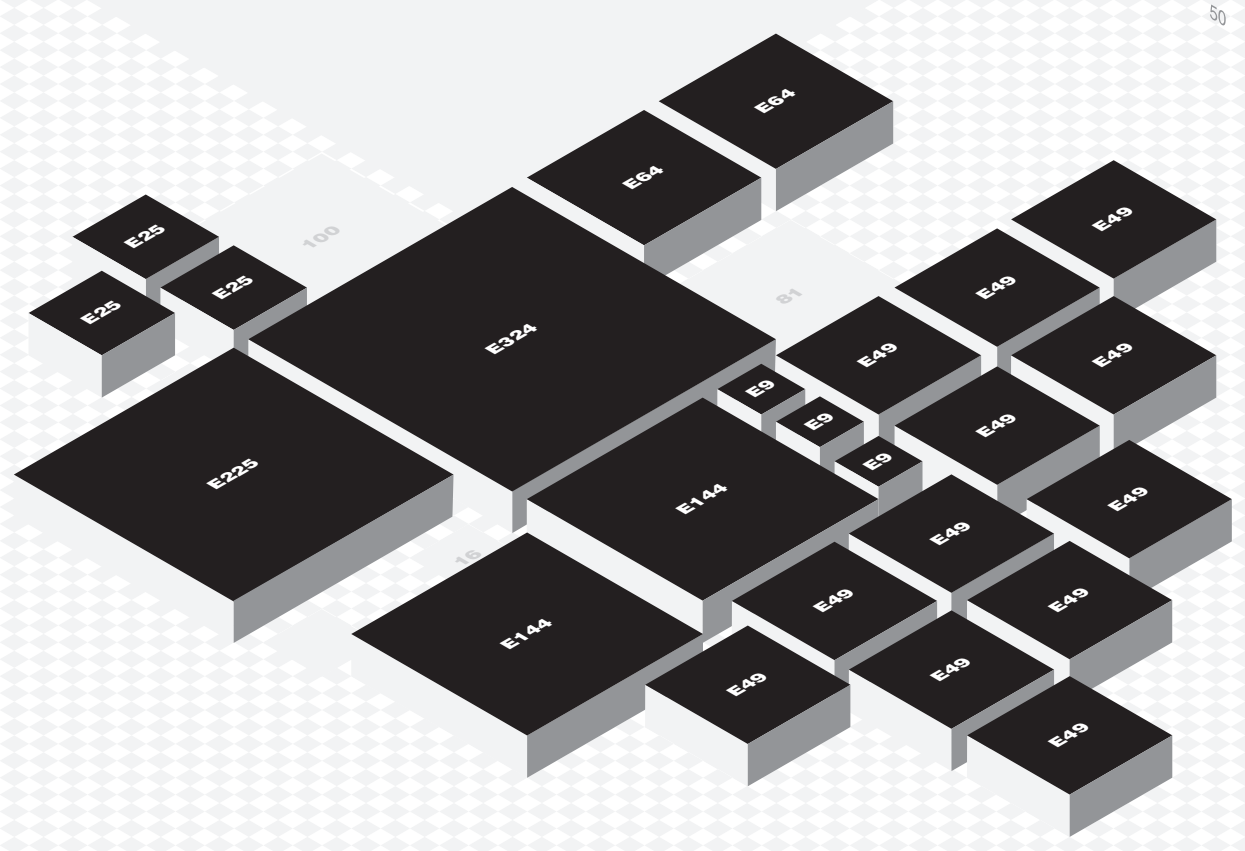




\section{CATÁLOGO DE EQUIPAMENTOS DSL}

ENSINO FUNDAMENTAL E MÉDIO. CIUDAD DEL PLATA

Ano 2013

Área total $2462 \mathrm{~m}^{2}$

Autor PAEMFE - Arq. Bernardo Martin

Localização Santa Lucia. UY.

Organização gestora CND

Organização responsável ANEP CES

Fonte Premio Vilamajó
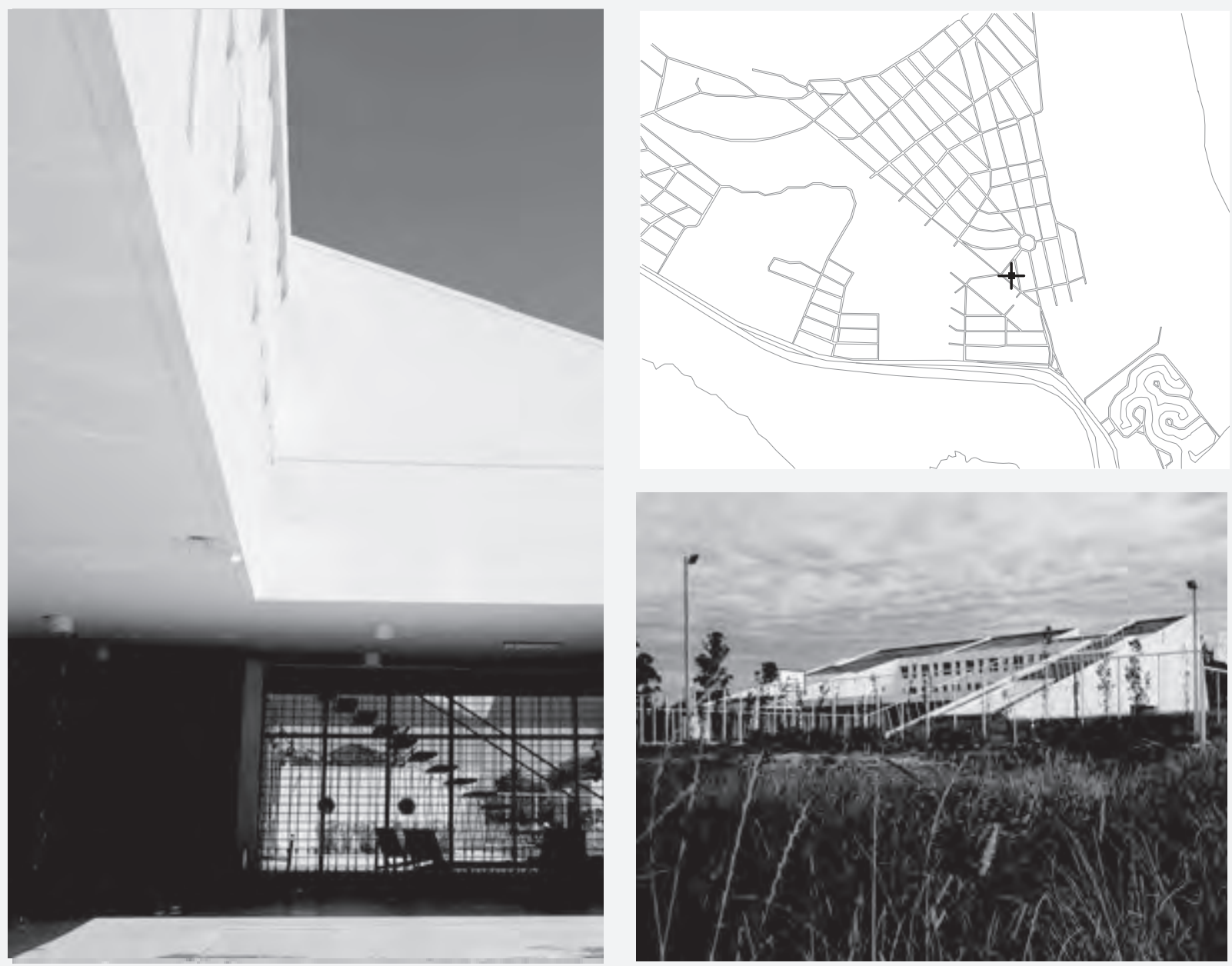
CATÁLOGO DE EQUIPAMENTOS DSL

ENSINO FUNDAMENTAL E MÉDIO. CIUDAD DEL PLATA

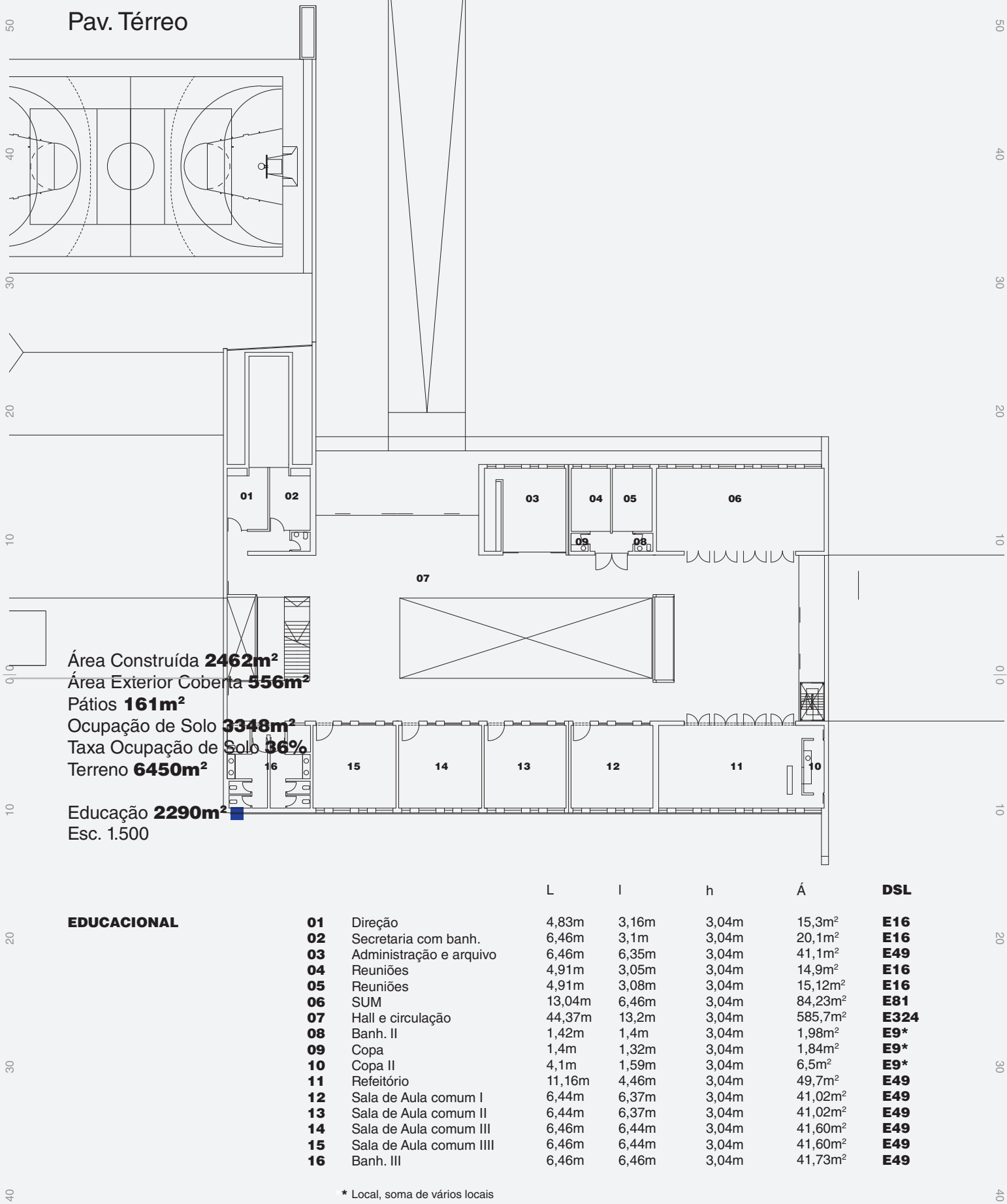


CATÁLOGO DE EQUIPAMENTOS DSL

ENSINO FUNDAMENTAL E MÉDIO. CIUDAD DEL PLATA

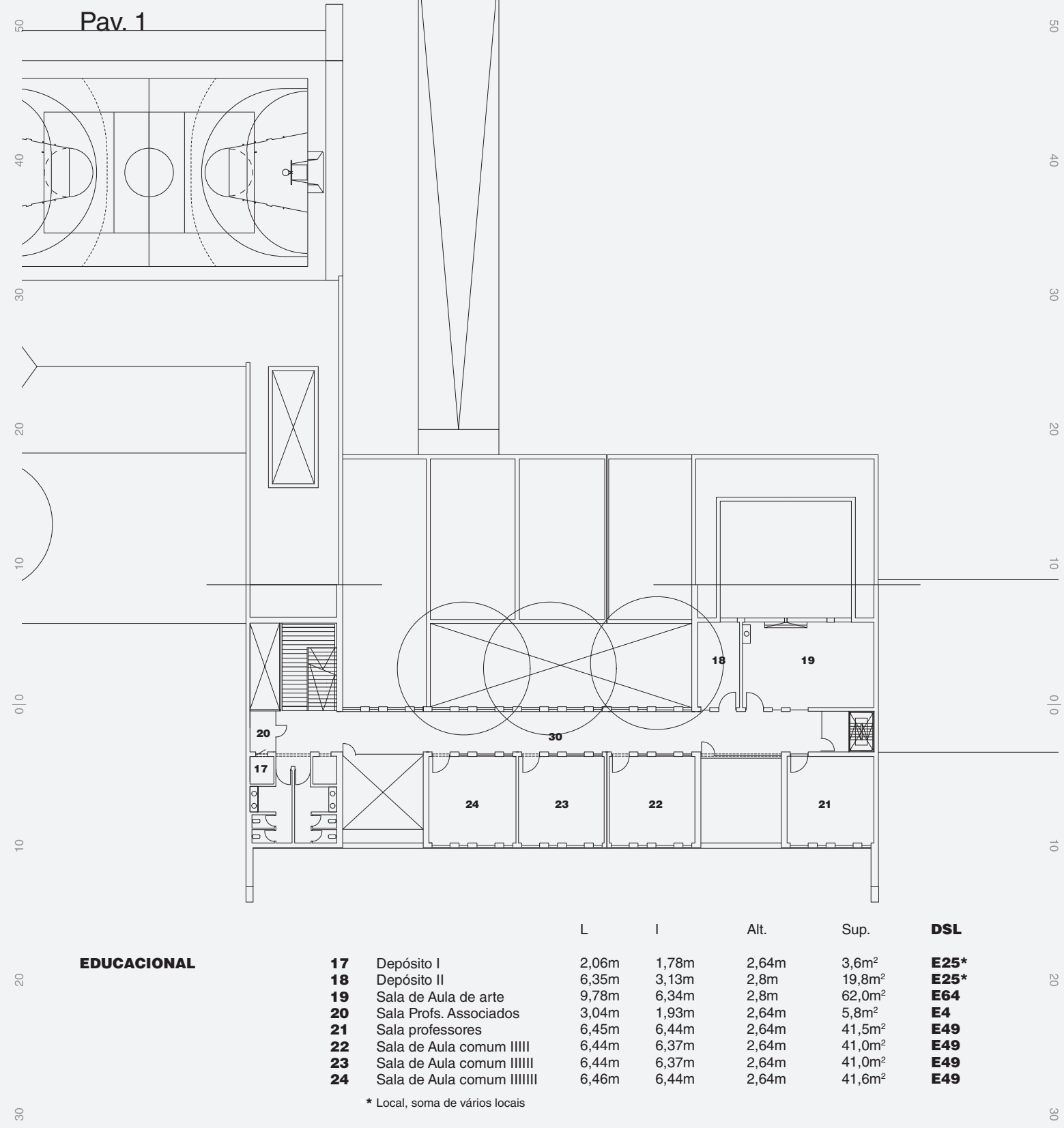


CATÁLOGO DE EQUIPAMENTOS DSL

ENSINO FUNDAMENTAL E MÉDIO. CIUDAD DEL PLATA

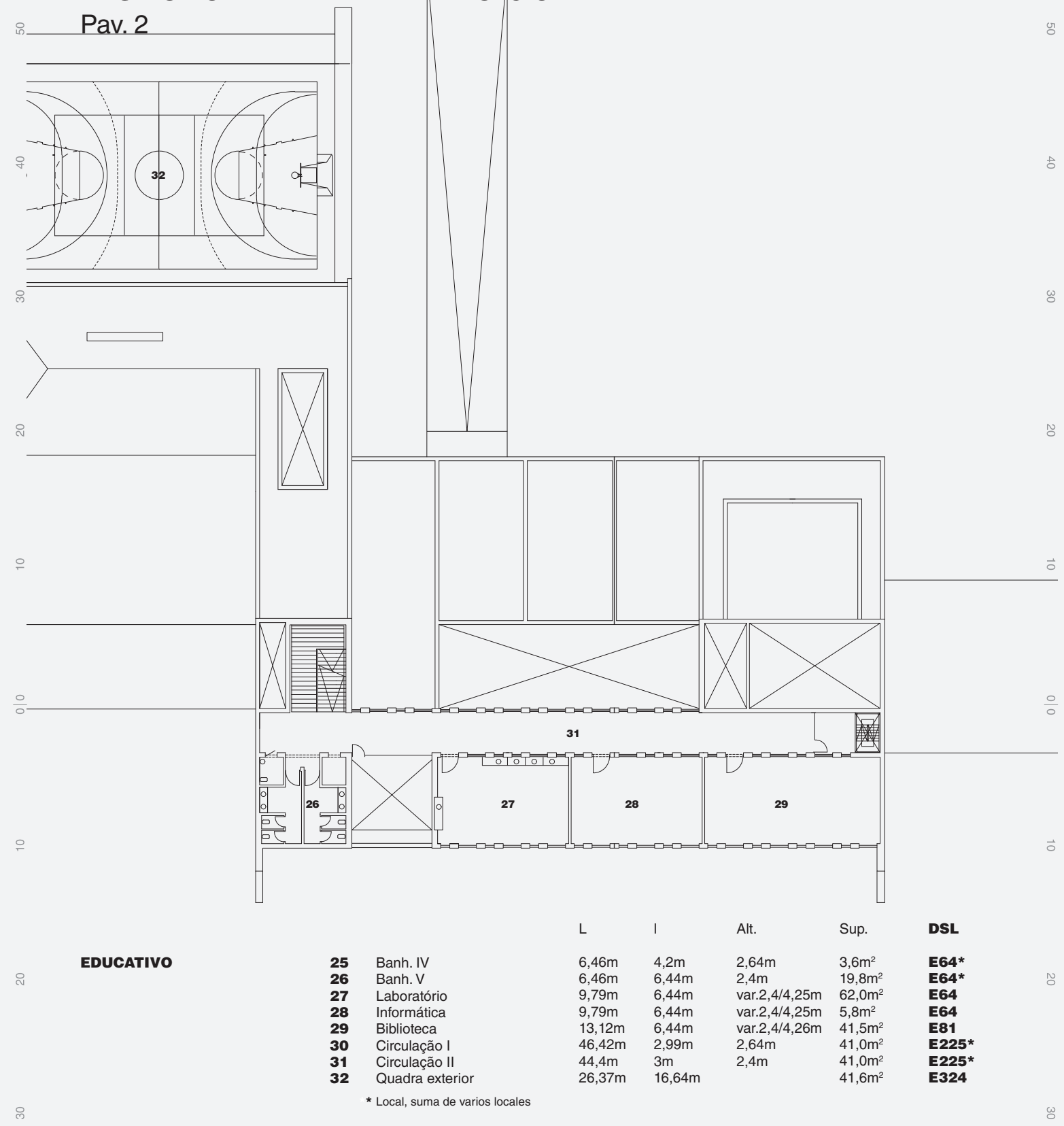




\section{CATÁLOGO DE EQUIPAMENTOS DSL}

ENSINO FUNDAMENTAL E MÉDIO DSL DISSOLUÇÃO PROGRAMÁTICA Educacional $2290 \mathbf{m}^{2}$

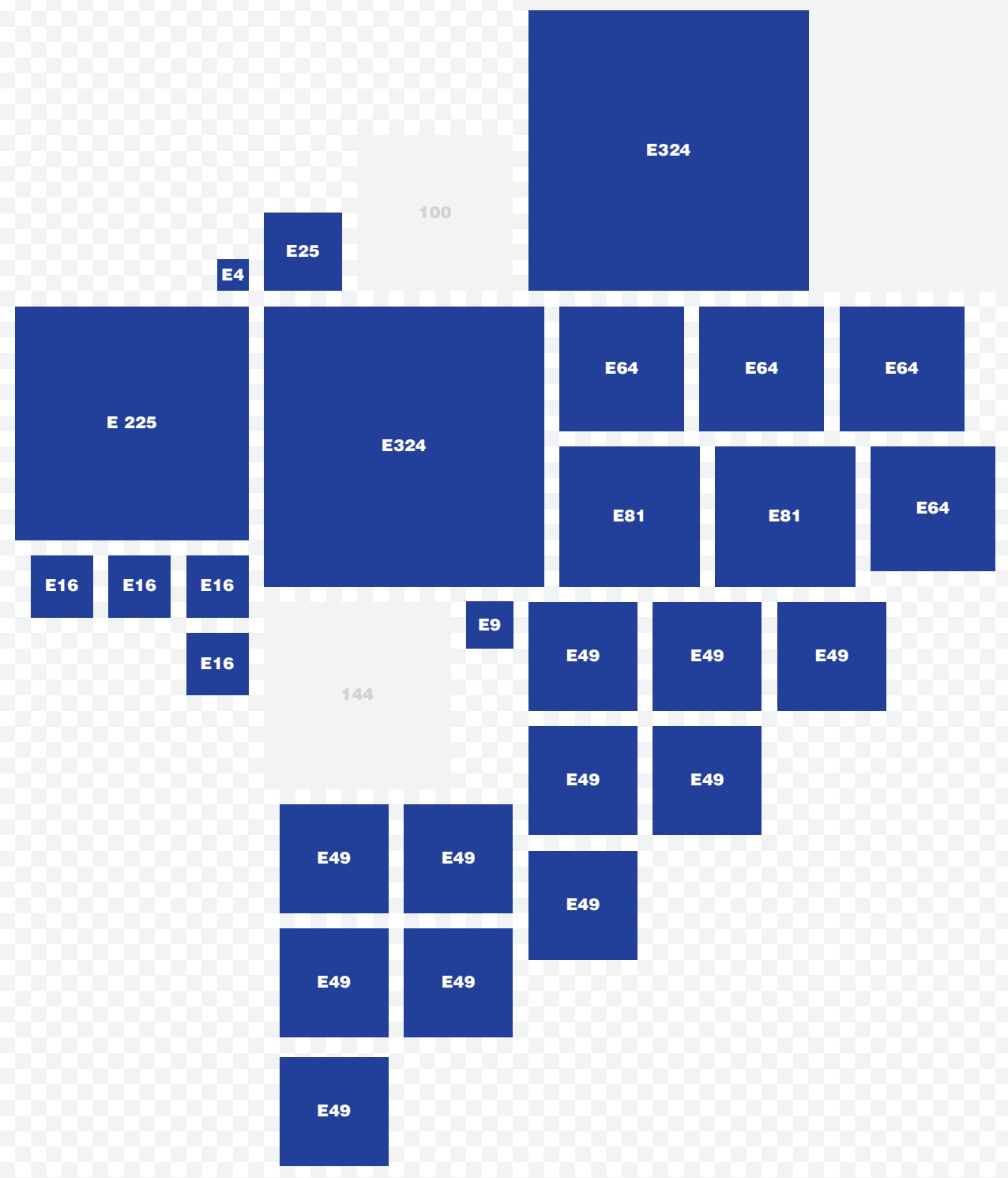




\section{CATÁLOGO DE EQUIPAMENTOS DSL}

ENSINO FUNDAMENTAL E MÉDIO DSL DISSOLUÇÃO ESPACIAL Área Construída $\mathbf{2 4 6 2 m ^ { 2 }}$

Área Exterior Coberta $556 \mathbf{m}^{2}$

Pátios $161 \mathrm{~m}^{2}$

Terreno 6450m

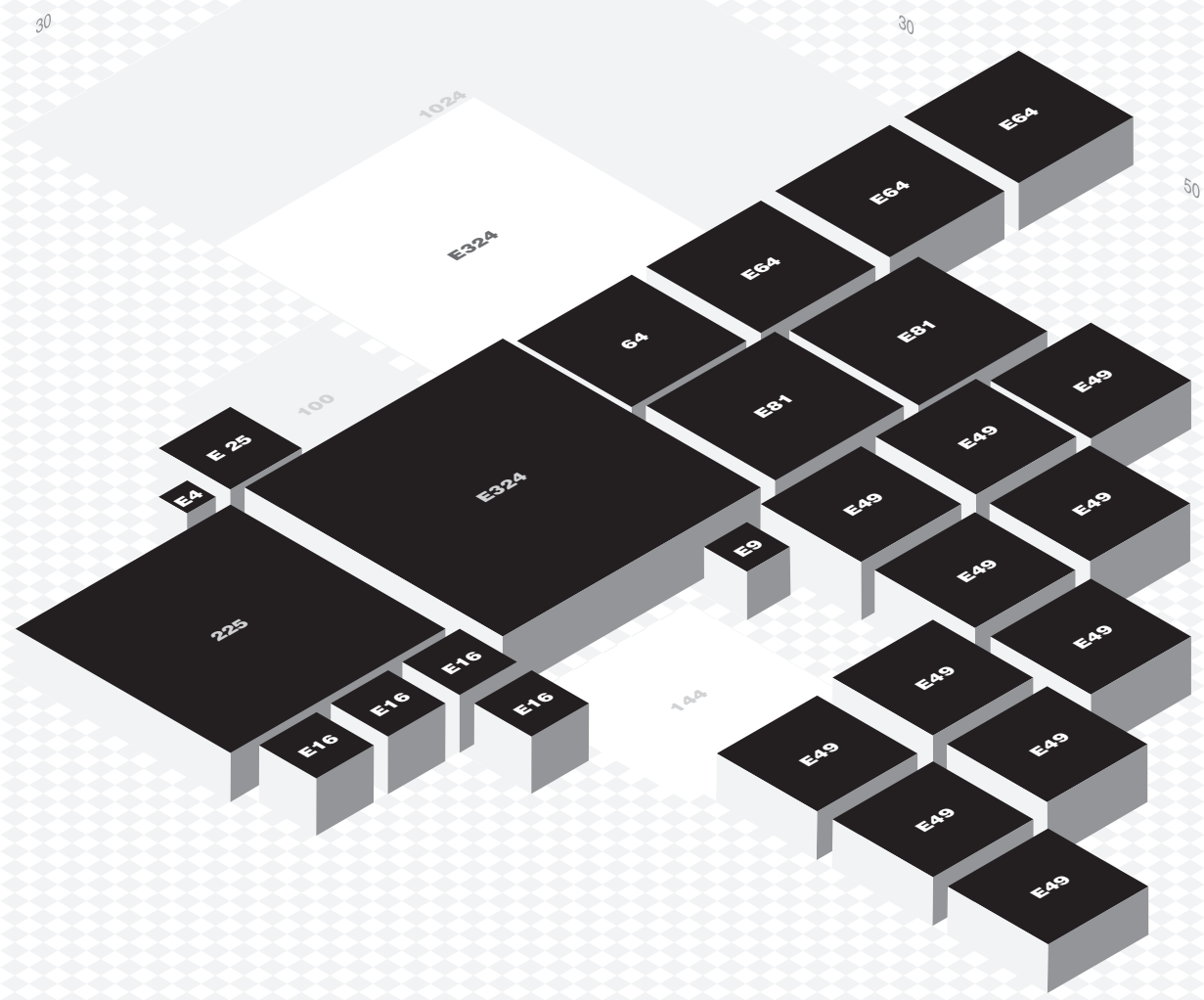


CATÁLOGO DE EQUIPAMENTOS DSL

POLO TECNOLOGICO MONTEVIDEO

Ano PROJETO 2017

Área total $\mathbf{2 7 2 7 \mathbf { m } ^ { 2 }}$

Autor PAEMFE

Localização PROYECTO TIPO Exemplo Barrio Pablo Estramin, Montevideo. UY.

Organização gestora CND

Organização responsável ANEP CETP

Fonte CND

https://www.cnd.org.uy/index.php/sala-de-prensa/1780-segundo-llamado-para -proyectos-ppp-en-infraestructura-educativa
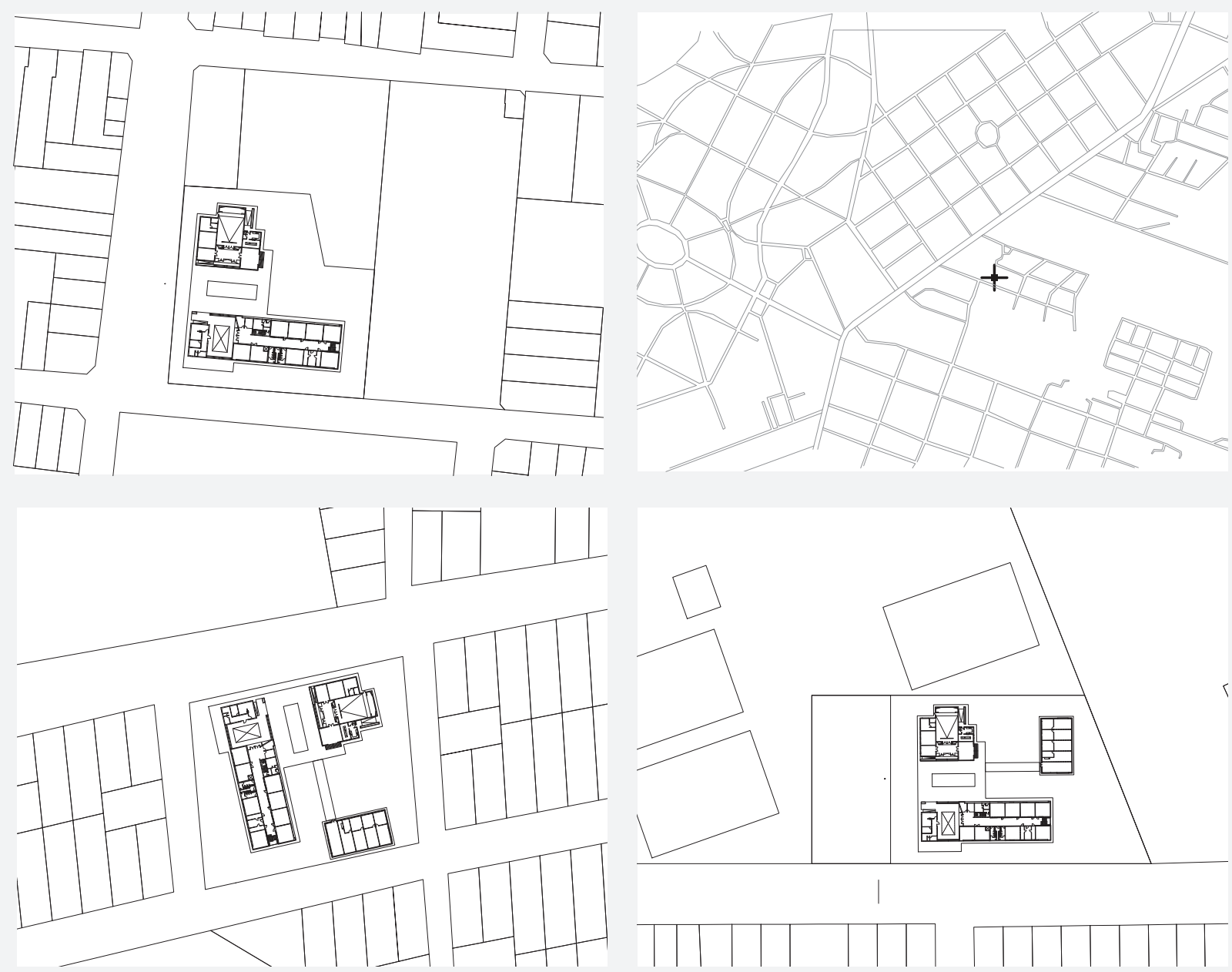
CATÁLOGO dE EQUIPAMENTOS DSL

POLO TECNOLOGICO MONTEVIDEO - ATELIÊ Pav. Térreo

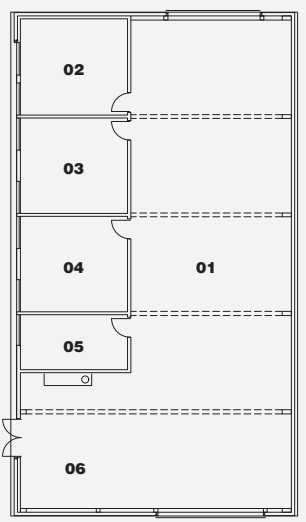

Área Construída $\mathbf{3 7 3 m ^ { 2 }}$

Área Exterior Coberta ----m²

Pátios ---m²

Ocupação de Solo $\mathbf{3 7 3} \mathbf{m}^{2}$

Taxa Ocupação de Solo $\mathbf{5 7 \%}$

Terreno $\mathbf{6 5 0 \mathrm { m } ^ { 2 }}$

Educação $\mathbf{3 7 5} \mathbf{m}^{2}$

Esc. 1.500

EDUCACIONAL

Sala de trabalho

Laboratório hidráulico

Simulador mecânico

Laboratório eletrônico

Depósito

Bancas de trabalho

L

$25,6 m$

$5,45 \mathrm{~m} \quad 4,87 \mathrm{~m}$

$5,45 \mathrm{~m} \quad 4,87 \mathrm{~m}$

$5,45 \mathrm{~m} \quad 4,87 \mathrm{~m}$

$5,45 \mathrm{~m} \quad 2,87 \mathrm{~m}$

$13,77 \mathrm{~m} \quad 4,8 \mathrm{~m}$
DSL

E225

E25

E25

E25

E16

E64 
CATÁLOGO dE EQUIPAMENTOS DSL

POLO TECNOLOGICO MONTEVIDEO - SALAS DE AULA

Pav. Térreo

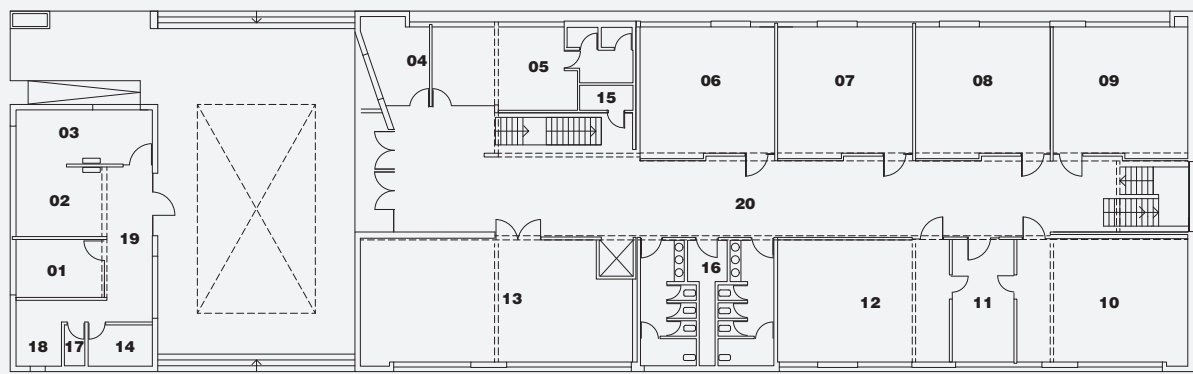

Área Construída $1880 \mathrm{~m}^{2}$

Área Exterior Coberta $183 \mathrm{~m}^{2}$

Pátios ---m²

Ocupação de Solo $1100 \mathbf{m}^{2}$

Taxa Ocupação de Solo 65\%

Terreno 1600m²

Educação $1320 \mathbf{m}^{2}$

Esc. 1.500

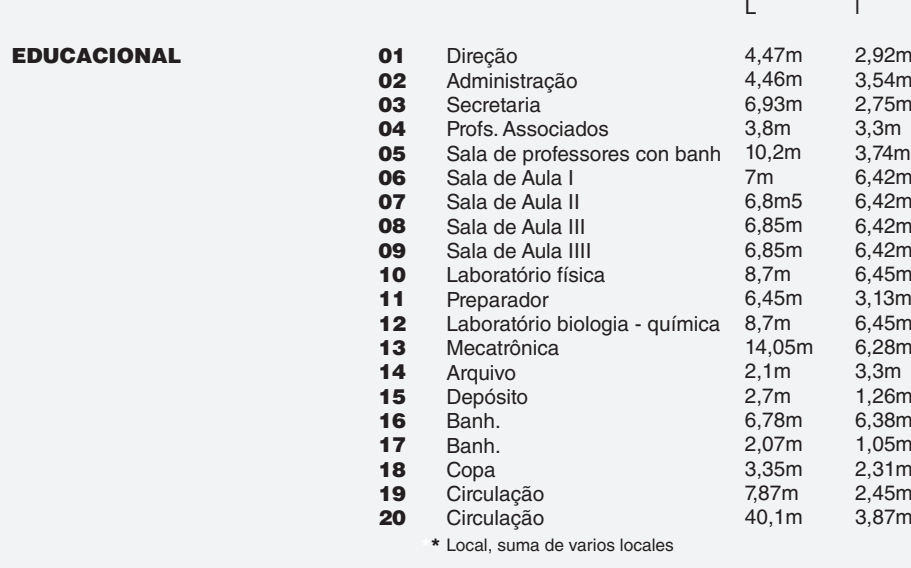

\begin{tabular}{|c|c|c|}
\hline Alt. & Sup. & DSL \\
\hline $3 m$ & $13,1 \mathrm{~m}^{2}$ & E16 \\
\hline $3 m$ & $15,78 \mathrm{~m}^{2}$ & E16 \\
\hline $3 m$ & $19,15 \mathrm{~m}^{2}$ & E16 \\
\hline $3 m$ & $12,54 \mathrm{~m}^{2}$ & E16 \\
\hline $3 m$ & $38,1 \mathrm{~m}^{2}$ & E49 \\
\hline $3 m$ & $44,94 \mathrm{~m}^{2}$ & E49 \\
\hline $3 m$ & $43,9 m^{2}$ & E49 \\
\hline $3 m$ & $43,9 \mathrm{~m}^{2}$ & E49 \\
\hline $3 m$ & $43,9 m^{2}$ & E49 \\
\hline $3 m$ & $56,1 \mathrm{~m}^{2}$ & E81* \\
\hline $3 m$ & $20,1 \mathrm{~m}^{2}$ & E81* \\
\hline $3 m$ & $56,1 \mathrm{~m}^{2}$ & E49 \\
\hline $3 m$ & $88,2 m^{2}$ & E81 \\
\hline $3 m$ & $6,9 \mathrm{~m}^{2}$ & E9* \\
\hline $3 m$ & $3,4 \mathrm{~m}^{2}$ & E9* \\
\hline $3 m$ & $43,2 m^{2}$ & E49* \\
\hline $3 m$ & $2,17 \mathrm{~m}^{2}$ & E49* \\
\hline $3 m$ & $7,73 m^{2}$ & E9 \\
\hline $3 m$ & $19,28 m^{2}$ & E144 \\
\hline $3 m$ & $155,18 \mathrm{~m}^{2}$ & E144 \\
\hline
\end{tabular}


CATÁLOGO DE EQUIPAMENTOS DSL

POLO TECNOLOGICO MONTEVIDEO - SALAS DE AULA

Pav. 1

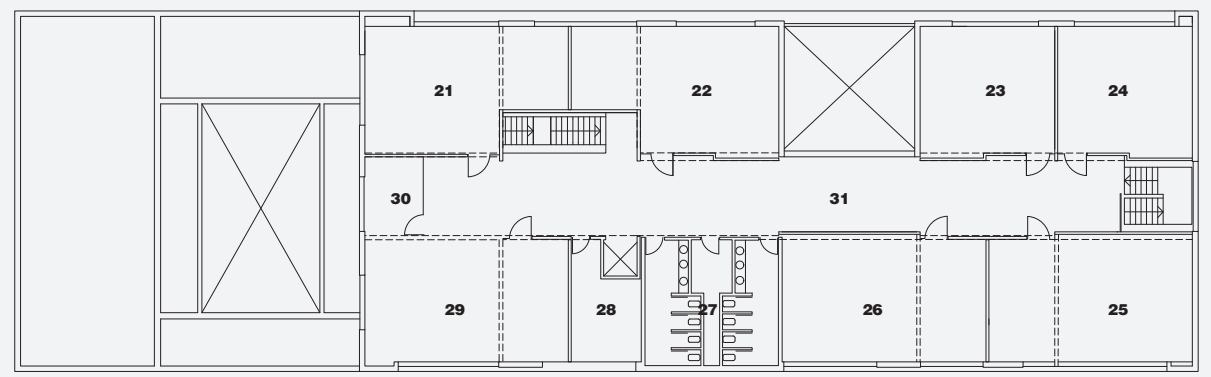

EDUCACIONAL

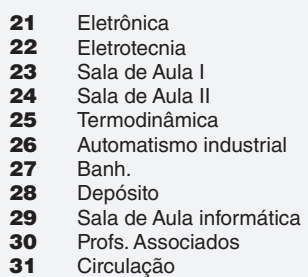

L

$10,33 \mathrm{~m} \quad 6,4 \mathrm{~m}$

$10,33 \mathrm{~m} \quad 6,4 \mathrm{~m}$

$6,8 \mathrm{~m} \quad 6,4 \mathrm{~m}$

$6,8 \mathrm{~m} \quad 6,4 \mathrm{~m}$

$10,33 \mathrm{~m} \quad 6,47 \mathrm{~m}$

$10,33 \mathrm{~m} \quad 6,47 \mathrm{~m}$

$6,78 \mathrm{~m} \quad 6,4 \mathrm{~m}$

$6,21 \mathrm{~m} \quad 3,55 \mathrm{~m}$

$10,33 \mathrm{~m} \quad 6,47 \mathrm{~m}$

$4 \mathrm{~m} \quad 2,95 \mathrm{~m}$

$\begin{array}{ll}4 \mathrm{~m} & 2,95 \mathrm{~m} \\ 38, \mathrm{~m} 9 & 3,6 \mathrm{~m}\end{array}$
Alt.
$3 m$
$3 m$
$3 m$
$3 m$
$3 m$
$3 m$
$3 m$
$3 m$
$3 m$
$3 m$
$3 m$
$3 m$

Sup.

DSL

$41,6 \mathrm{~m}^{2}$

$41,6 \mathrm{~m}^{2}$
$41,6 \mathrm{~m}^{2}$

$49,28 m^{2} \quad$ E49

$49,8 m^{2} \quad$ E49

$109,9 \mathrm{~m}^{2} \quad$ E100

$32 \mathrm{~m}^{2} \quad \mathbf{E 2 5}$

$31,6 \mathrm{~m}^{2}$

$42,1 \mathrm{~m}^{2}$

$6,63 \mathrm{~m}^{2}$

$140,04 \mathrm{~m}^{2} \quad \mathbf{E 1 4 4}$ 
CATÁLOGO DE EQUIPAMENTOS DSL

POLO TECNOLOGICO MONTEVIDEO - AUDITÓRIO

Pav. Térreo

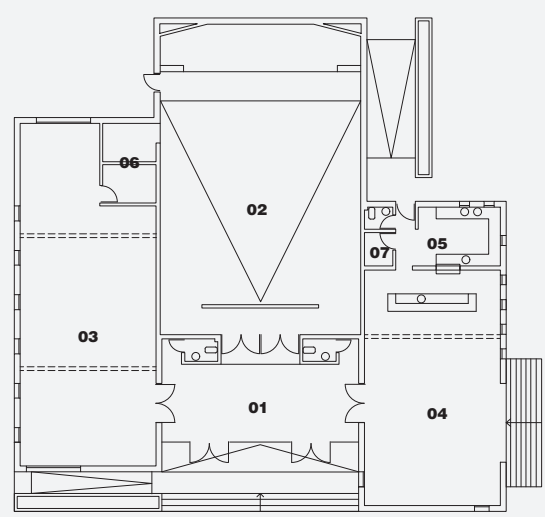

Área Construída $\mathbf{4 7 4 m ^ { 2 }}$

Área Exterior Coberta $\mathbf{5 0 \mathbf { m } ^ { 2 }}$

Pátios ---m²

Ocupação de Solo $\mathbf{5 6 3 \mathbf { m } ^ { 2 }}$

Taxa Ocupação de Solo $46 \%$

Terreno $1020 \mathbf{m}^{2}$

Educação $\mathbf{4 4 5} \mathrm{m}^{\mathbf{2}}$

Esc. 1.500

EDUCACIONAL

$\begin{array}{ll}01 & \text { Foyer com Banh. } \\ 02 & \text { Auditório } \\ 03 & \text { Biblioteca } \\ 04 & \text { Cafeteria } \\ 05 & \text { Cozinha com Banh. } \\ 06 & \text { Depósitos } \\ 07 & \text { Depósito } \\ 08 & \text { Banh. } \\ & \text { * }\end{array}$

$\begin{array}{ll}\mathrm{L} & \text { । } \\ 10 \mathrm{~m} & 5,26 \mathrm{~m} \\ 15,78 \mathrm{~m} & 10,2 \mathrm{~m} \\ 17,4 \mathrm{~m} & 6,9 \mathrm{~m} \\ 12 \mathrm{~m} & 6,9 \mathrm{~m} \\ 5,4 \mathrm{~m} & 3 \mathrm{~m} \\ 4 \mathrm{~m} & 2,7 \mathrm{~m} \\ 1,7 \mathrm{~m} & 1,43 \mathrm{~m} \\ 1,43 \mathrm{~m} & 1,14 \mathrm{~m}\end{array}$

* Local, soma de vários locais

$\begin{array}{ll}\text { Alt. } & \text { Sup. } \\ \text { 3m } & 52,6 \mathrm{~m}^{2} \\ \text { var. 3,20/3,01m } & 160,9 \mathrm{~m}^{2} \\ 3 \mathrm{~m} & 120,06 \mathrm{~m}^{2} \\ 3 \mathrm{~m} & 82,8 \mathrm{~m}^{2} \\ 3 \mathrm{~m} & 16,2 \mathrm{~m}^{2} \\ 3 \mathrm{~m} & 10,8 \mathrm{~m}^{2} \\ 3 \mathrm{~m} & 2,4 \mathrm{~m}^{2} \\ 3 \mathrm{~m} & 1,6 \mathrm{~m}^{2}\end{array}$

DSL

E49

E144

E144

E81

E16

E16*

E4 


\section{CATÁlOGO DE EQUIPAMENTOS DSL}

POLO TECNOLOGICO MONTEVIDEO

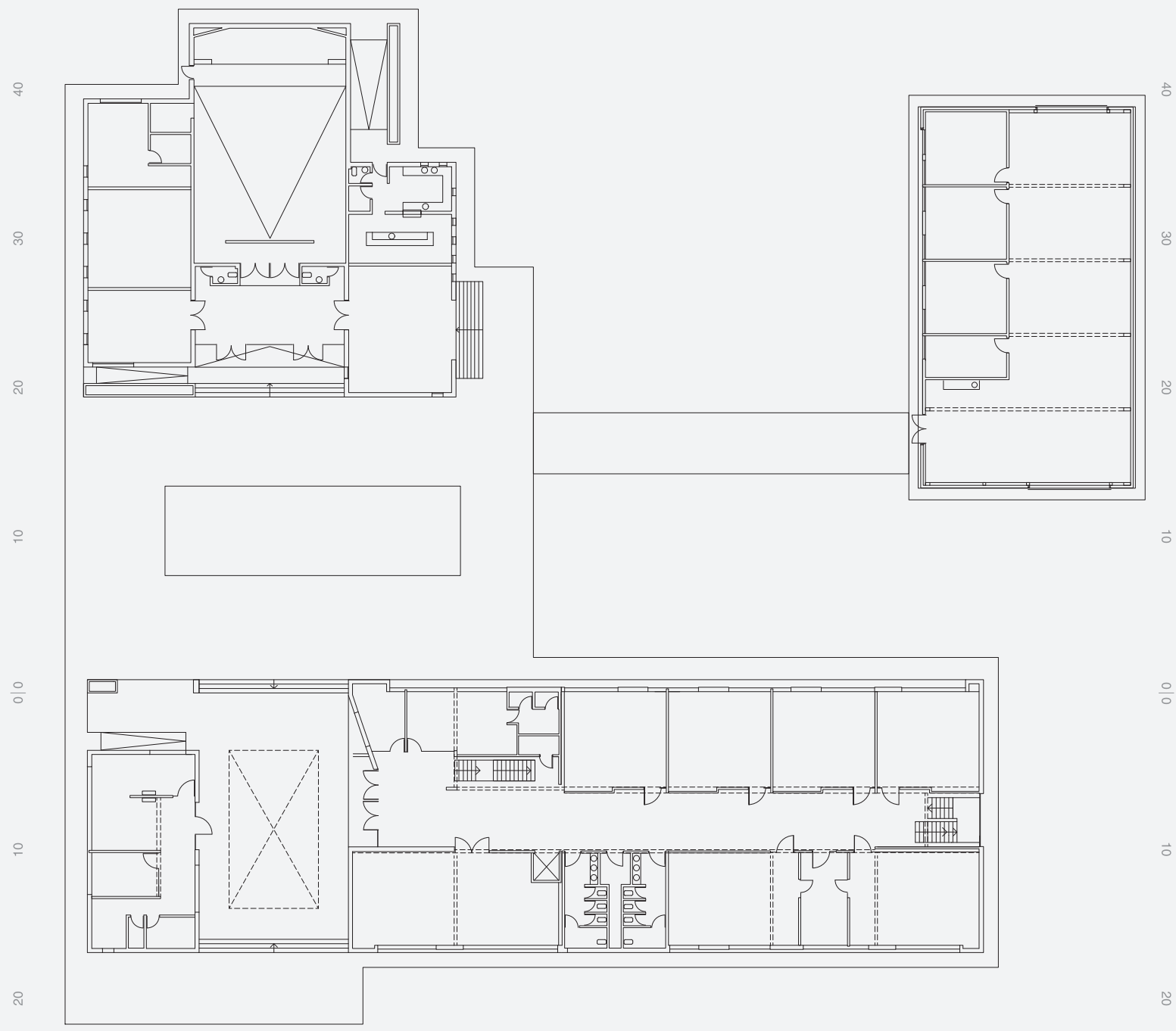

Área Construída $\mathbf{2 7 2 7 \mathbf { m } ^ { 2 }}$

Área Exterior Coberta $183 \mathrm{~m}^{2}$

Pátios 855m²

Ocupação de Solo $\mathbf{3 1 8 0 \mathbf { m } ^ { 2 }}$

Taxa Ocupação de Solo $\mathbf{3 8} \%$

Terreno $4900 \mathrm{~m}^{2}$

Educação 2140m²

Esc. 1.500 
CATÁLOGO DE EQUIPAMENTOS DSL

POLO TECNOLOGICO MONTEVIDEO DSL DISSOLUÇÃO PROGRAMÁTICA Educacional $2140 \mathbf{m}^{2}$

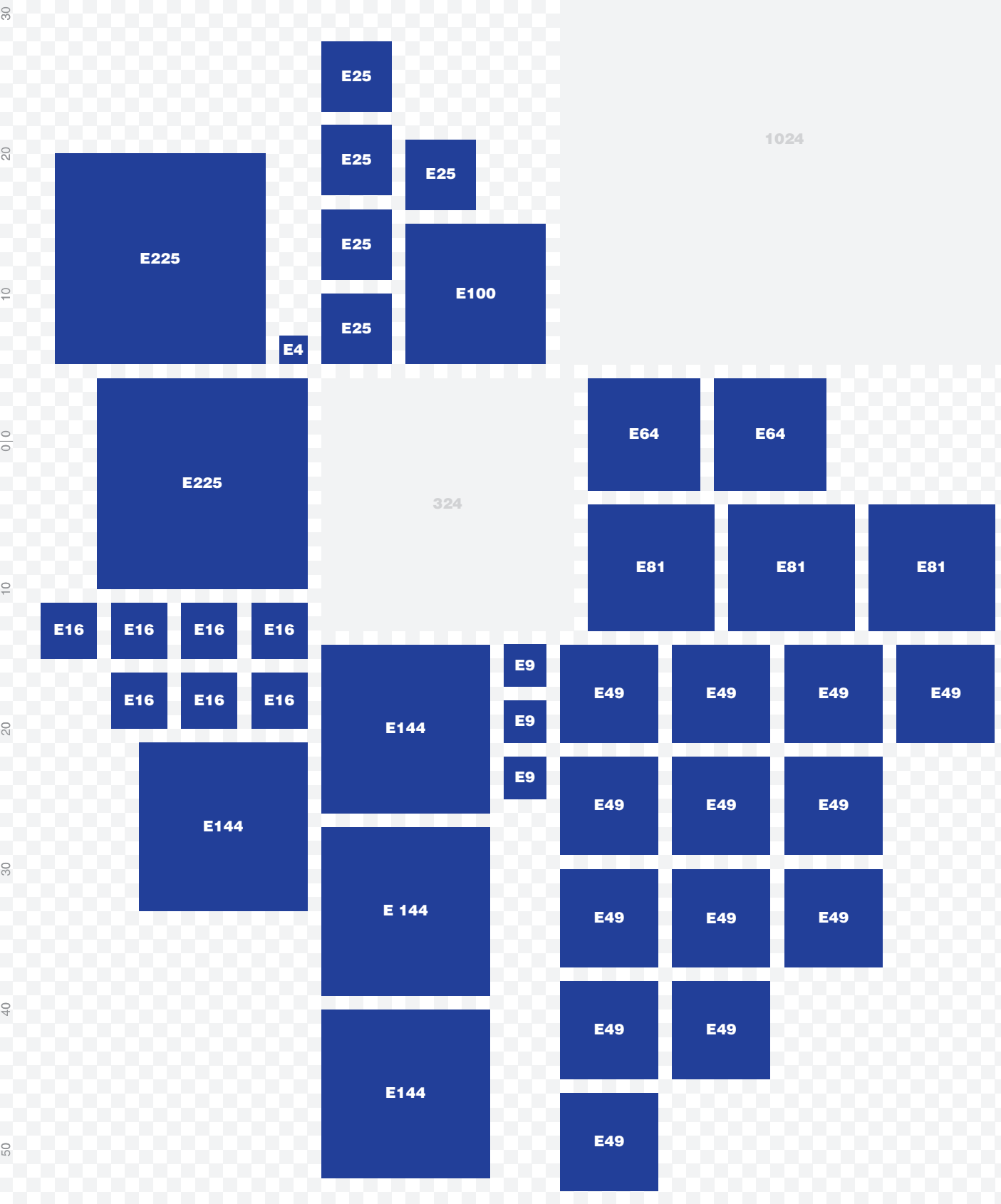




\section{CATÁLOGO DE EQUIPAMENTOS DSL}

POLO TECNOLOGICO MONTEVIDEO DSL DISSOLUÇÃO ESPACIAL Área Construída $\mathbf{2 7 2 7 \mathbf { m } ^ { 2 }}$

Área Exterior Coberta $\mathbf{1 8 3 m ^ { 2 }}$

Pátios $\mathbf{8 5 5 m ^ { 2 }}$

Terreno 4900m²

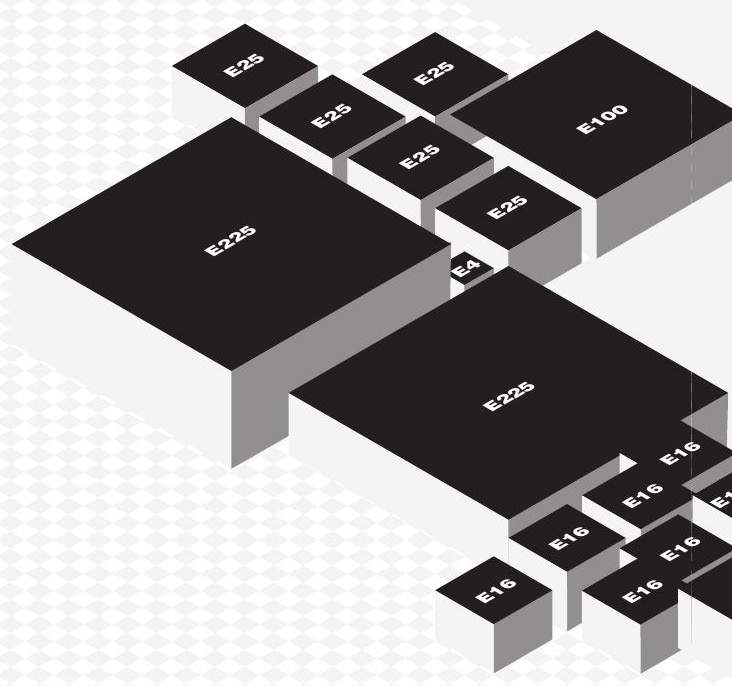




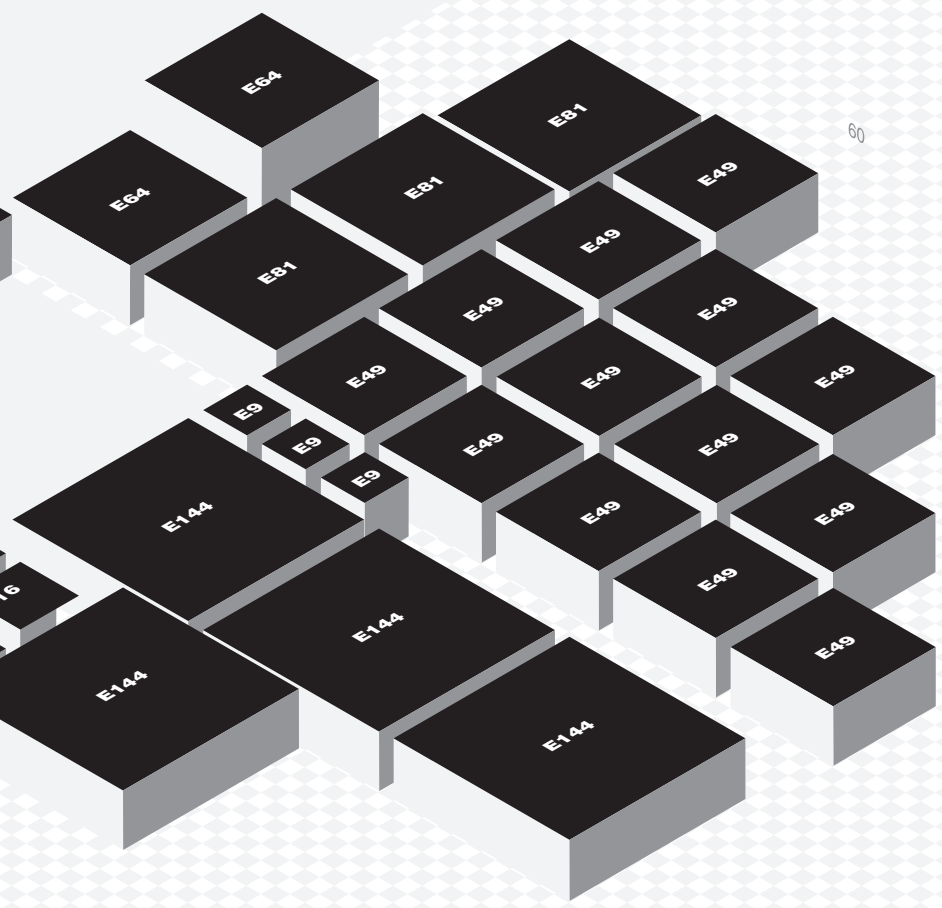




\section{CATÁLOGO DE EQUIPAMENTOS DSL}

\section{PROTOTIPO EDUCACIONAL}

Ano 1994

Área total $3214 \mathrm{~m}^{2}$

Autor PRIS Arq. Antonio Gervaz

Localização Melo, Uy.

Organização gestora PRIS

Organização responsável ANEP CES

Fonte Revista EI Arqa 17. 1996.
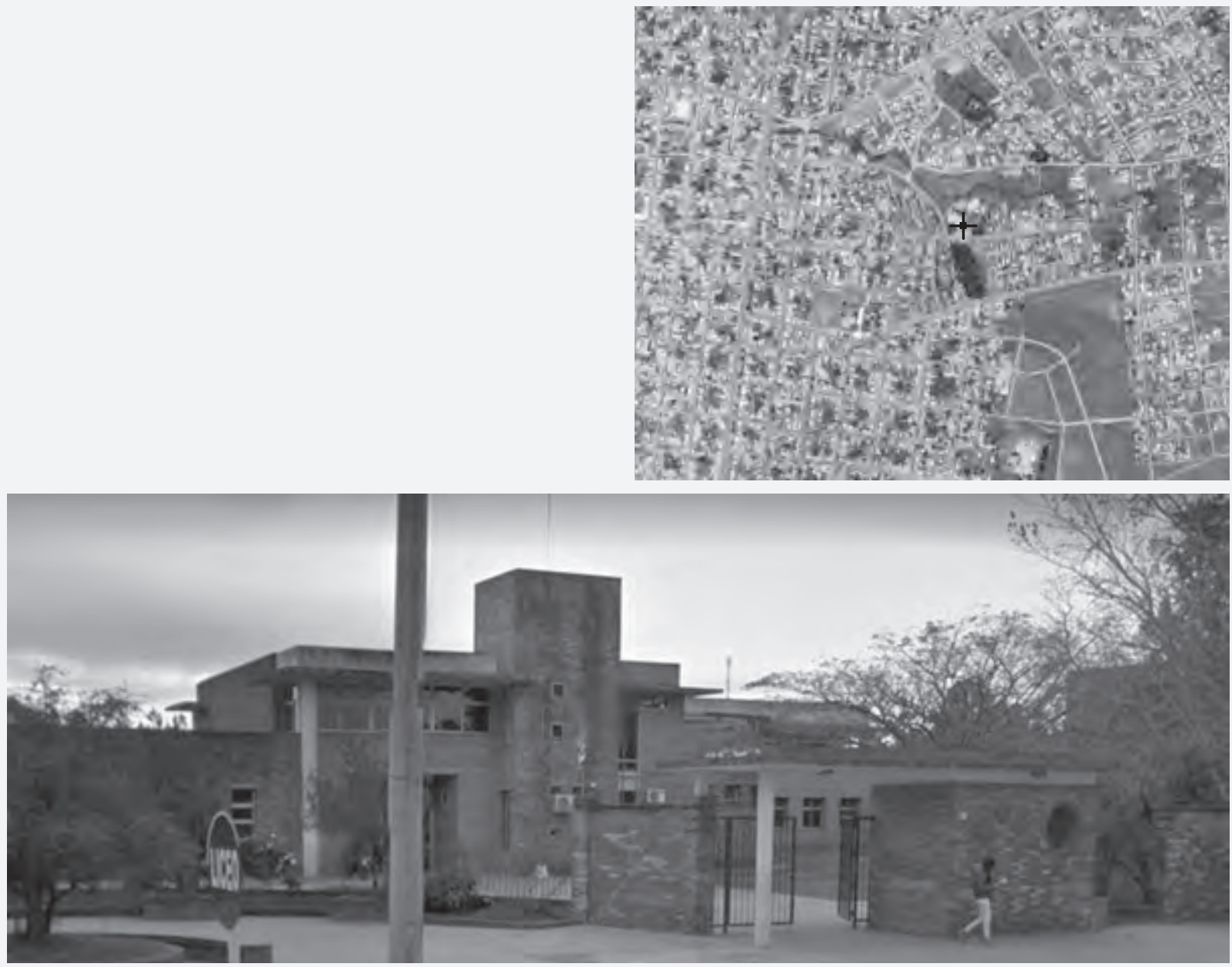
CATÁLOGO DE EQUIPAMENTOS DSL

PROTOTIPO EDUCACIONAL

Pav. Térreo

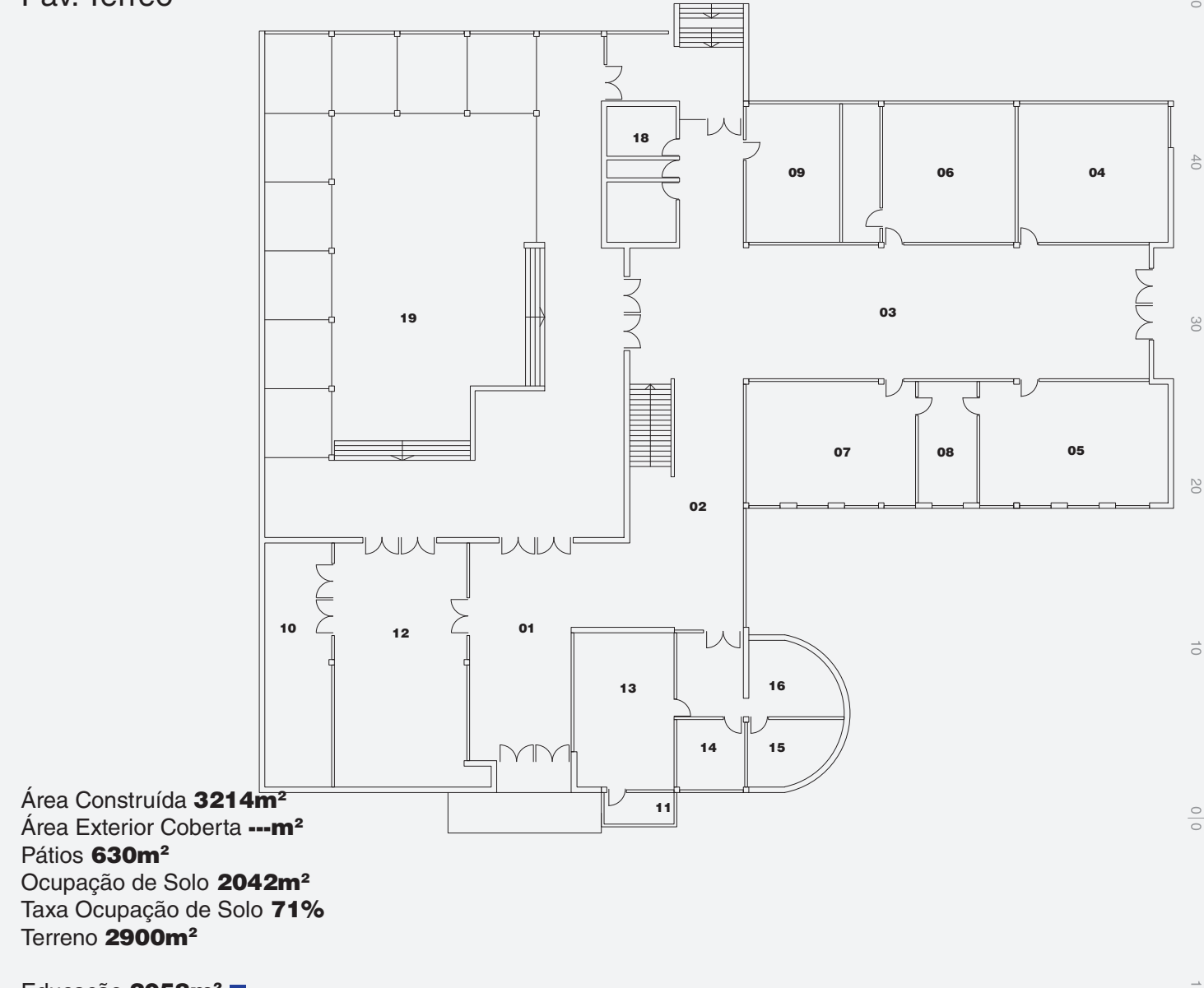

Educação $\mathbf{2 0 5 8 \mathbf { m } ^ { 2 }}$

Esc. 1.500

EDUCACIONAL

$\begin{array}{ll}\mathbf{0 1} & \text { Hall } \\ \mathbf{0 2} & \text { Circulação I } \\ \mathbf{0 3} & \text { Circulação II } \\ \mathbf{0 4} & 1 \\ \mathbf{0 5} & 2 \\ \mathbf{0 6} & 3 \\ \mathbf{0 7} & 4 \\ \mathbf{0 8} & 5 \\ \mathbf{0 9} & 6 \\ \mathbf{1 0} & 7 \\ \mathbf{1 1} & 7 \mathrm{i} \\ \mathbf{1 2} & 8 \\ \mathbf{1 3} & 9 \\ \mathbf{1 4} & 10 \\ \mathbf{1 5} & 11 \\ \mathbf{1 6} & 12 \\ \mathbf{1 7} & 13 \\ \mathbf{1 8} & 16 \\ \mathbf{1 9} & 17 \\ & \text { * Local, suma de varios locales }\end{array}$

$\begin{array}{lll}\mathrm{L} & \mathrm{l} & \mathrm{h} \\ & & \\ 9,3 \mathrm{~m} & 8,55 \mathrm{~m} & 2,8 \\ 23,4 \mathrm{~m} & 7 \mathrm{~m} & 2,8 \\ 25,3 \mathrm{~m} & 8,3 \mathrm{~m} & 2,8 \\ 9,3 \mathrm{~m} & 8,55 \mathrm{~m} & 2,8 \\ 11,6 \mathrm{~m} & 7,5 \mathrm{~m} & 2,8 \\ 8,55 \mathrm{~m} & 8,3 \mathrm{~m} & 2,8 \\ 10,45 \mathrm{~m} & 7,5 \mathrm{~m} & 2,8 \\ 7,6 \mathrm{~m} & 3,6 \mathrm{~m} & 2,8 \\ 8,55 \mathrm{~m} & 5,7 \mathrm{~m} & 2,8 \\ 15 \mathrm{~m} & 4,15 \mathrm{~m} & 2,8 \\ 4,3 \mathrm{~m} & 1,95 \mathrm{~m} & 2,8 \\ 15 \mathrm{~m} & 8,15 \mathrm{~m} & 2,8 \\ 9,5 \mathrm{~m} & 6,15 \mathrm{~m} & 2,8 \\ 4,3 \mathrm{~m} & 4,2 \mathrm{~m} & 2,8 \\ 5,8 \mathrm{~m} & 4,1 \mathrm{~m} & 2,8 \\ 5,8 \mathrm{~m} & 4,7 \mathrm{~m} & 2,8 \\ 8,8 \mathrm{~m} & 3,9 \mathrm{~m} & 2,8 \\ 8,4 \mathrm{~m} & 4,3 \mathrm{~m} & 2,8 \\ 30 & 21 & \\ & & \end{array}$

Á DSL

$79,5 \mathrm{~m}^{2}$

$163,8 \mathrm{~m}^{2}$

E324*

$79,51 \mathrm{~m}^{2}$

$70,9 \mathrm{~m}^{2}$

$78,3 \mathrm{~m}^{2}$

$27,36 \mathrm{~m}^{2}$

$48,73 \mathrm{~m}^{2}$

$48,73 \mathrm{~m}^{2}$

$62,25 m^{2}$

$8,4 \mathrm{~m}^{2}$

$122,25 \mathrm{~m}^{2}$

$58,42 \mathrm{~m}^{2}$

$18,06 \mathrm{~m}^{2}$

$23,78 \mathrm{~m}^{2}$

$27,26 \mathrm{~m}^{2}$

$34,32 \mathrm{~m}^{2}$

$36,12 \mathrm{~m}^{2}$

$630 \mathrm{~m}^{2}$

E324*

E81

$E 81$
E64

E64

E49

E64*

E64*

E100

E64

E25

E25

$E 25$
E64

E324 
CATÁLOGO DE EQUIPAMENTOS DSL

PROTOTIPO EDUCACIONAL

Pav. Superior

Área Construída $3214 \mathrm{~m}^{2}$

Área Exterior Coberta ----m ${ }^{2}$

Pátios $630 \mathrm{~m}^{2}$

Ocupação de Solo $\mathbf{2 0 4 2 \mathbf { m } ^ { 2 }}$

Taxa Ocupação de Solo $\mathbf{7 1 \%}$

Terreno $\mathbf{2 9 0 0 \mathbf { m } ^ { 2 }}$

Educação 2058m²

Esc. 1.500

EDUCACIONAL

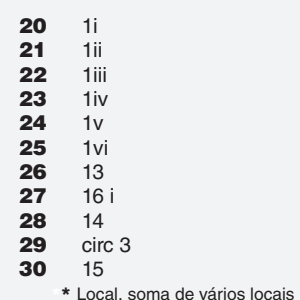

$\begin{array}{lll}\text { L } & \text { I } & \text { Alt. } \\ 8,55 \mathrm{~m} & 8,25 \mathrm{~m} & 2,8 \\ 8,55 \mathrm{~m} & 8,25 \mathrm{~m} & 2,8 \\ 8,55 \mathrm{~m} & 8,25 \mathrm{~m} & 2,8 \\ 8,25 \mathrm{~m} & 7,5 \mathrm{~m} & 2,8 \\ 8,25 \mathrm{~m} & 7,5 \mathrm{~m} & 2,8 \\ 8,25 \mathrm{~m} & 7,5 \mathrm{~m} & 2,8 \\ 8,9 \mathrm{~m} & 3,9 \mathrm{~m} & 2,8 \\ 8,4 \mathrm{~m} & 4,3 \mathrm{~m} & 2,8 \\ 8,3 \mathrm{~m} & 4,1 \mathrm{~m} & 2,8 \\ 20,1 \mathrm{~m} & 8,25 \mathrm{~m} & 2,8 \\ 16,9 \mathrm{~m} & 9,65 \mathrm{~m} & 2,8\end{array}$


CATÁLOGO DE EQUIPAMENTOS DSL

PROTOTIPO EDUCACIONAL DSL DISSOLUÇÃO PROGRAMÁTICA

Educacional 2058 $\mathbf{m}^{2}$

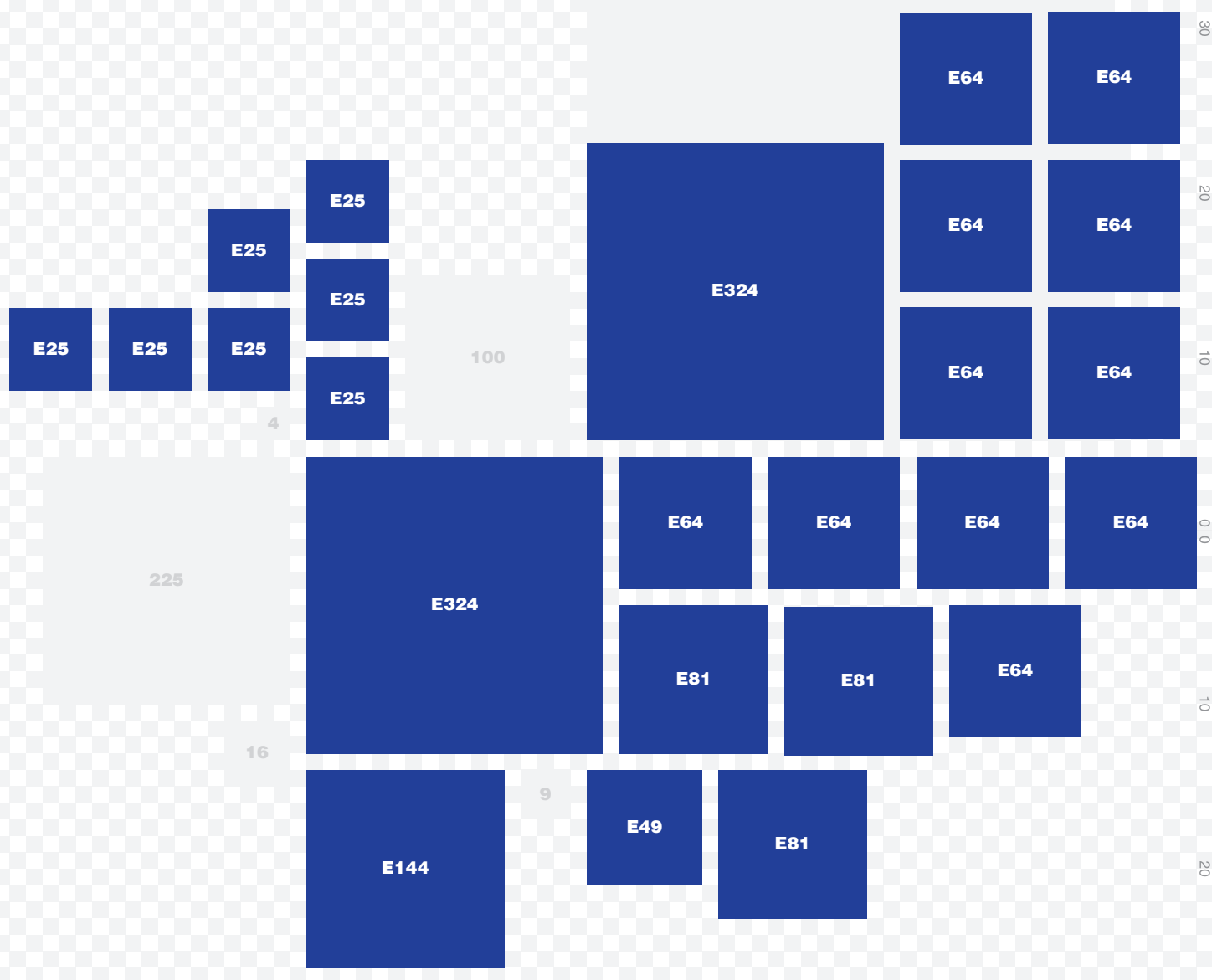




\section{CATÁLOGO DE EQUIPAMENTOS DSL}

PROTOTIPO EDUCACIONAL DSL DISSOLUÇÃO ESPACIAL Área Construída $3214 \mathrm{~m}^{2}$

Área Exterior Coberta ---m²

Pátios $630 \mathrm{~m}^{2}$

Terreno $2900 \mathrm{~m}^{2}$

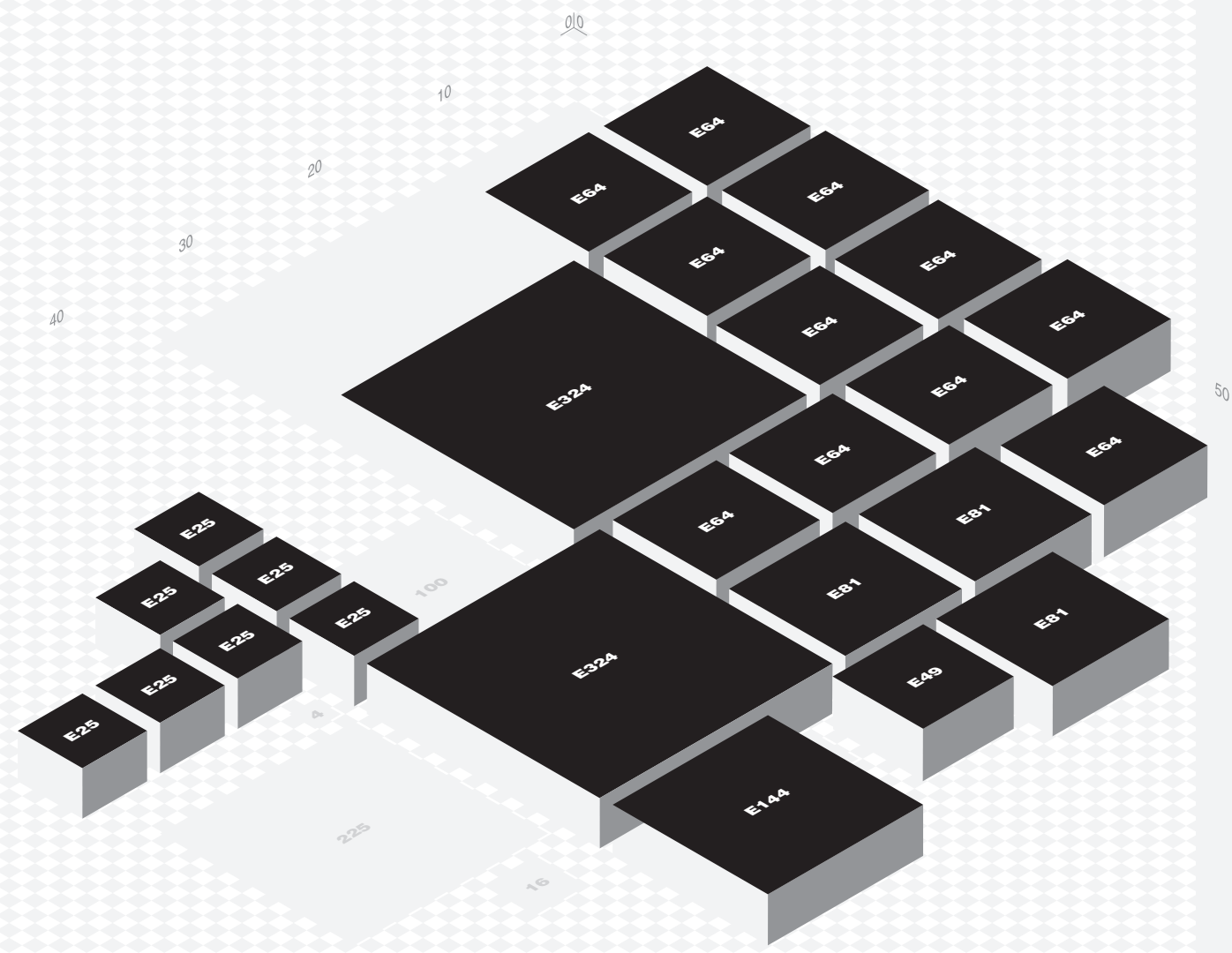


CATÁLOGO EQUIPAMENTOS DSL

POLICLÍNICA

Ano 2015

Área total $114 \mathrm{~m}^{2}$

Autor ASSE Div. Arquitetura

Ubicacion Montevideo. UY.

Organização gestora MSP ASSE

Organização responsável ASSE Div. Arquitetura, Engenharia e Manutenção

Fonte Arquitetura MSP 
CATÁLOGO EQUIPAMENTOS DSL

POLICLÍNICA

Pav. Térreo
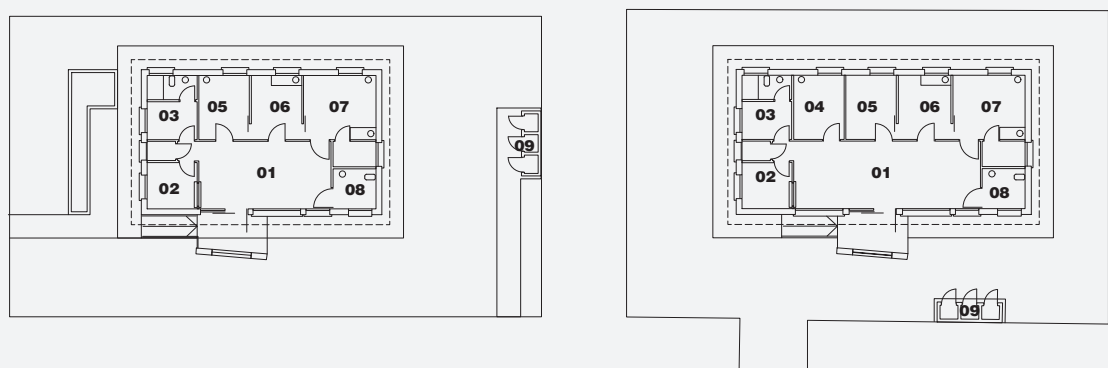

Área Construída $114 \mathrm{~m}^{2}$

Área Exterior Coberta $132 \mathrm{~m}^{2}$

Pátios ---m²

Ocupação de Solo $190 \mathrm{~m}^{2}$

Taxa Ocupação de Solo $\mathbf{2 3 , 8} \%$

Terreno $\mathbf{4 8 0 \mathbf { m } ^ { 2 }}$

Saúde $\mathbf{9 5 \mathbf { m } ^ { 2 }}$

Esc. 1.500

SAÚDE

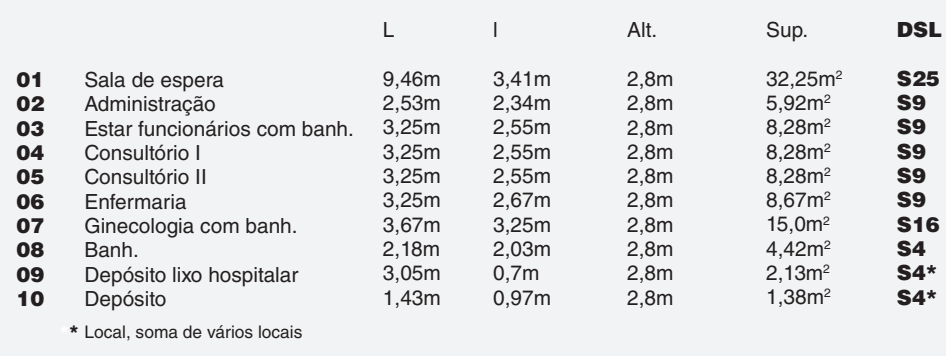

Alt.

Sup.

DSL

오

(1)

* Local, soma de vários locais 


\section{CATÁLOGO EQUIPAMENTOS DSL}

POLICLÍNICA DSL DISSOLUÇÃO PROGRAMÁTICA

Saúde $95 \mathbf{m}^{2}$ 
CATÁLOGO EQUIPAMENTOS DSL

POLICLÍNICA DSL DISSOLUÇÃO ESPẢCIAL

Área Construída $114 \mathrm{~m}^{2}$

Área Exterior Coberta $132 \mathrm{~m}^{2}$

Pátios ---m²

Terreno $\mathbf{4 8 0 m ^ { 2 }}$
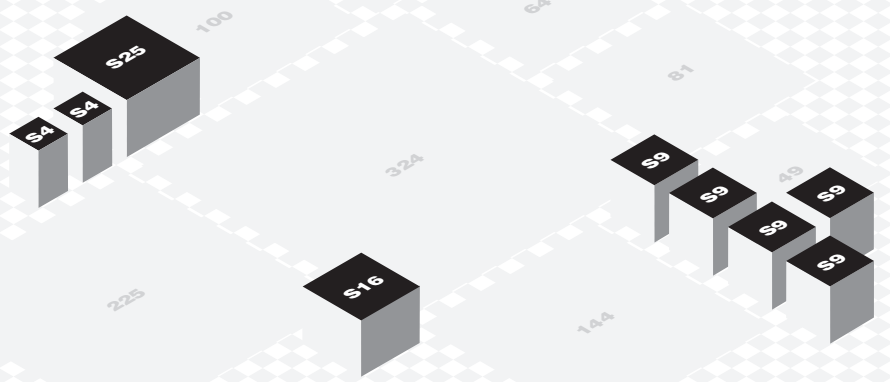


\section{CATÁLOGO EQUIPAMENTOS DSL}

\section{POLICLÍNICA CASAVALLE}

\section{Ano 2012}

Área total $860 \mathrm{~m}^{2}$

Autor IM DIv. Saude. Arq. Martha Gregorio

Localização Barrio Casavalle, Montevideo. UY.

Organização gestora CND

Organização responsável SND Secretaria Nacional de Esportes

Fonte IM
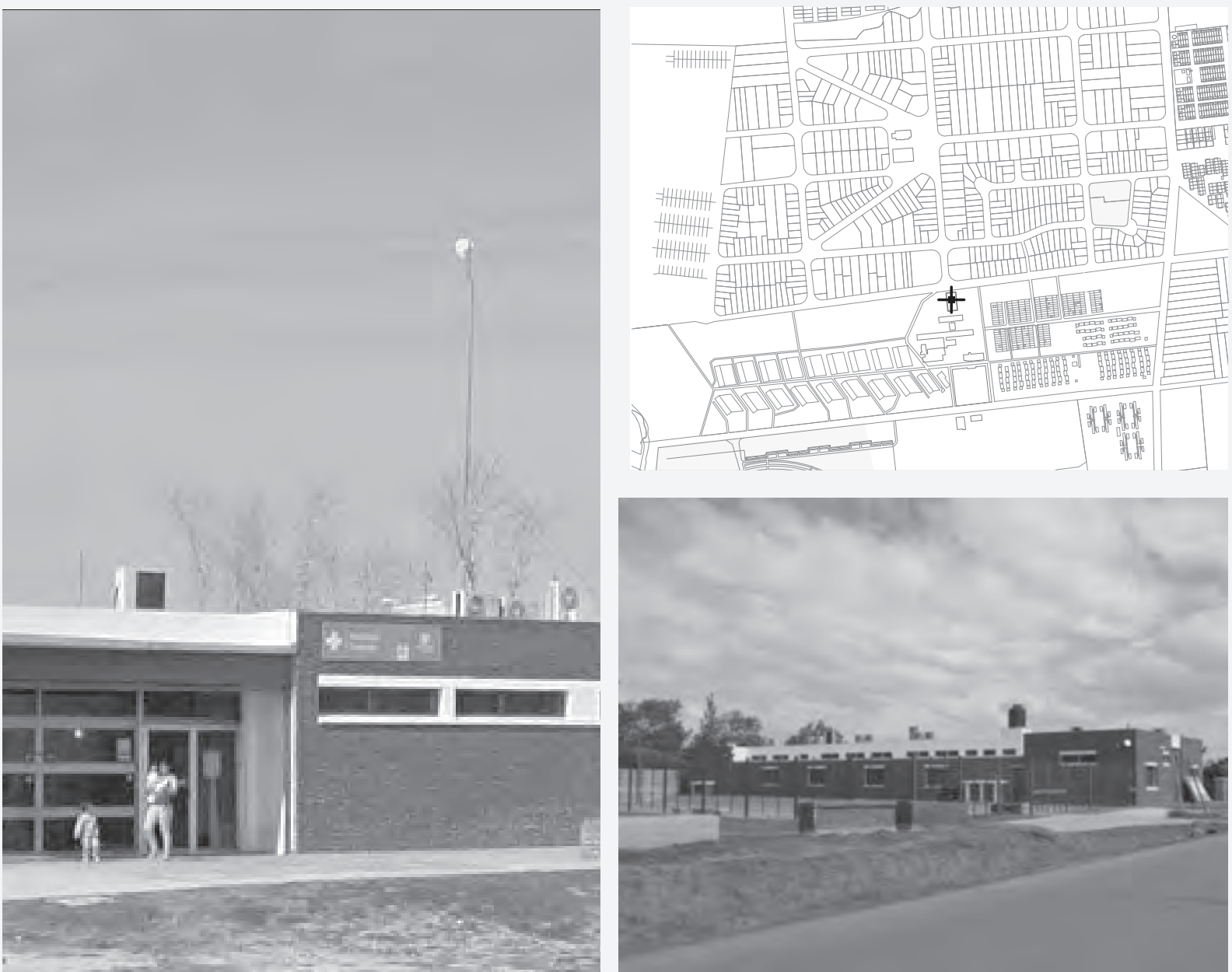
CATÁLOGO EQUIPAMENTOS DSL

POLICLÍNICA CASAVALLE

Pav. Térreo

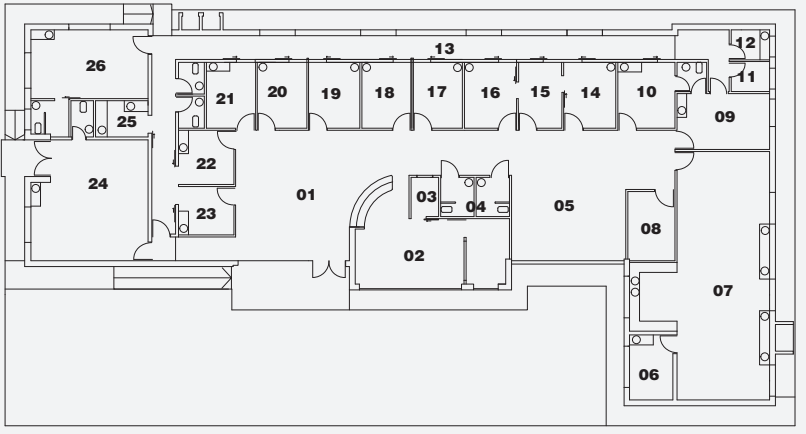

Área Construída $535 \mathrm{~m}^{2}$

Área Exterior Coberta $130 \mathrm{~m}^{2}$

Pátios 197m²

Ocupação de Solo $860 \mathrm{~m}^{2}$

Taxa Ocupação de Solo $\mathbf{6 2 \%}$

Terreno $\mathbf{8 6 0 \mathbf { m } ^ { 2 }}$

Saúde $425 \mathbf{m}^{2}$

$\begin{array}{lll}\mathbf{0 1} & \text { Sala de espera } & 6,62 \mathrm{~m} \\ \mathbf{0 2} & \text { Administração } & 7,8 \mathrm{~m} \\ \mathbf{0 3} & \text { Farmácia } & 2 \mathrm{~m} \\ \mathbf{0 4} & \text { Banh. I } & 3,5 \mathrm{~m} \\ \mathbf{0 5} & \text { Jogo infantil } & 5,8 \mathrm{~m} \\ \mathbf{0 6} & \text { Raios X } & 3,3 \mathrm{~m} \\ \mathbf{0 7} & \text { Odontologia } & 12,6 \mathrm{~m} \\ \mathbf{0 8} & \text { Nutrição } & 3,5 \mathrm{~m} \\ \mathbf{0 9} & \text { Ginecologia I } & 4,7 \mathrm{~m} \\ \mathbf{1 0} & \text { Ginecologia com banh. } & 4,4 \mathrm{~m} \\ \mathbf{1 1} & \text { Depósito } & 1,9 \mathrm{~m} \\ \mathbf{1 2} & \text { Limpeza } & 1,9 \mathrm{~m} \\ \mathbf{1 3} & \text { Circulação técnica } & 29 \mathrm{~m} \\ \mathbf{1 4} & \text { Pediatria I } & 3,35 \mathrm{~m} \\ \mathbf{1 5} & \text { Antropometria } & 3,35 \mathrm{~m} \\ \mathbf{1 6} & \text { Pediatria II } & 3,35 \mathrm{~m} \\ \mathbf{1 7} & \text { Saúde mental I } & 3,35 \mathrm{~m} \\ \mathbf{1 8} & \text { Saúde mental II } & 3,35 \mathrm{~m} \\ \mathbf{1 9} & \text { Medicina geral I } & 3,35 \mathrm{~m} \\ \mathbf{2 0} & \text { Medicina geral II } & 3,35 \mathrm{~m} \\ \mathbf{2 1} & \text { Vacinaria } & 3,35 \mathrm{~m} \\ \mathbf{2 2} & \text { Recuperação } & 2,8 \mathrm{~m} \\ \mathbf{2 3} & \text { Nebulizações } & 2,8 \mathrm{~m} \\ \mathbf{2 4} & \text { SUM com banh. } & 6,12 \mathrm{~m} \\ \mathbf{2 5} & \text { Enfermeria suja } & 2,66 \mathrm{~m} \\ \mathbf{2 6} & \text { Sala de funcionários com banh. } 6 \mathrm{~m} \\ & \text { * Local, soma de vários locais } \\ & & \end{array}$

$\begin{array}{ll}\text { I Alt. } \\ \text { 6m } & 3,25 \mathrm{~m} \\ 3,55 \mathrm{~m} & 3,25 \mathrm{~m} \\ 1,4 \mathrm{~m} & 3,25 \mathrm{~m} \\ 2 \mathrm{~m} & 3,25 \mathrm{~m} \\ 4,3 \mathrm{~m} & 3,25 \mathrm{~m} \\ 2,2 \mathrm{~m} & 3,25 \mathrm{~m} \\ 4,7 \mathrm{~m} & 3,25 \mathrm{~m} \\ 2,4 \mathrm{~m} & 3,25 \mathrm{~m} \\ 2,8 \mathrm{~m} & 3,25 \mathrm{~m} \\ 3,35 \mathrm{~m} & 3,25 \mathrm{~m} \\ 1,52 \mathrm{~m} & 3,25 \mathrm{~m} \\ 1,52 \mathrm{~m} & 3,25 \mathrm{~m} \\ 1,2 \mathrm{~m} & 3,25 \mathrm{~m} \\ 2,65 \mathrm{~m} & 3,25 \mathrm{~m} \\ 2,65 \mathrm{~m} & 3,25 \mathrm{~m} \\ 2,65 \mathrm{~m} & 3,25 \mathrm{~m} \\ 2,5 \mathrm{~m} & 3,25 \mathrm{~m} \\ 2,5 \mathrm{~m} & 3,25 \mathrm{~m} \\ 2,5 \mathrm{~m} & 3,25 \mathrm{~m} \\ 2,6 \mathrm{~m} & 3,25 \mathrm{~m} \\ 2,5 \mathrm{~m} & 3,25 \mathrm{~m} \\ 2,75 \mathrm{~m} & 3,25 \mathrm{~m} \\ 2,5 \mathrm{~m} & 3,25 \mathrm{~m} \\ 6 \mathrm{~m} & 3,25 \mathrm{~m} \\ 1,85 \mathrm{~m} & 3,25 \mathrm{~m} \\ 3,5 \mathrm{~m} & 3,25 \mathrm{~m}\end{array}$

Sup. DSL

$62 \mathrm{~m}^{2}$

$27,7 m^{2} \quad \mathbf{S 2 5}$

$2,8 \mathrm{~m}^{2} \quad \mathbf{S 2 5}$

$7 \mathrm{~m}^{2} \quad$ s9

$24,9 \mathrm{~m}^{2} \quad \mathbf{S 2 5}$

$7,3 \mathrm{~m}^{2} \quad$ s9

$59,2 \mathrm{~m}^{2} \quad \mathbf{S 6 4}$

$8,4 \mathrm{~m}^{2} \quad$ S9

$14,7 \mathrm{~m}^{2} \quad \mathrm{s16}$

$14,7 \mathrm{~m}^{2} \quad \mathbf{S 1 6}$

$\begin{array}{ll}2,9 \mathrm{~m}^{2} & \mathbf{S 4} \\ 2,9 \mathrm{~m}^{2} & \mathbf{S 4}\end{array}$

$46 \mathrm{~m}^{2} \quad$ S49

$8,9 \mathrm{~m}^{2}$

$8,9 \mathrm{~m}^{2} \quad \mathbf{s 9}$

$8,9 \mathrm{~m}^{2} \quad$ s9

$8,9 \mathrm{~m}^{2} \quad \mathbf{s 9}$

$8,4 \mathrm{~m}^{2} \quad$ S9

$8,4 \mathrm{~m}^{2} \quad$ s9

$8,4 \mathrm{~m}^{2} \quad$ S9

$8,7 \mathrm{~m}^{2} \quad$ S9

$8,4 \mathrm{~m}^{2} \quad$ S9

$7,7 \mathrm{~m}^{2} \quad$ s9

$36,7 \mathrm{~m}^{2} \quad$ S9

$4,9 \mathrm{~m}^{2} \quad \mathbf{S 9}$

$4,9 \mathrm{~m}^{2} \quad$ s. 
CATÁLOGO EQUIPAMENTOS DSL

POLICLÍNICA CASAVALLE DSL DISSOLUÇÃO PROGRAMÁTICA Saúde $425 \mathbf{m}^{2}$ -

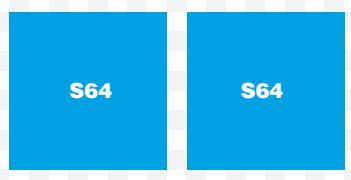

s16

516 
CATÁLOGO EQUIPAMENTOS DSL

POLICLÍNICA CASAVALLE DSL DISSOLUÇÃO ESPACIAL

Área Construída $535 \mathrm{~m}^{2}$

Área Exterior Coberta $130 \mathrm{~m}^{2}$

Pátios $197 \mathrm{~m}^{2}$

Terreno $\mathbf{8 6 0 \mathbf { m } ^ { 2 }}$
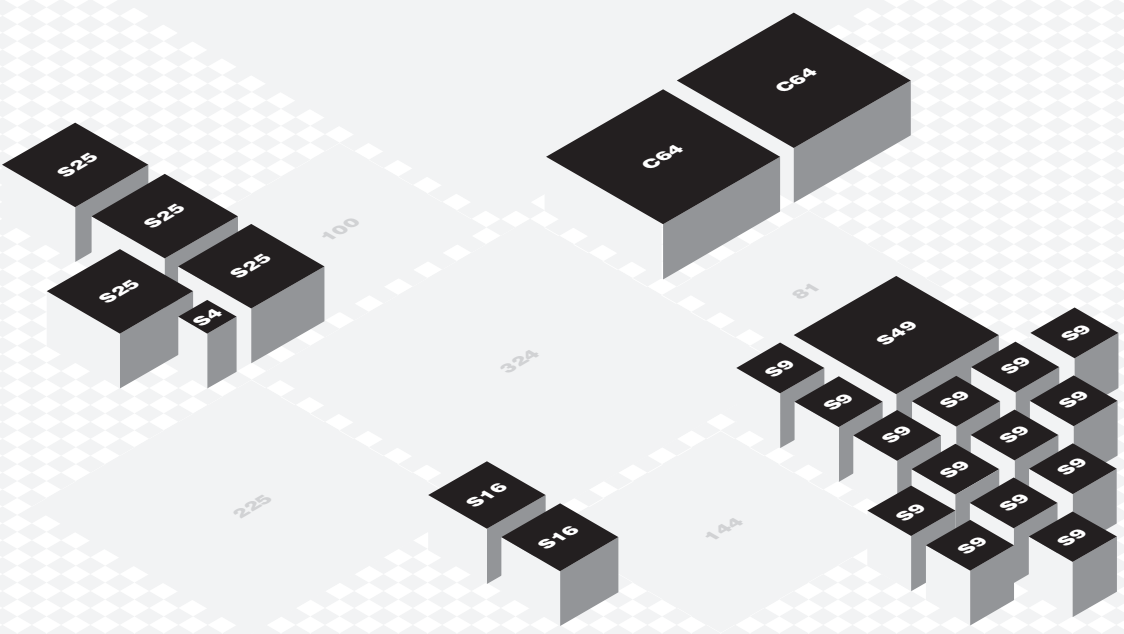


\section{CATÁLOGO EQUIPAMENTOS DSL}

\section{CIUDAD DEL PLATA}

Ano 1999-2016

Área total $1200 \mathrm{~m}^{2}$

Autor PRIS / ASSE Div. Arquitetura

Localização Ciudad del Plata, UY.

Organização gestora MSP ASSE

Organização responsável ASSE Div. Arquitetura, Engenharia e Manutenção

Fonte Arquitetura MSP
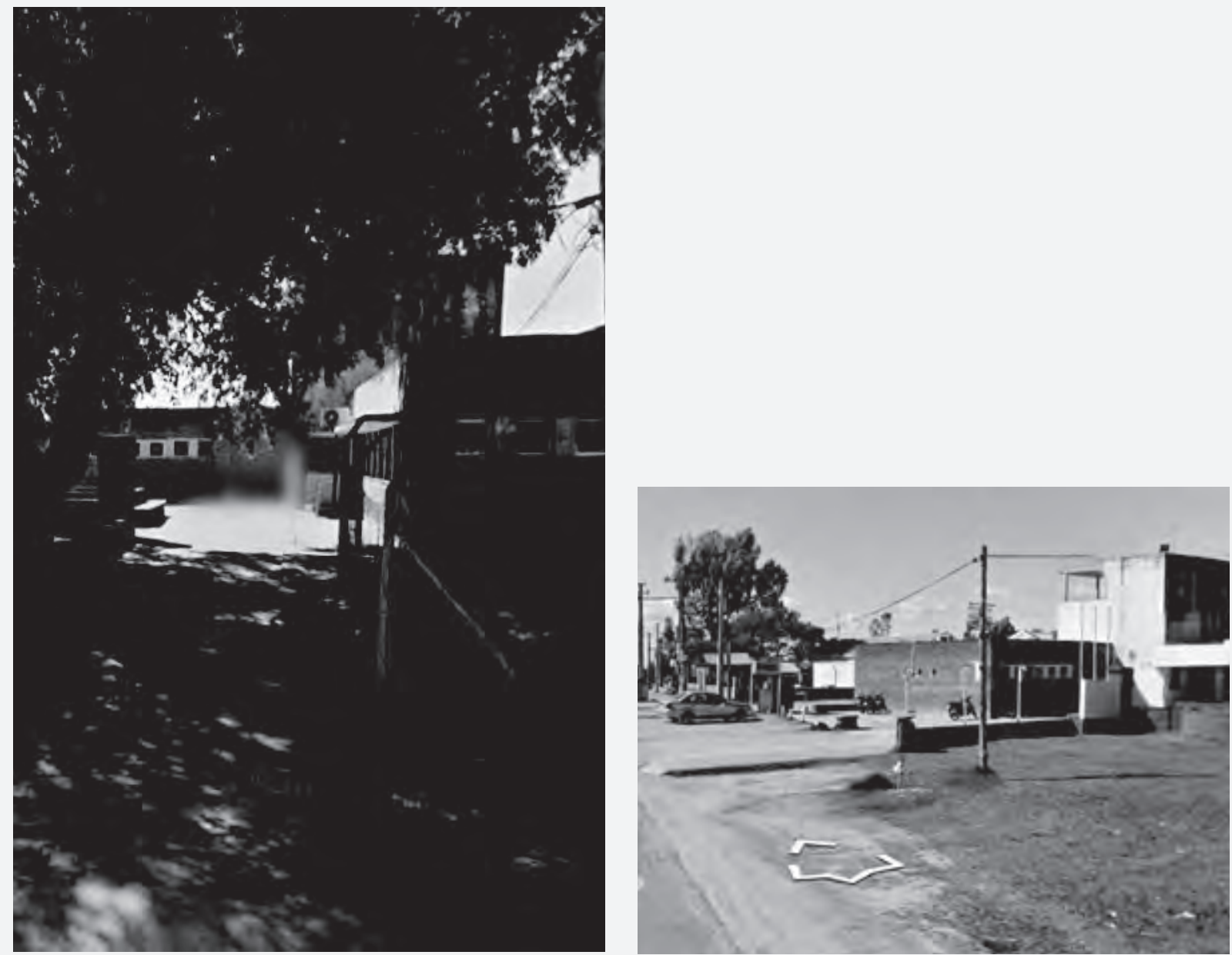


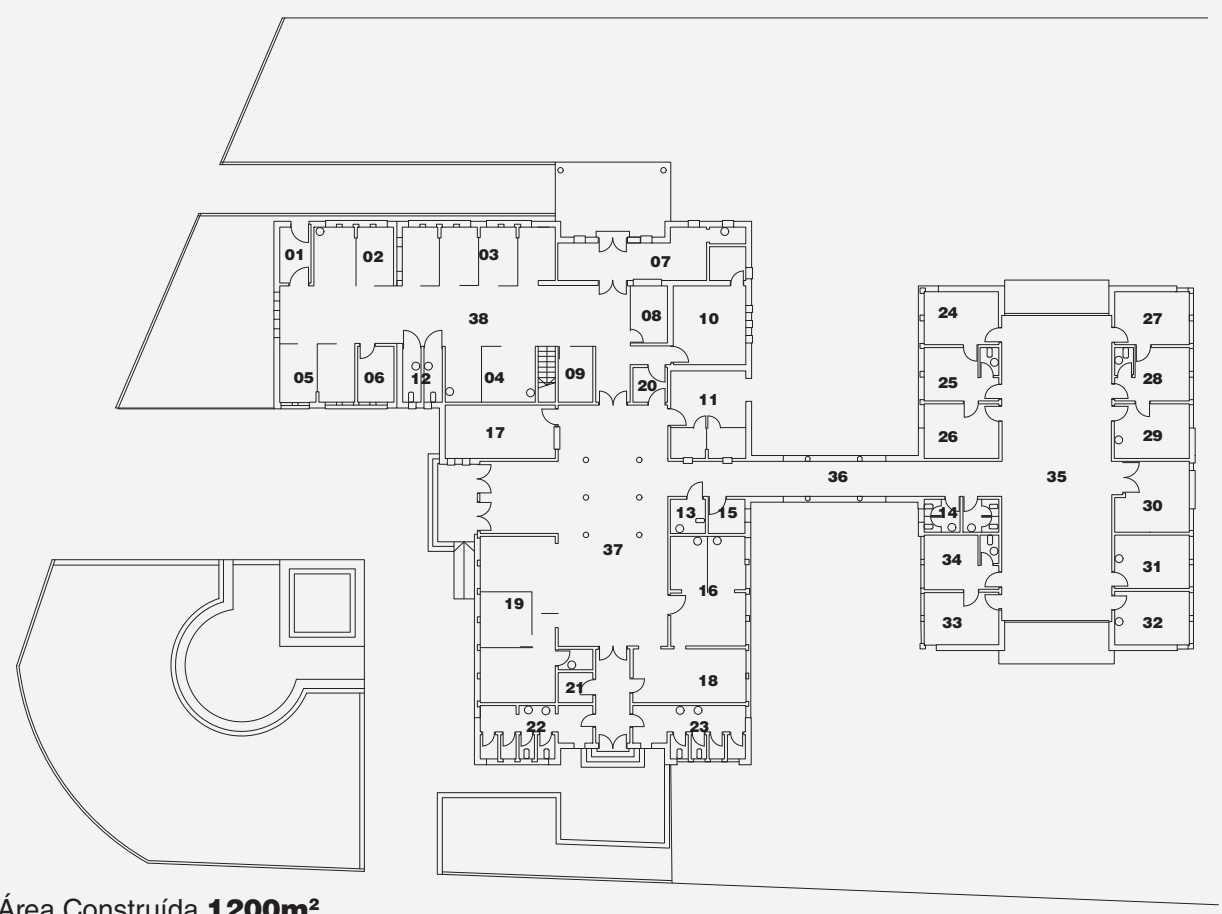

Área Exterior Coberta $\mathbf{2 1} \mathbf{m}^{\mathbf{2}}$

Pátios ---m²

Ocupação de Solo $\mathbf{9 3 0 \mathbf { m } ^ { 2 }}$

Taxa Ocupação de Solo $\mathbf{3 1 , 8 \%}$

Terreno 2400m²

Saúde $645 \mathrm{~m}^{2}$

Esc. 1.500

$\begin{array}{ll}\mathbf{0 1} & \text { Morgue } \\ \mathbf{0 2} & \text { Box I } \\ \mathbf{0 3} & \text { Box II } \\ \mathbf{0 4} & \text { Box III } \\ \mathbf{0 5} & \text { Box IIII } \\ \mathbf{0 6} & \text { Enf. suja } \\ \mathbf{0 7} & \text { Espera emergência } \\ \mathbf{0 8} & \text { Admissão } \\ \mathbf{0 9} & \text { Enfermaria I } \\ \mathbf{1 0} & \text { Raios } \\ \mathbf{1 1} & \text { Enfermaria externa } \\ \mathbf{1 2} & \text { Banh. I } \\ \mathbf{1 3} & \text { Banh. Desab. } \\ \mathbf{1 4} & \text { Banh. II } \\ \mathbf{1 5} & \text { G eletr. } \\ \mathbf{1 6} & \text { Enfermaria II } \\ \mathbf{1 7} & \text { Arquivo historias clinica } \\ \mathbf{1 8} & \text { Farmácia } \\ \mathbf{1 9} & \text { Administração com banh. } \\ \mathbf{2 0} & \text { Vestuário } \\ \mathbf{2 1} & \text { Copa } \\ \mathbf{2 2} & \text { Vestuário I } \\ \mathbf{2 3} & \text { Vestuário II } \\ \mathbf{2 4} & \text { Consultório 1 } \\ \mathbf{2 5} & \text { Consultório } 2 \text { com banh. } \\ \mathbf{2 6} & \text { Consultório } 3 \\ \mathbf{2 7} & \text { Consultório 4 } \\ \mathbf{2 8} & \text { Consultório } 5 \text { com banh. } \\ \mathbf{2 9} & \text { Consultório } 6 \\ \mathbf{3 0} & \text { Consultório } 7 \\ \mathbf{3 1} & \text { Consultório } 8 \\ & \text { * Local, soma de vários locais }\end{array}$

$\begin{array}{ll}\text { L } & \text { I } \\ 2,83 \mathrm{~m} & 1,57 \mathrm{~m} \\ 4,05 \mathrm{~m} & 2,98 \mathrm{~m} \\ 8,05 \mathrm{~m} & 2,98 \mathrm{~m} \\ 4,5 \mathrm{~m} & 2,83 \mathrm{~m} \\ 2,83 \mathrm{~m} & 2 \mathrm{~m} \\ 2,83 \mathrm{~m} & 1,83 \mathrm{~m} \\ 7,55 \mathrm{~m} & 2,7 \mathrm{~m} \\ 2,9 \mathrm{~m} & 1,88 \mathrm{~m} \\ 2,83 \mathrm{~m} & 1,75 \mathrm{~m} \\ 4 \mathrm{~m} & 3,68 \mathrm{~m} \\ 4,45 \mathrm{~m} & 3,81 \mathrm{~m} \\ 3,8 \mathrm{~m} & 2,95 \mathrm{~m} \\ 1,78 \mathrm{~m} & 1,74 \mathrm{~m} \\ 3,8 \mathrm{~m} & 1,7 \mathrm{~m} \\ 1,87 \mathrm{~m} & 1,74 \mathrm{~m} \\ 3,8 \mathrm{~m} & 2,7 \mathrm{~m} \\ 5,6 \mathrm{~m} & 2,7 \mathrm{~m} \\ 5,7 \mathrm{~m} & 2,7 \mathrm{~m} \\ 8,5 \mathrm{~m} & 3,8 \mathrm{~m} \\ 1,75 \mathrm{~m} & 1,75 \mathrm{~m} \\ 1,7 \mathrm{~m} & 1,5 \mathrm{~m} \\ 5,5 \mathrm{~m} & 2,7 \mathrm{~m} \\ 5,5 \mathrm{~m} & 2,7 \mathrm{~m} \\ 3,8 \mathrm{~m} & 2,7 \mathrm{~m} \\ 3,8 \mathrm{~m} & 2,7 \mathrm{~m} \\ 3,8 \mathrm{~m} & 2,7 \mathrm{~m} \\ 3,8 \mathrm{~m} & 2,7 \mathrm{~m} \\ 3,8 \mathrm{~m} & 2,7 \mathrm{~m} \\ 3,8 \mathrm{~m} & 2,7 \mathrm{~m} \\ 3,8 \mathrm{~m} & 3,6 \mathrm{~m} \\ 3,8 \mathrm{~m} & 2,7 \mathrm{~m} \\ & \end{array}$

Alt.

Sup.

* Local, soma de vários locais

$\begin{array}{ll}2.60 m & 4,4 \mathrm{~m}^{2} \\ 2.60 \mathrm{~m} & 12,1 \mathrm{~m}^{2} \\ 2.60 \mathrm{~m} & 23,9 \mathrm{~m}^{2} \\ 2.60 \mathrm{~m} & 12,7 \mathrm{~m}^{2} \\ 2.60 \mathrm{~m} & 5,6 \mathrm{~m}^{2} \\ 2.60 \mathrm{~m} & 5,2 \mathrm{~m}^{2} \\ 2.60 \mathrm{~m} & 20,3 \mathrm{~m}^{2} \\ 2.60 \mathrm{~m} & 5,4 \mathrm{~m}^{2} \\ 2.60 \mathrm{~m} & 4,9 \mathrm{~m}^{2} \\ 2.60 \mathrm{~m} & 14,7 \mathrm{~m}^{2} \\ 2.60 \mathrm{~m} & 16,9 \mathrm{~m}^{2} \\ 2.60 \mathrm{~m} & 11,21 \mathrm{~m}^{2} \\ 2.60 \mathrm{~m} & 3,09 \mathrm{~m}^{2} \\ 2.60 \mathrm{~m} & 6,46 \mathrm{~m}^{2} \\ 2.60 \mathrm{~m} & 3,25 \mathrm{~m}^{2} \\ 2.60 \mathrm{~m} & 10,26 \mathrm{~m}^{2} \\ 2.60 \mathrm{~m} & 15,12 \mathrm{~m}^{2} \\ 2.60 \mathrm{~m} & 15,39 \mathrm{~m}^{2} \\ 2.60 \mathrm{~m} & 32,3 \mathrm{~m}^{2} \\ 2.60 \mathrm{~m} & 3,06 \mathrm{~m}^{2} \\ 2.60 \mathrm{~m} & 2,55 \mathrm{~m}^{2} \\ 2.60 \mathrm{~m} & 14,85 \mathrm{~m}^{2} \\ 2.60 \mathrm{~m} & 14,85 \mathrm{~m}^{2} \\ 2.60 \mathrm{~m} & 10,26 \mathrm{~m}^{2} \\ 2.60 \mathrm{~m} & 10,26 \mathrm{~m}^{2} \\ 2.60 \mathrm{~m} & 10,26 \mathrm{~m}^{2} \\ 2.60 \mathrm{~m} & 10,26 \mathrm{~m}^{2} \\ 2.60 \mathrm{~m} & 10,26 \mathrm{~m}^{2} \\ 2.60 \mathrm{~m} & 10,26 \mathrm{~m}^{2} \\ 2.60 \mathrm{~m} & 13,68 \mathrm{~m}^{2} \\ 2.60 \mathrm{~m} & 10,26 \mathrm{~m}^{2} \\ & \end{array}$




\section{CATÁLOGO EQUIPAMENTOS DSL}

\section{CIUDAD DEL PLATA}

Pav. 1

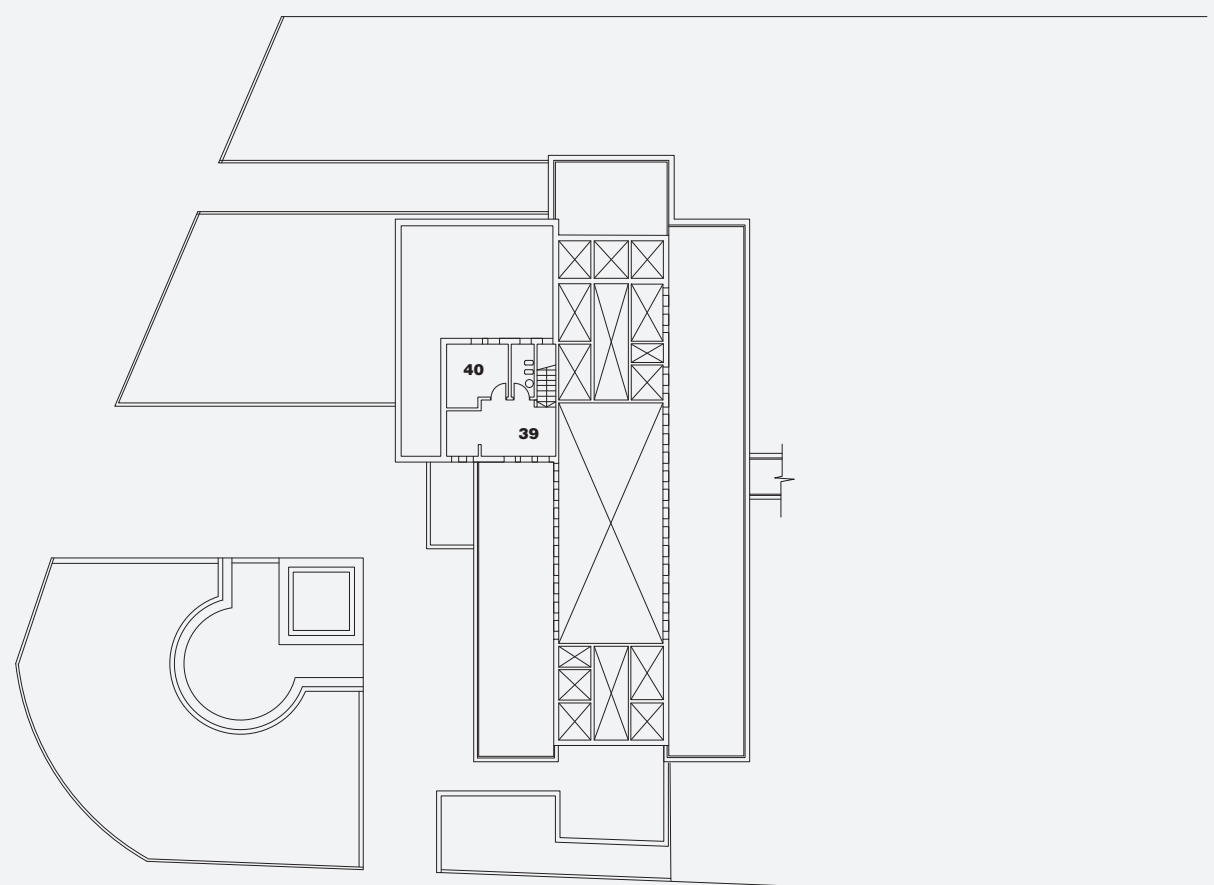


CIUDAD DEL PLATA DSL DISSOLUÇÃO PROGRAMÁTICA

$5 4 \longdiv { 5 4 } 5 4$
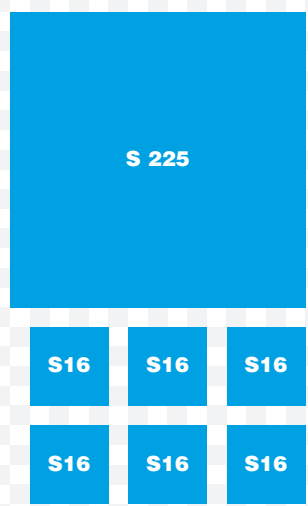

s9

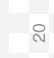


CATÁLOGO EQUIPAMENTOS DSL

CIUDAD DEL PLATA DSL DISSOLUÇÃOO ESPACIAL Área Construída $1200 \mathrm{~m}^{2}$

Área Exterior Coberta $\mathbf{2 1} \mathbf{~ m}^{2}$

Pátios ---m²

Terreno $\mathbf{2 4 0 0 \mathbf { m } ^ { 2 }}$

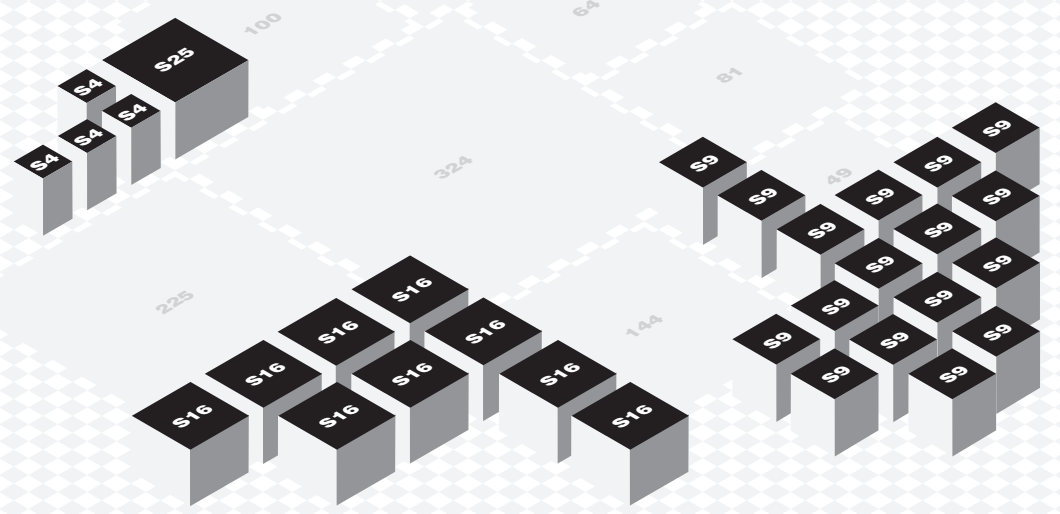


CATÁLOGO EQUIPAMENTOS DSL

POLIDEPORTIVO

Ano 2017

Área total $1391 \mathrm{~m}^{2}$

Autor CND. Arquitetura

Localização Varias, UY

Organização gestora CND

Organização responsável SND Secretaria Nacional de Esportes

\section{Fonte CND}

https://www.cnd.org.uy/index.php/sala-de-prensa/1780-segundo-Ilamado-para -proyectos-ppp-en-infraestructura-educativa
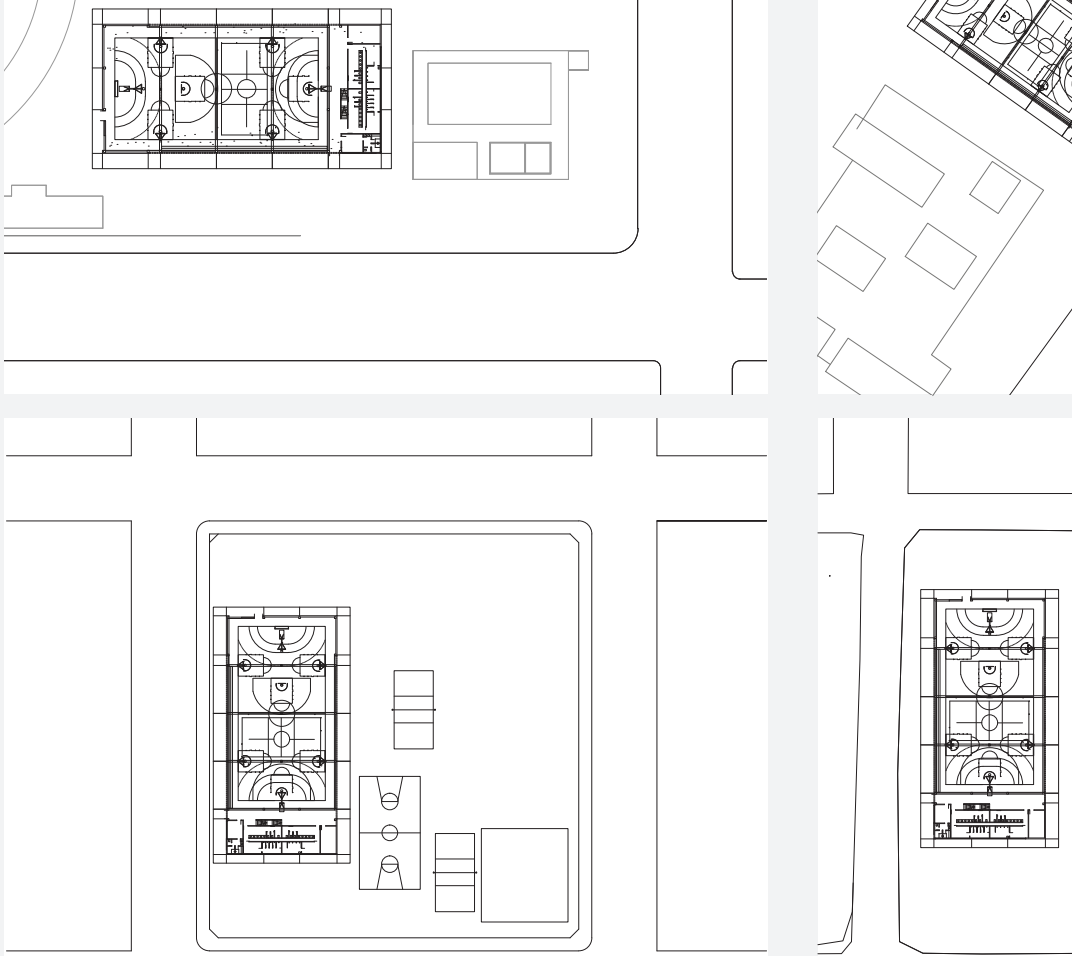


\section{CATÁLOGO EQUIPAMENTOS DSL}

\section{POLIDEPORTIVO}

Pav. Térreo

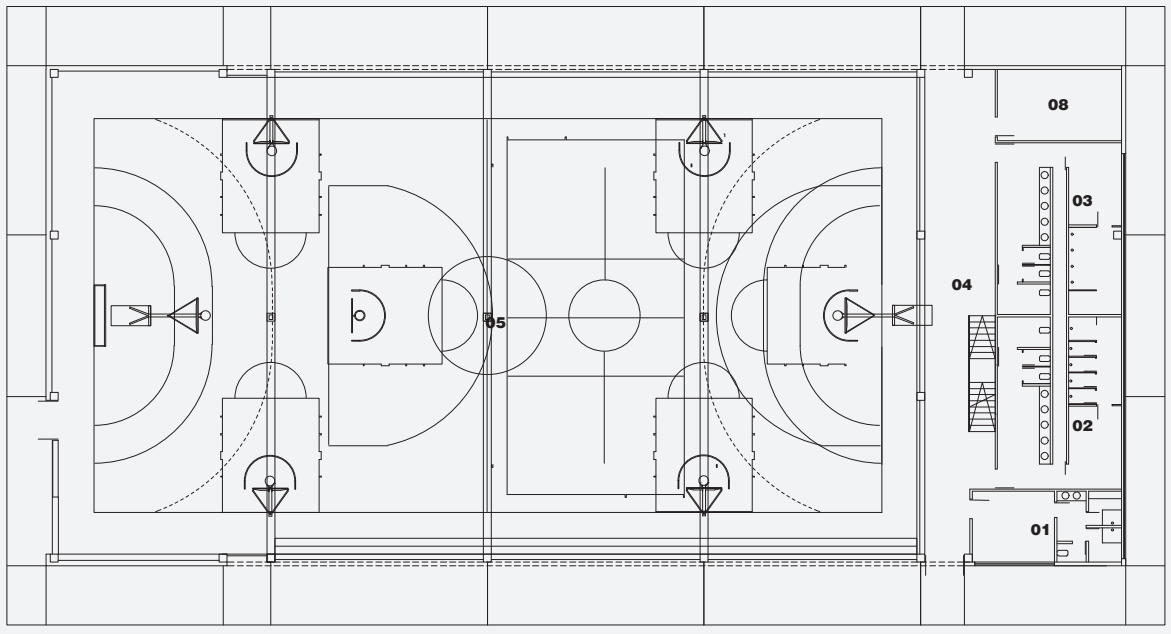

Área Construída $1391 \mathrm{~m}^{2}$

Área Exterior Coberta ---m²

Pátios ---m²

Ocupação de Solo $1391 \mathrm{~m}^{2}$

Taxa Ocupação de Solo $\mathbf{7 3} \%$

Terreno $1900 \mathrm{~m}^{2}$

Esporte $1546 \mathbf{m}^{2}$

Esc. 1.500

ESPORTE

$\begin{array}{ll} & \\ 01 & \text { Professores com banh. } \\ 02 & \text { Vestuário mulheres } \\ 03 & \text { Vestuário homens } \\ 04 & \text { Circulação } \\ 05 & \text { Quadra } \\ 06 & \text { Sala polivalente } \\ 07 & \text { Depósito II } \\ 08 & \text { Depósito I }\end{array}$

L $1 \quad$ Alt.

Sup.

DSL

$7,6 \mathrm{~m} \quad 3,6 \mathrm{~m} \quad 2,85 \mathrm{~m}$

$8,74 \mathrm{~m} \quad 6,3 \mathrm{~m} \quad 2,85 \mathrm{~m}$

$8,74 \mathrm{~m} \quad 6,3 \mathrm{~m} \quad 2,85 \mathrm{~m}$

$24,28 \mathrm{~m} \quad 3,58 \mathrm{~m} \quad 2,85 \mathrm{~m}$

$43,6 \mathrm{~m} \quad 24,2 \mathrm{~m} \quad 5,25 \mathrm{~m}$

$20,8 \mathrm{~m} \quad 10 \mathrm{~m} \quad 3,9 \mathrm{~m}$

$6,3 \mathrm{~m} \quad 3,3 \mathrm{~m} \quad 3,9 \mathrm{~m}$

$27,4 \mathrm{~m}^{2}$

$55,1 \mathrm{~m}^{2}$

$55,1 \mathrm{~m}^{2}$

$86,9 \mathrm{~m}^{2}$

$1055,1 \mathrm{~m}^{2}$

$225 \mathrm{~m}^{2}$

$20,8 \mathrm{~m}^{2}$

$20,8 m^{2}$ 
CATÁLOGO EQUIPAMENTOS DSL

POLIDEPORTIVO

Pav. 1

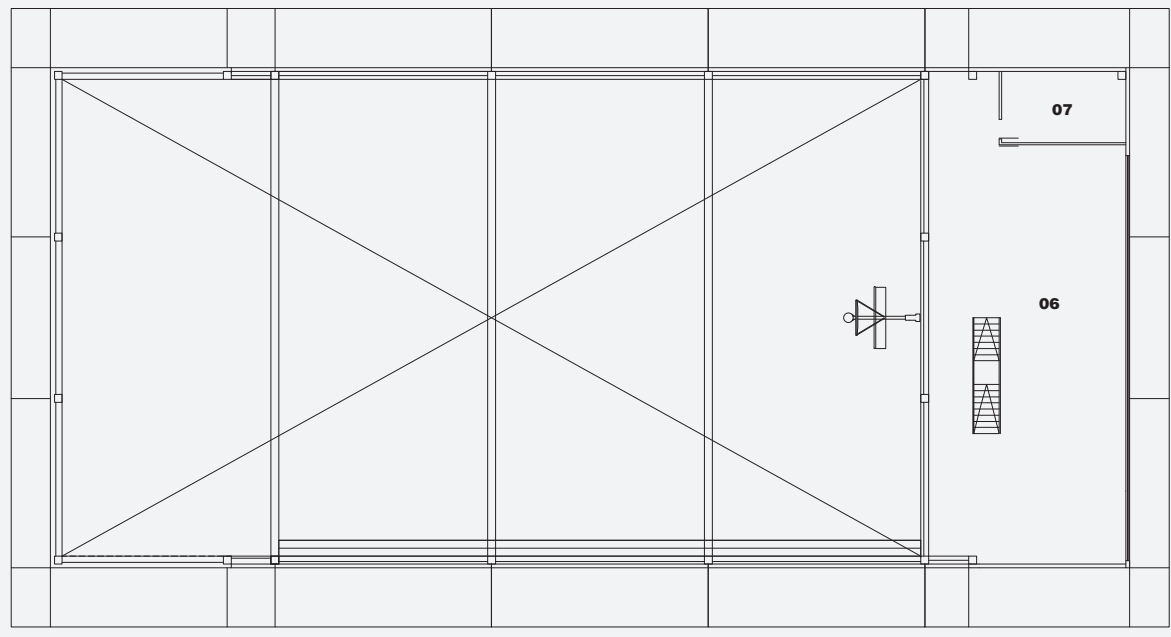




\section{CATÁLOGO EQUIPAMENTOS DSL}

POLIDEPORTIVO DSL DISSOLUÇÃO PROGRAMÁTICA

Esporte $1546 \mathbf{m}^{2}$
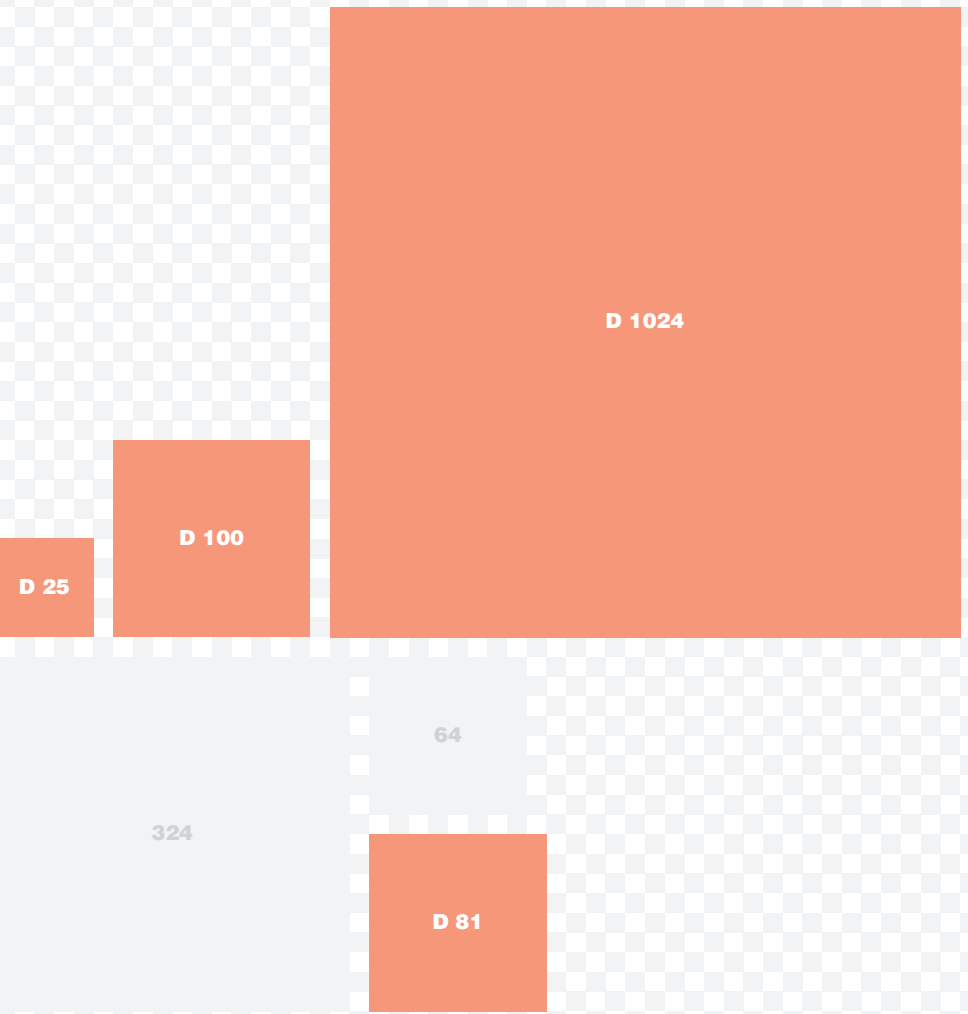
CATÁLOGO EQUIPAMENTOS DSL

POLIDEPORTIVO DSL DISSOLUÇÃO ÉSPACIAL

Área Construída $1391 \mathrm{~m}^{2}$

Área Exterior Coberta ----m²

Pátios ---m²

Terreno 1900m²

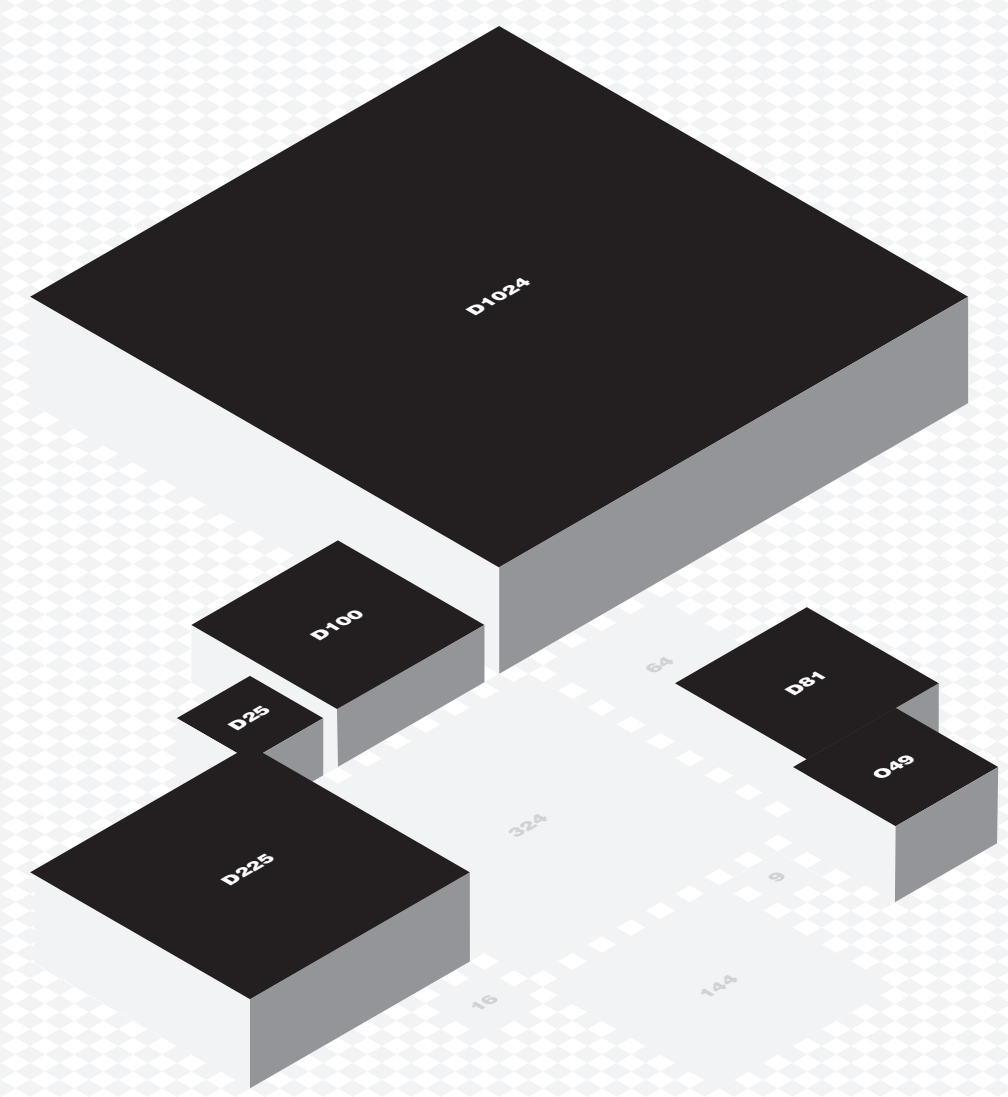




\section{CATÁLOGO EQUIPAMENTOS DSL}

PLAZA N ${ }^{\circ} 11$

Ano 2010

Área total $3059 \mathrm{~m}^{2}$

Autor Projeto Arq. Lucía Cracco / Secr. Nacional de Deportes

Localização Cerro, UY.

Organização gestora SND Secretaria Nacional de Deportes

Organização responsável SND Secretaria Nacional de Deportes

Fonte SND
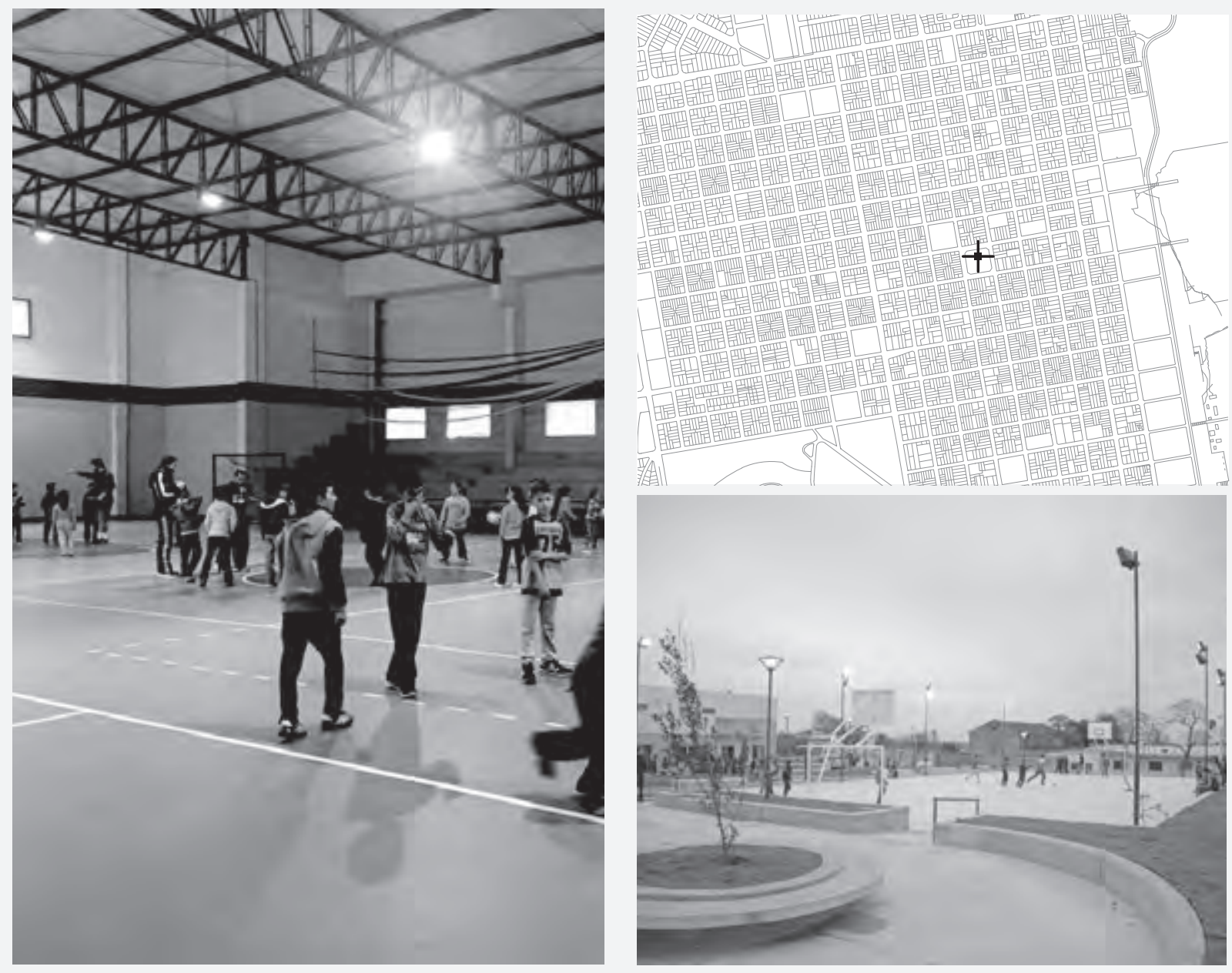
CATÁLOGO EQUIPAMENTOS DSL

PLAZA N ${ }^{\circ} 11$

Pav. Térreo

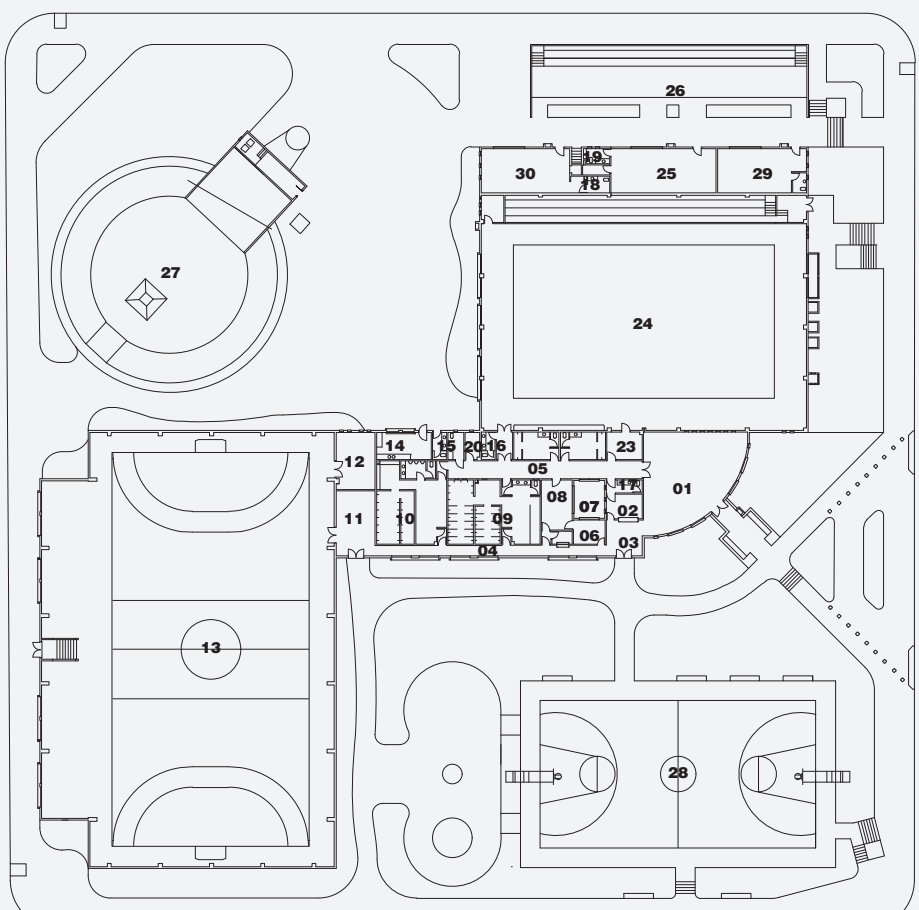

Área Construída $3059 \mathrm{~m}^{2}$

Área Exterior Coberta ----m²

Pátios --.-m²

Ocupação de Solo $\mathbf{8 5 4 7 m ^ { 2 }}$

Taxa Ocupação de Solo $\mathbf{4 5 \%}$

Terreno $8547 \mathrm{~m}^{2}$

Esporte $\mathbf{3 4 7 7 \mathbf { m } ^ { 2 }}$

Outros $40,5 \mathrm{~m}^{2}$

Saúde 40,5m²

ESPORTE $\quad 010$

$\begin{array}{ll}01 & \text { Sala de espera e estar } \\ 02 & \text { Atendimento } \\ 03 & \text { Hall } \\ \mathbf{0 4} & \text { Circulação 1 } \\ 05 & \text { Circulação 2 } \\ \mathbf{0 6} & \text { Direção } \\ \mathbf{0 7} & \text { Pátio } \\ \mathbf{0 8} & \text { Sala de professores } \\ \mathbf{0 9} & \text { Vestuário Mulheres } \\ \mathbf{1 0} & \text { Vestuário Homens } \\ \mathbf{1 1} & \text { Sala espera Academia } \\ \mathbf{1 2} & \text { Deposito Academia } \\ \mathbf{1 3} & \text { Quadra Fechada } \\ \mathbf{1 4} & \text { Cafeteria } \\ \mathbf{1 5} & \text { Banh. 1 } \\ \mathbf{1 6} & \text { Banh. 2 } \\ \mathbf{1 7} & \text { Banh. 3 } \\ \mathbf{1 8} & \text { Banh. 4 } \\ \mathbf{1 9} & \text { Banh. 5 } \\ \mathbf{2 0} & \text { Funcionários } \\ \mathbf{2 1} & \text { Prof. Homens } \\ \mathbf{2 2} & \text { Prof. Mulheres } \\ \mathbf{2 3} & \text { Deposito Piscina } \\ \mathbf{2 4} & \text { Piscina } \\ \mathbf{2 5} & \text { Club de "Bochas" } \\ \mathbf{2 6} & \text { Quadra de "bochas" e disco } \\ \mathbf{2 7} & \text { Pista skate } \\ \mathbf{2 8} & \text { Quadra aberta }\end{array}$

OUTROS
SAÚDE

$\begin{array}{ll}29 & \text { Delegacia policial/Pagos c/banh. } 9 \\ 30 & \text { Policlinica }\end{array}$

$10,55 \mathrm{~m} \quad 8,2 \mathrm{~m} \quad 3,1 \mathrm{~m}$

$3,6 \mathrm{~m} \quad 2,5 \mathrm{~m} \quad 3,1 \mathrm{~m}$

$3,7 \mathrm{~m} \quad 3,6 \mathrm{~m} \quad 3,1 \mathrm{~m}$

$23,6 \mathrm{~m} \quad 1 \mathrm{~m} \quad 3,1 \mathrm{~m}$

$\begin{array}{lll}19,7 \mathrm{~m} & 1,85 \mathrm{~m} & 3,1 \mathrm{~m} \\ 3,2 \mathrm{~m} & 2,45 \mathrm{~m} & 3,1 \mathrm{~m}\end{array}$

$3,82 \mathrm{~m} \quad 3,12 \mathrm{~m} \quad 3,1 \mathrm{~m}$

$6,5 \mathrm{~m} \quad 3,12 \mathrm{~m} \quad 3,1 \mathrm{~m}$

$9,32 \mathrm{~m} \quad 6,5 \mathrm{~m} \quad 3,1 \mathrm{~m}$

$\begin{array}{lll}7,11 \mathrm{~m} & 6,5 \mathrm{~m} & 3,1 \mathrm{~m}\end{array}$

$6,6 \mathrm{~m} \quad 3,96 \mathrm{~m} \quad 3,1 \mathrm{~m}$

$5,8 \mathrm{~m} \quad 3,96 \mathrm{~m} \quad 3,1 \mathrm{~m}$

$44,1 \mathrm{~m} \quad 29,7 \mathrm{~m} \quad$ var. $8,90 / 7,40 \mathrm{~m}$

$5,56 \mathrm{~m} \quad 2,75 \mathrm{~m} \quad 3,1 \mathrm{~m}$

$\begin{array}{lll}3,1 \mathrm{~m} & 2,75 \mathrm{~m} & 3,1 \mathrm{~m}\end{array}$

$\begin{array}{lll}2,8 \mathrm{~m} & 1,45 \mathrm{~m} & 3,1 \mathrm{~m} \\ 3,6 \mathrm{~m} & 1,33 \mathrm{~m} & 3,1 \mathrm{~m}\end{array}$

$3,9 \mathrm{~m} \quad 1,75 \mathrm{~m} \quad 3,1 \mathrm{~m}$

$2,7 \mathrm{~m} \quad 1,5 \mathrm{~m} \quad 3,1 \mathrm{~m}$

$2,75 \mathrm{~m} \quad 1,47 \mathrm{~m} \quad 3,1 \mathrm{~m}$

$4,6 \mathrm{~m} \quad 2,8 \mathrm{~m} \quad 3,1 \mathrm{~m}$

$\begin{array}{lll}4,6 \mathrm{~m} & 2,8 \mathrm{~m} & 3,1 \mathrm{~m}\end{array}$

$33 \mathrm{~m} \quad 23,8 \mathrm{~m} \quad$ var. $5,20 / 4 \mathrm{~m}$

$\begin{array}{lll}33,6 \mathrm{~m} & 4,8 \mathrm{~m} & \mathrm{var}\end{array}$

$47,7 \mathrm{~m}^{2} \quad$ D49

$\begin{array}{ll}7,25 \mathrm{~m}- & 202,27 \mathrm{~m}^{2} \quad \text { D225 }\end{array}$

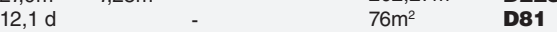

$\begin{array}{llll}32 \mathrm{~m} & 19 \mathrm{~m} \quad- & 608 \mathrm{~m}^{2} & \text { D324 }\end{array}$ 


\section{CATÁLOGO EQUIPAMENTOS DSL}

PLAZA N ${ }^{\circ} 11$

Subsolo - Pav. Superior
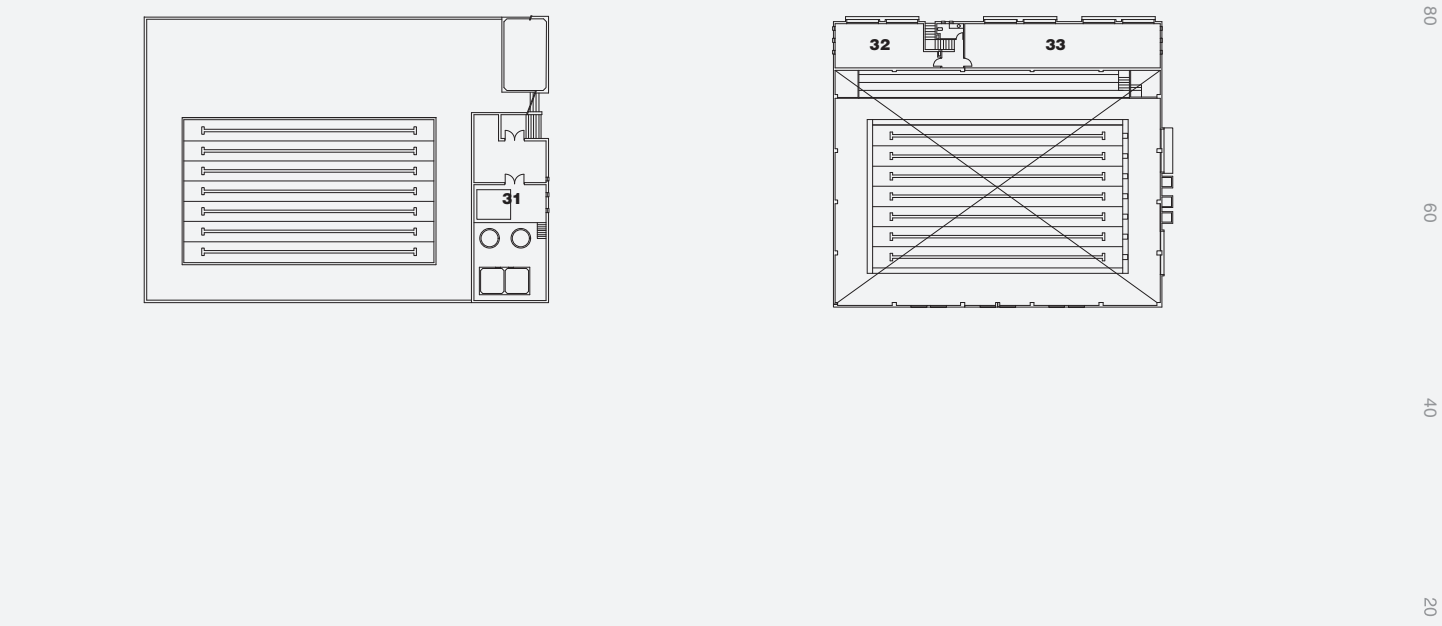

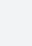
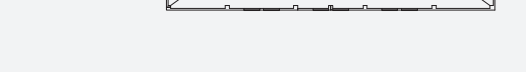

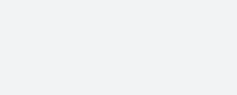

ESPORTIVO

$\begin{array}{ll}\text { 31 } & \text { Sala de máquinas } \\ \text { 32 } & \text { Ateliês artísticos } \\ \text { 33 } & \text { Sala web } \\ \text { 34 } & \text { Banh. } 6 \\ \text { * Local, soma de vários locais }\end{array}$
32 Sala de máquinas
32 Ateliês artísticos
* Local, soma de vários locais

$\begin{array}{lll}\text { L } & \text { I } & \text { Alt. } \\ & & \\ 18,9 \mathrm{~m} & 7,33 \mathrm{~m} & 3,1 \mathrm{~m} \\ 19,85 \mathrm{~m} & 4,5 \mathrm{~m} & 3,1 \mathrm{~m} \\ 8,9 \mathrm{~m} & 4,5 \mathrm{~m} & 3,1 \mathrm{~m} \\ 2,8 \mathrm{~m} & 2,6 \mathrm{~m} & 3,1 \mathrm{~m}\end{array}$

Sup.

$138,5 \mathrm{~m}^{2}$

$89,32 \mathrm{~m}$

$40,05 \mathrm{~m}^{2}$

$7,28 \mathrm{~m}^{2}$

DSL

D144

E100

D49

D25* 


\section{CATÁLOGO EQUIPAMENTOS DSL}

PLAZA N 11 DSL DISSOLUÇÃO PROGRAMÁTICA

Esporte $1546 \mathbf{m}^{2}$

Outros $40,5 \mathbf{m}^{2}$

Saúde $40,5 \mathbf{m}^{2}$

ㅁ
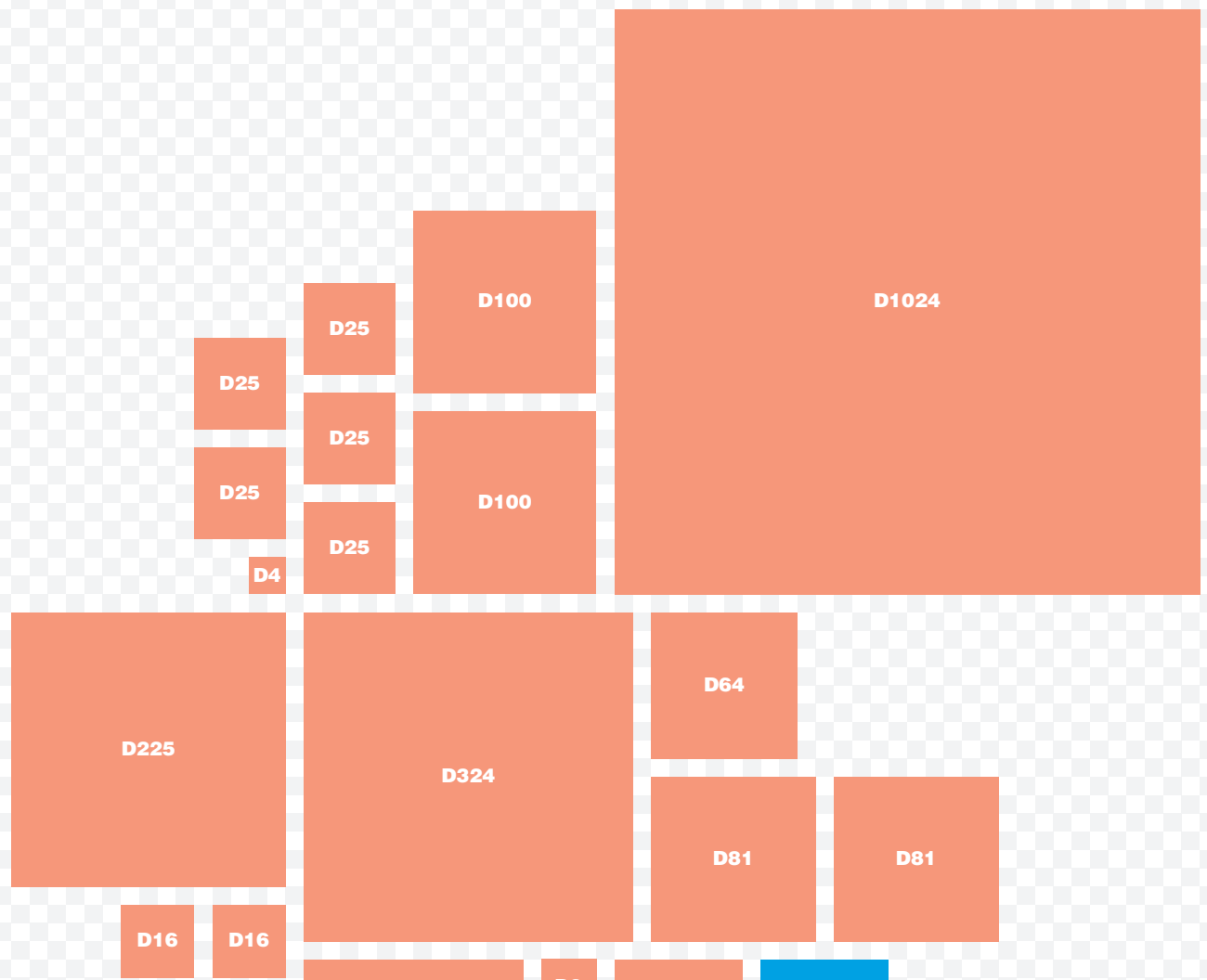

$\$ 49$
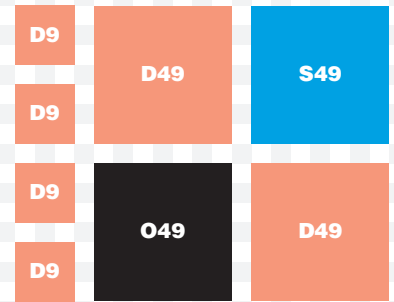


\section{CATÁLOGO EQUIPAMENTOS DSL}

PLAZA N 11 DSL DISSOLUÇÃO ESPÅCIAL

Área Construída $3059 \mathrm{~m}^{2}$

Área Exterior Coberta ---m

Pátios ---m²

Terreno $8547 \mathrm{~m}^{\mathbf{2}}$

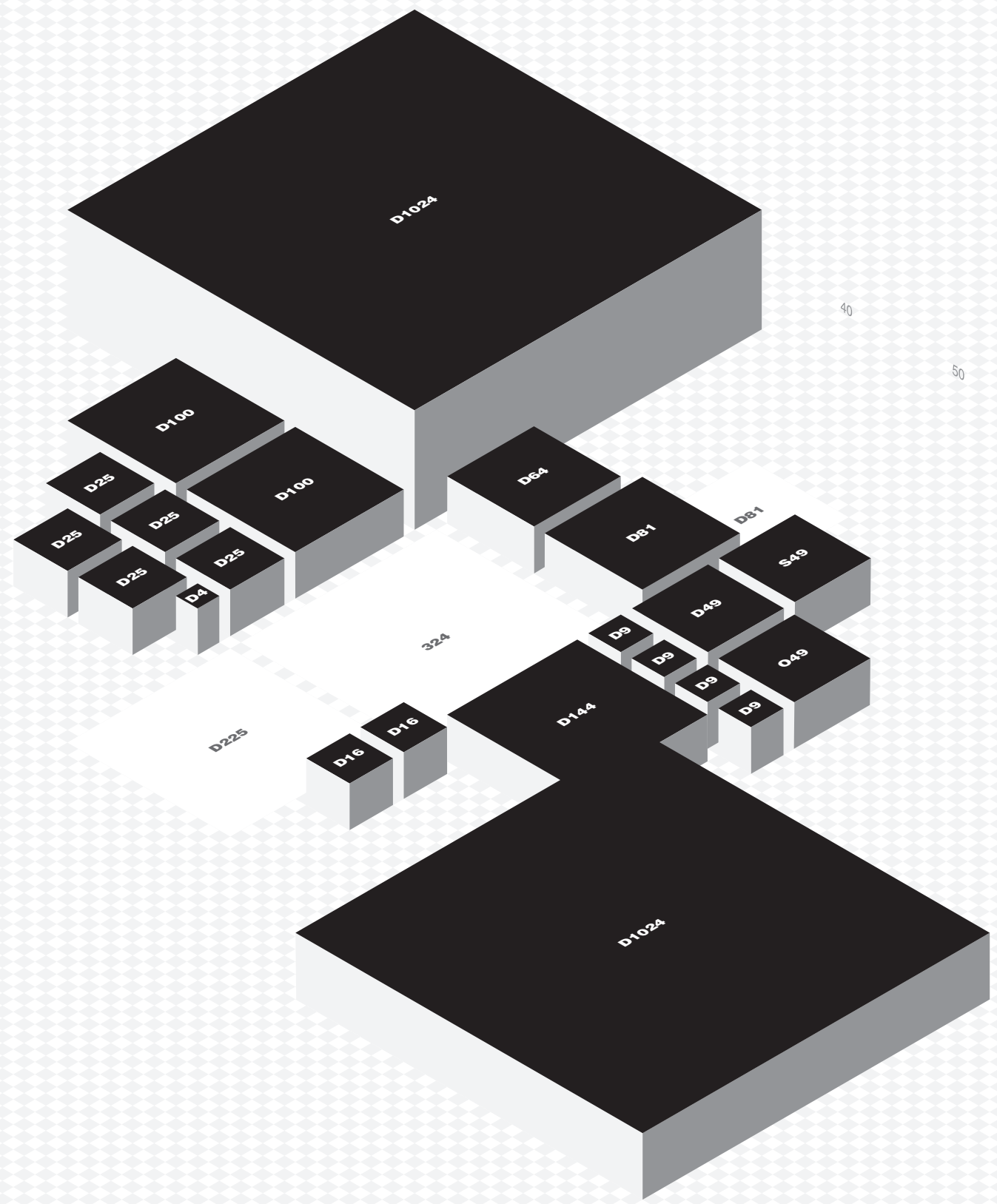


CATÁLOGO EQUIPAMENTOS DSL

PAC

Ano 2007/ 2013-hoje

Área total $\mathbf{4 m ^ { 2 }}$

Autor AGESIC

Localização Varias

Organização gestora

Organização responsável

Fonte AGESIC http://atencionciudadana.gub.uy 


\section{CATÁLOGO EQUIPAMENTOS DSL}

PAC

Pav. Térreo

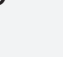




\section{CATÁLOGO EQUIPAMENTOS DSL}

PAC DSL DISSOLUÇÃO PROGRAMÁTICA

Atenção Cidadã $4 \mathbf{m}^{2}$ a 
CATÁLOGO EQUIPAMENTOS DSL

, 


\section{CATÁLOGO EQUIPAMENTOS DSL}

CENTRO DE BARRIO PEÑAROL

\section{Ano 2014}

Área total $\mathbf{5 7 6 \mathbf { m } ^ { 2 }}$

Autor Políticas Territoriais OPP Presidencia de la República

Localização Barrio Peñarol, Montevideo. UY.

Organização gestora Municipio G

Organização responsável Intendencia de Montevideo. OPP

Fonte MATILDE DE LOS SANTOS. El espacio público en las periferias críticas como lugar de integración social ¿entre-deux comunidad - institucionalidad? 2017
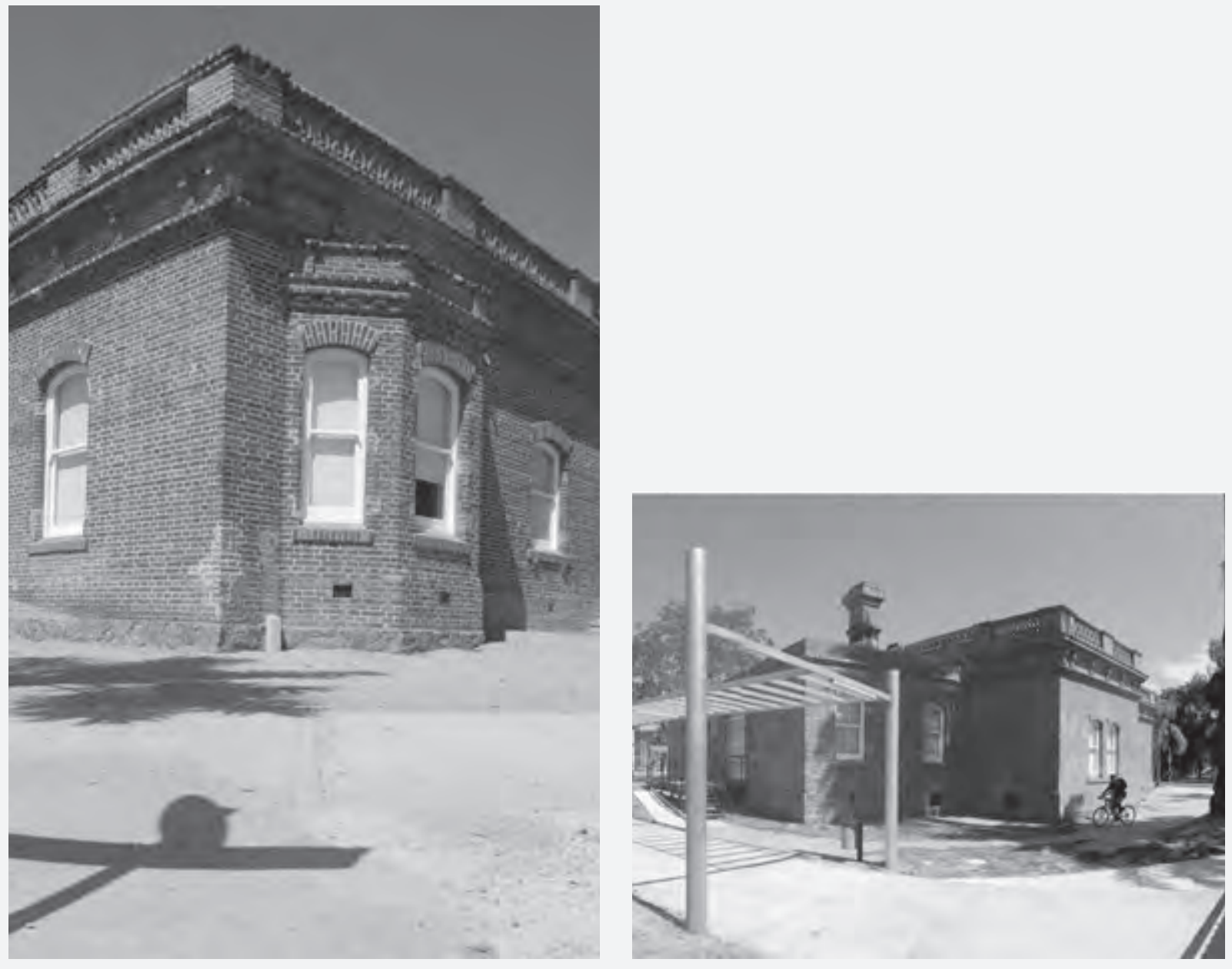
CATÁLOGO EQUIPAMENTOS DSL

CENTRO DE BARRIO PEÑAROL CJA

Pav. Térreo

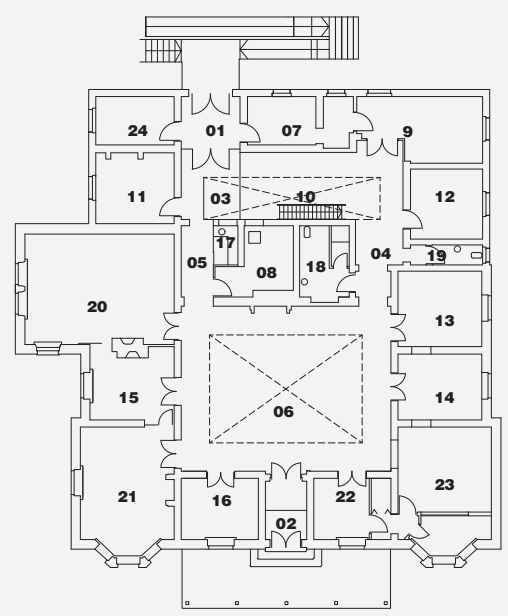

Área Construída $\mathbf{5 7 6 \mathbf { m } ^ { 2 }}$

Área Exterior Coberta $\mathbf{3 8 \mathbf { m } ^ { 2 }}$

Pátios ---m²

Ocupação de Solo $\mathbf{5 7 6} \mathbf{m}^{\mathbf{2}}$

Taxa Ocupação de Solo 16\%

Terreno $\mathbf{3 8 0 0 \mathbf { m } ^ { 2 }}$

Cultural 408m²

Atenção Cidadã $\mathbf{9} \mathbf{m}^{\mathbf{2}}$

\begin{tabular}{|c|c|c|c|c|c|c|c|}
\hline & & & $\mathrm{L}$ & 1 & Alt. & Sup. & DSL \\
\hline \multirow[t]{23}{*}{ SOCIAL E CULTURAL } & 01 & Entrada 01 & $3 m$ & $2,66 \mathrm{~m}$ & $4,26 m$ & $7,98 m^{2}$ & C9 \\
\hline & 02 & Entrada 02 & $2,96 \mathrm{~m}$ & $2,1 \mathrm{~m}$ & $4,26 \mathrm{~m}$ & $6,21 \mathrm{~m}^{2}$ & C9 \\
\hline & 03 & Hall I & $3,6 \mathrm{~m}$ & $3 m$ & $4,26 \mathrm{~m}$ & $10,8 \mathrm{~m}^{2}$ & C16* \\
\hline & 04 & Hall II & $2,4 \mathrm{~m}$ & $2,3 m$ & $3,1 \mathrm{~m}$ & $5,52 m^{2}$ & C16* \\
\hline & 05 & Circulação & $4 m$ & $1,63 \mathrm{~m}$ & $4,26 \mathrm{~m}$ & $6,52 \mathrm{~m}^{2}$ & C9 \\
\hline & 06 & Sala Multiuso & $10,65 \mathrm{~m}$ & $8,4 \mathrm{~m}$ & $3,55 \mathrm{~m}$ & $89,46 m^{2}$ & C81 \\
\hline & 07 & Deposito I & $5,4 \mathrm{~m}$ & $2,45 \mathrm{~m}$ & $3,55 \mathrm{~m}$ & $13,23 \mathrm{~m}^{2}$ & C25* \\
\hline & 08 & Deposito II & $3,3 m$ & $2,8 \mathrm{~m}$ & $4,26 \mathrm{~m}$ & $9,24 m^{2}$ & C25* \\
\hline & 09 & Ateliê Sujo & $6,4 \mathrm{~m}$ & $3,4 \mathrm{~m}$ & $4,26 \mathrm{~m}$ & $21,76 \mathrm{~m}^{2}$ & C25 \\
\hline & 10 & Ateliê Limpo & $8,3 \mathrm{~m}$ & $3,4 \mathrm{~m}$ & $4,26 \mathrm{~m}$ & $28,22 m^{2}$ & C25 \\
\hline & 11 & Sala I & $3,9 m$ & $3,6 \mathrm{~m}$ & $4,26 \mathrm{~m}$ & $14,04 \mathrm{~m}^{2}$ & C16 \\
\hline & 12 & Sala II & $3,7 \mathrm{~m}$ & $3,5 \mathrm{~m}$ & $4,26 \mathrm{~m}$ & $12,95 \mathrm{~m}^{2}$ & C16 \\
\hline & 13 & Sala III & $4,3 m$ & $3,85 \mathrm{~m}$ & $4,26 m$ & $16,55 \mathrm{~m}^{2}$ & C16 \\
\hline & 14 & Sala IV & $4,3 m$ & $3,2 \mathrm{~m}$ & $4,26 m$ & $13,76 \mathrm{~m}^{2}$ & C16 \\
\hline & 15 & Sala V & $4,3 m$ & $3,2 \mathrm{~m}$ & $4,26 m$ & $13,76 \mathrm{~m}^{2}$ & C16 \\
\hline & 16 & Sala VI & $3,9 m$ & $3,11 \mathrm{~m}$ & $4,26 m$ & $12,12 \mathrm{~m}^{2}$ & C16 \\
\hline & 17 & Oficina & $1,98 \mathrm{~m}$ & $1,25 \mathrm{~m}$ & $4,26 \mathrm{~m}$ & $2,47 m^{2}$ & C4 \\
\hline & 18 & Banh. I & $3,6 \mathrm{~m}$ & $2,52 \mathrm{~m}$ & $4,26 \mathrm{~m}$ & $9,07 \mathrm{~m}^{2}$ & C9* \\
\hline & 19 & Banh. II & $2,8 m$ & $1,02 \mathrm{~m}$ & $3,1 \mathrm{~m}$ & 2,856 & C9* \\
\hline & 20 & Sala Projeções & $7,58 \mathrm{~m}$ & $5,6 \mathrm{~m}$ & $4,26 \mathrm{~m}$ & $42,44 m^{2}$ & C49 \\
\hline & 21 & Administração & $6 \mathrm{~m}$ & $4,75 \mathrm{~m}$ & $4,26 \mathrm{~m}$ & $28,5 \mathrm{~m}^{2}$ & C25 \\
\hline & 22 & Edição & $3,9 m$ & $3,11 \mathrm{~m}$ & $4,26 m$ & $12,12 \mathrm{~m}^{2}$ & C16 \\
\hline & 23 & Gravação & $6 m$ & $4,75 \mathrm{~m}$ & $4,26 \mathrm{~m}$ & $28,5 m^{2}$ & C25 \\
\hline ATENCÃO CIDADÃ & 24 & Local AFE (Ferrocarril) & $3,9 m$ & $2,46 \mathrm{~m}$ & $4,26 \mathrm{~m}$ & $9,59 \mathrm{~m}^{2}$ & A9 \\
\hline
\end{tabular}




\section{CATÁLOGO EQUIPAMENTOS DSL}

CENTRO DE BARRIO PEÑAROL CJA DSL DISSOLUÇÃO PROGRAMÁTICA 


\section{CATÁLOGO EQUIPAMENTOS DSL}

CENTRO DE BARRIO PEÑAROL CJA 'DSLL DISSOLUÇÃO ESPACIAL Área Construída $576 \mathrm{~m}^{2}$

Área Exterior Coberta $\mathbf{1 6 \mathbf { m } ^ { 2 }}$

Pátios ---m²

Terreno $\mathbf{3 8 0 0 \mathbf { m } ^ { 2 }}$
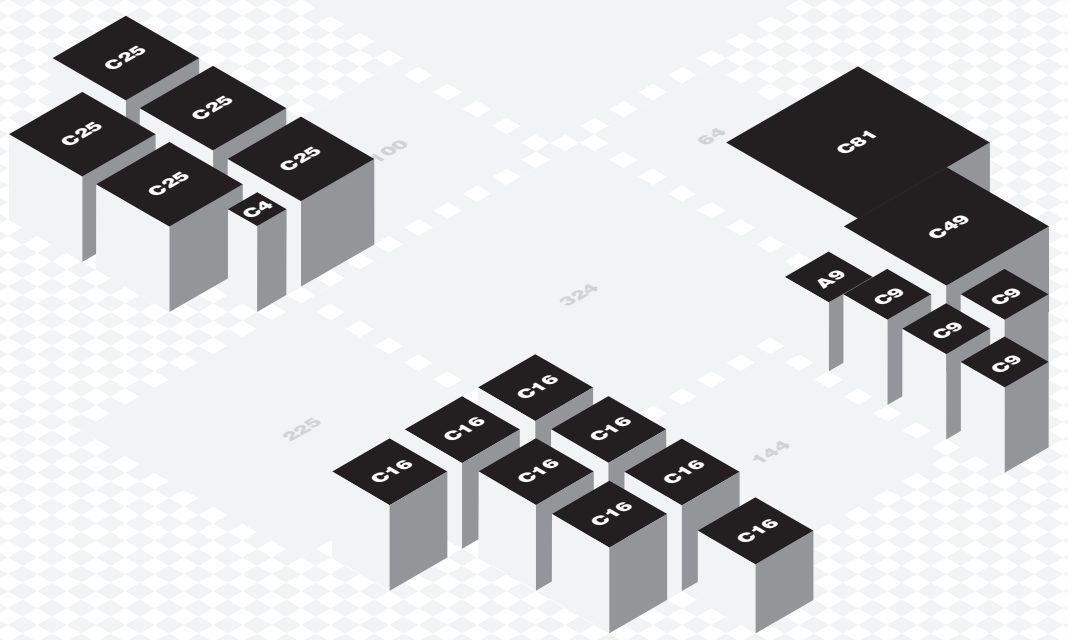
CATÁLOGO EQUIPAMENTOS DSL CENTRO DE BARRIO PEÑAROL CIM Pav. Térreo

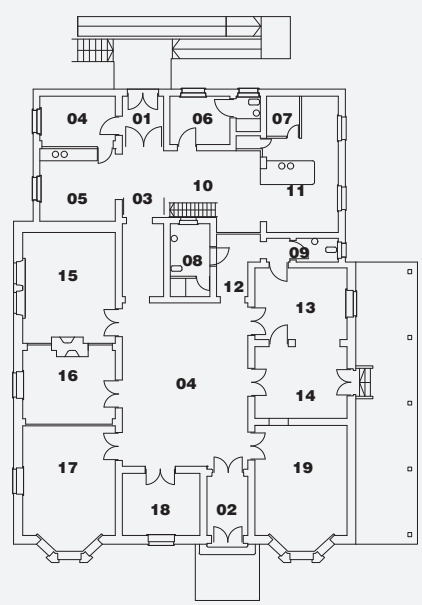

Área Construída $477 \mathrm{~m}^{2}$

Área Exterior Coberta $\mathbf{5 3} \mathbf{m}^{2}$

Pátios ---m²

Ocupação de Solo $\mathbf{4 7 7 m ^ { 2 }}$

Taxa Ocupação de Solo 12\%

Terreno $\mathbf{3 8 0 0 \mathbf { m } ^ { 2 }}$

Cultural 294m²

Atenção Cidadã $\mathbf{2 7} \mathbf{m}^{\mathbf{2}}$

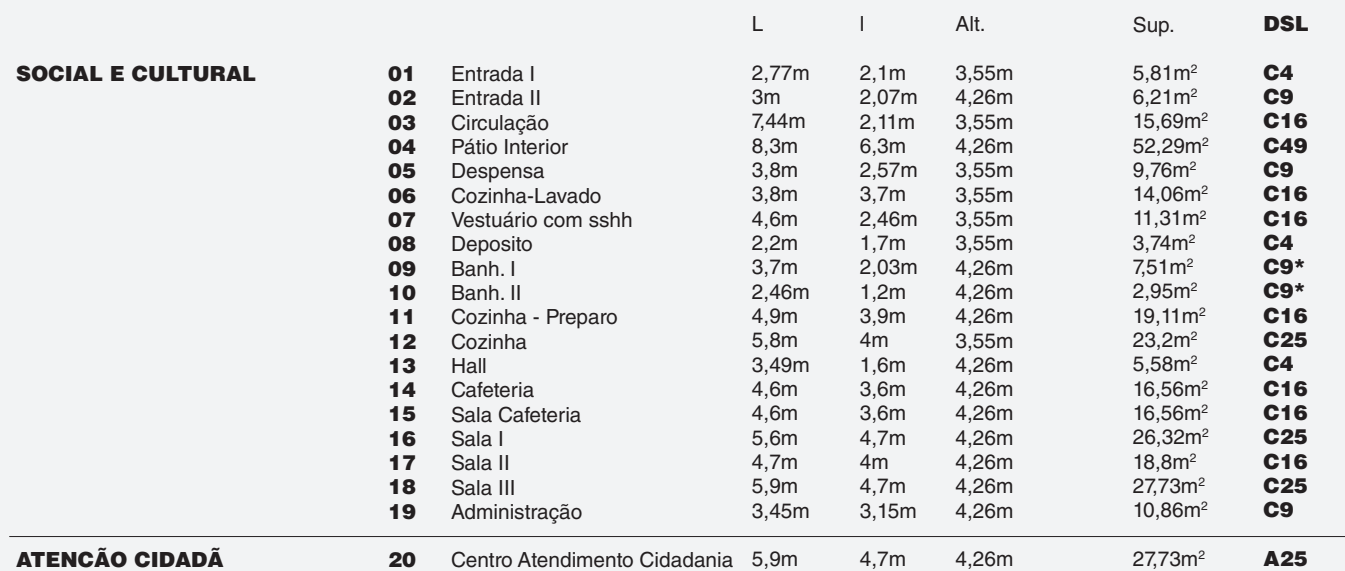




\section{CATÁLOGO EQUIPAMENTOS DSL}

CENTRO DE BARRIO PEÑAROL CIM DSL DISSOLUÇÃO PROGRAMÁTICA Cultural 294m²

Atenção Cidadã $\mathbf{2 7} \mathbf{m}^{\mathbf{2}}$ 


\section{CATÁLOGO EQUIPAMENTOS DSL}

CENTRO DE BARRIO PEÑAROL CIM DSL DISSOLUÇÃO ESPACIAL Área Construída $477 \mathrm{~m}^{2}$

Área Exterior Coberta $12 \mathrm{~m}^{2}$

Pátios ---m²

Terreno $\mathbf{3 8 0 0 \mathbf { m } ^ { 2 }}$ 

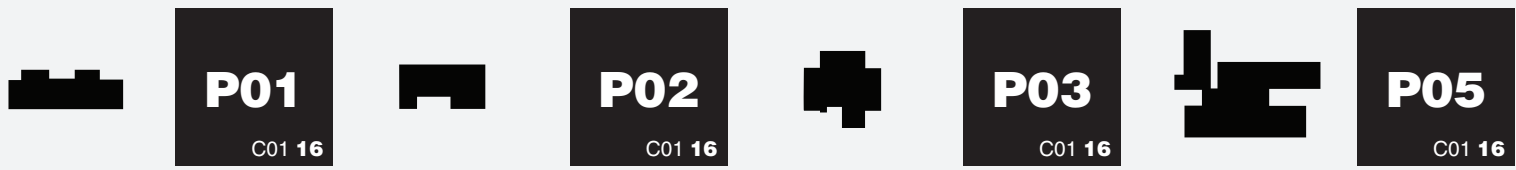

\section{CAIF}

Autor: Arquitectura INAU

Ano: 2018 e anteriores.

Localização: Casavalle, UY.

\section{CEC}

Autor: PAEMFE sd

Ano: 2010 e depois

Localização: Casavalle, UY.

JARDÍM DE INFÂNCIA

Autor: PAEPU - Arq. Carlos Sitya

Autor: PAE

Localização: Neptunia, UY.

C01 Pg 16

C01 Pg 16
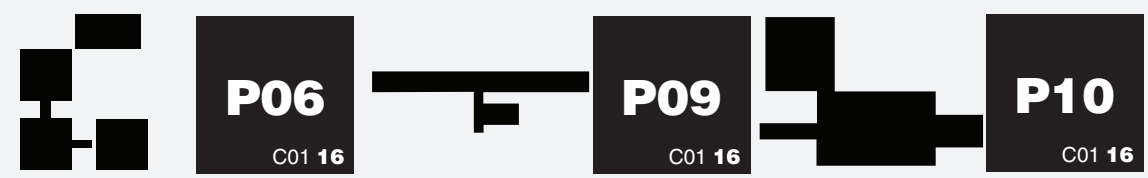

ESCOLA 178

ETC 91A Modular Autor: PAEPU. Arq. Pedro Barrán Ano:2017. Projeto

Localização: Projeto Tipo

C01 Pg 16

Autor: sd

Ano: 1956

Localização: Casavalle, UY.

C01 Pg 16
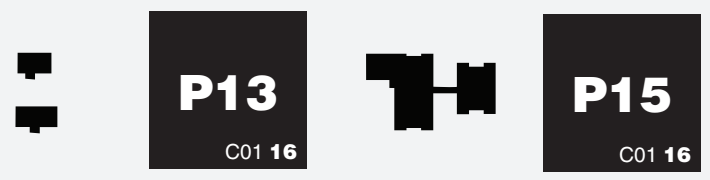

LICEO Ciudad del Plata Autor:PAEMFE - Arq. Bernardo Martin Ano: 2013

Localização: Ciudad del Plata, UY.

C01 Pg 16
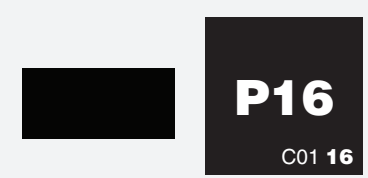

POLIDEPORTIVO

POLICINICA 2/3 consult POLICLÍNICA C. PLATA Autor: ASSE Div. Arquitetura Ano: 2015

Localização: Varias, UY.

C01 Pg 16

POLICL: PRIS / ASSE Div. Arquitetura Autor: PRIS / A

Localização: Ciudad del Plata, UY.

Autor: CND. Arquitetura

Ano: 2017

Localização: Varias, UY.

C01 Pg 16

C01 Pg 16

CEA

Autor: PAEMFE Arq. Andrea Gnesetti Ano: 2017

Localização: Casavalle, UY.

C01 Pg 16

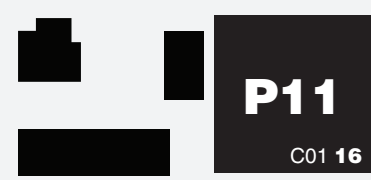

POLO TECNOLOGICO

Autor: PAEMFE. Projeto Tipo.

Ano: Projeto 2017

Localização: Varias, UY.

C01 Pg 16

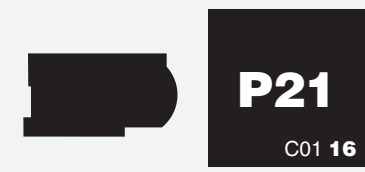

\section{CeDel}

Autor: Int. Montevideo. Arqs. Morán Sandoval.

Ano: 2004

Localização: Casavalle, UY.

C01 Pg 16

PAC

Autor: AGESIC

Ano: 2007/ 2013-hoje.

Localização: Varias, UY.
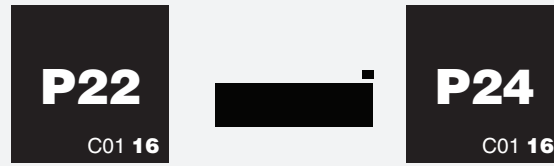

C01 Pg 16

\section{CENTRO Cívico}

Autor: Int. Montevideo. Arq. Juan Díaz Ano: 2014

Localização: Casavalle, UY

C01 Pg 16 


\section{ÁREAS}

EDUCAÇÃO

E4

므

E9

W

E16
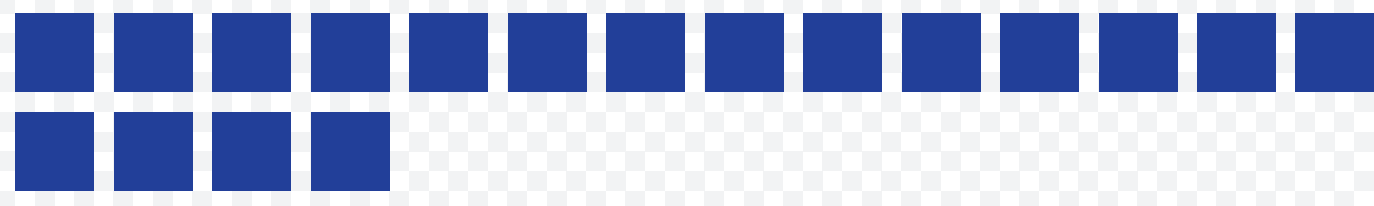

E25
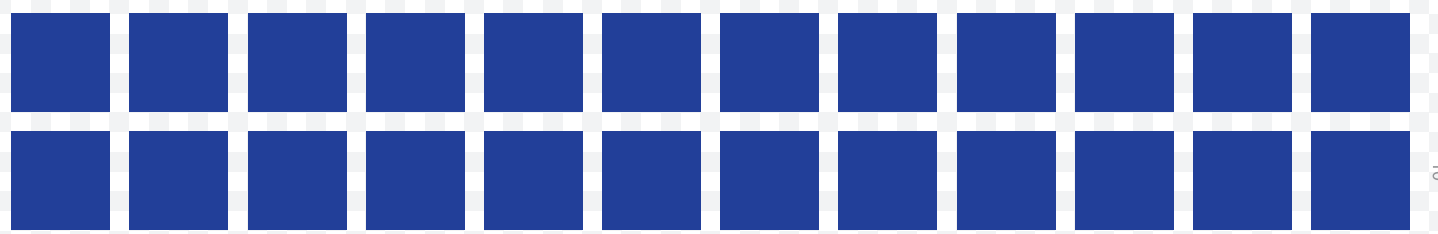

\section{E49}
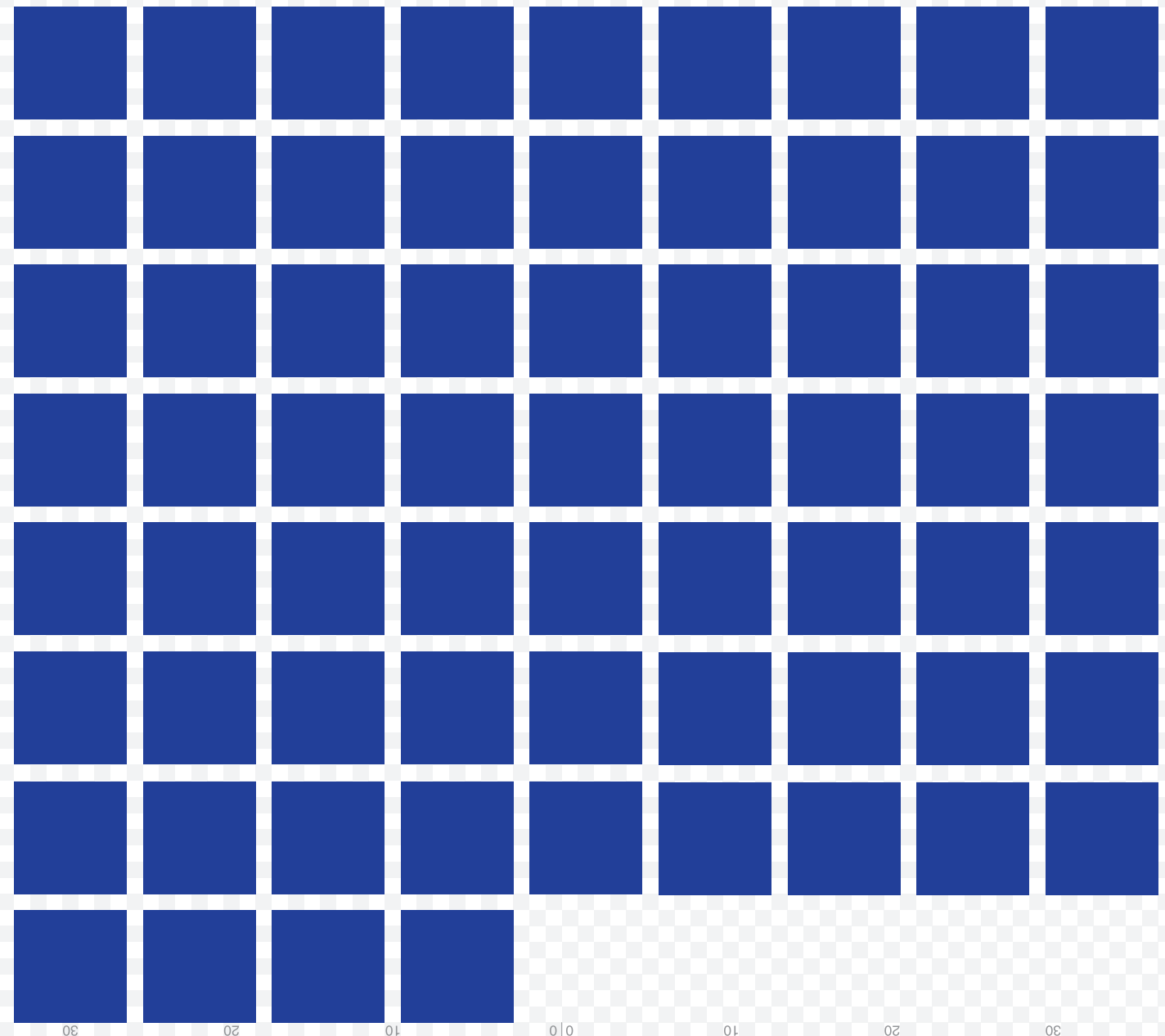


\section{ÁREAS}

EDUCAÇÃO

\section{E64}
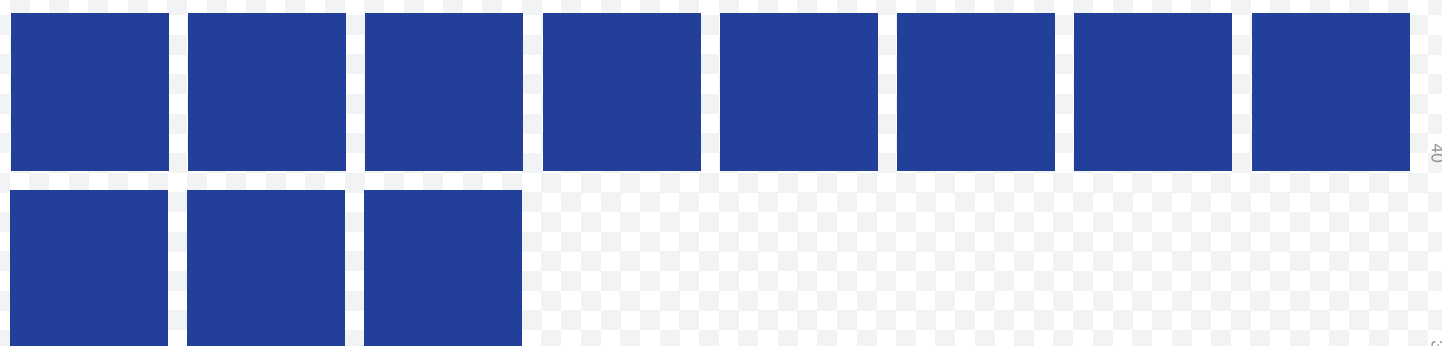

E81
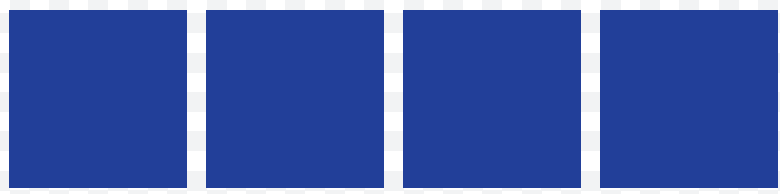

E144
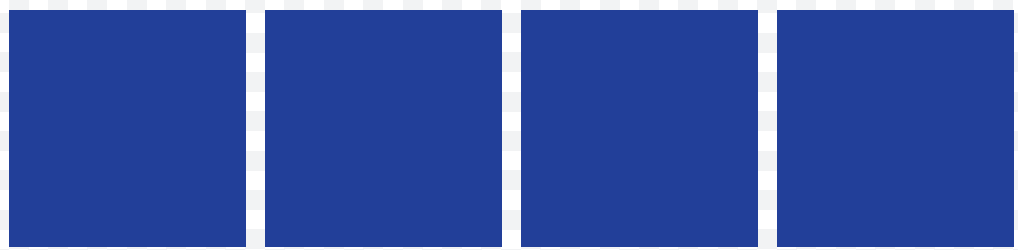

\section{E225}
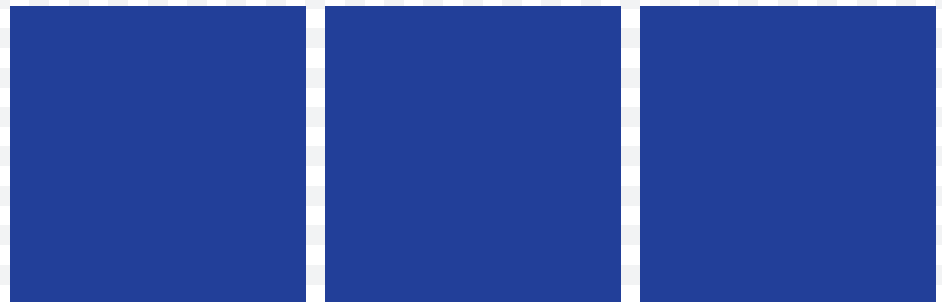

E324
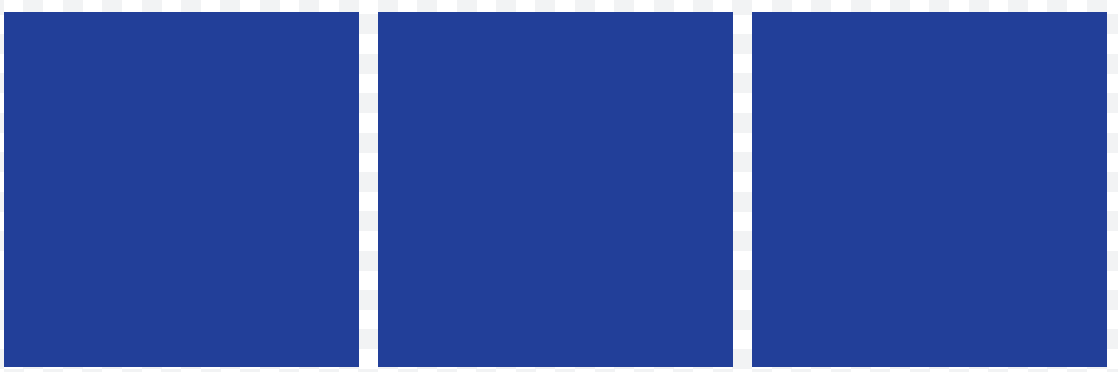


\section{ÁREAS}

EDUCAÇÃO

\section{E324}
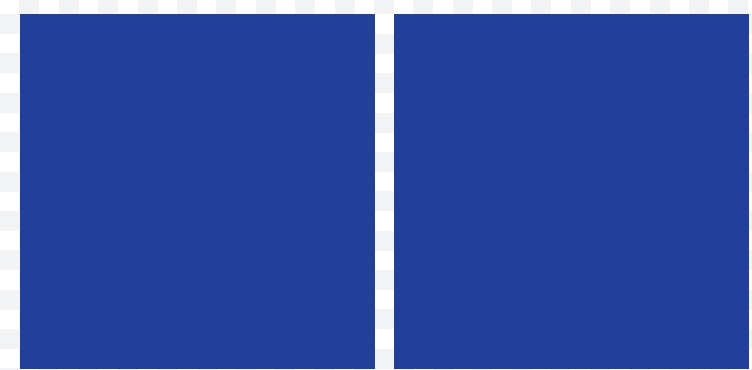


\section{ÁREAS}

SAÚDE

54

59

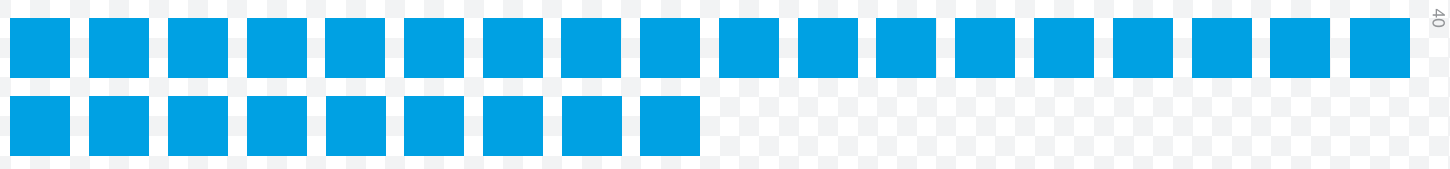

516

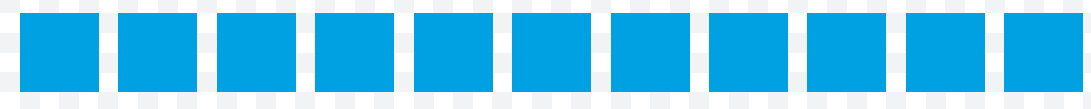

$\mathbf{S 2 5}$

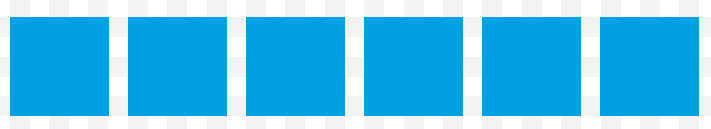

$\mathbf{S 2 2 5}$

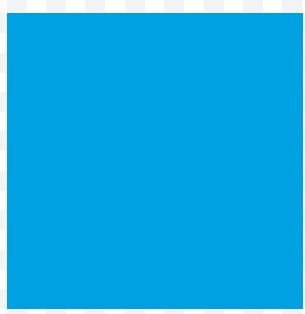


ÁREAS

SPORTE

D25

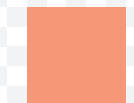

D49

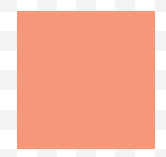

D81

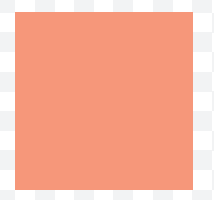

D100

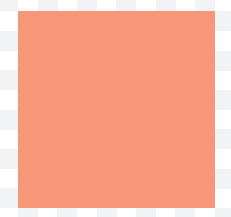

D225

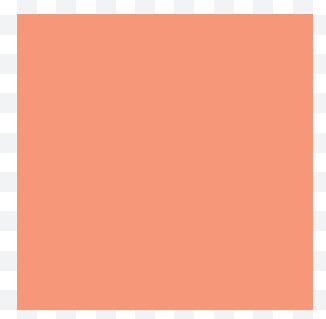

\section{D324}

D1024

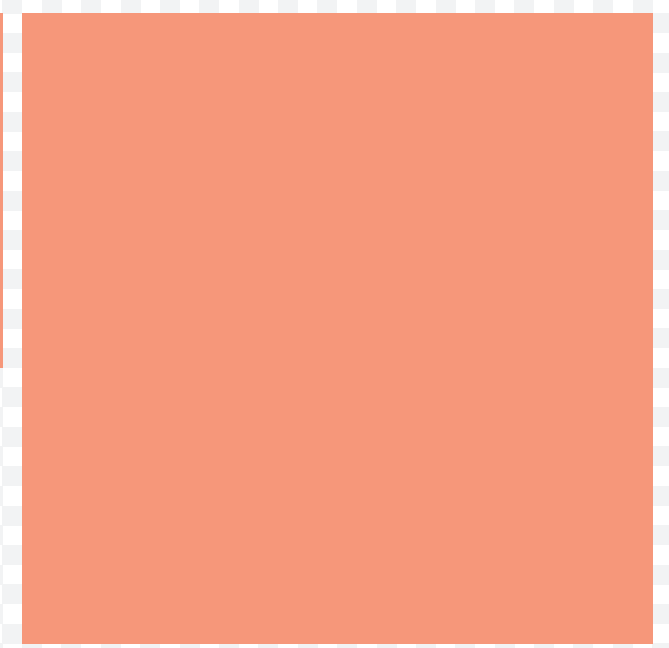




\section{ÁREAS}

TRABALHO E EMPREGO

T4

T16

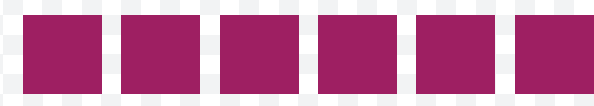

T25

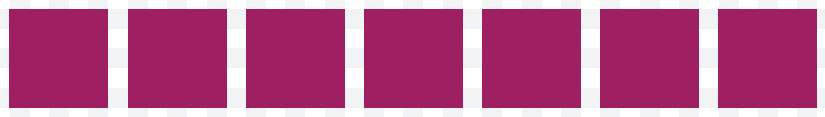

T49

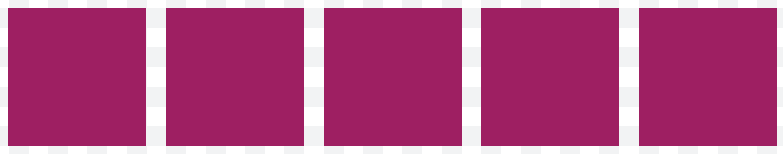

T64

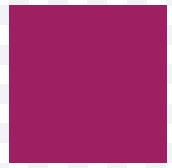

T81

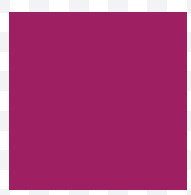

T225

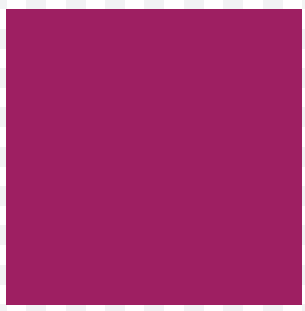




\section{ÁREAS}

SOCIAL E CULTURAL

59

516

E64

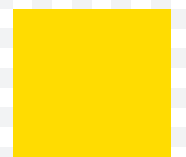

D100

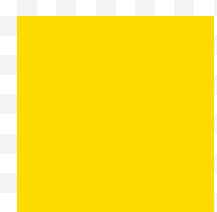

C144

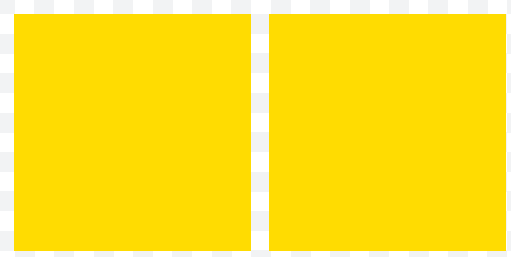

ATENÇÃO CIDADÃ

T4

E9

E16

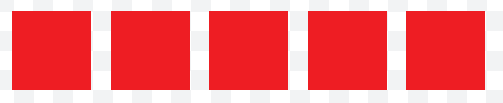

E25

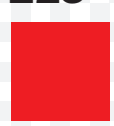




\section{ÁREAS}

Margem áreas

\section{4}

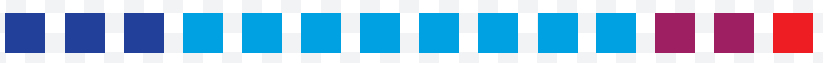

9

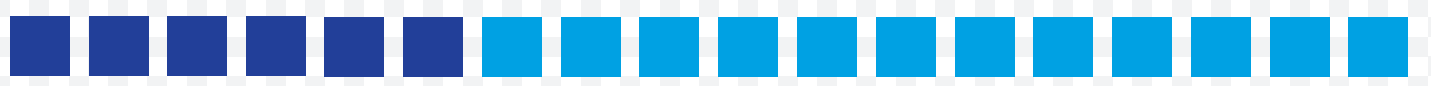

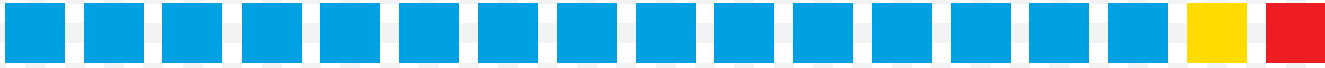

16

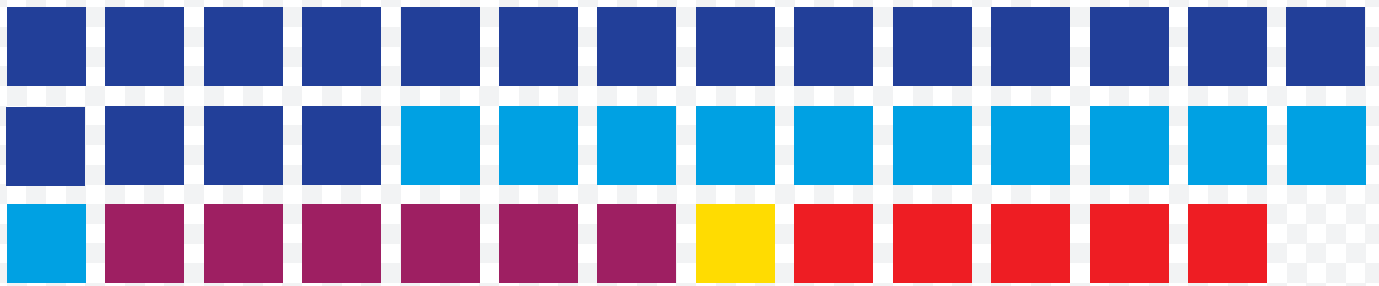

25
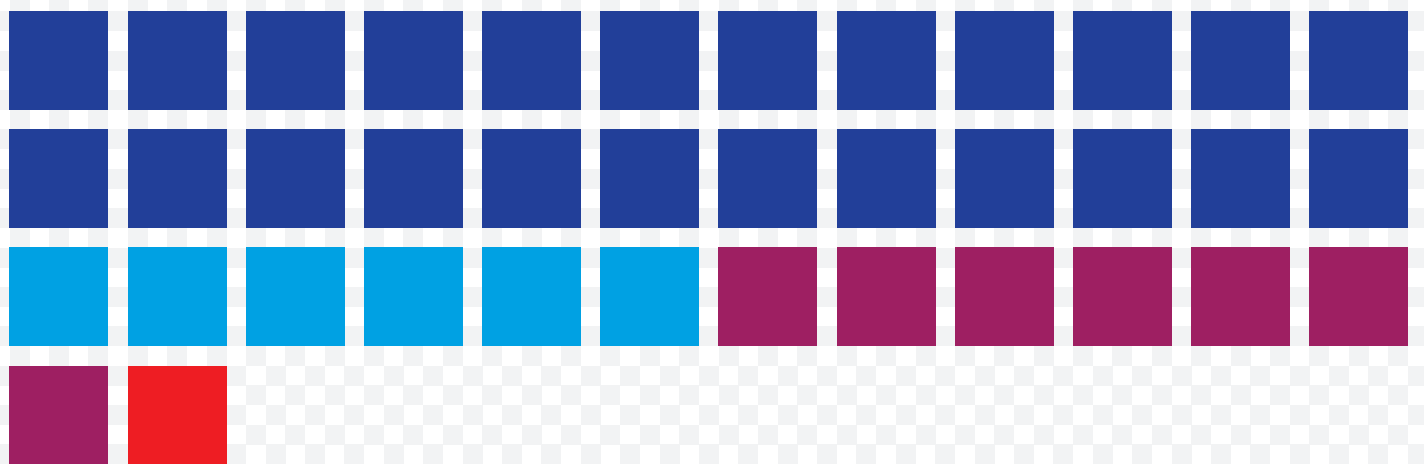

49
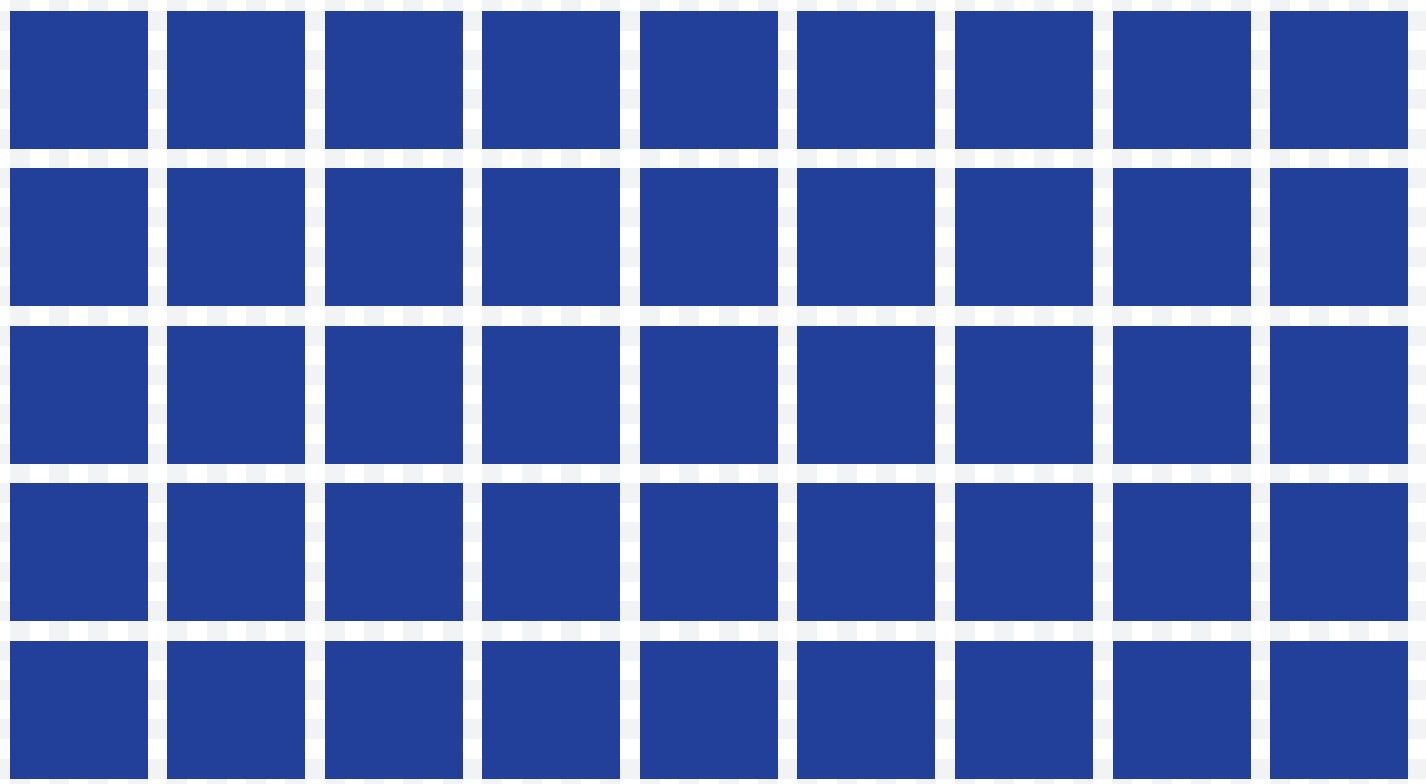

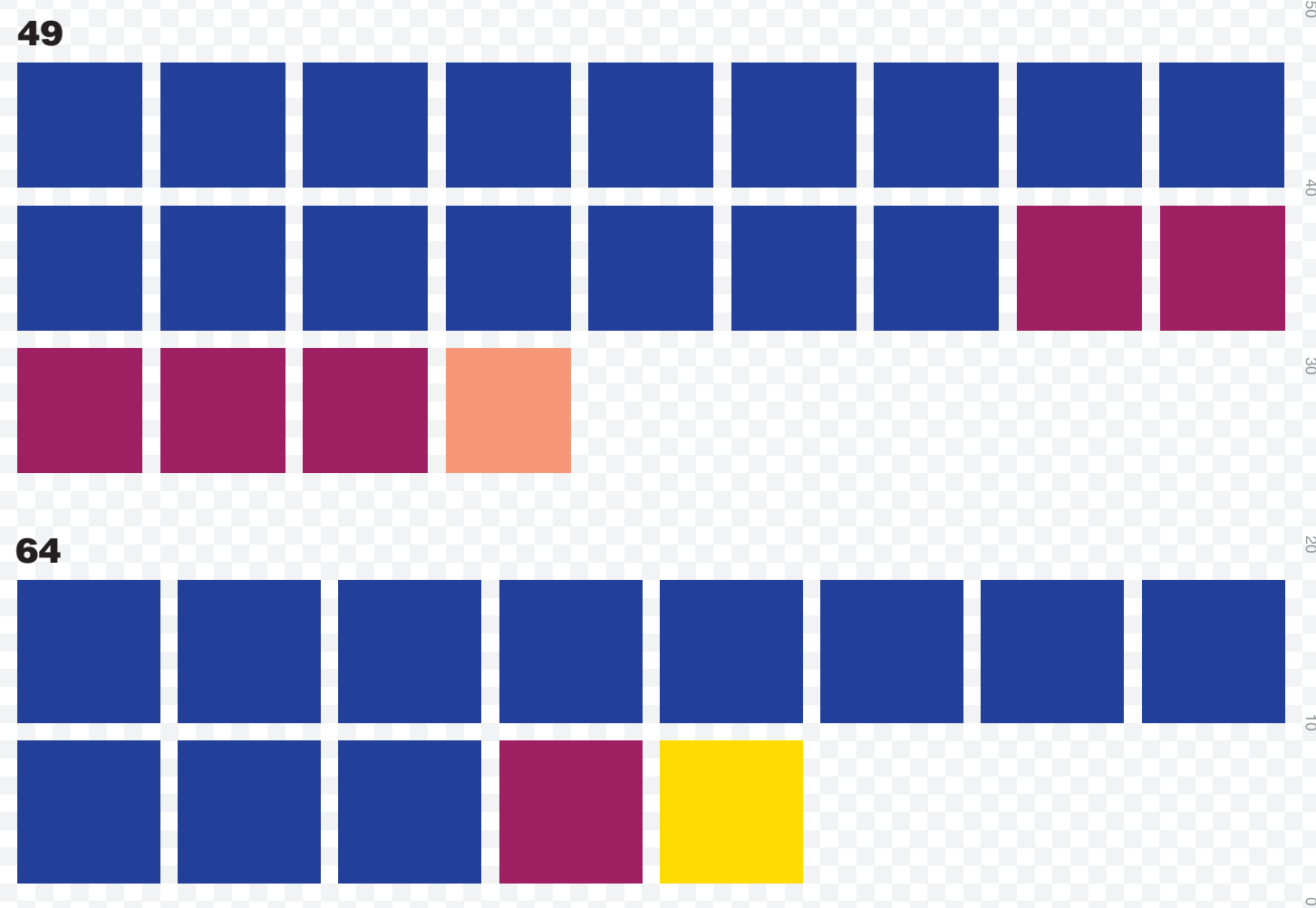

81
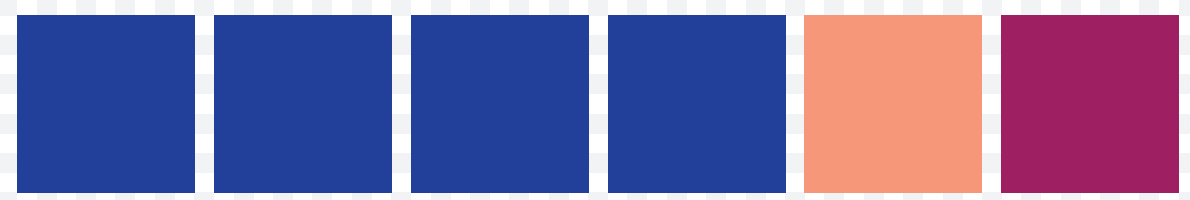

\begin{abstract}
100
\end{abstract}

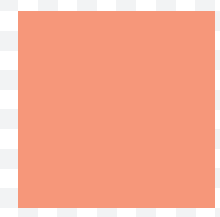

144
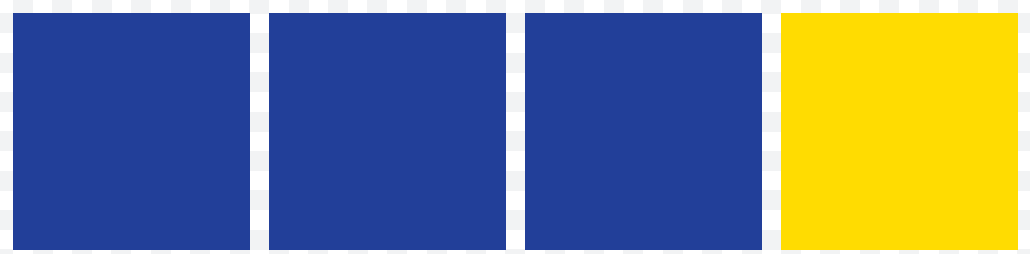

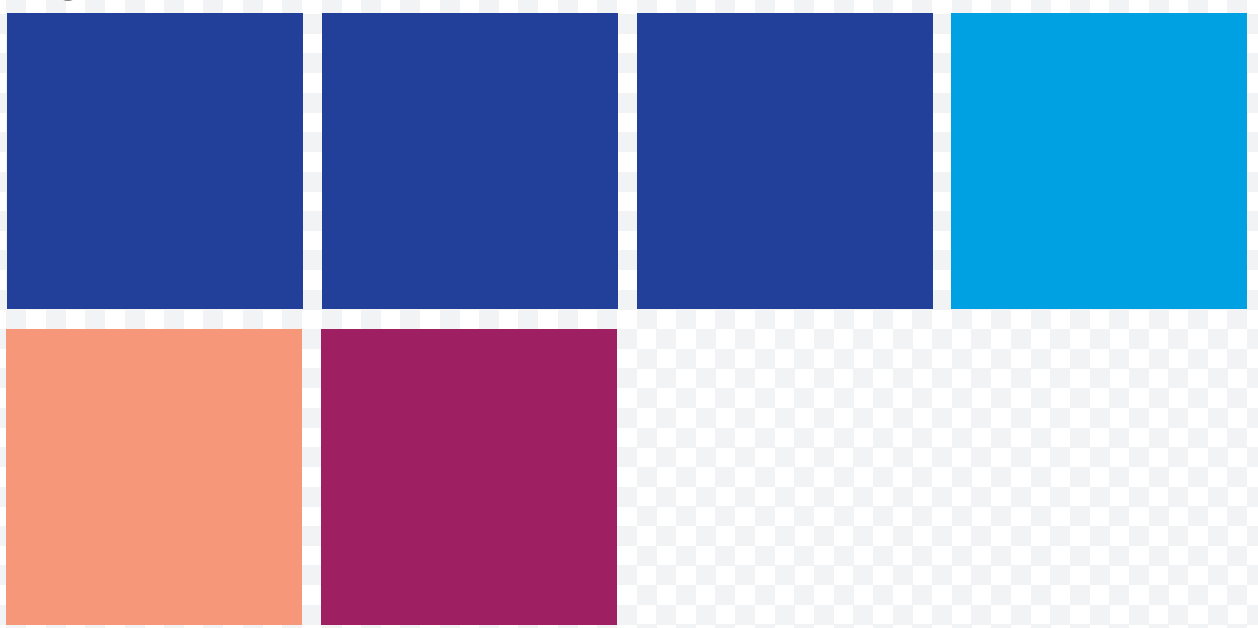

324
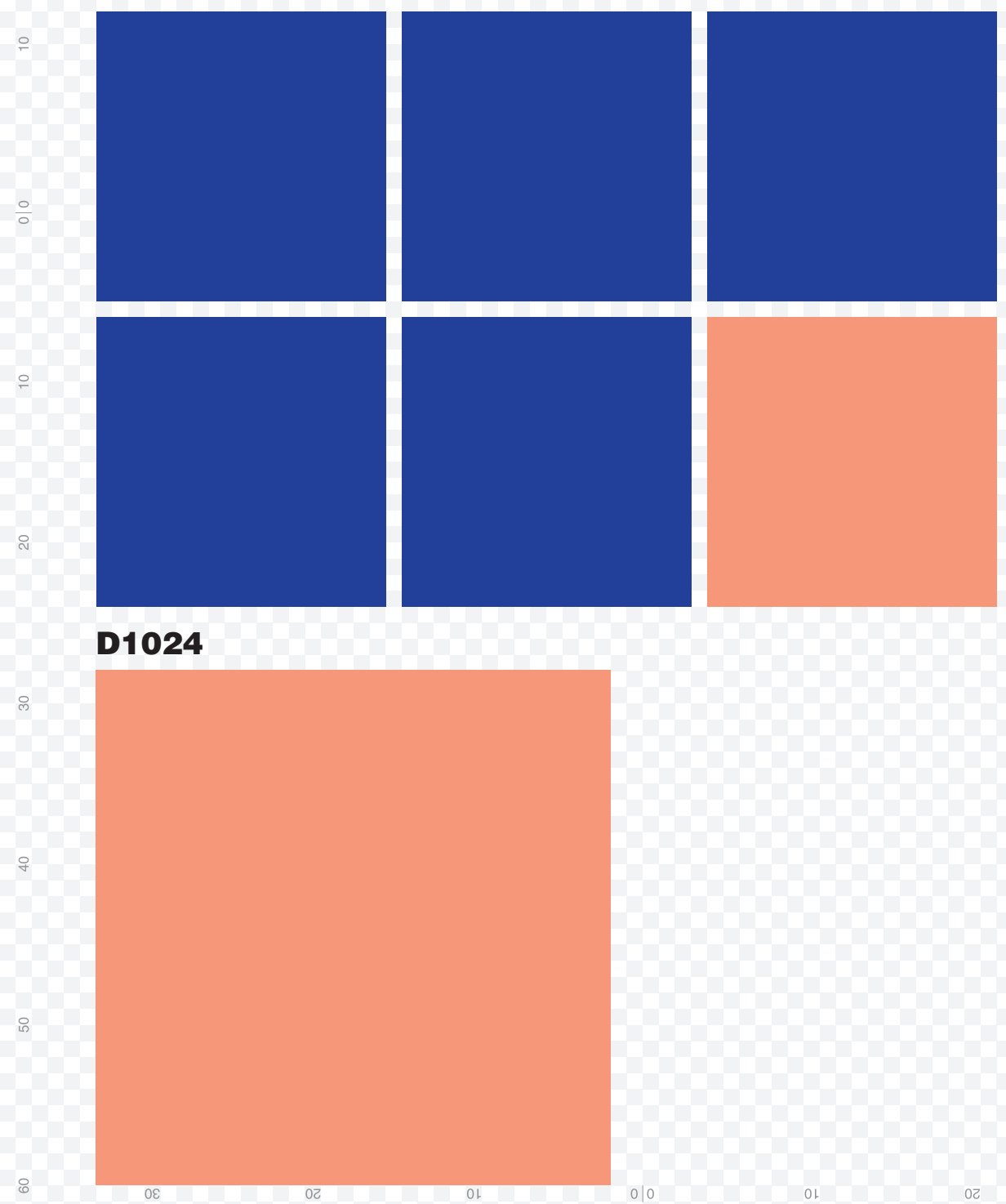

\section{D1024}




\section{ÁREAS}

Margem de áreas

4

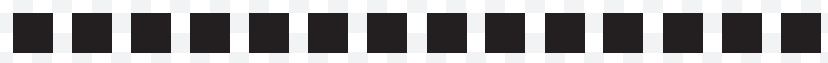

9

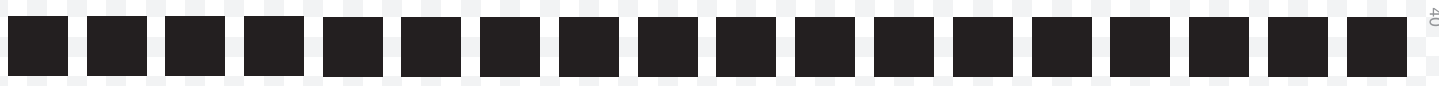

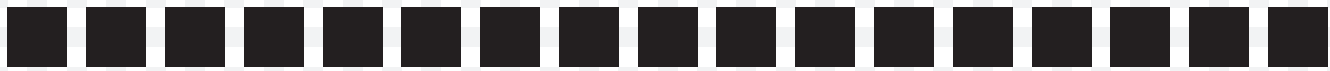

16

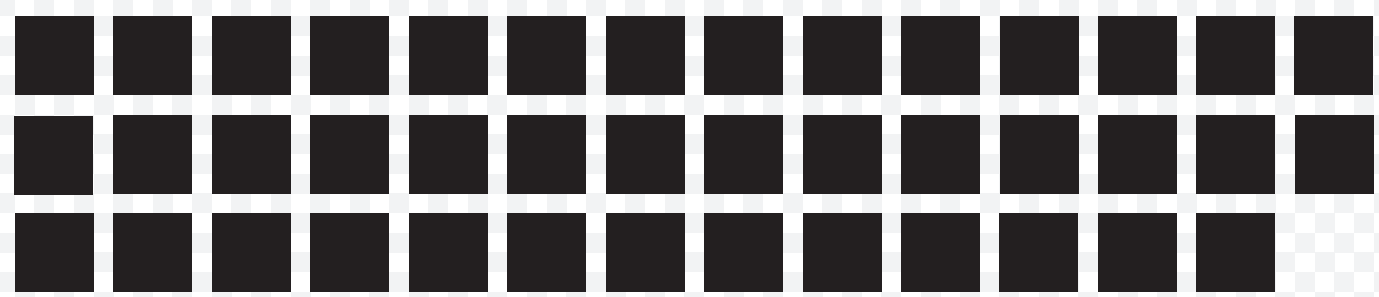

25

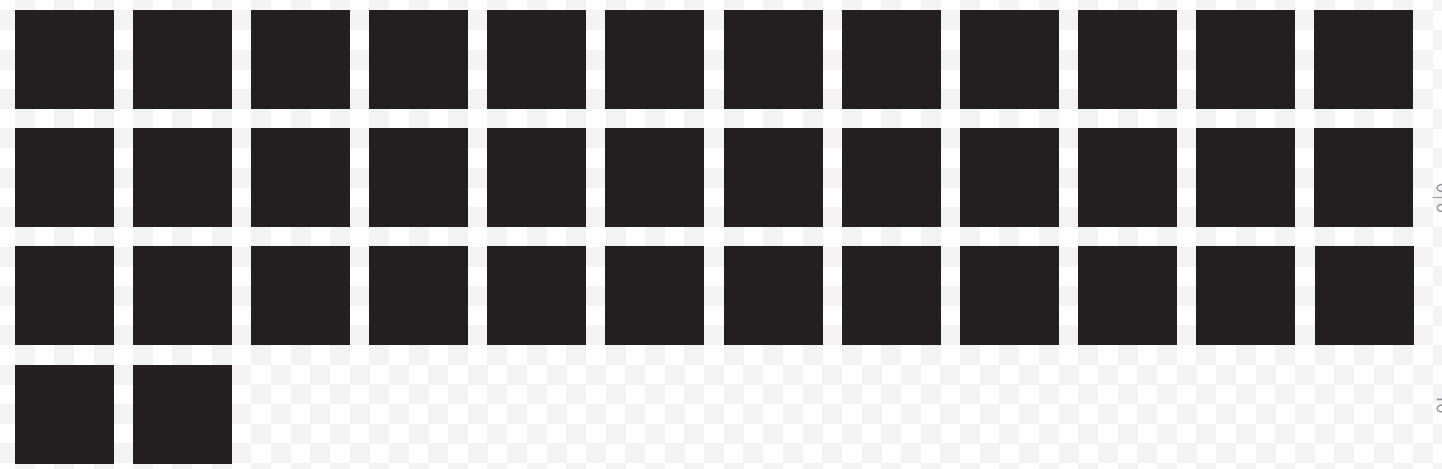

49

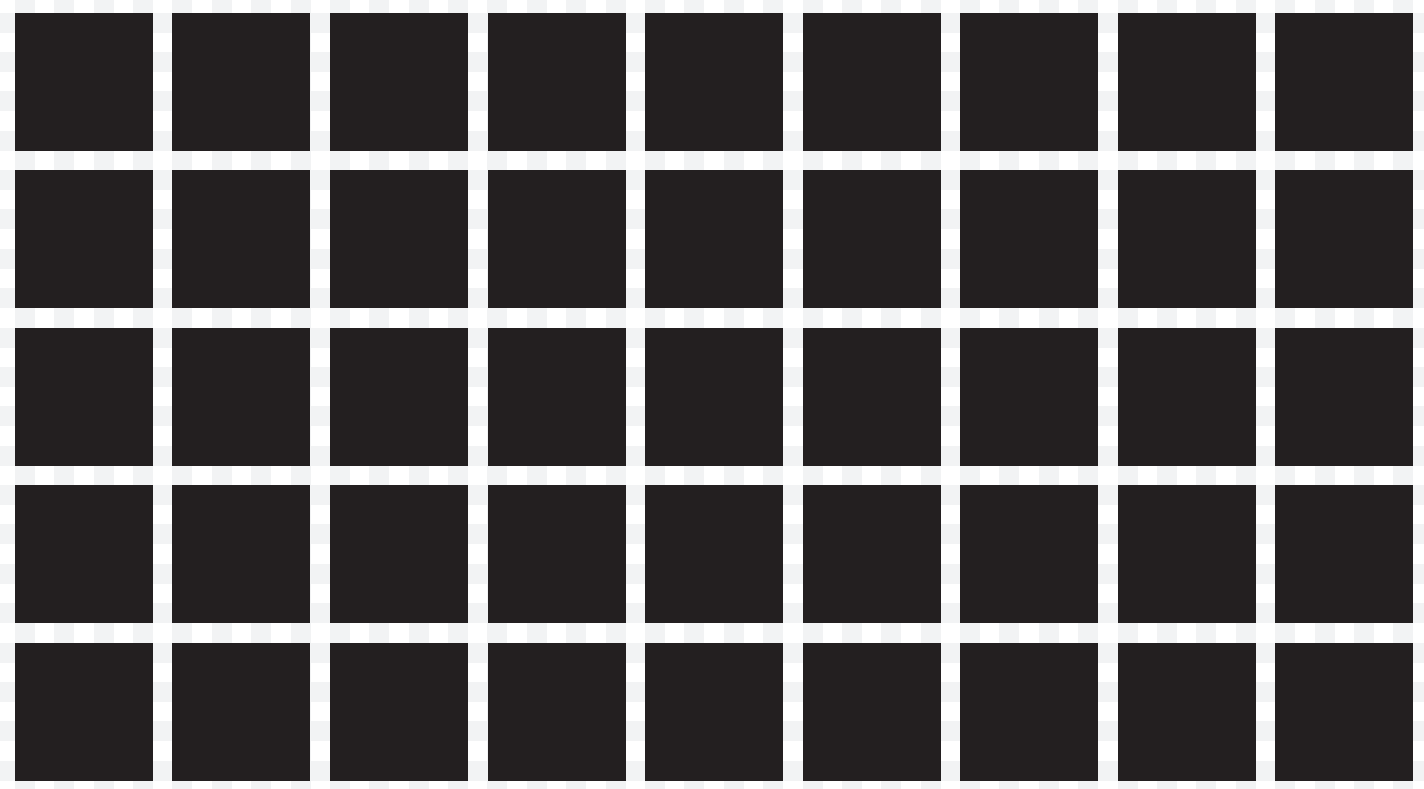


49
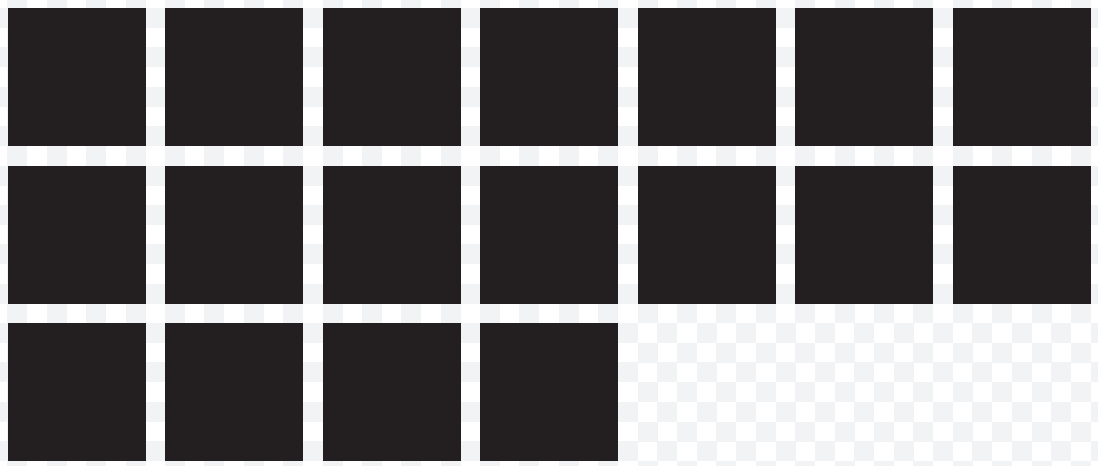

64
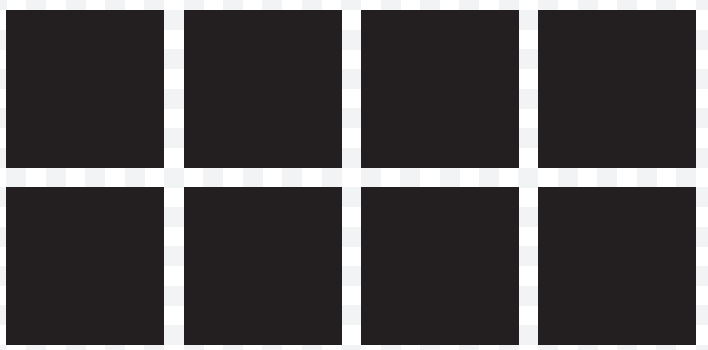

81
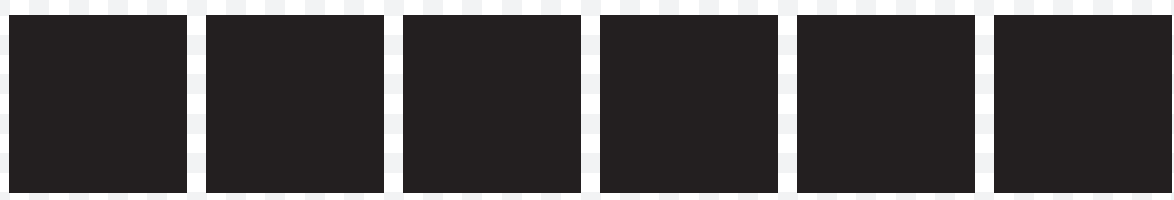

100
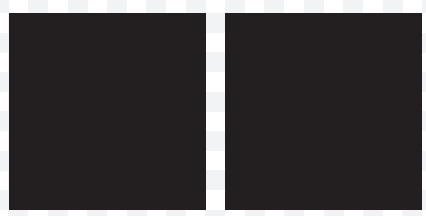

144
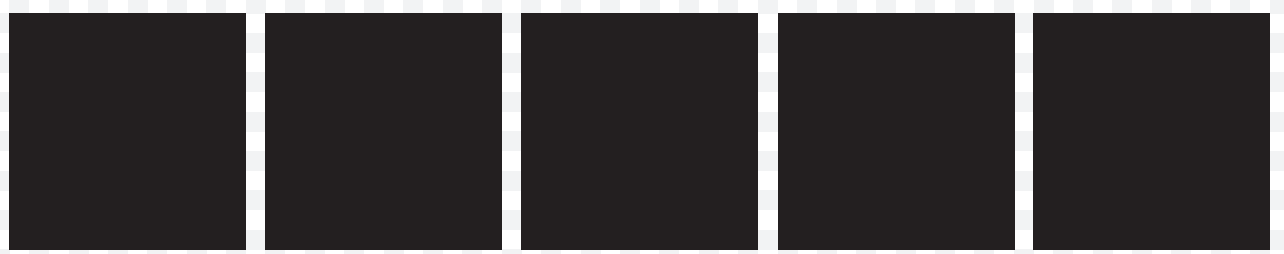
225

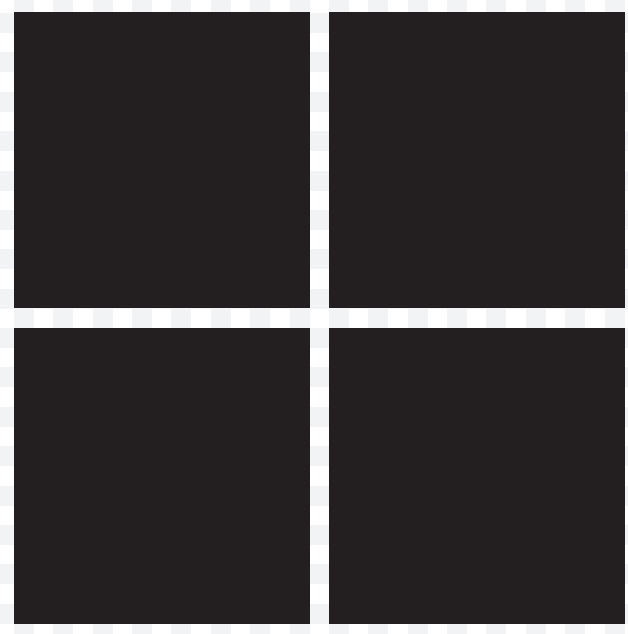

324
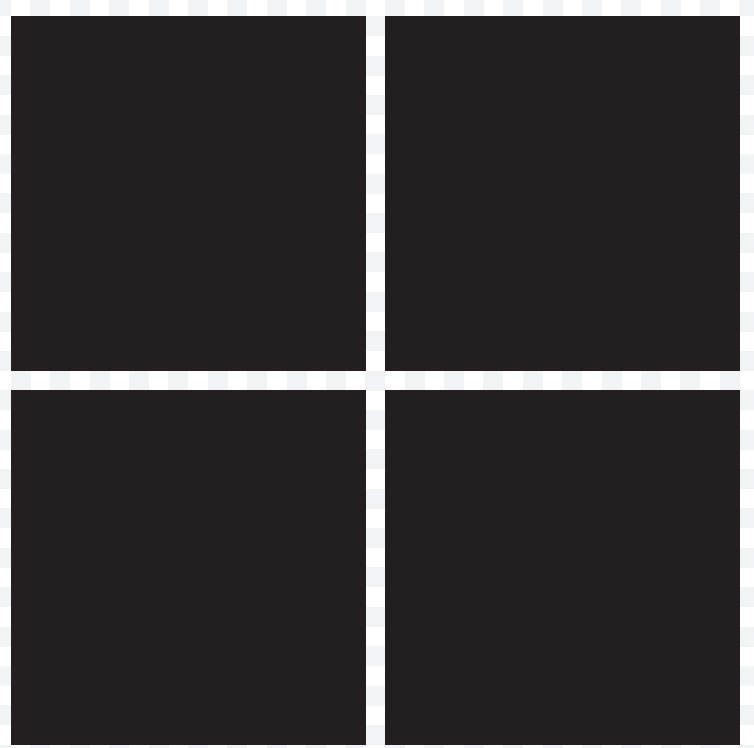

D1024

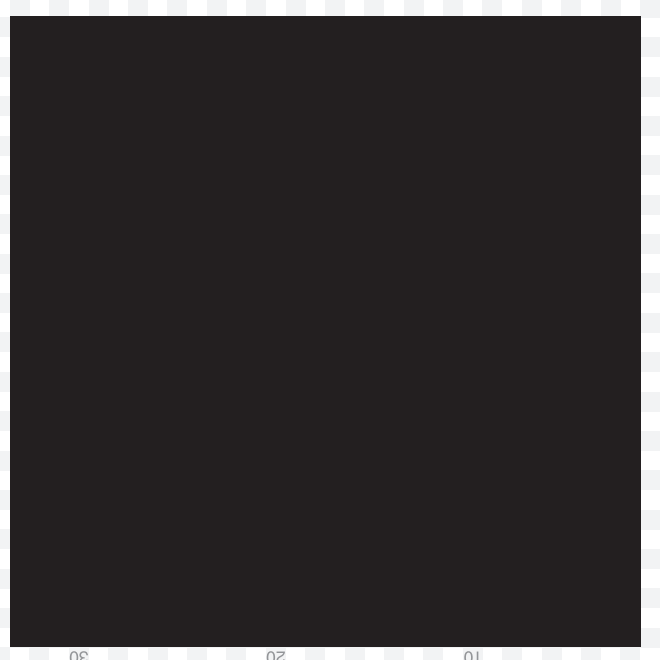

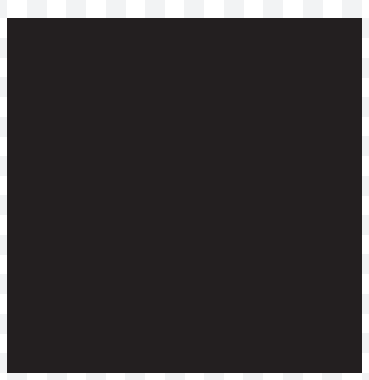

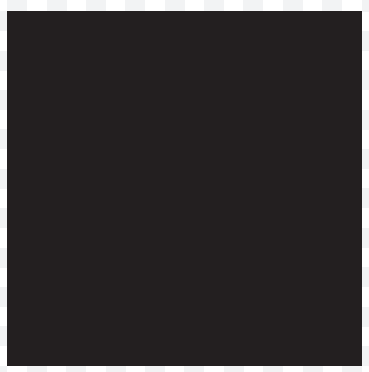

o

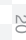




\section{ÁREAS}

Margem de áreas

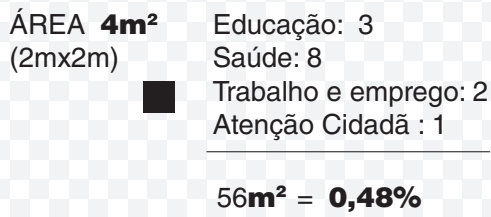

Trabalho e emprego: 2 Atenção Cidadã : 1

$56 \mathbf{m}^{2}=\mathbf{0 , 4 8} \%$

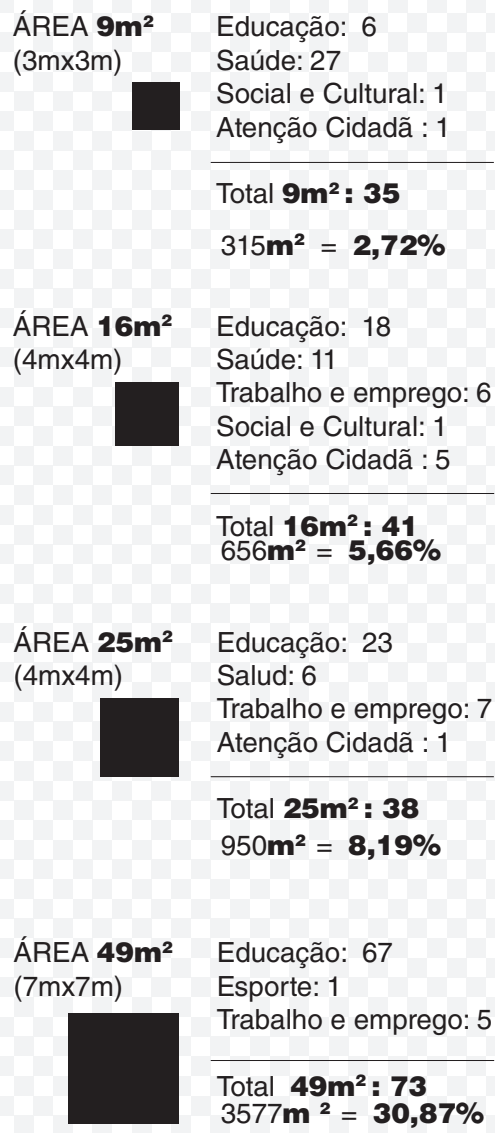

Trabalho e emprego: 6

Social e Cultural: 1

Atenção Cidadã : 5

\section{Total $16 \mathbf{m}^{2}$ : 41}

$656 \mathbf{m}^{2}=\mathbf{5 , 6 6 \%}$

ÁREA $\mathbf{2 5 \mathbf { m } ^ { 2 }}$ Educação: 23

$(4 \mathrm{~m} \times 4 \mathrm{~m})$

Salud: 6

Trabalho e emprego: 7

Atenção Cidadã : 1

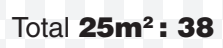

$950 m^{2}=\mathbf{8 , 1 9} \%$

ÁREA 49m² Educação: 67

(7mx7m)

\section{Esporte: 1}

Trabalho e emprego: 5

Total $49 \mathrm{~m}^{2}: \mathbf{7 3}$

$3577 \mathbf{m}^{2}=\mathbf{3 0 , 8 7 \%}$

ÁREA 64m²
$(8 \mathrm{~m} \times 8 \mathrm{~m})$

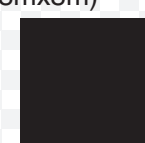

Eductativo: 11

Trabalho e emprego: 1

Social e Cultural: 1

Total $64 \mathrm{~m}^{2}: 13$

$832 \mathbf{m}^{2}=7,17 \%$

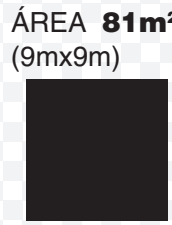

Eductativo: 4

Esporte: 1

Trabalho e emprego: 1

Total $81 \mathrm{~m}^{2}: \mathbf{6}$

$504 m^{2}=4,25 \%$

ÁREA 100m² Esporte: 1 $(10 \mathrm{~m} \times 10 \mathrm{~m})$

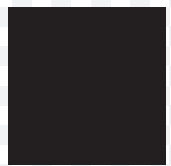

Social e Cultural: 1

Total $100 \mathrm{~m}^{2}: 2$

$200 m^{2}=1,74 \%$

ÁREA 144m² Educação: 3

$(12 m \times 12 m) \quad$ Social y Cultural: 2

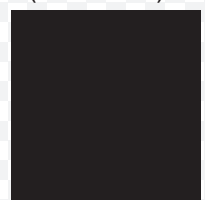

Total $144 \mathrm{~m}^{2}$ : 5

$720 m^{2}=6,8 \%$

ÁREA 225 $\mathbf{m}^{\mathbf{2}}$ Educação: 3

(15mx15m) Saúde: 1

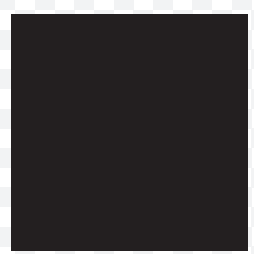

Esporte: 1

Trabalho e emprego: 1

Total $225 \mathrm{~m}^{2}$ : 6

$1350 m^{2}=11,65 \%$

ÁREA 324m² Educação: 5

$(18 \mathrm{~m} \times 18 \mathrm{~m}) \quad$ Esporte: 1

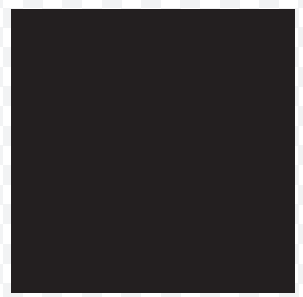

Total $324 \mathrm{~m}^{2}$ : 6

$1404 \mathbf{m}^{2}=\mathbf{1 2 , 1 1} \%$

ÁREA 1024m² Esporte: 1

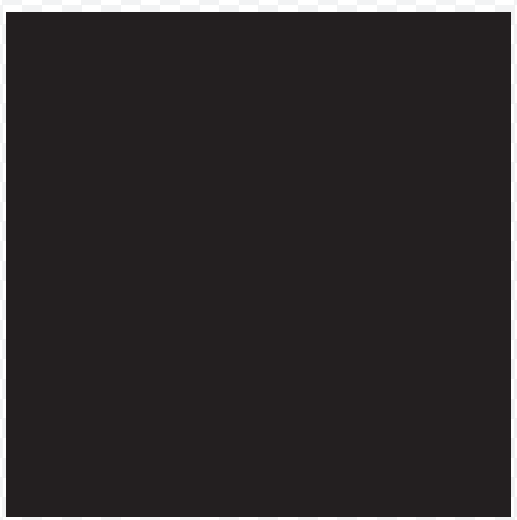

Total $1024^{2}$ : 1

$1024 \mathbf{m}^{2}=\mathbf{9 , 5} \%$ 

catalogo equipamentos casavalle

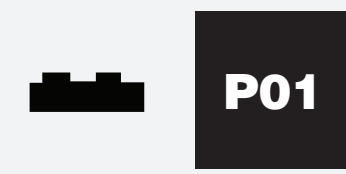

\section{CAIF}

Autor: Arquitectura INAU

Ano: 2018 e anteriores.

Localização: Casavalle, UY

V02 Pg 502

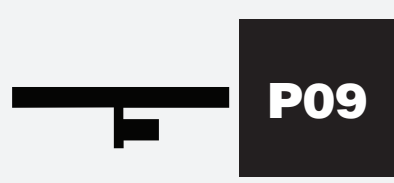

\section{ESCOLA 178}

Autor: sd

Localização: Casavalle, UY.

V02 Pg 519
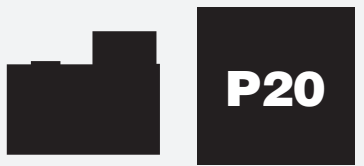

\section{SACUDE}

Autor: Int. Montevideo. PIA

Ano: 2013

Localização: Casavalle, UY.

V02 Pg 535
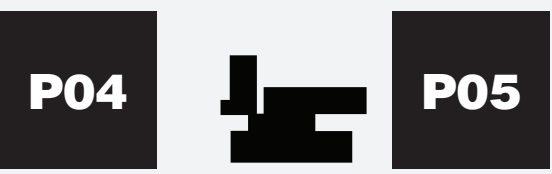

\section{ESCOLA 320}

Autor: sd

Ano: sd

Localização: Casavalle, UY.

V02 Pg 506

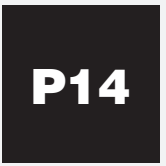

POLiclinica Casavalle Autor: IM DIv. Saude. Arq. M. Gregorio Ano: 2012

Localização: Casavalle, UY.

V02 Pg 523

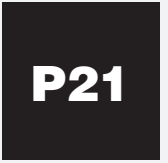

\section{CEDEL}

Autor: Int. Montevideo. Arqs. Morán e Sandoval.

Ano: 2004

Localização: Casavalle, UY

V02 Pg 541

\section{CEA}

Autor: PAEMFE Arq. Andrea Gnesetti

Ano: 2017

Localização: Casavalle, Montevideo.

UY

V02 Pg 510

\section{$\sqrt{2}$ \\ P18}

\section{COMISARIA} Ano: 2013

Localização: Casavalle, UY.

V02 Pg 527

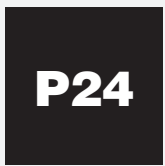

CENTRO Cívico

CASAVALLE

Autor: Int. Montevideo. Arq. Juan Díaz Ano: 2014

Localização: Casavalle, UY

V02 Pg 546
Autor: Ministerio Interior. Sd.

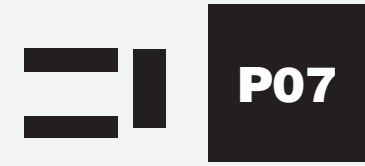

\section{ESCOLA CHINA}

Autor: PAEPU Arq. Lucía Lombardi

Ano: Projeto

Localização: Casavalle, UY.

V02 Pg 514

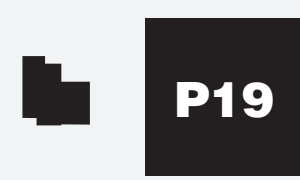

\section{BOMBEROS}

Autor: Dir. Bombeiros. Luis E. Salesi Ano: 1988

Localização: Casavalle, UY.

V02 Pg 531 


\section{catálogo casavalle dSL}

CAIF CENTROS DE ATENÇÃO À INFÂNCIA E A FAMÍLIA

\section{Ano 2018 e anteriores}

Área total $495 \mathrm{~m}^{2}$

Autor Arquitectura INAU

Localização PROYECTO TIPO - Barrio Casavalle, Montevideo. UY.

Organização gestora CND

Organização responsável INAU

\section{Fonte CND}

https://www.cnd.org.uy/index.php/sala-de-prensa/1672-infraestructura-educativa
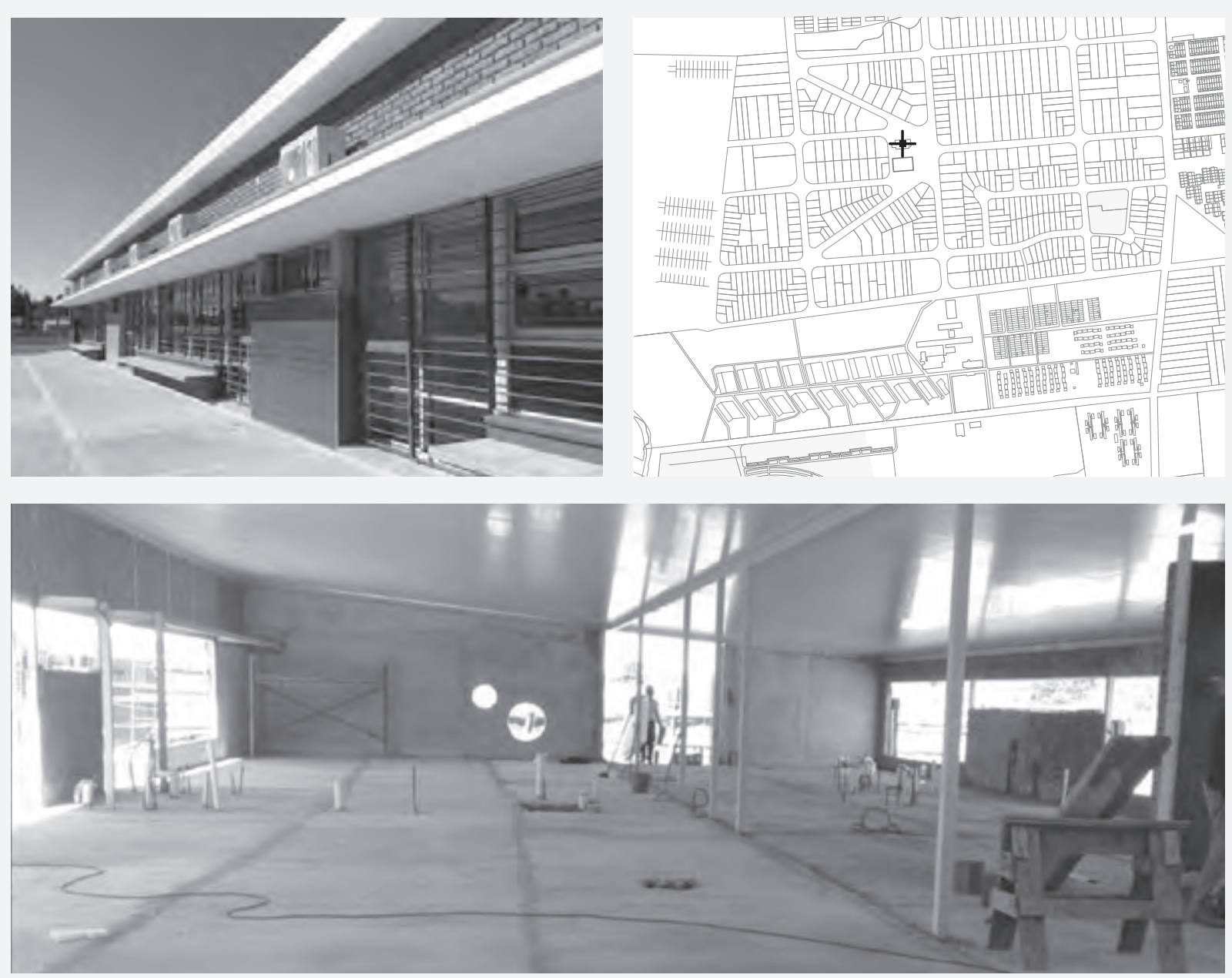
catálogo casavalle dSL

CAIF CENTROS DE ATENÇÃO À INFÂNCIA E A FAMÍLIA

Pav. Térreo

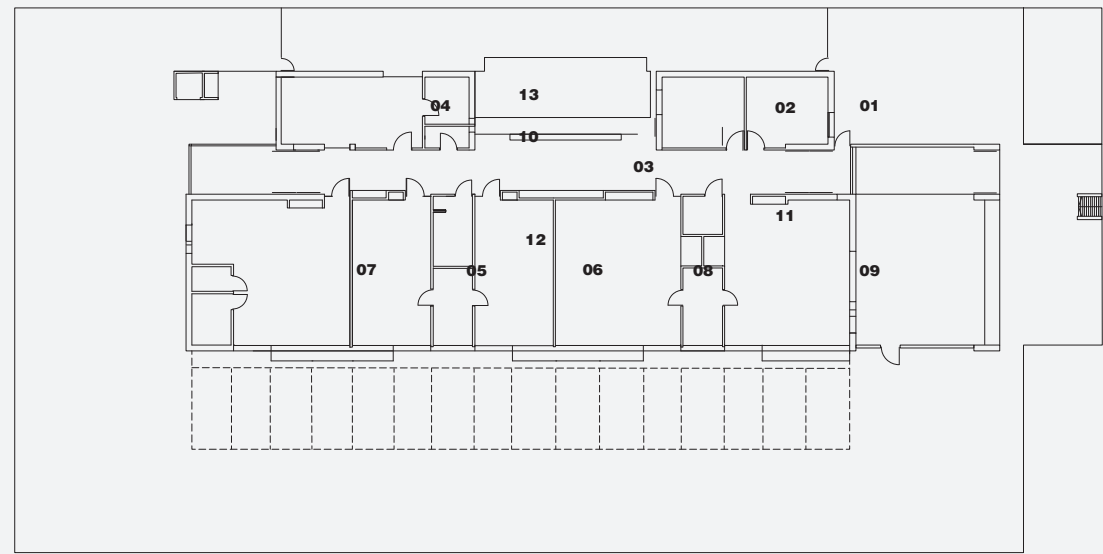

Área Construída 495m

Área Exterior Coberta $161 \mathrm{~m}^{2}$

Pátios ---m²

Ocupação de Solo $\mathbf{8 3 1} \mathbf{m}^{2}$

Taxa Ocupação de Solo $\mathbf{3 7 \%}$

Terreno $1350 \mathbf{m}^{2}$

Educação 253m²

Esc. 1.500

$\begin{array}{llllll} & & \mathrm{L} & \mathrm{I} & \text { Alt. } & \text { Sup. } \\ \mathbf{0 1} & \text { Administração } & 4,16 \mathrm{~m} & 3,5 \mathrm{~m} & \text { var. } 3,45 / 2,80 \mathrm{~m} & 14,56 \mathrm{~m}^{2} \\ \mathbf{0 2} & \text { Atendimento } & 4,16 \mathrm{~m} & 3,6 \mathrm{~m} & \text { var. } 3,45 / 2,80 \mathrm{~m} & 14,9 \mathrm{~m}^{2} \\ \mathbf{0 3} & \text { Hall } & 23,7 \mathrm{~m} & 2,25 \mathrm{~m} & \text { var. } 3,45 / 2,80 \mathrm{~m} & 53,3 \mathrm{~m}^{2} \\ \mathbf{0 4} & \text { Cozinha } & 7,16 \mathrm{~m} & 3,6 \mathrm{~m} & \text { var. } 3,45 / 2,80 \mathrm{~m} & 25,7 \mathrm{~m}^{2} \\ \mathbf{0 5} & \text { Sala 1 com Banh. } & 7,35 \mathrm{~m} & 4 \mathrm{~m} & \text { var. } 3,45 / 2,80 \mathrm{~m} & 33,9 \mathrm{~m}^{2} \\ \mathbf{0 6} & \text { Sala 2 com Banh. } & 7,35 \mathrm{~m} & 4 \mathrm{~m} & \text { var. } 3,45 / 2,80 \mathrm{~m} & 33,9 \mathrm{~m}^{2} \\ \mathbf{0 7} & \text { Sala Psicomotricidade com Banh. 8m } & 7,35 \mathrm{~m} & \text { var. } 3,45 / 2,80 \mathrm{~m} & 58,8 \mathrm{~m}^{2} \\ \mathbf{0 8} & \text { Berçário com Banh. } & 7,35 \mathrm{~m} & 6,35 \mathrm{~m} & \text { var. } 3,45 / 2,80 \mathrm{~m} & 53 \mathrm{~m}^{2} \\ \mathbf{0 9} & \text { Berçário com Banh. } & 7,35 \mathrm{~m} & 6,35 \mathrm{~m} & \text { var. } 3,45 / 2,80 \mathrm{~m} & 53 \mathrm{~m}^{2} \\ \mathbf{1 0} & \text { Banh. Adulto } & 2,25 \mathrm{~m} & 1,1 \mathrm{~m} & \text { var. } 3,45 / 2,80 \mathrm{~m} & 2,4 \mathrm{~m}^{2} \\ \mathbf{1 1} & \text { Banh. Discap } & 2 \mathrm{~m} & 1,95 \mathrm{~m} & \text { var. } 3,45 / 2,80 \mathrm{~m} & 3,9 \mathrm{~m}^{2} \\ \mathbf{1 2} & \text { Depósito } & 3,55 \mathrm{~m} & 2 \mathrm{~m} & \text { var. } 3,45 / 2,80 \mathrm{~m} & 7,1 \mathrm{~m}^{2} \\ \mathbf{1 3} & \text { Despensa } & 2,4 \mathrm{~m} & 2,25 \mathrm{~m} & \text { var. } 3,45 / 2,80 \mathrm{~m} & 5,4 \mathrm{~m}^{2} \\ & \text { * Local, soma de vários locais } & & & & \end{array}$

E25* 
CatÁlogo casavalle dSL

CAIF DSL DISSOLUÇÃO PROGRAMÁTICA 

Catálogo casavalle dSL

ESCOLA 320 CASAVALLE

Ano sd

Área total $840 \mathrm{~m}^{2}$

Autor sd

Localização Barrio Casavalle, Montevideo. UY.

Organização gestora ANEP

Organização responsável ANEP CEIP

Fontes IM / REVISTA SAU 235 noviembre 1958
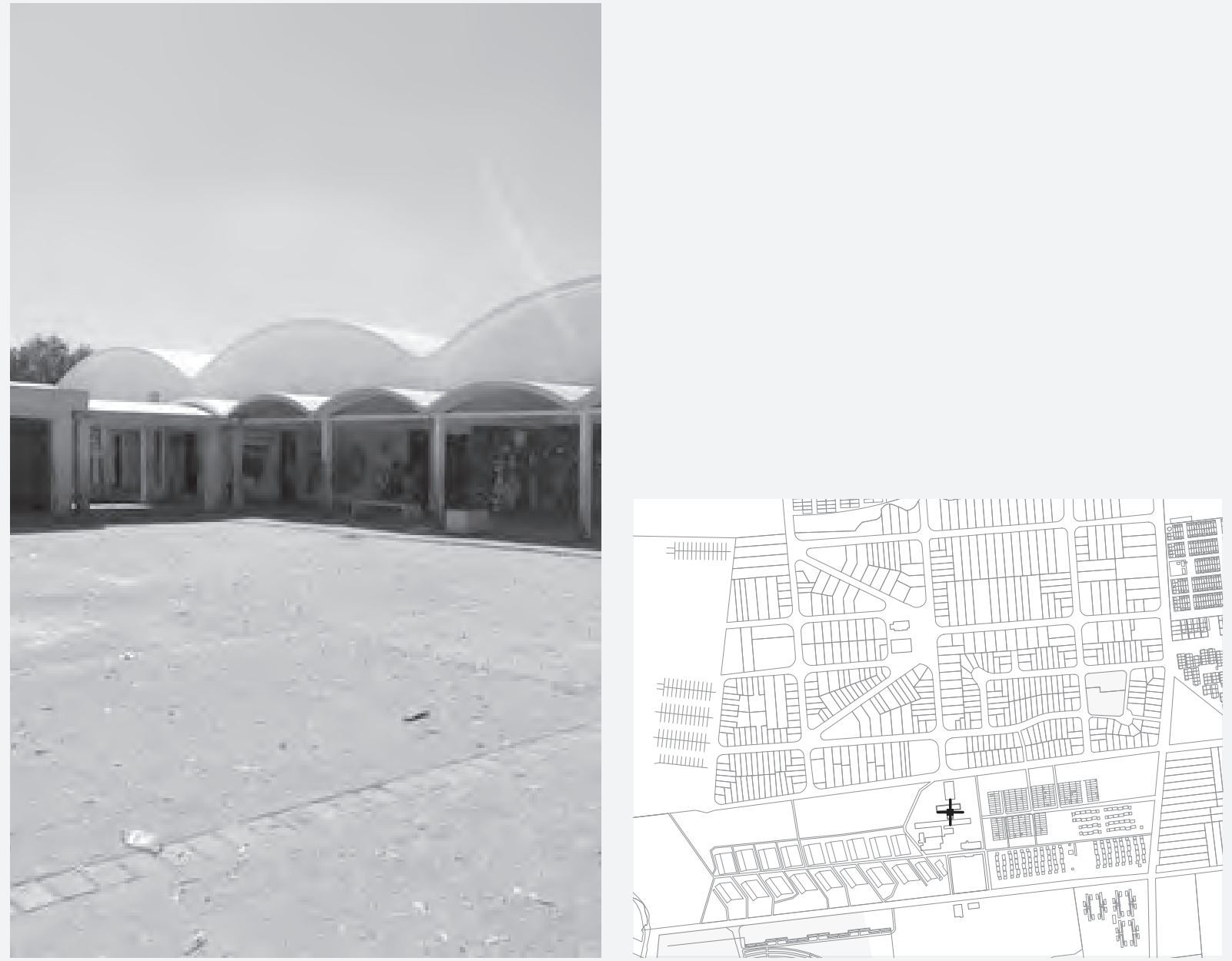
catálogo casavalle dSL

ESCOLA 320 CASAVALLE

Pav. Térreo

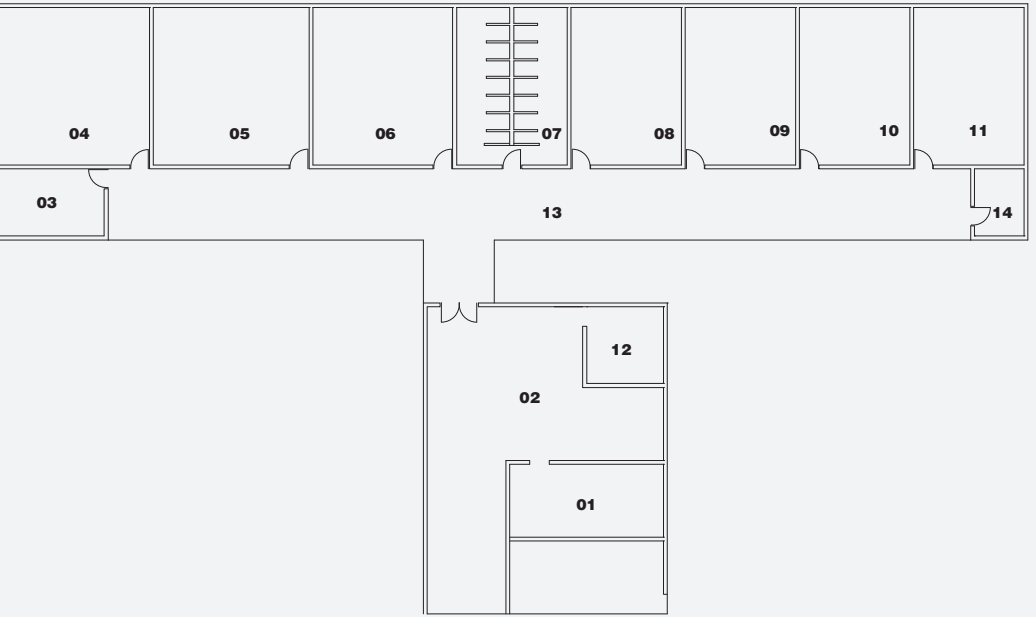

Area Construída $840 \mathrm{~m}^{2}$

Área Exterior Coberta ----m²

Pátios 930 $\mathbf{m}^{2}$

Ocupação de Solo $\mathbf{8 4 0 m ^ { 2 }}$

Taxa Ocupação de Solo $46 \%$

Terreno $\mathbf{1 8 0 0 \mathbf { m } ^ { 2 }}$

Educação $\mathbf{7 3 0 \mathbf { m } ^ { \mathbf { 2 } }}$

Esc. 1.500

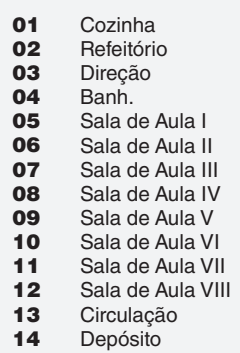

$\begin{array}{lll}\mathrm{L} & \mathrm{I} & \text { Alt. } \\ 7,8 \mathrm{~m} & 3,7 \mathrm{~m} & 2,5 \\ 12 \mathrm{~m} & 7,8 \mathrm{~m} & 2,5 \\ 5,6 \mathrm{~m} & 3,4 \mathrm{~m} & 2,5 \\ 8 \mathrm{~m} & 5,8 \mathrm{~m} & 2,5 \\ 8 \mathrm{~m} & 7,9 \mathrm{~m} & 2,5 \\ 8 \mathrm{~m} & 7,9 \mathrm{~m} & 2,5 \\ 8 \mathrm{~m} & 7,9 \mathrm{~m} & 2,5 \\ 8 \mathrm{~m} & 5,6 \mathrm{~m} & 2,5 \\ 8 \mathrm{~m} & 5,6 \mathrm{~m} & 2,5 \\ 8 \mathrm{~m} & 5,6 \mathrm{~m} & 2,5 \\ 8 \mathrm{~m} & 5,6 \mathrm{~m} & 2,5 \\ 3,9 \mathrm{~m} & 3,9 \mathrm{~m} & 2,5 \\ 43,8 \mathrm{~m} & 3,6 \mathrm{~m} & 2,5 \\ 3,5 & 2,4 \mathrm{~m} & 2,5\end{array}$

Sup.

DSL 
CATÁlogo casavalle dSL

ESCOLA 320 DSL DISSOLUÇÃO PROGRAMÁTICA

Educacional $730 \mathbf{m}^{2}$ -
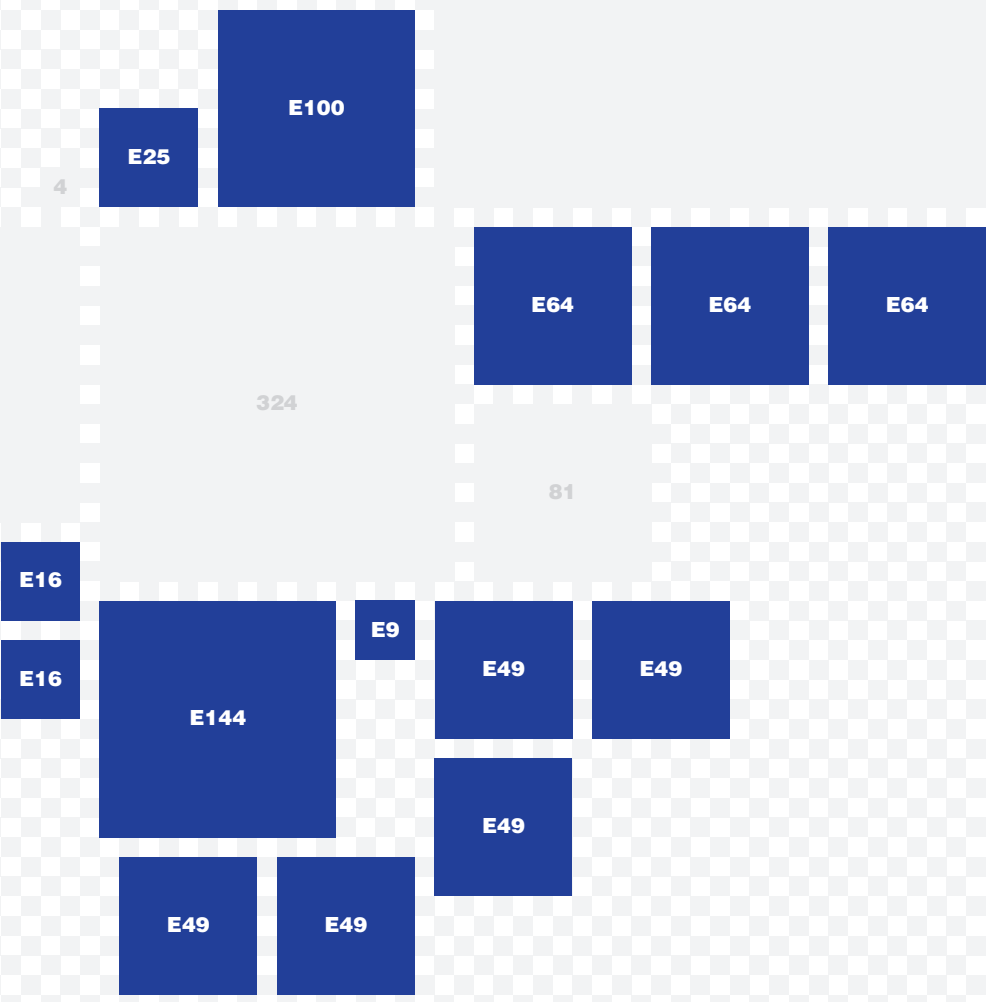

$\vec{o}$ 


\section{catálogo casavalle dsL}

ESCOLA 320 DSL DISSOLUÇÃO ESPÅCIAL

Área Construída $840 \mathrm{~m}^{2}$

Área Exterior Coberta ---m $\mathbf{m}^{2}$

Pátios $930 \mathbf{m}^{2}$

Terreno $1800 \mathbf{m}^{2}$

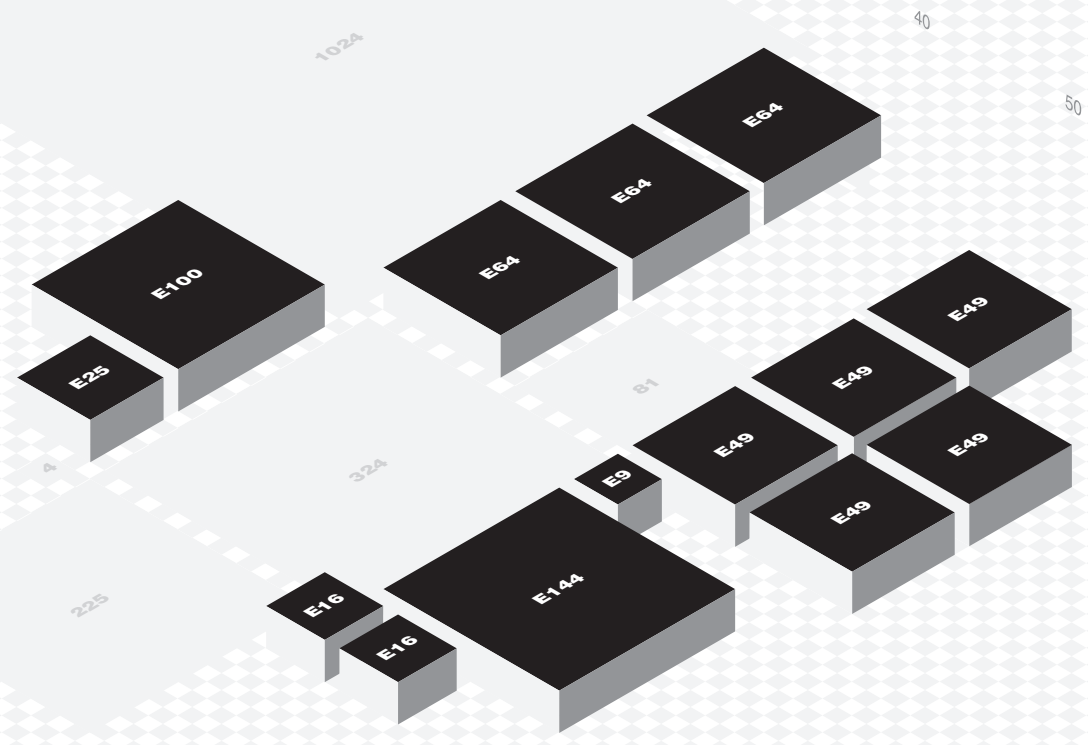




\section{catálogo casavalle dSL}

CEA CENTRO EDUCACIONAL ASSOCIADO (a escola 178)

Ano PROYECTO 2017

Área total $1000 \mathrm{~m}^{2}$

Autor PAEMFe Arq. Andrea Gnesetti

Localização Barrio Casavalle, Montevideo. UY.

Organização gestora CND

Organização responsável ANEP - CETP

Fonte IM

https://www.comprasestatales.gub.uy/consultas/detalle/mostrar-llamado/1/id/656035
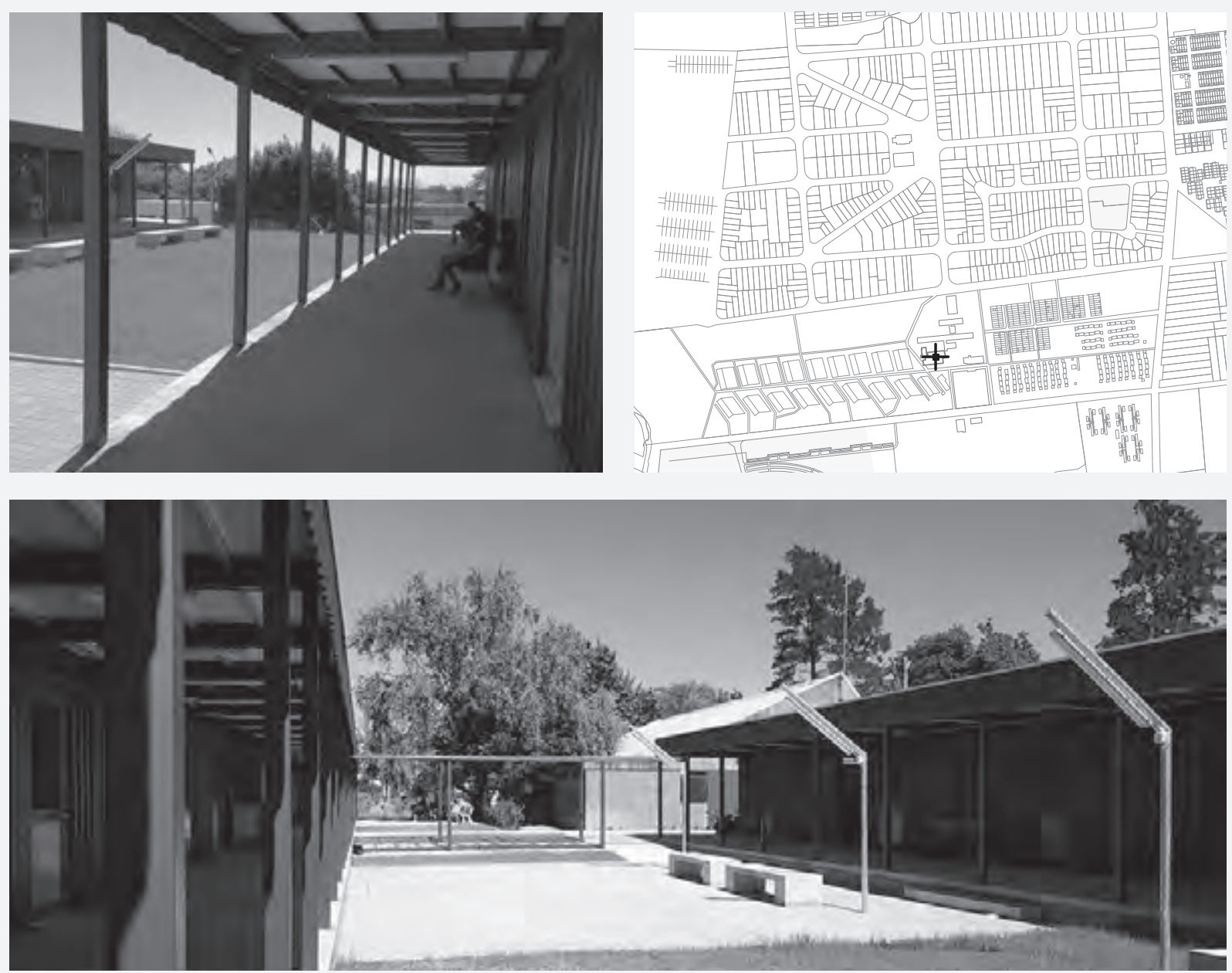
catálogo casavalle dsL

CEA CENTRO EDUCACIONAL ASSOCIADO (a escola 178)

Pav. Térreo

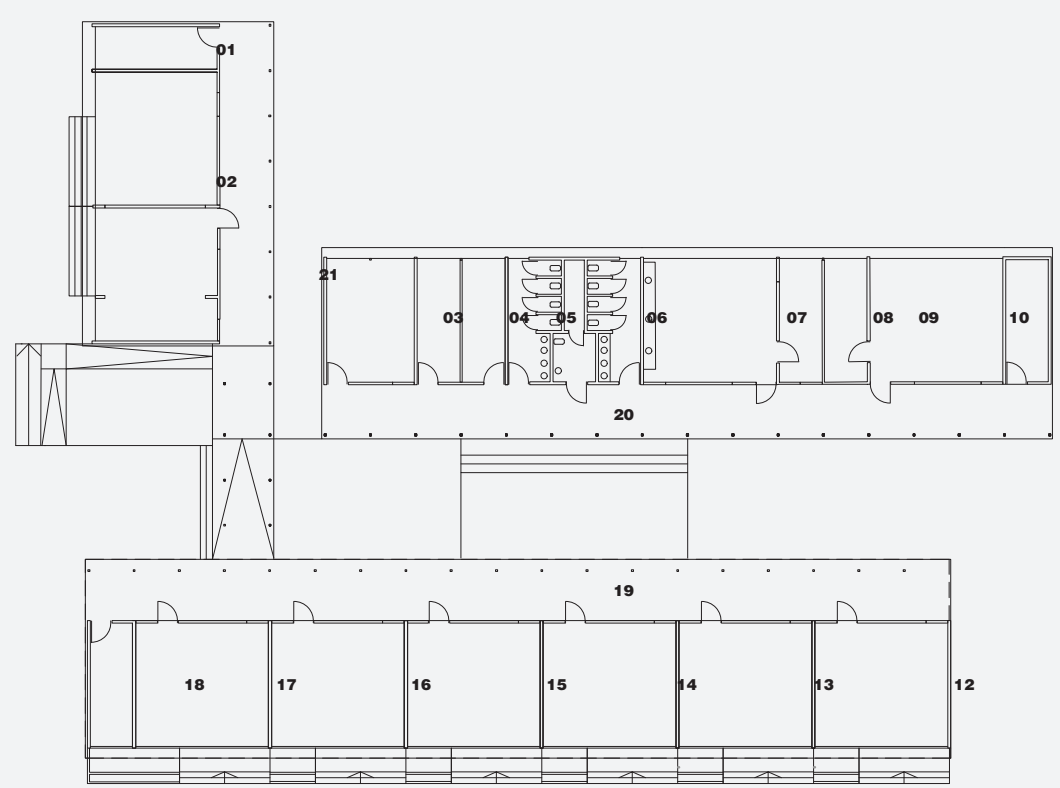

Área Construída $1000 \mathrm{~m}^{2}$

Área Exterior Coberta ----m² Pátios ---m²

Ocupação de Solo $1260 \mathbf{m}^{2}$ Taxa Ocupação de Solo $\mathbf{7 1 \%}$

Terreno $1400 \mathbf{m}^{2}$

Educação $\mathbf{9 1 5 m ^ { 2 }}$

Esc. 1.500$$
\begin{aligned}
& 01 \\
& 02 \\
& 03 \\
& 04 \\
& 05 \\
& 06 \\
& 07 \\
& 08 \\
& 09 \\
& 10 \\
& 11 \\
& 12 \\
& 13 \\
& 14 \\
& 15 \\
& 16 \\
& 17 \\
& 18 \\
& 19 \\
& 20 \\
& 21
\end{aligned}
$$

Direção primaria

Espaço funciona

Espaço docente

Direção

Administração

Banheiro

Laboratório de ciências

Ajudante Lab.

Depósito I

Sala de Aula Tecnológica

Depósito II

Sala de Aula comum I

Sala de Aula comum

Sala de Aula comum II

Sala de Aula comum III

Sala de Aula comum IV

Sala de Aula comum Vula comum VI

Profs. Associados

Circulação I

Circulação II

Circulação III

* Local, soma de vários locais

\begin{tabular}{|c|c|c|c|c|}
\hline L & 1 & Alt. & Sup. & DSL \\
\hline $6,2 \mathrm{~m}$ & $2,15 \mathrm{~m}$ & var.2,50 / 2,70m & $13,33 \mathrm{~m}^{2}$ & E16 \\
\hline $13,65 \mathrm{~m}$ & $6,2 m$ & var. $2,50 / 2,70 \mathrm{~m}$ & $84,63 \mathrm{~m}^{2}$ & E81 \\
\hline $6,28 \mathrm{~m}$ & $4,45 \mathrm{~m}$ & var. $2,50 / 2,70 \mathrm{~m}$ & $27,94 m^{2}$ & E25 \\
\hline $6,28 \mathrm{~m}$ & $2,16 \mathrm{~m}$ & var. $2,50 / 2,70 \mathrm{~m}$ & $13,56 \mathrm{~m}^{2}$ & E16 \\
\hline $6,28 \mathrm{~m}$ & $2,16 \mathrm{~m}$ & var. $2,50 / 2,70 \mathrm{~m}$ & $13,56 \mathrm{~m}^{2}$ & E16 \\
\hline $6,75 \mathrm{~m}$ & $6,28 \mathrm{~m}$ & var. $2,50 / 2,70 \mathrm{~m}$ & $42,39 m^{2}$ & E49 \\
\hline $6,75 \mathrm{~m}$ & $6,28 \mathrm{~m}$ & var. $2,50 / 2,70 \mathrm{~m}$ & $42,39 m^{2}$ & E49 \\
\hline $6,28 \mathrm{~m}$ & $2,16 \mathrm{~m}$ & var. $2,50 / 2,70 \mathrm{~m}$ & $13,56 \mathrm{~m}^{2}$ & E16 \\
\hline $6,28 \mathrm{~m}$ & $2,16 \mathrm{~m}$ & var. $2,50 / 2,70 \mathrm{~m}$ & $13,56 \mathrm{~m}^{2}$ & E16 \\
\hline $6,28 \mathrm{~m}$ & $6,75 \mathrm{~m}$ & var. $2,50 / 2,70 \mathrm{~m}$ & $42,39 m^{2}$ & E49 \\
\hline $6,28 \mathrm{~m}$ & $2,15 \mathrm{~m}$ & var. $2,50 / 2,70 \mathrm{~m}$ & $13,50 \mathrm{~m}^{2}$ & E16 \\
\hline $6,75 \mathrm{~m}$ & $6,28 \mathrm{~m}$ & var. $2,50 / 2,70 \mathrm{~m}$ & $42,39 m^{2}$ & E49 \\
\hline $6,75 \mathrm{~m}$ & $6,28 \mathrm{~m}$ & var. $2,50 / 2,70 \mathrm{~m}$ & $42,39 m^{2}$ & E49 \\
\hline $6,75 \mathrm{~m}$ & $6,28 m$ & var. $2,50 / 2,70 \mathrm{~m}$ & $42,39 m^{2}$ & E49 \\
\hline $6,75 \mathrm{~m}$ & $6,28 \mathrm{~m}$ & var. $2,50 / 2,70 \mathrm{~m}$ & $42,39 m^{2}$ & E49 \\
\hline $6,75 \mathrm{~m}$ & $6,28 \mathrm{~m}$ & var. $2,50 / 2,70 \mathrm{~m}$ & $42,39 m^{2}$ & E49 \\
\hline $6,75 \mathrm{~m}$ & $6,28 \mathrm{~m}$ & var. $2,50 / 2,70 \mathrm{~m}$ & $42,39 \mathrm{~m}^{2}$ & E49 \\
\hline $2,15 \mathrm{~m}$ & $6,28 \mathrm{~m}$ & var. $2,50 / 2,70 \mathrm{~m}$ & $13,50 \mathrm{~m}^{2}$ & E16 \\
\hline $43,9 m$ & $3,12 m$ & var. $2,50 / 2,70 \mathrm{~m}$ & $136,96 \mathrm{~m}^{2}$ & E324* \\
\hline $37,1 \mathrm{~m}$ & $3,12 \mathrm{~m}$ & var.2,50 / 2,70m & $115,75 \mathrm{~m}^{2}$ & E324* \\
\hline $27,3 \mathrm{~m}$ & $2,7 m$ & var. $2,50 / 2,70 \mathrm{~m}$ & $73,71 \mathrm{~m}^{2}$ & E324* \\
\hline
\end{tabular}

DSL

E16

E25

E16

E49 


\section{Catálogo casavalle dSL}

CEA DSL DISSOLUÇÃO PROGRAMÁTICA

Educacional $915 \mathbf{m}^{2}$ -

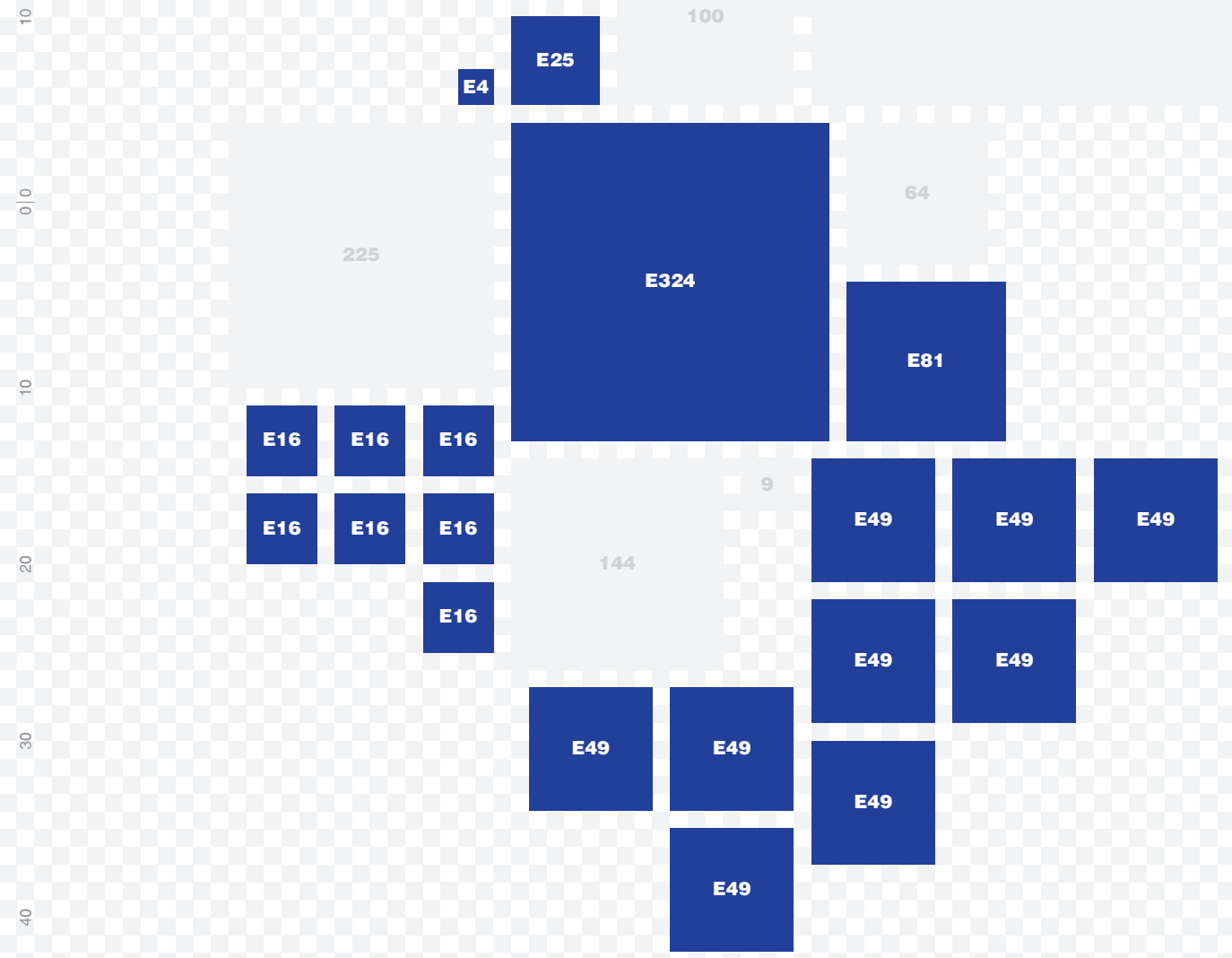



catálogo casavalle dSL

ESCOLA PRIMARIA CHINA

\section{Ano Projeto}

Área total $1165 \mathrm{~m}^{2}$

Autor PAEPU - Arq. Lucía Lombardi

Localização Barrio Casavalle, Montevideo. UY.

Organização gestora CND

Organização responsável ANEP CEIP

Fonte IM
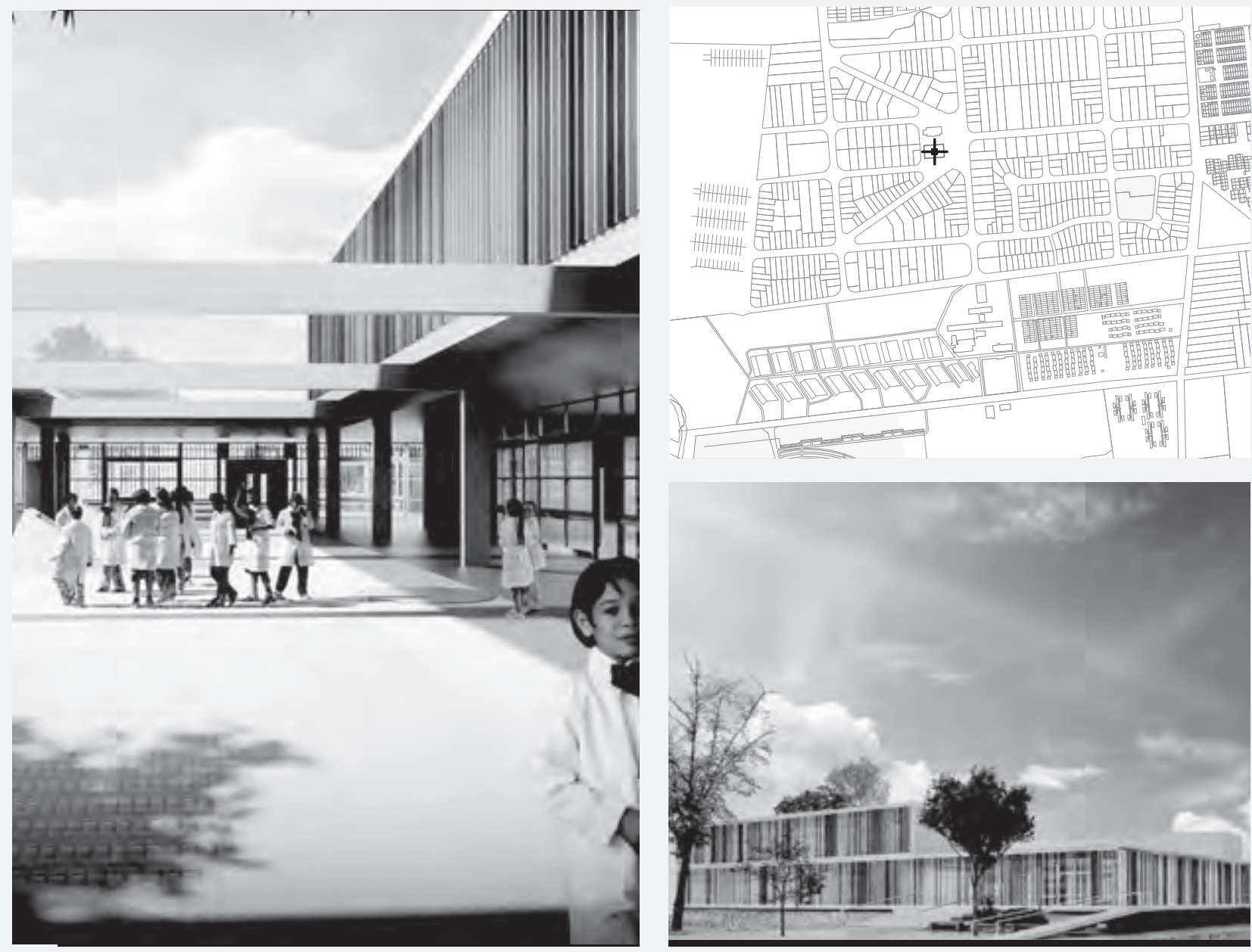
catálogo casavalle dSL

ESCOLA PRIMARIA CHINA

Pav. Térreo

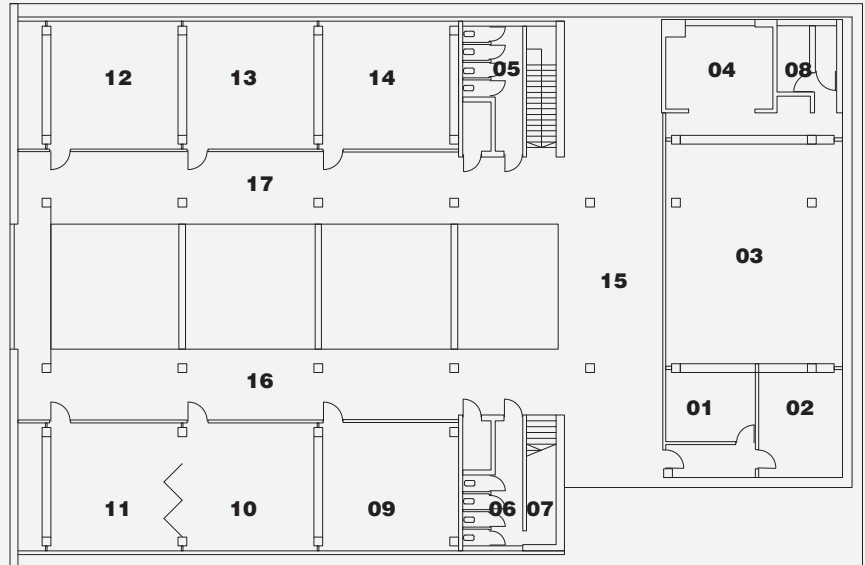

Área Construída $1165 \mathrm{~m}^{2}$

Área Exterior Coberta $480 \mathrm{~m}^{2}$

Pátios 163m²

Ocupação de Solo $1240 \mathrm{~m}^{2}$

Taxa Ocupação de Solo $\mathbf{8 4 \%}$

Terreno $1470 \mathrm{~m}^{2}$

Educação $1303 \mathrm{~m}^{2}$

Esc. 1.500

$\begin{array}{ll}01 & \text { Direção } \\ 02 & \text { Sala de maestros } \\ 03 & \text { Refeitório } \\ \mathbf{0 4} & \text { Cozinha } \\ \mathbf{0 5} & \text { Banh. I } \\ \mathbf{0 6} & \text { Banh. II } \\ \mathbf{0 7} & \text { Depósito } \\ \mathbf{0 8} & \text { Despensa } \\ \mathbf{0 9} & \text { Sala de Aula I } \\ \mathbf{1 0} & \text { Sala de Aula II } \\ \mathbf{1 1} & \text { Sala de Aula III } \\ \mathbf{1 2} & \text { Sala de Aula IV } \\ \mathbf{1 3} & \text { Sala de Aula V } \\ \mathbf{1 4} & \text { Sala de Aula VI } \\ \mathbf{1 5} & \text { Veranda I } \\ \mathbf{1 6} & \text { Veranda II } \\ \mathbf{1 7} & \text { Veranda III } \\ & \text { * Local, soma de vários locais }\end{array}$

$\begin{array}{lll}\text { L } & \text { I } & \text { Alt. } \\ 5,33 \mathrm{~m} & 4,25 \mathrm{~m} & 2,8 \\ 5,33 \mathrm{~m} & 4,54 \mathrm{~m} & 2,8 \\ 11,15 \mathrm{~m} & 8,95 \mathrm{~m} & 2,8 \\ 5,4 \mathrm{~m} & 4,16 \mathrm{~m} & 2,8 \\ 6,35 \mathrm{~m} & 3,05 \mathrm{~m} & 2,8 \\ 6,35 \mathrm{~m} & 3,05 \mathrm{~m} & 2,8 \\ 4,5 \mathrm{~m} & 1,5 \mathrm{~m} & 2,8 \\ 3,37 \mathrm{~m} & 3 \mathrm{~m} & 2,8 \\ 6,5 \mathrm{~m} & 6,45 \mathrm{~m} & 2,8 \\ 6,5 \mathrm{~m} & 6,45 \mathrm{~m} & 2,8 \\ 6,5 \mathrm{~m} & 6,45 \mathrm{~m} & 2,8 \\ 6,5 \mathrm{~m} & 6,45 \mathrm{~m} & 2,8 \\ 6,5 \mathrm{~m} & 6,45 \mathrm{~m} & 2,8 \\ 6,5 \mathrm{~m} & 6,45 \mathrm{~m} & 2,8 \\ 23,8 \mathrm{~m} & 5 \mathrm{~m} & - \\ 27,7 \mathrm{~m} & 3,6 \mathrm{~m} & - \\ 27,7 \mathrm{~m} & 3,6 \mathrm{~m} & -\end{array}$

Sup.

DSL 
Catálogo casavalle dSL

\section{ESCOLA PRIMARIA CHINA}

Subsolo - Pav. 1
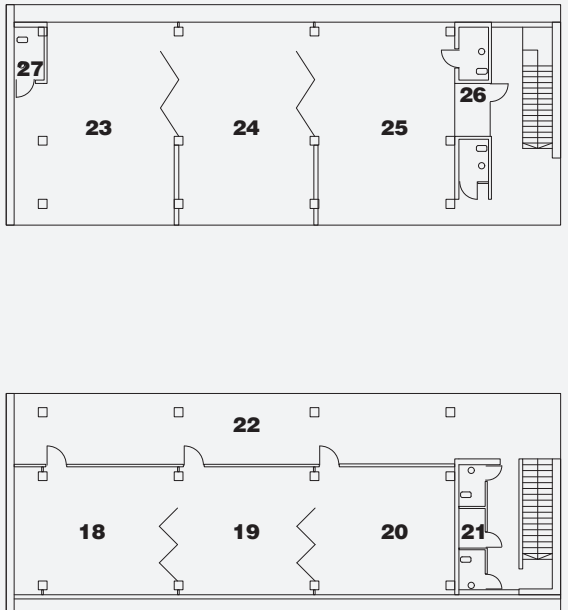

$\begin{array}{ll}\mathbf{1 8} & \text { Ateliê I } \\ \mathbf{1 9} & \text { Ateliê II } \\ \mathbf{2 0} & \text { Ateliê III } \\ \mathbf{2 1} & \text { Banh. III } \\ \mathbf{2 2} & \text { Veranda IV } \\ \mathbf{2 3} & \text { Sala de Aula pre-escolar I } \\ \mathbf{2 4} & \text { Sala de Aula pre-escolar II } \\ \mathbf{2 5} & \text { Sala de Aula pre-escolar III } \\ \mathbf{2 6} & \text { Banh. IV } \\ \mathbf{2 7} & \text { Banh. V }\end{array}$

$\begin{array}{lll}\text { L } & \text { I } & \text { Alt. } \\ 6,9 \mathrm{~m} & 6,5 \mathrm{~m} & 2,8 \\ 6,9 \mathrm{~m} & 6,5 \mathrm{~m} & 2,8 \\ 6,9 \mathrm{~m} & 6,5 \mathrm{~m} & 2,8 \\ 6,3 \mathrm{~m} & 1,35 \mathrm{~m} & 2,8 \\ 27,7 \mathrm{~m} & 3,6 \mathrm{~m} & 2,8 \\ 10,3 \mathrm{~m} & 6,8 \mathrm{~m} & 2,8 \\ 10,3 \mathrm{~m} & 6,8 \mathrm{~m} & 2,8 \\ 10,3 \mathrm{~m} & 6,8 \mathrm{~m} & 2,8 \\ 8,75 \mathrm{~m} & 1,5 \mathrm{~m} & 2,8 \\ 2,7 \mathrm{~m} & 1,5 \mathrm{~m} & 2,8\end{array}$

Sup. DSL

$44,85 \mathrm{~m}^{2}$

$44,85 \mathrm{~m}^{2}$

$44,85 \mathrm{~m}^{2}$
$8,505 \mathrm{~m}^{2}$

$99,72 \mathrm{~m}^{2} \quad \mathbf{E 3 2 4}$

$70,04 \mathrm{~m}^{2} \quad$ E64

$70,04 \mathrm{~m}^{2} \quad$ E64

$70,04 \mathrm{~m}^{2} \quad$ E64

$13,125 \mathrm{~m}^{2} \quad$ E64* 


\section{catálogo casavalle dSL}

ESCOLA CHINA DSL DISSOLUÇÃO PROGRAMÁTICA

Educacional $1303 \mathbf{m}^{2}$

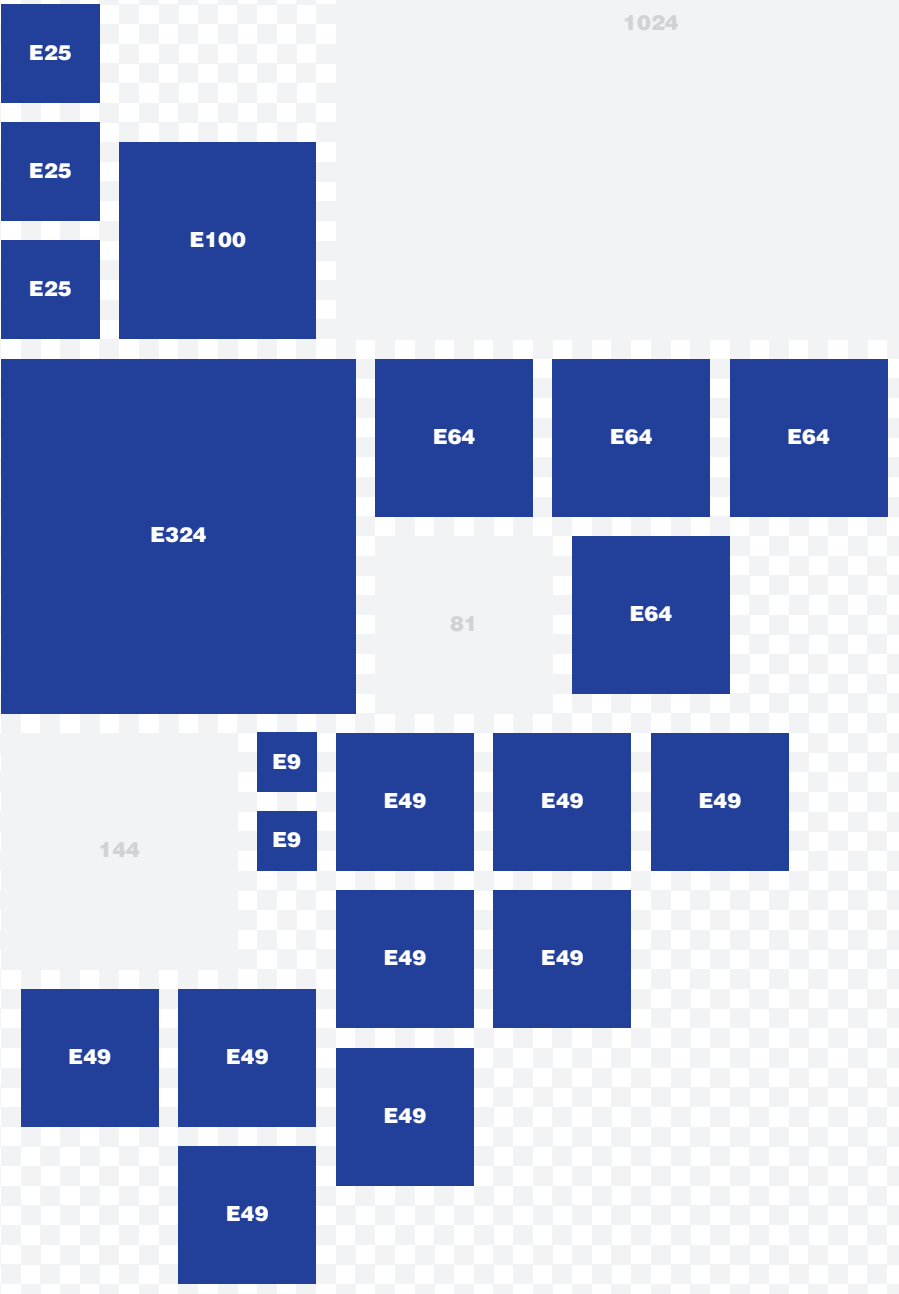




\section{catálogo casavalle dSL}

ESCOLA CHINA DSL DISSOLUÇÃO ESPACIAL Área Construída $1165 \mathrm{~m}^{2}$

Área Exterior Coberta $480 \mathrm{~m}^{2}$

Pátios $163 \mathrm{~m}^{2}$

Terreno $1470 \mathrm{~m}^{2}$
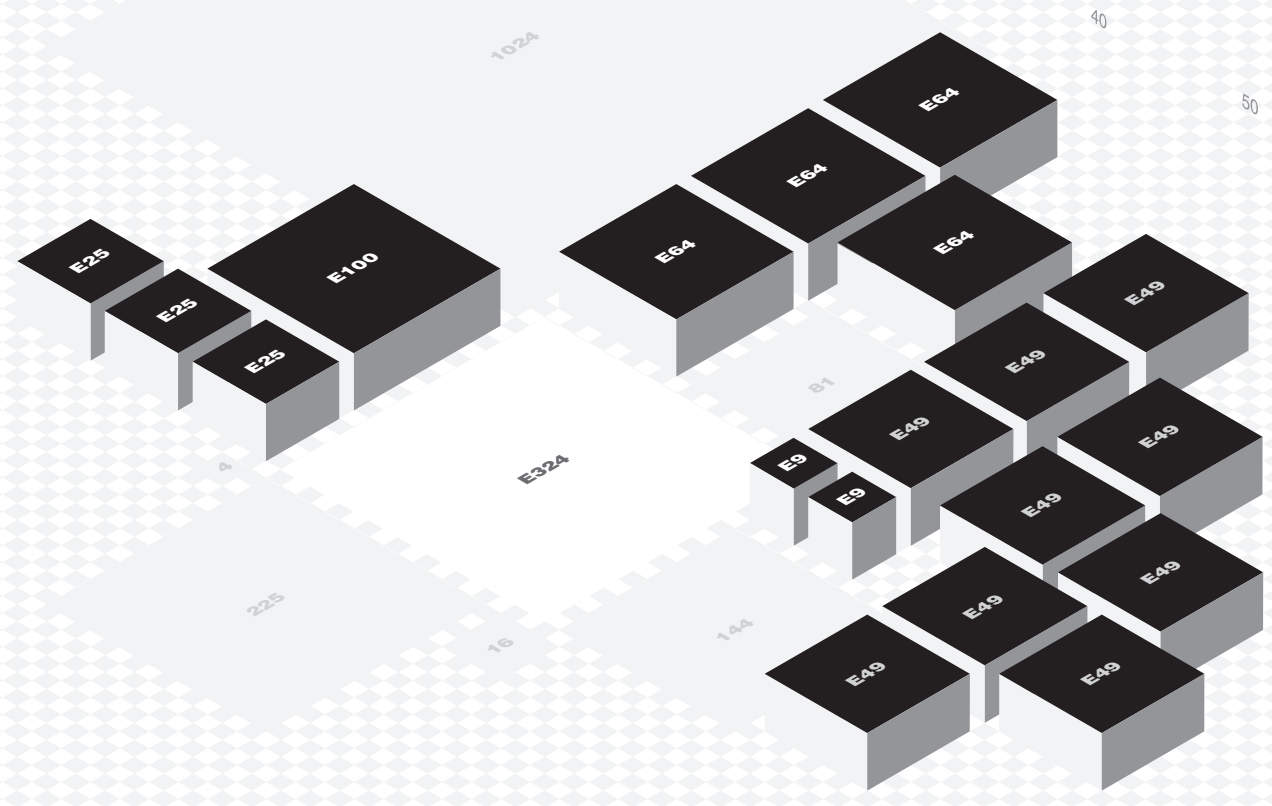
catálogo casavalle dSL

ESCOLA PRIMARIA 178 CASAVALLE

Ano 1956

Área total $1860 \mathrm{~m}^{2}$

Autor sd

Localização Barrio Casavalle, Montevideo. UY.

Organização gestora ANEP

Organização responsável ANEP CEIP

Fonte IM REVISTA SAU 235 noviembre 1958
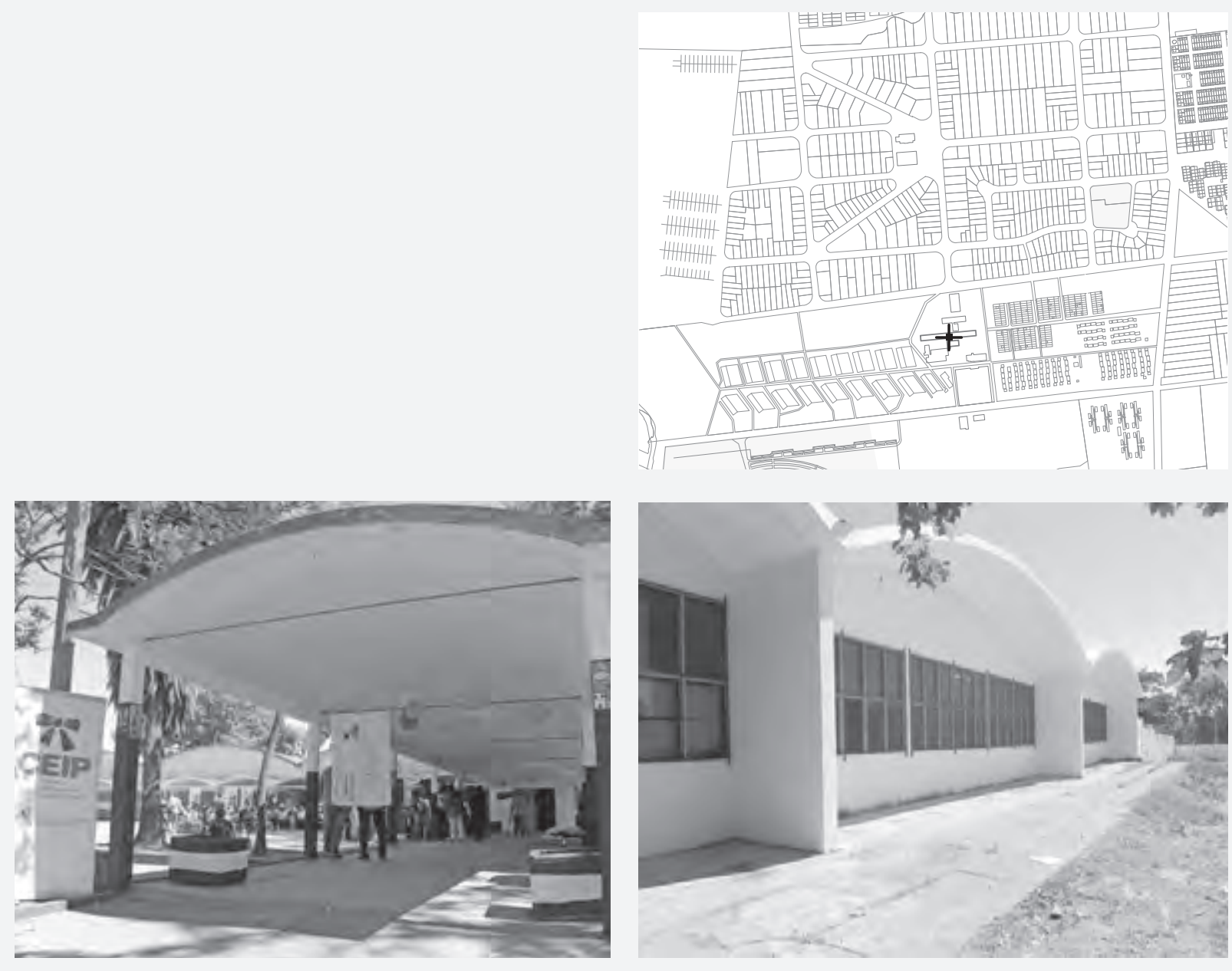
catálogo casavalle dSL

ESCOLA PRIMARIA 178 CASAVALLE

Pav. Térreo
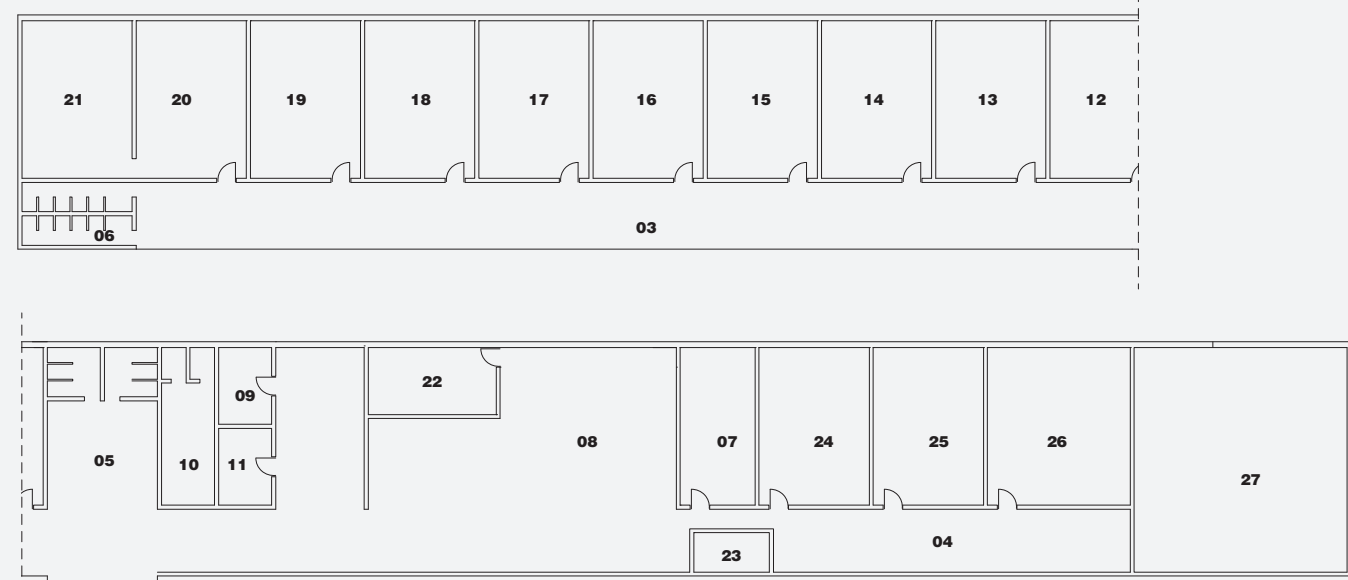

Construída $1860 \mathrm{~m}^{2}$

Área Exterior Coberta -...m²

Pátios $1435 \mathrm{~m}^{2}$

Ocupação de Solo $1860 \mathbf{m}^{2}$

Taxa Ocupação de Solo $\mathbf{5 6 \%}$

Terreno $\mathbf{3 3 0 0 \mathbf { m } ^ { 2 }}$

Educação $1705 \mathbf{m}^{2}$

Esc. 1.500

EDUCACIONAL

$\begin{array}{ll}\mathbf{0 1} & \text { SUM } \\ \mathbf{0 2} & \text { Circulação I } \\ \mathbf{0 3} & \text { Circulação II } \\ \mathbf{0 4} & \text { Circulação III } \\ \mathbf{0 5} & \text { Banh. I } \\ \mathbf{0 6} & \text { Banh. II } \\ \mathbf{0 7} & \text { Cozinha } \\ \mathbf{0 8} & \text { Refeitório } \\ \mathbf{0 9} & \text { Direção } \\ \mathbf{1 0} & \text { Secretaria } \\ \mathbf{1 1} & \text { Sala de Leitura } \\ \mathbf{1 2} & \text { Sala de Aula I } \\ \mathbf{1 3} & \text { Sala de Aula II } \\ \mathbf{1 4} & \text { Sala de Aula III } \\ \mathbf{1 5} & \text { Sala de Aula IV } \\ \mathbf{1 6} & \text { Sala de Aula V } \\ \mathbf{1 7} & \text { Sala de Aula VI } \\ \mathbf{1 8} & \text { Sala de Aula VII } \\ \mathbf{1 9} & \text { Sala de Aula VIII } \\ \mathbf{2 0} & \text { Sala de Aula IX } \\ \mathbf{2 1} & \text { Sala de Aula X } \\ \mathbf{2 2} & \text { Sala de Aula XI } \\ \mathbf{2 3} & \text { Sala de Aula XII } \\ \mathbf{2 4} & \text { Sala de Aula XIII } \\ \mathbf{2 5} & \text { Sala de Aula XIV } \\ \mathbf{2 6} & \text { Sala de Aula XV } \\ \mathbf{2 7} & \text { Habitação Caseiro } \\ & \text { * Local, soma de vários locais }\end{array}$

$\begin{array}{lll}\text { L } & \text { I } & \text { Alt. } \\ 19,8 m & 11,8 m & 2,5 m \\ 23,2 m & 5,6 m & 2,5 m \\ 68,3 m & 3,2 m & 2,5 m \\ 18,3 m & 3,2 m & 2,5 m \\ 8,2 m & 5,6 m & 2,5 m \\ 5,6 m & 3,2 m & 2,5 m \\ 8 m & 3,8 m & 2,5 m \\ 15,65 m & 11,4 m & 2,5 m \\ 3,9 m & 2,7 m & 2,5 m \\ 8 m & 2,7 m & 2,5 m \\ 3,9 m & 2,7 m & 2,5 m \\ 8 m & 5,6 m & 2,5 m \\ 8 m & 5,6 m & 2,5 m \\ 8 m & 5,6 m & 2,5 m \\ 8 m & 5,6 m & 2,5 m \\ 8 m & 5,6 m & 2,5 m \\ 8 m & 5,6 m & 2,5 m \\ 8 m & 5,6 m & 2,5 m \\ 8 m & 5,6 m & 2,5 m \\ 8 m & 5,6 m & 2,5 m \\ 8 m & 5,6 m & 2,5 m \\ 6,5 m & 3,4 m & 2,5 m \\ 3,4 m & 2,5 m & 2,5 m \\ 8 m & 5,6 m & 2,5 m \\ 8 m & 5,6 m & 2,5 m \\ 8 m & 7,25 m & 2,5 m \\ 11,4 m & 10,8 m & 2,5 m\end{array}$

Sup.

DSL

$233,6 \mathrm{~m}^{2}$

$129,9 \mathrm{~m}^{2}$

$218,5 \mathrm{~m}^{2}$

$58,5 \mathrm{~m}^{2}$

$45,9 \mathrm{~m}^{2}$

$17,9 \mathrm{~m}^{2}$

$30,4 \mathrm{~m}^{2}$

$178,4 \mathrm{~m}^{2}$

$10,5 \mathrm{~m}^{2}$

$21,6 \mathrm{~m}^{2}$

$10,53 \mathrm{~m}^{2}$

$44,8 \mathrm{~m}^{2}$

$44,8 \mathrm{~m}^{2}$

$44,8 \mathrm{~m}^{2}$

$44,8 \mathrm{~m}^{2}$

$44,8 \mathrm{~m}^{2}$

$44,8 \mathrm{~m}^{2}$

$44,8 \mathrm{~m}^{2}$

$44,8 \mathrm{~m}^{2}$

$44,8 \mathrm{~m}^{2}$

$44,8 \mathrm{~m}^{2}$

$44,8 \mathrm{~m}^{2}$

$22,1 \mathrm{~m}^{2}$

$8,5 \mathrm{~m}^{2}$

$44,8 \mathrm{~m}^{2}$

$44,8 m^{2}$

$58 \mathrm{~m}^{2}$

$123,12 m^{2}$ 
catálogo casavalle dSL

ESCOLA 178 DSL DISSOLUÇÃO PROGRAMÁTICA Educacional $1705 \mathbf{m}^{2}$

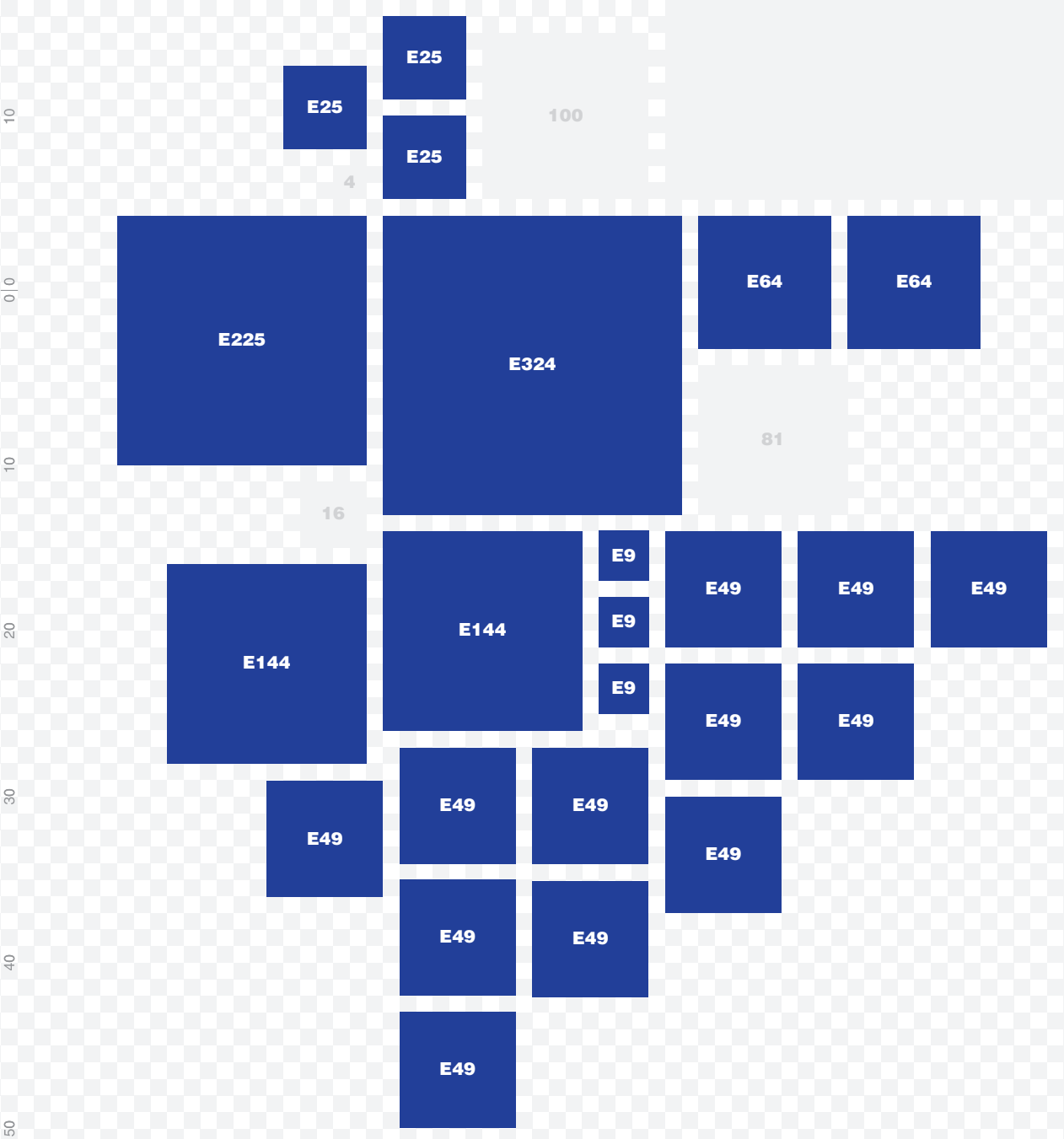


catálogo casavalle dsL

ESCOLA 178 DSL DISSOLUÇÃO ESPÅCIAL

Área Construída $1860 \mathrm{~m}^{2}$

Área Exterior Coberta ---m²

Pátios $1435 \mathrm{~m}^{2}$

Terreno $\mathbf{3 3 0 0 \mathbf { m } ^ { 2 }}$

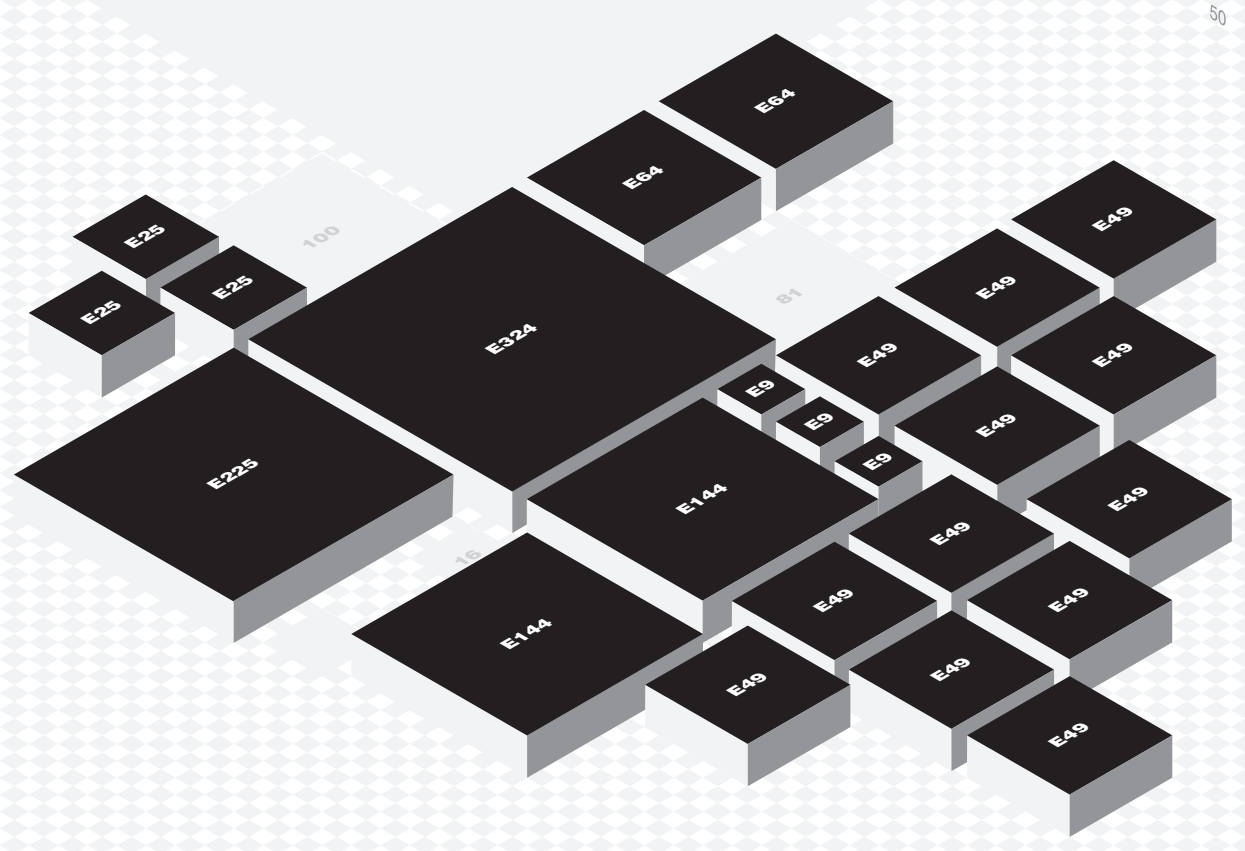




\section{catálogo casavalle dSL}

\section{POLICLINICA CASAVALLE}

\section{Ano 2012}

Área total $860 \mathrm{~m}^{2}$

Autor IM DIv. Saude. Arq. Martha Gregorio

Localização Barrio Casavalle, Montevideo. UY.

Organização gestora CND

Organização responsável SND Secretaria Nacional de Esportes

Fonte IM
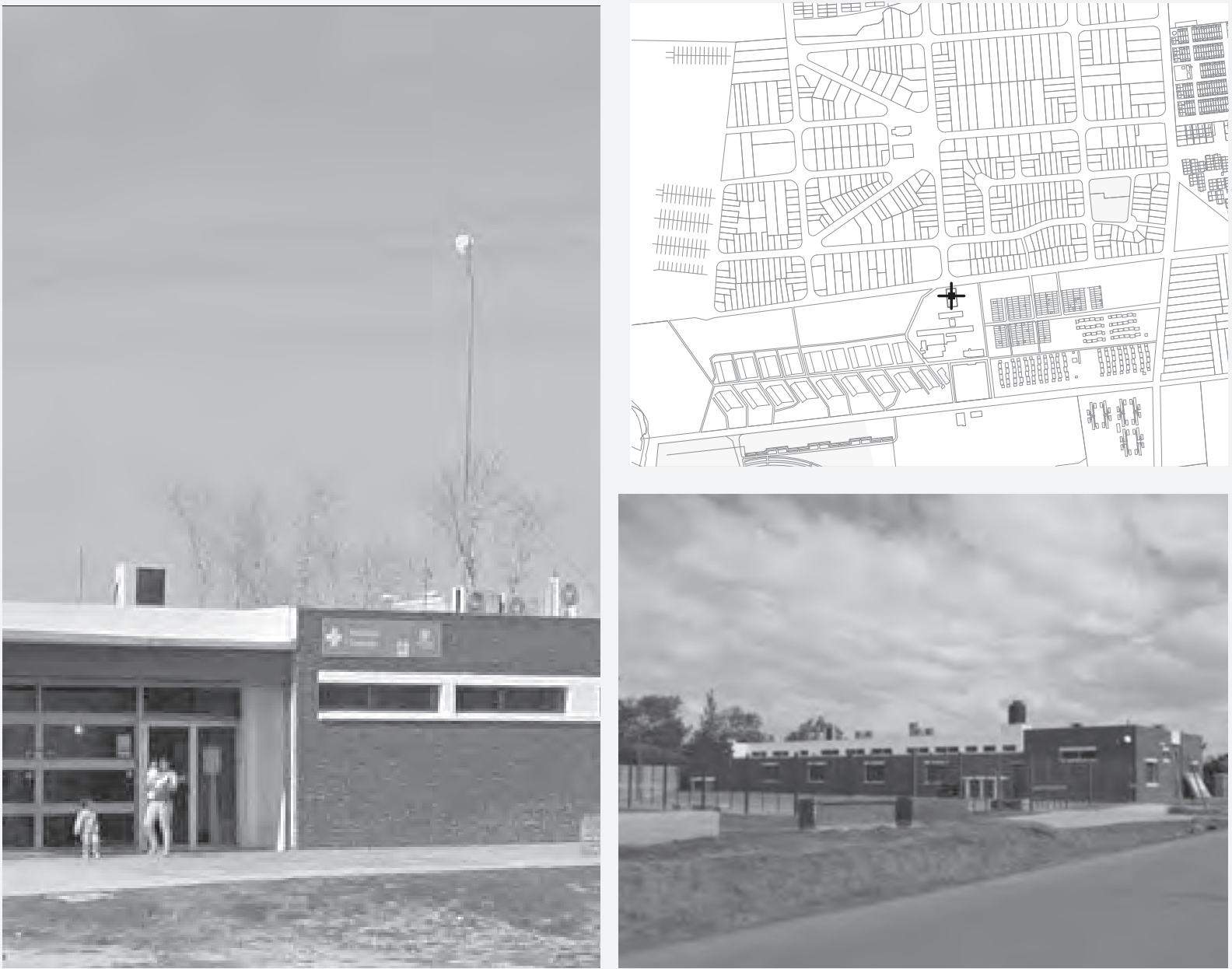
CATÁlogo casavalle dSL

POLICLINICA CASAVALLE

Pav. Térreo

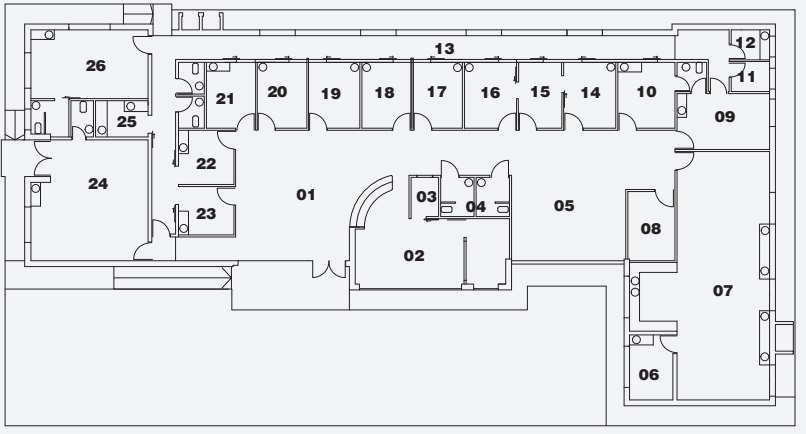

Área Construída $535 \mathrm{~m}^{2}$

Área Exterior Coberta $130 \mathrm{~m}^{2}$

Pátios 197m²

Ocupação de Solo $860 \mathrm{~m}^{2}$

Taxa Ocupação de Solo $\mathbf{6 2 \%}$

Terreno $\mathbf{8 6 0 \mathbf { m } ^ { 2 }}$

Saúde $425 \mathbf{m}^{2}$

$\begin{array}{lll}\mathbf{0 1} & \text { Sala de espera } & 6,62 \mathrm{~m} \\ \mathbf{0 2} & \text { Administração } & 7,8 \mathrm{~m} \\ \mathbf{0 3} & \text { Farmácia } & 2 \mathrm{~m} \\ \mathbf{0 4} & \text { Banh. I } & 3,5 \mathrm{~m} \\ \mathbf{0 5} & \text { Jogo infantil } & 5,8 \mathrm{~m} \\ \mathbf{0 6} & \text { Raios X } & 3,3 \mathrm{~m} \\ \mathbf{0 7} & \text { Odontologia } & 12,6 \mathrm{~m} \\ \mathbf{0 8} & \text { Nutrição } & 3,5 \mathrm{~m} \\ \mathbf{0 9} & \text { Ginecologia I } & 4,7 \mathrm{~m} \\ \mathbf{1 0} & \text { Ginecologia com banh. } & 4,4 \mathrm{~m} \\ \mathbf{1 1} & \text { Depósito } & 1,9 \mathrm{~m} \\ \mathbf{1 2} & \text { Limpeza } & 1,9 \mathrm{~m} \\ \mathbf{1 3} & \text { Circulação técnica } & 29 \mathrm{~m} \\ \mathbf{1 4} & \text { Pediatria I } & 3,35 \mathrm{~m} \\ \mathbf{1 5} & \text { Antropometria } & 3,35 \mathrm{~m} \\ \mathbf{1 6} & \text { Pediatria II } & 3,35 \mathrm{~m} \\ \mathbf{1 7} & \text { Saúde mental I } & 3,35 \mathrm{~m} \\ \mathbf{1 8} & \text { Saúde mental II } & 3,35 \mathrm{~m} \\ \mathbf{1 9} & \text { Medicina geral I } & 3,35 \mathrm{~m} \\ \mathbf{2 0} & \text { Medicina geral II } & 3,35 \mathrm{~m} \\ \mathbf{2 1} & \text { Vacinaria } & 3,35 \mathrm{~m} \\ \mathbf{2 2} & \text { Recuperação } & 2,8 \mathrm{~m} \\ \mathbf{2 3} & \text { Nebulizações } & 2,8 \mathrm{~m} \\ \mathbf{2 4} & \text { SUM com banh. } & 6,12 \mathrm{~m} \\ \mathbf{2 5} & \text { Enfermeria suja } & 2,66 \mathrm{~m} \\ \mathbf{2 6} & \text { Sala de funcionários com banh. } 6 \mathrm{~m} \\ & \text { * Local, soma de vários locais } \\ & & \end{array}$

$\begin{array}{ll}\text { I Alt. } \\ \text { 6m } & 3,25 \mathrm{~m} \\ 3,55 \mathrm{~m} & 3,25 \mathrm{~m} \\ 1,4 \mathrm{~m} & 3,25 \mathrm{~m} \\ 2 \mathrm{~m} & 3,25 \mathrm{~m} \\ 4,3 \mathrm{~m} & 3,25 \mathrm{~m} \\ 2,2 \mathrm{~m} & 3,25 \mathrm{~m} \\ 4,7 \mathrm{~m} & 3,25 \mathrm{~m} \\ 2,4 \mathrm{~m} & 3,25 \mathrm{~m} \\ 2,8 \mathrm{~m} & 3,25 \mathrm{~m} \\ 3,35 \mathrm{~m} & 3,25 \mathrm{~m} \\ 1,52 \mathrm{~m} & 3,25 \mathrm{~m} \\ 1,52 \mathrm{~m} & 3,25 \mathrm{~m} \\ 1,2 \mathrm{~m} & 3,25 \mathrm{~m} \\ 2,65 \mathrm{~m} & 3,25 \mathrm{~m} \\ 2,65 \mathrm{~m} & 3,25 \mathrm{~m} \\ 2,65 \mathrm{~m} & 3,25 \mathrm{~m} \\ 2,5 \mathrm{~m} & 3,25 \mathrm{~m} \\ 2,5 \mathrm{~m} & 3,25 \mathrm{~m} \\ 2,5 \mathrm{~m} & 3,25 \mathrm{~m} \\ 2,6 \mathrm{~m} & 3,25 \mathrm{~m} \\ 2,5 \mathrm{~m} & 3,25 \mathrm{~m} \\ 2,75 \mathrm{~m} & 3,25 \mathrm{~m} \\ 2,5 \mathrm{~m} & 3,25 \mathrm{~m} \\ 6 \mathrm{~m} & 3,25 \mathrm{~m} \\ 1,85 \mathrm{~m} & 3,25 \mathrm{~m} \\ 3,5 \mathrm{~m} & 3,25 \mathrm{~m}\end{array}$

Sup. DSL

$62 \mathrm{~m}^{2}$

$27,7 \mathrm{~m}^{2} \quad \mathbf{5 2 5}$

$2,8 \mathrm{~m}^{2} \quad \mathbf{S 2 5}$

$7 \mathrm{~m}^{2} \quad$ s9

$24,9 \mathrm{~m}^{2} \quad \mathbf{S 2 5}$

$7,3 \mathrm{~m}^{2} \quad$ s9

$59,2 \mathrm{~m}^{2} \quad \mathbf{S 6 4}$

$8,4 \mathrm{~m}^{2} \quad \mathbf{S 9}$

$14,7 \mathrm{~m}^{2} \quad \mathrm{s16}$

$14,7 \mathrm{~m}^{2} \quad \mathbf{S 1 6}$

$\begin{array}{ll}2,9 \mathrm{~m}^{2} & \mathbf{S 4} \\ 2,9 & \text { : }\end{array}$

$46 \mathrm{~m}^{2} \quad \mathbf{S 4 9}$

$8,9 \mathrm{~m}^{2}$

$8,9 \mathrm{~m}^{2} \quad \mathbf{s 9}$

$8,9 \mathrm{~m}^{2} \quad$ S9

$8,9 \mathrm{~m}^{2} \quad$ S9

$8,4 \mathrm{~m}^{2} \quad$ S9

$8,4 \mathrm{~m}^{2} \quad$ S9

$8,4 \mathrm{~m}^{2} \quad$ S9

$8,7 \mathrm{~m}^{2} \quad$ S9

$8,4 \mathrm{~m}^{2} \quad$ S9

$7,7 \mathrm{~m}^{2} \quad$ s9

$36,7 \mathrm{~m}^{2} \quad$ S2

$4,9 \mathrm{~m}^{2} \quad \mathbf{S 9}$

$21 \mathrm{~m}^{2} \quad \mathbf{S 2 5}$ 


\section{catálogo casavalle dSL}

POLICLINICA CASAVALLE DSL DISSOLUÇÃO PROGRAMÁTICA Saúde $425 \mathbf{m}^{2}$
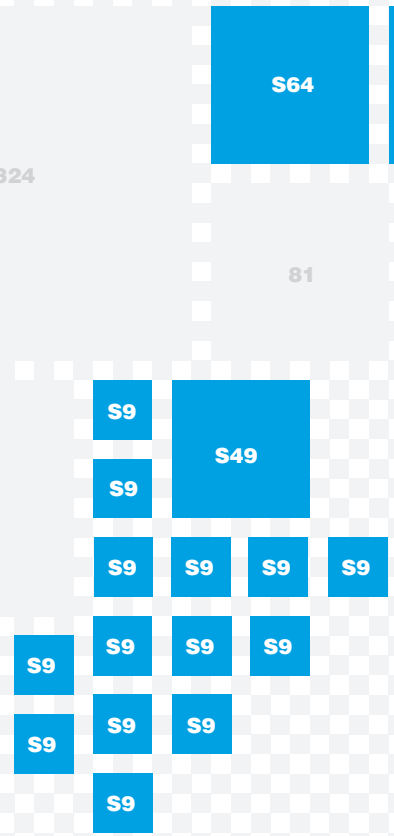
catálogo casavalle dSL

POLICLINICA CASAVALLE DSL DISSOLLUÇÃO ESPACIAL

Área Construída $535 \mathrm{~m}^{2}$

Área Exterior Coberta $130 \mathrm{~m}^{2}$

Pátios $197 \mathrm{~m}^{2}$

Terreno $860 \mathbf{m}^{2}$
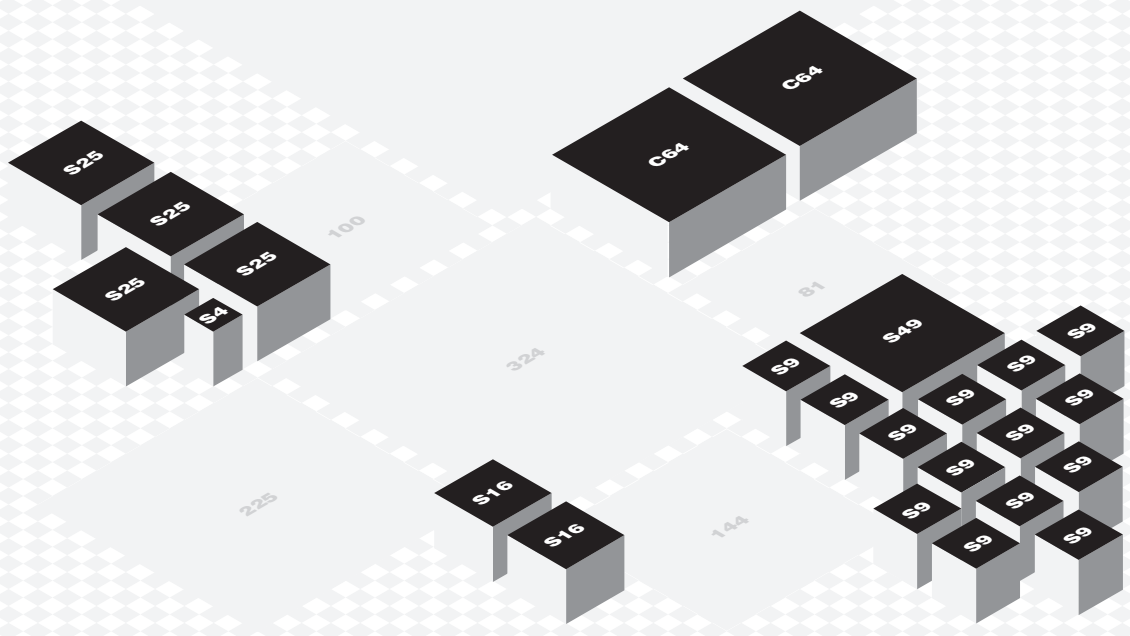


\section{catálogo casavalle dsL}

\section{COMISARIA CASAVALLE}

Ano 2013

Área total $\mathbf{2 8 7} \mathbf{m}^{2}$

Autor Ministerio del Interior. sd

Localização Barrio Casavalle, Montevideo. UY.

Organização gestora Ministerio del Interior. Dpto. Arquitectura.

Organização responsável MI. Ministerio del Interior

Fonte IM
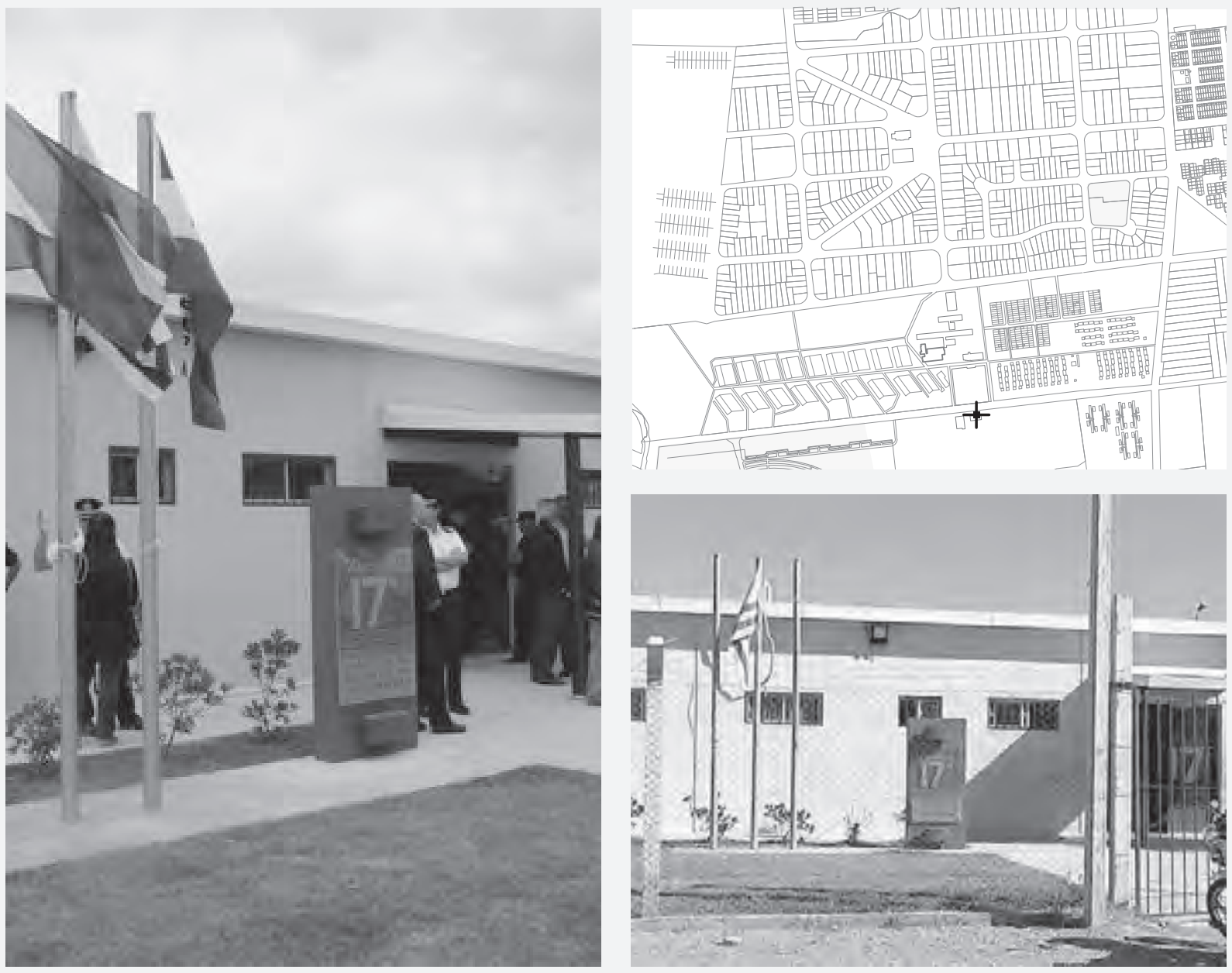
catálogo casavalle dSL

COMISARIA CASAVALLE

Pav. Térreo

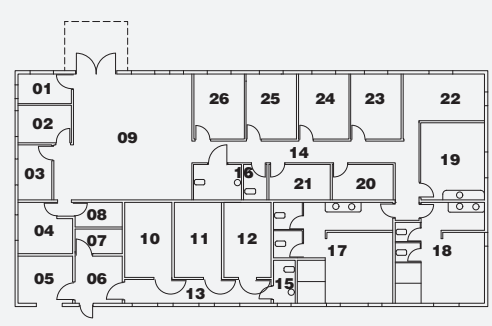

Área Construída $\mathbf{2 8 7} \mathrm{m}^{2}$

Área Exterior Coberta $\mathbf{9 \mathbf { m } ^ { 2 }}$

Pátios ---m²

Ocupação de Solo $\mathbf{2 8 7} \mathbf{m}^{2}$

Taxa Ocupação de Solo $\mathbf{5 3} \%$

Terreno $5 \mathbf{5 0 \mathbf { m } ^ { 2 }}$

Outros $256 \mathbf{m}^{2}$

Esc. 1.500

$\begin{array}{ll}\mathbf{0 1} & \text { Guarda } \\ \mathbf{0 2} & \text { Gabinete } \\ \mathbf{0 3} & \text { At.Personalizada I } \\ \mathbf{0 4} & \text { At. Personalizada II } \\ \mathbf{0 5} & \text { Guarda int. } \\ \mathbf{0 6} & \text { Sala de espera Presos } \\ \mathbf{0 7} & \text { Pre. e interrogatório I } \\ \mathbf{0 8} & \text { Pre. e interrogatório II } \\ \mathbf{0 9} & \text { Hall de aceso } \\ \mathbf{1 0} & \text { Calabouço I } \\ \mathbf{1 1} & \text { Calabouço II } \\ \mathbf{1 2} & \text { Calabouço III } \\ \mathbf{1 3} & \text { Circulação I } \\ \mathbf{1 4} & \text { Circulação II } \\ \mathbf{1 5} & \text { Banh. I } \\ \mathbf{1 6} & \text { Banh. II } \\ \mathbf{1 7} & \text { Vestuário homens } \\ \mathbf{1 8} & \text { Vestuário mulheres } \\ \mathbf{1 9} & \text { Refeitório } \\ \mathbf{2 0} & \text { Telefonia } \\ \mathbf{2 1} & \text { Radio } \\ \mathbf{2 2} & \text { Gabinete Administração } \\ \mathbf{2 3} & \text { Gabinete Jurídico } \\ \mathbf{2 4} & \text { Gabinete } \\ \mathbf{2 5} & \text { Chefe } \\ \mathbf{2 6} & \text { Subchefe } \\ & \text { * Local, soma de vários locais }\end{array}$

$\begin{array}{lll}\text { L } & \text { I } & \text { Alt. } \\ 2,7 \mathrm{~m} & 1,5 \mathrm{~m} & 2,4 \mathrm{~m} \\ 2,7 \mathrm{~m} & 1,9 \mathrm{~m} & 2,4 \mathrm{~m} \\ 2,8 \mathrm{~m} & 1,7 \mathrm{~m} & 2,4 \mathrm{~m} \\ 2,75 \mathrm{~m} & 2,6 \mathrm{~m} & 2,4 \mathrm{~m} \\ 2,75 \mathrm{~m} & 2,4 \mathrm{~m} & 2,85 \mathrm{~m} \\ 2,4 \mathrm{~m} & 2,4 \mathrm{~m} & 2,85 \mathrm{~m} \\ 2,4 \mathrm{~m} & 1,24 \mathrm{~m} & 2,85 \mathrm{~m} \\ 2,4 \mathrm{~m} & 1,24 \mathrm{~m} & 2,85 \mathrm{~m} \\ 6,4 \mathrm{~m} & 6 \mathrm{~m} & 2,85 \mathrm{~m} \\ 3,8 \mathrm{~m} & 2,4 \mathrm{~m} & 2,85 \mathrm{~m} \\ 3,8 \mathrm{~m} & 2,4 \mathrm{~m} & 2,85 \mathrm{~m} \\ 3,8 \mathrm{~m} & 2,4 \mathrm{~m} & 2,85 \mathrm{~m} \\ 7,44 \mathrm{~m} & 1,2 \mathrm{~m} & 2,85 \mathrm{~m} \\ 10,3 \mathrm{~m} & 1,1 \mathrm{~m} & 2,4 \mathrm{~m} \\ 2,19 \mathrm{~m} & 1,1 \mathrm{~m} & 2,85 \mathrm{~m} \\ 3,73 \mathrm{~m} & 1,8 \mathrm{~m} & 2,85 \mathrm{~m} \\ 6 \mathrm{~m} & 5,12 \mathrm{~m} & 2,85 \mathrm{~m} \\ 5,12 \mathrm{~m} & 4,53 \mathrm{~m} & 2,85 \mathrm{~m} \\ 3,9 \mathrm{~m} & 3,23 \mathrm{~m} & 2,4 \mathrm{~m} \\ 3,1 \mathrm{~m} & 1,8 \mathrm{~m} & 2,4 \mathrm{~m} \\ 3,1 \mathrm{~m} & 1,8 \mathrm{~m} & 2,4 \mathrm{~m} \\ 4,13 \mathrm{~m} & 2,4 \mathrm{~m} & 2,4 \mathrm{~m} \\ 3,31 \mathrm{~m} & 2,55 \mathrm{~m} & 2,4 \mathrm{~m} \\ 3,31 \mathrm{~m} & 2,55 \mathrm{~m} & 2,4 \mathrm{~m} \\ 3,31 \mathrm{~m} & 2,55 \mathrm{~m} & 2,4 \mathrm{~m} \\ 3,31 \mathrm{~m} & 2,55 \mathrm{~m} & 2,4 \mathrm{~m}\end{array}$

Sup.

DSL 


\section{catálogo casavalle dSL}

COMISARIA CASAVALLE DSL DISSOLUÇÃO PROGRAMÁTICA Outros $256 \mathbf{m}^{2}$

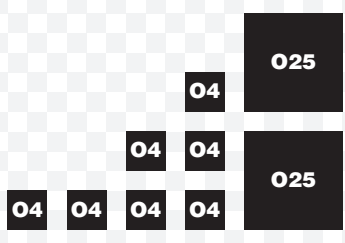




\section{catálogo casavalle dSL}

COMISARIA CASAVALLE DSL DISSOL̈UÇÃO ESPACIAL

Área Construída $\mathbf{2 8 7 \mathbf { m } ^ { 2 }}$

Área Exterior Coberta $\mathbf{9 \mathbf { m } ^ { 2 }}$

Pátios ---m²

Terreno $\mathbf{5 4 0 \mathbf { m } ^ { 2 }}$
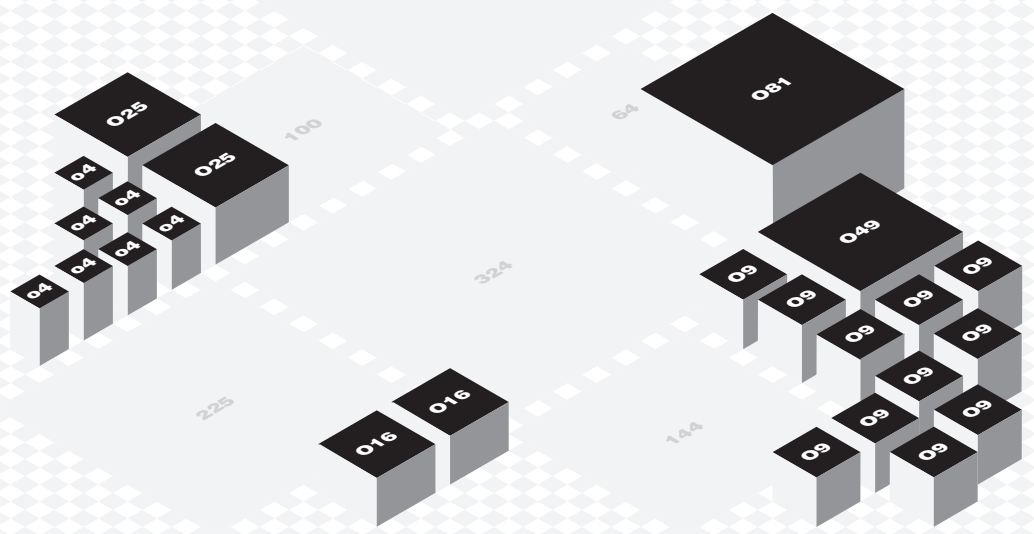


\section{catálogo casavalle dsL}

\section{BOMBEROS CASAVALLE}

\section{Ano 1988}

Área total $300 \mathrm{~m}^{2}$

Autor Dirección Nacional de Bomberos. Luis Eduardo Salesi

Localização Barrio Casavalle, Montevideo. UY.

Organização gestora Dirección Nacional de Bomberos. Dpto. Arquitectura.

Organização responsável MI. Ministerio del Interior

Fonte Dirección Nacional Bomberos
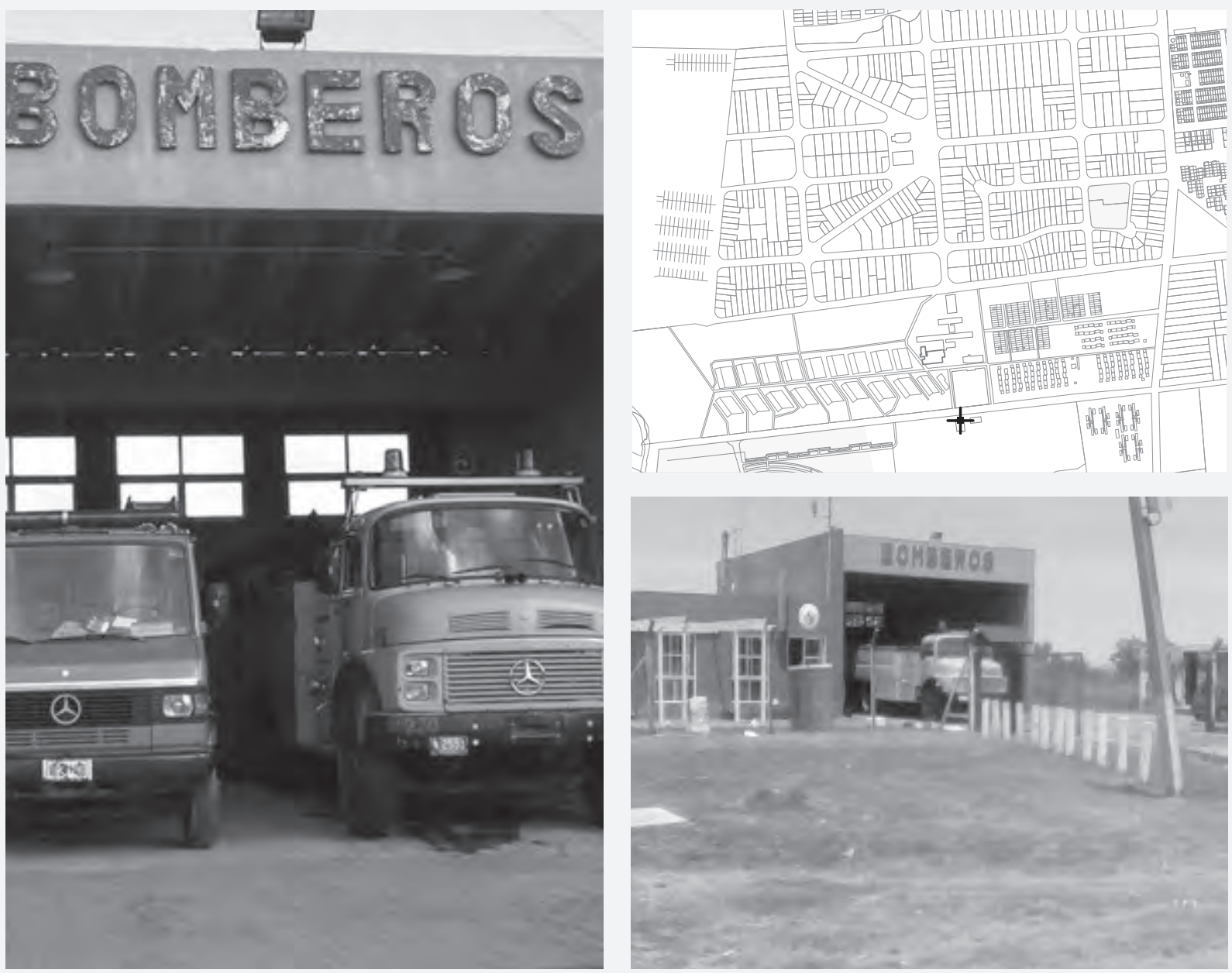
catálogo casavalle dSL

BOMBEROS CASAVALLE

Pav. Térreo

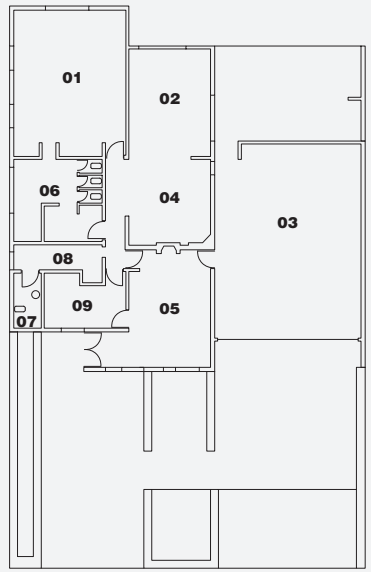

300m²

Área Exterior Coerta $195 \mathrm{~m}^{2}$

Pátios 230m²

Ocupação de Solo $490 \mathrm{~m}^{2}$

Taxa Ocupação de Solo $\mathbf{6 1 \%}$

Terreno $\mathbf{8 0 0 \mathbf { m } ^ { 2 }}$

Outros 220 m²

Esc. 1.500

$\begin{array}{ll}01 & \text { Quarto caseiro } \\ 02 & \text { Cozinha Refeitório } \\ 03 & \text { Garagem } \\ 04 & \text { Sala estar } \\ 05 & \text { Escritório } \\ 06 & \text { Banh. caseiro } \\ 07 & \text { Banh. } \\ 08 & \text { Quarto Chefe } \\ 09 & \text { Gabinete Chefe } \\ & \text { * Local, soma de vários locais }\end{array}$

$\begin{array}{lll}\text { L } & \text { I } & \text { Alt. } \\ 7,45 \mathrm{~m} & 5,7 \mathrm{~m} & 2, \\ 5,45 \mathrm{~m} & 4,15 \mathrm{~m} & 2, \\ 9,9 \mathrm{~m} & 7,4 \mathrm{~m} & 4, \\ 4,23 \mathrm{~m} & 4,15 \mathrm{~m} & 2, \\ 5,98 \mathrm{~m} & 4,15 \mathrm{~m} & 2, \\ 4,5 \mathrm{~m} & 4,18 \mathrm{~m} & 2, \\ 2,8 \mathrm{~m} & 1,4 \mathrm{~m} & 2, \\ 4,5 \mathrm{~m} & 1,3 \mathrm{~m} & 2, \\ 4,15 \mathrm{~m} & 2,5 \mathrm{~m} & 2,\end{array}$

Alt.

Sup. DSL

$42,5 \mathrm{~m}^{2}$

$22,6 \mathrm{~m}^{2}$

$73,26 \mathrm{~m}^{2}$

$17,55 \mathrm{~m}^{2}$

$18,8 \mathrm{~m}^{2}$

$3,9 \mathrm{~m}^{2}$

$5,85 \mathrm{~m}^{2}$

$10,3 m^{2}$

O25*

025*

04
09 


\section{catálogo casavalle dSL}

BOMBEROS CASAVALLE DSL DISSOLUÇÃO PROGRAMÁTICA Outros $220 \mathbf{m}^{2}$

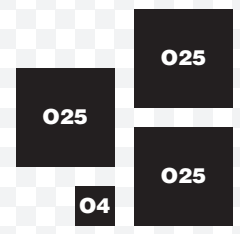


catálogo casavalle dSL

BOMBEROS CASAVALLE DSL DISSOLUUÇÃO ESPACIAL

Área Construída $\mathbf{3 0 0 \mathbf { m } ^ { 2 }}$

Área Exterior Coberta $195 \mathrm{~m}^{2}$

Pátios 230m²

Terreno $\mathbf{8 0 0 \mathbf { m } ^ { 2 }}$
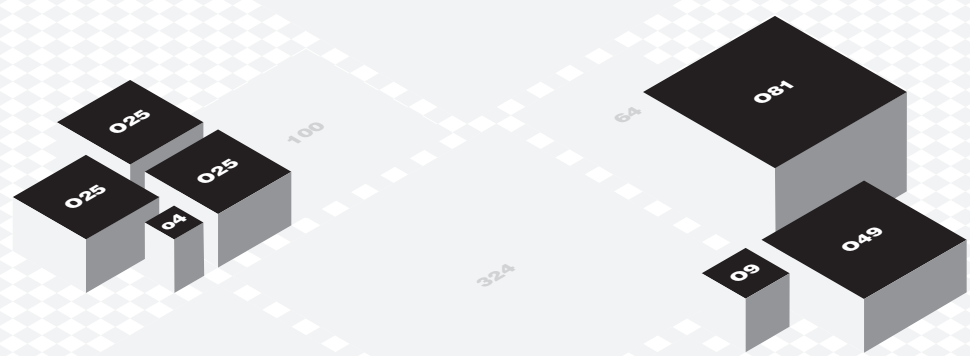


\section{catálogo casavalle dsL}

\section{SACUDE}

\section{Ano 2013}

Área total $2556 \mathbf{m}^{2}$

Autor Int. Montevideo. PIAI

Localização Barrio Casavalle, Montevideo. UY.

Organização gestora Intendencia de Montevideo. PIAI.

Organização responsável Intendencia de Montevideo

Fonte IM
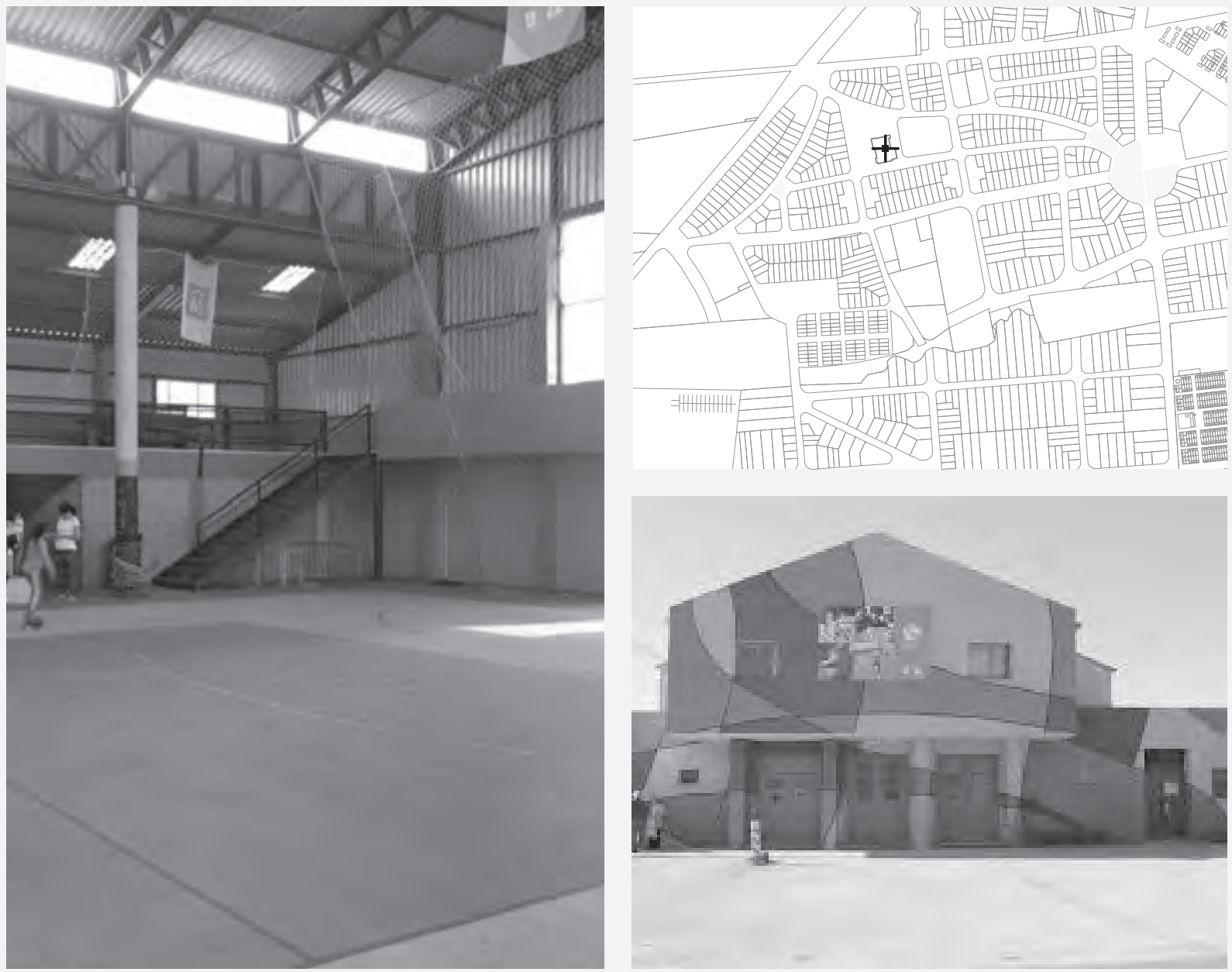
CATÁlogo casavalle dSL

SACUDE

Pav. Térreo

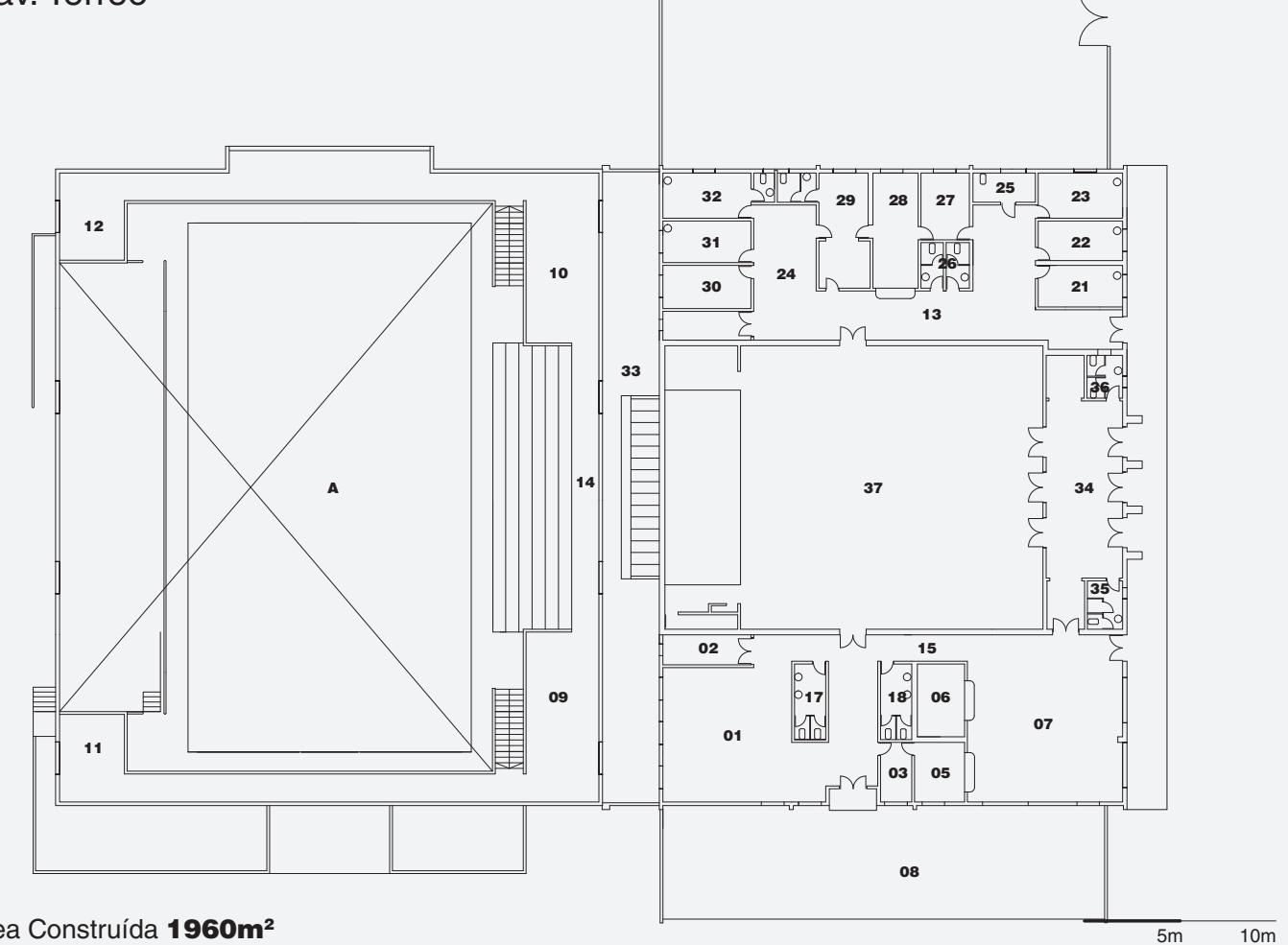

Área Exterior Coberta $195 \mathrm{~m}^{2}$

Pátios 295m²

Ocupação de Solo $\mathbf{2 5 5 6 \mathbf { m } ^ { 2 }}$

Taxa Ocupação de Solo $\mathbf{6 8 \%}$

Terreno 3300m²

Esporte $1305 \mathbf{m}^{2}$

Social e Cultural $408 \mathbf{m}^{2}$

Saúde $280 \mathbf{m}^{2}$

Esc. 1.500

ESPORTE

Local Trabalho

Depósito I

Depósito II

Cafeteria

Administração

Sala I

Área de jogos I

Área de jogos I

Área de jogos III

Área de jogos IV

Circulação I

Circulação II

Circulaçação II

Circulação V

Banh. I

Banh. II

Banh. III

Consultório I

Consultório II

Consultório III

Sala de espera

Banh. I

Banh. II

Enfermaria

Sala médicos com Banh.

Consultório odontológico

Consultório IV

Consultório com Banh.

Circulação

$\begin{array}{ll}\text { L } & \text { I } \\ 7.1 \mathrm{~m} & 6.7 \mathrm{~m} \\ 4.7 \mathrm{~m} & 1.7 \mathrm{~m} \\ 3.2 \mathrm{~m} & 1.7 \mathrm{~m} \\ 3.3 \mathrm{~m} & 1.7 \mathrm{~m} \\ 3.2 \mathrm{~m} & 2.7 \mathrm{~m} \\ 3.9 \mathrm{~m} & 2.5 \mathrm{~m} \\ 8.9 \mathrm{~m} & 8.2 \mathrm{~m} \\ 10.0 \mathrm{~m} & 3 . \\ 9.0 \mathrm{~m} & 3.9 \mathrm{~m} \\ 9.0 \mathrm{~m} & 3.9 \mathrm{~m} \\ 4.6 \mathrm{~m} & 3.4 \mathrm{~m} \\ 4.6 \mathrm{~m} & 3.4 \mathrm{~m} \\ 11.3 \mathrm{~m} & 1.4 \mathrm{~m} \\ 15.3 \mathrm{~m} & 1.4 \mathrm{~m} \\ 19.6 \mathrm{~m} & 1.5 \mathrm{~m} \\ 15.3 \mathrm{~m} & 1.5 \mathrm{~m} \\ 4.0 \mathrm{~m} & 1.7 \mathrm{~m} \\ 4.0 \mathrm{~m} & 1.7 \mathrm{~m} \\ 3.3 \mathrm{~m} & 1.7 \mathrm{~m} \\ 3.3 \mathrm{~m} & 1.7 \mathrm{~m} \\ & \\ 4.5 \mathrm{~m} & 2.2 \mathrm{~m} \\ 4.5 \mathrm{~m} & 2.1 \mathrm{~m} \\ 4.5 \mathrm{~m} & 2.4 \mathrm{~m} \\ 19.5 \mathrm{~m} & 3.3 \mathrm{~m} \\ 3.3 \mathrm{~m} & 1.6 \mathrm{~m} \\ 2.6 \mathrm{~m} & 2.4 \mathrm{~m} \\ 3.6 \mathrm{~m} & 2 . \\ 6.1 \mathrm{~m} & 2.4 \mathrm{~m} \\ 6.1 \mathrm{~m} & 2 . \\ 4.7 \mathrm{~m} & 2.3 \mathrm{~m} \\ 4.7 \mathrm{~m} & 2.2 \mathrm{~m} \\ 5.9 \mathrm{~m} & 2.4 \mathrm{~m} \\ 33.4 \mathrm{~m} & 3 . \\ & \\ & \end{array}$


CATÁlogo casavalle DSL

SACUDE

Subsolo

우
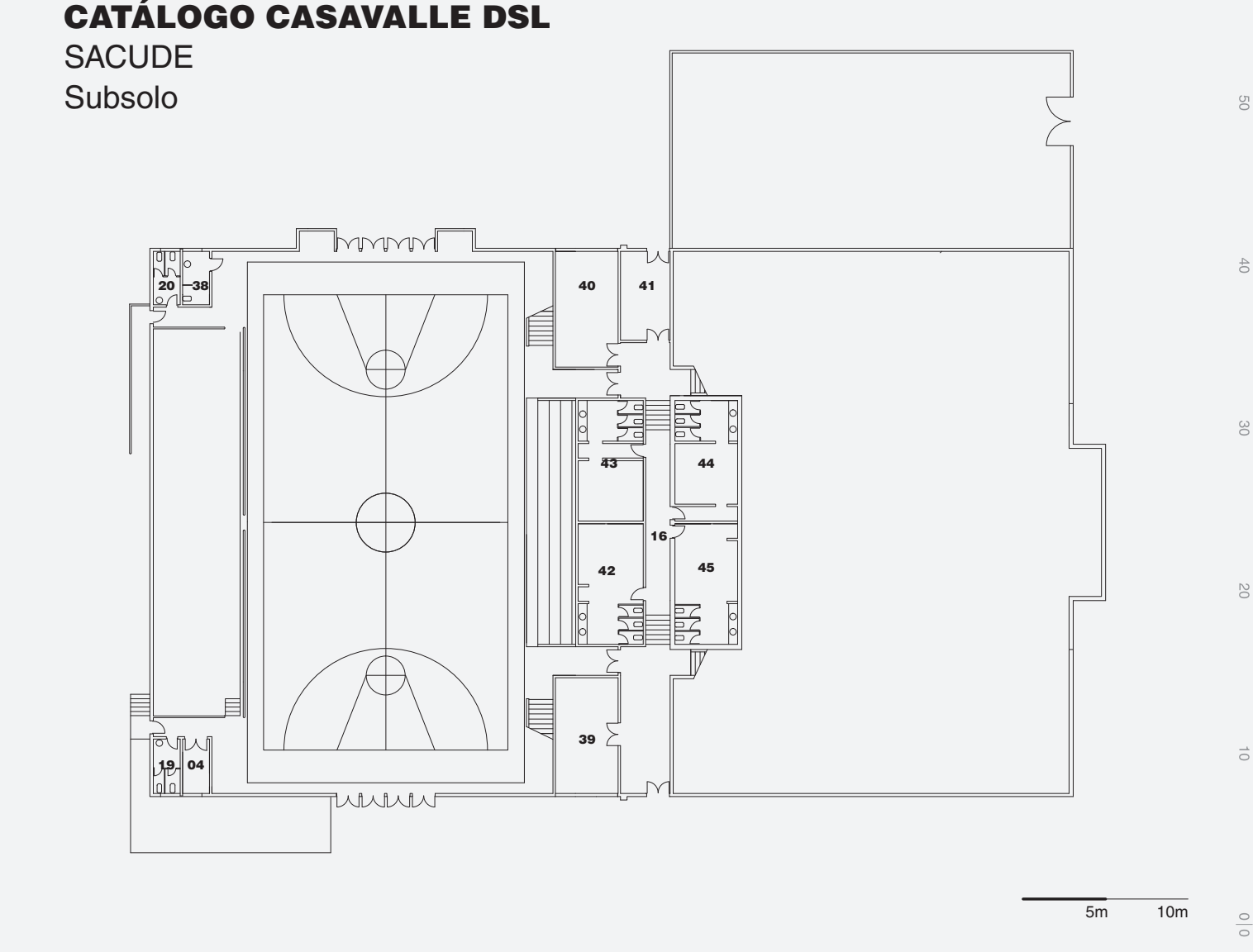

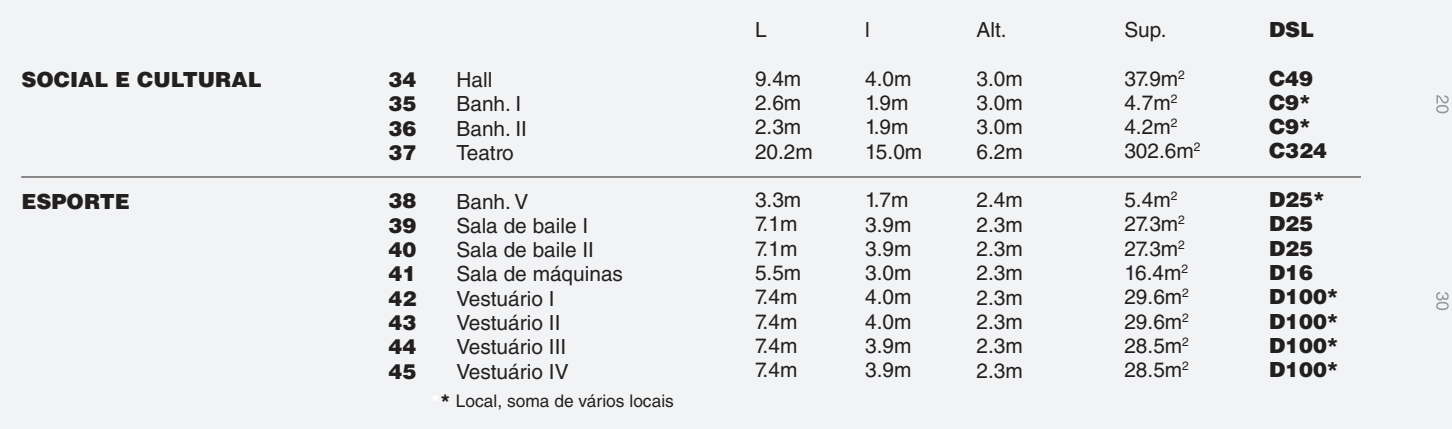


CATÁlogo casavalle dSL

SACUDE

Pav. 1

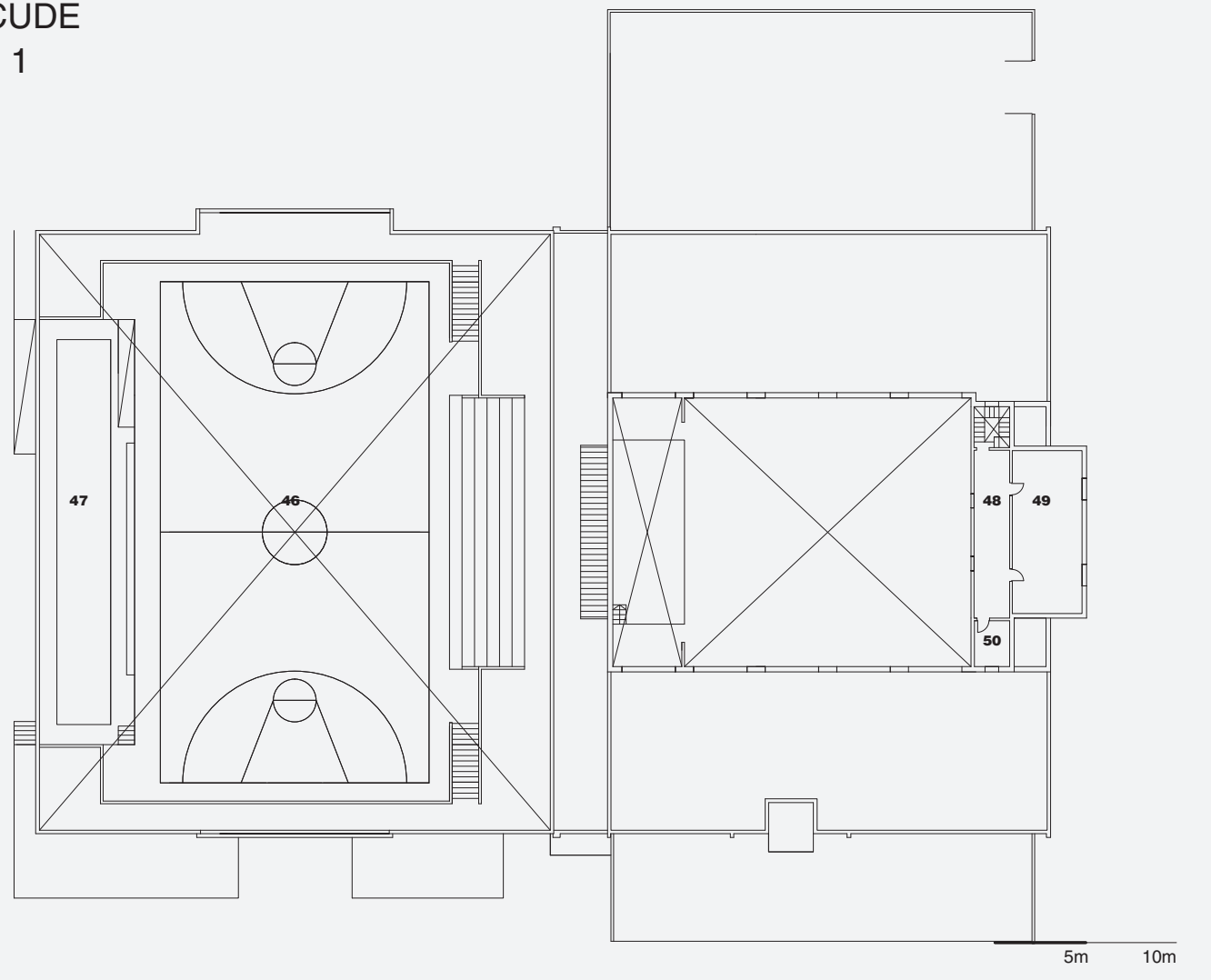

\begin{tabular}{|c|c|c|c|c|c|c|c|}
\hline & & & $\mathrm{L}$ & 1 & Alt. & Sup. & DSL \\
\hline ESPORTE & $\begin{array}{l}46 \\
47\end{array}$ & Quadra & $\begin{array}{l}33.3 \mathrm{~m} \\
23.8 \mathrm{~m}\end{array}$ & $\begin{array}{l}17.0 \mathrm{~m} \\
5.3 \mathrm{~m}\end{array}$ & $\begin{array}{l}7.0 \mathrm{~m} \\
5.7 / 72 \mathrm{~m}\end{array}$ & $\begin{array}{l}566.1 \mathrm{~m}^{2} \\
127.1 \mathrm{~m}^{2}\end{array}$ & $\begin{array}{l}\text { D324 } \\
\text { D144 }\end{array}$ \\
\hline SOCIAL E CULTURAL & $\begin{array}{l}48 \\
49 \\
50\end{array}$ & $\begin{array}{l}\text { Espaço projeções } \\
\text { Deposito } \\
\text { Sala }\end{array}$ & $\begin{array}{l}9.4 \mathrm{~m} \\
2.6 \mathrm{~m} \\
9.1 \mathrm{~m}\end{array}$ & $\begin{array}{l}2.0 \mathrm{~m} \\
2.0 \mathrm{~m} \\
3.9 \mathrm{~m}\end{array}$ & $\begin{array}{l}3.0 \mathrm{~m} \\
3.0 \mathrm{~m} \\
3.0 \mathrm{~m}\end{array}$ & $\begin{array}{l}18.7 \mathrm{~m}^{2} \\
5.0 \mathrm{~m}^{2} \\
35.3 \mathrm{~m}^{2}\end{array}$ & $\begin{array}{l}\text { C16 } \\
\text { C4 } \\
\text { C25 }\end{array}$ \\
\hline
\end{tabular}




\section{catálogo casavalle dSL}

SACUDE DSL DISSOLUÇÃO PROGRAMÁTICA

Esporte $1305 \mathbf{m}^{2}$

Social e Cultural $408 \mathbf{m}^{2}$

Saúde $280 \mathbf{m}^{2}$

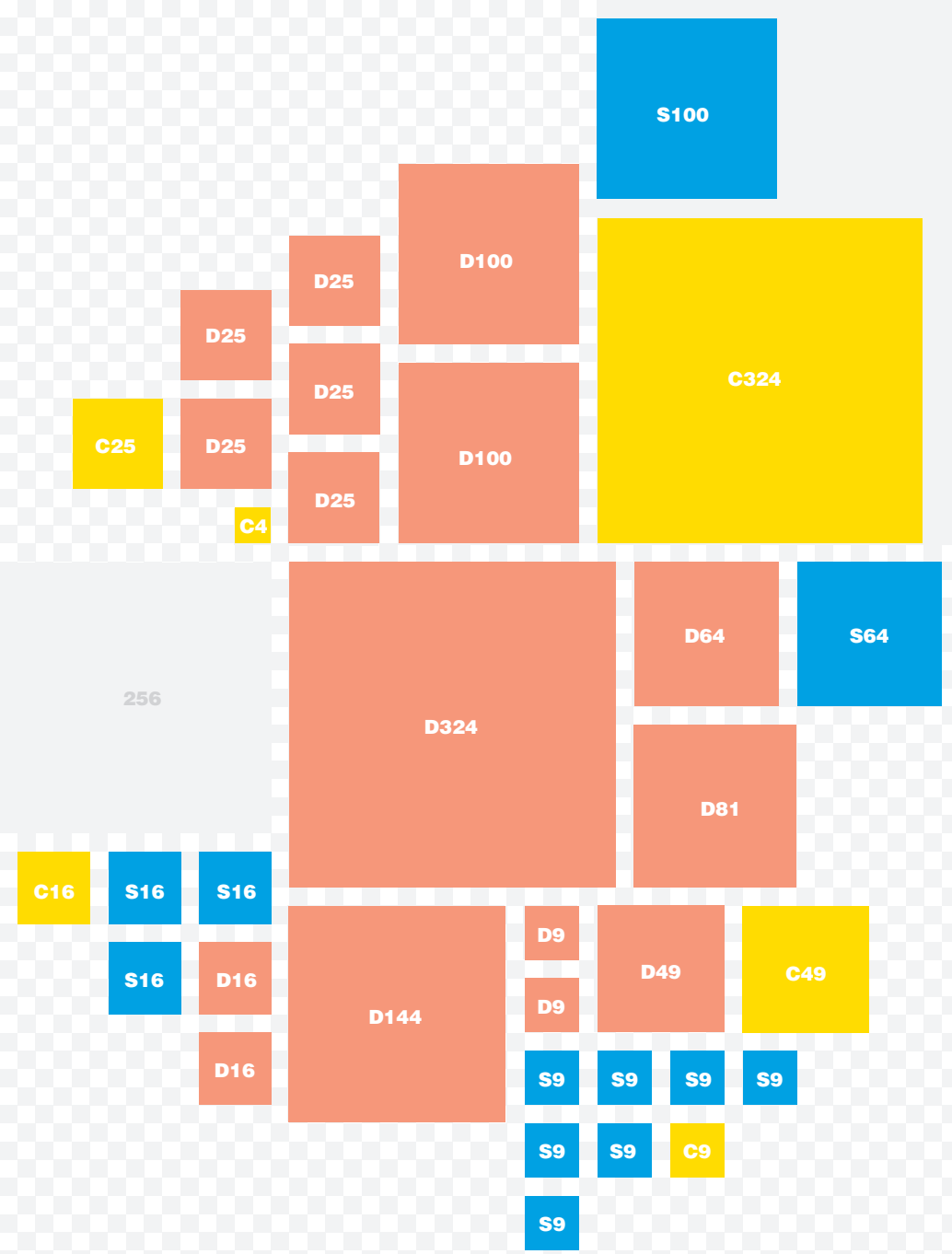


catálogo casavalle dSL

SACUDE DSL DISSOLUÇÃO ESPACIẢL Área Construída $1960 \mathrm{~m}^{2}$

Área Exterior Coberta 195m

Pátios 295m²

Terreno 3300m

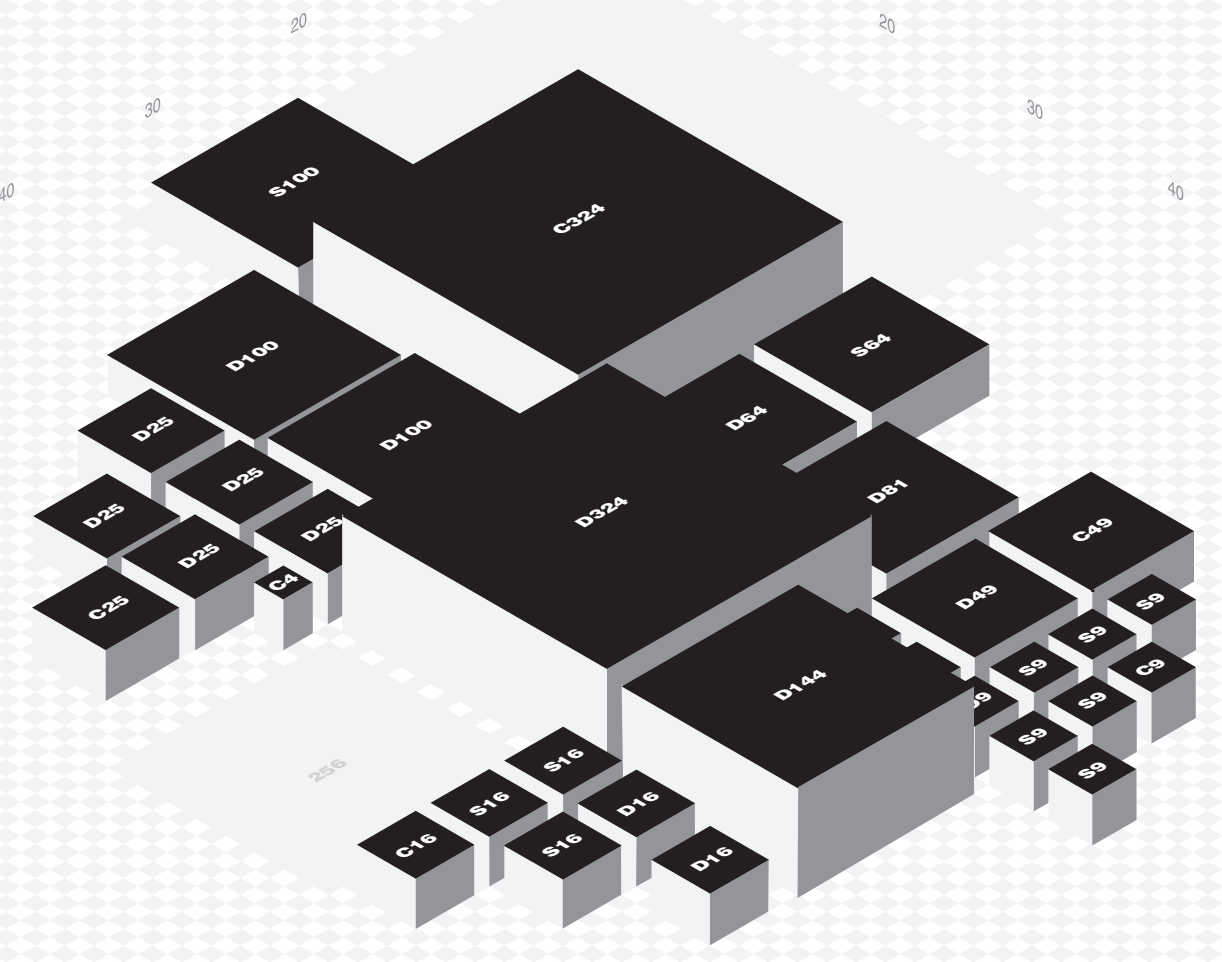




\section{catálogo casavalle dsL}

\section{CEDEL}

\section{Ano 2004}

Área total $2790 \mathrm{~m}^{2}$

Autor Int. Montevideo. Arq. Morán. Arq. Sandoval

Localização Barrio Casavalle, Montevideo. UY.

Organização gestora IM. Desarrollo Económico e Integración Regional

Organização responsável Intendencia de Montevideo

Fonte IM. CEDEL
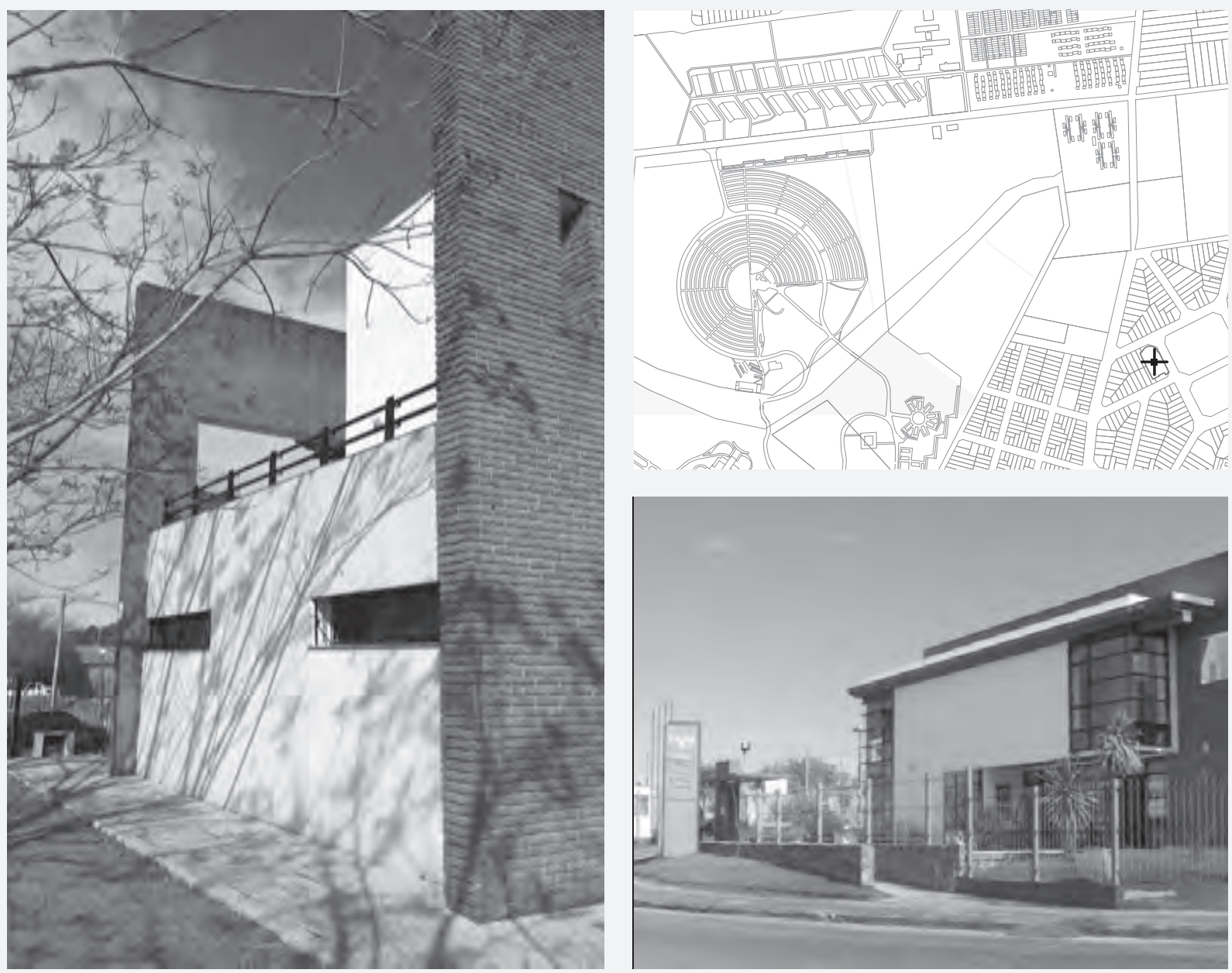
catálogo casavalle dSL

CEDEL

Pav. Térreo

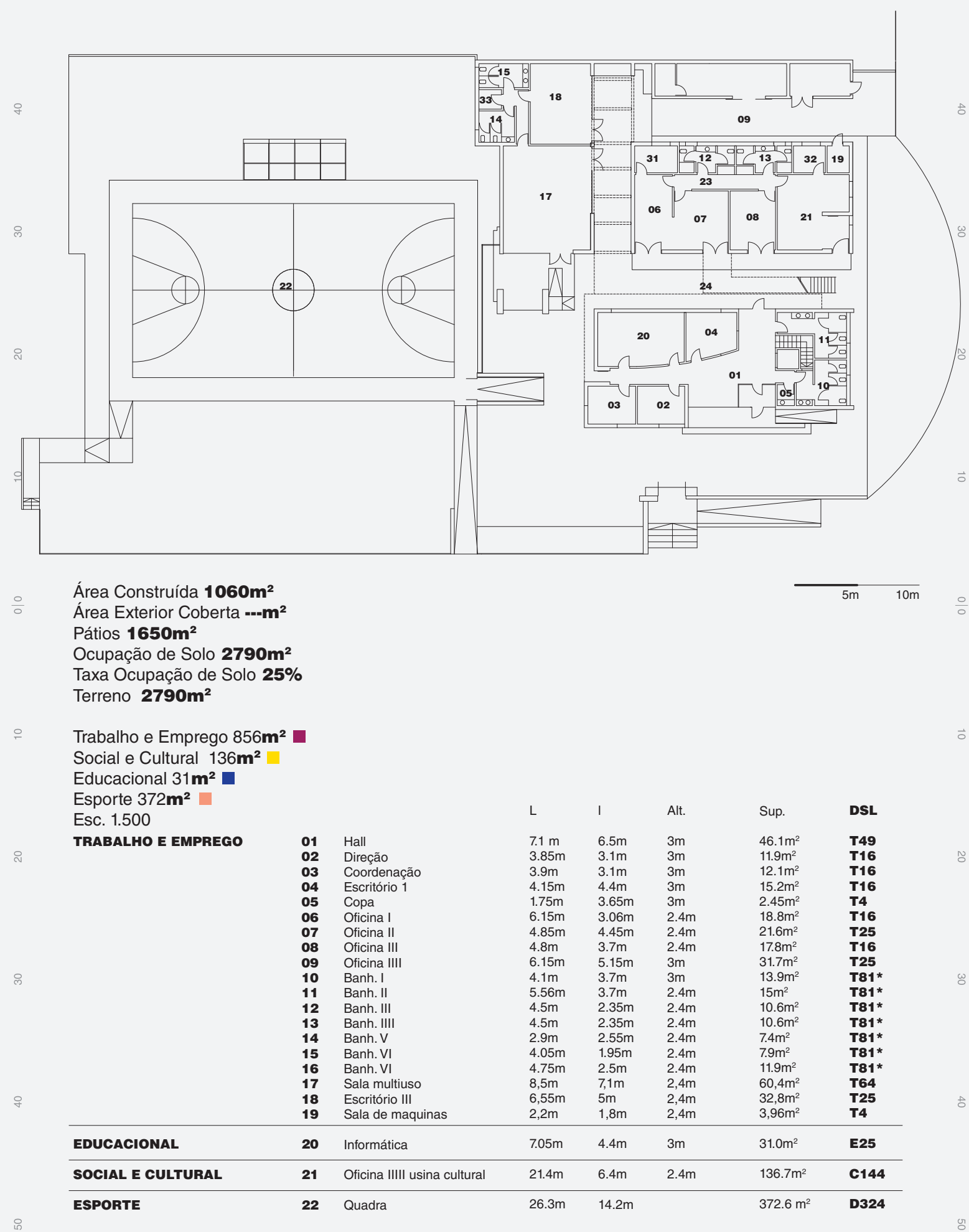




\section{catálogo casavalle dsl}

CEDEL

Pav. 1

(1) 


\section{catálogo casavalle dSL}

\section{CEDEL DSL DISSOLUÇÃO PROGRAMÁTICA}

Trabalho e Emprego $1230 \mathbf{m}^{2}$

Social e Cultural $136 \mathbf{m}^{2}$

Educacional $31 \mathbf{m}^{2}$

Esporte $372 \mathbf{m}^{2}$

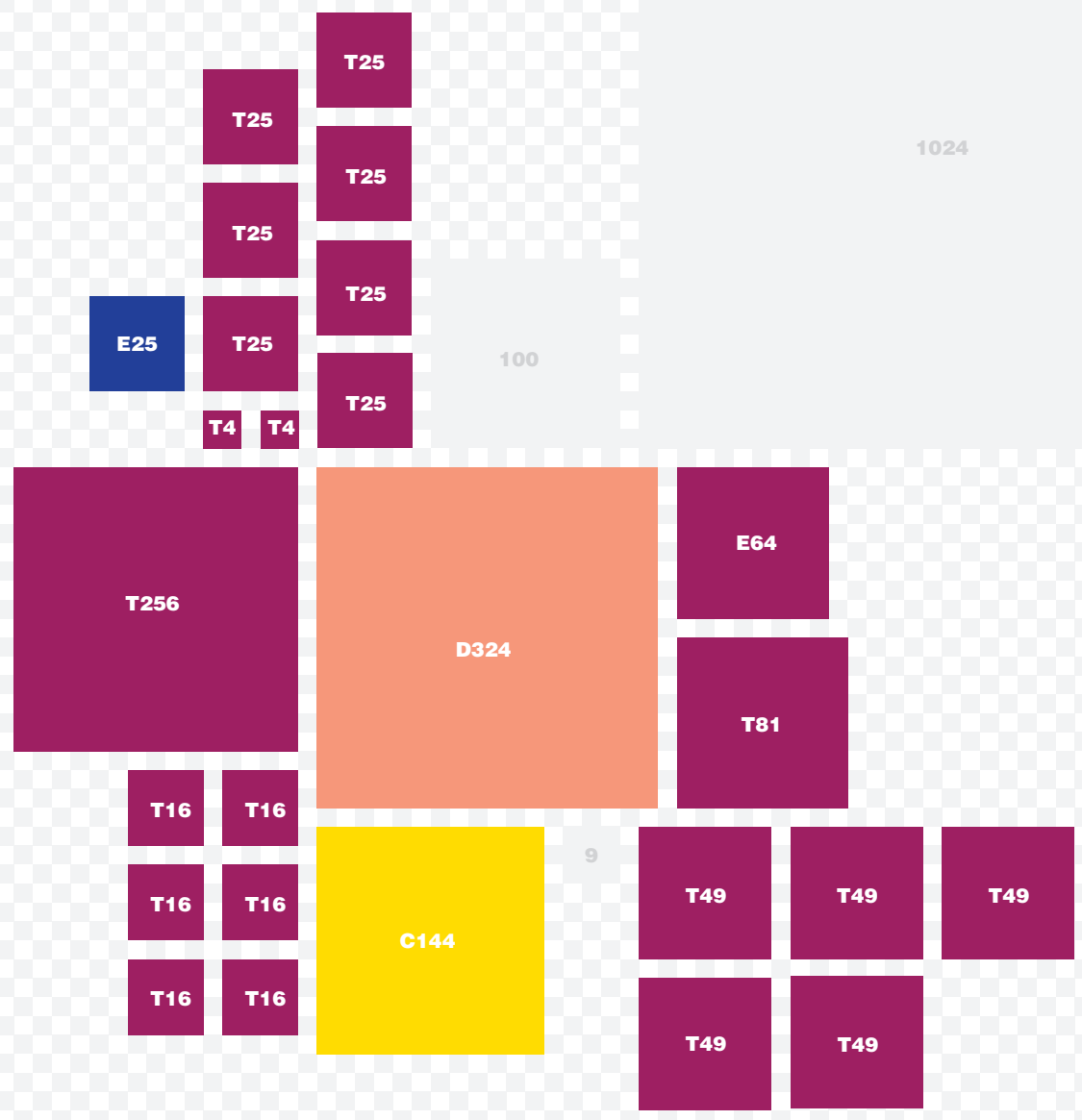




\section{catálogo casavalle dSL}

CEDEL DSL DISSOLUÇÃO ESPACIAL Área Construída $1060 \mathrm{~m}^{2}$

Área Exterior Coberta ---m²

Pátios $\mathbf{1 6 5 0 \mathrm { m } ^ { 2 }}$

Terreno $\mathbf{2 7 9 0 \mathbf { m } ^ { 2 }}$

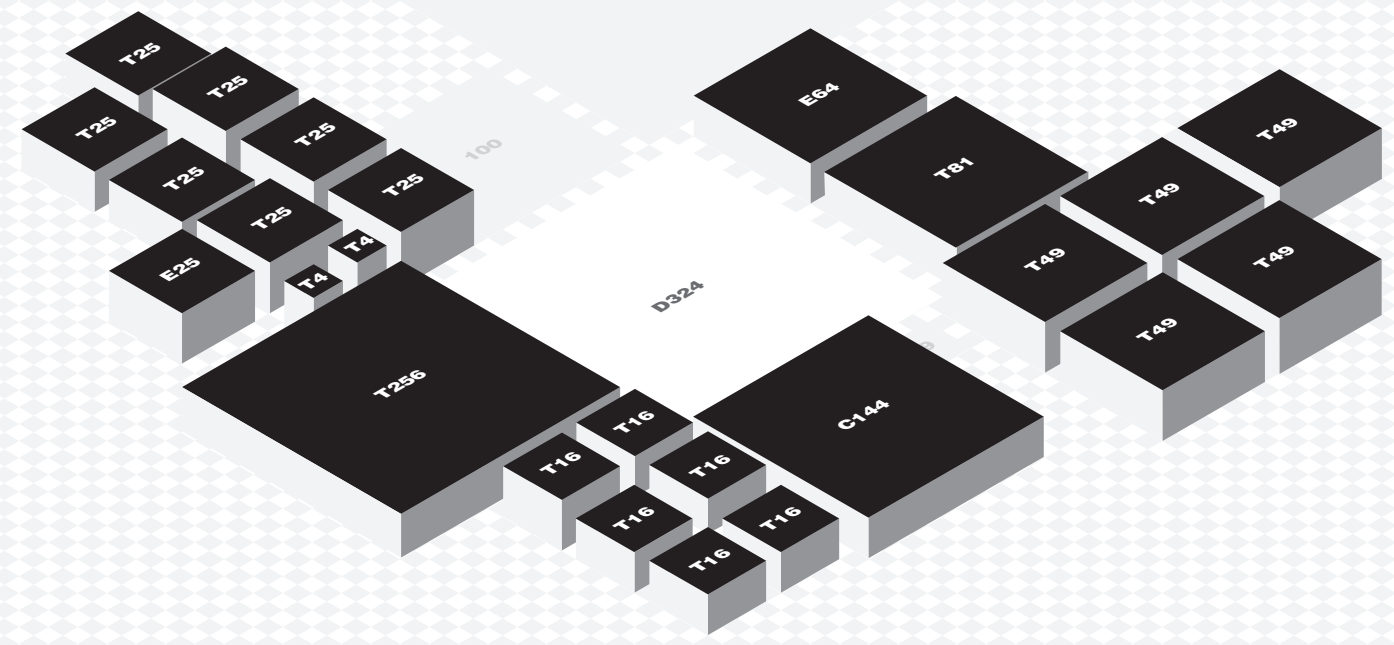




\section{catálogo casavalle dsL CENTRO CIVICO CASAVALLE}

\section{Ano 2014}

Área total $665 \mathrm{~m}^{2}$

Autor Int. Montevideo. Arq. Juan Díaz

Localização Barrio Casavalle, Montevideo. UY.

Organização gestora Municipio D

Organização responsável Intendencia de Montevideo

\section{Fonte IM}
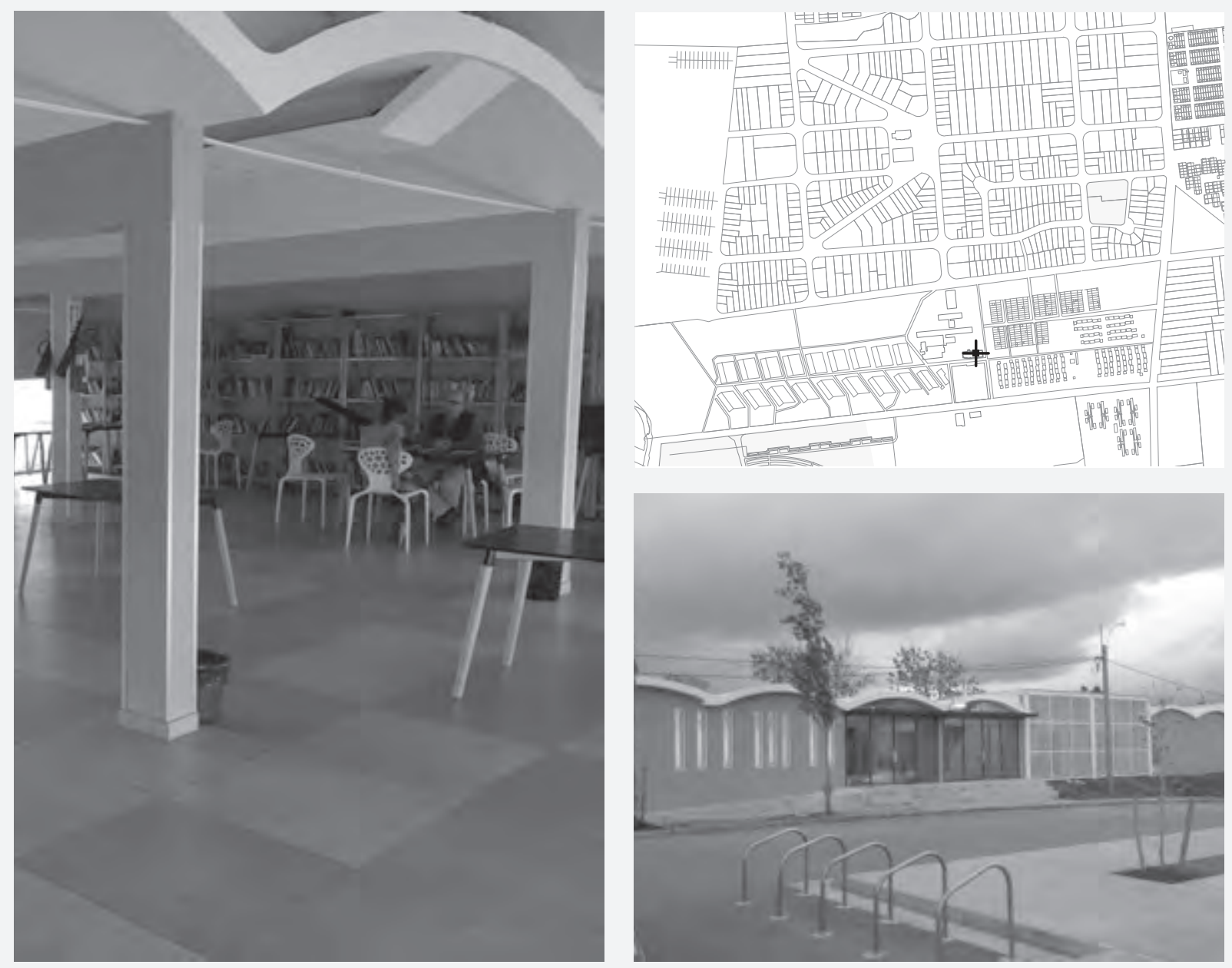
catálogo casavalle dSL

CENTRO CIVICO CASAVALLE

Pav. Térreo

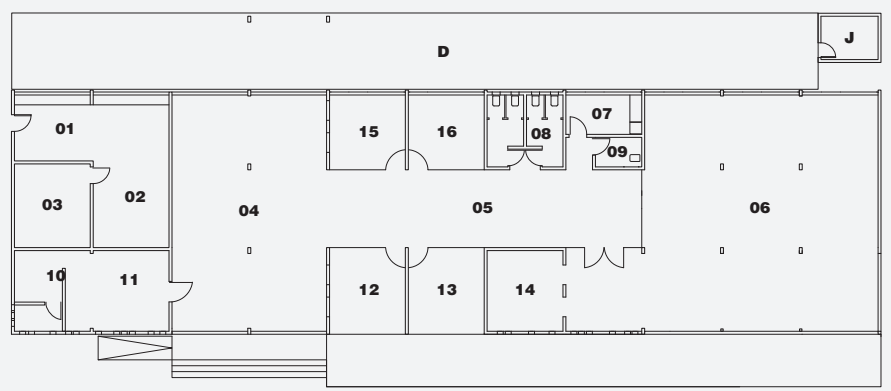

Área Construída $560 \mathrm{~m}^{2}$

Área Exterior Coberta ----m²

Pátios ---m²

Ocupação de Solo $665 \mathrm{~m}^{2}$

Taxa Ocupação de Solo $\mathbf{5 1} \%$

Terreno $1100 \mathbf{m}^{2}$

Educacional $60 \mathbf{m}^{2}$

Social e Cultural $342 \mathbf{m}^{2}$

Atenção Cidadã $110 \mathbf{m}^{2}$

Esc. 1.500

ESPORTE

01 Sala de Aulat

$\begin{array}{lllll} & \text { I } & \text { Alt. } & \text { Sup. } & \text { DSL } \\ 3.9 \mathrm{~m} & 3.4 \mathrm{~m} & 2.5 \mathrm{~m} & 12.9 \mathrm{~m}^{2} & \mathbf{E 1 6} \\ 7.8 \mathrm{~m} & 3.9 \mathrm{~m} & 2.5 \mathrm{~m} & 29.8 \mathrm{~m}^{2} & \mathbf{E 2 5} \\ 4.3 \mathrm{~m} & 3.9 \mathrm{~m} & 2.5 \mathrm{~m} & 16.4 \mathrm{~m}^{2} & \mathbf{E 1 6} \\ 12.0 \mathrm{~m} & 7.8 \mathrm{~m} & 2.5 \mathrm{~m} & 93.6 \mathrm{~m}^{2} & \mathbf{C 1 0 0} \\ 16.0 \mathrm{~m} & 4.0 \mathrm{~m} & 2.5 \mathrm{~m} & 63.2 \mathrm{~m}^{2} & \mathbf{C 6 4} \\ 16.0 \mathrm{~m} & 12.0 \mathrm{~m} & 2.5 \mathrm{~m} & 160.0 \mathrm{~m}^{2} & \mathbf{C 1 4 4} \\ 3.9 \mathrm{~m} & 2.0 \mathrm{~m} & 2.5 \mathrm{~m} & 7.7 \mathrm{~m}^{2} & \mathbf{C 9} \\ 3.9 \mathrm{~m} & 3.7 \mathrm{~m} & 2.5 \mathrm{~m} & 14.1 \mathrm{~m}^{2} & \mathbf{C 1 6} \\ .4 \mathrm{~m} & 1.5 \mathrm{~m} & 2.5 \mathrm{~m} & 3.5 \mathrm{~m}^{2} & \mathbf{C 1 6} \\ 4.1 \mathrm{~m} & 2.4 \mathrm{~m} & 2.5 \mathrm{~m} & 9.8 \mathrm{~m}^{2} & \mathbf{A 9} \\ 5.3 \mathrm{~m} & 4.1 \mathrm{~m} & 2.5 \mathrm{~m} & 21.7 \mathrm{~m}^{2} & \mathbf{A 2 5} \\ 4.4 \mathrm{~m} & 3.8 \mathrm{~m} & 2.5 \mathrm{~m} & 16.7 \mathrm{~m}^{2} & \mathbf{A 1 6} \\ 4.4 \mathrm{~m} & 3.9 \mathrm{~m} & 2.5 \mathrm{~m} & 16.9 \mathrm{~m}^{2} & \mathbf{A 1 6} \\ 4.1 \mathrm{~m} & 3.9 \mathrm{~m} & 2.5 \mathrm{~m} & 15.8 \mathrm{~m}^{2} & \mathbf{A 1 6} \\ 3.9 \mathrm{~m} & 3.8 \mathrm{~m} & 2.5 \mathrm{~m} & 14.6 \mathrm{~m}^{2} & \mathbf{A 1 6} \\ 3.9 \mathrm{~m} & 3.8 \mathrm{~m} & 2.5 \mathrm{~m} & 14.6 \mathrm{~m}^{2} & \mathbf{A 1 6}\end{array}$




\section{CatÁlogo casavalle dSL}

CENTRO CIVICO CASAVALLE DSL DISSOLUÇÃO PROGRAMÁTICA Educional $60 \mathbf{m}^{2}$

Social e Cultural $342 \mathbf{m}^{2}$

Atenção Cidadã $110 \mathbf{m}^{2}$ 




\section{CATALOGO EQUIPAMENTOS MUNDO}

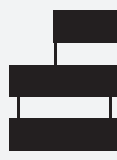

P25

CEU

Autor: Equipo CEU SMDU

Ano: 2013-2016 (não concluido)

Localização: San Pablo, BR.

V02 Pg 552
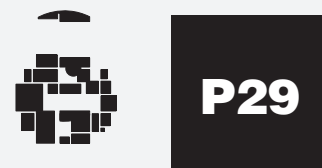

FUN PALACE

Autor: Cedric Price

Ano: 1960-1966

Localização: Londres, UK

V02 Pg 570

\section{P26}

P27
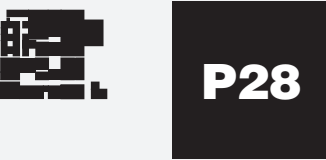

INTERACTION

Autor: Cedric Price

Ano: 1970-1981 2003

Localização: Camden Town, Londres,

UK

V02 Pg 574
P28

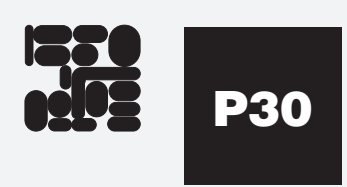

\section{STADSTHEATER}

Autor: SANAA

Ano: 1998-2007

Localização: Almere, NL

V02 Pg 580

MUSEO SIGLO XXI

Autor: SANAA

MUSEO DE TOLEDO

Autor: SANAA

Localização: Kanasawa, JP

Localização: Toledo, USA

V02 Pg 586

V02 Pg 592 


\section{CATÁLOGO EQUIPAMENTOS MUNDO}

CEU 3a Geração Agrupamento Educacional

Ano 2013-2016 (projeto não concluido)

Area total $15725 \mathrm{~m}^{2}$

Autor Equipo CEU SMDU

Localização Água Branca, São Paulo. BR.

Organização gestora Secretaria Municipal Desenvolvimento Urbano

Organização responsável Prefeitura de São Paulo

\section{Fonte SMDU Prefeitura São Paulo}
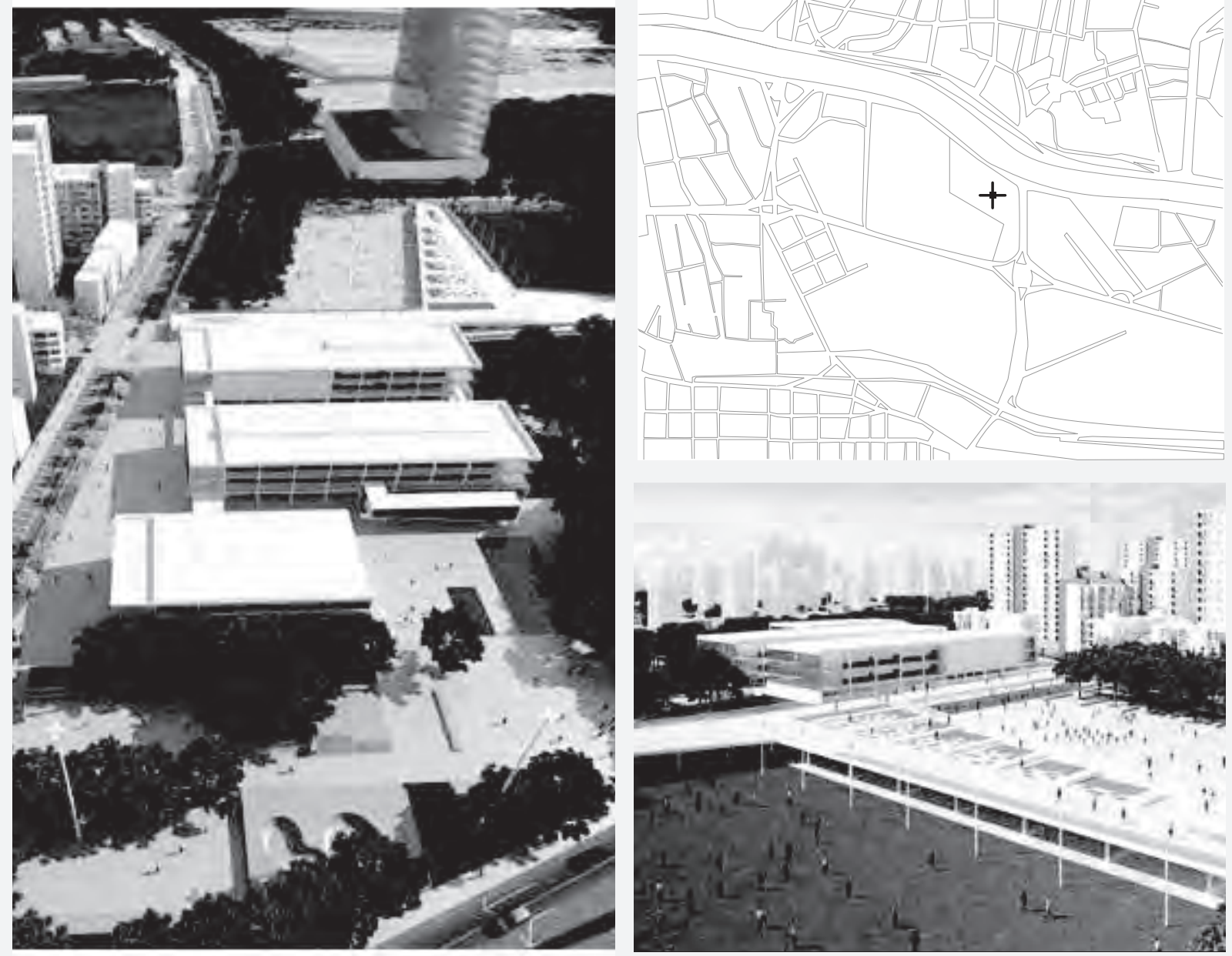
CATÁLOGO EQUIPAMENTOS MUNDO

CEU 3a Geração Agrupamento Educacional

Pav. Térreo

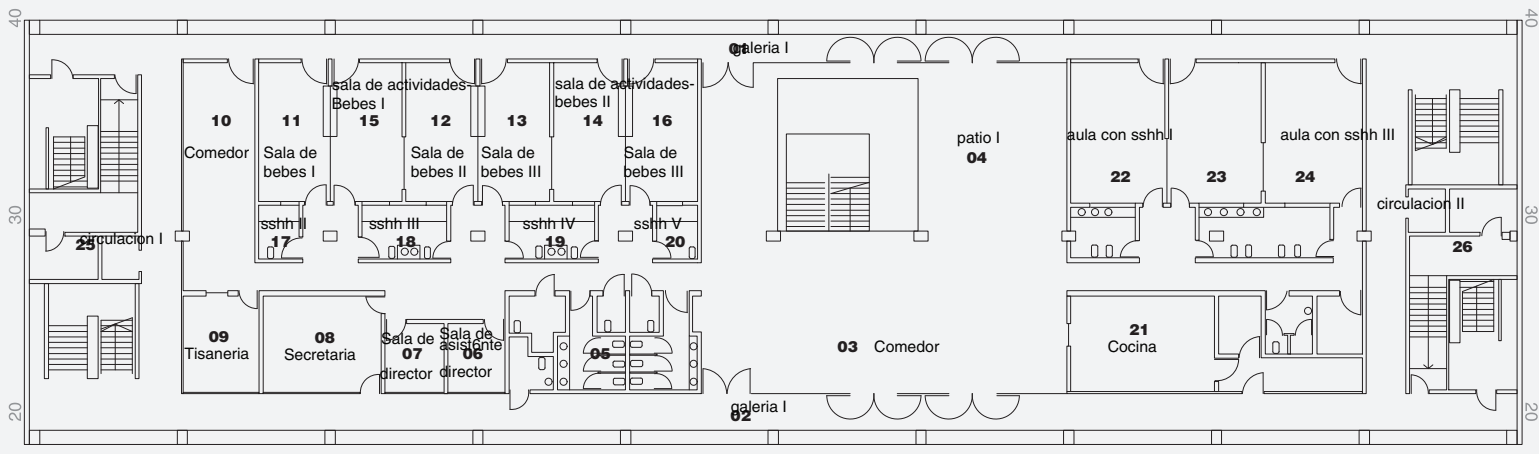

Área Construída $3380 \mathrm{~m}^{2}$

Área Exterior Coberta --- $\mathbf{m}^{2}$

Pátios ---m²

Ocupação de Solo $1690 \mathrm{~m}^{2}$

Taxa Ocupação de Solo $\mathbf{7 2 \%}$

Terreno $\mathbf{2 3 2 0 \mathbf { m } ^ { 2 }}$

Educação $\mathbf{2 7 8 3 \mathbf { m } ^ { 2 }}$

Esc. 1.500

EDUCACIONAL

Galeria

Galeria II

Pátio I

Banh. I

Sala assistente de direção

Sala direção

Secretaria

Refeitório do berçário

Berçário I

Berçário II

Berçário III

Berçário IV

Sala atividades Berçário II

Banh. II

Banh. II

Banh. IV

Banh. IV

Cozinha

Sala de Aula com Banh. I

Sala de Aula com Banh. II

Sala de Aula com Banh. II

Circulação I

* Local, soma de vários locais

$\begin{array}{lll}\mathrm{L} & \text { I } & \text { Alt } \\ 75,5 \mathrm{~m} & 1,8 \mathrm{~m} & 3 \\ 75,5 \mathrm{~m} & 1,8 \mathrm{~m} & 3 \\ 18,55 \mathrm{~m} & 8,3 \mathrm{~m} & 3 \mathrm{~m} \\ 18,55 \mathrm{~m} & 8,3 \mathrm{~m} & 3 \mathrm{~m} \\ 9,55 \mathrm{~m} & 4,8 \mathrm{~m} & 3 \\ 3,5 \mathrm{~m} & 2,95 \mathrm{~m} & 3 \\ 3,5 \mathrm{~m} & 2,95 \mathrm{~m} & 3 \\ 6 \mathrm{~m} & 4,9 \mathrm{~m} & 3 \\ 4,9 \mathrm{~m} & 3,85 \mathrm{~m} & 3 \\ 11,6 \mathrm{~m} & 3,6 \mathrm{~m} & 3 \\ 7 \mathrm{~m} & 3,65 \mathrm{~m} & 3 \\ 7 \mathrm{~m} & 3,65 \mathrm{~m} & 3 \\ 7 \mathrm{~m} & 3,65 \mathrm{~m} & 3 \\ 7 \mathrm{~m} & 3,65 \mathrm{~m} & 3 \\ 7 \mathrm{~m} & 3,65 \mathrm{~m} & 3 \\ 7 \mathrm{~m} & 3,65 \mathrm{~m} & 3 \mathrm{~m} \\ 2,73 \mathrm{~m} & 2 \mathrm{~m} & 3 \mathrm{~m} \\ 4,3 \mathrm{~m} & 2,73 \mathrm{~m} & 3 \mathrm{~m} \\ 4,3 \mathrm{~m} & 2,73 \mathrm{~m} & 3 \mathrm{~m} \\ 2,73 \mathrm{~m} & 2 \mathrm{~m} & 3 \mathrm{~m} \\ 14,8 \mathrm{~m} & 4,85 \mathrm{~m} & 3 \mathrm{~m} \\ 9,9 \mathrm{~m} & 4,7 \mathrm{~m} & 3 \mathrm{~m} \\ 9,9 \mathrm{~m} & 4,7 \mathrm{~m} & 3 \mathrm{~m} \\ 9,9 \mathrm{~m} & 4,7 \mathrm{~m} & 3 \mathrm{~m} \\ 16 \mathrm{~m} & 7,7 \mathrm{~m} & 3 \mathrm{~m} \\ 16 \mathrm{~m} & 7,7 \mathrm{~m} & 3 \mathrm{~m}\end{array}$

Alt.
$3 m$
$3 m$
$3 m$
$3 m$
$3 m$
$3 m$
$3 m$
$3 m$
$3 m$
$3 m$
$3 m$
$3 m$
$3 m$
$3 m$
$3 m$
$3 m$
$3 m$
$3 m$
$3 m$
$3 m$
$3 m$
$3 m$
$3 m$
$3 m$
$3 m$
$3 m$

Sup.

$135,9 \mathrm{~m}^{2}$

$135,9 \mathrm{~m}^{2}$

$153,9 \mathrm{~m}^{2}$

$153,9 \mathrm{~m}^{2}$

$45,84 \mathrm{~m}^{2}$

$10,32 \mathrm{~m}^{2}$

$10,32 m^{2}$

$29,4 \mathrm{~m}^{2}$

$18,86 \mathrm{~m}^{2}$

$41,76 \mathrm{~m}^{2}$

$25,55 \mathrm{~m}^{2}$

$25,55 \mathrm{~m}^{2}$

25

$25,55 \mathrm{~m}^{2}$

$25,55 \mathrm{~m}^{2}$

$25,55 \mathrm{~m}^{2}$

$1,73 \mathrm{~m}^{2}$

$11,73 \mathrm{~m}^{2}$

$5,46 \mathrm{~m}^{2}$

$71,78 \mathrm{~m}^{2}$

$46,53 \mathrm{~m}^{2}$

$46,53 \mathrm{~m}^{2}$

$46,53 \mathrm{~m}^{2}$

$123,2 \mathrm{~m}^{2}$

$123,2 \mathrm{~m}^{2}$
DSL

E324*

E324*

E144

E144

E144*

E9

E16

E16
E49

E25

525

E25

E25

E144*

E144*

E144*

E144*

64

E49

E49

E324*

E324* 


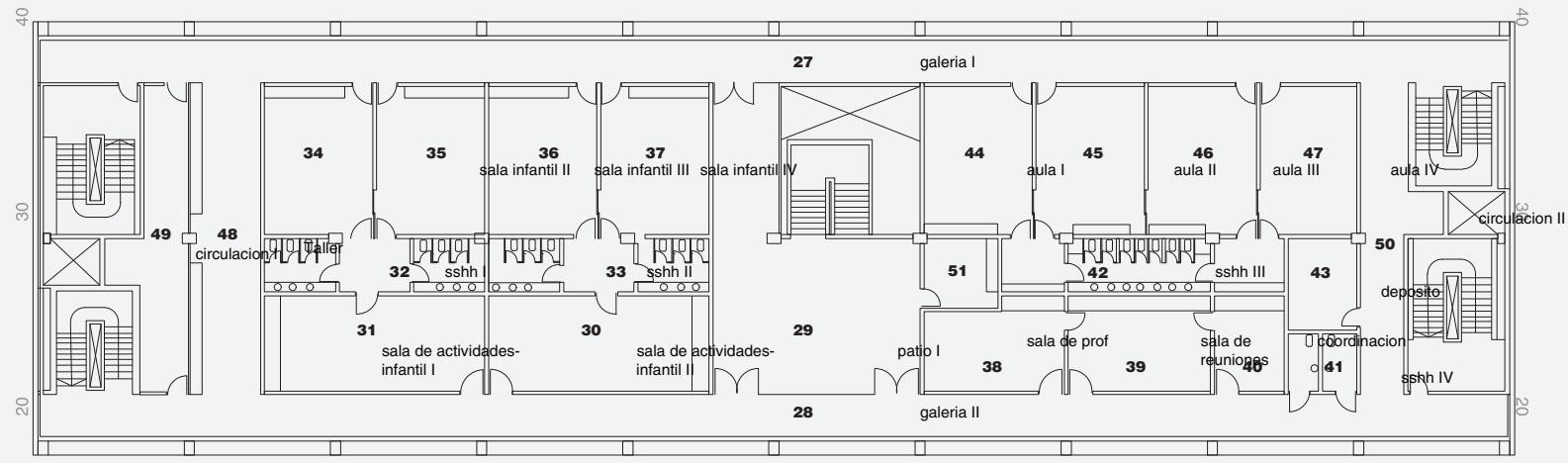

$\begin{array}{ll}\mathbf{2 7} & \text { Galeria III } \\ \mathbf{2 8} & \text { Galeria IV } \\ \mathbf{2 9} & \text { Pátio II } \\ \mathbf{3 0} & \text { Sala de atividade Infantil I } \\ \mathbf{3 1} & \text { Sala de atividade Infantil II } \\ \mathbf{3 2} & \text { Banh. V } \\ \mathbf{3 3} & \text { Banh. VI } \\ \mathbf{3 4} & \text { Sala infantil I } \\ \mathbf{3 3} & \text { Sala infantil II } \\ \mathbf{3 6} & \text { Sala infantil III } \\ \mathbf{3 7} & \text { Sala infantil IV } \\ \mathbf{3 8} & \text { Sala dos professores } \\ \mathbf{3 9} & \text { Sala de reuniões } \\ \mathbf{4 0} & \text { Coordenação } \\ \mathbf{4 1} & \text { Banh. VII } \\ \mathbf{4 2} & \text { Banh. VIII } \\ \mathbf{4 3} & \text { Depósito } \\ \mathbf{4 4} & \text { Sala de Aula I } \\ \mathbf{4 5} & \text { Sala de Aula II } \\ \mathbf{4 6} & \text { Sala de Aula III } \\ \mathbf{4 7} & \text { Sala de Aula IV } \\ \mathbf{4 8} & \text { Ateliê } \\ \mathbf{4 9} & \text { Circulação III } \\ \mathbf{5 0} & \text { Circulação IV } \\ \mathbf{5 1} & \text { Copa } \\ & \text { * Local, soma de vários locais }\end{array}$

$\begin{array}{lll}\text { L } & \text { I } & \text { Alt } \\ 75,5 \mathrm{~m} & 1,8 \mathrm{~m} & 3 \mathrm{~m} \\ 75,5 \mathrm{~m} & 1,8 \mathrm{~m} & 3 \mathrm{~m} \\ 16 \mathrm{~m} & 10,6 \mathrm{~m} & 3 \mathrm{~m} \\ 11,3 \mathrm{~m} & 4,9 \mathrm{~m} & 3 \mathrm{~m} \\ 11,3 \mathrm{~m} & 4,9 \mathrm{~m} & 3 \mathrm{~m} \\ 11,3 \mathrm{~m} & 2,75 \mathrm{~m} & 3 \mathrm{~m} \\ 11,3 \mathrm{~m} & 2,75 \mathrm{~m} & 3 \mathrm{~m} \\ 7,6 \mathrm{~m} & 5,55 \mathrm{~m} & 3 \mathrm{~m} \\ 7,6 \mathrm{~m} & 5,55 \mathrm{~m} & 3 \mathrm{~m} \\ 7,6 \mathrm{~m} & 5,55 \mathrm{~m} & 3 \mathrm{~m} \\ 7,6 \mathrm{~m} & 5,55 \mathrm{~m} & 3 \mathrm{~m} \\ 7,2 \mathrm{~m} & 4,9 \mathrm{~m} & 3 \mathrm{~m} \\ 7,2 \mathrm{~m} & 4,9 \mathrm{~m} & 3 \mathrm{~m} \\ 4,9 \mathrm{~m} & 3,6 \mathrm{~m} & 3 \mathrm{~m} \\ 3,5 \mathrm{~m} & 2,95 \mathrm{~m} & 3 \mathrm{~m} \\ 7,3 \mathrm{~m} & 2,75 \mathrm{~m} & 3 \mathrm{~m} \\ 4,7 \mathrm{~m} & 3,5 \mathrm{~m} & 3 \mathrm{~m} \\ 7,6 \mathrm{~m} & 5,55 \mathrm{~m} & 3 \mathrm{~m} \\ 7,6 \mathrm{~m} & 5,55 \mathrm{~m} & 3 \mathrm{~m} \\ 7,6 \mathrm{~m} & 5,55 \mathrm{~m} & 3 \mathrm{~m} \\ 7,6 \mathrm{~m} & 5,55 \mathrm{~m} & 3 \mathrm{~m} \\ 16 \mathrm{~m} & 3,6 \mathrm{~m} & 3 \mathrm{~m} \\ 16 \mathrm{~m} & 7,6 \mathrm{~m} & 3 \mathrm{~m} \\ 16 \mathrm{~m} & 7,6 \mathrm{~m} & 3 \mathrm{~m} \\ 3,8 \mathrm{~m} & 3,6 \mathrm{~m} & 3 \mathrm{~m}\end{array}$

Sup.

$135,9 \mathrm{~m}^{2}$

$135,9 \mathrm{~m}^{2}$

$169,6 \mathrm{~m}^{2}$

$55,37 \mathrm{~m}^{2}$

$55,37 \mathrm{~m}^{2}$

$31,07 \mathrm{~m}^{2}$

$31,07 \mathrm{~m}^{2}$

$42,18 \mathrm{~m}^{2}$

$42,18 \mathrm{~m}^{2}$

$42,18 \mathrm{~m}^{2}$

$42,18 \mathrm{~m}^{2}$

$35,28 \mathrm{~m}^{2}$

$35,28 \mathrm{~m}^{2}$

$17,64 \mathrm{~m}^{2}$

$10,32 \mathrm{~m}^{2}$

$20,07 m^{2}$
$16,45 m^{2}$

$16,45 \mathrm{~m}^{2}$
$42,18 \mathrm{~m}^{2}$

$42,18 \mathrm{~m}^{2}$

$42,18 \mathrm{~m}^{2}$
$42,18 \mathrm{~m}^{2}$

$42,18 \mathrm{~m}^{2}$

$57,6 \mathrm{~m}^{2}$

$121,6 \mathrm{~m}^{2}$

$121,6 \mathrm{~m}^{2}$

$13,68 \mathrm{~m}^{2}$
DSL

E324*

E324*

E144

E49

E49

E144*

E144

E49

E49

E49

E25

E25

E144*

E144*

E16

E49

E49

E49

E49

E324*

E324*

E16 
CATÁLOGO EQUIPAMENTOS MUNDO

CEU 3a Geração Agrupamento Cultural

Pav. 1

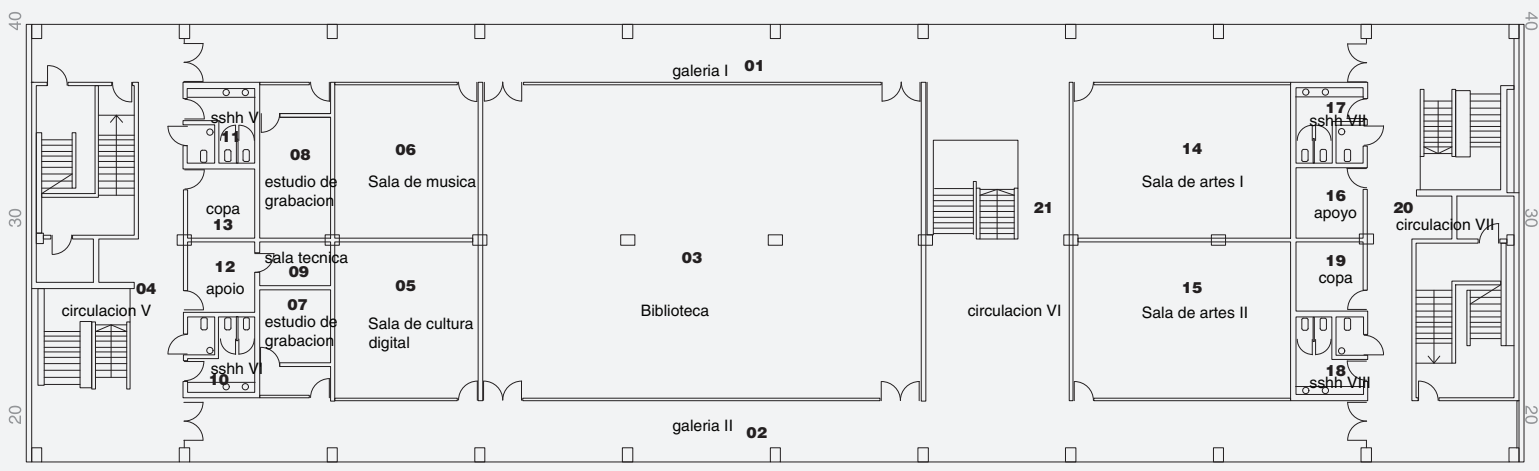

Área Construída $5070 \mathbf{m}^{2}$

Área Exterior Coberta --- $\mathbf{m}^{2}$

Pátios ---m²

Ocupação de Solo $1690 \mathrm{~m}^{2}$

Taxa Ocupação de Solo $\mathbf{7 2 \%}$

Terreno $\mathbf{2 3 2 0 \mathbf { m } ^ { 2 }}$

Social e cultural $3385 \mathbf{m}^{2}$

Esc. 1.500

SOCIAL E CULTURAL

$\begin{array}{ll}01 & \text { Galeria I } \\ 02 & \text { Galeria II } \\ 03 & \text { Biblioteca } \\ 04 & \text { Circulação I } \\ 05 & \text { Sala de cultura digital } \\ 06 & \text { Sala de música } \\ 07 & \text { Estúdio de Gravação I } \\ 08 & \text { Estúdio de Gravação II } \\ \mathbf{0 9} & \text { Sala técnica } \\ \mathbf{1 0} & \text { Banh. I } \\ \mathbf{1 1} & \text { Banh. II } \\ \mathbf{1 2} & \text { Apoio I } \\ \mathbf{1 3} & \text { Copa I } \\ \mathbf{1 4} & \text { Sala de artes I } \\ \mathbf{1 5} & \text { Sala de artes II } \\ \mathbf{1 6} & \text { Apoio II } \\ \mathbf{1 7} & \text { Banh. III } \\ \mathbf{1 8} & \text { Banh. IV } \\ \mathbf{1 9} & \text { Copa II } \\ \mathbf{2 0} & \text { Circulação II } \\ \mathbf{2 1} & \text { Circulação III } \\ & \text { * Local soma de vários locais }\end{array}$

$\begin{array}{ll}\text { L } & \text { I } \\ 60 \mathrm{~m} & 2,5 \mathrm{~m} \\ 60 \mathrm{~m} & 2,5 \mathrm{~m} \\ 22,2 \mathrm{~m} & 16 \mathrm{~m} \\ 16 \mathrm{~m} & 7,3 \mathrm{~m} \\ 7,9 \mathrm{~m} & 7,3 \mathrm{~m} \\ 7,9 \mathrm{~m} & 7,3 \mathrm{~m} \\ 5,4 \mathrm{~m} & 3,6 \mathrm{~m} \\ 7,8 \mathrm{~m} & 3,6 \mathrm{~m} \\ 3,6 \mathrm{~m} & 2,23 \mathrm{~m} \\ 3,85 \mathrm{~m} & 3,4 \mathrm{~m} \\ 3,85 \mathrm{~m} & 3,4 \mathrm{~m} \\ 3,6 \mathrm{~m} & 3,4 \mathrm{~m} \\ 3,6 \mathrm{~m} & 3,4 \mathrm{~m} \\ 11 \mathrm{~m} & 7,9 \mathrm{~m} \\ 11 \mathrm{~m} & 7,9 \mathrm{~m} \\ 3,6 \mathrm{~m} & 3,4 \mathrm{~m} \\ 3,85 \mathrm{~m} & 3,4 \mathrm{~m} \\ 3,85 \mathrm{~m} & 3,4 \mathrm{~m} \\ 3,6 \mathrm{~m} & 3,4 \mathrm{~m} \\ 22,2 \mathrm{~m} & 7,7 \mathrm{~m} \\ 22,2 \mathrm{~m} & 7,7 \mathrm{~m}\end{array}$

Alt.
$3 m$
$3 m$
$3 m$
$3 m$
$3 m$
$3 m$
$3 m$
$3 m$
$3 m$
$3 m$
$3 m$
$3 m$
$3 m$
$3 m$
$3 m$
$3 m$
$3 m$
$3 m$
$3 m$
$3 m$
$3 m$

Sup.

DSL

Local, soma de vários locais

$150 \mathrm{~m}^{2}$

$150 \mathrm{~m}^{2}$
$355,2 \mathrm{~m}^{2}$

$116,8 \mathrm{~m}^{2}$

$57,67 \mathrm{~m}^{2}$
$57,67 \mathrm{~m}^{2}$

$57,67 \mathrm{~m}^{2}$

$28,08 \mathrm{~m}^{2}$

$8,02 \mathrm{~m}^{2}$

$13,09 \mathrm{~m}^{2}$

$13,09 \mathrm{~m}^{2}$

$13,09 \mathrm{~m}^{2}$

$12, \mathrm{~m}^{2}$

12, $24 \mathrm{~m}^{2}$

$86 \mathrm{~m}^{2}$

$86,9 \mathrm{~m}^{2}$

$12,24 \mathrm{~m}^{2}$

$13,09 \mathrm{~m}^{2}$

$13,09 \mathrm{~m}^{2}$

$12,24 \mathrm{~m}^{2}$

$170,94 \mathrm{~m}^{2}$

$170,94 \mathrm{~m}^{2}$

S324*

S324*

5324

S1024*

564

564

516

525

S9

S100*

100*

S25*

S81

S81

S25*

S100*

S100*

525*

S1024

S1024* 


\section{CATÁLOGO EQUIPAMENTOS MUNDO}

CEU 3a Geração Agrupamento Cultural / Agrupamento Uso Múltiplo

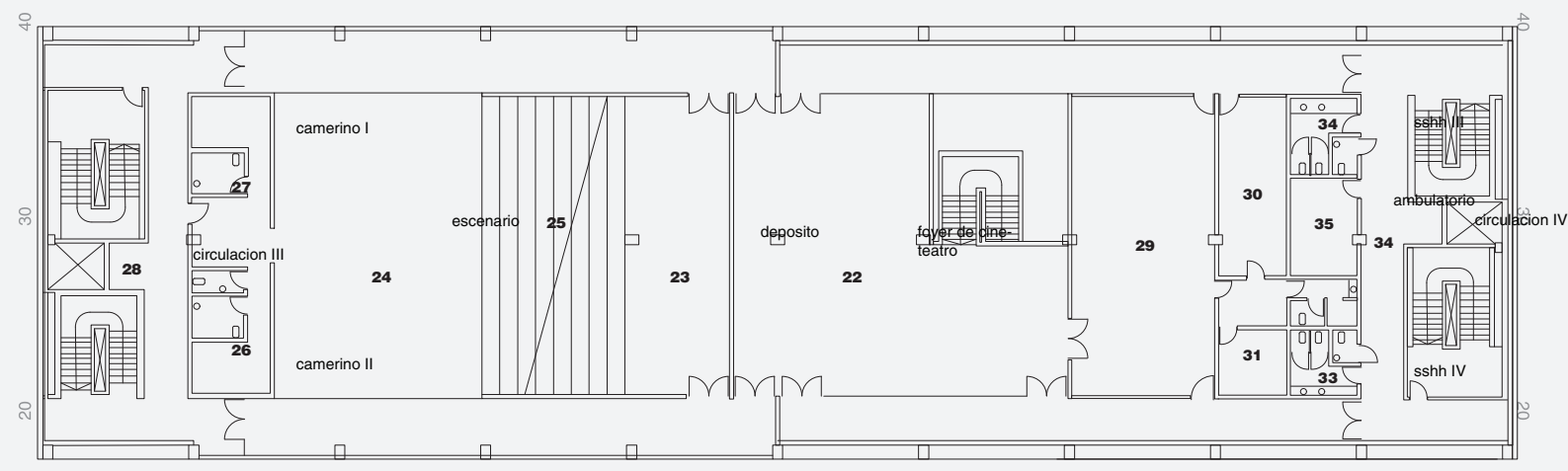

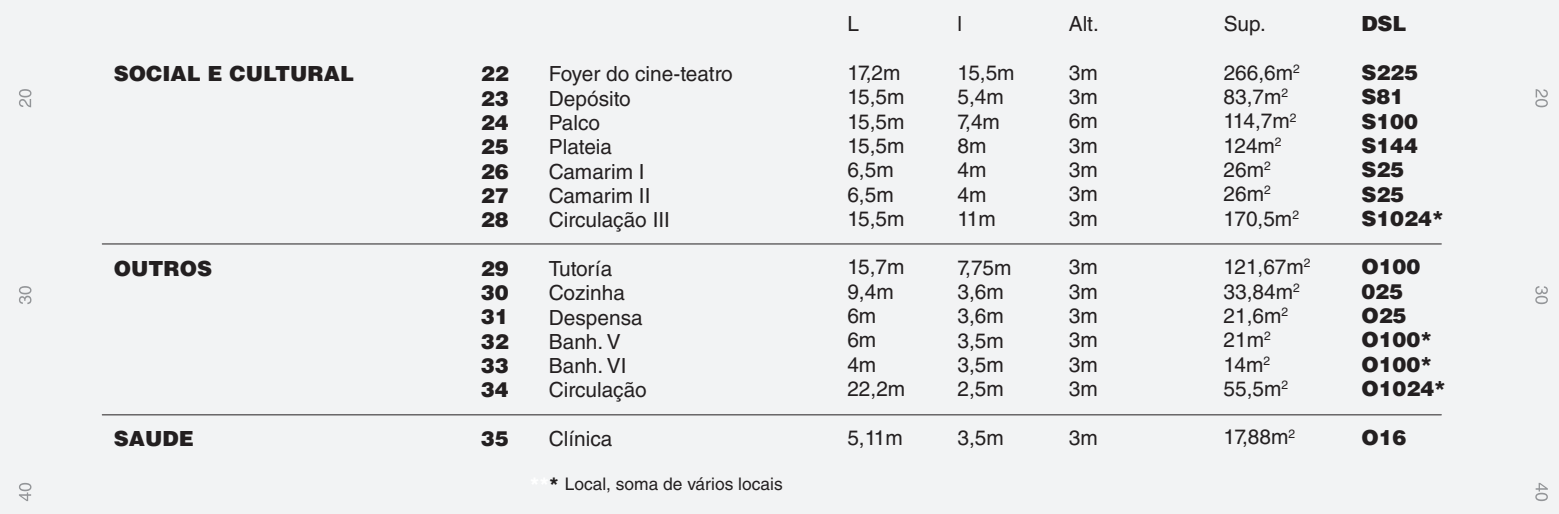


CATÁLOGO EQUIPAMENTOS MUNDO

CEU 3a Geração Agrupamento Cultural / Agrupamento Uso Múltiplo Pav. 3

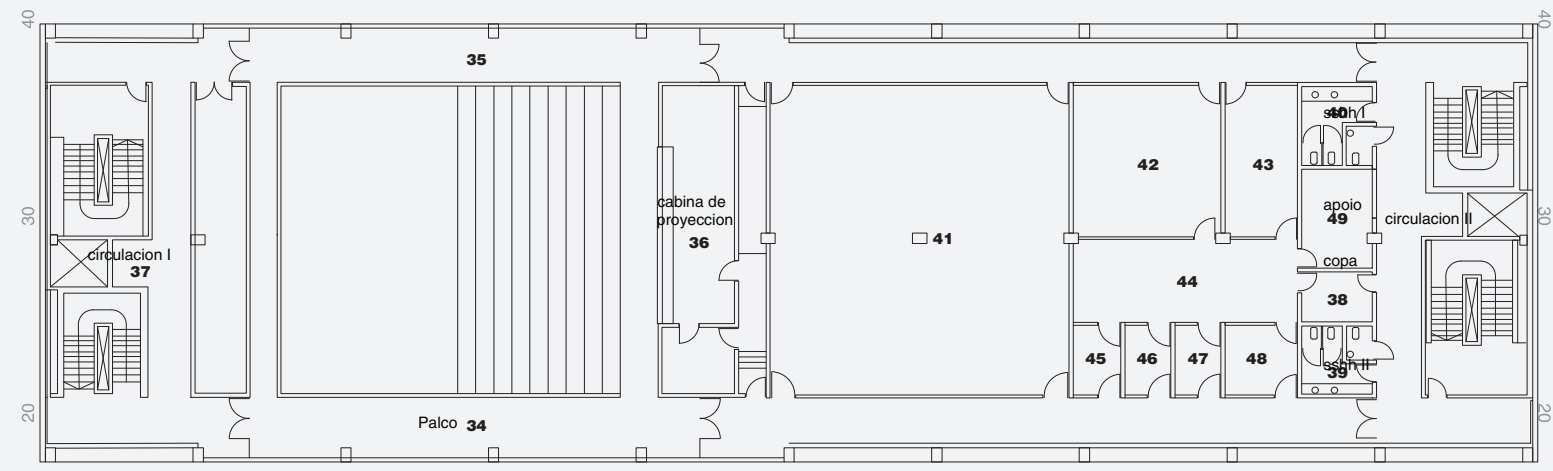

\begin{tabular}{|c|c|c|c|c|c|c|c|}
\hline & & & $\mathrm{L}$ & 1 & Alt. & Sup. & DSL \\
\hline \multirow[t]{4}{*}{ SOCIAL E CULTURAL } & 34 & Balcão I & $22,8 m$ & $3 m$ & $3 m$ & $68,4 m^{2}$ & S144* \\
\hline & 35 & Balcão II & $22,8 m$ & $3 m$ & $3 m$ & $68,4 m^{2}$ & S144* \\
\hline & 36 & Cabine de Projeção & $15,5 \mathrm{~m}$ & $5,3 \mathrm{~m}$ & $6 \mathrm{~m}$ & $82,15 \mathrm{~m}^{2}$ & S81 \\
\hline & 37 & Circulação VI & $22,2 m$ & $7,7 \mathrm{~m}$ & $3 m$ & $170,94 \mathrm{~m}^{2}$ & S1024* \\
\hline \multirow[t]{4}{*}{ OUTROS } & 38 & Copa & $3,5 \mathrm{~m}$ & $2,6 \mathrm{~m}$ & $3 m$ & $9,1 \mathrm{~m}^{2}$ & 025* \\
\hline & 39 & Banh. V & $4 m$ & $3,5 \mathrm{~m}$ & $3 m$ & $14 m^{2}$ & $0100 *$ \\
\hline & 40 & Banh. VI & $3,5 \mathrm{~m}$ & $3,4 \mathrm{~m}$ & $3 m$ & $11,9 m^{2}$ & $0100^{*}$ \\
\hline & 41 & Administração CEU & $15,7 \mathrm{~m}$ & $14,7 \mathrm{~m}$ & $3 m$ & $230,79 m^{2}$ & 0225 \\
\hline \multirow[t]{8}{*}{ ATENÇÃO CIDADÃ } & 42 & CRAS I & $7,7 \mathrm{~m}$ & $7,3 m$ & $3 m$ & $56,21 \mathrm{~m}^{2}$ & 049 \\
\hline & 43 & CRAS II & $7,7 \mathrm{~m}$ & $3,6 \mathrm{~m}$ & $3 m$ & $27,72 \mathrm{~m}^{2}$ & 025 \\
\hline & 44 & CRAS III & $11 \mathrm{~m}$ & $4,2 m$ & $3 m$ & $46,2 m^{2}$ & 049 \\
\hline & 45 & CRAS IV & $3,5 \mathrm{~m}$ & $2,3 \mathrm{~m}$ & $3 m$ & $8,05 \mathrm{~m}^{2}$ & 09 \\
\hline & 46 & CRAS V & $3,5 \mathrm{~m}$ & $2,3 m$ & $3 m$ & $8,05 \mathrm{~m}^{2}$ & 09 \\
\hline & 47 & CRAS VI & $3,5 \mathrm{~m}$ & $2,3 m$ & $3 m$ & $8,05 \mathrm{~m}^{2}$ & 09 \\
\hline & 48 & CRAS VII & $3,6 \mathrm{~m}$ & $3,5 \mathrm{~m}$ & $3 \mathrm{~m}$ & $12,6 \mathrm{~m}^{2}$ & 016 \\
\hline & 49 & CRAS VIII & $5 \mathrm{~m}$ & $3,5 \mathrm{~m}$ & $3 m$ & $17,5 \mathrm{~m}^{2}$ & 016 \\
\hline
\end{tabular}




\section{CATÁLOGO EQUIPAMENTOS MUNDO}

CEU 3a Geração Agrupamento Cultural / Agrupamento Uso Múltiplo

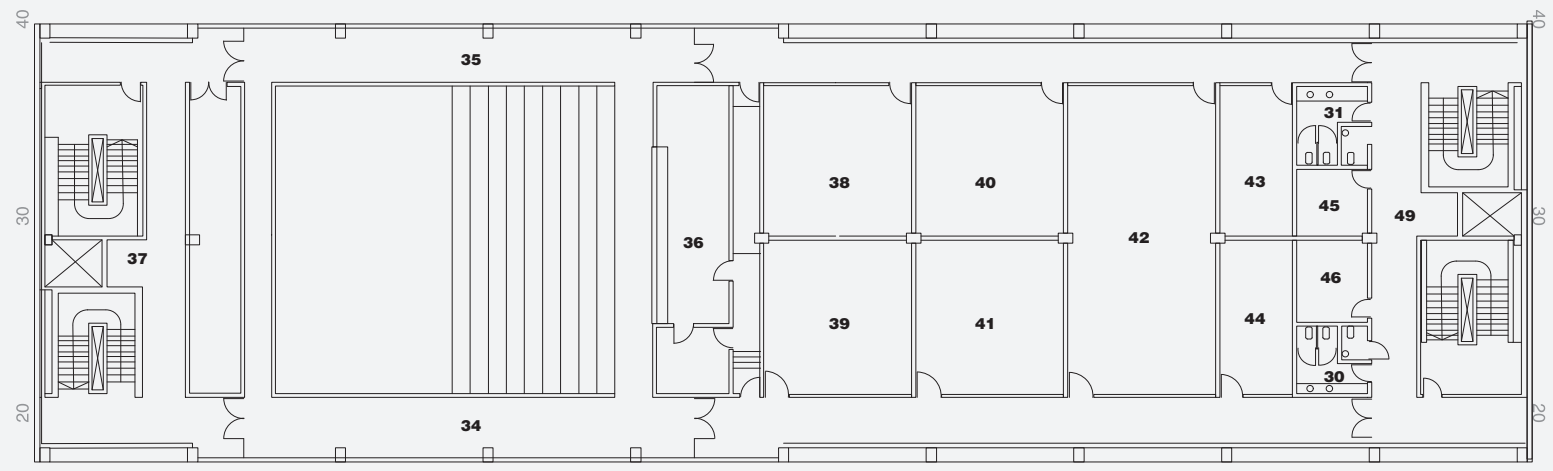

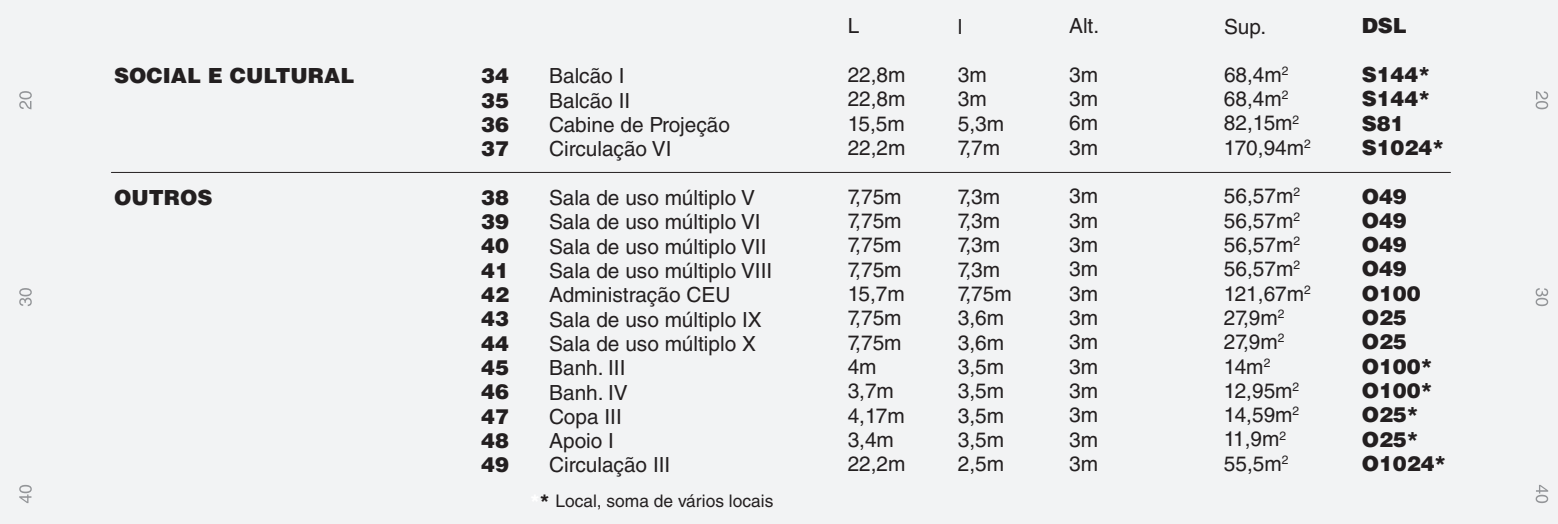


CATÁLOGO EQUIPAMENTOS MUNDO

CEU 3a Geração Agrupamento Esportivo

Pav. Térreo
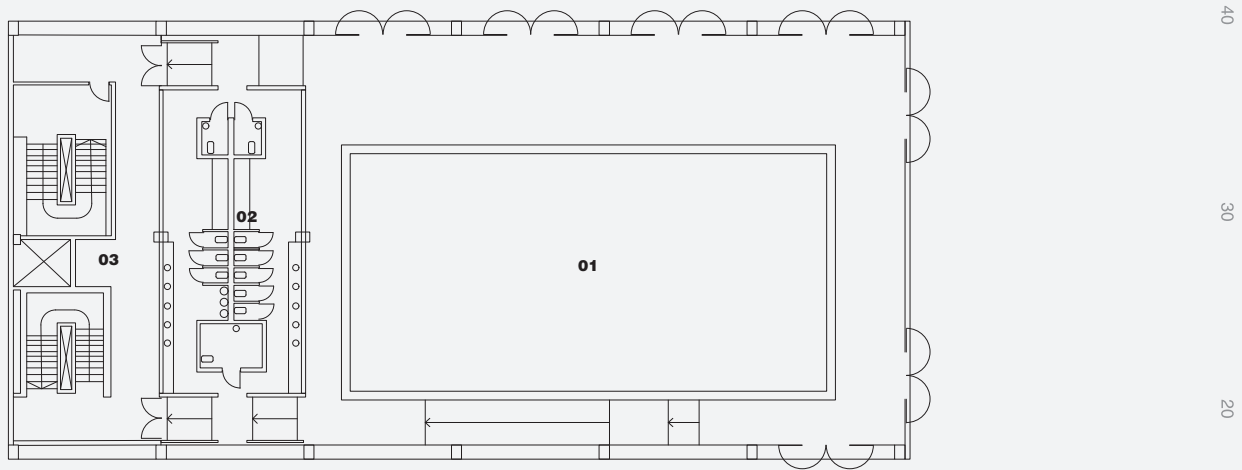

Área Construída $\mathbf{3 0 7 5 \mathrm { m } ^ { 2 }}$

Área Exterior Coberta --- $\mathbf{m}^{2}$

Pátios ---m²

Ocupação de Solo $1025 \mathrm{~m}^{2}$

Taxa Ocupação de Solo $69 \%$

Terreno $1470 \mathrm{~m}^{2}$

Esporte $2132 \mathbf{m}^{2}$

Esc. 1.500

ESPORTE

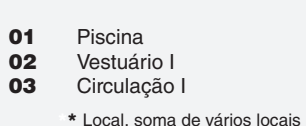

$\begin{array}{lll}\text { L } & \text { I } & \text { Alt. } \\ 30,4 \mathrm{~m} & 20,8 \mathrm{~m} & 6 \mathrm{~m} \\ 20,8 \mathrm{~m} & 7 \mathrm{~m} & 3 \mathrm{~m} \\ 20,8 \mathrm{~m} & 7,4 \mathrm{~m} & 3 \mathrm{~m}\end{array}$

Sup.

DSL

Esporte

* Local, soma de vários locais

$632,3 \mathrm{~m}^{2}$

$145,6 \mathrm{~m}^{2}$

$153,9 \mathrm{~m}^{2}$

D324

D225*

D324* 
CATÁLOGO EQUIPAMENTOS MUNDO

CEU 3a Geração Agrupamento Esportivo

Pav. Interm.

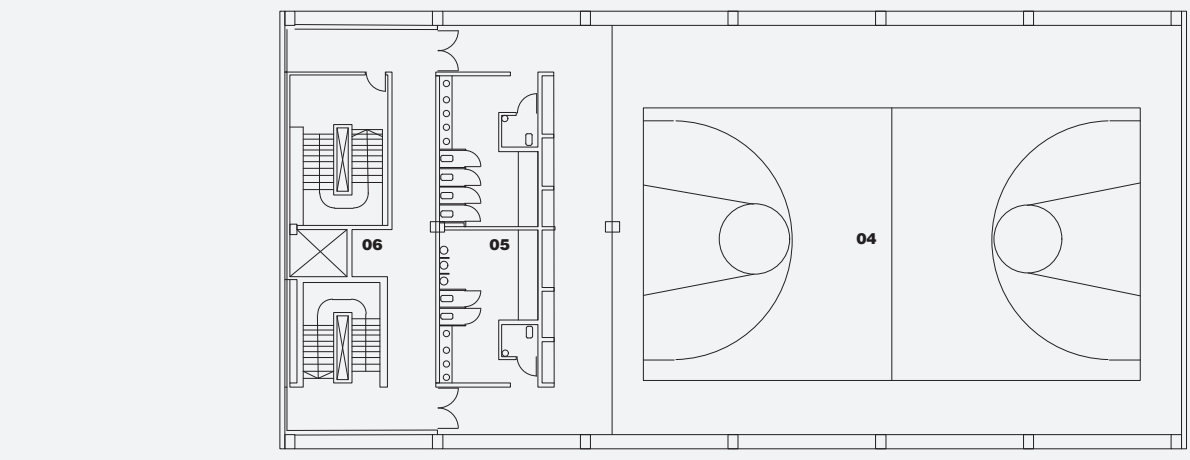




\section{CATÁlOGO EQUIPAMENTOS MUNDO}

CEU 3a Geração Agrupamento Esportivo

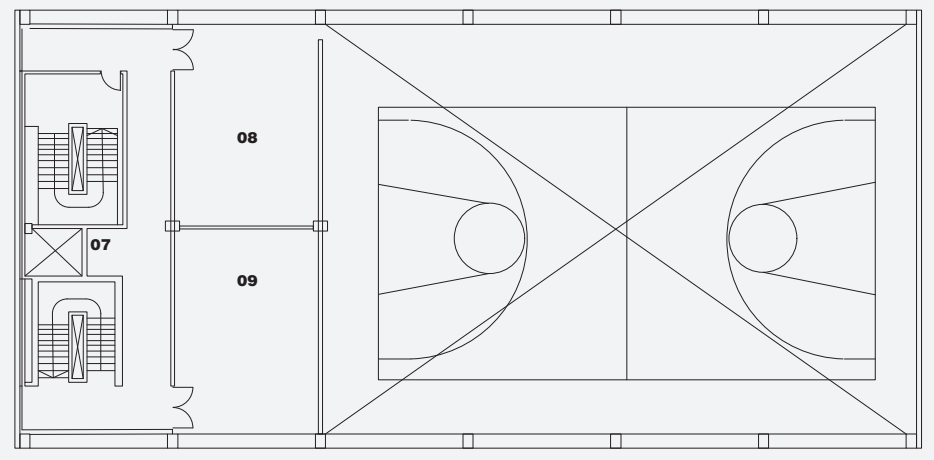




\section{CATÁLOGO EQUIPAMENTOS MUNDO}

CEU 3a Geração Agrupamento Uso Múltiplo

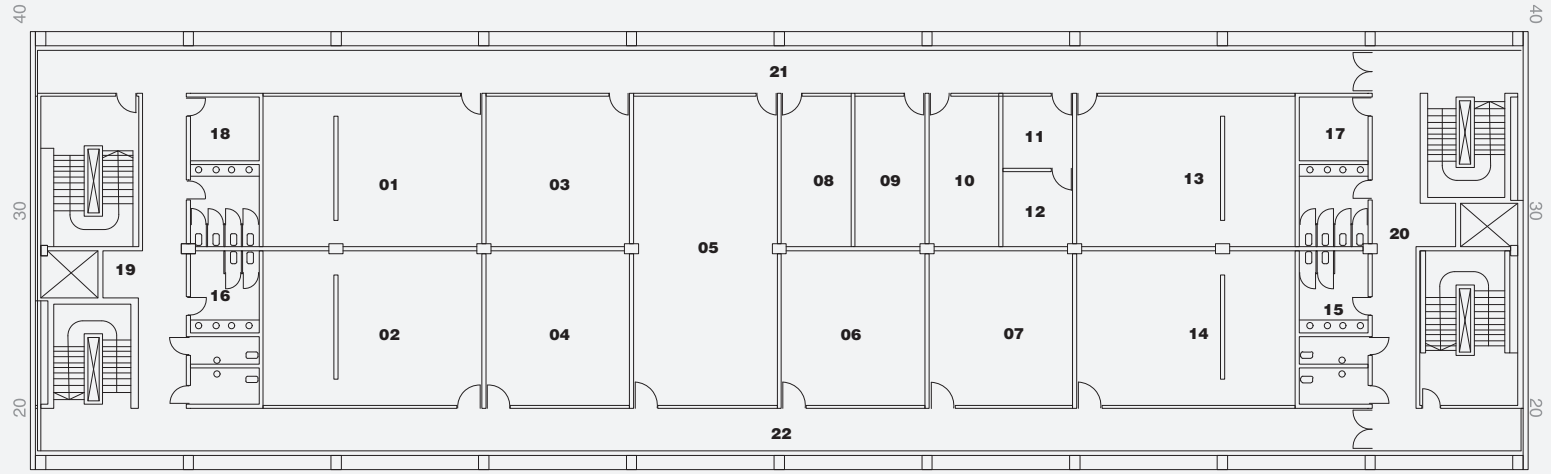

Área Construída $4200 \mathrm{~m}^{2}$

Área Exterior Coberta ---m²

Pátios ---m²

Ocupação de Solo $1690 \mathbf{m}^{2}$

Taxa Ocupação de Solo 69\%

Terreno $2320 \mathbf{m}^{2}$

Outros $2587 \mathbf{m}^{2}$

Saude $16 \mathbf{m}^{2}$

Atenção Cidadã $185 \mathbf{m}^{2}$

Esc. 1.500

OUTROS

Laboratório de química

Laboratório de biología

Sala de uso múltiplo I

Sala de uso múltiplo II

Sala de uso múltiplo III

Sala de uso múltiplo IV

Sala de videoconferência

Tutoría

Sala de estudos

Sala de reunião

Coordenação

Direção

Laboratório matemática

Laboratório física

Banh. I

Banh. II

Copa I

Copa II

Circulação I

Circulação II

Galeria I

Galeria II

* Local, soma de vários locais

$\begin{array}{lll}\mathrm{L} & \text { I } & \text { Alt. } \\ 11 \mathrm{~m} & 7,75 \mathrm{~m} & 3 \mathrm{~m} \\ 11 \mathrm{~m} & 7,75 \mathrm{~m} & 3 \mathrm{~m} \\ 7,75 \mathrm{~m} & 7,3 \mathrm{~m} & 3 \mathrm{~m} \\ 7,75 \mathrm{~m} & 7,3 \mathrm{~m} & 3 \mathrm{~m} \\ 15,7 \mathrm{~m} & 7,3 \mathrm{~m} & 3 \mathrm{~m} \\ 7,75 \mathrm{~m} & 7,3 \mathrm{~m} & 3 \mathrm{~m} \\ 7,75 \mathrm{~m} & 7,3 \mathrm{~m} & 3 \mathrm{~m} \\ 7,75 \mathrm{~m} & 3,55 \mathrm{~m} & 3 \mathrm{~m} \\ 7,75 \mathrm{~m} & 3,55 \mathrm{~m} & 3 \mathrm{~m} \\ 7,75 \mathrm{~m} & 3,55 \mathrm{~m} & 3 \mathrm{~m} \\ 3,7 \mathrm{~m} & 3,55 \mathrm{~m} & 3 \mathrm{~m} \\ 3,7 \mathrm{~m} & 3,55 \mathrm{~m} & 3 \mathrm{~m} \\ 11 \mathrm{~m} & 7,75 \mathrm{~m} & 3 \mathrm{~m} \\ 11 \mathrm{~m} & 7,75 \mathrm{~m} & 3 \mathrm{~m} \\ 12,17 \mathrm{~m} & 3,5 \mathrm{~m} & 3 \mathrm{~m} \\ 12,17 \mathrm{~m} & 3,5 \mathrm{~m} & 3 \mathrm{~m} \\ 3,25 \mathrm{~m} & 3,5 \mathrm{~m} & 3 \mathrm{~m} \\ 3,25 \mathrm{~m} & 3,5 \mathrm{~m} & 3 \mathrm{~m} \\ 22,2 \mathrm{~m} & 7,7 \mathrm{~m} & 3 \mathrm{~m} \\ 22,2 \mathrm{~m} & 7,7 \mathrm{~m} & 3 \mathrm{~m} \\ 60,2 \mathrm{~m} & 2,5 \mathrm{~m} & 3 \mathrm{~m} \\ 60,2 \mathrm{~m} & 2,5 \mathrm{~m} & 3 \mathrm{~m}\end{array}$

$\begin{array}{ll}\text { Sup. } & \text { DSL } \\ 85,25 \mathrm{~m}^{2} & \mathbf{O 8 1} \\ 85,25 \mathrm{~m}^{2} & \mathbf{O 8 1} \\ 56,57 \mathrm{~m}^{2} & \mathbf{O 4 9} \\ 56,57 \mathrm{~m}^{2} & \mathbf{O 4 9} \\ 114,61 \mathrm{~m}^{2} & \mathbf{O 1 0 0} \\ 56,57 \mathrm{~m}^{2} & \mathbf{O 4 9} \\ 56,57 \mathrm{~m}^{2} & \mathbf{O 4 9} \\ 27,512 \mathrm{~m}^{2} & \mathbf{O 2 5} \\ 27,512 \mathrm{~m}^{2} & \mathbf{O 2 5} \\ 27,512 \mathrm{~m}^{2} & \mathbf{O 2 5} \\ 13,13 \mathrm{~m}^{2} & \mathbf{O 1 6} \\ 13,13 \mathrm{~m}^{2} & \mathbf{O 1 6} \\ 85,25 \mathrm{~m}^{2} & \mathbf{O 8 1} \\ 85,25 \mathrm{~m}^{2} & \mathbf{O 8 1} \\ 42,59 \mathrm{~m}^{2} & \mathbf{O 1 4 4} \\ 42,59 \mathrm{~m}^{2} & \mathbf{O 1 4 4} \\ 11,37 \mathrm{~m}^{2} & \mathbf{O 2 5} \\ 11,37 \mathrm{~m}^{2} & \mathbf{O 2 5} \\ 170,94 \mathrm{~m}^{2} & \mathbf{O 3 2 4} \\ 170,94 \mathrm{~m}^{2} & \mathbf{O 3 2 4}^{*} \\ 150,5 \mathrm{~m}^{2} & \mathbf{O 3 2 4} \\ 150,5 \mathrm{~m}^{2} & \mathbf{O 3 2 4}^{*}\end{array}$


CATÁLOGO EQUIPAMENTOS MUNDO

CEU AGUA BRANCA

Pav. Térreo

Área Construída $15725 \mathrm{~m}^{2}$

Área Exterior Coberta ---m²

Pátios ---m²

Ocupação de Solo $\mathbf{6 0 9 5 m ^ { 2 }}$

Taxa Ocupação de Solo $\mathbf{7 3 \%}$

Terreno $\mathbf{8 4 3 0 \mathbf { m } ^ { 2 }}$

Educacional $2140 \mathbf{m}^{2}$

Social e cultural $3385 \mathbf{m}^{2}$

Esporte $2132 \mathbf{m}^{2}$

Outros $2587 \mathbf{m}^{2}$

Saude $16 \mathbf{m}^{2}$

Atenção Cidadã $185 \mathbf{m}^{2}$

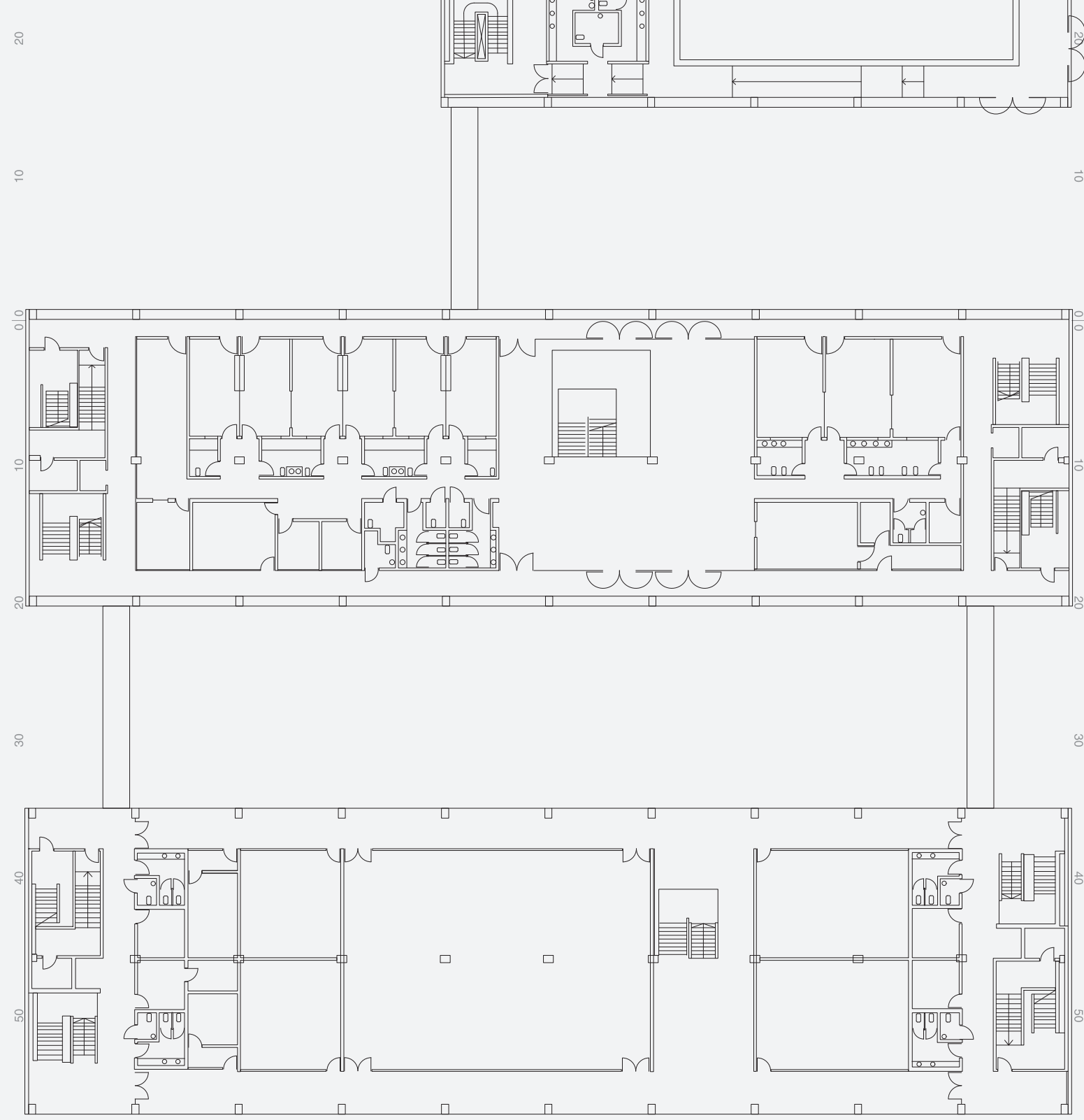


CATÁLOGO EQUIPAMENTOS MUNDO

CEU AGUA BRANCA
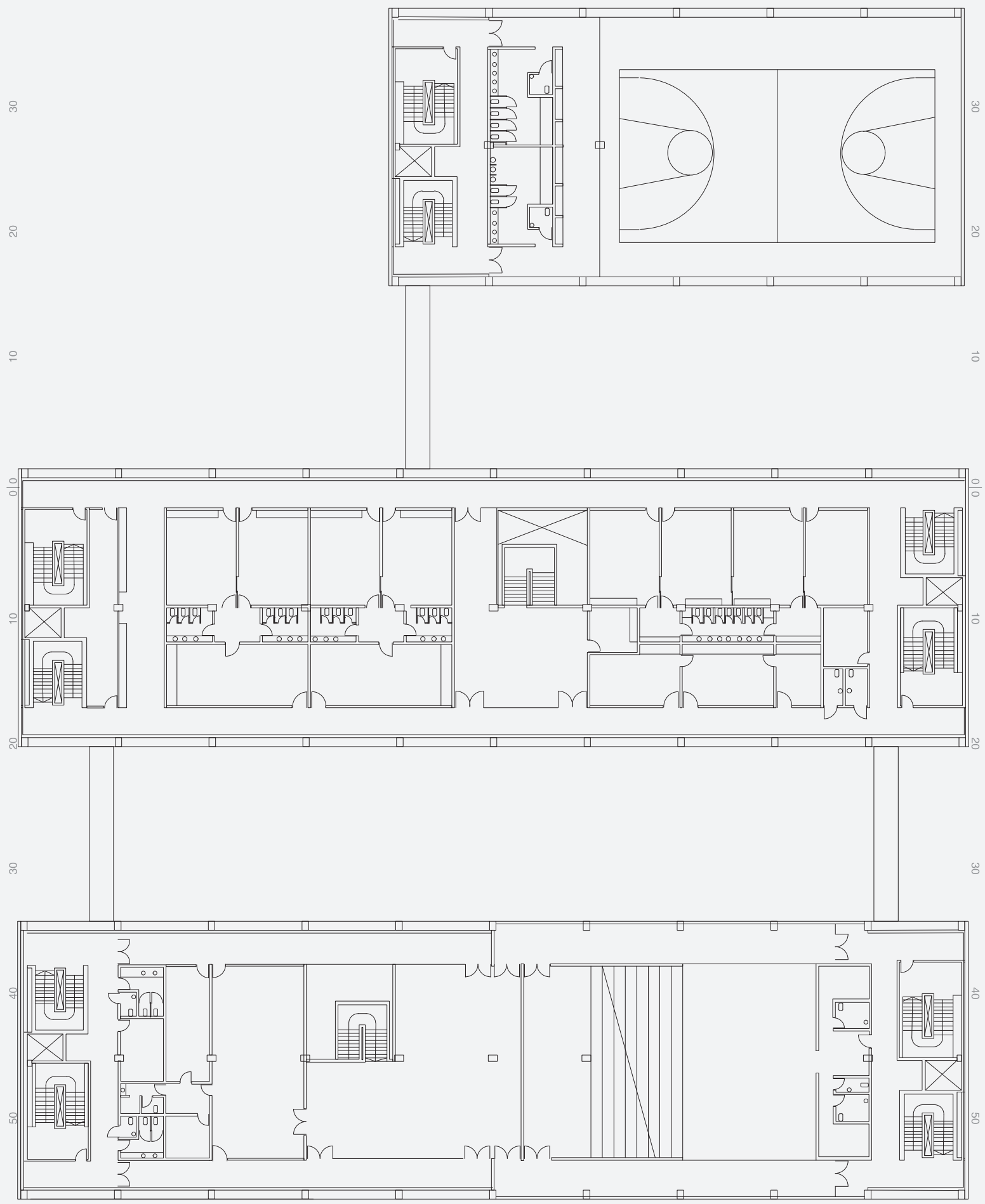

8 
CATÁLOGO EQUIPAMENTOS MUNDO

CEU AGUA BRANCA

Pav. Superior
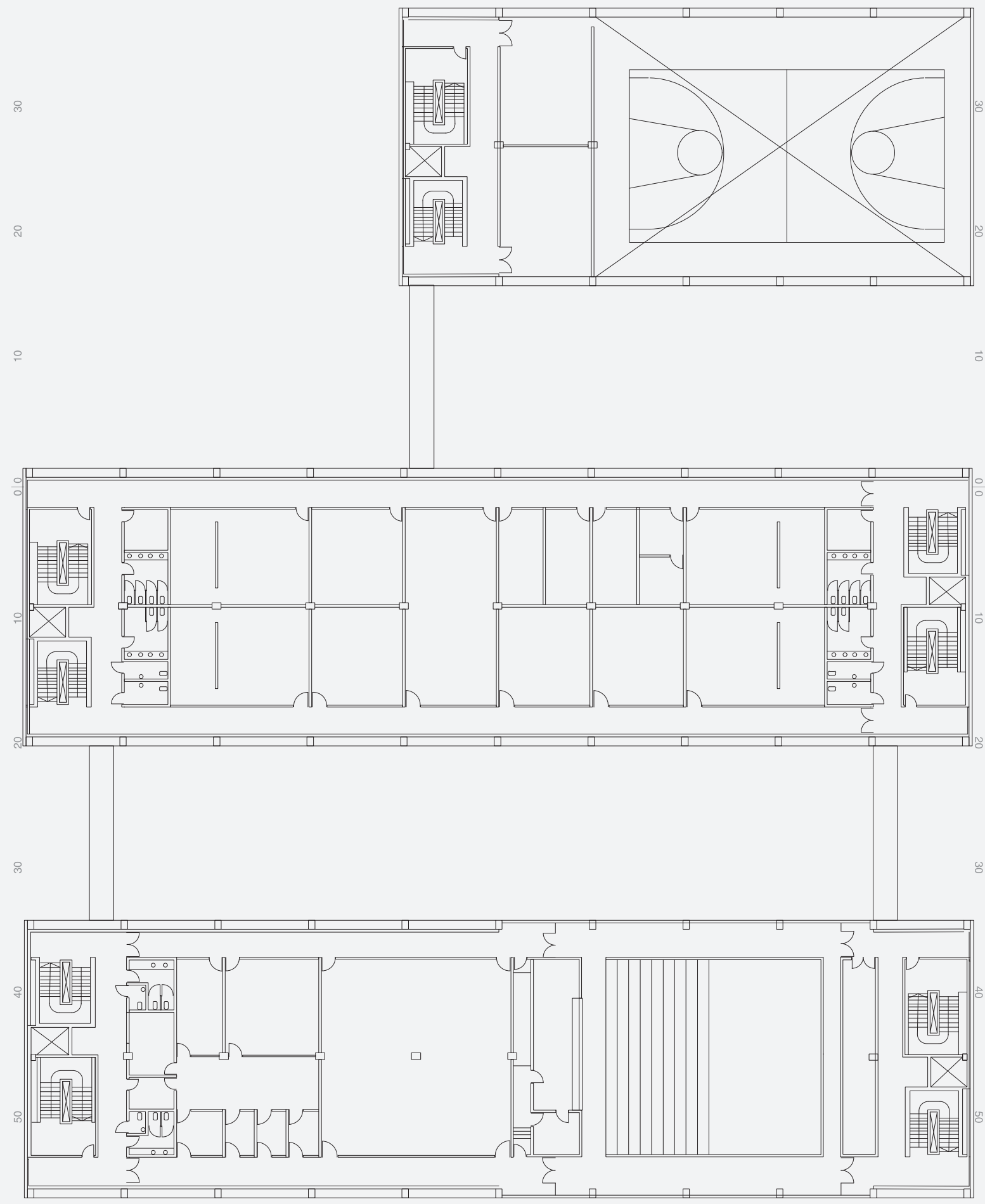
CATÁLOGO EQUIPAMENTOS MUNDO

CEU DSL DISSOLUÇÃO PROGRAMÁTICA

Educacional 2783 $\mathbf{m}^{2}$

Esporte $3385 \mathbf{m}^{2}$

Social e Cultural $3385 \mathbf{m}^{2}$

Outros $2587 \mathbf{m}^{2} \mathbf{\square}$

Saude $16 \mathbf{m}^{2}$

Atenção Cidadã $185 \mathbf{m}^{2}$ -
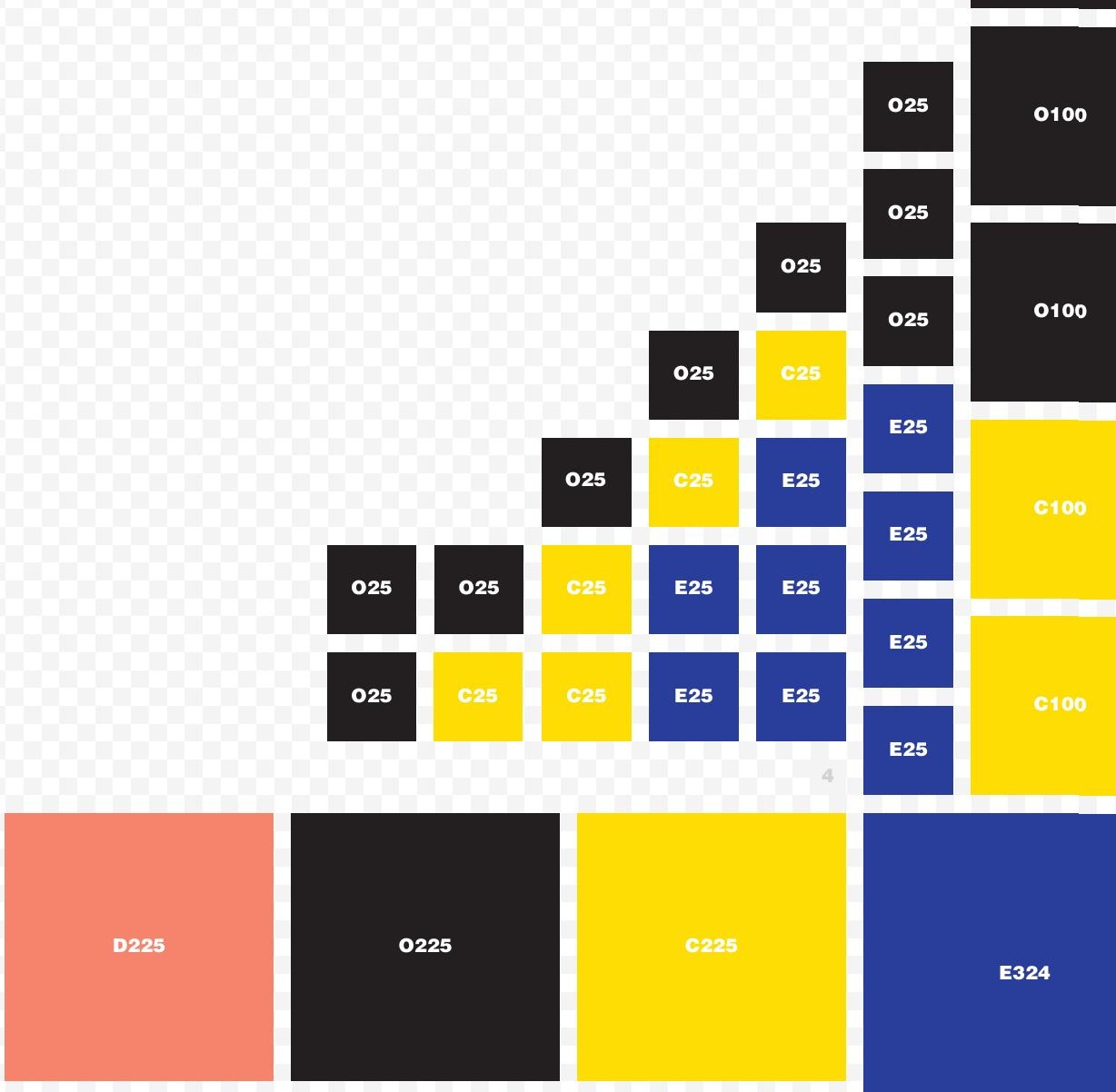

016
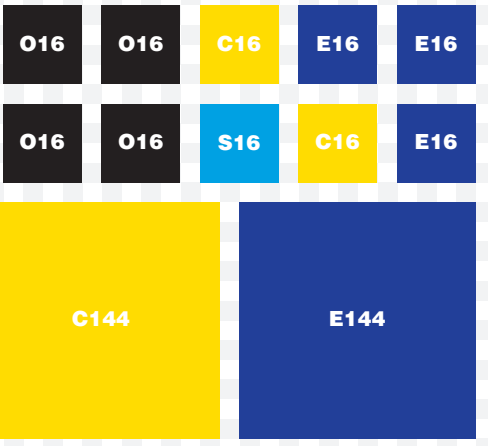

016

016

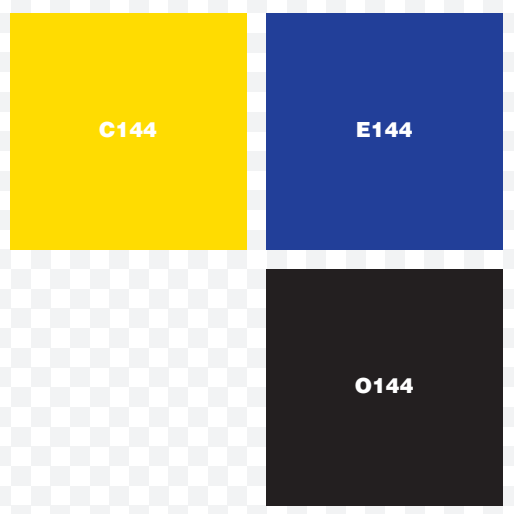

3324

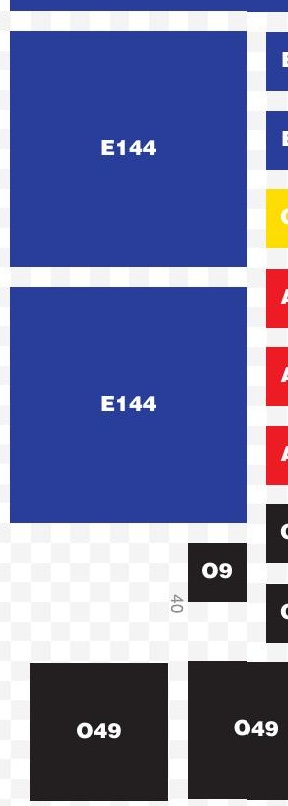




\section{CATÁLOGO EQUIPAMENTOS MUNDO}

CEU DSL DISSOLUÇÃO ESPACIAL

Área Construída $15725 \mathrm{~m}^{2}$

Área Exterior Coberta ---m $\mathbf{m}^{2}$

Pátios ---m²

Terreno $\mathbf{8 4 3 0 \mathbf { m } ^ { 2 }}$

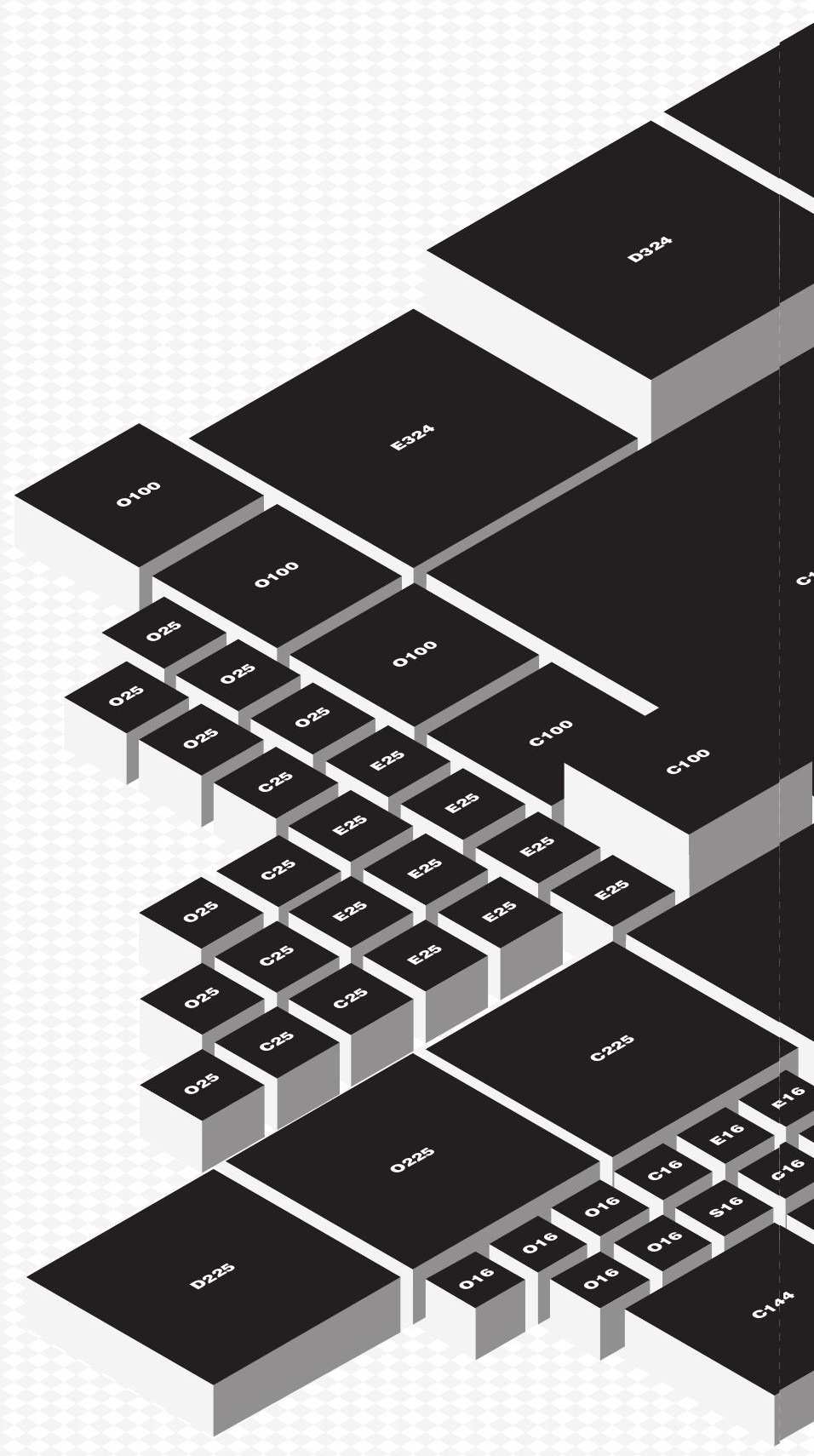




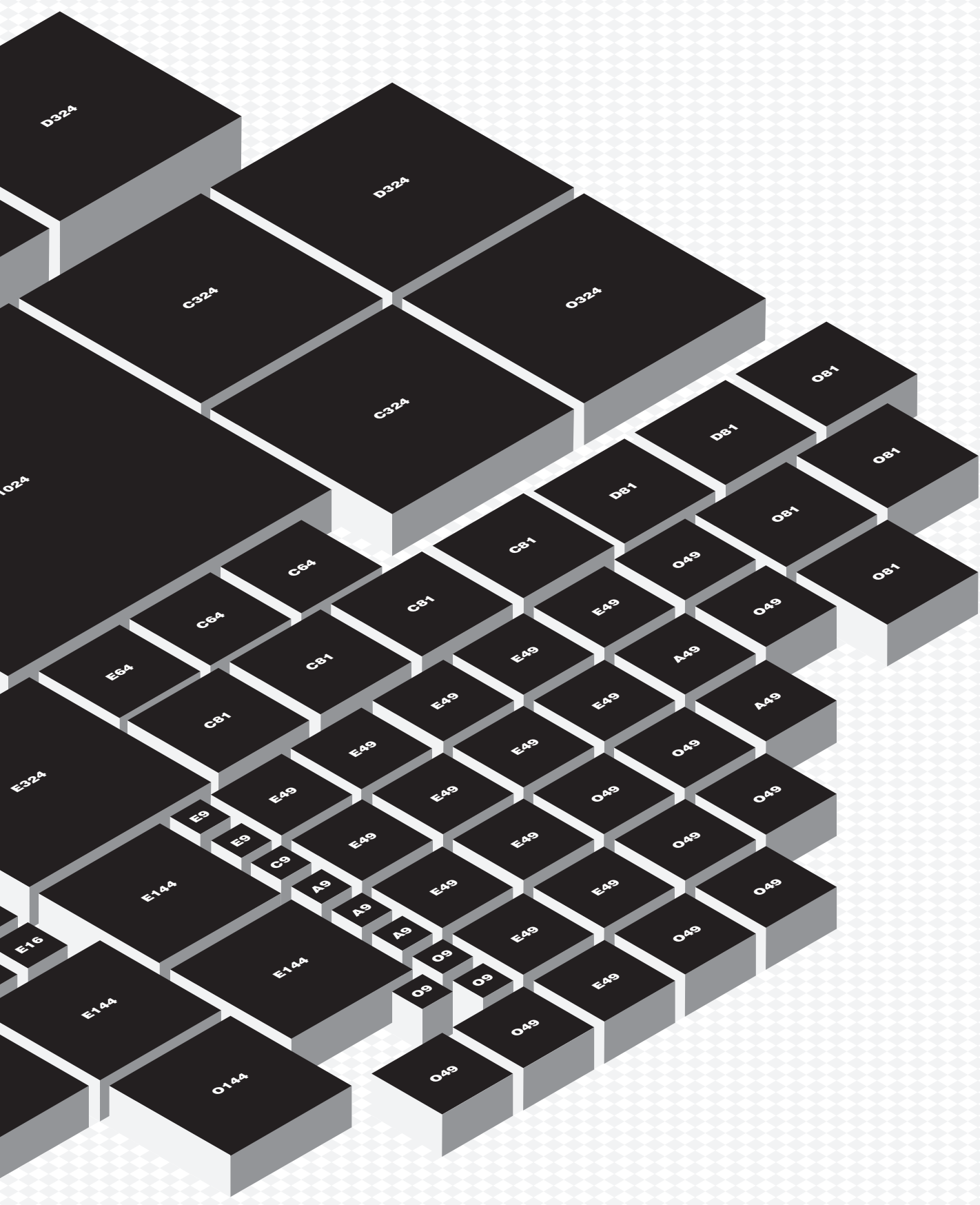




\section{CATÁLOGO EQUIPAMENTOS MUNDO}

\section{FUN PALACE}

Ano 1960-1966

Área total $59652 \mathrm{~m}^{2}$

Autor Cedric Price

Localização Londres, UK

Organização gestora

Organização responsável

Fonte CCA https://www.cca.qc.ca/en/search/details/collection/object/380477
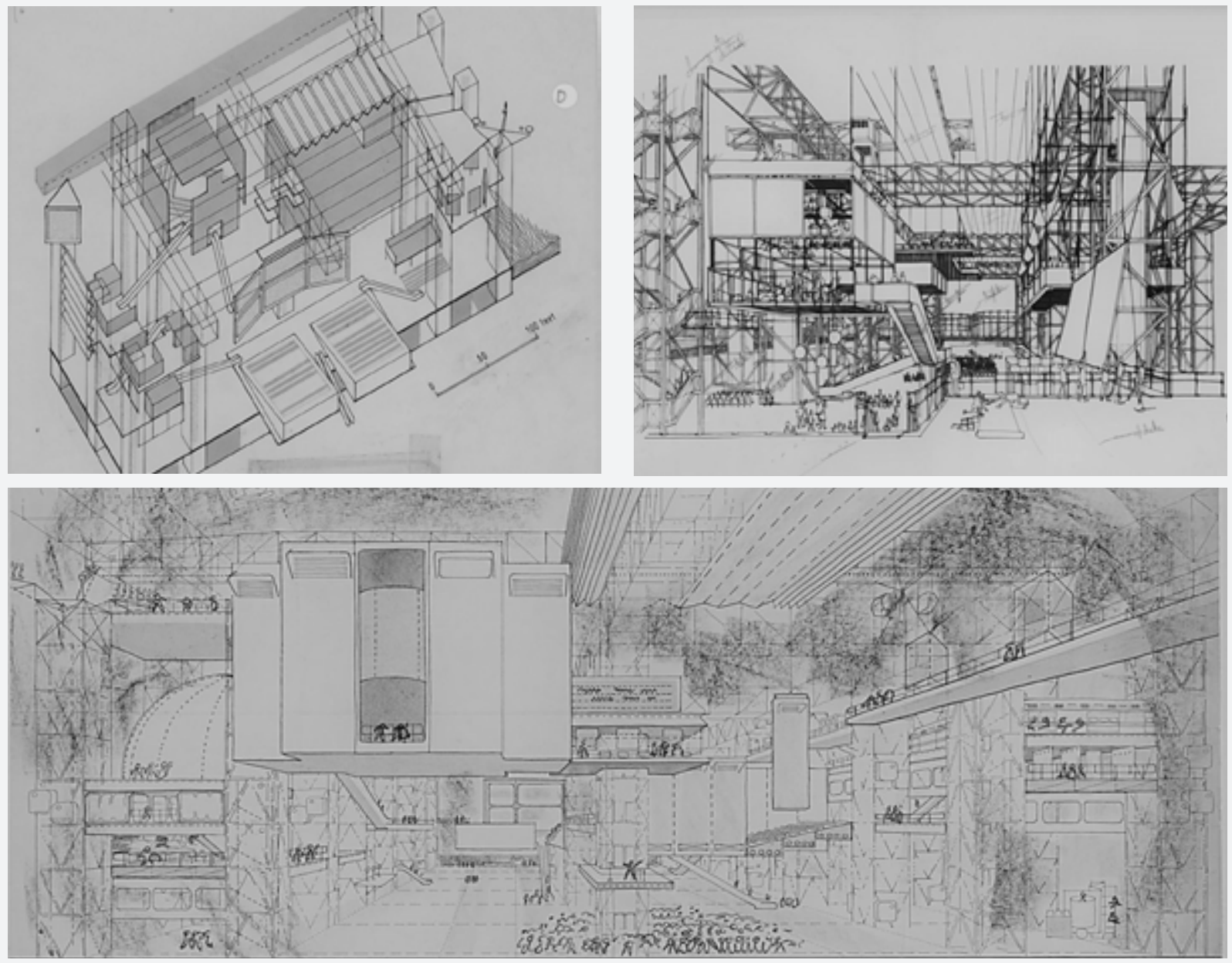


\section{CATÁLOGO EQUIPAMENTOS MUNDO}

FUN PALACE

Pav. Térreo

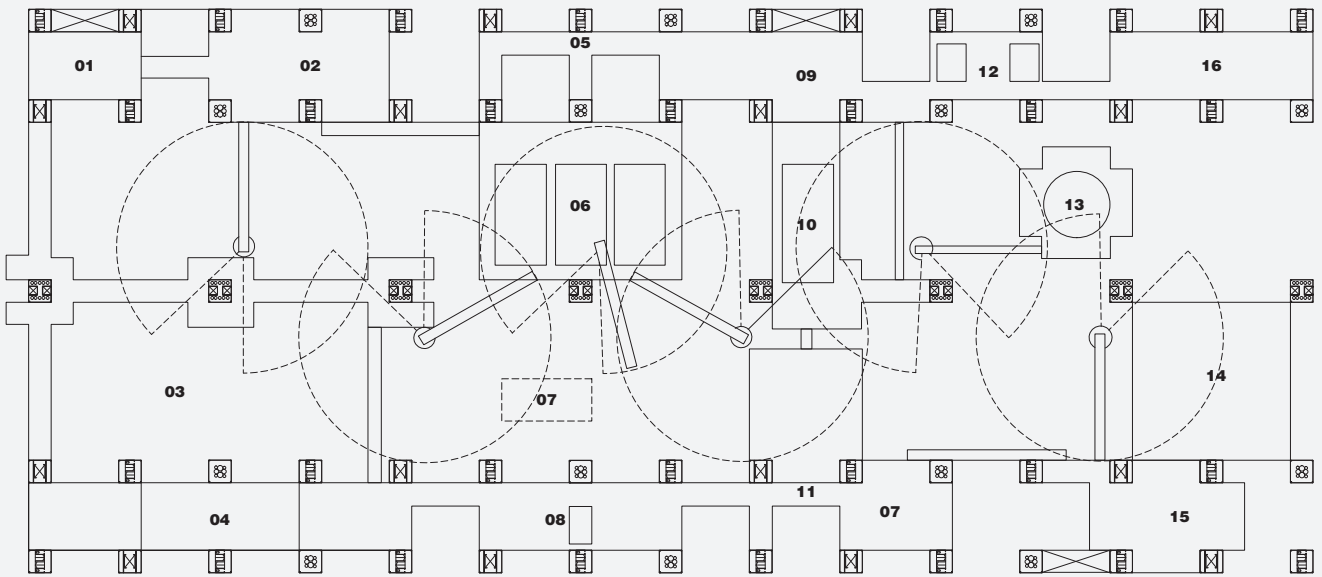

Área Construída 59652 m²

Área Exterior Coberta 29826 m²

Pátios ---m²

Ocupação de Solo 29826 m² $^{2}$

Taxa \%

Terreno ---m²

Outros $29826 \mathbf{~ m}^{2}$

Esc. 1.2000

OUTROS

\begin{tabular}{llll} 
& & $\mathrm{L}$ & $\mathrm{I}$ \\
$\mathbf{0 1}$ & Restaurante Refeitório & $22,87 \mathrm{~m}$ & $22,87 \mathrm{~m}$ \\
$\mathbf{0 2}$ & Sala Exibição & $36,6 \mathrm{~m}$ & $36,6 \mathrm{~m}$ \\
$\mathbf{0 3}$ & Demonstrações sobre os tetos. & $65,5 \mathrm{~m}$ & $65,5 \mathrm{~m}$ \\
$\mathbf{0 4}$ & Mirante & $32 \mathrm{~m}$ & $32 \mathrm{~m}$ \\
$\mathbf{0 5}$ & Área de descanso & $36,6 \mathrm{~m}$ & $36,6 \mathrm{~m}$ \\
$\mathbf{0 6}$ & Cine aberto de seis telas & $41,1 \mathrm{~m}$ & $41,1 \mathrm{~m}$ \\
$\mathbf{0 7}$ & Terapia & $18 \mathrm{~m}$ & $18 \mathrm{~m}$ \\
$\mathbf{0 8}$ & Restaurante Refeitório II & $41,1 \mathrm{~m}$ & $41,1 \mathrm{~m}$ \\
$\mathbf{0 9}$ & Vestuário & $41,1 \mathrm{~m}$ & $41,1 \mathrm{~m}$ \\
$\mathbf{1 0}$ & Teatro & $42 \mathrm{~m}$ & $42 \mathrm{~m}$ \\
$\mathbf{1 1}$ & Exposições II & $32 \mathrm{~m}$ & $32 \mathrm{~m}$ \\
$\mathbf{1 2}$ & Aprendizagem & $22,8 \mathrm{~m}$ & $22,8 \mathrm{~m}$ \\
$\mathbf{1 3}$ & Cine circular parcialm. fechado & $22,5 \mathrm{~m}$ & $22,5 \mathrm{~m}$ \\
$\mathbf{1 4}$ & Auditório inflável & $32 \mathrm{~m}$ & $32 \mathrm{~m}$ \\
$\mathbf{1 5}$ & Restaurante Refeitório III & $31,2 \mathrm{~m}$ & $31,2 \mathrm{~m}$ \\
$\mathbf{1 6}$ & Trabalho & $41,7 \mathrm{~m}$ & $13,7 \mathrm{~m}$ \\
& Circulação & $4,57 \times 4,57$ & $68 \mathrm{unid}$ \\
& * Local, soma de vários locais & \multicolumn{2}{c}{}
\end{tabular}
Sup. DSL
$523,03 \mathrm{~m}^{2}$
$4290,25 \mathrm{~m}^{2}$
$1024 \mathrm{~m}^{2}$
$1339,56 \mathrm{~m}^{2} \quad \mathbf{0 1 4 4}$
$1689,21 \mathrm{~m}^{2} \quad \mathbf{0 1 0 2 4}$
$324 \mathrm{~m}^{2}$
$1689,21 \mathrm{~m}^{2} \quad \mathbf{0 1 0 2 4}$
$1764 \mathrm{~m}^{2} \quad \mathbf{0 3 2 4}$
$1024 \mathrm{~m}^{2} \quad 01024$
$19,84 \mathrm{~m}^{2}$
19324
$506,25 \mathrm{~m}^{2} \quad 0324$
01024
$571,29 \mathrm{~m}^{2} \quad \mathbf{0 3 2 4}$
$1553,7 \mathrm{~m}^{2} \quad \mathbf{0 1 0 2}$


P26

§

60

40

20

$0 \mid 0$

20

40

60

$\overrightarrow{\widetilde{\delta}}$

CATÁLOGO EQUIPAMENTOS MUNDO

FUN PALACE

$\stackrel{\circ}{\circ}$

$\overrightarrow{\mathrm{o}}$

Elevação $\stackrel{\infty}{\circ}$

Pavimento

\&

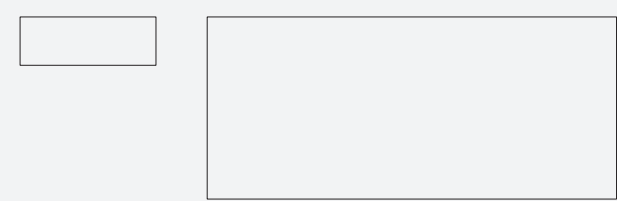

암

ำ
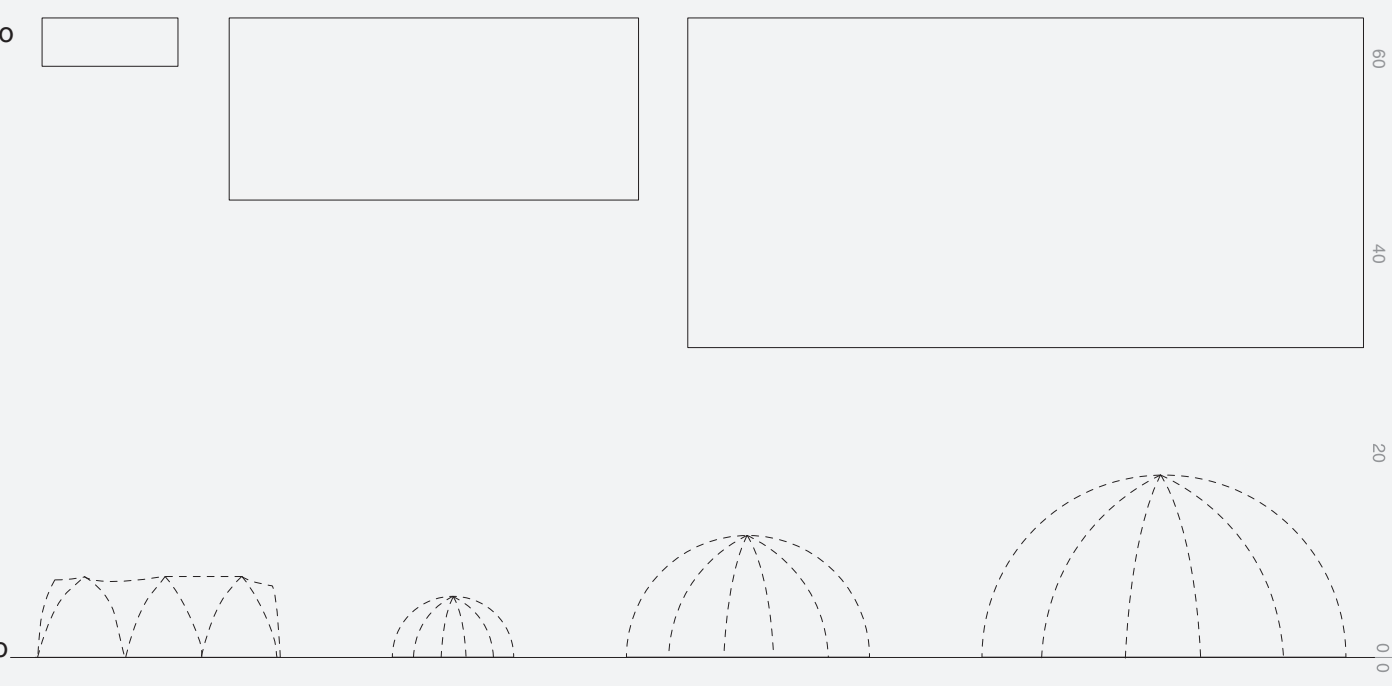

Pavimento

ㅇำ

앙

\&

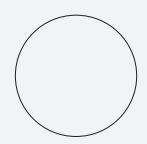

¿ Elevação

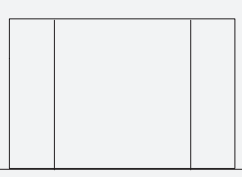

Pavimento

우

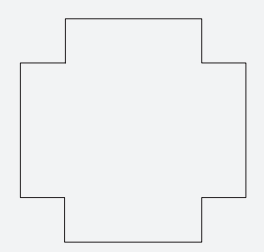

ํำ

Ot

oz

$0 \mid 0$

OZ
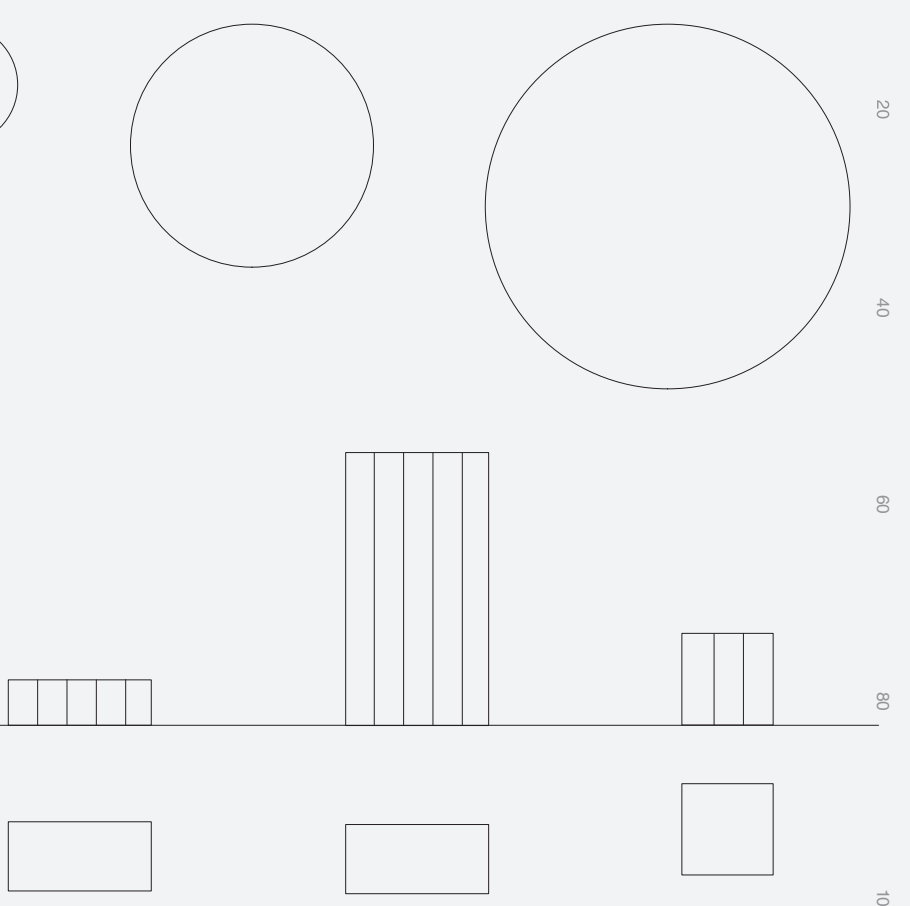

$\vec{\circ}$

$\overrightarrow{\widetilde{O}}$ 



\section{CATÁLOGO EQUIPAMENTOS DSL}

\section{INTERACTION CENTRE}

Ano 1970-1981 2003

Área total $5912 \mathrm{~m}^{2}$

Autor Cedric Price

Localização Camden Town, Londres, UK

Organização gestora

Organização responsável

Fonte CCA https://www.cca.qc.ca/en/search/details/collection/object/380477
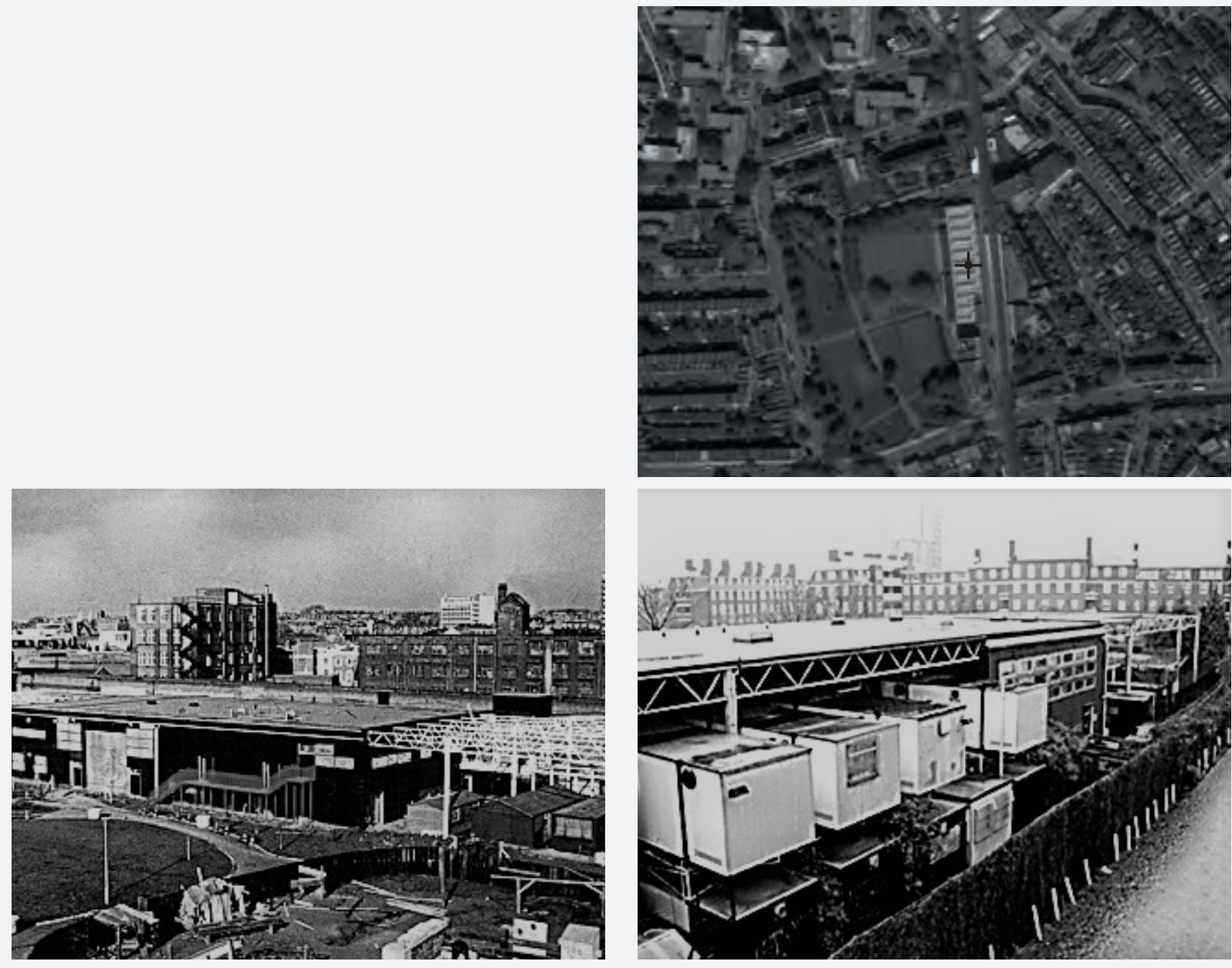


\section{CATÁLOGO EQUIPAMENTOS MUNDO}

\section{INTERACTION CENTRE}

Pav. Térreo

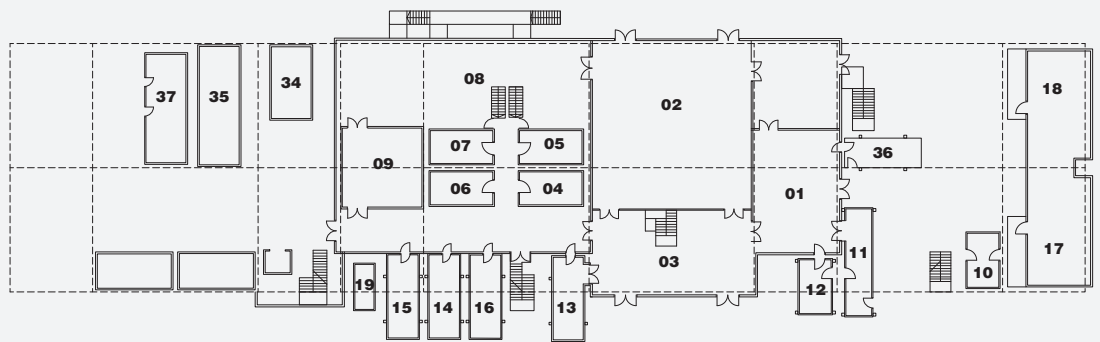

Área Construída 5912 m² $^{2}$

Área Exterior Coberta 2956 m² $^{2}$

Pátios ---m²

Ocupação de Solo 2956 m²

Taxa Ocupação de Solo \%

Terreno ---m²

Outros $2183 \mathbf{~ m}^{2}$

Esc. 1.1000

OUtRos

Cafeteria de funcionários

Auditório principal

Hall de entrada

Sala de projetos I

Sala de projetos II

Sala de projetos III

Sala de projetos IV

Loja

Academia

Banh. Criança

Cozinha principal

Cozinha funcionários

Banh. I

Ducha I

Ducha II

Reparações eletrônica

Armazem

Gerador I

Gerador II

* Local, soma de vários locais 


\section{INTERACTION CENTRE}

Pav. 1

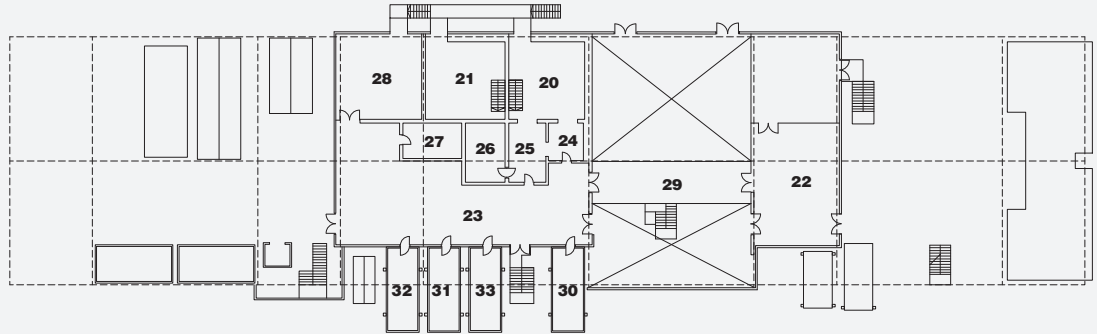

$\begin{array}{ll}\mathbf{2 0} & \text { Sala de ensaios I } \\ \mathbf{2 1} & \text { Sala de ensaios II } \\ \mathbf{2 2} & \text { Administração } \\ \mathbf{2 3} & \text { Design } \\ \mathbf{2 4} & \text { Estúdio de vídeo I } \\ \mathbf{2 5} & \text { Estúdio de vídeo II } \\ \mathbf{2 6} & \text { Estúdio de vídeo III } \\ \mathbf{2 7} & \text { Estúdio de vídeo IV } \\ \mathbf{2 8} & \text { Guarda-roupa } \\ \mathbf{2 9} & \text { Ponte } \\ \mathbf{3 0} & \text { Banh. II } \\ \mathbf{3 1} & \text { Quarto Escuro } \\ \mathbf{3 2} & \text { Ateliê } \\ \mathbf{3 3} & \text { Imprensa } \\ \mathbf{3 4} & \text { Edição de cine } \\ \mathbf{3 5} & \text { Bar } \\ \mathbf{3 6} & \text { Portaria } \\ \mathbf{3 7} & \text { Clube da terceira idade } \\ & \text { * Local, soma de vários locais }\end{array}$

$\begin{array}{lll}\text { L } & \text { I } & \text { Alt. } \\ 7,9 m & 7,73 m & 3 m \\ 8 m & 7,9 m & 3 m \\ 12,44 m & 8,7 m & 3 m \\ 25,5 m & 8,5 m & 3 m \\ 3,8 m & 3,55 m & 3 m \\ 6 m & 3,77 m & 3 m \\ 6 m & 4 m & 3 m \\ 6 m & 3,6 m & 3 m \\ 8,7 m & 8,7 m & 3 m \\ 16 m & 4,38 m & 3 m \\ 8,4 m & 3 m & 3 m \\ 8,5 m & 3,15 m & 3 m \\ 8,5 m & 3,15 m & 3 m \\ 8,5 m & 3,15 m & 3 m \\ 7,7 m & 7,7 m & \text { var. } 2,5 / 3 m \\ 12,35 m & 12,35 m & \text { var. } 2,5 / 3 m \\ 7,8 m & 7,8 m & 3 m \\ 11,3 m & 11,3 m & \text { var. } 2,5 / 3 m\end{array}$




\section{CATÁLOGO EQUIPAMENTOS MUNDO}

INTERACTION CENTRE DSL DISSOLUÇÃO PROGRAMÁTICA Outros $2183 \mathbf{m}^{2}$

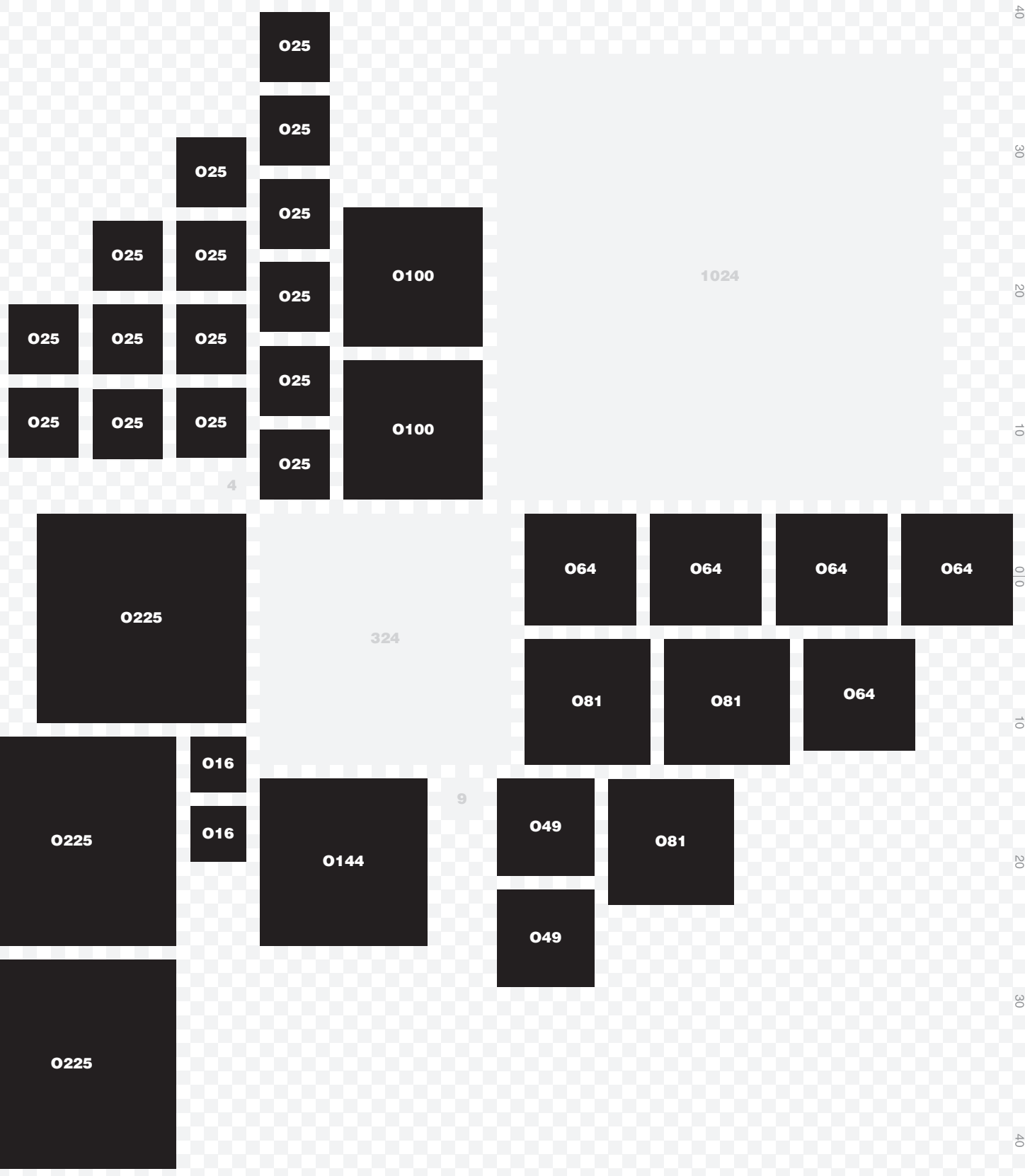




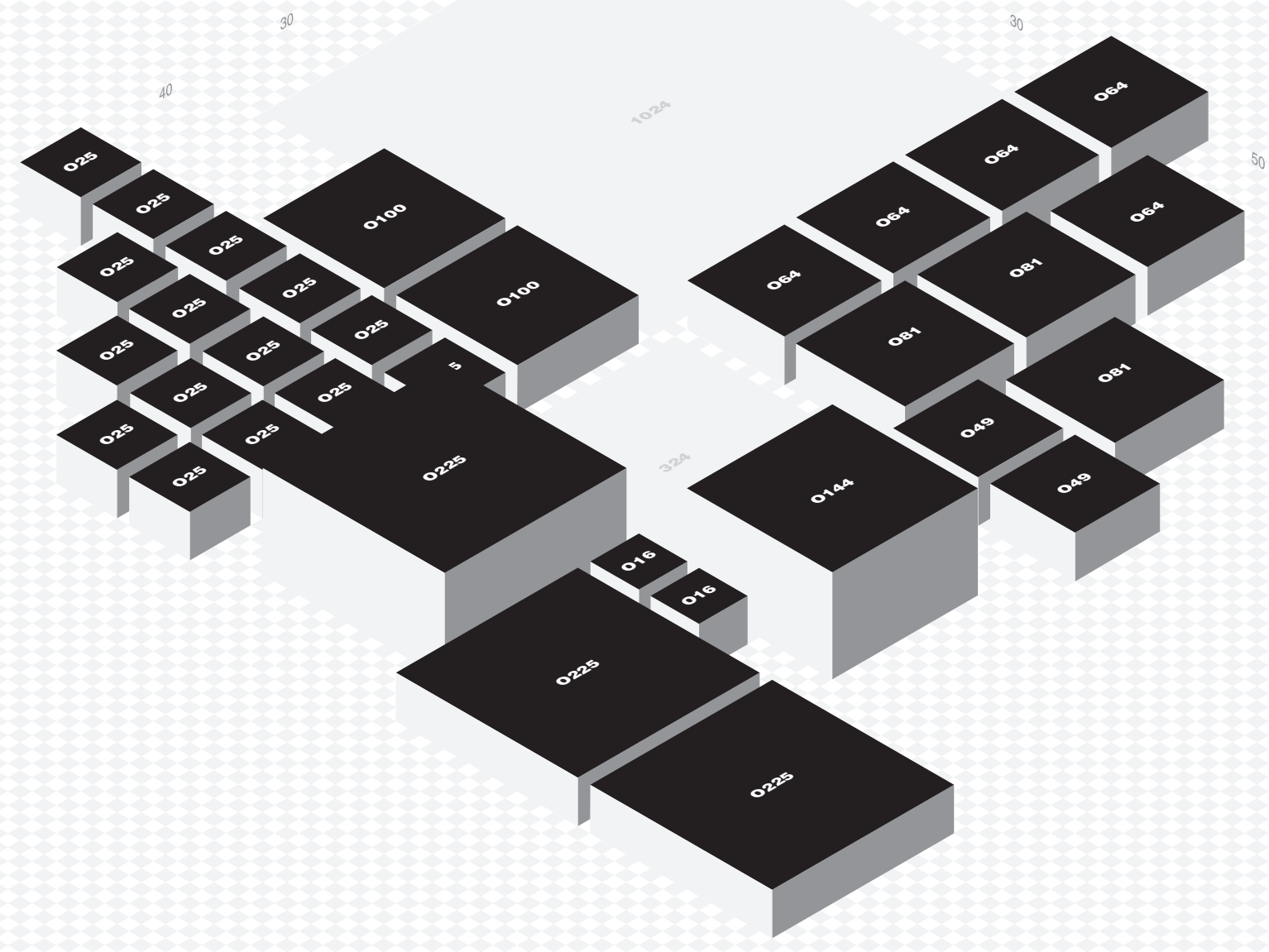


CATÁLOGO EQUIPAMENTOS MUNDO

INTERACTION CENTRE
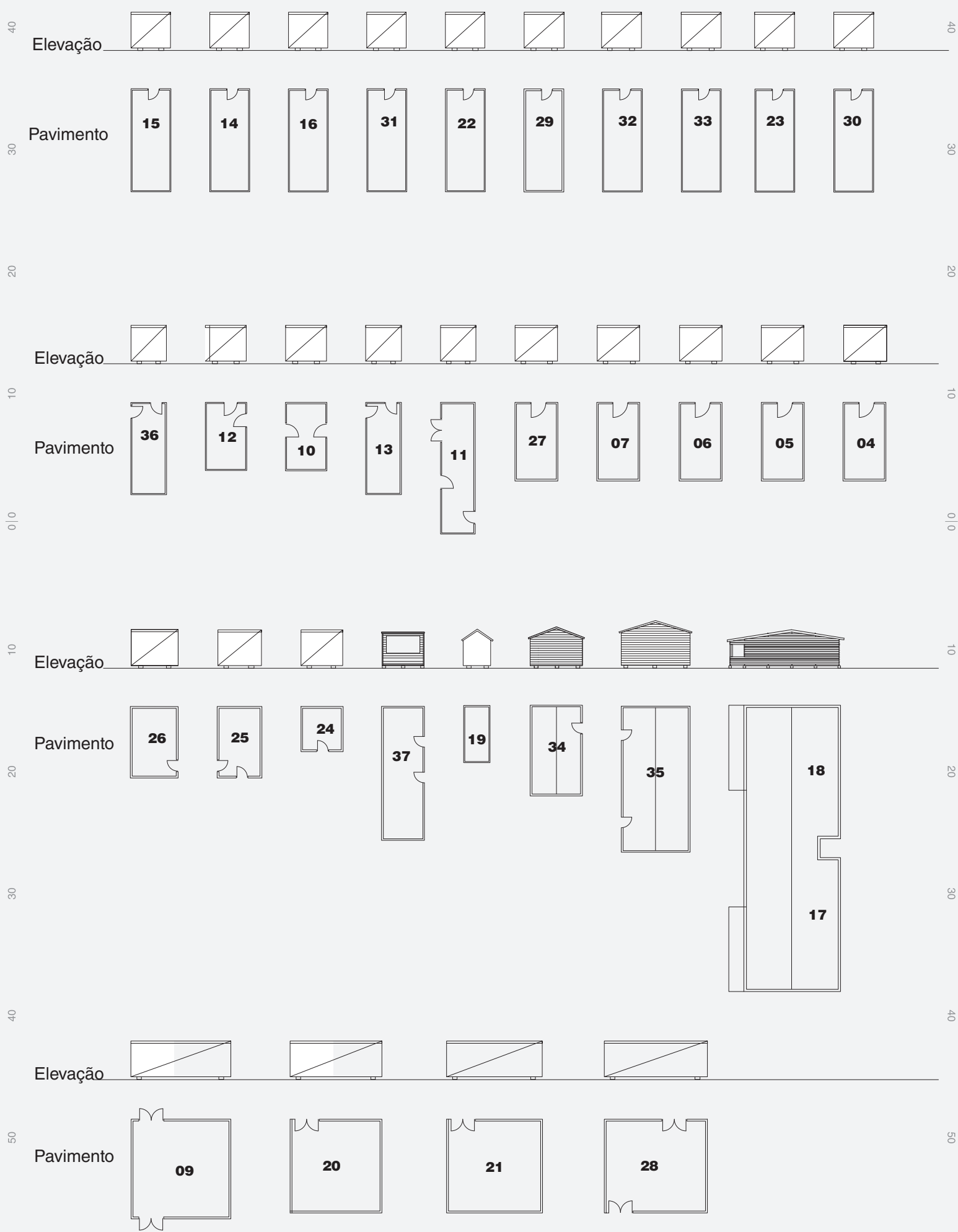


\section{CATÁLOGO EQUIPAMENTOS MUNDO}

\section{STADSTHEATER DE ALMERE}

\section{Ano 1998-2007}

Área total $1391 \mathrm{~m}^{2}$

Autor SANAA

Localização Almere, NL

Organização gestora

Organização responsável

Fontes HASEGAWA Yuko. Kazuyo Sejima+Ryue Nishizawa SANAA.

Revista EI Croquis 99,121-122,139
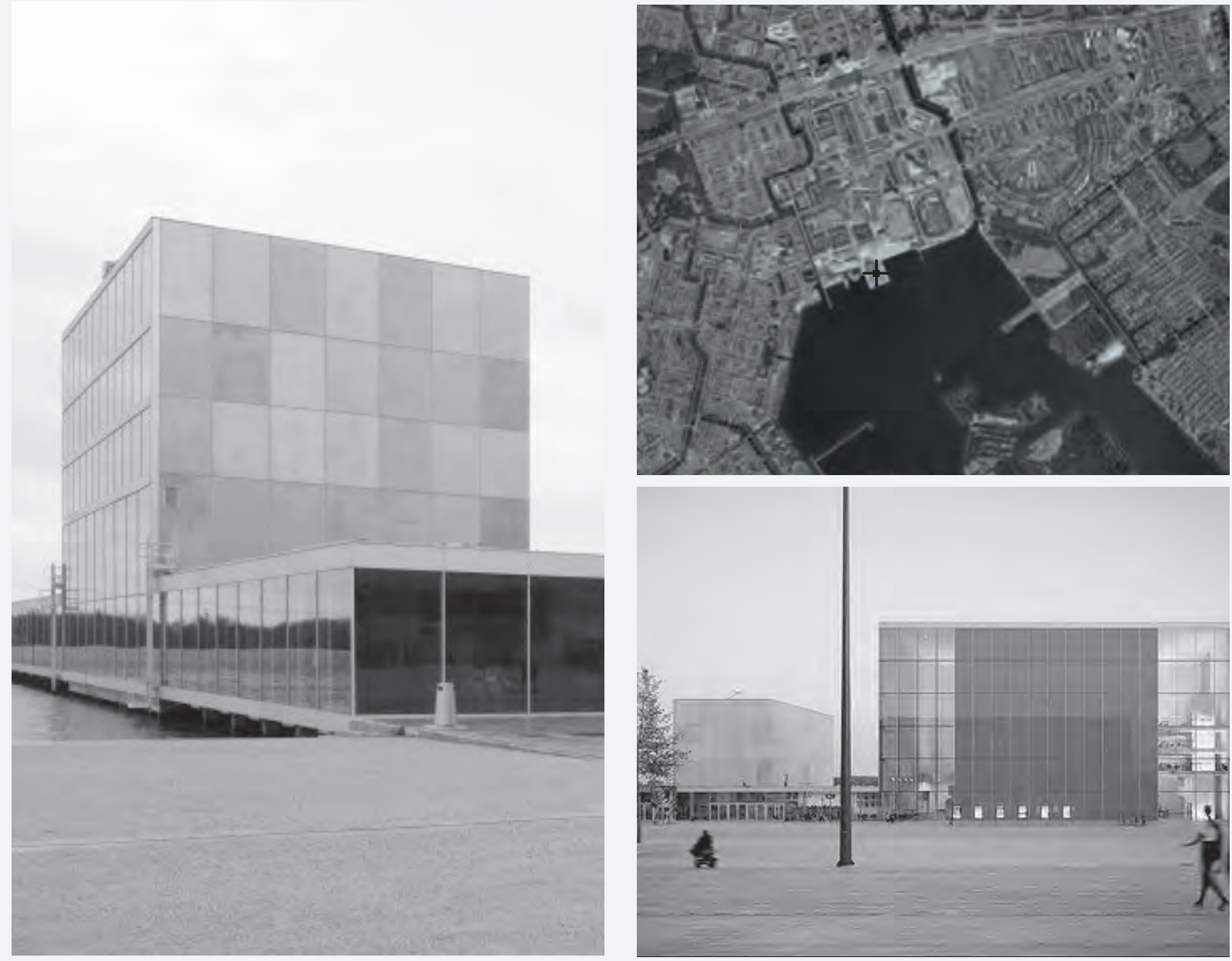


\section{CATÁLOGO EQUIPAMENTOS MUNDO}

\section{STADSTHEATER DE ALMERE}

Pav. Térreo

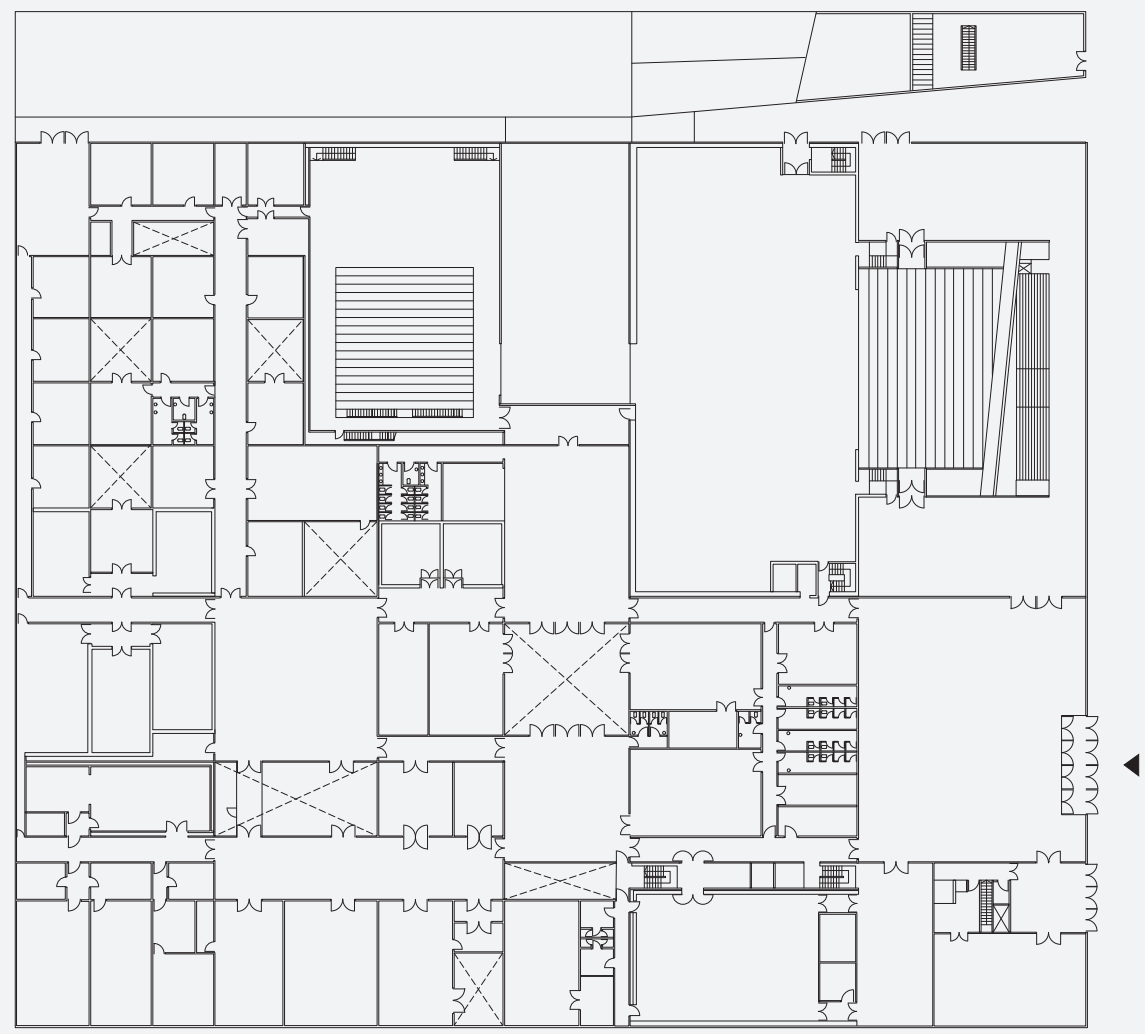

Área Construída $15500 \mathrm{~m}^{2}$

Área Exterior Coberta ---m²

Pátios 548m²

Ocupação de Solo $11230 \mathrm{~m}^{2}$

Taxa Ocupação de Solo $11230 \mathbf{m}^{2}$

Esc. 1.1000 
CATÁLOGO EQUIPAMENTOS MUNDO

STADSTHEATER DE ALMERE

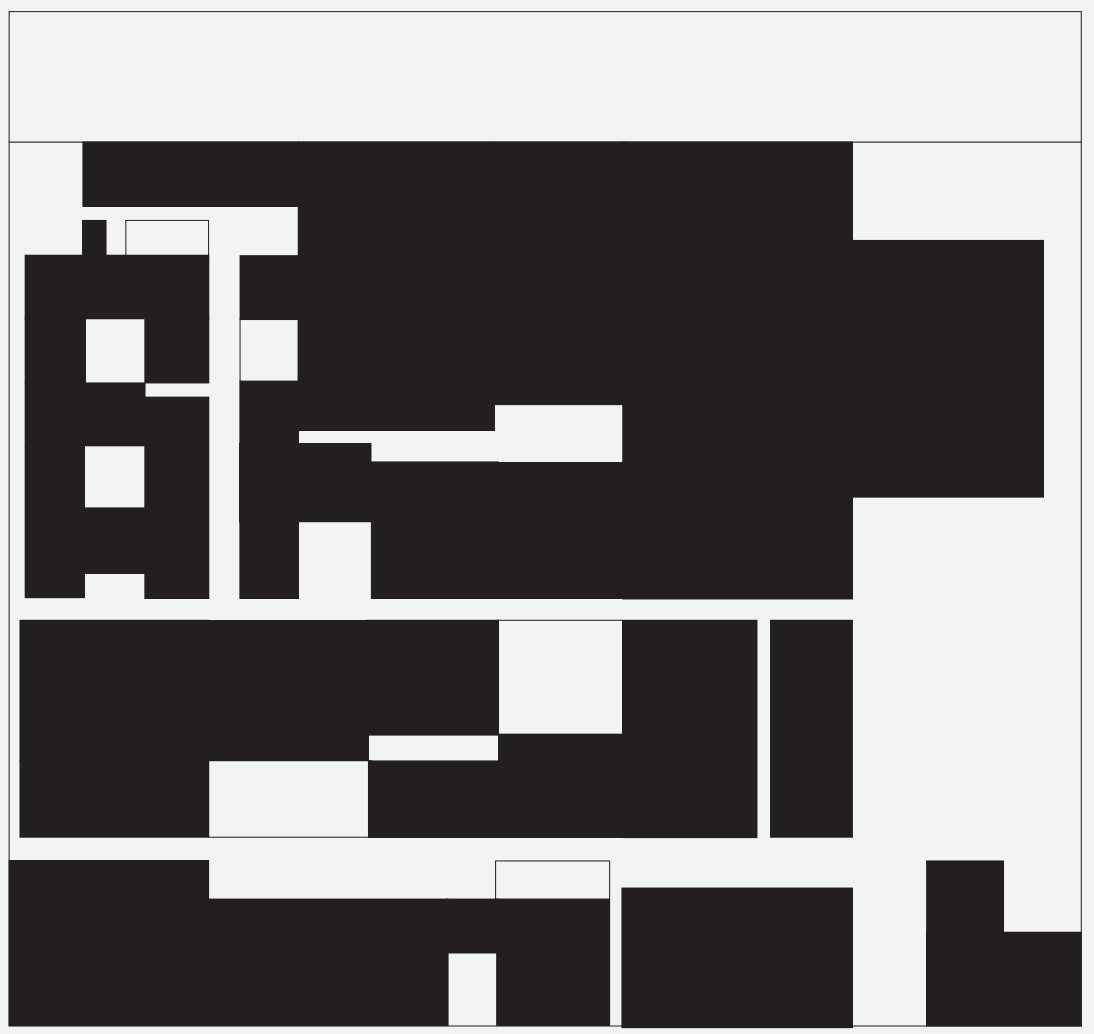


CATÁLOGO EQUIPAMENTOS MUNIDO

STADSTHEATER

DSL DISSOLUÇÃO PROGRAMÁTICA

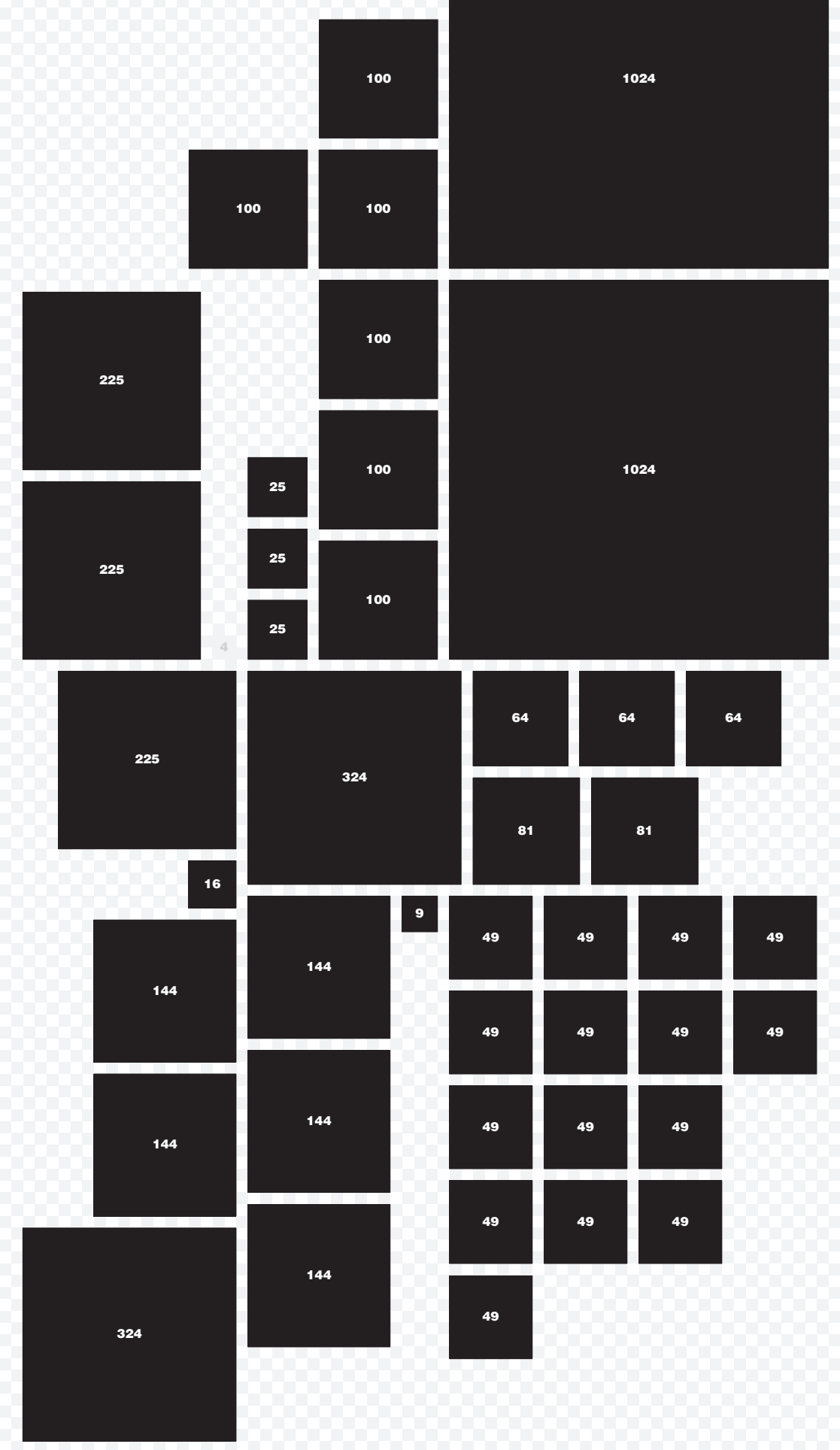




\section{CATÁLOGO EQUIPAMENTOS MUNDO}

STADSTHEATER DSL DISSOLUÇÃO ESPACIAL Área Construída $15500 \mathrm{~m}^{2}$

Área Exterior Coberta ---m²

Pátios 548m²

Ocupação de Solo $11230 \mathrm{~m}^{2}$

Terreno $11230 \mathrm{~m}^{2}$

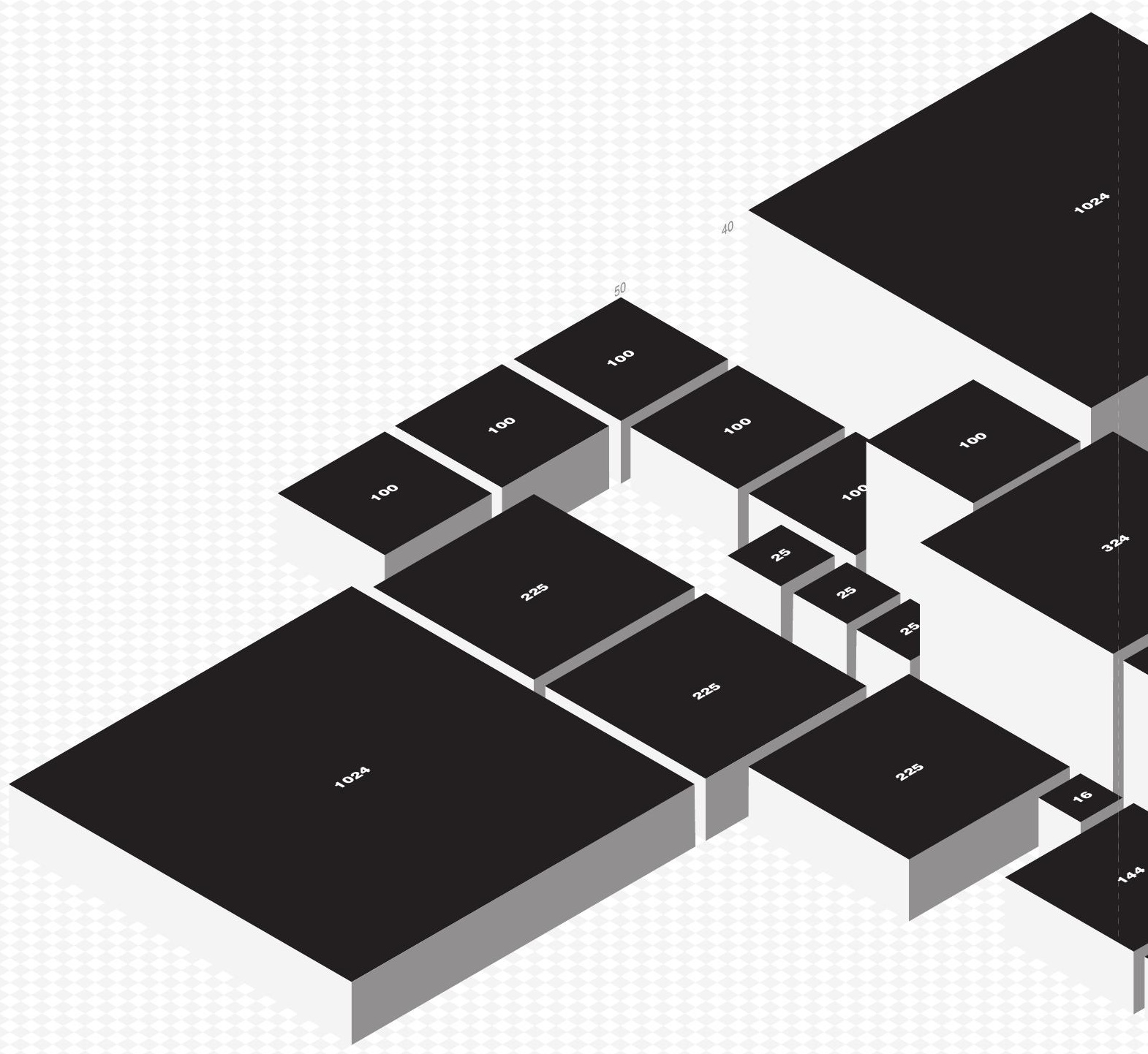




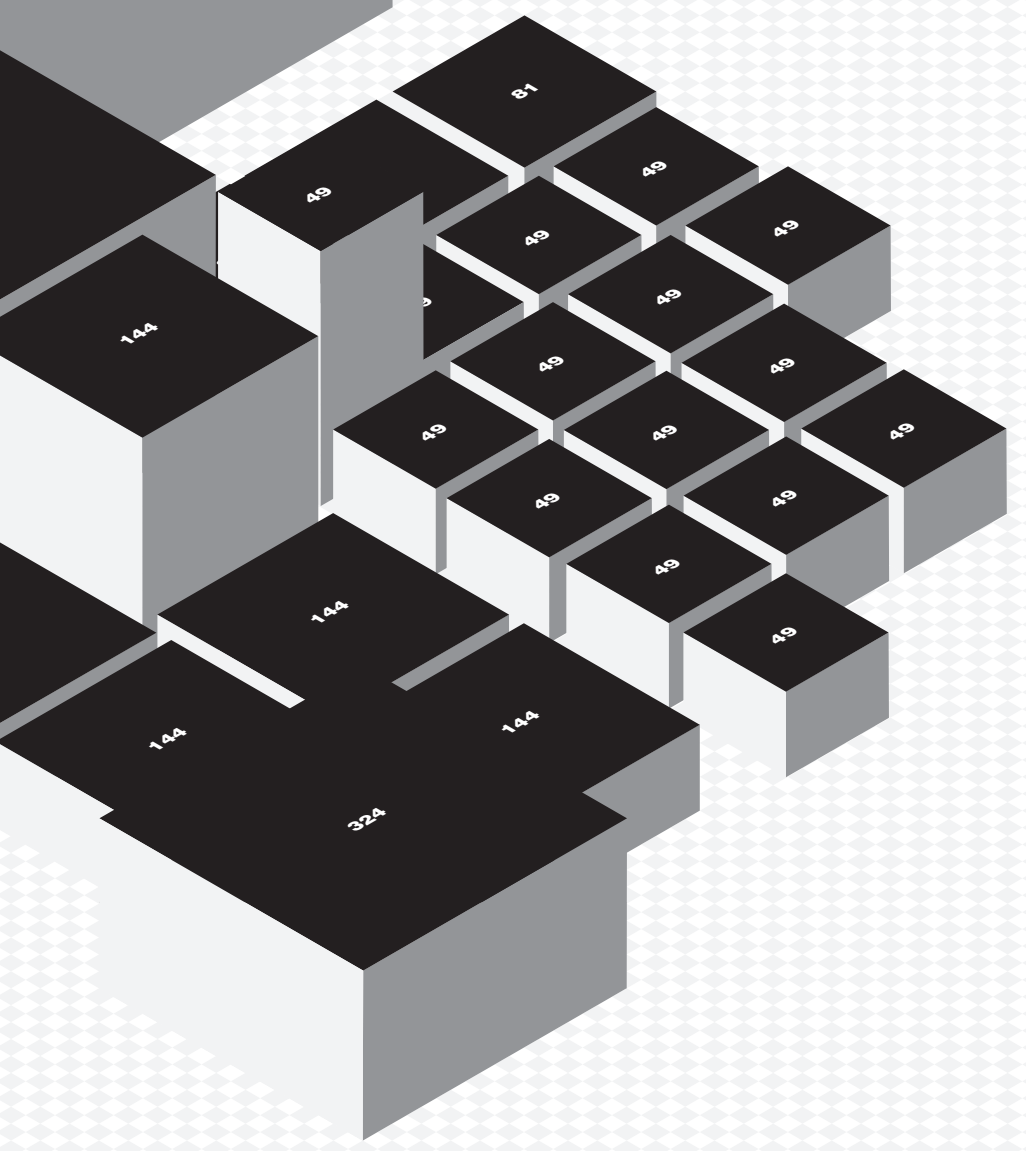




\section{CATÁLOGO EQUIPAMENTOS MUNDO}

21st CENTURY MUSEUM OF CONTEMPORARY ART, KANAZAWA

Ano 1999-2004

Área total $9940 \mathrm{~m}^{2}$

Autor SANAA

Localização Kanasawa, JP

Organização gestora

Organização responsável

Fontes HASEgAWA Yuko. Kazuyo Sejima+Ryue Nishizawa SANAA.

Revista El Croquis 99,121-122
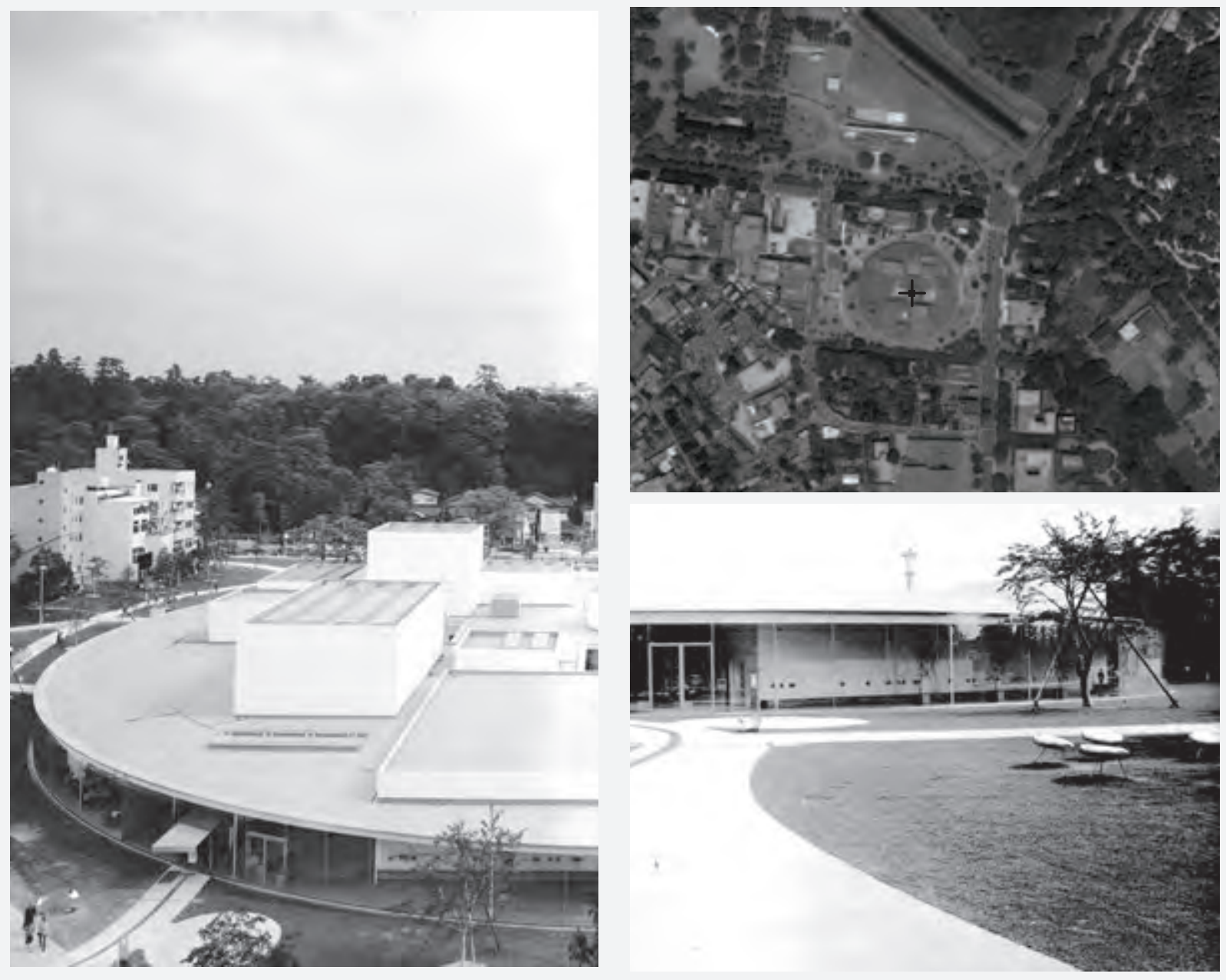


\section{CATÁLOGO EQUIPAMENTOS MUNDO}

21st CENTURY MUSEUM OF CONTEMPORARY ART, KANAZAWA

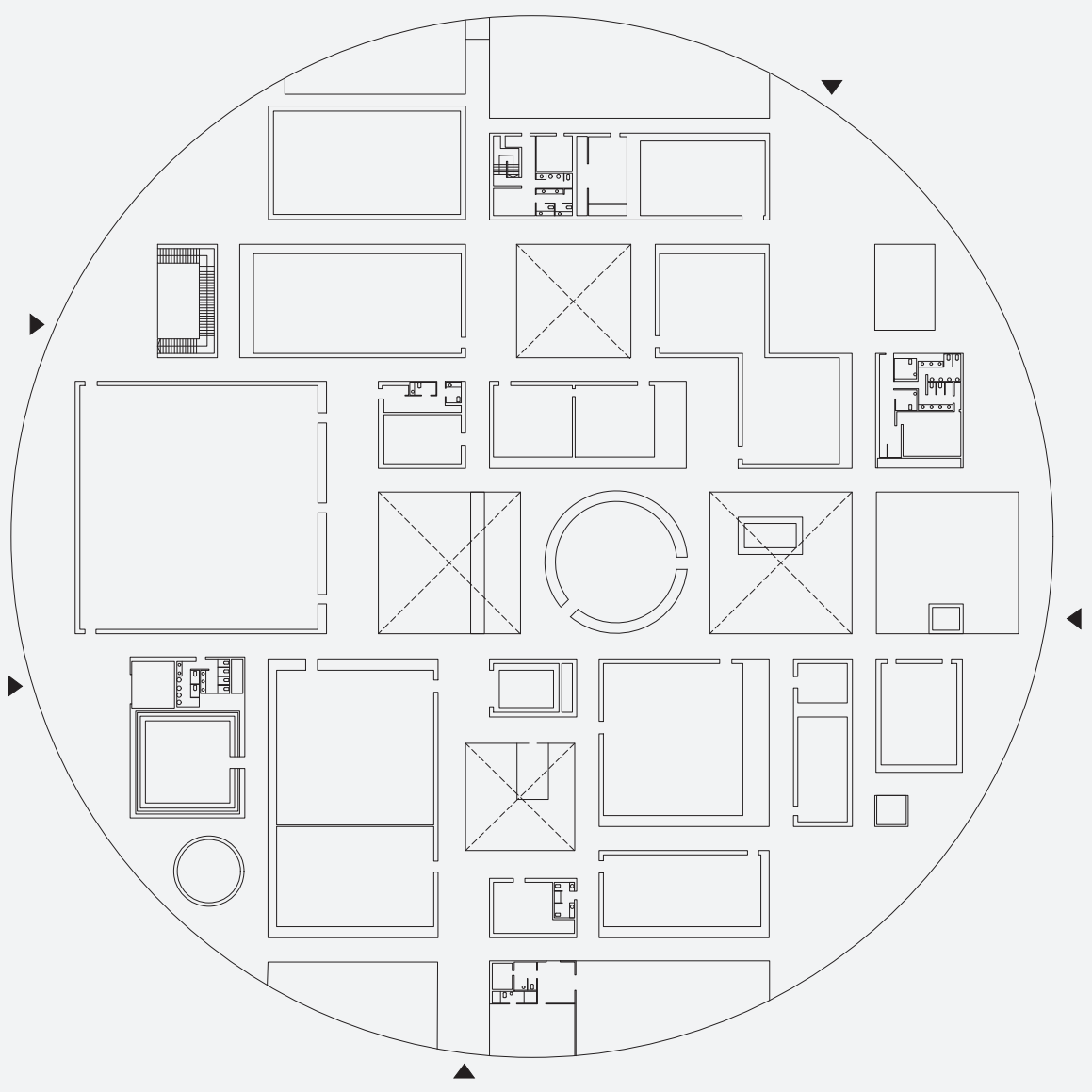

Área Construída $17.069 \mathbf{~ m}^{2}$

Área Exterior Coberta ---m²

Ocupação de Solo $9940 \mathbf{m}^{2}$

Terreno 29900m² 


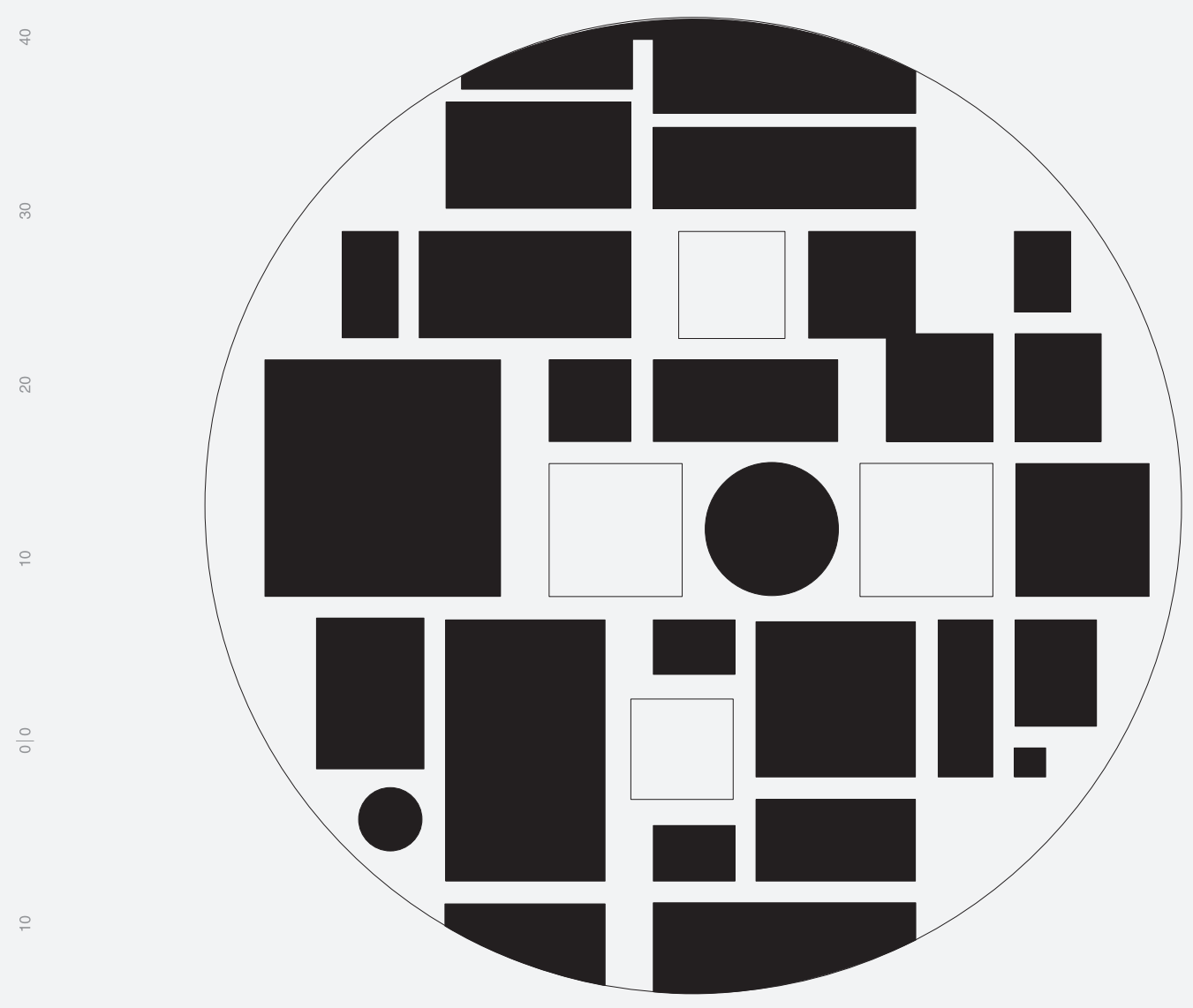




\section{CATÁLOGO EQUIPAMENTOS MUNDO}

21st CENTURY MUSEUM

DSL DISSOLUÇÃO PROGRAMÁTICA

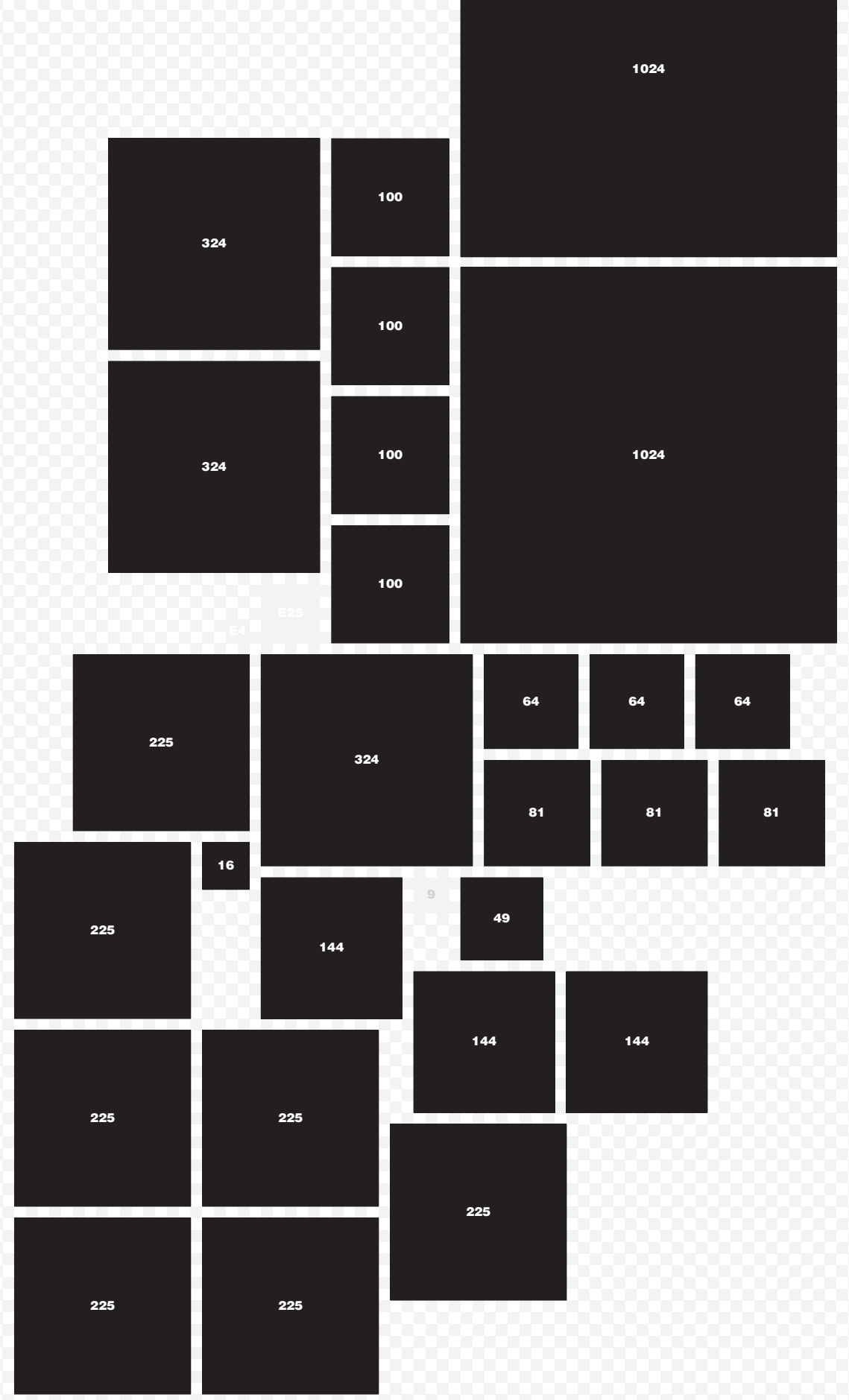




\section{CATÁLOGO EQUIPAMENTOS MUNDO}

21st CENTURY MUSEUM DSL DISSOLUÇÃO ESPACIAL

Área Construída $17.069 \mathrm{~m}^{2}$

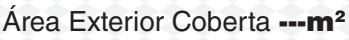

Pátios $\mathbf{7 5 6 m ^ { 2 }}$

Ocupação de Solo $9940 \mathbf{m}^{2}$

Terreno $\mathbf{2 9 9 0 0 \mathbf { m } ^ { 2 }}$

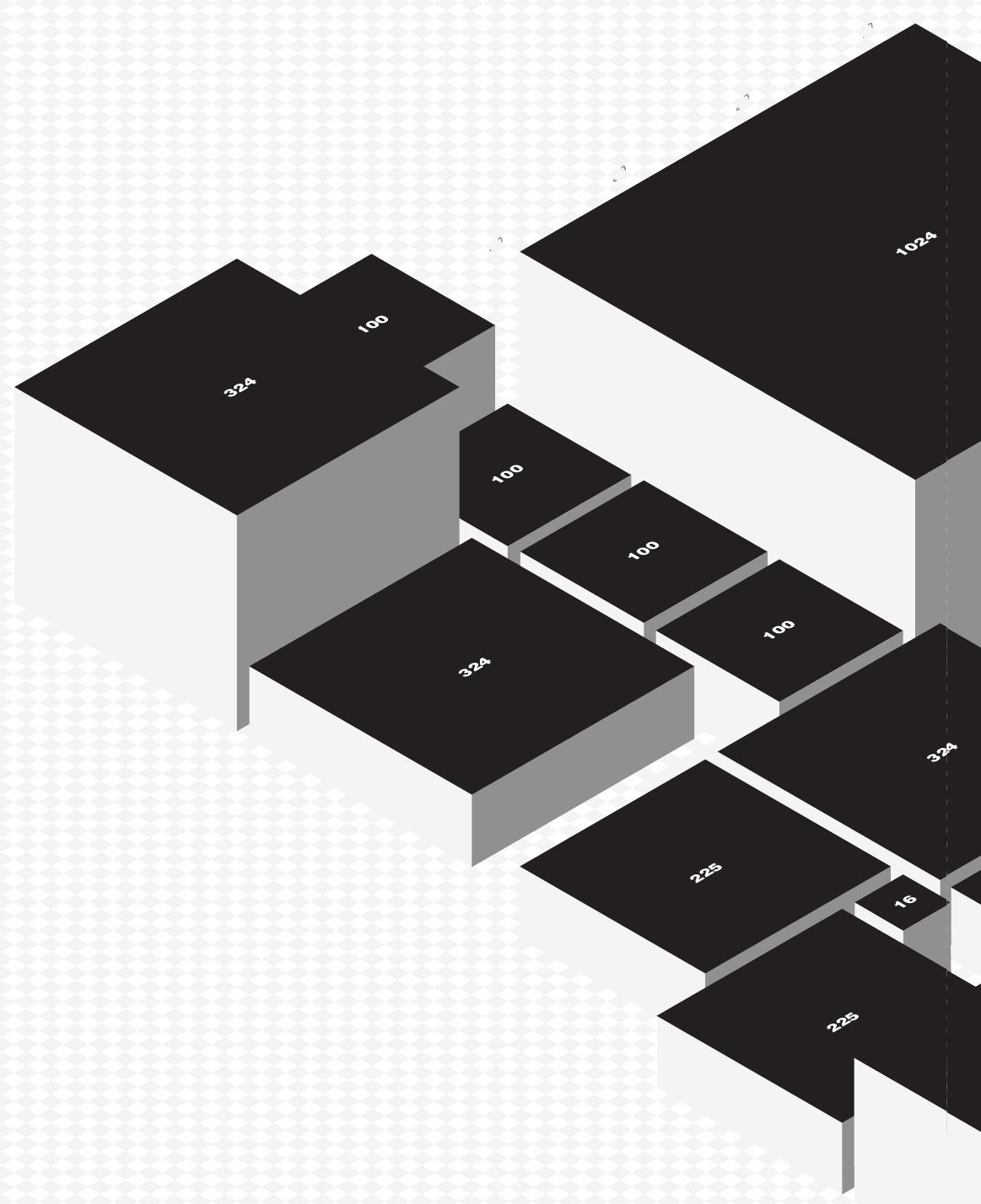




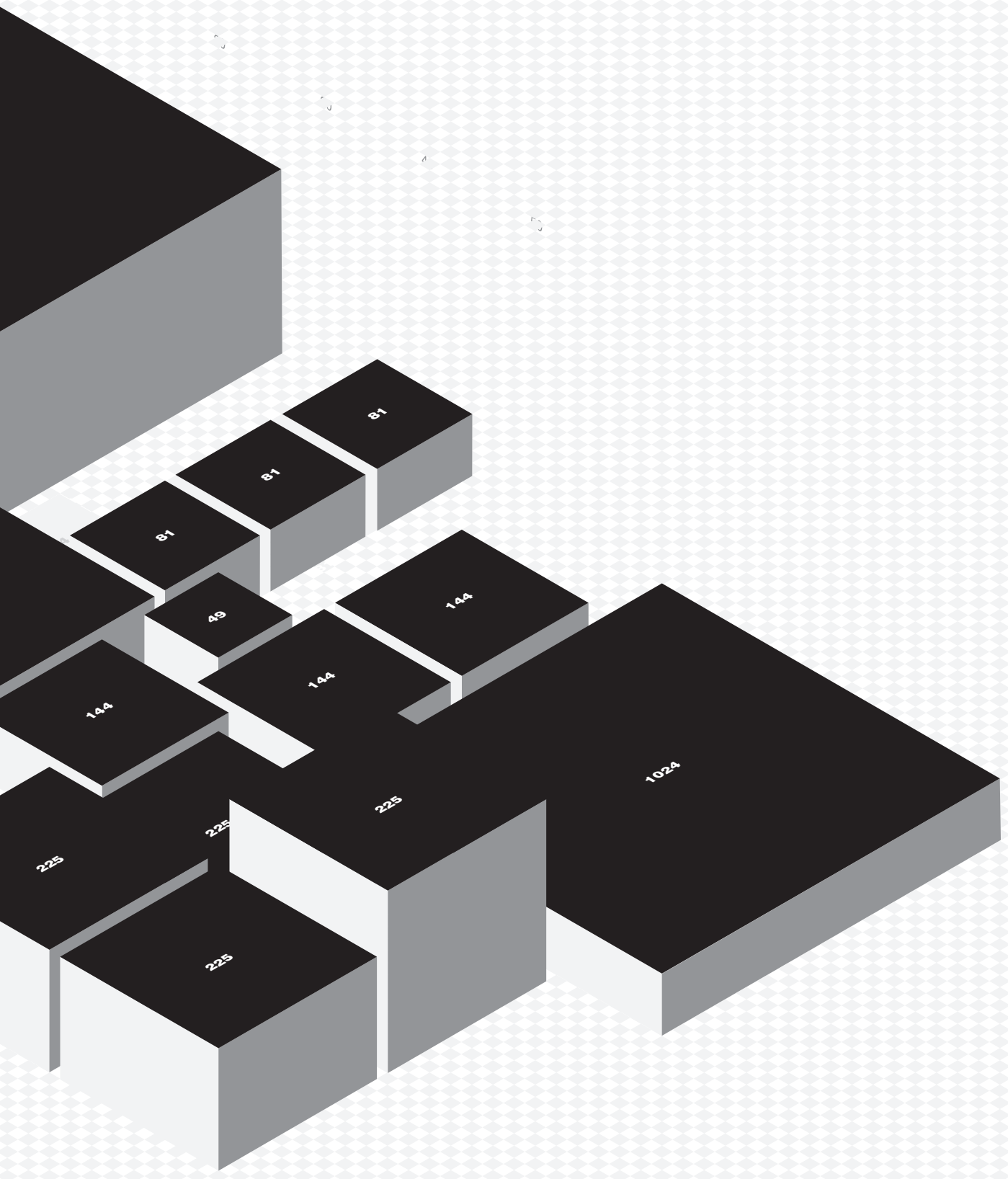




\section{CATÁLOGO EQUIPAMENTOS MUNDO}

GLASS PAVILLION - TOLEDO MUSEUM OF ART

Ano 2001-2016

Área total $3317 \mathrm{~m}^{2}$

Autor SANAA

Localização Toledo, USA

Organização gestora

Organização responsável

Fontes HASEGAWA Yuko. Kazuyo Sejima+Ryue Nishizawa SANAA.

Revista El Croquis 121-122,139
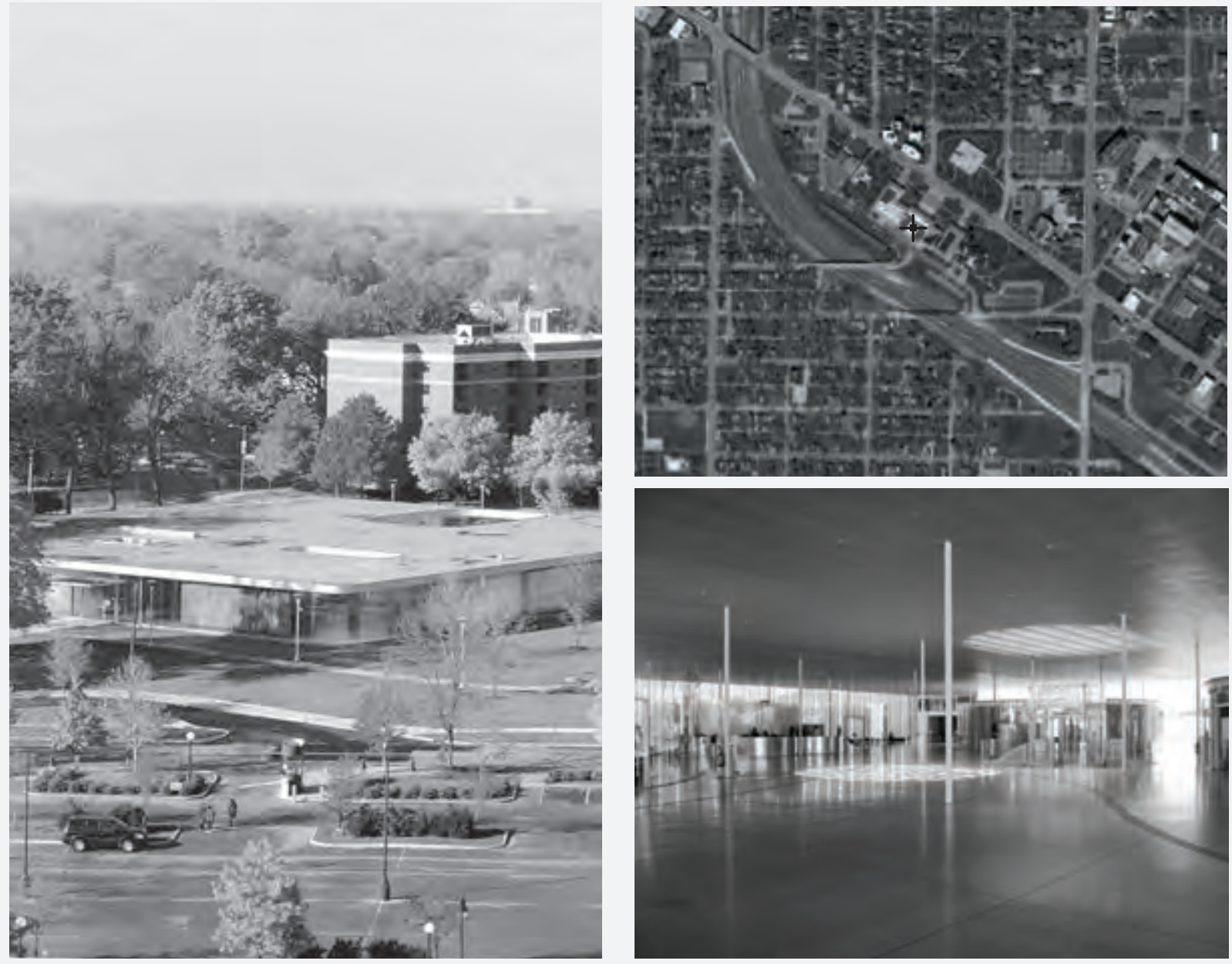
CATÁLOGO EQUIPAMENTOS MUNDO

GLASS PAVILLION - TOLEDO MUSEUM OF ART

Pav. Térreo

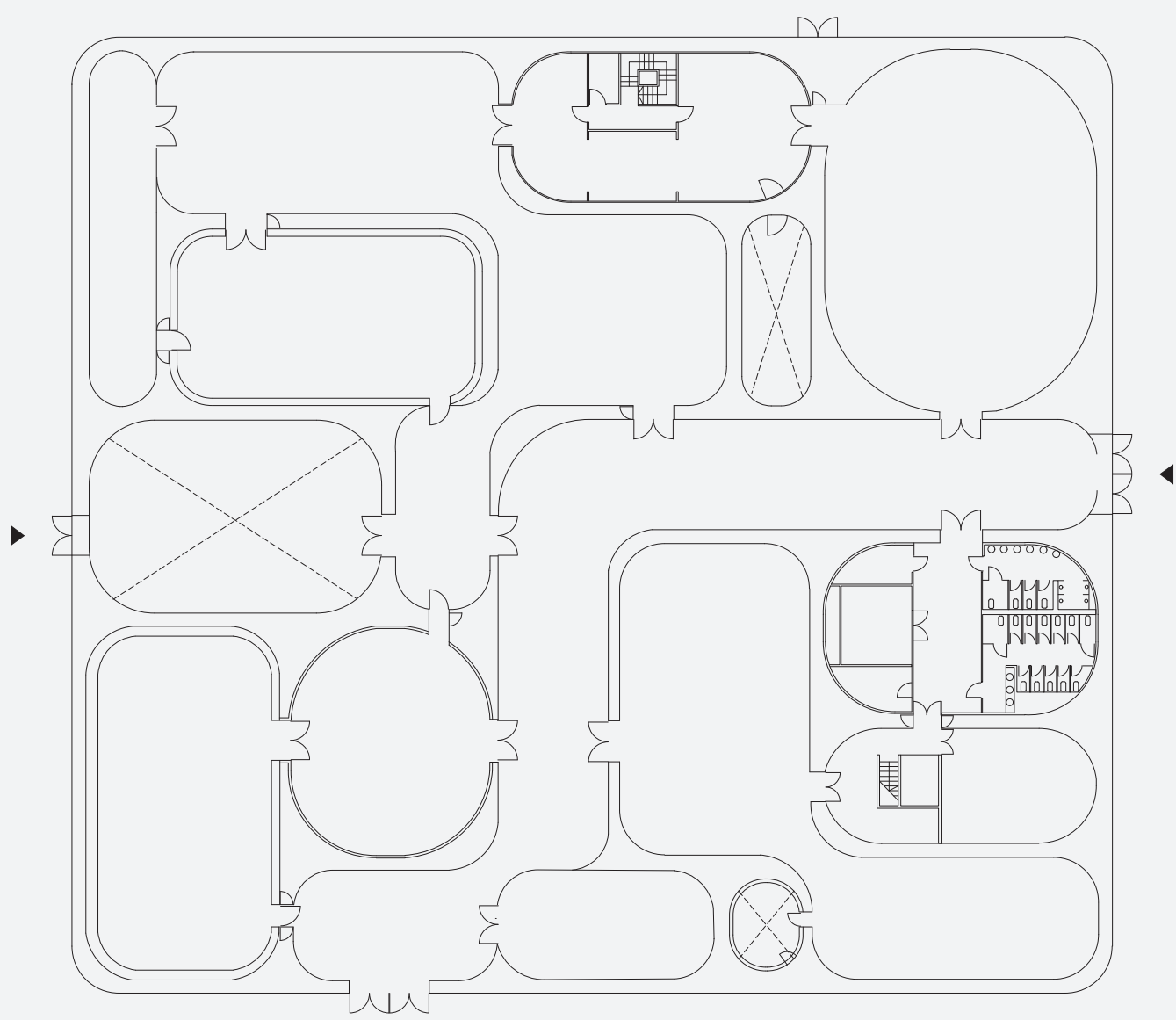




\section{CATÁLOGO EQUIPAMENTOS MUNDO}

GLASS PAVILLION - TOLEDO MUSEUM OF ART

Pav. Térreo

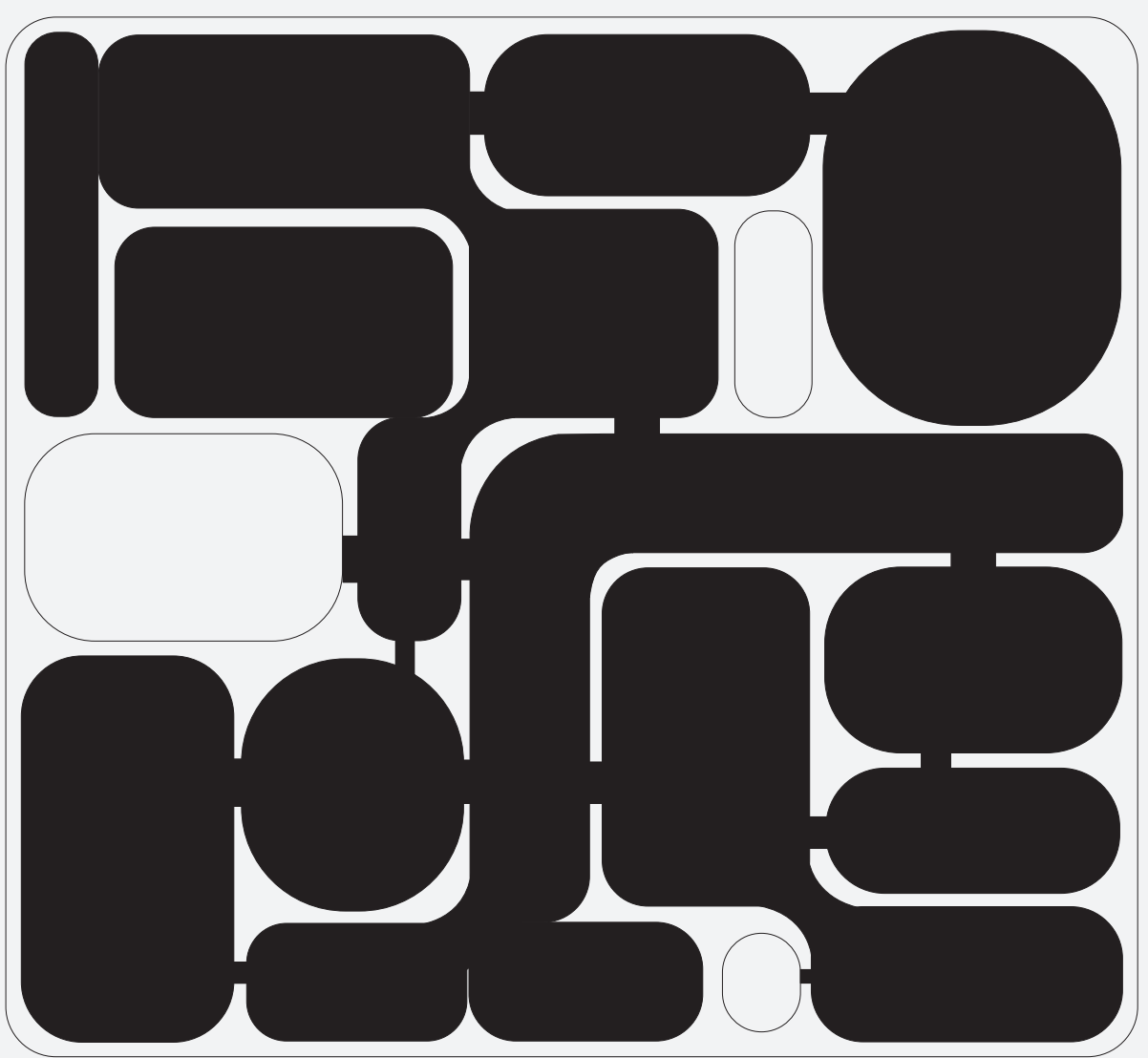




\section{CATÁLOGO EQUIPAMENTOS MUNDO}

GLASS PAVILLION DSL DISSOLUÇÃO PROGRAMÁTICA

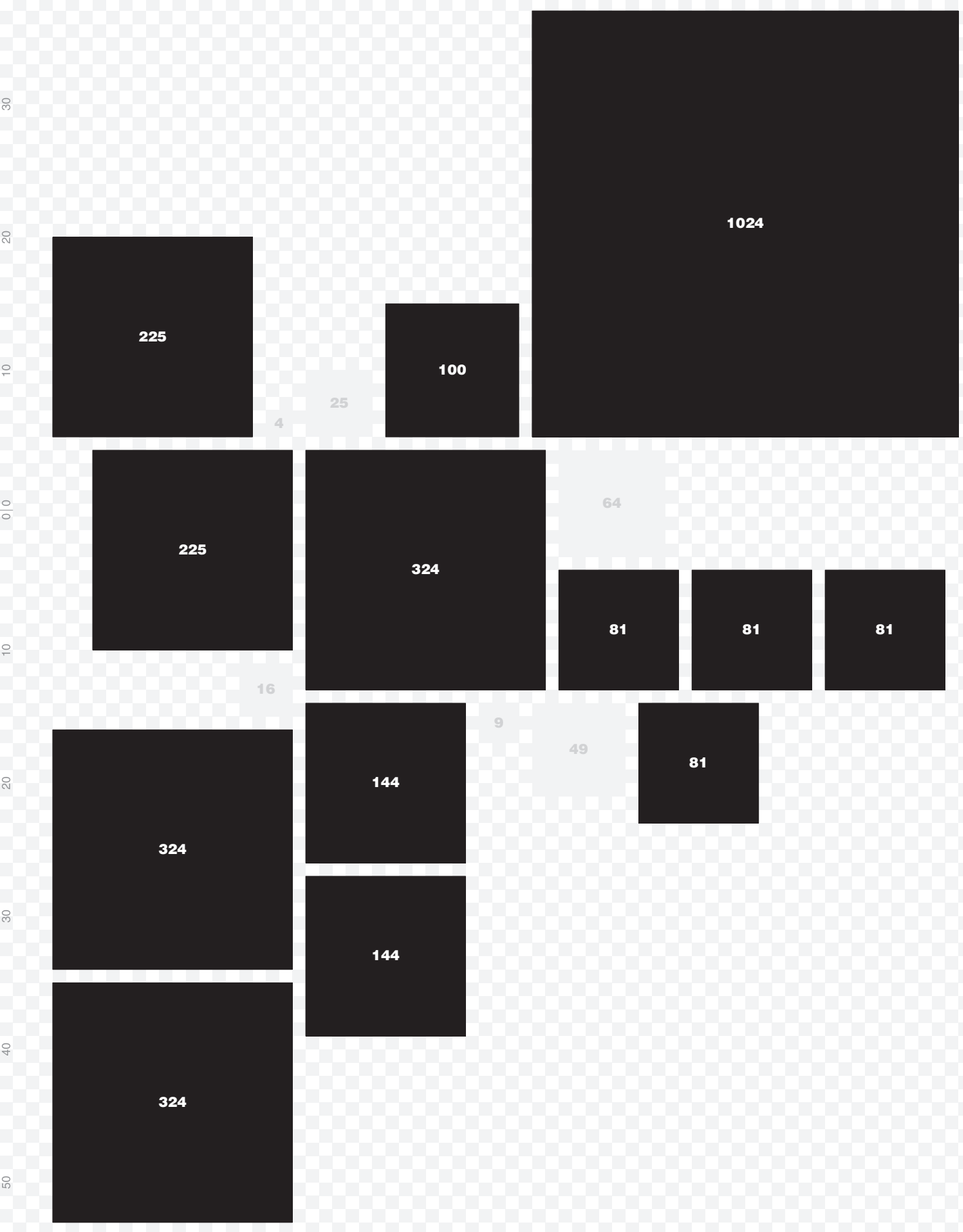




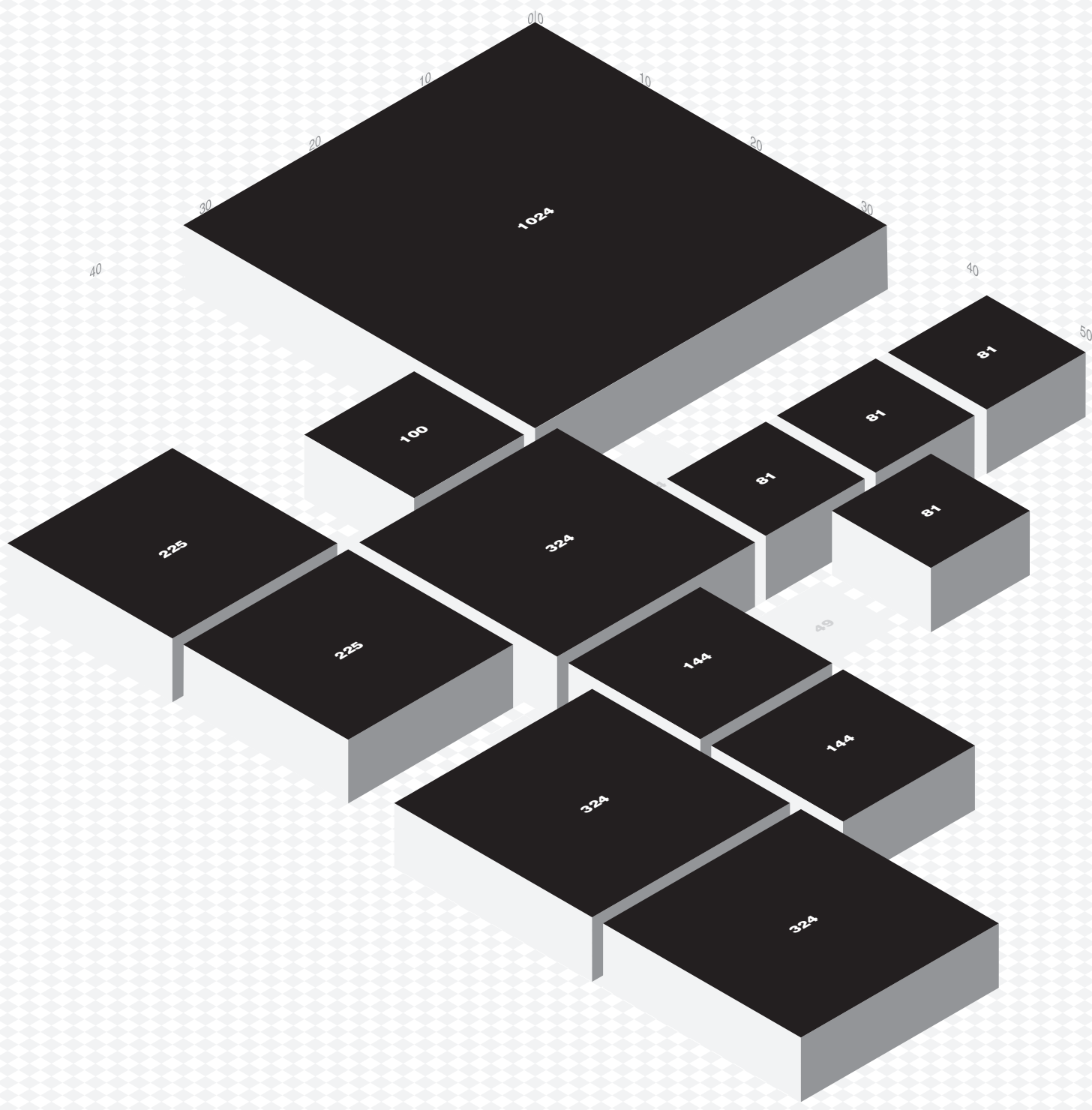



catálogo casavalle dsl

EQUIPAMENTOS PRINCIPAIS

凹

$\square$

$\sqrt[5]{55}$

$\square \square$ 


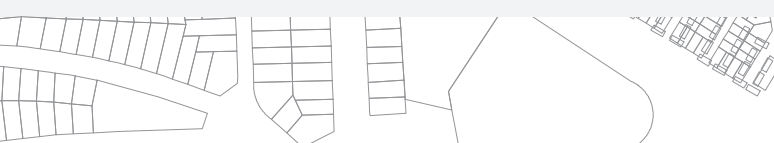

MIIIEETHC

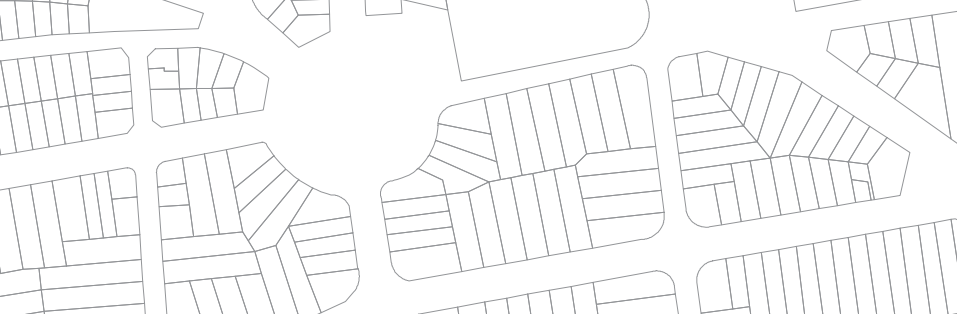

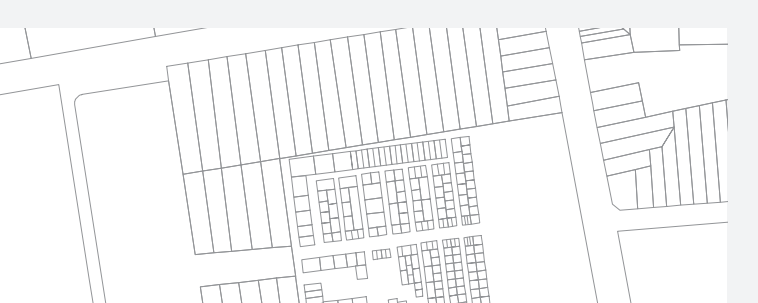

MUTIIF

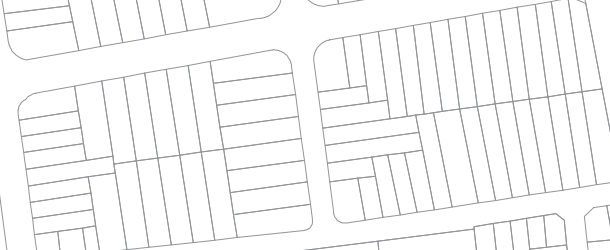

国lle
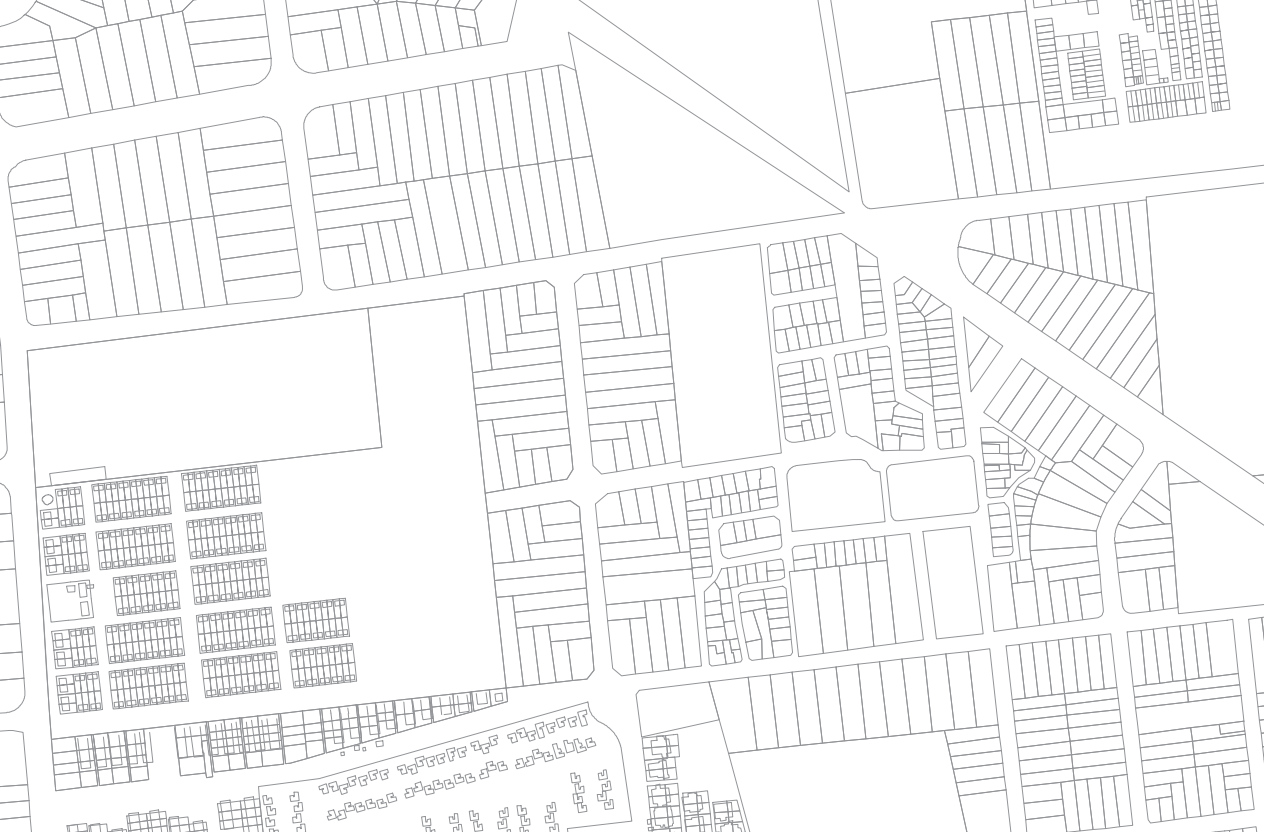

E(TII Fi
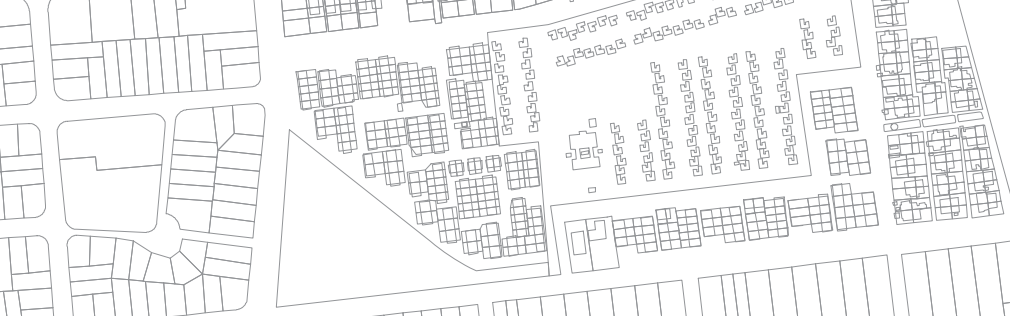

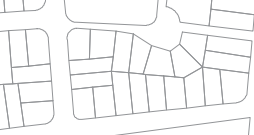
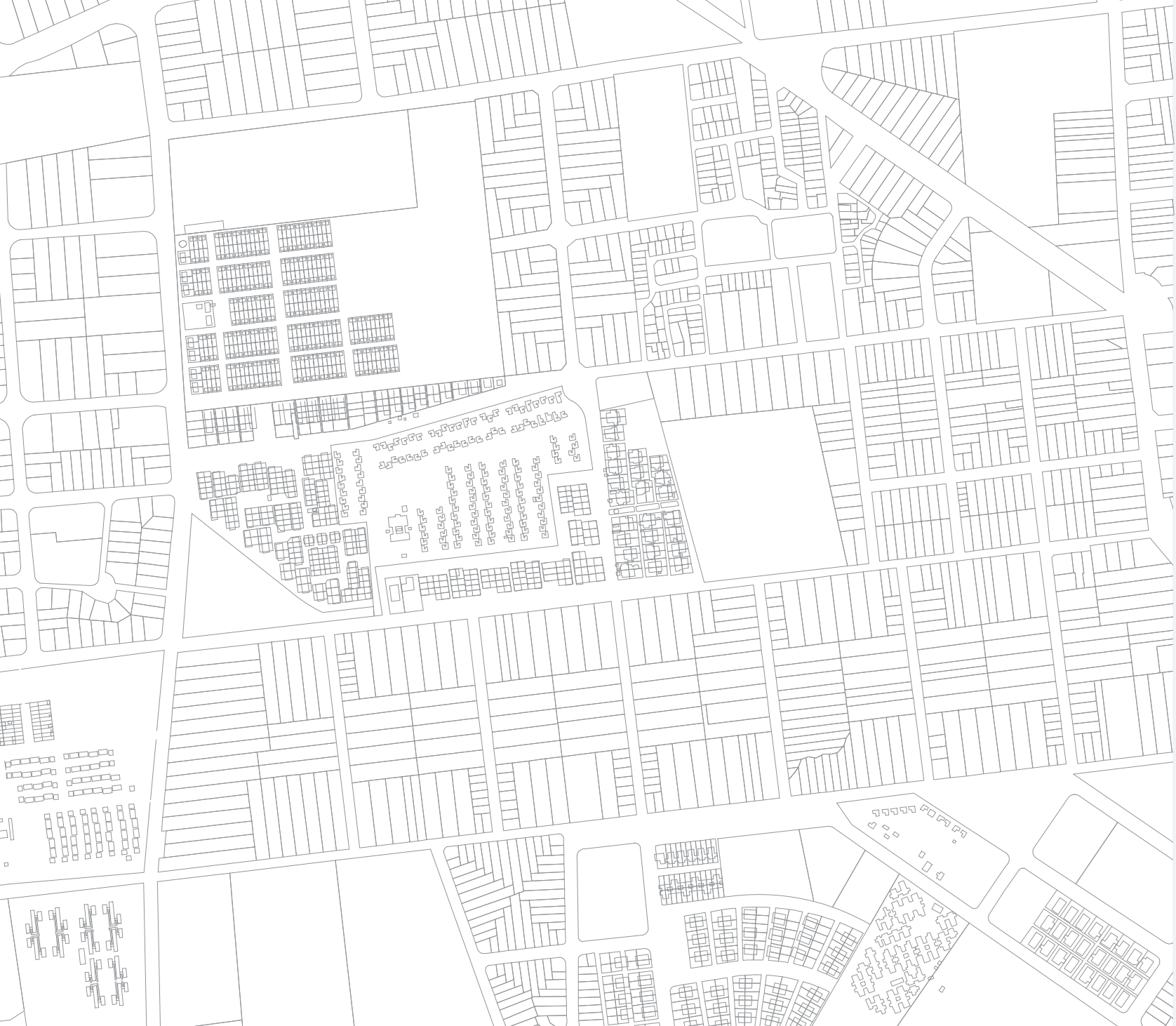


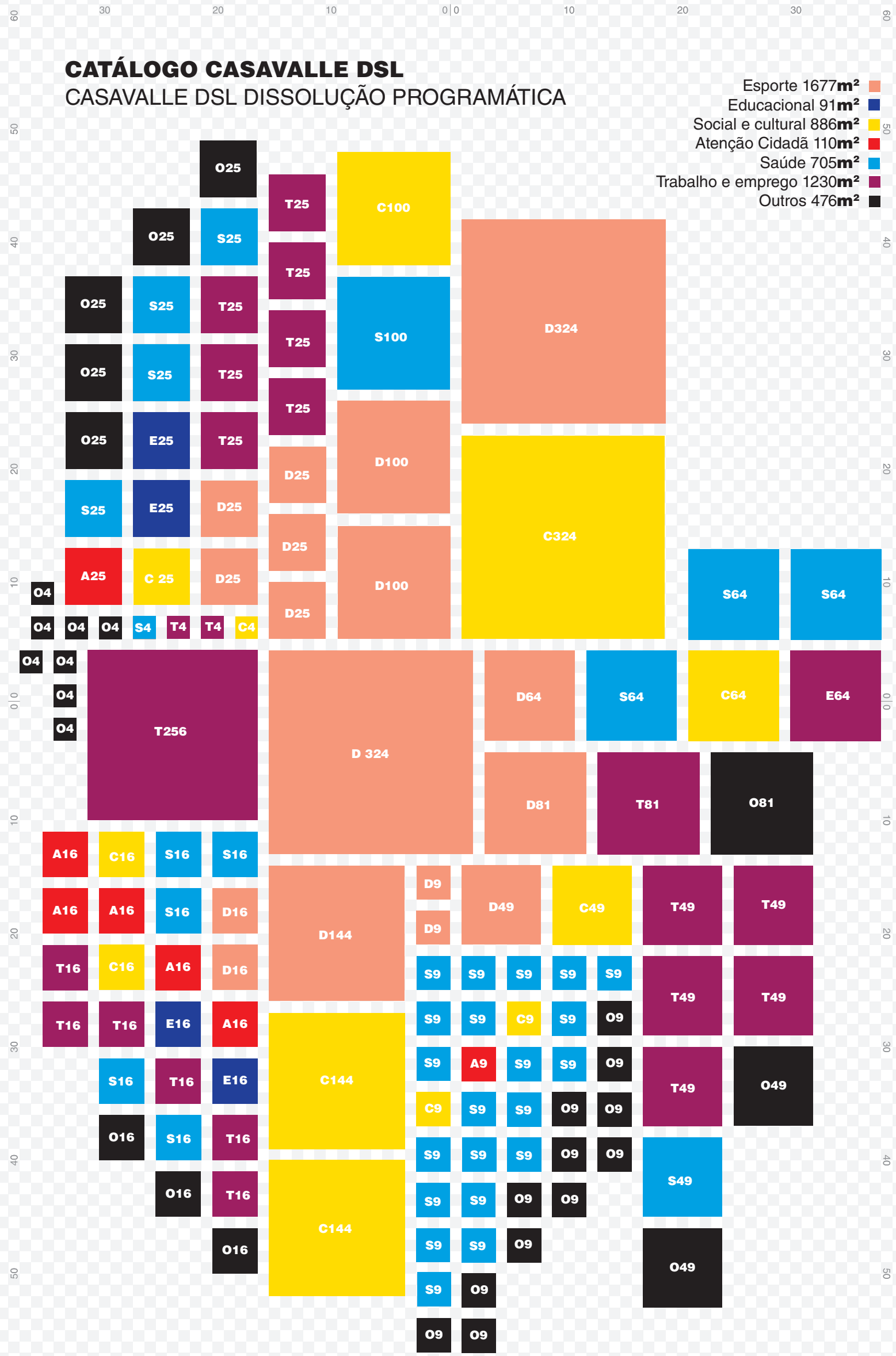




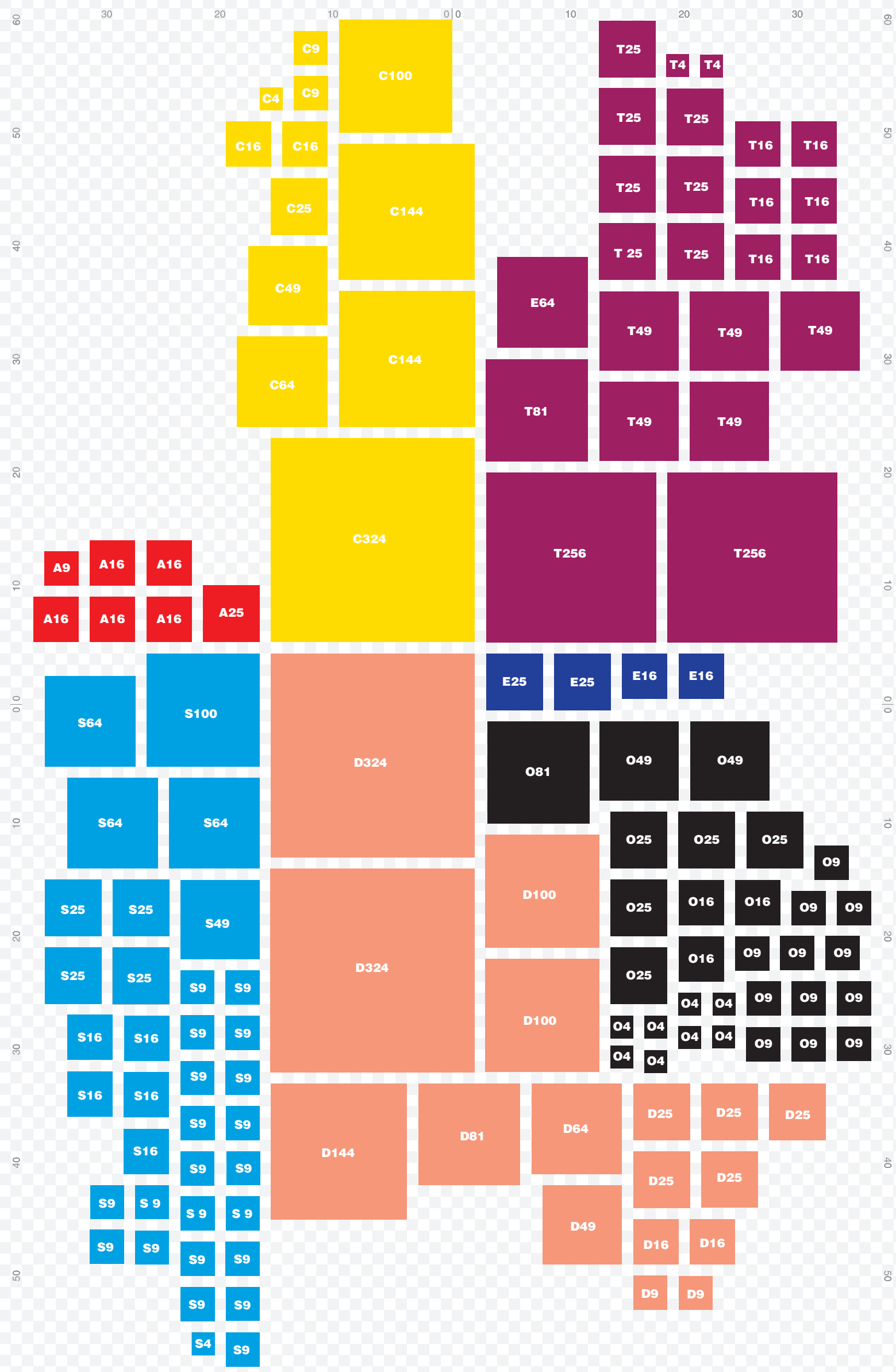




\section{catálogo casavalle dSL}

CASAVALLE DSL DISSOLUÇÃO ESPACIAL Área Construída $4702 \mathrm{~m}^{2}$

Área Exterior Coberta 529m

Pátios 2372m²

Terreno $12000 \mathrm{~m}^{2}$

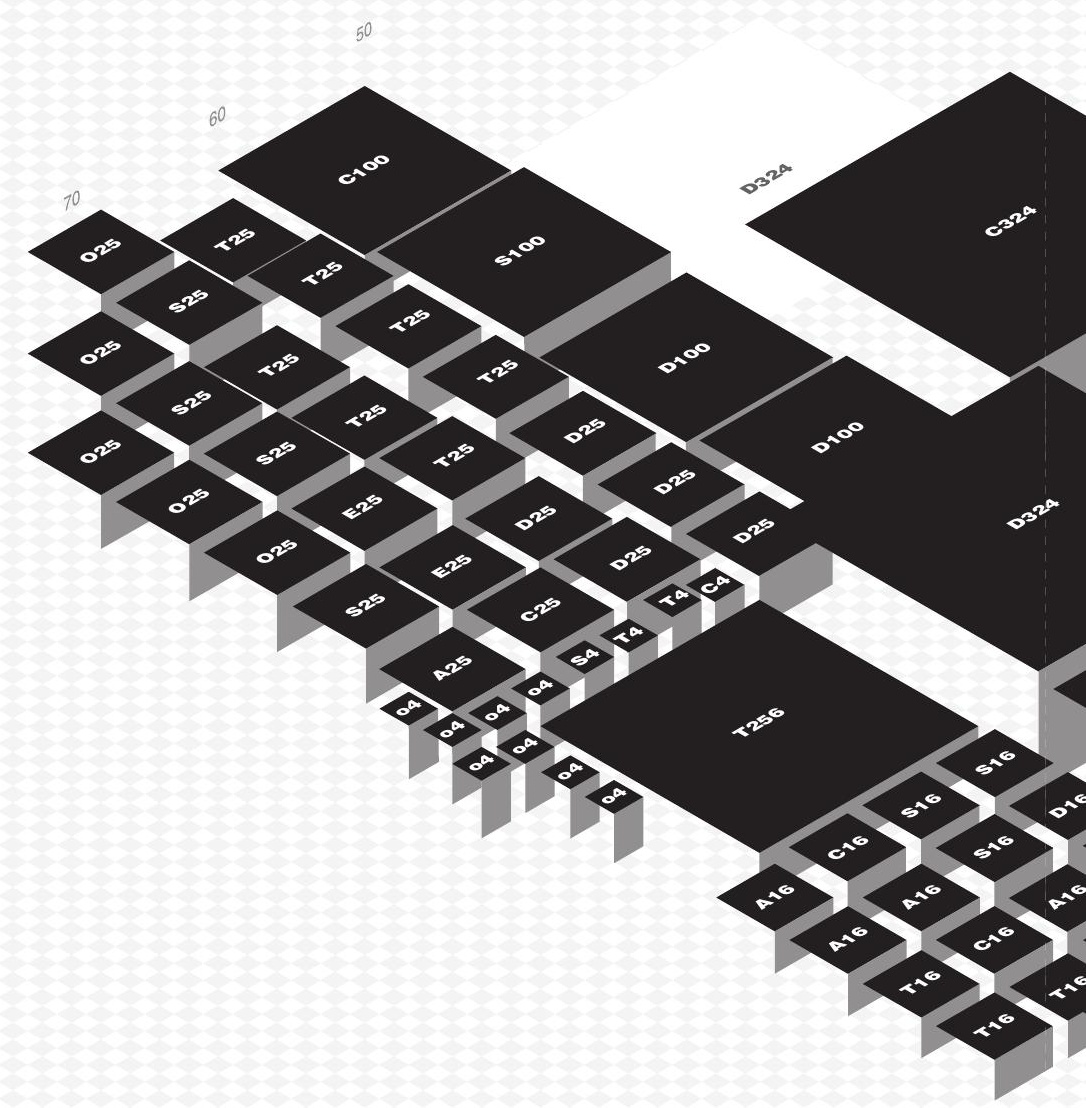


catálogo casavalle DSL

UM FÓRUM MONTEVIDEU

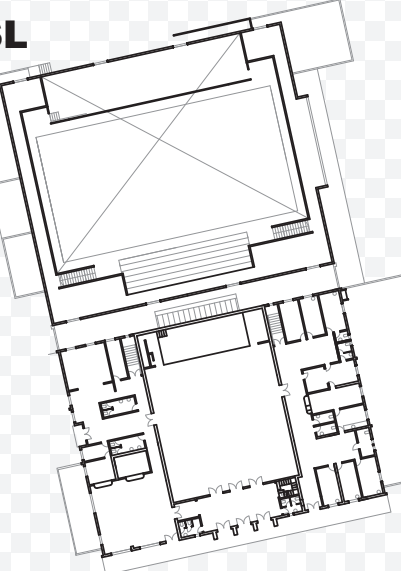

$\mathbf{K}$

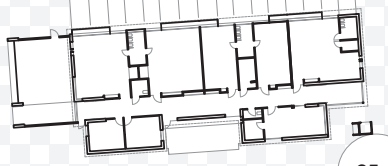

$25 \mathrm{~m}$

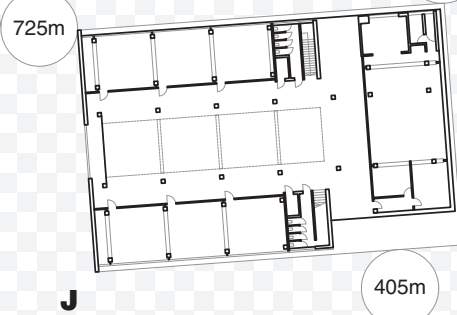
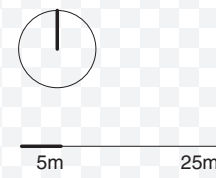
A Plaza Casavalle
B Centro Cívico Casavalle
C CEA
D Escuela 1
E Escuela 2
F Policlínica
G Bomberos
H Comisaría
I CEDEL
J Escuela China
K CAIF
L SACUDE 

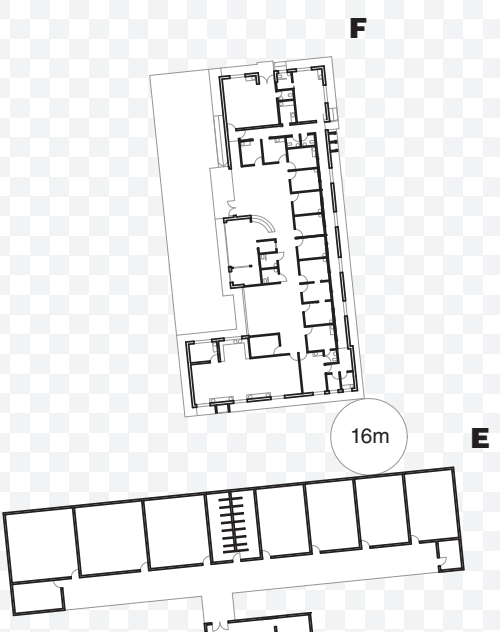

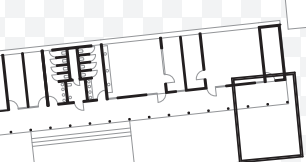

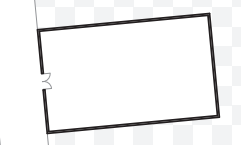

$177 \mathrm{~T}$
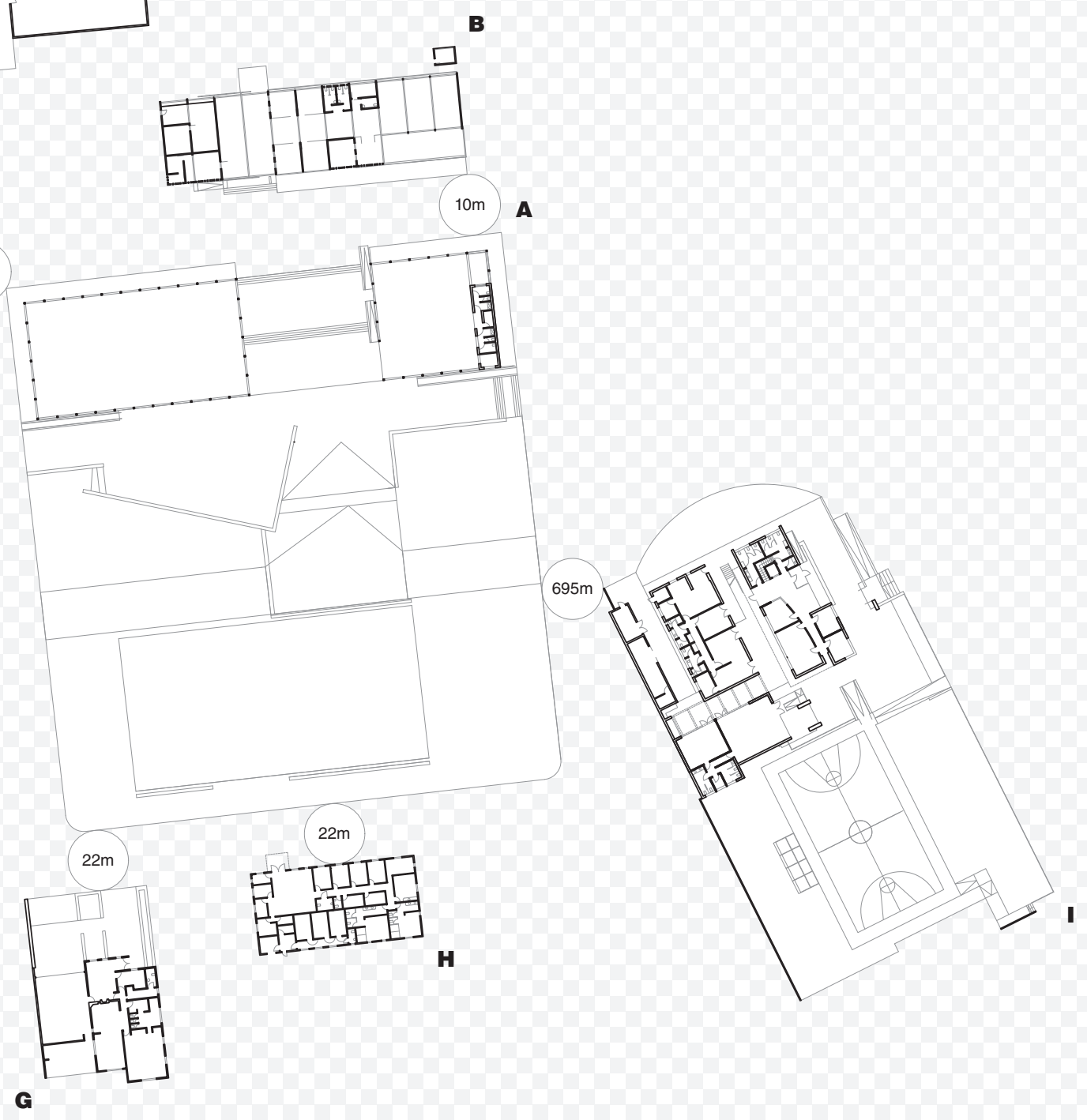
FORÚM CSVLL

FAVELAS

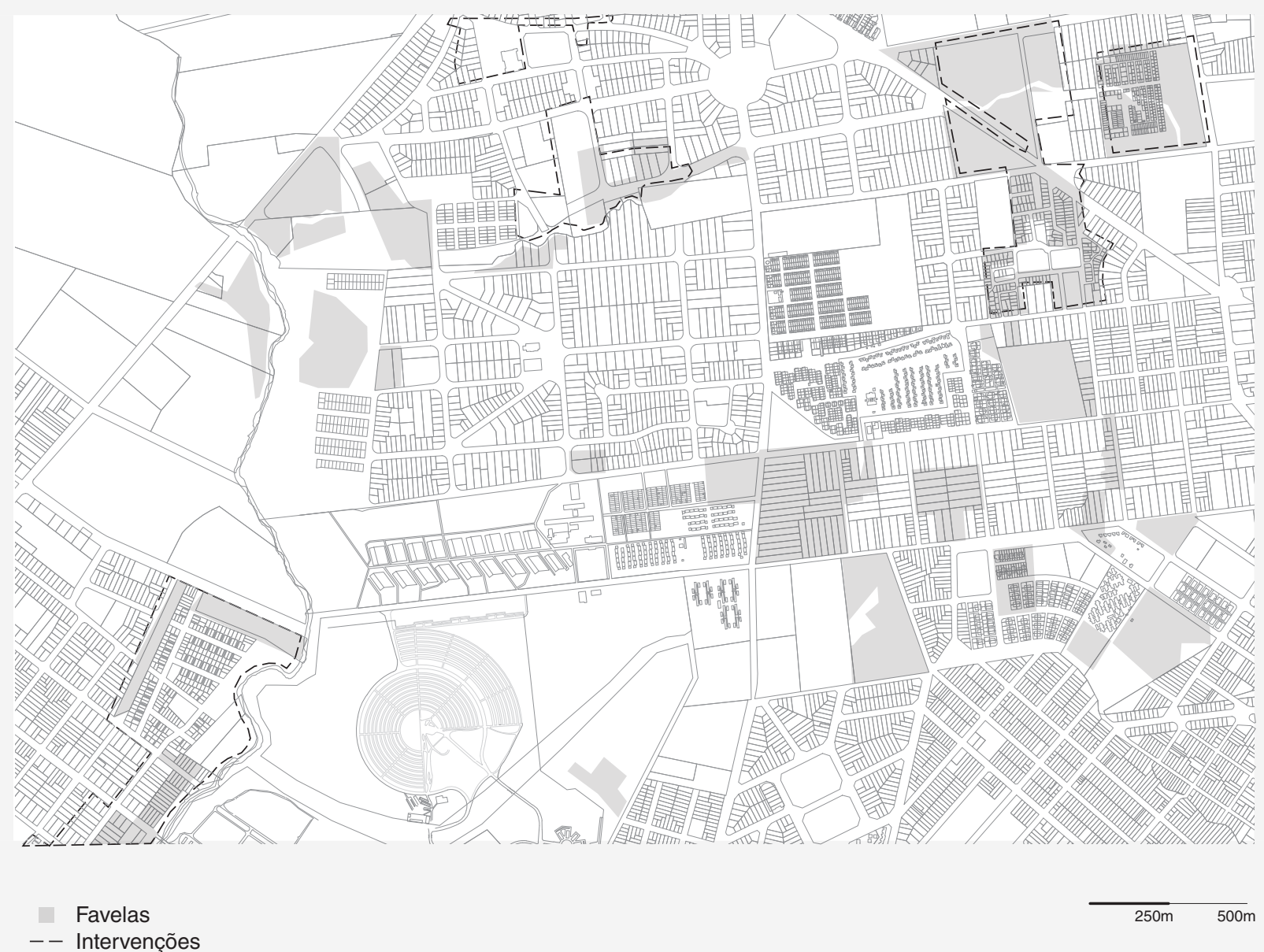




\section{FORÚM CSVLL}

EQUIPAMENTO PRINCIPAL E ESPAÇOS PÚBLICOS

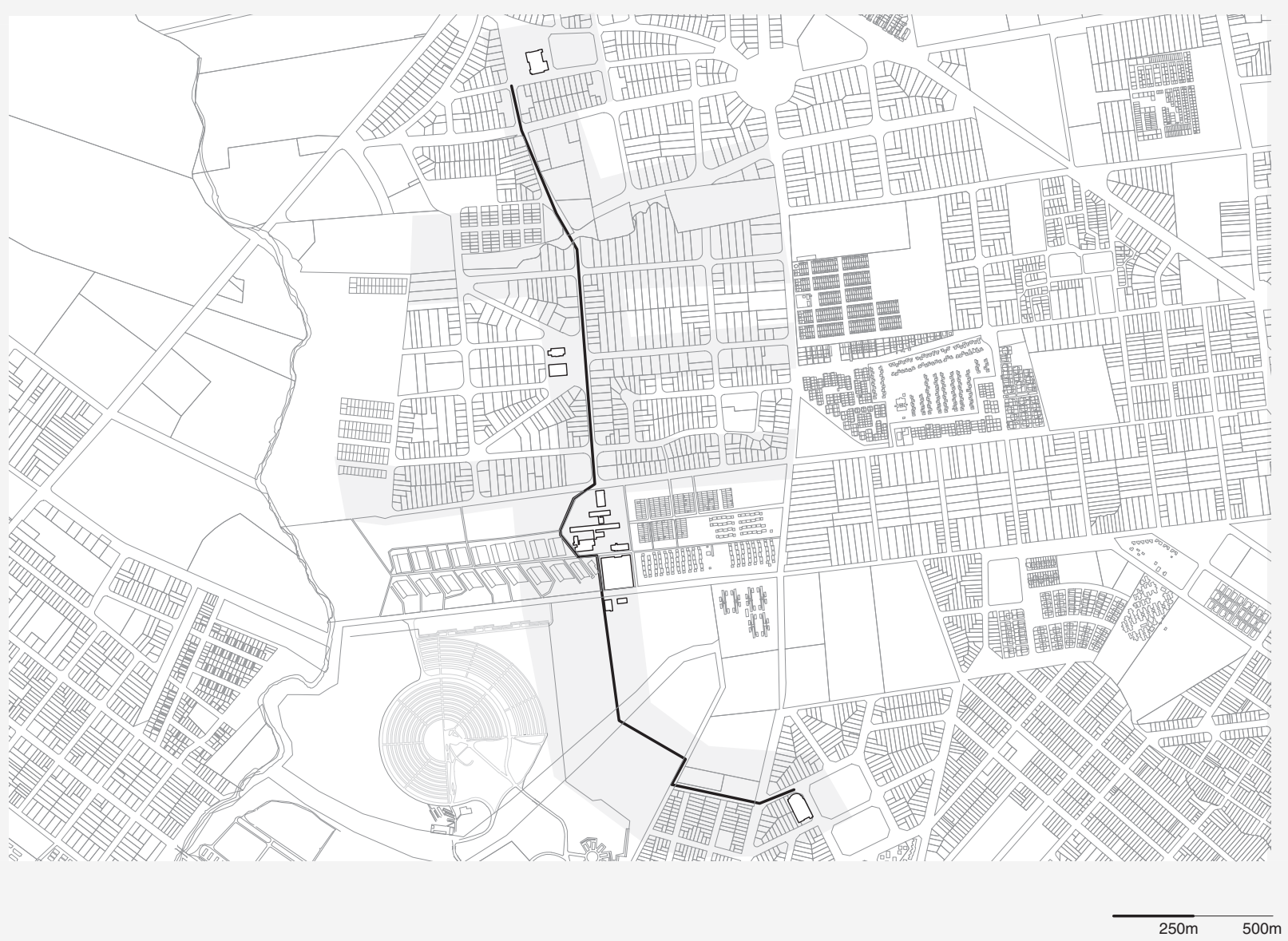


FORÚM CSVLL

EQUIPAMENTOS SEGUNDO PERFIS

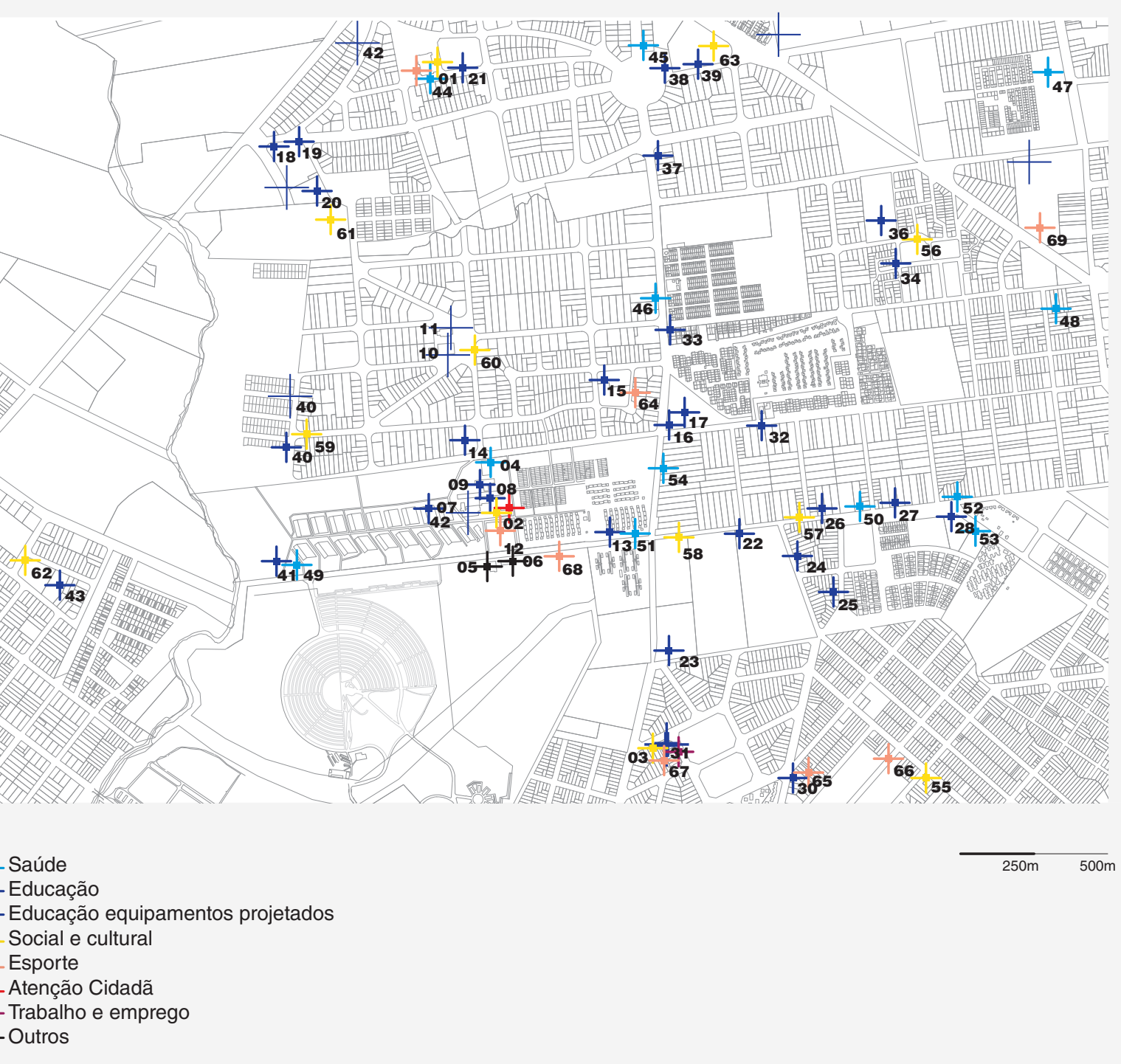

07 CEA

08 ESCUELA 178

09 ESCUELA 320
10 ESCUELA CHINA

11 CAIF 
FORÚM CSVLL

EQUIPAMENTOS SEGUNDO PERFIS

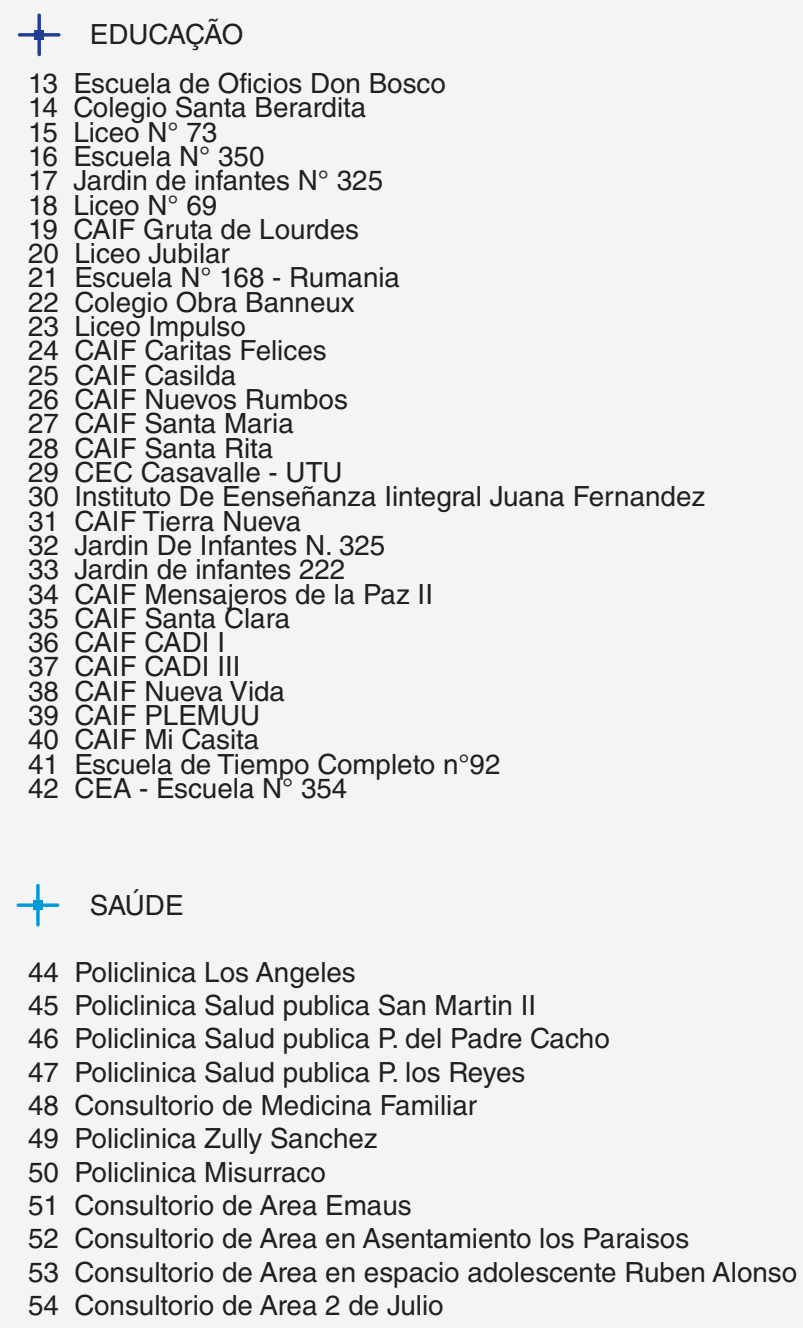

SOCIAL E CULTURAL

55 Centro Juvenil OMBU

56 Centro Juvenil LAS REDES

57 Centro Juvenil CARLOS FAVRE ESC OFICIOS

58 Centro Juvenil PIRINCHO

59 Centro Juvenil EDUCATIVO NUEVA VIDA

60 Centro Juvenil OBRA ECUMENICA

61 Centro Juvenil CUENCA CASAVALLE

62 Centro Juvenil TACURU APOYO PEDAGOGICO

63 Centro de Apoyo al Desarrollo Integral

\section{ESPORTE}

64 Cancha Sede Baby Futbol San Martin Bonomi

65 Sede y cancha de futbol Corralito

66 Estadio Cr. J P Damiani

67 Cancha Cedel

68 Club Flores Palma De Baby Futbol 


\section{FÓRUM CCZ17}

\section{FAVELAS}

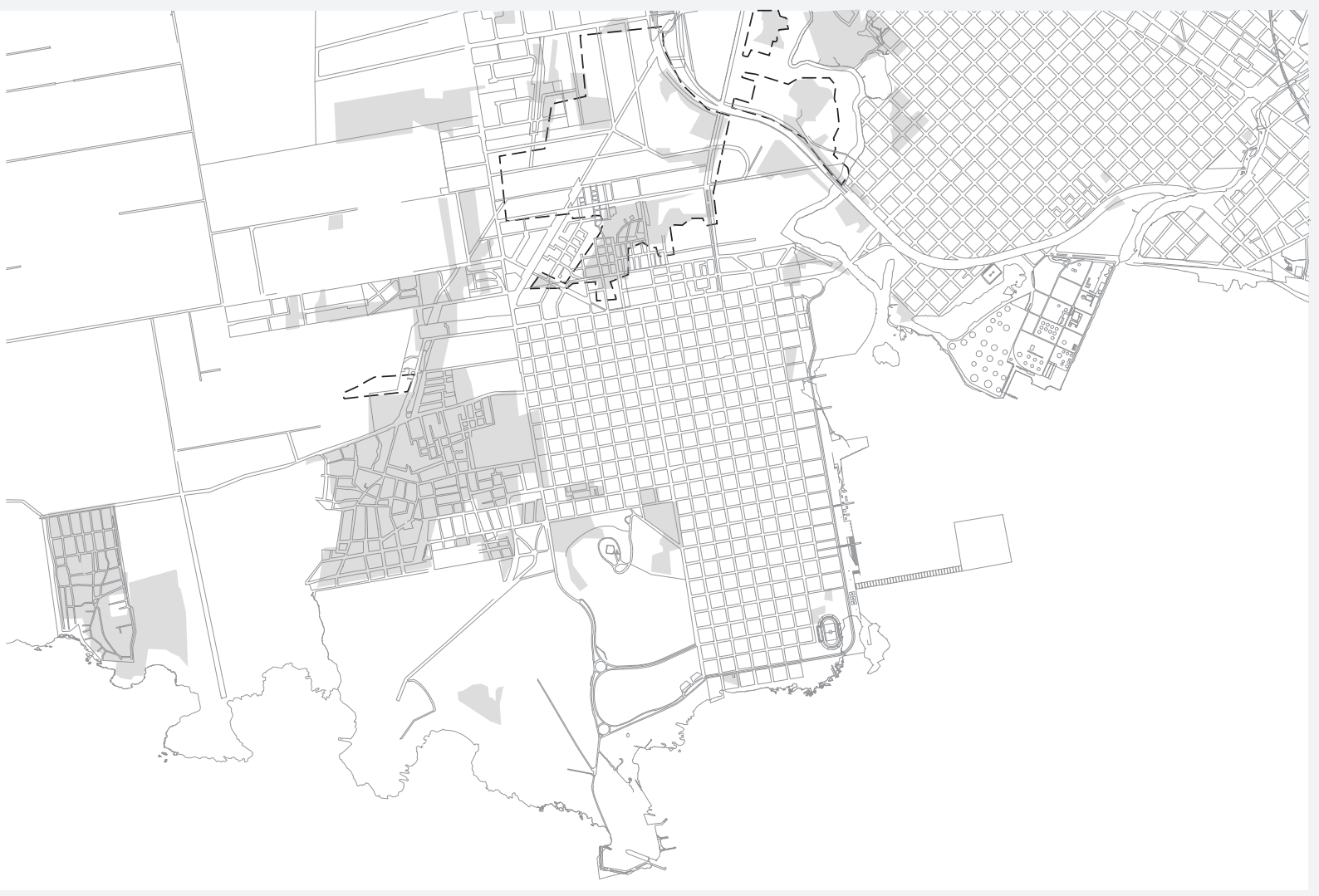




\section{FÓRUM CCZ17}

SANEAMENTO

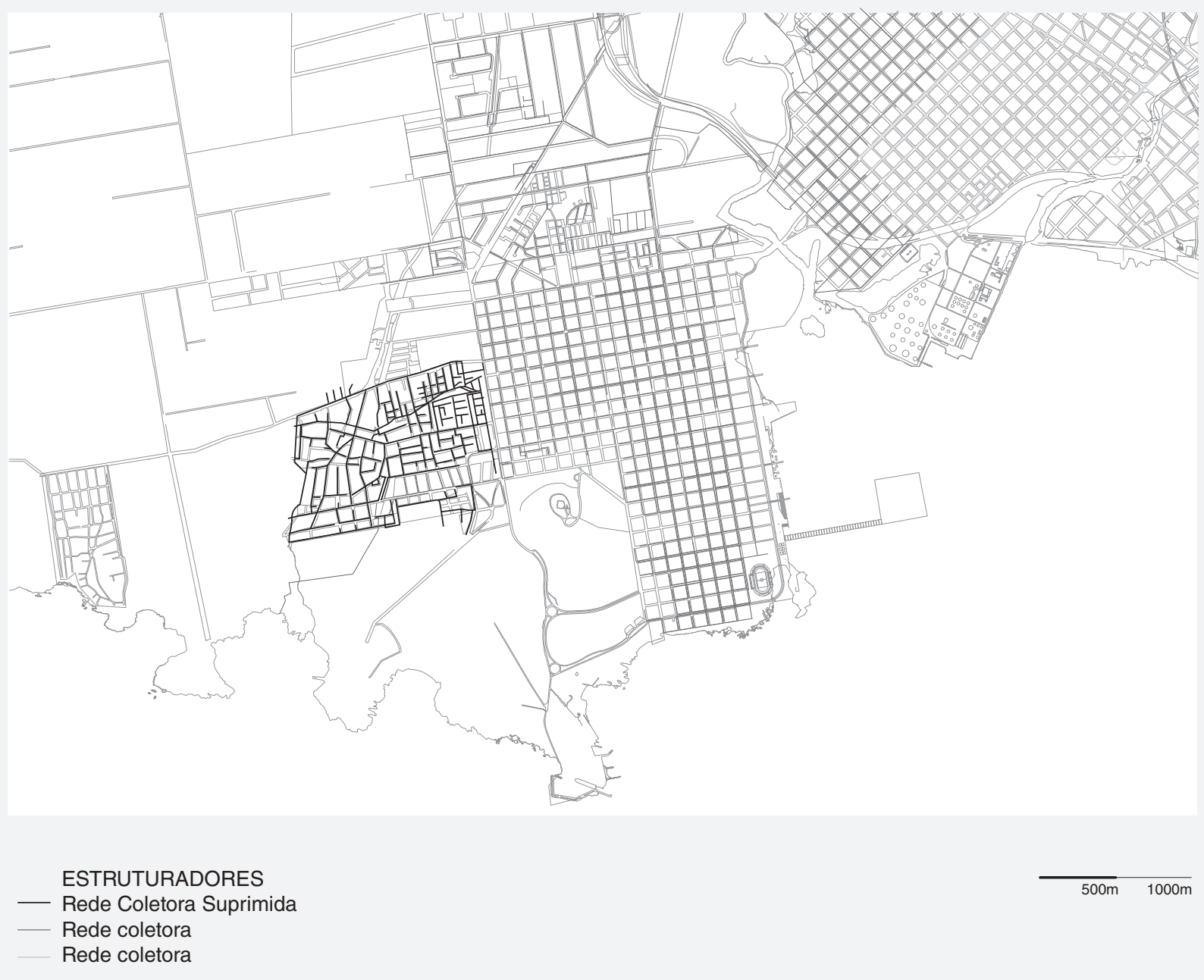




\section{FÓRUM CCZ17}

EQUIPAMENTOS SEGUNDO PERFIS

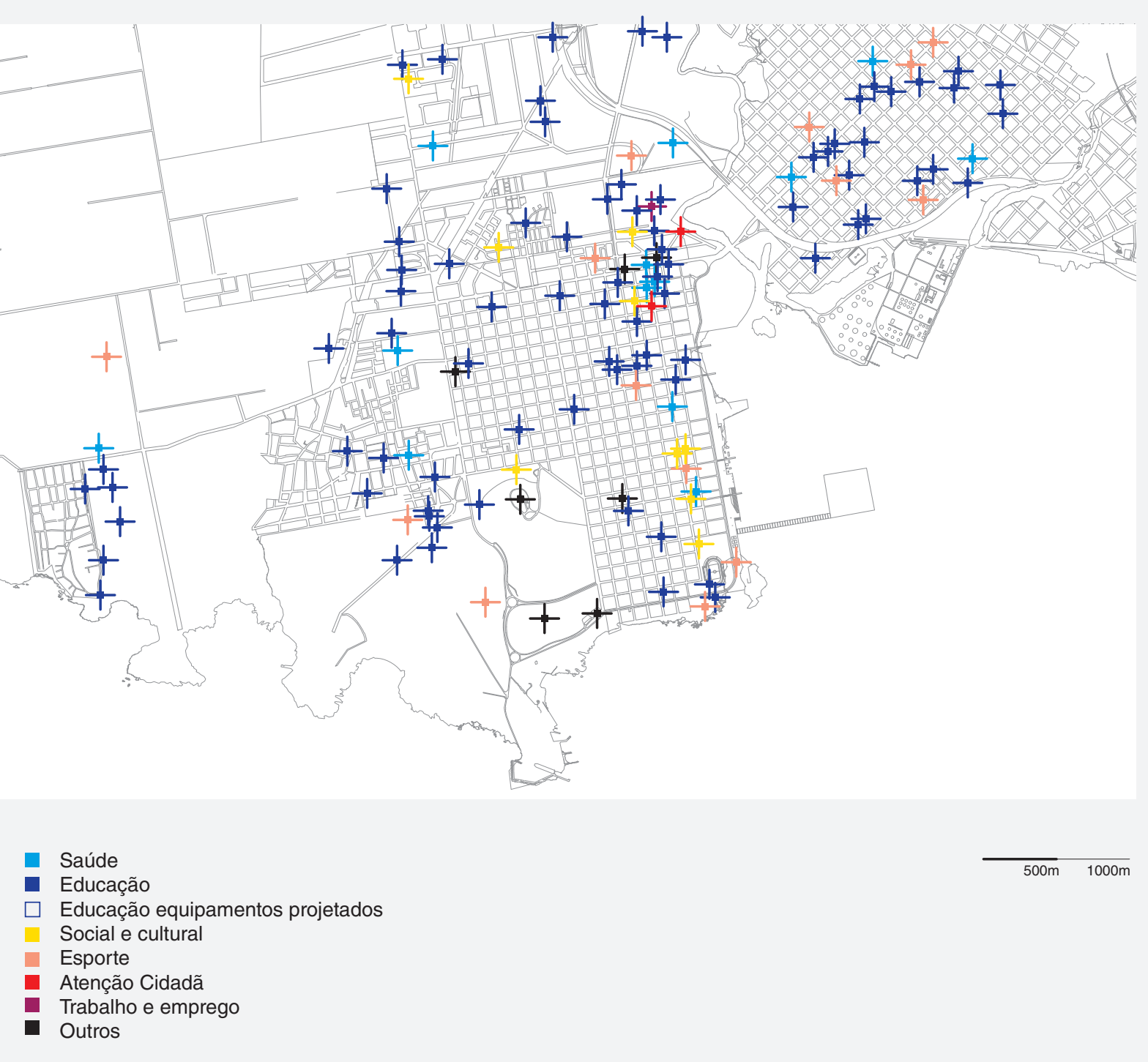


FÓRUM CCZ17

EQUIPAMENTOS SEGUNDO PERFIS
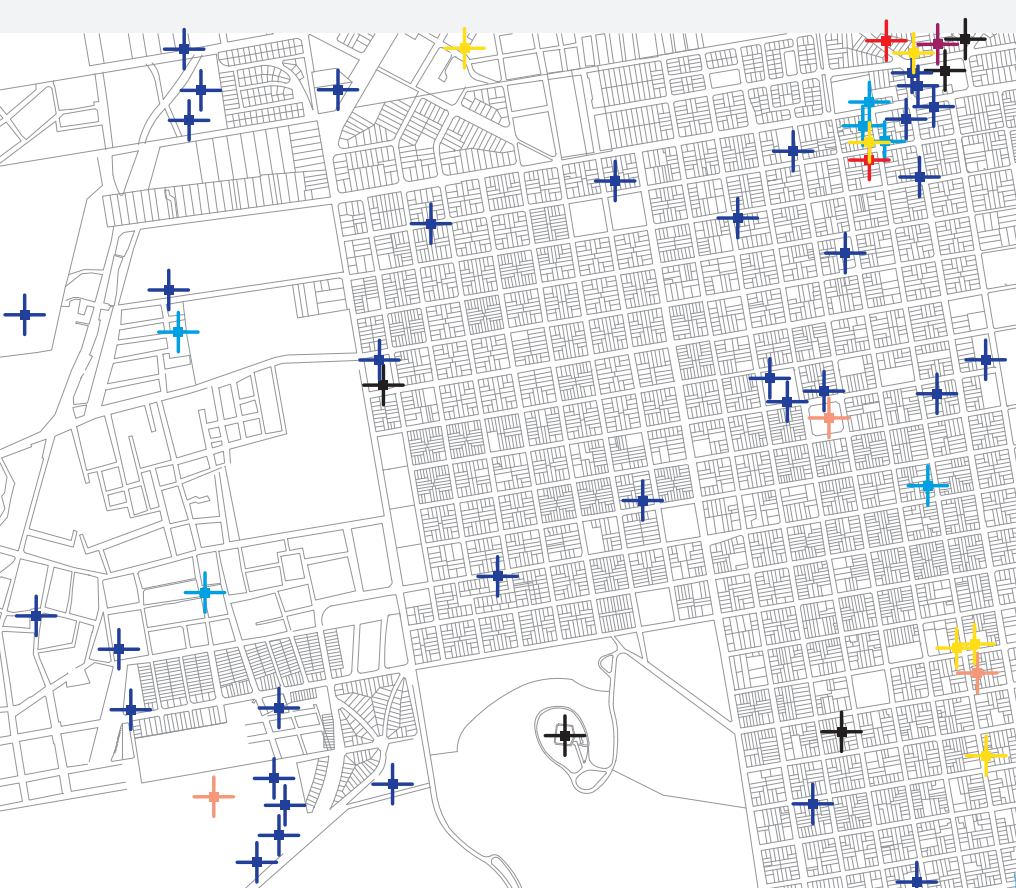

$+$

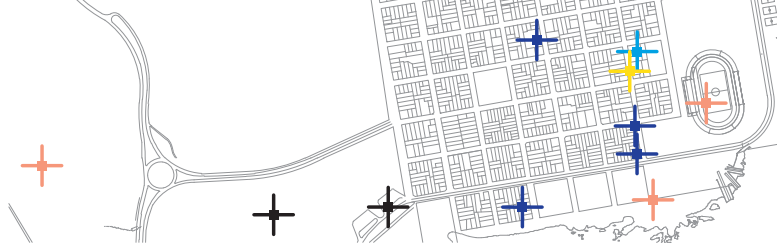

Saúde

- Educação

$\square$ Educação equipamentos projetados

Social e cultural

Esporte

- Atenção Cidadã

- Trabalho e emprego

- Outros 


\section{FÓRUM CCZ17}

EQUIPAMENTOS PRINCIPAIS

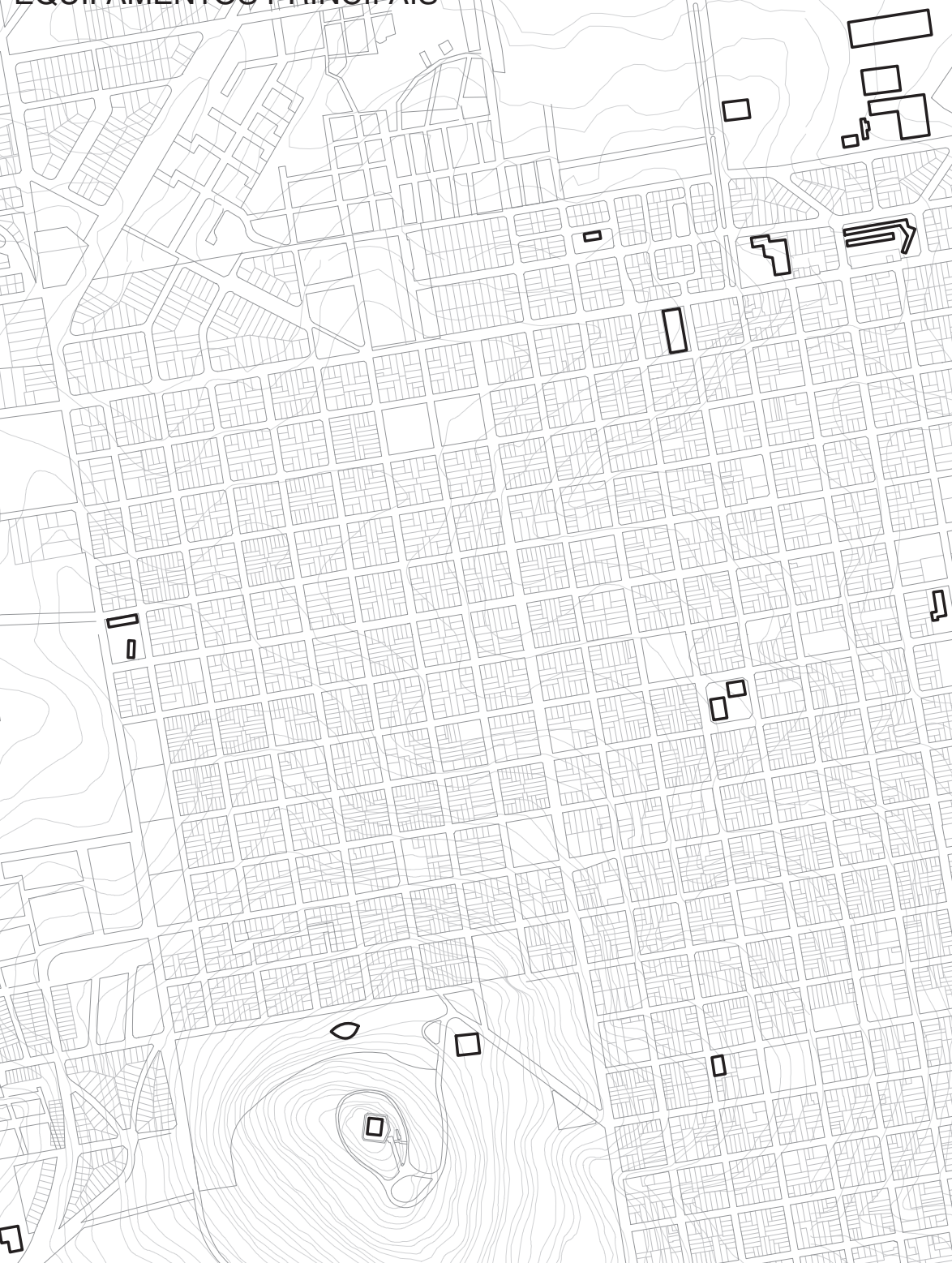

I

$\square$

$\diamond$

$[5$ 

MORE WITH LESS

ESTRUTURA DA TESE 


\section{DESIGUALDADES POR MUNICÍPIO}

Montevideo - San José - Canelones

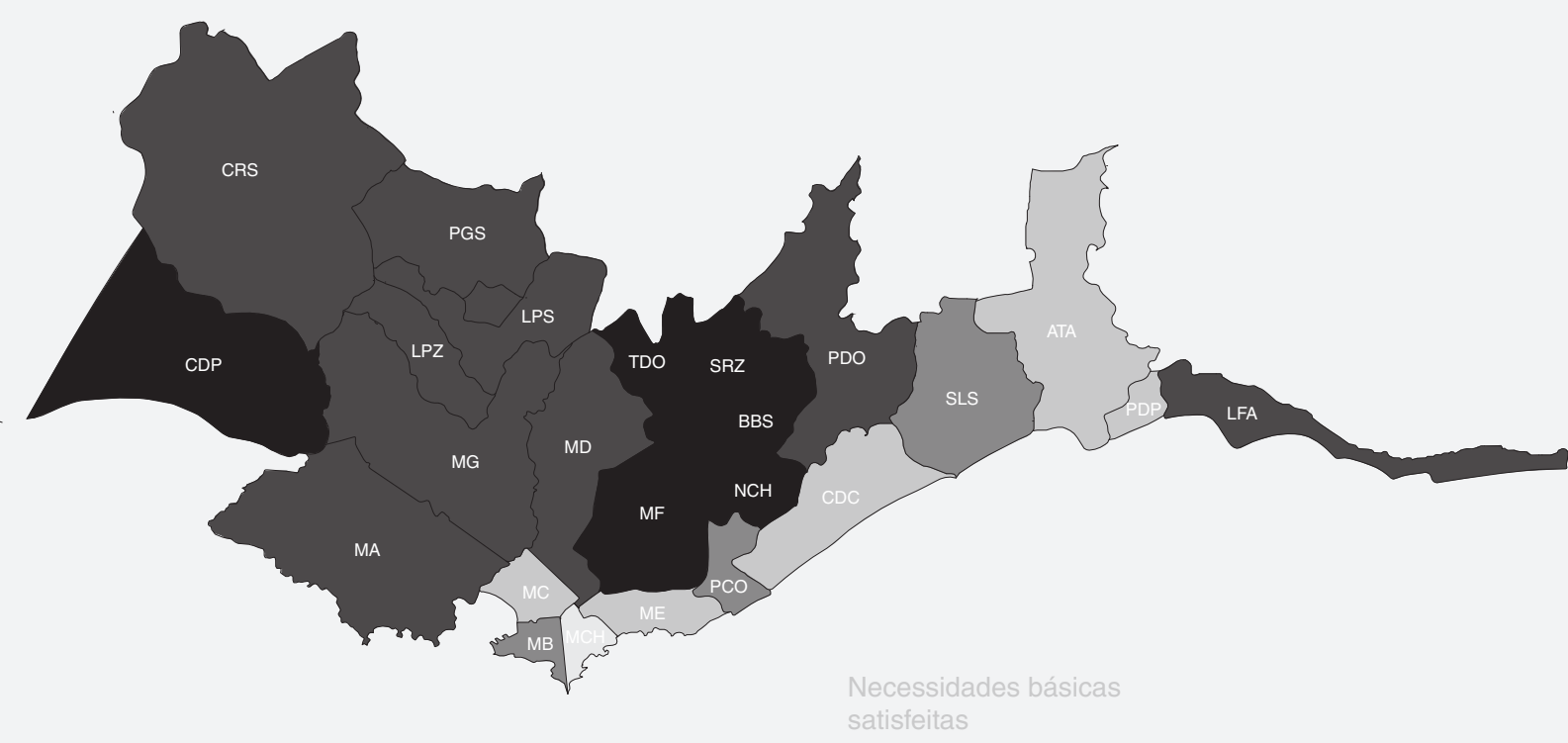

Uma NBI

Dois NBI

Três ou mais NBI

Municípios com ao menos uma necessidade básica insatisfeita (percentualmente)

$03.7 \%$ a $14.3 \%$

$14.3 \%$ a $21.1 \%$

$21.2 \%$ a $29.0 \%$

- $29.0 \%$ a $40.4 \%$

- $40.4 \%$ a $50.9 \%$

Municipios Montevideo: MA - Municipio A / MB - Municipio B / MC - Municipio C/ MCH - Municipio CH / MD - Municipio D / ME - Municipio E / MF - Municipio F / MG - Municipio G // Municipios Canelones: CRS - Cerrillos / LPZ - La Paz / LPS - Las Piedras / PGS - Progreso / TDO - Toledo / SRZ - Suarez / BBS - Barros Blancos / NCH - Colonia Nicholich / PCO - Paso Carrasco / PDO - Pando / CDC - Ciudad de la Costa / SLS - Salinas / ATA - Atlantida / PDP - Parque del Plata / LFA La Floresta // Municipios de San Jose: CPD - Ciudad del Plata Dados obtidos do site http://www.otu.opp.gub.uy 


\section{AREA METROPOLITANA POR MUNICÍPIOS}

Municípios com pelo menos uma necessidade básica insatisfeita

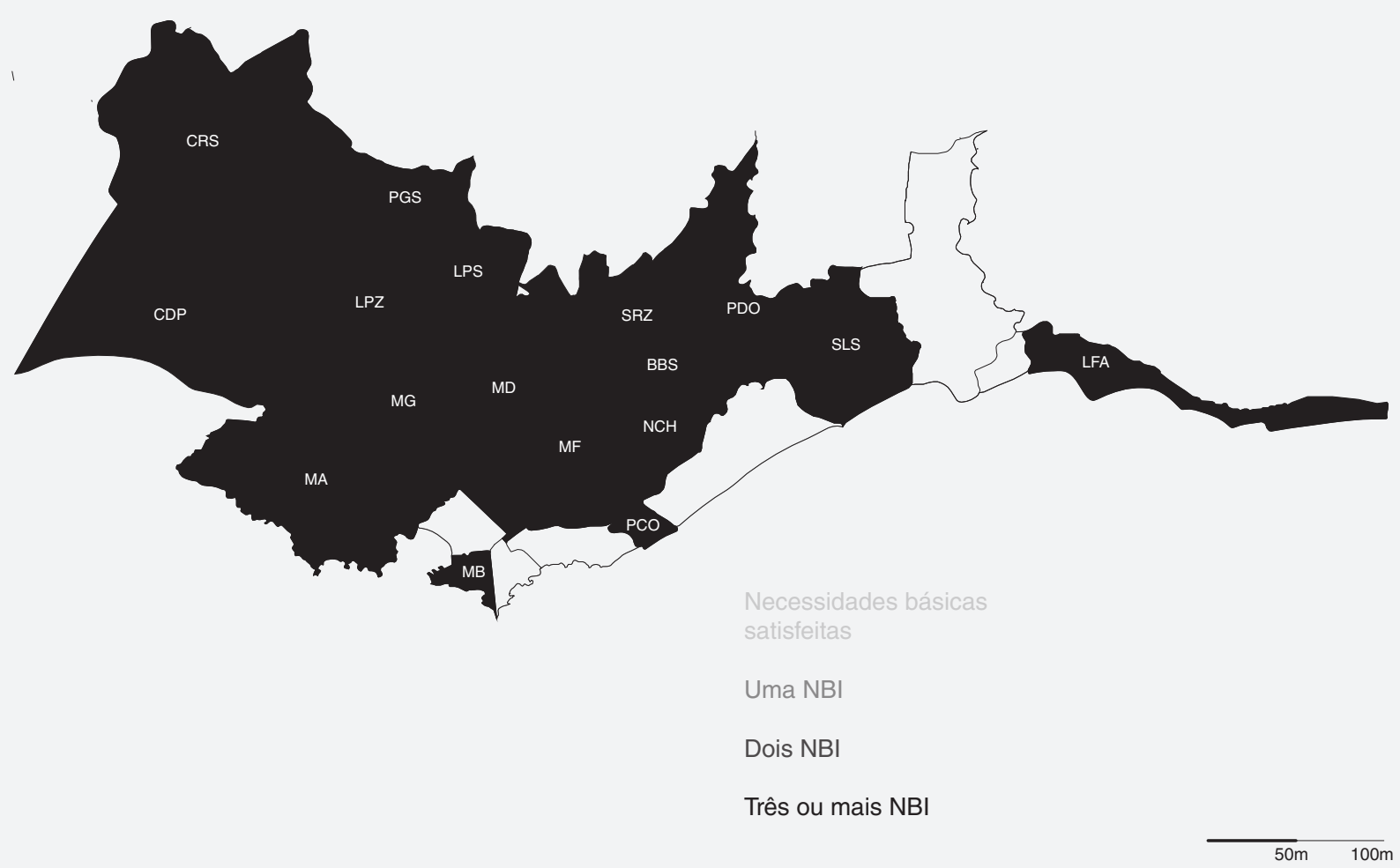

- Municípios com porcentagens maiores a 21,1\%

Municípios com porcentagens menores a $21,1 \%$ 


\section{AREA METROPOLITANA POR MUNICÍPIOS}

Municípios com pelo menos uma necessidade básica insatisfeita

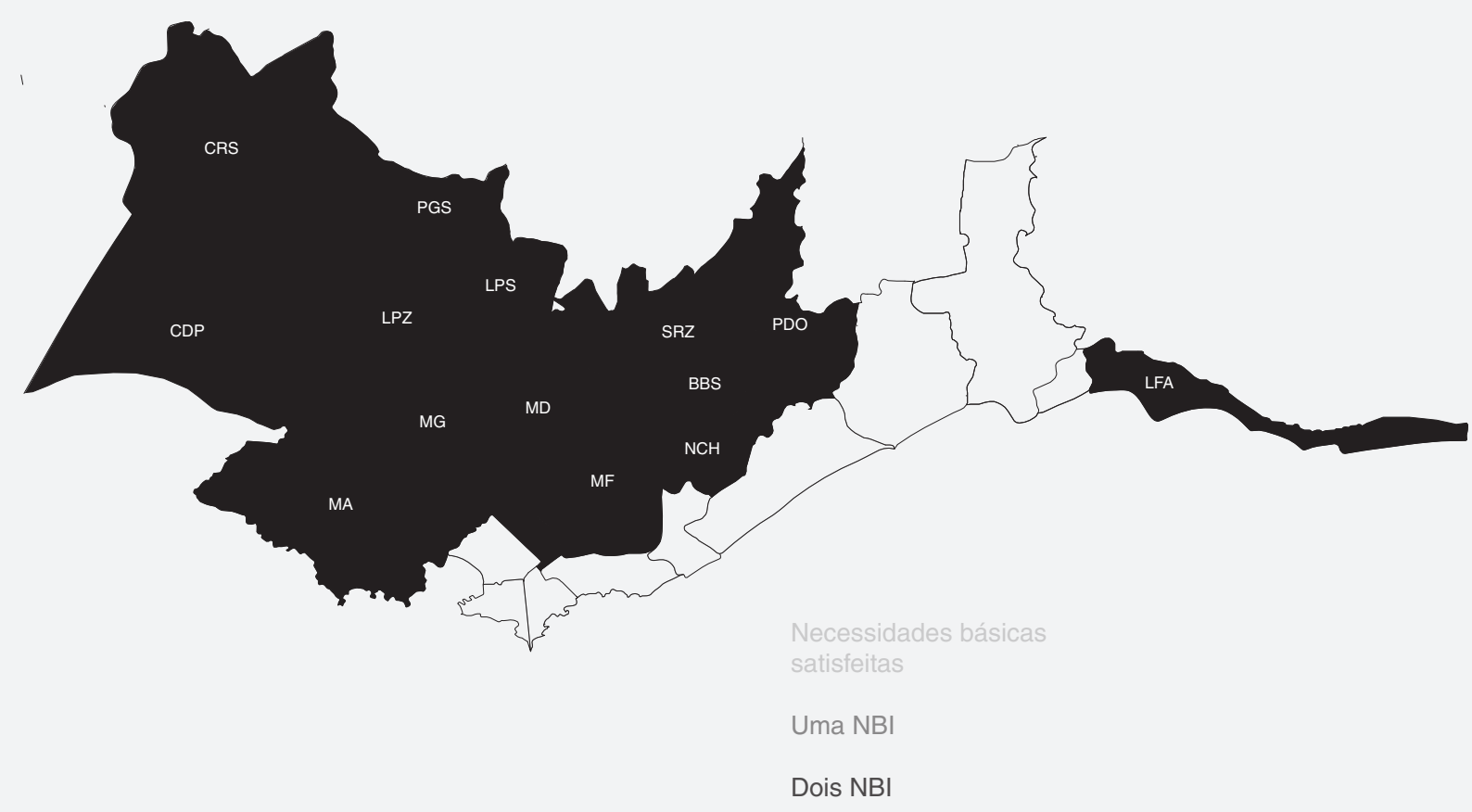

Três ou mais NBI

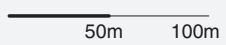

- Municípios com porcentagens maiores a 29,0\% Municípios com porcentagens menores a $29,0 \%$ 


\title{
MUNICÍPIO A
}

\author{
Montevidéu
}

Tendo os dados do Censo 2011 como base, o município contra com uma população de 207.911 habitantes. A densidade populacional é de 1.441,6 hab/km2, enquanto que a densidade de Montevidéu é de $2.488,2 \mathrm{hab} / \mathrm{km} 2.96,6 \%$ da população do município é urbana, majoritariamente de ascendência étnica branca (87,5\%), a população afro ou negra representa $6,6 \%$ da população. A proporção de pessoas com ao menos uma NBI é de $38,3 \%$, valor superior a media do departamento $(26,8 \%)$ e nacional $(33.8 \%)$

Os indicadores do mercado de trabalho do município apresentam uma situação similar à nacional nas taxas relativas à atividade e emprego, mas inferiores à média departamental. No entanto, a taxa de desemprego é maior que a departamental assim como a nacional, que são muito parecidas. O município tem uma taxa de atividade de 62,7\%, uma taxa de emprego de 57,3\% e uma taxa de desemprego de $8,6 \%$ (2011).

$1,5 \%$ da população de 15 anos ou mais deste município é analfabeta. Por outro lado, a taxa líquida de assistência (TLA) aos 6 primeiros anos do ensino fundamental é parecida a TLA departamental assim como à nacional. No entanto, a TLA ao ensino médio é menor tanto em comparação à TLA departamental como à nacional. O município tem uma TLA referente aos 6 primeiros anos do ensino fundamental de $92,5 \%$ enquanto que a departamental é de $92,4 \%$. Para o ensino médio a TLA é de $62 \%$ para o município e $69,8 \%$ para o departamento.

Texto livremente traduzido do site http://www.otu.opp.gub.uy

População: 207.911 habitantes

Área: $144,2 \mathrm{~km} 2$.

\section{DEMOGRAFIA}

População Urbana: $96.6 \%$

População por idades:

De 0 a 14 anos: 48.938 hab. $-23.54 \%$

De 15 a 24 anos: 34.143 hab. $-16.42 \%$

De 25 a 44 anos: 57.012 hab. $-27,42 \%$

De 45 a 64 anos: 42.395 hab. $-20.39 \%$

Mais de 65 anos: 25.423 hab. $-12.23 \%$

\section{RENDIMENTOS E BEM ESTAR}

Percentual da população que tem uma ou mais necessidades básicas insatisfeitas (moradia digna, saneamento, água potável, eletricidade, conforto, educação): $38,3 \%$ (superior a média nacional, 33,8\%)

\section{EDUCAÇÃO}

Nível de escolaridade da população compreendida entre 25 e mais anos:

Primeiros 6 anos do Ensino Fundamental: $36.8 \%$

Ensino Fundamental: $26.1 \%$

Ensino Médio: $17.6 \%$

Educação Técnica: $8.3 \%$

Universidade: $6.1 \%$

Percentual de crianças entre 6 e 11 anos que vão a escola: 92.5\%

Percentual de crianças e adolescentes entre 12 e 17 anos que vão ao ensino médio: $62 \%$

\section{MERCADO DE TRABALHO}

Percentual da população em atividade: $62.7 \%$ Percentual da população empregada: $57.3 \%$

Percentual da população em situação de desemprego: $8.6 \%$ (mais alta que a média do país, 6.3\% em 2011)

\section{TECNOLOGIA}

Percentual da população com acesso a conexão a Internet:

$38 \%$

Percentual da população que tem computador ou laptop: $43.6 \%$
Percentual de lares segundo a quantidade de NBI 2011

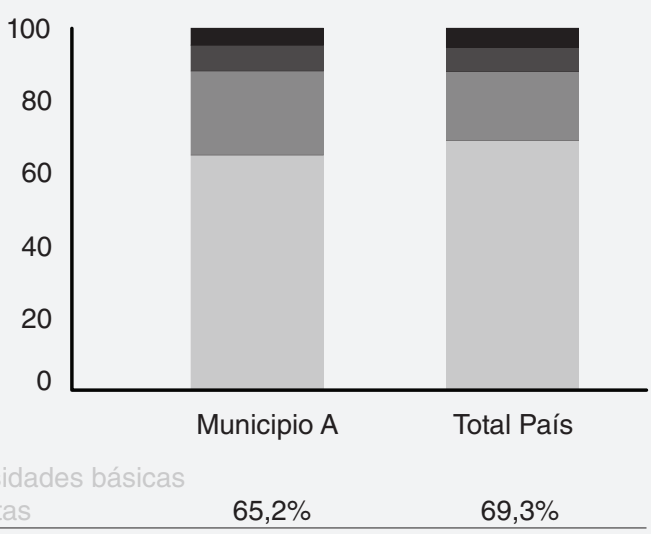

\begin{tabular}{lll}
\hline Satisfeitas & $65,2 \%$ & $69,3 \%$ \\
\hline Uma NBI & $23,5 \%$ & $19,6 \%$ \\
\hline Dois NBI & $6,9 \%$ & $6,4 \%$ \\
\hline Três ou mais NBI & $4,4 \%$ & $4,7 \%$ \\
\hline
\end{tabular}

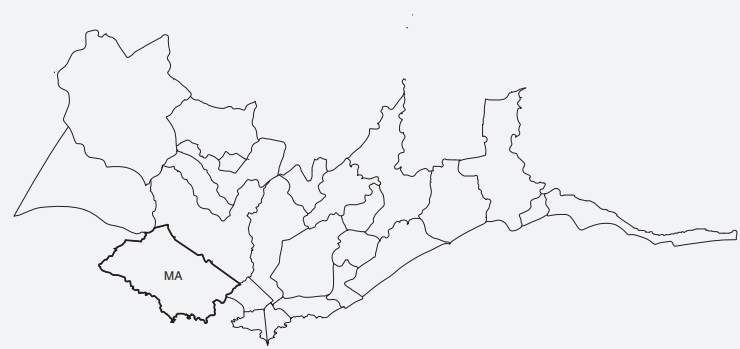




\section{MUNICÍPIO B}

\section{Montevidéu}

Tendo os dados do Censo 2011 como base, o município contra com uma população de 147.577 habitantes. A densidade populacional é de $12.493,8 \mathrm{hab} / \mathrm{km} 2$, enquanto que a densidade de Montevidéu é $2.488,2 \mathrm{hab} / \mathrm{km} 2.100 \%$ da população do município é urbana, majoritariamente de ascendência étnica branca $(92,9 \%)$, a população afro ou negra representa $2,6 \%$ da população. A proporção de pessoas com ao menos uma NBI é de $21,7 \%$, valor inferior a media do departamento $(26,8 \%)$ e nacional $(33.8 \%)$

Os indicadores do mercado de trabalho do município apresentam uma situação favorável em relação à média departamental e nacional nas taxas relativas à atividade, emprego e desemprego. O município tem uma taxa de atividade de $68,8 \%$, uma taxa de emprego de $65,0 \%$ e uma taxa de desemprego de $5,5 \%$ (2011).

$0,3 \%$ da população de 15 anos ou mais deste município é analfabeta. Por outro lado, a taxa líquida de assistência (TLA) aos 6 primeiros anos do ensino fundamental é parecida a TLA departamental assim como à nacional. No entanto, a TLA ao ensino médio é maior tanto em comparação à TLA departamental como à nacional. O município tem uma TLA referente aos 6 primeiros anos do ensino fundamental de $92,5 \%$ enquanto que a departamental é de $92,4 \%$. Para o ensino médio a TLA é de $82,5 \%$ para o município e $69,8 \%$ para o departamento.

Texto livremente traduzido do site http://www.otu.opp.gub.uy

População: 147.577 habitantes

Área: $11.8 \mathrm{~km} 2$.

\section{DEMOGRAFIA}

População Urbana: 100\%

População por idades:

De 0 a 14 anos: 16.755 hab. - $11.35 \%$

De 15 a 24 anos: 27.038 hab. $-18.32 \%$

De 25 a 44 anos: 47.064 hab. $-31.89 \%$

De 45 a 64 anos: 31.476 hab. $-21.33 \%$

Mais de 65 anos: 25.244 hab. $-17.11 \%$

\section{RENDIMENTOS E BEM ESTAR}

Percentual da população que tem uma ou mais necessidades básicas insatisfeitas (moradia digna, saneamento, água potável, eletricidade, conforto, educação): $25.3 \%$ (superior a média nacional, 33,8\%)

\section{EDUCAÇÃO}

Nível de escolaridade da população compreendida entre 25 e mais anos:

Primeiros 6 anos do Ensino Fundamental: 11.5\%

Ensino Fundamental: $10.6 \%$

Ensino Médio: $20.6 \%$

Educação Técnica: $7.3 \%$

Universidade: $36 \%$

Percentual de crianças entre 6 e 11 anos que vão a escola: $92.5 \%$

Percentual de crianças e adolescentes entre 12 e 17 anos que vão ao ensino médio: $82.5 \%$

\section{MERCADO DE TRABALHO}

Percentual da população em atividade: $68.8 \%$ Percentual da população empregada: $65 \%$ Percentual da população em situação de desemprego: 5.5\% (menor que a média do país, 6.3\% em 2011)

\section{TECNOLOGIA}

Percentual da população com acesso a conexão a Internet: $67.1 \%$

Percentual da população que tem computador ou laptop: $70.9 \%$

\begin{tabular}{lll} 
Uma NBI & $18.1 \%$ & $19.6 \%$ \\
\hline Dois NBI & $6.3 \%$ & $6.4 \%$
\end{tabular}

\begin{tabular}{ll} 
Três ou mais NBI $\quad 0.9 \%$ & $4.7 \%$ \\
\hline
\end{tabular}

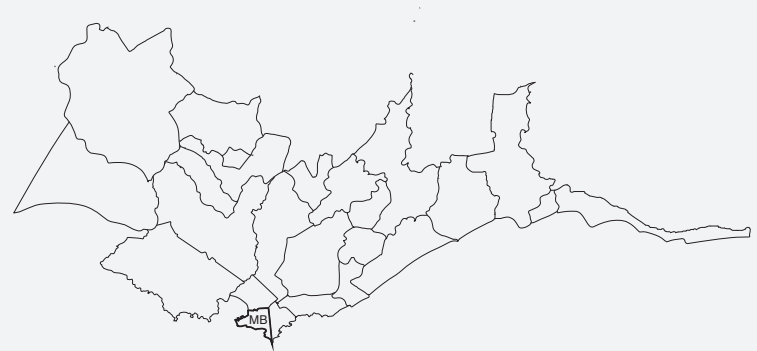




\title{
MUNICÍPIO C
}

\author{
Montevidéu
}

Tendo os dados do Censo 2011 como base, o município contra com uma população de 148.952 habitantes. A densidade populacional é de $8.444,3 \mathrm{hab} / \mathrm{km} 2$, enquanto que a densidade de Montevidéu é $2.488,2 \mathrm{hab} / \mathrm{km} 2.100 \%$ da população do município é urbana, majoritariamente de ascendência étnica branca (93,8\%), a população afro ou negra representa $2,5 \%$ da população. A proporção de pessoas com ao menos uma NBI é de $16 \%$, valor consideravelmente inferior a media do departamento $(26,8 \%)$ e nacional $(33.8 \%)$

Os indicadores do mercado de trabalho do município apresentam uma situação favorável em relação à média departamental e nacional nas taxas relativas à atividade, emprego e desemprego. O município tem uma taxa de atividade de $65,5 \%$, uma taxa de emprego de $61,9 \%$ e uma taxa de desemprego de 5,5\% (2011).

$0,4 \%$ da população de 15 anos ou mais deste município é analfabeta. Por outro lado, a taxa líquida de assistência (TLA) aos 6 primeiros anos do ensino fundamental é superior a TLA departamental assim como à nacional. A TLA ao ensino médio apresenta igual comportamento. O município tem uma TLA referente aos 6 primeiros anos do ensino fundamental de 93,6\% enquanto que a departamental é de $92,4 \%$. Para o ensino médio a TLA é de $82,8 \%$ para o município e $69,8 \%$ para o departamento

Texto livremente traduzido do site http://www.otu.opp.gub.uy

População: 148.952 habitantes

Área: $17.6 \mathrm{~km} 2$.

\section{DEMOGRAFIA}

População Urbana: 100\%

População por idades:

De 0 a 14 anos: 20.328 hab. $-12.74 \%$

De 15 a 24 anos: 21.259 hab. $-13.33 \%$

De 25 a 44 anos: 45.608 hab. $-28.59 \%$

De 45 a 64 anos: 39.275 hab. $-24.62 \%$

Mais de 65 anos: 33.058 hab. $-20.72 \%$

\section{RENDIMENTOS E BEM ESTAR}

Percentual da população que tem uma ou mais necessidades básicas insatisfeitas (moradia digna, saneamento, água potável, eletricidade, conforto, educação): $16.8 \%$ (inferior a média nacional, $33,8 \%$ )

\section{EDUCAÇÃO}

Nível de escolaridade da população compreendida entre 25 e mais anos:

Primeiros 6 anos do Ensino Fundamental: 17.6\%

Ensino Fundamental: $14.7 \%$

Ensino Médio: $24.2 \%$

Educação Técnica: $8.8 \%$

Universidade: $23.3 \%$

Percentual de crianças entre 6 e 11 anos que vão a escola:

$93.6 \%$

Percentual de crianças e adolescentes entre 12 e 17 anos que vão ao ensino médio: $82.8 \%$

\section{MERCADO DE TRABALHO}

Percentual da população em atividade: $65.5 \%$ Percentual da população empregada: $61.9 \%$

Percentual da população em situação de desemprego: 5.5\% (menor que a média do país 6.3\%, em 2011)

\section{TECNOLOGIA}

Percentual da população com acesso a conexão a Internet:

$60.2 \%$

Percentual da população que tem computador ou laptop: $64.1 \%$
Percentual de lares segundo a quantidade de NBI 2011

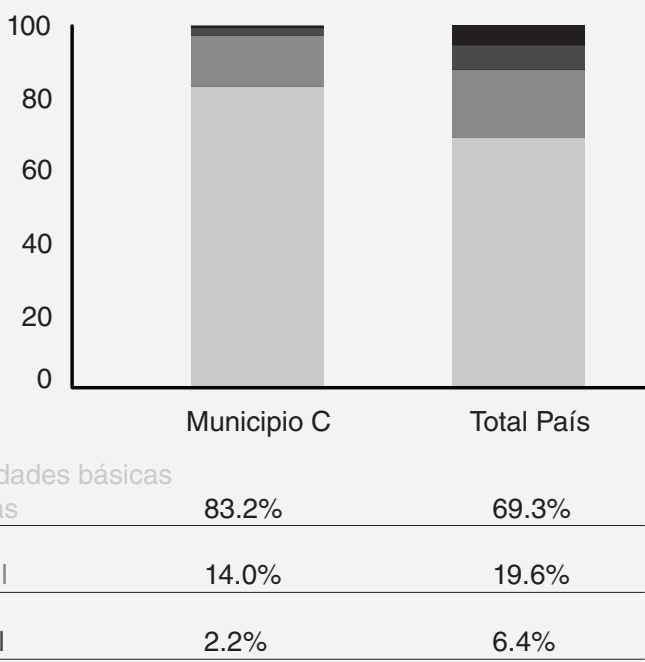

\begin{tabular}{lll} 
Necessidades básicas & & \\
\hline Satisfeitas & $83.2 \%$ & $69.3 \%$ \\
\hline Uma NBI & $14.0 \%$ & $19.6 \%$ \\
\hline Dois NBI & $2.2 \%$ & $6.4 \%$ \\
\hline Três ou mais NBI & $0.5 \%$ & $4.7 \%$ \\
\hline
\end{tabular}

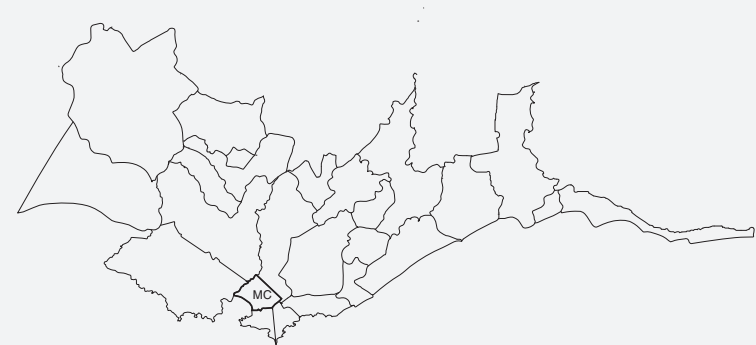




\title{
MUNICÍPIO CH
}

\author{
Montevidéu
}

Tendo os dados do Censo 2011 como base, o município contra com uma população de 159.528 habitantes. A densidade populacional é de $13.177,2 \mathrm{hab} / \mathrm{km} 2$, enquanto que a densidade de Montevidéu é $2.488,2 \mathrm{hab} / \mathrm{km} 2.100 \%$ da população do município é urbana, majoritariamente de ascendência étnica branca $(96,8 \%)$, a população afro ou negra representa $1,1 \%$ da população. A proporção de pessoas com ao menos uma NBI é de $9,5 \%$, valor consideravelmente inferior a media do departamento $(26,8 \%)$ e nacional $(33.8 \%)$

Os indicadores do mercado de trabalho do município apresentam uma situação favorável em relação à média departamental e nacional nas taxas relativas à atividade, emprego e desemprego. O município tem uma taxa de atividade de $64,6 \%$, uma taxa de emprego de $61,4 \%$ e uma taxa de desemprego de $4,9 \%$ (2011).

$0,2 \%$ da população de 15 anos ou mais deste município é analfabeta. Por outro lado, a taxa líquida de assistência (TLA) aos 6 primeiros anos do ensino fundamental é parecida a TLA departamental assim como à nacional. A TLA ao ensino médio é superior tanto em comparação com o departamento como a nacional. O município tem uma TLA referente aos 6 primeiros anos do ensino fundamental de $92,8 \%$ enquanto que a departamental é de $92,4 \%$. Para o ensino médio a TLA é de $88,8 \%$ para o município e $69,8 \%$ para o departamento.

População: 159.528 habitantes

Área: $12.1 \mathrm{~km}^{2}$

\section{DEMOGRAFIA}

População Urbana: 100\%

População por idades:

De 0 a 14 anos: 22.765 hab. $-15.28 \%$

De 15 a 24 anos: 20.325 hab. $-13.65 \%$

De 25 a 44 anos: 42.084 hab. $-28.25 \%$

De 45 a 64 anos: 35.485 hab. $-23.82 \%$

Mais de 65 anos: 28.293 hab. $-19.00 \%$

\section{RENDIMENTOS E BEM ESTAR}

Percentual da população que tem uma ou mais necessidades básicas insatisfeitas (moradia digna, saneamento, água potável, eletricidade, conforto, educação): 10.7\% (inferior a média nacional, $33,8 \%$ )

\section{EDUCAÇÃo}

Nível de escolaridade da população compreendida entre 25 e mais anos:

Primeiros 6 anos do Ensino Fundamental: $8.2 \%$

Ensino Fundamental: $7.7 \%$

Ensino Médio: $20.2 \%$

Educação Técnica: $6.1 \%$

Universidade: $42.5 \%$

Percentual de crianças entre 6 e 11 anos que vão a escola: $92.8 \%$

Percentual de crianças e adolescentes entre 12 e 17 anos que vão ao ensino médio: $88.8 \%$

\section{MERCADO DE TRABALHO}

Percentual da população em atividade: $64.6 \%$ Percentual da população empregada: $61.4 \%$

Percentual da população em situação de desemprego: $4.9 \%$ (menor que a média do país 6.3\%, em 2011)

\section{TECNOLOGIA}

Percentual da população com acesso a conexão a Internet: 73\% Percentual da população que tem computador ou laptop: $76.4 \%$ exto livremente traduzido do site http://www.otu.opp.gub.uy

Percentual de lares segundo a quantidade de NBI 2011

Percentual de lares segundo a quantidade de NBI 2011

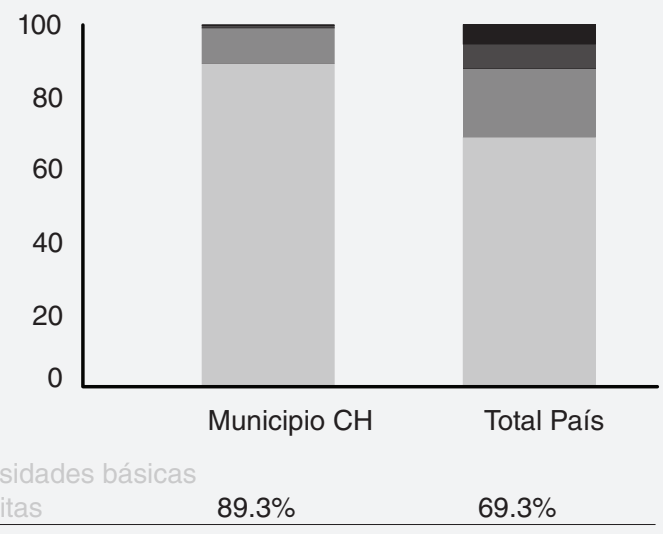

\begin{tabular}{lll} 
Uma NBI & $9.9 \%$ & $19.6 \%$ \\
\hline Dois NBI & $0.7 \%$ & $6.4 \%$ \\
\hline
\end{tabular}

$\begin{array}{lll}\text { Três ou mais NBI } \quad 0.1 \% & 4.7 \%\end{array}$

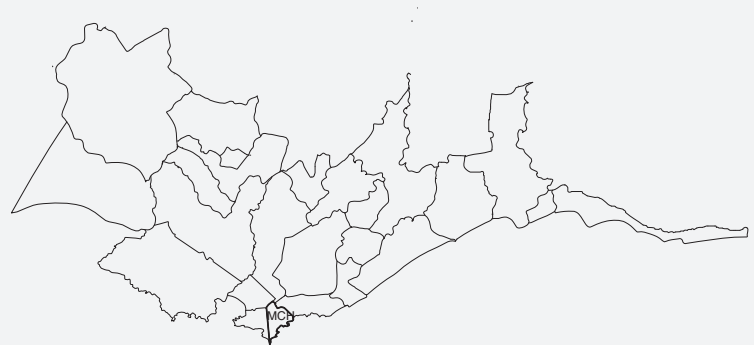




\title{
MUNICÍPIO D
}

\author{
Montevidéu
}

Tendo os dados do Censo 2011 como base, o município contra com uma população de 181.153 habitantes. A densidade populacional é de 2.095,3 hab/km2, enquanto que a densidade de Montevidéu é $2.488,2 \mathrm{hab} / \mathrm{km} 2.98,9 \%$ da população do município é urbana, majoritariamente de ascendência étnica branca $(85 \%)$, a população afro ou negra representa $8,7 \%$ da população. A proporção de pessoas com ao menos uma NBI é de 40,3\%, valor consideravelmente superior a media do departamento $(26,8 \%)$ e nacional $(33.8 \%)$.

Os indicadores do mercado de trabalho do município apresentam uma situação parecida em relação à média departamental e nacional nas taxas relativas à atividade e emprego. A taxa de desemprego é superior tanto em comparação a departamental quanto a nacional. O município tem uma taxa de atividade de $63,1 \%$, uma taxa de emprego de $58,3 \%$ e uma taxa de desemprego de $7,7 \%$ (2011).

1,8\% da população de 15 anos ou mais deste município é analfabeta. Por outro lado, a taxa líquida de assistência (TLA) aos 6 primeiros anos do ensino fundamental é parecida a TLA departamental assim como à nacional. A TLA ao ensino médio é inferior tanto em comparação com o departamento como a nacional. O município tem uma TLA referente aos 6 primeiros anos do ensino fundamental de $92,4 \%$ enquanto que a departamental é de $92,4 \%$. Para o ensino médio a TLA é de $61,1 \%$ para o município e $69,8 \%$ para o departamento.

Texto livremente traduzido do site http://www.otu.opp.gub.uy

População: 181.153 habitantes

Área: $86.5 \mathrm{~km} 2$.

Percentual de lares segundo a quantidade de NBI 2011

\section{DEMOGRAFIA}

População Urbana: $98.9 \%$

População por idades:

De 0 a 14 anos: 43.961 hab. $-24.27 \%$

De 15 a 24 anos: 28.569 hab. $-15.77 \%$

De 25 a 44 anos: 48.738 hab. $-26.90 \%$

De 45 a 64 anos: 37.746 hab. $-20.84 \%$

Mais de 65 anos: 22.139 hab. $-12.22 \%$

\section{RENDIMENTOS E BEM ESTAR}

Percentual da população que tem uma ou mais necessidades básicas insatisfeitas (moradia digna, saneamento, água potável, eletricidade, conforto, educação): $36 \%$ (superior a média nacional, 33,8\%)

\section{EDUCAÇÃO}

Nível de escolaridade da população compreendida entre 25 mais anos:

Primeiros 6 anos do Ensino Fundamental: $37.8 \%$

Ensino Fundamental: $25.2 \%$

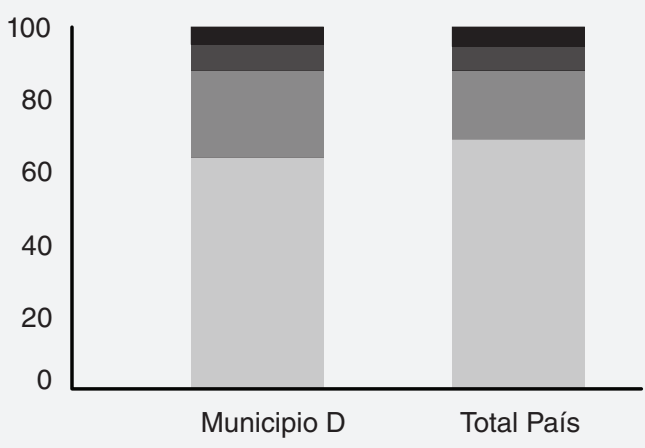

Ensino Médio: $17.6 \%$

Educação Técnica: $7.4 \%$

Universidade: $6.9 \%$

Percentual de crianças entre 6 e 11 anos que vão a escola: $92.4 \%$ Percentual de crianças e adolescentes entre 12 e 17 anos que vão ao ensino médio: $61.1 \%$

\section{MERCADO DE TRABALHO}

Percentual da população em atividade: $63.1 \%$ Percentual da população empregada: $58.3 \%$ Percentual da população em situação de desemprego: $7.7 \%$ (maior que a média do país, 6.3\% em 2011)

\section{TECNOLOGIA}

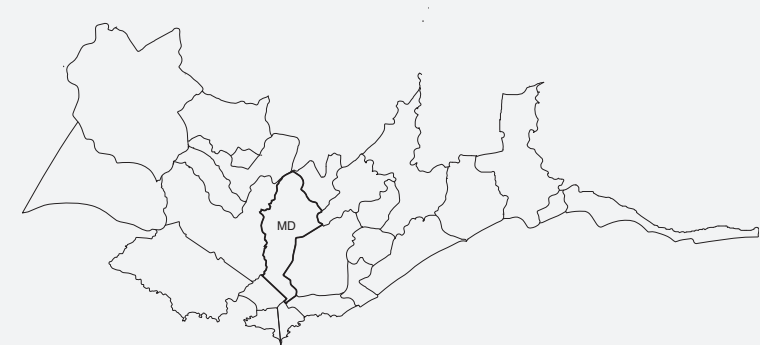

Percentual da população com acesso a conexão a Internet: $37.9 \%$ Percentual da população que tem computador ou laptop: $43.2 \%$ 


\section{MUNICÍPIO E}

\section{Montevidéu}

Tendo os dados do Censo 2011 como base, o município contra com uma população de 153.395 habitantes. A densidade populacional é de 5.682,3 hab/km2, enquanto que a densidade de Montevidéu é $2.488,2 \mathrm{hab} / \mathrm{km} 2.100 \%$ da população do município é urbana, majoritariamente de ascendência étnica branca (94\%), a população afro ou negra representa 2,6\% da população. A proporção de pessoas com ao menos uma NBI é de $14,4 \%$, valor consideravelmente inferior a media do departamento $(26,8 \%)$ e nacional $(33.8 \%)$

Os indicadores do mercado de trabalho do município apresentam uma situação parecida em relação à média departamental e nacional nas taxas relativas à atividade e emprego. A taxa de desemprego é inferior tanto à departamental como a nacional. $\mathrm{O}$ município tem uma taxa de atividade de 63,6\%, uma taxa de emprego de 60,0\% e uma taxa de desemprego de 5,8\% (2011).

$0,6 \%$ da população de 15 anos ou mais deste município é analfabeta. Por outro lado, a taxa líquida de assistência (TLA) aos 6 primeiros anos do ensino fundamental é parecida a TLA departamental assim como à nacional. A TLA ao ensino médio é superior tanto à TLA departamental como a nacional. O município tem uma TLA referente aos 6 primeiros anos do ensino fundamental de $92,2 \%$ enquanto que a departamental é de $92,4 \%$. Para o ensino médio a TLA é de $80,1 \%$ para o município e $69,8 \%$ para o departamento.

Texto livremente traduzido do site http://www.otu.opp.gub.uy

População: 153.395 habitantes

Área: $27 \mathrm{~km} 2$.

\section{DEMOGRAFIA}

População Urbana: $100 \%$

População por idades

De 0 a 14 anos: 25.671 hab. $-16.74 \%$

De 15 a 24 anos: 21223 hab. $-13.84 \%$

De 25 a 44 anos: 39.822 hab. $-25.96 \%$

De 45 a 64 anos: 38.814 hab. $-25.30 \%$

Mais de 65 anos: 27.865 hab. $-18.16 \%$

\section{RENDIMENTOS E BEM ESTAR}

Percentual da população que tem uma ou mais necessidades básicas insatisfeitas (moradia digna, saneamento, água potável, eletricidade, conforto, educação): $13.9 \%$ (inferior a média nacional, $33,8 \%$ )

\section{EDUCAÇÃO}

Nível de escolaridade da população compreendida entre 25 e mais anos:

Primeiros 6 anos do Ensino Fundamental: 16.1\%

Ensino Fundamental: 13.2\%

Ensino Médio: $22.5 \%$

Educação Técnica: $7.9 \%$

Universidade: $28,3 \%$

Percentual de crianças entre 6 e 11 anos que vão a escola: 92.2\% Percentual de crianças e adolescentes entre 12 e 17 anos que vão ao ensino médio: $80.1 \%$

\section{MERCADO DE TRABALHO}

Percentual da população em atividade: $63.6 \%$ Percentual da população empregada: $60 \%$

Percentual da população em situação de desemprego: $5.8 \%$ (menor que a média do país 6.3\%, em 2011)

\section{TECNOLOGIA}

Percentual de lares segundo a quantidade de NBI 2011

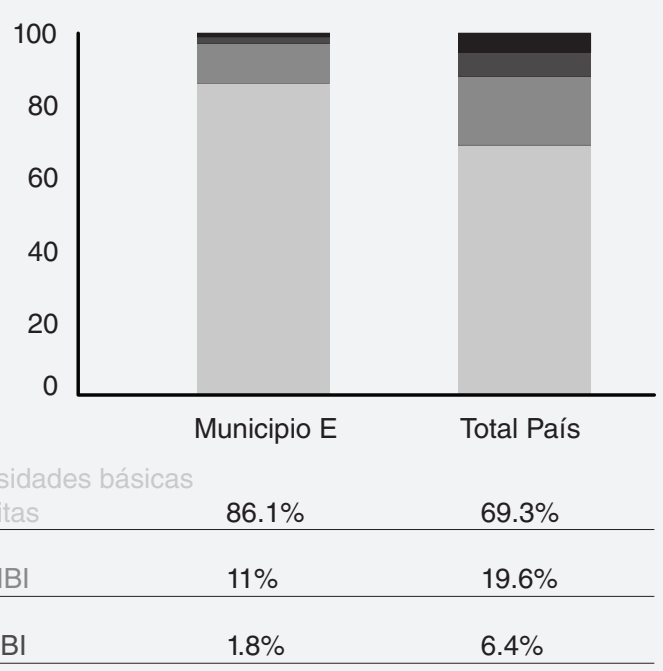

\begin{tabular}{lcc} 
Dois NBI & $1.8 \%$ & $6.4 \%$ \\
\hline Três ou mais NBI & $1 \%$ & $4.7 \%$ \\
\hline
\end{tabular}

Percentual da população com acesso a conexão a Internet: $64.7 \%$ Percentual da população que tem computador ou laptop: $68 \%$ 


\section{MUNICÍPIO F}

\section{Montevidéu}

Tendo os dados do Censo 2011 como base, o município contra com uma população de 168.937 habitantes. A densidade populacional é de $1.988 \mathrm{hab} / \mathrm{km} 2$, enquanto que a densidade de Montevidéu é $2.488,2 \mathrm{hab} / \mathrm{km} 2.99,3 \%$ da população do município é urbana, majoritariamente de ascendência étnica branca $(85,2 \%)$, a população afro ou negra representa $8 \%$ da população. A proporção de pessoas com ao menos uma NBI é de $40,6 \%$ valor superior a media do departamento $(26,8 \%)$ e nacional $(33.8 \%)$

Os indicadores do mercado de trabalho do município apresentam uma situação parecida em relação à média departamental e nacional nas taxas relativas à atividade e emprego. A taxa de desemprego é superior tanto em comparação à departamental como à nacional. O município tem uma taxa de atividade de $63,4 \%$, uma taxa de emprego de $58,4 \%$ e uma taxa de desemprego de $7,8 \%$ (2011)

$1,6 \%$ da população de 15 anos ou mais deste município é analfabeta. Por outro lado, a taxa líquida de assistência (TLA) aos 6 primeiros anos do ensino fundamental é levemente inferior a TLA departamental assim como à nacional. A TLA ao ensino médio apresenta igual comportamento. O município tem uma TLA referente aos 6 primeiros anos do ensino fundamental de 91,4\% enquanto que a departamental é de 92,4\%. Para o ensino médio a TLA é de 60,7\% para o município e 69,8\% para o departamento.

Texto livremente traduzido do site http://www.otu.opp.gub.uy

População: 168.937 habitantes

Área: $85 \mathrm{~km} 2$.

\section{DEMOGRAFIA}

População Urbana: $99.3 \%$

População por idades:

De 0 a 14 anos: 41.480 hab. $-24.55 \%$

De 15 a 24 anos: 27.319 hab. $-16.17 \%$

De 25 a 44 anos: 46.226 hab. $-27.36 \%$

De 45 a 64 anos: 34.139 hab. $-20.22 \%$

Mais de 65 anos: 19.773 hab. $-11.70 \%$

\section{RENDIMENTOS E BEM ESTAR}

Percentual da população que tem uma ou mais necessidades básicas insatisfeitas (moradia digna, saneamento, água potável, eletricidade, conforto, educação): $36,5 \%$ (superior a média nacional, 33,8\%)

\section{EDUCAÇÃo}

Nível de escolaridade da população compreendida entre 25 e mais anos:

Primeiros 6 anos do Ensino Fundamental: 38.3\%

Ensino Fundamental: $26.7 \%$

Ensino Médio: $17.3 \%$

Educação Técnica: $7.4 \%$

Universidade: $5.4 \%$

Percentual de crianças entre 6 e 11 anos que vão a escola: $91.4 \%$ Percentual de crianças e adolescentes entre 12 e 17 anos que vão ao ensino médio: $60.7 \%$

\section{MERCADO DE TRABALHO}

Percentual da população em atividade: $63.4 \%$ Percentual da população empregada: $58.4 \%$

Percentual da população em situação de desemprego: $7.8 \%$ (superior que a média do país 6.3\%, em 2011)

\section{TECNOLOGIA}

Percentual de lares segundo a quantidade de NBI 2011

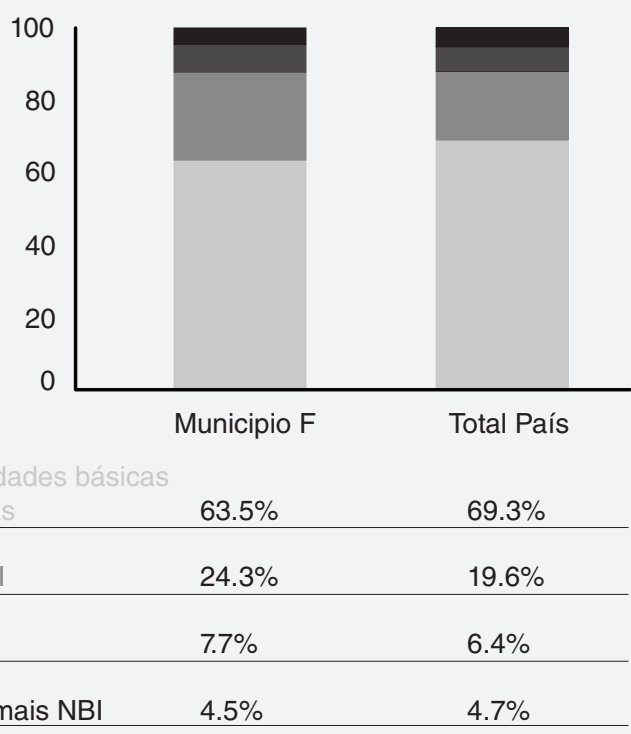

Percentual da população com acesso a conexão a Internet: $37.2 \%$ Percentual da população que tem computador ou laptop: $42.7 \%$ 


\title{
MUNICÍPIO G
}

\author{
Montevidéu
}

Tendo os dados do Censo 2011 como base, o município contra com uma população de 151.302 habitantes. A densidade populacional é de 1.060,1 hab/km2, enquanto que a densidade de Montevidéu é $2.488,2 \mathrm{hab} / \mathrm{km} 2$. $97,6 \%$ da população do município é urbana, majoritariamente de ascendência étnica branca $(89,0 \%)$, a população afro ou negra representa $5,4 \%$ da população. A proporção de pessoas com ao menos uma NBI é de $30,9 \%$, valor superior a media do departamento $(26,8 \%)$ e nacional $(33.8 \%)$

Os indicadores do mercado de trabalho do município apresentam uma situação favorável em relação à média departamental e nacional nas taxas relativas à atividade e emprego. A taxa de desemprego é superior tanto em comparação com a taxa departamental como nacional. O município tem uma taxa de atividade de $62,8 \%$, uma taxa de emprego de $58,0 \%$ e uma taxa de desemprego de $7,7 \%$ (2011).

$1,1 \%$ da população de 15 anos ou mais deste município é analfabeta. Por outro lado, a taxa líquida de assistência (TLA) aos 6 primeiros anos do ensino fundamental é parecida a TLA departamental assim como à nacional. A TLA ao ensino médio é inferior à média departamental e nacional. O município tem uma TLA referente aos 6 primeiros anos do ensino fundamental de 92,3\% enquanto que a departamental é de $92,4 \%$. Para o ensino médio a TLA é de $65,4 \%$ para o município e $69,8 \%$ para o departamento.

Texto livremente traduzido do site http://www.otu.opp.gub.uy

População: 151.302 habitantes

Área: $142.7 \mathrm{~km} 2$.

\section{DEMOGRAFIA}

População Urbana: 97.6\%

População por idades:

De 0 a 14 anos: 33.002 hab. $-21.81 \%$

De 15 a 24 anos: 23.299 hab. $-15.40 \%$

De 25 a 44 anos: 40.302 hab. $-26.64 \%$

De 45 a 64 anos: 33.290 hab. $-22.00 \%$

Mais de 65 anos: 21.409 hab. $-14.15 \%$

\section{RENDIMENTOS E BEM ESTAR}

Percentual da população que tem uma ou mais necessidades básicas insatisfeitas (moradia digna, saneamento, água potável, eletricidade, conforto, educação): $27,7 \%$ (inferior a média nacional, $33,8 \%$ )

\section{EDUCAÇÃO}

Nível de escolaridade da população compreendida entre 25 e mais anos:

Primeiros 6 anos do Ensino Fundamental: 31.9\%

Ensino Fundamental: 24.4\%

Ensino Médio: $19.8 \%$

Educação Técnica: $8.6 \%$

Universidade: $9.2 \%$

Percentual de crianças entre 6 e 11 anos que vão a escola: 92.3\% Percentual de crianças e adolescentes entre 12 e 17 anos que vão ao ensino médio: $65.4 \%$

\section{MERCADO DE TRABALHO}

Percentual da população em atividade: $62.8 \%$ Percentual da população empregada: $58 \%$

Percentual da população em situação de desemprego: $7.7 \%$ (maior que a média do país 6.3\%, em 2011)

\section{TECNOLOGIA}

Percentual da população com acesso a conexão a Internet: $44 \%$ Percentual da população que tem computador ou laptop: $49,8 \%$ 


\section{LOS CERRILLOS - CRS}

\section{Canelones}

Tendo os dados do Censo 2011 como base, o município contra com uma população de 7.713 habitantes. A densidade populacional é de $29,5 \mathrm{hab} / \mathrm{km} 2$, enquanto que a densidade de Canelones é $114,7 \mathrm{hab} / \mathrm{km} 2$. $37,1 \%$ da população do município é urbana, majoritariamente de ascendência étnica branca $(94,0 \%)$, a população afro ou negra representa $3,4 \%$ da população. A proporção de pessoas com ao menos uma NBI é de $30,8 \%$, valor inferior a media do nacional $(33,8 \%)$ e departamental $(33.6 \%)$.

Os indicadores do mercado de trabalho do município apresentam uma situação similar em relação à média departamental e nacional nas taxas relativas à atividade e emprego. A taxa de desemprego é inferior tanto em comparação com a taxa departamental como nacional. O município tem uma taxa de atividade de $62,8 \%$, uma taxa de emprego de $59,4 \%$ e uma taxa de desemprego de $5,4 \%$ (2011).

$1,7 \%$ da população de 15 anos ou mais deste município é analfabeta. Por outro lado, a taxa líquida de assistência (TLA) aos 6 primeiros anos do ensino fundamental é parecida a TLA departamental assim como à nacional. A TLA ao ensino médio é inferior à média departamental e nacional. O município tem uma TLA referente aos 6 primeiros anos do ensino fundamental de $92,4 \%$ enquanto que a departamental é de $93,1 \%$. Para o ensino médio a TLA é de $61,6 \%$ para o município e $67,5 \%$ para o departamento.

Texto livremente traduzido do site http://www.otu.opp.gub.uy

População: 7.713 habitantes

Área: $261.4 \mathrm{~km} 2$.

Percentual de lares segundo a quantidade de NBI 2011

\section{DEMOGRAFIA}

População Urbana: $37.1 \%$

População por idades:

De 0 a 14 anos: 1.624 hab. $-21.06 \%$

De 15 a 24 anos: 1.091 hab. $-14.02 \%$

De 25 a 44 anos: 2.094 hab. $-27.15 \%$

De 45 a 64 anos: 1.753 hab. $-22.73 \%$

Mais de 65 anos: 1.161 hab. $-15.04 \%$

\section{RENDIMENTOS E BEM ESTAR}

Percentual da população que tem uma ou mais necessidades básicas insatisfeitas (moradia digna, saneamento, água potável, eletricidade, conforto, educação): $30,4 \%$ (inferior a média nacional, $33,8 \%$ )

\section{EDUCAÇÃo}

Nível de escolaridade da população compreendida entre 25 e mais anos:

Primeiros 6 anos do Ensino Fundamental: 53.1\%

Ensino Fundamental: $17.3 \%$

Ensino Médio: $14.4 \%$

Educação Técnica: $3.9 \%$

Universidade: $5.9 \%$

Percentual de crianças entre 6 e 11 anos que vão a escola: $92.4 \%$

Percentual de crianças e adolescentes entre 12 e 17 anos que vão ao ensino médio: $61.6 \%$

\section{MERCADO DE TRABALHO}

Percentual da população em atividade: $62.8 \%$ Percentual da população empregada: $59.4 \%$ Percentual da população em situação de desemprego: $5.4 \%$ (menor que a média do país, 6.3\%, em 2011)

\section{TECNOLOGIA}

Percentual da população com acesso a conexão a Internet: $33.6 \%$

Percentual da população que tem computador ou laptop: $41 \%$ 


\section{LA PAZ - LPZ}

\section{Canelones}

Tendo os dados do Censo 2011 como base, o município contra com uma população de 20.194 habitantes. A densidade populacional é de $612,9 \mathrm{hab} / \mathrm{km} 2$, enquanto que a densidade de Canelones é $114,7 \mathrm{hab} / \mathrm{km} 2.94,2 \%$ da população do município é urbana, majoritariamente de ascendência étnica branca (90,9\%), a população afro ou negra representa $4,5 \%$ da população. A proporção de pessoas com ao menos uma NBI é de $38,1 \%$, valor superior a media do nacional $(33,8 \%)$ e departamental (33.6\%). Os indicadores do mercado de trabalho do município apresentam uma situação similar em relação à média departamental e nacional nas taxas relativas à atividade e emprego. A taxa de desemprego é superior tanto em comparação com a taxa departamental como nacional. O município tem uma taxa de atividade de $62,7 \%$, uma taxa de emprego de $57,0 \%$ e uma taxa de desemprego de $9,1 \%$ (2011).

1,3\% da população de 15 anos ou mais deste município é analfabeta. Por outro lado, a taxa líquida de assistência (TLA) aos 6 primeiros anos do ensino fundamental é parecida a TLA departamental assim como à nacional. A TLA ao ensino médio apresenta igual comportamento. O município tem uma TLA referente aos 6 primeiros anos do ensino fundamental de 93,3\% enquanto que a departamental é de $93,1 \%$. Para o ensino médio a TLA é de $67,6 \%$ para o município e $67,5 \%$ para o departamento.

Texto livremente traduzido do site http://www.otu.opp.gub.uy

População: 20.194 habitantes

Área: $32.9 \mathrm{~km} 2$.

\section{DEMOGRAFIA}

População Urbana: $94.2 \%$

População por idades:

De 0 a 14 anos: 4.587 hab. $-22.71 \%$

De 15 a 24 anos: 3.222 hab. $-15.96 \%$

De 25 a 44 anos: 5.479 hab. $-27.13 \%$

De 45 a 64 anos: 4.409 hab. $-21.83 \%$

Mais de 65 anos: 2.497 hab. $12.37 \%$

\section{RENDIMENTOS E BEM ESTAR}

Percentual da população que tem uma ou mais necessidades básicas insatisfeitas (moradia digna, saneamento, água potável, eletricidade, conforto, educação): $35,3 \%$ (superior a média nacional, $33,8 \%$ )

\section{EDUCAÇÃO}

Nível de escolaridade da população compreendida entre 25 e mais anos:

Primeiros 6 anos do Ensino Fundamental: 39.1\%

Ensino Fundamental: $25.2 \%$

Ensino Médio: $16.9 \%$

Educação Técnica: $6.5 \%$

Universidade: $7 \%$

Percentual de crianças entre 6 e 11 anos que vão a escola: 93.3\%

Percentual de crianças e adolescentes entre 12 e 17 anos que vão ao ensino médio: $67.6 \%$

\section{MERCADO DE TRABALHO}

Percentual da população em atividade: $62.7 \%$ Percentual da população empregada: $57 \%$

Percentual da população em situação de desemprego: 9.1\% (maior que a média do país, 6.3\% em 2011)

\section{TECNOLOGIA}

Percentual da população com acesso a conexão a Internet: $39.9 \%$

Percentual da população que tem computador ou laptop: $45.2 \%$
Percentual de lares segundo a quantidade de NBI 2011

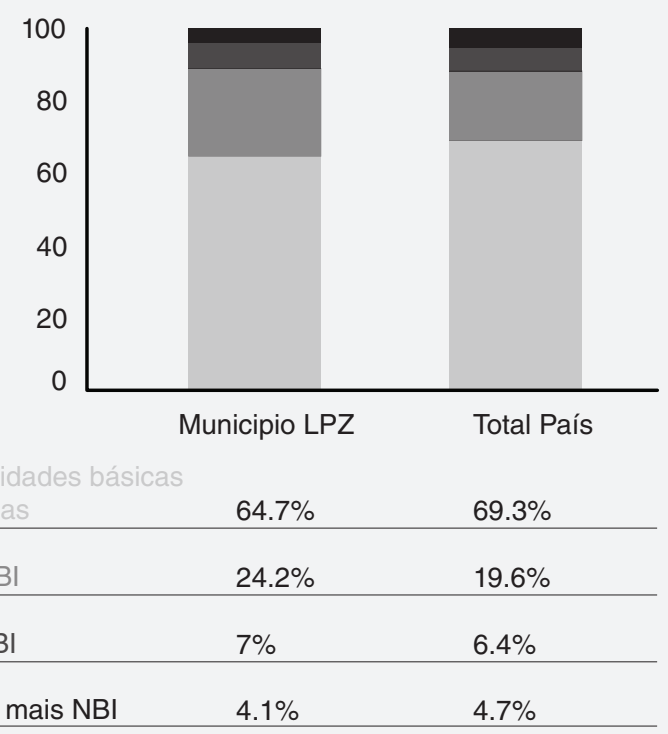

\begin{tabular}{lll} 
Necessidades básicas & & \\
\hline Satisfeitas & $64.7 \%$ & $69.3 \%$ \\
\hline Uma NBI & $24.2 \%$ & $19.6 \%$ \\
\hline Dois NBI & $7 \%$ & $6.4 \%$ \\
\hline Três ou mais NBI & $4.1 \%$ & $4.7 \%$ \\
\hline
\end{tabular}

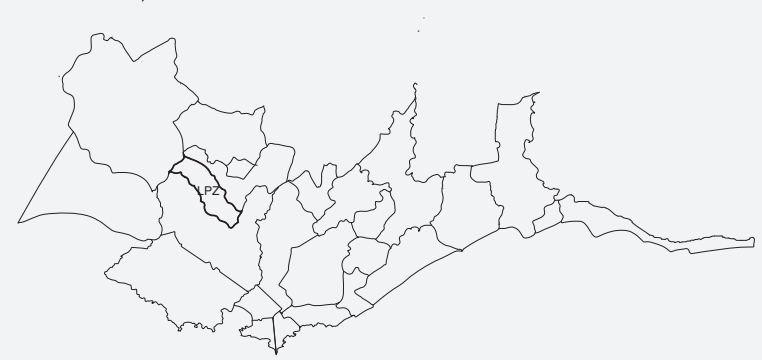




\section{LAS PIEDRAS - LPS}

\section{Canelones}

Tendo os dados do Censo 2011 como base, o município contra com uma população de 62.238 habitantes. A densidade populacional é de 1.155,7 hab/km2, enquanto que a densidade de Canelones é 114,7 hab/km2. 96,6\% da população do município é urbana, majoritariamente de ascendência étnica branca (89,9\%), a população afro ou negra representa $5,5 \%$ da população. A proporção de pessoas com ao menos uma NBI é de $40,1 \%$, valor superior a media do nacional $(33,8 \%)$ e departamental $(33.6 \%)$. Os indicadores do mercado de trabalho do município apresentam uma situação desfavorável em relação à média departamental e nacional nas taxas relativas à atividade, emprego e desemprego. O município tem uma taxa de atividade de 61,5\%, uma taxa de emprego de 55,9\% e uma taxa de desemprego de 9,1\% (2011).

$1,5 \%$ da população de 15 anos ou mais deste município é analfabeta. Por outro lado, a taxa líquida de assistência (TLA) aos 6 primeiros anos do ensino fundamental é parecida a TLA departamental assim como à nacional. A TLA ao ensino médio apresenta igual comportamento. O município tem uma TLA referente aos 6 primeiros anos do ensino fundamental de 92,7\% enquanto que a departamental é de $93,1 \%$. Para o ensino médio a TLA é de $66,2 \%$ para o município e $67,5 \%$ para o departamento.

Texto livremente traduzido do site http://www.otu.opp.gub.uy

População: 62.238 habitantes

Área: $53.9 \mathrm{~km} 2$.

Percentual de lares segundo a quantidade de NBI 2011

\section{DEMOGRAFIA}

População Urbana: $96.6 \%$

População por idades:

De 0 a 14 anos: 14.835 hab. $-23.84 \%$

De 15 a 24 anos: 9.888 hab. $-15.89 \%$

De 25 a 44 anos: 16.745 hab. $-26.90 \%$

De 45 a 64 anos: 12.992 hab. $-20.87 \%$

Mais de 65 anos: 7.778 hab. $-12.50 \%$

\section{RENDIMENTOS E BEM ESTAR}

Percentual da população que tem uma ou mais necessidades básicas insatisfeitas (moradia digna, saneamento, água potável, eletricidade, conforto, educação): $36,8 \%$ (superior a média nacional, $33,8 \%$ )

\section{EDUCAÇÃO}

Nível de escolaridade da população compreendida entre 25 e mais anos:

Primeiros 6 anos do Ensino Fundamental: $39.4 \%$

Ensino Fundamental: 26.4\%

Ensino Médio: $16.9 \%$

Educação Técnica: $5.6 \%$

Universidade: $6.1 \%$

Percentual de crianças entre 6 e 11 anos que vão a escola: $92.7 \%$

Percentual de crianças e adolescentes entre 12 e 17 anos que vão ao ensino médio: $66.2 \%$

\section{MERCADO DE TRABALHO}

Percentual da população em atividade: $61.5 \%$ Percentual da população empregada: $55.9 \%$ Percentual da população em situação de desemprego: $9.1 \%$ (mais alta que a média do país, 6.3\% em 2011)

\section{TECNOLOGIA}

Percentual da população com acesso a conexão a Internet: $35.9 \%$

Percentual da população que tem computador ou laptop: $42.9 \%$

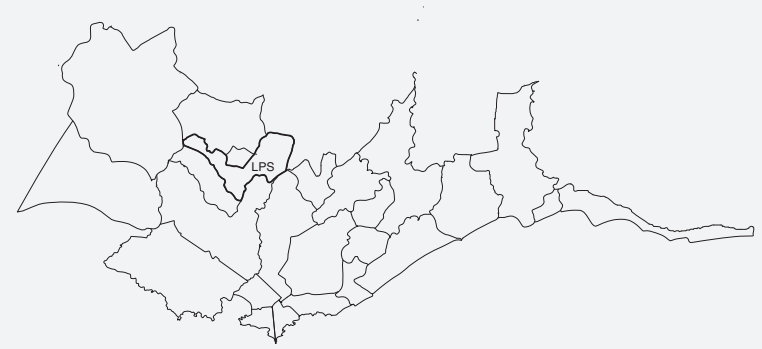

\begin{tabular}{lll} 
Necessidades básicas & & \\
\hline Uatisfeitas & $63.1 \%$ & $69.3 \%$ \\
\hline Dois NBI & $23.1 \%$ & $19.6 \%$ \\
\hline Três ou mais NBI & $5.2 \%$ & $6.4 \%$ \\
\hline
\end{tabular}




\section{PROGRESO - PGS}

\section{Canelones}

Tendo os dados do Censo 2011 como base, o município contra com uma população de 14.292 habitantes. A densidade populacional é de $182 \mathrm{hab} / \mathrm{km} 2$, enquanto que a densidade de Canelones é $114,7 \mathrm{hab} / \mathrm{km} 2.82,5 \%$ da população do município é urbana, majoritariamente de ascendência étnica branca (93,2\%), a população afro ou negra representa 3,0\% da população. A proporção de pessoas com ao menos uma NBI é de $36 \%$, valor superior a media do nacional $(33,8 \%)$ e departamental $(33.6 \%)$. Os indicadores do mercado de trabalho do município apresentam uma situação similar em relação à média departamental e nacional nas taxas relativas à atividade, emprego e desemprego. O município tem uma taxa de atividade de $61,2 \%$, uma taxa de emprego de $57,4 \%$ e uma taxa de desemprego de $6,3 \%$ (2011).

$1,3 \%$ da população de 15 anos ou mais deste município é analfabeta. Por outro lado, a taxa líquida de assistência (TLA) aos 6 primeiros anos do ensino fundamental é parecida a TLA departamental assim como à nacional. A TLA ao ensino médio apresenta igual comportamento. O município tem uma TLA referente aos 6 primeiros anos do ensino fundamental de 93,3\% enquanto que a departamental é de $93,1 \%$. Para o ensino médio a TLA é de $71 \%$ para o município e $67,5 \%$ para o departamento.

Texto livremente traduzido do site http://www.otu.opp.gub.uy

População: 14.292 habitantes

Área: $78.5 \mathrm{~km} 2$.

\section{DEMOGRAFIA}

População Urbana: $82.5 \%$

População por idades:

De 0 a 14 anos: 3.356 hab. $-23.48 \%$

De 15 a 24 anos: 2.155 hab. $-15.08 \%$

De 25 a 44 anos: 3.879 hab. $-27.14 \%$

De 45 a 64 anos: 3.088 hab. $-21.61 \%$

Mais de 65 anos: 1.814 hab. $-12.69 \%$

\section{RENDIMENTOS E BEM ESTAR}

Percentual da população que tem uma ou mais necessidades básicas insatisfeitas (moradia digna, saneamento, água potável, eletricidade, conforto, educação): $33,0 \%$ (inferior a média nacional, $33,8 \%$ )

\section{EDUCAÇÃO}

Nível de escolaridade da população compreendida entre 25 e mais anos:

Primeiros 6 anos do Ensino Fundamental: 42.1\%

Ensino Fundamental: $22.9 \%$

Ensino Médio: $18.6 \%$

Educação Técnica: $5 \%$

Universidade: $5.8 \%$

Percentual de crianças entre 6 e 11 anos que vão a escola: 93.3\% Percentual de crianças e adolescentes entre 12 e 17 anos que vão ao ensino médio: $71 \%$

\section{MERCADO DE TRABALHO}

Percentual da população em atividade: $61.2 \%$ Percentual da população empregada: $57.4 \%$

Percentual da população em situação de desemprego: 6.3\% (igual a média do país, 6,3 em 2011)

\section{TECNOLOGIA}

Percentual da população com acesso a conexão a Internet: 35\% Percentual da população que tem computador ou laptop: $42.6 \%$
Percentual de lares segundo a quantidade de NBI 2011

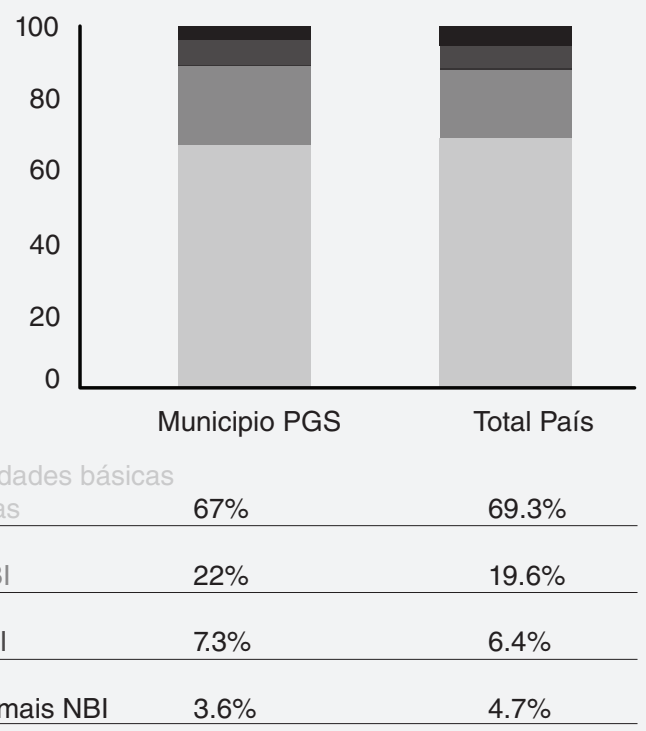

\begin{tabular}{lll} 
Necessidades básicas & & \\
\hline satisfeitas & $67 \%$ & $69.3 \%$ \\
\hline Uma NBI & $22 \%$ & $19.6 \%$ \\
\hline Dois NBI & $7.3 \%$ & $6.4 \%$ \\
\hline Três ou mais NBI & $3.6 \%$ & $4.7 \%$ \\
\hline
\end{tabular}

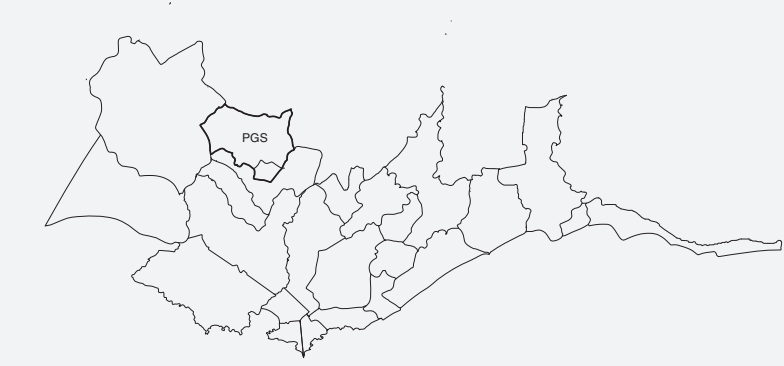




\section{TOLEDO - TDO}

\section{Canelones}

Tendo os dados do Censo 2011 como base, o município contra com uma população de 18.740 habitantes. A densidade populacional é de $618,9 \mathrm{hab} / \mathrm{km} 2$, enquanto que a densidade de Canelones é $114,7 \mathrm{hab} / \mathrm{km} 2.95,3 \%$ da população do município é urbana, majoritariamente de ascendência étnica branca (88,8\%), a população afro ou negra representa $5,4 \%$ da população. A proporção de pessoas com ao menos uma NBI é de 50,9\%, valor consideravelmente superior a media do nacional $(33,8 \%)$ e departamental (33.6\%).

Os indicadores do mercado de trabalho do município apresentam uma situação similar em relação à média departamental e nacional nas taxas relativas à atividade e emprego. A taxa de desemprego é um pouco superior tanto em comparação com a taxa departamental como nacional. O município tem uma taxa de atividade de $62, \%$, uma taxa de emprego de $57,2 \%$ e uma taxa de desemprego de $7,7 \%$ (2011).

$2 \%$ da população de 15 anos ou mais deste município é analfabeta. Por outro lado, a taxa líquida de assistência (TLA) aos 6 primeiros anos do ensino fundamental é parecida a TLA departamental assim como à nacional. A TLA ao ensino médio é inferior tanto em comparação com a departamental como com a nacional. O município tem uma TLA referente aos 6 primeiros anos do ensino fundamental de $92,7 \%$ enquanto que a departamental é de $93,1 \%$. Para o ensino médio a TLA é de $60,5 \%$ para o município e $67,5 \%$ para o departamento.

Texto livremente traduzido do site http://www.otu.opp.gub.uy

População: 18.740 habitantes

Área: $30.3 \mathrm{~km} 2$.

\section{DEMOGRAFIA}

População Urbana: 95.3\%

População por idades:

De 0 a 14 anos: 5.209 hab. $-27.80 \%$

De 15 a 24 anos: 3.244 hab. $-17.31 \%$

De 25 a 44 anos: 5.145 hab. $-27.45 \%$

De 45 a 64 anos: 3.555 hab. $-18.97 \%$

Mais de 65 anos: 1.587 hab. $-8.47 \%$

\section{RENDIMENTOS E BEM ESTAR}

Percentual da população que tem uma ou mais necessidades básicas insatisfeitas (moradia digna, saneamento, água potável, eletricidade, conforto, educação): $47,7 \%$ (superior a média nacional, $33,8 \%$ )

\section{EDUCAÇÃO}

Nível de escolaridade da população compreendida entre 25 e mais anos:

Primeiros 6 anos do Ensino Fundamental: $49.8 \%$

Ensino Fundamental: 25.1\%

Ensino Médio: $13.2 \%$

Educação Técnica: $5.1 \%$

Universidade: $2.9 \%$

Percentual de crianças entre 6 e 11 anos que vão a escola: $92.7 \%$

Percentual de crianças e adolescentes entre 12 e 17 anos que vão ao ensino médio: $60.5 \%$

\section{MERCADO DE TRABALHO}

Percentual da população em atividade: $62 \%$ Percentual da população empregada: $57.2 \%$

Percentual da população em situação de desemprego: $7.7 \%$ (mais alta que a média do país, 6.3\% em 2011)

\section{TECNOLOGIA}

Percentual da população com acesso a conexão a Internet: $29.6 \%$

Percentual da população que tem computador ou laptop: 35.2\%
Percentual de lares segundo a quantidade de NBI 2011

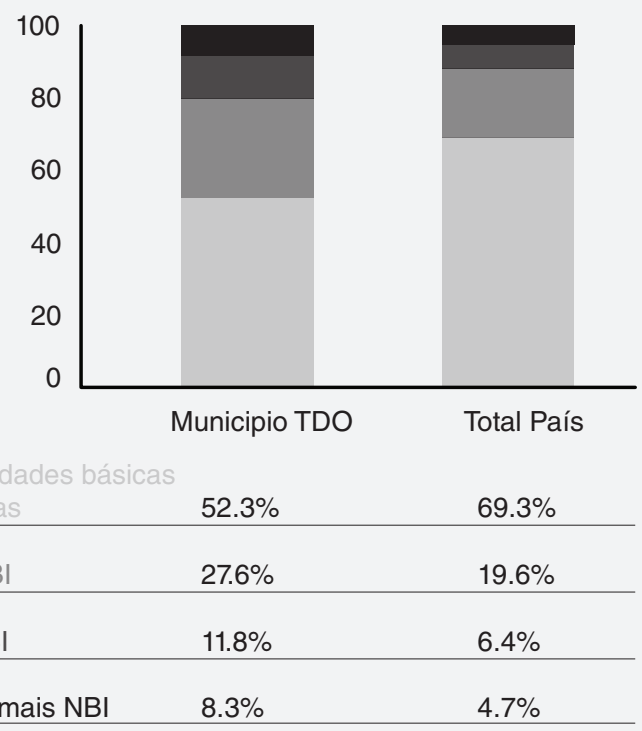

\begin{tabular}{lll} 
Necessidades básicas & & \\
\hline satisfeitas & $52.3 \%$ & $69.3 \%$ \\
\hline Uma NBI & $27.6 \%$ & $19.6 \%$ \\
\hline Dois NBI & $11.8 \%$ & $6.4 \%$ \\
\hline Três ou mais NBI & $8.3 \%$ & $4.7 \%$ \\
\hline
\end{tabular}

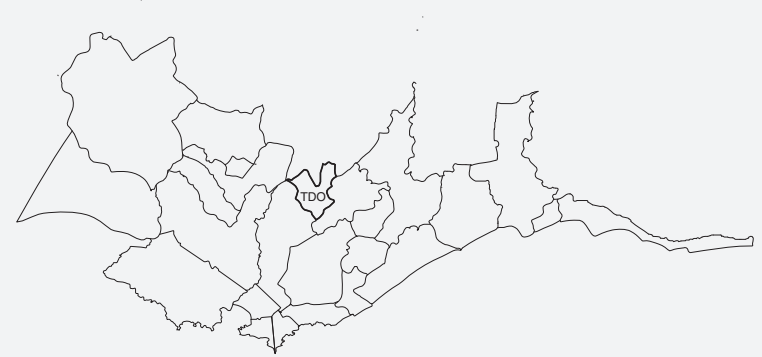

Dados obtidos do site http://www.otu.opp.gub.uy 


\section{SUAREZ - SRZ}

\section{Canelones}

Tendo os dados do Censo 2011 como base, o município contra com uma população de 18.153 habitantes. A densidade populacional é de $412,8 \mathrm{hab} / \mathrm{km} 2$, enquanto que a densidade de Canelones é $114,7 \mathrm{hab} / \mathrm{km} 2.93,2 \%$ da população do município é urbana, majoritariamente de ascendência étnica branca (86,7\%), a população afro ou negra representa $6,8 \%$ da população. A proporção de pessoas com ao menos uma NBI é de $50,4 \%$, valor superior a media do nacional $(33,8 \%$ ) e departamental (33.6\%). Os indicadores do mercado de trabalho do município apresentam uma situação similar em relação à média departamental e nacional nas taxas relativas à atividade e emprego. A taxa de desemprego é superior tanto em comparação com a taxa departamental como nacional. O município tem uma taxa de atividade de $63,3 \%$, uma taxa de emprego de $58,1 \%$ e uma taxa de desemprego de $8,2 \%$ (2011).

$1,9 \%$ da população de 15 anos ou mais deste município é analfabeta. Por outro lado, a taxa líquida de assistência (TLA) aos 6 primeiros anos do ensino fundamental é parecida a TLA departamental assim como à nacional. A TLA ao ensino médio é inferior a TNA departamental e nacional. O município tem uma TLA referente aos 6 primeiros anos do ensino fundamental de $92,1 \%$ enquanto que a departamental é de $93,1 \%$. Para o ensino médio a TLA é de $57,5 \%$ para o município e $67,5 \%$ para o departamento.

Texto livremente traduzido do site http://www.otu.opp.gub.uy

População: 18.153 habitantes

Área: $44 \mathrm{~km} 2$.

\section{DEMOGRAFIA}

População Urbana: $93.2 \%$

População por idades:

De 0 a 14 anos: 4.891 hab. $-26.94 \%$

De 15 a 24 anos: 3.273 hab. $-18.03 \%$

De 25 a 44 anos: 4.933 hab. $-27.17 \%$

De 45 a 64 anos: 3.375 hab. $-18.59 \%$

Mais de 65 anos: 1.681 hab. $-9.26 \%$

\section{RENDIMENTOS E BEM ESTAR}

Percentual da população que tem uma ou mais necessidades básicas insatisfeitas (moradia digna, saneamento, água potável, eletricidade, conforto, educação): 47,3\% (superior a média nacional, $33,8 \%$ )

\section{EDUCAÇÃO}

Nível de escolaridade da população compreendida entre 25 e mais anos:

Primeiros 6 anos do Ensino Fundamental: 47.7\%

Ensino Fundamental: $25.3 \%$

Ensino Médio: 13.4\%

Educação Técnica: $6.9 \%$

Universidade: $2.9 \%$

Percentual de crianças entre 6 e 11 anos que vão a escola: $92.1 \%$

Percentual de crianças e adolescentes entre 12 e 17 anos que vão ao ensino médio: $57.5 \%$

\section{MERCADO DE TRABALHO}

Percentual da população em atividade: $63.3 \%$ Percentual da população empregada: $58.1 \%$

Percentual da população em situação de desemprego: 8.2\% (maior que a média do país, 6.3\% em 2011)

\section{TECNOLOGIA}

Percentual da população com acesso a conexão a Internet: $26.9 \%$

Percentual da população que tem computador ou laptop: 33.5\%
Percentual de lares segundo a quantidade de NBI 2011
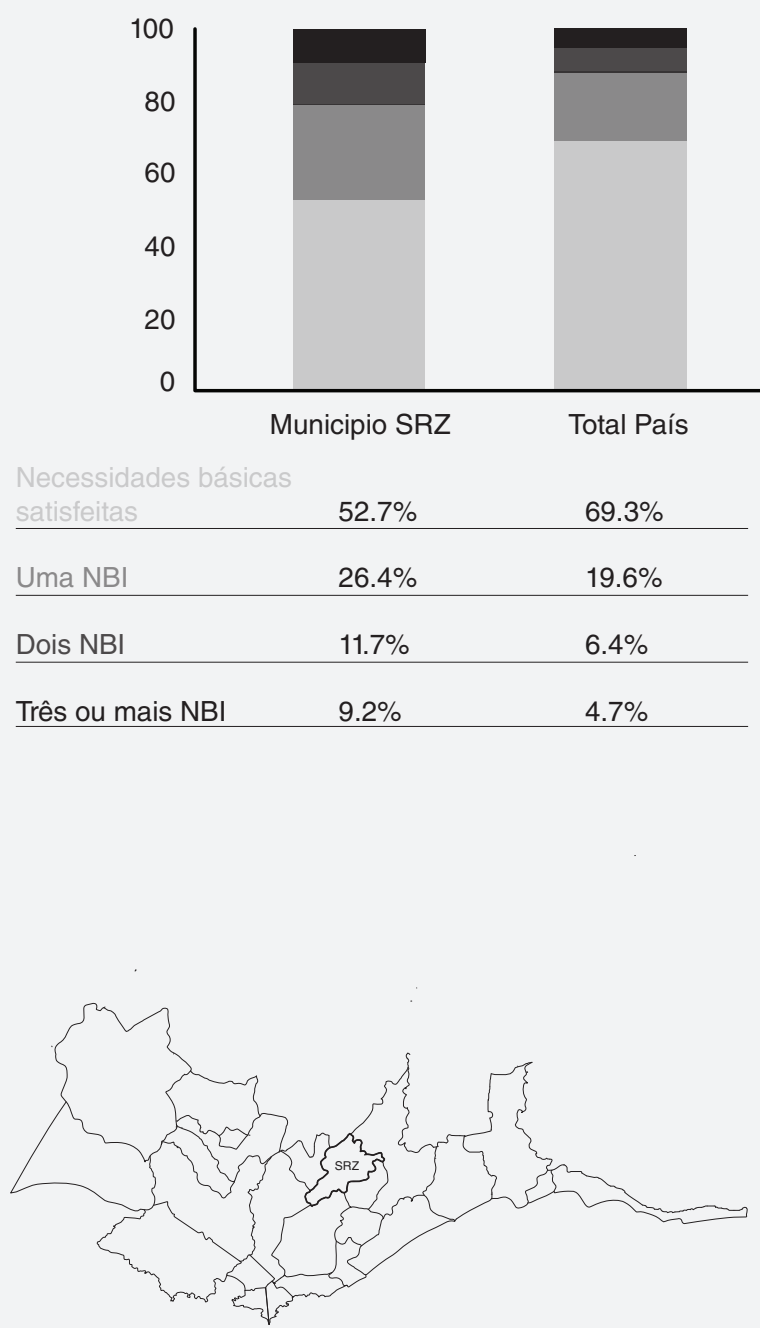


\section{BARROS BLANCOS - BBS}

\section{Canelones}

Tendo os dados do Censo 2011 como base, o município contra com uma população de 29.865 habitantes. A densidade populacional é de 1307,6 hab/km2, enquanto que a densidade de Canelones é $114,7 \mathrm{hab} / \mathrm{km} 2.99,9 \%$ da população do município é urbana, majoritariamente de ascendência étnica branca (86,0\%), a população afro ou negra representa $7,4 \%$ da população. A proporção de pessoas com ao menos uma NBI é de $45,7 \%$, valor superior a media do nacional $(33,8 \%)$ e departamental (33.6\%) Os indicadores do mercado de trabalho do município apresentam uma situação similar em relação à média departamental $e$ nacional nas taxas relativas à atividade e emprego. A taxa de desemprego é superior tanto em comparação com a taxa departamental como nacional. O município tem uma taxa de atividade de $62,5 \%$, uma taxa de emprego de $57,0 \%$ e uma taxa de desemprego de $8,8 \%$ (2011).

1,6\% da população de 15 anos ou mais deste município é analfabeta. Por outro lado, a taxa líquida de assistência (TLA) aos 6 primeiros anos do ensino fundamental é parecida a TLA departamental assim como à nacional. A TLA ao ensino médio é inferior a TLA do departamento e nacional. O município tem uma TLA referente aos 6 primeiros anos do ensino fundamental de $93,9 \%$ enquanto que a departamental é de $93,1 \%$. Para o ensino médio a TLA é de $60,5 \%$ para o município e $67,5 \%$ para o departamento.

Texto livremente traduzido do site http://www.otu.opp.gub.uy

População: 29.865 habitantes

Área: $22.8 \mathrm{~km} 2$.

\section{DEMOGRAFIA}

População Urbana: 99.9\%

População por idades:

De 0 a 14 anos: 7.832 hab. $-26.22 \%$

De 15 a 24 anos: 5.095 hab. $-17.06 \%$

De 25 a 44 anos: 8.206 hab. $-27.48 \%$

De 45 a 64 anos: 5.867 hab. $-19.65 \%$

Mais de 65 anos: 2.865 hab. $-5.59 \%$

\section{RENDIMENTOS E BEM ESTAR}

Percentual da população que tem uma ou mais necessidades básicas insatisfeitas (moradia digna, saneamento, água potável, eletricidade, conforto, educação): $42,8 \%$ (superior a média nacional, 33,8\%)

\section{EDUCAÇÃo}

Nível de escolaridade da população compreendida entre 25 e mais anos:

Primeiros 6 anos do Ensino Fundamental: $44.8 \%$

Ensino Fundamental: 26.2\%

Ensino Médio: $14.3 \%$

Educação Técnica: $6.8 \%$

Universidade: $3 \%$

Percentual de crianças entre 6 e 11 anos que vão a escola: $93.9 \%$

Percentual de crianças e adolescentes entre 12 e 17 anos que vão ao ensino médio: $60.5 \%$

\section{MERCADO DE TRABALHO}

Percentual da população em atividade: $62.5 \%$

Percentual da população empregada: $57 \%$

Percentual da população em situação de desemprego: $8.8 \%$ (maior que a média do país, 6.3\% em 2011)

\section{TECNOLOGIA}

Percentual da população com acesso a conexão a Internet:

$30.6 \%$

Percentual da população que tem computador ou laptop: 38.1\% 


\section{NICOLICH - NCH}

\section{Canelones}

Tendo os dados do Censo 2011 como base, o município contra com uma população de 14.788 habitantes. A densidade populacional é de 567,7 hab/km2, enquanto que a densidade de Canelones é 114,7 hab/km2. 97,5\% da população do município é urbana, majoritariamente de ascendência étnica branca (82.5,9\%), a população afro ou negra representa $9,4 \%$ da população. A proporção de pessoas com ao menos uma NBI é de $50,5 \%$, valor consideravelmente superior a media do nacional $(33,8 \%)$ e departamental $(33.6 \%)$

Os indicadores do mercado de trabalho do município apresentam uma situação favorável em relação à média departamental e nacional nas taxas relativas à atividade e emprego. A taxa de desemprego é superior tanto em comparação com a taxa departamental como nacional. O município tem uma taxa de atividade de 66,7\%, uma taxa de emprego de 61,3\% e uma taxa de desemprego de $8,1 \%$ (2011).

2,1\% da população de 15 anos ou mais deste município é analfabeta. Por outro lado, a taxa líquida de assistência (TLA) aos 6 primeiros anos do ensino fundamental é parecida a TLA departamental assim como à nacional. A TLA ao ensino médio é inferior a departamental e a nacional. O município tem uma TLA referente aos 6 primeiros anos do ensino fundamental de 92,6\% enquanto que a departamental é de $93,1 \%$. Para o ensino médio a TLA é de $56, \%$ para o município e $67,5 \%$ para o departamento.

Texto livremente traduzido do site http://www.otu.opp.gub.uy

População: 14.788 habitantes

Área: $26 \mathrm{~km} 2$.

\section{DEMOGRAFIA}

População Urbana: $97.5 \%$

População por idades:

De 0 a 14 anos: 4.281 hab. $-28.95 \%$

De 15 a 24 anos: 2.640 hab. $-17.85 \%$

De 25 a 44 anos: 4.146 hab. $-28.04 \%$

De 45 a 64 anos: 2.657 hab. $-17.97 \%$

Mais de 65 anos: 1.064 hab. $-7.19 \%$

\section{RENDIMENTOS E BEM ESTAR}

Percentual da população que tem uma ou mais necessidades básicas insatisfeitas (moradia digna, saneamento, água potável, eletricidade, conforto, educação): $47,4 \%$ (superior a média nacional, $33,8 \%$ )

\section{EDUCAÇÃO}

Nível de escolaridade da população compreendida entre 25 e mais anos:

Primeiros 6 anos do Ensino Fundamental: 47.7\%

Ensino Fundamental: $27 \%$

Ensino Médio: $12.2 \%$

Educação Técnica: $4.6 \%$

Universidade: $4.4 \%$

Percentual de crianças entre 6 e 11 anos que vão a escola: $92.6 \%$

Percentual de crianças e adolescentes entre 12 e 17 anos que vão ao ensino médio: $56 \%$

\section{MERCADO DE TRABALHO}

Percentual da população em atividade: $66.7 \%$

Percentual da população empregada: $61.3 \%$

Percentual da população em situação de desemprego: $8.1 \%$ (maior que a média do país, 6.3\% em 2011)

\section{TECNOLOGIA}

Percentual da população com acesso a conexão a Internet: $32.5 \%$

Percentual da população que tem computador ou laptop: 39\%
Percentual de lares segundo a quantidade de NBI 2011

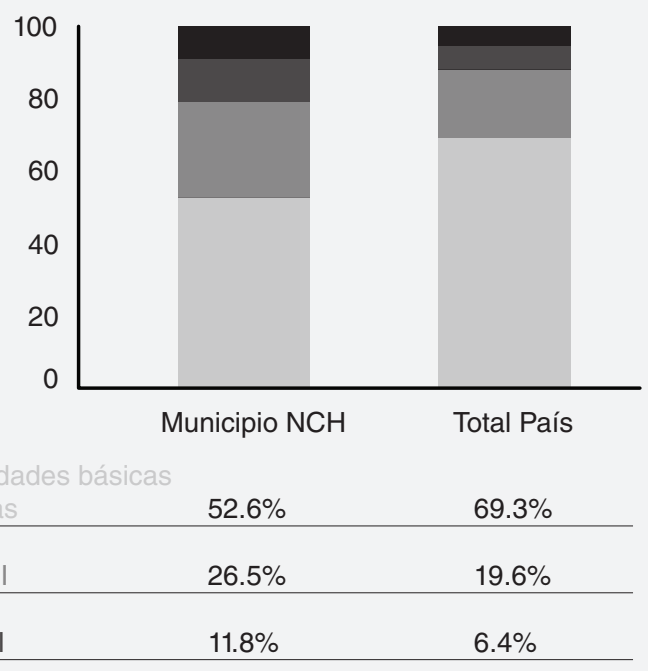

\begin{tabular}{lll} 
Necessidades básicas & $52.6 \%$ & $69.3 \%$ \\
\hline Uma NBI & $26.5 \%$ & $19.6 \%$ \\
\hline Dois NBI & $11.8 \%$ & $6.4 \%$ \\
\hline Três ou mais NBI & $9.1 \%$ & $4.7 \%$ \\
\hline
\end{tabular}

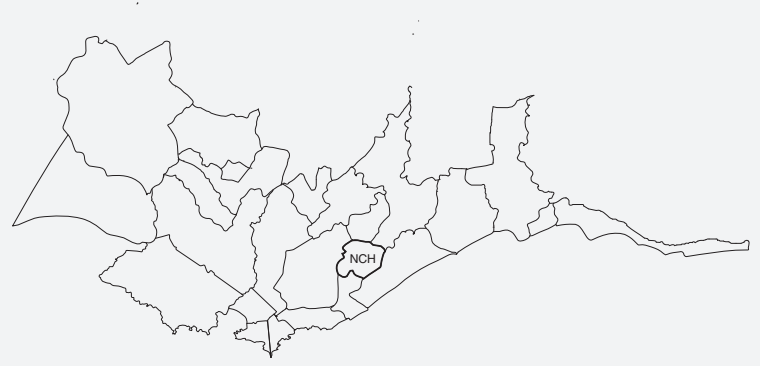

Dados obtidos do site http://www.otu.opp.gub.uy Datos extraidos de la página http://www.otu.opp.g ub.uy 


\section{PASO CARRASCO - PCO}

\section{Canelones}

Tendo os dados do Censo 2011 como base, o município contra com uma população de 20.842 habitantes. A densidade populacional é de 1007,2 hab/km2, enquanto que a densidade de Canelones é $114,7 \mathrm{hab} / \mathrm{km} 2.100 \%$ da população do município é urbana, majoritariamente de ascendência étnica branca (92,6\%), a população afro ou negra representa 3,7\% da população. A proporção de pessoas com ao menos uma NBI é de $25,2 \%$, valor superior a media do nacional $(33,8 \%)$ e departamental (33.6\%). Os indicadores do mercado de trabalho do município apresentam uma situação favorável em relação à média departamental e nacional nas taxas relativas à atividade e emprego. A taxa de desemprego é similar à nacional e levemente inferior a departamental. O município tem uma taxa de atividade de $67,4 \%$, uma taxa de emprego de $63,2 \%$ e uma taxa de desemprego de $6,3 \%(2011)$.

1,1\% da população de 15 anos ou mais deste município é analfabeta. Por outro lado, a taxa líquida de assistência (TLA) aos 6 primeiros anos do ensino fundamental é parecida a TLA departamental assim como à nacional. A TLA ao ensino médio é superior TLA departamental e nacional. O município tem uma TLA referente aos 6 primeiros anos do ensino fundamental de 92,8\% enquanto que a departamental é de $93,1 \%$. Para o ensino médio a TLA é de $69,1 \%$ para o município e $67,5 \%$ para o departamento.

Texto livremente traduzido do site http://www.otu.opp.gub.uy

População: 20.842 habitantes

Área: $20.7 \mathrm{~km} 2$

\section{DEMOGRAFIA}

População Urbana: 100\%

População por idades:

De 0 a 14 anos: 4.945 hab. $-23.78 \%$

De 15 a 24 anos: 3.231 hab. $-15.50 \%$

De 25 a 44 anos: 5.841 hab. $-28.03 \%$

De 45 a 64 anos: 4.462 hab. $-21.41 \%$

Mais de 65 anos: 2.352 hab. $-11.28 \%$

\section{RENDIMENTOS E BEM ESTAR}

Percentual da população que tem uma ou mais necessidades básicas insatisfeitas (moradia digna, saneamento, água potável, eletricidade, conforto, educação): $23,8 \%$ (superior a média nacional, 33,8\%)

\section{EDUCAÇÃO}

Nível de escolaridade da população compreendida entre 25 e mais anos:

Primeiros 6 anos do Ensino Fundamental: $26.9 \%$

Ensino Fundamental: $20.50 \%$

Ensino Médio: $19.9 \%$

Educação Técnica: $6.7 \%$

Universidade: $18 \%$

Percentual de crianças entre 6 e 11 anos que vão a escola: $92.8 \%$

Percentual de crianças e adolescentes entre 12 e 17 anos que vão ao ensino médio: $69.1 \%$

\section{MERCADO DE TRABALHO}

Percentual da população em atividade: $67.4 \%$

Percentual da população empregada: $63.2 \%$

Percentual da população em situação de desemprego: $6.3 \%$ (igual a média do país, 6.3\% em 2011)

\section{TECNOLOGIA}

Percentual da população com acesso a conexão a Internet:

$52.8 \%$

Percentual da população que tem computador ou laptop: $57.3 \%$
Percentual de lares segundo a quantidade de NBI 2011

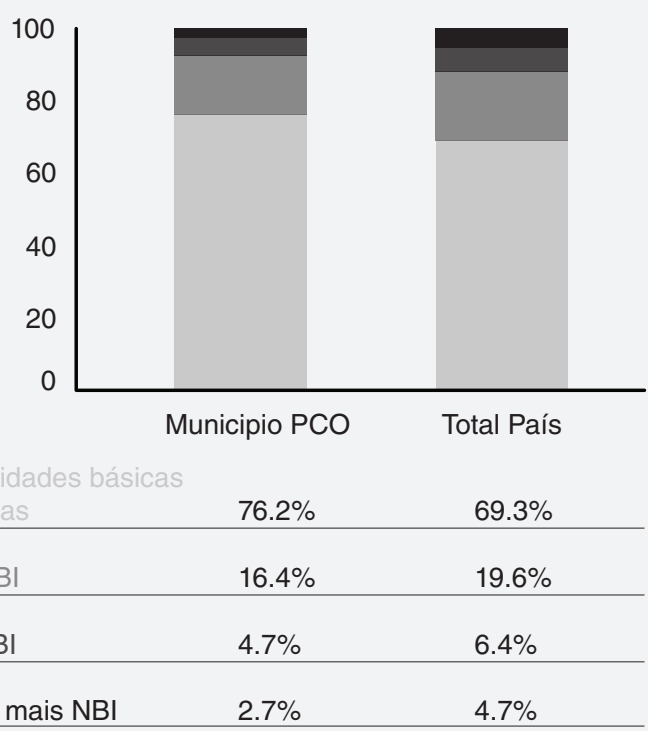

\begin{tabular}{lll} 
Necessidades básicas & & \\
\hline Satisfeitas & $76.2 \%$ & $69.3 \%$ \\
\hline Uma NBI & $16.4 \%$ & $19.6 \%$ \\
\hline Dois NBI & $4.7 \%$ & $6.4 \%$ \\
\hline Três ou mais NBI & $2.7 \%$ & $4.7 \%$ \\
\hline
\end{tabular}

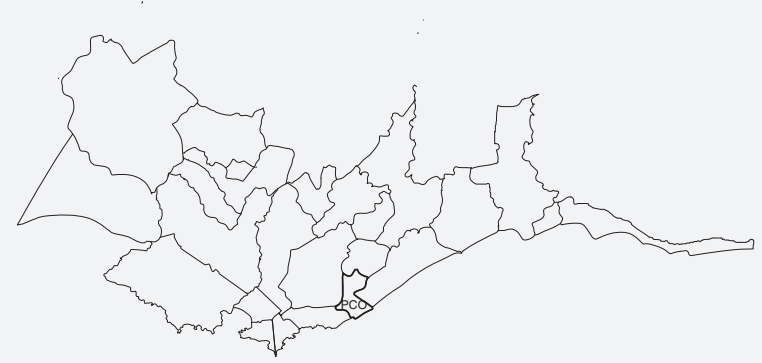




\title{
PANDO - PDO
}

\author{
Canelones
}

Tendo os dados do Censo 2011 como base, o município contra com uma população de 32.927 habitantes. A densidade populacional é de $286,6 \mathrm{hab} / \mathrm{km} 2$, enquanto que a densidade de Canelones é $114,7 \mathrm{hab} / \mathrm{km} 2.93,2 \%$ da população do município é urbana, majoritariamente de ascendência étnica branca $(90,1 \%)$, a população afro ou negra representa $4,9 \%$ da população. A proporção de pessoas com ao menos uma NBI é de $37,6 \%$, valor superior a media do nacional $(33,8 \%)$ e departamental $(33.6 \%)$. Os indicadores do mercado de trabalho do município apresentam uma situação um pouco mais favorável em relação à média departamental e nacional nas taxas relativas à atividade e emprego. A taxa de desemprego é superior tanto em comparação com a taxa departamental como nacional. O município tem uma taxa de atividade de $63,7 \%$, uma taxa de emprego de $59 \%$ e uma taxa de desemprego de $7,4 \%$ (2011).

$1,9 \%$ da população de 15 anos ou mais deste município é analfabeta. Por outro lado, a taxa líquida de assistência (TLA) aos 6 primeiros anos do ensino fundamental é um pouco superior a TLA departamental assim como à nacional. A TLA ao ensino médio é inferior a TLA departamental e nacional. O município tem uma TLA referente aos 6 primeiros anos do ensino fundamental de $94 \%$ enquanto que a departamental é de $93,1 \%$. Para o ensino médio a TLA é de $62,5 \%$ para o município e $67,5 \%$ para o departamento.

Texto livremente traduzido do site http://www.otu.opp.gub.uy

População: 32.927 habitantes Área: $114.9 \mathrm{~km} 2$.

\section{DEMOGRAFIA}

População Urbana: 93.2\%

População por idades:

De 0 a 14 anos: 7.602 hab. $-23.09 \%$

De 15 a 24 anos: 5.244 hab. $-15.93 \%$

De 25 a 44 anos: 8.923 hab. $-27.10 \%$

De 45 a 64 anos: 7.110 hab. $-21.59 \%$

Mais de 65 anos: 4.048 hab. $-12.29 \%$

\section{RENDIMENTOS E BEM ESTAR}

Percentual da população que tem uma ou mais necessidades básicas insatisfeitas (moradia digna, saneamento, água potável, eletricidade, conforto, educação): $35,1 \%$ (superior a média nacional, $33,8 \%$ )

\section{EDUCAÇÃO}

Nível de escolaridade da população compreendida entre 25 e mais anos:

Primeiros 6 anos do Ensino Fundamental: $39.6 \%$

Ensino Fundamental: 21.5\%

Ensino Médio: $17 \%$

Educação Técnica: $7.6 \%$

Universidade: $7.1 \%$

Percentual de crianças entre 6 e 11 anos que vão a escola: 94\% Percentual de crianças e adolescentes entre 12 e 17 anos que vão ao ensino médio: $62.5 \%$

\section{MERCADO DE TRABALHO}

Percentual da população em atividade: $63.7 \%$ Percentual da população empregada: $59 \%$

Percentual da população em situação de desemprego: 7.4\% (maior que a taxa do país, 6.3\% em 2001)

\section{TECNOLOGIA}

Percentual da população com acesso a conexão a Internet: $39.5 \%$

Percentual da população que tem computador ou laptop: $44.7 \%$
Percentual de lares segundo a quantidade de NBI 2011

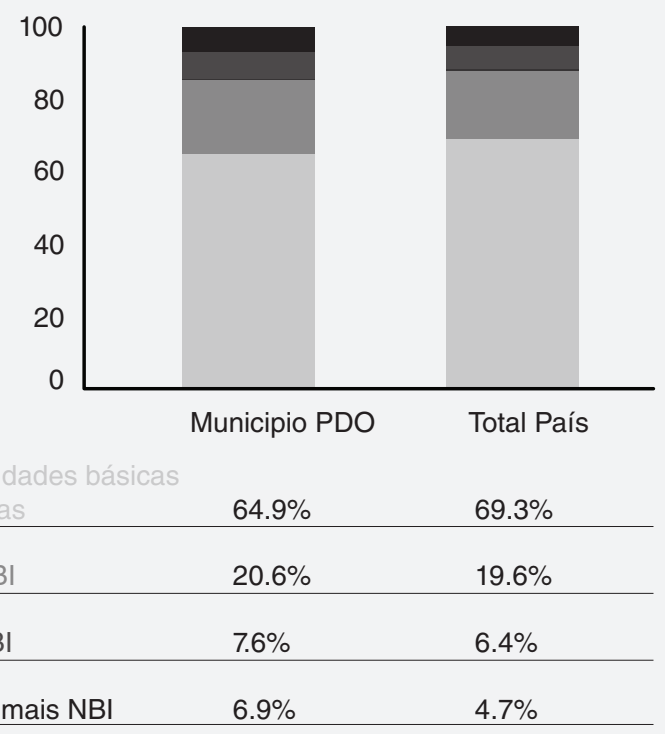

\begin{tabular}{lll} 
Três ou mais NBI & $6.9 \%$ & $4.7 \%$ \\
\hline
\end{tabular}

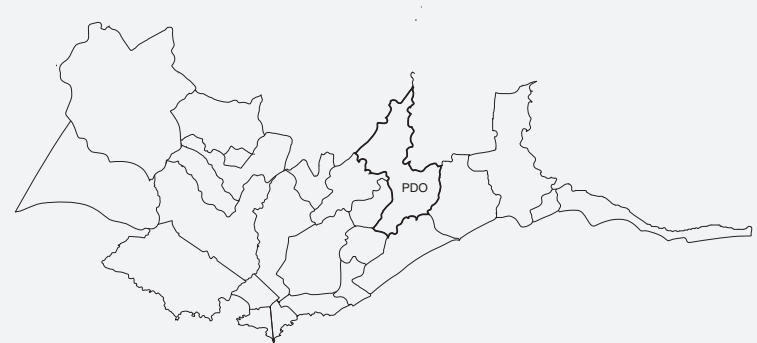




\section{CIUDAD DE LA COSTA - CDC}

\section{Canelones}

Tendo os dados do Censo 2011 como base, o município contra com uma população de 91.284 habitantes. A densidade populacional é de 1494 hab/km2, enquanto que a densidade de Canelones é 114,7 hab/km2. 99,9\% da população do município é urbana, majoritariamente de ascendência étnica branca (93,5\%), a população afro ou negra representa $2,9 \%$ da população. A proporção de pessoas com ao menos uma NBI é de 17,6\%, valor consideravelmente inferior a media do nacional (33,8\%) e departamental (33.6\%).

Os indicadores do mercado de trabalho do município apresentam uma situação mais favorável em relação à média departamental e nacional nas taxas relativas à atividade e emprego. A taxa de desemprego, por outro lado é parecida à nacional. O município tem uma taxa de atividade de 67,5\%, uma taxa de emprego de 63,4\% e uma taxa de desemprego de 6,2\% (2011).

$0,5 \%$ da população de 15 anos ou mais deste município é analfabeta. Por outro lado, a taxa líquida de assistência (TLA) aos 6 primeiros anos do ensino fundamental é parecida a TLA departamental assim como à nacional. A TLA ao ensino médio é superior a TLA departamental e nacional. O município tem uma TLA referente aos 6 primeiros anos do ensino fundamental de 92,9\% enquanto que a departamental é de $93,1 \%$. Para o ensino médio a TLA é de $78,5 \%$ para o município e $67,5 \%$ para o departamento.

Texto livremente traduzido do site http://www.otu.opp.gub.uy

População: 91.284 habitantes

Área: $61.1 \mathrm{~km} 2$.

\section{DEMOGRAFIA}

População Urbana: 99.9\%

População por idades:

De 0 a 14 anos: 19.559 hab. $-21.43 \%$

De 15 a 24 anos: 13.289 hab. $-14.56 \%$

De 25 a 44 anos: 26.475 hab. $-29.00 \%$

De 45 a 64 anos: 21.077 hab. $-23.09 \%$

Mais de 65 anos: 10.884 hab. $-11.92 \%$

\section{RENDIMENTOS E BEM ESTAR}

Percentual da população que tem uma ou mais necessidades básicas insatisfeitas (moradia digna, saneamento, água potável, eletricidade, conforto, educação): 16,8\% (inferior a média nacional, 33,8\%)

\section{EDUCAÇÃO}

Nível de escolaridade da população compreendida entre 25 e mais anos:

Primeiros 6 anos do Ensino Fundamental: 17.8\%

Ensino Fundamental: $17.5 \%$

Ensino Médio: $25.9 \%$

Educação Técnica: $8.4 \%$

Universidade: $20.7 \%$

Percentual de crianças entre 6 e 11 anos que vão a escola: 92.9\%

Percentual de crianças e adolescentes entre 12 e 17 anos que vão ao ensino médio: $78.5 \%$

\section{MERCADO DE TRABALHO}

Percentual da população em atividade: $67.5 \%$

Percentual da população empregada: $63.4 \%$

Percentual da população em situação de desemprego: $6.2 \%$ (menor que a taxa do país, 6.3\% em 2011)

\section{TECNOLOGIA}

Percentual da população com acesso a conexão a Internet:

$61.7 \%$

Percentual da população que tem computador ou laptop: 65.8\%
Percentual de lares segundo a quantidade de NBI 2011

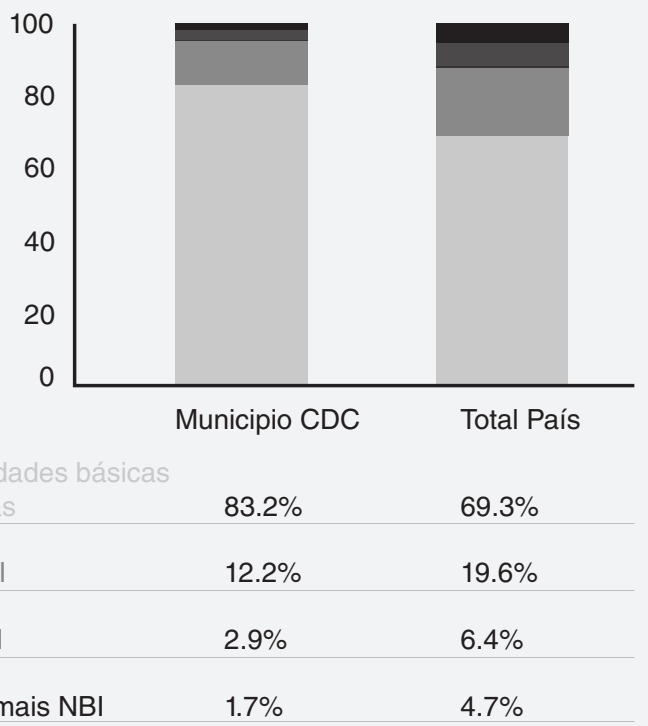

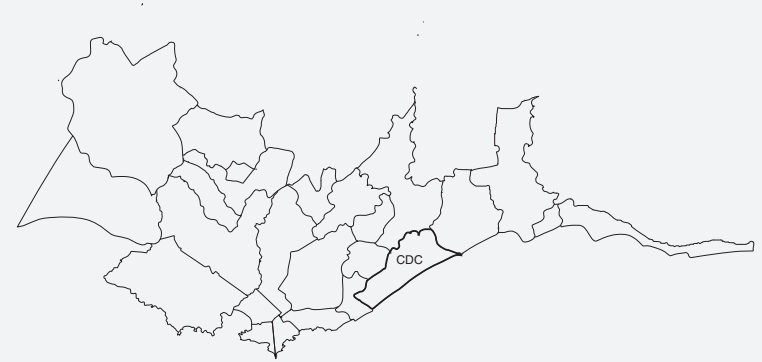

Dados obtidos do site http://www.otu.opp.gub.uy 


\title{
ATLANTIDA - ATA
}

\author{
Canelones
}

Tendo os dados do Censo 2011 como base, o município contra com uma população de 10.198 habitantes. A densidade populacional é de $94,3 \mathrm{hab} / \mathrm{km} 2$, enquanto que a densidade de Canelones é 114,7 hab/km2. 93,7\% da população do município é urbana, majoritariamente de ascendência étnica branca $(96,2 \%)$, a população afro ou negra representa 1,5\% da população. A proporção de pessoas com ao menos uma NBI é de $20,2 \%$, valor inferior a media do nacional (33,8\%) e departamental (33.6\%). Os indicadores do mercado de trabalho do município apresentam uma situação similar em relação à média departamental e nacional nas taxas relativas à atividade, emprego e desemprego. O município tem uma taxa de atividade de $61,1 \%$, uma taxa de emprego de 57,4\% e uma taxa de desemprego de 6,0 (2011).

$1 \%$ da população de 15 anos ou mais deste município é analfabeta. Por outro lado, a taxa líquida de assistência (TLA) aos 6 primeiros anos do ensino fundamental é parecida a TLA departamental assim como à nacional. A TLA ao ensino médio é um pouco superior à taxa departamental e nacional apresenta igual comportamento. O município tem uma TLA referente aos 6 primeiros anos do ensino fundamental de $93,8 \%$ enquanto que a departamental é de $93,1 \%$. Para o ensino médio a TLA é de $73,1 \%$ para o município e $67,5 \%$ para o departamento.

Texto livremente traduzido do site http://www.otu.opp.gub.uy

População: 10.198 habitantes

Área: $108.1 \mathrm{~km} 2$.

\section{DEMOGRAFIA}

População Urbana: $93.7 \%$

População por idades:

De 0 a 14 anos: 1.965 hab. $-19.27 \%$

De 15 a 24 anos: 1.487 hab. $-14.45 \%$

De 25 a 44 anos: 2.696 hab. $-26.44 \%$

De 45 a 64 anos: 2.421 hab. $-23.74 \%$

Mais de 65 anos: 1.629 hab. - $15.97 \%$

\section{RENDIMENTOS E BEM ESTAR}

Percentual da população que tem uma ou mais necessidades básicas insatisfeitas (moradia digna, saneamento, água potável, eletricidade, conforto, educação): $18,1 \%$ (menor que a média nacional, $33,8 \%$ )

\section{EDUCAÇÃO}

Nível de escolaridade da população compreendida entre 25 e mais anos:

Primeiros 6 anos do Ensino Fundamental: $32.2 \%$

Ensino Fundamental: $15.8 \%$

Ensino Médio: $21.8 \%$

Educação Técnica: $6.3 \%$

Universidade: $14.1 \%$

Percentual de crianças entre 6 e 11 anos que vão a escola: $93.8 \%$

Percentual de crianças e adolescentes entre 12 e 17 anos que vão ao ensino médio: $73.1 \%$

\section{MERCADO DE TRABALHO}

Percentual da população em atividade: $61.1 \%$ Percentual da população empregada: $57.4 \%$

Percentual da população em situação de desemprego: $6 \%$ (menor que a taxa do país, 6.3\% em 2011)

\section{TECNOLOGIA}

Percentual da população com acesso a conexão a Internet: $47.3 \%$

Percentual da população que tem computador ou laptop: $54.5 \%$
Percentual de lares segundo a quantidade de NBI 2011

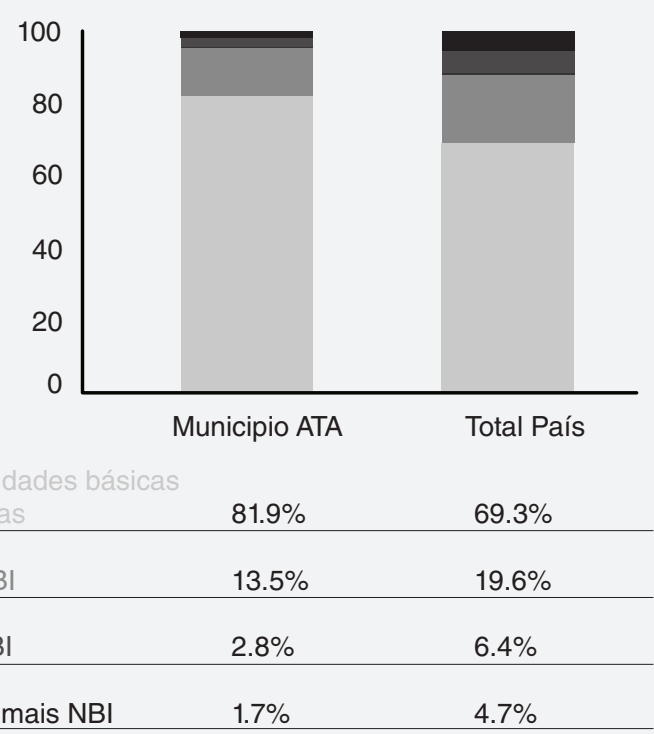

\begin{tabular}{lll} 
Três ou mais NBI & $1.7 \%$ & $4.7 \%$ \\
\hline
\end{tabular}

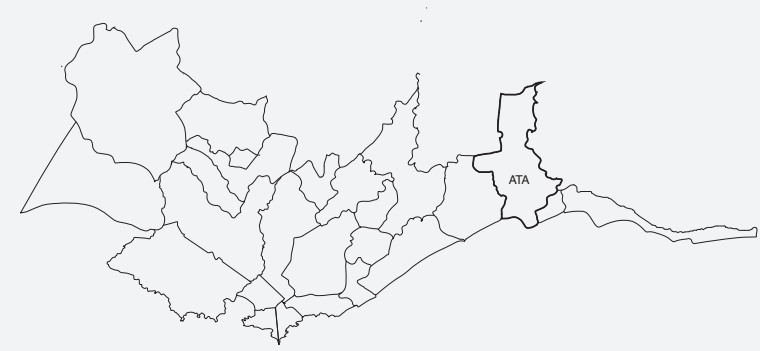




\section{PARQUe del PLATA- PDP}

\section{Canelones}

Tendo os dados do Censo 2011 como base, o município contra com uma população de 11.054 habitantes. A densidade populacional é de 863,8 hab/km2, enquanto que a densidade de Canelones é 114,7 hab/km2. 100\% da população do município é urbana, majoritariamente de ascendência étnica branca $(93,6 \%)$, a população afro ou negra representa $3 \%$ da população. A proporção de pessoas com ao menos uma NBI é de $20,2 \%$, valor consideravelmente inferior a media do nacional (33,8\%) e departamental (33.6\%).

Os indicadores do mercado de trabalho do município apresentam uma situação um pouco inferior em relação à média departamental e nacional nas taxas relativas à atividade, emprego e desemprego. O município tem uma taxa de atividade de $61,4 \%$, uma taxa de emprego de $56,4 \%$ e uma taxa de desemprego de $8,1 \%(2011)$.

0,9\% da população de 15 anos ou mais deste município é analfabeta. Por outro lado, a taxa líquida de assistência (TLA) aos 6 primeiros anos do ensino fundamental é parecida a TLA departamental assim como à nacional. A TLA ao ensino médio é maior do que a TLA departamental e nacional. O município tem uma TLA referente aos 6 primeiros anos do ensino fundamental de $93,5 \%$ enquanto que a departamental é de $93,1 \%$. Para o ensino médio a TLA é de $73 \%$ para o município e $67,5 \%$ para o departamento.

Texto livremente traduzido do site http://www.otu.opp.gub.uy

População: 11.054 habitantes

Área: 12.8 km2.

\section{DEMOGRAFIA}

População Urbana: 100\%

População por idades:

De 0 a 14 anos: 2.153 hab. - 19.48\%

De 15 a 24 anos: 1.469 hab. $-13.29 \%$

De 25 a 44 anos: 2.890 hab. $-26.14 \%$

De 45 a 64 anos: 2.648 hab. $-23.96 \%$

Mais de 65 anos: 1.894 hab. $-17.13 \%$

\section{RENDIMENTOS E BEM ESTAR}

Percentual da população que tem uma ou mais necessidades básicas insatisfeitas (moradia digna, saneamento, água potável, eletricidade, conforto, educação): 17,5\% (menor que a média nacional, 33,8\%)

\section{EDUCAÇÃO}

Nível de escolaridade da população compreendida entre 25 e mais anos:

Primeiros 6 anos do Ensino Fundamental: $25.9 \%$

Ensino Fundamental: $20.7 \%$

Ensino Médio: $23.5 \%$

Educação Técnica: $9.2 \%$

Universidade: $11.7 \%$

\section{MERCADO DE TRABALHO}

Percentual da população em atividade: $61.4 \%$ Percentual da população empregada: $56.4 \%$ Percentual da população em situação de desemprego: $8.1 \%$ (maior que a taxa do país, 6.3\% em 2011)

\section{TECNOLOGIA}

Percentual da população com acesso a conexão a Internet: $48.1 \%$

Percentual da população que tem computador ou laptop: $52.3 \%$
Percentual de lares segundo a quantidade de NBI 2011

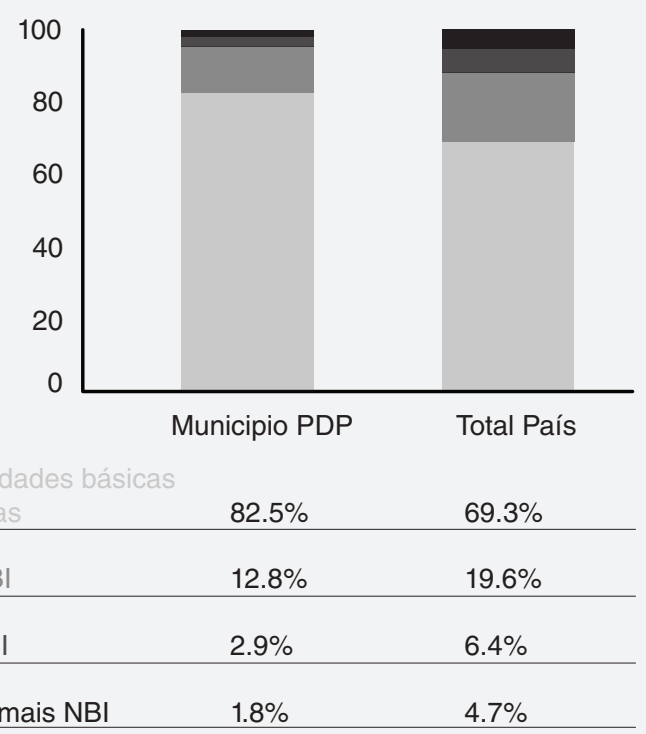

\begin{tabular}{lll} 
Três ou mais NBI & $1.8 \%$ & $4.7 \%$ \\
\hline
\end{tabular}

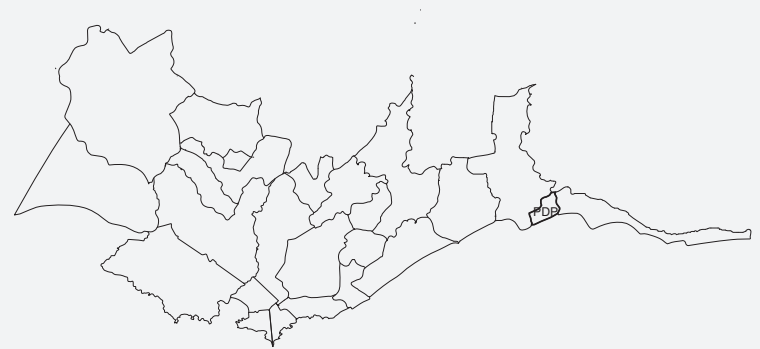




\section{LA FLORESTA - LFA}

\section{Canelones}

Tendo os dados do Censo 2011 como base, o município contra com uma população de 8.353 habitantes. A densidade populacional é de 141,4 hab/km2, enquanto que a densidade de Canelones é $114,7 \mathrm{hab} / \mathrm{km} 2.100 \%$ da população do município é urbana, majoritariamente de ascendência étnica branca $(92,5 \%)$, a população afro ou negra representa $3,2 \%$ da população. A proporção de pessoas com ao menos uma NBI é de $31,2 \%$, valor inferior a media do nacional $(33,8 \%)$ e departamental $(33.6 \%)$. Os indicadores do mercado de trabalho do município apresentam uma situação mais favorável em relação à média departamental e nacional nas taxas relativas à atividade e emprego. A taxa de desemprego é inferior tanto em comparação com a taxa departamental como nacional. O município tem uma taxa de atividade de 56,4\%, uma taxa de emprego de 53,4\% e uma taxa de desemprego de $5,5 \%$ (2011).

$1,5 \%$ da população de 15 anos ou mais deste município é analfabeta. Por outro lado, a taxa líquida de assistência (TLA) aos 6 primeiros anos do ensino fundamental é inferior a TLA departamental assim como à nacional. A TLA ao ensino médio apresenta igual comportamento. O município tem uma TLA referente aos 6 primeiros anos do ensino fundamental de $90,8 \%$ enquanto que a departamental é de $93,1 \%$. Para o ensino médio a TLA é de $61,5 \%$ para o município e 67,5\% para o departamento.

Texto livremente traduzido do site http://www.otu.opp.gub.uy

População: 8.353 habitantes

Área: $59.1 \mathrm{~km} 2$.

Percentual de lares segundo a quantidade de NBI 2011

\section{DEMOGRAFIA}

População Urbana: 100\%

População por idades:

De 0 a 14 anos: 1.615 hab. $-19.33 \%$

De 15 a 24 anos: 1.005 hab. $-12.03 \%$

De 25 a 44 anos: 2.008 hab. $-24.04 \%$

De 45 a 64 anos: 2.028 hab. $-24.28 \%$

Mais de 65 anos: 1.697 hab. $-20.32 \%$

\section{RENDIMENTOS E BEM ESTAR}

Percentual da população que tem uma ou mais necessidades básicas insatisfeitas (moradia digna, saneamento, água potável, eletricidade, conforto, educação): $27,1 \%$ (inferior a média nacional, $33,8 \%$ )

\section{EDUCAÇÃO}

Nível de escolaridade da população compreendida entre 25 e mais anos:

Primeiros 6 anos do Ensino Fundamental: $38.1 \%$

Ensino Fundamental: 22.7\%

Ensino Médio: $18.7 \%$

Educação Técnica: $4.9 \%$

Universidade: $8.6 \%$

Percentual de crianças entre 6 e 11 anos que vão a escola: $90.8 \%$

Percentual de crianças e adolescentes entre 12 e 17 anos que vão ao ensino médio: $61.5 \%$

\section{MERCADO DE TRABALHO}

Percentual da população em atividade: $56.4 \%$

Percentual da população empregada: $53.4 \%$

Percentual da população em situação de desemprego: 5.5\% (menor que a taxa do país, 6.3\% em 2011)

\section{TECNOLOGIA}

Percentual da população com acesso a conexão a Internet:

$36.7 \%$

Percentual da população que tem computador ou laptop: $41.3 \%$

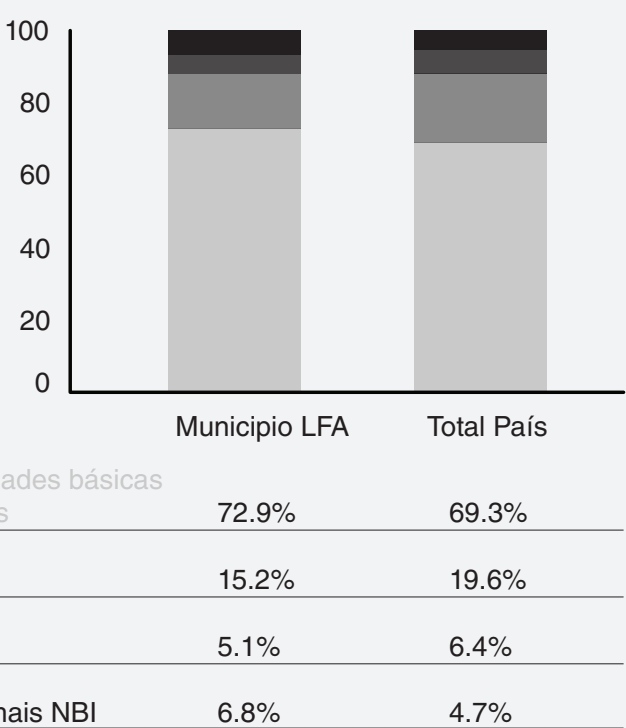

\begin{tabular}{lcc}
$\begin{array}{l}\text { Necessidades básicas } \\
\text { Satisfeitas }\end{array}$ & $72.9 \%$ & $69.3 \%$ \\
\hline Uma NBI & $15.2 \%$ & $19.6 \%$ \\
\hline Dois NBI & $5.1 \%$ & $6.4 \%$ \\
\hline Três ou mais NBI & $6.8 \%$ & $4.7 \%$
\end{tabular}

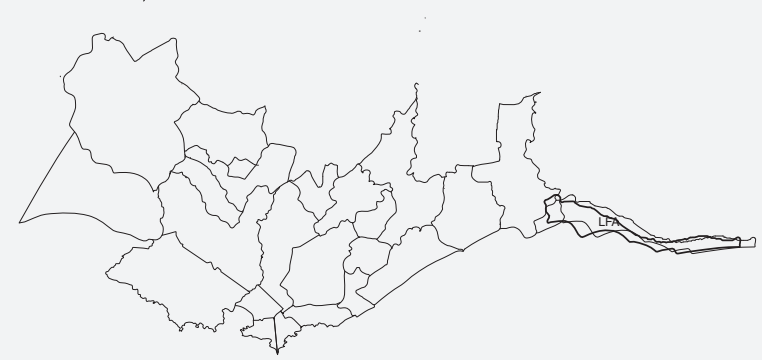




\section{CIUDAD DEL PLATA - CDP}

\section{San José}

Tendo os dados do Censo 2011 como base, o município contra com uma população de 32.154 habitantes. A densidade populacional é de 255,6 hab/km2, enquanto que a densidade de San José é $21,7 \mathrm{hab} / \mathrm{km} 2.97,2 \%$ da população do município é urbana, majoritariamente de ascendência étnica branca (88,6\%), a população afro ou negra representa $6 \%$ da população. A proporção de pessoas com ao menos uma NBI é de $46,8 \%$, valor superior a media do nacional $(33,8 \%)$ e departamental $(35,7 \%)$ Os indicadores do mercado de trabalho do município apresentam uma situação similar em relação à média departamental, entretanto desfavorável em relação à nacional nas taxas relativas à atividade e emprego. A taxa de desemprego por outro lado, é amplamente superior tanto em comparação com a taxa departamental como nacional. O município tem uma taxa de atividade de $63,5 \%$, uma taxa de emprego de $57,6 \%$ e uma taxa de desemprego de $9,2 \%$ (2011).

$1,5 \%$ da população de 15 anos ou mais deste município é analfabeta. Por outro lado, a taxa líquida de assistência (TLA) aos 6 primeiros anos do ensino fundamental é parecida a TLA departamental, e ambas maiores que a nacional. A TLA ao ensino médio é inferior tanto em comparação com a departamental como a nacional. O município tem uma TLA referente aos 6 primeiros anos do ensino fundamental de $94,3 \%$ enquanto que a nacional é de $92,9 \%$. Para o ensino médio a TLA é de $62,8 \%$ para o município e $67,7 \%$ para o país.

Texto livremente traduzido do site http://www.otu.opp.gub.uy

População: 32.154 habitantes

Área: $125.8 \mathrm{~km} 2$.

\section{DEMOGRAFIA}

População Urbana: $97.2 \%$

População por idades:

De 0 a 14 anos: 9.847 hab. $-27.51 \%$

De 15 a 24 anos: 5.484 hab. $-17.06 \%$

De 25 a 44 anos: 8.740 hab. $-27.18 \%$

De 45 a 64 anos: 6.102 hab. $-18.98 \%$

Mais de 65 anos: 2.981 hab. $-9.27 \%$

\section{RENDIMENTOS E BEM ESTAR}

Percentual da população que tem uma ou mais necessidades básicas insatisfeitas (moradia digna, saneamento, água potável, eletricidade, conforto, educação): $43,4 \%$ (superior a média nacional, $33,8 \%$ )

\section{EDUCAÇÃO}

Nível de escolaridade da população compreendida entre 25 e mais anos:

Primeiros 6 anos do Ensino Fundamental: $42.5 \%$

Ensino Fundamental: $28.9 \%$

Ensino Médio: $14.9 \%$

Educação Técnica: $6.4 \%$

Universidade: $3.4 \%$

Percentual de crianças entre 6 e 11 anos que vão a escola: $94.3 \%$

Percentual de crianças e adolescentes entre 12 e 17 anos que vão ao ensino médio: $62.8 \%$

\section{MERCADO DE TRABALHO}

Percentual da população em atividade: $63.5 \%$

Percentual da população empregada: $57.6 \%$

Percentual da população em situação de desemprego: $9.2 \%$

(maior que a média do país, 6.3\% em 2011)

\section{TECNOLOGIA}

Percentual da população com acesso a conexão a Internet: $31.6 \%$

Percentual da população que tem computador ou laptop: 38.7\%
Percentual de lares segundo a quantidade de NBI 2011

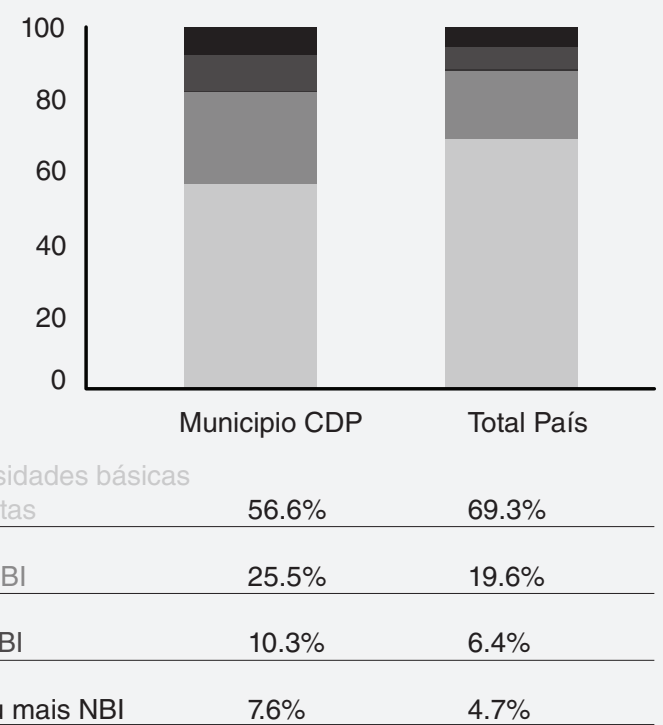

Três ou mais NBI

\begin{tabular}{lll} 
Necessidades básicas & $56.6 \%$ & $69.3 \%$ \\
\hline Umatisfeitas & $25.5 \%$ & $19.6 \%$ \\
\hline Dois NBI & $10.3 \%$ & $6.4 \%$ \\
\hline Três ou mais NBI & $7.6 \%$ & $4.7 \%$
\end{tabular}

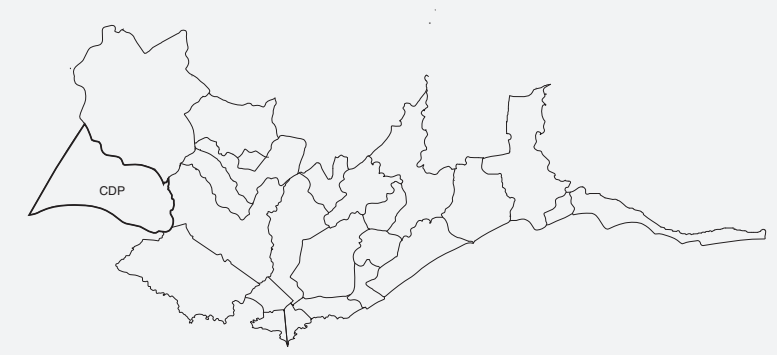




\section{MONTEVIDÉU LEVANTAMENTO DE OPINIÕES QUALIFICADAS SOBRE AS POLÍTICAS PÚBLICAS E OS EQUIPAMENTOS COLETIVOS GERADOS DESDE OS ANOS 90.}

A pesquisa expõe a necessidade de uma revisão da forma em que as políticas públicas propõem os equipamentos coletivos nas periferias de Montevidéu. A pesquisa sustenta-se em diversos estudos sobre casos uruguaios, internacionais, e num fundo teórico.

Este trabalho focaliza nos aspectos das políticas públicas para os equipamentos de Montevidéu, e para isso propõe um levantamento de opiniões qualificadas que avaliem as experiências e façam especulações projetivas. Três hipóteses com seus apoios em citações sintetizam os pontos de vista assumidos como pontos de partida para a pesquisa em desenvolvimento.

A estratégia de pesquisa propõe fugir de um possível círculo fechado autorreferencial que convalide sem revisão crítica ditas hipóteses. Então o propósito deste trabalho é revisá-las, ajustar e renová-las no seu processo de produção.

Embora exista um conjunto de referências diversas nacionais e internacionais apontadas no projeto de pesquisa e na bibliografia sobre a matéria, duas ideias complementares tem relação com a experiência uruguaia. As duas apoiam-se em citações que provêm dos pontos de vista de dois atores que mantém (ou tem mantido) em forma independente atuação acadêmica, prática profissional arquitetônico-urbanística, e exercício de responsabilidades no governo nacional ou da cidade de Montevidéu.

1. Os equipamentos coletivos são peças clave na intervenção pública na periferia. Mais essas politicas tem assumido uma modalidade que privilegiou a resolução dos problemas bem mais concretos de moradia, gerando uma periferia desqualificada de espaço público e centralidades.

"Desde a construção de um cenário de equidade de oportunidades para o conjunto dos cidadãos, é fundamental promover a requalificação das periferias urbanas que atualmente se encontram em condições críticas. Estes espaços de segmentação social e segregação urbano-residencial requerem de planos zonais minuciosamente elaborados. Parece sensato enfatizar na implementação de programas de melhoramento do bairro, acumulativos no tempo que sejam capazes de hierarquizar os estruturadores urbanos e os benfeitores de uso comunitário exteriores e fechados e evitar dentro do possível a densificação habitacional de estes benfeitores sem heterogeneidade social, o que significa uma mudança radical de enfoque". ${ }^{1}$

2. Neste ponto a questão da escala dos equipamentos tem muito a ver com a dimensão simbólica e a construção de uma identidade e orgulho nas periferias. Afirma-se no projeto de pesquisa que as políticas sociais dos governos de esquerda a partir da segunda metade dos anos 2000 (e já começadas quinze anos antes no governo municipal de Montevidéu) acrescentaram uma quantidade fragmentária e dispersa de programas e dispositivos de atenção aos problemas sociais de muito pobre visibilidade e qualidade em termos de geração de urbanidade.

"Outro aspecto importante para o enfoque de um urbanismo de periferias precárias é a importância da dimensão cultural e simbólica no que se refere à requalificação urbana, e especialmente em relação com algumas poucas operações "fortes" orientadas a criar espaços públicos e equipamentos excepcionais a escala zonal ou distrital. Uma das críticas que se realiza ao urbanismo 
"incrementalista" nas periferias é precisamente o esquecimento da escala zonal, a favor de intervenções demasiadamente vicinais ou pequenas para impactar na construção de verdadeira cidadania e de identidades coletivas mais amplas. ${ }^{2}$

3. O ponto de partida dessas hipóteses que tem convalidação externa na opinião de especialistas anima a definição de um dispositivo básico próprio formulado no projeto de pesquisa, com o nome de FÓRUM:

“...a investigação estará centrada nos dispositivos arquitetônicos de equipamentos públicos como parte das políticas públicas. Os equipamentos coletivos, em âmbitos urbanos tão frágeis, têm a demanda de promover o aspecto coletivo e público, antes de dar resposta a qualquer "função" (educação, saúde, recreação, esportes, etc.) e de organização particular (local, do bairro, municipal, etc.).

A investigação estará vinculada a casos e instituições concretas, configurando uma amostra operativa, mapeará os procedimentos de projeto e os equipamentos coletivos em funcionamento, e buscará atividades coletivas "outras", desinstitucionalizadas. Pretende-se especular e refletir para gerar novos âmbitos de convivência espacial, uma nova geração de Equipamentos capazes de se vincular em diferentes níveis com a Coletividade. A inovação se concentrará no mix programático e a organização espacial, a partir de conceitos como híbrido, polivalente, aberto e inesperado" ${ }^{3}$

Estabelecendo ao mesmo tempo uma estratégia múltipla para fazer a seleção da amostra do trabalho, a partir da hipótese provisional de abranger uma população de até 80 mil habitantes 4 . Confluem para a dita escolha: a realização de um Recorte Programático de poucos equipamentos principais, três no máximo. A escolha deve partir de um conhecimento sistemático do conjunto dos equipamentos e sua territorialidade, fazendo ao mesmo tempo um Recorte Territorial e Programático.

O Recorte Programático procura a determinação de aqueles Equipamentos que apresentem as seguintes qualidades: presença significativa nas áreas de estudo,

_programas diversos de políticas públicas e dirigidos a alvos diferenciados da sociedade para estimular a integração da diversidade.

Enunciados os Fóruns como espaços de complexidade e diversidade, os Programas escolhidos não serão os únicos a incluir esses equipamentos complexos, senão aquela combinação básica que dará consistência inicial ao Fórum, mesmo que a própria ideia de Fórum inclua a mudança de atividades no percurso do tempo.

A análise dos equipamentos coletivos faz parte da estratégia de pesquisa que assume um trânsito entre dois níveis: Teórico, e Concreto. Este trabalho prático propõe assistir a pontos de vista às

2 BERVEJILLO, Federico Arq. Urb. Empresa CSI Ingenieros - Equipos Mori. Informe final do "Plan Especial Casavalle", realizado em consultoria para a Prefeitura de Montevidéu. IM. 2012. Disponível em http://plancasavalle.blogspot.com/2012/11/plan-casavalle-setiembre-2012-en.html. Acesso em: 12 de fevereiro de 2014.

3 OREGGIONI, Luis. More with less. Orientador Dr. Arq. Francisco Spadoni.

Revisão do projeto de pesquisa feito como trabalho do Seminário de Pesquisa em projeto de arquitetura I. Professores Carlos Augusto Mattei Faggin, Rafael Antonio Cunha Perrone, Helena Aparecida Ayoub Silva. Julho a Outubro de 2012. FAU. USP.

4 A população prevista originalmente no projeto era de menos da metade desta. Os estudos desenvolvidos até agora permitem avaliar a hipótese de que os Fóruns devem ser equipamentos de maior referência urbana nas periferias, mas também na cidade inteira. O desenvolvimento da Tese propõe que o Fórum é uma entidade abstrata meta-projeto capaz de ter diferentes escalas segundo o território e as politicas públicas. 
vezes teóricos, às vezes concretos, e propõe também aos entrevistados situar-se no nível da especulação buscando uma cumplicidade com a construção da hipótese estratégica dos Fóruns.

A estratégia para fazer a seleção dos principais equipamentos a incluir nos Fóruns é dada por um conjunto de entrevistas. Os objetivos das entrevistas a informantes qualificados da área territorial e social da Montevidéu Metropolitana são os seguintes:

Obter uma visão critica desde a experiência acadêmica, institucional e social, que permita revisar e refinar as hipóteses de trabalho sobre a qualidade e condição dos equipamentos coletivos na periferia de Montevidéu.

Obter uma lista breve e significativa de experiências locais e internacionais de referência.

Receber opiniões para a escolha dos equipamentos que integram o Recorte Programático Principal, e ajustar as hipóteses da pesquisa. 
Foram entrevistados:

Prefeitura de Montevidéu Silvana Pissano, Patricia Roland, Ramón Mendez, Ana Rivera, Marcelo Bednarik. Adriana Rojas, Ing. Agrim. Ricardo Martínez (2018) Herbert Inchusti, Alvaro Trillo (2013 e seguintes)

MIDES. Ministerio de Desarrollo Social Julio Llanes, Juan Pablo Labat (2014.2018)

PMB. Programa de Mejoramiento de Barrios Fernando Cabezudo, Myrna Campoleoni. (2014)

Secretaria Nacional de Deportes Daniel Daners (2015-2018)

PAC Polos de Atención Ciudadana. AGESIC Daniel Velo. (2017)

Dirección Arquitectura Ministerio de Salud Pública Daniel Wainstein (2018)

Dirección Sectorial de Infraestructura ANEP. Responsavel pela totalidade da infraestrutura e producao de arquitetura da educacao publica uruguaia. Mario Corrales (2018)

Proyecto MECAEP Projeto edilício para Escolas, Liceus e Edifícios para formação tecnológica secundaria. Andrea Gnesetti (2017)

Corporación Nacional para el Desarrollo CND Alicia Dauría. (2017-2018)

Proyecto PAEPU Arquitetura de Escola Pública. Pedro Barrán, Lucía Lombardi.

Dirección Nacional de Bomberos Marcos Lowenstein. (2018)

Dirección de Arquitectura UDELAR Eduardo Laurito, Adriana Gorga, Santiago Lenzi. (2017-2018)

Prefeitura de São Paulo Eduardo Dalcanale Martins (2015) Alexandre Delijaicov, Andrei Takiya (2013)

Arquitetos com praticas em edifícios educacionais Gustavo Scheps, Bernardo Martín, Luis Fulco, Antonio Gervaz, Carlos Folco. (2012-2018)

Antropólogo Eduardo Alvarez Pedrosian (2014-2018)

Arquiteto Jack Couriel (2013-2018)

Sociólogo. Gustavo Leal (2014-2018)

Centros MEC. Ministerio de Educación y Cultura Roberto Elissalde. (2014) 


\section{TRANSCRIÇÃO ENTREVISTA EDUARDO ALVAREZ PEDROSIAN}

Data: 13/02/2014 Lugar: Farq. Taller Scheps.

Participantes. Eduardo Álvarez Pedrosián. Luis Oreggioni. Estagiária Rosina Cortegoso.

Resumo editado.

Eduardo Alvarez Pedrosian é antropólogo uruguaio. Doutor em Filosofia, menção Historia da Subjetividade. Faz estudos de Pós-doutorado na USP em Antropologia Social, onde coordena entre outros, trabalhos sobre os CEUs paulistas. É professor adjunto no "Departamento de Ciências Humanas e Sociais da Licenciatura em Ciências da Comunicação - UdelaR. Uruguai Currículos em linha:

http://www.anii.org.uy/buscador_sni/exportador/ExportarPdf?hash=0b78b5eb99a373b024888f90b7b6 7726

http://liccom1.liccom.edu.uy/docencia/curriculum/ealvarez.pdfÁrea de Trabalho.

Muitos de seus trabalhos focalizam em estudos antropológicos e etnográficos com ênfase na espacialidade como expressão social e cultural, como é o caso de "Espacialidades: antropología, arquitectura y comunicación":

http://eduardoalvarezpedrosian.blogspot.com/2011/06/espacialidades-antropologia.html. Tem feito pesquisa e trabalhos de extensão na periferia metropolitana e particularmente em Casavalle.

Citações referenciais do autor:

Artigo na revista Metrópole "A lógica de segregação vai acompanhada de uma de fragmentação com a qual os elementos se relacionam mais com os do exterior que com os contíguos e semelhantes. A produção de subjetividade fica fortemente determinada por estas premissas que atuam sobre todo tipo de estratificação: o trabalho, o consumo, a saúde, etc."

Livro: "Casavalle: una zona, un barrio, un lugar. Periferia urbana y fragmentación de la subjetividad". No prelo próximo a ser publicado. "Nas últimas décadas temos assistido à consolidação da chamada "marginalidade avançada", onde a pobreza e a exclusão se sustentam e se reproduzem principalmente nas determinações espaciais: bairros estigmatizados, abandonados por décadas, objetos de políticas explícitas de territorialidade assim como de deslocamentos da população a partir de diferentes tipos de exclusão cultural, social e econômica. Mas ademais dos chamados ghettos e antighettos, existem também o que poderíamos denominar "depósitos espaciais", onde não existe nem homogeneização étnico-racial nem existe a herança dos cinturões obreiros".

"Trata-se do processo de diferenciação e singularização identitária que, apesar de vir e terminar no mesmo lugar, apesar de compartilhar algumas mesmas procedências e umas condições gerais sincrônicas com outros, os caminhos tendem a divergir e mais especificamente, a dissociar-se. Quer dizer, a pobreza urbana constrói fragmentação ali onde se compartilham as mesmas condições de existência. A contradição não é tal quando vemos que a fragmentação e a dissociação são parte consubstancial das condições estruturais historicamente determinantes, sendo resultados e princípios de reprodução da realidade. Diferentes grupos de população ao longo de seis décadas, provenientes de zonas cêntricas desalojadas, do meio rural e de cidades menores, ocupando alguns complexos habitacionais de criação estatal, outros ocupando e levantando rancho a rancho uma favela, compartilhando as mesmas condições básicas de existência, se isolam em fragmentos fortemente fechados sobre si mesmos, justapostos, em um caleidoscópio de identidades locais fundadas no reconhecimento mútuo cotidiano e as relações de aliança e filiação em uma imanência desde a qual se torna muito difícil sair. É o que se denomina a necessidade da imediatez (Rostagnol, 2003:43)[2], mas no que respeita à construção de identidade cultural e em particular à relação da mesma com a espacialização, com a construção de um lugar antropológico em um espaço físico"

"Os vizinhos dos diferentes fragmentos têm versões parciais destas apreciações, mas no fundo sabem que o que começou como sendo algo transitório alguma vez terminará. Mas frente ao temor de voltar a ficar sem teto, como antes eles mesmos ou seus antepassados recentes, e adaptados estrategicamente às condições existentes, se eles se embarcam em algo mais que no reconhecimento mútuo, no processo de criação de novas formas de vida, não poderão ser novamente desiludidos e abandonados à sorte. Isto implica pôr em consideração o desejo de viver segundo 
meios mais urbanos ou mais rurais, segundo formas mais artificiais ou mais naturais. Dar a opção de repovoar os espaços abandonados da cidade consolidada aos que assim o desejem enquanto se qualifica positivamente o antigo depósito recuperando todo o potencial paisagístico que tinha. Como já foi afirmado, não podemos seguir negando a existência destes processos e seu rol como gerador do avance da cidade sobre o território. Como afirmam alguns urbanistas, aqui e assim é onde e como se está fazendo a cidade nova, isto é um fato (Cecilio, Couriel, e Spallanzani, 2003). Frente a isso parece possível, acreditamos, que a posta em prática de processos de desenho coletivo entre especialistas e vizinhos, em um contexto de recursos decididamente diferente -caso contrário seria mais do mesmo, unidades de mínimos custos que devêm em casebres, complexos que se fecham sobre si e afundam suas manutenções, espaços livres projetados para futuros parques convertidos em assentamentos- levaria a transformar o espaço a partir de uma experiência coletiva que fosse ao mesmo tempo um processo de transformação das subjetividades envolvidas, um fazer que gere novas formas de ser, esta vez com bastante armas como para destroçar ao estigma que sempre está ali para abortar toda gestação. Seria possível em definitiva, fazer da individualidade do fragmento uma singularidade em um fluxo, das diferenças em comunidades de centenas ou milhares de sujeitos, a matéria prima para desenhar una heterogeneidade de espaços e espacialidades. Com isso é possível transformar o atual conjunto de peças de diferentes quebra-cabeças em um collage aberto e múltiplo, conectado a todo o território e singular ao mesmo tempo como lugar, qualificado segundo semióticas e estéticas afirmadas em afetos e perceptos emergentes, e não erodido e desfigurado pela negação e o abandono fruto do estigma". 
Qual é a sua opinião sintética sobre as políticas públicas territoriais nas áreas da periferia de Montevidéu referidas especificamente aos equipamentos coletivos e ao espaço público desenvolvidas na cidade nos últimos $\mathbf{3 0}$ anos. (desde os anos 90).

Existem políticas deficitárias que respondem a lógicas específicas e fragmentárias. Muito deficitárias. No caso particular de Casavalle começam nos anos $50 \mathrm{com}$ as políticas da CEPAL que dão existência à Unidade Casavalle, que é proposta como uma política pública procurando um desenvolvimento urbano, mas num território isolado fisicamente dentro da cidade. Depois na ditadura houve intervenções terríveis que propõem a precariedade institucionalizada ("Conjunto Los Palomares"). Particularmente desde os anos 90 começa o PIAI ${ }^{5}$ que faz intervenções em assentamentos irregulares, mas sem políticas generalizadas, muito particularizadas e diversas, em muitas oportunidades negativas. Na "Cuenca de Casavalle "elas não têm repercussões positivas". Nas políticas atuais faltam conexões e articulação sinérgica entre atores institucionais. O urbanístico e sua especialização é uma dimensão particularmente significativa, privilegiada, desde o ponto de vista antropológico . É importante porque afeta a produção de subjetividade a partir da construção de um cenário, um suporte que habilita e reconhece a presença simultânea de todos os atores. Os últimos anos falam de um melhoramento na coordenação das políticas públicas, embora não tenhamos ainda as estratégias de coordenação claras. As políticas sociais de caráter geral, e particulares têm se multiplicado, às vezes respondendo à modelos internacionais ou modas, mas não instalando políticas profundas. Os programas estabelecem organização, relações de trabalho, etc. que acabam indo (mesmo sem vontade) contra a coordenação das políticas. A estrutura do estado, municipal, nacional, ministérios etc. não têm coordenação. Em modelos mais centralizados politicamente (e sem fazer juízo de valor político sobre eles) é bem mais fácil gerar processos de coordenação interestatais.

Os próprios espaços de trabalho que os Fóruns (do presente projeto de pesquisa) propõem não são somente benfeitores para a população alvo das políticas públicas senão também, podem gerar oportunidades para o próprio pessoal que trabalha nas políticas públicas que tem um certo desgaste e problemas laborais. O pessoal que trabalha nas políticas sociais fica insensível aos problemas básicos que já se tornam cotidianos, normais para eles.

\section{Destaque uma experiência especialmente positiva no assunto.}

Na verdade não posso destacar muitas, mas acho uma muito especial e significativa: a Rede Institucional Caminho Nordeste (procurou articular todas as instituições que trabalhavam numa região da periferia), e ela foi organizada pelos próprios trabalhadores sociais e não pelas instituições responsáveis. ${ }^{6}$

\section{Destaque uma experiência especialmente negativa no assunto.}

A fragmentação das políticas públicas é o principal problema, que gera certas lógicas burocráticas de alta rigidez, e que foi muito falada na resposta 1.

\section{Refira uma experiência internacional que entenda significativa como contribuição para pensar no melhoramento das políticas públicas sobre equipamentos coletivos na periferia de Montevidéu.}

\footnotetext{
${ }^{5}$ Programa de Integração de Assentamentos Irregulares

${ }^{6} \mathrm{http}: / /$ www.fcs.edu.uy/archivos/Red\%20Inerinstitucional\%20Camino\%20Nordeste.pdf http://www.extension.edu.uy/pim/csic
} 
Os CEUs paulistanos, que eu conheço bem pela minha atual participação na USP, são uma experiência interessante baseada e gerada desde a coordenação interinstitucional a nível de governo da cidade de São Paulo. Ela pode ser referida de maneira geral como a estratégia de produção de "centralidades periféricas" (título de projeto de Mestrado que está sendo desenvolvido pelo arquiteto Vinicius Spira em Antropologia na USP). O projeto dos CEUs está começando uma nova etapa de trabalho operando a partir da vinculação e a geração de redes entre equipamentos existentes na periferia. Aquela experiência a grande escala parece, embora completamente diferente à nossa realidade, tão fácil de aplicar em um país pequeno, com tão pouca população.

Outra experiência anterior que eu conheci e acho interessante é a renovação urbana na Barcelona democrática depois de Franco. Aí por exemplo, tem algumas experiências no bairro La Mina, na qual tem trabalhado o antropólogo Manuel Delgado, o principal referente da minha disciplina em Catalunha.

O filme "Urbanized"7 propõe uma série de estudos de casos de cidades no mundo inteiro. Muitos deles são conhecidos (Colômbia, Rotterdam, etc.), mas achei muito interessante para pensar desde a perspectiva de Montevidéu e em seu trabalho a apresentação que eles fazem do caso da África do Sul, atendendo à integração e renovação dos ghettos do apartheid como Soweto e demais. Eles propõem a conexão entre as intervenções, por meio da criação de alguns edifícios singulares separados regularmente, são centralidades que fazem parte de conexões lineares que contêm múltiplos equipamentos. São ícones cheios de gente e acessados às 24 horas. Achei extremamente interessante. Eles estão conectando, atravessando e ao mesmo tempo sendo parte desses ghettos.

\section{Quais entende que são os três principais recursos/equipamentos a articular num Fórum tal como é proposta nesta pesquisa, que tem a hipótese de servir a um conjunto de $\mathbf{8 0 . 0 0 0}$ pessoas.}

Pergunto-me de que forma sendo o problema educativo o principal assunto da agenda pública uruguaia, Fórum deve incluir um programa educativo, particularmente de que forma incluir nela, programas de caráter educativo assumindo que a Escola Pública é a mais consolidada rede do âmbito público no país inteiro.

Acho fundamental reconhecer sempre as particularidades e as singularidades a todas as escalas. Então se a escola publica é uma instituição consolidada e bem distribuída no território, a gente não deveria pegar literalmente a experiência dos CEUs paulistanos para a programação de escolas nos Fóruns

Mas concordo que o educativo tem que ter uma presença forte, decisiva no Fórum. Aí acho que se pode pensar em certos equipamentos para as escolas, mas que não são uma escola. Equipamentos sofisticados que possam apoiar e até nuclear a um conjunto de escolas (primária e secundária), com equipamentos de alta qualidade. Não dar uma dimensão unidimensional à presença dos equipamentos. Você já tem por exemplo no Marconi, um novo colégio, a nova praça, assuntos educativos atendidos no Sacude ${ }^{8}$ e no $\mathrm{Cedel}^{9}$. A ideia não seria competir senão integrar definindo um equipamento específico e de alta qualidade, que gere vínculos, como construir uma nova subjetividade capaz de reverter a grande fragmentação cultural das periferias e particularmente aquela do caso Casavalle. Acho que apostar nas crianças é uma maneira interessante, que elas façam experiências de integração que sem assegurar resultados, estimulem o encontro e o intercâmbio entre diferentes. A criança poderia pertencer, ser parte, da sua escola, aonde ele vai

\footnotetext{
${ }^{7}$ http://urbanizedfilm.com/

${ }^{8}$ SACUDE: "Salud, cultura y deporte". Saúde, cultura e esporte, é um equipamento do governo da cidade que concentra atividades esportivas, atenção de saúde, um teatro e um anfiteatro. A sigla significa "sacode" em português.

${ }^{9}$ CEDEL "Centro de Desarrollo Econômico Local Casavalle". O programa brinda formação para o trabalho e apoio a atividades comunitárias, empreendimentos e a formação de microempresas.
} 
estudar e fazer certas atividades básicas, mas também fazer parte de um Fórum, aonde fará atividades especiais (grandes atos, encontro com crianças de outras escolas). Acho que isso tem a capacidade de fazer "tecido" socialmente falando

De novo aparece a experiência de gestão dos novos CEUs.

\section{E como fazer especialmente com o ensino secundário? Ele tem mais problemas de inserção social, deserção, etc.}

Sim, esse é o maior problema. Mas uma chamada de atenção para pensar nos Fóruns que eu te faria é de não ficar reféns da complexa trama institucional. E atender uma questão que, trago novamente, o Fórum poderia privilegiar a atenção aos funcionários. Eles têm uma definição de trabalhador, não de servidor publico e assim é que devem ser tratados. Conseguir boas condições de trabalho, até espaciais para eles é importante. Propor condições de trabalho espaciais, seguras e de qualidade vai estimular o melhoramento nas políticas públicas.

Os argumentos dos trabalhadores, (dos professores, por exemplo) para criticar as políticas de renovação tem sempre o principal problema na qualidade das condições de trabalho. E você tem que escutar isso para construir, para dialogar.

Depois os outros equipamentos são mais fáceis de trabalhar. No caso da Saúde Publica, tem importância as linhas de trabalho em saúde comunitária Há uns trabalhos que publiquei, que acho podem ser de interesse para teu trabalho. Eles tratam sobre os espaços de espera numa pequena policlínica, o que fazer, e o que é aquele "tempo morto" que fica no freezer, que é o tempo da espera. ${ }^{10}$ O capítulo é "Olhares e vozes no espaço-tempo de espera" que atende a um espaço secundário na atenção pública, como se fosse um tempo morto, no freezer. Como fazer da espera uma experiência favorável, em vez de rejeitar às pessoas. Há também nesses espaços um corte de gênero muito forte, que é um espaço feminino culturalmente instalado.

Depois eu acho que a política dos CACs, os centros de atenção cidadã é importante porque propõe toda a dimensão da relação do cidadão com o estado. Sim, essa é bem interessante e tem a ver também com a espera como assunto.

\footnotetext{
${ }^{10}$ Olhares e vozes no espaço-tempo da espera. Notas etnográficas entre as mediações sanitárias. Álvarez Pedrosian, E. (2013) «Miradas y voces en el espacio-tiempo de la espera. Notas etnográficas entre las mediaciones sanitarias». Em: Abordajes hacia una etnografía de la comunicación contemporánea, Guigou, L. N. Álvarez Pedrosian, E. (comps.), UCEP-UdelaR, Montevideo, pp. 25-47.

http://eduardoalvarezpedrosian.blogspot.com/2013/07/mediaciones-en-el-universo-de.html
} 


\section{TRANSCRIÇÃO ENTREVISTA JACK COURIEL}

Data: 06/03/2014 Lugar: Escritório Jack Couriel.

Participantes. Jack Couriel. Luis Oreggioni. Estagiária Rosina Cortegoso.

Resumo editado.

Dados do entrevistado

Jack Couriel graduou-se como Arquiteto em 1983 e em 2008 obteve o título de Magister em

Planejamento Territorial e Desenvolvimento Urbano na "Facultad de Arquitectura Farq UDELAR", Montevidéu. Entre os anos 1973 e 1993 trabalhou no Instituto de Assistência Técnica às cooperativas, o Centro Cooperativista Uruguaio, que foi o principal protagonista do desenvolvimento do cooperativismo desde o ano 1968, ali ele desenvolveu diversas tarefas em relação à habitação social. Entre 1985 e 1998 foi professor adjunto de Projetos nos Ateliês Vanini e depois Pintos da Farq UDELAR. Entre 2008 y 2010 ocupou o cargo de Vice-Ministro no Ministério de Vivenda, Ordenamento Territorial e Meio Ambiente.

Área de Trabalho.

Tem pesquisado em temas de planejamento e habitação, com especial atenção ao cooperativismo e aos problemas das periferias.

Fez um estudo sobre a reabilitação de favelas "Caracterización física y social de los asentamientos irregulares y su entorno" 11 que propõe estratégias territoriais para fazer as intervenções de melhoramento das favelas, integrar-se com os territórios vizinhos, questionando um modelo de atuação fechado na própria favela.

Publicou o livro "De cercanías y lejanías" 12 que recolhe sua pesquisa de Mestrado e que aporta elementos significativos para a aproximação às periferias nesta pesquisa.

Recentemente publicou junto ao sociólogo Florentino Menéndez o volume da Coleção "Nuestro Tiempo: Vivienda13. Donde vivimos los uruguayos".

Citações referenciais de ou sobre o autor:

Prólogo do livro "De cercanías y lejanías" escrito pelo Sociólogo Fernando Filgueira:

"O texto que o leitor tem em suas mãos narra uma história trágica para a comunidade e fascinante para o cientista social. Introduz aos atores centrais, situa a época de seu desenvolvimento e oferece claves analíticas para desentranhar um roteiro que foi sendo construído a partir das decisões e das circunstâncias desses atores. Oferece um final aberto, carregado de ameaças, mas não carente de esperanças. O herói trágico desta história é a própria comunidade expressada em seus interesses e afãs políticos, econômicos e sociais. $\mathrm{O}$ autor nos conta o passado recente de uma sociedade urbana e a forma em que elegeu caminhos privados antes dos públicos para se relacionar e construir o território social. O trabalho de Couriel é um aporte fundamental para pensar e recolocar os temas centrais para a sociedade uruguaia: os desafios da exclusão e a desigualdade, e os mecanismos de sua reprodução. Jack Couriel nos lembra de que para pensar os problemas da desigualdade e a exclusão não basta com a adequada combinação de fatores derivados do mercado, o Estado e as famílias. Afirma que as dinâmicas de estas esferas devem ser lidas em seu desdobramento e interação com o território."

Crescimento e Declinação Populacional na Grande Montevidéu

"Se analisarmos a dinâmica demográfica no período intercensal 1985-1996, se verificam migrações preferentemente intrametropolitanas e polarizadas socialmente. Por um lado setores sociais de ativos médios e altos se deslocam à faixa costeira de Canelones. Por outro lado o crescimento populacional protagonizado por setores sociais de ativos baixos continuam densificando e expandindo periferias montevideanas e metropolitanas, duas dimensões demográficas integram este crescimento,

\footnotetext{
${ }^{11}$ CECILIO, Martha e COURIEL Jack. "Caracterización física y social de los asentamientos irregulares y su entorno". Proyecto PNUD, PIAI, MVOTMA. Documento. Montevideo.

${ }_{12}$ COURIEL Jack. De cercanías y lejanías. Fragmentación socio-urbana del Gran Montevideo. Siete propuestas. Pag. 133. Montevideo: Editorial Trilce, 2010.

${ }^{13}$ COURIEL Jack. MENÉNDEZ Florentino. Op. Cit.
} 
migrações intrametropolitanas e taxas de fecundidade maiores que a média nacional. Em ambos os casos os territórios apresentam carências críticas desde o ponto de vista urbano, ausência de esgoto e de espaços públicos. Estas deslocações populacionais têm como consequência o esvaziamento relativo de áreas urbanas consolidadas de Montevidéu desde o ponto de vista de suas infraestruturas edilícias e de serviço, desvitalizando deste modo o patrimônio urbano-habitacional de estes bairros. Simultaneamente a dinâmica demográfica da GM incorpora a persistente emigração internacional de população predominantemente jovem e capacitada". ${ }^{14}$

\section{Intervenção nas periferias:}

"Desde a construção de um cenário de equidade de oportunidades para o conjunto dos cidadãos, é fundamental promover a requalificação das periferias urbanas que atualmente se encontram em condições críticas. Estes espaços de segmentação social e segregação urbano-residencial requerem de planos zonais minuciosamente elaborados. Parece sensato enfatizar na implementação de programas de melhoramento no bairro acumulativos no tempo que sejam capazes de hierarquizar os estruturadores urbanos e os espaços de uso comunitário exteriores e fechados e evitar no possível a densificação habitacional destes espaços sem heterogeneidade social, o que significa uma mudança radical de enfoque" "Desde a construção de um cenário de equidade de oportunidades para o conjunto dos cidadãos, é fundamental promover a requalificação das periferias urbanas que atualmente se encontram em condições críticas. Estes espaços de segmentação social e segregação urbano-residencial requerem de planos zonais minuciosamente elaborados. Parece sensato enfatizar na implementação de programas de melhoramento do bairro, acumulativos no tempo que sejam capazes de hierarquizar os estruturadores urbanos e os benfeitores de uso comunitário exteriores e fechados e evitar dentro do possível a densificação habitacional de estes benfeitores sem heterogeneidade social, o que significa uma mudança radical de enfoque". ${ }^{15}$.

Documento Programa de Reabilitação Urbano Habitacional. PRUH. ${ }^{16}$

Reconhecendo esta complexa situação sócio-urbana, enquanto os moradores dos assentamentos irregulares frequentemente têm voz, os moradores pobres e de ativos médios, que se mantêm na formalidade e que frequentemente pagam os serviços urbanos e o IPTU não a têm.

De maneira que a implementação de uma multiplicidade de PRUH nas periferias críticas dirigido ao tecido residencial formal deprimido se constitui em um complemento e contrapeso equitativo ao PIAI. $[\ldots]$

O PRUH busca o mesmo objetivo, mas a nível da integração social no território, numa tentativa de fortalecer as estruturas de oportunidades (educação, emprego, e autoestima) para os bairros com carências críticas de infraestrutura de serviços e de qualidades habitacionais.

A permanência nestes bairros de setores sociais que contribuem na necessária mistura social é um objetivo inevitável.

Sobretudo pelas vulnerabilidades sociais que existem nestes espaços e que resultam acumulativas, especialmente pelas debilidades dos centros educativos que se verificam em diversos estudos e as carências em matéria de estândar urbano, em particular a ausência de espaços públicos abertos e fechados devidamente hierarquizados junto à deterioração bastante generalizada do parque habitacional existente.

Componentes Do PRUH, Plano-Projeto-Gestão

O esquema de raciocínio Plano-Projeto-Gestão guia estas notas. [...]O Plano necessariamente se classifica na categoria de um empreendimento Público- Público: Prefeituras - MVOTMA. [...] Projeto. Os projetos integram basicamente duas diretrizes de atuação: a consolidação de ruas e a criação de novas que procurem paulatinamente ir melhorando o estândar urbano das áreas selecionadas. [...]A ideia se compõe de dois âmbitos de atuação: o urbano e o habitacional; centrados na hierarquização do espaço público rua. [...] A dimensão urbana se concreta na consolidação/criação

\footnotetext{
${ }^{14}$ COURIEL Jack. Principales tendencias de la fragmentación socio-urbana en el gran Montevideo. Artigo em linha http://www.pvp.org.uy/fragmentacion.htm. Visitado em abril 2014.

${ }^{15}$ COURIEL Jack. De cercanías y lejanías. Fragmentación socio-urbana del Gran Montevideo. Siete propuestas. Pag. 133. Montevideo: Editorial Trilce, 2010.

${ }^{17}$ COURIEL Jack. Documento interno do Ministério de Vivenda, Meio Ambiente e Ordenamento Territorial (MVOTMA) para a criação de Programas de Reabilitação Urbano Habitacionais. 2008.
} 
de rua: arvorado, recuperação e/ou criação de calçadas, realização de pontos de ônibus, complementação de sinalização urbana, etc. [...] A dimensão habitacional integra uma série de subprogramas que se adaptam às necessidades de cada família e de suas capacidades de financiamento. [...] Gestão. A etapa de Projeto para as diferentes realidades habitacionais requer a conformação de equipes técnicas multidisciplinares. A etapa de obras será supervisada desde o ponto de vista técnico. Logo a etapa de pós-obra se organiza em função de assessorar aos vizinhos em pautas de manutenção. Obviamente a apropriação por parte dos vizinhos de um programa de estas características, supõe organizar equipes multidisciplinares que se integrem em todo o processo, plano-projeto-gestao, incluindo no conceito de gestão o monitoramento e a avaliação periódica das atuações, de modo de reformular o programa com os fundamentos necessários. [...] As claves do êxito deste programa radicam na acumulação de programas sociais existentes tanto a nível municipal como setorial (MIDES, MTSS, etc.) 


\section{Qual é a sua opinião sintética sobre as políticas públicas territoriais nas áreas de periferia de Montevidéu referidas especificamente aos equipamentos coletivos e ao espaço público desenvolvidas na cidade nos últimos $\mathbf{3 0}$ anos. (desde os anos 90)}

Eu acho que deveríamos falar de certas tendências negativas sócio-territoriais que aconteceram nesse período. Isso fala do que as políticas públicas não souberam ou não conseguiram implementar. Montevidéu está partida. Não é uma tendência, é uma realidade hoje. Isso estudou o sociólogo Florentino Menéndez conosco, num livrinho que é o nosso ultimo trabalho. ${ }^{17}$ Montevidéu cidade, perde 25.000 moradores entre 1996 e o ano 2011. E de onde perde esses moradores? - na cidade consolidada: a de altos ingressos e a cidade intermédia. Na periferia, a população de Montevidéu cidade cresce. E na Grande Montevidéu (Área Metropolitana fora dos limites territoriais do Departamento de Montevidéu) a população cresce em todos os tipos de cidade, mas principalmente na cidade periférica. Então o que está acontecendo é que a figura da Grande Montevidéu está ficando maior, com uma mancha da cidade periférica que é aquela que cresce. Mas não se trata de um crescimento na urbanização, um crescimento de cidade. Assistimos a uma expansão de frágeis serviços urbanos e frágeis soluções habitacionais, aquilo não é Cidade ${ }^{18}$.

Têm acadêmicos e políticos que falam da existência de muitos problemas: educação, pobreza, fratura social, insegurança. Mas isso na verdade é principalmente um problema de fratura social, os outros são problemas derivados. Nós chamamos o fenômeno de segmentação social e segregação urbana e habitacional.

Então voltando para atrás nós sempre insistimos num instrumento previsto no $\mathrm{POT}^{19}$, Plano de Ordenamento Territorial do Departamento de Montevidéu, que era o desenvolvimento de planos de zonas ou regiões. Isso não foi feito com a força que poderia ter. Existe uma múltipla escala evidente na cidade. O POT planeja a cidade, o departamento de Montevidéu. Ainda existe uma escala maior não sendo atendida com a adequada potência que é o planejamento da Área Metropolitana inteira ${ }^{20}$. Mas dentro de Montevidéu, os planos de zonas, pediriam depois planos de detalhe, questões mais locais.

Outros problemas que vemos, derivam da não aplicação integral de três instrumentos que para nós conformam uma única entidade da atuação urbana: Planejamento-Projeto-Gestão. Você tem que esquecer do planejamento como uma palavra isolada que ela pode resolver alguma coisa. Tem que se enfocar no Planejamento-Projeto-Gestão. Quem planeja tem que conhecer de projetos, quem faz projetos tem que conhecer verdadeiramente o planejamento, e quem realiza a gestão tem que conhecer e entender todo o processo anterior. $E$ tem que se definir o que é gestão porque não é só o controle das obras, senão principalmente o uso posterior quando a gestão atua para ativar os espaços. E sempre tem que avaliar, pesquisar, porque é necessário porque vão haver erros, equivocações. Especialmente numa época de mudanças aceleradas como a nossa, dos interesses das pessoas, dos modos de vida. Eu acho que os arquitetos acreditamos que temos a capacidade de levar em conta tudo, e isso não é possível. Sempre vão acontecer efeitos não desejados e eles têm que ser identificados.

\footnotetext{
${ }^{17}$ COURIEL Jack. MENÉNDEZ Florentino. Op. Cit. Pag 9-18.

${ }^{18}$ COURIEL Jack. MENÉNDEZ Florentino. Op. Cit. Ver pag.. 56

${ }^{19}$ POT. "Plan de Ordenamiento Territorial". Aprovado pela cidade de Montevidéu em 1998. Ele incorporou uma série de leituras e ferramentas sobre a cidade que renovaram regulações muito antigas, indiferenciadas e genéricas sobre a cidade.

http://www.montevideo.gub.uy/institucional/politicas/ordenamiento-territorial/plan-montevideo. Visita abril de 2014.

${ }^{20}$ COURIEL Jack. MENÉNDEZ Florentino. Op. Cit. El Gran Montevideo. pág. 57

${ }^{22}$ É um parque/praça feito no ano 2009 pela prefeitura, na cidade central numa região densa e com poucos espaços públicos de qualidade. Tem $16.000 \mathrm{~m} 2$ e uma setorização em três ambientes, praça, parque e zona de laser com quadras de basquete e futebol e pista de skate. Tem tido grande sucesso de público. É a maior criação de espaço público nos últimos anos em Montevidéu, originada na demolição de uns galpões abandonados.
} 


\section{Destaque uma experiência especialmente positiva na matéria.}

O parque Liber Seregni ${ }^{21}$, é uma intervenção superinteressante, porque justamente tem a ver com a qualificação da cidade intermédia, e estimula pela criação de espaço público as possibilidades de redensificação. Eu acho também que é um bom projeto, muito adequado para a sua localização. Há um investimento por trás de uma decisão urbana inteligente.

Tem escala bem relacionada, presença, poder simbólico, integra uma série de jogos para os jovens, ou seja, que desde o ponto de vista dos usos ele está conectado com os jovens, é muito atraente para eles e para a população em geral.

Outra intervenção que eu acho muito positiva é a recuperação da "Rambla Egipto"22 do bairro Cerro, e toda a sua continuidade na orla do mar até chegar ao Parque Vaz Ferreira e o Memorial aos Desaparecidos.

Outro caso que eu conheço o "Plan Especial Casavalle", a sua redação vai na direção da aproximação escalar aos planos zonais dos que eu falava, e nessa região é bem necessário. Mas, só como uma ideia que por acaso conheço bem Casavalle. Eu posso estar errado, e não vi essa ideia no projeto, mas acho que seria bonito reforçar o Bulevar Aparicio Saravia, que poderia ser a joia dentro da região. O bulevar é transversal e conecta toda uma série de bairros da periferia, e eu acho que isso poderia ser um caso como o de Bulevar Artigas, um estruturador de extrema qualidade urbana, como suas palmeiras, iluminação publica de última geração, etc. E o outro estruturador é a Avenida San Martín que conecta rapidamente com o centro da cidade, então o cruzamento poderia ser um ponto bem importante e singular.

\section{Destaque uma experiência especialmente negativa na matéria.}

Nesses mesmos exemplos há uma parte negativa que é que o projeto foi concebido isolado do planejamento e a gestão. Então agora o Parque Seregni tem problemas de mantimento, você pode ver coisas que não estão funcionando. Não sei se a gestão está acompanhando devidamente o espaço que foi criado. Por outro lado, essa ação unilateral da Prefeitura aconteceu quando eu era Vice-Ministro de Vivenda. E não houve uma coordenação. Esse projeto teria sido uma oportunidade muito grande para o Estado comprar terras antes de fazer a intervenção e depois construir habitação social com densidade alta. Aí faltou o planejamento e faltou também outra coisa muito importante que é a articulação interinstitucional. O caso da Rambla Egito foi similar nesse sentido, foi uma oportunidade muito maior do que realmente foi feito.

Você falava em termos de Habitação, e eu posso acrescentar desde o ponto de vista da pesquisa: Equipamentos.

Sim, Equipamentos e Habitação e Espaço Publico. Tudo tem que estar muito relacionado, isso é o que é a cidade. No livro "Vivienda" eu falo de que não há irracionalidades, nem obstáculos. Só há lógicas: a lógica do Mercado, a lógica do Estado, a lógica da Sociedade e a lógica Territorial. Agora o que tem que se fazer, particularmente para quebrar o processo de fragmentação, é conseguir que elas estejam cooperando na mesma direção.

${ }^{22}$ Criação de um novo trecho de "Rambla de Montevidéu" que dá frente à Baía e ao Porto. Ela permite a continuidade da orla como passeio e espaço público, o mais importante e popular da cidade que tem um percurso de $22 \mathrm{~km}$ junto a o Rio da Prata atravessando o Porto e muitas praias. 
Refira uma experiência internacional que entenda significativa como contribuição para pensar o melhoramento das políticas públicas sobre equipamentos coletivos na periferia de Montevidéu.

A experiência que eu conheço e que ela é exemplar justamente no sentido que estávamos falando, é a de Medellín. Eles apostaram aos equipamentos públicos, mas não é só isso, tem todas as convergências das que a gente falava. E aí a mobilidade, a infraestrutura, é de uma importância principal para conectar a periferia com o centro, particularmente numa cidade com a geografia de Medellín. Eu não a visitei, mais tenho a intuição, que uma experiência assim que dá identidade a cada bairro com esses equipamentos, também quando começam a chegar os turistas a conhecer a experiência, dá um orgulho, um sentido de pertença muito forte. Se essas pessoas chegam até aqui para conhecer nossa cidade é porque somos importantes.

Eu sei que na gestão dos equipamentos, em Medellín mas também na gestão das Bibliotecas de Bogotá, a "Bibliored" eles fazem funcionar os equipamentos em rede. Tem uma exposição que é itinerante e faz um percurso por varios equipamentos nas diferentes regioes, então ela fica sempre perto dos moradores, e também fazem a experiência contrária, quando chega uma exposição muito importante eles só a programam num determinado Parque Biblioteca, então toda a cidade tem que ir para essa região que vira centralidade.

\section{Quais entende os três principais recursos/equipamentos a articular numa Fóru tal como é proposta nesta pesquisa, que tem a hipótese de servir a um conjunto de 80.000 pessoas.}

O primeiro que eu diria é que temos que pensar no poder simbólico da arquitetura, dos equipamentos. Além dos programas, isso já e um fato importante. E como essa questão que você falava da Colômbia fiquei pensando que o poder simbólico e a rede não são incompatíveis de jeito nenhum. Quero voltar à questão do poder simbólico. Desde esta janela do escritório no Centro da Cidade estamos olhando para o Cerrito, perto de Casavalle. Aí fica a Igreja, na maior elevação do Bairro, e ela é muito importante. A gente está vendo ela desde aqui: assim deveriam ser os nossos equipamentos, nossos "Parques-Biblioteca".

A condição da mobilidade e também muito importante para pensar os equipamentos e a construção da cidade. A eleição dos terrenos adequados, coisa que pelo geral acontece por acaso, doações terras disponíveis, etc. O poder público tem que ter mais decisão para fazer expropriações se for necessário, escolher as melhores locações.

Pergunto-me de que forma sendo o problema do educativo o principal assunto da agenda pública uruguaia, o Fóru deve incluir um programa educativo, particularmente de que forma incluir nela programas de caráter educativo assumindo que a Escola Pública é a mais consolidada rede pública no pais inteiro.

Podem haver programas de educação informal, que tenham maior capacidade para capturar a atenção das crianças neste momento de mudança tecnológica e conexão permanente, instantânea. É importante olhar para as crianças, como eles começam a se incorporar ao sistema.

Aqui no Uruguai a Escola Pública também é um mito, ela tem muitas carências. Um professor de escola em contexto crítico é um jovem de 20 e poucos anos que está começando e não tem preparação alguma para lidar com essa realidade. Então eu conheço, por motivos pessoais, um programa bem interessante que é o Programa das Escolas a Tempo Integral Ele tem uma parte que está ligada à arquitetura que é a de projetar ou adaptar escolas para o regime de tempo integral. $\mathrm{E}$ tem um outro programa que é o de Formação em Serviços que está dirigido à capacitação dos Professores em quatro áreas: Língua, Matemática, Ciências Sociais e Ciências Naturais. Isso é muito importante para os professores poderem lidar desde a alta capacitação com as crianças das periferias, aquelas que têm uma casa, uma família que muitas vezes não pode ajudá-las. 


\section{TRANSCRIÇÃO ENTREVISTA GUSTAVO LEAL}

Data: 07/03/2014 Lugar: Ministério do Interior.

Participantes. Gustavo Leal, Gerardo Leyes (da equipe do Programa de Convivência do Ministério do Interior). Luis Oreggioni. Estagiária Rosina Cortegoso.

Resumo editado

Dados do entrevistado

Gustavo Leal. É Licenciado em Sociologia na Udelar. Mestre em Comunicação Social pela Universidade Católica UCUDAL. Pós-graduação de Especialização em Altos Estudos de Comunicação Social.

Mestre em Políticas Sociais do Centro Latino-americano de Economia Humana. Diplomado em Políticas Sociais.

Foi Coordenador da ONG "El Abrojo"23 focada em atenção dos problemas de crianças e adolescentes em situação de precariedade. Trabalhou como Coordenador do Sistema Nacional de Emergência, e atualmente é Assessor em Convivência do Ministro do Interior.

Área de Trabalho. Tem trabalhado em questões de políticas sociais desde diversas abordagens. Durante os últimos anos e ainda antes de ter assumido responsabilidades no governo, vem trabalhando sobre as relações entre a marginação social e a territorialidade. Desde esse ponto de vista, ele propõe a necessidade de intervenções de qualificação do espaço urbano das periferias como política pública e social. Desenvolveu o Plano "7 zonas desde o Ministério do Interior, como parte da Estratégia para a vida e a convivência".

Citações referenciais do autor:

Artigo Construir a Cidade para combater o medo e a insegurança. ${ }^{24}$ "O principal desafio de integração social que os uruguaios temos hoje é viver a cidade todos por igual. Neste aspecto em particular, a democracia não chegou igualitariamente. O país está dividido em três sociedades que mostram signos evidentes de não querer mesclar-se e que pouco a pouco não se reconhecem entre si. Hierarquizar os estruturadores urbanos e os espaços de uso comunitário exteriores e fechados e evitar no possível a densificação habitacional destes espaços sem heterogeneidade social, são medidas que significa uma mudança de enfoque radical.

Devemos mudar a pele da cidade com intervenções integrais, cujo sentido central seja recuperar lugares para estar, para viver, para intercambiar. A desigualdade territorial também se expressa na relação de metros quadrados de espaço público por bairro. Isto é qualidade de vida para uns e negação de oportunidades para outros.

Em muitas ocasiões se contrapuseram as obras de infraestrutura com as obras sociais, entre outras razoes porque somos herdeiros de estruturas ministeriais orientadas às estradas, caminhos, pontes e portos. Pouco se tem pensado em equipamentos públicos para melhorar a convivência social. À contraposição histórica de "muito concreto e poucas obras sociais" gostaria de propor a ideia de "muito concreto para obras sociais, com um fino sentido estético e alta funcionalidade". O melhor para quem mais necessita para poder saldar uma dívida histórica e garantir a viabilidade do país como projeto de vida comum.

É possível voltar a tecer a fratura social, mas devemos dispor de todas as ferramentas do desenvolvimento em determinadas zonas da cidade orientadas a sua transformação. Devemos recorrer a uma "acupuntura urbana", como dispositivo preciso de intervenções plurais, mas combinadas em um território. Os pontos de intervenção se constituem nos nós de uma rede de integração de serviços sociais que deverá ir-se tecendo na nova pele da cidade. Para que seu contato nos chame a uma carícia e não a uma distância".

\footnotetext{
${ }^{23}$ http://www.elabrojo.org.uy/

${ }^{24}$ Publicado em Blogs de Montevideo.com.uy em setembro de 2013.

http://blogs.montevideo.com.uy/blog_imprimir_52104_1.html. Visita abril de 2014.
} 
Proposta de Intervenção em zonas prioritárias. Resume Executivo ${ }^{25}$

Esta iniciativa é o componente de territorialização das políticas de inclusão e convivência $\mathrm{n}$ área metropolitana da Estratégia pela Vida e a Convivência

Esta iniciativa se inscreve dentro de uma perspectiva histórica do trabalho social que viemos desenvolvendo desde 2005, onde o território é concebido como um fator clave de produção e reprodução de desigualdade e exclusão, razão pela qual intervir nele para transformar a trama urbana, quer dizer o suporte onde se assentam populações, é uma tarefa substantiva para reverter à desigualdade persistente.

Para melhorar a convivência na área metropolitana, é necessário desdobrar um conjunto potente de intervenções urbanas, habitacionais e sociais com uma visão de desenvolvimento integral e integrado.

Assim se propõem:

- investimento em infraestrutura social e equipamento

- ampliação do acesso aos serviços sociais básicos

- estratégias de capacitação de jovens e mulheres chefe de família

E é feito em comunidades emblemáticas da área metropolitana, onde existe uma forte concentração de processos persistentes de exclusão social e marginalidade.

.É em função disso que a estratégia se orienta sobre estes eixos com várias intervenções:

- por um lado aprofundando iniciativas recentes que se potenciarão nestas seis zonas (Jovens em Rede, Uruguai cresce contigo e Cercanias);

- por outro incorporando um programa de habilidade de trabalho para jovens e mulheres complementado com um sistema de cuidados para seus filhos;

- em terceiro lugar com investimentos na infraestrutura social que façam utilizáveis o espaço público como âmbito de socialização;

- em quarto lugar com ações habitacionais que reduzam a precariedade das vivendas; finalmente com ações que garantam a segurança territorial e o uso dos espaços públicos.

Assim então esta iniciativa tem um primeiro componente que se refere ao aprofundamento necessário dos programas prioritários (Uruguai Cresce Contigo, Cercanias e Jovens em Rede), planificado desde as características específicas das zonas.

\footnotetext{
${ }^{25}$ Documento de trabalho. Fonte Ministério do Interior. Versão posterior à publicada em
} http://medios.presidencia.gub.uy/jm_portal/2013/noticias/NO_H096/p_intervencion.pdf. 


\section{Qual é a sua opinião sintética sobre as políticas públicas territoriais nas áreas de periferia de Montevidéu referidas especificamente aos equipamentos coletivos e ao espaço publico desenvolvidas na cidade nos últimos 30 anos. (desde os anos 90).}

Quando a gente fala de favelas (ou assentamentos irregulares como são chamados no Uruguai), fala de dispersão no território e localização fora da cidade consolidada. Trata-se de pessoas que foram expulsas do centro e da cidade velha, mas que muitas delas já moravam de maneira precária. Então houve uma etapa problemática desde o ponto de vista do diagnóstico, que foi entender que essas populações estavam longe dos serviços, desde o ponto de vista físico. A distância era física mas também cultural. Então o Estado fazia inversão para levar infraestruturas, ampliação das redes, do sistema de transporte. Por exemplo, dentro do programa que agora se chama Programa de Melhoramento de Bairros, $\mathrm{PMB}$ e antes se chamava $\mathrm{PIAl}^{26}$, que faz foco na geração de espaço público, ruas, infraestrutura, etc. Eles pediam para a população se organizar para fazer a gestão do espaço público, até dos Equipamentos. E essas populações, na generalidade, não têm capacidade de organização. Quando eles moravam na cidade formal não tinham exigência de organização, mas expulsos para a periferia tinham que desenvolver essa capacidade. $E$ isso levou a alguns fracassos que no fundo eram ideológicos, por não assumir que há uma obrigação do Estado para oferecer esses serviços, de gestão.

\section{Destaque uma experiência especialmente positiva na matéria.}

De um modo geral as populações pobres das periferias não têm maior capacidade organizativa. Tem exceções tradicionais dos bairros operários com muita tradição de trabalho dos sindicatos, como La Teja, ou El Cerro. Mas há uma experiência de um dos bairros do "Plan 7 zonas" que é o bairro "Tres Ombúes" ${ }^{27}$. Nele a população tem um compromisso elevado com o seu espaço publico. Eles conseguiram fazer não uma pista de skate, mas apenas uma rampa muito simples e rústica, eles têm muito orgulho do seu espaço e estão cuidando dele. Eles conseguiram limpar um córrego contaminado, conseguiram doações e estão acompanhando as intervenções do Estado para desenvolver Espaço Público e um Centro de Bairro. Eles têm uma capacidade de gestão que é uma exceção nas regiões mais críticas das periferias.

\section{Destaque uma experiência especialmente negativa na matéria.}

Com relação àquilo que falávamos sobre a exigência de participação dos moradores mais excluídos nos processos de melhoramento. Pesquisando para o desenvolvimento da "Estratégia pela Vida e pela Convivência", visitamos algumas intervenções do PMB/PIAI. E tem casos extremos nos quais equipamentos muito grandes ficaram abandonados, e foram vítimas de vandalismo. Tem um caso numa regularização do assentamento "Esperanza" perto de Colón em Montevidéu onde roubaram tudo, até uma pista de skate ficou cheia de lixo. Há um equilibro a ser tomado em conta, e a previsão da gestão é fundamental, para permitir que os equipamentos funcionem, ter atividades. E essa é uma responsabilidade, em primeiro lugar das políticas públicas.

Eu fui parte da ONG "El Abrojo" que trabalha com diversas questões da marginalidade, focalizado em crianças e adolescentes. E nós fizemos uma experiência muito reveladora sobre aquela questão da gestão dos equipamentos, em Casavalle. Nós trabalhamos ali por muitos anos, e num momento para atender as carências de espaço publico, propusemos e conseguimos fazer um Centro de Bairro junto a uma quadra de futebol, um espaço público que eram dois vagões que a gente conseguiu e

${ }^{26}$ Ver Entrevista ao Coordenador do PMB/PIAI Fernando

\footnotetext{
${ }^{27}$ http://municipioa.montevideo.gub.uy/comunicacion/noticias/lo-que-se-viene-en-tres-ombues
} 
trouxemos com a ajuda do exército. Mas ele ficava junto a "Los Palomares" que é um conjunto de habitação social terrível da época da ditadura, que hoje tem máfias operando lá. Então os vizinhos não conseguiram ter controle do Centro de Bairro e ele ficou como um espaço de delinquência. Aí tem a ausência do Estado, de uma presença pública que possa conter essa convivência. Agora eu acho que a presença do Sacude ${ }^{28}$ em Casavalle é bem diferente, vai pela direção correta, junto à nova Praça Casavalle, elas são intervenções com gestão, presença e orçamento públicos. Esse é um problema principal.

\section{Refira uma experiência internacional que entenda significativa como contribuição para pensar o melhoramento das políticas públicas sobre equipamentos coletivos na periferia de Montevidéu.}

Desde que começamos a trabalhar com os temas de convivência, conseguimos identificar algumas experiências muito interessantes na América Latina de maneira particular. Nossa atenção virou para a Colômbia e convidamos a Sergio Fajardo, Antanas Mockus, Jorge Melguizo a nos assessorar. A partir deles começamos a conhecer e estudar outras experiências, muitas das quais acabaram sendo parte da "Primeira Conferência sobre Cultura e Convivência nas Cidades de América Latina", que foi um espaço de posta em comum de experiências desenvolvidas também no Equador, México, Argentina, etc. Temos muito que aprender delas.

\section{Quais entende que são os três principais recursos/equipamentos a articular num Fórum tal como é proposta nesta pesquisa, que tem a hipótese de servir a um conjunto de $\mathbf{8 0 . 0 0 0}$ pessoas? Qual é a relação que estes equipamentos podem ter com o Sistema Educativo Público?}

Eu acho, o que o nosso Plano diz, é que as principais ferramentas são aquelas universais e próximas. Temos muitos programas específicos que tem validade, mas não são os centrais. Acho que os importantes são "Uruguai cresce contigo" que é um programa para a incorporação ao sistema de saúde das crianças desde o nascimento. Também programas educativos como o de Professores Comunitários, onde eles vão procurar as crianças que saíram fora do sistema educativo e desdobram uma estratégia de apoio à família, não só às crianças. Porque os problemas não ficam na instituição, eles têm origem na casa, na família, e a atenção assim vai para a casa da criança. Por outro lado eu tenho estudado, acabei no ano passado uma pesquisa sobre a deserção no liceu ${ }^{29}$, e o caso dos jovens que não tem trabalho nem estudam. E pensando nos Fóruns e seguindo com o exemplo de Casavalle eu pensaria na Usina Cultural Casavalle, que é um equipamento bem legal, muito bem equipado. Acho que os liceus deveriam ter equipamentos assim, um estudo de gravação de televisão ou para fazer filmes, que ofereçam oportunidades muito fortes e que se apresentem como possibilidades de inclusão, devem ser muito atraentes para quebrar a lógica da exclusão que é uma lógica que o próprio sistema esta propondo. Os números de deserção não têm ha ver com esta discussão, mas são realmente alarmantes, pensando no futuro do país.

Há outros programas que podem ser complementares dos anteriores. A ideia dos SOCAT, Centros de Orientação à população sobre os seus direitos e as possibilidades de acesso aos recursos públicos. Eles podem ser importantes para ter operação em rede, vinculando serviços e equipamentos.

Também os Centros de Atenção Cidadã $\mathrm{CAC}^{30}$, ou até a colocação de um Caixa Eletrônico num bairro desses, vão permitir melhorar a vinculação entre os sujeitos e o Estado, mas eles não são programas chave. Apenas podem fazer parte de um conjunto.

\footnotetext{
${ }^{28}$ Complejo Sacude. http://municipiod.montevideo.gub.uy/node/714. Ver Trabalho Programado 1 que refere a região de Casavalle.

${ }^{29}$ No sistema educativo uruguaio, "escola" corresponde ao que seria o ensino fundamental, e "liceu" o ensino médio. A educação escolar se completa em doze anos, seis de escolas e seis de liceu.

${ }^{30}$ Programa de atenção similar aos poupatempos brasileiros.
} 


\section{REGISTRO DE OUTRAS ENTREVISTAS}

\section{Entrevista a Roberto Elissalde.}

Data: 26/03/2014 Lugar: Casa de Elissalde.

Participantes. Roberto Elissalde. Luis Oreggioni. Pasante Rosina Cortegoso.

Existe transcrição completa em espanhol que fora incluída em TP de qualificação de Mestrado.

Datos del entrevistado (EN ESPAÑOL)

Estudió antropología en la Facultad de Humanidades y Ciencias y poco antes de terminar los estudios se dedicó de pleno al periodismo. Escribió en Opinar, La República y Brecha, siendo jefe de la sección Internacional de este semanario entre 1991 y 1996, cuando asumió como jefe de redacción de la Guía del Mundo (Instituto del Tercer Mundo). En 1994-1995 hizo una especialización sobre la Unión Europea en la escuela de Periodismo de la Federación Mundial de Periodistas (Journalistes en Europe), en París, y en 1997-98 una maestría en comunicación y nuevas tecnologías en la Brunel University en Londres.

Editor general de la Guía del Mundo en 2001-02 en sus ediciones en inglés y castellano y coordinador editorial de "Más allá del mercado", el anuario de políticas del TrasNational Institute (Holanda) en sus ediciones en inglés y castellano.

En 2009 editor y compaginador de "Gozos y sombras del gobierno progresista. Aportes al balance" un libro de 227 páginas sobre el primer gobierno de izquierda de Uruguay (2005-2010).

Trabajó desde el primer día del gobierno del Frente Amplio como asesor del ministro Mariano Arana en el Ministerio de Vivienda, Ordenamiento Territorial y Medio Ambiente. A partir de 2007 asumió la dirección del Proyecto Centros MEC del Ministerio de Educación y Cultura.

Hoy, con 123 locales en todo el país, Centros MEC es una dirección del MEC que trabaja principalmente en poblaciones de menos de cinco mil habitantes, desarrollando una amplia agenda cultural y educativa de arraigo local. 


\section{Entrevista Fernando Cabezudo, Myrna Campoleoni}

Data: 27/03/2014 Lugar: Programa de Mejoramiento de Barrios.

Participantes. Fernando Cabezudo, Myrna Campoleoni, Gerenta Técnica de la Unidad Coordinadora del Programa de Mejoramiento de Barrios. Luis Oreggioni. Estagiaria Rosina Cortegoso.

Existe transcrição completa em espanhol que fora incluída em TP de qualificação de Mestrado.

Datos del entrevistado (EN ESPAÑOL)

Fernando Cabezudo.

Es arquitecto desde 1986, Facultad de Arquitectura, UdelaR. Fue profesor de proyecto en la Facultad de Arquitectura Taller Parodi. Entre los años 1986 y 2005 desarrolló actividad profesional independiente con estudio instalado en la Ciudad de Mercedes, donde vive hasta ahora.Entre los años 1995 y 2005 asesoró a la ONG Provías en realojos a asentamientos irregulares en Mercedes. Entre 2005 y 2010 fue Arquitecto Coordinador General de la Intendencia de Soriano. Supervisó realojos de varios asentamientos irregulares.

De 2010 a la fecha es coordinador general de programas del PMB/PIAI, Programa de Mejoramiento de Barrios dependiente del Ministerio de Vivienda Ordenamiento Territorial y Medio Ambiente. Artículo: Un aporte a la gestión de programas masivos de realojo por autoconstrucción asistida. Realojo de población de asentamientos irregulares en Mercedes, junto con la Arquitecta María Noel Ferreira y las Licenciadas en Trabajo Social Graciela Cavallero y Cecilia Gadea, en la Revista Vivienda Popular número 22 de agosto 2012. Farq. Udelar. http://www.farq.edu.uy/viviendapopular/vp22/

Myrna Campoleoni.

Es arquitecta desde 1995, Facultad de Arquitectura, UdelaR. Maestría "Hábitat y Vivienda" en la Facultad de Arquitectura, Planeamiento y Diseño, Universidad Nacional de Rosario, 2001-2004. Fue Asistente de Investigación Grado 2 en el Instituto de la Construcción de Edificios de la Facultad de Arquitectura entre los años 1988 y 2000.

Entre 2005 y 2010 fue integrante del equipo de trabajo del área de Mejoramiento Barrial como Arquitecta Consultora contratada.

De 2011 a la fecha Gerenta Técnica de la Unidad Coordinadora del Programa de Mejoramiento de Barrios. 


\section{Entrevista Herbert Ichusti}

Data: 05/03/2014 Lugar: Intendencia Municipal de Montevideo.

Participantes. Herbert Ichusti. Luis Oreggioni. Pasante Rosina Cortegoso. Estudiante Mauricio Wood. Existe transcrição completa em espanhol que fora incluída em TP de qualificação de Mestrado.

Datos del entrevistado. (EN ESPAÑOL)

Herbert Ichusti es arquitecto desde 1986, Facultad de Arquitectura, UdelaR. Ingreso a trabajar a la Intendencia Municipal de Montevideo en 1985, donde desempeñó diferentes cargos.

En 2007 fue nombrado Arquitecto asesor del Departamento de planificación, a cargo de la Unidad de Integración de la Planificación. Integró el equipo designado por el Intendente Ehrlich, en representación del Departamento de Planificación, para el estudio de las leyes N18567 y 18659 , y la elaboración de un decreto municipal en concordancia, que resultó el Dto. №33209 y sus modificativos.Del 2010 a la fecha, continua con el cargo en la Unidad de Integración de la planificación, se desempeña como Coordinador del Consejo Cuenca Casavalle, y como integrante del Consejo Goes integrando la secretaría. Artículo sobre la Plaza Casavalle en el boletín de la SAU 


\section{Entrevista Julio Llanes}

Data: 25/02/2014 Lugar: MIDES.

Participantes. Julio Llanes. Luis Oreggioni. Pasante Rosina Cortegoso. Estudiante Diego Morera Existe transcrição completa em espanhol que fora incluída em TP de qualificação de Mestrado. Datos del entrevistado. (EN ESPAÑOL)

Trabajó en el planificación estratégica de la DINEM, integró el equipo que realizó el seguimiento a la ejecución del PANES y participa en diversos proyectos de investigación entre los que se destaca: "Mejoramiento de la entrega de servicios sociales en Uruguay a través de un Sistema de Monitoreo y Evaluación Participativos"; "Propuesta metodológica para aproximarse al fenómeno de la vivienda en la población PANES"; "Informe sobre el Gasto Público en Infancia en el Uruguay 1990 - 2009: insumos para la elaboración de una estrategia para la infancia y la adolescencia."; "Caracterización de la Cuenca Casavalle"; "Aportes para la discusión del régimen de AFAM en áreas rurales" e "Informe Cuenca del Arroyo Pantanoso". De 2005 a la fecha es integrante del equipo técnico de la Dirección Nacional de Evaluación y Monitoreo (DINEM) del Ministerio de Desarrollo Social (MIDES). 


\section{Entrevista Adriana Rojas.}

Equipo Técnico da Assessoria de Desenvolvimento Municipal e Participação.

Data: 03/2018. Lugar: IM Participantes. Rojas, Oreggioni

\section{Entrevista Marcelo Bednarik.}

Encarregado de Projeto Arquitetônico e Urbano da Direção de Planejamento da IM Data: 03/2018 Lugar: IM. Participantes. Bednarik, Oreggioni, colaboradora Mariana Facio.

\section{Entrevista Conjunta Prefeitura de Montevidéu:}

SILVANA PISSANO Diretora de Desenvolvimento Urbano, PATRICIA ROLAND Diretora de Espaços Públicos, RAMON MENDEZ Diretor de Planejamento da IM, ANA RIVERA Subdiretora de Planejamento, e MARCELO BEDNARIK Data: 02/2018 Lugar: IM Participantes. Mendez, Rivera, Pissano, Roland, Roux, Luis Oreggioni.

\section{Entrevista Juan Pablo Labat}

Diretor de Avaliação e Monitorização do MIDES

Data: 02/2018 Lugar: MIDES.

Participantes. Juan Pablo Labat. Luis Oreggioni.

\section{Entrevista Eduardo Laurito}

Arquiteto Projetista UDELAR

Data: 02/2018 Lugar: Canteiro de Obra da "Escuela Universitaria de Tecnología Médica" UDELAR.

Participantes Laurito, Oreggioni, colab. Mariana Facio.

\section{Entrevista Andrea Gnesetti}

Arquiteta Projetista MECAEp Arquitetura Educacional

Data: 02/2018 Lugar: Escritório do Pesquisador. Participantes. Gnesetti, Oreggioni.

\section{Entrevista Silvana Pissano e Patricia Roland}

Diretora de Planejamento Urbano da Prefeitura de Montevidéu e Diretora de Espaços Públicos Data: 02/2018 Lugar: IM

Participantes. Pissano, Roland, Roux, Luis Oreggioni.

\section{Entrevista Alvaro Trillo}

Arquiteto projetista de Planejamento Urbano da Prefeitura de Montevidéu.

Data: 12/2017 Lugar: IM

\section{Entrevista Daniel Daners}

Gerente da Direçao Nacional de Esportes DINADE

Data: 09/2017 Lugar: DINADE

\section{Entrevista Mario Corrales}

Arquiteto Diretor da Direção Setorial de Infraestrutura. Administração Nacional de Ensino Publico.

Data: 09/2017 Lugar: DIRSEC

\section{Entrevista Daniel Wainstein}

Arquiteto. Direção de Arquitetura. MSP Ministerio de Salud Pública. Dirección Arquitectura Ministerio Data: 01/2018 Lugar: MSP

\section{Entrevista Eduardo Dalcanale Martins}

Arquiteto Projetista do CEU 3a geração e o TERRITORIO CEU. Prefeitura de SÃO PAULO.

Data: 08/2015 Lugar: PREFEITURA SP 
Entrevista Alexandre Delijaicov e André Takiya

Arquitetos Projetistas do CEU 1a geração. EDIF Prefeitura de SÃO PAULO.

Data: 07/2013 Lugar: CEU Butantã

O resto das entrevistas se desenvolveu em conversações informais, geralmente acompanhadas de gravações digitais, e notas do pesquisador 


\section{CONClusões}

O trabalho reflete sobre o volume de informação obtido visando obter a maior clareza nas categorias empregadas e a metodologia de estudo. Referem-se aqui a assuntos que representam descobertas ou novidades no desenvolvimento da pesquisa.

Apresentam-se três entrevistas completas no formato final, e outras quatro em anexo com a transcrição em espanhol. O conjunto de informação das sete entrevistas é utilizado para a elaboração de estas conclusões.

A partir do conjunto de entrevistas serão explicitados e avaliada sua capacidade para redefinir aspectos conceituais ou da estrutura da pesquisa já formulados, especialmente da conceptualização do Fórum enquanto entidade, mas esta primeira série permite já avançar em algumas conclusões.

As conclusões estruturam-se segundo os três objetivos estabelecidos no começo do trabalho.

_Obter uma visão critica desde a experiência acadêmica, institucional e social, que permita revisar e refinar as hipóteses de trabalho sobre a qualidade e condição dos equipamentos coletivos na periferia de Montevidéu.

Os depoimentos são coincidentes com uma visão crítica sobre a maneira em que as políticas públicas de atenção social desdobram-se no território, confirmando ou salientando as hipóteses estabelecidas pelo projeto de pesquisa.

A complexa estrutura do estado, e os interesses setoriais, políticos e pessoais têm predominância sobre as ações centralmente coordenadas.

Existe coincidência sobre a dupla condição da rede de ensino público: ela é a mais extendida no território produto de antigas políticas de promoção, e ela é muito especializada nas suas funções específicas de ensino e fechada à coordenação territorial. Essa rede não necessariamente deveria ser incluída nos Fóruns.

Todos os referentes consultados concordam com a ideia de que a territorialidade virou uma condição definidora da segregação, novidade ainda não incorporada de maneira central e vigorosa pelo conjunto das políticas públicas e sim por ações setoriais muitas das quais são dirigidas por alguns dos entrevistados. Fora da área da pesquisa, e concentrando-se nas dimensões das múltiplas escalas em relação com o projeto de arquitetura, pode-se estabelecer a pergunta de se não faz falta uma redefinição estrutural da institucionalidade pública e suas principais direções de trabalho para atender o problema da segregação social e sua definidora expressão territorial.

_Obter uma lista breve e significativa de experiências locais e internacionais de referência.

Não é possível obter uma tendência sobre este assunto, mas as relações referidas pelos entrevistados são de dois tipos. Por um lado é generalizada a opinião altamente favorável sobre a experiência de Medellín. Por outro alguns dos entrevistados não parecem estar estudando experiências internacionais, o que parece ser um tema que também refere a falta de produção acadêmica e estudo de casos internacionais na matéria. Se houve um Uruguai nas primeiras décadas do século passado voltado para o mundo ávido e capaz de incorporar políticas de primeira linha, parece que hoje as referências internacionais ficam mais distantes.

A exceção nesta direção é a estratégia que Gustavo Leal vem impulsando desde o Ministério do Interior que está fortemente interessada em incorporar visões externas referenciais de varias partes do mundo e particularmente de América Latina. 
Os casos que ficarão na agenda, a partir das entrevistas para futuros estudos (geralmente experiências diretamente vinculadas a área de gestão dos entrevistados) na pesquisa que foram referidos pelos entrevistados e para conferir sua possível influência na definição das estratégias e propostas da pesquisa são os seguintes:

Revisão sistemática da experiência colombiana, e de todas as palestras e comunicações da "Primer Conferencia sobre Cultura y Convivencia en las ciudades de América Latina", onde houveram intervenções de sucesso em várias cidades. Organizada pelo "Ministério do Interior. PNUD". No contexto do "Plan 7 zonas".

Outubro 2013 - Montevidéu.

_Intervenções urbanas para a reversão das consequências territoriais e sociais do apartheid na África do Sul.

_Pontos de Cultura em Brasil que dependem do Governo Federal de Brasil e formar referidos por Roberto Elissalde.

_"Programa De Recuperación De Barrios en Chile". Experiência de melhoramento de Bairros em Chile, que abrange todas as escalas das intervenções publicas, referida pelo programa PMB/PIAI.

Experiência de Centros de Barrio em Rosário Argentina, e o programa "Rosario Habitat" referidos por Ichusti e Cabezudo, nas entrevistas anexas.

_Receber opiniões para a escolha dos equipamentos que integram o Recorte Programático Principal, e ajustar as hipóteses da pesquisa.

A dispersão de políticas e manifestações territoriais relevadas parece não aportar suficientes elementos para a obtenção de umas primeiras ideias dos recursos principais a incluir nos Fóruns. $O$ universo de entrevistas já realizado não é informação suficiente para obter algumas primeiras diretrizes provisionais sobre os programas a incluir. Existe a presunção do pesquisador que $o$ conjunto de entrevistas mais que conduzir o processo a uma síntese, vai acrescentar a dispersão de opções. Mas começam a aparecer algumas ideias que podem ser afins às hipóteses da pesquisa.

_Incorporação de um equipamento de excelência e singularidade (grande Teatro, Cinema, Conjunto Esportivo, Área expositiva, etc.) com abrangência para a região inteira na que se inclui o Fórum, e que tenha uma gestão pública própria, orçamento forte e seja de ingresso gratuito. Embora esses programas tenham uma alta especialização físico-espacial, a ideia deveria ser que eles sejam incluídos no processo de Dissolução Programática de maneira de serem, durante o processo de planejamento e projeto, intercambiáveis entre diferentes regiões.

_O primeiro programa a incluir, e que não existe agora nesse sentido, recolhe algumas tendências de vários programas parciais (Centros MEC, SOCAT, CAC, projeto de "Ventanilla Única del Estado" ainda não desenvovido) é um programa de Orientação e Mediação ativa entre os cidadãos e a complexa trama de recursos sociais e instituições publicas e ONGs que visam reverter a exclusão.

_ A priorização de programas de inclusão social dirigidos às crianças, como política de inclusão social a futuro. Existe no Uruguai a experiência do "Programa Ceibal" que universalizou a alfabetização digital no ensino público associado ao programa internacional "One Laptop per Child".

Sediar locais centrais que tenham o objetivo de oferecer atividades complementares a serem incluidas dentro das atividades das Escolas, Escolas de Tempo Integral, Ensino Médio, etc. Espaços para ateliês, oficinas, etc. com bom equipamento. Isso poderia colaborar com a inclusão e integração do Sistema Educativo Público.

_ A inclusão primária de recursos que brindem políticas universais, e só de maneira secundária incluir aquelas dirigidas à segmentos particulares da população. 
_Dar lugar às "Políticas de Cercania" que fazem parte das estratégias de recuperação dos excluídos nas áreas de Saúde, Educação, etc. De maneira geral essas políticas realizam sua ação cotidiana no território, mas o fato de elas estarem sediadas juntas e vinculadas espacialmente poderia colaborar com a sua coordenação.

_Os Fóruns devem ser espaços de encontro de diferentes gerações e pessoas, espaços de convivência. Programas dirigidos às famílias ou à capacitação para os pais, podem ser complementares àqueles dirigidos às crianças.

Três considerações finais associadas às Entrevistas, mas já concentradas nos temas do projeto:

Uma formulação de Equipamentos Coletivos numa região sempre deverá ser flexível em sua configuração programática, procurando conectar e disparar as atividades e interesses locais. A experiência, dos Centros MEC, embora em regiões bem menores, e significativa nessa capacidade para reconhecer as expressões locais.

Existe a coincidência entre os entrevistados de que a coordenação das ações é mais fácil no território concreto que a coordenação institucional. Poderíamos imaginar os Fóruns como territórios propiciadores da coordenação local.

Existe uma certa oposição entre a importância outorgada em algumas visões à qualificação do espaço público e à geração de equipamentos coletivos de qualidade. A proposta estabelecida no projeto de pesquisa de formular os Fóruns como um Equipamento e como um Espaço Público aberto é uma ideia forte e de alto potencial para o desenvolvimento de projetos inovadores. 


\section{MORE WITH LESS}

ESTRUTURA DA TESE 


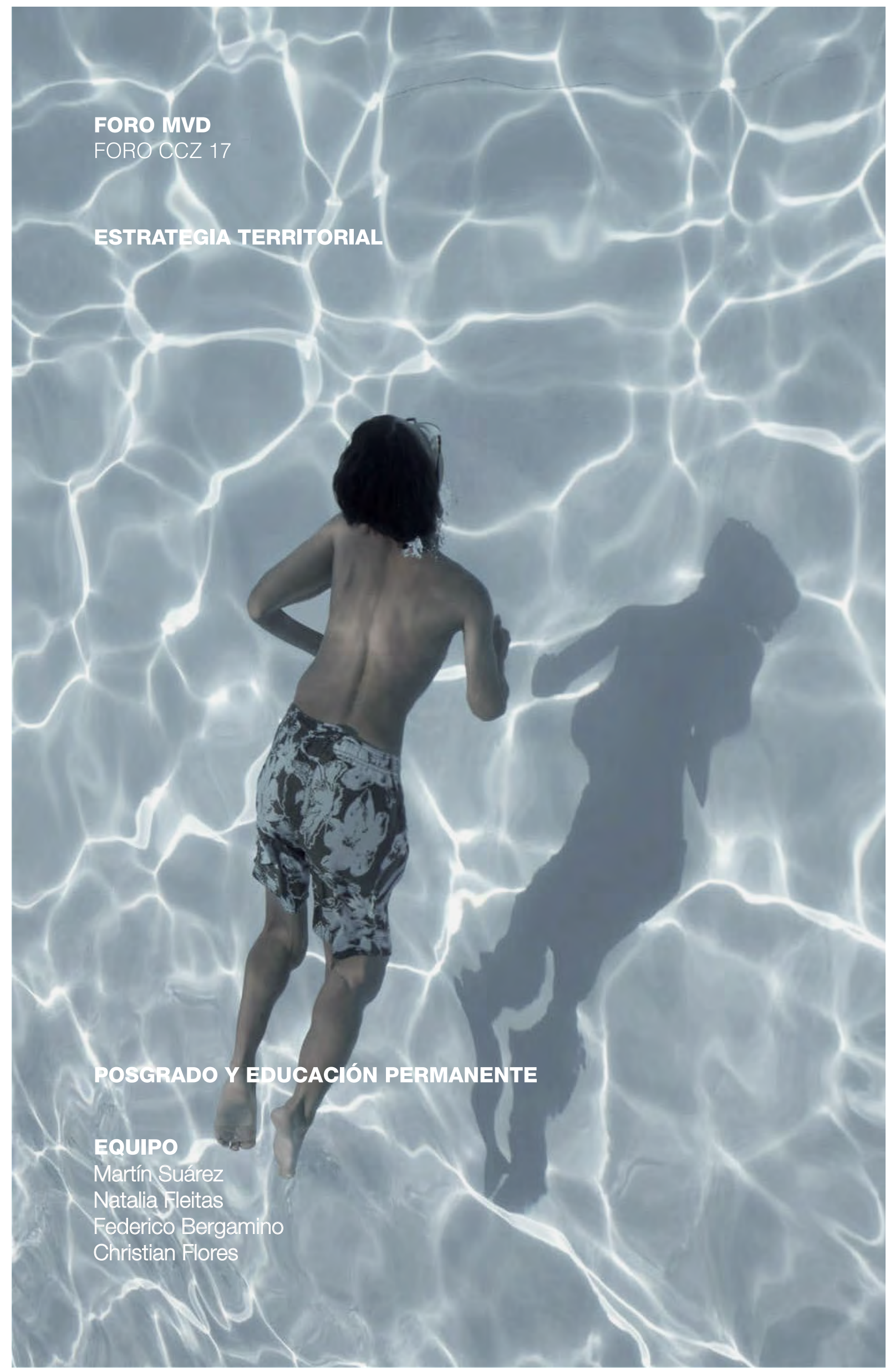




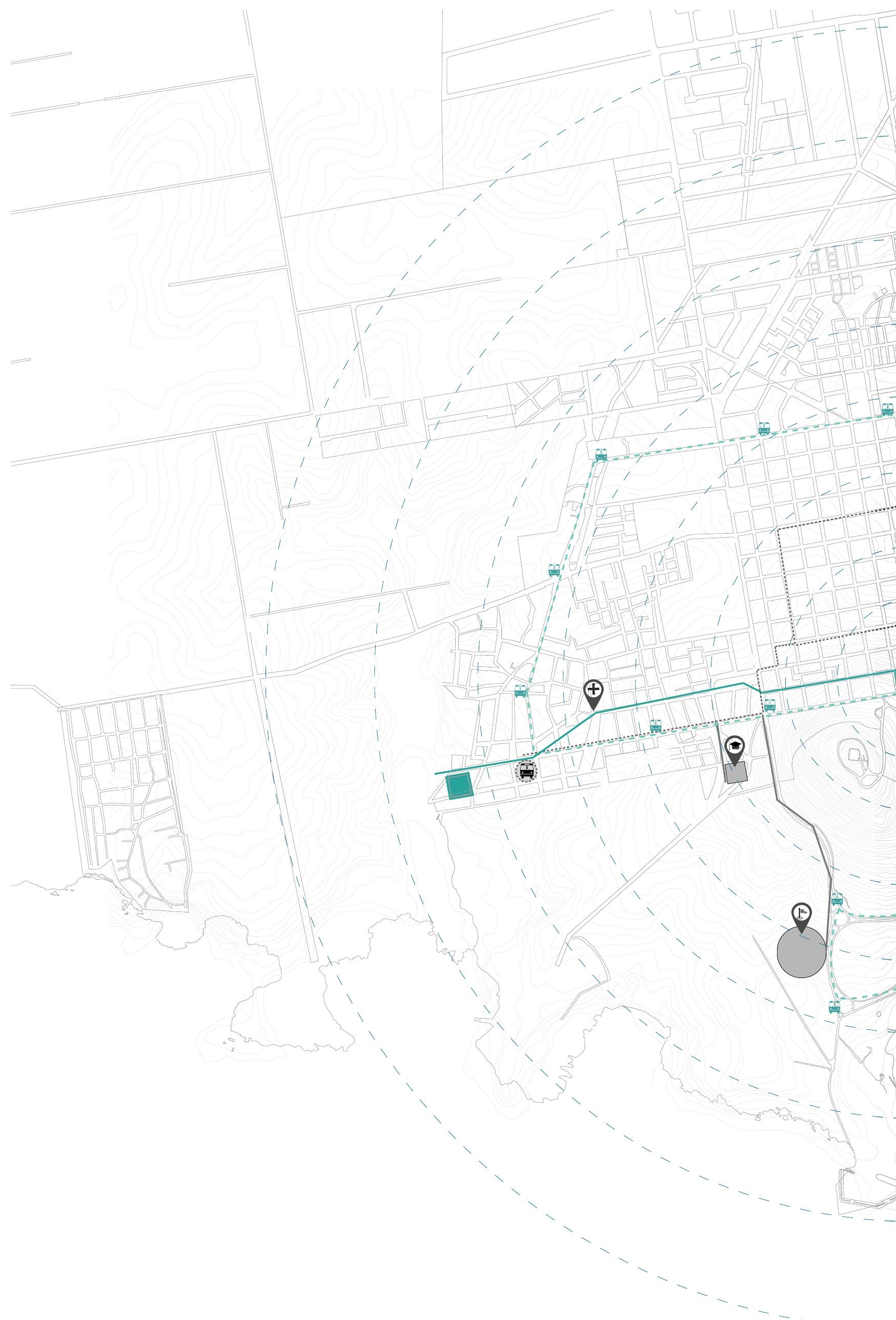




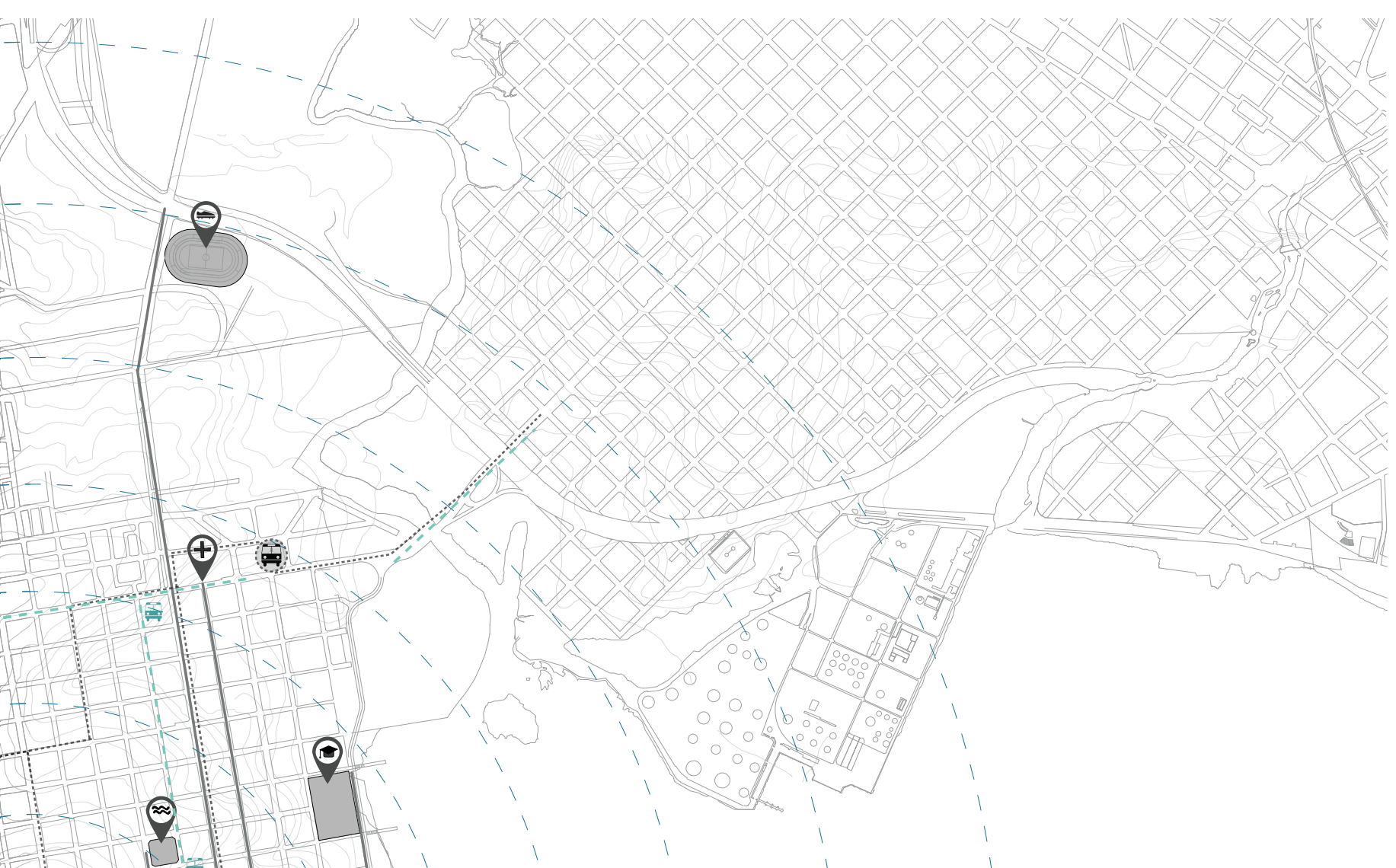

○

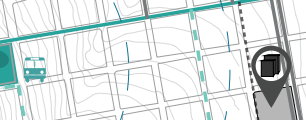

$\approx$
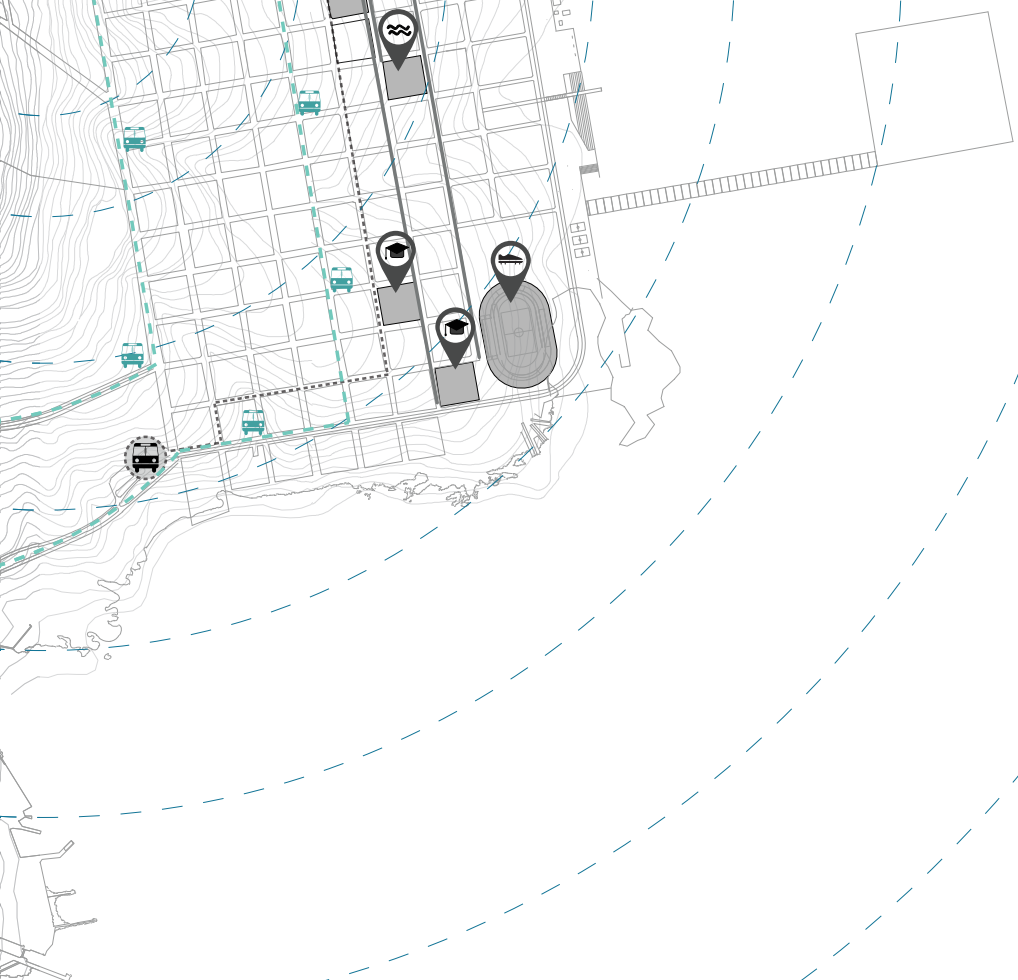

요 


\section{Ready made.}

Una oportunidad locativa es el disparador de este Foro. Una infraestructura existente, ubicada privilegiadamente en relación a la geografía y a la geometría más abstracta de la zona, es aprovechada como punto de partida ventajoso para la intervención.

Un tanque de agua se ubica por la naturaleza de su funcionamiento, en el punto más alto. En este caso además, en el punto más alto de la ciudad y a escasos metros de su icónica Fortaleza.

Geométricamente baricéntrico entre el la planta de bombeo del saneamiento en Casabo y la rambla de la bahía del Cerro, el punto es por tanto radialmente equidistante entre estos barrios que si bien son tangentes padecen una ruptura que los separa.

Se generan un eje a partir de los tres puntos que pone en evidencia el dialogo entre la topografía y la cuadricula existente.

El nuevo Foro toma esa ubicación privilegiada para desdoblar un equipamiento infraestructural en principio cerrado y volverlo lugar de oportunidad y encuentro. Se crea así el lugar del Foro.

Desde este punto la actuación que realizamos busca poner en la mesa de debate la forma en que las infraestructuras son incorporadas en la ciudad y mostrar una posible manera de utilizarlas como excusas para crear urbanidad. Planteamos un foro que permite múltiples usos a partir de la premisa del agua y que busca crear una plataforma abierta que de respuestas a múltiples necesidades más que la directa de carácter ingenieril, creándose un equipamiento urbano que responda a varias escalas, tanto barriales como metropolitanas.

En el marco de esta dualidad escalar, la implantación se da en un área que funciona como rótula de la trama urbana, implicando la concreción de una estrategia de intensificación urbana en un área consolidad pero de un alto grado de fragilidad.
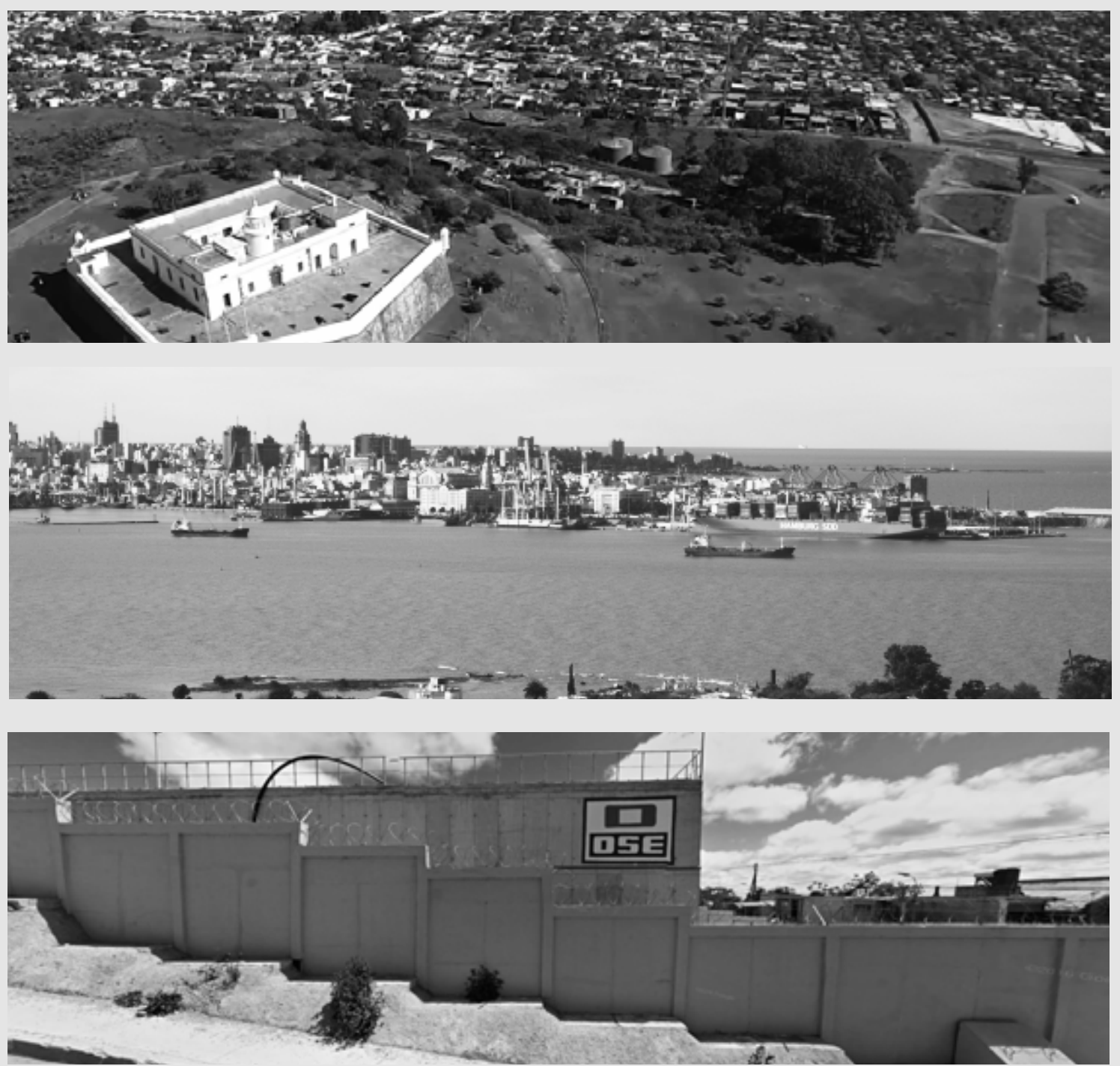
FORO MVD

FORO CCZ 17

INFOGRAFIAS

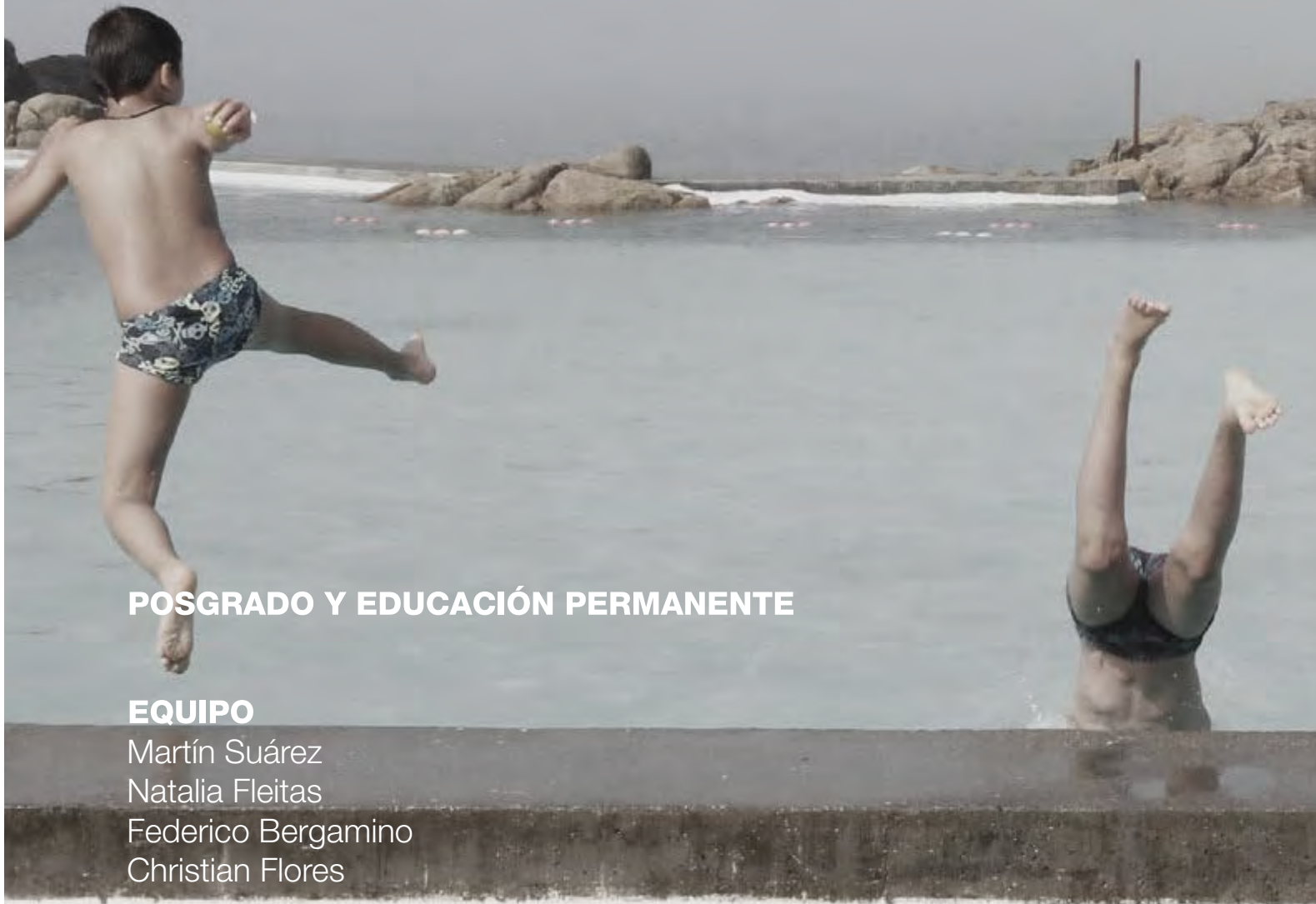


INFOGRAFÍA

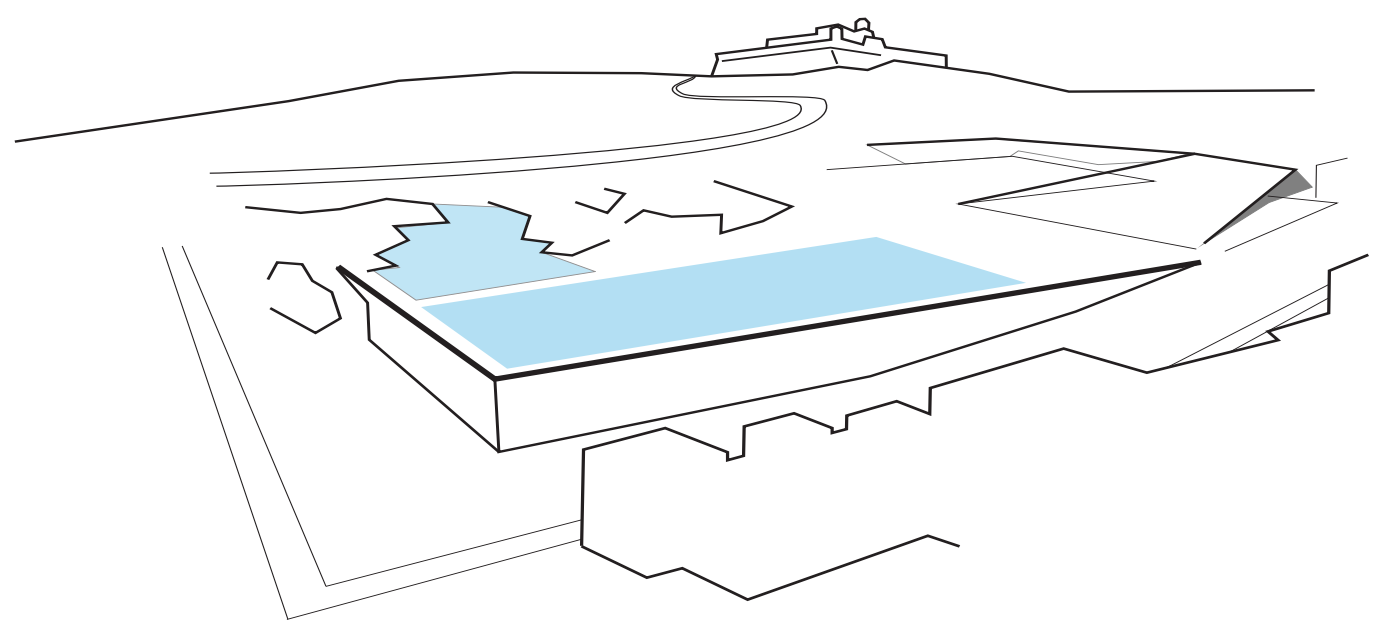

较

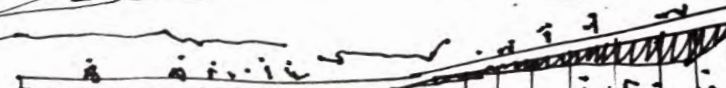

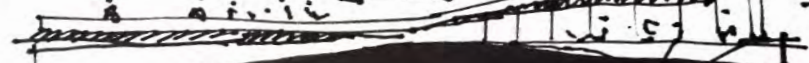




\section{MEMORIA GRÁFICA}

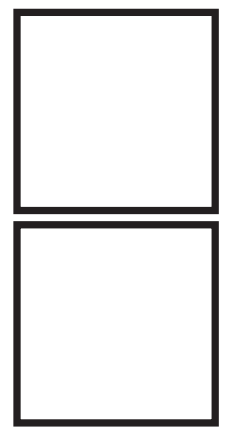

manzana

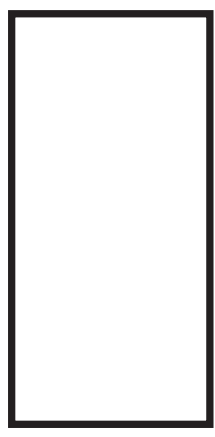

geometría

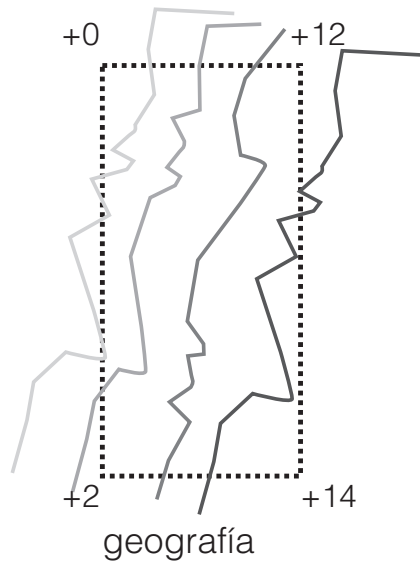

geografía
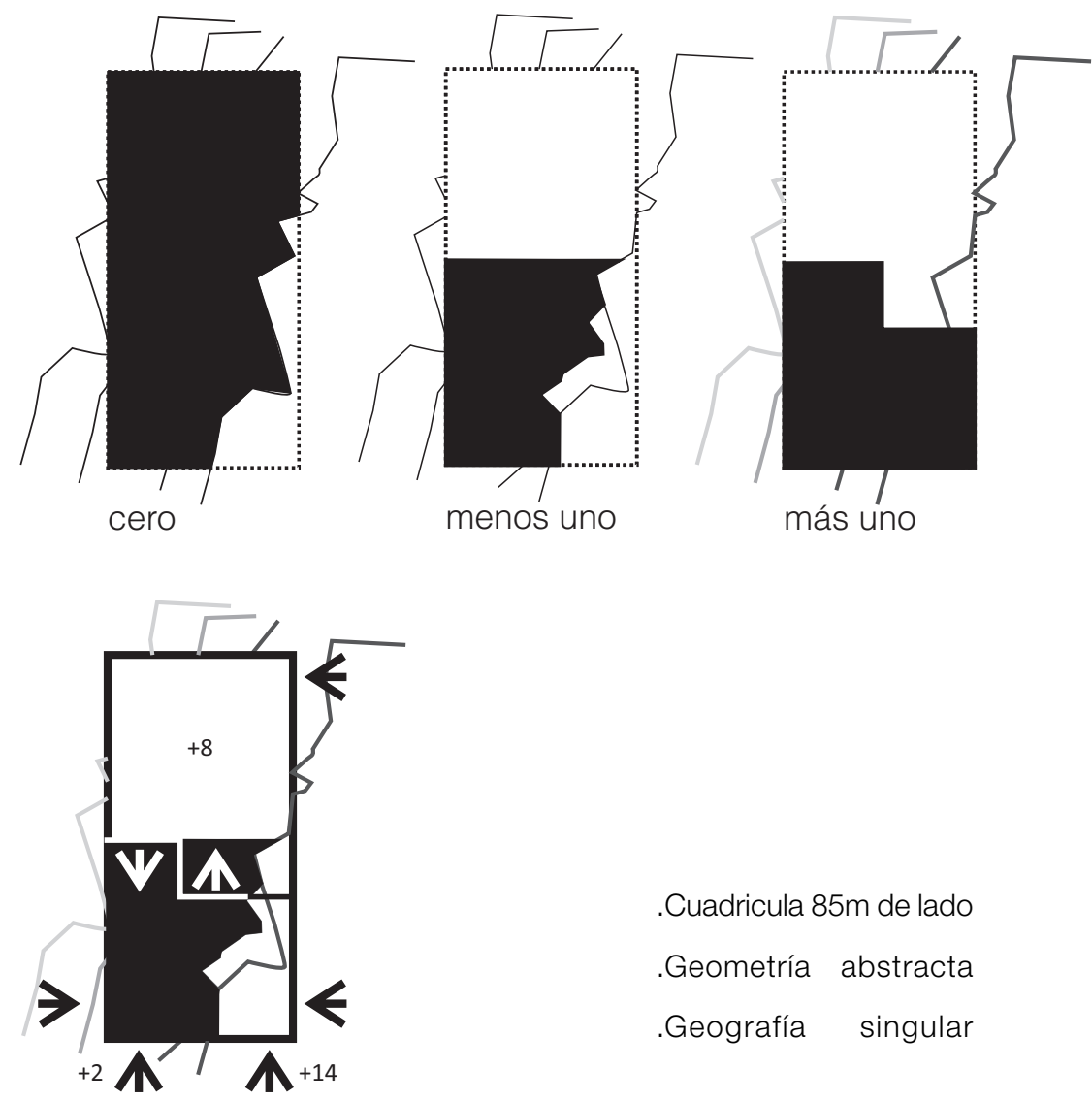

Cuadricula $85 \mathrm{~m}$ de lado

Geometría abstracta

Geografía singular 


\section{GEOGRAFÍA Y GEOMETRIA}

Dos manzanas del damero característico de Villa Cosmópolis, de $85 \mathrm{~m}$ de lado se toman como superficie geométrica base. La superficie plana del contenedor de agua da cota inicial al plano horizontal abstracto de la cuadrícula, que se intersecta con la geografía rocosa en pendiente enfatizando el encuentro de este binomio.

El plano abstracto se desdobla, se pliega, multiplicando las intersecciones con la roca y generando concavidades interiores, superficies cubiertas y exteriores, espacios de reunión de cara a la ciudad.

Su plegado helicoidal le otorga múltiples entradas tangentes a cada nivel topográfico, favorece el recorrido y la multiplicación de las relaciones barriales.

Su escala dimensional le otorga carácter de equipamiento metropolitano. Se crea así el espacio foro; edificio - topografía. / Edificio - desespecialización programática.

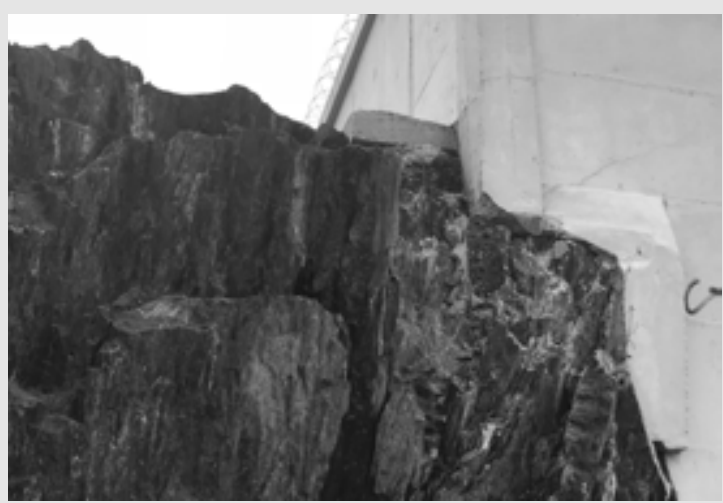

AGUA

Pudiendo ser cualquier otra, la excusa se presenta de la misma mano de la oportunidad infraestructural: el agua. Está ahí, es llevada a ese punto, alcanza con llevar más. Poéticamente se deja caer y ésta encuentra los cuencos producto del cruzamiento de la geometría abstracta con la geografía pétrea del lugar. Equipamiento de máxima calidad es un deber para las zonas carenciadas. Una playa artificial con las vistas más privilegiadas, el derecho al lujo para todos; un centro acuático de alto rendimiento, una oportunidad; un centro de salud vinculado al agua, una necesidad.

Se crea así, el Foro del Agua.

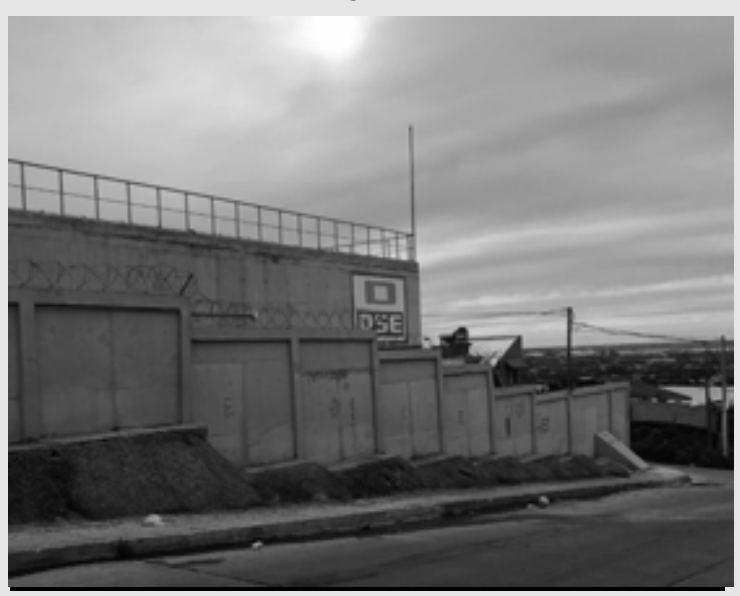

\section{CONEXIÓN}

Vemos de vital importancia mejorar la interconexión entre las distintas zonas, en donde se potencie el vínculo de los habitantes con la agrupación de barrios. En este sentido proponemos la incorporación de una red de transporte complementaria que conecte a modo de loop, la terminal de cerro con los distintos barrios y brinde fácil acceso desde la ciudad a los múltiples puntos de interés como la fortaleza, la rambla, el parque Vaz Ferreira, el Foro del Agua.

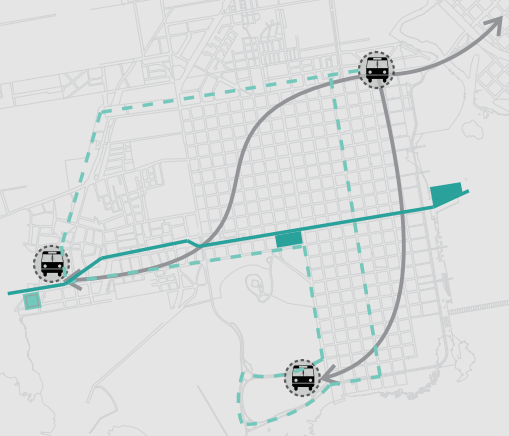

DEMOCRATIZACIÓN DEL PAISAJE

La implantación del Foro del Agua genera un doble impacto en la apreciación del paisaje, por un lado al plantearse como una plataforma equipada en el borde de la falda del cerro, crea un límite físico del parque, evitando la apropiación del suelo público por privados mediante asentamientos irregulares; Consolida una traza para el ascenso peatonal hasta la fortaleza, inexistente hasta la fecha. Por otro lado la incorporación del Foro del Agua a la red de transporte público genera una democratización del paisaje, brindándole a la población la posibilidad de vivencias una parte de la ciudad que en la actualidad es de difícil acceso.

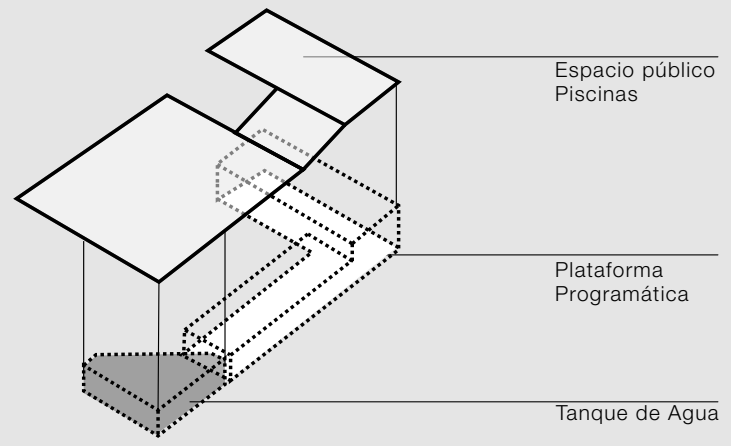

PUNTO DE ENCUENTRO / MIXUSE

El Foro del Agua se plantea como un punto de encuentro entre los ciudadanos de los distintos sectores, en momentos con la excusa de las piscinas y las actividades vinculadas al agua y en otros momentos con el uso de los espacios que materializan la plataforma debajo de la plaza, donde se da lugar a la incorporación de programas de carácter cívico y/o recreativos, variables a lo largo del tiempo, los cuales van a ser el motor de la apropiación del Foro del Agua. 


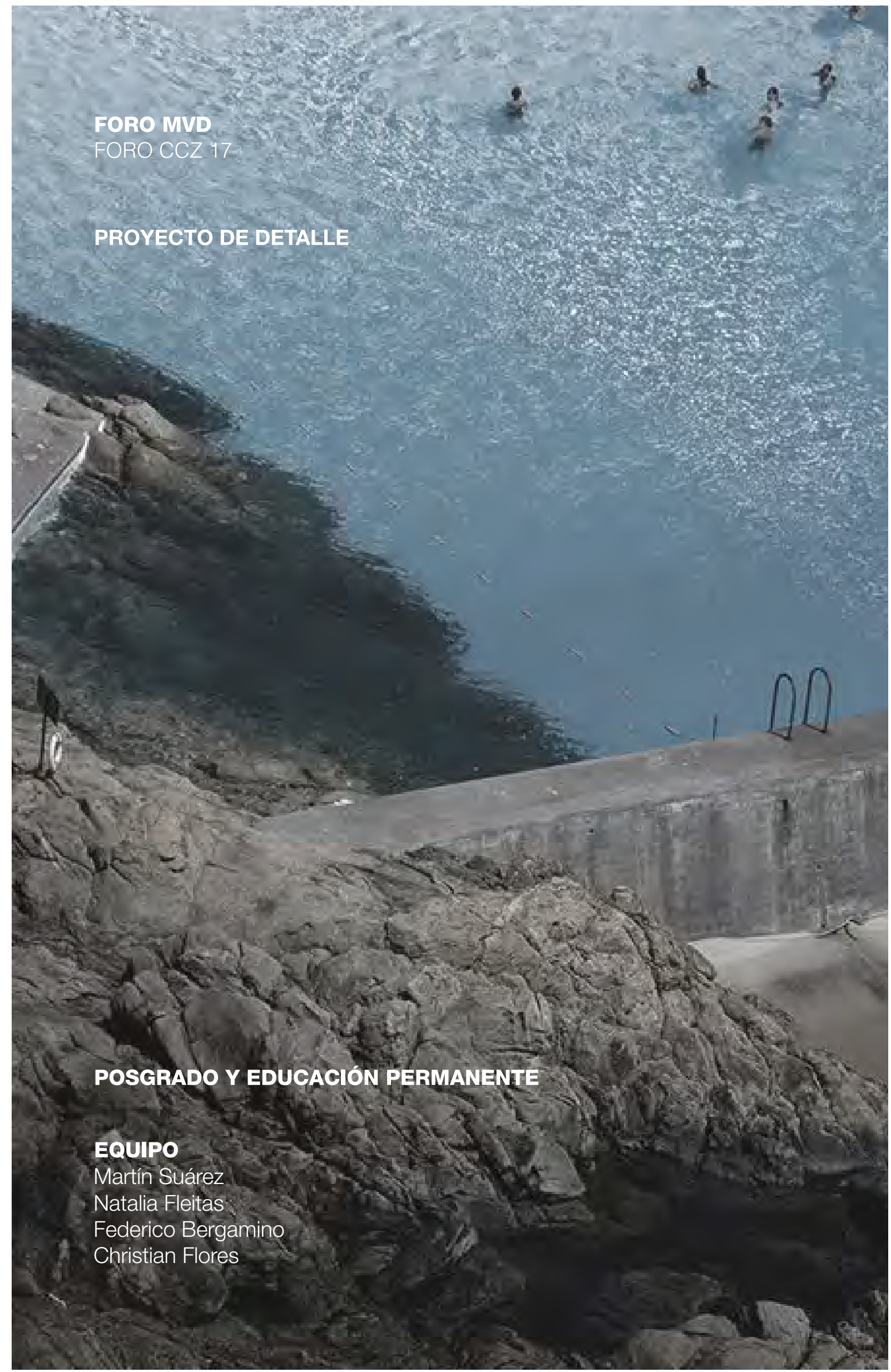




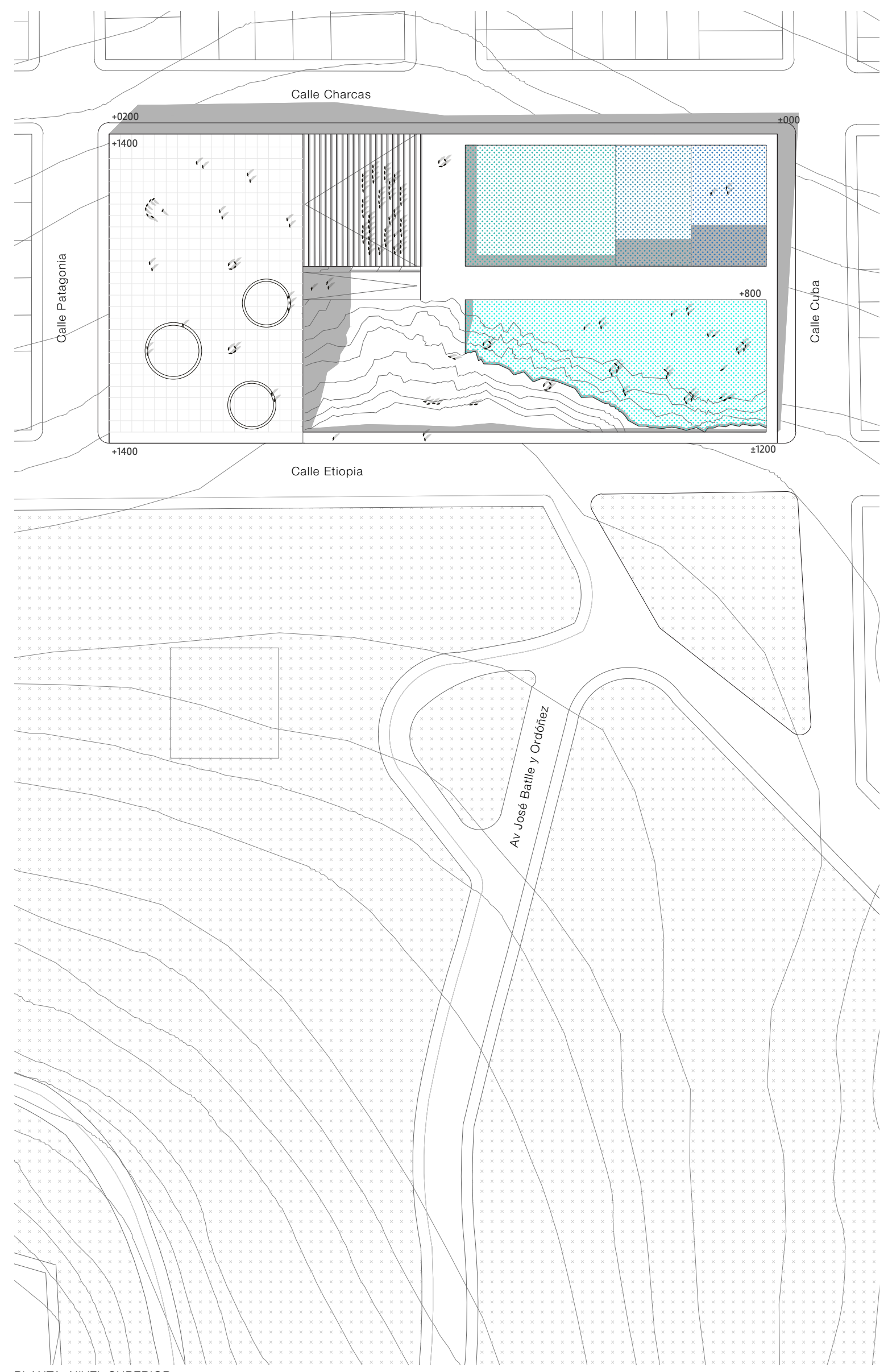



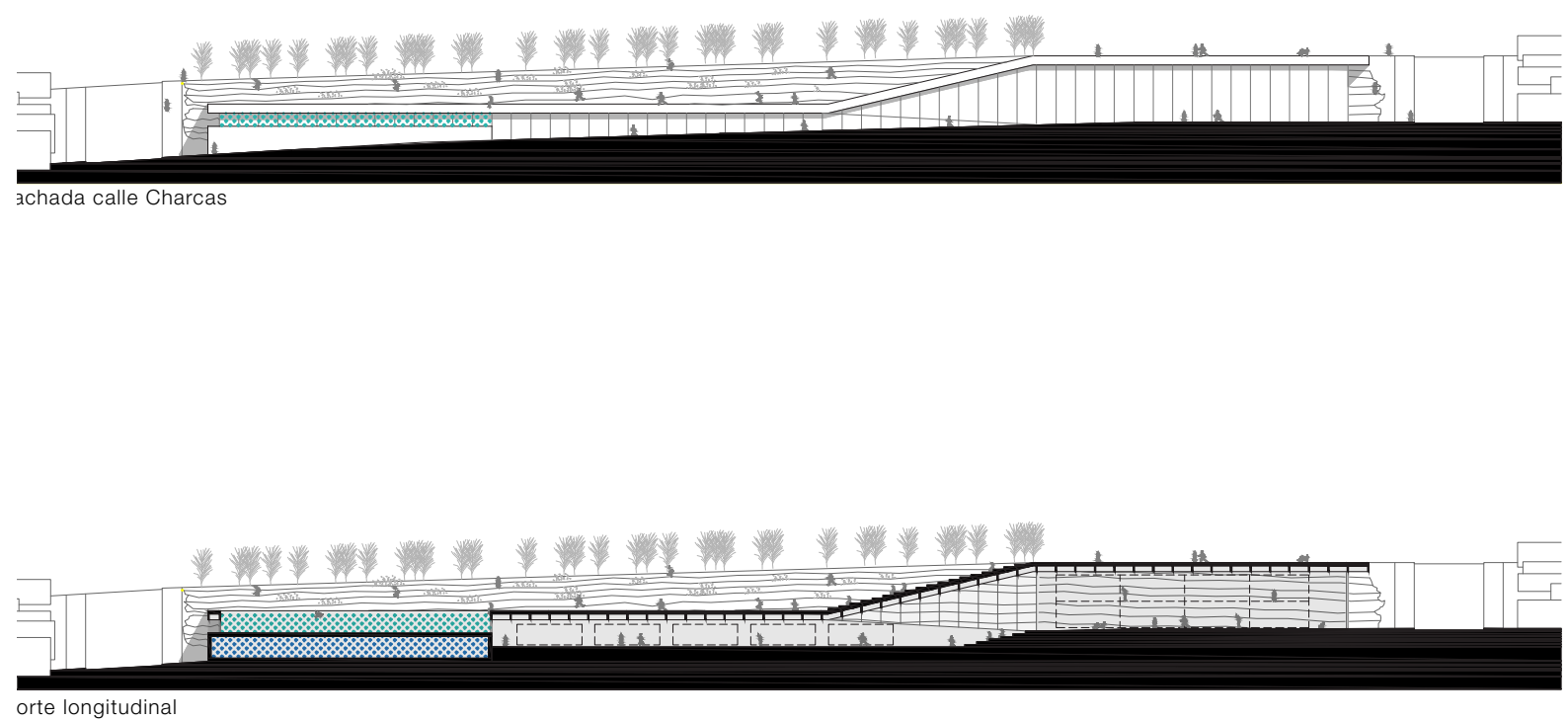

orte longitudinal
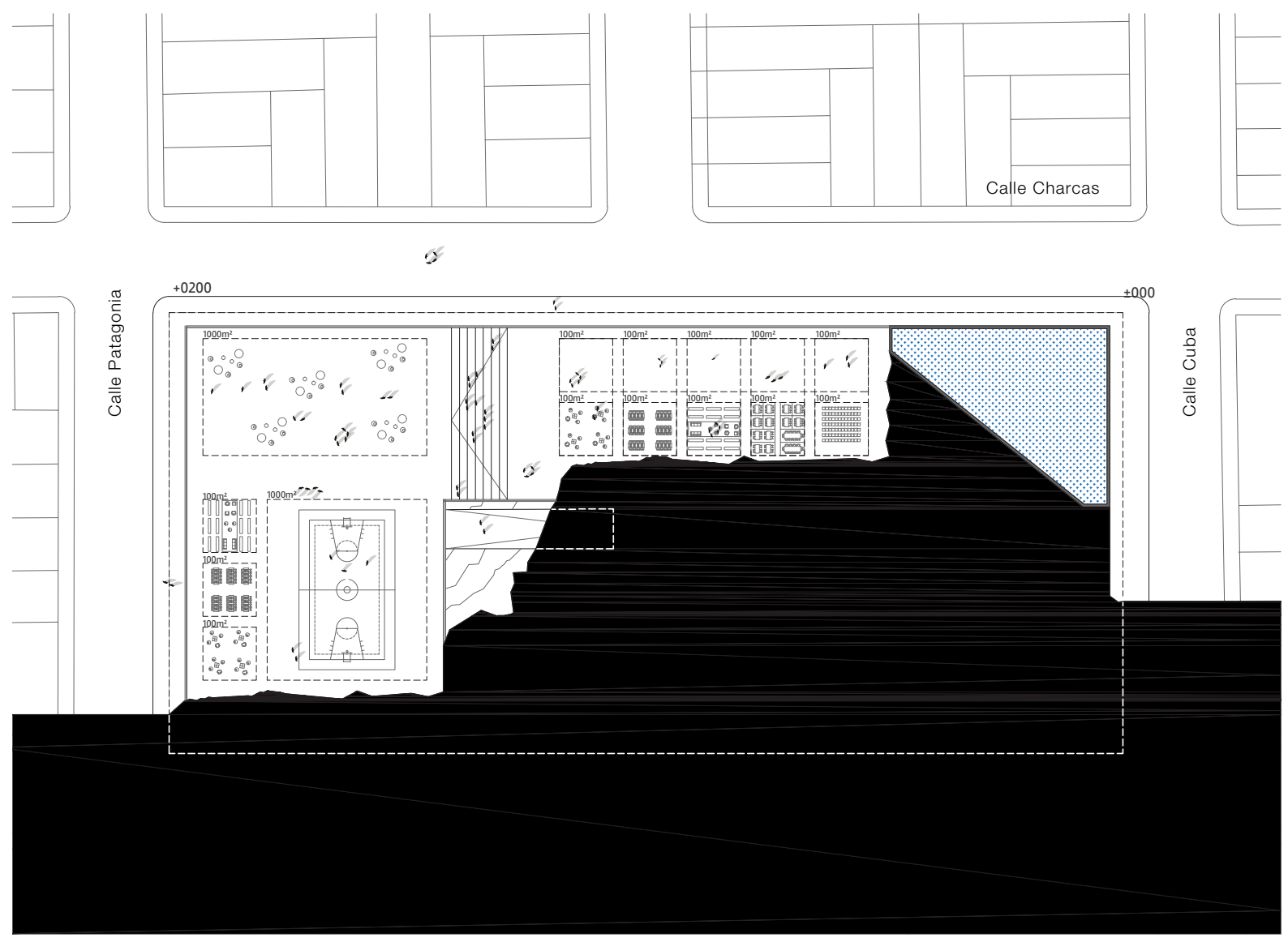

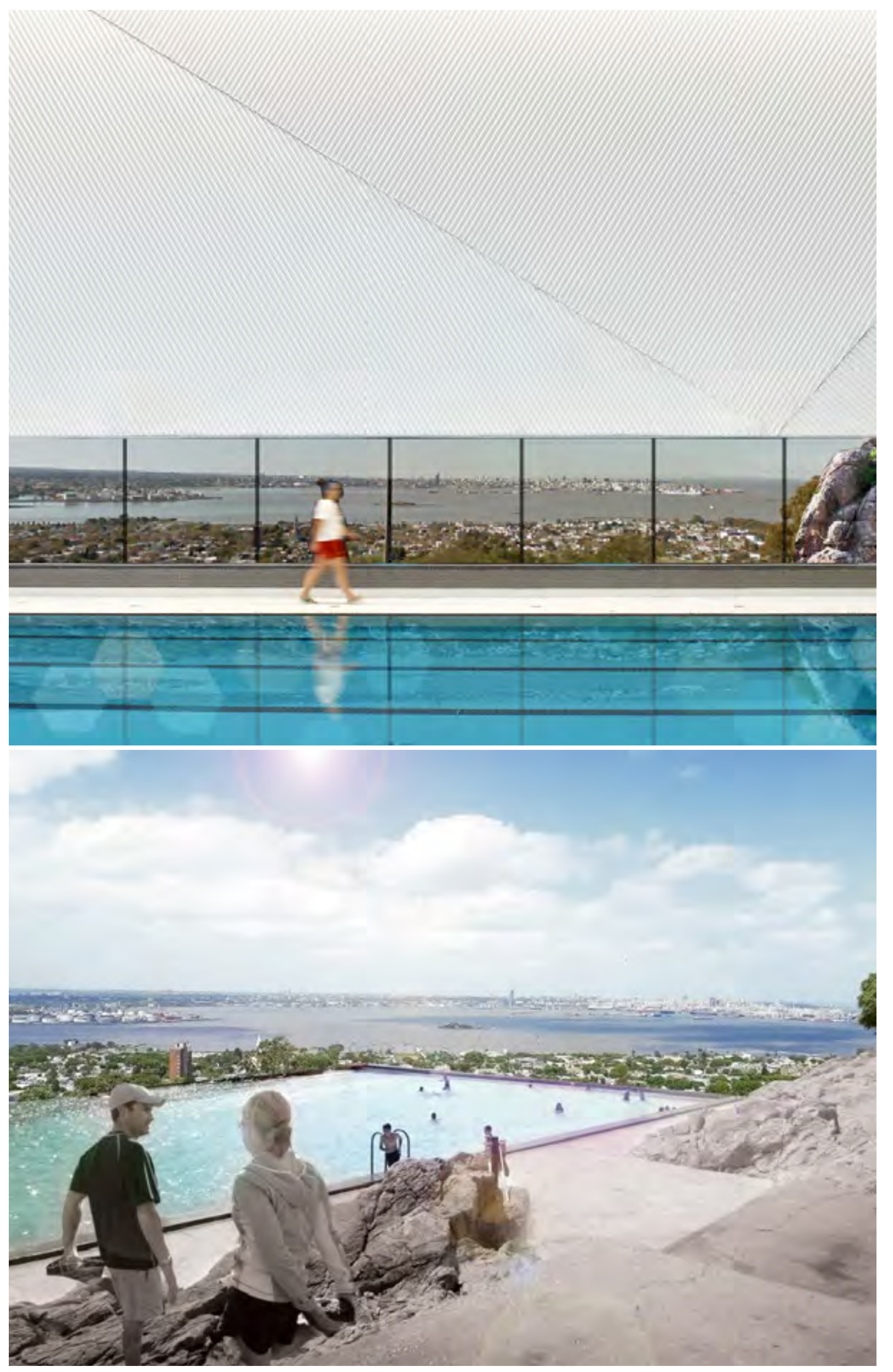


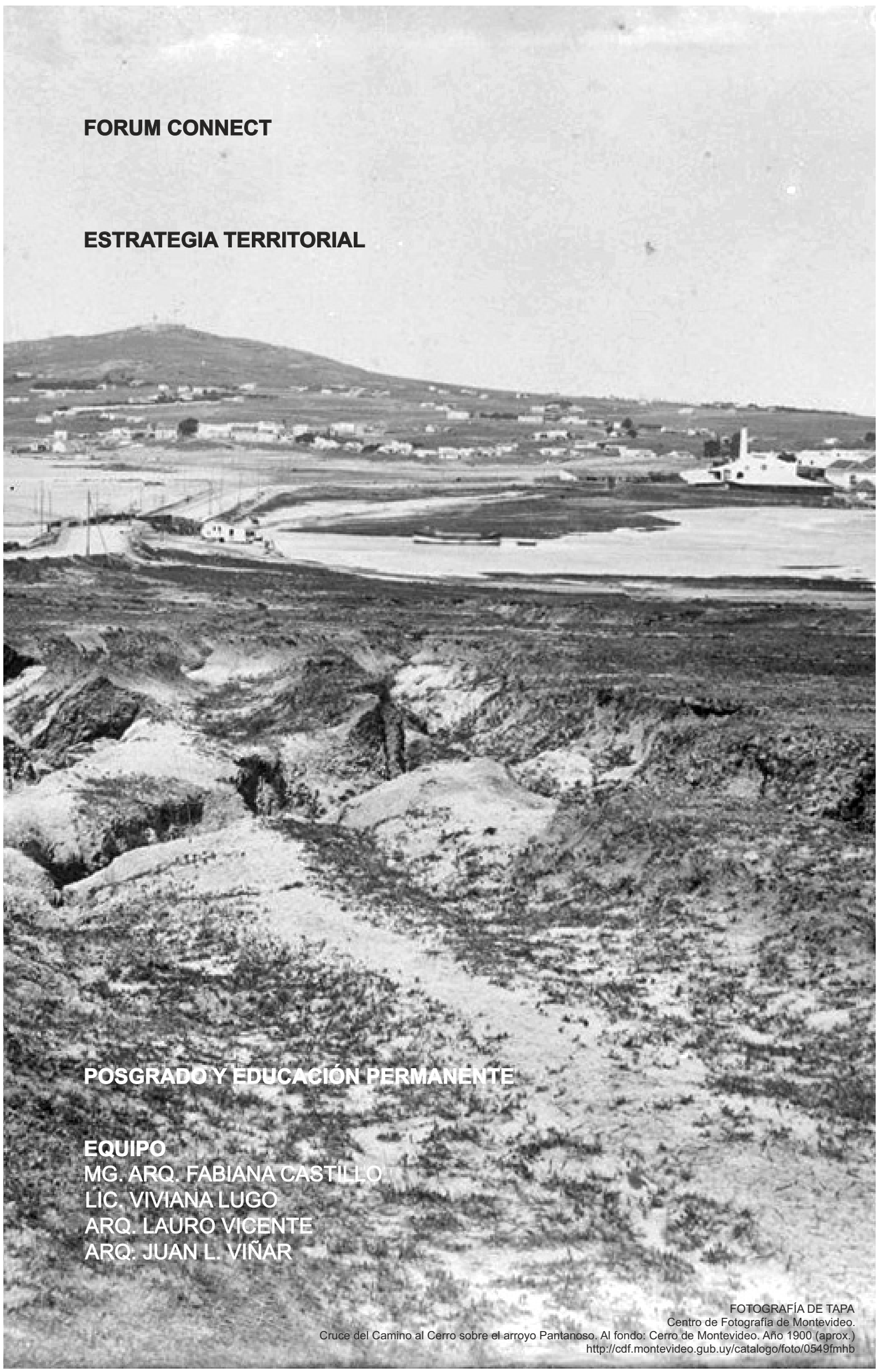




\section{Caracterización de la zona y el barrio}

Comenzando con la caracterización del barrio Cerro el mismo se encuentra en la costa de la bahía de la capital de nuestro país. Dentro de sus emblemas más destacados se encuentran el Cerro y su fortaleza los cuales se encuentran representados en nuestro escudo nacional. El Cerro ha sido una de las zonas con más historia dentro de nuestro país.

Hoy en día el Centro Comunal 17 cuenta con una población de 83.131 personas (Censo 2011), representando el $6.3 \%$ de la población de Montevideo. La mayoría de sus habitantes en su mayoría son de población joven, Otra de sus características es que es una de las mayores zonas dentro de Montevideo en donde su población vive en asentamientos irregulares, representando el $27.1 \%$ del total de la capital.

Dentro del Cerro se han desplegado un sinfín de recursos a nivel social para poder trabajar la multidimensionalidad de lapobreza.

De la caracterización de la zona se desprende que el barrio cuenta con recursos tanto a nivel social como cultural al alcance de sus habitantes. Por otra parte, es de conocimiento que no todos sus espacios son usados ni por sus habitantes ni por el resto de los montevideanos, las razones pueden ser varias dentro de las cuales podemos encontrar que el ser un barrio que se encuentra en la periferia montevideana, la estigmatización a nivel departamental genera que el Cerro hoy en día se encuentre "separado" del resto de la costa capitalina.

\section{Orígenes y actualidad}

Haciendo historia; en 1910 con la instalación de fábricas en el Cerro; "el trabajo (...), fue quien caracterizó en toda su historia el afincamiento residencial en la zona: quien le dio además características de aislación con respecto a la ciudad; característica que se mantuvo mientras existió en el Cerro fuente de trabajo segura y no hubo que salir de sus límites en busca del trabajo diario". Hoy en día éste aspecto se ve modificado debido a que su población debió insertarse, en su mayoría, en un mercado de trabajo que se encuentra fuera de las inmediaciones barriales.

A su vez, es un hecho que quienes vivimos fuera del Cerro no somos asiduos concurrentes a uno de los cascos históricos más importantes de nuestra capital y con más contenido histórico.

Estas dos poblaciones: habitantes del Cerro y resto de Montevideo, tenemos un punto en común de unión: la terminal del Cerro, siendo un punto de encuentro entre los habitantes del departamento.

En el Cerro hoy en día no existe un lugar que permita generar un espacio de recreación y de intercambio entre los montevideanos. La terminal es un lugar estratégico de encuentro tanto a nivel turístico como también de relacionamiento a nivel departamental; sin embargo, no cuenta con un espacio que cumpla la función de esparcimiento; es debido a ello que teniendo en cuenta la propuesta del curso se pensó como punto estratégico de instalación de FORO los accesos al barrio cerrense teniendo en cuenta la proximidad a la terminal del Cerro.

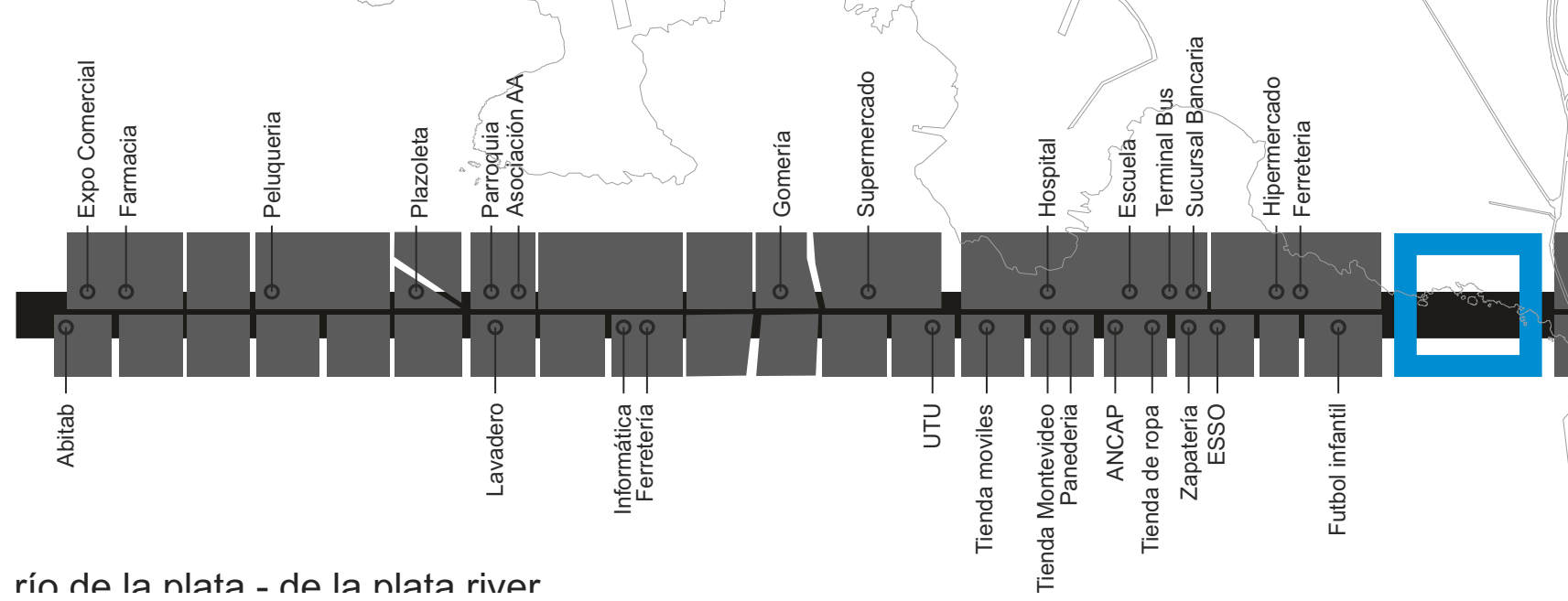




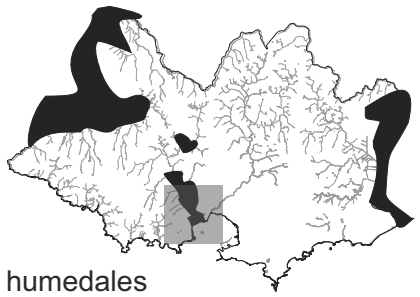

Abordaje

Se plantea una intervención que forme parte de un equipamiento colectivo localizado estratégicamente en el territorio de la ciudad de Montevideo, específicamente en el punto de acceso al Cerro. La idea de generar un espacio público dentro de una lógica macro de equipamiento que cosen toda la bahía del cerro con los humedales del pantanoso, trascendiendo de la escala local y abordar una escala más territorial, donde este FORO forme parte de una lógica de urbanización y re-calificación de los espacios degradados y con gran potencial.

Los dispositivos colectivos estarían articulados e interconectados para generar una acción de mayor impacto, donde estos centros de ocio, culturales, sociales, salud, educativos y deportivos de calidad, tengan un fuerte impacto en el entorno inmediato, fortaleciendo de las centralidades barriales y zonales.

\section{Objetivo General}

Generar un FORO público de calidad dentro de una estrategia territorial de equipamientos público y conectivo, trascendiendo la concepción físico-espacial logrando un enfoque que abarque una visión global del territorio, su población local y regional, las problemáticas y posibles puntos de abordaje.

\section{Objetivos específicos de FORO CONNECT}

Generar un FORO público que sea soporte de actividades gubernamentales, (re-ubicación del Municipio A), educativas y de investigación (centro APEX) contenida dentro de un espacio "plaza/puente" que permita desarrollar diversas actividades y mejorar la conectividad existente entre el Cerro y Montevideo, y en conjunto generar una sinergia con impacto regional (turismo interno y externo).

Promover la recuperación urbana y la conservación ambiental del Pantanoso, la revitalización de predios públicos, integración social, a través de espacios colectivos que apunten a mejorar la calidad de vida de los habitantes, mejorar los estructuradores viales e infraestructuras urbanas y el vínculo con el paisaje urbano y natural.

\section{Aspectos programáticos}

EI Sitio: la elección del sitio está dada por tres fuertes condicionantes; el humedal, la bahía de Montevideo y el eje cívico Carlos María Ramírez.

Humedal Pantanoso: forma parte de los recursos hídricos de Montevideo, espacio donde existe un gran potencial paisajístico como ecosistémico y es de un gran valor para que los habitantes de nuestro territorio lo disfruten y conserven.

Bahía: Escenario referente que siempre está en nuestro imaginario cuando hablamos de Montevideo, siempre fue un elemento reconocido de nuestra ciudad, desde los primeros años de la fundación de la ciudad, siendo la puerta de entrada a través del puerto, luego siendo el sitio donde se implantaron las industrias y hoy en día aprovechada por su potencial paisajístico y recreativo como espacio público.

Trama urbana / eje cívico: haciendo un análisis más en detalle de la zona de intervención se denota un "quiebre" y "estrecha conectividad" entre la trama del Cerro con la trama de La Teja, la cual si está "cocida" por un eje cívico en permanente desarrollo que es Carlos María Ramírez. Esta "debilidad" la entendemos como la oportunidad de actuar en este sitio, también entendido como la puerta del Cerro de Montevideo.

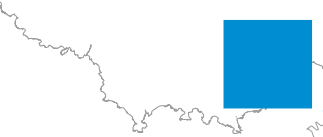
eje carlos maria ramirez Humedal Bahía de Montevideo trama urbana

Luis Vaia (1996) en "Al Oeste: el Cerro..." Exposición realizada en oportunidad del V Congreso Lațnoamericano de Cultura arquitectónica y urbanística. 


\section{FORUM CONNECT}

\section{PROYECTO DE DETALLE}

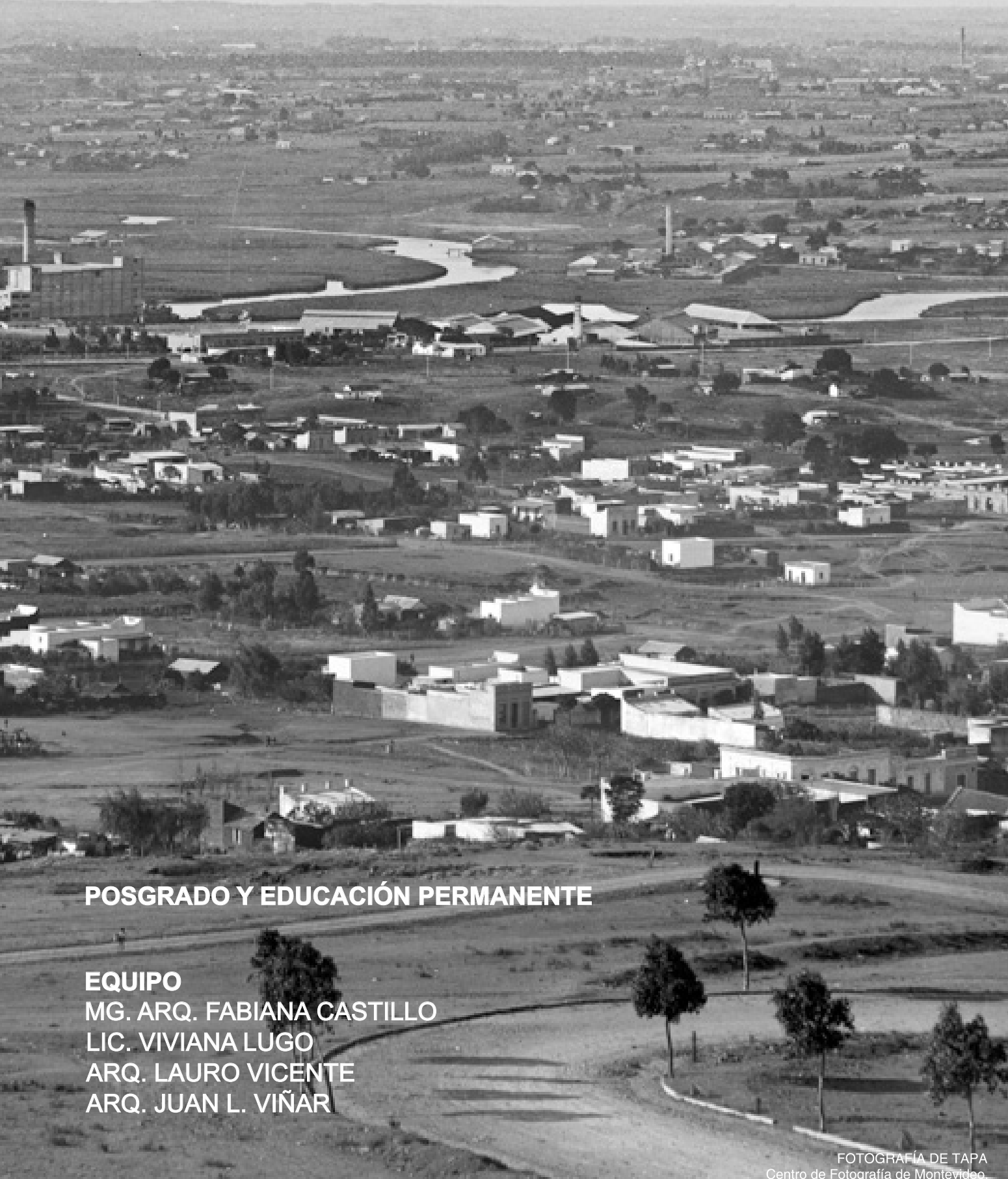




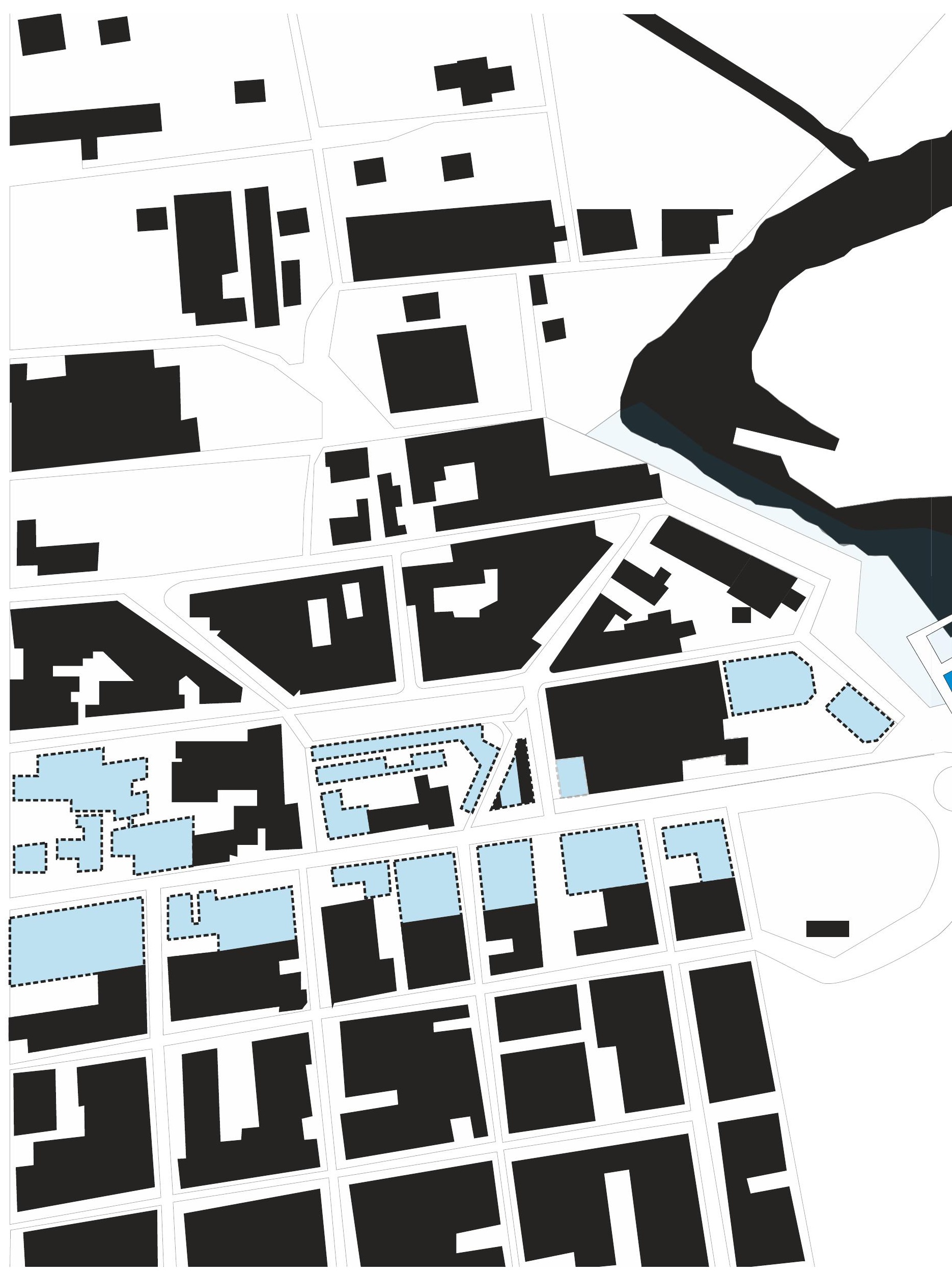




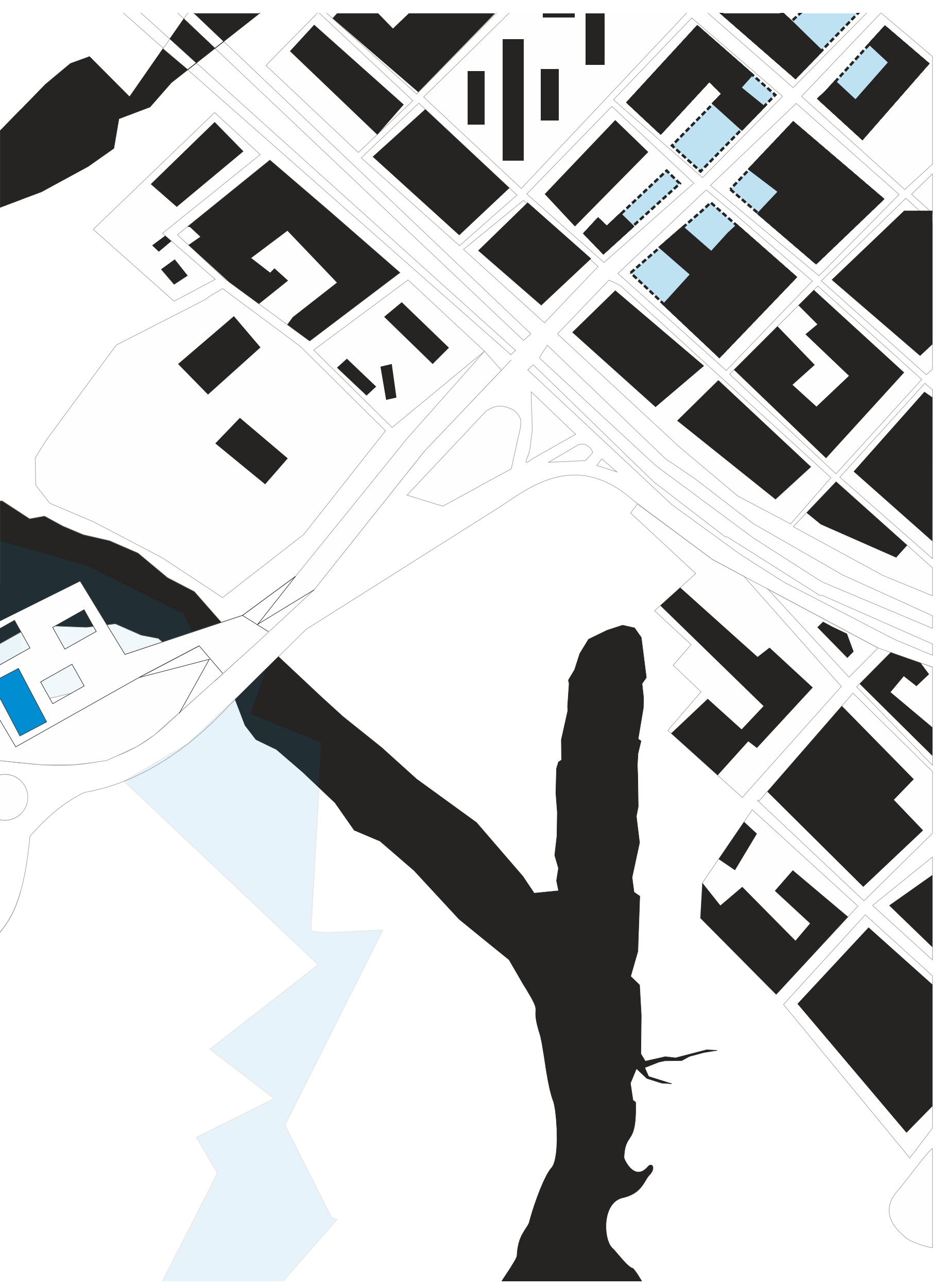



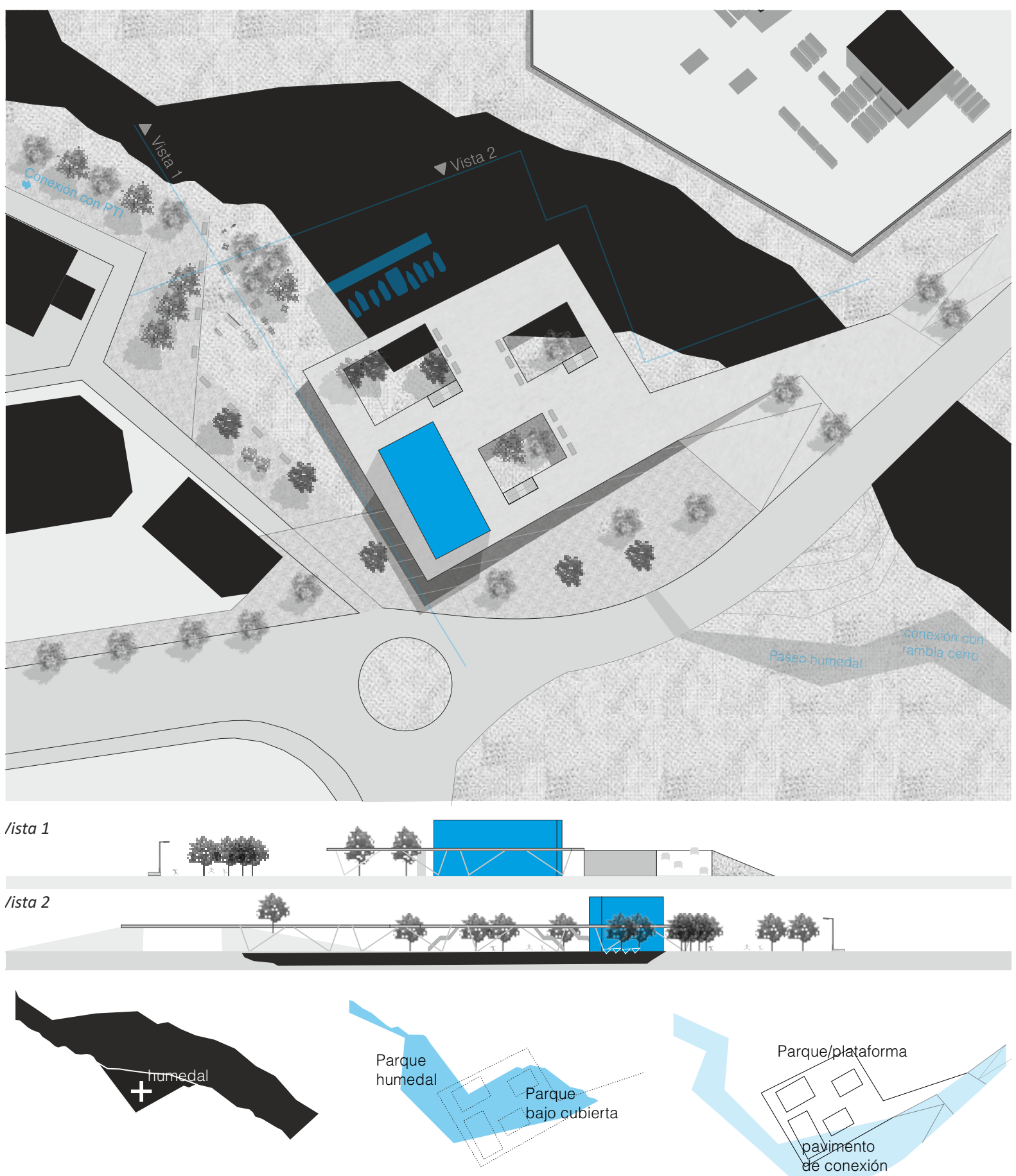

Actividades a incorporar al edificio

Je busca generar un espacio de referencia trasladando las oficinas del Municipio A y APEX Jerro, conformarían una estrategia de fomento de ciudadanía e intercambio por parte de lé joblación universitaria. El Municipio A actualmente se encuentra en las inmediaciones de le zalle Carlos María Ramírez, siendo parte del entramado urbano de la zona pero no siendo ur sspacio de referencia para el total de los habitantes del municipio. En cuanto al programe APEX - Cerro, cuenta hoy con una locación muy reducida que impide implementar sı sropuesta educativa que, un espacio descentralizado y único presenta. El generar ambitc erritorial con fomento recreativo a nivel de espacio público, con la posibilidad de impulsa əspacios de espectáculos artísticos, festivales, reforzando el enfoque cultural; sumado a lé aperturas de oficinas de atención social y educativo conforman una red potenciada que daré ın entorno único en la zona y que podrá ser aprovechada tanto por vecinos como también po əl resto de los ciudadanos de Montevideo. 
FORUM CONNECT

INFOGRAFÍAS

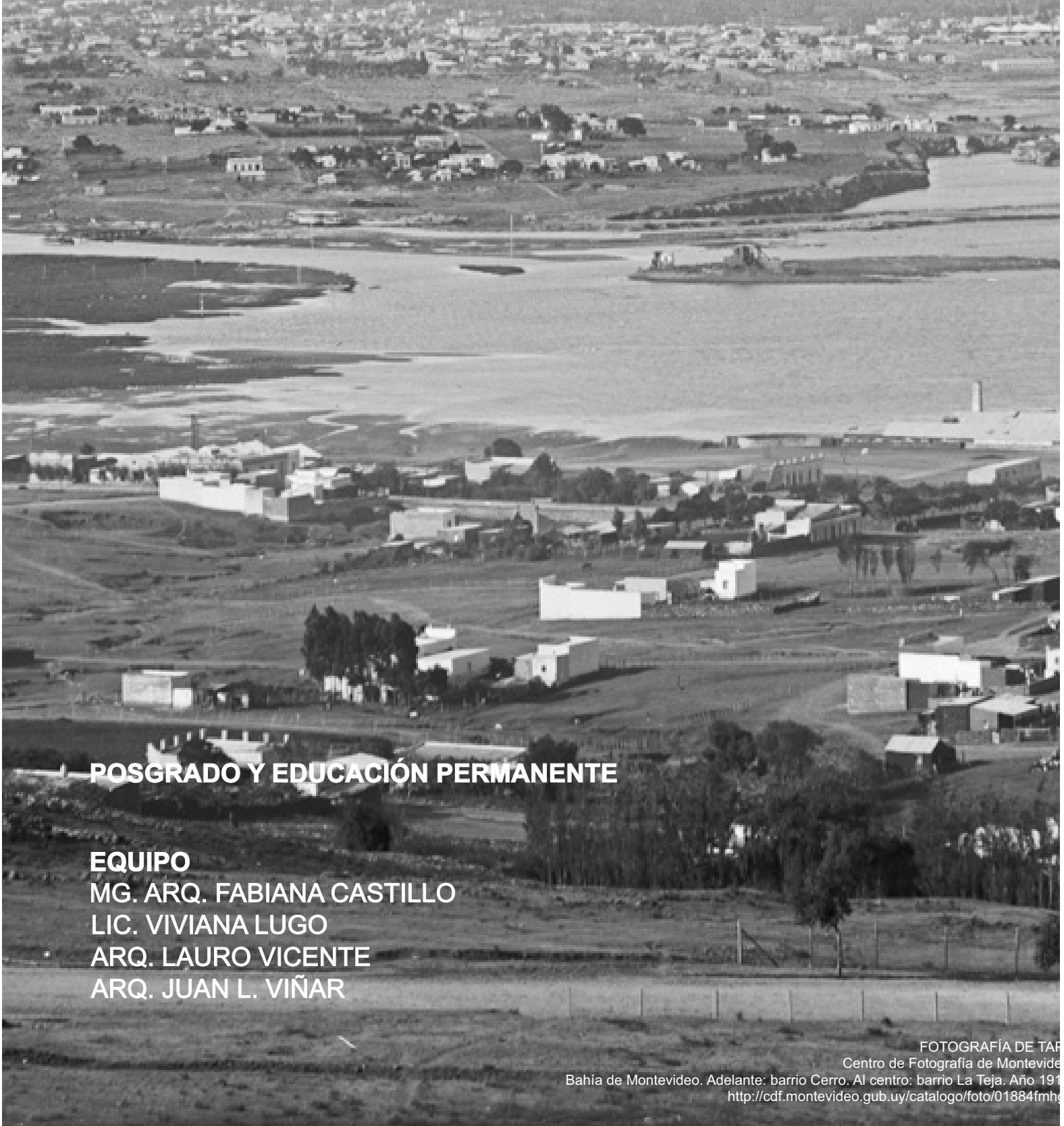




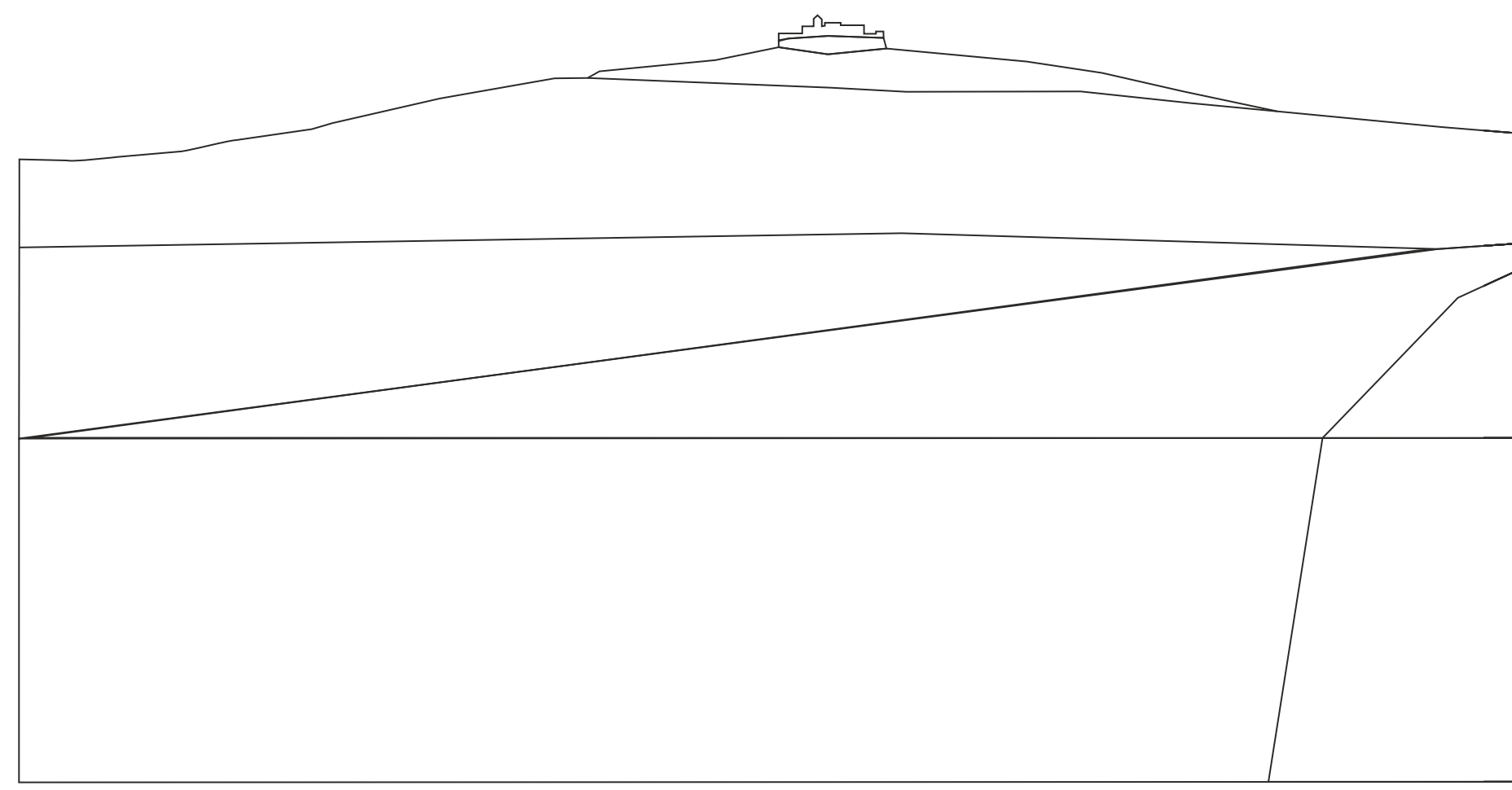

Croquis desde el eje hacia el foro
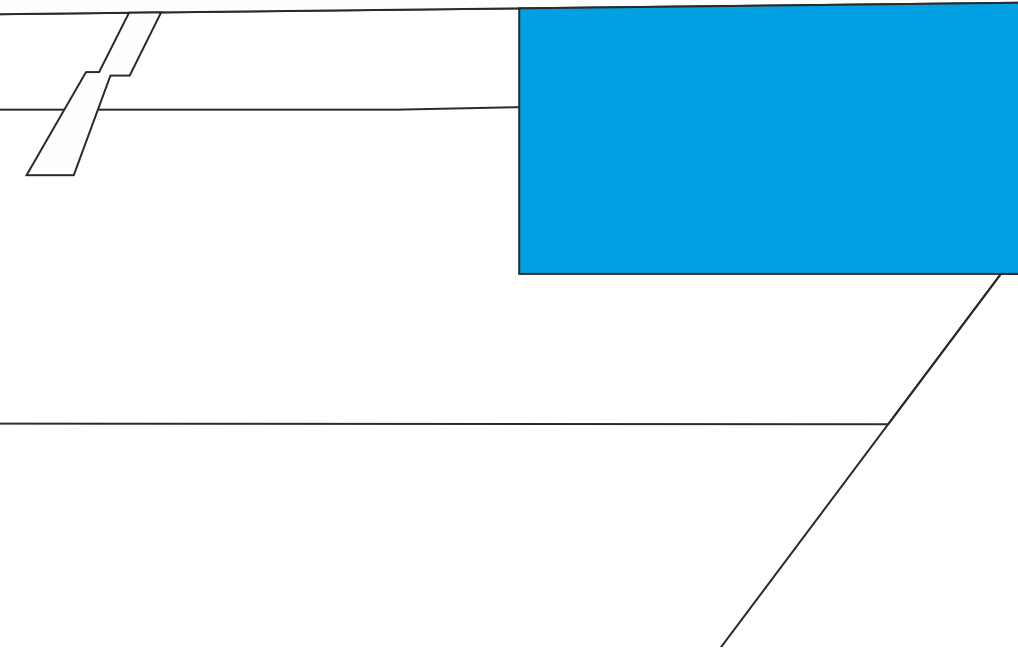

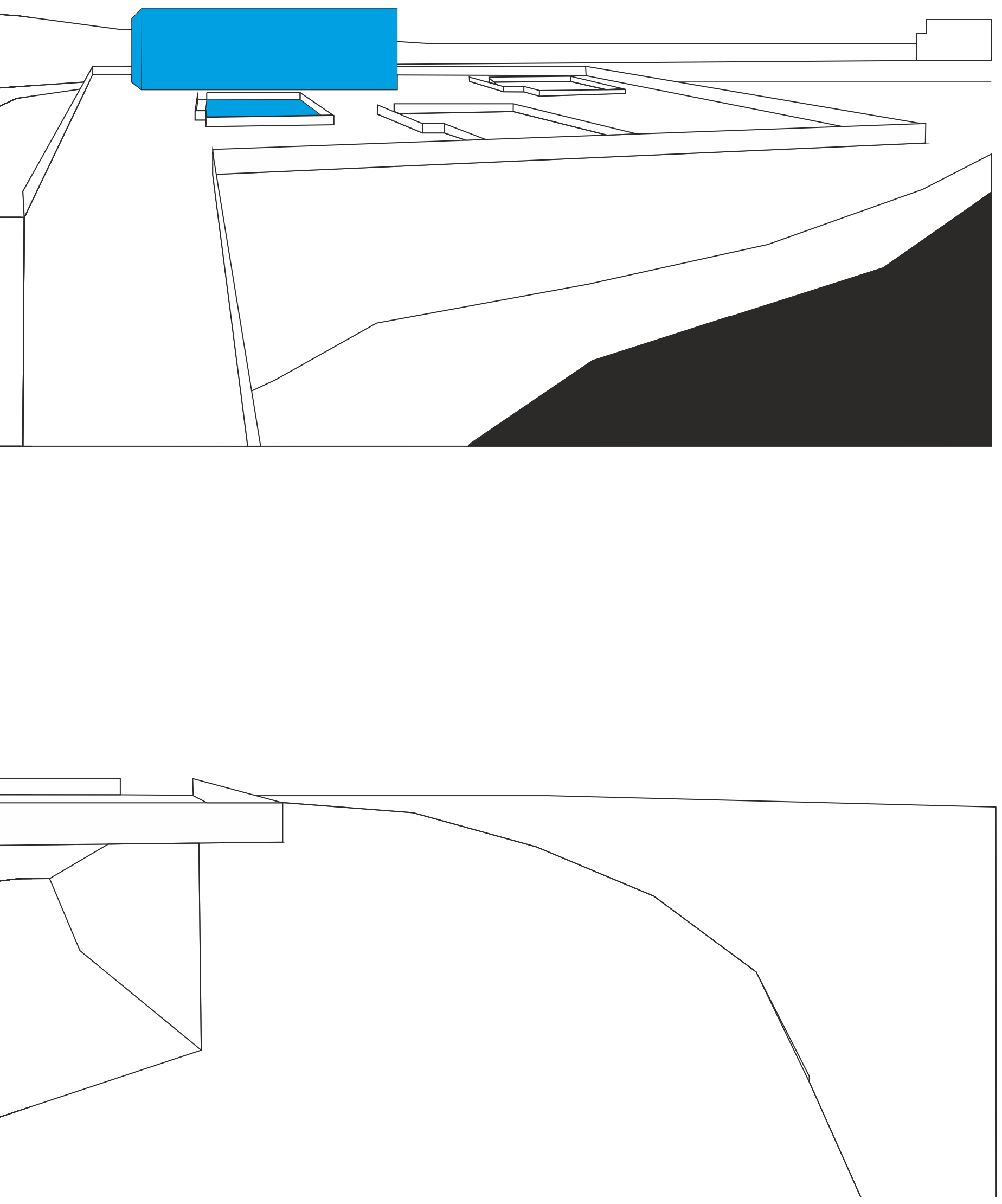


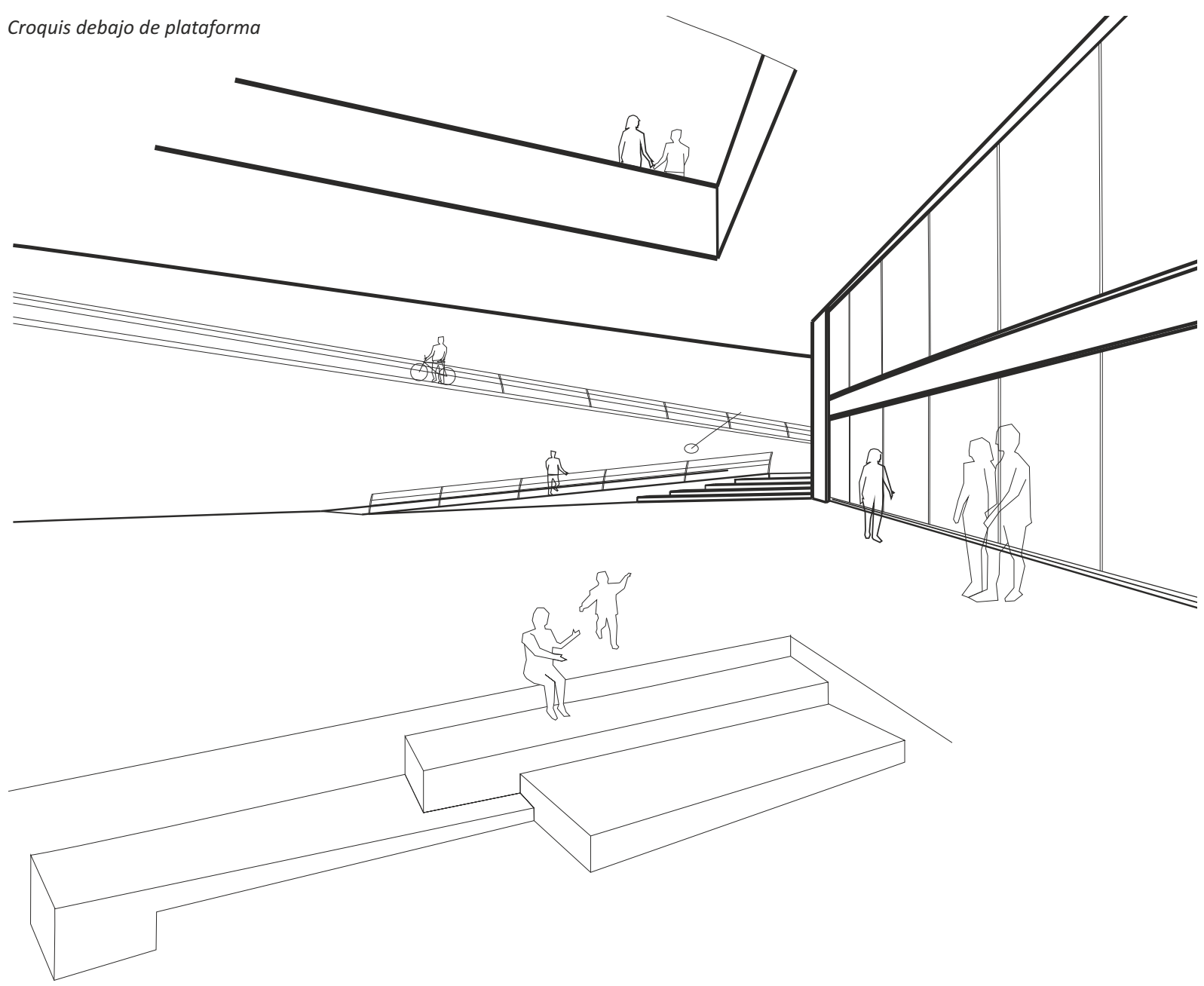

Croquis debajo de plataforma

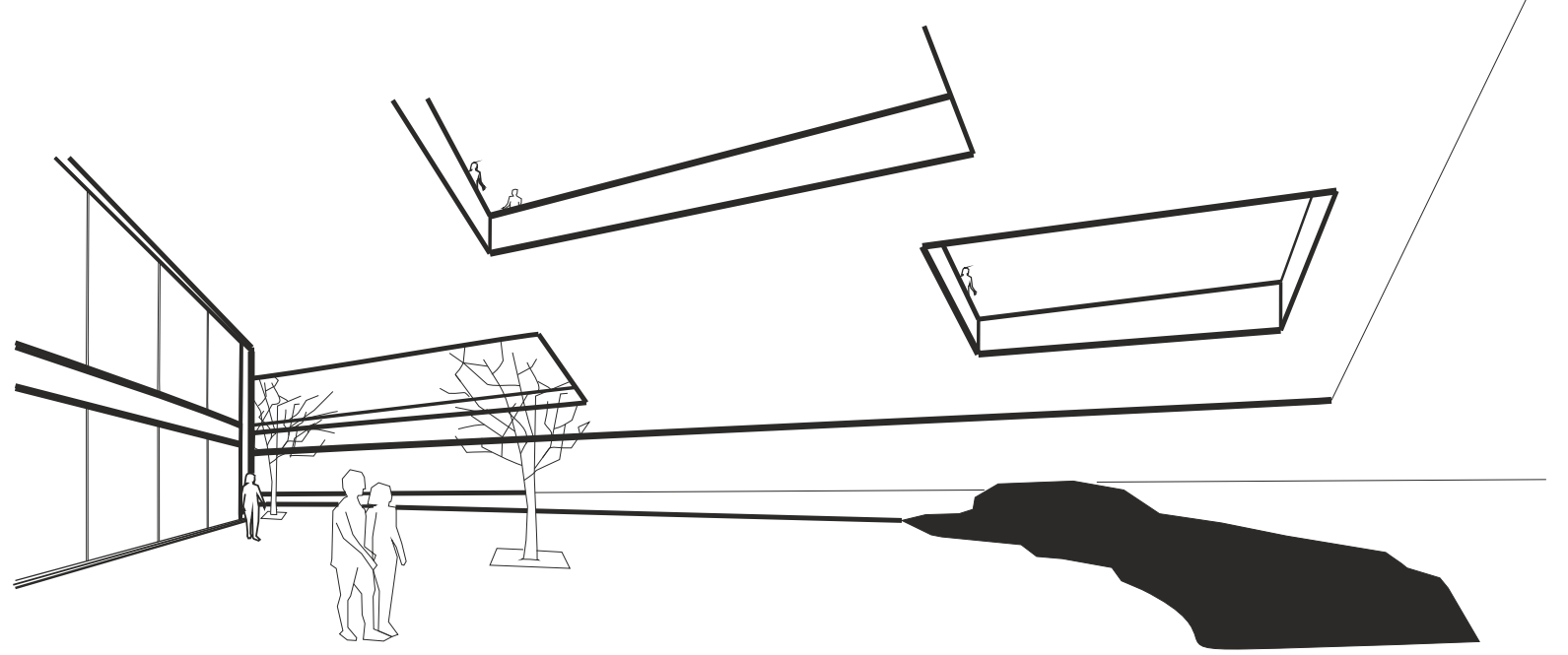




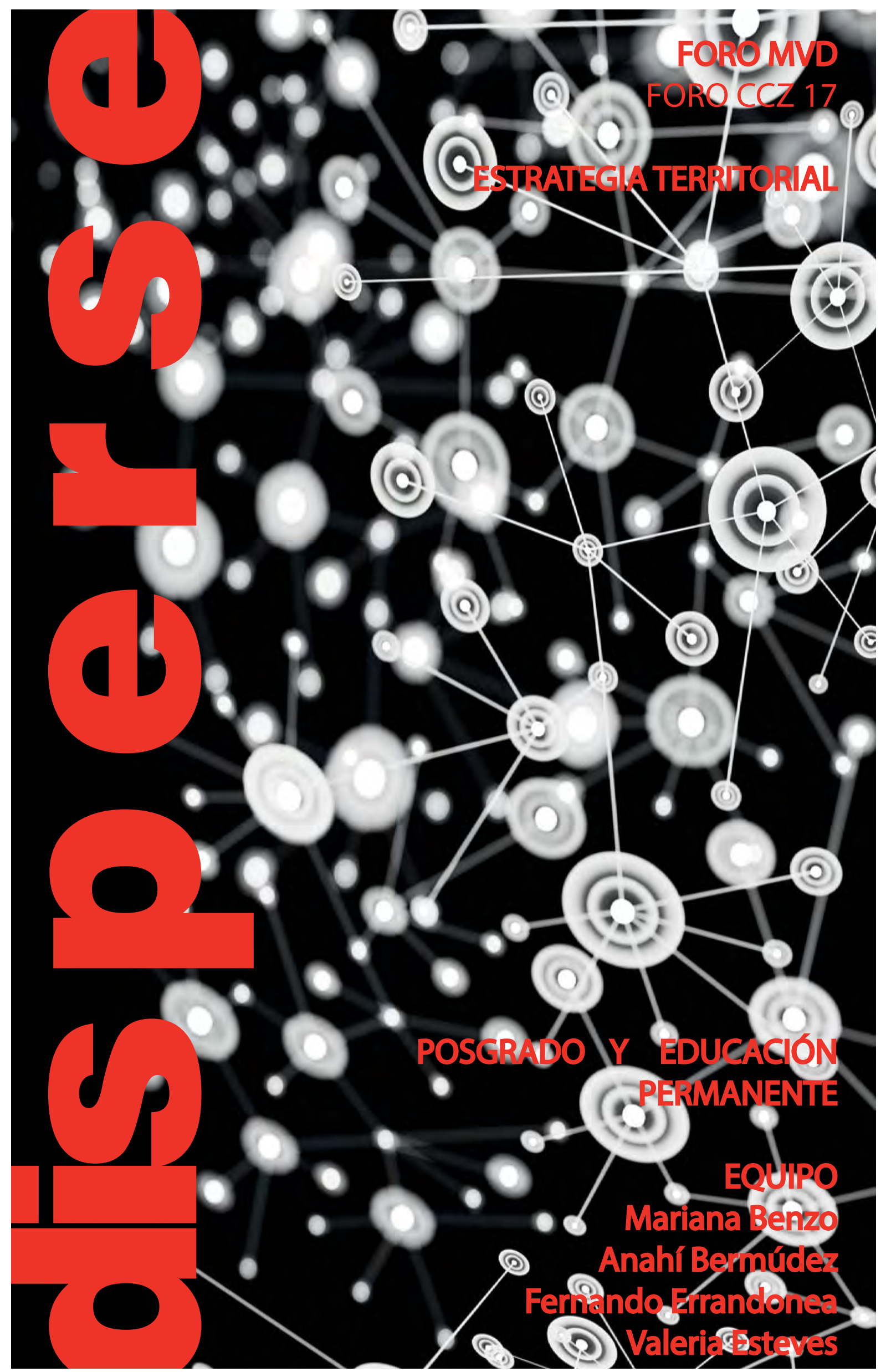




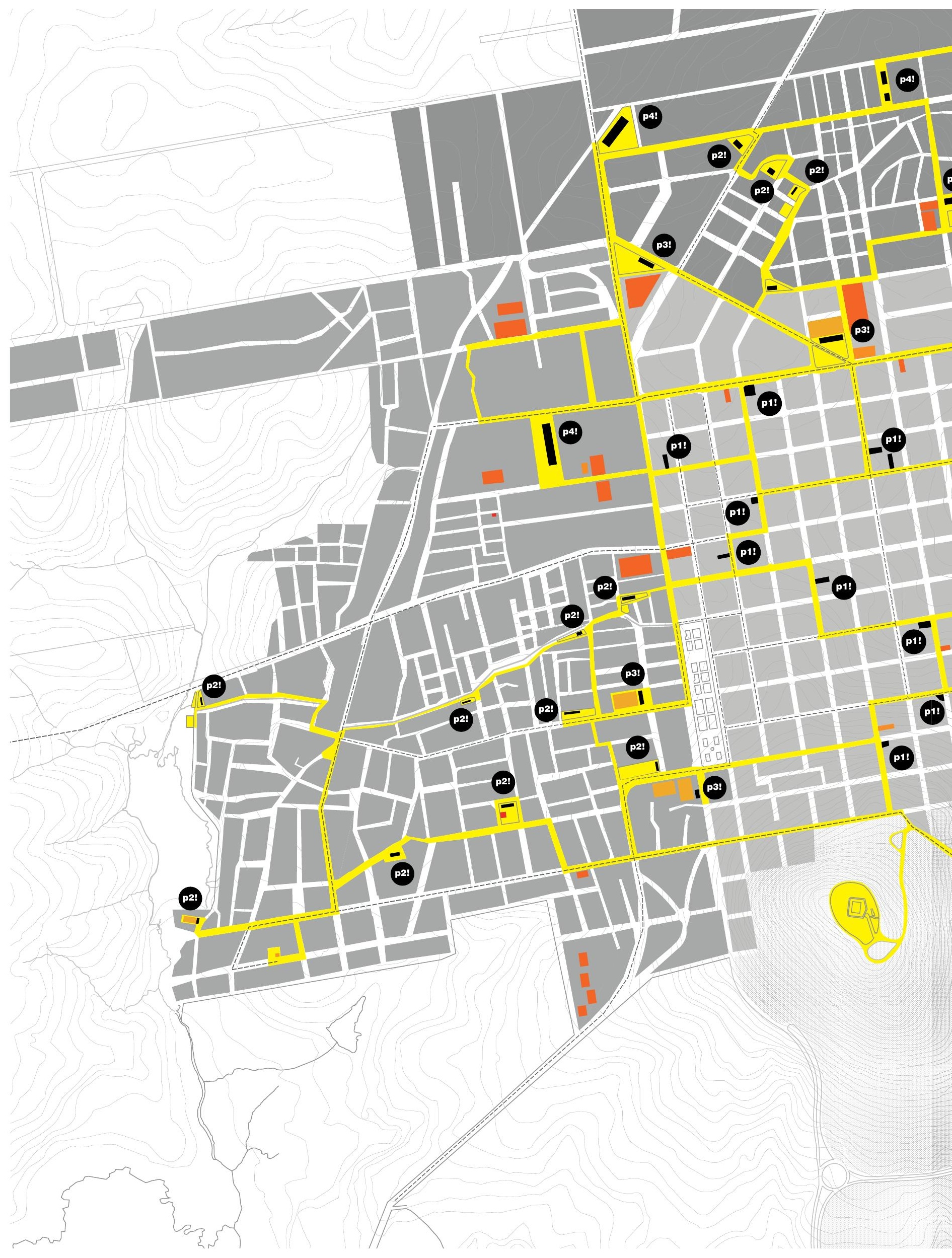



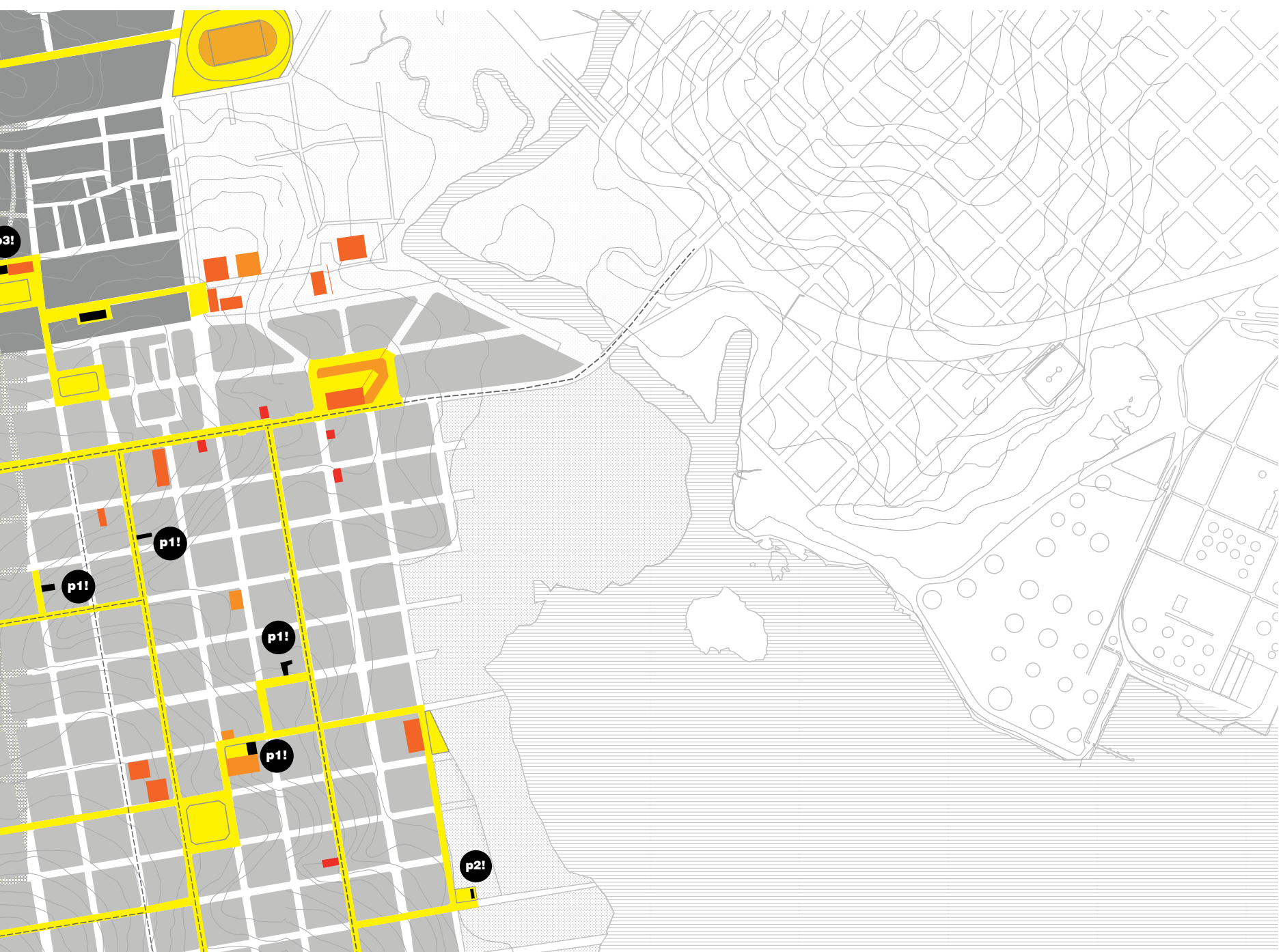

p11

(11)

-111)

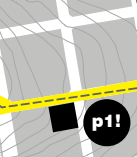

\section{0}

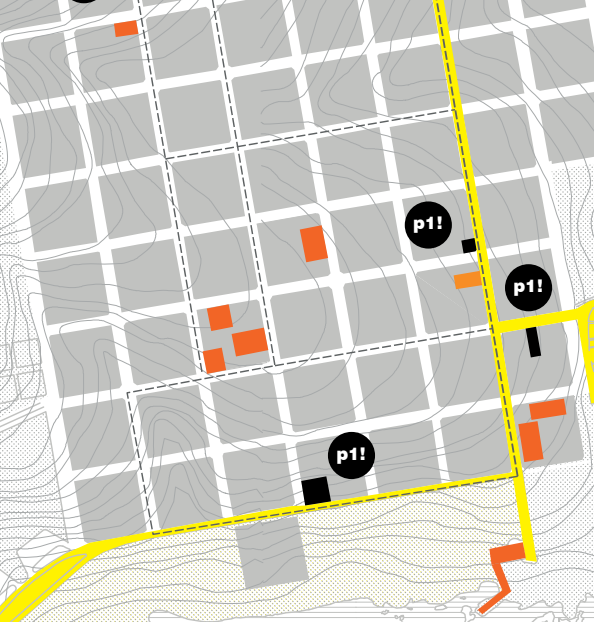

- trama histórica - cerro

- trama periférica - casabó-pajas blancas

- trama periférica - la paloma-tomkinson trama de valor paisajístico enclave estratégico

- servicios de salud

equipamiento educativo

- equipamiento cultural

- equipamiento deportivo

equipamiento de transporte público

... recorrido líneas de transporte

$\square$ espacio público existente red de espacios públicos a reactivar y/o intensificar

- posibles intervenciones en áreas de oportunidad 


\section{Concepto de FORO}

El foro se entiende como un ámbito del espacio público donde se intensifica su apropiación colectiva y la interacción social por el desarrollo de recursos materiales y espaciales que resultan en un acondicionamiento adecuado para el despliegue y coexistencia, en un continuo temporal, de un amplio abanico programático. Opera como referencia urbana para el entorno y la ciudad. Su desarrollo es una estrategia para activar el espacio público.

\section{Determinantes de la ESTRATEGIA}

Fragmentación territorial: En el Cerro se reconocen cuatro situaciones territoriales desarticuladas entre ellas que materializan un territorio fragmentado que surge de procesos de segmentación social y segregación territorial. El foro debe responder a estas diferentes situaciones favoreciendo la integración socio-territorial

- Trama periférica : áreas carentes de los recursos básicos de la ciudad.

- Trama histórica: trama consolidada con baja dinámica urbana y fuertes valores identitarios. El foro como posibilidad de activarla y revalorizarla.

- Valor paisajístico: áreas con cualidades paisajísticas subvaloradas u ocultas. El foro como oportunidad para su puesta en valor.

- Enclave estratégico: área junto a accesos al Cerro con diversidad de usos desarticulados, algunos de referencia urbana. Foro como posibilidad de caracterizar un área relevante para la integración del Cerro con la ciudad

Descaracterización del espacio público: En este contexto el espacio público no desarrolla su potencialidad de operar como estructurador e integrador del territorio. En general su materialización es anodina y se percibe como ámbito desprotegido

La fábrica, referencia en la memoria colectiva: la fábrica tuvo en el Cerro un rol relevante como contenedor de relaciones sociales en términos de relaciones de producción, de dependencia, de explotación, de clase.

\section{ESTRATEGIA}

Foro disperso: Se plantea conformar una red de espacios que operen como referencia urbana a diferentes escalas en forma complementaria.

Foro como facilitador de usos y actividades: Debe aportar la noción de protección en el espacio público y su acondicionamiento facilitar su apropiación con usos diversos durante las $24 \mathrm{hs}$ de los 365 días del año. El acondicionamiento básico que permite un cambio sustancial en el espacio público es el espacio "público techado", constituido por la Cubierta (sombra, impermeable, soporte de iluminación, carácter) y el Piso (con prestaciones diferenciales, que propone variaciones espaciales)

Foro como contenedor de relaciones de convivencia y diversidad: El foro se materializa como una nueva referencia espacial y edilicia como condensador social en términos de convivencia y diversidad. 


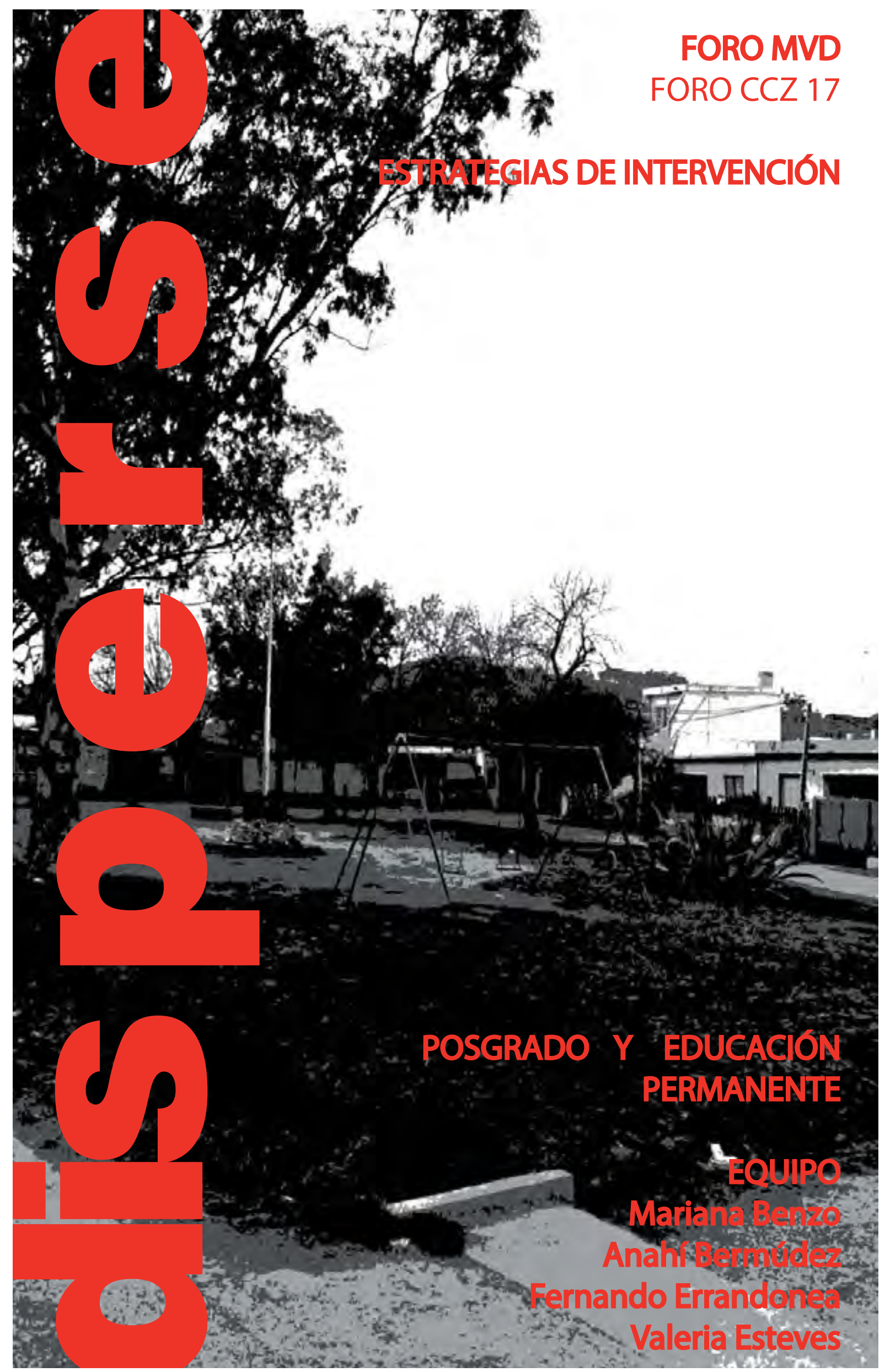



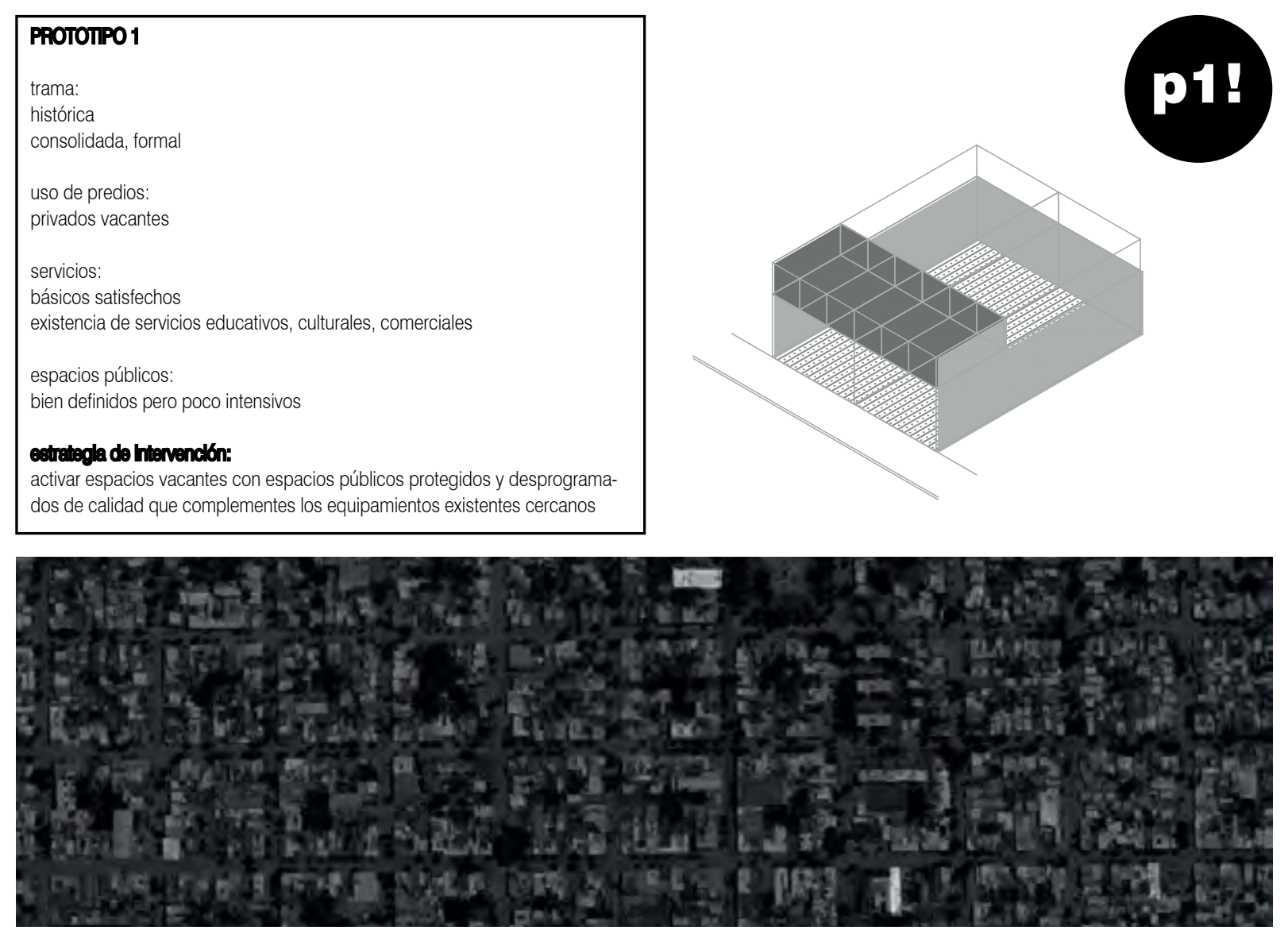

\section{PAOTOTPO2}

trama:

periférica, no consolidada, informal

ocupación total

uso de predios:

espacios residuales, vacíos urbanos

servicios:

falta de servicios básicos - saneamiento, pavimento

existencia de servicios educativos y de salud básicos

espacios públicos:

escaso, pobre, no calificado

\section{ostededa de hitervenclón:}

activación de espacios vacantes geerando espacios públicos de calidad
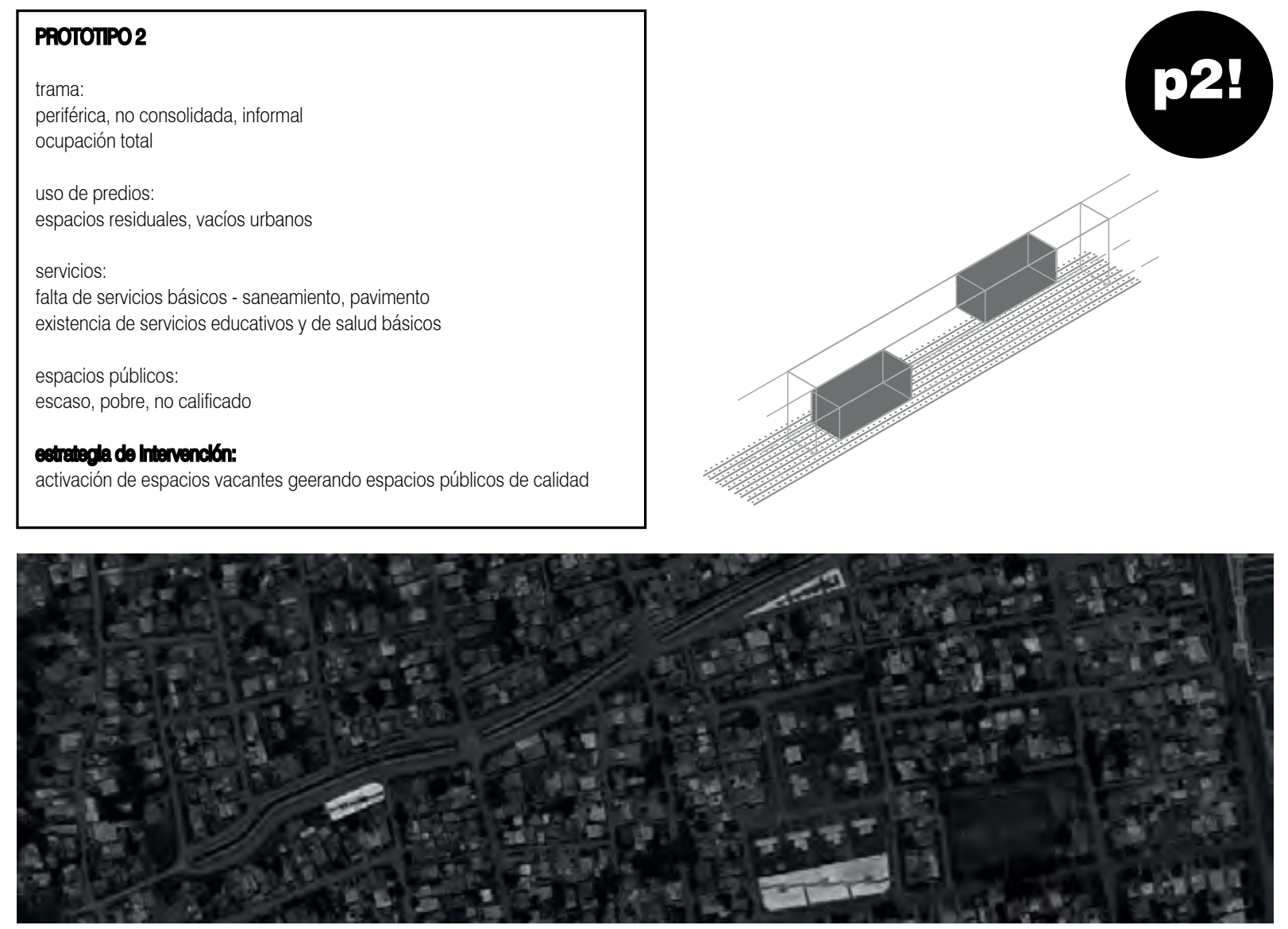


\section{PROTOTIPO3}

trama:

periférica, poco consolidada, formal

uso de predios:

públicos consecionados a privados de uso controlado

de mediana calidad

servicios:

básicos satisfechos

existencia de algunos servicios educativos, culturales, comerciales

espacios públicos:

escasos y poco intensivos, consedidos a privados

\section{estrabeda de htenvenclón:}

activar espacios vacantes complementando equipamientos existentes

potenciar uso de espacios públicos consedidos
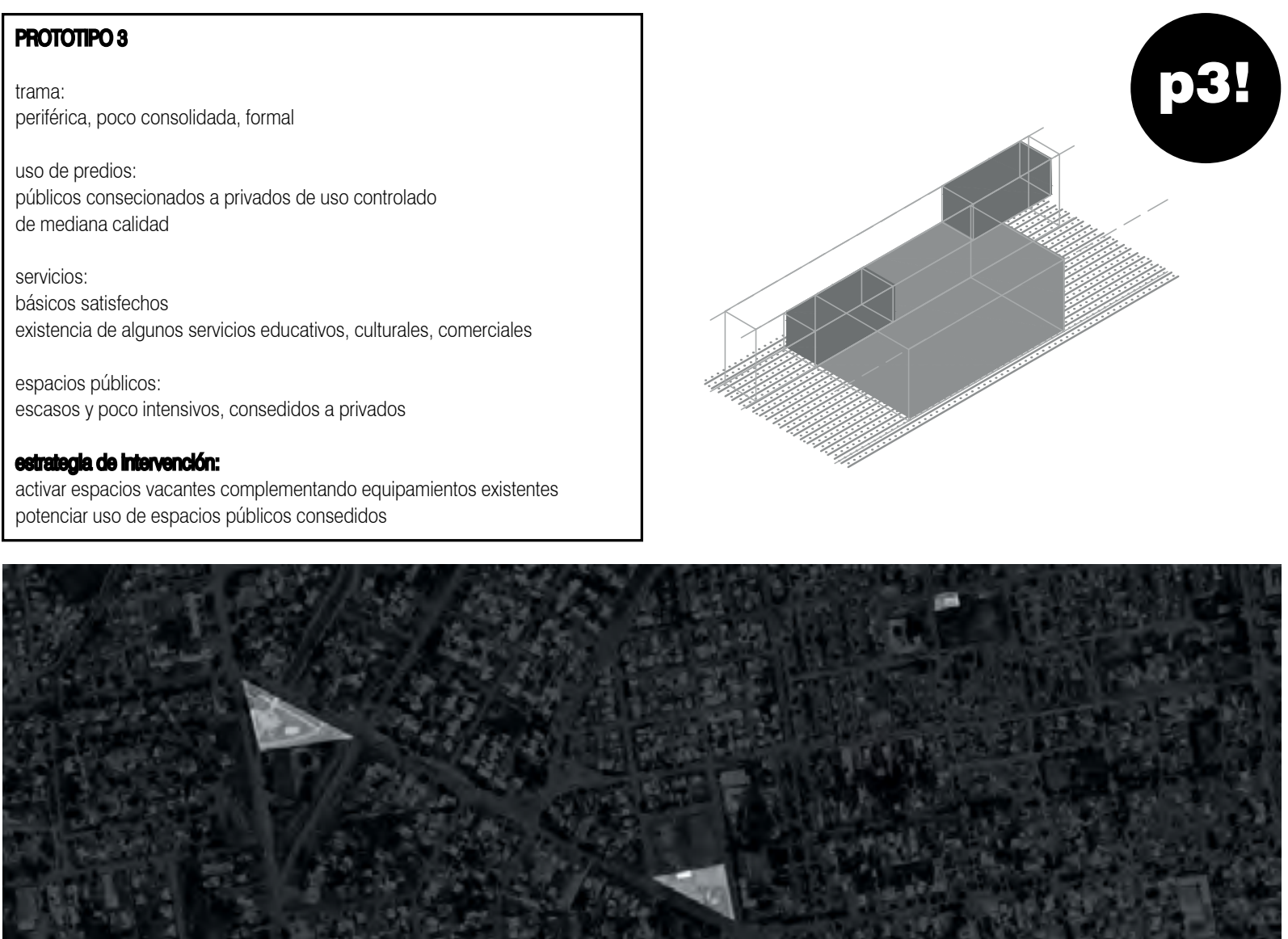

\section{PROTOTIPO 4 \\ trama \\ periférica, mixtura formal-no forma \\ muy baja densidad, manzanas de grandes dimensiones \\ falta de estructuradores urbanos \\ uso de predios: \\ predios privados vacantes/sub-aprovechados \\ servicios: \\ existencia de servicios educativos y de salud básicos escasos \\ espacios públicos: \\ inexistentes}

\section{estrebeda do htervenclion:}

activar espcios vacantes generando espacios públicos calificados y de grandes superficies que se conformen como estructuradores urbanos

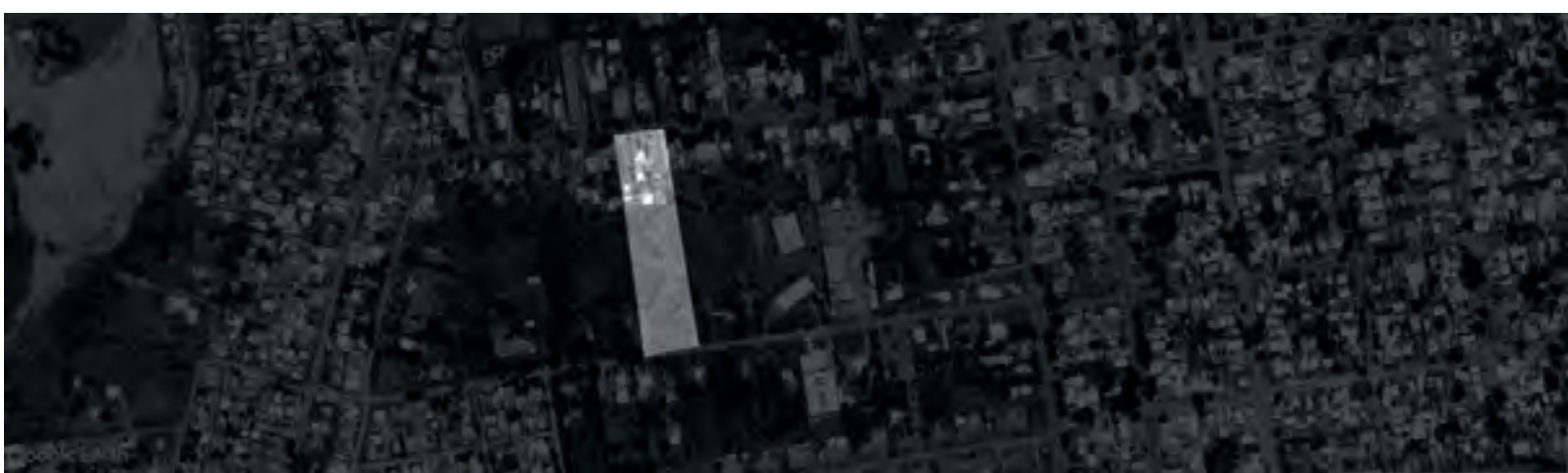




\section{Desfuncionalización programática}

El foro se plantea como un dispositivo espacial que no responde a una función concreta sino que opera como soporte facilitador dt usos y programas diversos, sincrónica y diacrónicamente:

Recreativos: Entendidos la recreación y el deporte como actividades promotoras de valores, calidad de vida y convivencia

Educativo-Culturales: Promoviendo el acceso de los ciudadanos a una amplia gama de ofertas culturales y educativas

Productivos: Facilitando el desarrollo formal de estrategias laborales individuales y colectivas diversas.

Cívicas: Acercando servicios públicos a la comunidad, generando una referencia edilicia y espacial integradora de diferentes política؛ sociales desplegadas en el territorio.

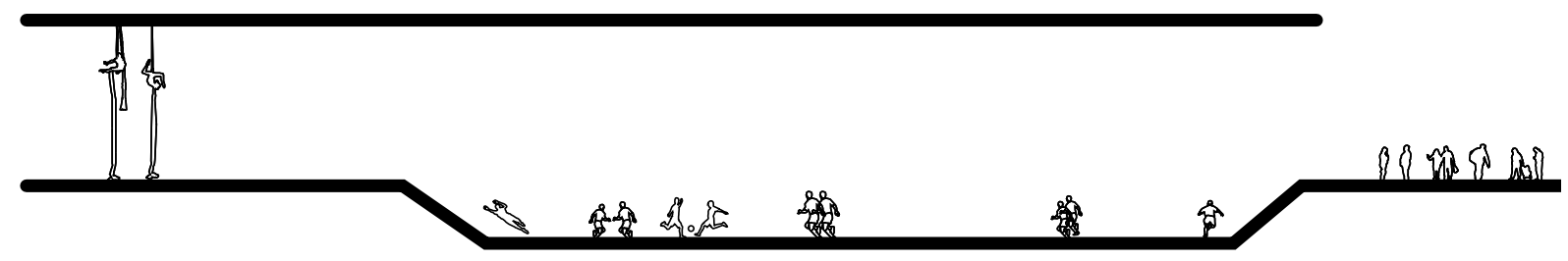

\section{Gostion}

El foro requiere una gestión interinstitucional y la participación ciudadana

El foro opera como catalizador de la articulación interinstitucional y la participación ciudadana

\section{Componentes espaciales}

Para el despliegue del foro se recurre básicamente a la articulación de tres componentes espaciales, caracterizados por su sección definida por un rango de ancho y altura y un rango de largo. Cada componente implica una capacidad diferente para soportar un abanico de usos y programas y el desarrollo de dispositivos de acondicionamiento diferentes.

Cada componente define una crujia, dentro de la cual se inserta, de largo y altura variable con implicancias estructurales particulares; La articulación entre estas crujías define un conjunto acotado de estrategias proyectuales que permiten una amplia gama de respuestas compositivas según las características del contexto urbano donde se implantan.

\section{Prototipos}

A efectos de desarrollar la estrategia de intervención, acotamos nuestro abordaje a la "trama periférica" y "la trama histórica". Identificamos situaciones urbanas de oportunidad para desarrollar el foro -definidas por la situación dominial del suelo, el grado de consolidación de la trama urbana, las características del espacio público existente, los usos presentes, entre otros aspectos -, para las cuales desarrollamos modos de actuación particulares.
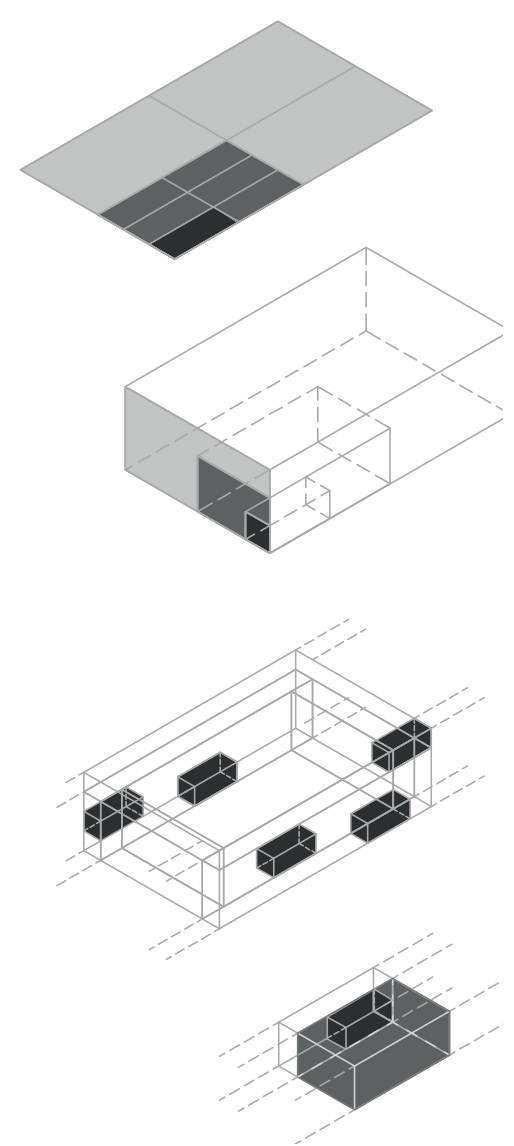


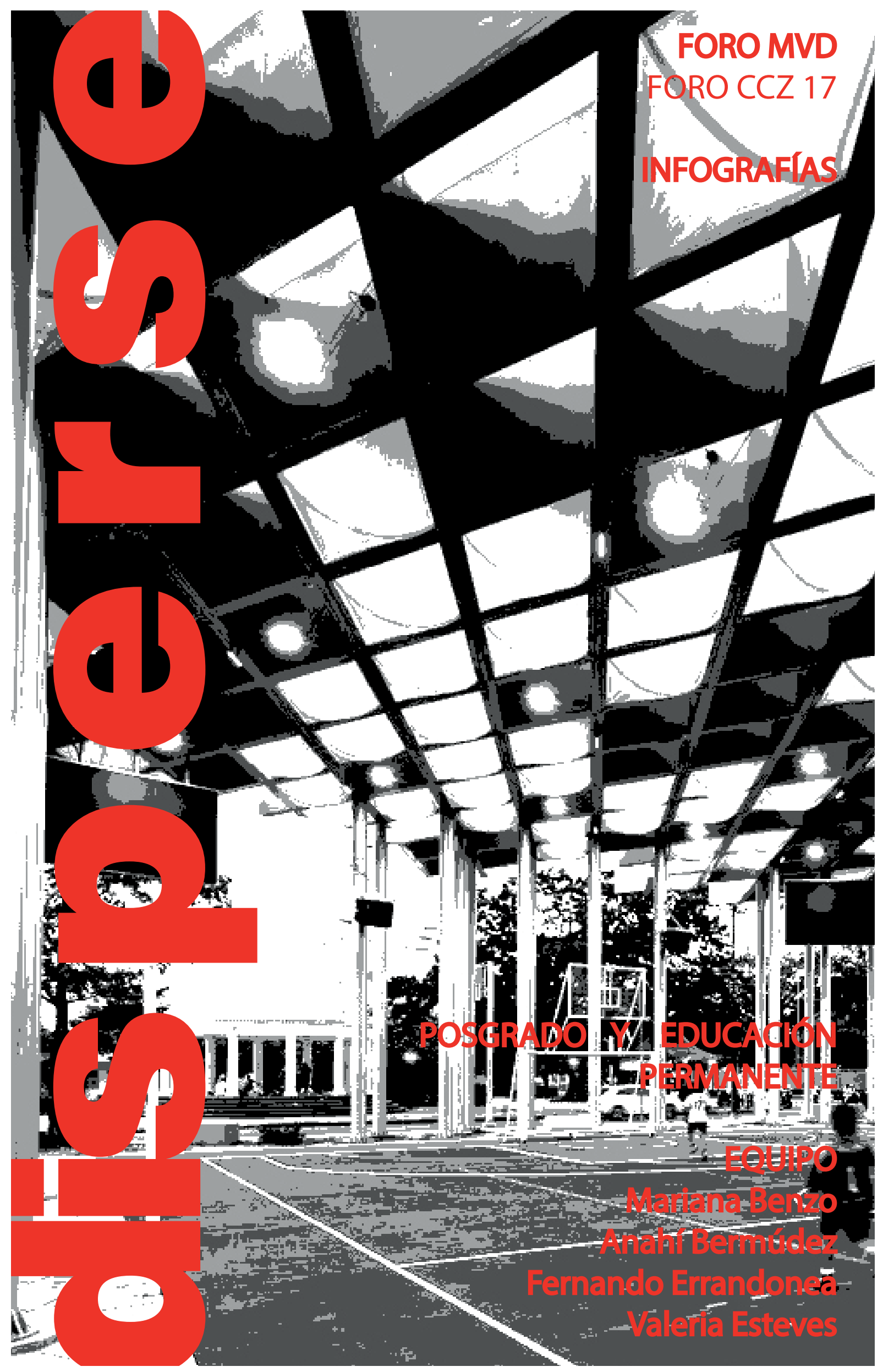



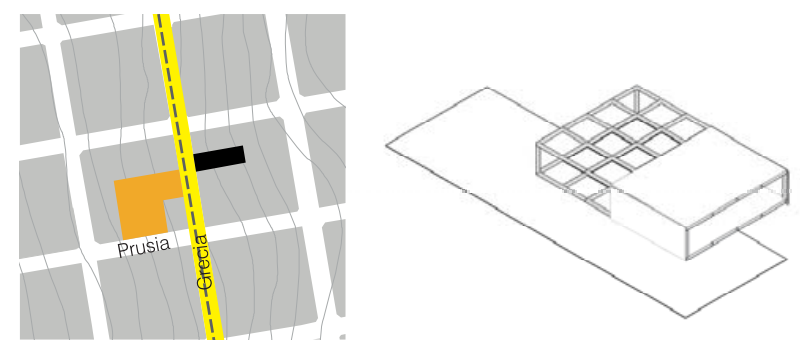

p1!
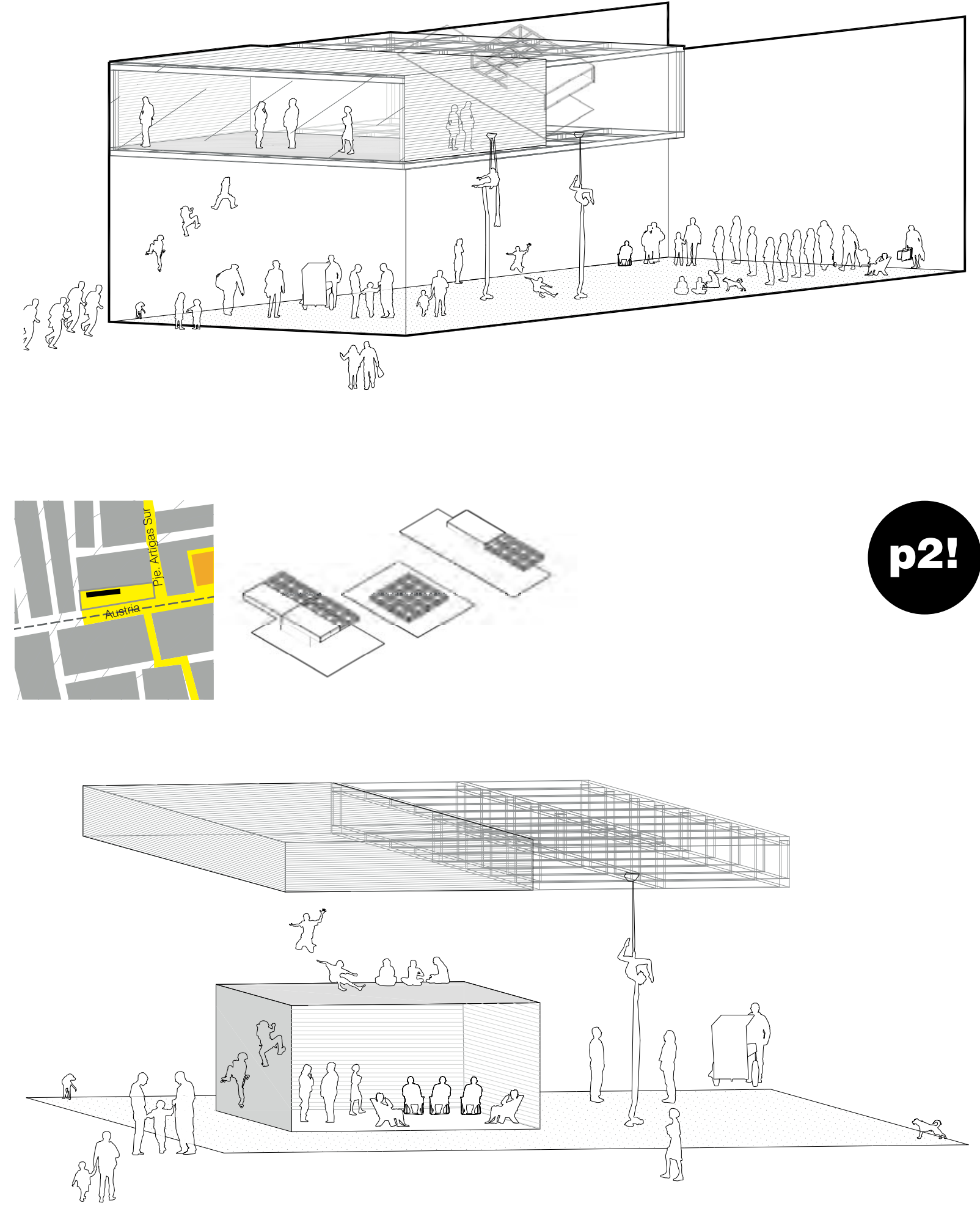

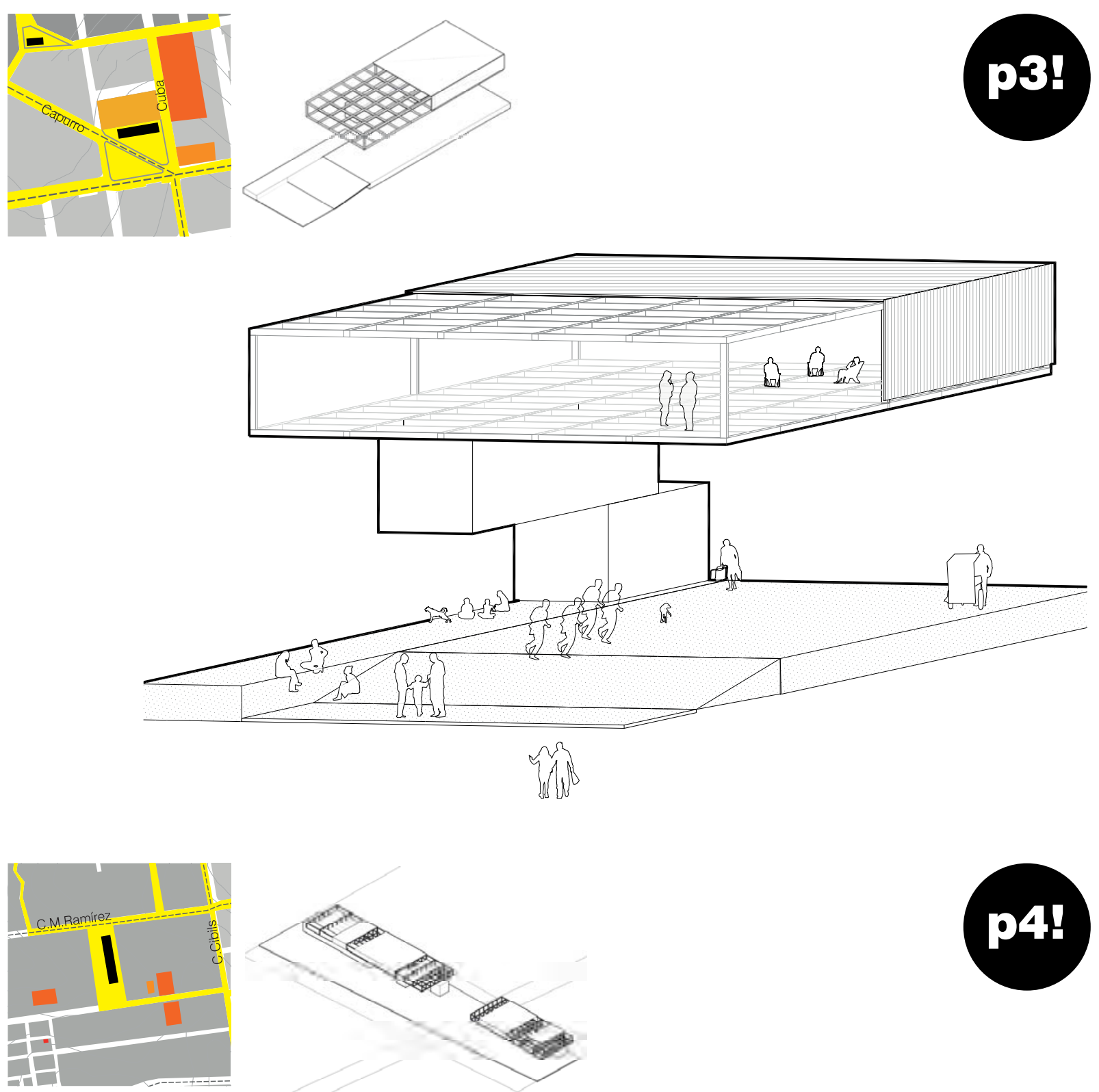

p4!

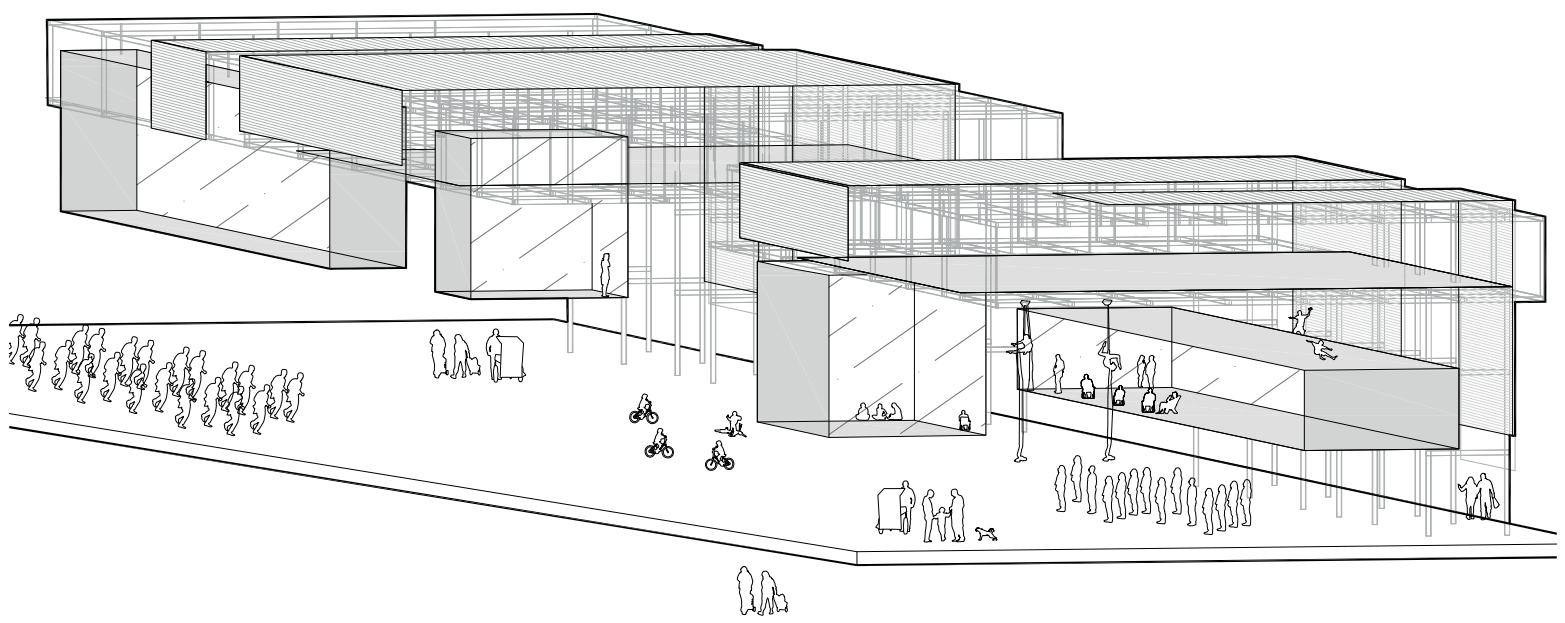




\section{Componentes materiales}

Cubierta: La cubierta define en el espacio público un recinto de protección y acondicionamiento destacado -sombra, protección de lluvias, soporte de instalaciones-. Resulta un elemento que le otorga carácter al espacio y opera como referencia que otorga identidad al sistema. Puede alternar en su modulación sectores impermeables y permeables, opacos y trasparentes.

Envolvente vertical: La envolvente vertical refuerza la noción de recinto e incorpora nuevas posibilidades de acondicionamiento. Puede materializarse como prolongación de la cubierta. Se la propone como celosía que permite el cierre y apertura de la espacialidad interior respondiendo a diferentes tensiones. Permite una gran permeabilidad espacial a nivel de planta baja permitiendo la continuidad del espacio público.

Estructura: La resolución del sistema estructural define en gran medida las características y posibilidades del sistema, haciendo viable y conformando las crujías y espacialidades consideradas. Pone en relación el conjunto de los componentes materiales y espaciales del sistema. Le confiere carácter al artefacto resultante.

Piso: Su materialización, las variaciones de niveles y la conformación de topografías incorporan prestaciones diferenciales y proponen variaciones espaciales que alientan nuevos usos. El piso genérico del foro es aquel que por su terminación superficial permite deslizar rodamientos pequeños de patín o skate. La incorporación de sectores que amortigüen impactos resulta un diferencial relevante.

Recintos cerrados: Se incorporan para responder a la necesidad de acondicionamientos más sofisticados, mayor privacidad y resguardo. En general se integran en la lógica de las diferentes crujías pero pueden jugar con mayor libertad dentro de espacialidades más amplias. La resolución de la envolventede estos recintos incorpora singulardades o establece vínculos con otros artefactos del sistema.

Dispositivos de circulación: Galerías, rampas, y escaleras se integran generando recorridos que conforman el espacio, enriquecen su percepción y multiplican las posibilidades de uso. Se integran dentro de las crujías consideradas o escapan de estas como singularidades.
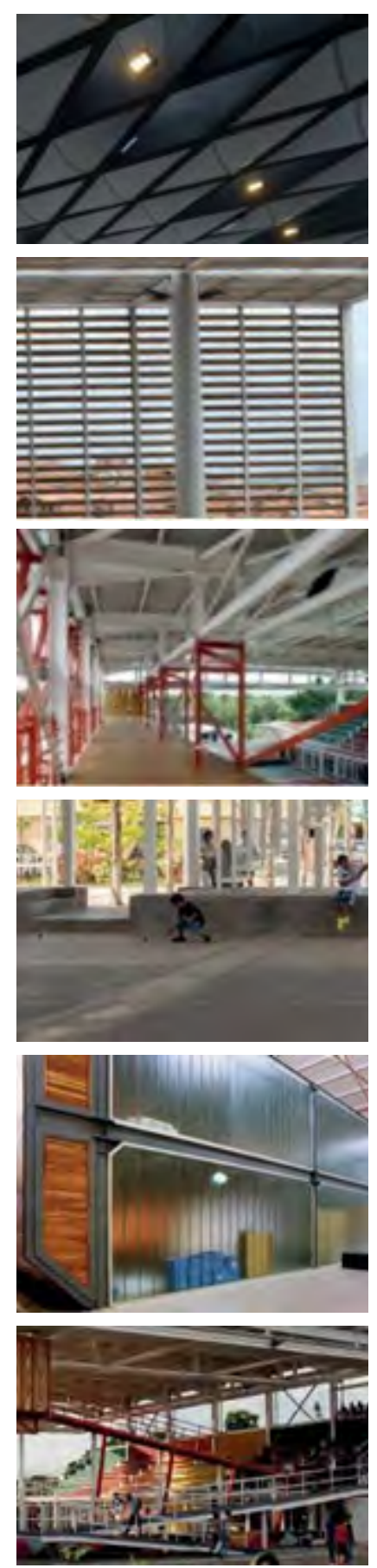

\section{Producción del sistema}

El foro se propone como sistema de componentes espaciales y materiales reproducible en red a diferentes escalas

Producción de componentes: se propone un sistema acotado de componentes materiales de fácil reproducción cuyos requeri mientos puedan ser asumidos con las capacidades industriales y constructivas del país, y en particular con una participaciór importante de las capacidades locales, donde el PTI podría cumplir un rol relevante

Reproducción del foro: Este sistema se plantea con la capacidad de extenderse al resto de la ciudad, colonizando el espacic público con una red de dispositivos espaciales que intensifican su apropiación y catalizan la construcción de un sistema dt espacios públicos. 
FORO MVD

FORO CCZ 17

\section{PIER \\ Habitar la Bahía}

POSGRADO Y EDUCACIÓN PERMANENTE

MARIA IMBERT

PABLO MARTÍNEZ

FEDERICO RODRIGUEZ

AGUSTINA SÁNCHEZ

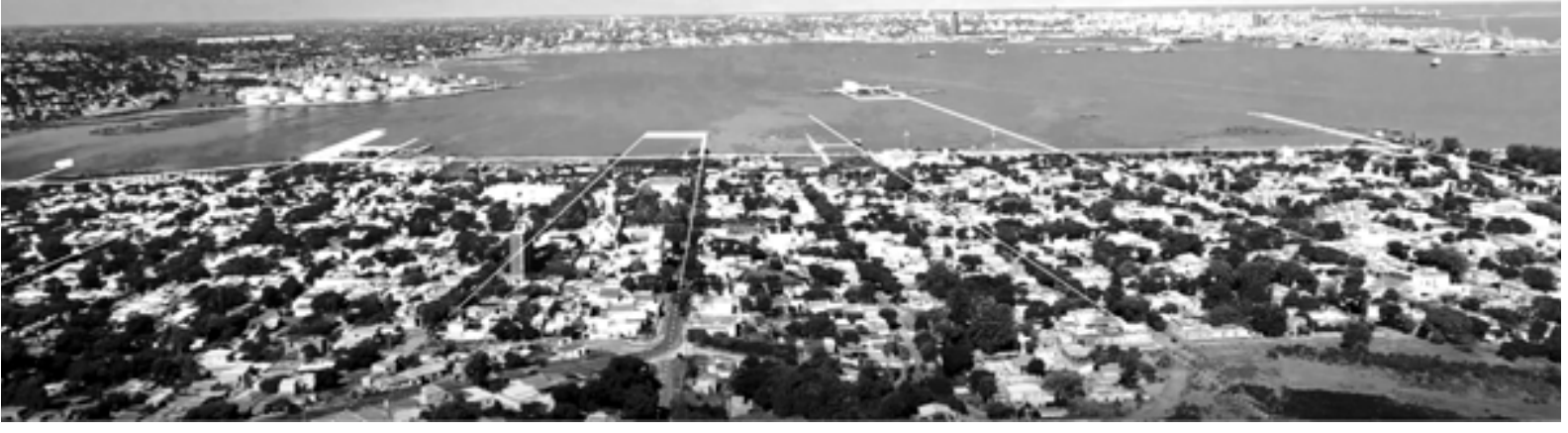




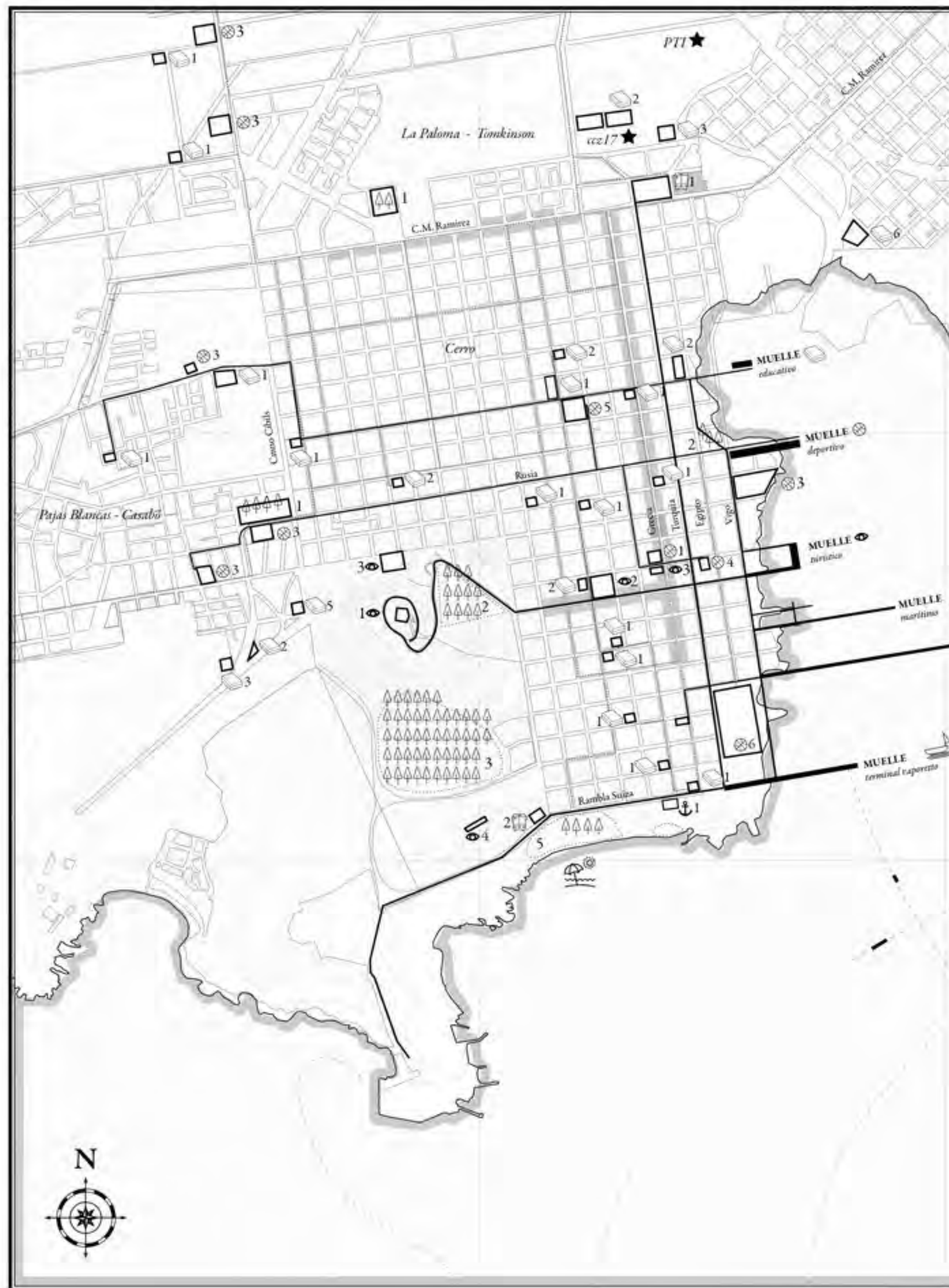


Desde una perspectiva de Derecho a la Ciudad y potenciando la generación de estrategias que densifiquen la ciudad consolidada en zonas intermedias del CCZ 17, territorio de estudio, se selecciona la zona sobre la bahía de Montevideo como escenario de diseño del Foro MVD, en base a las lógicas de no densificar a través de espacios públicos zonas consideradas no consolidadas en la actualidad.

El borde de la bahía actualmente se caracteriza por ser difuso en su lugar de límite barrial al igual que de borde costero, por tanto el propósito está en trasladar la relación histórica y paisajística a una propuesta concreta que potencie y revitalice la zona; generando nuevos espacios de convivencia y relacionamiento directamente asociados a la potencialidad de la bahía.

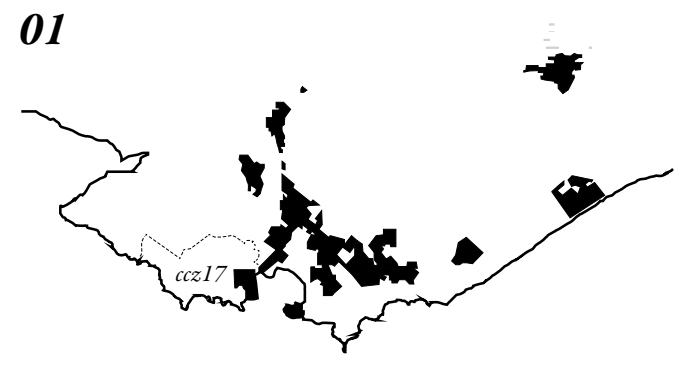

CCZ/CERRO / BAHÍA

El Barrio Cerro, la zona intermedia del CCZ, se encuentra estrechamente vinculado con la bahía de Montevideo. El vínculo con la bahía se podría considerar como una relación visual y perceptiva, careciendo de apropiación actual.

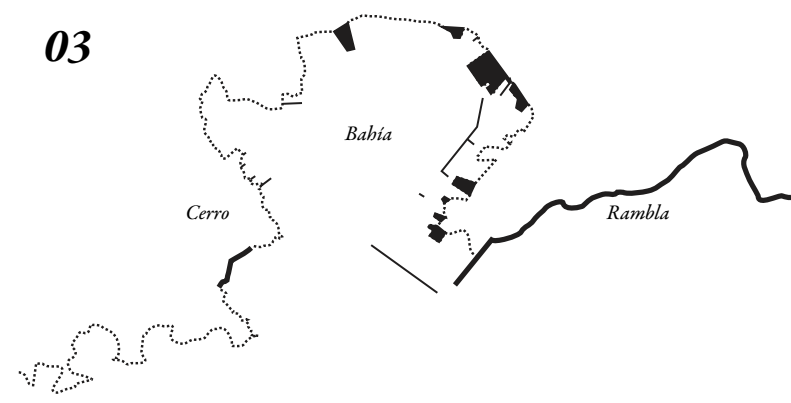

BAHÍA / PAISAJE

La bahía se encuentra marcada estrechamente por el puerto y el cerro de Montevideo, conformando un paisaje industrial con énfasis en lo saladeril y frigorífico; respondiendo al imaginario colectivo de la ciudad.

Ella cuenta con una lógica de conexión transversal con el agua y no lineal, teniendo un paisaje propio.

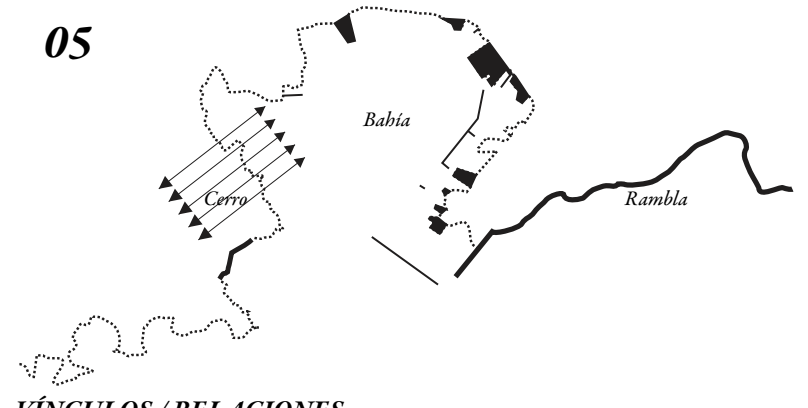

\section{VÍNCULOS / RELACIONES}

El Plan Pier continua con la trama barrio, con el concepto ciudad a través de sus calles y espacios públicos por excelencia, tanto que se introduzcen en el agua y se transforman en muelles. De esta forma se genera una lógica de conexión transversal con la bahía y la ciudad consolidada actual.
Se localizan varios puntos de referencia e interés, tanto a nivel barrial como metropolitano. Éstos fueron agrupados en las categorías: Educativo, Deportivo, Marítimo, Turismo, Cultural y Transporte; los cuales habilitaron al diseño de recorridos que agrupan los principales edificios y programas para cada una de las temáticas derivando en un Plan Pier.

Los escenarios y foros que conforman este plan son escogidos teniendo como base las principales características y proyecciones del barrio, entre ellas la densificación poblacional (aproximadamente 40.000 personas - 50\% de la pob. del CCZ 17), la necesidad de consolidación de la zona densificada y la proyección de la conformación de la rambla de Montevideo en la zona.

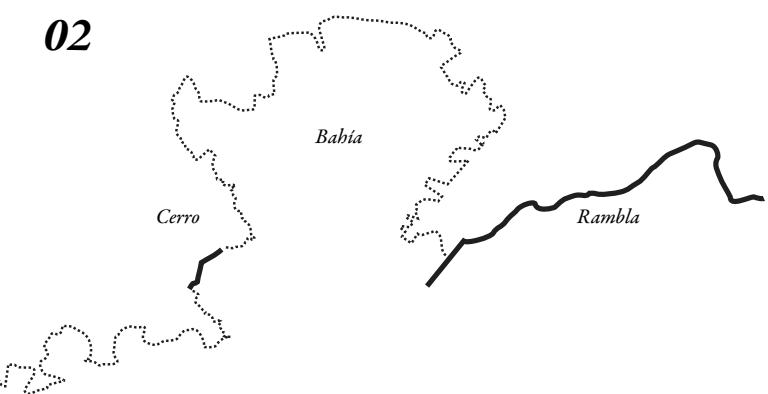

\section{BAHÍA DE MONTEVIDEO}

Uno de los espacios públicos de excelencia tanto a nivel de arquitectura, como paisajístico o social en nuestra ciudad es la rambla. Considerándose como foro lineal presente en la identidad de todos los montevideanos y como emblema del turismo. La misma se encuentra interrumpida por la bahía lo que amerita a ser continuada en la zona del Cerro.

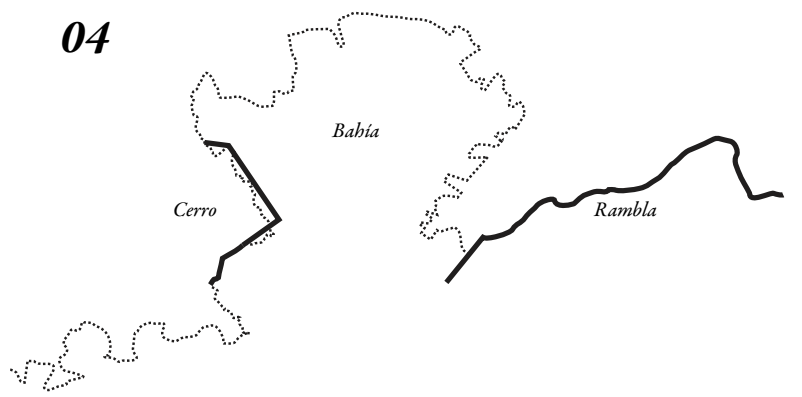

\section{PLAN/RAMBLACERRO}

La Intendencia de Montevideo diseña un proyecto para la rambla del Cerro que emula una situación conocida, pero al mismo tiempo aleja, o continúa alejando el barrio residencial de la bahía.

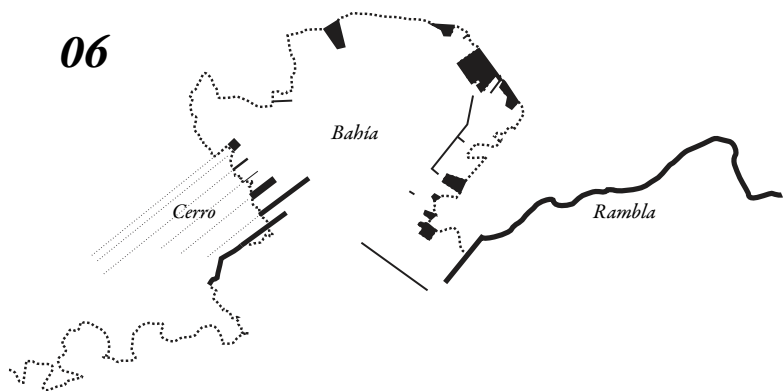

FORO! / Plan Pier Cerro

El Plan Pier en su globalidad posibilita proponer alternativas que otorguan espacios de valor cívico social y que atienden las condiciones propias del barrio. 
FORO MVD

FORO CCZ 17

\section{PIER \\ Habitar la Bahía}

POSGRADO Y EDUCACIÓN PERMANENTE

MARIA IMBERT

PABLO MARTÍNEZ

FEDERICO RODRIGUEZ

AGUSTINA SÁNCHEZ

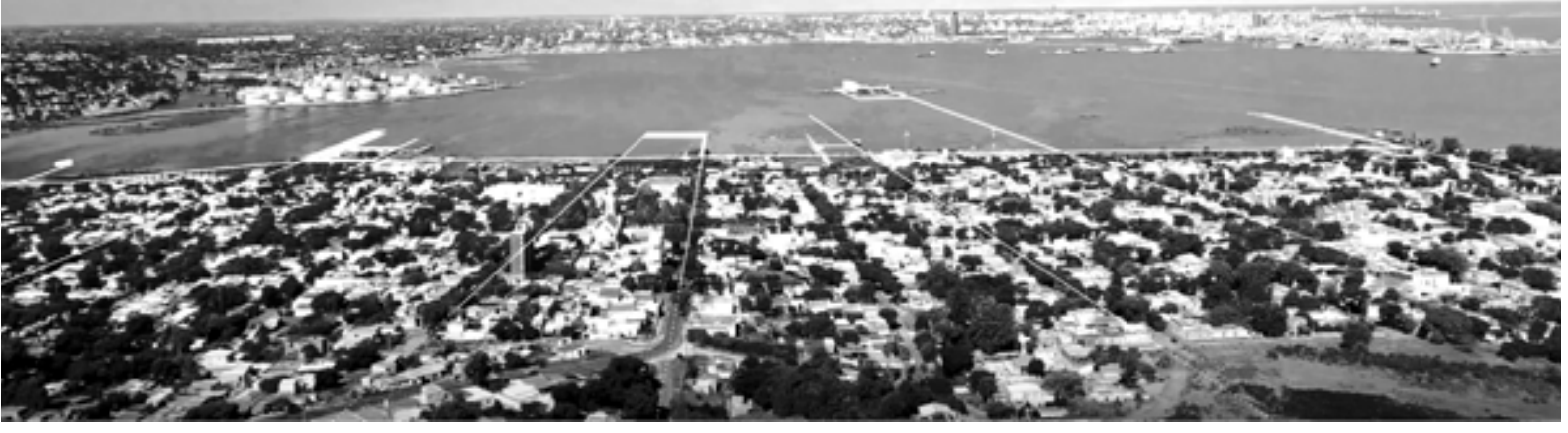


$0 I$

Plan Bahía Cerro

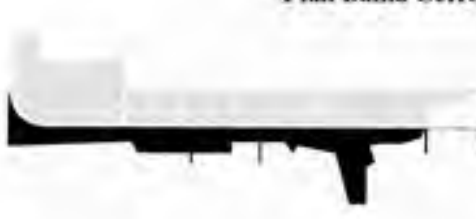

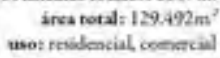

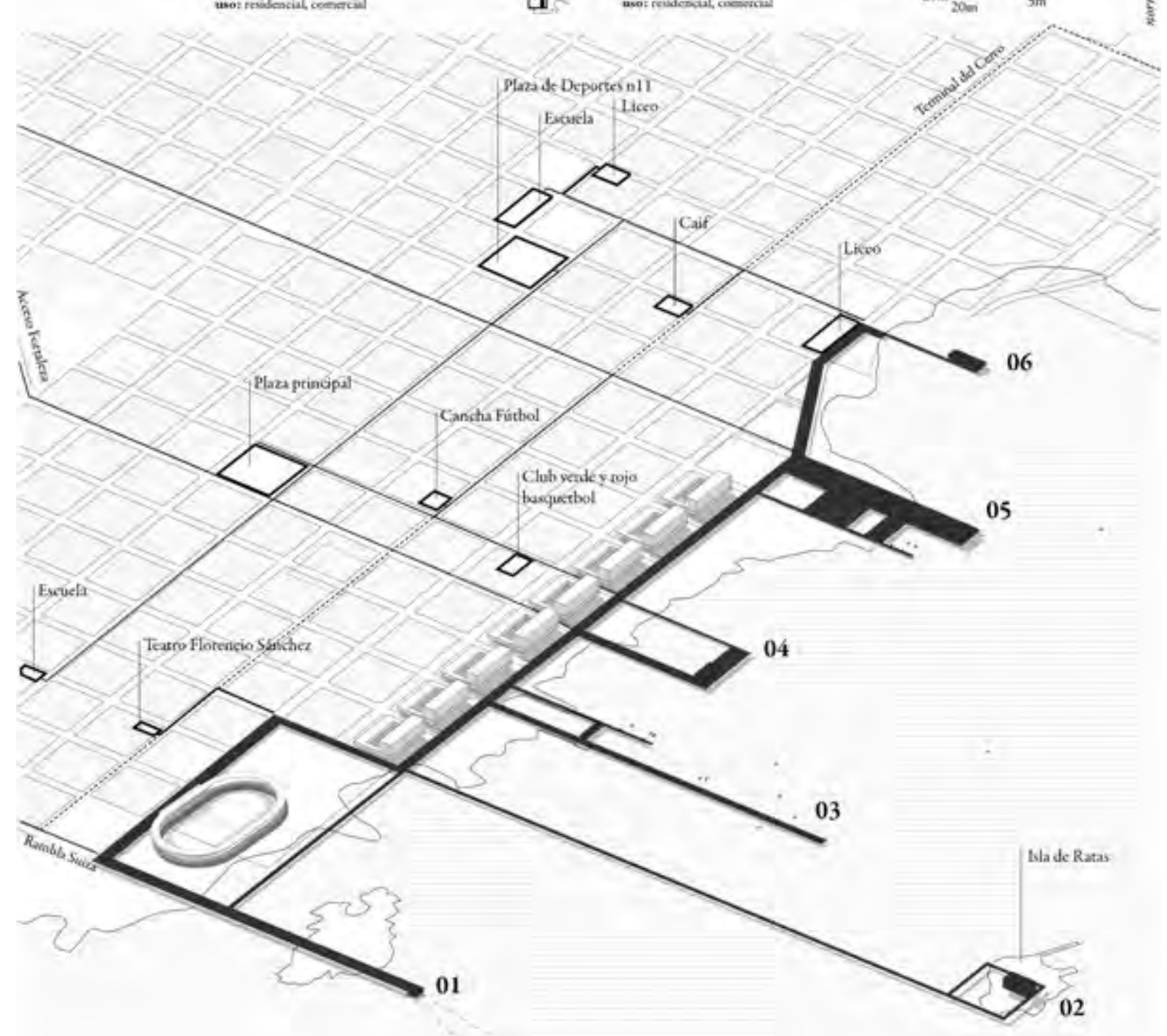

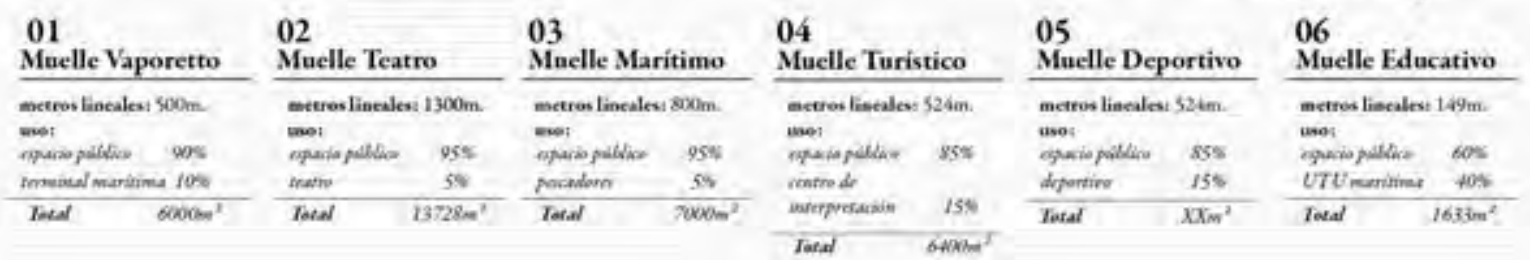

Plan Pier Cerro

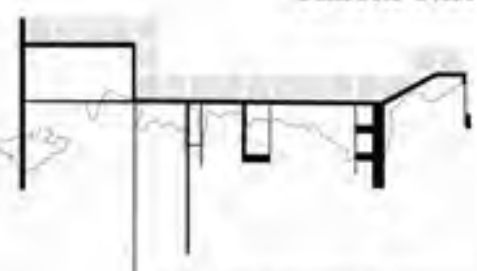

metres linestes totales: $5747 \mathrm{~m}$.
ifes toed $68.783 \mathrm{~m}$
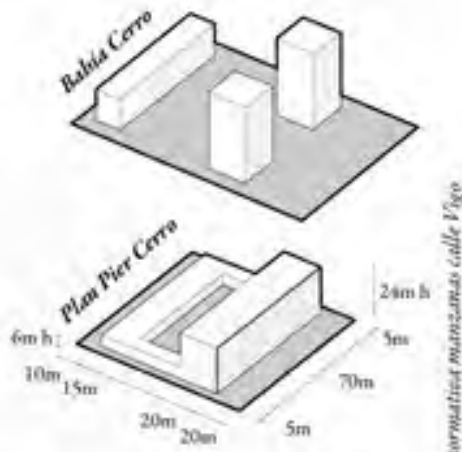

5 . 


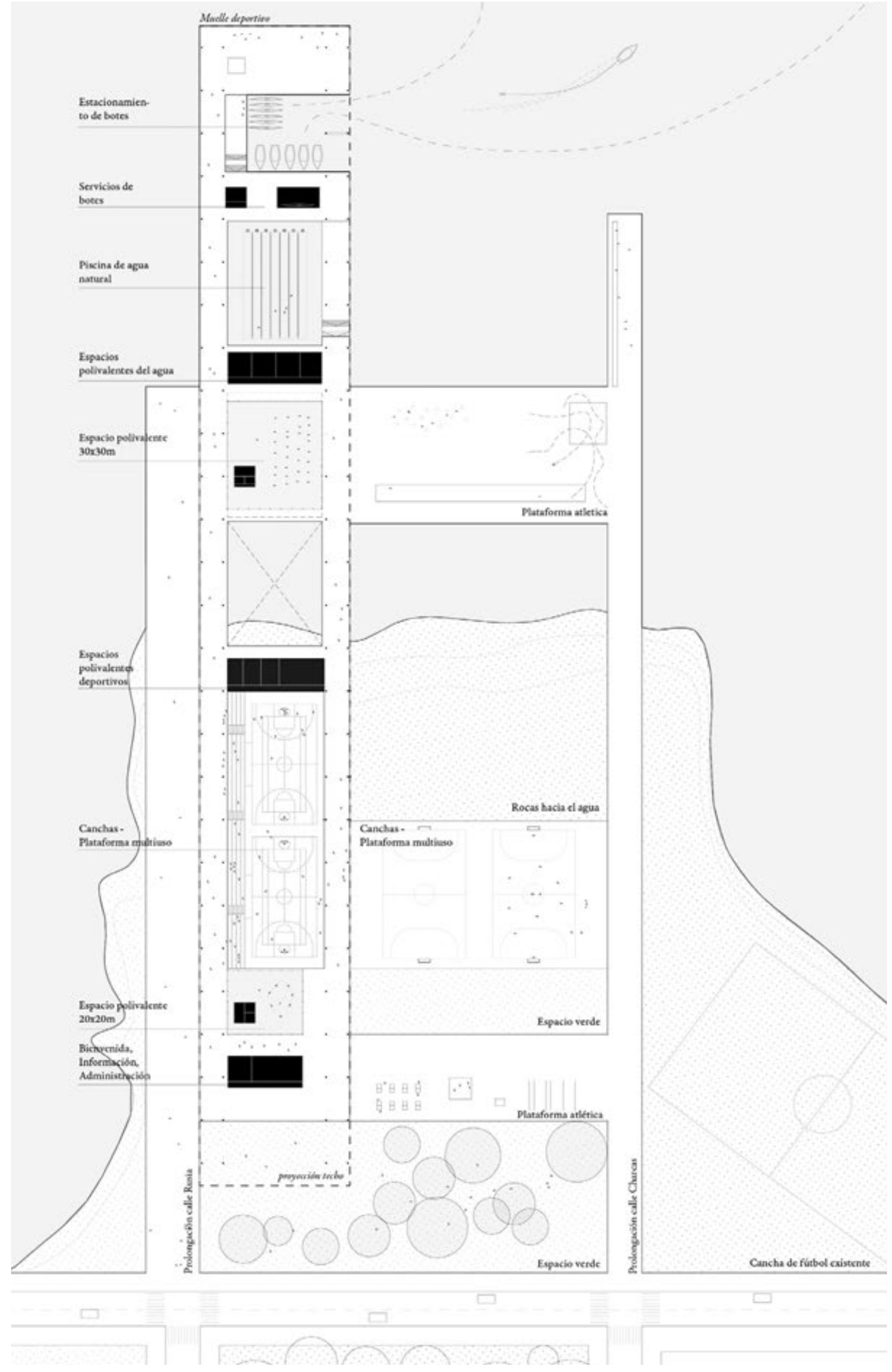


01

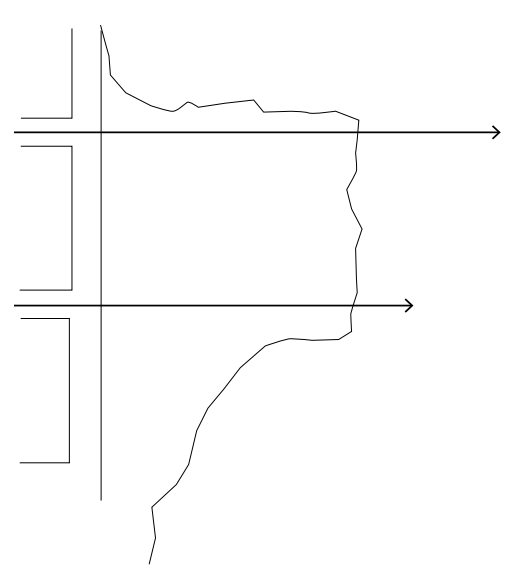

03

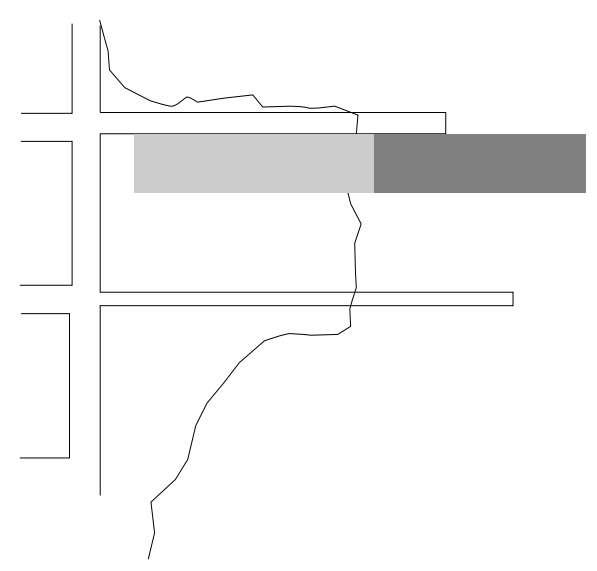

05

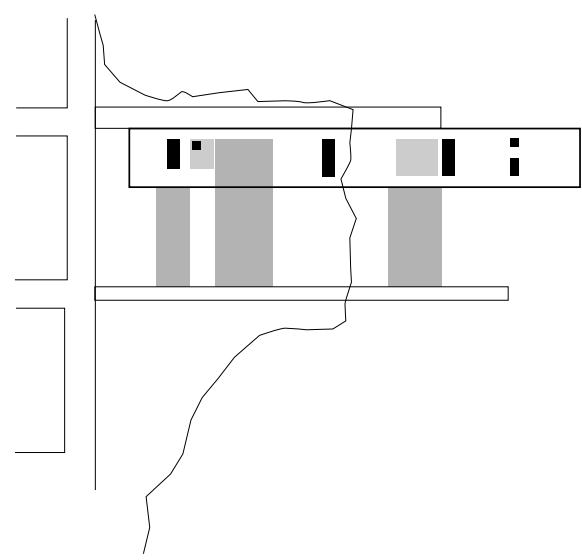

02

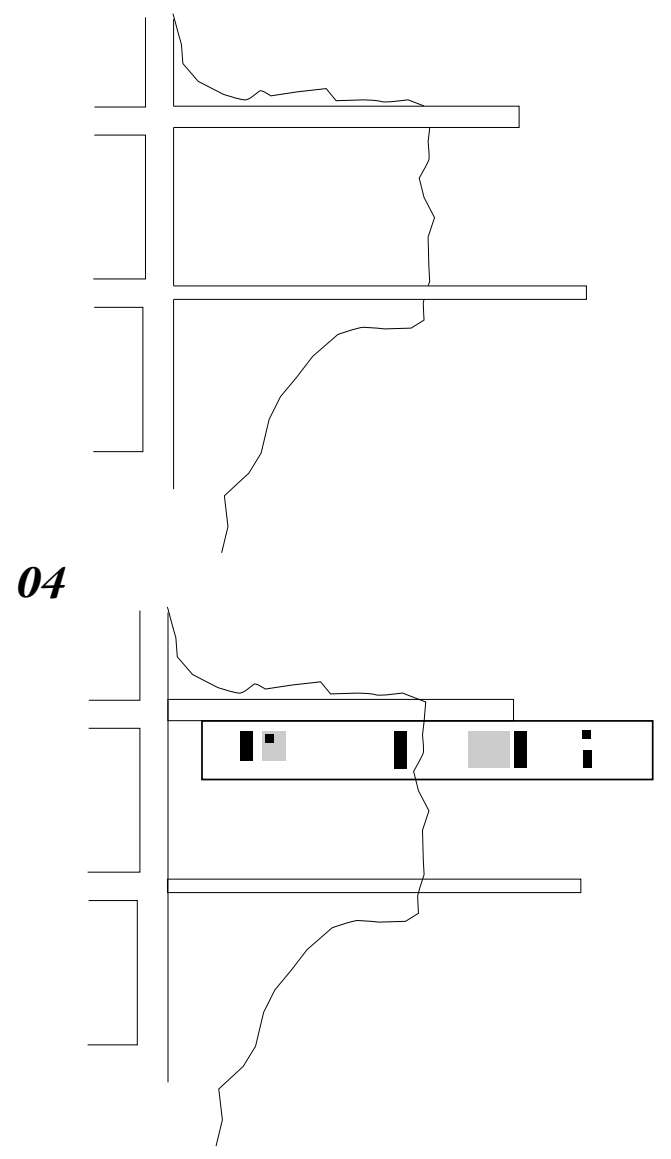

06

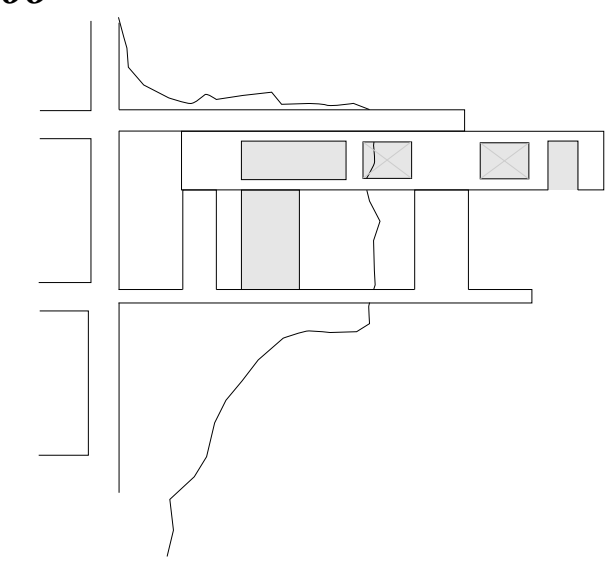

\section{1-02}

Se prolongan las calles Rusia y Charcas generando la continuidad de la ciudad intermerdia sobre la bahía fortaleciendo el vínculo con la bahía Se destaca la continuidad de la calle Rusia como vía vehicular y Charcas como paseo peatonal.

\section{3-04}

La propuesta se implanta paralelo a la calle Rusia, dando continuidad sobre la bahía en su condición de muelle. El proyecto se define como una base longitudinal, topográfica, debajo de una gran cubierta metálica. Se organiza en dos grandes zonas; cada uno contiene servicios y espacios multiproposito, capaces de albergar diversas actividades.

\section{5-06}

La sección del edificio permite generar relaciones visuales continuas, integración con la bahía y atravesamientos peatonales, disolviendo el límite entre interior y exterior. 
FORO MVD

FORO CCZ 17

\section{PIER}

Habitar la Babia

POSCRADO Y EDUCACIÓN PERMANENTE

MARIA IMBERT

PABLO MARTÍNEZ

FEDERICO RODRIGUEZ

AGUSTINA SÁNCHEZ

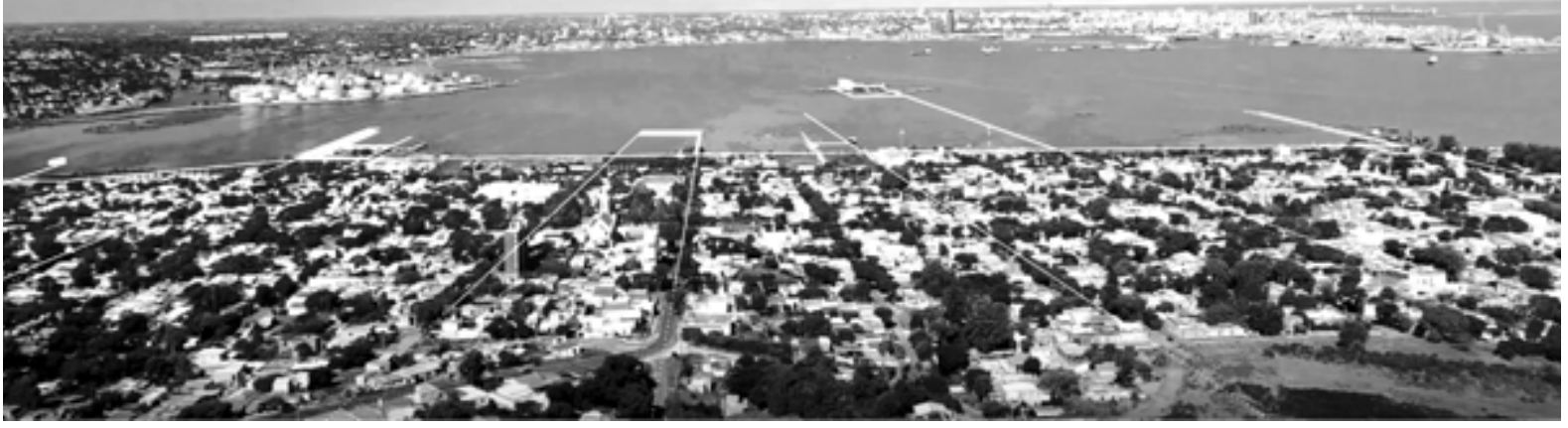




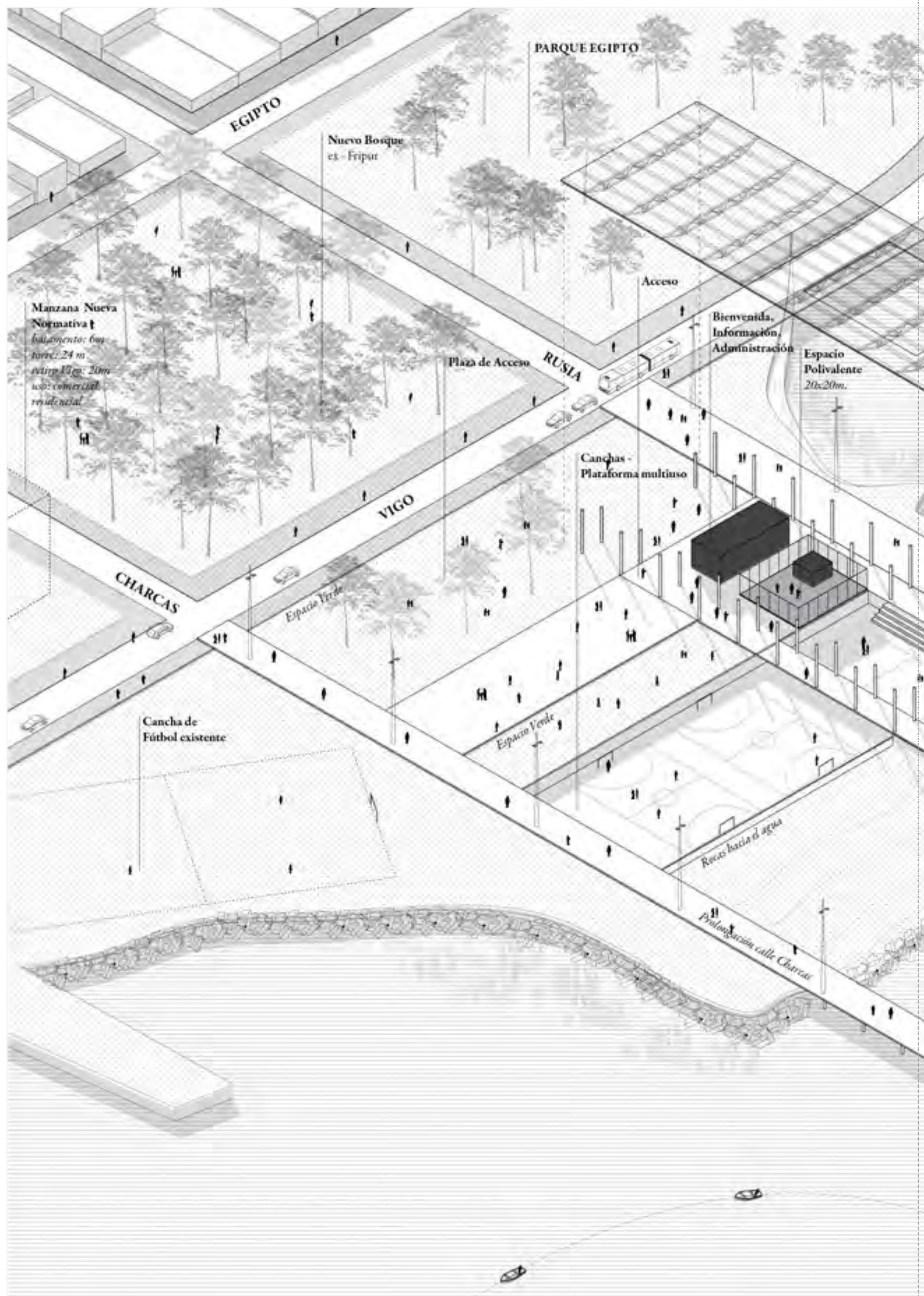




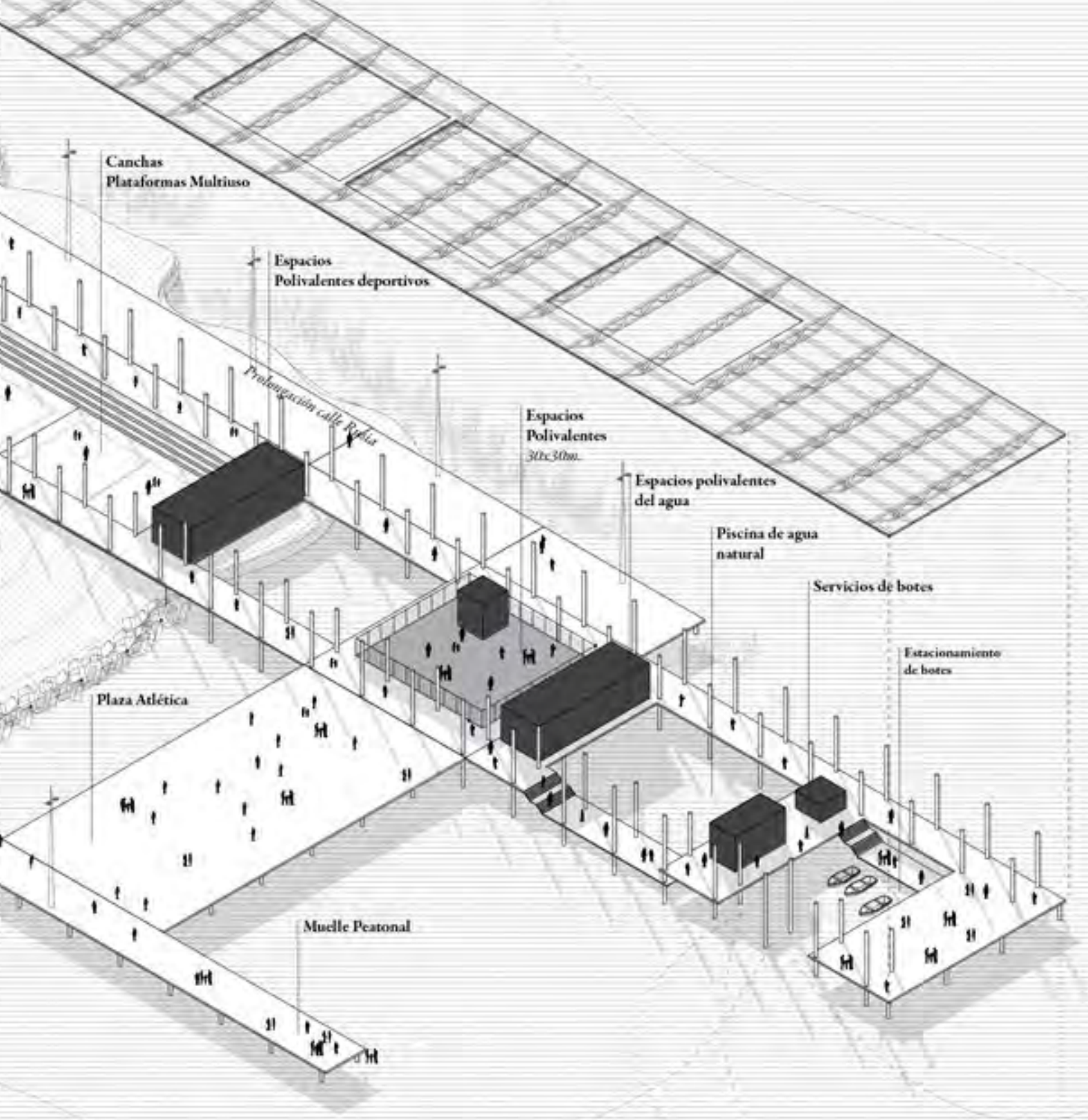




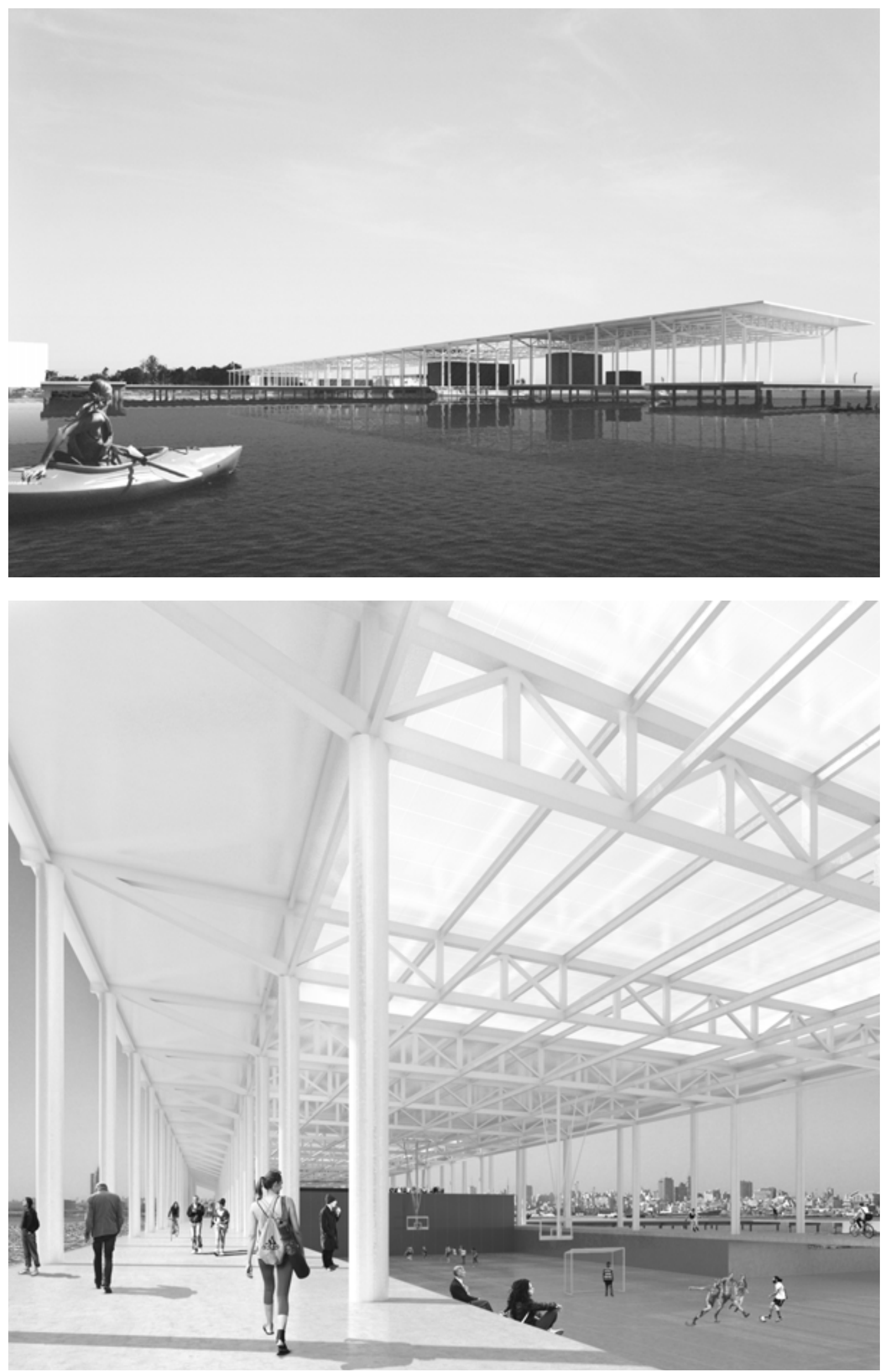


São Paulo

2018 